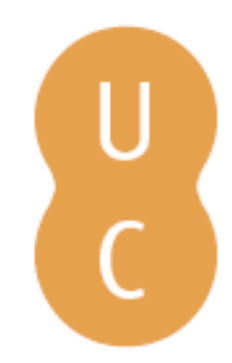

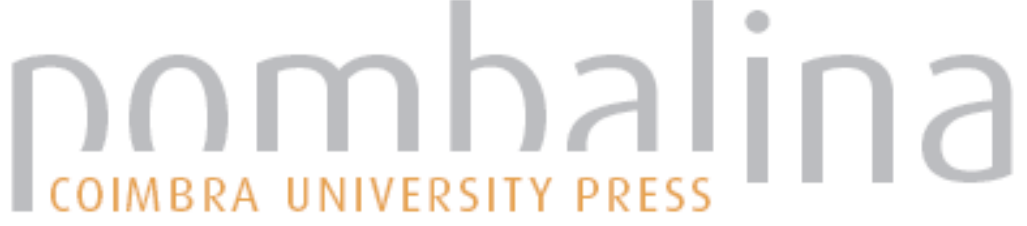

\section{Tempo e espaço da Paideia nas Vidas de Plutarco}

\author{
Autor(es): $\quad$ Pinheiro, Joaquim J. S.
}

Publicado por: Imprensa da Universidade de Coimbra

URL

persistente: $\quad$ URI:http://hdl.handle.net/10316.2/29850

DOI: $\quad$ DOI:http://dx.doi.org/10.14195/978-989-721-034-1

Accessed : $\quad$ 26-Apr-2023 10:23:44

A navegação consulta e descarregamento dos títulos inseridos nas Bibliotecas Digitais UC Digitalis, UC Pombalina e UC Impactum, pressupõem a aceitação plena e sem reservas dos Termos e Condições de Uso destas Bibliotecas Digitais, disponíveis em https://digitalis.uc.pt/pt-pt/termos.

Conforme exposto nos referidos Termos e Condições de Uso, o descarregamento de títulos de acesso restrito requer uma licença válida de autorização devendo o utilizador aceder ao(s) documento(s) a partir de um endereço de IP da instituição detentora da supramencionada licença.

Ao utilizador é apenas permitido o descarregamento para uso pessoal, pelo que o emprego do(s) título(s) descarregado(s) para outro fim, designadamente comercial, carece de autorização do respetivo autor ou editor da obra.

Na medida em que todas as obras da UC Digitalis se encontram protegidas pelo Código do Direito de Autor e Direitos Conexos e demais legislação aplicável, toda a cópia, parcial ou total, deste documento, nos casos em que é legalmente admitida, deverá conter ou fazer-se acompanhar por este aviso.

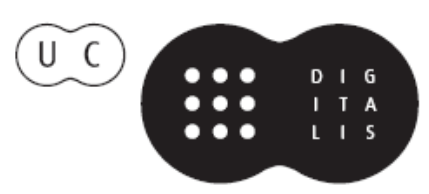




\section{Tempo e espaço da paideia nas Vidas de Plutarco}

\section{Joaquim J. S. Pinheiro}





\title{
Tempo e espaço da paideia nas Vidas de Plutarco
}

\author{
Joaquim J. S. Pinheiro
}


TODOS OS VOLUMES DESTA SÉRIE SÃO SUJEITOS A ARBITRAGEM CIENTÍFICA INDEPENDENTE.

Título - Tempo e espaço da Paideia nas Vidas de Plutarco

Autora • Joaquim J. S. Pinheiro

Série Hvmanitas Svpplementvm

Coordenador Científico do plano de edição: Maria do Céu Fialho

\section{Conselho Editorial}

José Ribeiro Ferreira

Maria de Fátima Silva
Francisco de Oliveira

Nair Castro Soares

Director Técnico: Delfim Leão

\section{Obra ReAlizada no ÂMbito DAs actividades da UI\&D Centro de Estudos Clássicos e Humanísticos}

EDIÇÃo

Imprensa da Universidade de Coimbra

URL: http://www.uc.pt/imprensa_uc

E-mail: imprensauc@ci.uc.pt

Vendas online:

http://livrariadaimprensa.uc.pt

COORDENAÇÃo EDITORIAL

Imprensa da Universidade de Coimbra

Concepçấo gráfica \& Paginação

Rodolfo Lopes \& Nelson Ferreira

Pré-IMPRESSÃo

Imprensa da Universidade de Coimbra
Impressáo e ACABAmento

Simốes \& LiNHARES

ISBN

978-989-721-033-4

ISBN DigITAL

978-989-721-034-1

DOI

http://dx.doi.org/10.14195/978-989-721-034-1

Depósito Legal

$353377 / 13$

(C) Novembro 2013 .

IMPRENSA DA UNIVERSIDADE DE COIMBRA

Classica Digitalia Vniversitatis Conimbrigensis (http://classicadigitalia.uc.pt)

Centro de Estudos Clássicos e Humanísticos da Universidade de Coimbra

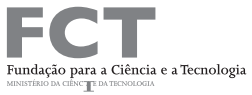

$\mathrm{POCI} / 2010$

Reservados todos os direitos. Nos termos legais fica expressamente proibida a reprodução total ou parcial por qualquer meio, em papel ou em ediçấo electrónica, sem autorizaçâo expressa dos titulares dos direitos. É desde já excepcionada a utilização em circuitos académicos fechados para apoio a leccionação ou extensão cultural por via de e-learning. 


\section{SuMÁRIO}

PreÂmbulo

Siglas e Abreviaturas $\quad 11$

Lista de Abreviaturas das Vitae $\quad 12$

Lista de Abreviaturas dos Moralia 13

$\begin{array}{ll}\text { INTRODUÇÃO } & 17\end{array}$

PARTE I

1. A Natureza das Biografias. Ethos e Praxis 25

2. A synkrisis 51

3. A problemática do Género das Vitae: bios e bistoria 61

4. O Paralelismo 85

5. A mimesis paidêutica

PARTe II

1. Plutarco e a Paideia 117

1.1. Preâmbulo às considerações sobre o sentido de paideia 117

1.2. As Vitae em análise 123

$\begin{array}{ll}\text { 1.2.1. Theseus-Romulus } & 124\end{array}$

1.2.2. Aristides-Cato Maior 136

$\begin{array}{lr}\text { 1.2.3. Coriolanus-Alcibiades } & 157\end{array}$

1.2.4. Demosthenes-Cicero 176

1.2.5. Sertorius-Eumenes 196

$\begin{array}{lr}\text { 1.2.6. Philopoemen-Flamininus } & 210\end{array}$

$\begin{array}{ll}\text { 1.2.7. Pelopidas-Marcellus } & 228\end{array}$

1.2.8. Alexander-Caesar 244

1.3. A paideia e a politeia $\quad 270$

1.3.1. Maxime cum principibus philosopho esse disserendum 281

$\begin{array}{ll}\text { 1.3.2. Ad principem ineruditum } & 284\end{array}$

1.3.3. An seni respublica gerenda sit $\quad 288$

1.3.4. Praecepta gerendae reipublicae 290

1.3.5. De unius in republica dominatione $\quad 294$

PARTE III

1. O conceito de paideia em Plutarco 301

2. Graecia capta ou Roma capta 359 
Conclusão

Bibliografia

Edições e comentários

405

Estudos

407

Índice Remissivo das VITAE E dos MoRALIA

439

ÍNDICE REMISSIVO GERAL

445 
Aos meus Pais e Avós.

À Cristina, à Mariana è à Madalena. 



\section{Preâmbulo}

O conteúdo deste volume corresponde, em larga medida, à nossa dissertação de doutoramento, apresentada à Universidade da Madeira, em Dezembro de 2007. Para tornar o texto mais acessível ao grande público, eliminámos da versão original várias citações de textos da Literatura Grega, aligeirámos algumas notas e esclarecemos o sentido de conceitos, mantendo a estrutura e o resultado da investigação sobre a obra de Plutarco.

Desde a nossa vinda para a Universidade da Madeira que temos tido o privilégio de poder contar com a orientação científica e o apoio do Doutor Arnaldo Espírito Santo. Assim aconteceu na elaboração das Provas de Aptidão Pedagógica e Capacidade Científica e em todo o processo do presente trabalho. Pelos ensinamentos que nos dispensou ao longo destes anos, queremos expressar-lhe a nossa profunda gratidão, pois é um exemplo de paideia que para sempre nos acompanhará.

Ao Doutor José Ribeiro Ferreira devo uma sentida palavra de agradecimento pelo interesse que sempre manifestou pela Dissertação e por, no âmbito das suas funções de Presidente da Sociedade Portuguesa de Plutarco, nos ter proporcionado a ida, muito enriquecedora, ao Colóquio da Rede de Plutarco, realizado em Madrid, e a integração na equipa do Projecto Plutarco e os Fundamentos da Identidade Europeia (PTDC/HAH68899/2006), além da sua disponibilidade para nos remeter artigos ou livros de apoio. Muito grato estamos também ao Doutor Delfim Leão, quer pela forma como tem vindo a coordenar cientificamente os trabalhos de tradução e estudo da obra de Plutarco, quer pelo interesse e preserverança que manteve, enquanto responsável pela biblioteca online Classica Digitalia (http://classicadigitalia.uc.pt ), na publicação do presente volume. À Doutora Cristina Pimentel pelo incentivo durante o nosso percurso académico, pelo interesse e sugestões, manifestamos o nosso sentido agradecimento. Pelo apoio que temos recebido, desde 2007, por 
parte do Centro de Estudos Clássicos e Humanísticos da Faculdade de Letras, da Universidade de Coimbra, expressamos à Doutora Maria do Céu Fialho, coordenadora científica, a nossa sincera gratidão. À equipa de trabalho dos Classica Digitalia endereçamos também um agradecimento pelo cuidadoso labor de edição.

À Universidade da Madeira, agradecemos, de forma especial, a confiança que depositou neste projecto e as condições que nos disponibilizou para o concluir, em particular a Unidade de Documentação e Arquivo pela maneira como tratou os múltiplos pedidos de empréstimo interbibliotecário e pelo suporte à leitura de alguns documentos em microfilme.

Pela forma como sempre estiveram presentes na nossa vida e pelos valores que nos têm transmitido, os nossos pais merecem um reconhecimento muito especial. Gostaríamos de estender à nossa família e aos nossos amigos os agradecimentos por terem sido um importante estímulo durante este percurso.

Guardamos as palavras finais para as três pessoas que mais de perto, com todas as consequências que desse facto advêm, conviveram com a investigação associada a este trabalho: a Cristina, a Mariana e, mais recentemente, a Madalena. Para elas, dirigimos um profundo obrigado por tudo o que representam e por darem sentido à nossa existência.

Funchal, Julho de 2013

Joaquim Pinheiro 


\section{Siglas e Abreviaturas}

Usámos, de um modo geral, a nomenclatura de H. G. Liddell \& $\mathrm{R}$. Scotт (A Greek-English Lexicon, with a revised supplement, 1996r) para a citação dos autores e obras da Literatura Grega e o dicionário editado por P. G. W. Glare (Oxford Latin Dictionary, 1997r) para as referências aos autores e obras da Literatura Latina. $\mathrm{O}$ facto de aludirmos com muita frequência às Vitae e aos Moralia de Plutarco fez com que adoptássemos, nas notas de rodapé, o sistema de abreviaturas convencionado pela generalidade dos estudos plutarquianos, que a seguir reproduziremos de modo a facilitar a leitura do nosso trabalho. No caso dos estudos modernos, o nome do autor vem seguido do ano de publicação e páginas (e. g. C. Pelling (2002: 1-44)), remetendo-se a informação completa para a bibliografia; como alguns estudos foram objecto de repetidas publicações em revistas ou livros, optámos por colocar um $r$ após o ano (2002r), nos casos em que não lemos o texto da primeira publicação (há casos, como T. Duff (2002r), em que o $r$ significa que nos referimos à reimpressão em paperback, pois a edição bardback é de 1999); para os estudos lidos em tradução antepusemos um $t$ ao ano de publicação (t1981). Refira-se, ainda, que as abreviaturas das publicações periódicas seguem as siglas usadas em L'Année Philologique e que para os nomes próprios usámos o vocabulário Índices de Nomes Próprios Gregos e Latinos, da autoria de M. H. Ureña Prieto ET AL. (1995).

Por fim, o nosso trabalho beneficiou do uso do CD ROM Thesaurus Linguae Graecae (University of California, Irvine, 1999), bem como do programa de leitura LECTOR 2003 (versão 1.06) e do DIOGENES.

$\mathrm{Na}$ recolha bibliográfica, a lista de estudos plutarquianos que a International Plutarch Society disponibiliza, em formato pdf e por ordem alfabética, na sua homepage (cf. http://www.usu.edu/historia/ploutarchos/plutbib.htm [Novembro, 2006]) foi de extrema utilidade, tal como, por exemplo, os artigos de A. Podlecki \& S. Duane (1992: 4053-4153) e F. Titchener (1992: 41284153). 


\section{Lista de Abreviaturas das Vitae (ordem alfabética)}

Aem. $=$ Aemilius Paulus

Ages. $=$ Agesilaus

Ag./Cleom. $=$ Agis/Cleomenes

Alc. $=$ Alcibiades

Alex. $=$ Alexander

Ant.$=$ Antonius

Arat.$=$ Aratus

Arist.$=$ Aristides

Art. $=$ Artaxerxes

Brut..$=$ Brutus

Gracch. $=$ T. Gracchus/ C. Gracchus

Caes. $=$ Caesar

Cam. $=$ Camillus

Cat. Ma. $=$ Catus Maior,

Cat. Mi.=Catus Minor

Cic. $=$ Cicero

Cim. $=$ Cimon

Comp. $=$ Comparatio (seguida das abreviaturas das duas vidas)

Cor. $=$ Coriolanus

Crass $=$ Crassus

Dem. $=$ Demosthenes

Demetr. $=$ Demetrius

Dion

Eum. $=$ Eumenes

Fab.=Fabius Maximus

Flam $=$ Flamininus

Galb. $=$ Galba

Luc. $=$ Lucullus

$L y c .=L y c u r g u s$

Lys. $=$ Lysander

Mar. $=$ Marius

Marc. $=$ Marcellus

Nic. $=$ Nicias

Num. $=$ Numa

Oth. $=$ Otho

Pel.=Pelopidas

Per $=$ Pericles

Phil. =Philopoemen

Phoc. $=$ Phocion

Pomp. $=$ Pompeius 
Publ. $=$ Plublicola

Pyrrh. $=$ Pyrrhus

Rom. $=$ Romulus

Sert. $=$ Sertorius

Sol. $=$ Solon

Sull. $=$ Sulla

Them. $=$ Themistocles

Thes. $=$ Theseus

Tim. $=$ Timoleon

\section{Lista de Abreviaturas dos Moralia}

De liberis educandis=De lib. educ.

Quomodo adulescens poetas audire debeat $=D e$ aud. poet.

De recta ratione audiendi $=D e$ aud.

Quomodo adulator ab amico internoscatur $=D e$ adul.

Quomodo quis suos in virtute sentiat profectus $=$ De prof. in virt.

De capienda ex inimicis utilitate $=$ De cap. ex inim. ut.

De amicorum multitudine $=$ De am. mult .

De fortuna $=$ De fort .

De uirtute et uitio=De virt. et vit.

Consolatio ad Apollonium=Cons. ad Apoll.

De tuenda sanitate praecepta=De tuenda san.

Coniugalia praecepta=Coniug. praec.

Septem sapientium conuiuium $=$ Sept. sap. conv.

De superstitione $=$ De superst.

Regum et imperatorum apophtegmata=Reg. et imp. apopht.

Apophtegmata Laconica=Apopht. Lac.

Mulierum virtutes $=$ Mul. uirt.

Quaestiones Romanae $=$ Quaest. Rom.

Quaestiones Graecae=Quaest. Graec.

Parallela Graeca et Romana=Paral. min.

De fortuna Romanorum=De fort. Rom.

De Alexandri fortuna aut uirtute $=D e$ Alex. fort. aut uirt.

De gloria Atheniensium =De gloria Ath.

De Iside et Osiride $=D e$ Is. et Os.

De E apud Delphos=De E Delph.

De Pythiae oraculis=De Pyth. or.

De defectu oraculorum $=$ De def. orac.

An uirtus doceri possit $=$ An uirt. doc.

De uirtute morali=De uirt. mor.

De cohibenda ira $=$ De coh. ira 
De tranquilitate animi=De tranq. an.

De fraterno amore $=$ De frat. am.

De amore prolis $=$ De am. prol.

An uitiositas ad infelicitatem sufficiat $=$ An uit. ad inf. suff.

Animine an corporis affectiones sint peiores $=A n$. corp. affect.

De garrulitate $=$ De garr.

De curiositate $=$ De curios.

De cupiditate diuitiarum $=D e$ cup. diu.

De uitioso pudore=De uit. pud.

De inuidia et odio=De inu. et od.

De se ipsum citra inuidiam laudando=De laude ips.

De sera numinis uindicta $=$ De sera num. uind.

De fato $=$ De fato

De genio Socratis=De gen. Socr.

De exilio=De exil.

Consolatio ad uxorem $=$ Cons. $u x$.

Quaestionum conuiualium $=$ Quaest. conu.

Amatorius=Amat.

Amatoriae narrationes $=$ Am. narr.

Maxime cum principibus philosopho esse disserendum =Max. cum princ.

Ad principem indoctum (ou ineruditum) $=$ Ad princ. ind.

An seni res publica gerenda sit $=$ An seni resp.

Praecepta gerendae reipublicae $=$ Praec. ger. reip .

De unius in republica dominatione $=$ De un. in rep. dom.

De uitando aere alieno=De uit. aer. al.

Decem oratorum uitae $=X$ or. uit .

Aristophanis et Menandri comparationes epitome=Comp. Arist. Men.

De Herodoti malignitate=De Herod. mal.

Placita philosophorum=Plac. philos.

Quaestiones naturales $=$ Quaest. nat.

De facie in orbe lunae=De fac. lun.

De primo frigido $=$ De primo frig.

Aqua an ignis utilior sit=Aq. an ign.

De sollertia animalium $=$ De soll. anim.

Bruta animalia ratione uti $($ Gryllus $)=$ Bruta anim .

De esu carnium $(A$ et $B)=$ De esu carn.

Platonicae Quaestiones = Plat. Quaest.

De animae procreatione in Timaeo=De an. procr.

De Stoicorum repugnantiis=De Stoic. rep.

Stoicos absurdiora poetis dicere=Stoic. absurd. poet.

De communibus notitiis aduersus Stoicos=De comm. not. 
Non posse suauiter vivi secundum Epicurum=Non posse suau. Adversus Colotem $=$ Adv. Col.

De latenter uiuendo=De lat. uiu.

De musica=De mus.

De libidine et aegritudine $=D e$ lib. et aegr.

Parsne an facultas animi sit vita passiva=Parsne an fac. an. Fragmenta $=$ Fragm . 



\section{INTRODUÇÃo}

Elaborar um trabalho de investigação tem quase sempre dois elementos subjacentes: a objectividade e a subjectividade. Em relação a esta, não escondemos o interesse pela literatura grega, em especial por autores cuja obra denote uma evidente intenção pedagógica. Poder-se-á dizer que qualquer autor ensina...É verdade, mas alguns fazem do propósito educativo um factor estruturante da sua obra. Neste grupo de autores incluímos Hesíodo, alguns pré-socráticos (Xenófanes, Parménides e Empédocles), Arato, Nicandro, entre outros. Se, no passado, o poema Trabalhos e Dias de Hesíodo constituiu a base da nossa investigação para a apresentação de Provas de Aptidão Pedagógica e Capacidade Científica, quisemos nesta fase do percurso académico escolher um autor que nos possibilitasse explorar o diálogo de culturas, mais especificamente, o intercâmbio cultural entre a Grécia e Roma. Além disso, a dinâmica que a International Plutarch Society trouxe ao estudo do corpus plutarcheum, com a publicação de estudos e a organização regular de congressos, não deixou de nos cativar. Quanto às circunstâncias objectivas que marcaram esta dissertação, a actual situação da área de Humanidades na Universidade da Madeira - a inexistência, por um lado, de cursos de Línguas e Literaturas, e, por outro, a tendência para os docentes da área de Estudos Clássicos e Humanísticos leccionarem disciplinas como Estudos Europeus, Estudos Políticos ou Fundamentos da Cultura, em cursos interdisciplinares - levou-nos a considerar que a nossa investigação deveria fundamentar-se num autor e num corpus que se tivessem revelado de enorme importância para o estudo da memória histórica da Europa e das suas matrizes culturais.

Por estas razões, a nossa atenção recaiu em Plutarco e na sua vasta obra que a tradição divide em duas partes: os Moralia e as Vitae. Num tempo em que a circulação de saber era intensa e num espaço cultural, o Mediterrâneo, com ténues fronteiras, propomo-nos interpretar o significado da paideia, conceito de génese grega que remete para uma etapa formativa equivalente a um processo de conhecimento e aprofundamento. Neste período, a que se junta o aliciante de a Grécia estar sob o domínio do Império Romano, os sentidos e as formas da paideia ultrapassam, acreditamos, o âmbito da cultura grega, passando a definir, com unidade e coerência, as atitudes, as experiências, as manifestações e os ensinamentos da cultura greco-romana. Logo, Plutarco, que recebeu a cidadania romana e os ornamenta consularia entre 98 e 117, não inscreve somente a sua obra na literatura grega, mas também na literatura 
da Época Imperial, o que lhe confere universalidade, e o próprio autor tem consciência dessa configuração mais global.

A sua formação intelectual e religiosa, as viagens pela Ásia, Egipto, Itália setentrional e Roma ${ }^{1}$, as actividades de pedagogo, as funções de sacerdote de Delfos e o cargo de procurador imperial na Acaia habilitaram-no certamente a reflectir sobre o encontro de Roma com a cultura grega. Daí resulta uma produção policromática e repleta de conexões internas e externas. Convicto desta faceta do corpus plutarcheum, S. Goldhill (2002: 292) considera que "Plutarch's encyclopedia is his Empire of knowledge".

Outro factor decisivo para termos escolhido este tema foi a actualidade e a relevância dos valores legados pela obra de Plutarco. No entanto, outras questões se colocaram previamente: o estudo teria como corpus base os Moralia e as Vitae ou faríamos uma outra selecção, com base em critérios temáticos? Seria possível dissociar as Vitae dos Moralia? Sobre o volume da obra produzida pelo polígrafo de Queroneia não é necessário tecer grandes considerações, uma vez que ele é sobejamente conhecido, mas é óbvio que esse facto foi tido em conta. Juntamente com estas questões, era do nosso interesse definir critérios de selecção capazes de conferir unidade e coesão à temática a aprofundar. Ora, as Vitae oferecem esses requisitos. Não incluir no núcleo central do trabalho uma parte substancial dos Moralia não significa abdicar das concepções, ideias e exemplos aí contidos, pois recorreremos várias vezes aos tratados, nem traduz uma concordância com a ideia de que os principais vectores do pensamento plutarquiano estariam salvaguardados pelas Vitae, se por qualquer razão do destino os Moralia não tivessem vencido as vicissitudes do tempo ${ }^{2}$. Considera-se somente que as Vitae, atendendo à sua estrutura paralela e por focalizarem uma personagem, constituem o campo ideal para os nossos objectivos. Uma segunda razão prende-se com o facto de as Vitae oferecerem uma linha temática mais sólida e linear do que os Moralia, nos quais impera a diversidade, uma vez que temos desde tratados que fazem do amor o tema central até ensaios filosóficos

${ }^{1}$ Cf. R. Barrow (1967: cap. 5); C. Jones (1971: cap. 6); J. Geiger (1974: 141).

${ }^{2}$ E. g., R. Flacelière (1979: 275) escreveu o seguinte sobre esta questão: "Supposons un instant que les Euvres dites (très improprement) morales aient complètement disparu dans le grand naufrage de la littérature antique, et que les Vies seules aient échappé a cet engloutissement; grâce à elles, et surtout à leurs digressions... le philologue pourrait facilement reconstituer la pensée morale, philosophique et religieuse de Plutarque, en un mot, toute, la personnalité du grand Chéronéen”. Registe-se ainda a opinião de F. Frazier (1992 : 4535): "Si la biographie requiert une écriture spécifique de tendance mimétique, celle-ci est mise au service d'intentions et de valeurs morales et philosophiques très proches de celles des traités. La distinction traditionnelle des deux séries d'oeuvres ne correspond qu'à une commodité de classement: il n'y a en réalité aucune solution de continuité entre elles et un même esprit les anime”. Já D. Russel (1968: 130) havia salientado a diferença entre as Vitae e os Moralia, considerando que os tratados, pela sua diversidade temática, têm uma dimensão diferente e mais abrangente. Veja-se que em alguns casos Plutarco remete das Vitae para os Moralia, dizendo que aí será mais exaustivo (cf. Rom.15.7 ; Cam. 19.2). 
e educacionais, bem como outros mais de cariz religioso e político, entre muitos outros temas. Uma terceira razão, talvez a mais importante, resulta da forma, do conteúdo e das personagens biografadas nas Vitae. A originalidade não reside no facto de escrever a vida de personagens ilustres, mas antes no facto de, por um lado, Plutarco escrever biografias de figuras históricas e apresentar de forma consistente e sistemática um Grego e um Romano em comparação (synkrisis), realçando diferenças e analogias, e, por outro lado, na forma como o autor combina a sua individualidade e interesses pessoais com a documentação ao seu dispor e com o peso da tradição que o precede.

É neste contexto, sem obviamente negligenciar os vários elementos inerentes à composição de cada uma das biografias, que interpretaremos os valores transversais às duas culturas, de modo a definir o significado de paideia. Como referiu J. Ribeiro Ferreira (2002: 22) na Sessão de Abertura do Congresso Plutarco Educador da Europa: “(...) as Vidas fazem brilhar a paideia antiga, propondo como ideal o de um herói instruído, culto (ou seja pepaideumenos), e são elas próprias obras-primas de paideia, destinada a aumentar a paideia dos leitores: os heróis aí biografados tornaram-se paradigmas e foram imitados ao longo dos tempos."

Não há dúvida de que os heróis biografados não são de um período estranho e alheio ao homem actual, pois partilham connosco um mesmo e único tempo por tudo aquilo que nos fazem sentir e reflectir. Além disso, o resultado da análise dos heróis dir-nos-á que a sua acção tem um sentido e um benefício colectivo. Sendo assim, a paideia expressa nas Vitae não será, muito provavelmente, apenas uma experiência pessoal, mas implica um processo conjunto e harmonioso, entre o indivíduo e a sociedade em que se insere.

Plutarco procura o pormenor nas acções das personagens, os seus sentimentos e estados de espírito reveladores da personalidade de cada uma delas, mostrando ser um arguto observador do comportamento humano. Seduzido pelo contributo pedagógico que as personagens e os feitos do passado podem dar, elabora, como o nosso trabalho demonstrará, a partir do carácter e das acções dos seus heróis, um código ético - numa interdependência de ethos e praxis - , que sublinha a responsabilidade do homem no tratamento da causa pública, defendendo, numa vertente mais filosófica, a liberdade de espírito na procura da eudaimonia.

Num outro momento dos trabalhos preparatórios desta dissertação foi necessário decidir se seria exequível tratar e aprofundar os sentidos da paideia em todos os vinte e dois pares de biografias (quarenta e seis biografias no total, pois um dos pares tem quatro vidas, referimo-nos às Vitae de Agis e Cleomenes, e Tiberius Gracchus e Caius Gracchus), mais as quatro Vitae sem par, as de Aratus, Artaxerxes, Galba e Otho. Tendo em conta a natureza do trabalho, a reflexão analítica que se exige e a probidade da investigação, optámos por fazer uma selecção das Vitae, baseada nos critérios que exporemos de forma resumida. 
Antes, porém, registe-se que a nossa primeira decisão foi a de recorrer à cronologia da composição das Vitae, quer à cronologia relativa (ordem e método de composição), quer à cronologia absoluta (data de publicação). A vasta bibliografia que existe sobre esta matéria - J. Mewaldt (1907), C. Stoltz (1929), M. Brozek (1963), C. Jones (1966: 61-74), só para referir os mais importantes demonstra como é complexo definir a cronologia das Vitae, uma questão que se mantém ainda em aberto. Parece, no entanto, não haver dúvidas de que o conjunto das biografias foi escrito antes do principado de Adriano. Dadas as referências recíprocas existentes, é possível fixar o terminus ante e o terminus post para alguns pares. Mas, pelo facto de em alguns casos as referências entrarem em contradição, a fixação de uma cronologia relativa completa torna-se, sem dúvida, uma tarefa repleta de incertezas. Há ainda dois aspectos que não podemos deixar de referir: em primeiro lugar, o prólogo do primeiro par escrito por Plutarco, EpaminondasScipio, par que infelizmente não chegou até nós, definiria certamente alguns vectores do programa das Vitae; em segundo, o prólogo de Aemilius Paulus parece revelar a falta de um plano prévio para o conjunto da obra.

Posto isto, abandonámos a intenção de usar a cronologia como critério, até porque não está provado que a escolha e a ordem dos heróis tenha tido em conta um interesse puramente historiográfico. Em muito deve ter contribuído a admiração pessoal de Plutarco por alguns heróis, o contexto histórico da sua época e as fontes necessárias à elaboração biográfica. Nesse sentido, concordamos com as seguintes palavras de A. Pérez Jiménez (2000r: 84): “(...) la elección de los héroes se mueve en el terreno de lo fortuito y de los gustos personales o, más a menudo, en el de la admiración general, en esa época, por la historia de otro tiempo como depositaria de más altos valores que el presente y en el de las fuentes, que, en algunos casos, le imponen tanto el tema como el modo de enfocarlo". Assim, a nossa selecção do corpus sobre o qual incidirá a dissertação baseou-se mais no conteúdo das Vitae do que em aspectos externos à sua composição (fontes disponíveis, ordem cronológica dos biografados ou ordem de composição das biografias). Assim, compõem o corpus principal: TheseusRomulus; Aristides-Cato Maior, Coriolanus-Alcibiades; Demosthenes-Cicero; Sertorius-Eumenes; Philopoemen-Flamininus; Pelopidas-Marcellus e AlexanderJulius Caesar. De um modo geral, todas estas Vidas têm, à semelhança das outras, um sentido moralizante. Contudo, uma análise mais cuidada permite diferenciar alguns grupos temáticos: um par mítico-lendário (Theseus-Romulus); um par formado por aqueles que a tradição consagrou como os mais insignes oradores das suas culturas (Demosthenes-Cicero); um par de traidores (Coriolanus-Alcibiades), em que a paideia e a mimesis se constrói pela negativa; um par de "estrangeiros" e desterrados (Sertorius-Eumenes); um par em que se realça a virtude no exercício da vida pública (Aristides-Cato Maior); dois pares marcados pelo filo-helenismo dos Romanos (Philopoemen-Flamininus e Pelopidas-Marcellus) e, por fim, a escolha 
do par Alexander-Julius Caesar, que se impõe-se, sobretudo, pelo significado ímpar que as duas personagens desempenham na Antiguidade.

Além disso, como nos interessa verificar o conteúdo da paideia e a forma como Plutarco a consegue conciliar nas duas culturas, a grega e a romana, não só colocámos de parte as Vitae sem par, como também escolhemos aquelas que são seguidas da synkrisis, sendo o par Alexander-Julius Caesar a única excepção. Por exemplo, a integração dos pares Philopoemen-Flamininus e PelopidasMarcellus, em detrimento das vidas de Cimon-Lucullus e Agesilaus-Pompeius, onde também se desenvolve o tema da sedução dos Romanos pela paideia helénica, deveu-se ao facto de, segundo Plutarco, Flaminino ser o expoente máximo do filo-helenismo romano e de Marcelo ter sido o primeiro Romano a manifestar a sua admiração e interesse pela paideia. Sublinhamos o facto de nos pares Coriolanus-Alcibiades e Sertorius-Eumenes a ordem normal, Grego-Romano, estar invertida. Este é um aspecto de ordem formal, mas que pode ter implicações importantes no momento de interpretarmos o processo de synkrisis. Por fim, também foi determinante o nosso gosto pessoal na escolha do corpus. Daí termos preferido, por exemplo, as vidas de Coriolanus-Alcibiades, em detrimento do par Demetrius-Antonius, onde a mensagem biográfica também se faz pela negativa. Neste caso, pesou ainda na nossa escolha o facto de o par Demetrius-Antonius merecer, em geral, mais atenção por parte da crítica.

Temos consciência de que o processo de leitura e reflexão exigido pelas Vitae não é uma tarefa simples. O erudito de Queroneia recebeu influências de várias correntes filosóficas, de vários autores, não sendo indiferente ao espírito da sua época, conhecida por "Segunda Sofística", em que a Hélade vive, com um estatuto especial, sob administração romana. Sobre a Segunda Sofística escreveram S. SAÏD ET AL (Eds., 2004 : 453) as seguintes palavras: "La seconde sophistique incarne plus que tout autre genre le compromis historique entre la culture grecque e le pouvoir romain”. Ora, Plutarco, mesmo não conseguindo alhear-se da sua condição de heleno, tenta preservar o equilíbrio entre as duas culturas, sem ter a intenção de anular qualquer uma delas.

Quanto à disposição das matérias no nosso trabalho, optámos por desenvolver numa Primeira Parte, de carácter mais teórico, questões relacionadas com a génese, a estrutura, o valor da imitação, a problemática do género literário e as motivações das Vitae, socorrendo-nos também de alguns textos dos Moralia. Esta parte inicial ajudará a enquadrar melhor a questão da paideia e o seu papel no ethos e na praxis, além de ser imprescindível para se compreender o efeito imitativo que a obra pretende ter junto dos seus leitores e, em particular, dos indivíduos do período imperial.

Depois, na Segunda Parte, dedicar-nos-emos exclusivamente à interpretação da paideia nas Vitae de Plutarco e a relação que se estabelece entre paideia e politeia. Por conseguinte, contamos analisar os textos, par a 
par, seguindo a ordem das biografias da edição teubneriana, que consideramos mais significativos para o estudo da paideia, extraindo as diversas informações e remetendo para alguns dos valores que estão associados a ela. A análise tenderá, assim, a procurar os motivos que permitam definir a paideia, daí que não se deve esperar uma análise exaustiva das biografias seleccionadas, uma vez que não cabem neste estudo desenvolvimentos sobre fontes usadas, estruturas das biografias ou a análise pormenorizada das diferentes personagens.

Como estamos perante figuras que desempenharam funções políticas e uma vez que a paideia não se situa num plano meramente filosófico, mas sobretudo na acção pública dos biografados, teremos em conta a concepção de Plutarco sobre a politeia, desenvolvida nos tratados políticos dos Moralia (Maxime cum principibus uiris philosopho esse disserendum, 776A-779B; Ad principem indoctum, 779C-782F; An seni sit gerenda res publica, 783A-797F; Praecepta gerendae reipublicae, 798A-825F; De unius in republica dominatione, 826A-827C 3 ).

Após este percurso pela obra de Plutarco, estaremos em condições, no capítulo final, de problematizar e aprofundar o significado da paideia plutarquiana, coligindo e desenvolvendo alguns dos traços que a análise evidenciou, sem esquecer a sua relação com o tempo e o espaço, daí que na parte final nos detenhamos na relação ambígua entre a Grécia dominada e a hegemonia romana e de que modo a paideia de Plutarco nos pode auxiliar a compreender esse momento histórico, abordando a problemática da identidade cultural.

Este é o trabalho que nos propomos realizar com base num autor que foi lido, admirado, citado e imitado por Erasmo, Rabelais, Shakespeare, Agrippa d'Aubigné, Carlos IX, Henrique IV, Montaigne, Voltaire, Rousseau, Almeida Garrett, Eça de Queirós ou Oliveira Martins, entre muitos outros, e que constitui, sem dúvida, uma figura incontornável no estudo das matrizes culturais do mundo ocidental, persuadindo os estudiosos a encontrar incessantemente temas que provem a pervivência da sua obra, bem como a actualidade do seu paralelismo cultural, num momento em que se reflecte sobre os efeitos da multiculturalidade e de um suposto choque de culturas.

No nosso estudo, a análise da paideia nas biografias não deixará de ser apelativa por nos remeter para questões como a identidade e o contacto cultural. Pela pujança didáctica e mimética do texto, que é um valioso testemunho da complementaridade e da aproximação entre dois legados, o Grego e o Romano, num tempo e num espaço em que fazem parte de uma só cultura.

A arte biográfica do Queronense, em suma, é representativa de uma nova forma, ainda em construção, de encarar o conhecimento, com conteúdos abrangentes, convocando o passado para reflectir sobre o momento presente, mas sempre com uma atitude activa e pragmática.

\footnotetext{
${ }^{3}$ Aguns autores incluem neste grupo temático o tratado De uitando aere alieno 827D-832A, apesar de apresentar um perspectiva social e não ser propriamente político.
} 
Parte I 



\section{A Natureza das Biografias. Ethos e PraXis}

Interessa-nos, num primeiro momento, apresentar e desenvolver a conceptualização das Vitae e a intencionalidade de Plutarco, uma vez que isso contribuirá para contextualizar o sentido da paideia, como educação e cultura, e perceber melhor o papel que ela desempenha na experiência moral do autor. É que a construção ideológica da paideia não é independente, por exemplo, da estética paralela das biografias ou da synkrisis, do mesmo modo que a opção por colocar, frente a frente, duas culturas não é irrelevante para a sua mais profunda compreensão, sendo as Vitae um dos casos literários em que a concepção estética ou de forma tem repercussões no conteúdo. Antes de verificarmos se o paralelismo corresponde a uma paideia também ela paralela, será vantajoso definir, entre outros assuntos, que ideia preside às biografias, qual o efeito emulador que Plutarco pretende gerar entre os seus modelos e os ouvintes, qual a relação entre ethos e praxis ou a inclinação para retratar caracteres, em detrimento de grande batalhas, seguindo em parte o princípio aristotélico segundo o qual as acções são sinais da alma.

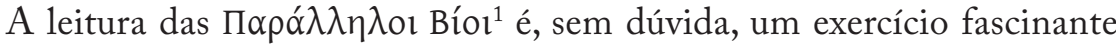
e complexo, ainda que muito facilitado pelas diversas edições modernas, em que abundam notas históricas e literárias, entre outras. Percorrer as letras legadas pelo pensador de Queroneia implica, quase invariavelmente, descobrir cidades, itinerários, personagens históricas ${ }^{2}$, governos e políticas, obrigando a uma constante ligação entre o passado e o presente, em que os exemplos do passado servem para entender melhor as realizações do tempo presente $^{3}$, ou seja, a formação ou a consolidação da paideia faz-se por meio desses heróis do passado4:

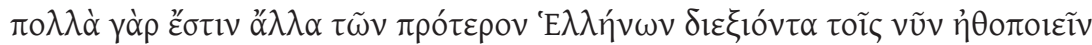

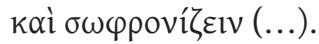

\footnotetext{
${ }^{1}$ É assim que Plutarco chama a sua obra em Thes 1. 2, Dem. 3.1, Dion 2.4 e Cim. 2.3; doravante, usaremos apenas Vitae para designar o conjunto das biografias paralelas.

${ }^{2}$ Segundo F. Frazier (1996: 125), podem encontrar-se nas Vitae cerca de mil e oitocentas personagens, número que não deixa de impressionar.

${ }^{3}$ A análise de G. Aalders (1982: 60) parece remeter essencialmente para uma formação do presente, mas A. Barigazzi (1984b: 264-286), por exemplo, acha que Plutarco tem também a intenção de preparar o futuro.

${ }^{4}$ Praec. ger. reip. 814A.
} 
quanto ao carácter dos nossos contemporâneos, referindo-lhes múltiplas acções de Gregos que viveram num outro tempo (...).

$\mathrm{ou}^{5}$

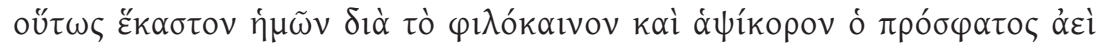

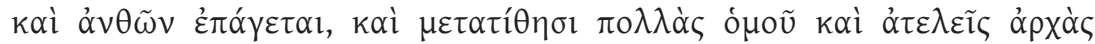

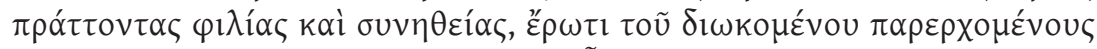

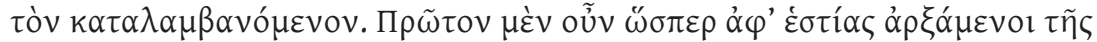

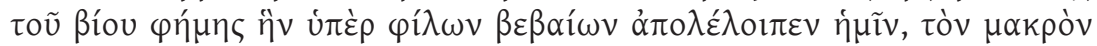

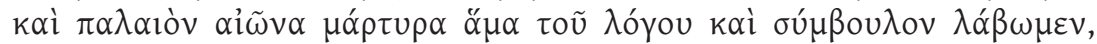

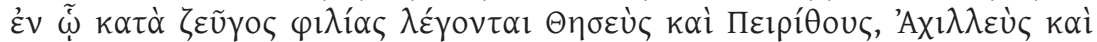

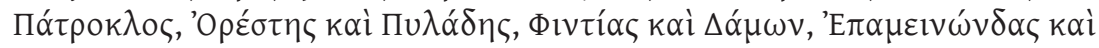

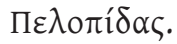

Da mesma forma, a cada um de nós, por causa do amor à novidade e por cansaço, persuade-nos sempre aquilo que é mais recente e florido, e traz-nos, ao mesmo tempo, muitas ocupações com princípios de amizade e de hábitos imperfeitos, de modo a ultrapassarmos o que já possuímos por amor ao que perseguimos. Assim, em primeiro lugar, comecemos, como Vesta, por contar a vida de homens, que a tradição a propósito de amigos fiéis nos legou. Tomemos um vasto e antigo tempo como testemunha e, simultaneamente, como conselheiro do nosso discurso, no qual se mencionam os seguintes pares de amigos: Teseu e Pirítoo, Aquiles e Pátroclo, Orestes e Pílades, Fíntias e Dámon, Epaminondas e Pelópidas.

Plutarco encontra-se, desta forma, entre o tempo presente em que ele vive e onde participa activamente enquanto pensador, educador, político e até sacerdote em Delfos ${ }^{6}$, e um tempo passado que ele pretende ilustrar na techne estética da sua arte biográfica. Os dois textos citados mostram, também, que é por meio do bios de figuras de um tempo distante que o autor

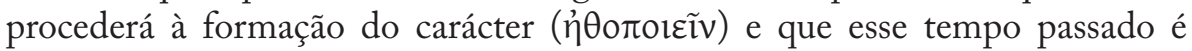
não só testemunha ( $\mu \alpha \alpha \rho \tau u \rho \alpha)$, mas também confidente ( $\sigma u ́ \mu \beta o u \lambda o v)$ na hora da narrativa. Plutarco não se limita a coligir fontes, a juntar exemplos ou a descrever comportamentos, mas, de forma mais ou menos subtil, vai deixando as suas reflexões de carácter moral e até político, como cidadão activo.

O Queronense, como testemunha a inscrição na estátua de Adriano em Delfos, haveria de obter a cidadania romana. Recebeu o nome gentilício

\footnotetext{
${ }^{5}$ De am. mult. 93D-E.

${ }^{6}$ Como bem considera Ph. Stadter (2002: 1), "his position at Delphi made him a spokesman for the cultural memory of Greece"; sobre o percurso de vida do Queronense, as obras de R. Barrow (1967), C. Jones (1971), D. Russel (2001²) e, mais recentemente, J. Sirinelli (2000) e R. Lamberton (2002) oferecem uma visão global com muita utilidade para qualquer leitor.
} 
Mestrius (L. Mestrius Plutarchus), uma vez que terá sido decisiva a intervenção do seu amigo L. Méstrio Floro ${ }^{7}$, homem com uma natureza filosófica ${ }^{8}$ e muito instruído na cultura grega. Também este facto é elucidativo do contexto político em que vivia, e disso dá conta na sua obra, pois o encontro de Gregos e Romanos é um elemento que caracteriza a sua escrita.

Ainda que, no primeiro texto citado, Plutarco se refira apenas aos Gregos do passado, não deixa de mencionar o exemplo de Romanos ao longo da sua obra. Convém também esclarecer que no tratado Praecepta gerendae reipublicae não se mencionam os feitos do passado relacionados com a guerra, pois o autor prefere recolher exemplos de harmonia social e cívica. Promovendo a concórdia, aconselha mesmo os aristocratas gregos a não enfrentarem o dominador e, além disso, a estabelecerem amizades com pessoas ligadas ao poder romano, de forma que essa atitude possa trazer benefícios aos cidadãos.

Resgata, assim, heróis do passado num registo literário pejado de valores e com profundidade filosófica considerável. Esses heróis não são simples figuras ilustrativas ou estátuas do passado ${ }^{9}$, mas têm alma e valores trans-temporais e distinguiram-se, em geral, na sua politeia ou na carreira militar ${ }^{10}$.

Além de terem visitado Plutarco em Queroneia ${ }^{11}$, os heróis das Vitae vêm, como confidentes, ao encontro de muitos leitores. A este propósito escreve J. Sirinelli (2000: 310): "La réssurrection littéraire des héros servant à animer le for intérieur du philosophe, c'est une découverte de Plutarque qui marque une époque et donne à l'histoire et au passé un autre sens, plus profond.” No

${ }^{7}$ Cf. C. Jones (1971: 48-9) e Sylloge Inscriptionum Graecarum 3 829A; curiosamente, Plutarco não faz nenhuma referência ao longo da obra à sua cidadania romana, facto que, segundo R. Barrow (1967: 13), significa a sua relutância face à identidade romana e ao apelo forte da grecidade; há também quem considere que isso se justifica pelo facto de a cidadania romana ser concedida a um membro da elite grega não constituir uma grande novidade (cf. C. Jones (1971: 45)).

${ }^{8}$ Cf. Quaest. conu. 734D.

${ }^{9}$ Em Praec. ger reip. 820B-F, reprova a necessidade de se honrar alguém por meio de uma estátua, uma vez que estas suscitam a inveja, um dos grandes males da sociedade, além de que não resistem ao tempo e podem sempre ser destruídas, como as de Demétrio de Falero; Cf. Cat. Ma. 19.6; em Max. cum princ. 776C-D, defende que o objectivo do discurso filosófico não é erguer estátuas, mas gerar a aç̧ão, que deve ser pautada pela beleza, pela inteligência, pela grandeza de espírito, pela doçura e pela simplicidade; o próprio Alexandre recusa que se faça uma imagem dele no Monte Atos, na Trácia, pois serão as conquistas que imortalizarão o seu nome (cf. De Alex fort. aut uirt. 335C-E); para Plutarco, a palavra tem mais valor do que a imagem exterior ou o corpo (cf. Cat. Ma. 7.3).

${ }^{10}$ Para C. Jones (1971: 104), a escolha deste género de homens, muito ligados à acção, em detrimento de, por exemplo, filósofos, resulta do facto de Plutarco poder colher neles mais elementos caracterizadores do ethos. Outra razão pode encontrar-se no próprio contexto histórico em que Plutarco vive, em que homens deste cariz poderiam mais facilmente suscitar o interesse do leitor e, deste modo, ser emulados.

${ }^{11}$ Cf. Prefácio de Aem.-Tim., do qual nos ocuparemos nesta Primeira Parte (pp. 106 ss.). 
prólogo do par Cimon-Luculus, Plutarco expressa da seguinte forma a distância temporal que o separa das figuras biografadas: ${ }^{12}$

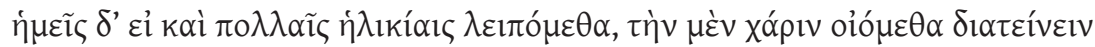

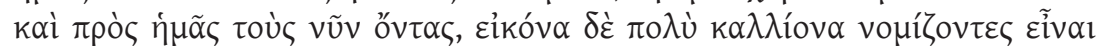

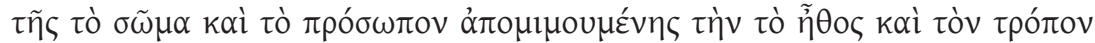

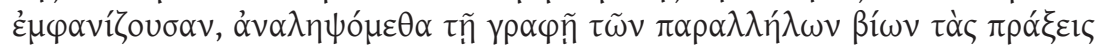

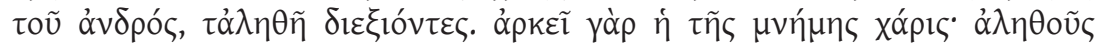

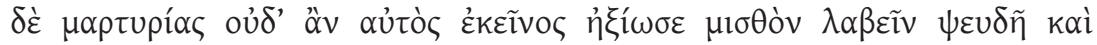

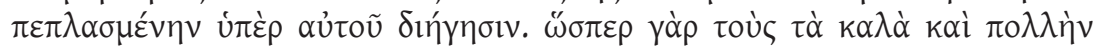

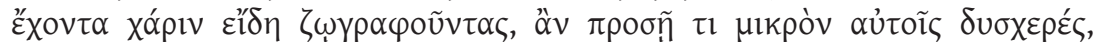

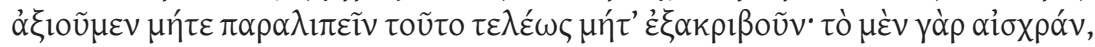

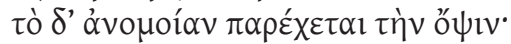

Nós, ainda que muitas gerações nos separem, pensamos estender o agradecimento até nós, os que agora existimos, por julgarmos que a imagem mais bela é a que reproduz o corpo e a face, revelando o carácter e a conduta de vida. Por isso, retomaremos na escrita das Vidas Paralelas as acções desse homem [Luculo], expondo-as com verdade. Este é um sinal suficiente de agradecimento. Nem ele próprio [Luculo] apreciaria receber uma recompensa que forjasse uma narração falsa a favor dele, em vez de um testemunho verdadeiro. Como aqueles que pintam imagens belas e com muita graça, ainda que tenham pequenos defeitos, nós julgamos não dever omiti-los, por completo, nem realçá-los. Isto certamente ofereceria uma aparência deformada e diferente da realidade.

Plutarco enfatiza, além da distância temporal que o separa dos biografados,

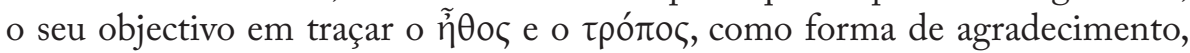
atitude que não porá em causa a sua procura da verdade e de retratar fielmente a realidade. Compara, na parte final do excerto, a sua tarefa à do pintor, imagem recorrente nas $V$ itae ${ }^{13}$, pois também nos seus retratos os defeitos estarão presentes, clarificando, contudo, que não intenciona dar excessivo protagonismo aos vícios na redacção das biografias. Este texto, em conjunto com as palavras que escreveu no prefácio da biografia de Alexandre, ajuda a perceber o objectivo de focar o carácter dos biografados, assumindo estes como figuras principais e não se detendo nas restantes ${ }^{14}$.

Os Moralia as Vitae constituem, no fundo, dois conjuntos literários com um vínculo muito forte ao tempo presente, mas que usam o passado como modelo, paradigma e base a partir da qual se constrói uma mensagem intemporal ${ }^{15}$

\footnotetext{
12 2.2-4.

${ }^{13}$ Cf. e.g. Alex. 1.

${ }^{14}$ Cf. Ph. Stadter (1997: 65 ss.) para uma interpretação deste passo.

${ }^{15}$ Como escreve C. Pelling (1995: 358): “(...) egli ama aspetti che trascendono le circostanze
} 
de paideia. Assim, Plutarco elabora um puzzle, com imagens que vão desde a Atenas Clássica ${ }^{16}$ até ao fim da República, para melhor intelectualizar a sua própria sociedade, fundindo, dessa forma, passado e presente.

As Vitae - escritas entre $96^{17}$, ano da morte de Domiciano, e cerca do ano 120, ano próximo da morte de Plutarco, coincidindo, assim, em larga medida com o principado de Trajano $(98-117)^{18}$ — não são apenas um conjunto de biografias, com centenas de citações ${ }^{19}$, nomes ou alusões, sem dúvida muito úteis para os filólogos e curiosos da Antiguidade, mas, constituem, paralelamente, uma prova da capacidade literária e retórica ${ }^{20}$ de Plutarco, do seu estilo ${ }^{21}$, da sua diversidade de conhecimentos (política, ciência, educação, estratégia militar, etc.) e de uma especial sensibilidade pelo belo e pelas contingências do ser humano e da sua vida em sociedade ${ }^{22}$.

Homem de muitas viagens (Atenas-Delfos-Alexandria-Roma) e de ampla cultura que tanto as numerosas citações e referências de autores clássicos como as reflexões morais e os conhecimentos científicos, jurídicos, históricos e políticos deixam transparecer, Plutarco era um pepaideumenos consciente do tempo em que vivia e do papel que poderia e deveria desempenhar. Contemporâneo de Epicteto, Díon de Prusa, Estácio, Marcial, Juvenal, Plínio-o-Jovem, Tácito e Suetónio, o Queronense compõe a sua obra numa época em que Roma assume uma extraordinária supremacia

particolari del suo tempo"; já D. Russel (1966: 141) advertira para o facto de ser errado pensar-se que as Vitae são essencialmente um trabalho de referências contemporâneas.

${ }^{16}$ Sobre Plutarco e Atenas vide A. Podlecki (1988: 231-243), que salienta, como outros o têm feito, a admiração do autor pela época de Péricles e pelas proezas helénicas; vide, a título de

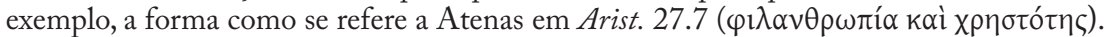

${ }^{17} \mathrm{~J}$. Geiger (2002: 95) prefere apontar para início da escrita das Vitae o ano de 99.

${ }_{18}$ Note-se que o nome de Trajano só uma vez surge na obra de Plutarco, quando se lhe

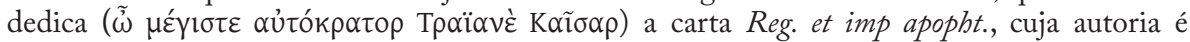
discutida; sobre a dedicatória e a carta vide M. Beck (2002: 163-173), que vem argumentar a favor da sua autenticidade; apesar de não ser mencionado o nome de Trajano, supõe-se que a alusão de Plutarco, no De prim. frig. 949E, a um imperador que passou o Inverno no Danúbio seja uma referência àquele, durante a Segunda Guerra Dácia.

${ }^{19}$ São cerca de setecentas citações, na sua maioria de autores gregos; vide W. Helmbold \& E. O’Neil (1959) e D. Russel (2001r: 46-7).

${ }^{20}$ Tome-se como exemplo de conexão entre filosofia e retórica, o facto de a leitura de Plutarco ser recomendada em Bizâncio; vide a propósito A. Garzya (1998: 25).

${ }^{21}$ Sobre o estilo e a linguagem de Plutarco, vide S. Yaginuma (1992: 4726-42).

${ }^{22}$ Sobre a sensibilidade em relação ao belo, M. H. Rocha Pereira (1999: 18) sublinha a diferença entre a descrição que Plutarco faz da Acrópole de Atenas e a do Templo de Júpiter Capitolino em Roma (Pub. 12-15), pois à beleza e magnificência da Acrópole (cf. Per. 13) contrapõe a fragilidade e flacidez do templo romano; S. Swain (1997: 1), por sua vez, resume da seguinte forma o valor da biografia no contexto do Império Romano: "In this period the biographical focus on individuals does not aim simply to recount the facts of their lives: $i$ tis concerned with the setting of these portraits in social, political, and religious contexts. By writing it, we are studying the workings of society as constituted in writing at the level of the individual". 


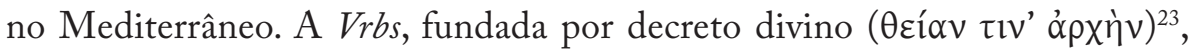
estende o seu domínio a todo o mundo então conhecido por causa da virtude dos seus heróis e da vontade divina ${ }^{24}$. Tendo isso sempre presente, dirige aos romanos e aos gregos, estes ainda desconfiados com a realidade do Império, uma mensagem que balança entre o louvor da antiga Grécia e o reconhecimento do destino imperial de Roma. Sabendo-se que a literatura da Época Imperal e, em especial, da Segunda Sofística está marcada pelo compromisso entre a cultura grega e o império romano ${ }^{25}$, Plutarco antecipa esse encontro entre cultura e poder, ainda que os heróis romanos de Plutarco não se distingam apenas pelas suas conquistas, mas também em alguns casos pelo seu helenismo (Marcelo, Emílio Paulo, Luculo). Assim, escreve a sua obra sem ser indiferente ao sentido abrangente e às conotações da palavra helénico, especialmente após as conquistas de Alexandre, nem é alheio às alterações sociais e culturais da Época Imperial. Ainda que a literatura grega dessa época seja sobretudo conhecida pela diversidade, pela curiosidade intelectual e pelo interesse formal, em particular pela relação imitativa com os escritores áticos, bem como por se fundar em doutrinas filosóficas que exprimem o desejo de uma vida pacifíca, sendo geralmente classificada como uma produção literária pouco inspirada, a verdade é que Plutarco e os outros autores desempenham um papel importante na história da cultura, pois deve-se a eles uma boa parte do conhecimento que temos do mundo antigo.

Resultado de um processo interior e de estímulos exteriores, as Vitae representam, sem dúvida, uma extraordinária aventura temporal e intelectual, em que Plutarco é, simultaneamente, autor e personagem. Transporta para as biografias uma série de reflexões que inquietam o seu espírito, tendo quase todas elas como epicentro a condição humana e a procura da felicidade, num contexto não só individual mas também comunitário ${ }^{26}$, influenciado, porventura, pelas lições do seu mestre Amónio, figura ligada à filosofia e à retórica ${ }^{27}$. O papel do indivíduo na defesa e salvaguarda da pátria é, por isso,

${ }^{23}$ Cf. Rom. 8.9.

${ }^{24}$ Tese que Plutarco desenvolve no tratado De fort. Rom.

${ }^{25}$ Cf. S. Saï et al. (Eds., 2004: 453).

${ }^{26} \mathrm{Em}$ Ad princ. ind. 781F-782A, Plutarco apresenta o homem como um instrumento dos deuses ao serviço da sociedade e dos homens; na synkrisis do par Phil.-Flam. realça que os sucessos de Filopémen são uma obra individual (idios), enquanto os de Flaminino têm um sentido colectivo (koinos); em Pel. 25.13, por sua vez, Pelópidas manifesta-se contra o decreto de Meneclides, uma vez que considera que não se deve honrar um indivíduo em particular, mas antes atribuir a glória da vitória a toda a pátria. Os valores mais importantes no serviço pela

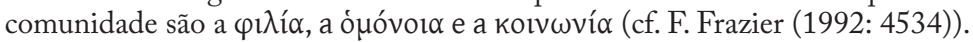

${ }^{27}$ As informações sobre Amónio são escassas, pois apenas Plutarco, nos Moralia, e Eumópio se referem a ele. Seria originário do Egipto e teria vindo para Atenas, onde acabaria por morrer. Para outras informações de Amónio, vide C. Jones (1967: 205-213). 
um dos temas com maior expressão nas $V_{i t a e^{28}}$. A este respeito, existe o caso curioso de Fócion que tomou uma decisão certa do ponto de vista moral, mas que merece a crítica de Plutarco por ter colocado em perigo a pátria ${ }^{29}$ :

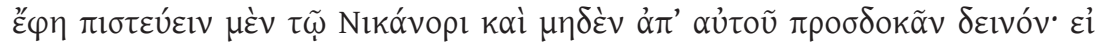

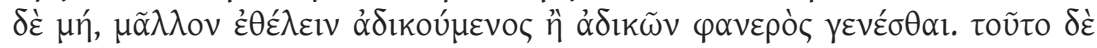

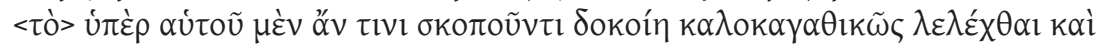

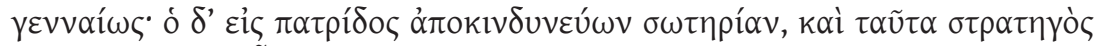

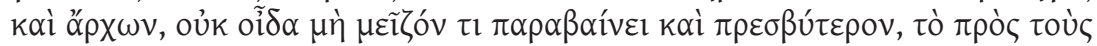

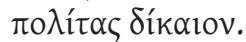

[Fócion] respondeu que acreditava em Nicanor e que não esperava nenhum mal vindo dele. Embora não o fosse, preferia - afirmou - ser vítima de uma injustiça do que ser claramente o culpado. Isto dito por ele próprio pareceria uma observação com probidade e nobreza. Porém, como, na qualidade de estratego e arconte, colocou em perigo a salvação da sua pátria, não sei se não violou a justiça, que é muito importante e respeitável para os cidadãos.

Note-se no texto o relevo que se dá ao fim último da acção governativa ( $\tau$ ò

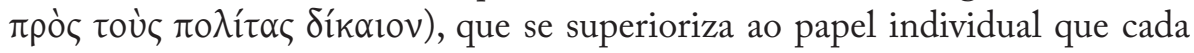
um possa assumir, exigindo ao que toma escolhas difíceis, como a de optar entre a justiça e a utilidade. No tratado An seni respublica gerenda sit ${ }^{30}$, Plutarco é esclarecedor sobre o que pensa da politeia e da participação cívica: $\lambda \varepsilon ı$ toupүía

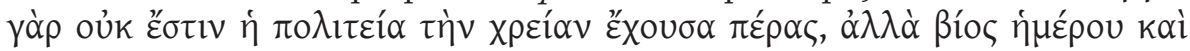

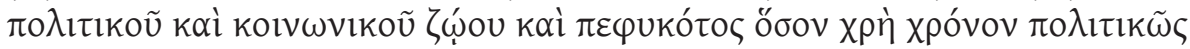

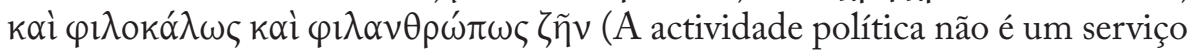
público que tenha como fim o proveito, mas é a forma de vida de um animal domesticado, político, social e que nasceu para viver quanto for necessário em prol do bem dos cidadãos, das acções virtuosas e dos homens). O texto enfatiza a estreita conexão entre bios e politikos, no fundo, um binómio que sobressai na temática das Vitae, dando eco às acepções platónica e aristotélica que preconizam que o bom é o homem ser um animal domesticado ${ }^{31}$ tendo em vista a vida política e social ${ }^{32}$. Ao homem politikos exige-se entrega à pátria e que pugne por fomentar nela os verdadeiros valores.

Mesmo não querendo escrever história ${ }^{33}$, o conjunto das biografias que

${ }^{28}$ Cf. e. g. a biografia de Aristides, estratego que coloca os valores da pátria acima do interesse individual, elemento que será objecto de análise na Parte II.

${ }^{29}$ Phoc. 32.6-7; cf. An seni resp. 791D.

30 791C; cf. ibid. 796CD e Praec. ger. reip. 823C.

${ }^{31}$ Cf. P1. $L g .766$ A.

${ }^{32}$ Cf. Arist. EE $1242 \mathrm{~A}, 22-26$.

${ }^{33} \mathrm{Cf}$. Alex. 1.1, texto a que voltaremos nas pp. 78 ss. 
dedica ao seu amigo romano Q. Sósio Senécio ${ }^{34}$ tem não só a marca do tempo do autor, como constitui um itinerário erudito pelos valores, pela cultura, pela literatura e pelo pensamento da Antiguidade. Não se limita, contudo, a traçar as características dos heróis que escolhe, mas junta-lhes os seus juízos qualitativos, o tom ético-didáctico e a interacção com o leitor-espectador ${ }^{35}$, o qual deve saber observar e imitar as virtudes dos heróis biografados. As biografias, com toda a profundidade filosófica e moral, não servem apenas para o próprio Plutarco encontrar paradigmas, no espelho ${ }^{36}$ da história, para a sua vida $^{37}$, mas também para conseguir persuadir a sua audiência ${ }^{38}$, constituída sobretudo pela elites grega e romana ${ }^{39}$, bem patente nas Quaestiones conuiuales,

${ }^{34}$ Ilustre personagem romana que viveu durante os principados de Domiciano e Trajano, de origem incerta (cf. T. Duff (2002r: 289, n.3)), tendo contraído matrimónio com a filha de Sexto Júlio Frontino; durante o seu proconsulado na Acaia, tornou-se, muito provavelmente, amigo de Plutarco; na Grécia, foi questor no ano 80, cônsul ordinário duas vezes e obteve os ornamenta triumphalia pela sua participação na 2a Guerra da Dácia em 105-6. Ainda que tenha tido, como acredita R. Syme (1958: 599), uma origem provinciana, Plutarco dedica-lhe os nove livros das Quaest. conu., o tratado De prof. in uirt. e as Vitae, por representar a fusão da Grécia e de Roma, da carreira militar e do espírito de humanista culto (Cf. C. Jones (1971: 55), que demonstra nos Moralia com o seu interesse pela música, pela filosofia e pela poesia (cf. K. Ziegler (1951); cf. Dem. 1.1; 31.7 e Dion 1.1 para outras referências ao seu nome; S. Fuscagni (2000: 27) atribui a Sósio um curioso simbolismo dentro da estrutura paralela das Vitae: “(...) una personalità che, nella commistione tra origine greco-origine greco-orientale e cariera senatoria, rappresenta al meglio l'ecumenismo politico e culturale dell'età traiano-adrianea."; ainda sobre Sósio, vide B. Puech (1992: 4883). Plutarco dedica outros tratados a amigos romanos (Cf. C. Jones (1971: 48 ss.)): aos irmãos Avídio Nigrino e Avídio Quieto o De frat. am., e o tratado De sera num. vind. apenas a Quieto; a Pácio o De tranq. an.; além disso, vários Romanos surgem nos diálogos como interlocutores: Sêxtio Sula e Minício Fundânio, no De cohib. ira; Sêxtio Sula também surge nas Quaest. conu., tal como Méstrio Floro (cf. n. 10); Sula, no De fac. lun.; seguindo a notícia da

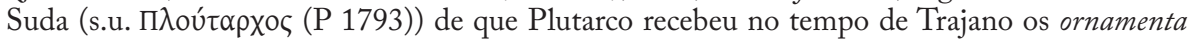
consularia, pensa-se que Sósio, enquanto consul ordinarius pela segunda vez, terá tido influência nessa distinção do Queronense.

${ }^{35}$ Recorrendo a Aristóteles, para a mensagem ética ser entendida é necessário que se adapte o carácter da escrita ao carácter do leitor (cf. Rhet. 1390A 24-27), não se devendo negligenciar esta relação para o resultado do efeito persuasivo (cf. ibid. 1395B).

${ }^{36}$ Sobre o uso da imagem do espelho em Plutarco, vide F. Fuhrmann (1964: 98).

${ }^{37}$ Cf. Aem. 1.

${ }^{38}$ Para C. Pelling (2002j: 253-265), o efeito que Plutarco procura criar é similar ao da tragédia junto da audiência; Ph. Stadter (2000: 494), contudo, sem contradizer esta opinião, prefere fazer uma leitura mais positiva e educativa do conteúdo das biografias e da retórica da persuasão.

${ }^{39}$ Segundo E. Valgiglio (1992: 4027): "Pare verosimile che il pubblico di Plutarco non sia in maggioranza un publico popolare, strumento di ampia divulgazione delle opere, ma sostanzialmente ristretto ad una minoranza, ad una élite, soprattutto ai giovani che intraprendono lo studio della filosofia e ad essa attendono...”; no entanto, se existe consenso em relação ao elitismo dos seus destinatários, o mesmo não acontece em relação ao facto de as Vitae se dirigirem sobretudo a estudantes. Atendendo às várias figuras a quem se destinam as suas palavras (cf. B. Puech (1992: 4831-93) e C. Jones (1971: 39-64)), Ph. Stadter (2000: 499) conclui que os Moralia têm como destinatário um público mais jovem (e.g. Menémaco de Sardes nos Praec. ger. reip.), enquanto as Vitae têm uma audiência mais madura e experiente: 
certamente familiarizada com as temáticas políticas, literárias e sociais, logo de um nível cultural elevado. Ainda que se saiba que, no caso das elites romanas, a formação literária e retórica era importante ${ }^{40}$, não possuímos elementos suficientes para avaliar, por exemplo, a receptividade que o trabalho de Plutarco teve junto de Trajano, homem que aliava à sua capacidade militar um grande interesse intelectual, defendendo os valores da paideia, como demonstra a sua decisão de fazer regressar os mestres de retórica e filosofia, após o exílio a que foram votados por Domiciano ${ }^{41}$.

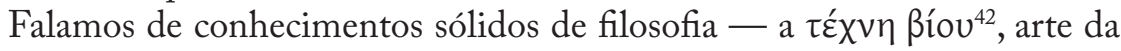
vida, pois ela empenha-se nas coisas concretas da realidade -, e de retórica, que levam Plutarco a prescindir de desenvolver os princípios morais básicos. Para que a mensagem política e moral da biografia plutarquiana tenha uma maior eloquência e força persuasiva muito contribui o facto de a narrativa distinguir um protagonista, com o qual a audiência mais rapidamente se pode identificar.

O leitor de hoje, tal como certamente o de outras épocas, não é indiferente ao diálogo pedagógico que o autor pretende gerar com a sua obra. Plutarco, por acreditar que o ser humano tem uma propensão natural para a aprendizagem e para a observação das coisas que o rodeiam, faz da função pedagógica um dos elementos mais constantes das Vitae, como o atesta o proémio da vida de Péricles ${ }^{43}$, um modelo de ordem e razão:

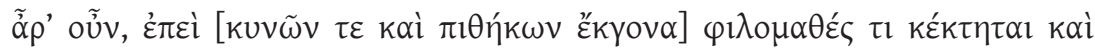

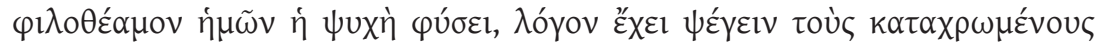

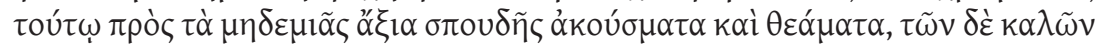

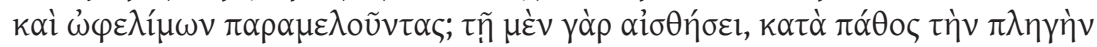

\footnotetext{
"His audience was not schoolboys, but Senecio, the Avidii, and which would help them live according to their philosophical principles in the confused, conflicting, and often dangerous pressures of their world"; incorrecta, no entanto, parece-nos a leitura que A. Zadorojnyi (1999: 9) faz sobre o valor filosófico de Plutarco, por basear a sua argumentação numa "popular audience".

${ }^{40}$ Vide o estudo de S. Mattern (1999).

${ }^{41}$ Plin. Pan. 47.1-3 ; R. Flacelière (1963: 40-44) e C. Jones (1971: 25), ao desenvolverem a ideia de que em alguns tratados Plutarco tem uma atitude hostil para com os Flávios, colocam a hipótese de o próprio autor ter sido um dos filósofos condenados ao exílio; R. Syme (1958), por sua vez, considera Trajano sobretudo um militar com as qualidades necessárias para ser como os antigos heróis romanos, muito dedicado às suas campanhas, embora isso não constitua, parecenos, um entrave para se dedicar a coisas mais culturais.

${ }_{42}$ Cf. De aud. 43A-B, De prof. in virt. 75F e 84E, Quaest. conu. 613B e An seni resp. 796C-D.

${ }^{43}$ Per. 1.2-4; pode questionar-se o facto de Plutarco apenas fazer esta declaração de princípios no décimo par de vidas por si composto (Cf. C. Jones (1966)); para J. Sirinelli (2000: 308), isso compreende-se por se tratar da biografia de um dos maiores modelos da história de Atenas, respeitado pela sua acção política; sobre este proémio R. Flacelière (1969: 11) escreve "propylées assez majestueux à cette biographie".
} 


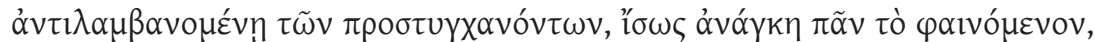

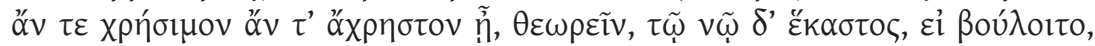

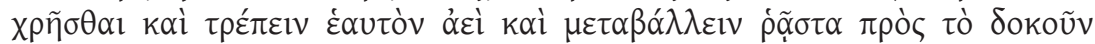

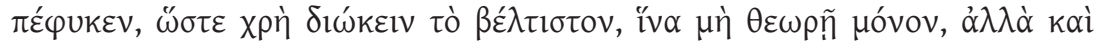

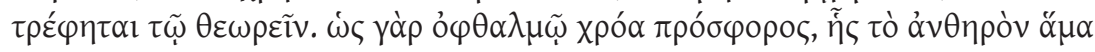

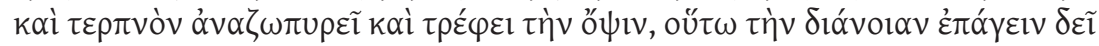

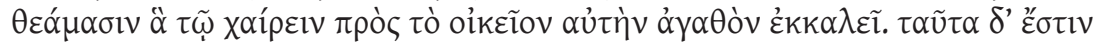

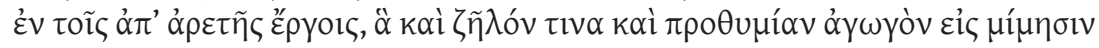

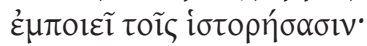

Pois se a nossa alma possui por natureza o desejo de aprender e de observar, não é com razão que se censura os que têm a tendência para ouvir e ver coisas que não são dignas de atenção, descuidando aquilo que é belo e útil? De facto, aos sentidos, como se apoderam deles tudo o que vai ao seu encontro, é certamente necessário ver tudo o que revelam, seja útil ou inútil; quanto à mente, cada um pode, como quiser, usá-la, pois por natureza podemos transformá-la e alterar, com facilidade, o seu sentido para onde nos pareça melhor. Por conseguinte, é necessário perseguir aquilo que é melhor, para que não se fique pela observação, mas também nutrir-se com essa contemplação. Tal como a cor mais benéfica para os olhos é aquela cujo brilho e doçura estimulam e tonificam a visão, assim mesmo se torna necessário encaminhar o pensamento para a contemplação de espectáculos que, por efeito do prazer que suscitam, conduzem aquele ao bem que lhe é intrínseco. Tais espectáculos consistem nas acções nascidas da virtude e despertam, nos homens que os observam, um sentimento de emulação e o desejo de os imitar.

$\mathrm{O}$ autor revela, assim, a intencionalidade pedagógica dos seus textos e o efeito emulador que eles devem provocar no leitor ${ }^{44}$, não havendo dúvidas de que a imitação é um dos topos da escrita biográfica, inserida geralmente na narrativa entre os elementos relativos à paideia e à proairesis ${ }^{45}$, ganhando dessa forma um maior significado. Por se acreditar que a imitação pode desempenhar um papel importante na conduta moral, nota-se neste texto a influência platónica ${ }^{46}$ no pensamento de Plutarco, apresentando-se ele próprio como um leitor ${ }^{47}$ ou um bom intérprete do passado. Distinguindo os sentidos ( $\left.\alpha i \sigma \theta \eta ́ \sigma \varepsilon l\right)$ da mente $(v \tilde{\omega})$, cabe a cada um usar esta para atingir aquilo que é melhor ( $\tau$ ò

${ }^{44}$ A propósito da concepção de imitação de Plutarco, vide A. Wardman (1974: 21 ss.).

${ }^{45}$ Cf. A. Wardman (1974: 107-15), A. Pérez Jiménez (1995: 363-81) e (2002a: 105-114) e T. Duff (2002r: 39) ; cf. Thes. 6.8, Alex. 5.5, Arist. 2.1, Cat. Ma. 12, Cor. 4.3, Dem. 5.4 e Phil. 3.1; neste último exemplo, o tópico do $\zeta \tilde{\eta} \lambda$ os serve para dizer que Filopémen desejava imitar Epaminondas, mas também para se constatar que não tinha as mesmas qualidades políticas do

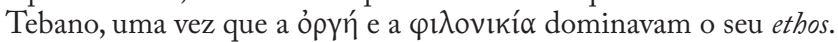

${ }^{46}$ Cf. Rep. III, 395C ss..

${ }^{47}$ São várias as imagens que se encontram nas suas obras sobre a leitura: De aud. poet. e De aud.. 
$\beta \varepsilon ́ \lambda \tau \imath \sigma \tau o v)$, ou seja, a arete, de forma a suscitar a mimesis. Atendendo ao papel que atribui a esta mimesis, Plutarco corrige a teoria platónica ao conceder à biografia uma função moral positiva na vida do homem. Veja-se a ênfase que

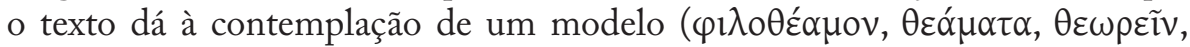
$\theta \varepsilon \omega \rho \tilde{\eta}, \theta \varepsilon \alpha \dot{\alpha} \mu \alpha \sigma \mathrm{lv})$, seja um homem ou uma acção ${ }^{48}$, estimulando-se dessa forma a emulação ( $\zeta \tilde{\eta} \lambda o ́ v)^{49}$. No fundo, ligada à tradição retórica do exemplum, esta é a cadeia imitativa na qual se baseia a concepção biográfica de Plutarco,

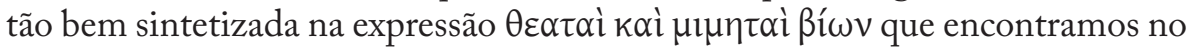
prólogo de Demetrius-Antonius ${ }^{50}$.

A techne biográfica deverá saber reproduzir a realidade, valorizando-se sobretudo o conteúdo da mimesis em detrimento da sua forma, em virtude

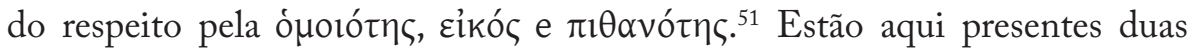
características literárias muito importantes da época imperial: a imitação e o regresso ao passado para o usar como modelo. Se a galeria de retratos das Vitae pode parecer um museu, entrevendo-se um olhar nostálgico (nostos-algos, literalmente), também nos parece que Plutarco se preocupa com o presente

${ }^{48}$ Os próprios animais são por vezes usados como modelos de comportamentos, vide a este propósito J. Martos Montiel (1996: 205-210).

49 A emulação de um modelo, como complemento da paideia, é orientada no sentido de aqueles que pretendem desempenhar funções relevantes na politeia da cidade seguirem os bons exempla nas suas praxeis e não apenas em palavras, num processo contínuo e muito exigente, mesmo após algum feito merecedor de louvor, assim o considera Temístocles após Milcíades ter dado provas da sua audácia (cf. De prof. in uirt. 84B); deste modo, aqueles que emulam os grandes valores tornam-se eles próprios $\zeta \eta \lambda \omega \tau$ oí ou modelos, como o seguinte

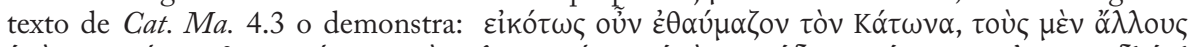

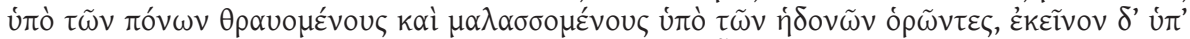

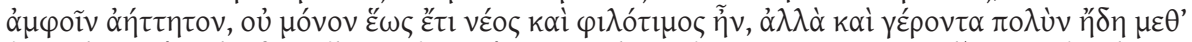

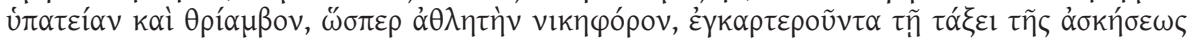

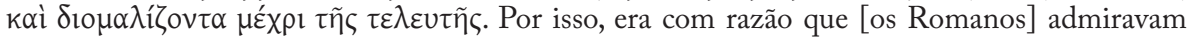
Catão, pois viam os outros quebrarem perante as fadigas e tornarem-se doces com os prazeres, enquanto ele, pelo contrário, era invencível perante ambos, não só durante o tempo em que ainda era jovem e ambicioso, mas também quando já era muito velho, após o consulado e o triunfo, como um atleta que atinge a vitória e se mantém firme na ordem do seu exercício e permanece sempre igual até ao fim.

${ }^{50}$ Vide infra pp. 95 ss.

${ }^{51}$ No tratado De aud., defendendo o papel pedagógico e moral que a poesia, pela sua beleza estética, pode exercer, Plutarco dedica especial atenção ao conteúdo mimético e à necessidade de se evitarem alguns temas; sobre a experiência estética da mimesis, L. Van der Stockt (1990: 27 ss.), apoiando-se sobretudo nas Quaest. conu. 673, diferencia Plutarco de Aristóteles: "Si pour Aristote le plaisir esthétique de la mimèsis consiste dans l'accumulation de l'expérience intelligente, pour Plutarque c'est une intuition d'une opération intelligente“, explicando que a posição de Plutarco, que situa o prazer estético num nível espiritual, serve para se opor à posição sensualista dos Epicuristas; parece-nos, em jeito de síntese, que a produção formal da mimesis é já um sinal da capacidade individual do homem, a qual faz um apelo artístico às intuições e também ao lado mais racional dos leitores, existindo sempre a dificuldade de estes se colocarem no plano do autor da mimesis e de sentirem as mesmas emoções, seja por incapacidade ou por indiferença. 
e até com a preparação do futuro, cabendo à paideia um lugar ímpar nessa mensagem.

Nas Vitae, até as próprias personagens revelam, em alguns casos, a vontade de imitar os feitos de outros: Teseu, por exemplo, tentava imitar os feitos de Héracles ${ }^{52}$; Filopémen lia obras que lhe estimulavam o seu progresso na virtude ${ }^{53}$; Aristides $^{54}$ e Ágis ${ }^{55}$ admiravam Licurgo; Demóstenes tinha por modelo Calístrato ${ }^{56}$; Pelópidas seguia o exemplo de Trasibulo ${ }^{57}$; Timoleonte o de Epaminondas ${ }^{58}$; António e Demétrio emulavam Dionísio ${ }^{59}$; Tibério Graco inspirava-se em Cipião Emiliano ${ }^{60}$; Temístocles admirava o sucesso de Milcíades em Maratona ${ }^{61}$. A propósito da imitação, ela também é um sinal de louvor e admiração por aqueles que levaram a cabo grandes feitos: ${ }^{62}$

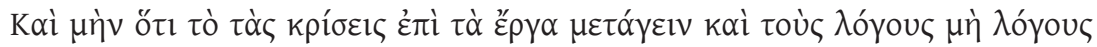

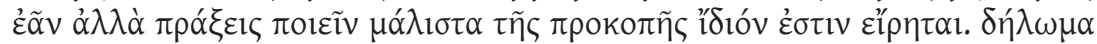

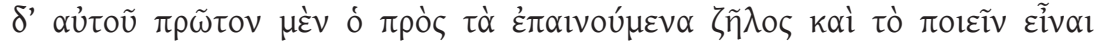

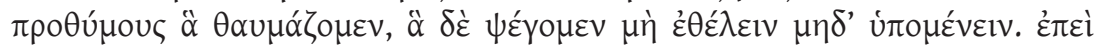

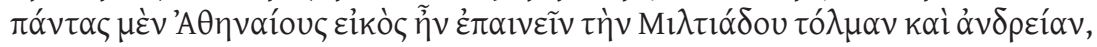

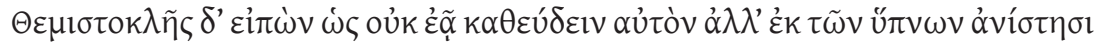

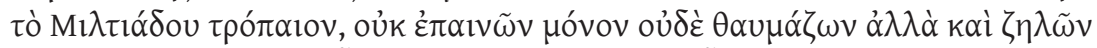

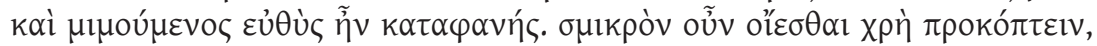

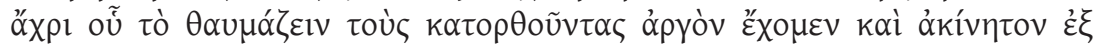

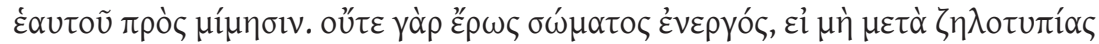

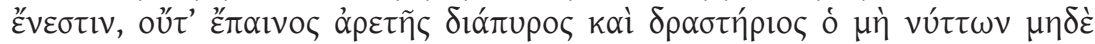

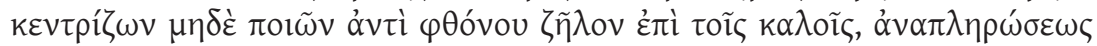

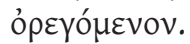

$\mathrm{Na}$ verdade, transferir os juízos para as acções e não deixar que as palavras originem palavras, mas acções, é sobretudo um sinal de progresso. Uma prova disto, é, em primeiro lugar, a vontade de emular aquilo que se louva e ser benévolo com o que admiramos, mas não querer, nem sequer suportar, o que censuramos. Posto que era natural todos os Atenienses louvarem a audácia e a

${ }^{52}$ Cf. Thes. 6.8-9, 25.5.

${ }^{53}$ Cf. Phil. 4.8-9; sobre Filopómen, Plutarco também diz que procurava imitar Epaminondas, mas não conseguiu atingir a doçura, nem a gravidade, nem a filantropia deste, por causa da sua philonikia e orge (cf. Phil. 3).

${ }^{54}$ Cf. Arist. 2.1.

${ }^{55}$ Cf. Ag./Cleom. 4.2

${ }^{56}$ Cf. Dem. 5.1-5.

${ }^{57}$ Cf. Pel. 7.2.

${ }^{58}$ Cf. Tim. 36.1.

${ }^{59}$ Cf. Demetr. 2.3 e Ant. 24.

${ }^{60}$ Cf. Gracch. 4.5.

${ }^{61}$ Cf. Them. 3.4-5.

${ }^{62}$ De prof. in uirt. 84B-C. 
coragem de Milcíades, todavia Temístocles ao dizer que o troféu de Milcíades não o deixava dormir, mas que o levantava em sonhos, era concerteza claro que não só o louvava e admirava, como também o invejava e imitava. Por isso, é necessário pensar que progredimos pouco, enquanto a admiração por quem alcança o êxito se mantém, por causa de si própria, inactiva e imóvel para a imitação. De facto, nem o amor do corpo é enérgico, se não está presente a emulação, nem o louvor da virtude é ardente e eficaz se não fere nem pica e nem substitui o cíume pela inveja das coisas belas, para assim alcançar a satisfação.

Desta forma, a imitação não se pode cingir apenas às palavras ou aos

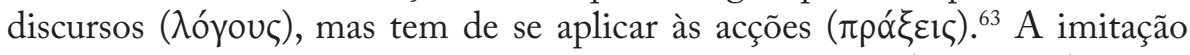
daquilo que se louva e admira contribui para o progresso ( $\pi \rho \kappa_{0} \pi \tilde{\eta} \varsigma$ ) e para a satisfação (ảva $\pi \lambda \eta \rho \omega ́ \sigma \varepsilon \omega \varsigma)$, querendo isto dizer que a imitação é um sinal da grandeza humana e, em última instância, justifica a intenção do autor em estabelecer uma relação pedagógica entre a sua obra e os leitores, os quais são chamados a desempenhar um papel activo na interpretação dos factos, uma vez que isso os ajudará a viver melhor e a encarar com maior optimismo os desafios do tempo presente.

Se antes nos detivemos na estreita ligação que existe na obra de Plutarco entre bios e politeia, pretendemos, agora, analisar a forma como o desejo de imitar os grandes homens do passado pode despertar a proairesis política ${ }^{64}$.

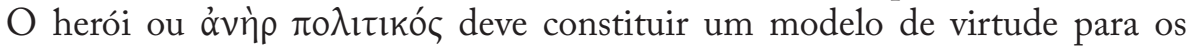
cidadãos e inspirar neles uma conduta de vida exemplar: ${ }^{65}$

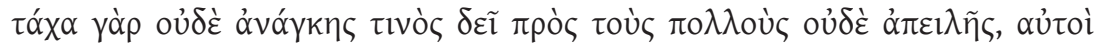

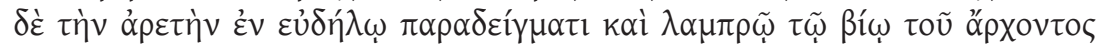

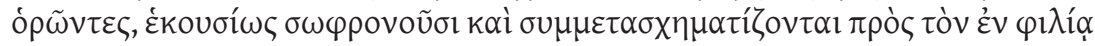

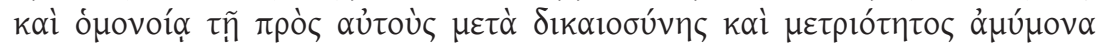

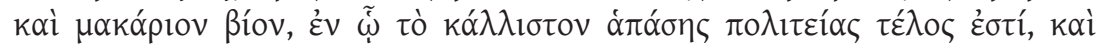

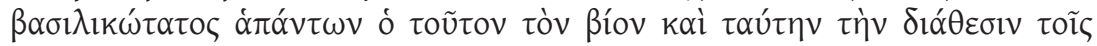

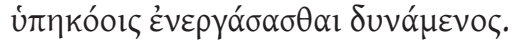

De imediato, não é necessário qualquer uso da força contra a multidão, nem de ameaça, pois os próprios cidadãos observando a virtude no claro exemplo e na vida insigne do governante, espontaneamente se tornam moderados e se configuram com uma vida irrepreensível e feliz na amizade e na concórdia

${ }^{63}$ A mesma ideia sobre a coerência que deve existir entre palavras e acções aparece em De Stoic. rep. 1033A-B; este seu preceito está relacionado com o papel activo na política que defende para o filósofo, pois este não se deve limitar a desenvolver pensamentos abstractos ou teorias políticas, mas deve experienciar os seus ideais. 381).

${ }^{64}$ Cf. Praec. ger. reip. 800B-C; sobre a proairesis política, vide A. Pérez Jiménez (1995: 363-

${ }^{65}$ Num. 20.8. 
mútuas, mediante a justiça e a moderação, já que nesta vida está o fim mais belo de todo o Estado, e é o melhor rei de todos o que pode inspirar este estilo de vida e esta disposição aos súbditos.

Neste texto, a arete surge associada a dois valores de enorme repercussão

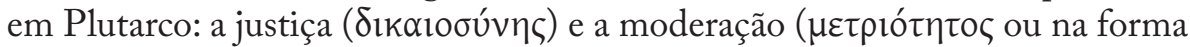
verbal $\sigma \omega \varphi \rho \circ v o \tilde{\sigma} \sigma$ ), valores que contribuem para uma vida melhor. Além disso, este passo deixa transparecer um desejo do próprio autor-educador, na medida em que os leitores, ao verem os paradeigmata, devem sentir, interiormente, o apelo por alterarem $(\sigma \cup \mu \mu \varepsilon \tau \alpha \sigma \chi \eta \mu \alpha \tau i ́ \zeta o \mu \alpha l)$ o seu comportamento, daí que a mimesis, tal como a paideia, seja transformativa.

Em relação ao trabalho que Plutarco se propõe, os heróis do passado permitirão uma exposição concreta da concepção das teorias éticas, a partir das suas aretai e kakiai ${ }^{66}$. Mediante a descrição e a tentativa de compreensão

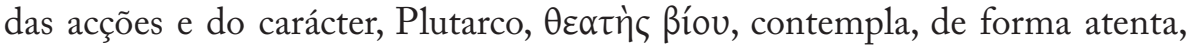
as motivações, as paixões, as tendências naturais ou as iniciativas fundadas na razão e no conhecimento, elaborando uma mensagem de tom moralista ${ }^{67}$, facto que se sobrepõe muitas vezes à preocupação historicista, o que leva alguns filólogos a falar, numa expressão sintética, em distorção biográfica, ao notarem, por exemplo, que um herói tem um retrato mais favorável no bios em que é protagonista do que em outras biografias em que aparece como personagem secundária ${ }^{68}$.

Os biografados patenteiam a valorização plutarquiana da liberdade individual ${ }^{69}$, que os leva a trilhar ou não o caminho da virtude. Nesse sentido, a justificação e a responsabilidade do sucesso, da vitória, da felicidade e do infortúnio está, sobretudo, na conduta humana, que se torna independente da acção divina ou do destino, ainda que Plutarco admita o papel que a tyche e os daimones possam ter no devir histórico.

Mas, afinal, de que heróis do passado temos estado a falar? A tradição legou-nos, como descrevemos nas palavras introdutórias deste trabalho, vinte e

${ }^{66}$ Em relação às kakiai, Plutarco atribui aos estóicos o costume de as designar com termos mais suaves; cf. De uirt. mor. 449A-B, De coh. ira 456F e 462F, e An corp. affect. 501B.

${ }^{67}$ F. Frazier (1992: $4528 \mathrm{~s}$.) refere que Plutarco, confrontado com episódios mais escandalosos, usa a sua elevação moral, como no caso do par Demetr.-Ant.; sobre o moralismo de Plutarco, vide C. Pelling (2002i: 237-251).

${ }^{68}$ Cf. C. Jones (1971: 80, 99, 102).

${ }^{69} \mathrm{E}$ curioso que as qualidades mais recorrentes nas Vitae tenham esse cunho pessoal e individual: a preocupação de se encontrar um meio-termo entre a demagogia e a tirania; não agir em função da inveja; encarar o êxito sem incorrer no excesso; não se expor a riscos pessoais desnecessários; cultivar um nível justo de ambição (cf. A. Wardman (1974: 49-132); B. BucherIsler (1972) elenca, de forma mais precisa, diversos valores plutarquianos, tal como os estudos de M. Cerezo Magán (1992) e (1996a) e F. Frazier (1996: esp. 177-218, 231-270)). 


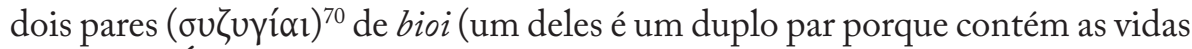
dos gregos Ágis e Cleómenes, e dos irmãos Tibério Graco e G. Graco, pela parte romana), além de quatro biografias sem par ou isoladas, referimo-nos a Aratus, Artaxerxes, Galba e Otho ${ }^{71}$. Enquanto se julga que as biografias de Galba e Otão pertenceriam a uma série de vidas dedicadas aos imperadores romanos, desde Augusto, o segundo dos Césares ${ }^{72}$, a Vitélio, escritas provavelmente durante o principado de Domiciano ${ }^{73}$, já em relação a Arato e Artaxerxes desconhece-se a série de que faziam parte ${ }^{74}$.

É, assim, mediante este conjunto de bioi, pertencentes a épocas e culturas diferentes, que Plutarco transmite a essência do seu pensamento, propondo uma reflexão sobre a identidade cultural, onde harmoniza, com mestria, o ético com o histórico. Sobretudo por acreditar que a palavra conduz à acção ${ }^{75}$, não se devendo limitar a distrair, sem qualquer objectivo ${ }^{76}$, formula uma retórica activa e consequente, pois qualquer virtude só se realiza plenamente quando experimenta a acção. $\mathrm{Na}$ verdade, Plutarco segue a tradição daqueles que

\section{${ }^{70}$ Cf. Demetr. 1.5 .}

${ }^{71}$ As Vidas de Galba e Otão dada a sua extensão e por terem um fundamento distinto das restantes são consideradas biografia menor por pertencerem mais à historiografia do que à biografia (cf. A. Pérez Jiménez (2000a: 29) e R. Giannattasio (2000: 81-91); deixamos de parte os tratados Decem oratorem vitae (breves biografias dos dez canónicos oradores áticos dos séculos V e IV a. C.) e De Homero por haver dúvidas quanto à sua autoria.

${ }^{72}$ Cf. Num. 19.6; note-se que para Plínio (Nat. 9.143) Augusto era o primeiro dos Césares; só na época de Trajano se viria a considerar César como o primeiro dos Césares; Apiano (Proem. 6) e Suetónio consideram-no fundador da monarquia.

${ }^{73}$ Essa é a opinião de C. Jones (1971: 72-3), G. Bowersock (1998: 193-210) e de C. Pelling (2002j: 253), embora se coloque também a hipótese de terem sido escritas no principado de Nerva, ficando assim a questão em aberto; J. Geiger (2002: 93-102), no seguimento de outros estudos por ele realizados e partindo da constatação de que as Vidas dos Césares de Plutarco começam com Augusto e que as de Suetónio com Júlio César, defende a segunda tese: "I referred to the fact of the changing image of the Dictator, whose reputation underwent a highly favourable revaluation under Trajan. Since there is no compelling reason to place any of Plutarch's writings prior to the assassination of Domitian, I maintained that the date of his Lives of the Caesars is best put in the short reign of Nerva, at exactly the same time as the composition of Tacitus' Agricola"; R. Syme (1980: 108-110) faz coincidir esse grupo de biografias com a época de Trajano; Ph. Stadter (2005a: 419 e ss.) discorda das anteriores teses, preferindo situá-las no principado de Vespasiano; registe-se, ainda, que, ao contrário do que se poderá inicialmente pensar, o projecto das Vidas dos Césares seria extenso, a acreditar nas conjecturas que Ph. Stadter desenvolve no estudo acima citado, maior do que as Quaest. conu., a maior obra que integra os Moralia.

${ }^{74} \mathrm{O}$ Catálogo de Lâmprias, que se pensa ser um inventário em blocos temáticos de uma biblioteca dos séculos III-IV, faz referência a outras vidas: Héracles (faz referência a esta biografia em Thes. 29.5; cf. Gel. 1.1: Plutarchus in libro quem de Herculis), Hesiodo, Pindaro, Crates, Daifanto e Aristomemes (cf. fr. 6-12 Sandbach); sobre este Catálogo vide J. Irigoin (1986: 318-331) e R. Flacelière \& J. Irigoin (1987: ccxxviii e ss.).

${ }^{75}$ Por isso critica a $\alpha$ $\pi \rho \alpha \xi i ́ \alpha$ ('ócio', 'descanso') epicurista em relação à vida pública (cf. De tranq. an. $465 \mathrm{C}-466 \mathrm{~A})$.

${ }^{76}$ Cf. Phil. 4.8; os tratados De Alex. fort. aut uirt. i-ii desenvolvem a mesma ideia. 


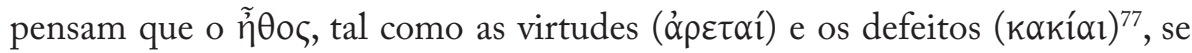

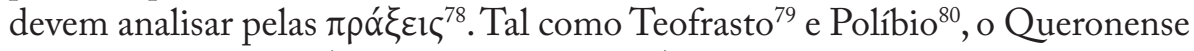

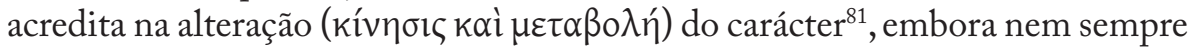
seja muito fácil distinguir nas suas personagens as qualidades que foram objecto de uma modificação consciente e as que se alteraram fruto de actos involuntários, uma vez que o $\tilde{\eta} \theta$ os pode ser influenciado pelas circunstâncias

${ }_{77}$ Ao binómio aretai/kakiai, que muito marcará as Vitae, Plutarco dedica o tratado De uirt. et uit. 100B-101E; neste opúsculo, considera que a arete, ao contrário da kakia, proporciona uma vida feliz e honrada, pois a eudaimonia não se consegue por meio de riqueza e do poder; a arete melhora o brilho das coisas, enquanto a kakia ofusca e piora; além disso, será o estudo da filosofia que ajudará o homem a preparar-se para o sucesso e o insucesso, para a fortuna e para a desventura; acima de tudo, a eudaimonia depende mais do homem e do seu carácter do que de coisas exteriores; Epicteto (1.12.16), argumentando sobre os contrários, afirmou ter sido Zeus que ordenou que houvesse Verão e Inverno, abundância e esterilidade, bem como virtude e vício, pois a harmonia resulta dessas oposições; Crisipo, por sua vez, refere que a virtude não pode viver sem vício (SVF II, 1169 ss.).

${ }^{78}$ No tratado De gloria Ath., onde reflecte sobre se a glória de Atenas se deve mais aos sábios ou aos políticos ou estrategos, Plutarco afirma que, se por acaso os homens de acção

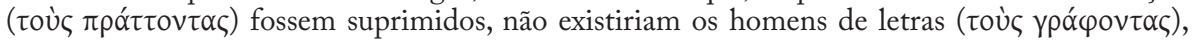
fazendo assim depender o conteúdo das obras das realizações humanas (cf. 345C-D). J. Hershbell (1997: 233-4) interpreta essas palavras de Plutarco como uma apreciação negativa dos historical writings, bem como o seguinte passo (347D-E), em que compara os historiadores com os cabreiros e pastores que assistiram a feitos que, depois de os terem contado, julgam

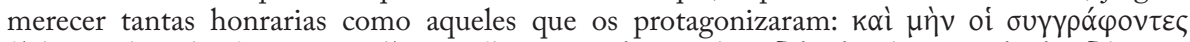

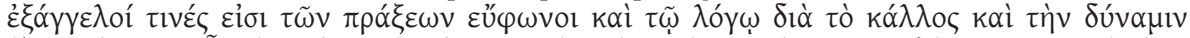

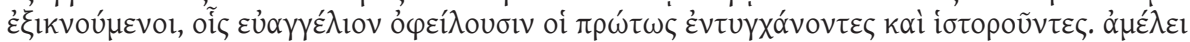

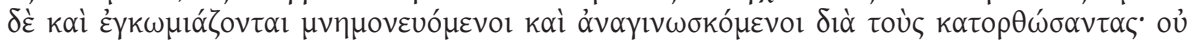

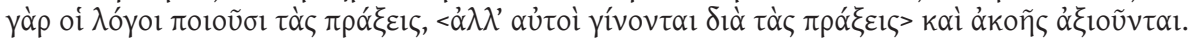
$\mathrm{Na}$ verdade, os compiladores de histórias são uns mensageiros, com voz harmoniosa, de feitos e alcançam êxito por causa da beleza e do poder da sua palavra; os que, em primeiro lugar, a encontraram e a contaram devem a eles a transmissão da boa notícia. Na realidade, lembrados e reconhecidos por causa dos êxitos alcançados, eles também são louvados. É que as palavras não criam os feitos, mas elas surgem por causa dos feitos e são dignas de serem ouvidas.

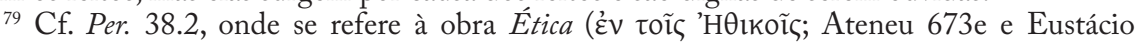

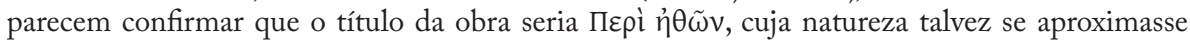
da $E N$ de Atistóteles) de Teofrasto, na qual ele havia analisado a forma como os caracteres se transformam com as circunstâncias, parecendo claro que o comportamento do homem pode ser influenciado por razões exteriores; em $A l c .10 .4$, elogia da seguinte forma Teofrasto: $\alpha v \delta \rho i$

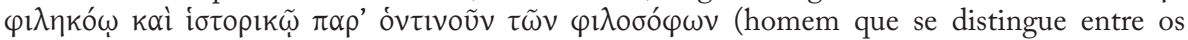
filósofos pela atenção e pela forma exacta como conta as histórias); apesar de nem sempre ter sido reconhecido, Teofrasto, autor dos Characteres e da Historia plantarum, entre outras obras, legou-nos uma obra com muito valor histórico e também para o pensamento político, como, por exemplo, A. Podlecki (1988: 231-249) põe em evidência; de acordo com o Catálogo de Lâmprias (n 53), Plutarco terá escrito um tratado sobre Teofrasto; note-se que é, por meio das cerca de setenta vezes que Plutarco se refere a Teofrasto nas Vitae e nos Moralia, que trinta e um fragmentos da sua obra chegaram até nós; para mais elementos sobre a presença de Teofrasto na obra do Queronense, vide J. Boulogne (2005: 287-300).

${ }^{80}$ Cf. 9.22-23; a propósito de Plutarco e Políbio, vide E. Gabba (2004: 311-316).

${ }^{81} \mathrm{Um}$ bom exemplo encontra-se em Sull. 30.5. 
ou por um esforço pessoal de correcção. Para o nosso trabalho é mais profícuo verificar o desenvolvimento do carácter do que a sua hereditariedade ${ }^{82}$, embora a maioria dos heróis tenha um carácter bastante estável ${ }^{83}$.

Além disso, a descrição do $\tilde{\eta} \theta$ oৎ desenvolve-se com várias noções de conteúdo filosófico e moral, que têm, por exemplo, em atenção a sua relação com a tyche, o bem público, a virtude e a humanidade. Assim sendo, a biografia plutarquiana segue, de uma forma geral, três princípios: o primeiro é que aquilo que o homem faz é determinado pelo seu $\tilde{\hat{\eta}} \theta$ o uma participação decisiva; o segundo é o interesse de Plutarco em interpretar e julgar as qualidades morais de cada biografado, deixando espaço, por exemplo nas synkriseis, para que o próprio leitor forme uma opinião moral; o terceiro, por fim, é que a construção moral e ideológica deve ter por objectivo educar o leitor, tornando-o melhor ser humano e estimulando-o a um auto-exame, que o próprio autor, acreditamos, também faria ${ }^{84}$. Assim, dentro do $\tilde{\eta} \theta 0 \varsigma$ agiriam a $\varphi v ́ \sigma ı$, , a $\pi \alpha \iota \delta \varepsilon i ́ \alpha$ e as $\pi \rho \alpha ́ \xi \varepsilon ı \varsigma$, contribuindo cada um desses elementos, à sua medida, para a concepção do carácter, muito embora persistam os actos $\pi \alpha \rho \grave{\alpha}$ $\varphi u ́ \sigma ı v^{85}$. Numa avaliação dos elementos éticos e históricos que enformam as Vitae, diríamos que os primeiros, com a reconhecida conceptualização filosófica bebida em Platão ${ }^{86}$, Aristóteles e outros filósofos ${ }^{87}$, têm maior preponderância,

${ }^{82}$ Sobre a parte do $\tilde{\eta} \theta$ o५ que se herda, vide Aem. 2 e Cat. Mi. 1.

${ }^{83}$ Cf. S. Swain (1989a: 62-68); as biografias de Sula e Sertório são os dois exemplos que se costumam dar de uma alteração de carácter.

${ }^{84}$ Cf. Aem. 1.1.

${ }^{85}$ Cf. Rom. 28.10, Comp. Lyc.-Num. 4.1, Per. 7.4, Cor. 18.2, Tim. 14.4, Aem. 30.1, Mar. 28.1, Sull. 18.6, Luc. 6.2, Nic. 18.11, Pomp. 28.3, Ag./Cleom. 2.5, Gracch. 5.5, Demetr. 14.3 e Arat. 49.1, ocorrências que provam o significado desse tipo de atitudes; nos Moralia acontece o mesmo: e.g., De adul. 68D, Cons. ad Apoll. 102D, De tuenda san. 125C e 128E, De fort. Rom. 320B, De def. orac. 424C, De uirt. mor. 450E, De coh. ira 456B, De sera num. uind. 551B e 567B, Quaest. conu. 624D e 649B, Amat.751C e Praec. ger. reip. 824A.

${ }^{86} \mathrm{O}$ platonismo em Plutarco é um tema recorrente nos estudos plutarquianos; para uma bibliografia resumida sobre este assunto, vide J. Hershbell (1995: 209, n.3), bem como A. Pérez Jiménez \& J. Garcia López \& R. Aguilar (1999), neste caso também útil para a presença do aristotelismo nas Vitae e nos Moralia. Ainda sobre Platão, importa recordar que Plutarco lhe

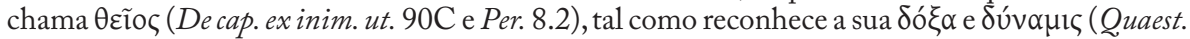
conu. 700B). Consciente das divergências entre Platão e Aristóteles (cf. Plat. Quaest. 1007AB, Adu. Col. 1115A-C), Plutarco, normalmente mais conotado com o filósofo da Academia, mostra-se interessado e persuadido por Aristóteles e pelos Peripatéticos, especialmente nas temáticas relacionadas com a psicologia, a physis e a lógica (cf. De virt. mor. 442B, De cup div. 527A e Pel. 3.1); é curioso que esta tendência é acompanhada por Apuleio, enquanto Eudoro de Alexandria e Ático rejeitam Aristóteles; sobre a presença deste filósofo em Plutarco vide, e.g., P. Donini (1974), (1986b: 214-222), (1988a), (1988b) e (1994: 35-60).

${ }^{87}$ Embora Plutarco critique em alguns tratados os Estóicos (e. g., Stoic. rep., Comm. not. e Stoic. absurd. Poet.), encontramos temas paralelos, como a definição da virtude, do vício, da paixão ou da razão, até com alguns pontos de contacto. Ainda assim, não era um adepto desta corrente que tanto sucesso teve na filosofia helenística. O mesmo se poderia dizer do Epicurismo. Temas epicuristas como o prazer, a felicidade ou a dor não são alheios a Plutarco, mas se aqueles 
tendo Plutarco procedido a um apurado trabalho de selecção dessas fontes, díspares em relação ao seu contéudo temático, de modo a fundamentar as suas próprias convicções.

É óbvio que estes três elementos, aparentemente simples, se tornam complexos porque se aplicam a personagens de espaços e tempos diferentes e que, na maior parte das vezes, não partilharam o mesmo contexto histórico. Note-se ainda que também os Moralia obedecem a estes princípios, denotando, contudo, uma variedade temática muito grande, desde tratados de temática amorosa e religiosa a outros sobre política ${ }^{88}$. Parece-nos, no entanto, que a habitual atribuição da vertente teórica e prática aos Moralia e às Vitae, respectivamente, não corresponde em absoluto ao conteúdo dessas obras. Ainda que usem registos diferentes e as Vitae focalizem o biografado, ambas dão exemplos práticos da conduta civil e política do indivíduo, e também é a partir das duas que Plutarco vai construindo a sua visão sobre o mundo em que vive. Como analisar a forma como o polígrafo de Queroneia olha para os Romanos sem nos determos nas biografias de Marcelo ou Flaminino, por exemplo, e nos tratados De fortuna Romanorum e nas Quaestiones Romanae? Ou como analisar a ética política sem conjugarmos a leitura das vidas de Aristides ou de Filopémen com o tratado Praecepta gerendae reipublicae? A resposta só pode ser uma: a leitura conjunta dos Moralia e das Vitae ajuda a consolidar a interpretação dos textos e das suas ideias. Aliás, os múltiplos trabalhos académicos que os textos plutarquianos originaram não deixam de estabelecer pontes entre os dois grupos, pois a análise complementar das Vitae e dos Moralia ajuda a entender melhor o significado dos conceitos. No caso do presente estudo, não temos dúvidas de que a análise da paideia só tem a beneficiar com o manuseio constante quer dos Moralia quer das Vitae, em especial porque estas obras revelam uma unidade assinalável, não querendo com isto dizer que se repetem ${ }^{89}$. Para o comprovar, basta dar o exemplo da biografia de Alexandre e dos tratados De Alexandri fortuna aut uirtute $i$-ii, com interpretações algo distintas ${ }^{90}$, que apenas uma leitura complementar pode

recusam a ambição política já as Vitae desenvolvem bastante este tema.

88 Alguns estudiosos abordam a questão da macrotextualidade da obra de Plutarco, considerando que cada uma das partes do corpus pertence a um projecto que se poderia chamar ética antropológica, a qual abarca os mais diversos temas: história, ciência, paideia, psicologia, religião, mito ou política, entre outros; vide, sobre este tema, D’Ippolito (1991) e (1996) e A. Zadorojnyi (1999: 6).

${ }^{89}$ Sobre a discussão da unidade e diversidade das Vitae, J. Sirinelli (2000: 302) escreveu: «La biographie est un instrument autant et plus qu'un genre et Plutarque en découvre peu à peu les ressources tout en conservant les mécanismes. Il n'est pas sûr qu'il l'ait perfectionnée mais il en a exploré toutes les possibilités. Le jour où l'on aura une chronologie sûre des Vies et des œuvres annexes, on s'apercevra peut-être que cette période du règne de Trajan a été la plus enrichissante pour notre Plutarque ».

${ }^{90}$ Cf. J. Hamilton (2002²: xxiii-xxxiii) e S. Asirvatham (2005: 107-125). 
detectar e levar-nos a perceber aquilo que Plutarco pensava sobre os feitos do conquistador macedónio que helenizou o Oriente, pois os tratados, escritos na sua juventude, seguindo as leis da eloquência epidíctica, são muito mais laudatórios do que a biografia, que retrata com maior cuidado e pormenor os acontecimentos e o próprio perfil psicológico de Alexandre. Em verdade, nos tratados, por causa de se responder à questão dominante (tyche ou arete?), Plutarco valoriza, sobretudo, o lado filosófico de Alexandre.

Voltando ao conjunto das Vitae, nos estudos sobre a obra de Plutarco muito se tem conjecturado a propósito das razões que presidiram às suas escolhas. Em síntese, a galeria de heróis que nos chegou e as biografias perdidas Augusto, Tibério, Cláudio, Nero, Gaio e Vitélio (imperadores romanos ${ }^{91}$ ), e as de Epaminondas ${ }^{92}$ e Cipião - manifestam as seguintes razões: a subjectividade do autor e as suas tendências ${ }^{93}$; as circunstâncias próprias do tempo vigente; o condicionalismo do material e das fontes disponíveis para compor uma obra desta grandeza, com tantas citações e reminiscências, razão que também esteve subjacente às escolhas de Cornélio Nepos na composição de De uiris illustribus, especialmente no que diz respeito aos heróis não-romanos; as regras do género biográfico. Atendendo a este conjunto de circunstâncias e ao facto de Plutarco ter um conhecimento mais profundo da cultura grega do que da romana e, por isso mesmo, existir uma maior intimidade com as figuras gregas, J. Geiger (1995: 171), com razão, escreveu: "Yet it is significant and characteristic of Plutarch that in the choice of his Greek heroes he displays an attitude of detachment without opposition or spite, of maintaining an individual outlook without necessarily dismissing the mainstream of contemporary opinion".

Do ponto de vista cronológico, Plutarco escreveu biografias de figuras desde os tempos míticos ou lendários até ao início do Império Romano. Se olharmos para a selecção dos heróis gregos, notamos que a maior parte pertence ao período arcaico (Sólon) e clássico (Temístocles, Aristides, Címon, Péricles, Nícias, Alcibíades, Lisandro, Demóstenes, Pelópidas, Epaminondas (biografia

${ }^{91}$ Biografias que sugerem a influência da biografia e historiografia latinas, muito marcadas pela figura do imperador.

${ }_{92}$ Plutarco não esconde a admiração que tem pelo seu compatriota da Beócia, que considera ser o maior dos Helenos. Só Alexandre supera as numerosas referências que faz a Epaminondas nas Vitae e nos Moralia; Cf. Pel. 3.6, 7.5, 25.4, 26.1, 29; Cat. Ma. 8.14, Ages. 27.6-28.2 (Plutarco refere claramente a admiração que sentia pelo estratego beócio, adversário acérrimo de Agesilau, pois ele possuía as características indispensáveis para comandar uma estrutura pan-heléncia, e que lhe havia dedicado uma biografia, infelizmente perdida), 32.4, 35.2; Tim. 36.1; Dem. 20.1; Phoc. 3.7; Epaminondas, morto em Mantineia (362 a.C.), era conhecido pela aplicação da filosofia à vida política, e pela sua acção em prol da liberdade da sua cidade (vide, em particular, De gen. Socr. 576D-E e 585D; Pel. 3.6, 4. e Ages. 27.4).

${ }_{93}$ Cf. J. Geiger (1995: 167-8). 
perdida $)^{94}$, Demóstenes, Fócion, Agesilau, Díon, Timoleonte); ao período helenístico pertencem: Êmenes ${ }^{95}$, Arato, Demétrio, Pirro, Ágis, Cleómenes e Filopémen ${ }^{96}$. Refira-se que dos heróis anteriores ao período helenístico que Plutarco retrata, só Sólon, Péricles, Nícias, Demóstenes e Alexandre não surgem em Cornélio Nepos ${ }^{97}$, enquanto em relação aos da época helenística só Êmenes é biografado.

Quanto às personagens romanas, a maior parte viveu no período da República, pertencendo alguns dos Romanos à fase final (os Gracos, Bruto e António ${ }^{98}$. A razão para esta escolha de Plutarco pode estar relacionada com as fontes e meios que tinha ao dispor para a elaboração da narrativa biográfica ou, acredita-se, a uma influência das biografias de Cornélio Nepos.

Refira-se, sem querer aprofundar muito esta questão, que o problema da cronologia ${ }^{99}$ das Vitae continua por resolver, quer a cronologia relativa (ordem

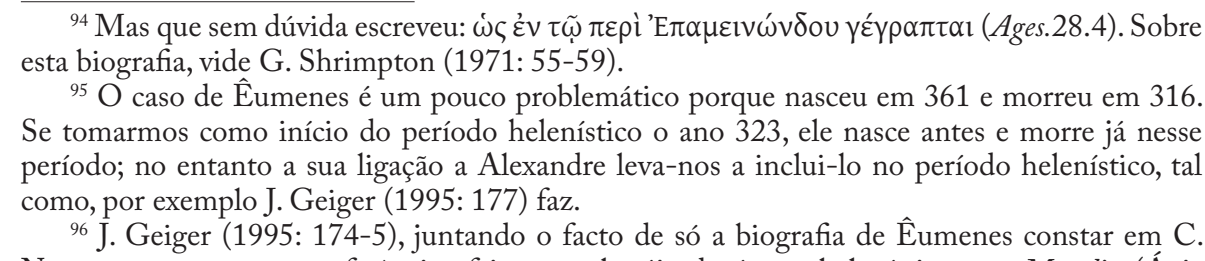
Nepos com as poucas referências feitas aos heróis da época helenística nos Moralia (Ágis (nenhuma referência); Arato e Êumenes (uma referência cada um; Êmenes, aqui tratado, apenas surge em De garr. 506D); Cleómenes (duas vezes); Pirro e Filopémen (quatro vezes cada um); Demétrio (nove vezes)), considera que o conjunto de biografias da época helenística não fazia parte do plano original de Plutarco, tendo sido adicionado quando Plutarco se apercebeu posteriormente do sucesso do seu trabalho. Esta tese ganha alguma força ao verificar-se que os Romanos António, Flaminino, os Gracos, Mário e Sertório, precisamente os que fazem par com os Gregos da Época Helenística, são muito menos mencionados nos Moralia do que os restantes heróis romanos; é curioso que este nível de ocorrências seja acompanhado pela referência que faz aos historiadores, embora isso não signifique necessariamente a quantidade de vezes que os usou (e.g. Dionísio de Halicarnasso não é muitas vezes referido, mas supomos que terá sido muito útil na hora de escrever as Quaest. Rom.), a saber: Heródoto (cerca de 260 vezes); Tucídides (130 vezes), Xenofonte (120 vezes); da Época Helenística o mais citado é Políbio (50 vezes), muito longe do número dos historiadores do período clássico.

${ }^{97}$ Em Reg. 2.1, explica a ausência de Alexandre e de outros.

98 J. Geiger (2005: 233) relaciona este facto com a produção das Vidas dos Césares: "for Plutarch the line between Republic and Empire was firmly drawn as can be seen from the composition of the series of Lives of the Caesars"; neste mesmo artigo, J. Geiger coloca a hipótese de as esculturas do Foro de Augusto poderem ter tido alguma influência na escolha dos retratos literários de Plutarco, hipótese que carece de elementos mais concretos, como referências do próprio Plutarco, mas que deixamos registada, até porque Plutarco, no prólogo do par AlexCaes., estabelece uma conexão entre a arte biográfica e a pintura, uma figura literária recorrente; se a biografia dedicada a Augusto estivesse ao nosso dispor talvez fosse mais fácil compreender esta questão e perceber, ainda, a razão principal da "autonomia" da Vida dos Césares; vide ainda J. Geiger (2002: 93-102).

${ }_{99}$ Remetemos para os principais trabalhos publicados sobre esta matéria: J. Mewaldt (1907: 564-78); C. Stolz (1929), obra recenseada, com algumas discordâncias, por J. Mewaldt (1930: 431-4); R. Flacélière (1948); K. Ziegler (1951: 708-19, 899-903); C. Theander (1958: 12-20); 
de composição), quer a cronologia absoluta (data da publicação). Como já referimos, os vários estudos sobre este assunto revelam que é possível fixar para alguns pares o terminus ante e o terminus post da sua composição, sendo mais difícil determinar a data e a forma ${ }^{100}$ de publicação. As referências internas nas Vitae a outras biografias são uma preciosa ajuda para, em alguns casos, se poder definir a ordem de redacção ${ }^{101}$. Porém, o facto de existir a hipótese de Plutarco trabalhar simultaneamente em várias biografias, formando grupos temáticos (e.g. as Guerras Medo-Persas, o conflito do Peloponeso, os primórdios da história romana, as guerras civis romanas), dificulta muito a tentativa de encontrar uma ordem de composição ${ }^{102}$. Assim, como acontece repetidas vezes nesta área de estudos, as afirmações não passam de meras hipóteses.

A escolha das personagens para integrar um par não obedece a critérios cronológicos, mas sobretudo a critérios temáticos que o autor privilegia. Entre Aristides e Catão Censor, por exemplo, existe uma distância temporal de cerca de trezentos anos e entre Nícias e Crasso ou entre Agesilau e Pompeio essa distância ainda é maior. Se temos pares em que os heróis têm poucas afinidades, no caso de Demosthenes-Cicero, Alexander-Caesar e Agis/Cleomenes-T. Gracchus/C. Gracchus ressalta, pelo contrário, a naturalidade destes pares ${ }^{103}$.

Ainda em relação à selecção dos heróis para formarem o par biográfico, alguns estudos ${ }^{104}$ lembram a equivalência que Plutarco estabelece entre as épocas grega e romana, nomeadamente a equivalência entre as Guerras MedoPersas e as Guerras Púnicas ${ }^{105}$ ou a semelhança entre o valor das vitórias ${ }^{106}$. Contudo, recordamos que as equivalências não são sistemáticas, mas meramente pontuais, até porque a diversidade de épocas não possiblita a elaboração de um sistema de equivalências ${ }^{107}$. Se Aristides, Temístocles e Címon têm em comum o facto de terem participado nas Guerras Medo-Persas, já os seus pares, Catão

M. Brozek (1963: 68-80); C. Jones (1966: 61-74); F. Frazier (1988b: 297-309); J. Geiger (1995: 165-90); G. Delvaux (1995: 97-113); A. Nikolaidis (2005: 283-324).

${ }^{100}$ Por exemplo, enquanto J. Mewaldt (1907: 564-78) e R. Flacelière (1948) concordam com a tese de publicação por grupos, C. Stolz (1929: 6-7) discorda; A. W. Gomme (1945: 83, n.3) e M. Brozek (1963) sugerem que as vidas romanas do final da República terão sido preparadas em simultâneo.

${ }^{101}$ Apenas o par Sert.-Eum. e a biografia de Artaxerxes não fazem referência a outras vidas nem são referidas, pois a maioria dos pares contém menções a outras vidas e são eles próprios referidos, facto que dificulta ainda mais a tentativa de definir com rigor a ordem cronológica; vide uma lista completa dessas referências internas em A. G. Nikolaidis (2005: 318-321).

${ }^{102}$ Cf. C. Pelling (2002a: 2 ss.).

${ }^{103}$ Para F. Frazier (1987: 66), os pares Dem.-Cic. e Alex.-Caes. já existiam antes de Plutarco (cf. F. Focke (1923: 350)).

${ }^{104}$ E. g. M. van der Valk (1982: 301-337).

${ }^{105}$ Cf. Pel.-Marc. 1.7.

${ }^{106}$ Cf. Pel.-Marc. 1.6, Per.-Fab. 2.1; Aem.-Tim. 1.2.

${ }^{107}$ Cf. F. Frazier (1987: 69). 
Censor, Camilo e Luculo, respectivamente, não têm nada de substancial que os una. Ora, é por pensar que o vínculo à época histórica não desempenha um papel importante que F. Frazier (1987: 69) sugere que "l'essentiel ne reside pás dans l'époque, mais dans l'action"108.

Outro elemento caracterizador do conjunto das Vitae é o facto de apenas no par Pbilopoemen-Flamininus encontrarmos duas personagens contemporâneas ${ }^{109}$. Internamente, as biografias colocam outro problema cronológico ao leitor: Plutarco sacrifica muitas vezes a ordem cronológica nas vidas, em favor da organização temática, chegando a interromper a narração cronológica para se deter na descrição e análise do $e^{t h o s}{ }^{110}$. Esses períodos, não muito extensos, são por vezes preenchidos com relatos anedóticos (chreiai), recurso retórico que pode servir para exemplificar uma qualidade admirável, para clarificar alguma característica ou para ilustrar melhor as suas palavras ${ }^{111}$, enquadrando-se no sentido ético da narrativa ${ }^{112}$, como era apanágio da literatura da Segunda Sofística ${ }^{113}$.

Temos, além disso, pares desequilibrados, como os casos de Cimon-Luculus e de Pericles-Fabius Maximus ${ }^{114}$. Neste último caso, é notória não só uma acentuada diferença na extensão das biografias, mas também no significado das personagens para as sociedades em que vivem ${ }^{115}$. Se na maioria dos pares a primeira biografia é menos complexa do que a segunda ${ }^{116}$, no caso do par

${ }^{108}$ No mesmo estudo, divide as Vitae em três grupos temáticos: 1) «role» politique; 2) «conduite politique»; 3) une action marquant. Concordamos, em geral, com os agrupamentos, mas parece-nos que, em alguns casos, isso obrigaria a colocar um par em dois ou três grupos temáticos. Por exemplo, o par Pel.-Marc. surge no grupo 3), mas também deveria aparecer no grupo 2) pelo valor dos elementos políticos que constam nesse par.

${ }^{109} \mathrm{O}$ facto de serem contemporâneos tem consequências na estrutura comparativa, como veremos mais à frente.

${ }^{110}$ Cf. G. Polman (1974: 169-77).

${ }^{111}$ M. Beck (2000: 15-32) analisa o papel da anedota na descrição do carácter, sumarizando a concepção aristotélica sobre esta matéria. Para ele, "the term anecdote will be treated as a

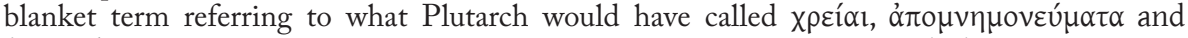

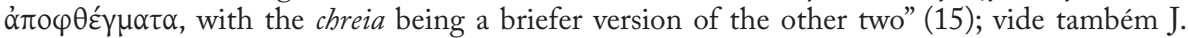
Dillon (2004: 183-209).

${ }^{112}$ Cf. Arist. Rhet. 1395B 13-17 e 1417A 16-25.

${ }^{113}$ Sobre o humor em Plutarco, vide J. Fernández Delgado (1996: 381-403).

${ }^{114} \mathrm{Ph}$. Stadter (2000: 509), a partir da análise destes pares e de outros (Nic.-Cras. ou Phoc.Cat. Mi.), conclui que as vidas dos romanos do final da República são mais extensas do que as dos gregos, com excepção do par Alex.-Caes., sugerindo que Plutarco teria mais interesse nas biografias romanas. Poder-se-á também pensar que Plutarco fez isso por se enquadrar melhor na forma como pretende educar os seus leitores, alongando-se em personagens que viveram um momento conturbado e cheio de peripécias, da mesma forma que no seu tempo presente se vivem semelhantes crises políticas, bem como a luta pelo poder.

${ }^{115} \mathrm{O}$ facto de Plutarco ser um cidadão da Beócia e de olhar para a Atenas do século V a. C. com algumas reservas, torna aos seus olhos este par menos desequilibrado do que para o actual leitor.

${ }^{116}$ Cf. C. Pelling (2002o: 349-363). 
Pericles-Fabius Maximus, a complexidade do carácter de Péricles entendese melhor com a leitura da biografia de Fábio $^{117}$, bem como a philotimia de Filopémen em relação à philotimia de Flaminino ou o patriotismo e a simplicidade de Aristides em face da austeridade e defesa dos valores ancestrais dos Romanos por parte de Catão Censor, ou seja, existe, em geral, uma complementaridade entre as duas biografias do par.

Outro aspecto formal digno de registo é o facto de, nos pares AemiliusTimoleon, Sertorius-Eumenes e Coriolanus-Alcibiades, a ordem normal gregoromano estar invertida. Segundo alguns estudiosos ${ }^{118}$, o facto de o herói romano preceder o grego significa que a primeira vida, menos complexa ${ }^{119}$, estabelece o padrão a partir do qual a segunda vida se estrutura e se desenvolve.

Além de agrupar um herói grego e um romano em cada par, repetem-se outros aspectos formais. Em geral, as vidas são introduzidas por uma espécie de prólogo, onde Plutarco tece algumas considerações sobre a escolha dos biografados e os motivos do paralelismo, estabelecendo os primeiros laços da relação entre narrador e narratário, além de aí esclarecer algumas linhas programáticas ${ }^{120}$. Após esta parte, o autor de Queroneia desenvolve um conjunto

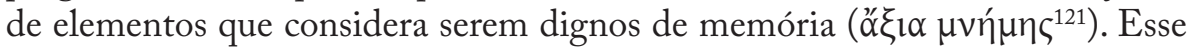
conjunto, normalmente, abarca três partes ${ }^{122}$. A primeira parte contempla os primeiros anos, desde a génese até ao início da actividade pública:

a) a origem e o estatuto social da personagem;

b) a caracterização física, distribuída pela narrativa, aproveitada, algumas vezes, para realçar uma qualidade moral $^{123}$;

${ }^{117}$ Cf. Ph. Stadter (2000: 508).

${ }^{118}$ E. g. C. Pelling (1994r: 23 ss.) e (2002o: 357), que rejeita justificar esta ordem com base na cronologia ou num erro de transmissão textual, rejeição seguida por T. Duff (2002r: 206, n.3); J. Geiger (1995: 189) considera que, no caso do par Aem.-Tim., se deve atribuir à estrutura

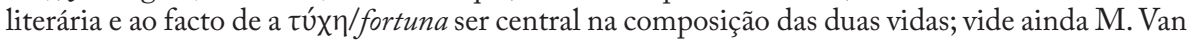
der Valk (1982) e E. Valgiglio (1992: 4029).

${ }^{119}$ C. Pelling (2002o: 357 e ss.) tece interessantes considerações sobre o uso da técnica "theme and variation" na composição das Vitae. Dando como exemplos os pares em que a ordem grego-romano é invertida, e ainda os casos de Demetr.-Ant., Per.-Fab., Ag./ Cleom.-Gracch., Dion-Brut. e Arist.-Cat. Ma., prova o uso recorrente da referida técnica, ainda que no final do estudo ressalve que Plutarco não a adopta em todos os pares.

${ }^{120}$ Nos pares Sol.-Pub., Them.-Cam., Arist.-Cat. Ma., Cor.-Alc., Phil.-Flam., Pyrrh.-Marc., Lyc.-Num., Lys.-Sull. e Ages.-Pomp. falta o prólogo; para uma análise sistemática desta estrutura e do seu papel na tradição biográfica vide Ph. Stadter (1988: 275-295), T. Rosenmeyer (1992: 205-230), T. Duff (2002r: 53), C. Pelling (2002k: 267-282).

${ }^{121}$ Cf. Comp. Dem. Cic. 1.1.

${ }^{122}$ Cf. A. Pérez Jiménez (2000r: 100-105), que serviu de modelo para a nossa estrutura. Para as $1^{\text {a }}$ e $2^{\text {a }}$ Partes, vide G. Polman (1974: 169-77).

${ }^{123}$ E. g. Caes. 17.2; Per. 5.1.; Ag./Cleom. 2.4; Ant. 4.1; Arat. 3.2; Cat. Mi. 1.3; Demetr. 2.2; Mar., 2.1; Phoc. 5; Pyrrh. 3.3-6; Sull. 2.1-2 e Gracch. 2.2.; e alguns casos a descrição física é exigida pela própria narrativa, como em Cic. 3.7, Dem. 4.4, Per. 7, 1-2 e Thes. 6.2. 
c) as qualidades espirituais, importantes no conteúdo didáctico-moral;

d) a formação da personagem, acreditando-se que a paideia tem um papel vital no comportamento do indivíduo ${ }^{124}$; daqui resulta, por vezes, a exploração da emulação por parte de Plutarco, que tem por fim revelar o carácter e consequente orientação na vida pública;

e) a iniciação na vida pública, fase que marca a passagem da juventude para a idade adulta.

$\mathrm{Na}$ segunda parte apresenta os principais feitos da idade adulta, ao nível da acção militar e política, em que se estabelece uma relação entre as praxeis e o ethos:

a) os primeiros feitos que levam ao reconhecimento público;

b) a akme do herói, lembrando o biógrafo as razões;

c) os últimos feitos ou acções do herói.

$\mathrm{Na}$ terceira parte, Plutarco recolhe várias informações sobre a morte do herói ${ }^{125}$ e a sua memória (o cadáver, a descendência e as homenagens dos cidadãos), descrição feita com maior ou menor dramatismo, consoante se trate de um suicídio ${ }^{126}$, de um assassinato ${ }^{127}$ ou mesmo a reprodução dos ultima verba do herói ${ }^{128}$.

Esta estrutura, do genos até à morte, ajudaria certamente o autor a organizar o material que tinha disponível, servindo como uma forma aproximada de

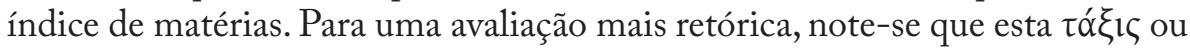

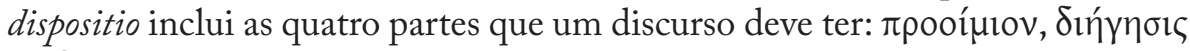

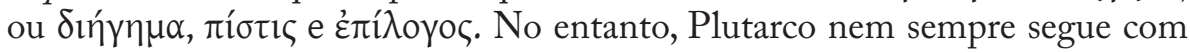
rigor esta ordem na sua narrativa biográfica: nos bioi de César e Nícias não temos qualquer referência ao genos, à família ou à formação, e nas vidas de Publícola, Camilo e Fábio Máximo, a narração começa pela maturidade. Além disso, o peso que cada uma das partes tem na economia narrativa é também diferente: a descrição do assassinato de César é mais extensa do que a narração do fim de Alexandre ${ }^{129}$.

${ }^{124}$ Cf. Alex. 7-8 e Cat.Ma. 2,4 ; Cat. Mi. 4.2 ; Brut. 1.3 ; Dion 4.6 ; noutros casos, Plutarco realça os efeitos da ausência da paideia: por exemplo, Alc. 2.1, Cim. 4.5, Cor. 1.3, Mar. 2.3, Them. 2.7.

${ }^{125}$ Há casos em que Plutarco não termina com a morte do protagonista da biografia, mas com um ou mais capítulos dedicados ao descendentes ou ao destino dos seus inimigos; Dem. 31, Pel. 35, Demetr. 53 e Ant. 78-81, são alguns exemplos.

${ }^{126}$ E.g. Dem. 29, Ant. 77, Cleom. 31 e Brut. 40.5-12; para uma análise da praxis do suicídio, vide Lyc. 29.8 (não deve ser um abandono egoísta, mas a última possibilidade logo que não exista qualquer esperança individual ou comunitária).

${ }^{127}$ E.g. Pomp. 78-79 e Caes. 66.

${ }^{128}$ E.g. Eum. 17.5-18.2.

${ }^{129}$ Cf. Caes. 63-68. e Alex. 75, respectivamente. 
Note-se, ainda, que Plutarco não tem a intenção de relatar toda a vida do biografado, como referirá no prólogo do bios de Alexandre, mas, sem estar preso ao rigor cronológico e à continuidade temporal, selecciona os episódios que melhor podem delinear o ethos. É, pois, mediante uma fragmentação narrativa de episódios, em sucessivas sequências, detentores de uma certa autonomia dentro do conjunto da biografia, que Plutarco procura o efeito imitativo. 



\section{A SYNKRISIS}

No final dos dois pares biográficos, surge uma estrutura formal, conhecida por synkrisis ${ }^{130}$ ou comparatio - para Montaigne ${ }^{131}$ : "la piece plus admirable de ses oeuvres et en laquelle, à mon avis, il s'est autant pleu"-, em que se sumariam, para se estimular a reflexão $0^{132}$, os aspectos positivos e negativos de ambas as personagens ${ }^{133}$, reforçando, sem dúvida, a tendência para se estabelecerem paralelismos, por meio de analogias e discrepâncias entre Gregos e Romanos, com especial realce para a análise, por um lado, da componente moral e, por outro, das acções militares e políticas ${ }^{134}$. Este recurso tinha já uma longa tradição na literatura grega $^{135}$, não sendo mais do que um "standard rhetorical school exercise", segundo R. Burridge (1997: 382), que servia para caracterizar personagens, formas de agir, povos ou sistemas políticos. Pode mesmo dizer-se que a cultura grega está marcada por variadíssimas polarizações, entre as quais podemos realçar: os Aqueus e os Troianos; os homens de condição livre e os escravos; os Gregos e os Bárbaros; os Atenienses e os Espartanos; o homem e a mulher ${ }^{136}$.

Até ao século IV a. C., as comparações localizam-se, essencialmente, no domínio do mito ou como instrumento para a crítica literária, sendo o célebre

${ }^{130}$ Cf. Arist., Rhet. 1368a19-26, Quint. 2.4.21, Apht., Prog. 10 e Theon, Prog. 112-15; uma extensa listagem de estudos sobre a synkrisis nas Vitae em T. Duff (2002r: 250, n.25) ou em S. Swain (1992b: 101, n. 1) e C. Pelling (2002o: 349-363) e (2005: passim), tendo estes dois estudos contribuído para aprofundar a nossa análise; na senda dos estudos de H. Erbse (1956: 398-424), B. Bucher-Isler (1972: 74-8), ambos influenciados, como notou S. Swain (1992b: 106), por A. Stiefenhofer (1914: 462-503), e D. Russel (20012: 110-113), tendo escrito este último que "sunkriseis are thus an essential part of the plan of 'parallels"; hoje a crítica tende a valorizar o conteúdo das synkriseis, ao contrário do que fizeram R. Hirzel (1912: 71 s.), U.von WilamowitzMoellendorf (1995r: 59) ou K. Ziegler (1951: 909).

${ }^{131}$ Essais 2.32.

${ }^{132}$ Talvez por isso encontremos nas synkriseis perguntas retóricas (cf. T. Duff (2002r: 245) e S. Swain (1992b: 101-11)); também nas Quaest. Rom., por exemplo, Plutarco avança com várias hipóteses de resposta, deixando ao seu leitor a escolha da melhor.

${ }^{133}$ Nos pares Alex.-Caes., Phoc.-Cat. Mi., Pyrrh.-Mar. e Them.-Cam. a synkrisis não nos chegou. Para Erbse (1956: 398 ss.) a synkrisis nestes pares nunca se chegou a escrever, opinião contrária, por exemplo, à de S. Costanza (1955: 127-56) e de S. Swain (1992b: 111).

${ }^{134}$ Como refere S. Swain (1992b: 104), na synkrisis dos pares Dem.-Cic., Dion-Brut., Pel.Marc. e Sert.-Eum., o Queronense não faz a análise da parte moral e dos feitos militares e políticos em secções diferentes.

${ }^{135}$ Sobre a tradição deste recurso na literatura grega, vide F. Focke (1923: 327-51).

136 Esta estrutura simétrica e paralela, secundada por meios estilísticos, tem recebido diversos nomes: "doublets", "schemi binari" ou "strutture coordinate", "duality in expression" (cf. T. Schmidt (2000: 455). 
Certamen Homeri et Hesiodi $i^{137}$ o texto mais conhecido. Registem-se mais três exemplos sobejamente conhecidos: na Ilias sugere-se uma comparação entre Aquiles e Heitor; o confronto entre Aquiles e Ulisses no diálogo platónico Hippias Minor, e, por último, as comédias Nubes e Ranae, de Aristófanes, que desenvolvem a synkrisis entre os raciocínios Justo e Injusto e entre Ésquilo e Eurípides, respectivamente. A estes exemplos podemos acrescentar o uso que os historiadores como Tucídides e Xenofonte fazem da synkrisis ${ }^{138}$.

É, contudo, com Isócrates que este recurso é aplicado no campo da história, mais precisamente na synkrisis entre Evágoras e Ciro ${ }^{139}$. Refira-se ainda que a synkrisis, muito por culpa dos tratados de retórica, se converteu num elemento recorrente da técnica encomiástica. A partir de Posidónio ${ }^{140}$, filósofo estóico e historiador, e Políbio, a historiografia clássica também a incorporará nos seus procedimentos. Por isso, não é de estranhar que as escolhas de Plutarco tenham sido condicionadas por alguns pares biográficos já formados: Catão de Útica e César (Salústio $\left.{ }^{141}\right)$; Cipião e Licurgo (Políbio $\left.{ }^{142}\right)$; César e Filipe (Posidónio); Temístocles e Coriolano (Cícero ${ }^{143}$ ); Alexandre e César (Estrabão $\left.{ }^{144}\right)$; Demóstenes e Cícero $\left(\right.$ Cícero $\left.^{145}\right)$; Aníbal e Cipião (T.

${ }^{137}$ Desconhece-se o autor e a data de composição do Certamen. Acredita-se que uma parte deve ser posterior à morte de Adriano (séc. II d. C.), pois o imperador é mencionado nos versos 32-34; outra parte é mais antiga, uma vez que os versos 107-108 são citados na comédia aristofânica Pax 1280-81, apresentada em 421 a. C.. Sabemos que Alcídamas (séc. V-IV a. C.) escreveu uma obra intitulada Museion - a subscriptio do papiro Michigan 2754 informa-nos de que o Certamen fazia parte do Museion -, que poderia muito bem ter sido a base da versão posterior à morte de Adriano. Porém, a citação encontrada no comediógrafo invalida essa possibilidade. Alcídamas terá recolhido uma tradição mais antiga, relacionada com competições poéticas, que sofreu diversas interpolações ao longo dos tempos. Por todas estas dúvidas, o Certamen deve ser usado com algumas precauções.

${ }^{138}$ Para mais elementos sobre estes dois autores, vide, respectivamente, F. Cairns (1982) e E. Lévy (1990); outros exemplos de synkrisis, tanto na literatura grega como na literatura latina são referidos pelo modelar estudo de E. Valgiglio (1992: 4022 ss.), bastante útil para a nossa análise; T. Duff (2002r: 244-5), com razão, junta aos exemplos já dados por E. Valgiglio as Controuersiae de Séneca; F. Focke (1923: 356 ss.) relaciona o propósito da synkrisis de Plutarco com os três princípios processuais que Hermógenes (Progymn. 19.14-19) havia enunciado: tratamento igual das duas partes; preferência por uma parte; crítica de uma e consequente louvor da outra parte.

${ }^{139}$ Evag. 37-38 (cf. Panathen. 39-40); Plutarco refere-se diversas vezes ao orador ateniense, rival de Demóstenes, nos seus textos: e.g., Alc.12.3, Cat. Ma. 23.2, Dem. 5.6-7; De gloria Ath. 350C-E, Quaest. conu. 613A e $X$ or. uit. 836C-D.

${ }^{140}$ Uma das fontes privilegiadas de Plutarco, revelando-nos, com admiração, que Posidónio foi ouvido por Cícero em 78 e por Pompeio, depois da vitória sobre Mitridates. Também Panécio, outro filósofo estóico, será uma das suas fontes.

${ }^{141}$ Cf. Cat. 54; sobre a synkrisis em Salústio, vide W. Batstone (1988: 1-29).

${ }^{142}$ Cf. 10.2 .8 ss.; 24.13 .

${ }^{143}$ Cf. Brut. 10-11, 42-43.

${ }^{144}$ Cf. 13.1.27; Lívio 9.16.19-9.19.17; Suet. Div. Jul. 7.1.

${ }^{145}$ Cf. Cic. De opt. gen. 13; Quint. 10.1.105-12; Ps.-Longinus, De sub. 12.4-5. 
Lívio ${ }^{146}$ ); Ágis/Cleómenes e os Gracos (Cícero ${ }^{147}$ ); Pompeio e Alexandre (Salústio e Plínio) ${ }^{148}$. Políbio, Varrão nas Imagines maiorum e Cornélio Nepos oferecem exemplos da escolha de um grego e um romano para comparação. No caso particular de Cornélio Nepos, sabemos que Plutarco conhecia a sua obra $^{149}$ e que certamente não terá sido indiferente ao facto de ele já colocar em paralelo figuras romanas e não romanas, em livros separados, pois do biógrafo latino chegaram-nos as biografias de Gregos e também as de Aníbal e Amílcar. Infelizmente, porém, não é possível avaliar, com probidade, o nível de influência, pois das vidas dos romanos só nos restam as de Catão Censor e de Ático, do livro De viris illustribus.

Não se pense, contudo, que a synkrisis é um exclusivo das Vitae, pois nos Moralia recorre-se a esta técnica em vários tratados ${ }^{150}$. Dos vários exemplos que poderíamos dar, escolhemos três tratados ${ }^{151}$ que não deixam de revelar que a intenção de Plutarco no uso da synkrisis não é demonstrar a superioridade de uma coisa sobre a outra, mas, sobretudo, encarar o confronto como um momento de reflexão, cabendo aos ouvintes ou leitores ${ }^{152}$ a escolha do melhor paradigma $^{153}$.

\footnotetext{
${ }^{146}$ vide A. Rossi (2004: 359-381).

${ }^{147}$ Cf. De off. 2.80.

${ }^{148}$ Cf. Focke (1923: 348-351) que desenvolve mais elementos sobre a synkrisis antes de Plutarco.

${ }^{149}$ Cf. Marc. 30.5, Comp. Marc.-Pel. 1.8, Luc. 43, Gracch. 21; Cf. V. Ramón Palerm (1992); J. Geiger (1988: 245-56), (1995: 177 ss.).

${ }^{150}$ Elementos mais pormenorizados em E. Valgiglio (1992: 4023 s.); T. Duff (2002r: 245-8).

${ }^{151}$ No caso dos tratados Quaest. Rom. e Quaest. Graec., parece evidente o paralelismocomparativismo; deixámos de parte o tratado Parallela Graeca et Romana por se considerar que é espúrio.

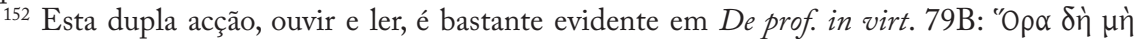

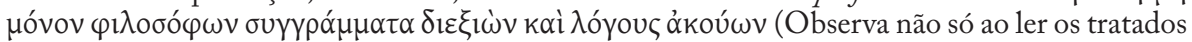
dos filósofos e a ouvir os seus discursos); os ouvintes/leitores são identificados por Plutarco com a abelha, numa metáfora que serve para transmitir a seguinte ideia: tal como a abelha procura o melhor mel, também os jovens devem perseguir o que é o melhor (cf. De aud. poet. 32E); note-se que em outros autores a abelha, além de ser sinónimo de organização e trabalho árduo, representa muitas vezes o poeta (cf. e.g. Simon. Frg. 593 Page, Pind. Pyth. 10.54, Bacch. 10.10, Pl. Ion 534B); cf. F. Fuhrmann (1964: 135-136), J. García López (1984: 411-419) e E. Borthwick (1991: 560-562); em De coh. ira 461A, a imagem das abelhas surge num contexto negativo, quando se equipara a acumulação da ira na alma a um enxame de abelhas; Plutarco dá muito valor à leitura e à observação, pois delas depende a concretização do passo seguinte, a efectiva emulação, chegando ao ponto de comparar um comum apreciador de arte com aquele que tem capacidade crítica (cf. De gen. Socr. 575A-D).

${ }^{153}$ Também Favorino, um bom exemplo de um Romano que se deixou seduzir pela paideia

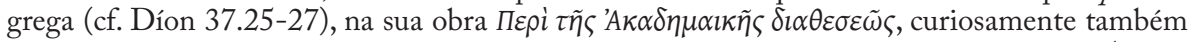

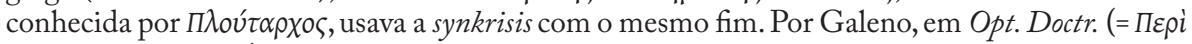

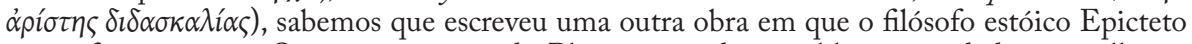
se confrontava com Onésimo, escravo de Plutarco, sendo o público convidado a escolher o melhor dos dois. Terá sido Onésimo o vencedor da contenda; a propósito de Favorino, e também
} 
Em primeiro lugar, o tratado De Alexandri Magni fortuna aut uirtute $i-i i^{154}$ confronta a tyche $e^{155} \mathrm{com}$ a arete. O Macedónio é comparado a outras grandes figuras como Platão, Sócrates, Ciro, Agesilau ou Temístocles, defendendose que as suas conquistas se devem mais às suas qualidades do que à tyche. Um segundo exemplo pode encontrar-se no discurso De gloria Atheniensium, que enumera um conjunto de personalidades ligadas às artes e à literatura em paralelo com históricos generais e políticos. Este tratado, elaborado na juventude de Plutarco, defende a ideia de que a glória de Atenas se deve mais aos homens que se distinguiram no polemos do que aos que se aplicaram à sophia ${ }^{156}$, tese interessante e que não está isenta de alguma ironia, mas que nos permitirá, no momento de discorrer sobre a identidade cultural, avaliar com maior acuidade a típica diferenciação entre Gregos e Romanos ou entre cultura e acção. Torna-se claro que, por meio deste tratado, Plutarco não desvaloriza os méritos que se atingem com os feitos guerreiros. Socorremo-nos do tratado De superstitione para o último exemplo. Aí se compara aquele que acredita na superstição (deisidaimon) com o ateu (atheos), sendo o primeiro motivo de maiores críticas do que o segundo ${ }^{157}$.

Adriano, vide E. Bowie (1997: 1-15) e J. Opsomer (1997: 17-39), o qual, dentro do contexto do cepticismo que caracteriza Favorino e Plutarco, afirma: “(...) Plutarch and Favorinus remain faithful to the true Academic spirit, never considering the truth a definitive accomplishment and taking the ever-continuing search for the truth itself as the goal of philosophy".

${ }^{154}$ Com claras semelhanças temáticas com este, o tratado De fort. Rom. também discorre sobre a tyche e a arete, ainda que neste caso se conclua que o sucesso dos romanos se deve mais à tyche, enquanto no primeiro caso se realce o facto de as conquistas de Alexandre serem sobretudo fruto das suas qualidades; para St. Schröder (1991: 151-7), os dois discursos de Plutarco sobre Alexandre tinham um par a defender a tese contrária. Parece-nos, no entanto, que a argumentação não é suficientemente sólida para sustentar essa tese, até porque é possível encontrar-se o efeito comparativo e de contraste entre os discursos sobre Alexandre e os Romanos. Note-se, por fim, que não se deve pensar que, nas Vitae, o sucesso grego se deve sempre em exclusivo à arete. Por exemplo, em Pel. 25.1 diz-se que os feitos de Pelópidas e Epaminondas no Peloponeso e na Lacónia mereceram a exaltação conjunta da arete e da tyche.

155 A sophia e a pronoia, como realizações da arete, opõem-se à tyche (cf. De fort. Rom. 316D; Arist., ENII 5, 1105b ss. e 1107a).

${ }^{156}$ Esta opção indica o apreço que Plutarco tinha pelos homens que passavam das palavras e das ideias aos actos, entendendo mesmo a filosofia como a simbiose de ideias e acção, como se conclui do tratado Alexandri Magni fortuna aut uirtute $i-i$.

${ }^{157}$ Para Plutarco, o homem deve estar consciente das suas limitações e recorrer à filosofia para as suas incapacidades. Nesse sentido, a superstição não é mais do que uma consequência da ignorância humana em apreender a natureza das coisas. Por isso se percebe que Plutarco pretenda apagar a influência da superstição entre os Gregos, até porque os Bárbaros têm uma inclinação para ela (cf. De superst. 166A e Sert. 11.6). A razão pela qual discute estes temas na sua obra está muito provavelmente relacionada com a fusão de religiões e cultos no séc. I d. C., pretendendo o autor, com a demonstração de concepções diferentes por parte de Gregos e Bárbaros, precaver os seus compatriotas contra a influência malévola da superstição. Note-se a preocupação de Plutarco em reconhecer Eros como um deus grego e não um estrangeiro, originário das superstições bárbaras (cf. Amat. 756C); vide ainda Alex. 2.9. 
As synkriseis plutarquianas, que são parte integrante das biografias ${ }^{158}$ mas com uma formalização própria ${ }^{159}$, desempenham, sem dúvida, um papel na intenção pedagógica ou moralizadora do autor, por recordarem, de forma tipificada e muito objectiva, os ensinamentos dos heróis do passado, pesandose nos pratos da balança as aretai e as kakiai, que se cruzam na avaliação final, muitas vezes numa sequência quiástica. A juntar a esta intenção, teremos de sublinhar a função que cumprem no paralelismo sócio-cultural entre Gregos e Romanos.

Em verdade, não é de todo despiciendo o contributo dado pelas synkriseis à metodologia comparativa de Plutarco, uma vez que elas têm evidentes implicações culturais, no aprofundamento da paideia grega e dos valores romanos. Além da natural ilação de que os feitos do passado se repetem e de que a análise desse passado histórico tem como benefício a identificação padronizada de atitudes e conceitos sócio-culturais, as Vitae de Plutarco testemunham que existe um paralelismo entre a história grega e a romana. Das synkriseis emerge, assim, o desenho de um homem onde se fundem, numa krasis cultural, as qualidades gregas e romanas. Se em relação à paideia verificaremos que é nas biografias romanas que se encontram mais elementos, não existindo um declarado desequilíbrio, quanto às synkriseis interessa notar que não pertence ao Grego a supremacia sobre o Romano, enveredando-se por uma análise que resulta num equilíbrio ou numa diferença que nem sempre é fácil de julgar. Catão Censor, por exemplo, participou em combates mais grandiosos do que Aristides, mas do ponto de vista moral talvez a vida do Ateniense esteja mais isenta de faltas, embora a sabedoria política de Catão tenha tido mais resultado prático ${ }^{160}$. Já no par Nicias-Crassus, Plutarco não tem qualquer dúvida em reconhecer a superioridade de Crasso sobre Nícias pela forma como aquele lutou contra César e Pompeio ${ }^{161}$. Do mesmo modo, os Gracos têm vantagem pela sua distinta paideia ${ }^{162}$.

Apesar da sua forma abreviada e de uma estrutura variável ${ }^{163}$, estes epílogos comparativos ${ }^{164}$ tornam-se muito importantes para o leitor perceber

158 Antes dos estudos de F. Focke (1923) e H. Erbse (1956), havia a tendência para menosprezar o seu conteúdo, considerando que eram uma estrutura que não fazia parte do par biográfico.

${ }^{159}$ Surge no final do par, recuperando, por vezes, a análise feita no prólogo; nesta parte, acentua-se o discurso antitético e recuperam-se, de forma sistematizada, temas desenvolvidos ao longo das biografias. Sobre a estrutura formal das synkriseis vide F. Focke (1923), S. Costanza (1956), D. Larmour (1992: 4154-62), S. Swain (1992b), J. Boulogne (1994: 62-9).

${ }^{160}$ Cf. Comp. Arist.-Cat.Ma. 1.3-4 e ss.

${ }^{161}$ Cf. Comp. Nic.-Cras. 2.4.

${ }^{162}$ Cf. Comp. Ag./Cleom.-Gracch. 1.2.

${ }^{163}$ Por exemplo, as synkriseis dos pares Dem.-Cic., Sol.-Publ. e Per.-Fab. diferem na sua estrutura interna (cf. J. Boulogne (1994: 60 ss.).

${ }^{164}$ J. Boulogne (2000: 33,39) define as synkriseis como "bilans comparatifs"; partindo da 
o pensamento de Plutarco, por se tratar de um exercício intelectual e moral ${ }^{165}$, pois até os episódios mais anedóticos têm por fim promover a reflexão ${ }^{166}$. Além disso, o seu conteúdo permite-nos perceber como é importante para Plutarco a análise da conduta humana, independentemente da grandiosidade das acções, bem como do tempo e do espaço em que se realizaram. Mais do que lidas como um sumário das biografias, as synkriseis devem ser encaradas como uma mensagem final, que reúne os principais vectores do pensamento ético de Plutarco.

Esta estrutura retórica ${ }^{167}$ permite expor e aprofundar diferentes manifestações do carácter humano (arete, andreia, philotimia, philonikia, sophrosyne, politeia, entre outras), ajudando a compreender melhor o código de valores que se repete em personagens de diferentes culturas e períodos históricos ${ }^{168}$. Desenvolvendo, em geral, temas relacionados com a acção militar e a politeia, ou seja, com a guerra e a paz ${ }^{169}$, numa estrutura que privilegia os argumentos favoráveis a um dos dois biografados, Plutarco foca mais os valores, as ambiguidades e as curiosidades do que as próprias personagens. Esta constatação liga-se a uma reflexão que é transversal a toda a obra: até que ponto o homem é responsável pelos sucessos e infortúnios da sua vida militar e política?

Preside, por exemplo, aos tratados De Alexandri Magni fortuna aut uirtute e De fortuna Romanorum ${ }^{170}$ a preocupação de abordar esta questão, estabelecendo a relação entre tyche e $\operatorname{arete}^{171}$, que são dois topoi retóricos ligados à concepção do homem e da mundividência humana ${ }^{172}$. O sucesso deve apenas ser imputado

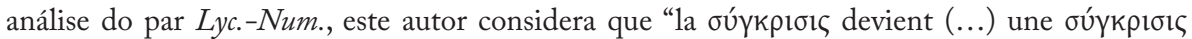
et la rhétorique du parallèle ne met en oeuvre son logos diacritique qu'afin de recueillir les individuations ainsi isolées dans une espèce de creuset où se fond un éthos de synthèse, puisqu'elle parvient à produire un troisième éthos, né d'une sorte de purification mutuelle des deux caracteres comparés, ainsi débarrassés de leurs défauts respectifs" (op. cit.: 43).

${ }^{165} \mathrm{D}$. Russel (20012: 110) considera que a synkrisis é essencialmente um exercício retórico.

${ }^{166}$ Cf. e.g. Comp. Phil.-Flam. 2.6; Comp. Dem.-Cic. 4.4; Comp. Pel.-Marc. 1.7-8.

${ }^{167}$ Cf. T. Duff (2000: 141, n. 3), sobre a integração da synkrisis nos progymnasmata; vide ainda H. Martin Jr. (1997: 724 ss.), J. Boulogne (2000: 33-44), C. Pelling (2002o: 349-363) e F. Pordomingo Pardo (2005: 117-132).

${ }^{168}$ Da leitura de Phoc. 3. 6-8, texto que mais adiante citaremos, resulta a ideia de que a mesma qualidade se pode manifestar de diferentes formas e em diferentes homens; talvez por isso, se encontrem nas Vitae mais elementos intemporais do que elementos concretos e limitados ao período e ao meio envolvente de Plutarco (cf. C. Pelling (1995: 348 ss.)). Recorde-se que em P1., Men. 71e-73c, Sócrates defende que a virtude, embora possa ter manifestações diferentes, é na essência a mesma.

${ }^{169}$ Cf. L. de Blois (1992: 4583 s.).

${ }^{170}$ Cf. L. Pernot (1983); S. Swain (1989: 504-516); G. Anderson (1993: 114 ss.); T. Duff (2002r: 263-4); refira-se que se tem discutido qual o período em que Plutarco escreveu este tratado e as implicações daí decorrentes (Cf. C. Pelling (2002a: 1, n. 5 e 6), (2002c: 84, n. 63).

${ }^{171}$ Cf. Comp. Sol.-Pub. 3.5.; Phoc. 1.4-6, 3.1-4; Dion 1.3.

${ }^{172}$ F. Frazier (1987: 67) chama a atenção para a presença da arete e da tyche na introdução 
à tyche? a uma divindade? ou ao mérito humano? ${ }^{173}$ Quando não consegue encontrar uma explicação clara e sustentada para um acontecimento, Plutarco atribui, em geral, à tyche a sua causa. Assim, a tyche surge como uma força divina que actua na história dos homens, de acordo com as atitudes morais desses mesmos homens, tornando-se estes os agentes principais do seu destino. Contudo, a palavra tyche pode ter um sentido muito diverso (e.g., "sorte", "aquilo que é fortuito", "providência"), logo pode traduzir uma influência mais providencial ou não, aplicando-se, dessa forma, a uma acção que tanto teve a colaboração humana como a divina ${ }^{174}$.

Nas synkriseis, vários factores concorrem para responder a esta questão. Temáticas relacionadas com a família e a cidade $^{175}$, a ajuda recebida por companheiros ${ }^{176}$, o papel dos rivais ${ }^{177}$, o uso da riqueza para benefício da comunidade $^{178}$ ou a forma como os heróis se relacionam com os cidadãos, ajudam, obviamente, a determinar a capacidade, o empenho e a acção. Note-se que a paideia, um valor transversal na obra plutarquiana, não é um elemento importante nas synkriseis, ao contrário daquilo que acontece na narrativa das biografias. Tal omissão justifica-se pelo facto de o epílogo servir para comparar o carácter de dois adultos, com um longo percurso formativo ${ }^{179}$.

Esta diferença entre a synkrisis e a narrativa das biografias - também aí o autor usa o método comparativo ${ }^{180}$ — permite-nos salientar que muitas vezes entram em contradição ${ }^{181}$, quer ao nível da interpretação, quer pela introdução

das biografias e para o facto de ambos os conceitos fazerem parte da justificação das semelhanças entre os dois heróis do par biográfico.

${ }^{173}$ Cf. Aem. $12.1-3 ; 24.1-4$.

${ }^{174}$ S. Swain (1989b: 272-302) desenvolve os vários sentidos de tyche, incluindo um anexo com as várias terminologias que encontrou em Plutarco para a intervenção da providência na história.

${ }^{175}$ Cf. Comp.Aem.-Tim.1.2-7; Comp. Cim.-Luc. 2.2; Comp. Lys.-Sull. 5.1-2; Comp. Phil.-Flam. 2.2-5; Comp. Sert.-Eum.1.3-5; Comp. Demetr.-Ant.1.1-3; Comp.Ag./Cleom.-Gracch. 1.3-5.

${ }^{176}$ Cf. Comp. Sol.-Pub. 3.3; Comp. Pel.-Marc. 2.2-3; Comp. Per.-Fab. 1.1-5; Comp. Arist.-Cat. Ma. 2.1-3; Comp. Demetr.-Ant. 5.5; Comp. Nic.-Crass. 5.1-2.

${ }_{177}$ Cf. Comp. Arist.-Cat.Ma. 1. 2-4; Comp. Nic.-Crass. 2.4; Comp. Lys.-Sull. 1.2-7; Comp. Dion-Brut. 4.1-4; Comp. Sert.-Eum.1.6-9.

${ }^{178}$ Comp. Sol.-Pub. 1.7-8; Comp. Cim.-Luc. 1.5-6; Comp. Per.-Fab. 3.5; Comp. Nic.-Crass. 1.4; Comp.Ag./Cleom.-Gracch. 1.7-8.

${ }^{179}$ Cf. T. Duff (2002r: 264).

${ }^{180}$ Por exemplo, do par Phoc.-Cat. Mi. não nos chegou a synkrisis, mas no prooimion e na narrativa estabelece-se várias vezes a comparação entre os dois biografados; vide J. Geiger (1988: 252-6).

181 T. Duff (2002r: 286) acredita que são dissonâncias deliberadas; também C. Pelling (2002o) se refere às contradições, pondo-se assim em causa algumas das considerações do marcante estudo de H. Erbse (1956), provavelmente influenciado pela análise de A. Stiefenhofer (1914: 462 ss.), que vê nas semelhanças e diferenças expostas no prooimion e na synkrisis a base da narrativa; T. Duff (2000: 150 ss.) explora algumas das contradições entre a synkrisis e a narrativas das biografias. Além da análise comparativa entre o conteúdo e o sentido da synkrisis 
de outros elementos. Em geral, Plutarco revela-se mais crítico na synkrisis do que na narrativa ${ }^{182}$.

A consequência mais importante das dissonâncias é, desde logo, a necessidade que o leitor tem de reconsiderar a sua própria análise, assumindo, dessa forma, um papel activo no julgamento das acções das personagens. Por isso, não se deve encarar a synkrisis como um sumário repetitivo da narrativa que a precede, mas como uma estrutura retórica apelativa ${ }^{183}$ e que pode oferecer uma nova perspectiva dos biografados. Alem disso, o final de um texto é uma boa oportunidade para deixar ao leitor temas mais complexos, de difícil resposta ${ }^{184}$. Assim acontece, por exemplo, quando Plutarco compara as acções de Marcelo e Pelópidas em Siracusa e Esparta, respectivamente, sem declarar qual das acções considera ser mais digna de admiração ou repulsa ${ }^{185}$. Note-se que a dificuldade em avaliar as acções dos heróis também está condicionada pelo facto de a diferença entre uma virtude e outra ou entre um defeito e outro ser pouco substancial, podendo a alteração da qualidade do ethos ser moldada por razões diversas, pois, como refere em Quaestiones conuiuales ${ }^{186}$, o vinho e o vinagre não são absolutamente diferentes, mas têm uma base comum. Do mesmo modo, percebe-se no tratado De inuidia et odio que a invídia e o ódio são diferentes, mas também partilham alguns aspectos semelhantes ${ }^{187}$.

Plutarco, sem abdicar de estabelecer os princípios comparativos, prova, assim, que a sua obra ao invés de dar respostas a todos assuntos que explana, coloca questões profundas sobre a condição humana. $\mathrm{Na}$ sua análise não se vislumbra uma inclinação clara por declarar a superioridade helénica, mas apenas se assume que os valores da sua cultura, a Grega, são os que mais interessam no actual momento, aliados ao poderio romano e aos nobres princípios da própria cultura romana.

e a narrativa das biografias, outro campo que tem originado vários estudos e interpretações interessantes é a comparação entre a synkrisis e o prooimion que introduz o par biográfico. De uma forma geral, o prooimion concentra-se mais nas semelhanças (ónoó diferenças ( No prooimion da biografia de Teseu, Plutarco afirma que partiu de um Romano ilustre para encontrar um Grego o mais semelhante possível. As palavras de Pel. 2.12 constituem um

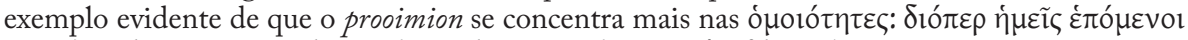

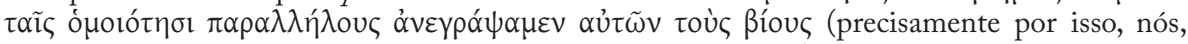
atendendo às semelhanças, escrevemos as suas vidas paralelas); vide, sobre este assunto, os trabalhos de Ph. Stadter (1988), D. Larmour (1992: 4157-8) e S. Swain (1992b).

${ }_{182}$ Cf. e.g. Cim. - Luc. e a respectiva synkrisis.

${ }^{183} \mathrm{O}$ tom mais directo e íntimo é testemunhado pelo uso recorrente da primeira pessoa verbal.

${ }^{184}$ E. g. Brut.; esta não é uma novidade de Plutarco, senão vejam-se os seguintes exemplos:

S. OT 1524-30 e Tr. 1278; Hdt. 1.32.1-9; Xen. Cir. 8.8; D. C. 56.43-45.

${ }^{185}$ Cf. Comp.Pel.-Marc. 2.2.

${ }^{186}$ Cf. 732B-C.

${ }^{187}$ Cf. 536E-F. 
Compara, sobretudo, povo com povo, virtudes com virtudes, vícios com vícios ${ }^{188}$, não usando sempre a mesma metodologia. Olhando para as synkriseis das biografias que são objecto de análise mais profunda no nosso estudo, poderíamos dizer que o polígrafo de Queroneia, nos pares TheseusRomulus, Pelopidas-Marcelus, Sertorius-Eumenes e Demosthenes-Cicero, está mais preocupado em identificar as semelhanças, apontanto apenas diferenças circunstanciais ${ }^{189}$, enquanto nos pares Coriolanus-Alcibiades, Aristides-Cato Maior e Philopoemen-Flamininus as diferenças são mais valorizadas, ainda que, por vezes, seja difícil discerni-las ${ }^{190}$. Apesar desta distinção, que não é muito profunda, convém referir que as palavras de Plutarco acerca das diaphorai e das homoiotes reflectem, acima de tudo, julgamentos morais.

Além disso, apesar de não ter como finalidade principal revelar a superioridade de uma personagem em relação à outra ${ }^{191}$, Plutarco não deixa de salientar os aspectos que mais distinguem cada uma das vidas que compõem o par biográfico, quer no plano meramente pessoal e privado, quer como membros de uma sociedade, e explicando a que nível participaram na vida pública e com que qualidade, pois Sertório e Eumenes ou Aristides e Catão Censor protagonizaram carreiras públicas importantes, mas cujo valor é distinto. É curioso verificar que a synkrisis consegue aproximar temporalmente as personagens, esbatendo as distâncias, o que parece provar que é recorrente na história aparecerem personagens, independentemente da cultura que representam, com iguais qualidades e defeitos ${ }^{192}$.

${ }^{188}$ No tratado $M u l$. uirt. isso é evidente, quando não estabelece a comparação com base numa virtude feminina e numa virtude masculina, mas prefere integrar mulheres e homens numa sociedade com aretai e kakiai.

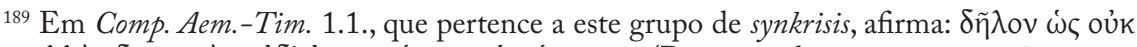

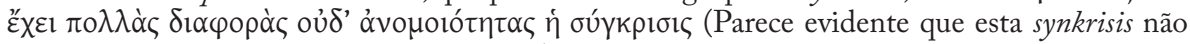
tem muitas diferenças nem dissemelhanças).

${ }^{190}$ Cf. Comp. Phil.-Flam. 3.5.

${ }^{191}$ Tal como acontece nos tratados De Alexandri Magni fortuna aut uirtute, De fortuna aut uirtute Romanorum, De superstitione ou De sollertia animalium, também nas Vitae o propópisto do autor é aprofundar valores ou assuntos com implicação na condição humana. Sobre isto afirma T. Duff (2002r: 245): "He often uses synkrisis not to demonstrate the superiority of one side of the equation over the other, but rather to explore the issues raised as a whole."; cf. S. Swain (1992b: 101-11). Por exemplo, no tratado De soll. anim. não se procura identificar quais os animais mais inteligentes, mas defender que todos possuem inteligência.

192 F. Brenk (1992: 4377-9) foi mais longe na análise, estabelecendo uma ligação entre a synkrisis e reincarnação da alma. 



\section{A PROBlemática do GÉNERo dAS VITAE: bios E historla}

A arte de representar a vida tem na literatura grega diversas manifestações, sendo de realçar nomes como os de Isócrates, Xenofonte, Aristóxeno, Hermipo, Sócion, Sátiro, Fílon de Alexandria, Luciano, Diógenes Laércio, Filóstrato e, mais tarde, Porfíro e Eusébio. Neste leque de autores encontra-se Plutarco, autor da mais significativa coleç̧ão de vidas que a Antiguidade nos legou.

Usamos, propositadamente, o termo "vida" (bios), uma vez que apenas numa obra de Damáscio (século V), dedicada à vida de Isidoro, e, uns séculos mais tarde, na Bibliotheca do lexicógrafo Fócio ${ }^{193}$ surge o vocábulo ßıүрафí́a.

Em relação às obras produzidas pelo conjunto de autores que atrás referimos, convém dizer, em primeiro lugar, que nem sempre é fácil distinguir o que é tipicamente biográfico daquilo que caracteriza, em regra, a história ou o encómio. Acresce o facto de nem sempre a natureza da biografia ser semelhante: por exemplo, o Agesilaus de Xenofonte ${ }^{194}$ encontra-se mais próximo do género historiográfico do que as vidas de filósofos escritas por Diógenes Laércio; de igual modo, o tom satírico e filosófico das biografias de Luciano (Demonax, Nigrinus e Alexander) não se encontra no Evagoras de Isócrates e muito menos na biografia religiosa e filosófica do De vita Mosis de Fílon da Judeia. Atendendo aos três géneros de discurso propostos por Aristóteles, a saber, o deliberativo, o judicial e o epidíctico, diríamos que a biografia pode fazer uso dos três, embora, no caso de Plutarco, nos pareça que sobressai o uso do discurso epidíctico.

Não se pense, por aquilo que acabámos de afirmar, que a Literatura Latina não oferece exemplos do género biográfico. Assume especial relevância o papel dos epitáfios, das inscrições ou dos elogios fúnebres na reconstituição da vida. Além destes casos, é obrigatório referir as Imagines de Varrão, a colecção biográfica De Viris illustribus de Cornélio Nepos, a biografia laudatória de Augusto escrita por Nicolau de Damasco ${ }^{195}$, as Res Gestae de Augusto, o Agricola

${ }^{193}$ Remetemos, a propósito de Fócio e dos extractos das Vitae na sua Bibliotheca, para o estudo de J. Schamp (1995: 155-184).

${ }^{194}$ Também a Cyropaidia de Xenofonte é uma obra de difícil classificação quanto ao género: tratado educacional, história romanceada, biografia romanceada ou apenas história são algumas das hipóteses; refira-se que Xenofonte apenas dedica a primeira parte dessa obra à educação de Ciro, revelando como a educação entre os Persas era diferente daquela que se pratica em Atenas, uma vez que, além de simples e rudes exercícios físicos, não dedicavam nenhuma atenção à formação cultural.

${ }^{195}$ Cf. FGrH 90 F125-30. 
de Tácito ${ }^{196}$ e a De vita Caesarum de Suetónio. Tal como os exemplos gregos, estamos perante um conjunto híbrido e heterogéneo de biografias, revelador da natureza compósita do género biográfico na Antiguidade. Esta listagem dos autores mais importantes evidencia que a representação do indivíduo teve uma expressão assinalável durante o período imperial ${ }^{197}$.

Para melhor avaliarmos o conteúdo das Vitae parece-nos relevante abordar, ainda que de forma exígua, uma questão que continua a merecer o interesse de vários filólogos: o modelo biográfico de Plutarco. Alertámos, previamente, para o facto de não se poder transpor por completo a actual concepção do género biográfico para a Antiguidade, e em particular para as Vitae, pois, como lembra F. Frazier (1996: 11) em relação a Plutarco, “(...) sa notion du bios ne correspond pas à notre idée de la biographie; il n'analyse pas le développement d'une personalité tout au long de sa vie, mais il élabore le portrait morale en action de grands hommes d'État." Na verdade, a intenção moral, ética e pedagógica das Vitae é um elemento fundamental da biografia plutarquiana, algo que poucas vezes se assume nas actuais realizações do género.

Encontramos, desde cedo, na literatura grega material de natureza biográfica, sem que isso signifique que estejamos na presença de obras pertencentes ao género biográfico, até porque só mais tarde esse género ganhou, por se ter definido melhor a sua forma, autonomia. Deste modo, tanto nos Poemas Homéricos, como nos poemas compostos por Hesíodo, podem-se encontrar elementos biográficos e, no caso do poeta de Ascra, também apontamentos autobiográficos: no episódio de Glauco e Diomedes na Iliada ${ }^{198}$, por exemplo, ambas personagens acabam por dar algumas informações relativamente aos seus pais, de tal forma que vêm a descobrir que havia uma relação amistosa entre as suas linhagens e, por isso, trocaram armas e abraçaram-se; o neikos de Hesíodo e Perses, que se desenrola ao longo dos

${ }^{196}$ Um pouco à semelhança da problemática que as Vitae geram em relação ao género, também no Agricola de Tácito se detecta um confronto entre história e biografia, como atestam as seguintes palavras de J. Marincola (1999: 320): "Similarly in the Agricola, although biography and history are present, the two genres are not amalgamated, nor does the work ever ever abandon its biographical form - even the annual campaigns are mined for what they reveal about Agricola's character. But biography and history do confront each other in the work, in the conflict engendered by autocratic government and the matrix of relationships that developed from it”; para S. Swain (1997: 24), por sua vez, a biografia experimental de Tácito merece o seguinte comentário: "That sophisticated but misjudged combination of family loyalty and high-style historiography (with full accounts of battle, general's orations, political history at Rome, geographical excursuses) apparently found no imitators", ao contrário do que acontecia com a biografia de Suetónio.

${ }^{197}$ Cf. S. Swain (1997: 1-37).

${ }^{198}$ 6. 119-236. 
Erga, ou a epifania poética ${ }^{199}$ atestam, por sua vez, o carácter autobiográfico da poesia didáctica de Hesíodo. Podemos juntar a estes exemplos os epítetos genealógicos, que também fornecem uma informação biográfica ou a poesia de Arquíloco, Tirteu, Sólon ou Píndaro, que contém vários elementos biográficos ou autobiográficos. No caso particular das referências sobre o genos, também Plutarco, em especial nos primeiros capítulos dos seus bioi, fornece dados sobre a ascendência dos heróis, salientando, por vezes, o seu carácter aristocrático. Quando, pelo contrário, se omite qualquer referência à ascendência do herói pode significar que se pretende atribuir o mérito todo ao biografado ou que o seu carácter não depende das suas origens. Aliás, o interesse em descrever os feitos de figuras do passado é uma característica da literatura grega que não é exclusiva da biografia, se tivermos em conta as obras de Heródoto, Tucídides ou mesmo a tragédia ática, que coloca no centro da sua trama figuras míticas. Registe-se, ainda, o interesse suscitado em diferentes épocas pelos Sete Sábios $^{200}$, revelador desse interesse biográfico.

Sem querer retirar importância a estes elementos, não podemos deixar de constatar que pouco nos ajudam a definir com exactidão a origem da biografia grega $^{201}$. O estudo de F. Leo (1901), considerado o primeiro grande estudo sobre a biografia na Antiguidade, refere que a estrutura das biografias de Plutarco é cronológica, e que assenta numa caracterização indirecta ${ }^{202}$. Isto justifica-se pelo facto de as Vitae seguirem a tradição do Peripatos (Aristóteles, Teofrasto $\left.{ }^{203}\right)$, mais vocacionada para caracterizar os homens de acção e a sua psicologia, sem descurar uma certa preocupação artística ${ }^{204}$. Esta dependência

199 Theog. 22-34.

${ }^{200}$ Em Heródoto, Platão, Diógenes Laércio e o próprio Plutarco, que escreveu um tratado sobre este tema (Sep. sap. conu.); vide, e.g., A. Busine (2002) e D. Leão (2003: 23-41) e (2006: 35-78).

${ }^{201}$ Sobre a historiografia e a biografia no período alexandrino, assim lhe chama o autor, vide N. Barbu (1976: 11-35).

${ }^{202}$ Este autor aplicou ao conjunto das biografias a metodologia de identificação das fontes proposto por E. Meyer (1899) para a biografia de Címon, que defende a tese de que Plutarco terá usado uma fonte intermédia.

${ }^{203}$ Atribui-se-lhe uma obra intitulada historika hypomnemata, fonte importante para os biógrafos; vide, sobre o nome "peripatético", An seni resp. 796D. A influência peripatética é evidente no tratado que defende a participação dos anciãos na actividade política, pois os Estóicos tinham ideia contrária; é curioso que na biografia de Cícero (cf. Cic. 24.5-6) surgem referências a Platão, Aristóteles e Teofrasto, autores incontornáveis para se perceber a obra de Plutarco.

${ }^{204}$ F. Leo (1901) contrapõe à biografia de Plutarco a de Suetónio, baseada numa estrutura temática, com uma caracterização directa, crítica e mais exacta, por seguir a tradição alexandrina. T. Duff (2002r: 7-8) discorda quando escreve: "The differences between Plutarch and Suetonius should be assigned not to the influence of literary traditions or sources which they blindly followed, but to their own choice, their own conception of the biographer's task and their own cultural identity". No caso de Suetónio, influenciou a sua biografia a ideologia do Principado e a tradição retórica romana do enkomion. 
de Plutarco parece negar a sua criatividade ou liberdade para estabelecer uma metodologia própria para as biografias.

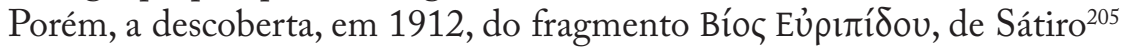
(POxy. 1176), datado do século II a. C., e a de outros papiros ${ }^{206}$ que colocaram a hipótese da existência de biografia política na época helenística indicam que, por um lado, a produção biográfica continou, muito provavelmente, na época helenística e que, mais importante ainda, se terão escrito biografias políticas ${ }^{207}$. Logo, sem retirar valor e mérito ao valioso estudo de F. $\mathrm{Leo}^{208}$, parece-nos que as fronteiras entre as duas tradições não seriam tão rígidas ${ }^{209}$. Contudo, qualquer estudo sobre a biografia grega se debate com o problema da falta de testimonia, pois, com excepção de Cornélio Nepos e Plutarco, poucos são os textos que podem ajudar um estudioso. Por isso, W. Uxkull-Gyllenband (1927: 91-112) procura demonstrar que Cornélio Nepos e Plutarco, atendendo às semelhenças que evidenciam, teriam usado as mesmas fontes biográficas, de cariz político, acreditando ter existido uma escola dessas biografias no século II. M. Levi (1955: 196-227), mais atento às diferenças entre os dois biógrafos referidos, admite a existência de biografias políticas antes deles, mas defende que Cornélio Nepos fez um trabalho de síntese, enquanto Plutarco ampliou a informação que lhe serviu de base.

Outros estudiosos tentam desvalorizar a influência da tradição do Peripatos no florescimento da biografia grega: A. Dihle (1956: 34), observando o papel de Sócrates, considera o diálogo platónico Apologia uma biografia; H. Homeyer (1962: 75-85) sustenta que as primeiras manifestações biográficas são as narrações sobre Ciro e Cambises em Heródoto, que considera o "pai da biografia”; A. Momigliano (1991t), seguindo esta corrente, propõe Cílax

${ }^{205}$ Cf. I. Gallo (1997r: 7-39); o mesmo filólogo italiano refere-se ao Bíoৎ Eủpıtí́ov com as seguintes palavras: "L'estremo interesse della Vita di Euripide di Satiro, pur nella sua frammentarietà, era ed è dovuto principalmente al fatto che essa costituisce il piú antico esempio di biografia costituita in genere letterario, con sue regole, strutture e funzione" (op. cit:: 168); W. Paton (1913: 131-2), pouco depois da descoberta do papiro, aponta algumas reminiscências verbais entre este e De adul. 68B e Coniug. praec. 141B.

${ }^{206}$ Cf. T. Larsen (1942).

${ }^{207}$ J. Geiger (1985), apesar disso, afirma que "political biographies of this kind [as de Plutarco] did not exist in the Hellenistic age".

$208 \mathrm{O}$ estudo deste filólogo admite a influência de biografias helenísticas no esquema plutarquiano, nomeadamente por meio de Aristóxeno, discípulo de Aristóteles; A. Momigliano (1991t: 111 ss.) chega mesmo a considerar plausível ter sido Aristóxeno o primeiro autor de biografias no Liceu e que a introdução de histórias anedóticas no género biográfico se deve a ele; parece-nos, no entanto, que a falta de textos não permite atribuir um papel tão relevante a este discípulo de Aristóteles, mas compreende-se que a intenção de F. Leo e A. Momigliano era a de provar a existência de biografias políticas na época helenística, com o qual J. Geiger (1985: 57) não concorda.

${ }^{209}$ Cf. B. Gentili \& G. Cerri (1983: 80 ss.), que mostram como é difícil distinguir biografia, encómio e historiografia antes da época helenística. 
como o primeiro biógrafo; I. Gallo (1997r: 169) e (2000: 12), por sua vez, defende que é pouco provável que a biografia grega se tenha iniciado na escola peripatética, mas que teria surgido antes dessa escola, em paralelo com a historiografia, tendo mais tarde sido estabelecida a canonização da biografia, embora o próprio estudioso italiano não precise o autor ou a data em que isso ocorreu.

Ainda que se considere que algumas obras de Platão, as narrações sobre Ciro e Cambises de Heródoto ou a biografia de Agesilau de Xenofonte nos ajudam a perceber os primórdios da caracterização de uma personalidade, com o tempo, as teorias que interpretam essas realizações literárias como biografias têm sido rejeitadas ${ }^{210}$, pelo facto de faltar aos exemplos indicados uma clara intenção por parte dos autores de escrever uma biografia e por nem sempre, do ponto de vista formal, tais obras se poderem enquadrar nesse género. Contudo, de uma forma indirecta e inconsciente, elas introduziram a ideia de individualização que nos levaria mais tarde à biografia. Ao contributo dos autores já referidos, juntamos o de Teágenes de Régio, autor de uma biografia de Homero (VI a. C.) ${ }^{211}$, o de Cílax de Carianda que escreveu uma biografia, de cariz político, sobre Heraclides (início do século $\mathrm{V}$ a. C.), o de Xanto da Lídia que dedicou uma biografia a Empédocles ${ }^{212}$ (finais do século $\mathrm{V}$ a. C.), e as obras de Íon de Quios e Estesímbroto de Tasso ${ }^{213}$. Com estes exemplos podemos verificar que o género biográfico terá criado as suas raízes nos séculos VII e VI a. C., sofrendo posteriormente diversas mutações e aperfeiçoamentos até ao momento em que se assumiu como género. Esse momento é difícil de precisar, porque a tradição biográfica anterior a Plutarco está, como já referimos, muito mal documentada, ainda que haja a tendência para indicar os séculos IV e III a. C. como a altura provável para o início dessa produção.

Gostaríamos de referir, além dos casos a que já aludimos, o estudo de J. Bollansée (1999) — filólogo que incorpora o projecto que visa dar continuidade à obra Die Fragmente der griechischen Historiker de F. Jacoby - que, a partir da análise de alguns fragmentos de Hermipo de Esmirna (III a. C.), autor de uma

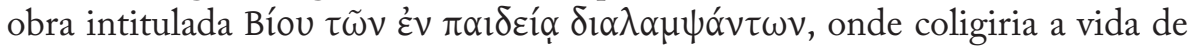
ilustres oradores, filósofos e legisladores, como Pitágoras, Aristóteles, Teofrasto, Isócrates, entre outros, chega à conclusão de que Hermipo terá sido o primeiro biógrafo grego. Este estudo só não é mais conclusivo porque se baseia em

${ }^{210}$ J. Geiger, I. Gallo e A. Pérez Jiménez são alguns exemplos.

${ }^{211}$ Para I. Gallo (1997r: 175), "La prima attestazione di una biografia greca (...) che fa iniziarle la produzione biografica com Scilace di Carianda.”

${ }^{212}$ Cf. Diog. Laert. VIII.63. e FGrHist 765 F 32-33.

${ }^{213}$ Sobre o contributo destes dois autores ao género biográfico, S. Mazzarino (1966: 86 s.) nota que o valor e o significado que o ethos ganha na biografia se deve a estes autores. 
fragmentos, embora ajude a perceber que a actividade biográfica existiu na época helenística e que a obra de Hermipo foi influenciada na sua concepção e metodologia por Aristóteles e Calímaco. Sublinhe-se, ainda, que Plutarco recorre diversas vezes a Hermipo ${ }^{214}$, discípulo de Calímaco pertencente à escola filosófica e histórica peripatética, facto que assume um significado que não deve ser negligenciado na análise das influências que recebeu dessa escola na composição das suas Vitae ${ }^{215}$.

Para a génese da biografia, o género encomiástico ${ }^{216}$, cultivado em especial no século IV a. C., terá tido um contributo decisivo. Os exemplos geralmente referidos são os encómios de Evagoras (orat. 9) de Isócrates ${ }^{217}$ e de Agesilaus de Xenofonte ${ }^{218}$ — com diferenças no seu esquema formal, uma vez que o primeiro está mais de acordo com o epainos e o segundo com o enkomion-, que procedem à caracterização histórica de uma personagem, em função dos seus feitos, descrevendo diversos traços do carácter dos protagonistas. Porém, apesar das semelhanças, não podemos confundir encómio com biografia ${ }^{219}$, pois enquanto o encómio tem como objectivo a idealização da personagem, o que condiciona a selecção das fontes, a biografia procura descrever o ethos das personagens, com as suas virtudes e defeitos, ora elogiando, ora criticando, concentrando nesse aspecto a força persuasiva dos princípios veiculados, como Aristóteles havia postulado ${ }^{220}$.

Deste modo, a diferença entre biografia e encómio reside mais na intenção do que na metodologia formal. Acreditamos que Plutarco sabia desta diferença, como se pode comprovar pelo tratamento que faz da figura de Alexandre. Enquanto em De Alexandri Magni fortuna aut uirtute $i-i i^{221}$

${ }^{214}$ Cf. Lyc. 5.4, 23.2, Sol. 2.1, 6.7, 11.2, Per. 32.1, 33.8, Alex. 54.1, Dem. 11.4, 28.3, 30.1; De gen. Socr. 586E e 598F, $X$ or. uit. 839E e 849C; Cf. L. Piccirilli (1977: 1007-1016) e C. Bearzot (1985: 31-34) (Hermipo fonte usada por Plutarco para o bios de Fócion); em Dem. 5.7

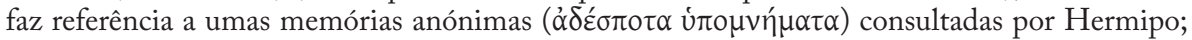
segundo alguns, a biografia que Ctesíbio de Cálcis escreveu sobre Demóstenes terá chegado ao conhecimento de Plutarco por intermédio de Hermipo.

${ }^{215}$ Em relação aos Moralia, P. Donini (1988: 126-44) demonstra como o Queronense usa as doutrinas peripatéticas e estóica para reflectir sobre a filosofia natural no De fac. lun..

${ }^{216}$ Há quem estabeleça uma relação entre este género e o epitáfio, as imagines maiorum ou a laudatio funebris dos Romanos.

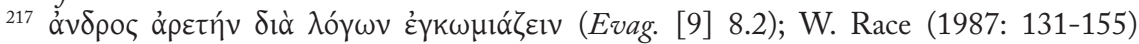
compara este texto com alguns epinícios de Píndaro.

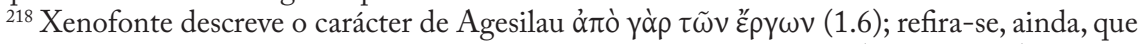
algum do material historiográfico usado no Ages. é partilhado com a $H G$ (ou Hellenika), sinal da proximidade dos géneros e da metodologia de trabalho do autor.

${ }^{219}$ E. Jenkinson (1973: 703-719), num artigo que ajuda a contextualizar a biografia de Cornélio Nepos, classifica os referidos textos de Isócrates e Xenofonte como "biografia encomiástica”.

${ }^{220}$ Cf. Rhet. 1356 a.

${ }^{221}$ Cf. J. Hamilton (2002r: xxxi-xxxiii), S. Humbert (1991: 170) e M. Cammarota (1992: 
colige uma série de argumentos favoráveis ao conquistador macedónio, na biografia que lhe dedica, pelo contrário, revela outros elementos negativos, conhecidos pela tradição. Além disso, estas diferenças demonstram a capacidade de Plutarco em argumentar a favor ou contra um assunto ou matéria em textos diferentes ${ }^{22}$. Ainda assim, a biografia e o encómio, tal como a oratória epidíctica, evidenciam vários traços retóricos em comum, não sendo de excluir a sua coexistência ${ }^{223}$.

Percebe-se, deste modo, que historiografia, encómio e biografia partilham semelhanças várias e, em especial, debruçam-se sobre povos, personagens, acontecimentos e caracteres, enfatizando cada um desses géneros aspectos distintos. A biografia de Plutarco, objecto do nosso estudo, conta os factos em função da personagem e do seu ethos, ainda que, do ponto de vista formal, não se distinga muito do encómio e siga, em muitos casos, a metodologia histórica ${ }^{224}$.

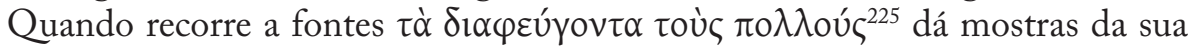
tarefa de investigação e demonstra que não se limitou a transmitir a tradição mais canónica ${ }^{226}$.

Ninguém duvida de que uma das características mais marcantes da obra de Plutarco, que não deixa indiferentes os seus leitores, é a quantidade e a variedade de autores citados ou referidos, que atestam bem o processo de investigação do autor. Isto tem suscitado várias questões, permanecendo algumas delas sem uma resposta satisfatória: que tipo de fontes tinha o autor à sua disposição? Fazia as citações a partir de documentação ou de memória, ou de ambas? Que tipo de metodologia prosseguiu a partir das fontes?

Antes de aludirmos a alguns dos aspectos que nos parecem ser os mais importantes sobre o uso que Plutarco fez dos autores que o precederam, convém sublinhar que só alguém com cultura, um verdadeiro pepaideumemos, e com uma panóplia assinalável de leituras poderia avançar para uma empresa desta

105-124); L. Prandi (2000: 375-386) defende, porém, que esta diferença se deve mais à evolução intelectual do autor.

${ }^{222}$ Cf. A. Nikolaidis (1991:153-186).

${ }^{223}$ Cf. Ph. Stadter (1987: 251-269).

${ }^{224}$ Note-se que, para Plutarco, não são apenas os encomiastas que cometem exageros, levados pela vontade de elogiarem os protagonistas, mas também os historiadores cometem tais

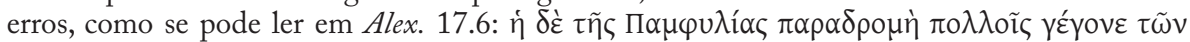

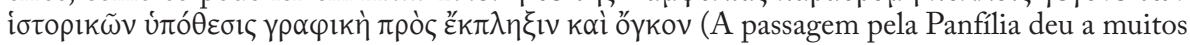
dos historiadores matéria de composição para o espanto e o exagero); com a questão dos limites fluidos da biografia estão relacionados, obviamente, os próprios limites da história (vide sobre esta questão C. Kraus (Ed., 1999)).

${ }^{225}$ Nic. 1.5; para L. Piccirilli (1998: 54): "A differenza di Cornelio Nepote e di Svetonio, Plutarco mostra una sorta di compiacimento nel palesare di conoscere non solo la vulgata, ma anche i dati ignoti ad altri, su vicende, fatti e comportamenti dei suoi eroi."

${ }^{226}$ Em Sol. 27, por exemplo, reivindica o direito de histórico-biográfico de utilizar fontes tradicionais sobre o encontro simbólico entre Sólon e Creso, isto é, entre duas civilizações diferentes. 
dimensão intelectual ${ }^{227}$, não sendo difícil de imaginar que a consulta das diversas fontes acompanham a sua escrita, quase simultânea, das Vitae e dos Moralia. Além disso, as questões levantadas ganham enorme interesse porque da definição do uso directo ou indirecto das fontes textuais, sem esquecermos outras como os monumentos, os costumes ou a tradição ora ${ }^{228}$, bem como da localização precisa dessas mesmas fontes, se pode tentar perceber até que ponto Plutarco se deixou condicionar por elas e até que ponto foi original ou, pelo contrário, se deixou condicionar pelas ideias, temáticas e personagens de outros autores ${ }^{229}$.

No entanto, muito embora as múltiplas fontes citadas ao longo das Vitae possam ser uma prova da erudição do autor ${ }^{230}$, não podemos daí concluir que tenha acedido em primeira-mão a todos esses autores. A. W. Gomme (1945: 54-84), nome de referência nos estudos historiográficos pelo seu monumental comentário à obra de Tucídides, sustenta que é pouco provável que Plutarco tenha resumido a sua consulta a um grupo restrito de autores para a redacção das Vitae e que ele foi o único responsável por essa selecção. Seguindo esta linha, C. Theander (1951: 1-32) defende que o Queronense conhecia bem a tradição historiográfica ${ }^{231}$.

Se pensarmos, ainda que percorramos um caminho com muitas incertezas, que Plutarco não se limita a descrever o ethos dos seus heróis ${ }^{232}$, pois não resiste a incluir nas biografias reflexões pessoais, em especial relacionadas com a conduta política, e que a redacção das Vitae se prolongou por vários anos (quinze ou mais), o tempo necessário para recolher uma diversificada e volumosa documentação e o consequente período de reflexão e escrita, com viagens e todas as suas actividades pedagógicas pelo meio, alterando por vezes os seus interesses e mesmo os objectivos, julgamos ser forçoso considerar que as suas fontes, múltiplas ou em número reduzido, seriam algo muito presente no seu trabalho de escrita. Aliás, o corpus das biografias forma uma unidade certamente marcada pelo tempo de composição; daí alguns filólogos terem tentado definir a cronologia das Vitae.

Parece, no entanto, que a dimensão do trabalho e a quantidade de referências exigiriam um grande esforço de memória ${ }^{233}$ e um apoio documental razoável. F.

${ }^{227}$ Cf. C. Pelling (2002a: 1 ss.) e T. Duff (2002r: 8, n.37).

${ }^{228}$ Cf. C. Theander (1951).

${ }^{229}$ Cf. M. Cerezo Magán (1996b: 267-280).

${ }^{230}$ J. Hamilton (2002r: xlvii-xlviii) considera que Plutarco deveria ter um conhecimento profundo dos autores citados.

${ }^{231}$ Toda esta discussão sobre a Quellenforchung justifica o aparecimento de uma obra exclusivamente dedicada a listar as citações de Plutarco. Referimo-nos ao estudo de W. C. Helmbold \& E. N. O’Neil (1959).

${ }^{232} \mathrm{~A}$ análise do ethos de uma personagem serve também para Plutarco revelar o seu próprio ethos, em alguns casos diferentes, como acontece em relação a Catão Censor (cf. Cat.Ma. 5.6-7).

${ }^{233}$ C. Pelling (2002a: 1, n. 2) refere os vários estudos que defendem o uso da memória. 
Frost (1961: 182-194) salienta no seu estudo as dificuldades que Plutarco terá sentido para ter acesso à documentação e que terá recorrido em larga medida aos seus conhecimentos e à sua memória. No entanto, tentar definir até que ponto recorreu à memória é sempre um exercício muito duvidoso, ainda que não seja improvável que muitas das citações tenham sido feitas sem um rolo à frente. Se juntarmos a estas dificuldades o recurso a fontes em "segunda-mão" 234 , logo susceptíveis de alguma incorrecção, a omissão de Plutarco em relação a algumas fontes que manuseou, ou, ainda, o aproveitamento das já referidas fontes "não livrescas" (monumentos, tradição oral, etc) ${ }^{235}$, convencemo-nos de que muitas respostas não passarão de meras hipóteses, com a certeza, porém, de que o autor combinou materiais de origem e natureza diversas ${ }^{236}$. Quando se propõe, por exemplo, escrever os bioi de Teseu, Rómulo, Licurgo e Numa, quatro biografias que formam um grupo autónomo, Plutarco tem consciência de que elementos pertencentes à tradição lendária e oral serão fundamentais para a sua composição, por haver $\tau \varepsilon \rho \alpha \tau \omega \dot{\delta} \delta \eta^{237}$ e $\mu \nu \theta \tilde{\omega} \delta \varepsilon \varsigma^{238}$ nessas histórias. Ao

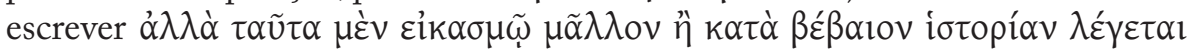
(Mas contam-se estas coisas mais por conjectura do que por uma narração segura ${ }^{239}$, Plutarco distingue claramente a qualidade dos relatos, ou seja, se existia fundamentação ou não nas fontes.

A forma como Plutarco trabalhou na sua obra ${ }^{240}$, seleccionando e excluindo umas fontes ${ }^{241}$, alterando outras ou simplificando-as apenas, revela a forma

${ }^{234}$ Cf. G. Delvaux (1988) (1989) (1996) enumera vários exemplos; A. W. Gomme (1945: 59) nota que Plutarco não faz uma diferenciação científica entre fontes de primeira, segunda ou terceira-mão, com o qual D. Russel (2001²: 46) concorda, salientando o facto de Plutarco ter usado certamente compilações ou antologias de citações.

${ }^{235}$ Cf. Theander (1951: 42 ss.), Ph. Stadter (1965: 125-148) e B. Scardigli (1995: 1-46).

${ }^{236} \mathrm{Em} \mathrm{De}$ def. orac. 422D é honesto ao dizer que não leu o livro a que se refere; vide D. Russel (20012: 42-62).

${ }^{237} \mathrm{Cf}$. Thes. 1.3.

${ }^{238}$ Cf. Ibid. 1.5 .

${ }^{239}$ Mar. 11.12.; cf. Cor. 37-38.

${ }^{240}$ E.g. D. Larmour (1992: 4162 ss.).

${ }^{241}$ Em relação ao uso que Plutarco fez das suas fontes, A. Barigazzi (1984b: 277) nota, com razão, que é preciso ter em conta que Plutarco pretendia fundir duas culturas, a grega e a romana: "ma va da sé che una persona seria come Plutarco non procede ad alterazioni o falsificazioni arbitrarie, che potrebbero apparire in contrasto specialmente con la tradizione della storiografia romana e recare un qualche discredito all'opera dell'autore, tendente tutta alla compenetrazione delle due culture e alla fusione dei due popoli, in un'epoca in cui diminuivano le differenze fra cittadini romani e provinciali (un secolo dopo, nel 212, la 'civitas' fu accordata a tutti in orbe Romano) e le province erano amministrate in modo diverso che nell'età repubblicana, cioè con più rispetto ed onestà, ed era agevolata una certa osmosi fra classi e popolazioni diverse e si andava attuando una progressiva uniformità specialmente nell'educazione e nella cultura, facilitata dalla stabilità politica e dalla pace generale"; acrescente-se que o menor conhecimento da cultura romana certamente condicionou o uso de fontes, sendo notório, por exemplo, nas Quaest. Rom. e Quaest. Graec. a maior referência a autores gregos: Tito Lívio é apenas mencionado uma vez (cf. 
complexa como concebeu a sua metodologia ${ }^{242}$. Basta listar alguns casos para compreendermos a forma intrincada do seu corpus: a repetição de citações ${ }^{243}$; a alteração de citações para as adaptar ao contexto ${ }^{244}$; a atribuição de uma mesma acção a duas personagens diferentes ${ }^{245}$; a falta de rigor quando se refere às magistraturas romanas ${ }^{246}$; a confrontação de fontes diferentes, mas sem se decidir por nenhuma delas ${ }^{247}$; a atribuição errónea de fontes ${ }^{248}$. Além destes casos, há outros em que Plutarco expande, para não dizer que inventa, um facto que não se encontraria no seu material base ${ }^{249}$. Perante estes exemplos, não faltarão opiniões que tendem a demonstrar a falta de rigor de Plutarco, por culpa própria ou em consequência da rapidez com que elaborou a sua obra. Outra razão, bastante plausível, para se encontrarem alguns elementos de difícil confirmação histórica poderá resultar da natureza das fontes que Plutarco usou. Um dos casos mais estudados é a pretensa intenção de Péricles de convocar uma reunião pan-helénica ${ }^{250}$, após a vitória nas Guerras MedoPersas, com os seguintes temas a discutir: os templos gregos destruídos pelos bárbaros, os sacrifícios de agradecimento aos deuses pela salvação da Grécia contra os bárbaros, a navegação segura do mar e a salvaguarda da paz. ${ }^{251}$ Pelo facto de a historiografia do século $V$ a. C., e não nos textos epigráficos fazerem

Quaest. Rom. 269E), e precisamente numa ocasião em que Plutarco rejeita a tese do conceituado historiógrafo romano, preferindo seguir as suas convicções filosóficas e religiosas, com o apoio, curiosamente, de um general grego, Temístocles.

${ }^{242}$ C. Pelling (2002d: 91-115) refere as seguintes técnicas no uso das fontes: "conflation", "chronological compression", "chronological displacement", "transfer"(outra forma de displacement), "expansion" " "fabrication of a context"; apesar de a identificação destes processos ser obviamente correcta, a nossa dúvida reside em saber até que ponto Plutarco, com tão vasto número de fontes, recorria a elas no seu trabalho de escrita e se não prevalecia, algumas vezes, a sua memória e, em outras, a imaginação.

${ }^{243}$ E.g. cita Simónides em De cap. ex inim. ut. 91E, Praec. ger. reip. 809B, An seni resp. 784B e Tim. 37.1; vide, em Ma . Barrigón (1996: 447-458) e J. Ribeiro Ferreira (2004: 47-54), mais elementos sobre a presença de Simónides de Ceos em Plutarco.

${ }^{244}$ E.g. Praec. ger. reip. 805A.

${ }^{245}$ E.g. em Reg. et imp. apopht. $181 \mathrm{~F}$ atribui a Démades uma acção que em De Alex.fort.aut. uirt. 336F é protagonizada por Leóstenes.

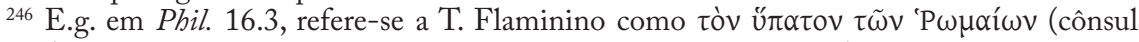
romano), mas nessa altura ele foi enviado à Grécia como uir consularis (L. Flaminino é que era cônsul); em Flam. 10.5 diz que o protagonista era cônsul quando ele era de facto procônsul.

${ }^{247}$ Éforo (500), Calístenes (700) e Políbio (900).

${ }^{248}$ E.g. em Marc. 30.5 cita Cornélio Nepos, Valério Máximo, T. Lívio e Augusto, mas nos casos em que é possível fazer a verificação (Valério Máximo e T. Lívio) o texto não corresponde.

${ }^{249}$ E.g. D. Russell (1963: 23-5) aponta alguns exemplos na biografia de Coriolano; J. Moles (1988: 36-8) na de Cícero; D. Larmour (1992: 4169 e 4171) nas de Teseu e Rómulo; C. Pelling (1997: 284 e 381) na de Flaminino.

250 Sobre o pan-helenismo, tema que marca os autores gregos dos séculos V e IV a. C., remetemos, por exemplo, para os estudos de J. Ribeiro Ferreira (1992: passim) e para J. Hall (2002: passim).

${ }^{251}$ Cf. Per. 17. 
qualquer alusão a esta reunião, acredita-se que Plutarco terá usado uma fonte literária, na linha da tradição oratória propagandística do século IV a. C., ${ }^{252}$ fazendo com que um hipotético facto não passe de uma deformação, sem real fundamento histórico.

Sem querermos omitir essas lacunas na redacção das Vitae, julgamos que o biógrafo de Queroneia manifesta um espírito crítico e uma metodologia que não se afasta muito da historiografia ${ }^{253}$, embora o seu objectivo fosse escrever biografias e não história. Quando, na biografia de Aristides, discute a questão do arcontado, revela bem a sua preocupação em indagar e confrontar as fontes ${ }^{254}$. Além disso, foi o seu interesse por nomes e informações menos divulgadas que nos permitiu ter conhecimento, por exemplo, dos nomes das filhas de Agesilau, a saber, Cleora e Eupólia ${ }^{255}$, uma vez que Xenofonte não nos dá essa informação na biografia que dedica a Agesilau, ou que foi

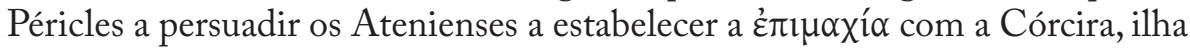
fustigada pela luta que mantinha com Corinto ${ }^{256}$. Nem sequer podemos dizer que a preocupação principal de Plutarco era encontrar a fonte mais credível e limitar-se a reproduzi-la, pois mesmo quando não concorda com uma fonte apresenta-a, de forma a reforçar a versão que considera mais fidedigna ${ }^{257}$. O próprio Plutarco explica nas palavras introdutórias do tratado De uirtute morali a razão do recurso a outras opiniões, atribuindo à palavra iotopía o

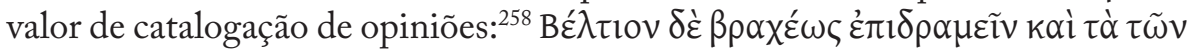

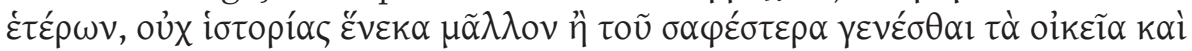

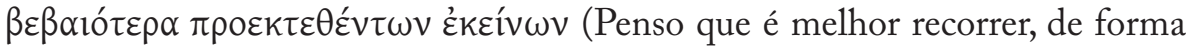

${ }^{252}$ Cf. C. Schrader (1997: 51-63) e A. Tronson (2000: 359-394).

${ }^{253}$ A diferença nota-se mais na técnica que usa para relatar alguns acontecimentos, como, por exemplo, as batalhas. A este propósito, escreveu F. Frazier (1992: 4512): "pour celui-ci [o historiador] le regard apporte moins une impression sensible que des renseignements sur une situation; la phrase type d'un historien suit un schéma du style «voyant telle chose, le général (ou l'homme d'Etat) pris telle décision»; le processus intellectuel ne cède le pas au spectacle perçu que dans quelques cas exceptionnels ; chez le biographe, au contraire, la valeur concrète et spectaculaire prime et si, bien sûr, les héros réfléchissent, ils voient aussi les êtres devant eux, bougent et vont vers eux.” ; sobre a proximidade entre biografia e história, B. Scardigli (1995 : 17), nas palavras introdutórias, escreve: “one must conclude that Plutarch's Greek Lives occupy a fluid and intermediate position in the history of biography. If anything, they approximate more closely to the work of a historian".

${ }^{254}$ Cf. Arist. 1.2-8, 5.9-10.

${ }^{255}$ Cf. Ages. 19.9-10 (cf. D. Shipley (1997: ad 19.9-10);

${ }^{256}$ Cf. Per. 29.1. Outros exemplos de notícias que devemos à indagação de Plutarco em L. Piccirilli (1998: 56).

${ }^{257}$ E.g. Per. 10.7-8 (confronta as versões de Idomeneu de Lâmpsaco e de Aristóteles sobre a morte de Efialtes, desacreditando a primeira); A. Nikolaidis (1997: 329) acredita que a

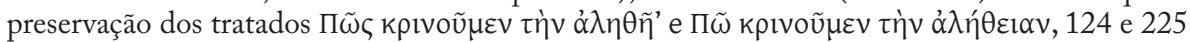
no Catálogo de Lâmprias, respectivamente, nos ajudariam a perceber os critérios históricos de Plutarco e, por consequência, a forma como teria seleccionado as suas fontes.

$258440 \mathrm{E}$. 
breve, às opiniões de outros, não para fazer uma investigação, mas sobretudo para tornar as minhas próprias opiniões mais seguras e sólidas, expondo antes as deles).

No tratado De Herodoti malignitate - este, o De Thucydides de Dionísio de Halicarnasso e Quomodo historia conscribenda sit de Luciano de Samósata são os três únicos tratados completos sobre a arte de escrever história que nos chegaram da Antiguidade 259 -, Plutarco lança duras críticas à historiografia de

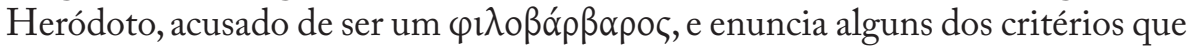
devem ser usados por um bom historiador, que ele próprio terá supostamente seguido $^{260}$ : correcta análise das personagens e dos factos, para não se incorrer na censura nem no elogio ${ }^{261}$; a tyche não deve servir para explicar os sucessos, pois não se pode tirar valor à arete; quando se está perante versões duvidosas, deve-se escolher a que oferece melhores garantias e a que se aproxima mais da verdade. Tucídides e Xenofonte, ao contrário de Heródoto, são para Plutarco modelos de bons historiadores. Consegue-se perceber, com estes critérios, que, quando há opiniões divergentes, Plutarco segue a da maioria ${ }^{262}$, procurando inquirir sobre a probabilidade e a plausibilidade da fonte ${ }^{263}$. Contudo, por vezes torna-se difícil fazer coexistir a acribia histórica e a valorização moral, uma vez que Plutarco nem sempre consegue, na avaliação "científica" das fontes, pôr de lado o seu julgamento moral. Do mesmo modo, é necessário não esquecer que, tal como na selecção das biografias existe uma apreciação pessoal, também as fontes não são imunes à subjectividade de Plutarco, como acontece com qualquer outro autor.

Resulta evidente que a distinção entre íđopía e ßíos, proposta por Plutarco no prefácio da biografia de Alexandre, não tem os limites bem

${ }^{259}$ Sobre estes tratados e a existência de outros atribuídos a Teofrasto e a Praxífanes, vide J. Hershbell (1997: 225, n. 1); o Catálogo de Lâmprias inclui ainda na sua lista os dois tratados mencionados na n. 258, que estariam relacionados com a história, mas que se perderam.

${ }^{260}$ As críticas que lança ao malicioso historiador (cf. De Herod. mal. 855B), sumariadas por D. Russel (20012: 61), não as consegue ele próprio evitar na totalidade, como C. Pelling (2002f) se encarregou de demonstrar; sobre a escrita das Vitae (biografia ou história biográfica), vide Cim. 2.4-5.

${ }^{261}$ Em Cim. 2.4-5, Plutarco mostra a sua intenção de respeitar a verdade e de não esconder os defeitos das suas personagens, mesmo daquelas que merecem os mais nobres elogios, até porque a perfeição humana é algo em que Plutarco parece não acreditar; ainda sobre o elogio, afirma, em Comp. Arist.-Cat.Ma. 5.3, que aquele que não precisa do elogio dos outros está mais preparado para a arete do que quem se auto-elogia, evidenciando os pruridos com que trata a questão do elogio ou do protagonismo.

${ }^{262}$ Dem. 23.4.

${ }^{263}$ Sobre alguns dos critérios usados por Plutarco nas Vitae, vide A. Nikolaidis (1997: 329341), que valoriza o trabalho de Plutarco, não se coibindo de apontar diversos aspectos que podem ter deformado a exactidão histórica, sem que isso coloque em causa o valor do seu trabalho. 
definidos $^{264}$. Não se pode simplesmente dizer que as Vitae são um exercício biográfico, mas é imperioso aduzir que Plutarco desenvolve um labor profundo de indagação histórica, de forma a compreender a physis e o ethos do ser humano, entrando muitas vezes no campo da filosofia. O modo como história, biografia/ethos e filosofia aparecem associados na construção da paideia faz-nos

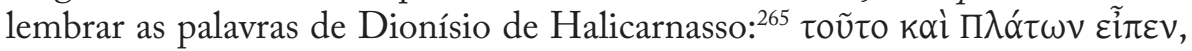

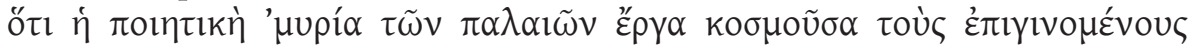

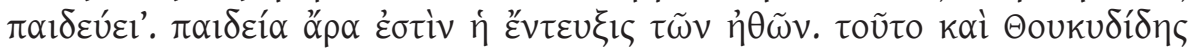

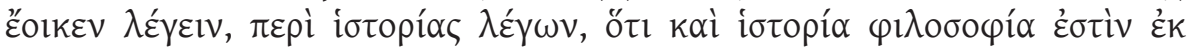
$\pi \alpha \rho \alpha \delta \varepsilon ı \mu \mu \alpha ́ \tau \omega \nu$ (Também Platão disse isto: a poesia, por embelezar inúmeras aç̧ões dos antigos, educa os que nasceram mais tarde; então, a educação é a procura dos caracteres; Tucídides, ao discorrer sobre a história, parece ter dito que a história é filosofia a partir dos exemplos). Quanto a Plutarco, julgamos poder afirmar que ele prefere introduzir nas biografias elementos dramáticos, problematizando a relação que a arete e a tyche têm com os acontecimentos. Põe a descoberto, em geral, as emoções e os desejos ( $\tau \dot{\alpha}$ đá́ $\theta \eta$ ), em vez de

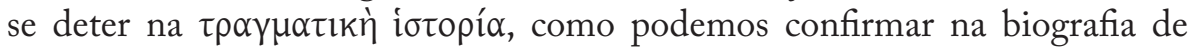
Alexandre. Transparecem, por isso, muitos traços psicológicos na descrição das Vitae, traços que são resultado da aventura de cada indivíduo e que dão uma tonalidade trágica à narrativa.

Se tivermos em conta que os géneros literários não teriam uma divisão rígida e que haveria uma espécie de contaminatio entre eles $^{266}$ - como acontece com o encómio, a novela e a biografia romanceada ${ }^{267}$ - percebe-se a necessidade de classificar o género usado por Plutarco como biografia política ${ }^{268}$,

${ }^{264}$ C. Pelling (2002a) (2002d), analisando as fontes e a forma como elas terão condicionado a composição de Plutarco (e.g., técnicas de simplificação e de compressão cronológica), conclui que o género biográfico tem uma natureza flexível e versátil.

265 Ars Rhet. 11.2.

${ }^{266}$ Cf. I. Gallo (2000: 9-17); considerando o que L. Rossi (1971) propõe para as leis (escritas ou não) dos géneros literários na Antiguidade (na época arcaica: leis não escritas, mas os autores tinham consciência delas e respeitavam-nas; na época clássica: leis são escritas e respeitadas; na época helenística: as leis são escritas mas não respeitadas), I. Gallo, seguindo a mesma formulação, afirma que na época de Plutarco "si potrebbe parlare di leggi non scritte, ma rispettate, come in epoca arcaica”; recordamos que $\mathrm{Ph}$. de Lacy (1952:159-171), defendendo que Plutarco segue mais a tradição platónica do que a aristotélica, aponta diversos elementos trágicos (e.g., o declínio e a hybris) na biografia plutarquiana, chegando mesmo a considerar que "Demetrius is a Plutarchian tragedy"; ainda a propósito de elementos trágicos nas Vitae, vide C. Pelling (2002d: 98, n. 27 e 101).

${ }^{267}$ Cf. I. Gallo (1997r: 170-1) e (1997r: 198-200).

${ }^{268}$ Expressão mais usada para designar a biografia plutarquiana (e.g., N. Barbu, J. Geiger ou A. Pérez Jiménez fazem-no nos seus trabalhos), embora, como realça S. Fuscagni (2000: 22), opinião que apoiamos, não se pode entender com essa expressão que Plutarco seguia uma estratégia política, mas apenas que a politeia e o seu exercício servem de base para a caracterização do ethos. 
biografia ético-moral ou simplesmente biopsicografia ${ }^{269}$, especificando-se, desse modo, a natureza e o conteúdo das suas biografias, que transformam a indagação histórica num meio para o objectivo central: aprofundar o ethos. A designação de biografia histórica aplica-se às Vitae, mas, como Ph. Stadter (1965: 7, 9-12, 125-140) demonstrou, encontra-se a mesma metodologia nos perfis masculinos e femininos do tratado Mulierum uirtutes ${ }^{270}$. Por sua vez, a opinião de B. Scardigli (1995: 7) sobre o binómio bistoria-bios e a sua presença nas Vitae é bastante elucidativa: "Plutarch occupies an intermediate position and represents a special case, both because he discusses the difference between history and biography and because he knows and uses historical writings." Esta opinião tem claramente em conta a influência peripatética na elaboração dos bioi e não neglicencia a tarefa de pesquisa levada a cabo por Plutarco.

A biografia de Plutarco caracteriza-se por desenvolver os momentos em que uma personagem central participou, com uma componte individual (o genos, o ethos, a paideia, a conduta moral, etc.) vocacionada para o bem do colectivo (a cidade, as lutas, a politeia) ${ }^{271}$. Para melhor conseguir definir o protagonista e realçar as suas qualidades ${ }^{272}$, associa-lhe uma personagem, que pode ser um rival (Aristides e Temístocles) ${ }^{273}$ ou um modelo (Pelópidas e Epaminondas) ${ }^{274}$.

Ainda em relação ao uso das fontes, parece óbvio que Plutarco tinha à sua disposição mais elementos sobre as vidas gregas do que sobre as romanas. Terá mesmo tido alguma dificuldade em reunir documentação para escrever a vida dos heróis romanos ${ }^{275}$, pois não sabia Latim $^{276}$ nem o acesso aos textos

${ }^{269}$ Inspiramo-nos na designação "biopsicologia” usada por F. Becchi (2001).

${ }^{270}$ Cf. A. Pérez Jiménez (2000a: 35-37).

${ }^{271}$ As acções de Pelópidas em Leuctra (Pel. 15-17), de Aristides em Maratona (Arist. 5) ou de Sertório em Cina (Sert. 5.5) provam a tendência para se atribuir a uma personagem individual algo que era sobretudo uma acção colectiva.

${ }^{272}$ E.g. Fábio e Aníbal (Fab. 5.3-5, 8); Pisístrato e Sólon (Sol. 30-31); Tulo e Coriolano (Cor. 22.1-4); outros exemplos em A. Pérez Jiménez (2000a: 32 ss.).

${ }^{273}$ Cf. Arist. 2.2; Them. 3.3.

${ }^{274}$ Cf. Pel. 3.2-4, 4.

${ }^{275}$ C. Pelling (2002a: 1) considera que a pesquisa prévia sobre a história de Roma não terá sido muito profunda; M. Mazza (1995: passim) demontra que Plutarco omite ou simplifica vários elementos característicos da época tardo-republicana (e.g., o contraste entre ao proletariado urbano e o rural, a heterogeneidade da população de Roma, secundarização dos equites ou dos socii Italici); cf. C Pelling (2002i) define esta simplificação histórica com a expressão "bouledemos conflict".

${ }^{276}$ D. Russel (20012: 54, n. 27) e L. Gamberale (1995) fazem referência aos erros na tradução das fontes latinas; vide ainda A. Strobach (1997:1-46) para uma análise do uso que Plutarco faz da língua latina, onde se inclui um catálogo extenso de etimologias (55-141), além da problemática do conhecimento de línguas na Antiguidade (Fremdsparchenproblematik); em Quaest. Rom. 280A-B e Quaest. conu. 726D-727A, por exemplo, manifesta algum desconhecimento das etimologias ou simplesmente desvaloriza esse tipo de análise; para exemplos de palavras gregas na língua latina vide Quaest. Rom. 274C, Num. 7.10, Marc. 8.7, Rom. 15.4; mostra-se relutante 
era fácil. ${ }^{277}$ Aliás, essa pode ser uma razão para, como Plutarco explica no prefácio do par Theseus-Romulus, escolher o herói grego em função do romano, ou seja, só depois de reunir os elementos necessários para compor a biografia romana seleccionaria, com alguma facilidade, uma figura da história helénica. O prólogo de Demosthenes, onde Plutarco afirma ter um conhecimento insuficiente da língua latina, assume especial interesse se tivermos em conta que as Vitae retratam heróis romanos e que para isso terá tido necessidade de ler muitos textos em língua latina. Como poderia aprofundar elementos históricos ou literários ao abordar a vida dos Romanos sem conhecer a língua de Vergílio? Talvez por não a dominar em pleno se tenha limitado a descrever o seu carácter e as suas carreiras, como acontece na biografia de Cícero, fazendo o mesmo na de Demóstenes. A produção literária destes dois oradores não é comparada nem aprofundada, focando-se apenas aspectos relacionados com a conduta pública e privada de ambos. Além disso, o desconhecimento da língua de Cícero poderá explicar a importância que o autor dedica à cultura grega nas biografias dos heróis romanos.

Quanto aos métodos de trabalho de Plutarco, parece que tinha um problema de documentação em Queroneia, pois fala-nos, com alguma inveja, daqueles que vivem em cidades célebres, onde o ambiente cultural e quantidade de informação favoreciam os escritores. ${ }^{278}$ Aproveitaria certamente as suas viagens a Atenas e a Roma para juntar alguma documentação ou tirar

em aceitar que a língua latina descende da grega (cf. Marc. 22.7).

${ }^{277}$ Em Quaest. conu. 675 afirma, com orgulho, ter consultado poucas obras, porventura para valorizar a sua capacidade individual e a sua erudição.

${ }^{278}$ Cf. Dem. 2.1; apesar de ser o próprio Plutarco a afirmá-lo, parece-nos um pouco estranho que um homem com reduzidos conhecimentos da língua latina se tivesse lançado numa empresa tão grande e exigente como as Vitae. J. Hamilton (2002r: xliv) defende que teria um bom conhecimento da língua latina, atendendo às cerca de quarenta fontes romanas que se podem encontrar nas biografias, às quais certamente se acrescentarão muitas outras que não são mencionadas, pois é estranho que Vergílio, Ovídio, Marcial, Plauto ou Terêncio nunca sejam citados, nem haja uma análise mais profunda dos tratados filosóficos de Lucrécio, Cícero ou Séneca. Trata-se então de uma afirmação que denota falsa modéstia? A. Burlando (2000: 61-68), analisando a narração ex abrupto do par Dem.-Cic. e sabendo que é pouco normal Plutarco fazer apontamentos autobiográficos, coloca a hipótese de essa declaração ser uma forma de captatio benevolentiae, qualificando a afirmação de "falsamente modesta"; muitas vezes a tendência é para se pensar que Plutarco leu uma versão grega das fontes latinas que usou, como acontece quando

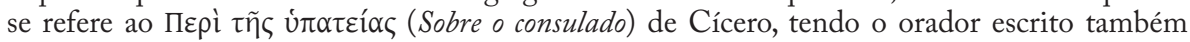
uma versão poética na sua língua materna (cf. Caes. 8.4); a propósito do nível de conhecimento de Latim do Queronense, vide C. Jones (1971: 76, 81-7), Ph. Stadter (1988: 286-7), A. de Rosalia (1991: 445-459), A. Strobach (1997: 33-9), C. Pelling (2002a: 1-22); parece-nos que Plutarco, quando avisa os leitores sobre o nível dos seus conhecimentos da língua latina, tenta justificar o facto de não se alongar na biografia de Cícero em análises sobre a extensa obra deste; para J. Mossman (1999), o problema da falta de livros não existiria, pois facilmente os poderia encontrar em Atenas; remetemos, ainda, para a análise que A. Zadorojnyi (2005: 493-512) faz do prólogo de Dem.. 
notas para a sua produção literária, pois a dimensão erudita das suas obras faz supor, como vimos, que terá usado muitos textos. No tratado De defectu oraculorum pede aos seus conhecidos de Atenas que lhe enviem livros. Como os especialistas da Quellenforschung, podemos pensar que muitas das obras dos autores mencionados não foram realmente consultadas e que se limitou a usar fontes intermédias ou excerpta. Acreditando-se que trabalharia em simultâneo nas diversas vidas, a documentação teria um uso abrangente e não apenas exclusivo de uma ou outra biografia. ${ }^{279} \mathrm{~A}$ documentação usada serviu certamente para várias biografias, o que explica as repetições que se podem encontrar.

Quando ele próprio não leu um autor que cita, faz referência a uma fonte de segunda-mão. ${ }^{280}$ Outras vezes, reproduz quase literalmente um autor mas sem o nomear. ${ }^{281}$ Quando não confia na fonte também não se coíbe de dizer que ela the merece pouca credibilidade ${ }^{282}$. Assume, quando não tem ao seu dispor todos os elementos, que não pode tomar uma posição sobre uma questão. Assim acontece, por exemplo, no momento em que refere o que Ésquines disse

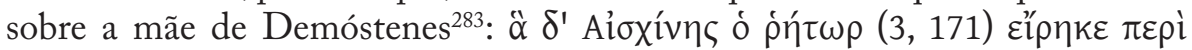

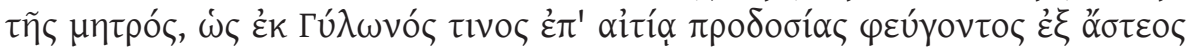

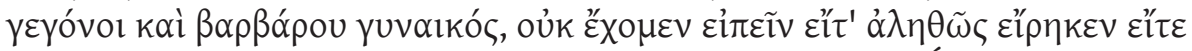

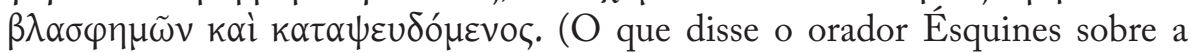
mãe dele [Demóstenes], que era filha de um tal Gilón, desterrado da cidade por motivo de traição, e de uma mulher bárbara, não consigo dizer se é verdade o que afirmou ou se é uma calúnia difamadora).

Plutarco faz uso de alguns dos métodos próprios de um historiador, nomeadamente a referência a diferentes versões e a sua consequente análise e, além de, em alguns casos, ter a preocupação de contar a verdade ${ }^{284}$. Por isso mesmo, como fazem Arriano, Apiano e Díon Cássio, Plutarco integra geralmente a lista dos historiadores do período imperial ${ }^{285}$. Na verdade, Plutarco salienta e desenvolve questões históricas, mas com uma perspectiva moralista, centralizada no carácter de personagens. ${ }^{286}$ Contudo, não é isto

${ }^{279}$ J. Sirinelli (2000: 284) relaciona a documentação usada com a ordem cronológica que terá supostamente presidido à composição das Vitae.

${ }^{280}$ Cf. Dem. 5.7; 10.2; 30.1; Rom.17.5; Sol. 6.7 e 11.2.

${ }^{281}$ Cf. Dem. 16.3-5 (cf. Dem. Ep. 237).

${ }^{282}$ Cf. Per. 28.3.

${ }^{283}$ Dem. 4.2.

${ }^{284}$ Cf. Dem. 20.1; note-se que para Plutarco a verdade pode ser difícil de encontrar, mas como objecto de procura filosófica ela existe (cf. De adul. 49C, De exil. 559C, Quaest. conu. 684D e Quaest. Plat. 1000B-D).

${ }^{285}$ E.g. I. Moxon et al. (1986), estudando-se a história na literatura greco-romana, tal como Heródoto, Tucídides, Xenofonte, também Plutarco é incluído na lista dos que merecem um estudo sobre a historical writing.

${ }^{286}$ E.g. Sull. 12.7-9. 
que o afasta do género historiográfico, que também não deixa de ter uma preocupação moralista, dando, além disso, prioridade à utilidade ( $\omega \varphi \varphi \varepsilon ́ \lambda \varepsilon l \alpha)$,

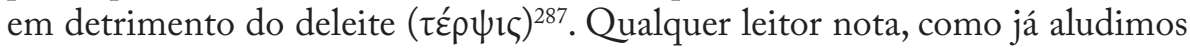
anteriormente, que Plutarco considera relevante recuperar os feitos do passado para a pedagogia do presente, sublinhando os padrões sociais e individuais que se repetem ao longo do tempo. Ora, este não é mais do que um topos da historiografia grega ${ }^{288}$, que prova a sua utilidade a partir da análise dessas repetições históricas, apontando causas e consequências. Se é verdade que também a historiografia tem, por vezes, um tom moralista, o que mostra uma similitude com as Vitae, não podemos ignorar que para Plutarco a ética moralista assume-se como um leitmotiv da sua composição, capaz de o levar a sacrificar o rigor da descrição dos factos históricos.

No entanto, Plutarco está longe de ser tão exaustivo no relato das versões dos factos quanto a acribia histórica o exige. Por exemplo, na sua estruturação interna das biografias dedica, em geral, os últimos capítulos à morte do biografado. Nessa parte específica, costuma referir diferentes versões, mas o próprio autor não pretende alongar-se muito nessas referências. Cite-se, a título de exemplo, um passo, em que depois de se fazer alusão a várias versões sobre a morte de Demóstenes, se diz o seguinte ${ }^{289}: \tau \tilde{\omega} v \delta^{\prime}$

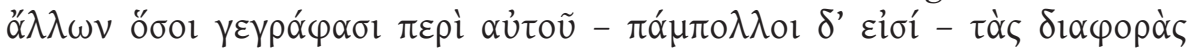

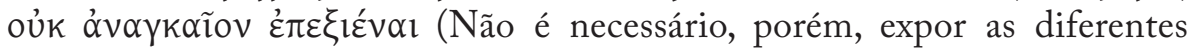
versões ${ }^{290}$ de todos aqueles que escreveram sobre ele [Demóstenes], e que são numerosas). Apesar desta intenção, descreverá uma última versão, de Demócares, familiar de Demóstenes, claramente benévola para o orador ${ }^{291}$ :

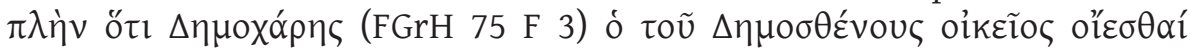

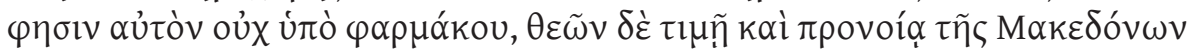

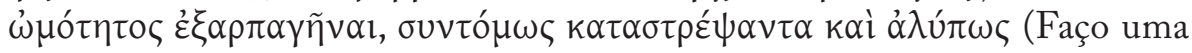
excepção para Demócares, parente de Demóstenes, que afirma acreditar que ele não pereceu por causa de um veneno, mas que foi salvo da crueldade dos Macedónios por estima e providência dos deuses, que lhe deram um fim rápido e sem dor).

As dúvidas sobre se Plutarco leu em primeira-mão 292 os autores

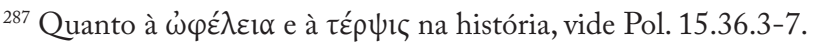

${ }^{288}$ Cf. e.g. Th. 1.22.4 e 2.48.3: Tucídides considera que a sua obra pode ser útil no caso de situações similares às que relata se repetirem no futuro.

28930.4 .

${ }^{290}$ Em Ps.-Plut., Vit. X or. 847A-B entre as várias fontes usadas sobre a morte do orador ateniense surge o nome de Filócoro que em Dem. não aparece, além de fazer alusão a outras fontes anónimas segundo as quais Demóstenes morreu de falta de respiração.

29130.4 .

${ }^{292}$ H. Erbse (1956: 420-4), Ph. Stadter (1965), C. Jones (1971: 81-7), J. Geiger (1985:5862), L. Piccirilli (1990), J. Walsh (1992 : 231-3) e J. Buckler (1992) concordam que Plutarco foi 
clássicos ou se se limitou a ler uma espécie de resumos desses autores, tidos por fontes intermédias, irão manter-se, a menos que seja descoberto algum papiro que venha esclarecer esta matéria, tal como se torna difícil saber como procedeu à adaptação e selecção dos autores e textos que tinha à sua disposição ${ }^{293}$.

Plutarco tinha consciência de que escrever bistória e biografia não era exactamente a mesma coisa, ainda que ambas partilhassem algumas semelhanças, tais como o uso de fontes, o relato mais ou menos extenso de episódios ou a descrição do carácter daqueles que participam nos feitos. Tanto assim é que no prólogo da biografia de Alexandre faz a seguinte declaração de princípios: ${ }^{294}$

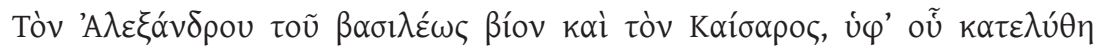

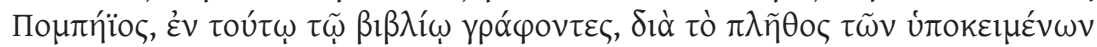

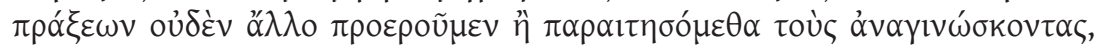

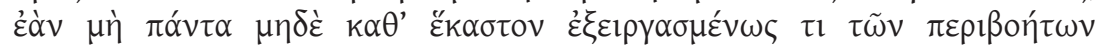

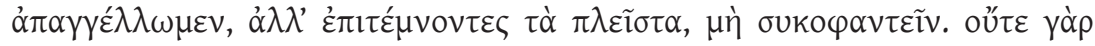

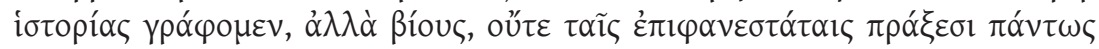

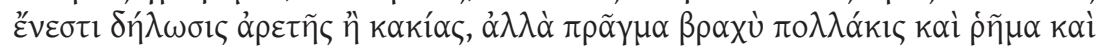

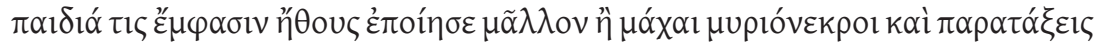

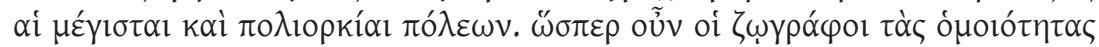

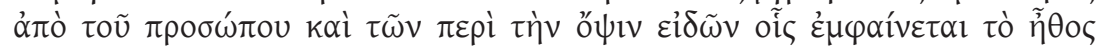

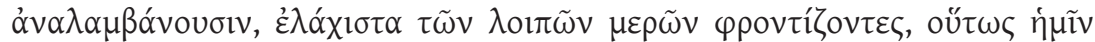

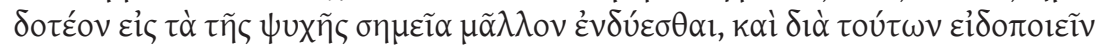

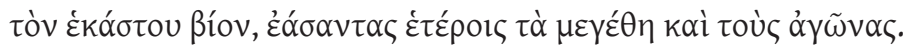

Ao escrevermos neste livro a vida do rei Alexandre e de César, por quem Pompeio foi derrotado, por causa do grande número de acções que servem de fundamento ao assunto, não diremos outra coisa em jeito de prólogo senão pedir aos leitores que, se não contarmos de forma exaustiva todos e cada um dos célebres feitos, mas resumirmos a maioria, não nos censurem. $\mathrm{Na}$ verdade, nós não escrevemos histórias mas biografias, nem a demonstração da virtude ou do vício está, por completo, nas acções mais extraordinárias; pelo contrário, muitas vezes um acto irrelevante, uma palavra ou uma brincadeira testemunham melhor o carácter do que os combates com inumeráveis mortos ou os maiores alinhamentos de exércitos e assédios a cidades. Tal como os pintores querem

um leitor profícuo.

${ }^{293}$ Cf. D. Russel (1963), C. Pelling (2002a), (2002b), (2002d), (2002e) e (2002f), A. Nikolaidis (1997), S.-T. Teodorsson (1997).

${ }^{294}$ Alex. 1.1-3; cf. Fab. 16 e Galb.2; T. Duff (2002r: 5) salienta a influência desta concepção de biografia na actualidade; este mesmo estudioso considera que é errado aplicar este manifesto a todas as Vitae, pois Plutarco pretende distinguir a sua biografia de Alexandre dos outros trabalhos historiográficos (ibid: 14 ss.). 
captar as semelhanças a partir da face e da expressão dos olhos, que são um reflexo do carácter, preocupando-se muito pouco com o resto do corpo, de igual modo nós devemos dar mais atenção aos sinais da alma e, mediante estes, representar cada vida, deixando a outros os feitos grandiosos e os combates.

Plutarco deixa claro que não é sua intenção escrever histórias, mas

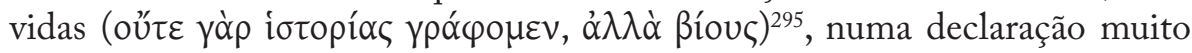
semelhante à de Políbio ${ }^{296}$, e que, além disso, o leitor — o aviso serve também para o actual leitor que deve ter em conta a intencionalidade de Plutarco, ainda que possa lamentar o facto de ele nem sempre ter sido fiel no uso das fontes ou não ter sido mais preciso e exaustivo na identificação de personagens ou no

${ }^{295}$ Apesar de aqui distinguir iozopía de ßíos, refira-se que nas cinquenta e duas ocorrências da palavra ícopía nas Vitae - distribuídas por vinte e sete biografias - nem sempre o sentido semântico é igual: em Sol. 2.1, Per. 2.4 e Cat.Mi. 12.2 historia surge com o sentido de "conhecimento" que se adquire por meio da experiência e do contacto directo; pode também significar "narração" ou "compilação de narrações, em especial quando Plutarco se refere às fontes (cf. Thes. 26.3, Rom. 2.8, Aem. 19.7, Pomp. 37.3, Cat. Ma. 12.6, Dem. 30.1, Ant. 82.4, Them. 32.4); por sua vez, em Dem. 2.1, Cat. Mi. 12.1; Thes. 1.2, Nic. 1.5, Cim. 2.5, Fab. 1.1 e Aem. 1.1, chama iotopía ao texto que pretende escrever, mas também aí parece estar mais próximo do sentido herodotiano de "pesquisa" do que de "obra histórica"; sobre este assunto, foram para nós de grande utilidade os estudos de A. Momigliano (t1991), E. Valgiglio (1987: 50-70), B. Gentili \& C. Cerri (1978: 7-27), P. Desideri (1992b: 4537-4545), P. Gómez \& F. Mestre (1997: 209-228) T. Duff (2002r: 18 ss.); pelo seu valor, transcrevemos as palavras de D. Russel (20012: 102) sobre o sentido de bios neste prólogo: "bios means roughly, 'way of life', whether in an individual or in a society (...) It also has some connotations of ordinary life, and is associated with the realm of comedy rather than with the grand topics of epic or, for the matter, history (...) Thus to describe the bios of a great man was to say 'what sort of man he was' (poios tis en) and regard him, in a sense, as one of ourselves”; sobre a concepção de história em Plutarco, além das semelhanças e diferenças entre biografia e historiografia na Antiguidade, vide J. Moles (1988: 32-6) e G. Press (1982: esp. 71-74); neste último estudo, o autor afirma que bistoria podia ter três sentidos: pesquisa, género literário e narrativa ou história (p. 23 ss.); segundo J. Hershbell (1997: 230 e 233): "no doubt that Plutarch understood history as research or inquiry after the facts. He could also think of «history» as «story», what is told or narrated (...) it is tempting to conclude that for Plutarch the difference between history and biography was that between a study of past events, and a study of human character. History has no concern with ethical judgements; biography does"; no entanto, parece-nos que, se é verdade que o móbil principal da escrita histórica não é produzir avaliações morais ou éticas, também não é totalmente correcto afirmar-se que não as faz, como o próprio autor, anteriormente citado, acaba por concluir, ao recordar a moralização do passado feita pelos historiadores gregos; por esse motivo, concordamos com E. Valgiglio (1987: 54-5): "la grande storia fa, si, anche emerger il carattere dell'uomo, ma in línea subordinata e marginale; in linea primaria stanno le pravxei" in riferimento alle nazioni, ai popoli, agli stati, e non in relazione agli individui che sono oggetto specifico della biografia”. Por fim, notamos que usar o número

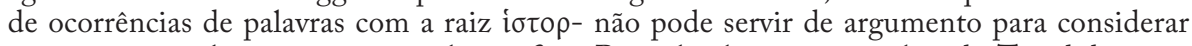
um autor mais histórico ou mais biográfico. Basta lembrar que na obra de Tucídides, que

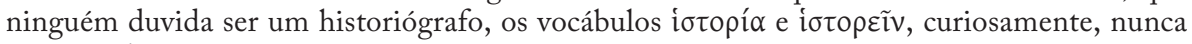
aparecem!

29610.21 . 
relato de acontecimentos que incorporam os bioi - não deve esperar o relato

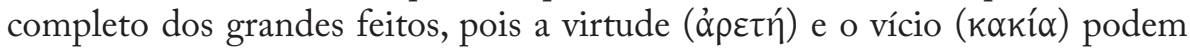
ser melhor observados nas pequenas demonstrações do carácter humano ${ }^{297}$. Convicto disso, será a partir de pequenos episódios ( $\pi \rho \tilde{\alpha} \gamma \mu \alpha \beta \beta \rho \chi \bigcup \grave{\text { ) }}$, que são normais na vida quotidiana, e muitas vezes anedóticos ${ }^{298}$, que Plutarco delineará o $e^{t h o s^{299}}$, embora saibamos que a caracterização global do indivíduo se faz com base em acções grandiosas, dignas de figurar na história, tal como os agentes que as protagonizam ${ }^{300}$.

Estabelecida a diferença básica entre o género histórico e o biográfico ${ }^{301}$

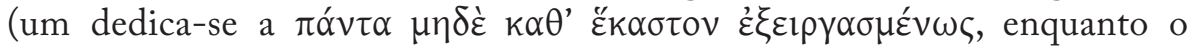

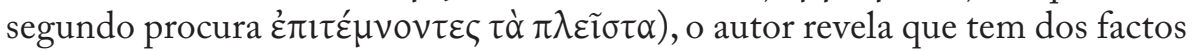
históricos um indiscutível conhecimento mas que não está interessado em usá-los na sua produção literária, pois, como vimos, o seu objectivo é outro. Além disso, quando refere a sua intenção de aprofundar a análise dos sinais da alma ( $\tau \dot{\alpha} \tau \tilde{\eta} \varsigma \psi \cup x \tilde{\eta} \varsigma$ $\sigma \eta \mu \varepsilon \tilde{\imath} \alpha)^{302}$, fazendo disso um pilar do seu projecto literário, Plutarco inscreve também os seus retratos biográficos no campo psicológico ${ }^{303}$. Como ele próprio confessa, o seu trabalho assemelha-se ao do pintor, que escolhe os traços que lhe parecem mais convenientes para ilustrar uma determinada pessoa ou a alma humana. ${ }^{304}$ Embora seleccione heróis que, pelos seus feitos políticos ou militares, merecem figurar na história, prefere apresentá-los como agentes morais. A intenção de escrever vidas e não história é comprovada pelo exercício de composição e estruturação das

${ }^{297}$ Em Nic. 1.1-5, lembra, de igual modo, aos leitores que não tem a intenção de rivalizar com Tucídides ou Timeu, mas de procurar pormenores que exemplifiquem o carácter e o comportamento do biografado, deixando de referir aquilo que não contribui para essa análise. As palavras ou discursos são, por vezes, mais reveladores do carácter de um indivíduo do que os feitos (cf. De Alex. fort. aut uirt. 330E (cf. Reg. et imp. Apopht. 172D), Phoc. 5 e Comp. Dem.Cic. 1.4.) e do que a própria fisionomia (cf. Cat. Ma. 7.3; De tuenda san. 137E); vide H. Tracy (1941-2: 213-6),

${ }^{298}$ Cf. N. Barbu (1976: 134 ss.).

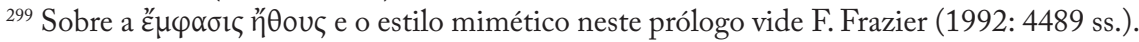

${ }^{300}$ Cf. Demetr. 1.5-8, Pomp. 8.7 e Nic. 1.5; cf. C. Pelling (20021: 283-300).

${ }^{301}$ Cf. N. Barbu (1976: 37); vide ainda a distinção feita por Políbio entre biografia e história (10.21.8; 16.14.6).

${ }^{302}$ Cf. Arist. 25.10 e Cat. Mi. 24.1.

${ }^{303}$ Este elemento reveste-se de especial significado, porque a alma está na base de um das suas divergências com os Estóicos: enquanto para estes a alma é uma entidade racional, susceptível de ser influenciada pelas paixões, Plutarco, seguindo a tradição platónica e aristotélica, identifica na alma uma parte racional e uma outra irracional, que agem entre si, devendo a parte racional saber refrear as acções suscitadas pelo thymos, pela orge ou pelos pathe; vide W. Harris (2001: 88 ss.), sobre a proximidade de sentido entre thymos e orge, bem como as distinções que os Peripatéticos operaram nestes vocábulos, estando o thymos mais relacionado com actos de coragem (cf. e.g. Arist. EN 3.8.1116b-1117a e Eud. Eth. 3.1.1229b).

${ }^{304} \mathrm{cf}$. Cim. 2.3; sobre Plutarco como pintor de caracteres e comportamentos morais, vide F. Frazier (1996: esp. 55-67) 
biografias, pois é uma pessoa singular que é deliberadamente apresentada como protagonista. Sabe-se, por exemplo, como as relações entre Pompeio e César marcaram o século I a. C.; contudo, Pompeio só aparece na biografia de César para valorizar a figura deste ${ }^{305}$. O mesmo acontece com Címon na biografia de Péricles.

Apenas para problematizarmos um pouco esta questão da proximidade entre os dois géneros, consideramos que Políbio e Dionísio de Halicarnasso nos oferecem dois bons testemunhos da relação entre biografia e história ${ }^{306}$. A este propósito, é elucidativo o que escreve Políbio sobre a biografia que dedicou a Filopémen e a relação dessa obra com as Historiae: ${ }^{307}$

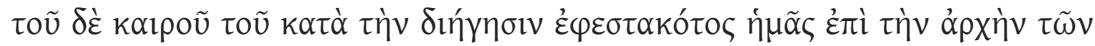

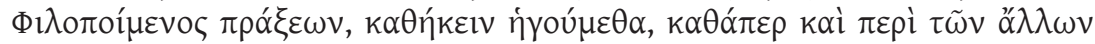
$\tau \tilde{\omega} v$ åł

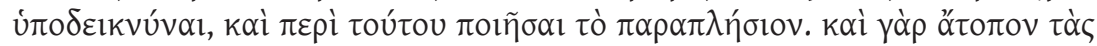

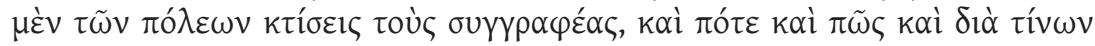

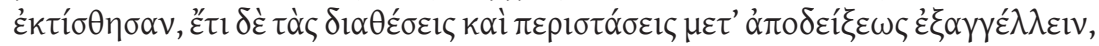

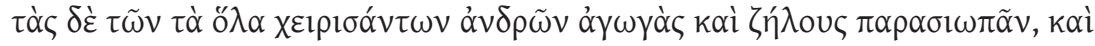

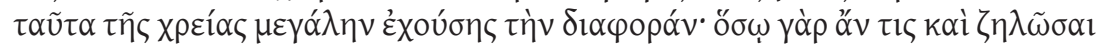

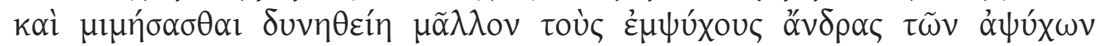

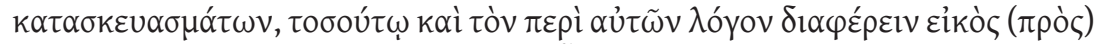

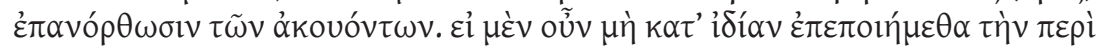

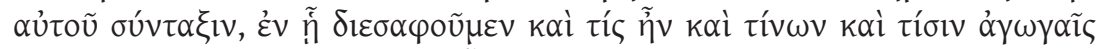

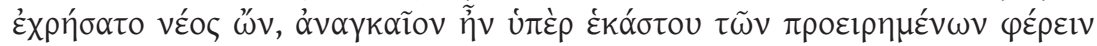

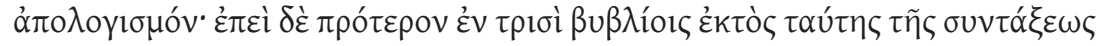

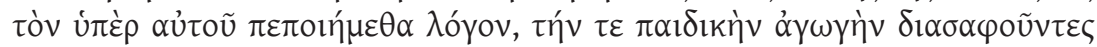

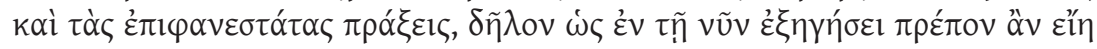

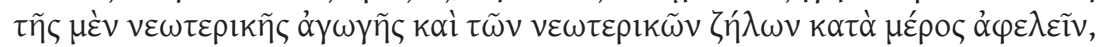

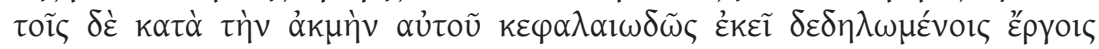

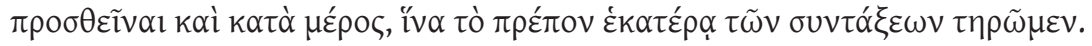

Uma vez que o percurso da narração nos colocou no início da actividade pública de Filopémen, julgamos ser conveniente fazer para ele algo semelhante ao que tentámos para outros homens distintos, que foi apresentar a formação e a natureza de cada um deles. $\mathrm{Na}$ verdade, é absurdo que os historiadores de fundações de cidades expliquem quando, como e por quem foram fundadas, e ainda revelem, para demonstração, as condições e as vicissitudes em que

${ }^{305}$ Cf. Caes. 5.7, 11.2, 13.3 , 13.5, 14.1, 14.4-7, 15.3, 21.5-9, 28-31, 33.4-6, 35-36, 40-41, 42.1, 43.6, 44.3, 45.1, 46.1, 48, 51.3, 56.6, 57.6-7, 66; vide C. Pelling (2002d: 91-115).

${ }^{306}$ Refira-se que também Tito Lívio, no praefatio da sua narrativa histórica, afirma que irá contar como o Império se gerou e como cresceu por meio da forma de vida, dos costumes, dos homens e das políticas.

307 10.21.2-7. 
isso sucedeu, mas dos homens que dirigiram estas empresas silenciam a sua formação e as suas ambições, as quais têm uma grande variedade de proveitos, na medida em que é mais profícuo admirar e imitar os homens vivos do que as construções sem vida. Desse modo, é mais conveniente para o aperfeiçoamento dos ouvintes a obra que trate dessas coisas. Se, no entanto, não tivéssemos composto sobre esse homem [Filopémen] uma obra à parte, na qual explicávamos quem era, de quem descendia e a formação que recebeu enquanto jovem, era necessário ter em conta o que havia sido dito sobre cada um destes assuntos. Mas como antes, exceptuando esta obra, escrevemos uma sobre este homem em três livros, onde expusemos a sua formação na infância e as acções mais famosas, torna-se evidente que, na presente narração, conviria tirar o que concerne à formação e às ambições na juventude. No entanto, ao que na outra obra apresentámos de forma sumária juntamos agora o que diz respeito ao momento alto da vida dele, uma vez que convém respeitar cada uma das duas obras.

Estas palavras encontram eco na concepção das Vitae.Políbio, à semelhança daquilo que fará Plutarco uns séculos depois ${ }^{308}$, pretende que se dê mais valor ao homem, quer à sua formação quer às suas ambições, e não apenas às coisas que empreendeu, uma vez que a sua obra tem por objectivo a غ̇ंavó $\beta \theta \omega \sigma l \varsigma$ dos ouvintes ou leitores por meio de coisas vivas, ou seja, o homem, autor da acção. Na verdade, o historiador de Megalópolis entendia que escrever história deveria ter um telos didáctico que os leitores entendessem, objectivo que estava acima da beleza estética do texto. Além disso, é o próprio Políbio que nos fala da obra que dedicou a Filopémen, e que na obra que está a escrever no momento não pretende repetir o que já havia escrito, apenas dar agora mais relevo à ỏkuń. Infelizmente os três livros dedicados a Filopémen não chegaram até nós para permitirem uma maior avaliação do seu conteúdo, no entanto, por aquilo que o historiador nos diz haveria certamente pontos de contacto entre as formas biográficas dos dois autores.

Quanto a Dionísio de Halicarnasso, também as suas palavras se revelam muito significativas, pois defendia que a escrita histórica não podia alhear-se da descrição do carácter:309

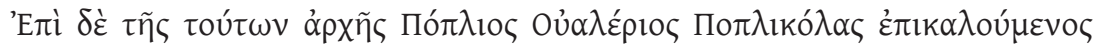

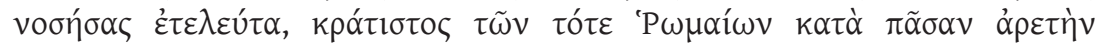

308 Não esqueçamos que as variadas referências a Políbio provam o conhecimento que Plutarco tinha da sua obra (cf. W. C. Helmbold \& E. N. O’Neil (1959: 63-4)), usando o historiador de Megalópolis como fonte válida: e.g. Phil. 16.4 (cf. Pol. 21.32.3) e Cat. Ma. 10.3 (cf. Pol. 19.1), embora também haja casos em que o critique: De fort. Rom. 325F (cf. Pol. 2.18.3) e Aem. 15.5 (cf. Pol. 29.14).

309 Ant. rom. 5.48.1 


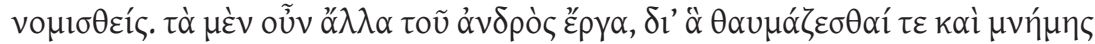

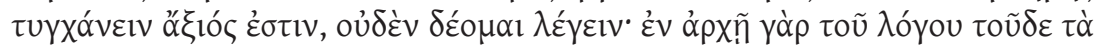

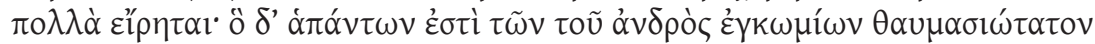

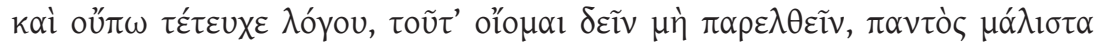

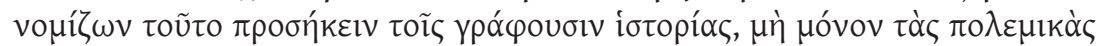

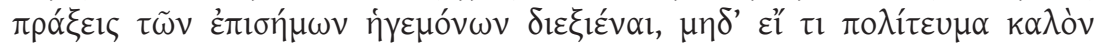

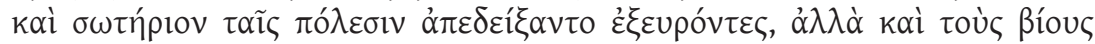

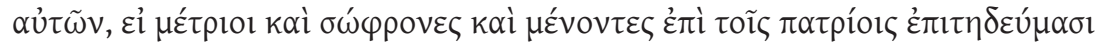

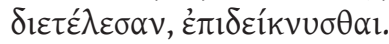

Durante o consulado destes, morreu de doença Públio Valério, chamado Publícola, considerado superior em virtude a todos os homens do seu tempo. Não preciso de referir outras acções deste homem, pelas quais é digno de ser admirado e recordado, pois no início desta narração referi muitas delas. Porém, o que é mais admirável de todos os elogios deste homem ainda não o mencionei, o que penso que não se deve omitir, pois, acima de tudo, considero que interessa ao que escreve histórias não apenas expor as acções guerreiras de distintos generais, nem somente se por sua iniciativa estabeleceram uma política conveniente e segura para as suas cidades, mas também descrever abertamente as suas vidas, se levaram uma vida com mesura e temperança, permanecendo fiéis aos costumes da pátria.

Como se constata, também Dionísio de Halicarnasso valoriza a exposição de aspectos relacionados com a conduta de vida dos protagonistas da História. Note-se que tanto Políbio como Dionísio de Halicarnasso provam a proximidade entre história e biografia ${ }^{310}$, pois pretendem aprofundar nas suas obras aspectos intimamente relacionados com o indivíduo (a génese, a formação, o carácter, a conduta, inter alia), aquilo que na biografia de Plutarco ocupa o primeiro plano. Os dois textos citados mostram como num registo literário distinto existem elementos que se repetem, pois o autor de história ou de biografia trabalha com acções e indivíduos, cabendo-lhe determinar uma metodologia própria para os seus propósitos, sem deixar de ter um fim educativo, embora a biografia procure uma educação mais moral e a história, por sua vez, uma educação mais direccionada para a política ${ }^{311}$.

As incertezas sobre a biografia antes de Plutarco podem justificar o facto de alguns estudiosos compararem as Vitae com os retratos biográficos de Cornélio Nepos ${ }^{312}$, por causa da proximidade temporal e por haver heróis retratados pelos dois. Que Plutarco tinha conhecimento da obra de Nepos não

${ }^{310}$ Cf. Nic. 1.5 (história e biografia).

${ }^{311}$ Cf. P. Desideri (1992a: 4473).

${ }^{312}$ E.g. J. Geiger (1985) (1995) (2000), V. Ramon Palerm (1992); J. Moles (1989: 232-3) manifesta algumas reservas sobre este método. 
restam dúvidas ${ }^{313}$, da mesma maneira que se aceita facilmente que terão usado fontes semelhantes. Classificar os textos de Cornélio Nepos e de Plutarco como biografia histórica não oferece grande resistência, mas nada disto se pode sobrepor às diferenças latentes entre os dois autores. Das várias diferenças, salientamos apenas duas: Nepos expõe uma visão romanocêntrica ${ }^{314}$, enquanto Plutarco faz da paideia grega a ponte entre as duas culturas; para Plutarco, ao contrário de Nepos, é primordial colocar em paralelo Gregos e Romanos, acima de tudo homens que podem servir de modelo pela forma como souberam superar as dificuldades que se atravessam no caminho de qualquer ser humano ${ }^{315}$.

Estas diferenças e outras que distinguem as Vitae de Plutarco muito contribuem para que não só se diga que ele foi herdeiro de uma longa tradição biográfica, mas que lhe juntou muita da sua criatividade ${ }^{316}$, especialmente ter conseguido aliar uma estrutura formal paralela a uma reflexão sobre a politeia, a paideia, os valores e a conduta humana, numa época muito exigente para os Gregos, ou seja, o próprio paralelismo tem um sentido pedagógico, intensificado pela synkrisis, que acaba por dominar o teor narrativo.

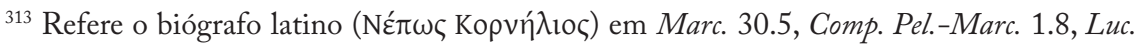
43.1, Gracch. 21.3.

${ }^{314}$ Sobre a vontade romana de afirmar a igualdade com a cultura literária grega, vide Quint. 10.1.46-131, Luc. 1.926-30, Verg. Ecl. 6.1-2, Prop. 4.1.64, 2.34.65-6, 3.1.1-2; mais elementos sobre esta matéria no último capítulo.

${ }^{315}$ Cf. De tranq. an. 467E.

${ }^{316}$ Já K. Ziegler (1951: 911-28) havia enfantizado a originalidade de Plutarco. 


\section{O Paralelismo}

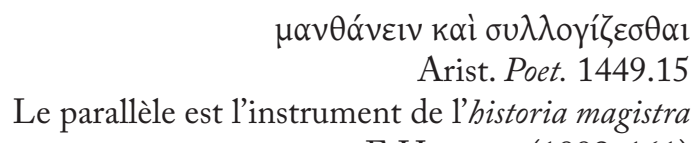

F. HARTOG (1998: 161)

Como já afirmámos, Plutarco conheceria bem os historiógrafos gregos. Porém, enquanto estes preferem dedicar-se às lutas internas e externas ou a histórias de carácter local, ele prefere colocar em paralelo Gregos e Romanos ${ }^{317}$, sugerindo que uma igualdade entre os heróis ou que a história política e feitos militares são comparáveis. A estrutura paralela das Vitae, com diversas possibilidades interpretativas, constitui para o nosso trabalho um elemento fulcral. De referir, ainda, que a tendência para estabelecer paralelismos e analogias entre a antiga e a nova potência é também evidente nos Moralia, bastando citar os tratados Quaestiones romanae, Quaestiones graecae, De fortuna Romanorum e De Alexandri fortuna aut uirtute $i-i i^{318}$, ainda que, ao contrário das Vitae, a metodologia seja aqui mais dispersa e menos sistemática. No tratado Consolatio ad Apollonium, por exemplo, encontra-se um bom exemplo desta polaridade: ${ }^{319}$

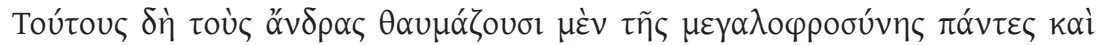

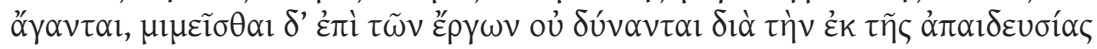

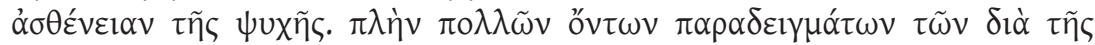

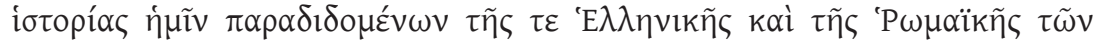

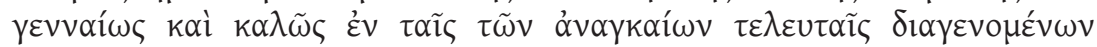

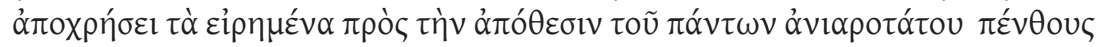

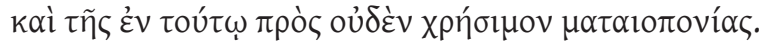

Todos admiram estes homens e invejam a sua grandeza de alma, mas não é possível imitá-los nas acções por causa da debilidade da alma que advém da falta de educação, com excepção dos muitos exemplos que nos foram transmitidos pela história helénica e romana de homens que conservam sentimentos necessariamente generosos e nobres até à morte deles; estas coisas que referi bastam para colocar de parte o luto, que é o mais penoso de tudo, e os actos inúteis, sem qualquer vantagem, que existem nele.

${ }^{317}$ Cf. E. Bowie (1970: 3-41).

${ }^{318}$ Não referimos o tratado Parallela Graecae et Romana, apesar de constar no Catálogo de Lâmprias, uma vez que pelos seus traços estilísticos não terá sido escrito pelo autor de Queroneia. 319 119D. 
Não se pode duvidar, todavia, que o binómio civilizacional e cultural Gregos-Romanos ocuparia um papel basilar nas cogitações do autor. Como têm referido vários estudos ${ }^{320}$, um dos temas abordados pela Segunda Sofística é precisamente a relação entre a Grécia e Roma, da qual Plutarco faz eco ${ }^{321}$, como depois também Díon de Prusa haveria de desenvolver nas Orationes. Essa marca estruturante da obra de Plutarco merece o seguinte comentário de D. Russel (2001²: 8): “(...) a literary demonstration of the parity and partnership of Greece and Rome, each with its contribution to make towards the development of true political virtue. The intellectual unity of the GraecoRoman world was a precarious thing; Plutarch fitly represents it at the moment before the split became incurable." Apesar das dúvidas que a unidade greco-romana gera, o diálogo entre essas duas identidades ocupa uma parte significativa nas representações literárias da época imperial, sendo interessante avaliar o tipo de paralelismo ou simetrias que se desenham nos textos, em particular na estética das Vitae.

A concepção paralela pode ser um sinal de equidade ou, inversamente, uma forma subtil de mostrar que as diferenças são muito mais marcantes do que as semelhanças. No entanto, seria redutor tentar interpretar apenas o paralelismo numa perspectiva de superioridade ou inferioridade, parecendo-nos mais correcto entender a estrutura idealizada por Plutarco, e posta em prática de forma sistemática, como uma forma de atribuir a Gregos e a Romanos, artífices de duas culturas com semelhanças e diferenças, um lugar especial e simbólico na história humana, atendendo às realizações de que foram autores: arquitectura, literatura, educação, direito, ciência, filosofia e os confrontos que travaram (por exemplo, as Guerras Medo-Persas e as Guerras Púnicas), só para referir algumas das experiências mais relevantes de ambas as civilizações e culturas, que muito marcaram e continuam a marcar o Ocidente. O desejo de estabelecer paralelos culturais obriga Plutarco a escolher os heróis que melhor

${ }^{320}$ E. g. G. Bowersock (1969), C. Jones (1971), E. Bowie (1982) e (1989), S. Swain (1998r), G. Anderson (1993), T. Schmitz (1997) e T. Whitmarsh (2001a) e (2005); estes estudos analisam a Segunda Sofística de forma diferenciada, assunto a que dedicaremos alguma atenção no ponto sobre o conceito de paideia em Plutarco.

321 Como mais adiante desenvolveremos, não é pacífica a delimitação cronológica da Segunda Sofística. Nos estudos sobre a matéria, é possível encontrar Plutarco incluído na lista dos autores que fazem parte da dela. Há também autores que acham que ele não a representa, como H. Martin Jr. (1997: 718), uma vez que Filóstrato nem o menciona nas VS; no entanto, são muitas as características que Plutarco partilha com os autores que, sem problemática, pertencem à Segunda Sofística, por isso S. Swain (1998r: 137), logo nas primeiras linhas que dedica a Plutarco, escreve: "Plutarch of Chaironeia in Boeotia is perhaps the most important author of the second sophistic period". Parece-nos abusivo colocar Plutarco à margem ou fazer dele um dos mais importantes representantes Segunda Sofística, por isso preferimos dizer que é um precursor desse fenómeno cultural, pois será em autores como Luciano, Élio Aristides ou Filóstrato que se atingirá a plenitude do movimento sofístico. 
se prestariam a ilustrar os seus objectivos, escolhas que parecem ser feitas em função do elemento romano do $\operatorname{par}^{322}$.

Além disso, como Plutarco tem a preocupação de tornar o leitor/ espectador participante da sua obra, a mensagem paralela ou a interligação cultural pode mesmo destinar-se aos seus contemporâneos, como defende S. Fuscagni (2000: 19): "[Plutarco] lo storico che ha letteralmente "inventato" il paralelismo biográfico ritenendolo, consapevolmente, il medium adatto — più di ogni argomentazione esplicita - per comunicare ai suoi contemporanei la sua idea sul come fondare una duratura e necessária intesa tra Greci e Romani." Esta estrutura paralela ${ }^{323}$ ganha, assim, um significado que ultrapassa a simples forma ou estética: dois povos, com a sua idiossincrasia, lado a lado. $\mathrm{O}$ que se torna curioso verificar é que alguns dos heróis romanos se comportam mais de acordo com os valores helénicos do que os próprios gregos, aspecto que será tratado quando aprofundarmos o conceito de paideia. Mas vejamos apenas

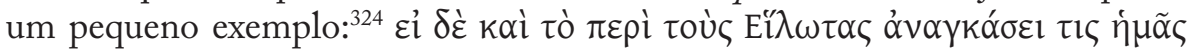

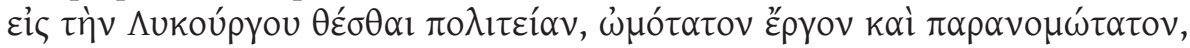

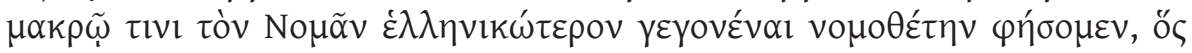

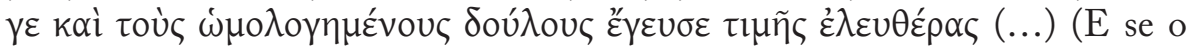
tratamento dado aos hilotas nos obriga a atribui-lo à constituição de Licurgo, prática muito cruel e ilegal, podemos dizer que Numa foi um legislador mais de acordo com o espírito helénico, pois aos que eram escravos deu a provar a dignidade da liberdade (...)). Parece não haver dúvidas de que no momento da synkrisis, onde o confronto cultural adquire especial significado, Plutarco considera a partir da análise do carácter e da acção, que um romano, neste caso Numa, tem uma conduta mais helénica do que Licurgo.

A originalidade do paralelismo de Plutarco não é tratar da história romana, pois já Políbio, por meio da teoria da symploke, se havia dedicado a analisar a ascensão romana, e Dionísio de Halicarnasso, nas suas Antiquitates Romanae, torna os Romanos o epicentro da sua obra. O que distingue verdadeiramente Plutarco é o facto de colocar, de forma sistemática e metodológica, a história grega e a história romana em paralelo, sugerindo que a história política e militar dos Gregos pode ser comparada ao imperium, tal como os "sinais da alma” podem ser retratados em conjunto. Mas, quando refere que Cícero projectava escrever uma história nacional com vários elementos da história grega $^{325}$, ou seja, uma obra com uma ideologia semelhante ao paralelismo plutarquiano, embora com uma perspectiva mais romana, Plutarco revela que

${ }^{322}$ Cf. Cim. 3.1 e Thes. 1.5.

${ }^{323}$ Para P. Desideri (1992a: 4475), artigo a que devemos muitas considerações, o paralelismo é o elemento de maior novidade formal das Vitae.

${ }^{324}$ Comp. Lyc.-Num. 1.4-5.

${ }^{325}$ Cf. Cic. 41.1. 
tinha consciência de que no passado essa estrutura já havia sido usada.

Acredita-se que o incipit do par perdido Epaminondas-Scipio exporia as razões do paralelismo das Vitae. Ainda assim, é no tratado Mulierum uirtutes, uma colecção de pequenas biografias femininas, que Plutarco explica a opção da estrutura paralela e as diferentes formas que uma mesma virtude pode tomar, ou seja, como cada indivíduo desenvolve características próprias que o distinguem ${ }^{326}$. Plutarco parece, nesse texto, acreditar que a estrutura paralela é a que melhor pode evidenciar o seu propósito de avaliar as semelhanças e as

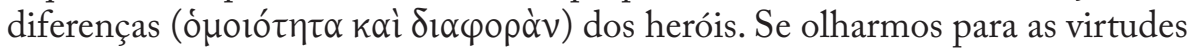
que se pretendem confrontar ( $\mu \varepsilon \gamma \alpha \lambda \circ \pi \rho \alpha \gamma \mu \circ \sigma u ́ v \eta, ~ \sigma u ́ v \varepsilon \sigma l \varsigma, ~ \varphi \rho o ́ v \eta \mu \alpha$,

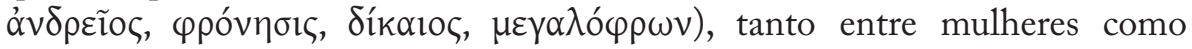
entre homens, percebemos, desde logo, que são aquelas que recorrentemente surgem nas Vitae. Como o autor gosta de referir, essas virtudes estão sujeitas

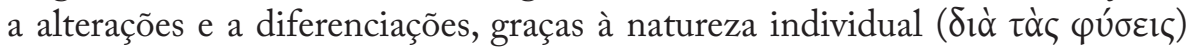
e aos hábitos ( $(\varepsilon \theta \varepsilon \sigma l)$ de cada um. O final do texto deixa entender que a Plutarco interessa, sobretudo, perceber a essência de cada personagem, sem deixar que a descoberta das diferenças se torne um processo obsessivo. Assim, estamos na presença de uma metodologia que, por meio do paralelismo, visa sobretudo aprofundar o carácter individual dos heróis. Aliás, a ênfase dada

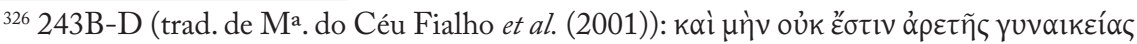

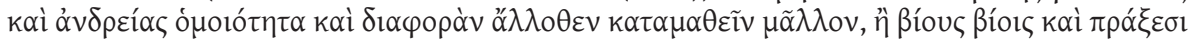

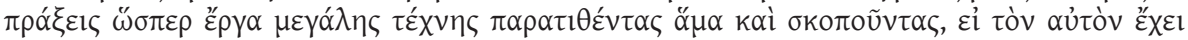

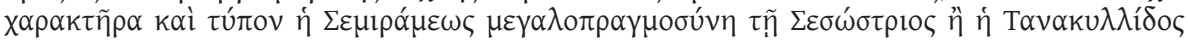

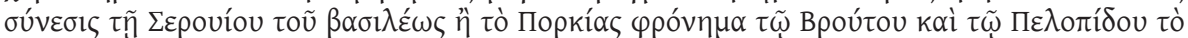

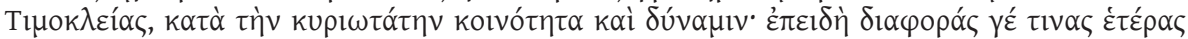

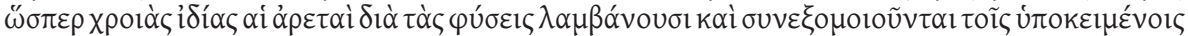

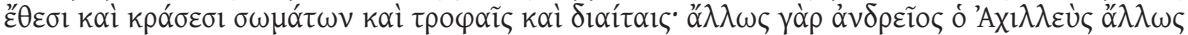

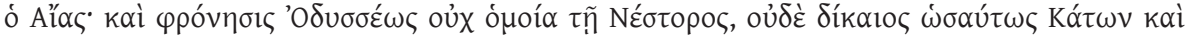

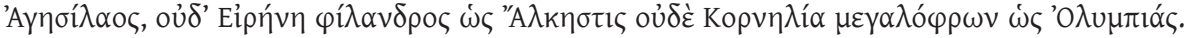

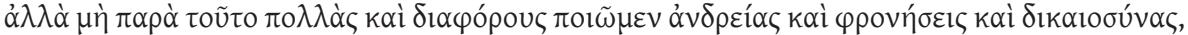

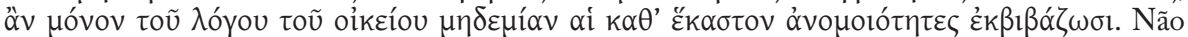
é, decerto, possível apreender melhor a similaridade e a diferença entre a virtude feminina e masculina de um outro modo que não seja através do confronto de vidas com vidas, feitos com feitos, como se faz com grandes obras de arte, e verificando se a magnificência de Semíramis tem o mesmo carácter e tipo que a de Sesóstris, ou se a inteligência de Tanaquil é a mesma que a de Sérvio, o rei, ou se a sensatez de Pórcia é a mesma de Bruto, e a de Pelópidas idêntica à de Timocleia, no que toca aos aspectos mais importantes de identidade comum e de força moral. De facto, as virtudes adquirem certas diferenças, graças à sua natureza, como se se tratasse de um cromatismo próprio, e assumem semelhanças por via dos costumes em que radicam, do temperamento das pessoas, da sua criação e modo de vida. Por exemplo, Aquiles era corajoso de um modo diferente de Ájax. A sabedoria de Ulisses não era igual à de Nestor, e Catão não era um homem justo da mesma maneira que Agesilau o era. Nem o afecto de Irene pelo marido era igual ao de Alceste, nem Cornélia era magnânima do mesmo modo que Olímpia. No entanto, não partamos destas diferenças para estabelecer uma multiplicidade e diversidade de coragens, de sabedorias e de justiças, se as disparidades particulares, por si só, não impedem cada uma destas virtudes de receber a sua própria classificação. 
à condição individual faz com que a narrativa se detenha mais nos valores e nas virtudes do que em pormenores sobre a sua acção. Nas biografias dos monarcas espartanos do século IV a. C., Ágis e Cleómenes, por exemplo, pouco se desenvolve o impacto que as reformas levadas a cabo por estes tiveram na sociedade $^{327}$. Do mesmo modo, na biografia de Fócion, estadista ateniense que é elogiado pelo seu patriotismo e firme sentido de dever, Plutarco preocupa-se com a valorização das qualidades políticas deste, omitindo quase por completo a tensão, entre a elite e uma multidão descontente com a situação social e política, que se vivia em Atenas, após as alterações políticas provocadas pela morte de Alexandre na governação macedónia. Pode dizer-se que os factos históricos, sofrendo processos de elisão e compressão ou, noutros casos, de ampliação e de invenção ${ }^{328}$, são superados pelo desejo de descrever o carácter das personagens.

Os homens retratados por Plutarco, embora revelem diferenças entre si, têm um denominador comum: a energia que dedicam à sua missão cívica ${ }^{329}$. Aliás, não é qualquer pessoa que tem qualidades para se dedicar à politeia, uma vez que ela requer, entre outras qualidades, moderação, elegância e habilidade psicológica. Esse denominador comum adquire uma expressão civilizacional pelo facto de se colocarem em paralelo Gregos e Romanos, que são julgados com critérios semelhantes, muito embora tenham vivido e agido em épocas e contextos diferentes. No entanto, a narrativa de Plutarco consegue diluir essas distâncias espaciais e temporais por assumir a primazia da caracterização do ethos, tornando os heróis actores de uma história maior, que se prolonga no tempo. Isso também se consegue pelo facto de o autor não remeter, de forma directa, para as considerações que faz para o seu próprio tempo, pois muito subtilmente o faz, ganhando a obra um sentido muito mais transversal e intemporal.

Ora, se Heródoto ${ }^{330}$, pai da história e da antropologia, ou Ésquilo, na tragédia Persae $e^{331}$, puseram em confronto Gregos e Bárbaros, e Tucídides opôs Atenienses e Lacedemónios, Plutarco, por sua vez, coloca em paralelo heróis gregos e romanos, como agentes morais e não apenas como simples actores

327 Para J. Martínez-Lacy (1988: 476-481), Plutarco interessa-se sobretudo pelos sujeitos literários, deixando para segundo plano o discernimento da verdade histórica. Refira-se que, em relação a Esparta, Plutarco parece mais interessado na valorização da mítica constituição de Licurgo do que noutro tipo de avaliação político-moral.

${ }^{328}$ Cf. D. Russel (2001²) e C. Pelling (2002a: 1-44) e (2002d: 91-115).

${ }^{329}$ É curioso que o amor, elemento essencial no romance, surge nas Vitae como um obstáculo ao cumprimento dos deveres militares e políticos, como nos casos de Demétrio e António.

${ }^{330}$ Cf. J. Redfield (2002: 24-49).

${ }^{331}$ Cf. S. Goldhill (1988: 128-93); sobre os Gregos e Bárbaros nas tragédias de Eurípides, vide S. Saï (1984: 27-53). 
históricos ${ }^{332}$. Como vimos, é possível localizar este procedimento antes de Plutarco. A escrita historiográfica de Políbio, por exemplo, está fortemente marcada pela cultura romana, embora a estrutura paralela não seja tão óbvia como a do Queronense.

As circunstâncias históricas e os condicionalismos políticos ditaram, contudo, comportamentos distintos entre Políbio e Plutarco. Este, ao contrário do historiador de Megalópolis, vive numa época em que, com Trajano, se goza em Roma um clima filo-helénico, incrementado especialmente, durante o principado de Adriano ${ }^{333}$, imperador que marca a última fase de vida de Plutarco. Favorecido pelas suas amizades romanas e pela sua reputação, este disporá de condições para avaliar ambos os povos num plano de igualdade, sem anular a sua génese grega.

Embora a narrativa biográfica esteja assente numa estrutura paralela, não se pode daí concluir que Plutarco forme sempre pares biográficos que nos pareçam naturais: por exemplo, o percurso de vida de Sertório e Eumenes não tem muitas semelhanças, formando, por causa disso, um par com ténues relações. Porém, na maioria das vidas encontramos com facilidade pontos de contacto entre os elementos do par: Coriolanus-Alcibiades, os dois mantiveram um relação problemática e conflituosas com as suas respectivas pátrias; Demosthenes-Cicero, além de oradores, participaram de forma crítica na actividade política; Philopoemen-Flamininus, ambos lutaram, à sua maneira, pela liberdade. O autor tinha plena consciência da difícil tarefa de escolha das personagens e disso dá conta nas palavras introdutórias da biografia de Teseu, em que cita, ou melhor, adapta os versos de Ésquilo: ${ }^{334}$

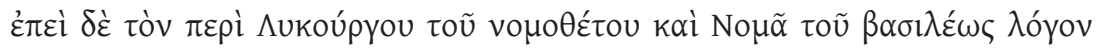

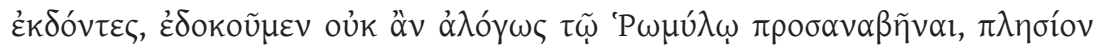

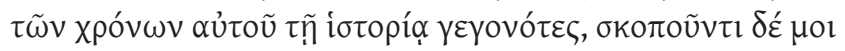

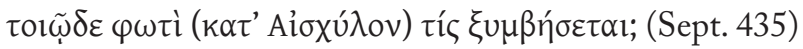

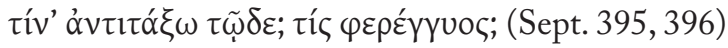

${ }^{332}$ Cf. Ph. Stadter (1997: 65-81).

${ }^{333}$ Costuma-se dar como exemplo de filo-helénicos os imperadores Nero, Adriano e Marco Aurélio, ainda que tenham tido um fascínio diferenciado pela Grécia, como nota G. Woolf (1994: 133-5): "At first sight Hadrian's attraction to sophistic culture may seem to reflect a contemporary fashion, but the same cannoot be said for Nero's interest in the Panhellenic games or for Marcus' in philosophy", facto que evidencia a diversidade do Helenismo; em relação à cultura na época de Trajano, vide E. Cizek (1989: 3-35).

334 1.4-5. 


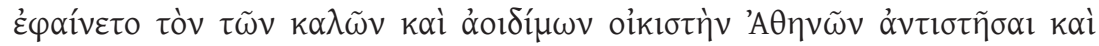

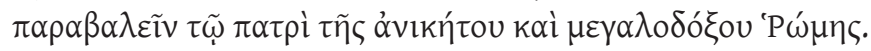

Depois que publicámos o livro sobre o legislador Licurgo e o rei Numa, não nos parecia ilógico remontar a Rómulo, pois a nossa pesquisa estava perto do tempo dele, e interrongando-me, com Ésquilo:

Quem se comparará a este homem?

Quem oporei a este? Quem é apropriado?

Pareceu-me evidente opor e comparar o fundador da bela e cantada Atenas com o pai da invencível e gloriosa Roma.

Associada ao paralelismo social, histórico e psicológico está a synkrisis. Este processo ligado à metodologia historiográfica desempenha, como vimos, um papel muito relevante na biografia plutarquiana. Note-se, no entanto, que nas synkriseis se tipificam comportamentos ou se formulam juízos de natureza ética, mas estas não são uma estrutura usada para fins encomiásticos. É, aliás, muito curioso que as synkriseis atestem bem o princípio de que os factos históricos emanam do indivíduo.

$\mathrm{Na}$ verdade, Plutarco, sem prescindir do material historiográfico, aborda o indivíduo de uma perspectiva psicológica, à qual os Antigos chamam ética. $\mathrm{Na}$ estrutura paralela, ele combina feitos históricos e apreciações morais, resultando desta fusão um conjunto de padrões éticos, adaptados às contigências do seu tempo. Acrescente-se que o paralelismo, ainda que por vezes não disfarce os desequilíbrios, que a synkrisis acentua, entre os elementos do par biográfico, exige uma leitura complementar e inclusive remete para outros outras biografias, indicador de que Plutarco, no momento da composição, trabalharia as vidas em simultâneo. De facto, isso não evitou repetições e algumas incoerências, mas reforçou a coesão e o espírito paralelo da sua arte biográfica. 



\section{A MIMESIS PAIDÊUTICA}

[Frankenstein:] “The volume of Plutarch's Lives, which I possessed, contained the histories of the first founders of the ancient republics. This book had a far different effect upon me from the Sorrows of Werter. I learned from Werter's imaginations despondency and gloom: but Plutarch taught me high thoughts; he elevated me above the wretched sphere of my own reflections to admire and love the heroes of past ages. (...) I read of men concerned in public affairs, governing or massacring their species. I felt the greatest ardour for virtue rise within me, and abhorrence for vice, as far as I understood the signification of those terms, relative as they were, as I applied them, to pleasure and pain alone. Induced by these feelings, I was of course led to admire peaceable lawgivers, Numa, Solon, and Lycurgus, in preference to Romulus and Theseus".

M. Shelley, Frankenstein, cap. 15

Nas Vitae, Plutarco, acreditando que a arte ou a estética literária tem por objectivo não só o deleite, mas também a utilidade ${ }^{335}$, procura dar aos leitores exemplos de virtude para que sintam o desejo de emulação ${ }^{336}$, pois "a alma

${ }^{335}$ Sobre a estética literária vide, em particular, A. Tagliasacchi (1961:71-117), que interpreta a techne literária como uma imitação da vida, a qual provoca, por causa da verosimilhança do seu conteúdo, impregnado de interpretações filosóficas e de mensagens de alcance moral, o desejo de transformação do indivíduo.

336 Outro testemunho revelador do interesse do autor pela emulação encontra-se em $D e$

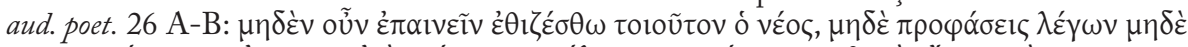

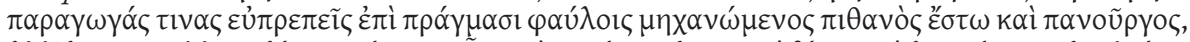

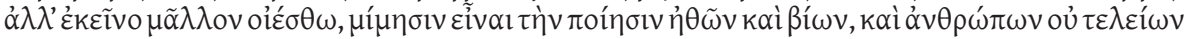

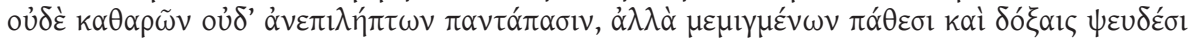

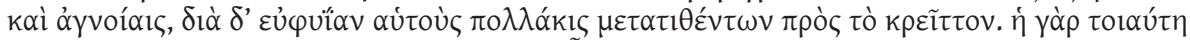

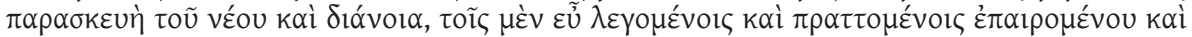

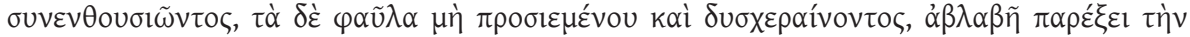

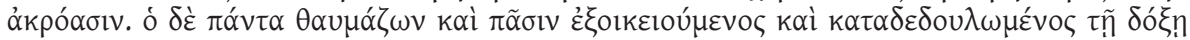

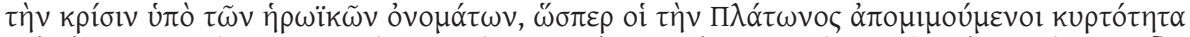

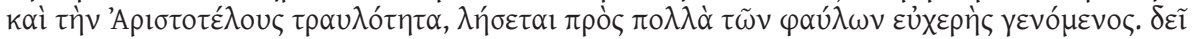

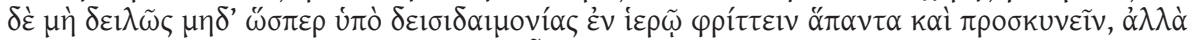

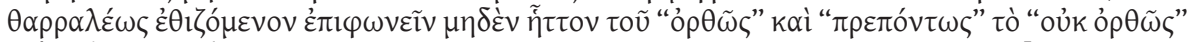

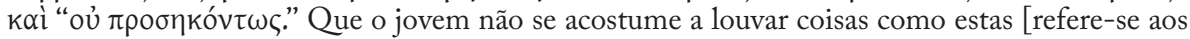
Poemas Homéricos que citou antes] nem seja persuasivo, nem hábil para encontrar pretextos, nem para maquinar enganos apropriados nas más acções, mas que acredite mais nisto: a poesia é a imitação dos caracteres e das vidas, de homens que não são perfeitos, nem puros, nem absolutamente irrepreensíveis, mas ligados a paixões e a opiniões falsas e ignorantes, mas que, muitas vezes, por meio de uma disposição natural, se alteram a si próprias para melhor. $\mathrm{Na}$ verdade, tal preparação e forma de pensar de um jovem, estimulado e entusiasmado com as coisas bem ditas e bem feitas, e sem admitir ou recusar as más, tornará inconsequente a acção de ouvir. Pelo contrário, aquele que admire todas estas coisas e as assimile e seja escravizado na sua opinião pela maneira de ser das personagens heróicas, como os que imitam a forma curva do corpo de Platão e a tartamudez de Aristóteles, sem perceber que se deixavam levar para muitos males. Por isso, é necessário não tremer timidamente ante tudo nem prostrar-se num templo, como sob a influência da superstição, mas acostumar-se a falar de forma resoluta, não menos que 


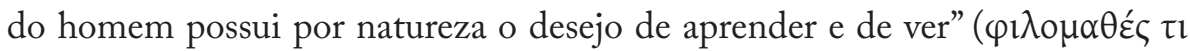

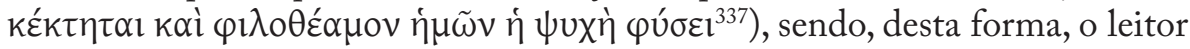
também uma espécie de espectador. Como refere nas palavras introdutórias da biografia de Péricles, ao analisar as diferentes formas de imitação, a simples observação da virtude leva a imitá-la: ${ }^{338}$

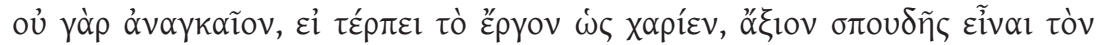

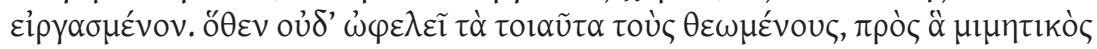

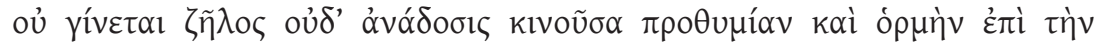

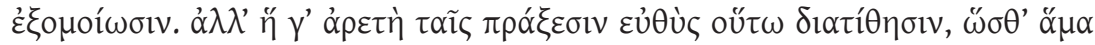

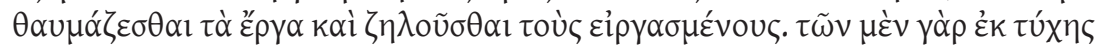

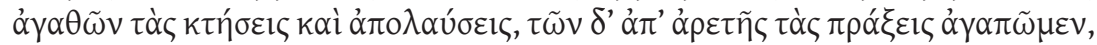

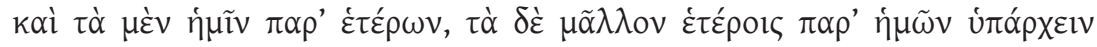

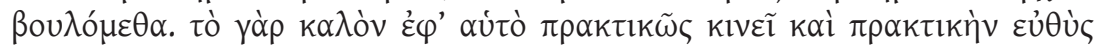

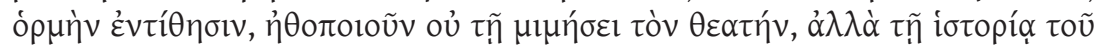

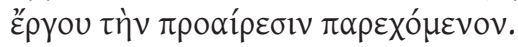

É possível que uma obra possa deleitar com a sua graça, mesmo quando o autor não é forçosamente digno de ser estimado. Por isso os que observaram as obras que tratamos não tiraram proveito, por não lhe suscitar o desejo de imitação, nem o desejo que move a vontade e o impulso para ser semelhante. No entanto, a virtude, com as suas acções, depressa dispõe o espírito de tal forma que, ao mesmo tempo, admira essas obras e imita os que as realizaram. De facto, dos bens vindos da fortuna satisfaz-nos o sentimento de posse e o prazer, enquanto dos que nascem da virtude preferimos as acções; desejamos que os primeiros bens resultem para nós de outros, enquanto os segundos desejamos mais que os outros os tenham por nosso intermédio. É que a beleza moral exerce uma viva atracção e gera de imediato um desejo pela acção, não por moldar o carácter daquele que a contempla pela simples imitação, mas, acima de tudo, porque desperta a vocação ${ }^{339}$ pelo conhecimento prático da acção.

Repare-se na forma como Plutarco enfatiza as acções que são geradas pela arete, por oposição aos benefícios que o homem pode receber por intermédio da tyche, sem que se proponha a renúncia a estes. Apenas se valoriza a arete por ela ter a capacidade de gerar o efeito mimético pretendido pelo autor, pois somente o que se consegue pelo impulso da arete revela empenho e capacidade pessoal, capazes de suscitar nos outros o apelo por realizar obras de tamanha grandeza. Nesse sentido, a arete está ligada ao mérito individual, enquanto

\footnotetext{
"é justo" e "convém" ou "não é justo" e "não convém".

${ }^{337}$ Per. 1.2.

${ }^{338}$ Per. 2.1-4; vide a análise que T. Duff (2001: 351-364) faz deste prólogo.

${ }^{339}$ Sobre o sentido de proairesis, vide A. Pérez Jiménez (1995) e T. Duff (2002r: 39).
} 
a tyche resulta de um processo transcendente, podendo não ter qualquer participação voluntária. O texto, na reflexão final, diz-nos que a formação do carácter do leitor-espectador $(\theta \varepsilon \alpha \tau \eta ́ v)^{340}$ não se faz apenas pela imitação, mas também pela investigação das aç̧ões ${ }^{341}$, na qual tanto o escritor como o leitor estão implicados ${ }^{342}$. Significa, ainda, que a intenção das Vitae não se resume à simples criação de um impulso (ópuń) ${ }^{343}$ de mimesis no leitor, mas implica

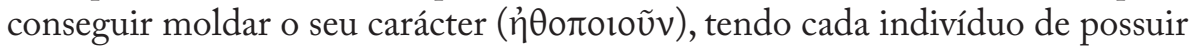
a capacidade de fazer as melhores escolhas, precisamente aquelas que lhe trarão a eudaimonia. Assim, as Vitae são, simultaneamente, uma interpretação das acções do passado e um primeiro impulso auxiliar na hora de se tomarem as opções na praxis. Nesse sentido, imitar, educar e aprender são, por conseguinte, indissociáveis para o autor e também para o leitor/ouvinte.

Se Plutarco pretende, como temos tentado demonstrar, que o leitor imite as acções virtuosas do passado, como se compreende que inclua no conjunto das Vitae exemplos de homens que não se distinguiram pelo seu carácter virtuoso, mas pelos seus defeitos? Figuras como Marco António, Demétrio, Mário ou Coriolano dificilmente se enquadram no modelo de virtude a emular! O próprio autor nos dá a resposta a esta questão no prólogo do célebre par DemetriusAntonius $^{344}$, em que justifica a introdução de homens com mais vícios do que

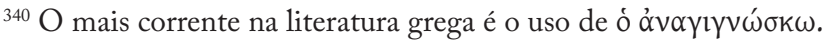

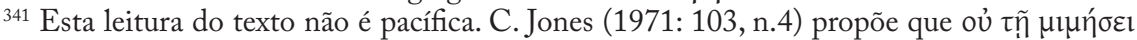

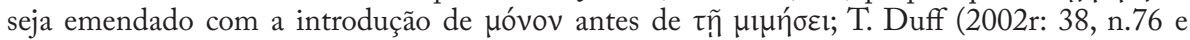
77), no entanto, julga que a emenda não é necessária, pois é possível considerar que a frase introduzida por $\dot{\alpha} \lambda \hat{\lambda} \dot{\alpha}$ ganha supremacia sobre a frase anterior.

${ }^{342}$ Também Tucídides implica o escritor e o leitor no mesmo acto de investigação (cf. 1.1.3; 1.21.2; 1.22.2-4).

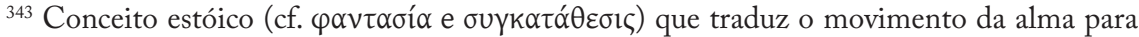
alguma coisa ou um acto de rejeição; em outros momentos, Plutarco usa a palavra porń (e.g. Cam. 28.5, Per. 11.2, Cor. 1.1, Pel. 29.2, Arist. 5.2, Comp. Pyrrh.-Mar. 5.4, Luc. 22.4 e Cic. 5. 6), que tem um sentido muito próximo.

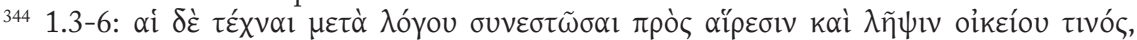

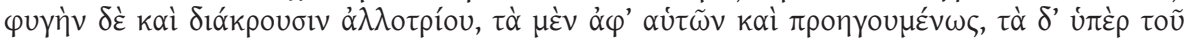

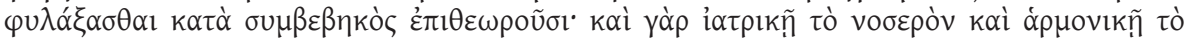

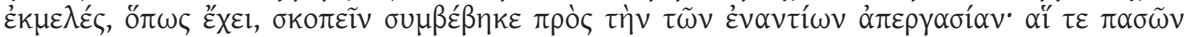

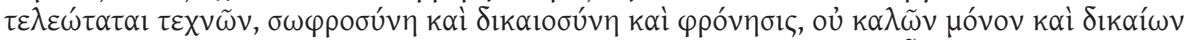

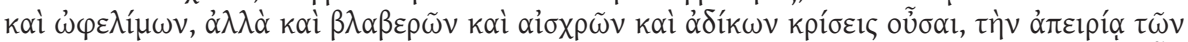

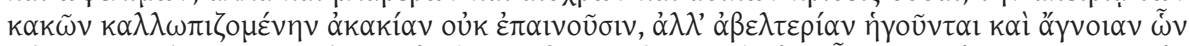

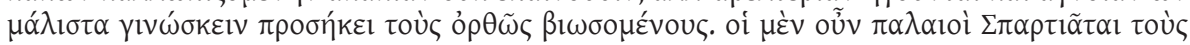

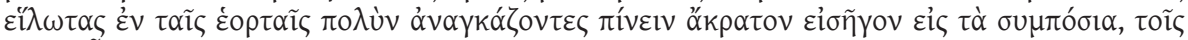

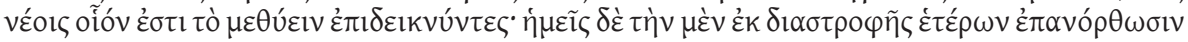

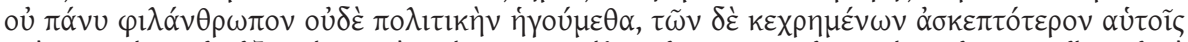

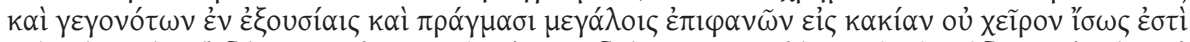

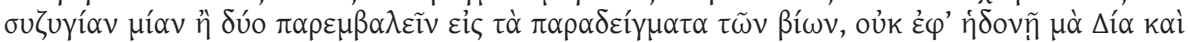

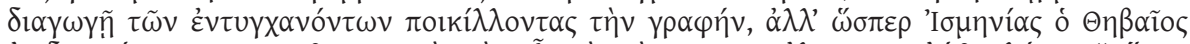

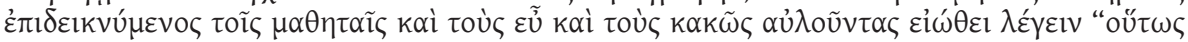

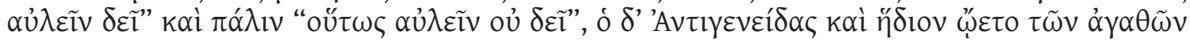


virtudes nas suas Vitae, tal como acontece com o par Coriolanus-Alcibiades ${ }^{345}$.

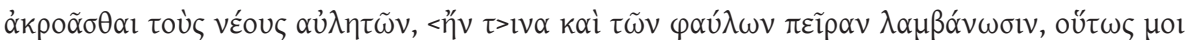

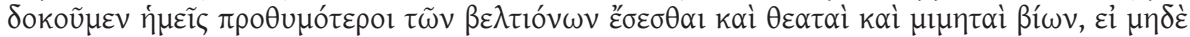

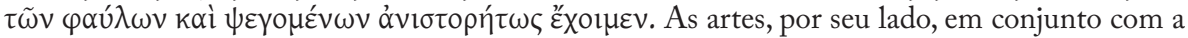
razão, escolhem e recebem o que lhes é conveniente ou fogem e afastam-se do que lhes é hostil; examinam, no início, as coisas por elas próprias com atenção e defendem-se, de seguida, contra o que vai ao seu encontro de forma fortuita. De facto, sucede que também cabe à medicina observar a doença e à música o que é dissonante, de forma a produzirem o oposto. As mais perfeitas das artes, isto é, a moderação, a justiça e a inteligência, não ajuizam apenas o que é belo, justo e útil, mas também aquilo que é funesto, ignominioso e injusto, pois não aprovam a inocência que se vangloria com a ignorância do mal, mas consideram isso uma patetice e um desconhecimento de que convém sobretudo conhecer os que sabem viver correctamente. Nesse sentido, os antigos Espartanos obrigavam, nas festas, os hilotas a beber muito vinho puro e introduziam-nos a seguir nos banquetes, para mostrar aos jovens o que é a embriaguez. Pela nossa parte, não consideramos que corrigir uns com a perversão de outros seja humano ou esteja em conformidade com a acção política, mas talvez possa não ser má ideia introduzir nos exemplos das minhas vidas um ou dois pares de homens que se guiaram por algo sem valor, que chegaram ao poder e com grandes actos de renome se entregaram ao vício (....); de igual forma, parece-me que nós seremos espectadores e imitadores mais benévolos das vidas dos melhores se não deixarmos de mencionar os que foram vis e dignos de censura.

Sobre a introdução de jovens nas festas espartanas para aprenderem os efeitos nocivos do álcool, Plutarco, em Lyc. 28.8 e 12, não apresenta esta metodologia da educação espartana como um defeito, mas realça os seus efeitos positivos; vide, ainda, De coh. ira 455E. Além disso, a afirmação, no fim do texto, de que é necessário mencionar aqueles que não foram um bom exemplo remete-nos para Platão, Rep. 396C-E.

${ }^{345}$ L. Piccirilli (1989: 14-16), F. Titchener (1991), H. Martin (1995) juntam o par Nic.Cras., como um exemplo negativo; A. G. Nikolaidis (1988: 331-2) junta, além do par Nic.-Cras., o par Pyrrh.-Mar.; L. Piccirilli (1990: xxix-xxxiv) considera que é necessário agrupar as vidas por 3 categorias: os bons, os maus e uma categoria intermédia onde figurariam os pares Nic.Cras. e Cor.-Alc. (embora nos estudos (1989:14-16) e (1993: xiii-xiv) classifique o par Nic.-Cras. como um exemplo negativo); a propósito do par Cor.-Alc., vide D. Russel (1963) e (2001²: 108) e T. Duff (2002r: 205-240); por exemplo, C. Pelling (2002e: 117-141), comparando os aspectos negativos que Plutarco aponta com os de Tucídides, não concorda com os que pretendem juntar Nic. ao grupo dos "maus exemplos". Parece-nos que a tripartição proposta por L. Piccirilli, ainda que seja legítima, limita um pouco a análise dessas vidas, pois os heróis não são globalmente maus ou bons, e, mesmo no par Demetr.-Ant., é possível encontrar virtudes (Cf. C. Pelling (1994r: 10-18)). J. Walsh (1992: 217-8), por sua vez, deixando de lado a biografia de Flaminino, considera que também a vida de Filopémen, por causa da sua philonikia, é um exemplo negativo. Atendendo ao significado da figura de Filopémen, o "último dos Gregos" que dedicou a sua vida à luta pela liberdade, não nos parece que Plutarco o quisesse apresentar como um mau exemplo; por fim, notar que de acordo com a cronologia proposta por C. Jones (1966: 66-68) os pares Phil.-Flam., Cor.-Alc., Nic.-Cras., Dem.-Ant. e Pyrrh.-Mar. (o par Lys.-Sull. também contém vários elementos negativos, mas não faz parte da produção final do autor) pertencerão, com as reservas que uma classificação desta sempre suscita, à fase final da escrita das Vitae. Será isto uma mera coincidência? T. Duff (2002r: 63) acha que não: "It is surely also no coincidence that the majority of these challenging pairs of Lives, whose subjects have something of the great nature turned bad in them, are of men who lived outside of what Plutarch would have considered the golden age of their countries, in which he considered the exercise of virtue was more difficult or the temptations of power very great". O que julgamos que não merece qualquer

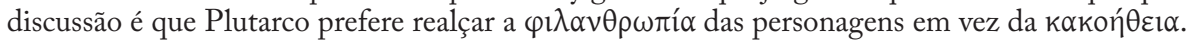


Da mesma forma que o médico ${ }^{346}$ ou o músico precisam, respectivamente, de prestar atenção à doença e aos sons dissonantes, também Plutarco não pode ser indiferente às kakiai para expor a verdadeira arete, uma vez que, para se

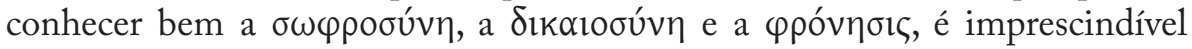
aprofundar os seus contrários. Desta forma, o autor, ao interligar virtude e conhecimento, partilha do pensamento tradicional helénico, valorizando o esforço pessoal na procura dos melhores modelos. Até porque, no texto, o logos não é alheio às techna $i^{347} \mathrm{e}$, bem pelo contrário, aquele que pratica a arete tem poder de discernimento para distinguir o que deseja assimilar e o que prefere censurar e rejeitar. Além disso, é necessário que o leitor, fazendo uso da paideia, saiba que a literatura não representa ou imita apenas bons modelos, mas é preciso saber distinguir aquilo que é bom e mau ${ }^{348}$.

Por isso mesmo, Plutarco não receia dar o exemplo na sua obra de homens com vícios, pois pensa que o leitor deve, em primeiro lugar, conhecer e, depois, saber discernir o bom do mau. Não se fique, contudo, com a ideia de que Demétrio e António são exemplos totalmente negativos, sem qualquer tipo de virtude. No seguimento do texto que citámos, Plutarco, certamente

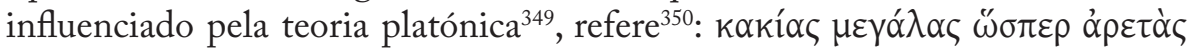

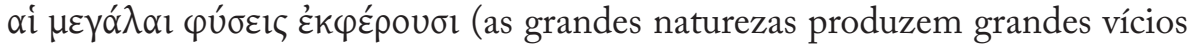
como grandes virtudes). Apresenta, assim, Demétrio e António - que D.

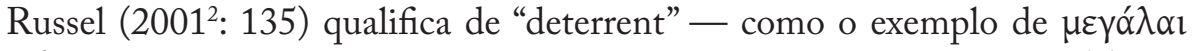

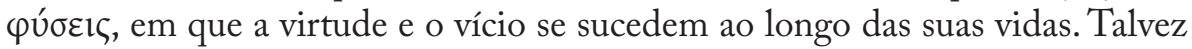
seja pelo facto de estarmos na presença de "grandes naturezas", que se torna tão complicado entender onde se encontra a fronteira entre o bom e o mau paradigma. O próprio Alexandre Magno não surge apenas como paradigma de virtudes e da paideia grega, mas tem também outros atributos menos positivos, como o vício da bebida e a forma pouco "democrática" como exerce o poder, factos presentes na biografia que Plutarco lhe dedica.

Ainda em relação a este prólogo, cabe referir que a exposição dos vícios tem igualmente uma função dentro da ideologia da paideia. Será muitas vezes

${ }^{346}$ Sobre o uso do médico como referente educacional, vide J. Martín del Pozo (1996: 185192).

${ }^{347}$ Enquanto no prólogo de Per.-Fab. existe uma antítese entre logos e aisthesis, neste caso a razão é associada às technai.

${ }^{348}$ Distanciando-se, neste caso, dos preceitos platónicos, em De aud. 26A, defende que o estudante não deve apenas aprender aquilo que se deve imitar, até porque a poesia não representa apenas o que é bom, mas caracteres excessivos e longe da perfeição. Este princípio, como já referimos, aumenta a responsabilidade da paideia, no papel que tem em educar a interpretação textual, havendo o risco de a poesia não ser devidamente analisada em meios menos cultos, o que não era o caso das elites greco-romanas.

${ }^{349}$ Cf. Rep. 491b-492a; vide também De sera num. uind. 551D-552D.

${ }^{350}$ Demetr. 1.7. 
a paideia, aliada ao logos, que corrigirá a physis do ser humano e as anomaliai ${ }^{351}$ que lhe são inerentes, como se constata em relação a Temístocles: ${ }^{352}$

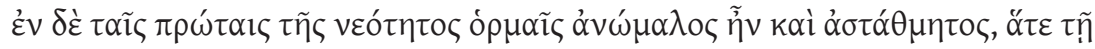

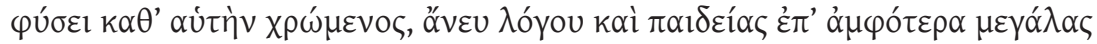

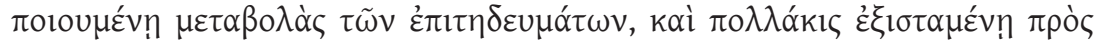

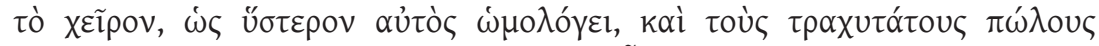

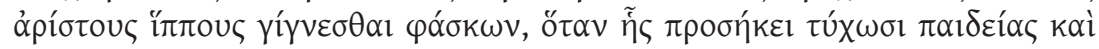

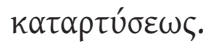

[Temístocles] Era desigual e instável nos primeiros impulsos da juventude, deixando-se seguir pela sua natureza, que, sem a razão e a educação, induz grandes transformações na forma de vida, tanto para um como para outro extremo, e que muitas vezes pende para o pior lado, como ele próprio mais tarde confessa, afirmando que mesmo os mais irascíveis potros se tornam excelentes cavalos, quando recebem a educação e a disciplina que convém.

No fundo, quer a natureza seja boa quer nos casos em que ela seja menos perfeita, a paideia tem sempre um papel a desempenhar, algo de positivo a acrescentar. É nisto que Plutarco acredita, pois - permita-se esta imagem - tal como ao médico é possível atenuar ou curar um doença, também a boa educação pode conduzir o indivíduo para aquilo que é justo e verdadeiro, num processo de exigência e esforço: a physis e a paideia necessitam continuamente de ser estimuladas no sentido do bem e da dignificação e realização pessoal do indivíduo ${ }^{353}$.

Por um lado, o autor, ao escrever, lega aos leitores do seu tempo e aos vindouros uma memória ${ }^{354}$ com uma evidente função didáctica, um pouco à semelhança do princípio "aprender com o passado", e, por outro, muitas vezes

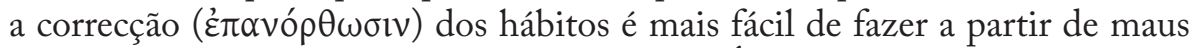
exemplos do que com base nos bons exemplos. É o que veremos em relação ao par Alcibiades-Coriolanus. Além disso, vivendo Plutarco numa época de conflitos e de crise de valores, a apresentação só de homens virtuosos não reflectiria com

${ }^{351}$ Cf. anomalia no carácter de Sull. 6.7-8, 14-15, 30.6, ainda que neste casos, e por isso os referimos, Plutarco não estabeleça uma relação com a paideia deficiente; cf. Lyc. 8.1, 9.1, Num. 18.1-3, Them. 2.7, Alc. 16.9, Phil. 3.4, Mar. 1.5, 20.10, Alex. 16.2, Phoc. 6.2, Cic. 10.5; se, em alguns destes casos, a anomalia é da physis, outros - a maioria —, são fruto das circunstâncias da vida, da tyche, do divino ou da incorrecta paideia que faz com que o indivíduo seja incapaz de discernir o correcto do incorrecto, o bem do mal.

352 Them. 2.7.

${ }^{353}$ Plutarco usa a figura do médico para explanar as suas ideias sobre a educação, recuperando, no fundo, uma metáfora platónica, a qual relaciona a arte da medicina com o método dialéctico de Sócrates, sem deixar de apontar algumas diferenças (cf. P1. Sph. 230b 4).

${ }^{354}$ E.g. Tácito considera que o vício deve ser recordado para a posteridade (cf. Ann. 3.65). 
exactidão a realidade, algo que não seria o seu objectivo, se atendermos à ênfase que coloca na imitação dos valores pela praxis. Embora haja a tendência de olhar para o passado como algo glorioso e modelar, não pode o historiador ou biógrafo apagar os exemplos menos edificantes. Seguindo este princípio, não deixa de ser curioso que Plutarco critique Heródoto por este fazer referência a alguns factos desfavoráveis às cidades gregas, classificando o autor das Historiae como um $\varphi \imath \lambda o \beta \alpha ́ \alpha \beta \alpha \rho \circ \varsigma^{355}$.

Ainda sobre as potencialidades pedagógicas dos exemplos menos dignificantes, Plutarco, defendendo que a literatura pode ser um boa introdução ao estudo da filosofia, disciplina que integrava o nível superior, sabe que muitas vezes os textos descrevem acções menos próprias, mas que, mesmo assim, podem ter o seu valor: ${ }^{356}$

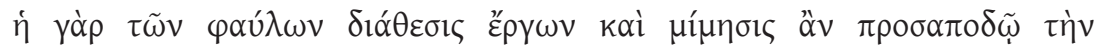

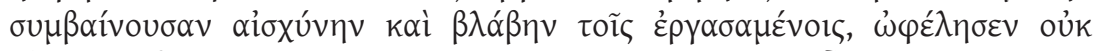

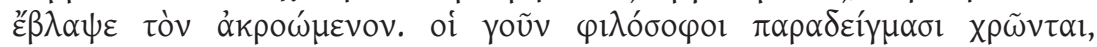

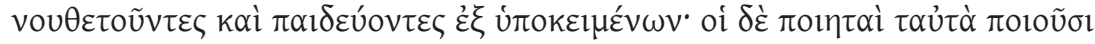

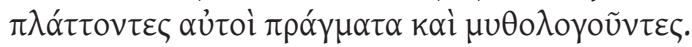

De facto, a descrição e a imitação das acções funestas, se representarem a desonra e o dano que causam aos que as realizam, têm utilidade e não prejudicam os que as ouvem. Os filósofos recorrem sem dúvida a exemplos, quando pretendem corrigir e ensinar a partir dos feitos que estão perto; os poetas, por sua vez, fazem estas coisas inventando eles próprios os factos e dando-lhes a forma de mitos.

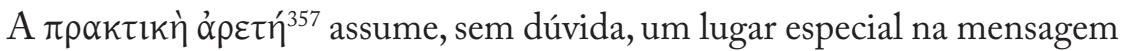
das Vitae e também dos Moralia, pois Plutarco tinha consciência de que não poderia basear a sua estratégia na filosofia abstracta ou na pura eloquência formal ${ }^{358}$, mas no exercício da virtude prática, sendo necessário para isso educar aqueles que detinham o poder ${ }^{359}$, não tivesse ele vivido numa época

${ }^{355}$ De Herod. mal. 857A; em De Alex. fort. aut uirt. 344B o mesmo vocábulo é aplicado à tyche, sendo sintomático que Plutarco não volte a usar mais este adjectivo na sua obra.

${ }^{356}$ De aud. 20B-C; sobre o uso de acções malévolas para ensinar, S.-T. Teodorsson (2005a: 662) opina o seguinte: "Plutarco arguye incluso, a favor de la descripción de malas acciones y sus consecuencias nocivas y deshonrosas, que pueden ser más útiles que la filosofía, puesto que clarifican con mayor eficacia, mediante acciones inventadas, mientras que la filosofía utiliza sobre todo admonición e instrucciónes sistemáticas.”

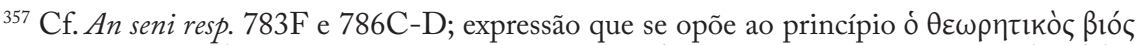

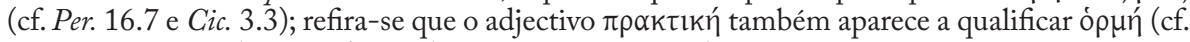

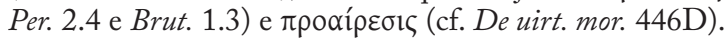

358 Considera que para o político vale mais o conteúdo do que os aspectos formais do discurso (cf. Praec. ger. reip. 802E-F).

${ }^{359}$ Sobre as virtudes que um político deve ter vide Praec. ger. reip. 799A, 800B-801A e 821B; 
decadente a nível moral. Mas, ao valorizar os actos em vez das ideias, não estará a ser incongruente com a sua obra? Talvez não. Um primeiro argumento pode encontrar-se no De Alexandri fortuna aut uirtute, em que Alexandre é considerado um filósofo e a própria filosofia é acção. Por sua vez, no tratado $D e$ gloria Atheniensium, discutindo se a glória de Atenas se deve mais aos homens ligados à arte ou aos generais e políticos, o autor confessa que prefere o general ao pintor, o troféu à pintura e a verdade à imitação ${ }^{360}$, chegando mesmo a dizer que até os poetas consideram os actos mais importantes do que as palavras. ${ }^{361}$ Saliente-se que, nesse mesmo tratado, Plutarco esboça uma acusação aos Atenienses por gastarem mais tempo com os dramas trágicos do que com as guerras contra os bárbaros, em favor da hegemonia e da liberdade da sua pátria. Segundo ele, a gloriosa Atenas, que fomentou tão diferentes artes ${ }^{362}$, não teve nenhum autor épico ou lírico célebre, a comédia era indigna e a tragédia só foi divulgada por causa do espectáculo ${ }^{363}$. Por isso, comparando, em tom irónico, a acção de Péricles e de Isócrates, afirma que o polemos contribuiu mais do que a sophia para a sua glória: ${ }^{364}$

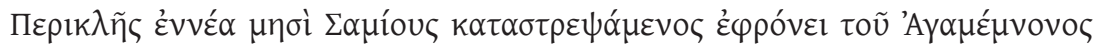

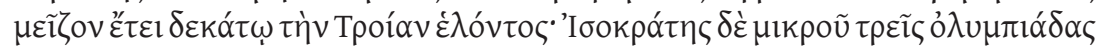

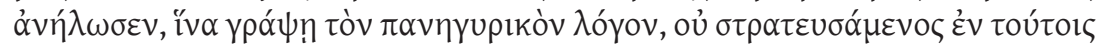

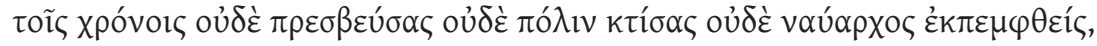

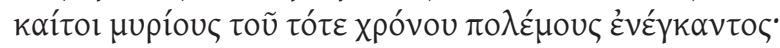

Após ter subjugado os Sâmios em nove meses, Péricles orgulhava-se mais do que Agamémnon pela conquista de Tróia no décimo ano; Isócrates gastou quase três Olimpíadas [doze anos] para escrever o Panegírico ${ }^{365}$, e durante esse tempo não participou em nenhum conflito, nem fez parte de embaixadas, nem fundou nenhuma cidade, nem foi enviado como chefe de uma frota, embora tivessem ocorrido muitas guerras nesse tempo.

Este tratado, ao recordar os feitos heróicos do passado, de homens como Péricles e Temístocles, evoca eloquentemente uma memória, que serve de sinal para o tempo presente e tem também um papel pedagógico. Não é um apelo a que surjam combatentes que lutem contra Roma, mas que os Gregos saibam

Cor. 15.4.

${ }^{360}$ Cf. De gloria Ath. $346 \mathrm{~F}$.

${ }^{361}$ Cf. ibid., 347F-348A.

${ }^{362}$ Cf. ibid. $345 \mathrm{~F}$.

${ }^{363}$ Cf. ibid. 348B-C.

${ }^{364}$ Ibid. 350E-F.

${ }^{365} \mathrm{Em} X$ or. uit. $837 \mathrm{~F}$ afirma-se que para uns demorou dez e para outros quinze anos a escrever o Panegírico; Quint. Inst. Or. 10.4.4 segue a lição que indica a duração de dez anos: panegyricum Isocratis qui parcissime decem annis dicunt elaboratum. 
permanecer fiéis a uma herança cultural, repleta de confrontos grandiosos e de sabedoria, bem representada nos diversos tipos de arte.

Para que o efeito mimético não se perdesse, tendo em conta que retratava figuras de um passado distante e outras, as Romanas, pouco familiares para os Gregos, e para que não houvesse um desfasamento entre os biografados e a realidade, Plutarco, na redacção das Vitae, teve de aproximarse da metodologia do historiador, de modo a ser o mais objectivo possível, partilhando a este nível muitas características com os seus contemporâneos. Assim, logo que tivesse definido o objectivo da narrativa e a leitura prévia das fontes estivesse realizada, passava à elaboração de um bypomnema que seguia geralmente uma só fonte, embora aludisse a muitas outras. Depois, redigia uma versão definitiva a partir das fontes, apoiada em larga medida na memória ${ }^{366}$. A forma "peculiar" como utilizava as suas fontes, atestada pela forma como atribui a uma personagem determinados feitos ou atitudes que os historiadores não registaram, quer quando omite ou sobrevaloriza outros elementos em favor da caracterização do biografado, revelam a sua liberdade criativa. Como refere na biografia de Demóstenes, tinha a firme intenção de

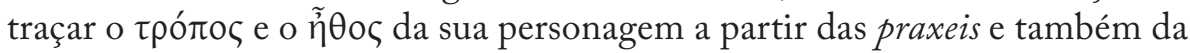
actividade política. ${ }^{367}$

De tal forma valoriza o indivíduo, sem o desvincular do tempo histórico em que viveu, que, como sustenta B. Bucher-Isler (1972) ao fazer o catálogo de virtudes e vícios das personagens, a documentação histórica é apresentada em função da perspectiva ética ${ }^{368}$. Note-se, aliás, que o facto de o herói ser a figura central se prova pela seguinte constatação: quando o herói é o protagonista da narrativa, o relato é feito na terceira pessoa do singular, enquanto no momento da narração histórica ( forma impessoal. É o herói e as suas características que dominam a narrativa, mesmo que isso signifique prescindir do relato integral da acção.

Plutarco sabe que antes dele outros discorreram sobre as personagens que agora seleccionou para as Vitae, mas isso não o parece preocupar, antes o incentiva a procurar um estilo próprio. No prólogo da biografia de Nícias, por exemplo, manifesta o desejo de abreviar o que outros autores já desenvolveram de forma até mais pormenorizada: ${ }^{370}$

${ }^{366}$ Cf. C. Pelling (2002a: 1-44).

${ }^{367}$ Dem. 11.7.

${ }^{368}$ Também os estudos de C. Pelling (2002d: 91-116) e de D. Russel (1963: 21-8) revelam a interdependência entre o indivíduo e a história, considerando que Plutarco dá notoriamente a primazia ao indivíduo.

${ }^{369}$ De Herod. mal. 856B.

${ }^{370}$ Nic. 1.5 . 


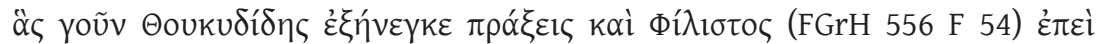

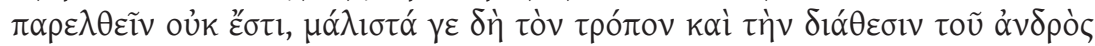

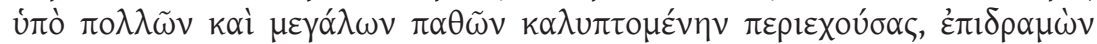

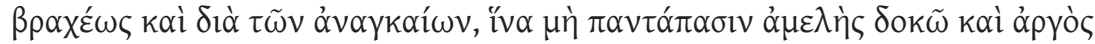

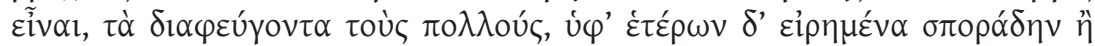

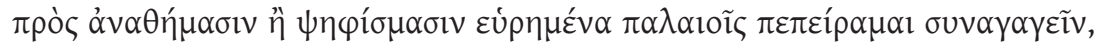

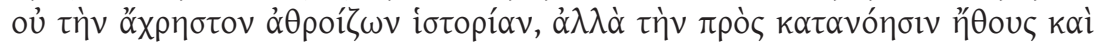

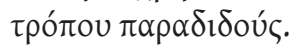

Em relação às acções que Tucídides e Filisto descreveram, não é possível omiti-las por conterem variadíssimos elementos sobre o carácter e a disposição do homem, dissimulados sob muitas e grandes paixões, que percorri de forma breve e cingindo-me ao essencial, para que não pareça totalmente descuidado e preguiçoso. $\mathrm{O}$ que muitos ignoraram e que se encontra esporadicamente em outros [autores] ou se descobre nas oferendas votivas ou nos antigos decretos é o que me esforço por reunir, não para coligir material inútil, mas para dar um contributo à compreensão dos caracteres e da conduta.

Este texto fornece, desta forma, mais elementos para determinarmos a metodologia de Plutarco. Desde logo, assume que teve em conta duas fontes, Tucídides e Filisto, mas que também usou material "alternativo" que

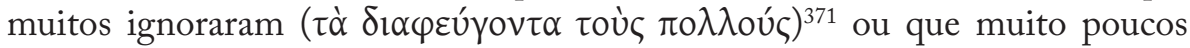

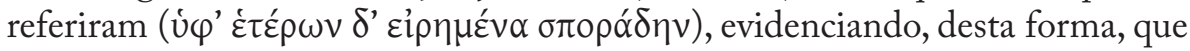
desenvolveu um trabalho de investigação e de procura de outras fontes: as

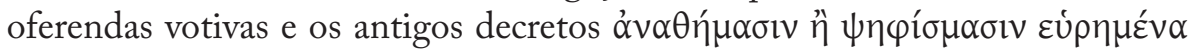
$\pi \alpha \lambda \alpha$ เoĩ $)$. Recorda, por fim, o seu objectivo de reunir a documentação credível

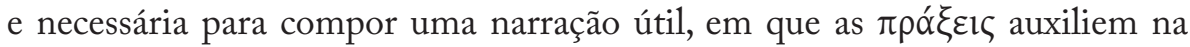

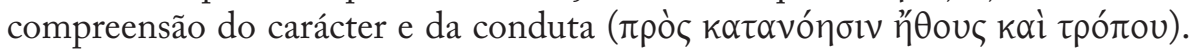
Repare-se como Plutarco nos confirma, mais uma vez, o seu cuidado no manuseamento das fontes e na selecção de autores mais fidedignos, entre os quais figura Tucídides ${ }^{372}$.

Conhecedor e estudioso do passado e das fontes, Plutarco tem plena consciência do efeito erosivo do xpóvoৎ na consolidação ou pervivência dos factos históricos, bem como as alterações a que o $\lambda o ́$ os poderá estar sujeito. Se os acontecimentos distantes se degradam com o evolver do tempo, podendo

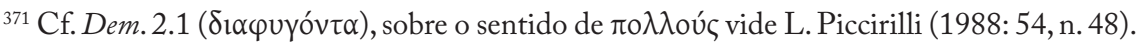

${ }^{372}$ Em Nic.1.1 e 1.4, critica Timeu, um historiador da época helenística, por querer superar a

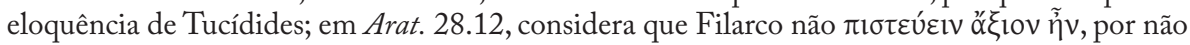
ter tido em conta Políbio; em relação a Heródoto, critica-o por condicionar a narrativa de modo

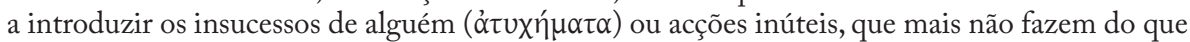
desacreditar as fontes, coisa que, segundo Plutarco, Tucídides não fez (cf. De Herod. mal. 855CD); são muitas as vezes que se refere a Tucídides e o cita, com especial incidência nas biografias

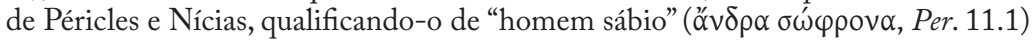


mesmo ficar irremediavelmente perdidos, os factos próximos, pela sua parte, estão sujeitos à subjectividade e à intencionalidade do relator. Disso nos dá

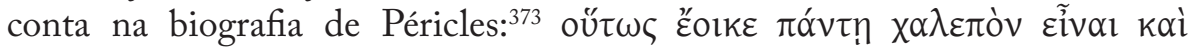

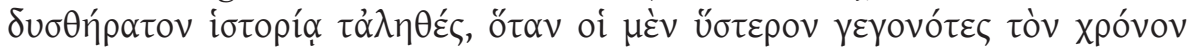

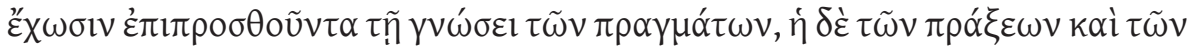

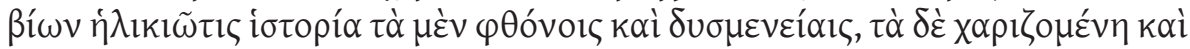

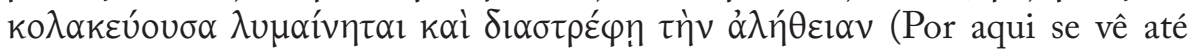
que ponto é árdua e difícil para a história a tarefa de apurar a verdade: quando os que nasceram depois se debatem com o obscurecimento provocado pelo tempo no conhecimento dos factos, e a narração contemporânea das acções e das vidas contemporâneas desfigura e distorce a verdade, ora por invejas e malevolências, ora por complacências e lisonjas). Deste modo, as acções que ocorreram no passado colocam ao investigador problemas de credibilidade, por se terem afastado da realidade e aproximado do mito ou da falsidade, sendo, nestes casos, exigido um processo de depuração, como Plutarco faz no par Theseus-Romulus ${ }^{374}$; além disso, as narrações contemporâneas dos factos não são uma garantia de veracidade por quatro razões: invejas ( $\varphi \theta$ óvorৎ), malevolências

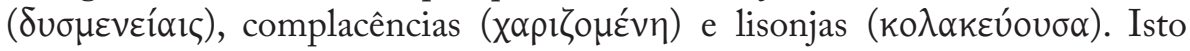
indicia que Plutarco, perseguindo a verdade na sua narração biográfica, terá usado com cautela as suas fontes ${ }^{375}$.

Outro aspecto a ter em conta é o facto de nenhum leitor dos Moralia ou das Vitae ser indiferente ao elemento moral, pois ele é determinante na sua composição. O biógrafo de Queroneia procura nos seus retratos sublinhar a prática da virtude, que funciona quase como leitmotiv da obra. Entende a virtude como uma defesa contra o mal, tal como aparece nos textos aristotélicos ${ }^{376} . \mathrm{Na}$ biogafia de Catão de Útica é esclarecedor sobre esta matéria: ${ }^{377}$

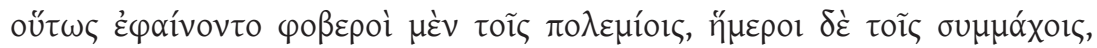

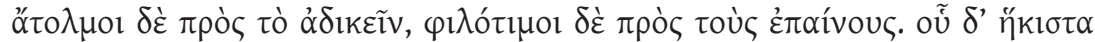

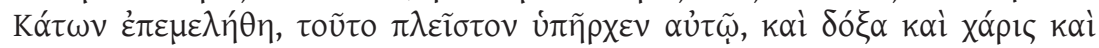

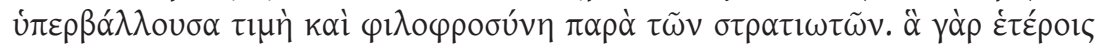

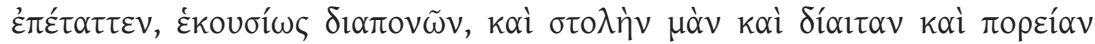

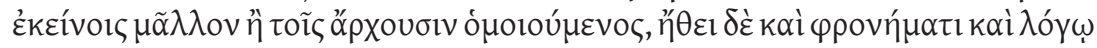

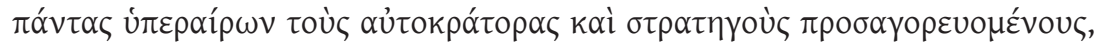

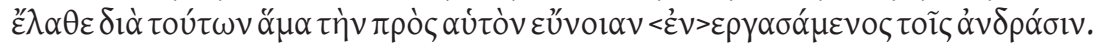

37313.16 .

${ }^{374}$ Sobre o papel do mito no pensamento de Plutarco, remetemos para os trabalhos de Y. Vernière (1977) e Ph. Hardie (1992: 4743-4787), embora os autores não se dediquem sobretudo a analizar o material mitográfico dos Moralia.

${ }^{375}$ Cf. Nic.1.5.

${ }^{376}$ E.g. EN 1107b 3.

${ }^{377}$ Cat. Mi. 9.7-10. 


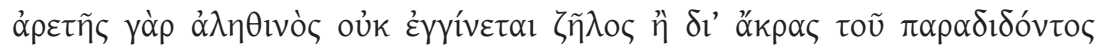

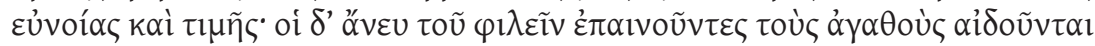

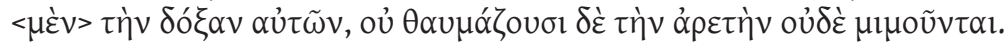

Tanto se podem mostrar terríveis com os inimigos, como amáveis com os aliados, quer pouco dados a cometer injustiças, quer ambiciosos por receberem louvores. Aquilo de que Catão pouco se ocupou foi o que conseguiu em grande número: a glória, o respeito, a honra sem limite e a bondade entre os soldados. De facto, o que ordenava aos outros, eles faziam-no de forma voluntária, pois era, por causa do seu modo de vestir, do seu regime e da sua forma de andar, mais parecido com os soldados do que com os chefes. Sobressaiu pelo seu carácter, grandeza de espírito e eloquência de entre todos os comandantes e generais nomeados; por causa destas coisas, inspirou, ao mesmo tempo, a benevolência entre os homens, sem ele próprio ter consciência disso; pois, a verdadeira emulação da virtude não existe senão na benevolência e honra mais elevadas que se transmitem. Os que louvam os homens bons sem os amar, certamente que respeitam a sua glória, mas não admiram nem imitam a sua virtude.

Veja-se como Catão de Útica se torna um modelo para aqueles que o acompanham, pelo facto de estes admirarem o seu carácter e comportamento, conseguindo-o pela $\varepsilon u ̋ v o r \alpha$, qualidade indispensável para quem deseja exercer cargos de comando.

Qualquer homem deve ter como objectivo principal da sua vida a prática da virtude. Contudo, não se trata de uma virtude meramente contemplativa ${ }^{378}$, sem efeito no quotidiano, mas de uma virtude ética, com evidentes consequências

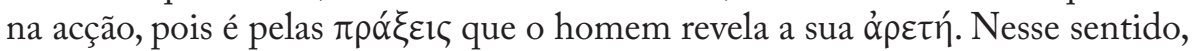
não podemos classificar Plutarco como um teorizador puro, uma vez que advoga no seu corpus, em especial nas Vitae e nos tratados políticos, uma participação activa na vida pública, fazendo alusão a situações concretas. Nem o próprio filósofo deixa de ser um elemento fundamental para o bem colectivo da sociedade pela influência que deve exercer nos governantes, pois a sophia é essencial para a politeia ${ }^{379}$.

De facto, a virtude assume-se como o bem mais precioso ${ }^{380}$, não apenas a que se revela nas grandes empresas, mas também aquela que se manifesta nas pequenas ocasiões da vida. Aliás, Plutarco detém-se mais nos comportamentos do que nos grandes sucessos históricos dos heróis que retrata, por acreditar que um pormenor ou um simples facto pode ser significativo para definir

${ }^{378} \mathrm{Em}$ De uirt. mor. 440D, distingue a virtude moral da virtude contemplativa, mostrando interesse sobretudo pela primeira; sobre o tratado De uirt. mor., vide M. Baldassarri (1992: 1621).

${ }^{379}$ Vide, em particular, os tratados Max. cum princ. e Ad princ.ind..

${ }^{380}$ Cf. Sol. 81D-E. 
a personalidade de uma personagem. A esses pormenores junta pequenas anedotas, intercaladas com algumas narrações dramáticas e muitas citações, o que torna as biografias uma leitura muito proveitosa para a compreensão que o autor tem dos comportamentos humanos e sobre os condicionalismos que a história impõe ao percurso normal de um indivíduo, ou mesmo à sua physis.

Nesse sentido, o exercício da vida pública oferecerá ao biógrafo dados para reflexão sobre a melhor virtude. Assim sendo, o agente da actividade pública deve, por um lado, estar consciente das suas competências e responsabilidades, e, por outro, conhecer a natureza humana, pois só desta forma poderá atingir a perfeição ${ }^{381}$. De uma forma ou outra, quase todos os heróis biografados exerceram funções políticas relevantes, o que permite a Plutarco tirar ilações sobre a qualidade e as consequências desse exercício, tanto para o indivíduo, como para a sociedade. Além de ser muito sensível, como moralista, aos perigos do poder ${ }^{382}$. Estando os heróis muito expostos aos perigos inerentes ao exercício de funções governativas, Plutarco lembra como se deve manter uma atitude equilibrada, por meio da paideia e do logos, pois a exaltação desnecessária com o êxito só conduz a decisões irracionais e pouco benéficas para aqueles que dependem do poder, ou seja, os cidadãos.

Desta forma, facilmente se conclui que a educação ocupa um lugar ímpar na formação humana, uma vez que será ela a moderar as paixões e as emoções. Não queremos com isto dizer que Plutarco se manifesta contra a livre expressão dos prazeres humanos, mas que é a favor da disciplina da alma e do corpo como meio para a obtenção da virtude e da felicidade ${ }^{383}$, insurgindo-se, ao invés, contra os excessos. Para se enfrentar a adversidade e se alcançar a felicidade, a educação é o melhor suporte, tendo uma presença transversal no

${ }^{381}$ Cf. Praec. ger. reip. 799B-C.

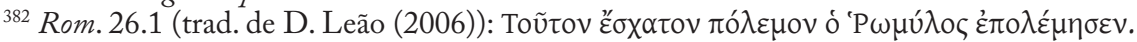

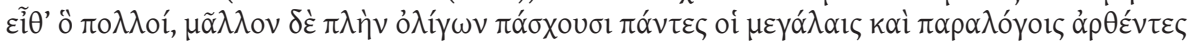

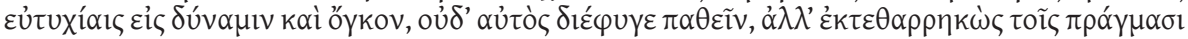

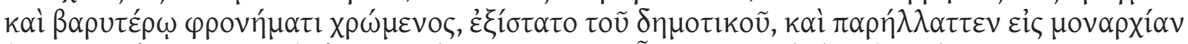

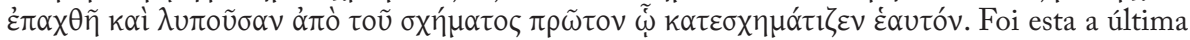
batalha combatida por Rómulo. Em seguida, não conseguiu evitar o que acontece também a muitos, ou melhor, a quase todos os que se viram projectados, através de grandes e inesperados sucessos, para o poder e a glória. Orgulhoso dos seus feitos e tomando-se em demasiada consideração, começou a afastar-se da soberania popular e a assumir um governo monárquico, que se tornou odioso e insuportável, devido ao comportamento que ele foi o primeiro a adoptar. Vide também Syll. 30.6 ; as reflexões que Plutarco formula sobre o poder merecem de F. Frazier (1995: 168) o seguinte comentário: «Une telle conception du pouvoir et une vision si «défensive» de la vie de la cité, bien en accord avec la réalité de son époque, ne prédisposent guère Plutarque à approfondir le problème de la raison d'État et à développer le genre de réflexions qu'ont pu inspirer le développement de l'emoire à Thucydide ou la conquête du pouvoir à Machiavel.»

${ }^{383}$ Cf. De lib. educ. 7D-E; da leitura do corpus plutarcheum percebe-se que, para atingir a felicidade, o homem precisa de compreender e aprofundar o sentido das coisas, daí o papel basilar que a paideia desempenha para o indivíduo e para a sociedade. 
binómio ethos-praxis ${ }^{384}$ que marca as Vitae ${ }^{385}$, pois a felicidade não se atinge por meio de riquezas ou pelo exercício de poderes, mas por um carácter bem formado e capaz de enfrentar os obstáculos e o sucesso com elevação ${ }^{386}$.

$\mathrm{O}$ conjunto de ideias que Plutarco aprofunda sobre a virtude, a justiça, o mal ou a felicidade ajusta-se à sua experiência de vida. $\mathrm{O}$ pensamento, multiforme e repleto de concepções sobre o homem e tudo o que o rodeia, percorre de forma coerente e rectilínea um caminho que vai de Queroneia a Roma, dos Moralia às Vitae, da história à biografia, da filosofia moral à religião tradicional ${ }^{387}$.

O facto de o primeiro par biográfico - questão consensual entre os estudiosos da cronologia das Vitae - a ser composto por Plutarco, isto é, Epaminondas-Scipio ${ }^{388}$ (no 7, no Catálogo de Lâmprias), não nos ter chegado, obra em que certamente exporia o projecto das Vitae $e^{389}$, faz com que tenhamos de procurar nas outras biografias as razões que o levaram a tomar determinadas opções (formais e de conteúdo) na composição. Por exemplo, no prólogo de

${ }^{384}$ Repare-se como o vocábulo arete, central na cultural helénica, contém estes dois elementos: por um lado a acção (militar ou política) e, por outro, o sentido de valor moral.

${ }^{385}$ Por exemplo, quando aborda a educação de Filopémen, “o último dos Gregos”, diz que os seus mestres, Ecdelo e Demófanes, orientaram a "filosofia para a política e a acção" (cf. Phil.1.3).

${ }^{386}$ Cf. De uirt. et uit. $100 \mathrm{C}$ ss.

${ }^{387}$ Cf. E. Valgiglio (1992).

${ }^{388}$ A escolha de Epaminondas e de Cipião para fazerem parte do primeiro par das Vitae encerra um significado que merece alguma atenção, embora o facto de não nos ter chegado o texto dificulte, sem dúvida, uma análise mais profunda. Epaminondas, herói tebano por excelência, além de ser um corajoso comandante de tropas, é também um homem que se dedica ao pensamento e à reflexão, como se constata a partir do testemunho que Plutarco nos dá em $D e$ genio Socratis, onde o herói, não só, liberta a cidade de Tebas do jugo espartano, como também discorre sobre o Bem e o Mal, numa discussão de carácter religioso e filosófico; nesse mesmo tratado (575E), Plutarco demonstra como os Beócios, seus conterrâneos, amam a filosofia, e por isso terá decidido começar as Vitae por Epaminondas, herói emblemático para as gentes da Beócia, com o provável conhecimento de Sósio Senécio dessa decisão. Quanto a Cipião, a figura romana correspondente, também terá sido escolhido com o conhecimento de Sósio Senécio, por ser um figura importante em Roma, como Epaminondas em Tebas e na Grécia. Mas afinal de que Cipião se trataria, uma vez que o Catálogo de Lâmprias, no no 28 , apresenta uma biografia

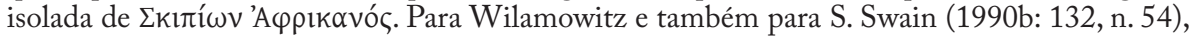
o Cipião que faz par com Epaminondas é Cipião Emiliano (185/4-129 a. C.), que destruiu Cartago em 146 a. C., enquanto K. Ziegler (1951: 895-6) opta por Cipião Africano, conhecido, entre outras coisas, por ter derrotado Aníbal na batalha de Zama, em 202 a. C.; vide ainda K. Herbert (1957: 83-8); qualquer uma das leituras tem interessantes pontos de defesa, mas o que se pode dizer do par Epam.-Scip. é que se trata de uma escolha curiosa para inaugurar as Vitae: dois chefes militares, estrategas e homens de cultura, revelando, além disso, o propósito de agrupar heróis Gregos e Romanos com significado especial para os respectivos povos ou para Plutarco e Sósio Senécio, com o objectivo de identificar semelhanças e diferenças. Para J. Sirinelli (2000: 288), este procedimento é um «jeu révélateur d'une société hautement cultivée, consciente de sa dualité et de son unité».

${ }^{389}$ Esperar-se-ia um discurso análogo ao das primeiras linhas do tratado Quaest. conu. 
Aemilius Paulus-Timoleon ${ }^{390}$, texto elucidativo sobre as relações entre autor e personagens, fornece elementos valiosos relativamente aos critérios que presidiram à composição das Vitae:

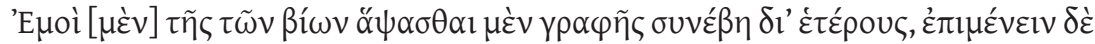

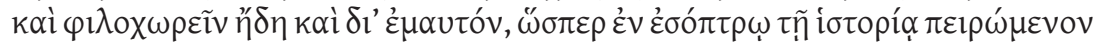

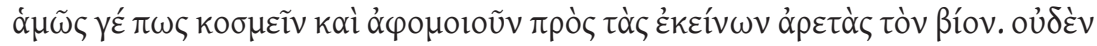

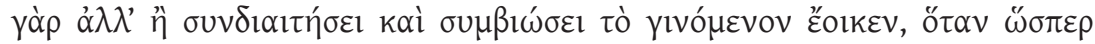

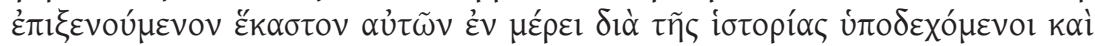
$\pi \alpha \rho \alpha \lambda \alpha \mu \beta \alpha ́ v 0 v \tau \varepsilon \varsigma \grave{\alpha} v \alpha \theta \varepsilon \omega \rho \tilde{\omega} \mu \varepsilon v$

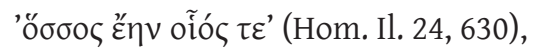

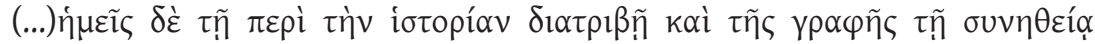

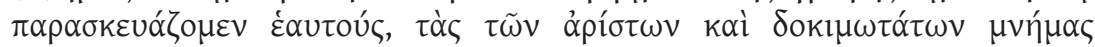

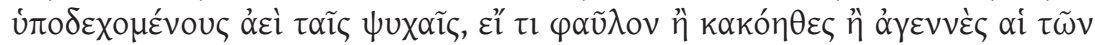

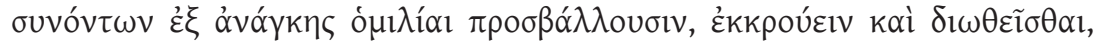

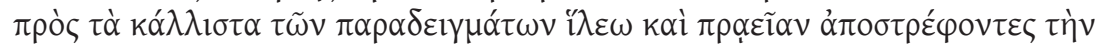

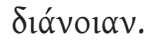

Aconteceu-me ter começado a composição destas vidas por instigação de outros, mas, se continuo essa tarefa, faço-o já no meu próprio interesse; é como se a história [dos grandes homens] fosse um espelho onde procuro, de alguma forma, ordenar e conformar a minha vida à imagem das suas virtudes. É que nada há de mais semelhante à companhia e convívio com uma pessoa do que quando, através da sua história, os recebo a cada um deles como hóspede em minha casa, mantendo-os e conservando-os comigo e contemplando «como era alto e belo ", seleccionando, para as dar a conhecer, de entre as suas acções, as mais notáveis e as mais belas.

(...) Quanto a nós, com a prática das questões históricas e o hábito de as passar à escrita, preparamo-nos para preservar para sempre no espírito a memória dos varões melhores e mais famosos, e, se os contactos com aqueles com quem a necessidade nos obriga a conviver nos confrontam com a baixeza, a imoralidade e a vileza, desviamo-nos deles e afastamo-nos, volvendo os nossos pensamentos, com disponibilidade e doçura, para os mais altos paradigmas.

Estamos, sem dúvida, perante uma declaração sobre o papel que a escrita desempenha na pervivência dos factos e dos seus actores e também sobre a dimensão mimética da biografia plutarquiana, que anuncia a profundidade ética das Vitae, em que a observação e a interpretação dos comportamentos humanos

390 1.1-2,5 (trad. de M.H. Rocha Pereira (1999: 14), vide, para comparação com o texto citado, De prof. in uirt. 79B, onde se confirma o sujeito das Vitae; cf. C. Jones (1971: 103-9) e A. Wardman (1974: 18-26); para uma análise deste prólogo, vide P. Desideri (1989: 199-215). 
são processos essenciais na metodologia plutarquiana ${ }^{391}$.Usando a história como

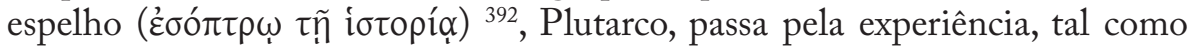
qualquer leitor das suas Vitae, de ver reflectidos os feitos virtuosos do passado,

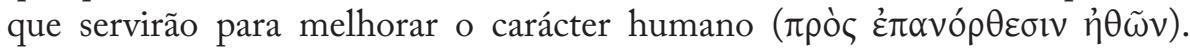
Nesse sentido, o autor comporta-se, um pouco à semelhança do conservador de um museu, como aquele que preserva a memória dos grandes feitos do passado, fazendo um trabalho de selecção para que a sua mensagem seja mais

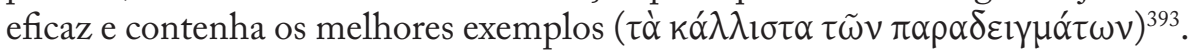
No texto atrás citado, esses homens do passado não surgem apenas como exemplos, mas também como elementos vivos que vêm à presença do autor que, por sua vez, deixa os leitores partilhar desse convívio. Assim sendo, temos um duplo efeito do espelho: a conduta virtuosa dos grandes homens é um espelho para Plutarco e a própria obra de Plutarco é um espelho para os seus leitores.

Percebe-se, ao longo da leitura, que Plutarco conta com a ajuda da história para descrever as virtudes das personagens, não se contendo no momento de sacrificar a verdade dos factos à idealização do carácter dos biografados. Selecciona, em geral, o que é digno de ser imitado, em detrimento daquilo

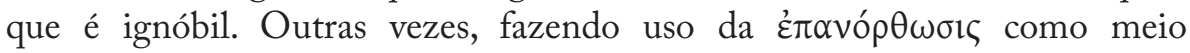
pedagógico, numa espécie de paideia ex contrario, aponta os defeitos ou vícios das personagens com um fim moralizador ${ }^{394}$.

O polígrafo de Queroneia reconhece que não existe uma pessoa perfeita ${ }^{395}$, mas que se deve evitar a imitação das acções ignominiosas ou desprovidas de virtude. ${ }^{396}$ Plutarco reconhece, desta forma, as lacunas naturais do homem e

${ }^{391}$ Cf. De uirt. et uit. 101C, De coh. ira 455F, De laude ips. 547D e De sera num. uind. 551A.

${ }^{392} \mathrm{O}$ uso da imagem do espelho é, como facilmente se depreende, uma constante na literatura de cariz moralizante e didáctico: os pais devem ser exemplo/espelho para os filhos; os que exercem cargos públicos para os cidadãos ou os filósofos para aqueles que os seguem, etc; também serve para descrever algo que imita bem a realidade (cf. Pl., Lg. 905b, Phd. 255d; De soll. anim. 967D); olhar para o espelho nos momentos de ira, num estado fora do normal, pode ser uma forma para se corrigirem os defeitos, parecendo ser esse o princípio que Plutarco desejaria aplicar nas suas Vitae, conjunto de biografias-espelho com fim pedagógico e moral; também no tratado Reg. et imp. apoth. 172D se refere ao espelho como forma de olhar a mente de cada homem de Estado e de conseguir o auto-conhecimento.

${ }^{393}$ Cf. Tim. 24.3.

${ }^{394}$ Cf. Demetr. 1.4-5 (a propósito dos elementos negativos desta biografia, vide J. Candau (1999: 139-144)); ainda sobre este assunto, Plutarco, em Alex. 53.4, conta-nos que Alexandre pediu ao eloquente filósofo Calístenes para fazer um discurso sobre os defeitos dos Macedónios, de modo que estes fossem capazes de reconhecer os seus erros e se corrigissem.

${ }^{395}$ E.g. Nic. 8.6 ou Alc. 15.7.

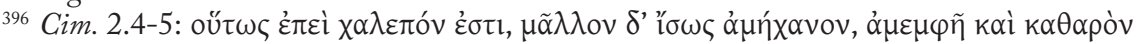

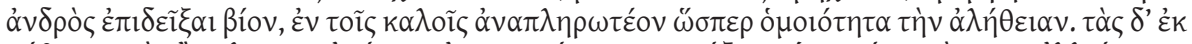

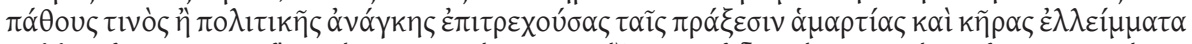

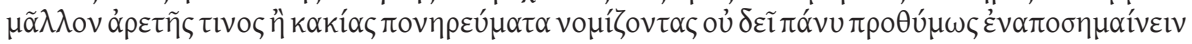


da sua arete. Não esconde, por conseguinte, as limitações e as imperfeições nas suas biografias, embora as qualidades positivas ocupem maior espaço do que as negativas, e prefere realçar a necessidade e as potencialidades da paideia e do logos.

Na biografia de Luculo, onde se enfatiza a cultura helénica do protagonista, o Queronense expõe o que pensa sobre as virtudes e os vícios inerentes a qualquer vida ${ }^{397}$, perspectivando uma atitude consentânea com a paideia e reflexo da sua falta ou deficiência. Numa primeira fase, durante a adolescência,

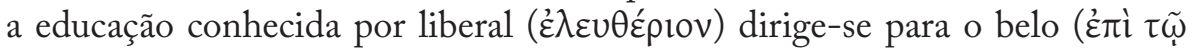
$\kappa \alpha \lambda(\tilde{\omega})$, para, de seguida, nos momentos em que se está livre das tarefas públicas

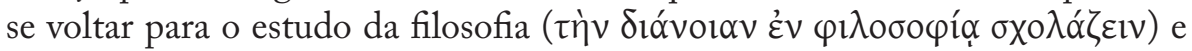

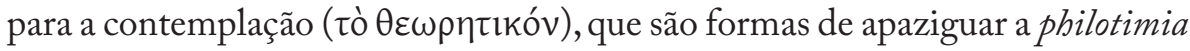
de Luculo e o seu diferendo com Pompeio.

$\mathrm{Na}$ verdade, como refere em De Herodoti malignitate ${ }^{398}$, não existe um carácter puramente bom, nem, por aquilo que narra nas biografias, a paideia consegue eliminar por completo as imperfeições, que muitas vezes tomam conta do indivíduo, especialmente quando este se encontra em situações complexas, perante a possibilidade de perder uma guerra ou próximo da morte. Plutarco formula, desta forma, a sua convicção de que em qualquer ser humano se conjugam erros e virtudes, como o corpus das suas biografias comprova $^{399}$. Se é verdade que não idealiza por completo cada um dos heróis, também não deixa de deformar a realidade ao apresentar os erros como fraquezas próprias de quem, em detrimento da razão (logos), agiu com paixão. Por exemplo, apesar da dimensão histórica de Alexandre ou César, Plutarco não apresenta a cólera e a ambição desmedida, respectivamente, como as principais características desses heróis. Aliás, as palavras do prólogo da vida de Címon, atrás traduzidas, são elucidativas da forma como Plutarco procura equilibrar a imperfeição e a grandeza ${ }^{400}$. Não esconde a dimensão dos vícios de duas grandes naturezas (megalai physeis), Demétrio e António, nem a obstinação de Coriolano e de Alcibíades, homens cujo carácter se revela desequilibrado. Mas

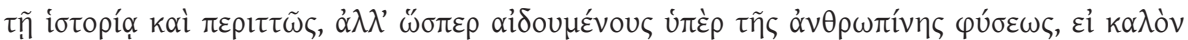

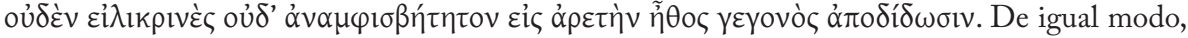
parece que é difícil, ou mesmo impossível, mostrar uma vida livre de censura e sem mácula, logo deve fruir das coisas belas, como se elas fossem semelhantes à verdade. Quanto aos erros e aos infortúnios que, por causa das paixões ou por necessidade política, contêm as acções, são mais uma lacuna da virtude do que uma má acção do vício; não é de todo necessário que se revelem na narrativa de forma favorável ou excessiva, mas de maneira a respeitar a natureza humana, no caso de não se poder atribuir à virtude um carácter perfeito nem puro ou sem crítica.

397 1. 4-8. A par disso, Plutarco realça a philologia de Luculo, que se terá dedicado a escrever

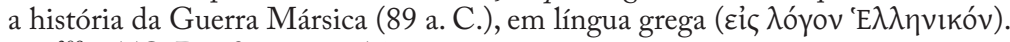

398 855C-D; cf. Sert. 10.5-7 e Sull. 30.6.

${ }^{399}$ Cf. Alex. 1.

${ }^{400}$ Cim. 2.2-5; cf. Phoc. 3.7 e Cleom. 16.8; vide D. Babut (t2003: 334-5). 
outras figuras mais modelares, como Aristides, Catão Censor, Alexandre ou Flaminino, também não estão isentas de erro: Aristides termina a sua vida de forma pouco honrada, deixando os seus descendentes na miséria, pois a pátria ocupava para ele o lugar primacial, e não tinha por isso tempo para a família; Catão Censor, mais pragmático do que Aristides, ocupa-se em demasia com questões monetárias e não consegue, mais importante do que isso, manter uma atitude moderada e razoável para com aquilo que é helénico; Alexandre, protagonista de conquistas ímpares, personifica a combinação do épico com o trágico, muito embora tenha sido discípulo de Aristóteles, pensador da ética e da felicidade humana; Flaminino, movido pela philotimia, nem sempre é moderado nos seus sentimentos, ainda que tenha o mérito de ter libertado a Grécia, tirando os Romanos obviamente proveito dessa situação. Deste modo, Plutarco não foge de caracteres paradoxais, antes os deseja usar como modelos, acreditando que a paideia aperfeiçoa e melhora a parte irracional da alma.

Pelo facto de Plutarco reconhecer a complexidade e a individualidade da natureza humana, as suas biografias atestam cabalmente a diversidade de caracteres, oferecendo muitas pinturas de circunstâncias diversas. $\mathrm{O}$ texto que se segue parece-nos ainda mais esclarecedor sobre essa complexidade e a intenção de Plutarco de tirar daí algum proveito retórico, recusando uma narrativa simplesmente laudatória, ao estilo do panegírico imperial: ${ }^{401} \dot{\alpha} \lambda \lambda \grave{\alpha}$

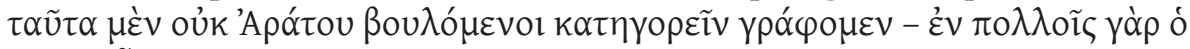

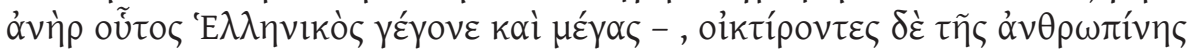

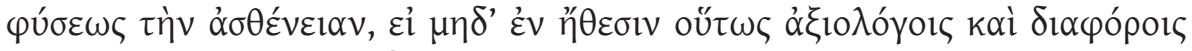

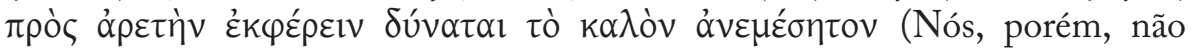
escrevemos estas coisas por querermos acusar Arato - ele é, de facto, em muitos aspectos, um grande homem e um homem digno da Grécia - mas por lamentarmos a debilidade da natureza humana, pois nem nos caracteres dignos de serem lembrados e que se interessam pela virtude se pode expor o belo isento de censura). Por conseguinte, qualquer vida está sujeita ao erro e ao vício, mesmo as que nascem com uma natureza nobre. Diríamos que a fatalidade da imperfeição humana torna indispensável a paideia, a qual não é, por si só, uma garantia total para o sucesso.

Como breve conclusão desta Primeira Parte, gostaríamos de referir que as Vitae de Plutarco continuam a ser muito apelativas para os leitores, e isso devese ao facto de o espaço e o tempo das personagens ser distinto e de os valores, que se moldam de acordo com as épocas, poderem adquirir sentidos positivos ou negativos. T. Duff (2002r: 71), dando conta de que Plutarco, na maior parte das vezes, desenvolve os conceitos morais de forma implícita e não explícita,

${ }^{401}$ Ag./Cleom. 37.8 
usa uma expressão que classifica correctamente as ambiguidades que se geram nas biografias: "challenging moralism"! Para se entender o efeito de mimesis das Vitae, Plutarco pressupõe que o leitor é instruído, logo capaz de interpretar e de fazer julgamentos próprios, estimulando, em grande medida, um diálogo pedagógico com o leitor nas synkriseis.

Atendendo à profundidade ética e espiritual da sua mensagem, o sentir do próprio autor está muito presente ao longo dos textos. Facilmente se depreende que nem sempre se dirige aos seus leitores ou espectadores, mas a ele próprio e ao seu "espelho", como participante da História. A contemplação dos heróis do passado, dos $\pi \alpha \rho \alpha \delta \varepsilon i ́ \gamma \mu \alpha \tau \alpha \tau \tilde{\omega} \nu$ ßí $\omega v$, visa levar os leitores a imitar o que de melhor aqueles protagonizaram ${ }^{402}$, de modo a concretizar o estilo mimético da biografia, que se evidencia por interligar aspectos psicológicos e juízos sobre valores com episódios mais dramáticos e simbólicos, onde os imitadores (heróis que tentam imitar outros) acabam por ser, eles próprios, modelos para os leitores. Plutarco não escreve apenas para fazer perdurar a memória dos acontecimentos, mas para retirar deles um ensinamento para o presente

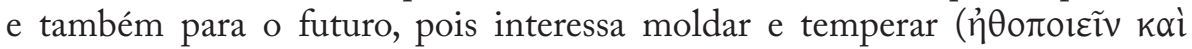
$\sigma \omega \varphi \rho v^{\prime}\langle\bar{\zeta} \varepsilon \mathrm{lv})^{403}$ a alma dos seus concidadãos, numa época tão exigente. Por causa da amplitude temática da sua obra e da natureza da sua obra, Plutarco assume-se como umas das principais fontes de informação para os que se interessam pela Antiguidade Clássica.

Com maior ou menor relevo histórico, as várias personagens não surgem apenas para serem dignas de admiração, mas carregam uma dimensão social, política e histórica, que as torna modelos intemporais, até porque nunca deixam de ser humanas, com virtudes e defeitos. Mas, mais importante ainda, é o facto de Plutarco, herdeiro dos preceitos éticos e psicológicos dos peripatéticos, colocar em paralelo Gregos e Romanos, pondo em confronto, dessa forma, duas culturas, com semelhanças e diferenças, numa síntese do mundo grecoromano, carregada de sentido.

Esta polaridade cultural, também presente nos Moralia e reforçada pelas synkriseis, ganha especial significado por Plutarco conhecer bem a dimensão do imperialismo romano e por recear a reacção dos seus compatriotas a esse domínio, como prova o tratado Praecepta gerendae reipublicae. Se não queria que os Gregos se insurgissem contra os Romanos, também não deseja que a liberdade dos Gregos seja posta em causa. Embora não remeta muitas vezes para o contexto histórico em que vive, percebe-se que a sua obra não é de todo alheia a essas circunstâncias, tal como a biografia de Suetónio ${ }^{404}$ ou de

\footnotetext{
${ }^{402}$ Cf. Demetr. 1.4-6.

${ }^{403}$ Cf. Praec. ger. reip. 814B.

${ }^{404} \mathrm{O}$ estudo de D. Pausch (2004) constitui um dos mais recentes trabalhos sobre o papel
} 
Cornélio Nepos têm fortes ligações com o contexto histórico. Temos, por isso, uma biografia que combina a história com a ética política e filosófica, em que o tom moralístico é marcante, tom que não tinha sido ignorado por historiadores como Tucídides, Xenofonte ou Políbio.

Ir ao passado para iluminar o presente é um topos normal na literatura grega, que pode ser entendido como sinal de respeito, admiração ou nostalgia por um tempo mais ou menos longínquo, e como forma de Plutarco conseguir uma maior capacidade crítica. Deste modo, a mensagem aparece mais de forma implícita do que explícita, como o "moralismo protrettico" de que fala C. Pelling (1995: 346). Parece-nos ainda que o uso de factos e de personagens do passado, numa estrutura paralela, se inscreve na mensagem de proximidade e universalidade de Plutarco: Gregos e Romanos partilham o tempo histórico e, apesar de se individualizarem, demonstram muitas semelhanças. Por exemplo, Catão é diferente de Aristides, mas Aristides também não é igual a Temístocles. Logo, colocam-se em paralelo Gregos e Romanos, mas são, acima de tudo, os seus caracteres, os valores e experiências pessoais, que podem diferir de Grego para Grego ou de Romano para Romano, que são comparados. O tempo adquire, como temos referido, especial significado, pois, como nos diz

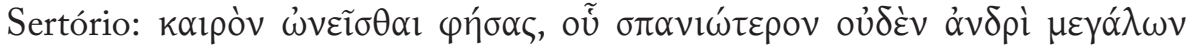
$\dot{\varepsilon} \varphi ı \mu \varepsilon^{\prime} \nu \omega$ (Eu compro o tempo, que não é pouco para um homem que aspira a grandes realizações) ${ }^{405}$.

Por isso, com algumas cautelas, defende uma convivência, em que os dois povos, com as suas formas de pensar e actuar, se respeitem e se ensinem mutuamente. Nesse processo, Plutarco, um sofista (etimologicamente, aquele que pratica a sophia), não esconde que são a paideia grega e os seus valores que devem lançar os alicerces do homem novo do Império.

A sua capacidade de reflectir sobre a personalidade ou carácter de modelos do passado, fez dele um autor lido e imitado por muitas gerações de intelectuais no Ocidente, facto que leva S. Goldhill (2002: 246-293) a questionar "Why save Plutarch?", encontrando a seguinte justificação: "Saving Plutarch is saving a figure engaged in the preservation of a cultural tradition - a preservation which is also a creative act of formation”. A construção da identidade cultural que o Queronense formula na sua obra, com o reconhecimento e a apropriação dos valores do passado, convida-nos a reflectir sobre o papel que a paideia e a tradição cultural desempenham nas nossas acções e formas de ser. Por causa da versatilidade temática, o escritor Frederick Marryat, em Masterman Ready

cultural da biografia no século II, a partir das cartas de Plínio-o-Jovem e das biografias de Suetónio, incluindo ainda A. Gélio; vide, ainda, J. Sanchéz Marín (1982: 211-220), para uma análise comparativa do conceito de biografia em Nepos, Plutarco e Suetónio.

${ }^{405}$ Sert. 6.6. 
(1841), conta-nos como uma família sobreviveu, com a ajuda do experiente Masterman Ready, a um naufrágio e no meio dessa fatalidade sobrou uma caixa de livros onde se encontravam as biografias de Plutarco, o que leva $\mathrm{Mr}$ Seagrave, patriarca da família, a dizer: "Plutarch's Lives. I am glad I have them: they are excellent reading for young or old; there is no occasion to open any more, as I know all the other books in the case are 'History'; perhaps the best case which could have been saved".

No seu trabalho, semelhante ao do pintor, detém-se nas acções que ilustram a moral e o ethos $^{406}$ dos heróis e que suscitam a emulação dos ouvintes, cabendo à paideia um papel privilegiado, seja na fase mais formativa ou na avaliação das suas consequências nas praxeis. Ocupar-nos-emos desta temática nos capítulos que se seguem, começando por apontar e interpretar as informações que se podem colher do conjunto de Vitae previamente definido, para depois aprofundarmos o sentido de paideia em Plutarco.

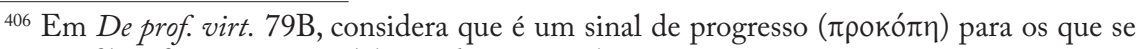
dedicam à filosofia passarem a elaborar discursos sobre o carácter e as paixões. 

Parte II 



\section{Plutarco e a paidela}

\subsection{PreÂmbulo Às Considerações Sobre o SENTIDo de paideIa}

Se existe um conceito transversal na cultura grega, esse é, sem dúvida, o de paideia em paralelo com os seus efeitos no destino de cada ser humano. A ideia de paideia ultrapassa em muito o fenómeno literário, pois, ao traduzir o conhecimento e a tentativa de interpretar as contingências humanas, incorpora uma vertente filosófica. Além disso, a paideia traduz o processo educativo institucionalizado que um indivíduo deve trilhar para a sua plena formação cultural e moral, e daí resulta o facto de ela estar omnipresente nas actividades políticas e sociais. Consciente dessa abrangência, W. Jaeger (t2001) entendeu a paideia como a formação integral do homem, identificando dois processos transformativos por ela gerados: um a nível interior, que diz respeito ao próprio homem, e outro que aponta para a sociedade em geral. Nesse sentido, a paideia (trans)forma e educa o indivíduo, que tem depois a responsabilidade e a missão de contagiar a polis com a sua curiosidade, os seus conhecimentos e os seus valores, participando também nesse processo a família, quer pelas funções que exerce na educação, quer pelas consequências positivas que sofrerá com a formação dos membros que fazem parte dela.

Identificámos, assim, três elementos fundamentais na definição de paideia: indivíduo, família e polis ${ }^{1}$. Estes espelham o carácter intelectual, ético e político da aprendizagem e do crescimento integral do homem. Por conseguinte, a paideia tem como objectivo, segundo Plutarco, a educação dos cidadãos com vista a garantir a estes uma vida digna e feliz, devidamente integrada na sociedade. Uma vez que a vida é praxis ${ }^{2}$, outro objectivo da paideia é ensinar o cidadão a agir.

Não se trata apenas de viver, pois também as plantas e os animais vivem, mas de atingir uma vida com qualidade, usando a inteligência e a razão, que a paideia ajuda a modelar ${ }^{3}$. Para se atingirem as coisas mais nobres e excelentes,

${ }^{1}$ Platão, em Prt. 325c ss., expressa que a família, a escola e os seus mestres, e a cidade, com as suas leis, são, se quisermos, instituições educativas, que participam, em diferentes etapas da vida, no crescimento moral, intelectual e político do homem.

${ }^{2}$ Cf. Arist. Pol. $1254 a 7$.

${ }^{3}$ Hesíodo, no poema didáctico Trabalhos e Dias, serve-se do apólogo do falcão e do rouxinol para demonstrar que o homem, ao contrário dos animais, conhece a dike e pode usufruir dela. Uns séculos depois, Isócrates preferirá afirmar que o homem se superioriza aos animais pela capacidade de usar o logos (cf. Nicocles 5-9). 
é preciso cultivar o conhecimento e exercitar as faculdades intelectuais. Encontraremos em Plutarco este nível e ainda outro, o da educação moral, que forma o ethos, evitando que os excessos e as paixões dominem a praxis.

Se o poeta Simónides de Ceos entendia que "a cidade é mestra do homem"4, ou seja, que o Estado molda o indivíduo, Plutarco é, essencialmente, herdeiro de uma tradição em que compete ao homem consolidar e renovar a sua formação, de modo a servir a polis. Como é sobejamente conhecido, não havia na Antiga Grécia uma paideia uniforme: recordem-se os modelos educativos de Esparta e Atenas ${ }^{5}$, as propostas de Platão, Isócrates ou Aristóteles, que defendem perspectivas e objectos diferentes para o acto educativo, além de nem sempre se repetirem de autor para autor as competências dos que guiam a educação dos jovens, nem o conteúdo das matérias que ensinam.

Embora não haja muitas dúvidas de que na época clássica se assistia a um interessante incremento da literacia ${ }^{6}$ e da cultura, para o qual os Sofistas, com a sua cultura itinerante, terão dado um assinalável contributo, torna-se complexo reconstituir com exactidão o processo pedagógico, uma vez que a educação não se baseava na palavra escrita, mas sobretudo na oralidade. Pela voz do Raciocínio Justo (Kreitton Logos), nas Nubes de Aristófanes ${ }^{7}$, sabemos que a educação antiga (archaia paideia) se reduzia a aprender música com o kitharistes e a praticar ginástica, o que, no fundo, demonstra a divisão habitual entre uma educação focalizada no corpo e outra na mente e nos princípios morais. Como adverte T. Morgan (2000r: 10 ss.), a mousike deveria incluir dança, canto e poesia ${ }^{8}$, ou seja, as crianças aprendiam literatura, mas de forma oral ${ }^{9}$. Quer isso significar que não se aprendia por meio da leitura

${ }^{4}$ Fr. 15 Page. Em An seni resp. 784B-C, Plutarco comenta da seguinte forma o muito

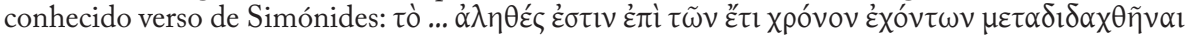

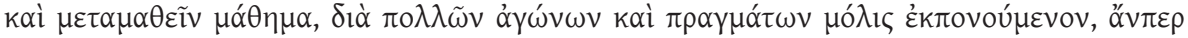

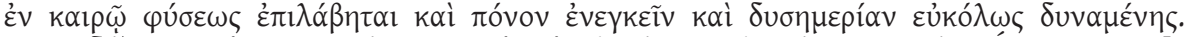

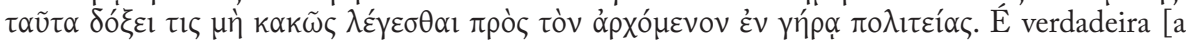
afirmação de Simónides] para os que dispõem de tempo para ensinar coisas novas e renovar o conhecimento, o qual se exercita, com dificuldade, por meio de muitas lutas e acções, se por acaso se apodera, no momento oportuno, de uma natureza com capacidade para suportar, de forma complacente, a fadiga e o fracasso. Estas palavras poderão parecer ajustadas para aquele que escolhe a actividade política na velhice. Sobre o conhecido fragmento de Simónides (" $\pi o ́ \lambda ı \varsigma$

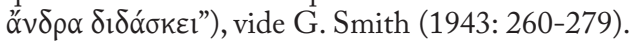

${ }^{5}$ Vide J. Ribeiro Ferreira (2006: 13-34). Sobre o modelo educacional espartano remetemos para os estudos de N. Kennel (1995), E. Warren (2005) e J. Ducat (2006), onde também se debatem as diferenças em relação ao modelo que se praticava em Atenas.

${ }^{6}$ Cf. R. Thomas (1989). O facto de, a partir do final do século V a.C., se usar preferencialmente o vocábulo didaskaleion para indicar o local onde se aprende, pode indiciar que a literacia e o ensino da literatura se assume como o mais importante; vide mais elementos em K. Robb (1994).

7961 ss.

${ }^{8}$ T.Morgan (1999: 48) salienta que as matérias da mousike tinham em conta uma preocupação ética.

${ }^{9}$ Cf. Ar. Eq. 188-93. 
de livros? Julgamos que não, atendendo, por exemplo, ao facto de o coro das Ranae dizer que os homens aprendiam as manobras da guerra lendo o biblion ${ }^{10}$. Deste modo, dominam a paideia do século V a. C., por um lado, a oralidade e a leitura (maioritariamente de poesia ${ }^{11}$ ), e por outro, a prática da ginástica. À mousike e à gymnastike juntaram-se, gradualmente, os grammata, ou seja, o ensino das letras ou da literatura ${ }^{12}$. O conteúdo das lições de mousike e de grammata ter-se-ão distinguido, com a gradual valorização do conteúdo cultural da última. Acredita-se, por isso, que, no final da época clássica, o contraste seria mais entre a gymnastike e os grammata e não entre a mousike e os grammata $^{13}$. Pelas informações que podemos colher, por exemplo, de alguns textos de Platão, a paideia na época clássica baseava-se na complementaridade entre o exercício corporal e o treino intelectual: diz-se,

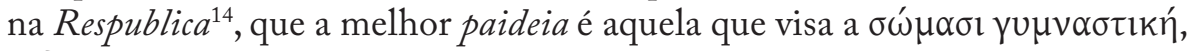

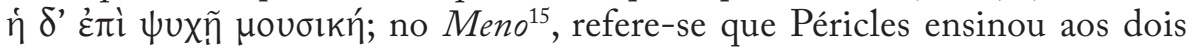

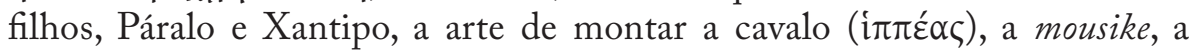
agonia e outras technai. Também Isócrates ${ }^{16}$ e Aristóteles ${ }^{17}$ reconhecem que a paideia deve incidir no corpo e na mente.

Convém notar ainda, que, num primeiro momento, a educação decorria no âmbito cívico - recorde-se, a este propósito e a título de exemplo, o papel preponderante do teatro - para, gradualmente e com a Academia de Platão, a escola de Isócrates ${ }^{18}$ e o Liceu de Aristóteles, passar a ter um local determinado, onde se aprofundavam as matérias que deveriam levar ao conhecimento e à

101113.

${ }^{11}$ Cf. P1. Prt. 325e.

${ }^{12}$ Cf. ibid. $312 \mathrm{a}-\mathrm{b}$.

${ }^{13}$ Cf. T. Morgan (2000r: 13).

${ }^{14} 376 \mathrm{e}$.

15 94b.

${ }^{16}$ Cf. Antid. 180-1.

${ }^{17}$ Cf. Pol. 1337 a 34.

${ }^{18}$ Ao contrário do que acontece com Platão e Aristóteles, os discursos de Isócrates, embora valorizem a paideia, não descrevem claramente a metodologia nem os ciclos que perspectivava para a educação. É possível, no entanto, dizer que, para o orador ateniense, a paideia podia beneficiar a physis, sendo necessário que o discípulo tivesse uma predisposição natural para a virtude. Os pais, sendo afectuosos com os filhos, devem ensinar-lhes a obediência, com o recurso a exemplos práticos. Como era habitual entre os Gregos, Isócrates defendia a educação corporal e a filosofia para a alma. Por valorizar a retórica, a qual pertencia à fase superior do ensino, considerava que saber falar era uma prova de inteligência que nenhum politikos podia desprezar. Segundo Isócrates, o homem não pode alcançar a verdade, nem por meio da paideia, ainda que esta seja útil, especialmente pela forma como educa para o uso da palavra ou do discurso (logos), formas que relaciona com as leis e a vida em comunidade. Assim, a formação moral precede a retórica e o agente da educação é aquele que governa, o homem culto e os que ensinam a eloquência, usando como método de ensino o recurso a modelos do passado ou, em alternativa, o próprio didacta - assim acontece com Isócrates - afirma-se como um exemplo para os seus discípulos. 
reflexão. Não quer isto dizer que não se responsabilizassem os pais, uma vez que estes deveriam ser diligentes nas escolhas dos mestres para os filhos.

Especialmente com Aristóteles e Isócrates a paideia passa a valorizar a formação cultural, na sua vertente literária e escrita, como uma preparação para a politei $a^{19}$. Para Isócrates, orador que sonhava com uma construção panhelénica que fosse capaz de enfrentar os Bárbaros ${ }^{20}$, Atenas é um centro difusor de cultura e o local privilegiado para os que aspiram aprender a oratória: ${ }^{21}$

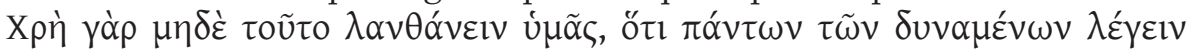

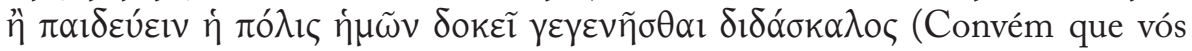
nunca esqueçais que a nossa cidade é vista como a educadora de todos os que falam com autoridade e dos que ensinam).

Platão, por sua vez, assume que o conhecimento e a virtude são importantes para o exercício do poder, mas é mais selectivo e elitista do que Aristóteles e Isócrates, pois o acesso à Academia não seria livre. Estes autores marcam decisivamente a história da paideia, pelo facto de considerarem que a literacia e a formação cultural e intelectual são pré-requisitos para a politeia. Ainda em relação a Platão, parece-nos relevante a forma como define, pela voz da personagem Ateniense, a paideia e a sua eficácia (dynamis): ${ }^{22}$

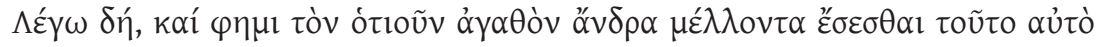

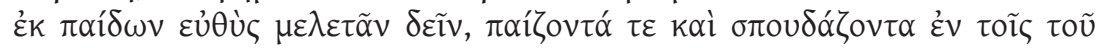

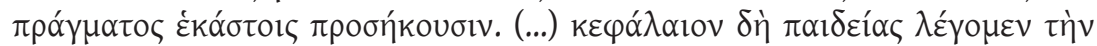

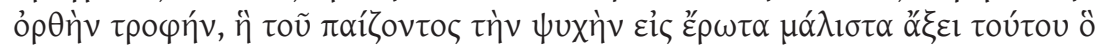

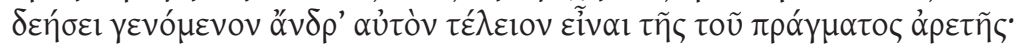

Com efeito, digo e defendo que, para um homem chegar a atingir a excelência em alguma coisa,é necessário aplicar-se logo desde a infância, por meio de jogos ou de matérias sérias, em todas as aç̧ões. (...) Afirmamos, certamente, que o mais importante da educação é a correcta disciplina, que conduza, sobretudo, a alma do educando para o amor daquilo que, logo que chegue à idade adulta, deverá tornar-se mais perfeito com a virtude da sua actividade.

${ }^{19}$ Y.Too (1995: 114) considera que "Isocrates is the ancient author who more than any other establishes writing as a medium of political expression and activity”.

${ }^{20} \mathrm{O}$ orador Demóstenes também perfilhava o ideal do pan-helenismo, como defesa contra os perigos externos, não contra os Persas, como entendia Isócrates, mas contra os Macedónios, uma vez que temia, e o desenrolar dos acontecimentos dar-lhe-ia razão, o fim da liberdade dos Gregos. Não pretendemos, com isto, afirmar que a opção de Isócrates se revelou devastadora para a Grécia, pois, não o esqueçamos, Alexandre e, antes, o seu pai foram responsáveis pela difusão da paideia grega, tendo-se servido de uma base pan-helénica.

${ }^{21}$ Ant. 295; Tucídides, por sua vez, apresenta Atenas, a cidade de Péricles, como a "escola da Hélade" (2.41.1). vide ainda An seni resp. 784B; em Lyc. 30, Plutarco usa esta imagem referindo-se à polis de Esparta.

${ }^{22} \operatorname{Lg}$. 643b e d. 
O cuidado com a educação, desde tenra idade ${ }^{23}$, visa formar bons cidadãos

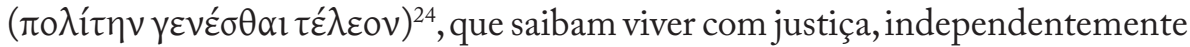
de exercerem o poder ou não. Esse é o papel que a paideia, em linhas gerais, exerce na vida das personagens de Plutarco, embora o sentido de paideia, enquanto cultura, assuma nas Vitae especial significado.

$\mathrm{O}$ percurso pedagógico em três etapas que $\mathrm{Plutarco}^{25}$, de forma pouco sistemática, apresenta na sua obra, reproduz o currículo proposto por Platão: uma primeira fase, onde se entra em contacto com os grammata, a mousike e a gymnastike ${ }^{26}$; uma segunda, dedicada a matérias relacionadas com a matemática, as ciências e também a literatura; e a última em que se ensina a retórica ou dialéctica e a filosofia. Para este percurso ser consequente e proveitoso, Plutarco apela à dedicação dos jovens para conseguirem ter sucesso nas suas carreiras políticas, sem nunca se esquecerem de continuar a cultivar os ensinamentos e a melhorar a sua arete.

Existe na cultura grega, desde os primórdios, a reflexão sobre o papel do homem no seu devir ou, por outras palavras, sobre o que pode o homem fazer para alterar a sua physis ou aquilo que herda no nascimento. Hesíodo, por exemplo, não se cansa, nos Erga, de fazer a apologia do esforço, do trabalho e do empenho do homem na prosperidade, na sua felicidade e na do oikos, mesmo em condições adversas para a condição humana. Numa perspectiva mais aristocrática, contudo, outros autores parecem não acreditar na educação como forma de alterar a physis. É o caso de Píndaro, que apenas admite a paideia para os aristoi, aqueles que já têm à nascença a arete, uma vez que ôs

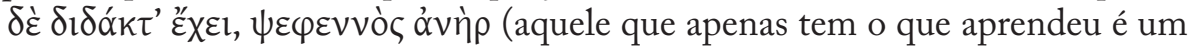
homem obscuro) ${ }^{27}$. J. Ribeiro Ferreira (1977-78: 25) recorda a este propósito um texto de Tucídides, onde o historiador da Guerra do Peloponeso reproduz um discurso de oradores que defendem as qualidades impregnadas nas suas physeis, as quais os habitantes de Atenas não possuem e que só podem atingir pela paideia, exemplificando-se, desse modo, a antítese entre physis e $\delta 1 \delta \alpha x \eta ́$, e as oposições, tão presentes no século $\mathrm{V}$ a. C., entre physis e nomos e physis e

${ }^{23}$ Cf. ibid. 789 e, onde se coloca a hipótese de fazer aprovar uma lei que obrigue a grávida a

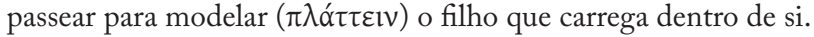

${ }^{24}$ Cf. ibid. 643e.

${ }^{25}$ A obra de K. Westaway (1922) oferece elementos sobre a paideia com muito interesse, embora coloque no centro da análise quase exclusivamente os Moralia.

${ }^{26}$ Xenofonte (Lac. 2.1) reparte, igualmente, por três disciplinas esta primeira fase: $\gamma \rho \alpha ́ \alpha \mu \alpha \tau \alpha$

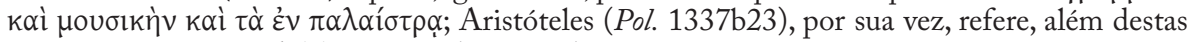
disciplinas, a үраүıкń; T. Morgan (1999: 51) nota que, no século IV a. C., as grammata e a mousike formarem um grupo separado da gymnastike (cf. P1. Prt. 326c ss., Euthd. 276a, Resp. 376e; Isoc. Antid. 266-7).

${ }^{27}$ Nem. 3.41. 


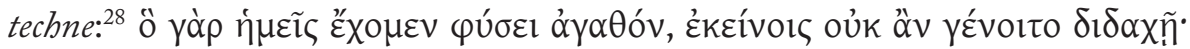

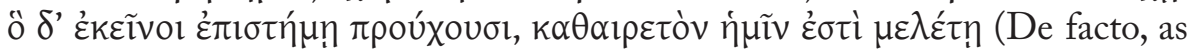
boas qualidades que nós possuímos por natureza não as podem eles adquirir pela aprendizagem e o que, graças aos seus conhecimentos, os superioriza podemo-lo nós eliminar pelo exercício).

Outro texto que aborda esta questão é o drama Philoctetes de Sófocles ${ }^{29}$, uma vez que a acção das personagens, particularmente a de Filoctetes e Neoptólemo, ora parece condicionada pela sua physis, ora influenciada pelo contacto humano (relações sociais) e pela paideia.

O debate que Platão desenvolve no Protagoras sobre se a virtude pode

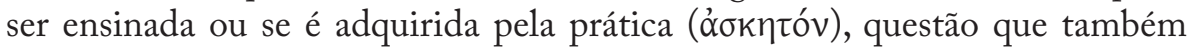
aborda no início do $M e n o^{30}$, isto é, se é possível a paideia intervir na physis, é recuperado, em parte, por Plutarco, no tratado An uirtus doceri possit, com uma resposta que não deixa grande margem de dúvida: a paideia, por intermédio do logos e do ethos, é possível, como é possível o homem aprender e formar a sua physis para atingir as aretai.

Esta formação da alma e da mente deve ser complementada, segundo a tradição, com o exercício do corpo, conselho que transmite no tratado $D e$ tuenda sanitate praecepta, em particular sobre os cuidados a ter com a saúde e a alimentação ${ }^{31}$. Mesmo aqueles que têm conhecimentos em saúde podem ser chamados philosophoi, sem se transgredir os limites do vocábulo ${ }^{32}$. No fundo, a

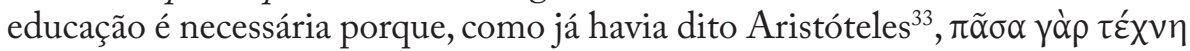

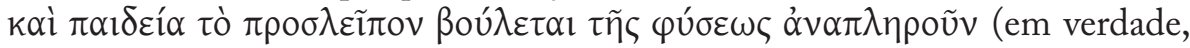
toda a arte e educação desejam suprir o que falta na natureza).

No tratado De liberis educandis ${ }^{34}$, para ilustrar o papel da educação, da conduta de vida e dos hábitos, na formação da virtude, conta-se que Licurgo treinou dois cachorros, filhos dos mesmos pais, de forma diferente: a um tornou-o guloso e a outro incutiu-lhe o gosto pela caça. Quando colocou no meio deles um prato e uma lebre, um correu para o prato e o outro para a lebre, num claro sinal da influência da educação. Conclui-se que a paideia pode modelar o carácter, mesmo quando se tem a mesma origem.

${ }^{28} 1.121 .4$.

${ }^{29} \mathrm{O}$ artigo de J. Ribeiro Ferreira (1977-78: 21-50) analisa, de forma exaustiva, esse drama e a problemática da educação que ele coloca.

30 70a; sobre outros elementos da paideia grega em Platão, vide C. Pancera (2006: 47-186).

${ }^{31}$ Note-se que Plutarco neste tratado aborda questões relacionadas com a saúde, as dietas e os exercícios, mas fá-lo de numa 'perspectiva' filosófica.

${ }^{32} \mathrm{Cf}$. De tuenda san. $122 \mathrm{E}$.

${ }^{33}$ Pol. 1337a1-3.

34 A-B. 


\subsection{As VITAE EM ANÁLISE}

Analisaremos, de seguida, o corpus das Vitae previamente definido. Tal como Plutarco avisa os seus leitores/ouvintes nas palavras introdutórias da biografia

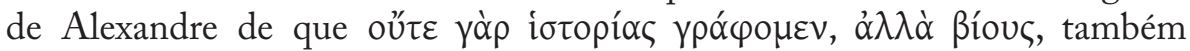
nós queremos sublinhar que não é nosso objectivo fazer uma interpretação minuciosa de cada um dos pares, mas uma abordagem que realce os elementos que concorrem para uma definição da paideia, com especial incidência na formação educativa dos heróis e nos valores éticos que demonstram na sua conduta de vida.

Possuir uma boa natureza, ter uma formação conveniente e o mais abrangente possível, saber pensar e reflectir, estar habilitado para avaliar os perigos e as consequências dos actos, reconhecer os erros e recusar uma acção que, mesmo podendo daí advir glória pessoal, pode colocar em risco o bem comum, observar normas morais e códigos éticos que tornem o herói modelo para os seus pares, são alguns dos traços que Plutarco desenvolve e que incorporam a estruturação do género. Não se trata, por isso, como temos

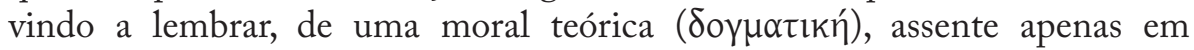
princípios gerais, mas de uma moral concreta e prática, através da parenética ( $\pi \alpha \rho$ $\propto v \varepsilon \tau \imath k \eta ́)$, uma vez que se considera que os princípios filosóficos, ficando no plano das ideias e do abstracto, não são suficientes para se saber agir ${ }^{35}$.

Nesse sentido, a própria paideia tem um nível mais teórico e outro mais prático. Nem sempre uma boa educação é sinal de uma vida exemplar e isenta de defeitos. Aí reside uma das características dos heróis de Plutarco: o carácter contraditório. Luculo, a título de exemplo, é descrito como sendo praotes e amável no trato, tenta evitar guerras civis, dedica-se à filosofia grega e é um apaixonado pela paideia grega em geral, além de se revelar um bom comandante. No entanto, também mostra ser em algumas ocasiões arrogante, cruel e amante da luxúria. Cícero é um pepaideumenos e esforça-se por aprofundar os seus conhecimentos, mas nem por isso a sua vida está isenta de actos controversos. Que pode isto significar? Que os acontecimentos que se atravessaram no seu caminho o obrigaram a agir dessa forma e que nenhum ser humano é perfeito? Sem dúvida. Do nosso ponto de vista, isso acontece, acima de tudo, porque o herói não conseguiu assimilar todos os valores da sua formação, nem se esforçou para os consolidar e aprofundar, uma vez que a paideia não se resume a um etapa inicial ou à recepção de conhecimentos, mas acompanha cada indivíduo, confundindo-se com as suas experiências de vida.

35 Semelhante concepção surge em Cic. de off. 3 e Sen. Ep. 94 (neste caso dá mesmo o exemplo de algumas figuras biografadas por Plutarco (62-66)). 
Para avaliarmos a paideia, conceito que agrega valores morais e formas de agir, procuraremos, assim, compreender o perfil ético-pedagógico dos heróis, adoptando uma estrutura semelhante à das synkriseis.

\subsubsection{Theseus-Romulus}

O par Theseus-Romulus, que tem o amigo de Plutarco, Sósio Senécio, por destinatário, é muito significativo pelo facto de os dois biografados pertencerem mais ao domínio do mito e da lenda do que da história, tendo Teseu,em particular, uma natureza mítica mais acentuada. Sem pôr em causa o seu método, muito próximo da historiografia, Plutarco tenta respeitar as suas ideias religiosas e, sobretudo, respeitar as tradições. Daí que assistamos a um processo, quase sistemático, de racionalização dos elementos míticos $(\mu \nu \theta \tilde{\omega} \delta \varepsilon \varsigma)^{36}$, de forma

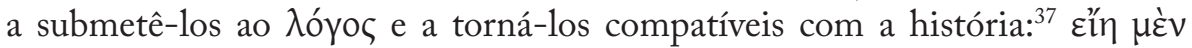

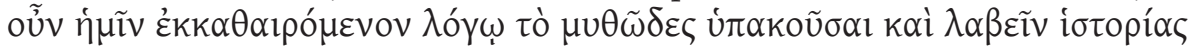
ó $\psi$ iv (Seja-me então lícito submeter a lenda ao processo de depuração que a razão opera, para que aquela ganhe o aspecto de história). Para Plutarco, a prosa, seguindo a concepção platónica, aproxima-se mais da realidade do que a poesia $^{38}$, conseguindo, desse modo, dar maior credibilidade aos factos, processo que conta com múltiplas referências a elementos arqueológicos ${ }^{39}$ para se provar a historicidade do mito. No entanto, segundo A. Pérez Jiménez (2005: 345 s.), esse objectivo do autor é conseguido, em grande medida, com o recurso a múltiplas fontes, insuspeitas quanto à sua credibilidade ${ }^{40}$.

Além disso, estas palavras introdutórias também se aplicam ao par Lycurgus-Numa, por se tratar de personagens que pertencem a um período das histórias grega e romana em que a distinção entre a realidade e o mito não é clara: Teseu, com dupla paternidade (Egeu e Posídon) ${ }^{41}$, e Rómulo estão ligados a relevantes aspectos sociológicos. Teseu, herdeiro de Egeu, enfrenta o desafio

${ }^{36}$ Em Alex. 35.10, a propósito da substância usada por Medeia para incendiar o peplo e a grinalda, e depois de abordar a existência de petróleo na Babilónia, Plutarco afirma que alguns autores ajustaram o mythos à aletheia ao dizerem que a dita substância era petróleo.

${ }^{37}$ Thes. 1.5. Em 14.2, por exemplo, afirma que o mito de Hécale e da sua hospitalidade não carece por completo da verdade e em 27.6, ao relatar as aventuras de Teseu com as Amazonas, Plutarco constata que, quando os factos se reportam a acções de um passado distante, é natural

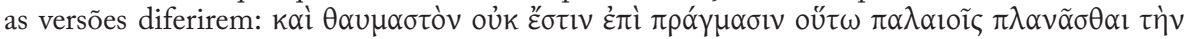

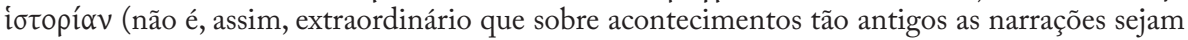
discordantes); sobre a depuração do material mítico, vide L. Séchan (1942: 83-106), C. Morales Otal (1994: 625-630), C. Pelling (2002g: 171-195), Ma . do Céu Fialho (2002: 67-79), A. Pérez Jiménez (2004b: 165-178) e (2005: 340 ss.).

${ }^{38}$ Cf. ibid. 2.3.

${ }^{39}$ Vide a enumeração das referências em F. Frost (1984: 66 ss.).

${ }^{40}$ Thes. 15.1, 22.7, 26.1, 29.1 são alguns dos exemplos mencionados pelo citado estudo.

${ }^{41}$ Thes. 6: a dualidade paternal responde à dualidade Trezena-Atenas, tão importante na concepção do mito de Teseu. 
de libertar Atenas, criando as bases sociais para uma nova realidade política na Ática, enquanto Rómulo, que aceitou partilhar o poder com Tácio para consolidar a união entre Romanos e Sabinos, promoveu a organização militar do seu povo e deu forma aos principais órgãos políticos que continuariam a funcionar na República. Em termos gerais, Teseu é o fundador (oikistes) heróico de Atenas e Rómulo, pater de Roma, é o responsável pela vocação militar do povo Romano, algo que foi decisivo para a grandeza futura da $\operatorname{Vrbs}$.

Estas duas personagens têm vários aspectos em comum: ${ }^{42}$ são filhos ilegítimos, mas gozaram da fama de descenderem de deuses; associaram nas suas acções a inteligência à força; raptaram mulheres; sofreram infortúnios e vinganças; e, no final das suas vidas, viveram momentos de conflito com os seus concidadãos. $\mathrm{O}$ biógrafo tenta, assim, dar uma dimensão histórica às suas personagens, numa tentativa de racionalização mitológica, sem deixar de lado as experiências do seu tempo, especialmente no momento de definir os valores éticos dos seus heróis. Veja-se, como logo no prólogo, ao comparar Teseu e Rómulo, Plutarco define os elementos estruturantes das duas biografias: a sua origem, as virtudes pessoais, o papel que tiveram como fundadores e raptores de mulheres, as suas desgraças familiares e o declínio final ${ }^{43}$.

Quanto à educação de Teseu, herói que serve para Plutarco manifestar a sua admiração por Atenas, refere-se que foi criado por Piteu e que teve como preceptor e mestre um homem chamado Cónidas, por quem os Atenienses teriam mais respeito do que pelo escultor Silânion (IV a. C) ou pelo escultor Parrásio (V-IV a. C.), autores de representações do herói Teseu: ${ }^{44}$

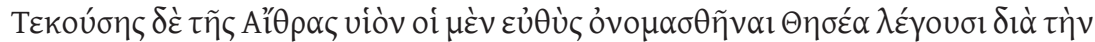

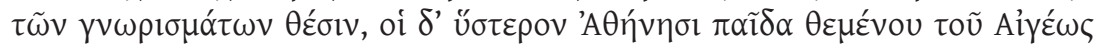

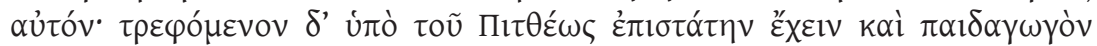

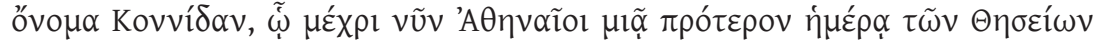

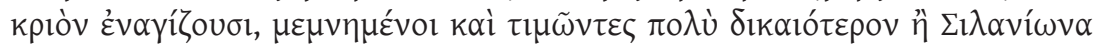

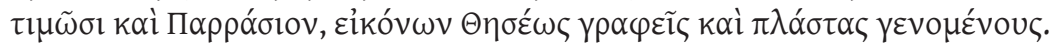

Tendo dado Etra à luz um filho, alguns chamaram-no Teseu por causa da exposição dos sinais de reconhecimento, outros quando, mais tarde, em Atenas,

${ }^{42}$ Cf. ibid. 2.

${ }^{43}$ Cf. ibid. 2.1-3; vide A. Pérez Jiménez (2005: 341-354), sobre a estrutura interna da biografia de Teseu: capítulos 1-5 (origem, infância e educação); 6-12 (philotimia do herói e os seus primeiros feitos); 13-23 (outras realizações dos heróis; vocação e virtudes políticas); 24-30 (principais feitos); nos capítulos restantes descreve o declínio de Teseu. O artigo de D. Larmour (1988: 361-371) analisa, com muita profundidade, a metodologia de composição plutarquiana adaptada a este par, realçando o paralelismo que existe ao longo das biografias.

${ }^{44}$ Cf. ibid. 4.1; veja-se como o texto procura uma etimologia para o nome de Teseu ( $\Theta \eta \sigma \varepsilon ́ \alpha<$

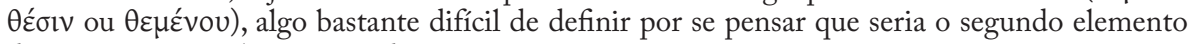
do composto a atribuir o sentido ao nome. 
Egeu o considerou seu filho. Criado por Piteu, teve um preceptor e mestre com o nome de Cónidas, a quem, até hoje, os Atenienses sacrificam um carneiro no dia anterior às Teseias, recordando-o e honrando-o de forma mais justa do que honram a Silânion e Parrásio, autores de pinturas e esculturas de imagens de Teseu.

Durante a viagem para Atenas, após Etra lhe revelar a verdade sobre a sua origem, versão só transmitida pelo Queronense, Teseu rege a sua acção pela arete, sobrepondo-se esta à techne ou melete. ${ }^{45} \mathrm{~A}$ forma como põe cobro à vida de Sinis, por exemplo, demonstra como a virtude se superioriza à técnica e ao exercício, pois, tal como explica no prefácio da biografia de Péricles ${ }^{46}$, a contemplação da virtude é suficiente para a exercitar e imitar, sem necessidade de aprendizagem ou prática. A viagem que Teseu empreende, numa clara analogia com os feitos de Héracles, serve para Plutarco imprimir uma dimensão ética a esse feito,

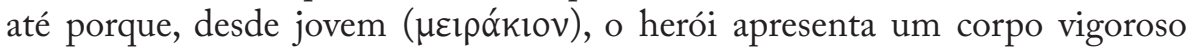

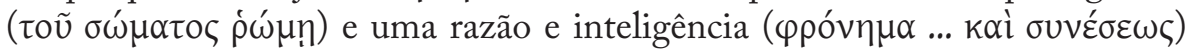
bem fundamentadas ${ }^{47}$. A imitação do herói dos doze trabalhos desempenha, sem dúvida, uma importante função na estrutura literária da biografia, usando Plutarco as histórias que vêm desde Baquílides, Eurípides, Diodoro Sículo e outros, sem esquecer o Helenae encomium de Isócrates, onde se comparam Teseu e Héracles, igualando-se a glória de ambos. Prefere Plutarco, no entanto, salientar o sentido pedagógico da mimesis, bem como a virtude que patenteiam nas suas acções.

Outro traço de Teseu, comum a muitos heróis plutarquianos e característica típica de um homem de Estado ${ }^{48}$, é o sacrifício pela pátria, como a seguir se prova: ${ }^{49}$

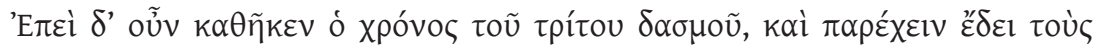

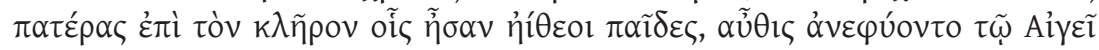

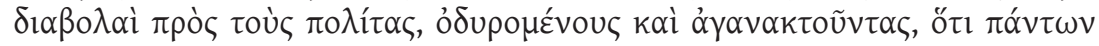

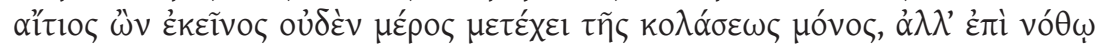

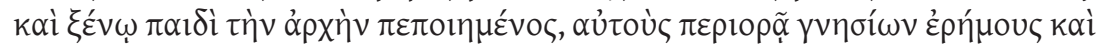

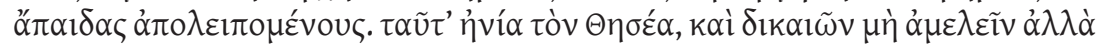

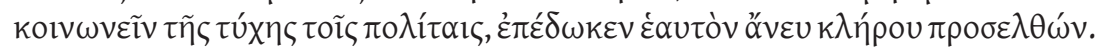

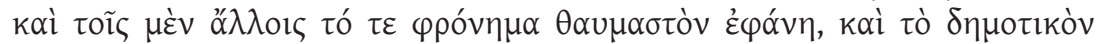

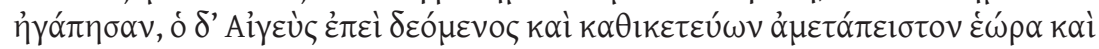

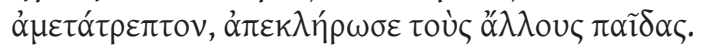

\footnotetext{
${ }^{45}$ Thes. 8.2.

${ }^{46} 1-2$.

${ }^{47}$ Cf. Thes. 6.2 .

${ }^{48}$ Cf. A. Wardman (1974: 67-78).

${ }^{49}$ Thes. 17.1; vide J. Duchemin (1969: 533-535).
} 
Quando chegou o tempo do terceiro tributo e era necessário apresentarem-se para o sorteio os pais que tinham filhos adolescentes, começaram, de novo, para Egeu as desavenças com os cidadãos, que se lamentavam e indignavam por, sendo ele o responsável de tudo, ser o único a não participar em qualquer parte do castigo, e por, depois de ter colocado no poder um filho ilegítimo e estrangeiro, olhar com indiferença para os que ficavam sem filhos legítimos e sem crianças. Estas coisas preocupavam Teseu e, por ser justo não se desinteressar, mas antes partilhar da sorte dos cidadãos, avançou para se oferecer ele próprio, sem sorteio. Pareceu aos outros uma decisão admirável e ficaram satisfeitos com o seu amor pelo povo; Egeu, porém, após preces e súplicas, quando viu que Teseu se mantinha inflexível e firme, tirou à sorte o nome dos outros jovens.

A atitude de Teseu, com elevado grau de dramaticidade, é um bom exemplo do conflito que pode existir entre o interesse pessoal e o público. Neste caso, ele sacrifica o seu próprio interesse e também o do seu pai, para dar primazia à comunidade, numa atitude filantrópica, valor também associado ao sentido de justiça. São estas qualidades que legitimam Teseu a traçar objectivos mais ambiciosos, como a reunião dos habitantes da Ática numa mesma cidade. É precisamente nos capítulos 24 e 25 que Plutarco faz eco do célebre e controverso sinecismo promovido por Teseu. ${ }^{50}$ Plutarco descreve, nesses capítulos, a intenção de Teseu em formar ( $\sigma u v \omega ̣$ kı $\sigma \varepsilon)$ uma comunidade democrática, o sinecismo, entendendo que este não implicaria somente uma unificação política mas também uma transferência populacional ${ }^{51}$. De historicidade muito discutida, o programa do sinecismo de Teseu, tal como

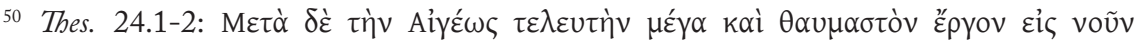

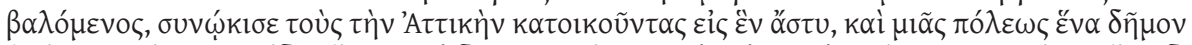

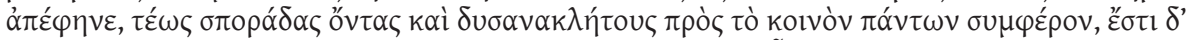

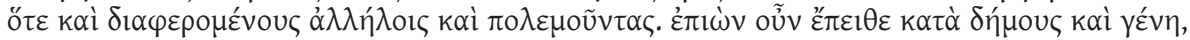

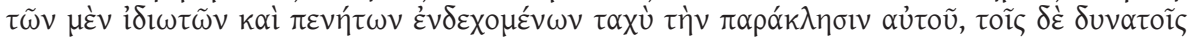

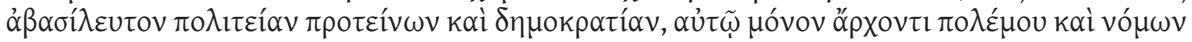

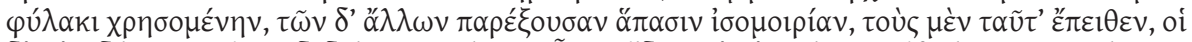

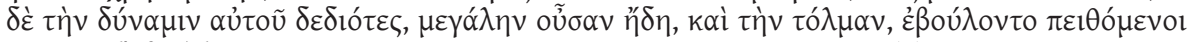

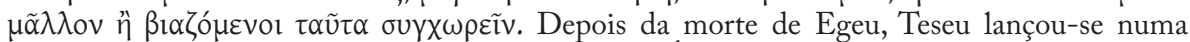
grande e admirável empresa: reuniu os habitantes da Ática numa só cidade e declarou-os um só povo de uma só cidade, eles que até esse momento estavam dispersos e eram difíceis de orientar para o bem comum, pois discordavam uns dos outros e guerreavam-se. Então, aproximando-se dos povos e famílias, procurava persuadi-los; enquanto os particulares e os pobres acolheram de imediato o seu projecto, para os poderosos a proposta de um regime sem rei e democrático, que o teria apenas a ele próprio como comandante da guerra e como guardião das leis, e quanto aos outros assuntos permitiria a todos uma parte igual, conseguiu persuadir uns, outros temendo o poder dele, que já era grande, e a sua audácia, preferiram aceitá-la pela persuasão, em vez do uso da força.

${ }^{51}$ Em Th. 2.14-15, o sinecismo da Ática surge apenas como uma unificação política; cf. Teoph. Char. 26. 
Plutarco o apresenta, pretende transmitir o perfil de um herói democrático e não despótico, imagem que prevalecerá na época helenística ${ }^{52}$. Segundo o texto citado, nem todos concordaram com a organização política proposta por Teseu, que não era a monarquia e que previa a isonomia. Para conseguir o sinecismo, o herói executou diversos actos: ${ }^{53}$ derrubou os pritaneus e consistórios; aboliu as magistraturas; construiu um pritaneu e um consistório comum; deu ao Estado o nome de Atenas; instituiu as Panateneias; celebrou as Metécias; abdicou do poder absoluto; organizou um Estado respeitador dos deuses; além de ter, por exemplo, mandado cunhar moeda e instituído, à semelhança de Héracles, os Jogos Istmicos ${ }^{54}$. Todos estes princípios tinham por objectivo engrandecer ( $\alpha \dot{\xi} \xi \tilde{\eta} \sigma \alpha l)$ a polis e reunir todos num mesmo espaço, fundando, assim, um povo comum..$^{55}$

No entanto, a esse povo único faltou, como a synkrisis evidenciará, o vínculo conjugal que lhe permitiria criar uma estrutura social mais sólida, algo que Rómulo não neglicenciaria na construção de Roma e que viria a ser um dos pilares do sucesso da Vrbs. Além disso, em Atenas, a ausência de um líder, pois as aventuras de Teseu ocupam-no mais do que o governo da cidade, mais não trouxe do que a confusão social. ${ }^{56} \mathrm{Na}$ verdade, o projecto de Teseu não agradou a todos, em especial aos poderosos, que se viram privados dos lugares de chefia, além de a confusão gerada com a falta de um governo estável ter sido aproveitada por demagogos como Menesteu. Este relato pode levarnos a colocar a hipótese de Plutarco estar a tentar fazer uma interpretação do presente, pois também a aristocracia grega, com o domínio romano, perdeu parte da sua liderança e os Gregos, em geral, passaram a viver uma eleutheria diferente.

Ainda assim, Plutarco, no final da biografia, realçará a philanthropia de Teseu para com os mais necessitados, fazendo do herói um símbolo de veneração por parte da classe menos favorecida junto do seu túmulo: ${ }^{57} \kappa \alpha i ̀ ~ \kappa \varepsilon \tilde{\tau} \tau \alpha l ~ \mu \grave{\varepsilon} \nu$

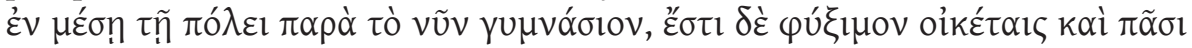

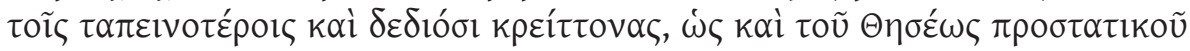

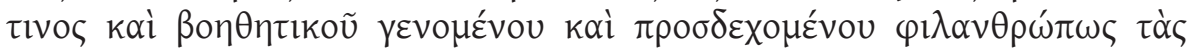

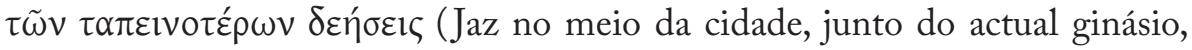
e é um local de refúgio para os servos, para todos os mais humildes e para os que temem os mais poderosos, pois também Teseu foi protector e caridoso, e acolheu com humanidade as súplicas dos mais humildes).

\footnotetext{
${ }^{52}$ Também nas Suplicantes de Eurípides, Teseu aparece como polemarca.

${ }^{53}$ Cf. Thes. 24.3.

${ }^{54}$ Sobre estes dois últimos aspectos, vide Thes. 25.3 e $25.5-6$, respectivamente

55 Thes. 25.1.

${ }^{56}$ Thes. 32.1.

57 Thes. 36.4.
} 
A biografia de Rómulo acompanha, em linhas gerais, a estrutura da de Teseu. No entanto, Plutarco além de apontar diferenças entre os dois heróis, interessa-se, ainda, pela comparação entre Rómulo e Remo. A descrição que Plutarco faz dos dois deixa perceber que o primeiro manifestou, desde cedo, alguns traços que o haveriam de distinguir do irmão: ${ }^{58}$

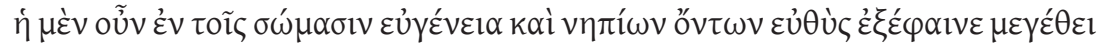

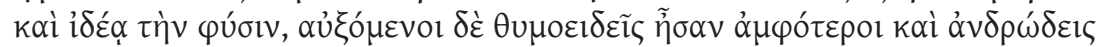

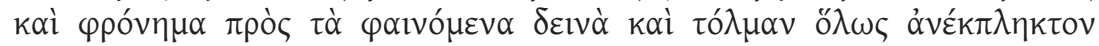

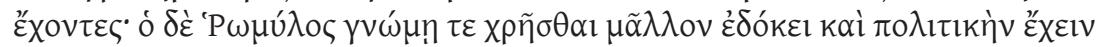

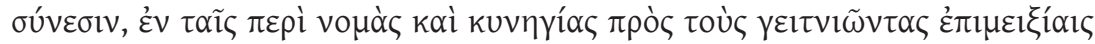

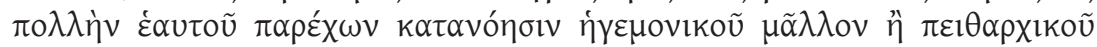

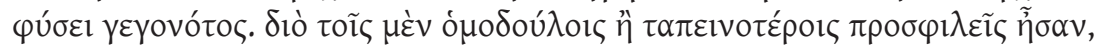

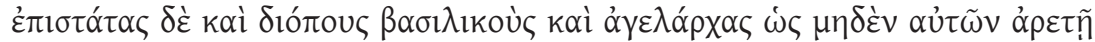

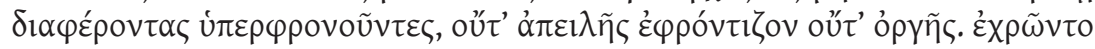

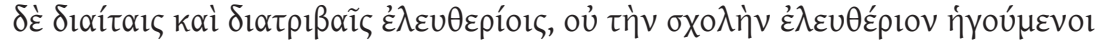

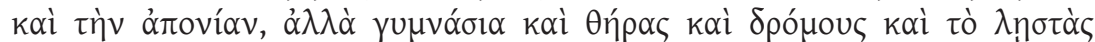

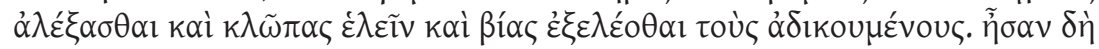

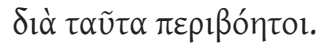

Além disso, desde a mais tenra idade, a nobreza do seu físico deixava logo transparecer a verdadeira natureza que possuíam, pois eram de boa estatura e belos. Depois de crescerem, mostravam-se ambos corajosos e viris, exibindo um espírito disposto a enfrentar os perigos que surgissem e uma audácia a toda a prova. Rómulo, porém, parecia usar melhor o discernimento e a intuição política, pois no relacionamento com os vizinhos, a propósito de problemas com os prados e a caça, dava a impressão de possuir um espírito mais disposto por natureza a mandar do que a obedecer. Por esta razão, eles eram bem vistos pelos companheiros de servidão e pelos mais humildes, ao mesmo tempo que desprezavam os intendentes, os emissários do rei e os chefes dos pastores (pois estes não lhes eram superiores em valor), não se preocupando com o facto de suscitarem ameaças e fúrias. Dedicavam-se ainda a actividades e passatempos próprios de pessoas livres e não consideravam coisa enobrecedora a indolência e a falta de canseiras, mas antes o exercício físico, a caça, as corridas, o pôr em fuga piratas, capturar ladrões e livrar da violência os injustiçados. Por estes motivos, atraíam grande fama.

Como acontece muitas vezes nas Vitae, as características que os biografados revelam numa fase ainda incipiente da vida são um sinal daquilo que marcará

\footnotetext{
${ }^{58}$ Rom. 6.3-5 (seguimos, para a biografia de Rómulo, a tradução de D. Leão (2006)).
} 
as suas acções no futuro ${ }^{59}$. Tanto Rómulo como Remo possuem qualidades indispensáveis para a guerra, como o poder físico, a valentia ou audácia, que os tornam destemidos perante o perigo. Em que aspecto se distinguiu Rómulo?

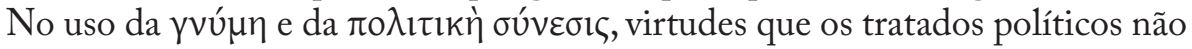
deixam de realçar e que habilitam o indivíduo a assumir funções de chefia. Tal como Teseu, Rómulo ganha o respeito e a admiração dos mais desfavorecidos, pela forma abnegada como ele e o irmão lutavam em prol dos seus intuitos. Note-se que, embora o ambiente pastoril que envolve o crescimento dos gémeos, as actividades a que se dedicavam, referidas no final do texto, são, por oposição, próprias de pessoas livres, ou seja, uma educação que segue a linha da aristocracia grega.

Se no tratado De fortuna Romanorum Plutarco sublinha a cooperação entre a fortuna e a virtude no nascimento, na salvação e no crescimento de Rómulo ${ }^{60}$, também na biografia deste repetirá essa ideia, até porque, para Plutarco, foi dessa cooperação com a providência divina que resultou o esplendor de Roma ${ }^{61}$. Para os acontecimentos que envolvem Numitor, Remo, Rómulo e Amúlio, Plutarco nota uma vez mais que se terá servido de Fábio Pictor e Díocles Peparécio ${ }^{62}$. Já antes havia dito que eles foram os primeiros que publicaram para os Gregos uma versão da história romana digna de credibilidade ${ }^{63}$, ainda que não deixe de advertir que a natureza dos

${ }^{59}$ Cf. e.g. Alex. 5.4 e Tim. 3.4-5.

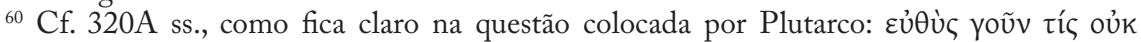

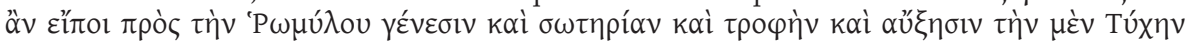

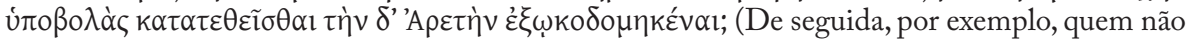
diria sobre o nascimento, a salvação, a criação e o crescimento de Rómulo que a Fortuna colocou os fundamentos e a Virtude acabou a construção?); no mesmo tratado, Plutarco refere que a tyche e o daimon conduziram os Romanos aos feitos mais célebres e à sua grandeza, mas também se deve imputar à tyche a origem dos maiores desastres: os Celtas acamparem no Capitólio e sitiarem a Acrópole ou o assalto nocturno dos Gauleses (cf. ibid. 324D ss.).

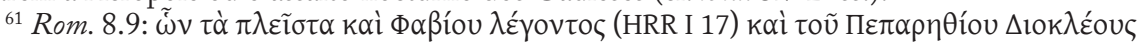

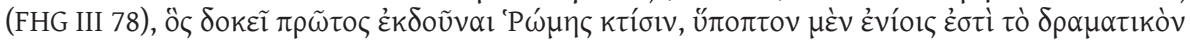

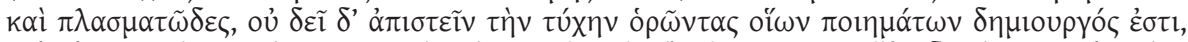

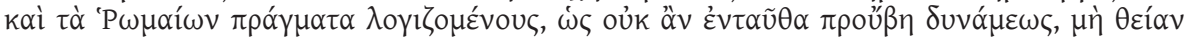

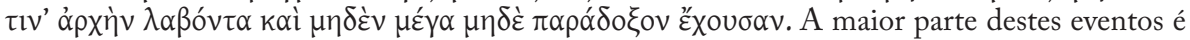
narrada por Fábio e Díocles de Peparetos, o qual - segundo consta — havia sido o primeiro a publicar uma Fundação de Roma; alguns, porém, mostraram-se renitentes, por causa da presença de elementos farsescos e fictícios. Em todo o caso, não se justifica a desconfiança, ao constatarmos de que tipo de obras foi artífice a fortuna e ao enumerarmos as façanhas dos Romanos: de facto, não teriam chegado a uma tamanha força, se não houvessem tido uma origem divina, magnífica e extraordinária.

${ }^{62}$ Díocles foi um historiador grego da Época Helenística e Fábio Pictor, escrevendo em Grego, foi o primeiro analista entre os Romanos.

${ }^{63}$ Cf. Rom. 3.1; a relação entre Díocles e Fábio Pictor tem suscitado alguma discussão, sendo geralmente aceite que o segundo terá usado a história sobre a fundação da urbs escrita por Díocles, embora as incertezas se mantenham. 
acontecimentos inspira algum cuidado pelo seu teor dramático ( $\delta \rho \alpha \mu \alpha \tau \imath k o ̀ v)$ e fabuloso ou fictício $(\pi \lambda \alpha \sigma \mu \alpha \tau \tilde{\omega} \delta \varepsilon \varsigma)$. Onde não tem dúvidas é em atribuir

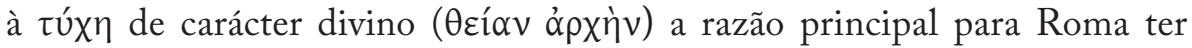
atingido tal dimensão e esplendor, sem deixar de apontar a arete romana como outro dos factores ${ }^{64}$.

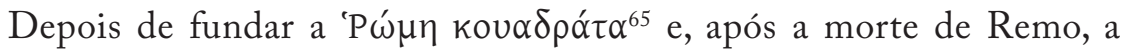
cidade de Roma, Rómulo entrega-se à árdua tarefa da organização social

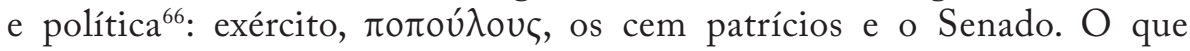
claramente ilustra a concepção organizacional de Rómulo é o facto de os mais poderosos terem por obrigação tratar os mais humildes de forma

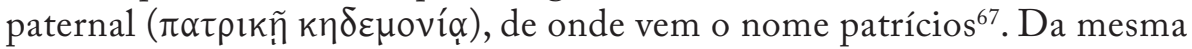
forma, os poderosos deveriam merecer o respeito e a consideração de $\operatorname{todos}^{68}$.

A descrição do carácter de Rómulo, que era $\varphi \imath \lambda \circ \theta u ́ \tau \eta \varsigma ~ \kappa \alpha i ̀ ~ \mu \alpha v \tau \imath \kappa o ́ s \varsigma^{69}$ (duas qualidades que atestam o seu valor guerreiro e a sua religiosidade), assume especial interesse pelas facetas que a descrição manifesta no rapto das Sabinas ${ }^{70}$. Plutarco introduz da seguinte forma as motivações do rapto: ${ }^{71}$

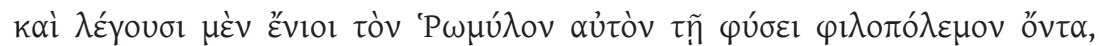

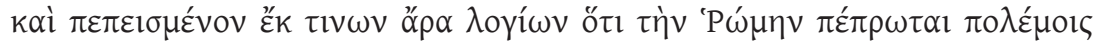

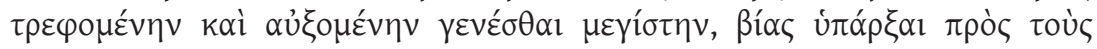

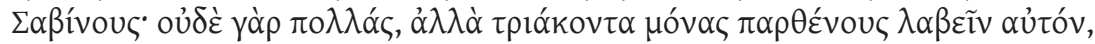

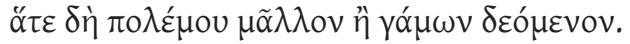

${ }^{64}$ Sobre a natureza dupla do sucesso romano, vide De glor. Athe. 345E, 348E, Flam. 11.5 e Comp. Arist.-Cat. Ma. 1.3; registem-se, a propósito desta matéria, as palavras de S. Swain (1989:

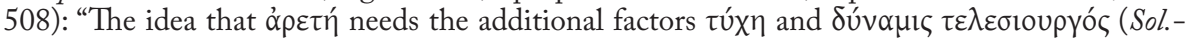
Publ. synk. 3.5, Dion 1.3) is fundamental to Plutarch's thought elsewhere and to his conception here of Rome's rise to greatness"; o mesmo estudioso, num outro artigo (1989: 272-302), defende que Plutarco acreditava num passado pré-determinado e que o sucesso de Roma se devia à providência divina.

${ }^{65}$ Cf. Rom. 9.4; enquanto Remo fundou, no Aventino, a Remoria.

${ }^{66}$ Cf. Rom. 13.

${ }^{67}$ Cf. T. Lívio 1.8.7 ou Cic. Rep. 2.14, onde se encontram explicações semelhantes.

${ }^{68}$ Cf. Rom. 13.5

${ }^{69}$ Cf. Rom. 7.2., desenvolvido em 9.5-7 (auspício anterior à fundação) e 22-3 (festas e cerimónias dos Romanos e Sabinos).

${ }^{70}$ Cf. Rom. 14; para a datação do rapto, Plutarco segue a versão de Fábio Pictor (FGrHist 809 F5a), ou seja, ocorreu no quarto mês após a fundação de Roma, mais precisamente a 21 de Agosto, por ocasião dos jogos em honra de Neptuno Equestre, os Consualia, data também seguida por Cícero (Rep. 2.7.12) e Tito Lívio (1.9.6); outros, como Dionísio de Halicarnasso (Antiq. Rom. 2.31.1), situam o rapto quatro anos depois da fundação; cf. J. Poucet (1972: 48135); em 15.7, Plutarco refere uma data diferente, o dia dezoito do mês Sextílio (o uso de $\Sigma \varepsilon \xi \tau \imath \lambda$ íou mostra que a sua fonte é da Época Republicana), que erroneamente situa os Consualia.

71 Ibid. 14.1 
Ora alguns sustentam que teria sido Rómulo a provocar à força os Sabinos, pois era por natureza amante da guerra e estava convencido, por influência de alguns oráculos, de que Roma tinha um destino marcado por guerras, que a fariam crescer e a tornariam majestosa. De facto, ele teria raptado não muitas donzelas (somente umas trinta), com a intenção de, através delas, atingir mais depressa a guerra do que de o casamento.

Logo, o rapto das Sabinas era muito mais um acto de guerra do que uma forma de superar a falta de mulheres, uma vez que, segundo estas versões não identificadas ( $\lambda \varepsilon ́$ ́

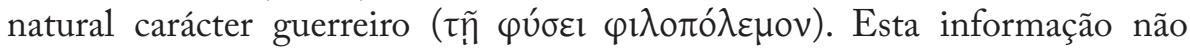
coincide, por exemplo, com a interpretação de Tito Lívio, que encontra na penuria mulierum a motivação principal para o rapto ${ }^{72}$, leitura que o próprio Plutarco prefere ${ }^{73}$. Quanto ao número de mulheres raptadas, há também várias versões, embora, neste caso, Plutarco aborde a questão directamente. ${ }^{74}$ Atribui-se, de facto, uma dimensão sociológica ao rapto, independentemente do número de virgens raptadas. Aliás, Plutarco, ainda que recusando a versão de que os Romanos raptaram trinta virgens, número que dava uma imagem selectiva do rapto, e, por isso, negativa para Rómulo ${ }^{75}$, não opta pela versão de Valério Antias, autor de uns Annales que descreviam a história ab urbe condita até à morte de Sula $\left(78\right.$ a. C. ${ }^{76}$, nem pela de Juba, autor de uma Historia romana, a quem Augusto nomeou rei da Mauritânia, com o nome de Juba II, e que promoveu a cultura grega no Norte de África. Para dar uma boa imagem de Rómulo, Plutarco salienta que apenas raptaram jovens solteiras e, por mero acaso, Hersília ${ }^{77}$, a única casada. Não era, deste modo, intenção dos

${ }^{72}$ Cf. 1.9.1.

${ }^{73}$ Cf. Rom.14.2.

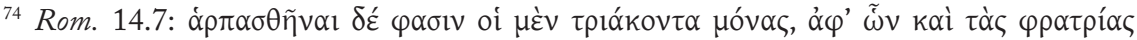

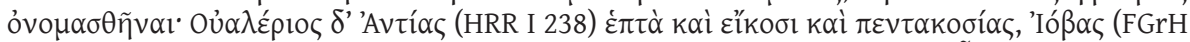

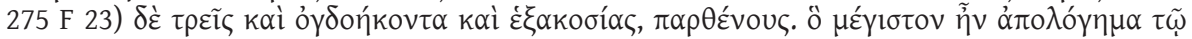

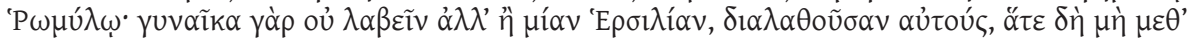

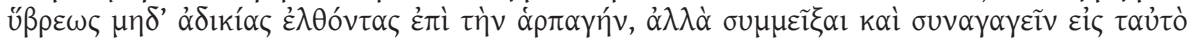

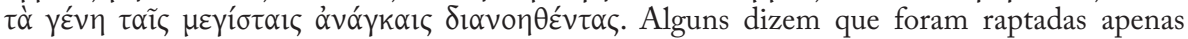
trinta donzelas, sendo a partir delas que se deu o nome às tribos; porém, Valério Antias fala em quinhentas e vinte e sete, e Juba em seiscentas e oitenta e três. Um aspecto muito importante abona em defesa de Rómulo: de facto, não tomaram nenhuma mulher casada a não ser Hersília, e esta por engano, o que mostra que eles avançaram para o rapto não por violência ou injustiça, mas antes para fundirem e juntarem os dois povos - e ainda assim movidos por imperiosas necessidades.

${ }^{75}$ Cf. Rom. 20.3.

${ }^{76} \mathrm{Na}$ synkrisis de Teseu e Rómulo, 6.2, Plutarco refere que Rómulo raptou cerca de oitocentas, número que não coincide com nenhuma das outras versões e que manifesta a intenção de apontar um número elevado.

${ }^{77}$ Para Tito Lívio (1.11.2), Hersília é a coniunx de Rómulo. Após a sua morte e com o nome de Hora, tornou-se a divindade do matrimónio e da fecundidade, venerada no templo 
Romanos destruir os laços matrimoniais dos Sabinos, até porque o rapto não

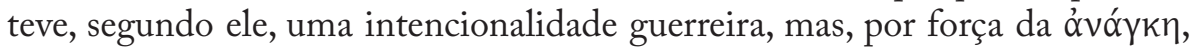
promoveu a união entre povos diferentes. Este episódio, como o capítulo 15 da biografia de Rómulo prova, serve para Plutarco tratar dos costumes matrimoniais dos Romanos, temática que já tinha sido objecto de algumas considerações nas Quaestiones Romanae ${ }^{78}$.

Os Sabinos, como relata a tradição, desejavam o regresso das jovens e enviaram uma embaixada para persuadir Rómulo. Como este se mantinha irredutível, preferindo convencer os Sabinos da validade da união, o confronto entre as tropas de Ácron, rei da cidade de Cenina, e Rómulo foi inevitável. ${ }^{79}$ Além da ajuda divina, como vimos anteriormente, outro aspecto que, segundo Plutarco, mais contribuiu para a grandeza de Roma foi a sua política de assimilação dos povos vencidos, pacificando-os e fazendo-os participar dos seus direitos de cidadania. Em relação a este episódio, Dionísio de Halicarnasso ${ }^{80}$, numa perspectiva menos filo-romana, tem uma interpretação diferente, pois Rómulo teria convertido os homens e os seus filhos em escravos, versão que, obviamente, não serve para Plutarco idealizar a imagem de Rómulo. Além disso, percebemos, em definitivo, na synkrisis, que o rapto das Sabinas tem outro alcance: ${ }^{81}$

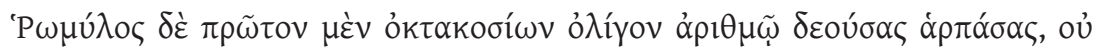

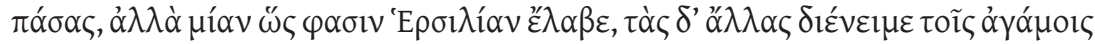

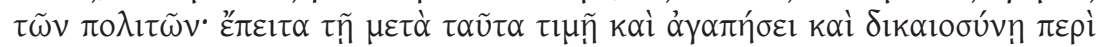

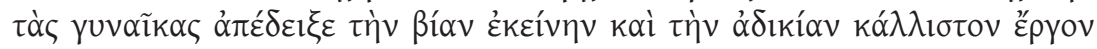

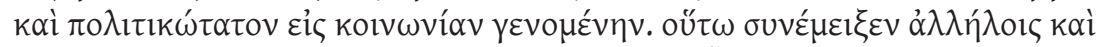

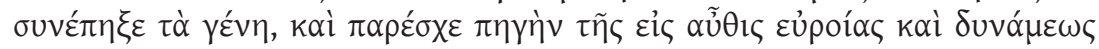

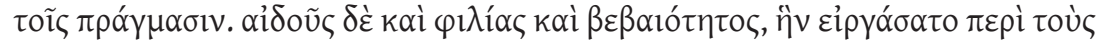

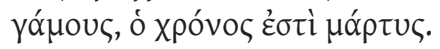

de Quirino (Rómulo divinizado). Em Plutarco, no entanto, Hersília não surge como esposa de

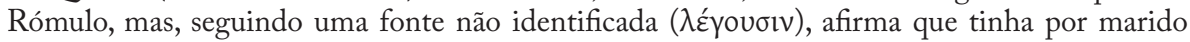
Hóstio Hostílio, avô do rei Tulo Hostílio (cf. Rom. 14.8 e 18.6).

${ }^{78}$ Cf. Rom. 15.7;

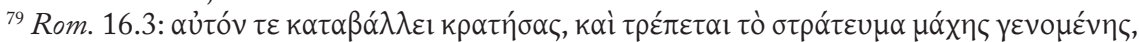

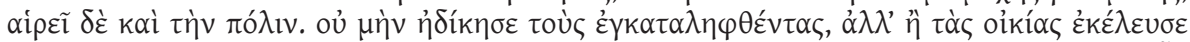

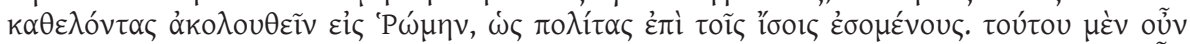

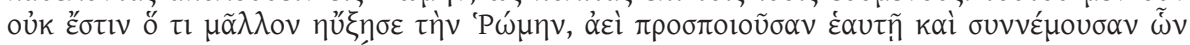

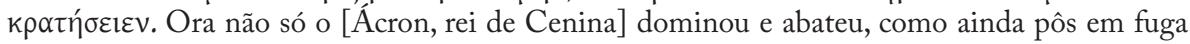
o exército, depois de entrar em combate, e conquistou também a cidade. Mesmo assim, não exerceu violência sobre os prisioneiros, mas ordenou-lhes que derrubassem as suas casas e o seguissem até Roma, onde se tornariam cidadãos com direitos iguais. Em boa verdade, foi esta atitude, mais do que qualquer outra razão, que permitiu a Roma tornar-se grande: conciliar consigo mesma e integrar sempre os povos que ia vencendo.

${ }^{80}$ Antiq. Rom. 2.34.1.

${ }^{81} 6.2-3$. 
Contudo, Rómulo, antes de mais, apesar de ter raptado quase oitocentas mulheres, não as guardou a todas para si mas apenas a Hersília, segundo se conta, repartindo as restantes pelos cidadãos que não estavam casados. Mais tarde e na sequência destes acontecimentos, o respeito, amor e correcção que observaram no trato com as mulheres transformaram aquela violência e injustiça no acto mais belo e politicamente mais proveitoso para a comunidade. $\mathrm{E}$ assim, misturou uns com os outros e fundiu os dois povos, preparando o Estado para a torrente futura de abundância de poder. E quanto ao pudor, amizade e firmeza que logou incutir nos matrimónios, pode servir de testemunha o tempo.

Deste modo, o rapto da Sabinas, mais do que um acto de guerra, é para Plutarco a base da consolidação social, assente em matrimónios estáveis, o que permite a Rómulo construir os fundamentos do futuro poder romano, algo que Teseu não conseguiu com o sinecismo. Se Rómulo procurou construir de raiz uma cidade, Teseu intentou algo mais ousado e, sem dúvida, mais arrojado, que foi a dissolução de povos e a alteração das instituições tradicionais destes para as juntar numa só.

Mesmo que a história nos diga que a grandeza e a excelência da civilização romana se conseguiu com muito sangue, Plutarco, revelando alguma isenção na análise e até deixando transparecer algum louvor à estratégia de conquista dos Romanos, salienta que Rómulo, sem fazer da violência o seu principal aliado, procurou construir $(\kappa \tau \hat{\zeta} \zeta \omega)^{82}$, ao invés de Teseu, que quis substituir uma estrutura por outra. No fundo, o Queronense baseia nesta diferença a estrutura das duas biografias, como a seguir se percebe: ${ }^{83}$

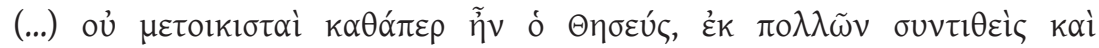

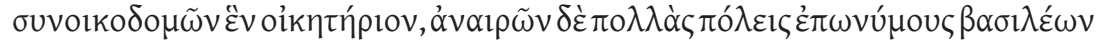

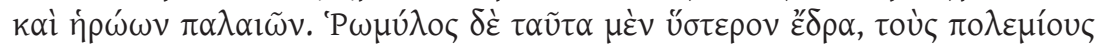

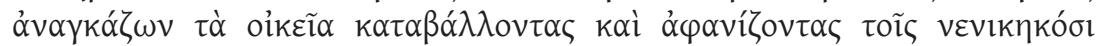

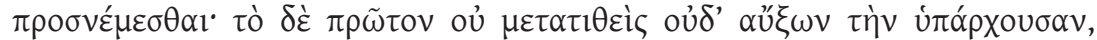

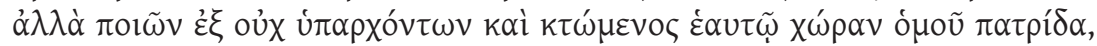

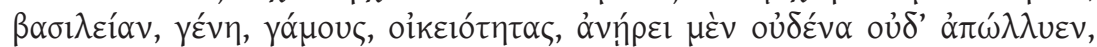

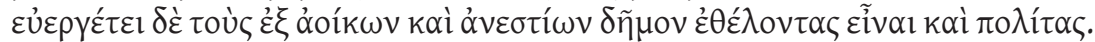
$\lambda$ nб

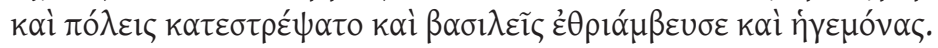

(...) e não propriamente transferidos [os Latinos] de residências como foi o caso de Teseu, que juntou e fundiu diferentes povoações numa única, destruindo muitas cidades cuja designação derivava do nome de reis e antigos

${ }^{82} \mathrm{O}$ mesmo verbo é, por exemplo, usado quando se refere às cidades que Alexandre fundou no Oriente (cf. De Alex. fort. aut. uirt. 328B)

${ }^{83}$ Comp. Thes. - Rom. 4.2-3. 
heróis. Rómulo tomou essas medidadas mais tarde, ao forçar os inimigos a abater e destruir as próprias casas, a fim de irem viver com os conquistadores. No início, porém, não transferiu nem alargou uma cidade já existente, antes a construiu a partir do nada, sendo obrigado a lutar ele mesmo e de uma só vez por conseguiur uma terra, uma pátria, um reino, estirpes, casamentos e relações de parentesco; não abateu nem eliminou ninguém, mas de bom grado acolheu os que não tinham casa nem lar e desejavam ser contados entre o povo e os cidadãos. Não matou ladrões nem malfeitores, mas submeteu nações pela guerra, aniquilou cidades e triunfou sobre reis e comandantes.

A acção de Rómulo, em suma, é um sinal do que viria a ser o Império, facto que confere a esta biografia - e o mesmo se aplica à de Teseu —, um sentido pedagógico e etiológico.

Em virtude da sua origem e do seu ethos, Rómulo marcará, segundo Plutarco, a história romana. Por exemplo, o amor dos Romanos pelo combate ${ }^{84}$ e o seu comportamento bélico ${ }^{85}$ serão explicáveis pelo facto de Rómulo ser filho de Marte, deus da guerra. Além disso, Rómulo recusou-se a estabelecer os limites da $V r b s^{86}$, num claro sinal do seu desejo de conquista, antevendo-se, desta forma, a vocação imperialista de Roma. Outro sinal do espírito guerreiro de Rómulo encontra-se na sua decisão de fazer começar o ano em Março, mês consagrado ao deus da guerra. Note-se que o carácter de Rómulo é oposto ao de Numa, rei pacificador, que dirigiu os homens mais para o trabalho do campo do que para combates ${ }^{87}$ e que os incitava a contentarem-se com o seu território a fim de viverem em paz com os seus vizinhos ${ }^{88}$. No entanto, nem as reformas de Numa alteraram o gosto dos Romanos pela guerra, demonstrando-se, desta forma, que as leis, mesmo reconhecendo-se-lhes um papel pedagógico, nem sempre são capazes de moldar ou alterar a íntima natureza humana.

$\mathrm{Na}$ synkrisis ${ }^{89}$ deste par, Plutarco salientará que Teseu agiu por sua própria iniciativa e vontade, enquanto Rómulo o fez mais por necessidade. ${ }^{90}$ Também no par Sertorius-Eumenes realçaremos a distinção entre acção voluntária e involuntária dos heróis, que é determinante para a avaliação do ethos. O processo de racionalização mitológica torna-se evidente quando Plutarco compara, por exemplo, a guerra contra as Amazonas com as lutas travadas por Rómulo. Também o amor, que marca o percurso de Teseu, é considerado uma maquinação dos deuses para bem deste, acabando o autor por considerar que

\footnotetext{
${ }^{84}$ Cf.Quaest. Rom. 47, 276B.

${ }^{85}$ Cf. ibid. $19,268 \mathrm{C}$.

${ }^{86}$ Cf. ibid. $15,267 \mathrm{C}$.

${ }^{87}$ Cf. ibid. $19,268 \mathrm{C}$.

${ }^{88}$ Cf. ibid. $15,267 \mathrm{C}$.

${ }^{89}$ Análise da synkrisis em T. Duff (2002r: 257-8).

${ }^{90}$ Cf. Comp.Thes.-Rom. 1.1.
} 
aqueles que não se apaixonam são mais merecedores de censura. Mas Plutarco não pretende desculpabilizar os seus heróis por intermédio da acção divina: ${ }^{91}$

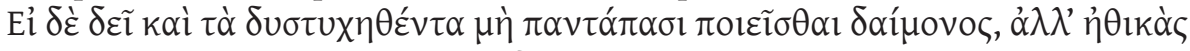

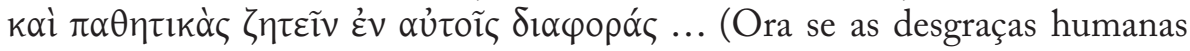
não podem ser consideradas apenas responsabilidade divina, mas a sua causa deve buscar-se também nos diferentes caracteres e paixões de cada um ...).

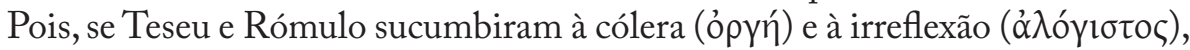
o mesmo aconteceu com o filho do primeiro e com o irmão do Romano, ainda que esses erros tenham origens diferentes e às quais é difícil de resistir: o amor (Teseu) e os deveres de Estado (Rómulo). No entanto, Plutarco inclina a sua preferência para Teseu, por achar que a ira de Rómulo teve um final infeliz, enquanto a do filho de Egeu se ficou pela palavra e pelo insulto, tendo Hipólito sido vítima da tyche.

Mesmo reconhecendo que ambos foram, por natureza, políticos, Plutarco critica o facto de não terem implementado a monarquia, o sistema político que o biógrafo prefere: Teseu promove a democracia, logo a demagogia, enquanto Rómulo instaura a tirania, ou seja, o despotismo, dois sistemas fomentadores do ódio entre os governados. ${ }^{92}$

Pela forma como Plutarco desenvolve o seu raciocínio ao longo destas biografias, elas constituem uma espécie de physis primária dos dois povos. As diferenças e semelhanças que fomos apontando acabarão por se repetir noutros bioi e, o que é ainda mais importante, os alicerces lançados por estes dois heróis determinaram bastante a identidade e a história dos Gregos e dos Romanos.

O par Theseus-Romulus é muito importante, apesar de as referências directas à paideia serem quase escassas, por Plutarco nos apresentar heróis fundadores, num contexto de construção identitária, que será determinante no devir histórico. As biografias de Teseu e Rómulo, onde mito e história confluem, são uma base, não negligenciável, dos valores que moldam e integram a paideia, até pela acção política de ambos.

\subsubsection{Aristides-Cato Maior}

Tanto Aristides como Catão Censor, duas personagens históricas que surgem algumas vezes associadas nos $\mathrm{Moralia}^{93}$, tiveram, segundo Plutarco, uma entrada tranquila na vida política ${ }^{94}$ e viveram momentos decisivos para as suas

\footnotetext{
${ }^{91}$ Comp.Thes.-Rom.3.1.

${ }^{92}$ Cf. Comp. Sol.-Pub. 2.4-6; Comp. Lyc.-Num. 1.1-5; Comp. Aem.-Tim. 2.1-7; Comp. DionBrut. 1.6-8 .

${ }_{93}$ Cf. e.g. De coh. ira 463E, An seni resp. 797A e Praec. ger. reip. 805E.

${ }^{94}$ Em Praec. ger. reip. 805E, Plutarco explica que ambos cresceram junto de homens célebres e experientes, Aristides junto de Clístenes e Catão de Máximo (Cf. Arist. 2.1 e Cat. Ma. 2.3, 3.4).
} 
pátrias. Aristides participou activamente nas Guerras Medo-Persas, confrontos tão decisivos para a Europa como ainda hoje a conhecemos, e Catão Censor ${ }^{95}$ na Hispânia, na Segunda Guerra Púnica ou na Batalha das Termópilas (191 a. C.), tendo sido tribuno militar (214 a. C.), questor (204), edil (199), pretor (198), cônsul (195) ${ }^{96}$ e censor (184), as magistraturas do cursus honorum $^{97}$. No caso de Catão, por ter vivido 85 anos (234-149 a. C.), assiste e participa em vários acontecimentos que ditariam o domínio do espaço mediterrânico por Roma. Apesar disso, as biografias que protagonizam, concentram-se na análise ética, em particular na qualidade moral do exercício da politeia, abordando também na biografia de Catão Censor a relação entre os tradicionais valores romanos e a paideia grega.

A pobreza, a justiça e o amor pela pátria ${ }^{98}$ merecem da parte do biógrafo de Queroneia realce especial na composição do bios de Aristides ${ }^{99}$, tal como a prática da virtude, que, fundada na razão, brota da actividade pública do herói. Assim, Plutarco descreve acções concretas de Aristides, a partir das quais nos é possivel entender o ethos.

Não se detendo nas questões relacionadas com a formação educativa do herói ${ }^{100}$, Plutarco começa por descrever a condição social, por ser um elemento relevante na análise do carácter de Aristides, filho de Lisímaco ${ }^{101}$, e dos possíveis benefícios que a sua vida política lhe possa ter trazido, apresentando

${ }^{95}$ Sobre a figura de Catão, além da bibliografia que indicaremos em nota ao longo das próximas páginas, foi-nos útil a leitura do livro de C. Pimentel (1997). 12.1).

${ }^{96}$ Depois de cônsul, serviu novamente como tribuno militar por sua vontade (cf. Cat. Ma.

${ }^{97}$ Cf. Cat. Ma. 3.3: Plutarco faz referência ao cursus honorum e como Catão Censor partilhou com Valério Flaco as mais elevadas magistraturas.

${ }^{98}$ Cf. A. Pérez Jiménez (1980). Note-se que para este estudioso o patriotismo é a qualidade mais realçada por Plutarco; podemos encontrar um argumento a favor desta tese em An seni

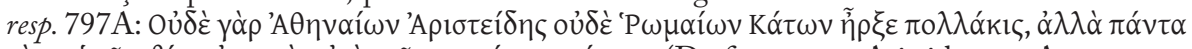

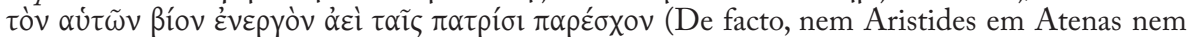
Catão em Roma tiveram muitas vezes o poder, mas entregaram a sua vida inteira ao serviço da pátria); a philopatria é, sem dúvida, um valor apreciado por Plutarco, mas quando o patriotismo se torna exacerbado é muitas vezes nocivo e inoportuno, como prova a biografia de Fócion; em J. Pinheiro (2006: 23-24), desenvolvemos alguns dos traços do carácter de Aristides.

${ }_{99}$ Apesar de o nosso estudo não contemplar a comparação entre o texto de Plutarco e o de Cornélio Nepos (vide V. Ramon Palerm (1992: 81-112)), gostaríamos de referir que são notórias as semelhanças que se podem encontrar, levando os estudiosos da Quellenforschung a acreditar que ambos seguiram a mesma fonte moralizante para escreverem a vida de Aristides, à qual Plutarco juntou as suas próprias convicções morais (Cf. A. Pérez Jiménez (1980: 152-3)).

100 Este, como veremos adiante com mais pormenor, não é um caso único, uma vez que, em diversas biografias, não se faz qualquer referência à educação do herói, nem ao nome dos educadores.

${ }^{101}$ Aristides teve um filho que herdou, como era habitual, o nome do seu pai, personagem principal do diálogo aporético de Platão intitulado Laches, onde o valor da paideia surge como um dos temas. 


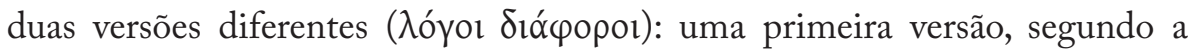
qual ele viveu na pobreza (penia), não identificando, contudo, a fonte; e uma segunda versão, apoiada na obra Sócrates ${ }^{102}$ do gramático e orador peripatético Demétrio de Falero ${ }^{103}$, que procura provar a riqueza (euporia) de Aristides, apontando três razões:

1. se Aristides ocupou o cargo de arconte epónimo, então é porque era um indivíduo com elevados rendimentos;

2. a condenação de Aristides ao ostracismo ${ }^{104}$ revela que era uma personagem importante e incomodativa, pois apenas esses sofriam tal condenação;

3. desempenhou a função de coregia, tendo depositado no santuário de Dioniso trípodes como oferenda pela sua vitória. Ora, tal só estava ao alcance daqueles que tinham posses para suportar as despesas inerentes à representação do coro.

Apoiando-se em Idomeneu de Lâmpsaco ${ }^{105}$ (IV-III a. C.) e em Panécio de Rodes ${ }^{106}$ (II a. C.), Plutarco refutará, em absoluto, cada um destes três argumentos, pois defende a tese contrária. Sendo adverso à luxúria e à ostentação, Plutarco sublinha, em vários passos da biografia de Aristides ${ }^{107}$, a sua pobreza ${ }^{108}$, evidenciando, desse modo, que considera a pobreza voluntária um valor. Dito de outra forma, apesar dos cargos, dos títulos e das vitórias que a vida pode proporcionar, fruto da sorte ou do mérito, conseguir manter a

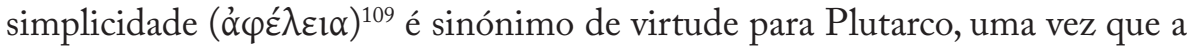

${ }^{102}$ Cf. FGrH 228 F 43.

${ }^{103}$ Terá participado, segundo alguns, na fundação do Museu e da Biblioteca de Alexandria, além de ter governado, em nome da Macedónia, a cidade de Atenas, entre 317 e 307 a. C.

${ }^{104}$ Cf. Arist. 7.2,6; Cim. 17.3, Nic. 11.1, Per. 10.1; vide L. Piccirilli (1988: 46 ss).

${ }^{105}$ Cf. FGrH 338 F 5; protector e amigo de Epicuro, Idomeneu de Lâmpsaco exerceu

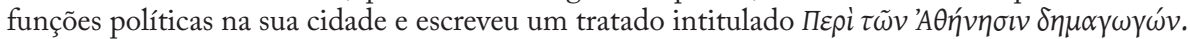

${ }^{106}$ Cf. Fr. 131 v. Str.; Panécio de Rodes foi um importante filósofo da escola estóica que muito influenciou os membros do círculo de Cipião.

${ }^{107}$ Cf. 5.6; 24.1;25.3-9;27.1-7; Comp. Arist. -Cat. Ma. 3-4. Parece evidente que Plutarco reuniu as duas vidas, a de Aristides e de Catão Censor, pelo facto de ambos levarem uma vida simples e frugal; para Catão, a luxúria romana, que ele critica, tem origem na adopção na

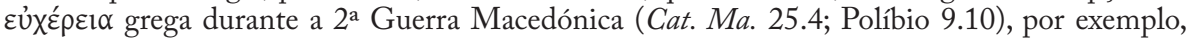
salienta o impacto moral negativo causado pelos artefactos siracusanos em Roma); refira-se que

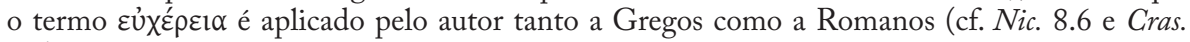
7.7); para outras referências sobre a riqueza e a luxúria na República e no Império, vide Mar. 34.4, Luc. 39.2 e Publ. 15.3-6.

${ }^{108}$ Para M. B. Artacho (2001: 337 n.1): “El culpable en su origen de esta atribución parece haber sido el diálogo Calias de Esquines de Efesto, en el que se pretendió hacer de Aristides un "anti-Calias" (Plut., Arist., 25.4-9=Aesch. Socr., F.36 Dittmar). La figura de Aristides "E1 Justo" parece que fue transferida en tiempos de Sócrates a la de Arístides "El virtuoso", por lo que la escuela socrática y quizás también la cínica exaltaron la pobreza de Sócrates, asimilando a ésta aquélla de Aristides."

${ }^{109}$ Em Praec. ger. reip. 820F, considera-se que a melhor honra é a simplicidade; Plutarco usa,

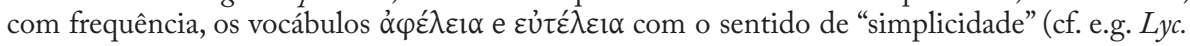


nobreza de espírito vale mais do que qualquer quantia em ouro ${ }^{110}$. Observando o papel da pobreza nas biografias de Aristides e Catão, C. Pelling (2002: 1445) afirma: "Aristides' poverty will be important to his literary presentation of the pair, both confirming the famous incorruptibility and making it more remarkable". Segundo o pensamento plutarquiano, a apheleia e a autarkeia garantem a liberdade do indivíduo, enquanto a luxúria apenas conduz à escravidão ${ }^{111}$.

Outra questão abordada na biografia de Aristides é o equilíbrio entre justiça e utilidade na acção política ${ }^{112}$. Um episódio emblemático sobre a dificuldade de se aliarem estes dois elementos ocorre quando Aristides se recusa a apoiar o plano de Temístocles, que projectava o incêndio da armada naval dos inimigos, embora isso resultasse na supremacia de Atenas na Grécia ${ }^{113}$. Para Aristides, prevalece o valor da dikaiosyne, o que merece a aprovação de Plutarco: ${ }^{114}$

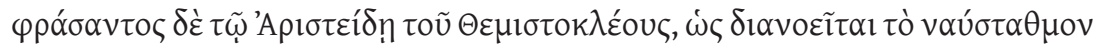

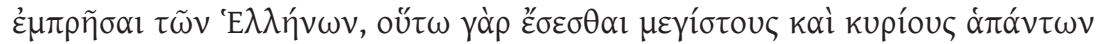

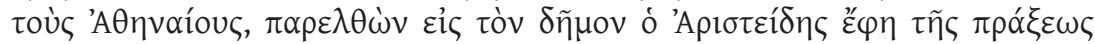

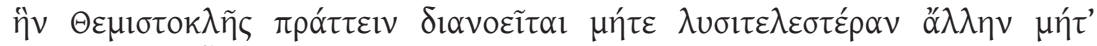

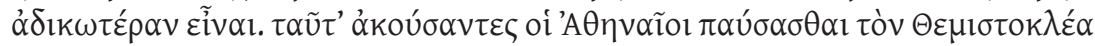

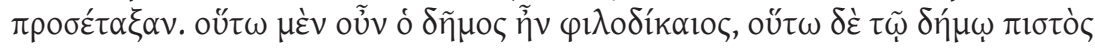

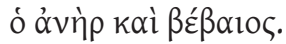

Tendo Temístocles revelado a Aristides que projectava incendiar o porto dos Gregos, e, dessa forma, tornar os Atenienses os mais poderosos e os soberanos de todos, Aristides aproximando-se da assembleia do povo afirmou não existir acção mais útil nem mais injusta que aquela que Temístocles projectava empreender. Depois de ouvirem estas palavras, os Atenienses ordenaram a

12.1, 24.4, Phil. 2.1, Sull. 35.3, Cim. 5.5, 14.4 e Caes. 2.4), qualidade que é uma manifestação da sophrosyne; por isso, Plutarco associa algumas vezes a sophrosyne e a apheleia ou a euteleia (cf. Cim. 14.4, Luc. 40.3, Ages. 14.1 (neste caso junta no mesmo sintagma o vocábulo metriotes), Phoc. 19.1, Cat.Mi. 19.8 e Ag. 53.5).

${ }^{110} \mathrm{Ph}$. Stadter (1997: 75-78) reflecte, de forma interessante, sobre a riqueza e a pobreza no contexto específico da participação na vida pública por parte de Aristides e de M. Pórcio Catão.

${ }^{111}$ Cf. De cup. diu. 523D e De uit. ear. al. 828C; Comp. Lyc. -Num. 4.7;

${ }^{112}$ Cf. Praec. ger. reip. 817D. Em De coh. ira 458C, ao tratar das acções que se executam em estado colérico, Aristides, juntamente com Camilo, Q. Cecílio Metelo e Sócrates, é mencionado como um exemplo de benevolência e moderação. Sobre a utilidade e a justiça na biografia de Aristides, vide A. Pérez Jiménez (1980: 147-153), A. Nikolaidis (1995: 301-12) e F. Frazier (1996: 161-164).

${ }^{113}$ A. Pérez Jiménez (2004a: 134-5) acha que o facto de Aristides considerar essa medida injusta é um sinal do sentimento pan-helénico, da mesma forma que Plutarco elogia Agesilau por não concordar com a entrega de algumas cidades aos Persas pelos Espartanos (cf. Ages. 23.23), ou seja, a paz de Antálcidas; sobre este passo, vide D. Shipley (1997: 273-284)

${ }^{114}$ Arist. 22.3-4; em Flam. 11.4, afirma que a coragem (andreia) e a prudência (phronesis) são muito importantes, mas que ser justo é o melhor bem. 
Temístocles que abandonasse o plano. Tal era, sem dúvida, o amor do povo pela justiça e tal a credibilidade e a segurança que o povo tinha neste homem.

Demonstra-se, assim, a autoridade e a reputação que Aristides gozava junto do povo, granjeadas pelo carácter evidenciado nas batalhas decisivas de Maratona e Plateias. Essas qualidades têm todas um sentido colectivo, uma vez que Aristides se define por aquilo que faz em prol da pátria e não tanto por aquilo que consegue para si próprio. ${ }^{115}$ Tendo o homem público por primeiro dever o bem comum ${ }^{116}$, também a relação entre justiça e utilidade se define por esse parâmetro, como defende A. Pérez Jiménez (2004a: 127-136), ao apontar três tipos de conflito que se podem gerar: entre a justiça e a utilidade própria, entre a justiça, o interesse pessoal e o público, e, por fim, entre a justiça e a utilidade pública. Se, por um lado, existe justificação para cometer injustiças em benefício da pátria, também há casos em que o rigor pode pôr em causa o interesse público ${ }^{117}$, o que revela que Plutarco prefere a justiça pública à pessoal.

Eleito estratego em 478, Aristides vai, na companhia de Címon, ao encontro de Pausânias para subtrair Chipre e Bizâncio do domínio Persa ${ }^{118}$, ocasião que Plutarco aproveita para realçar a $\pi \rho \alpha \alpha_{o} \zeta$ e a $\varphi \imath \lambda \alpha v \theta \rho \omega \pi i ́ \alpha$ de Aristides, e a preferência deste em usar meios justos, pacíficos e respeitadores dos princípios para atingir o poder. Refira-se, no entanto, que, se é verdade que Plutarco admira Aristides por não cometer injustiças, também não censura deliberadamente Temístocles por este afirmar que não desejaria ocupar um posto com o qual os seus amigos não tivessem vantagem sobre os inimigos ${ }^{119}$. Veremos, mais à frente, que no tratado Praecepta gerendae reipublicae se assume que, em algumas circunstâncias, os fins justificam os meios, especialmente quando estão em causa grandes feitos e o interesse interfere com o próprio Estado $^{120}$.

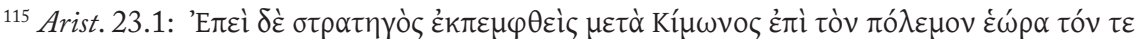

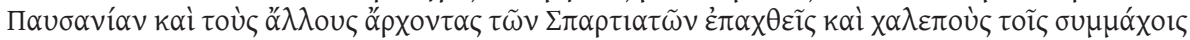

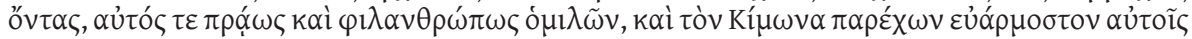

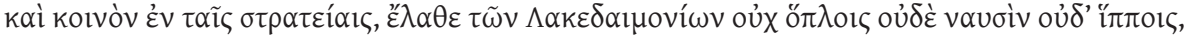

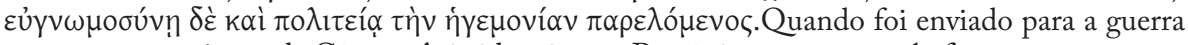
como estratego, junto de Címon, Aristides viu que Pausânias e os outros chefes espartanos eram insuportáveis e hostis para os aliados; então, com a afabilidade e humanidade que punha no relacionamento, com a companhia de Címon, sendo harmonioso com eles e imparcial nas acções militares, Aristides apoderou-se do comando não por meio das armas, dos navios e dos cavalos, mas de forma benevolente e democrática, e escapou dos Lacedemónios.

${ }^{116}$ Cf. Phoc. 2.7-9.

${ }^{117}$ Cf. e.g. Mar. 42.4 e Phoc. 32.6-7.

${ }^{118}$ Cf. Th. 1.94.

${ }^{119}$ Cf. Arist. 2.5-6.

${ }^{120}$ Sobre esta questão, vide T. Duff (2002r: 132 s.). 


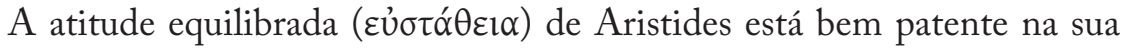
aç̧ão política, pois não se envaidecia com as honras e perante as dificuldades agia com serenidade, qualidades indispensáveis para os que exercem cargos de liderança. ${ }^{121}$ Aliás, o seu equilíbrio e ética política podem ser demonstrados por meio de diversas atitudes que tomou, algumas delas de grande coragem: ${ }^{122}$

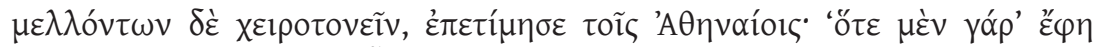

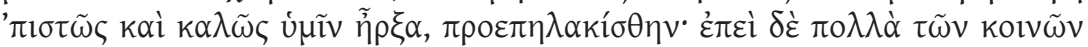

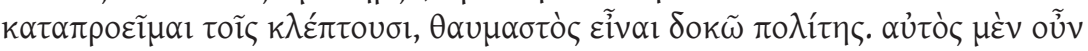

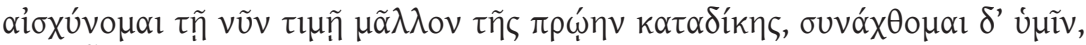

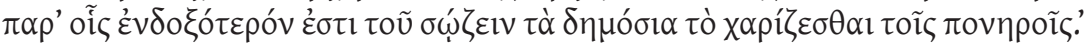

Preparando-se para votar de mão estendida, ele repreendeu os Ateninenses ao dizer: "Quando vos governei com fidelidade e justiça, fui ultrajado. Depois que deixei fugir os que roubam uma grande parte dos bens comuns, passo a ser um cidadão admirável. Eu envergonho-me sem dúvida mais com a presente honra do que com a condenação do passado e aflijo-me convosco, por vos merecer mais glória aquele que agrada aos perversos do que o que preserva o erário público".

ou

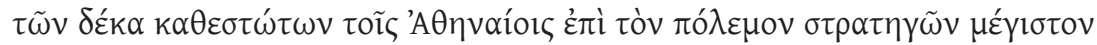

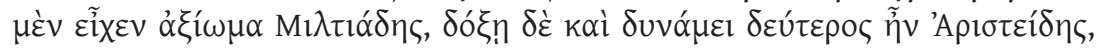

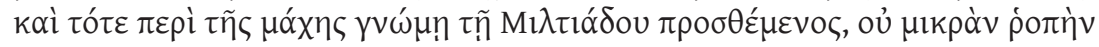

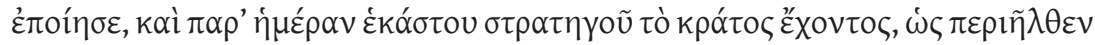

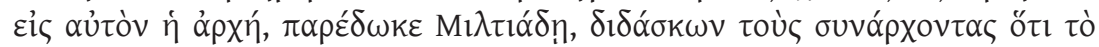

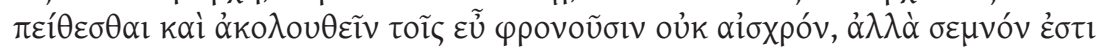

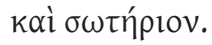

Dos dez estrategos eleitos pelos Atenienses para a guerra, Milcíades usufruía da maior honra e, em segundo lugar, estava Aristides pelo seu juízo e força; nesse momento, aplicando no combate o plano de Milcíades, não provocou pouco impacto; como em cada dia um estratego exercia o poder, quando o comando chegou a Aristides entregou-o a Milcíades, explicando aos restantes estrategos

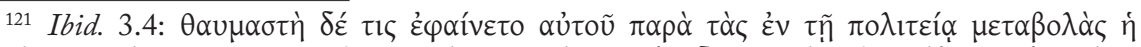

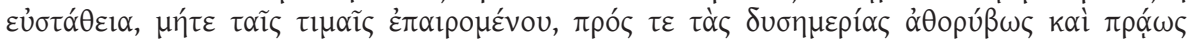

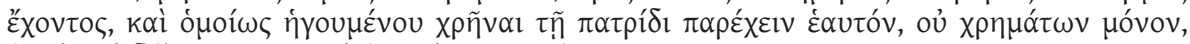

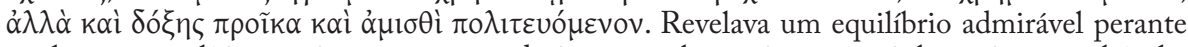
as alterações políticas, pois não se engrandecia com as honrarias e mantinha-se imperturbável e sereno na desgraça; acreditava que era necessário entregar-se, de igual forma, à pátria e participar na vida pública sem recompensas e desinteressadamente, quer a nível monetário, quer em relação aos louvores.

${ }^{122}$ Arist. 4.6-7 e 5.1-2, respectivamente. 
que obedecer e seguir os que são verdadeiramente sensatos não é vergonhoso, mas é venerável e salutar.

Ambos os textos são suficientemente elucidativos para atestar o sentido ético de Aristides e mostrar como colocava o bem comum à frente da honra pessoal. No primeiro texto, Plutarco condena aqueles que louvam uma atitude condescendente para com aqueles que mais não fazem do que gastar os bens comuns. Por assim agir, Aristides perderia certamente o voto da maioria, mas obtinha o apoio sincero dos que comungavam desses ideais ${ }^{123}$. Em relação ao segundo texto, Aristides dá uma lição de autoridade ao prescindir do lugar de comando, em favor de Milcíades, uma vez que a estratégia deste havia dado bons resultados. Percebe-se também o valor que para um estratego deve ter a obediência, pois quanto maior ela for maior será a autoridade daquele que comanda perante os seus pares. Com esta atitude, Aristides conseguiu ainda

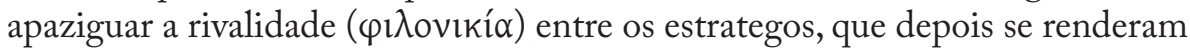
à superioridade e ao sucesso atingido por Milcíades, cedendo também eles o seu lugar ${ }^{124}$.

A tal ponto Aristides coloca a Hélade acima de tudo que dirige a Temístocles, seu rival ${ }^{125}$ e proeminente figura da célebre batalha de Salamina, palavras sensatas, de modo a evitar constrangimentos pessoais que coloquem em causa o bem superior que é a pátria: ${ }^{126}$

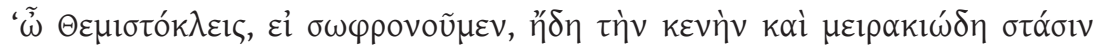

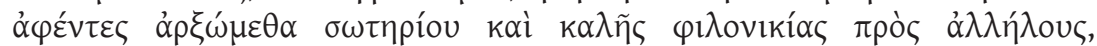

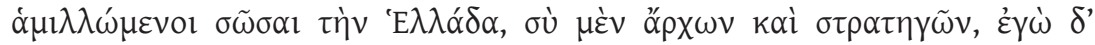

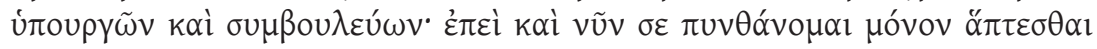

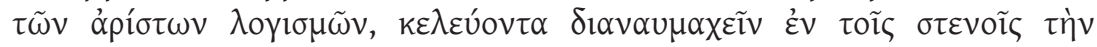

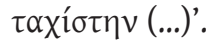

“Temístocles, se somos sensatos, esqueçamos a nossa vã e frívola rivalidade e comecemos uma rivalidade sã e bela, na qual nos esforçaremos por salvar a Hélade. Tu ao comando como estratego e eu às tuas ordens dando-te conselhos. $\mathrm{Na}$ verdade, noto agora que és o único capaz das melhores estratégias, por quereres travar, o mais depressa possível, um combate naval nos estreitos (...)”.

${ }^{123}$ Cf. Arist. 4.8.

${ }^{124}$ Heródoto (6.110) não refere a atitude de Aristides, mas conta como os estrategos cederam o cargo a de Milcíades.

${ }^{125} \mathrm{Em}$ Pel. 4.3, para realçar o afecto e a amizade de Epaminondas e Pelópidas, critica a rivalidade entre Temístocles e Aristides, por terem passado mais tempo a combaterem-se entre si do que a vencer o inimigo, tal como Címon e Péricles ou Nícias e Alcibíades.

${ }^{126}$ Arist. 8.3. 
O patriotismo de Aristides, pela forma como assume que a defesa da liberdade da Hélade é um valor prioritário, torna-se, em simultâneo, o principal objectivo do herói e uma virtude, certamente muito apreciada por Plutarco, que viveu numa época em que essa liberdade está ameaçada pelo Império: ${ }^{127}$

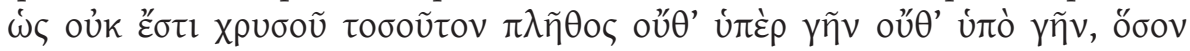

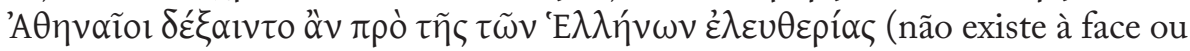
por baixo da terra quantidade de ouro suficiente que levasse os Atenienses a trocarem-na pela liberdade dos Gregos).

Apesar de ter a seu encargo um assunto tão importante, a constituição económica da Liga de Delos, e que certamente agitaria vários interesses, Aristides provou que entendia a politeia como um serviço pelo bem público e não para tirar proveito pessoal dele, uma vez que abandonou o cargo mais pobre do que quando o assumiu, tendo feito um registo dos bens de forma transparente ( $\kappa \alpha \theta \alpha \rho \tilde{\omega} \zeta)$, justa ( $\delta$ เ $\alpha i ́ \omega \varsigma)$, conciliadora $(\pi \rho \circ \sigma \varphi \imath \lambda \tilde{\omega} \varsigma)$ e coerente

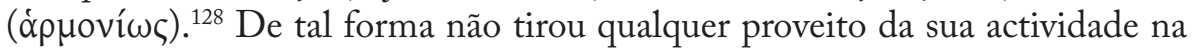
Liga de Delos que a sua descendência viveu na miséria. Depois da sua morte, nem ele próprio mereceu um túmulo digno dos seus feitos em prol da Hélade, nem a sua família e nem as suas próprias filhas, que casaram graças a um dote suportado por fundos públicos, herdaram bens que lhes evitassem a pobreza. ${ }^{129}$ Note-se que todos estes episódios relacionados com a sepultura de Aristides

\footnotetext{
${ }^{127}$ Ibid. 10.5; por exemplo, Calícrates dá a vida pela Hélade (cf. 17.8).

${ }^{128}$ Ibid. 24.2 .

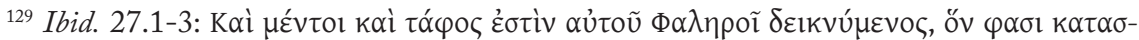

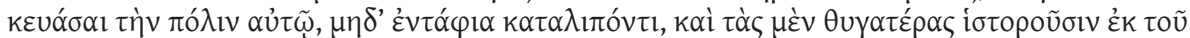

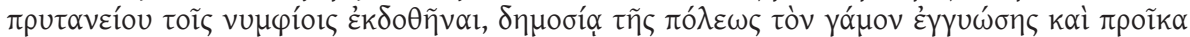

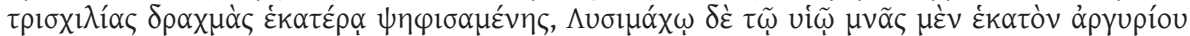

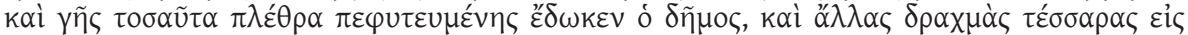

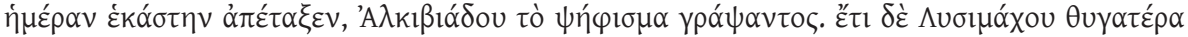

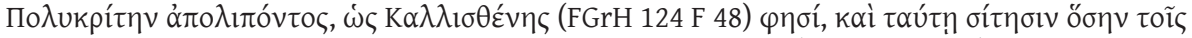

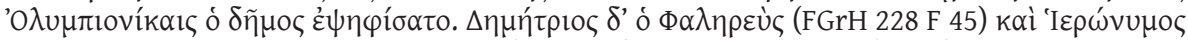

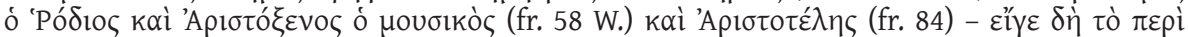

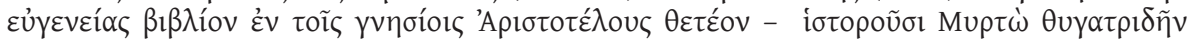

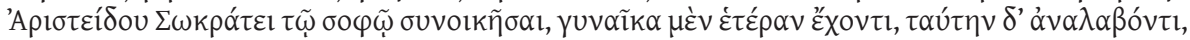

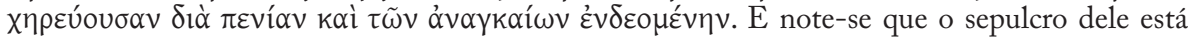
exposto em Falero e que, segundo dizem, foi a cidade que o preparou para ele, pois Aristides nada deixou para a cerimónia fúnebre; contam que as filhas dele casaram com jovens noivos graças ao pritaneu, pois a cidade financiou com bens públicos o casamento, ao decretar que se desse três mil dracmas, a título gratuito, para cada uma delas. Ao filho Lisímaco o povo deu cem minas de prata e igual número de pletros em terra cultivada, e consignou-lhe outras quatro dracmas ao dia, por decreto de Alcibíades. Depois, Lisímaco ao morrer deixou uma filha de nome Polícrite, para a qual, como refere Calístenes, o povo decretou um alimento igual ao dos vencederos olímpicos. Demétrio de Falero, Jerónimo de Rodes, o músico Aristóxeno e Aristóteles - se é que se pode considerar o pequeno livro Sobre a nobreza como uma obra autêntica de Aristóteles - contam que Mirto, neta de Aristides, viveu com o sábio Sócrates, que já tinha uma mulher, mas acolheu-a, por ela estar desamparada pela sua pobreza e carecer dos bens essenciais. 
e o apoio da polis à sua família reforçam a primazia que durante a vida deu à moralidade e à ética no exercício de funções públicas, não deixando fortunas como herança aos seus descendentes, mas a sua reputação de homem justo, indulgente e patriótico.

Além disso, o notável exercício de Aristides na Liga Délica ${ }^{130}$ permite a Plutarco acentuar as diferenças entre este e Temístocles, que o próprio Aristides considera um perigo para a cidade ${ }^{131}$. Enquanto para Temístocles a maior virtude de um estratego assentava na capacidade de antever os movimentos do inimigo, para Aristides o uso idóneo, e nunca em benefício próprio, dos dinheiros públicos era mais digno de louvor. Também Teofrasto de Éreso ${ }^{132}$ confirma a seriedade e a rectidão de Aristides no tratamento dos assuntos de Estado e na protecção da justiça $a^{133}$.

Pela forma como exerceu a politeia, a virtude de Aristides assemelha-se à da divindade ${ }^{134}$, ao mesmo tempo que cria uma conexão modelar entre o herói, o nomos ${ }^{135}$ e o interesse público ${ }^{136}$. O filho de Lisímaco conquistou, assim, o direito de ser conhecido como "justo", no fundo, a qualidade moral mais elevada a que um político pode aspirar ${ }^{137}$.

Catão Censor ${ }^{138}$ (Marcus Porcius Cato) era um homem conservador e conhecido por, numa época em que Roma começava a estabelecer o seu poder imperial, tentar defender os valores e os costumes ancestrais dos Romanos. A biografia de Plutarco oferece-nos vários elementos sobre a sua paideia e a relação que manteve com a cultura grega. $\mathrm{O}$ quadro educativo é introduzido da seguinte forma: ${ }^{139}$

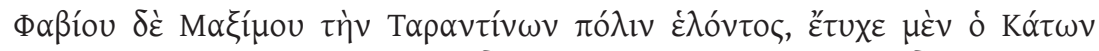

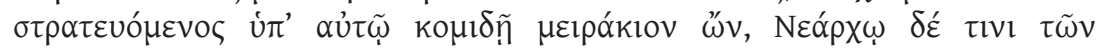

${ }^{130}$ Pelo facto de os aliados de Atenas louvarem o tributo fixado por Aristides (quatrocentos e sessenta talentos; cf. Th. 1.96), Plutarco compara, de forma algo exagerada, esta época à de Cronos, ou seja, à Idade de Ouro (cf. Arist. 24.3).

${ }^{131}$ Também Catão de Útica considera Pompeio uma ameaça.

${ }^{132}$ Fr. 136 W.

${ }^{133} \mathrm{Pl}$. Gorg. 526a refere que é possível encontrar pessoas boas entre as que exercem cargos públicos importantes, como é o caso de Aristides.

${ }^{134}$ Cf. Arist. 6.3, 6.5.

${ }^{135} \mathrm{Cf}$. Arist. 2.6 (vocabulário normativo).

${ }^{136}$ Cf. ibid. 13.2 (o herói, a lei e o interesse público).

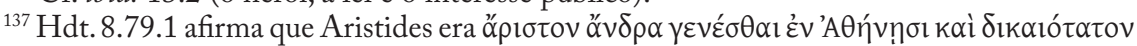
(o melhor e mais justo homem em Atenas); também Agesilau, Fócion e Numa são considerados homens justos, embora tenham cometido injustiças necessárias (cf. Phoc. 3.8).

${ }^{138}$ Em Cat. Ma. 1.3, Plutarco diz-nos que no princípo era chamado por Prisco, o terceiro

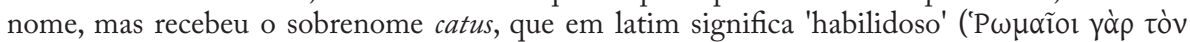

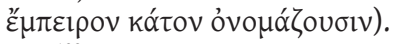

${ }^{139}$ Cat. Ma. 2.3-6. 


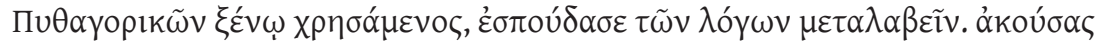

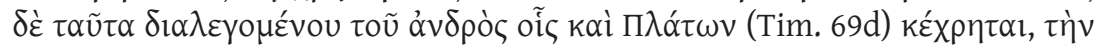

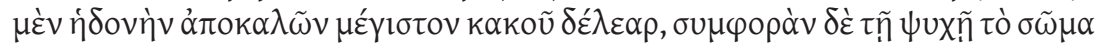

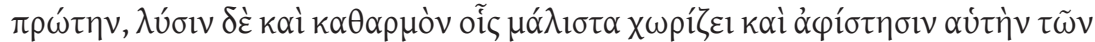

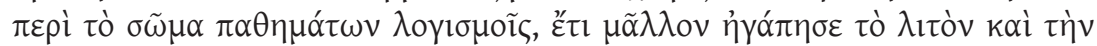

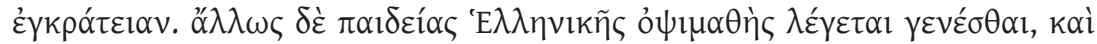

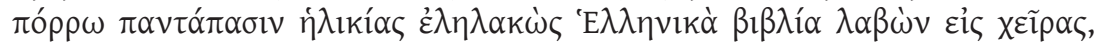

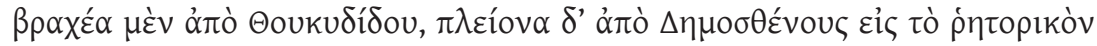

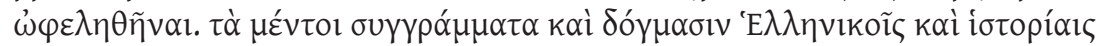

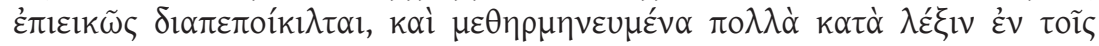

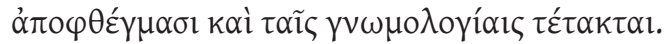

Quando Fábio Máximo tomou a cidade de Tarento ${ }^{140}$, Catão, ainda um jovem, servia em campanha ao seu cuidado; aí encontrou-se com Nearco, um estrangeiro da escola dos Pitagóricos e apressou-se diligentemente a participar nas suas lições. Ao ouvir este homem falar de temas sobre os quais também Platão se debruçou, filósofo que considerava o prazer a maior atracção do mal e o corpo a primeira desgraça para a alma, cuja libertação e purificação por meio da reflexão mais isola e afasta a alma dos sofrimentos do corpo, Catão preferiu, sobretudo, a simplicidade e a moderação. De resto, conta-se que começou tarde a estudar a cultura grega, pois já tinha uma idade muito avançada quando pegou nos livros em língua grega ${ }^{141}$, e que tirou proveito para o estudo da retórica um pouco de Tucídides e mais de Demóstenes. Contudo, as suas composições estão, de forma equilibrada, adornadas com variados princípios e histórias dos Gregos, e nos apotegmas e nas sentenças aproxima-se em muito da tradução da expressão grega. ${ }^{42}$

Por meio deste texto, somos informados de que Nearco, um pitagórico, participou na formação inicial de Catão e que foi, por intermédio daquele que tomou conhecimento de alguns princípios platónicos sobre a alma. Essas lições terão ajudado a consolidar duas características fundamentais do carácter

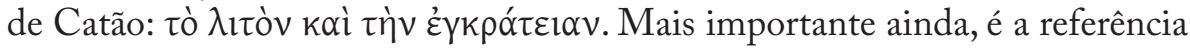

${ }^{140}$ Aníbal perdeu a cidade de Tarento para Fábio Máximo em 209.

${ }^{141}$ Cf. Cic., De sen. 8, 10, 39, 41; Cícero procura enfatizar a familiaridade de Catão com a cultura helénica, citando várias figuras gregas ao longo do De sen. (Homero, Hesíodo, Semónides, Sófocles, Sólon e Platão, entre outros).

${ }^{142}$ Por vezes, Plutarco refere-se, ao citar as máximas de Catão, à fonte grega. Assim acontece

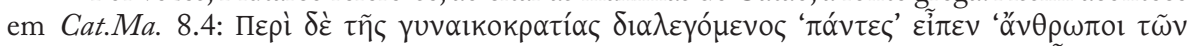

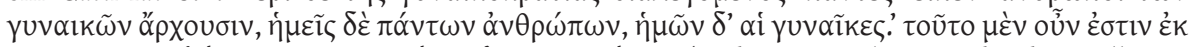

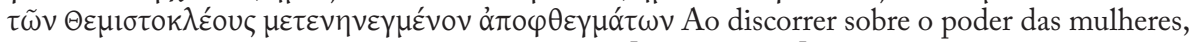
disse: "Os homens mandam nas mulheres, nós [os Romanos] sobre todos os homens e as mulheres sobre nós”, isto é, sem dúvida, uma adaptação dos apotegmas de Temístocles. Se neste caso é Temístocles, o rival de Aristides, a fonte de Catão, Plutarco, em Cat.Ma. 24.8, serve-se de Pisístrato para uma outra máxima. 
à educação tardia na $\pi \alpha \imath \delta \varepsilon i ́ \alpha$ 'E $\lambda \lambda \eta \nu \imath k n ́$ e na língua de Homero, em especial os ensinamentos retóricos tirados de Tucídides e Demóstenes, particularmente deste, sendo a obra de Catão uma prova de que em muitas situações adoptou as expressões gregas ${ }^{143}$. Prova disso são os vários testemunhos sobre o conhecimento que Catão Censor teria da cultura grega que são descritos

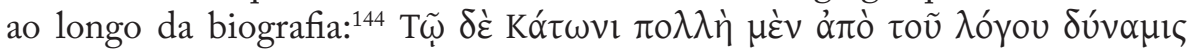

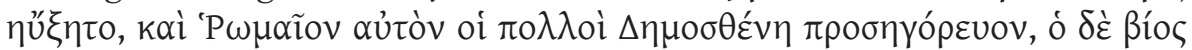

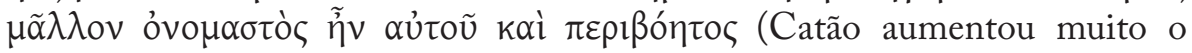
seu poder graças à sua eloquência, e muitos chamavam-no o "Demóstenes romano". Na verdade, a vida dele era o facto mais nomeado e célebre); oủ $\delta$ Év $\alpha$

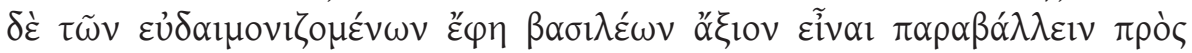

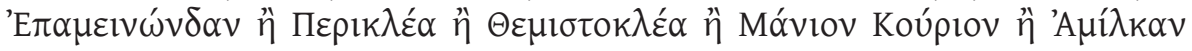

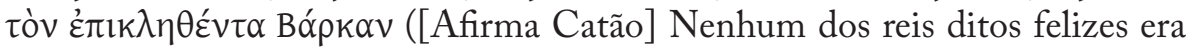
digno de se comparar a Epaminondas, Péricles, Temístocles, Mânio Cúrio ou

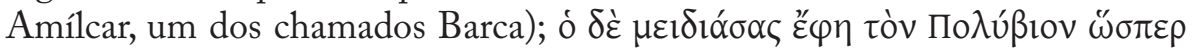

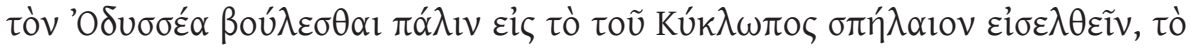

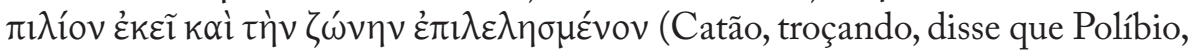
como Ulisses, queria novamente entrar na caverna do Ciclope, pois tinha-se ali esquecido do chapéu e do cinturão). Além de, como se afirma no texto, a sua capacidade oratória lhe valer o epíteto de "Demóstenes romano", Catão, ainda que mantendo reservas em relação à influência helénica ${ }^{145}$ e privilegiando, como Mário, Sula e Crasso, os valores tradicionais dos Romanos revela, como testemunham o segundo e o terceiro texto citados, conhecimentos da história e da cultura grega, quando alude a Epaminondas, Péricles e Temístocles ou

${ }^{143}$ Em Cat. Ma. 12.5-7, Plutarco, ao relatar a acção de Catão como tribuno militar, na Grécia, refere que ele terá proferido, segundo uma fonte ( $\lambda \varepsilon ́ \gamma \varepsilon \tau \alpha \mathrm{l})$, um discurso em língua grega, embora o próprio Plutarco não concorde (dado que parece contradizer Cat. Ma. 2.5, onde, seguindo fontes que não cita, afirma que Catão aprendeu Grego na velhice; ou então, Catão teria aprendido Grego antes de chegar à velhice), preferindo aceitar que ele usou um tradutor

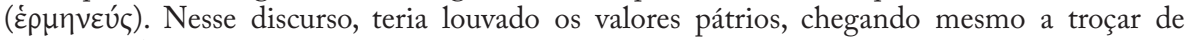
Postúmio Albino, autor de uma obra histórica em Grego, por este ter pedido desculpa pelo uso dessa língua. Os ouvintes gregos admiraram a breuitas de Catão, enquanto o tradutor era lento e usava muitas palavras, ficando, assim, evidenciada uma oposição entre Gregos e Romanos, que

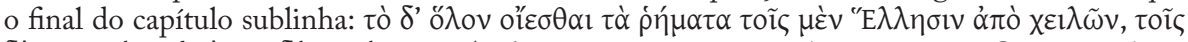

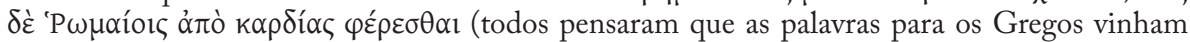
dos lábios, enquanto para os Romanos do coração); ainda sobre a questão de Catão saber falar Grego e quando aprendeu, A. Astin (1978: 159-161, 166-8) e E. Gruen (1993: 56-9) rejeitam que Catão não soubesse falar Grego, possibilidade que algumas fontes antigas referidas por Cic. Luc. 5 e Sen. 8.26 colocam, preferindo realçar que Catão, como os aristocratas romanos do seu tempo, tinha uma cultura que também incluía a paideia grega, embora gostasse de ostentar a sua atitude romanófila; Cic. Sen. 1.3 e Acad.pr. 2.5, Val. Max. 8.7.1 e Quint. Inst. 12.11.23 referem que Catão aprendeu Grego em idade avançada.

${ }^{144}$ Cat. Ma. 4.1, 8.14 e 9.3, respectivamente.

145 Sobre Catão e o helenismo, vide E. Gruen (1995: 52-83). 
quando compara a atitude de Políbio - o conhecido historiador grego que fazia parte do conjunto de reféns entregues a Roma após a derrota de Pidna, e que viveu durante dezassete anos em Roma, integrando o círculo dos Cipiões - com a de Ulisses, no famoso episódio homérico do Ciclope. No entanto, Catão, um kaıvò ă $\alpha \theta \rho \omega \pi$ os (em latim, homo nouus) ${ }^{146}$, é mais conhecido pelas atitudes que toma em prol dos valores romanos.

Plutarco relata-nos o episódio da embaixada de filósofos que chega a Roma ${ }^{147}$, no ano 155 , entre os quais se encontravam o neoplatónico Carnéades e o estóico Diógenes. Os jovens romanos, seduzidos pelas suas palavras, acorrem em massa aos seus discursos, em especial aos de Carnéades. De tal forma que os jovens se entusiasmaram pela filosofia, deixando de parte outras paixões, ao mesmo tempo que outros Romanos também se sentiram atraídos pelos ensinamentos desses filósofos e surpreendidos com o efeito que provocaram nos jovens. Precisamente por temer os efeitos da embaixada, Catão decide afastar os filósofos da cidade. ${ }^{148}$ Teria Catão tomado esta atitude por causa de Carnéades? Plutarco, apoiando-se em fontes que não especifica, diz-nos que

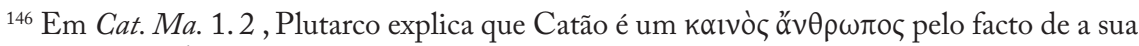

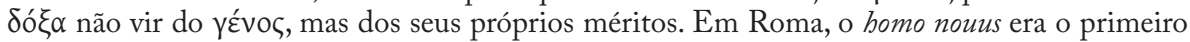
da família a atingir as mais altas magistraturas, passando depois a fazer parte, juntamente com os seus, da nobilitas. Como nos conta Plutarco, para Catão atingir essas magistraturas muito contribuiu o apoio dos Valérios. Refira-se, por fim, que também Cícero e Mário foram homines noui.

${ }^{147}$ Cf. Cat. Ma. 22.

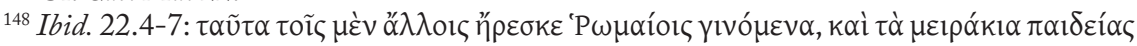

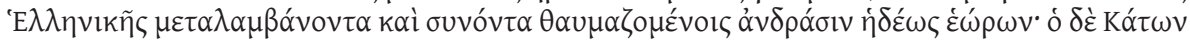

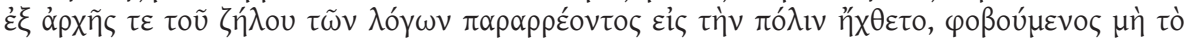

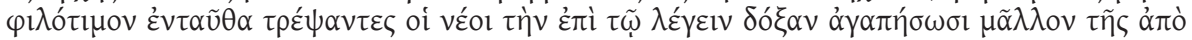

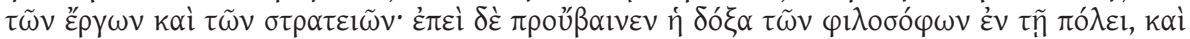

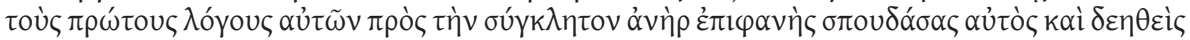

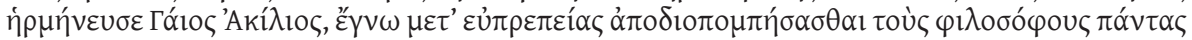

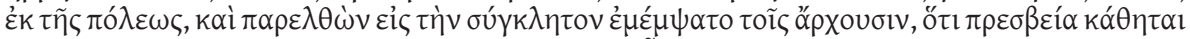

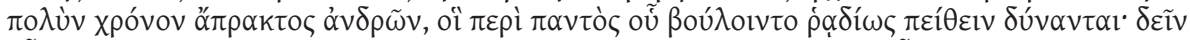

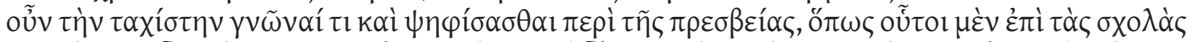

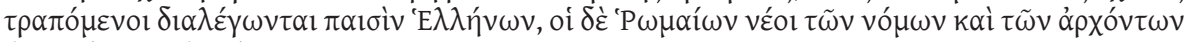

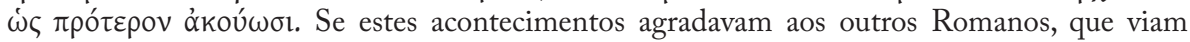
os jovens a receber a cultura grega e a acompanhar com admiração os encantadores homens, Catão, pelo contrário, irritava-se desde o início com a forma como o ardor pelos discursos deles percorria a cidade, temendo que os jovens, mudando a sua ambição, preferissem mais a fama por aquilo que se diz do que pelos actos e campanhas militares. Como a reputação dos filósofos crescia na cidade e um homem ilustre, Gaio Acílio, traduziu, por sua própria diligência e desejo, os primeiros discursos deles perante o senado, Catão resolveu afastar, por conveniência, todos os filósofos da cidade e, entrando no senado, repreendeu os magistrados por uma embaixada ali permanecer com homens inactivos, que podem, com facilidade, convencer sobre tudo o que quiserem. Era, pois, necessário decidir algo rapidamente e votar sobre a embaixada, para que eles, voltando para as suas escolas, conversassem com os filhos dos Gregos, enquanto os jovens ouviam, como antes, as leis e os magistrados romanos. 
não. ${ }^{149}$ Não seria, então, nada de pessoal contra Carnéades, mas resultava da atitude anti-helénica, ou melhor, romanocêntrica de Catão, tema que Plutarco não deixa de aproveitar na biografia, tal como o patriotismo havia sido uma característica muito explorada na figura de Aristides. No seguimento do texto anterior, Plutarco dá alguns pormenores sobre a posição de Catão Censor em

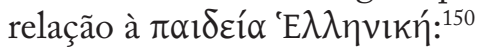

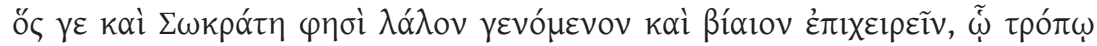

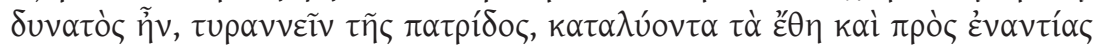

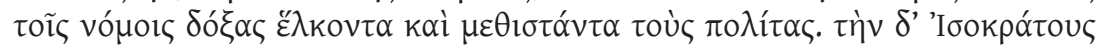

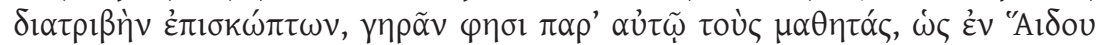

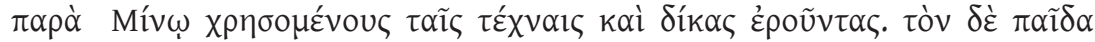

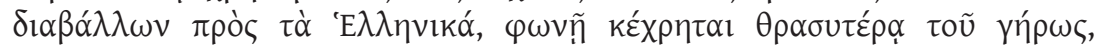

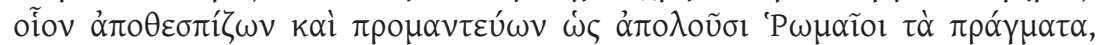

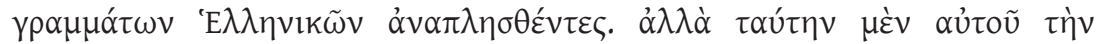

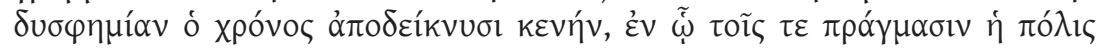

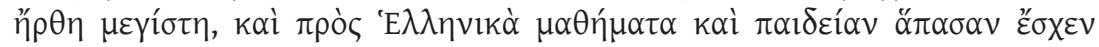

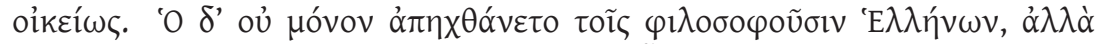

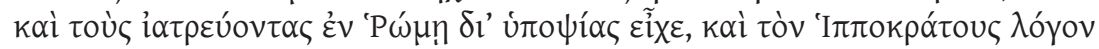

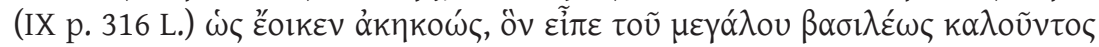

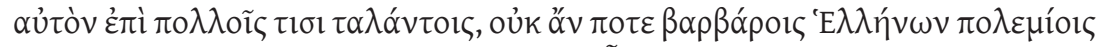

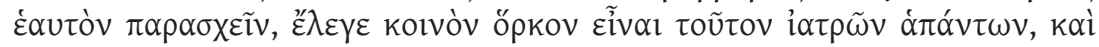

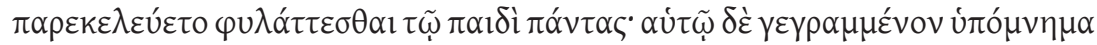

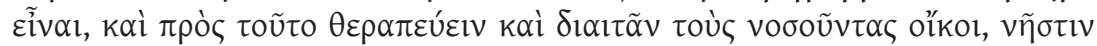

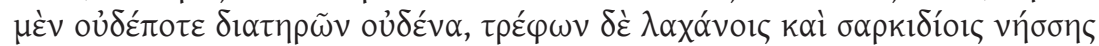

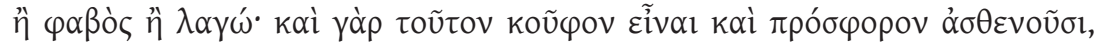

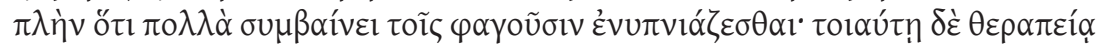

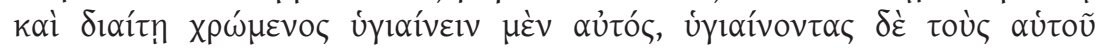

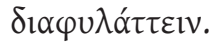

Ele também disse que Sócrates era um charlatão e que se esforçou, segundo lhe permitia a sua maneira de ser, por tiranizar a pátria, dissolvendo os hábitos, e por arrastar e mudar os cidadãos para opiniões adversas às leis. Zombando da ocupação de Isócrates no tempo livre, disse que os seus discípulos envelheciam junto dele, como se, no Hades junto de Minos, fizessem uso das artes e pronunciassem juízos. Convencendo o filho contra o que era helénico, ele usava um tom muito arrogante para um ancião, semelhante ao anúncio de um

${ }^{149}$ Ibid. 23.1.

${ }^{150}$ Ibid. 23.1-6; cf. Plin. HN 29.14; a crítica que Catão faz à paideia e aos médicos gregos terá sido desenvolvida por Catão no seu Ad Marcum filium, que reuniria conselhos sobre várias matérias para a instrução do seu filho; vide, a este propósito, A. Astin (1978: 332-340) e E. Gruen (1993: 76-80); é opinião corrente que esse livro seria uma espécie de enciclopédia, onde se coligiam ensinamentos sobre medicina, legislação, agricultura, retórica ou estratégia militar. 
oráculo ou de um vaticínio, na medida em que temia que os Romanos, ao serem contagiados pelas letras gregas, fossem derrotados nas suas empresas. Porém, o tempo vem provando que esta blasfémia dele é vã, pois a cidade atingiu o topo nas suas acções quando tinha como familiar o conhecimento e toda a cultura dos Gregos. Não só odiava aqueles que de entre os Gregos filosofavam, mas também desconfiava daqueles que exerciam a medicina em Roma; e, tendo ouvido, segundo parece, a resposta que Hipócrates deu ao convite, com muitos talentos, do grande rei, de que ele jamais se mostraria disponível para os bárbaros inimigos dos Gregos, Catão, por este motivo, dizia que este juramento era comum a todos os médicos e exortava o filho para se proteger deles todos; afirmava, ainda, que havia escrito ele mesmo um tratado com o qual cuidava e curava os doentes de casa. De modo algum prescrevia o jejum a alguém, mas alimentava-os com legumes e pequenos bocados de carne de pato, de pombo e de lebre. Na verdade, esta alimentação era ligeira e benéfica para os que estavam enfermos, não fosse o facto de os que assim comem terem muitos sonhos. Ele próprio dizia que, seguindo tal cuidado e regime, tinha saúde, além de conseguir manter saudáveis os da sua casa.

Evidencia-se, deste modo, a posição de Catão, com poucos seguidores na República ${ }^{151}$, contra a influência dos Gregos nos costumes e nas artes romanas, a ponto de tentar evitar o contacto do seu filho com as coisas helénicas ('E $\lambda \lambda \eta v i k a ́)$, até porque as considerava um entrave e motivo de desconcentração para os grandes objectivos romanos. Essa posição defensora da romanidade, a qual não aceita a helenização da cultura romana, vai ao ponto de Catão preferir as suas receitas caseiras, em detrimento de médicos gregos, para curar o filho e a mulher. Por isso, refere Plutarco, Catão terá perdido, por influência divina, o filho e a mulher ${ }^{152}$.

Para Catão, prevalece a defesa dos costumes autóctones, pois a sedução pelo helénico desviará Roma da obtenção de grandes vitórias. Assim, diríamos que a posição de Catão em face dos Gregos é uma "estratégia cultural"153, pois ele é acima de tudo um defensor da cultura romana e não um inimigo da Grécia. Por isso, critica aqueles que, como A. Postúmio Albino, um filohelénico, imitando Fábio Pictor e Cíncio Alimento, escrevem uma história de Roma em língua grega ${ }^{154}$. 266).

${ }^{151}$ Sobre o filo-helenismo na República e os seus opositores, vide E. Gruen (1986r: 260-

${ }^{152}$ Cf. Cat. Ma. 24.1.

${ }^{153}$ Expressão de E. S. Gruen (1993: 80).

${ }^{154}$ Cf. Cat. Ma. 12.6; sobre a imitação que A. Postúmio Albino fez dos Gregos vide Pol. 39.1. e Gel. 11.8; note-se que as Origines, inaugurando um novo conceito historiográfico contrário ao dos Annales dos Pontífices, são a primeira obra histórica a ser escrita em língua latina, de acordo com aquilo que nos foi legado, demonstrando assim o seu autor que a sua língua já tem suficiente nível literário para veicular a sua própria história. 
Se até aqui Plutarco se havia limitado a reproduzir aquilo que as fontes possivelmente lhe transmitiram sobre esta personalidade romana, entende ser oportuno introduzir a sua própria interpretação da atitude de Catão, que é a seguinte: os factos provam que Roma se tornou grande na medida em que passou a conhecer a $\pi \alpha 1 \delta \varepsilon i ́ \alpha$ 'E $\lambda \lambda \eta v i k n ́$, posição natural num heleno culto como o Queronense. Esta posição, em parte contida no tratado De fortuna Romanorum, surge aqui expressa de forma directa e ganha ainda maior evidência por ser proferida na biografia de um Romano que olha para os valores helénicos como uma ameaça. Adianta, ainda, que Catão desprezava a filosofia grega e que desconfiava dos Gregos que exerciam a medicina em Roma, pois, se Hipócrates se havia recusado a dar apoio ao rei Persa por ele ser um bárbaro inimigo, então como poderiam os Romanos, que para alguns Gregos eram também eles bárbaros, confiar nos médicos gregos? Por conseguinte, o próprio Catão, sem dúvida um homem com engenho e cultura, terá escrito um tratado de medicina para uso doméstico, que incluía dietas à base de legumes e pequenos bocados de carnes magras, regime que garantiu a Catão uma longa vida, embora, com alguma ironia, nos diga que, por castigo divino, a sua mulher e o filho, mesmo com esse regime, morreram.

Queremos chamar a atenção para o facto de o texto acima citado, que tão bem ilustra a posição de Catão em face da paideia helénica, ser precedido por um capítulo onde Plutarco aborda o tratamento pouco humano que Catão dava aos escravos ${ }^{155}$, do mesmo modo que o seu casamento, no final da vida, com uma jovem escrava, cujo nome não é mencionado, é revelador de falta de moderação ${ }^{156}$. Não parecem existir dúvidas de que Plutarco pretende associar essas atitudes pouco humanas e excessivas à posição anti-helénica de Catão.

Como homem dedicado à sua nobre e pouco rica esposa ${ }^{157}$, Licínia, e ao filho, Catão considerava que era mais digno de louvor um bom marido do que um grande senador (

155 Cf. Cat.Ma. 21. Veja-se como a diferença de atitude entre Gregos e Romanos é assim realçada, se compararmos este relato com a forma humana com que os animais são tratados pelos Gregos (ibid. 5.3-5), ao contrário de Catão, que não teve qualquer pejo em abandonar o cavalo (ibid. 5.7) que usou nas campanhas por terras da Hispânia, para poupar o dinheiro do seu transporte. O uso de um animal para descrever o ethos de Catão e elucidar os ouvintes/leitores pode estar relacionado com o facto de na época imperial haver vários espectáculos com animais (cf. De soll. anim.963C), por exemplo as uenationes, e de ser necessário reconhecer o afecto que Plutarco sentia por eles (cf. R. Barrow (1967: 112-117)); vide C. Pelling (1989: 215), a propósito do anti-helenismo de Catão e da estrutura da biografia para pôr em relevo o efeito que a cultura helénica provocou nos Romanos, a ponto de se considerar essencial para o êxito destes.

${ }^{156}$ Cf. ibid. 24.1-8: na versão plutarquiana, Catão faz do seu segundo casamento quase uma manifestação patriótica, uma vez que o seu desejo é deixar mais filhos para proveito próprio e da pátria.

\footnotetext{
${ }^{157}$ Cf. Cat. Ma. 20.2.
} 


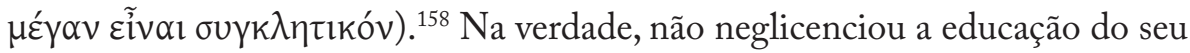
filho ${ }^{159}$, procurando, também nesse processo, defendê-lo dos perigos de uma educação contrária aos genuínos valores romanos: ${ }^{160}$

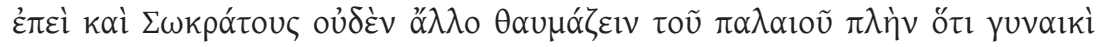

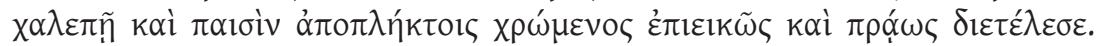

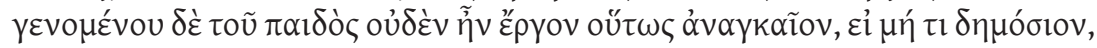

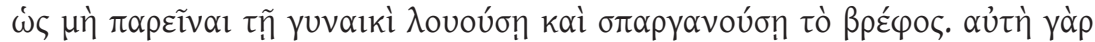

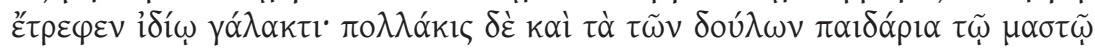

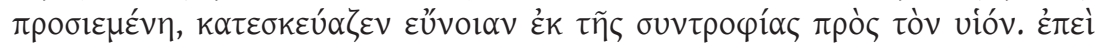

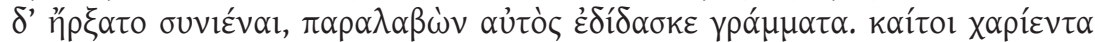

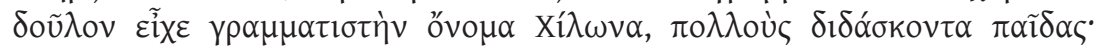

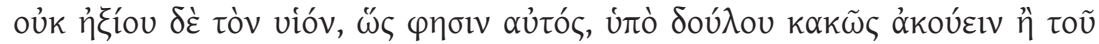

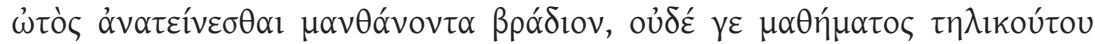

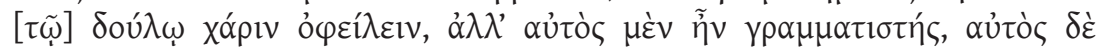

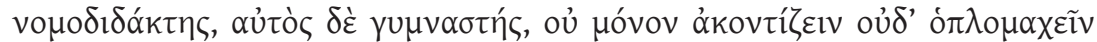

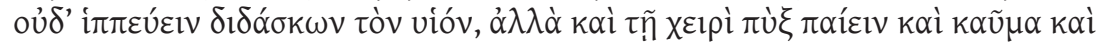

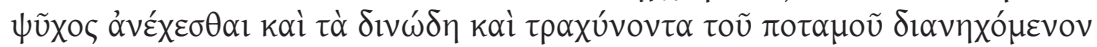

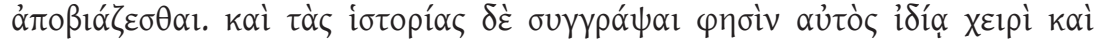

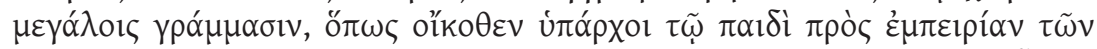

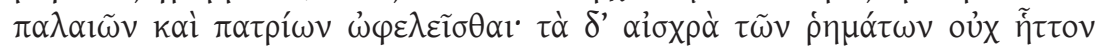

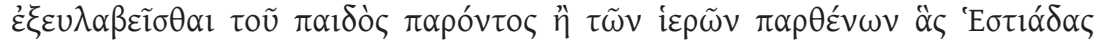

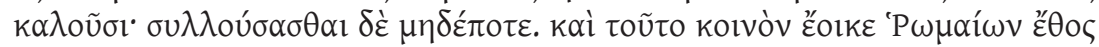

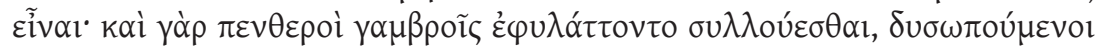

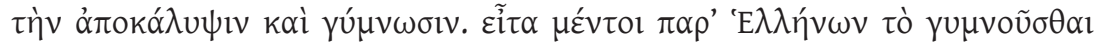

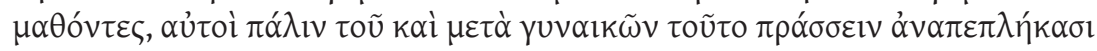

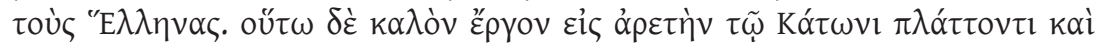

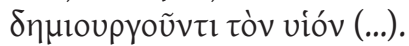

Em verdade, ele não admirava outra coisa no antigo Sócrates a não ser o facto de, mesmo tendo uma mulher difícil e filhos estúpidos, passar a vida com temperança e brandura. Depois de nascer o filho, Catão não tinha nenhuma ocupação obrigatória, a não ser as de âmbito público, que o privasse de assistir a mulher a dar banho e a envolver em cueiros o recém-nascido. Ela, na verdade, criou-o com o seu próprio leite. Por ter amamentado muito vezes os filhos dos escravos, com esta alimentação em comum ela conquistou a benevolência deles para o filho. Quando o filho começou a ter compreensão, Catão tomou-o e ensinou-lhe as primeiras letras, embora tivesse um bom mestre, o escravo de

${ }^{158}$ Ibid. 20.3 .

${ }^{159}$ Igual virtude é apontada a Licurgo, que não entregou os filhos dos espartanos a um qualquer pedagogo, encarregando-se ele próprio da sua educação. Péricles, pelo contrário, contratou um escravo, Zópiro, para ensinar Alcibíades (cf. Lyc. 16.3-5; Alc. 1.3).

${ }^{160}$ Cat. Ma. 20.3-9. 
nome Cílon, que ensinava muitas crianças. Mas não julgava digno, como ele próprio disse, que o filho ouvisse ignomínias de um escravo ou que este the puxasse a orelha por aprender com lentidão, e nem que ficasse a dever favores a um escravo por causa de uma matéria tão importante. Assim, o próprio Catão foi o mestre do filho nas primeiras letras, o professor de leis, o mestre de ginástica, e não só ensinou o filho a lançar dardos, a combater com armas pesadas e a montar a cavalo, como também a bater com a mão fechada, a manter-se firme no calor e no frio e a vencer na travessia a nado os rápidos e os redemoinhos do rio. Diz-se que escreveu ele mesmo as Histórias com a sua própria mão e em letras grandes, de modo que o filho começasse, em casa, desde criança a tirar proveito da experiência dos seus antepassados. $\mathrm{Na}$ presença do filho evitava usar palavras ignominiosas tal como na presença das virgens sagradas a que chamam Vestais. Catão jamais tomou banho com o filho. Isto parece que era um costume comum entre os Romanos, pois também os sogros evitavam tomar banho com os genros, envergonhando-se de se revelarem e de se desnudarem. Não obstante, aprendendo de imediato com os Gregos a desnudarem-se, eles, em sentido inverso, levaram os Gregos a praticar isso também com as mulheres. Assim foi o belo trabalho de Catão para modelar e formar o filho para a virtude.

Este texto é bastante elucidativo sobre o empenho que Catão colocou

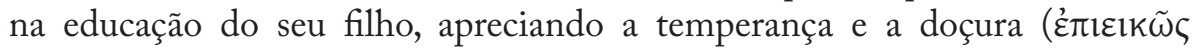

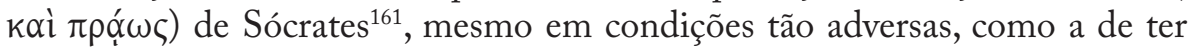
uma mulher complicada e filhos estúpidos. Deixando para segundo plano as suas tarefas políticas ${ }^{162}$, Catão, além de acompanhar de perto momentos tão ternurentos como o banho ou a mudança de cueiros, assume a função de primeiro mestre do filho, prescindindo do escravo Cílon, por querer incutir no filho nobres virtudes, que não estivessem sujeitas à deturpação de um escravo, ou seja, à mercê de princípios helénicos. Chegou mesmo a escrever um livro, as Histórias, para transmitir os valores ancestrais dos Romanos ao filho e para que ele tivesse consciência histórica. No final do texto, Plutarco acaba por estabelecer uma conexão entre a paideia de Catão e a vida virtuosa, isto é, a paideia é essencial para formar o ethos e dotá-lo das melhores aretai. $\mathrm{O}$ costume entre pais e filhos ou sogros e genros de tomar banho sem roupa ( $\gamma \cup \mu \nu o \tilde{\sigma} \sigma \theta \alpha \mathrm{l})$, hábito próprio dos gregos e, por isso, criticado por Catão, é um exemplo elucidativo do processo recíproco de assimiliação cultural, pois os Romanos influenciaram os Gregos a fazer o mesmo com as mulheres.

Apesar de viver numa época em que Roma, atendendo à sua dimensão, ia assimilando hábitos de vida diversos ${ }^{163}$, Catão continuava fiel aos costumes do

${ }^{161}$ Sobre a figura de Sócrates em Plutarco, vide J. Hershbell (1988: 365-81).

${ }^{162}$ Atitude diferente da de Coriolano, que sempre colocou os assuntos da pátria à frente da preocupação com a mãe, a mulher e os filhos (cf. Cor. 33.9).

${ }^{163}$ Cf. Cat. Ma. 4.2. 
passado, por fazer da austeridade ${ }^{164}$, da recusa do supérfluo e dos prazeres e da firmeza de espírito os princípios basilares da sua vida. Por causa do seu gosto pela austeridade, Catão admirava Mânio Cúrio ${ }^{165}$, facto também lembrado por Cícero ${ }^{166}$. Apesar das suas vitórias sobre os Samnitas, os Sabinos e sobre Pirro, rei do Epiro, que expulsou da Itália, em 275 a. C., se dedicava, ele próprio, ao

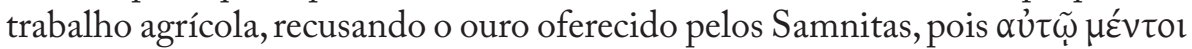

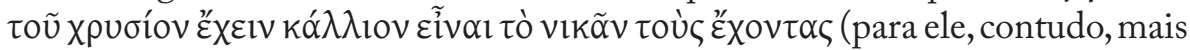
belo do que ter ouro era vencer os que o tinham) ${ }^{167}$. Por isso, Catão dedicouse também ao trabalho, desde cedo, até porque assim conseguia poupar nas despesas domésticas ${ }^{168}$. Por influência de Valério Flaco $^{169}$, convencido das qualidades que ele patenteava, Catão haveria de enveredar pela vida pública. Resta-nos referir um outro paradigma de Catão: Fábio Máximo, que ajuda a delinear a sua carreira e a própria oposição a Cipião ${ }^{170}$.

Tendo em conta este traço do carácter de Catão, Plutarco considera que no trato com os outros, se deve usar, sobretudo, a philanthropia ${ }^{171}$, podendo, por

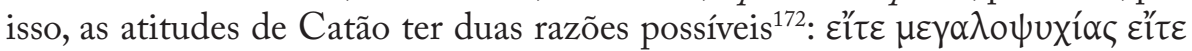

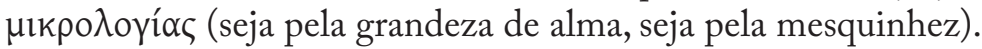

Rival de Cipião ${ }^{173}$, que era conhecido pelo seu filo-helenismo ${ }^{174}$, Catão mostra toda a sua firmeza e objectividade pela maneira como reage à vitória

${ }^{164}$ Cf. ibid. 5.1: Plutarco critica a austeridade e a rigidez de Catão; note-se que, confundidose com a austeridade, Catão também ficou conhecido pela sua seueritas: em Cat. Ma. 17.7, como sinal desse seu modo de ser, Plutarco conta o episódio anedótico do momento em que Catão expulsou Manílio do Senado por este ter beijado, em plena luz do dia, a esposa na presença da

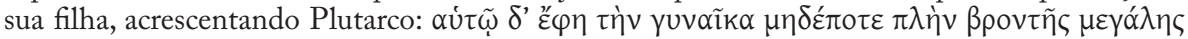

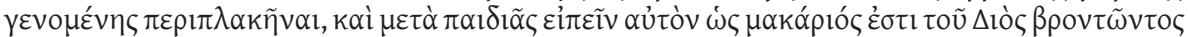
(Ele [Catão] disse que a sua mulher nunca o abraçava, excepto quando havia trovões muito fortes, e que em brincadeira ela disse que ele era um homem feliz quando Júpiter trovejava); refira-se que a estrutura sintáctica deste período levanta algumas questões, que podem alterar significativamente a sua leitura. Concordamos, no entanto, com as observações de J. Churchill (2001: 98-107) às várias traduções já publicadas e, por isso, seguimos na nossa tradução a sua proposta.
${ }^{165}$ Cf. Cat. Ma. 2.1-3.
${ }^{166}$ Cf. De sen. 55.
${ }^{167}$ Cat. Ma. 2.2.; Valério Máximo também conta esta história (4.3-5).
${ }^{168}$ Cf. ibid. 1.5 e 2.3 .
${ }^{169}$ Cf. ibid. 3.1-4.
${ }^{170}$ Cf. ibid. 3.5-6
${ }^{171}$ Cf. ibid. 5.5.
172 Ibid. 5.7.
${ }^{173}$ Cf. ibid. 11.4

${ }^{174}$ A. Henrichs (1995: 250) aborda o helenismo de Cipião, a partir da descrição de App. Pun. 132=Pol. 32.22, onde reflecte sobre os ciclos da vida e a mutabilidade da condição humana, pensamento próprios de um Grego; o mesmo helenista lembra que Xerxes, ao olhos de um grego também ele bárbaro, fez a mesma reflexão (cf. Hdt. 3.14 e 9.16); Cipião parece ter a consciência de que a vitória em Cartago será no futuro substituída pela queda do imperium, visão cíclica da vida que se encontra abundantemente na tragédia grega. 
e ao êxito ${ }^{175}$, uma vez que, contrariamente à maioria, não se entregou aos

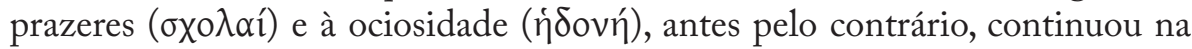
vida pública, procurando novos desafios para demonstar a sua ỏ $\rho \varepsilon \tau \eta ́$, tanto na

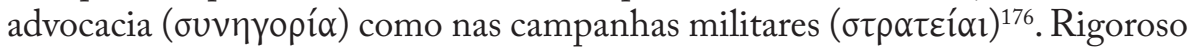
no exercício da politeia, Catão manteve-se activo até ao final da sua vida ${ }^{177}$ princípio que Plutarco aprecia e defende nos tratados políticos - sabendo, por

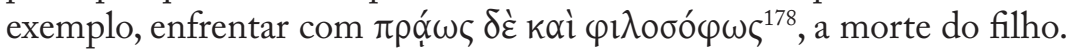

Após os elementos que acabámos de analisar, percebe-se, como Plutarco reconhece no início da synkrisis, que, no meio de tantas semelhanças, é difícil notar diferenças entre Aristides e Catão Censor. Ambos empregaram a

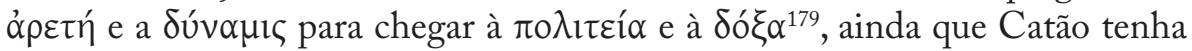
conseguido ser o primeiro em algumas vitórias, como a das Termópilas (191 a. C.), contra Antíoco III da Síria, ao invés de Aristides que se limitou a ajudar outros a ser os primeiros: Milcíades em Maratona, Temístocles em Salamina e Pausânias em Plateias. Numa avaliação posterior, o biógrafo de Queroneia dirá, no entanto, que Aristides participou nas mais belas batalhas (Maratona, Salamina e Plateias) e Catão não conseguiu com as suas vitórias nada de muito significativo, nem para Roma nem para o Império ${ }^{180}$.

Plutarco não deixa também de apontar o ostracismo de Aristides e a sua derrota por Temístocles como acontecimentos que provam o seu fracasso, enquanto Catão, muito por causa da sua eloquência, conseguiu ficar incólume. ${ }^{181}$ Também em relação à forma como os dois souberam administrar os bens, aponta diferenças: ${ }^{182}$

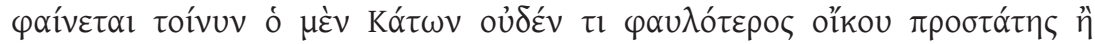

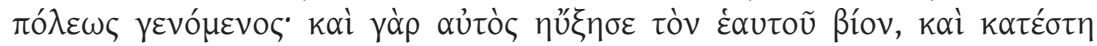

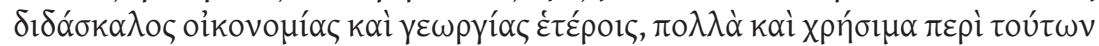

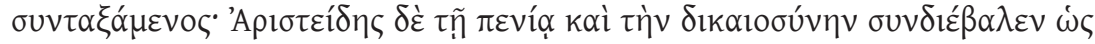

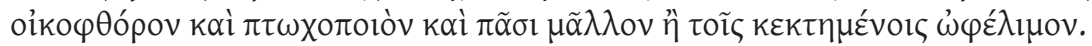

175 cf. Cat. Ma. 19.6: reprova o louvor por estátuas (cf. Praec. ger. reip. 820B e E).

${ }^{176}$ Ibid. 11.4.

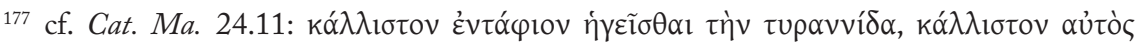

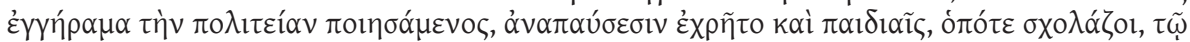

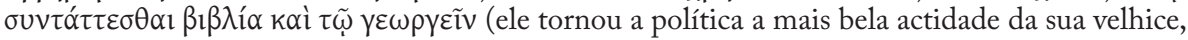
e quando estava num momento de ócio, entrega-se a escrever livros e a trabalhar na agricultura, para descansar e se entreter); cf. Alex.40.2, quase igual a Dem. 22.3 (alopos e praos).

${ }^{178}$ Cat. Ma. 24.10.

${ }^{179}$ Cf. Comp. Arist.-Cat.Ma. 1.2; em 3.1, considera que a politeia a virtude mais perfeita que um homem pode alcançar.

${ }^{180}$ Cf. Comp. Arist.-Cat.Ma. 5.1.

${ }^{181}$ Cf. Comp. Arist.-Cat.Ma. 2.4-5.

${ }^{182}$ Comp. Arist.-Cat.Ma. 3.2. 
Parece evidente que Catão não foi mais protector da sua casa do que da cidade. Pois, aumentou ele próprio os seus recursos e tornou-se um mestre para os outros em economia caseira e agricultura, coligindo sobre isso muitos e úteis conselhos. Aristides, por sua vez, caluniou a justiça com a pobreza, como se o que leva à ruína e dá origem a mendigos fosse mais últil para todos do que para os que a praticam.

Plutarco critica, assim, aqueles que, como os Sofistas ${ }^{183}$, pensam que a justiça só serve para beneficiar os que governam e mesmo os injustos, prejudicando quem a pratica, como parece ser o caso de Aristides ${ }^{184}$. No seguimento do pensamento hesiódico ${ }^{185}$, é digno de louvor para o biógrafo aquele que consegue conciliar a economia doméstica com a justiça, pois acredita-se que a organização do Estado se começa a construir no seio da família, o que leva o biógrafo a censurar o facto de Aristides ter deixado a sua própria família na miséria. Foi o Estado quem, em virtude dos feitos dele, prestou auxílio aos seus familiares ${ }^{186}$. Estará, assim, Plutarco a fazer a apologia da riqueza, contradizendo o que havia exposto na narrativa das biografias? Não nos parece, pois tenta sobretudo elaborar um pensamento que realce

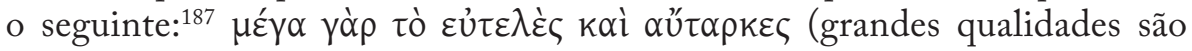
a simplicidade e a auto-suficiência). E estes são os dois princípios que um

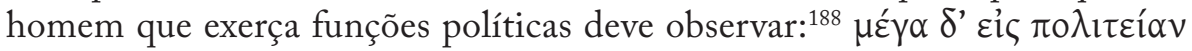

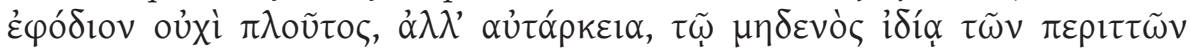

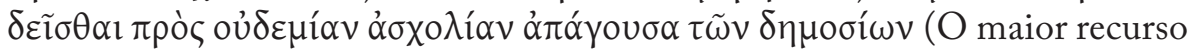
para o exercício político não é a riqueza, mas a auto-suficiência, que, não levando a negligenciar os assuntos de Estado, de forma alguma precisa, particularmente, de coisas inúteis). Contudo, atendendo ao facto de o próprio Plutarco ser um aristocrata e de o facto de pertencer a uma elite com posses monetárias ser um pré-requisito importante para a vida política, é curioso Plutarco elogiar a origem humilde de Aristides e a frugalidade de Catão. Isto revela, desde logo, que uma vida simples pode ser combinada com a política. Foi o que aconteceu precisamente com Sócrates ${ }^{189}$ ou Epaminondas. Porém, Plutarco não dá uma resposta explícita sobre qual dos dois modelos prefere: em Catão o justo uso do erário público e o interesse por acumular riqueza ou

${ }^{183}$ Cf. P1. Grg. 482E-483D, Prt. 300C e Resp. 343C-E.

${ }^{184}$ Em Comp. Arist.-Cat.Ma. 4.6, sintetizar-se-á melhor a condição de Aristides, quando se fala na pobreza involuntária, digna de vergonha, e da pobreza por opção, da qual Aristides é um exemplo, merecedora de admiração.

${ }^{185}$ Erga 286 ss.

${ }^{186}$ Cf. Arist. 27.2 e 27.5.

${ }_{187}$ Comp. Arist.-Cat. Ma. 4.5.

${ }^{188}$ Comp. Arist.-Cat. Ma. 4.2.

${ }^{189}$ Cf. Arist. 1.9, 27.3-4, Cat. Ma. 7.1, 20.3, 23.1. 
em Aristides o desinteresse pelo dinheiro? Talvez a verdade seja que nenhum dos dois pode ser imitado por completo, o que prova que Plutarco gosta de promover nas Vitae um paralelismo cooperante e integrado, uma vez que, da junção das qualidades das duas figuras do par, resulta um modelo mais perfeito para o leitor. Neste caso, a boa gestão de Catão e o espírito pouco materialista de Aristides são dignos de ser evocados, enquanto a philoploutia, como motivação central no exercício da politeia, é rejeitada.

Aristides e Catão, que Plutarco descreve com a ajuda dos seus antagonistas, Temístocles e Cipião, respectivamente, revelaram, sem dúvida, uma conduta política diferente, pois o Grego privilegiou mais a discrição, enquanto o Romano mostrou mais inclinação para o protagonismo ${ }^{190}$.

Se, durante a narrativa biográfica, Plutarco não esconde a sua admiração pela dedicação de Catão à família, e os seus esforços que ele fez por transmitir a que considerava ser a melhor paideia, termina a synkrisis com uma análise moral, pouco abonatória, sobre o segundo casamento de Catão ${ }^{191}$, com uma jovem de baixa condição, que o Queronense acha pouco digno de um ancião com um filho já casado, aduzindo várias considerações éticas que só servem para fazer sobressair o carácter impoluto da arete de Aristides.

Para a análise da paideia nesta duas biografias temos de ter em conta dois aspectos: nada se refere de concreto quanto à formação de Aristides e em Catão temos um exemplo, único entre os biografados de Plutarco, de alguém que defende de forma acérrima os valores e a cultura romana, em detrimento da cultura helénica. Esse tipo de pensamento pode evitar que o Império tenha sucesso ${ }^{192}$, o que mostra que, segundo Plutarco, a paideia helénica deve constituir a base cultural da nova estrutura político-social.

A atitude de Catão Censor face ao "helenismo", diferente da de Cipião, enriquece as possibilidades de análise, uma vez que na época de Plutarco a cultura helénica era, em geral, admirada pelas elites romanas. Estaria o autor a tentar passar uma mensagem aos seus leitores gregos, no sentido de também eles saberem preservar os valores ancestrais? Talvez, mas não podemos esquecer que a paideia, seja ela romana ou grega, não é o tema principal nas duas vidas. Esse lugar pertence sobretudo ao exercício da politeia em prol da pátria, tendo cada indivíduo quase a obrigação de preservar uma conduta política em que o todo se sobreponha à vontade ou aos caprichos pessoais. Nesse aspecto, não deixa de ser significativo que Aristides se superiorize a Catão pela maneira simples e desinteressada como exerceu as suas funções, sem qualquer ambição de protagonismo. Assim, Plutarco prefere expor o carácter, as virtudes e os

\footnotetext{
${ }^{190}$ Cf. Comp. Arist.-Cat. Ma. 5.4.

${ }^{191}$ Cf. Cat.Ma. 24.2-9.

192 Ibid. 23.2-3.
} 
vícios dos biografados, enquadrando a posição conservadora e defensiva de Catão em relação à educação no objectivo mais alargado da temática patriótica.

Catão Censor, ao contrário de Aristides, é muito mais pragmático na acção política, pois tenta equilibrar o sucesso económico com a consolidação política de Roma, sem deixar de perseguir a sua própria glória.

\subsubsection{Coriolanus-Alcibiades}

Refira-se, em primeiro lugar, que neste par, à semelhança de Aemilius Paulus-Timoleon e Sertorius-Eumenes, a biografia do herói romano precede a do grego na ordem da estrutura biográfica ${ }^{193}$. Além disso, Coriolano ${ }^{194}$ e Alcibíades, tal como Demétrio e Marco António, são duas personagens sedutoras, apaixonadas e que nem sempre agiram de acordo com o código moral e ético que Plutarco defende nas Vitae ${ }^{195}$.

Quer as aventuras amorosas e as traições de Alcibíades, quer a traição à pátria e o dramatismo da vida de Coriolano, são ingredientes próprios de um romance, com alguns contornos dramáticos, também eles próprios desse género, mas o Queronense consegue conciliá-los na sua narrativa biográfica.

Aquele que exerce funções públicas deverá ter em conta que os cidadãos estão atentos a tudo, ao que ele diz e à forma como age, esperando que consiga ser um modelo e que contribua para a felicidade de todos. Alcibíades é um bom exemplo disso, pois a tendência que tinha para levar uma vida dissoluta fez com que a polis não tirasse proveito da sua inegável energia e capacidade de comando ${ }^{196}$.

Quando se acusa Plutarco de não ter qualidades de historiador, dá-se normalmente como exemplo a biografia de Coriolano, por causa das inexactidões cronológicas e interpretativas da sua vida ${ }^{197}$, mas não é por isso que esta biografia perde interesse, antes pelo contrário, pois a figura de Coriolano permite-nos perceber melhor o que Plutarco entendia por paideia.

Coriolano não recebeu uma educação helénica. Não que a tivesse recusado, como Mário fez ${ }^{198}$, mas porque não teve oportunidade para isso. Plutarco

${ }^{193}$ Cf. pp. 35-6.

${ }^{194}$ Recordamos que Plutarco nunca refere o cognome Coriolanus, mas Gaius Marcius, no entanto à semelhança dos estudos modernos usámos apenas o cognome; para a explicação dos tria nomina, vide Cor. 11.

${ }^{195}$ Sobre a estrutura destas biografias, vide T. Duff (1996: 333-349).

${ }^{196}$ Cf. Praec. ger. reip. 800D.

${ }^{197}$ A este respeito vide F. Frazier (1996: 110).

${ }^{198}$ Valério Máximo elogia Mário por recusar a retórica grega na velhice; segundo T. Carney (1961), Plutarco não refere, ou não sabia, que Mário terá tido educação helénica com um grammaticus Graecus; ora, a própria biografia de Plutarco parece que não confirma a atitude de recusa de Mário: dedicação dos jogos gregos ao templo da Honos et Virtus (cf. Mar. 2.2); Mário cita Píndaro (cf. ibid. 29.5); Mário fala da tyche (cf. ibid. 45.9); em paralelo afirma que foi pela sua falta de logos oratório que Mário não conseguiu atingir o sucesso político (cf. ibid. 6.3, 32.2). 
parece, assim, ter consciência de que Coriolano viveu numa época pré-helénica, em que os valores gregos não estavam ao alcance de Roma. Assim, refere no prólogo da vida de Coriolano que em Roma se exaltam os valores relacionados com a guerra e com as acções militares, ou seja, a uirtus. É precisamente nos capítulos iniciais que podemos colher vários elementos sobre a paideia: ${ }^{199}$

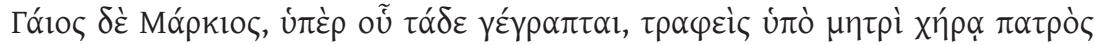

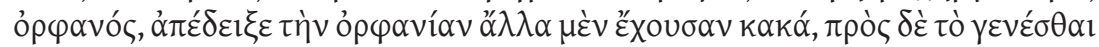

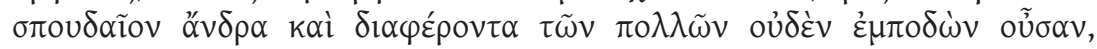

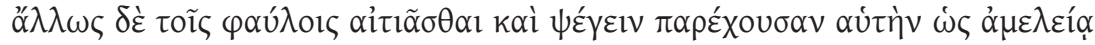

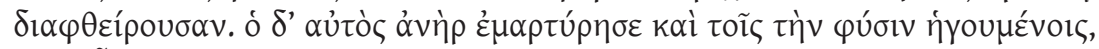

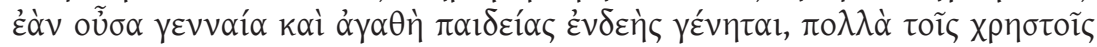

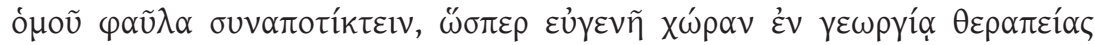

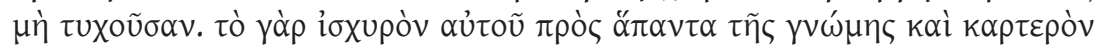

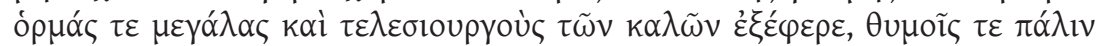

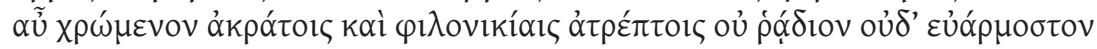

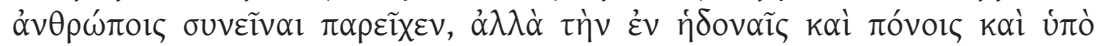

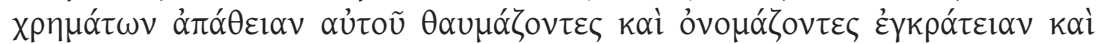

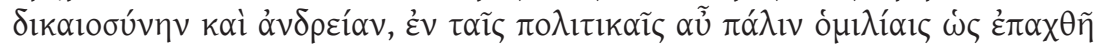

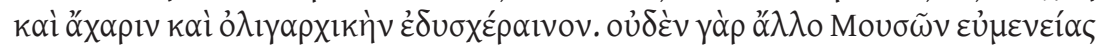

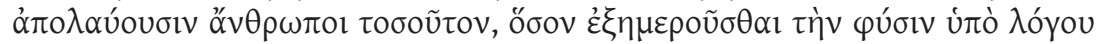

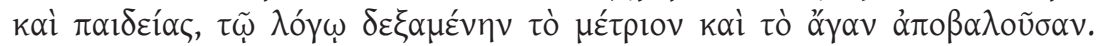

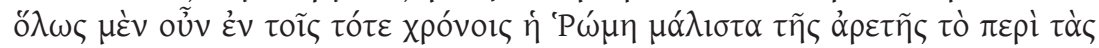

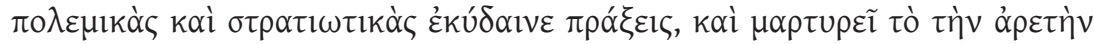

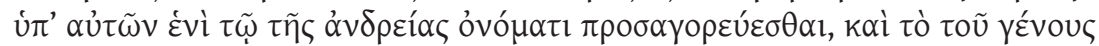

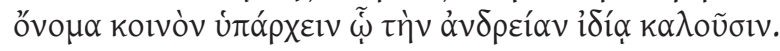

Gaio Márcio, sobre quem agora se escreve, ficou órfão de pai e foi educado pela mãe viúva; demonstrou que a orfandade, embora tendo outras desvantagens, não é de todo um impedimento para que um homem se torne importante e se distinga de muitos, ainda que haja outros que acusem e responsabilizem a referida orfandade pelos actos vis, na medida em que ela se deixou corromper por negligência. Pois o próprio Márcio serviu de testemunha para os que pensam que a natureza, ainda que seja nobre e boa, se tiver uma educação insuficiente, produz muitos defeitos juntamente com qualidades, tal como acontece na agricultura a um campo fértil que fica sem cultivo ${ }^{200}$. De facto, a força e a firmeza do seu juízo em cada momento levaram-no a realizar grandes empresas e com nobres resultados. Pelo contrário, o facto de possuir uma ira impetuosa e uma inclinação constante para o litígio levava Márcio a ter relações difíceis e pouco amistosas com os homens; se admiravam a sua indiferença em relação aos prazeres, à fadiga e ao dinheiro, classificando isso como moderação, justiça

\footnotetext{
199 1.2-6; cf. Mar. 2.2-4.

${ }^{200}$ A mesma ideia é referida no prólogo de Demetr.-Ant. (cf. pp. 95 ss.).
} 
e coragem, pelo contrário, nas relações públicas, indignavam-se com ele por ser insuportável, odioso e arrogante. $\mathrm{Na}$ verdade, os homens não tiram um outro benefício tão grande da benevolência das Musas quanto cultivar a natureza com a razão e a educação, acolhendo a mesura com a razão e repelindo o excesso. Em geral, Roma, naqueles tempos, honrava mais a virtude relacionada com as acções guerreiras e militares. E testemunha disso é para eles a virtude ter o mesmo nome de coragem, e é com o nome de igual origem que designam o valor em particular.

Plutarco, aproveitando o facto de Coriolano ser órfão de pai ${ }^{201}$, refere que tal situação não justifica só por si os sucessos ou os fracassos, as virtudes ou os defeitos, pois prefere enfatizar a noção de que mesmo uma natureza boa precisa de ser cultivada, ou seja, a paideia, a par do logos, ajuda a aperfeiçoar esse tipo de naturezas, a racionalizá-las, de modo que aqueles que não têm consciência disso podem ver as suas qualidades transformarem-se em defeitos. Coriolano é um exemplo disso, pois tinha um carácter particularmente paradoxal e com

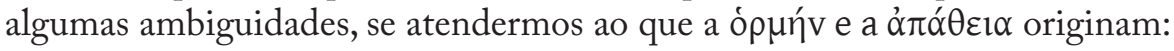

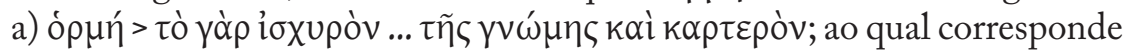

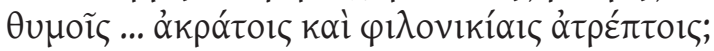

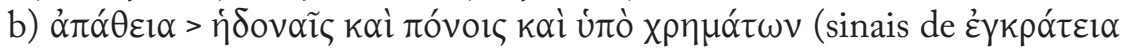

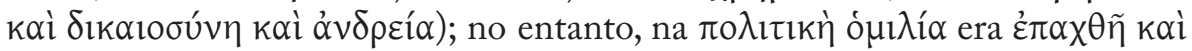

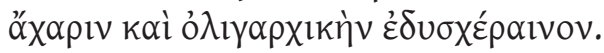

A este herói romano, que competia consigo próprio para superar continuamente as provas de heroísmo e aumentar a sua fama ${ }^{202}$ - num sinal que pode ser interpretado como arrogância por considerar-se o melhor paradigma

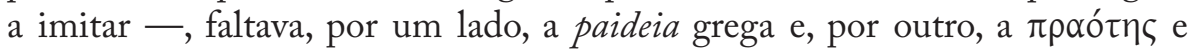
a $\varphi \imath \lambda \alpha v \theta \rho \omega \pi i ́ \alpha$, virtudes políticas basilares, pois o seu ethos fundava-se, em especial, na ópyń e na $\varphi \imath \lambda o \tau \imath \mu i ́ \alpha .{ }^{203}$ Para que Coriolano superasse os opostos da sua natureza, de modo a agir com equilíbrio, seria necessário que conciliasse,

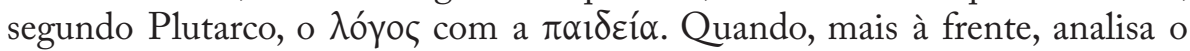

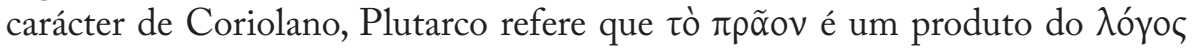
e da $\pi \alpha 1 \delta \varepsilon i ́ \alpha$, defendendo-se o valor da educação para se fomentarem os

${ }^{201}$ Analisando as personagens órfãs das Vitae, F. Albini (1997: 65) considera que existem dois tipos psicológicos de órfãos: um que continua perto da mãe e outro que é adoptado; isso justifica alguns traços do ethos destas personagens ou de outras como Coriolano e Alcibíades. Apesar disso, Plutarco realçará, aquando do discurso da mãe de Coriolano, que o Romano sempre colocou a pátria em primeiro lugar, mas será precisamente a mãe a apaziguar o desejo de vingança que sentia, apelando à sua ligação com a pátria. Parece-nos que todo este enredo serve os dois objectivos: reforçar os laços de Coriolano com a mãe e também o seu vínculo com Roma.

${ }^{202}$ Cf. Cor. 4.3.

${ }^{203}$ Ideia já defendida e desenvolvida por D. Russel (1963: 27). 
verdadeiros valores e se evitarem os maus costumes: ${ }^{204}$

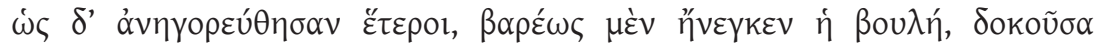

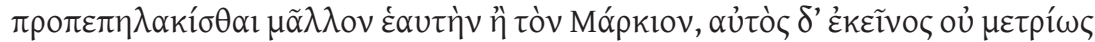

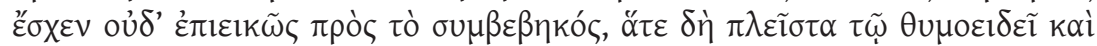

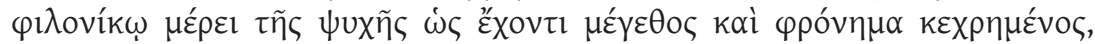

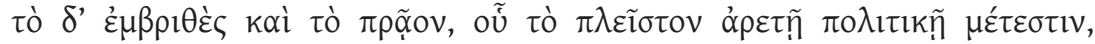

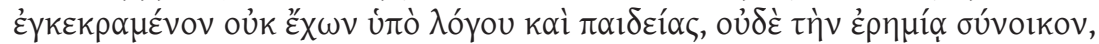

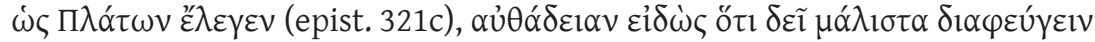

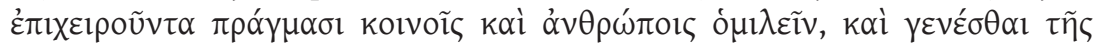

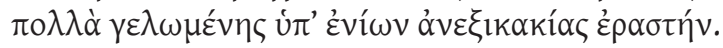

Como outros foram eleitos cônsules, o senado aceitou com dificuldade isso, considerando que era um ultraje mais a ele próprio do que a Márcio, que não foi comedido nem moderado perante o sucedido, pois, na maioria das vezes, agia com a parte corajosa e belicosa da alma, como se isso tivesse alguma relação com a grandeza e o espírito. Ele carecia de gravidade e doçura, qualidades muito importantes para a virtude política, que, quando não se têm, se adquirem pela razão e pela educação. Parece que ignorava que quem comanda assuntos públicos ou trata de assuntos com homens não necessita de todo da arrogância, "a companheira da solidão", como disse Platão ${ }^{205}$, e que se torna um grande amante da resignação que é ridicularizada por alguns.

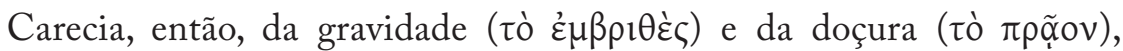
qualidades indispensáveis num homem que deseja ser virtuoso nas suas

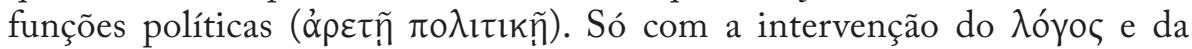
$\pi \alpha_{1} \delta \varepsilon \varepsilon^{206}$, Coriolano, que era, como Mário ${ }^{207}$, uma pessoa muito pouco sociável, poderia corrigir a sua inaptidão política ${ }^{208}$. Este texto traça, assim, um quadro psicológico do herói, especialmente quando afirma que "na maioria das vezes, age com a parte corajosa e belicosa da alma". Com efeito, é nessa parte que se situam as qualidades irracionais que precisam de ser aperfeiçoadas pela paideia.

Prova de que a sua formação está longe de ser perfeita é o facto de, tal como Marcelo ${ }^{209}$ ou Flaminino ${ }^{210}$, se ter entregue à actividade guerreira desde muito

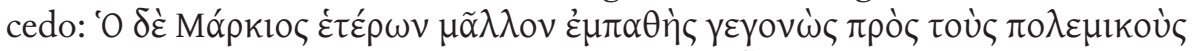

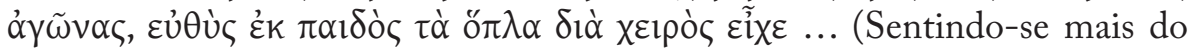

\footnotetext{
${ }^{204}$ Ibid. 15.4.

${ }^{205}$ Cf. Ep. 321c; Plutarco volta a citá-lo em De adul. 96F.

${ }^{206}$ Cf. Brut. 1.3.

${ }^{207}$ Cf. Mar. 32.2.

${ }^{208}$ Cf. Comp. Cor.-Alc. 4.7-9, 5.1.

${ }^{209}$ Cf. Marc. 1.2-5.

${ }^{210}$ Cf. Flam. 1.4.
} 
que outros apaixonado pelo confronto guerreiro, Márcio começou, logo desde a infância, a manusear armas... $)^{211}$. Para se preparar, tentou harmonizar a capacidade física com a preparação interior para enfrentar os inimigos, dando provas de uma intrépida andreia.

Ainda em relação à sua orfandade, facilmente se supõe que a mãe, a quem Plutarco atribui o nome de Volúmnia ${ }^{212}$, exerce no filho um fascínio e um poder especial. Em primeiro lugar, a maior glória ou o telos da acção de Coriolano era sentir que a mãe se regozijava com as suas vitórias, preocupação que seria uma consequência da sua orfandade. ${ }^{213}$ Neste aspecto, a atitude de Coriolano é comparável à de Epaminondas. Também o general tebano considerava que a maior alegria era o pai e a mãe terem tido oportunidade de ver os seus sucessos ${ }^{214}$, ainda que Coriolano vá mais longe nesta relação, uma vez que casou a pedido da mãe e, mesmo depois de ter filhos, continuou a viver com ela ${ }^{215}$. É digno de nota o dramatismo do momento em que Coriolano se despede da mãe e da esposa, antes de seguir para o exílio, pedindo-lhes para suportar essa desgraça com equilíbrio $\left(\mu \varepsilon \tau \operatorname{cí}^{\omega}\right)^{216}$. Após várias tentativas falhadas, a mãe de Coriolano desempenhará um papel decisivo em aplacar a ira e o desejo de vingança do filho contra a sua pátria. Ao pedido de Valéria, irmã de Publícola, para demover Coriolano, Volúmnia responde da seguinte forma: ${ }^{217}$

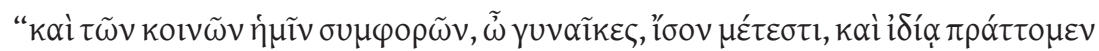

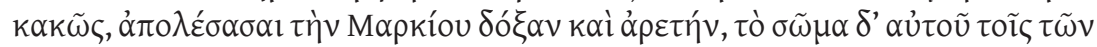

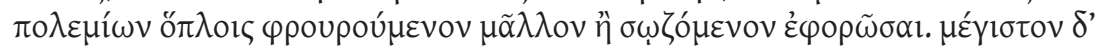

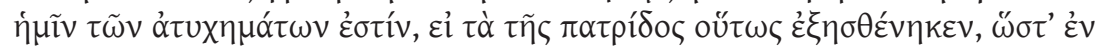

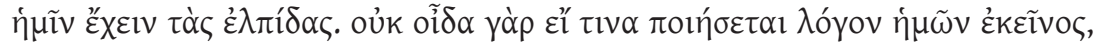

${ }^{211}$ Cor. 2.1.

${ }^{212}$ Para Dionísio de Halicarnasso (e.g. Ant. rom. 8.39.4) chama-se Vetúria e em Tito Lívio (2.40.1) pode ler-se: Tum matronae ad Veturiam matrem Coriolani Volumniamque uxorem frequentes coeunt (Então, as numerosas mães aproximam-se de Vetúria, mãe de Coriolano, e da sua mulher, Volúmnia).

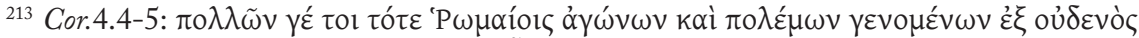

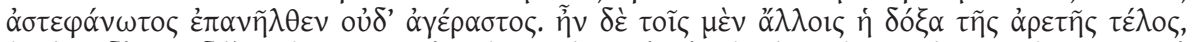

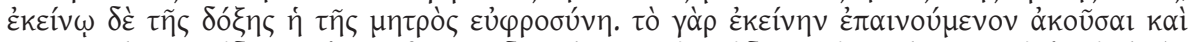

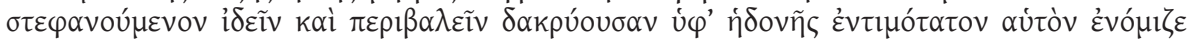

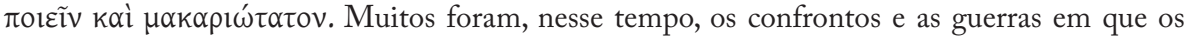
Romanos participaram e de nenhuma delas Márcio regressou sem coroa ou sem ser premiado. Enquanto para outros o objectivo da virtude era a fama, para ele o fim da fama era a alegria da sua mãe. Na verdade, significava para ele a maior honra e felicidade que ela ouvisse os elogios, que o visse coroado ou o abraçasse chorando de prazer. Os confrontos a que Plutarco se refere são aqueles que, por exemplo, os Sabinos ou os Volscos protagonizaram.

${ }^{214}$ Em especial, a vitória de Tebas sobre Esparta na batalha de Leuctra, em 371 a. C.; vide, ainda, An seni resp. 786D e Non posse suau. 1098A.

${ }^{215}$ Cf. Cor. 4.4.

${ }^{216}$ Cf. ibid. 21.3.

${ }^{217}$ Cor. $33.7-10$. 


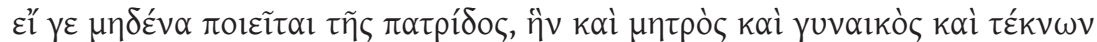

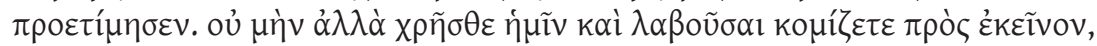

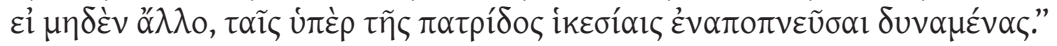

"Mulheres, não sentimos de igual forma que vós os infortúnios comuns, mas sofremos em privado pela perda da glória e da virtude de Márcio e por ver o seu corpo mais guardado por armas dos inimigos do que a salvo da morte. Mas o maior dos infortúnios para nós é a pátria se encontrar de tal forma impotente que deposita em nós as suas esperanças. Não sei, contudo, se ele nos prestará atenção, quando não prestou à pátria, a qual ele sempre preferiu em detrimento da mãe, da mulher e dos filhos. Não obstante, servi-vos de nós e, tomando-nos, conduziu-nos até ele, para, no caso de não podermos fazer mais nenhuma coisa, expressarmos as últimas súplicas pela pátria”.

O texto mostra como o sentimento das mulheres de Roma era diferente do da mãe e da mulher de Coriolano, que sofriam por ele se ter sempre dedicado mais à pátria do que à sua família ${ }^{218}$. Neste momento de sofrimento e provação, é precisamente a pátria, que ele sempre amou, que está dependente do sucesso da sua família para o demover do ataque ${ }^{219}$. Esses dois elementos, a pátria e a família, estarão presentes no momento em que Coriolano, com muita emoção, recebe a mãe, a mulher e os filhos no seu acampamento ${ }^{220}$, facto que não deixa de ser um testemunho importante para Plutarco reforçar a ideia do patriotismo como um elemento basilar da sua doutrina ética e filosófica. Num discurso ${ }^{221}$ comovente, a mãe procura persuadir Coriolano a mudar de atitude, lembrando-lhe que, por causa do seu exílio, ela e a nora se tornaram as

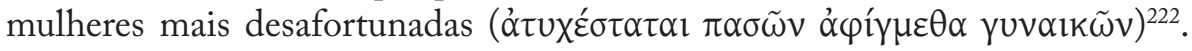
Recorda-o da dor que é ver um filho ou, no caso de Virgília, um marido, junto das muralhas pátrias e do conflito que lhes domina a alma, entre o desejo

${ }^{218}$ Era diferente a atitude de Catão Censor que dispensava grande atenção à mulher e ao seu filho.

${ }^{219}$ Uma embaixada de senadores, amigos de Coriolano (cf. Cor. 30.3-8), e uma outra composta por sacerdotes (cf. ibid. 32.1-3), com o objectivo de apaziguar a revolta de Coriolano e de discutir as condições impostas por ele em nome dos Volscos, não surtiram qualquer efeito.

${ }^{220}$ Cf. Cor. 34.3.

${ }^{221}$ Cf. ibid. 35 (35.1-6 corresponde ao exórdio; 35.7-9 à argumentação); A. Pérez Jiménez (2000b: 341-353) analisa o discurso e aborda o valor da retórica do silêncio (Coriolano é um interlocutor eloquentemente (!) silencioso na versão de Plutarco), salientando, com o recurso à metrica de 35.1-36.3, que o registo biográfico de Plutarco, ao contrário do extenso relato de Dionísio de Halicarnasso, atinge maior dramaticidade: "barajado con gran habilidad retórica por Volumnia, cuya figura pone de relieve las deficiencias humanas de Coriolano, crea una profunda confusión psicológica en éste, denunciada por su silencio. Un silencio que es la clave literaria del texto plutarqueo; un silencio que crea una tensa situación entre madre e hijo rota bruscamente con las preguntas retóricas de aquélla, que se erige así en intérprete de las contradicciones psicológicas del héroe" (342).

${ }^{222}$ Cf. ibid. 35.2. 
de que se salve a pátria e o desejo que se salve ele, que é filho, marido e pai. Volúmnia apela a Coriolano para que substitua as desavenças e a hostilidade

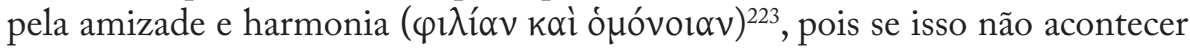
algo mais grave pode acontecer: ${ }^{224}$

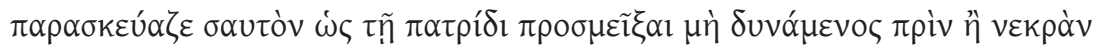

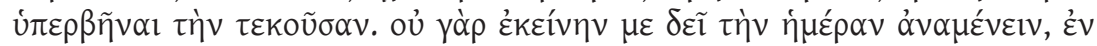

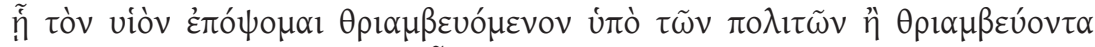

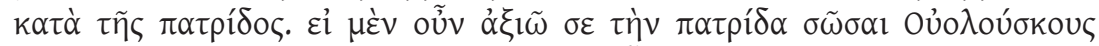

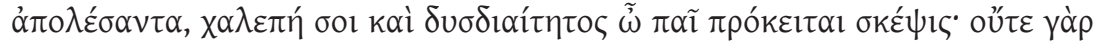

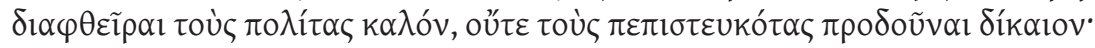

"Prepara-te, pois não poderás atacar a tua pátria sem antes passar por cima do cadáver de quem te deu à luz. De facto, não preciso de esperar o dia em que assistirei ao meu filho ser conduzido triunfalmente pelos concidadãos ou a triunfar contra a pátria. Se eu te pedisse para salvar a tua pátria, destruindo os Volscos, era colocar-te, meu filho, perante uma decisão penosa e muito complicada. Pois, nem é bom prejudicar os concidadãos, nem é justo atraiçoar os que antes confiaram em ti”.

A mãe diz-lhe que, se travar a guerra,nem em caso de vitória nem de derrota, o desfecho será bom e digno para ele. Apenas a paz lhe trará a verdadeira vitória, e os próprios Volscos serão recordados como aqueles que, mesmo sendo os mais

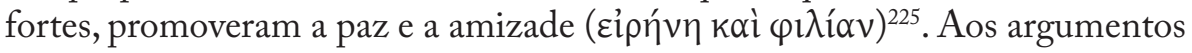
que Volúmnia dirige simultaneamente ao guerreiro, ao filho, ao marido e ao

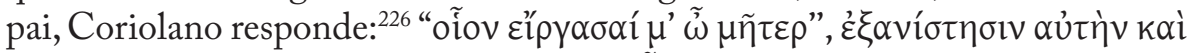

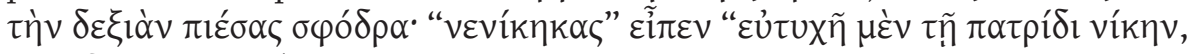

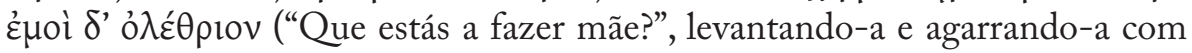
força pela mão direita, prosseguiu: "Conseguiste uma vitória afortunada para a pátria, mas ruinosa para mim”). Foi desta forma que Volúmnia, exercendo a sua influência junto dele por ser sua mãe e apelando aos sentimentos pessoais, conseguiu demover Coriolano, criando as condições para a paz e a harmonia ${ }^{227}$,

${ }^{223}$ Cf. ibid. 35.5 .

${ }^{224}$ Ibid. 35.5-7.

${ }^{225}$ Ibid. 35.8.

${ }^{226}$ Ibid. 36.5; cf. 36.1-4 (aquilo a que se costuma chamar a peroratio, onde o apelo dos sentimentos vence a lógica dos argumentos).

${ }^{227}$ Em Cor. 37, Plutarco descreve as honrarias que o Senado e o povo dedicaram às mulheres, artífices da paz; além disso, este momento foi acompanhado de alguns acontecimentos que a simples razão não consegue explicar, como, por exemplo, estátuas a derramar lágrimas ou gotas de suor, manifestações divinas que Plutarco explica com o apoio de Heraclito de Éfeso, frg. 86

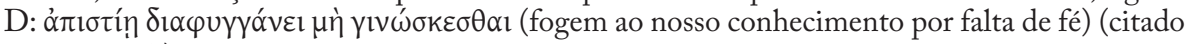
em Cor. 38.7). 
sobretudo porque o filho viu na mãe a identificação da pátria, que se tornou o argumento central no logos persuasivo.

O momento do encontro entre a mãe com o filho, que pode ser identificado como o clímax da biografia, adquire especial significado por a mãe representar uma parte importante e insubstituível da paideia e por ela conseguir atingir os seus objectivos, tendo superado o obstáculo de Coriolano ser um guerreiro muito intransigente. Percebe-se, ao longo da biografia, que para o herói romano um soldado deve ser audaz, vigoroso e terrível no seu aspecto exterior ${ }^{228}$, não deixando Coriolano de criticar, por exemplo, aqueles que após a tomada da cidade dos Coriolanos, se dedicaram à rapina ${ }^{229}$. Depois, numa atitude que colhe sempre grande admiração junto dos companheiros e concidadãos, rejeita despojos, com a excepção de um cavalo, por os considerar mais um pagamento do que uma honra, preferindo que lhe entregassem um amigo que era prisioneiro, em vez de o venderem ${ }^{230}$, por entender, segundo

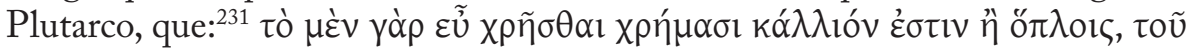

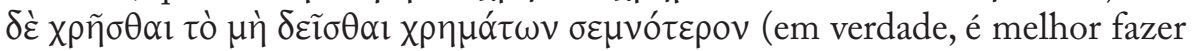
bom uso das riquezas do que das armas, e ainda mais nobre do que usar as riquezas é não as desejar).

O thymos de Coriolano, onde confluíam qualidades guerreiras com manifestações excessivas, não convivia bem com a derrota e isso ficou bem demonstrado quando o povo, temendo que usufruísse de muito poder, rejeitou a sua candidatura ao consulado, revelando a reacção de Coriolano que não conseguia conciliar o logos e a paideia ${ }^{232}$. Se, nesta ocasião, não escondeu a sua revolta, o mesmo não acontece quando é condenado ao exílio perpétuo

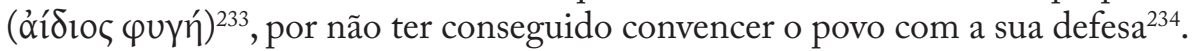
Perante esta decisão, que causou a alegria do povo e a tristeza dos patrícios ${ }^{235}$, Coriolano procura disfarçar os seus sentimentos, merecendo de Plutarco o

${ }^{228}$ Cf. e.g. ibid. 8.3.
${ }^{229}$ Cf. ibid. 9.1.
${ }^{230}$ Cf. ibid. 10.
${ }^{231}$ Cor. 10.8.
${ }^{232}$ Cf. ibid. 15.4 .
${ }^{233}$ Cf. ibid. 20.7 ; esta pena é, no entanto, anacrónica, uma vez que só na época de Sula o recurso ao exílio se tornou habitual.

${ }^{234}$ Compare-se a falta de retórica de Coriolano com Alc. 10.3-4; contudo, em 27.1, Plutarco

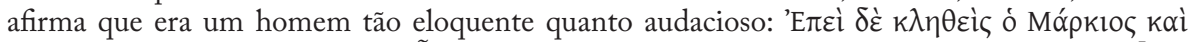

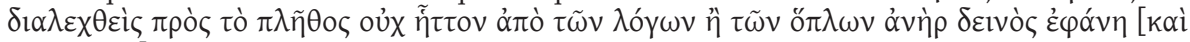

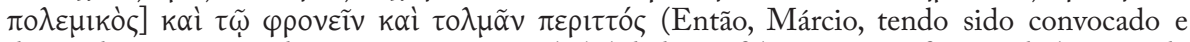
dirigindo-se ao povo, demonstrou que a sua habilidade em falar não era inferior à do homem de armas e que era extraordinariamente dotado de inteligência e de audácia); também em 39.6 se elogia a capacidade oratória de Coriolano).

${ }^{235}$ Cf. ibid. 20; em 24.1, Plutarco conta que os patrícios acusaram o povo do exílio de Márcio, o que deu origem a várias revoltas na cidade. 
seguinte comentário: ${ }^{236}$

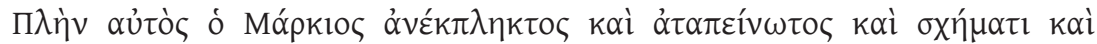

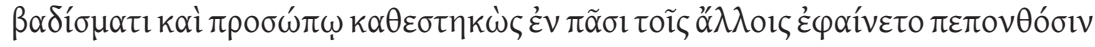

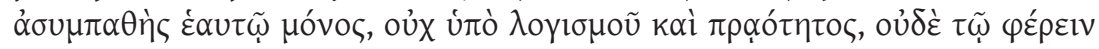

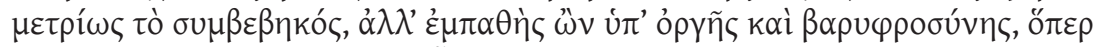

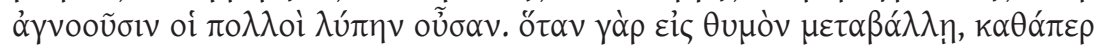

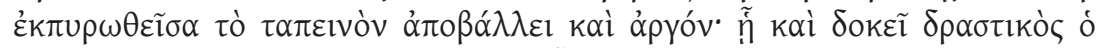

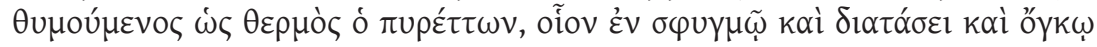

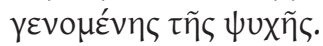

[Ao contrário dos patrícios] O próprio Márcio era uma excepção, pois não parecia estar assustado nem abatido: no seu aspecto, na forma de andar e na sua face, revelava estar tranquilo. Enquanto todos os outros sofriam, somente ele não se compadecia, o que não acontecia por cálculo ou por afabilidade, nem por estar a suportar isso com equilíbrio, mas por estar afectado pela ira e pela irritação, que muitos ignoram ser uma manifestação de dor. Quando esta se transforma em ira, como que se incendeia e perde a humildade e a inacção. Por isso, quem sente ira está activo, como o que tem febre sente calor, porque a alma está palpitante, dilatada e inflamada.

A partir deste momento, as suas acções estão dominadas pela ira contra Roma ${ }^{237}$, a ponto de se propor ajudar os Volscos e o seu arqui-inimigo, Tulo Ácio. Com esse objectivo entra na cidade dos Volscos disfarçado ${ }^{238}$, tal como Ulisses. Aí, após revelar a sua identidade, proferiu um discurso suficientemente persuasivo para Tulo o acolher e aceitar a sua ajuda. No referido discurso, Coriolano manifesta o seu desejo de vingança, argumentando que poderá ser útil, uma vez que conhece bem as estratégias dos Romanos ${ }^{239}$.

Logo que Coriolano passou a combater pelos Volscos, estes começaram a ganhar batalhas, fazendo com que Roma sentisse a sua hegemonia ameaçada. Talvez ainda pior do que isso, instala-se na Vrbs uma assinalável desordem social, agravada com a emblemática conquista de Lavínio, cidade sagrada e a primeira a ser fundada por Eneias ${ }^{240}$. Este acontecimento levou o povo a mudar de opinião, pedindo então a revogação da pena aplicada a Coriolano. $\mathrm{O}$

${ }^{236}$ Ibid. 21.1-2.

${ }^{237}$ Vem a propósito a citação que Plutarco faz de Heraclito de Éfeso (fro. 85 Diels-Kranz)

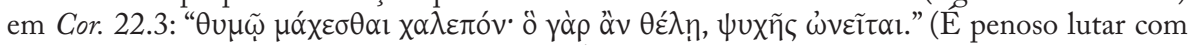
ira, pois o que se deseja compra-se com a vida); também citado em De cohib. ira 457D e Amat. $755 \mathrm{D}$.

${ }^{238}$ Cf. Cor. 22.4, onde cita Od. 4.246.

${ }^{239}$ Cf. ibid. 23. 3-10

${ }^{240}$ Cf. ibid. 29.2 . 
Senado, pelo contrário, deliberou não haver razões para mudar a sentença ${ }^{241}$. Plutarco interpreta como sinal de ira tanto esta atitude do Senado como a

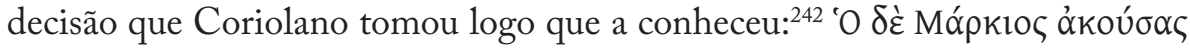

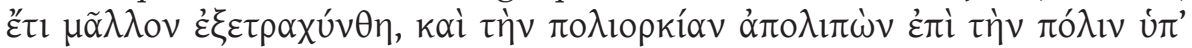

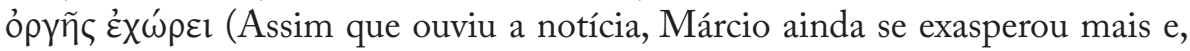
abandonando o assédio [de Lavínio], dirigiu-se com ira contra Roma); $\tau \grave{v} v$

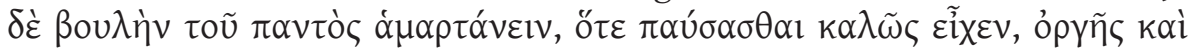

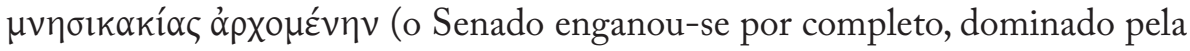
ira e pelo ressentimento, quando podia ter terminado de forma justa o exílio). Em verdade, Plutarco reparte as atitudes provocadas pela ira por Coriolano e pelo Senado romano, mas as de Coriolano são de maior gravidade, uma vez que ele agiu, conscientemente, contra a sua própria cidade, revelando com isso a sua falta de moderação, de praotes $^{243}$ e a excessividade natural do seu thymos ${ }^{244}$.

$\mathrm{O}$ autor constrói, assim, o sentido da paideia, num contexto de vários excessos, em que ela surge como o método mais eficaz para se combater uma natureza conturbada. Como defensor da impossibilidade de se encontrar um indivíduo perfeito, Plutarco sabe como por vezes é difícil escolher entre seguir a natureza ou ir contra ela: ${ }^{245}$

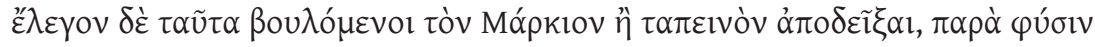

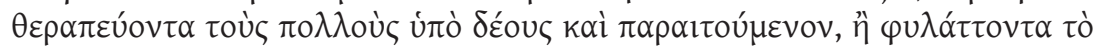

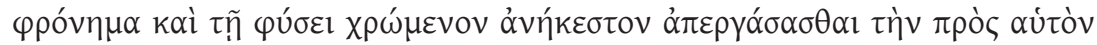
ópyńv*

Diziam estas coisas por quererem humilhar Márcio, para o caso de ele, contra a sua natureza, fosse adular, o povo, por medo e implorasse o perdão, ou, se ele conservasse o espírito conforme a natureza, moverem, de forma perniciosa, a ira do povo contra ele.

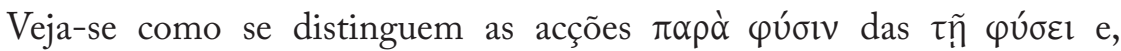
consequentemente, as reacções diversas que podem gerar por parte dos tribunos. No caso de Coriolano, ir contra a natureza é tomar uma atitude mais

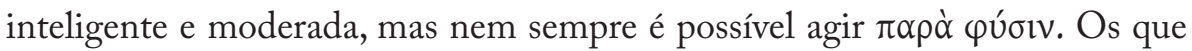

${ }^{241}$ Em Cor. 29. 4, Plutarco sugere três propostas de análise sobre a tomada de posição do

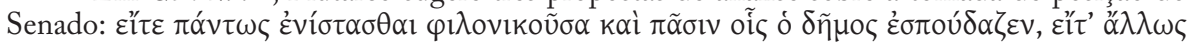

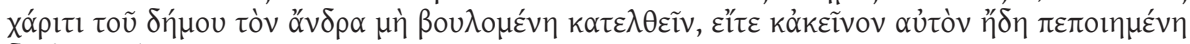
$\delta l^{\prime}$ ópүñ (fosse por se opor frontalmente a todas as medidas que o povo solicitava, fosse por simplesmente não desejar que ele regressasse com a graça do povo ou por já estar irado com o próprio Márcio).

${ }^{242}$ Cor. 30.1 e 30.2 , respectivamente.

${ }^{243}$ Cf. H. Martin Jr. (1960: 69).

${ }^{244}$ Cor. 21.5-6: desejo de vingança dominado pelo thymos.

${ }^{245}$ Cor. 18.2 . 
o conseguem fazer absorveram já os princípios da paideia e, nesses casos, a acção é o resultado natural da formação, ou seja, existe uma causalidade entre paideia e praxis. No entanto, nas Vitae, como acontece no caso específico da biografia de Coriolano, torna-se sempre mais fácil apontar os casos em que se nota a carência da paideia, do que aqueles em que uma determinada atitude é o resultado indiscutível do processo formativo.

Mas é curioso que Coriolano, mesmo carecendo de instrução, era, à semelhança de Alcibíades ${ }^{246}$, um orador brilhante ${ }^{247}$, qualidade que terá desenvovido com a sua experiência de vida ou, então, por fazer parte da sua physis. Além disso, Coriolano, ao contrário do comportamento que Cícero teve quando se encontrava no exílio, deixou que o seu pathos fosse vencido pelo logos, tendo contribuído para isso, de forma decisiva, a intervenção da sua mã $\mathrm{e}^{248}$.

Não restam dúvidas de que, embora se atribuam os defeitos de Coriolano à falta da cultura helénica ${ }^{249}$, este Romano é examinado sobretudo no campo da conduta moral e ética, por meio de um apurado retrato psicológico, e não pela forma como aprofundou a sua paideia. Plutarco fará o mesmo na biografia de Alcibíades ${ }^{250}$, que aspirava a ocupar o lugar político de Péricles, após a morte deste. As suas qualidades, no entanto, estavam longe de reunir consenso entre os Atenienses ${ }^{251}$.

Do bios de Alcibíades, o conhecido discípulo de Sócrates, nascido no seio de uma família aristocrata, retemos, desde logo, o facto de Plutarco evidenciar o seu ethos paradoxal252, elemento que o aproxima de Coriolano. $\mathrm{Na}$ figura de

${ }^{246}$ Cf. Alc. 10.3-4.

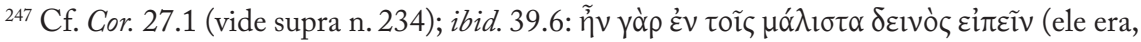
de facto, um dos mais hábeis a falar).

${ }^{248}$ Este pode ser mais um exemplo do ideal feminino de Plutarco, em que as mulheres, tal como a mãe de Coriolano, desempenham um poder especial de mediação e conciliação (cf. F. Frazier (1992: 4534-5)); vide também Ag./Cleom. 17 e Dion 51.

${ }^{249}$ Cf. Cor. 1.3-6, 15.4, 21.1.

${ }^{250}$ Cf. Alc. 15.4-5, 18.3, 21.1-2, 35.5 e Comp. Cor.-Alc. 5.1-2.

${ }^{251}$ A particularidade do seu carácter, que dificilmente o torna um esteriótipo, é a razão que leva Aristóteles, ao apontar as diferenças entre a história (universal) e a poesia (particular), a dor o exemplo de Alcibíades (Pol.1451b). No entanto, Plutarco, em De adul.52E, diz que Alcibíades foi o maior кó $\lambda \alpha \xi$, característica relacionada com a sua xópıs (Alc. 1.6, 10.3, 24.5), a qual lhe garantiu alguns sucessos. Estes traços do ethos de Alcibíades podem ter conotações positivas ou negativas, fazendo dele umas vezes um bom exemplo outras um mau. Sobre este aspecto, T. Duff (1996: 343) tem a seguinte opinião: "Plutarch's Alkibiades, one of his most memorable characters, is above all na individual. If there is any lesson here, it is that the moral categories do not always work - especially not for the great"; Cornélio Nepos, provavelmente uma das fontes de Plutarco para escrever a vida de Alcibíades, realça no início da biografia que lhe dedica o seu carácter paradoxal: "ut omnes admirarentur in uno homine tantam esse dissimilitudinem tamque diversam naturam" (Alc. 1.4).

${ }^{252}$ Talvez por isso a sua natureza suscite opiniões diferentes, como bem ilustra a seguinte

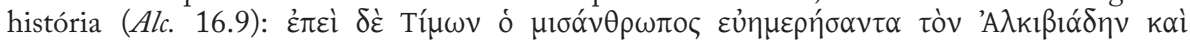

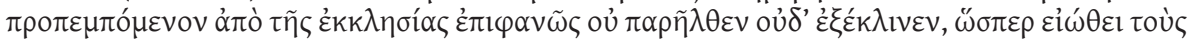


Alcibíades combinam-se aspectos tão negativos como a arrogância, os excessos ou a manipulação com qualidades tão apreciadas como a habilidade política e

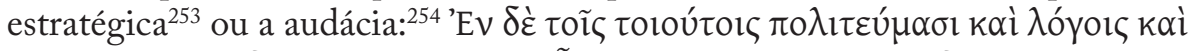

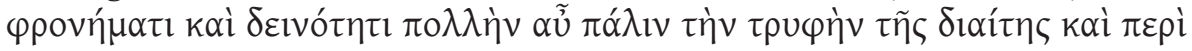

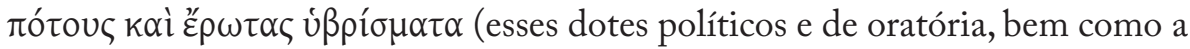
sua inteligência e audácia, opunham-se muito ao desdém do seu estilo de vida, aos excessos na bebida e no amor).

Em comparação com a biografia de Coriolano, Plutarco é muito mais explícito sobre a paideia de Alcibíades. Logo nas primeiras linhas da biografia menciona os nomes dos que acompanharam a primeira fase da educação de Alcibíades:255

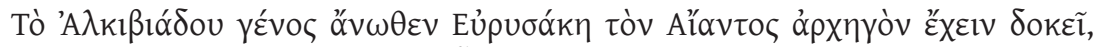

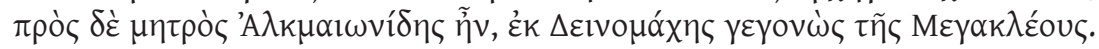

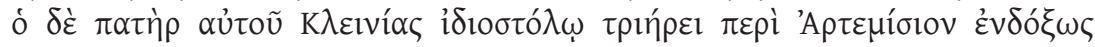

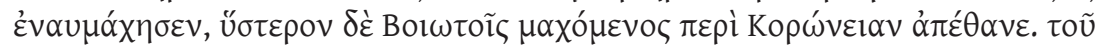

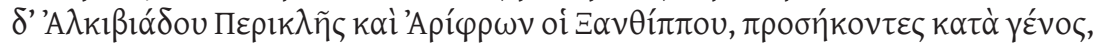

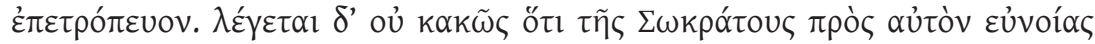

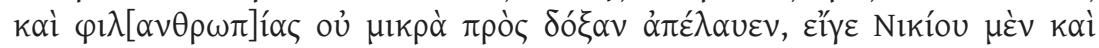

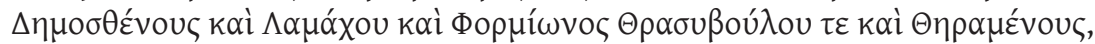

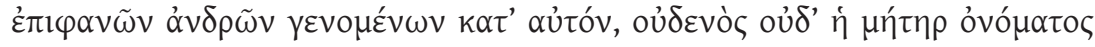
ह̌兀

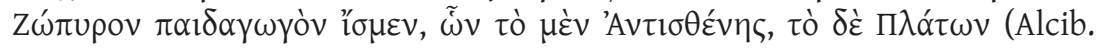

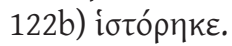

A estirpe de Alcibíades parece ter tido como fundador Eurísaces, filho de Ájax. Pelo lado da mãe, Dinómaque, filha de Mégacles, era Alcmeónida. O seu pai Clínias combateu gloriosamente em Artemísio com uma trirreme equipada por ele próprio, vindo a morrer mais tarde perto de Coroneia num confronto com

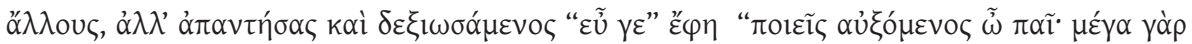

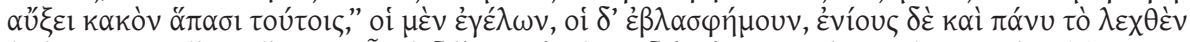

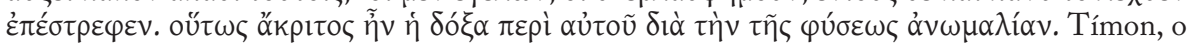
misantropo, ao ver Alcibíades a sair da assembleia com ar de felicidade e acompanhado, não passou ao lado nem o evitou, como era costume outros fazerem, mas indo ao seu encontro e saudando-o disse-lhe: "Jovem, fazes bem em te glorificares, mas a tua glória transformar-se-á num grande mal para todos estes que te acompanham”. Uns riram, outros caluniaram-no, e noutros o que ele disse causou muita apreensão. Assim, a opinião sobre Alcibíades era incerta por causa da inconstância da sua natureza.

${ }^{253}$ A sua habilidade fica bem patente quando consegue evitar o ostracismo, combinando com um dos possíveis condenados (Nícias ou Feace, conforme as versões) a votação em Hipérbolo, que era usado pelo povo para caluniar as figuras mais importantes (cf. Alc. 13.4-9).

${ }^{254}$ Ibid. 16.1.

255 Alc. 1.1-2. 
os Beócios ${ }^{256}$. Péricles e Árifron, filhos de Xantipo, foram tutores de Alcibíades, unidos a ele por laços familiares. ${ }^{257}$ Diz-se, e com razão, que Alcibíades tirou muito benefício para a sua fama da benevolência e da bondade que lhe dedicou Sócrates; certo é que de Nícias, Demóstenes, Lâmaco, Fórmion, Trasibulo e Terâmenes, homens célebres ${ }^{258}$ que foram seus contemporâneos, nem sequer o nome da mãe sabemos, enquanto de Alcibíades até conhecemos o da ama, chamada Amicla, de origem Lacónia, e o do mestre, Zópiro; Antístenes refere o dela e Platão o dele.

É desta forma que somos informados de que nem o pai nem a mãe participaram activamente na formação de Alcibíades, um jovem a quem ninguém era indiferente por causa da sua beleza. Uma maior influência terão

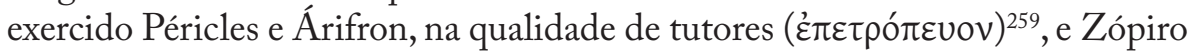
como mestre ( $\pi \alpha 1 \delta \alpha \gamma \omega \gamma o ́ v)$, ou até a própria ama ( $\tau i ́ \tau \theta \eta v)$, Amicla $^{260}$. Quanto à sua célebre relação com Sócrates e aos benefícios que tirou dessa amizade, Plutarco é mais esclarecedor no seguinte texto: ${ }^{261}$

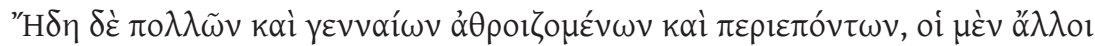

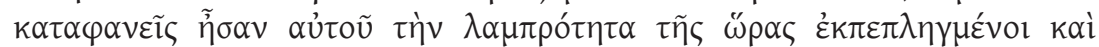

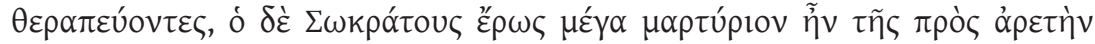

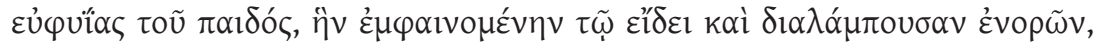

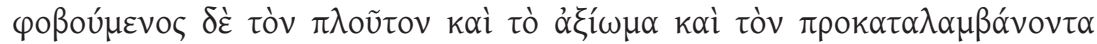

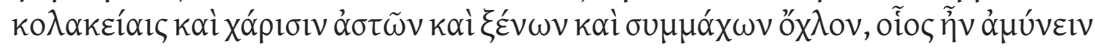

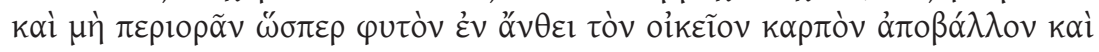

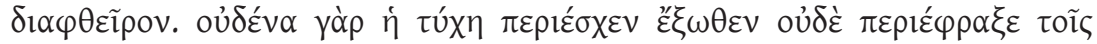

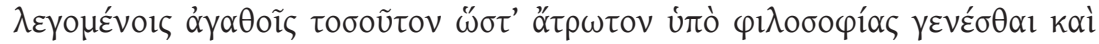

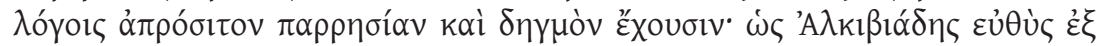

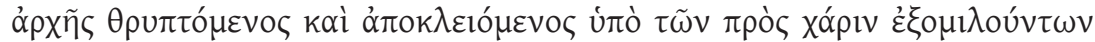

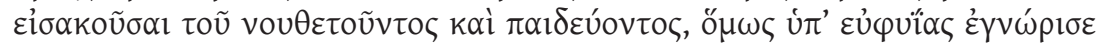

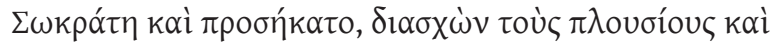

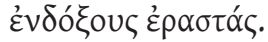

${ }^{256}$ Este confronto, datado de 447 a. C., não provocou só a derrota dos Atenienses, mas também a saída da Beócia, da Fócida e da Lócrida da aliança ateniense.

${ }^{257}$ Agariste, mulher de Xantipo (cf. Per. 3.2), um general que participou activamente nas guerras contra os Persas, era irmã de Mégacles, o avô materno de Alcibíades, daí os laços familiares a que se refere o texto. Refira-se que P1. Alc. 104b, não menciona Árifron como tutor de Alcibíades.

${ }^{258}$ Todos eles participaram na Guerra do Peloponeso.

259 Vide H. Jolowicz (1974: 82-90), sobre a má reputação que os tutores teriam na Antiguidade.

${ }^{260}$ Em Lyc. 14.2-4, Plutarco refere que as amas lacónias, por causa da sua boa preparação, eram requisitadas em diferentes regiões gregas, dando o exemplo de Amicla. Quanto a Zópiro, critica o facto de Péricles ter escolhido alguém que em muito pouco diferia dos outros escravos.

${ }^{261}$ Alc. 4.1-2. 
Já muitos homens de origem ilustre se concentravam à sua volta e o enchiam de cuidados, enquanto outros eram claramente atraídos por ele e o cortejavam por causa do brilho da sua juventude. Porém, o grande amor de Sócrates era um testemunho da disposição natural da criança para a virtude, fixando Sócrates o olhar no esplendor e no aspecto da sua beleza; temendo a riqueza, a estima social e o conjunto de cidadãos, estrangeiros e aliados, que se apoderavam de Alcibíades com adulações e recompensas, Sócrates protegeu-o e olhou por ele como se não permitisse que uma planta em flor perdesse ou destruisse o fruto natural. $\mathrm{Na}$ verdade, a sorte de modo algum protegeu ou cumulou alguém com os chamados bens a ponto de o poder tornar invulnerável à filosofia e insensível a argumentos elaborados com franqueza e corrosividade. Embora tenha sido logo de início acarinhado e limitado, com recompensas, a dar ouvidos aos que advertiam e ensinavam, Alcibíades descobriu, contudo, graças ao seu talento natural, Sócrates e juntou-se a ele, libertando-se dos amantes ricos e distintos.

Realça, assim, a عủpuía de Alcibíades, palavra que ocorre duas vezes no texto que acabámos de citar, uma vez ligada à ỏpetŕ, outra a Sócrates, que personifica o amor pela filosofia e pelo saber, em geral. Apesar de atrair a paixão daqueles que só se interessam pelas coisas exteriores, o jovem Alcibíades, que tinha uma inclinação natural para a arete, consegue vencer essas limitações e, por meio da sabedoria de Sócrates descobrir outro tipo de ensinamentos, porventura menos tangíveis, mas mais duradouros e capazes de serem consequentes, de onde se fomentará a paideia. Na verdade, Alcibíades amava

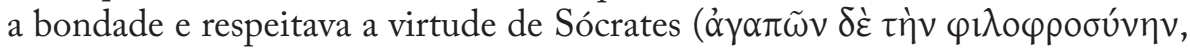

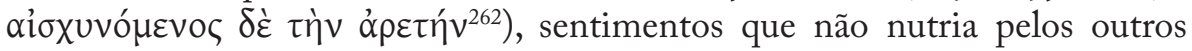
amantes $^{263}$, pois tratava-os com alguma aspereza ${ }^{264}$.

Sabemos também como encarou os seus primeiros tempos na escola, onde, segundo Plutarco, prestaria atenção a todas as matérias com excepção das lições de flauta: ${ }^{265}$

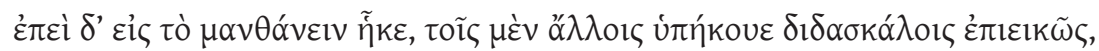

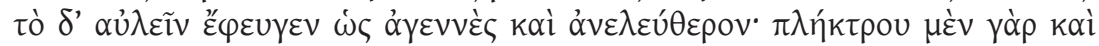

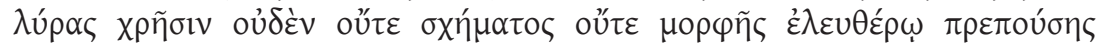

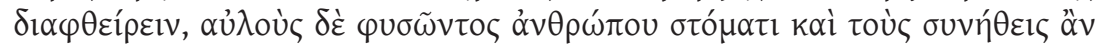

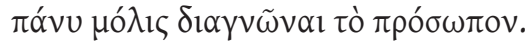

${ }^{262}$ Alc. 4.4.

${ }^{263}$ Plutarco conta algumas histórias anedóticas sobre a relação de Alcibíades com os amantes em 4.5 e 5.

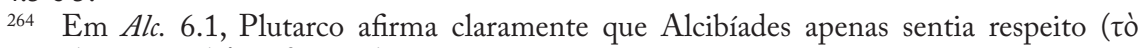
$\alpha \hat{i} \delta \varepsilon \tilde{\imath} \sigma \theta \alpha \mathrm{l})$ e temor ( $\tau$ ò $\varphi \circ \beta \varepsilon \tilde{\sigma} \sigma \theta \alpha \mathrm{l})$ por Sócrates, enquanto os outros amantes apenas mereciam

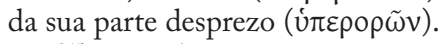

265 Alc. 2.5. 
Quando chegou o momento de estudar, ouvia com bondade os outros professores, mas recusava tocar flauta por considerar isso algo vulgar e indigno de um homem livre. Na verdade, o uso do plectro e da lira em nada prejudica a figura e o aspecto que convém a um homem livre. Ao invés, quando um homem sopra a flauta, até os que vivem perto dele teriam muita dificuldade em reconhecer a sua figura.

Num outro passo da biografia, relata-se o encontro de Alcibíades com um professor das primeiras letras (grammatodidaskalos), onde fica registado o seu interesse por Homero e o sarcasmo na resposta ao professor de crianças que afirmava ter corrigido Homero: ${ }^{266}$

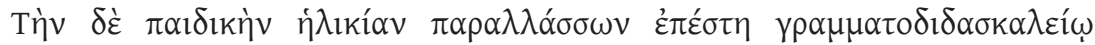

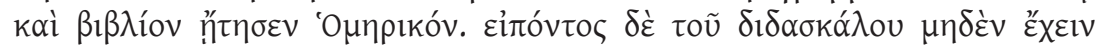

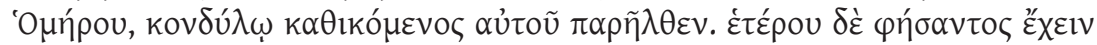

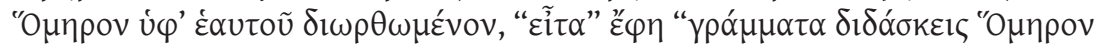

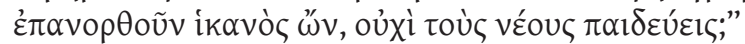

Ao passar a idade infantil parou junto de uma escola para crianças e pediu um livro de Homero. Como o professor the respondeu que não tinha nenhum de Homero, Alcibíades deu-lhe um murro e continou a andar. Quando um outro professor lhe disse que tinha um de Homero corrigido por ele mesmo, disse de imediato: "Ensinas as letras às crianças quando és capaz de corrigir Homero? Por que motivo não ensinas os jovens?”

Além de revelar o carácter de Alcibíades, este episódio anedótico é interessante por nos dar a conhecer a matéria de ensino do grammatodidaskalos: era um professor de literatura, de nível elementar, não de teoria ou crítica literária, assuntos que ficavam para um nível mais avançado.

Alcibíades revelou, desde cedo, ter uma natureza excessiva e uma vontade indomável de atingir sempre o primeiro lugar em todas as acções em que participava: ${ }^{267}$

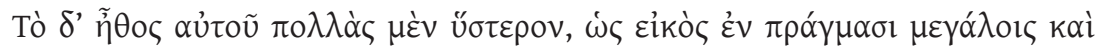

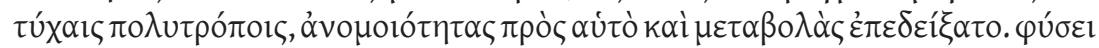

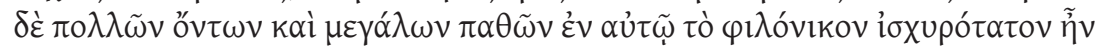

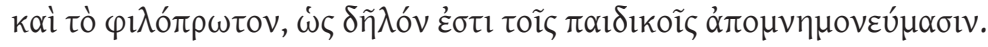

Mais tarde, o carácter dele exibiu muitas diferenças e mutações, o que é natural atendendo aos seus grandes feitos e às sortes muito variadas. Por natureza, ele

${ }^{266}$ Cf. Alc. 7.1 .

2672.1. 
tinha muitas e grandes paixões, sendo a vontade por vencer e o desejo de ser o primeiro ${ }^{268}$ a mais forte, como demonstram os testemunhos da sua infância.

Como Tucídides sugere na sua obra ${ }^{269}$, Alcibíades tinha inclinação para

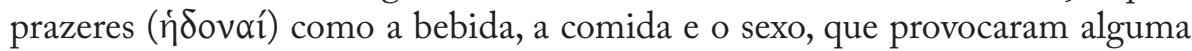
desordem na sua vida. Da mesma forma que outros biografados de Plutarco, também Alcibíades começou cedo a conhecer o fervor da luta e a evidenciar nesse âmbito a sua $\varphi \imath \lambda o \tau \imath \mu i ́ \alpha$ e $\varphi \imath \lambda \circ \delta \circ \xi i ́ \alpha$, facto que pode ter interrompido o natural percurso da sua formação: ${ }^{270}$

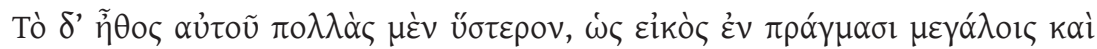

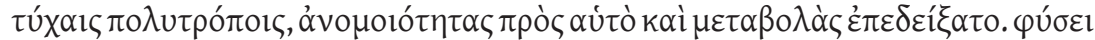

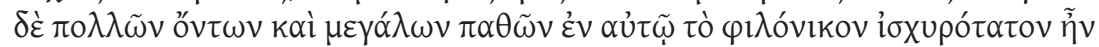

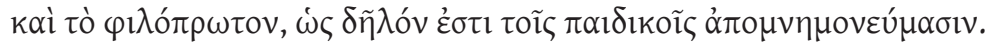

Não obstante, atacando, sobretudo, a sua ambição e corrompendo o seu desejo de glória, lançaram-no numa idade prematura em grandes empresas, persuadindo-o de que, ao entrar cedo na participação dos assuntos públicos, não só obscureceria imediatamente os outros estrategos e demagogos, mas também ultrapassaria o poder e a fama de Péricles entre os Gregos.

É essa vontade de vencer e de ultrapassar os que eventualmente lhe poderiam fazer frente, associada à sua audácia, que o levará, por exemplo, a desejar conquistar a Sicília, Cartago e a Líbia ${ }^{271}$.

Assim, para que Alcibíades desse os primeiros passos na politeia muito contribuiu o genos, o ploutos e a capacidade evidenciada no combate. Juntamente com estas qualidades, Plutarco aborda os dotes de eloquência (logos) de Alcibíades, qualidade que o autor tem especial cuidado em aliar à politeia. Se a sua eloquência parecia impressionar os ouvintes ${ }^{272}$, até porque ainda era muito jovem, Plutarco também não omite as hesitações que tinha em público, quando tentava encontrar a expressão mais correcta ${ }^{273}$.

${ }^{268}$ Por exemplo, quando percebe o ascendente de Nícias e a forma como os Lacedemónios o acarinhavam, Alcibíades sente inveja e procura por meio de alguns artifícios manchar a imagem de Nícias (cf. Alc. 14).

${ }^{269}$ 6.15.4; cf. Alc. 6.3.

${ }^{270}$ Alc. 6.4 .

${ }^{271}$ Ibid. 17.1 ss.

${ }^{272}$ Cf. ibid. 10.4: Plutarco recolhe dados sobre a eloquência de Alcibíades em Demóstenes, In Mid. 143.1-5, e em Teofrasto; ainda sobre a capacidade oratória de Alcibíades, vide Alc. 13.

${ }^{273}$ Cf. Cor. 20.6; em De prof. in uirt. 80D, também se refere às hesitações e aos equívocos de Alcibíades quando este tentava encontrar a melhor expressão. 
O próprio Plutarco oferece-nos um resumo de como era Alcibíades, que havia sido nomeado estratego ${ }^{274}$ e que era bastante admirado pelos seus dotes políticos, oratórios e pela sua inteligência, e como os Atenienses corresponderam às suas qualidades e aos excessos que cometeu: ${ }^{275}$

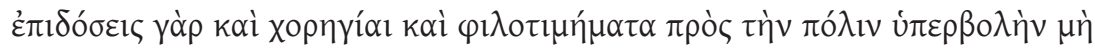

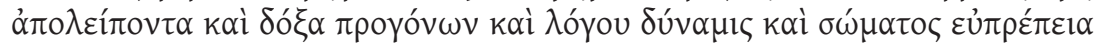

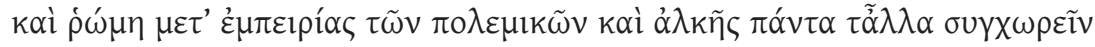

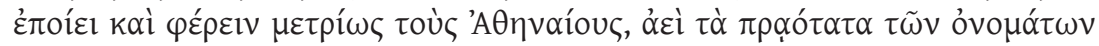

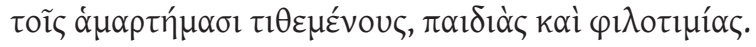

$\mathrm{Na}$ verdade, os donativos, a coregia, a sua prodigalidade excessiva para com a cidade, a glória dos seus antepassados, o poder da sua palavra, a beleza e a força do seu corpo, juntamente com a experiência guerreira e o vigor, faziam com que os Atenienses estivessem de acordo com todas e suportassem as outras coisas com moderação, dando nomes suaves aos seus erros, pois eram próprios de uma brincadeira ou da ambição.

Como se constata, Alcibíades protagonizou um conjunto de acções que atenuaram os seus defeitos. Por um lado, a humanidade (philanthropia) que evidencia quando, por exemplo, cria o filho que teve da relação com uma concubina de $\mathrm{Melos}^{276}$, analisada em conjunto com o apoio que deu à terrível carnificina contra os Mélios ${ }^{277}$, mostra como o seu carácter é antagónico e ambíguo. É por esta razão que Plutarco resolve expô-lo por meio de vários exemplos e factos anedóticos ${ }^{278}$.

Após ter sido condenado à morte pelos Atenienses ${ }^{279}$, Alcibíades junta-se aos Lacedemónios, que lhe garantem segurança e fidelidade, a troco da sua colaboração. Alcibíades continua a mostrar a sua capacidade de liderança, mas, neste caso, à semelhança de Coriolano, é dominado pelo desejo de vingar a sua pátria. Se antes conseguiu facilmente persuadir os Atenienses, agora são os Lacedemónios que se deixam seduzir pela forma como Alcibíades assumiu a

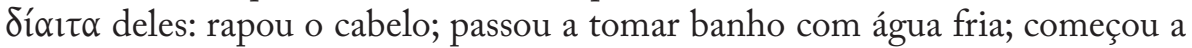
comer pão de cevada e caldo negro ${ }^{280}$. A forma como depressa se adaptou aos

274 Alc. 15.1.

${ }^{275}$ Alc. 16.4.

${ }^{276}$ Cf. Alc. 16.5 .

${ }^{277}$ Cf. ibid. 16.6.

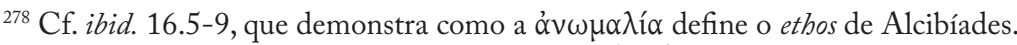

${ }^{279}$ Cf. ibid. 19-22; em 21.7, Plutarco salienta a ópyń do povo, que, como vimos, também esteve presente na condenação de Coriolano.

${ }^{280} \mathrm{Cf}$. ibid. 23.3; por causa das qualidades de Alcibíades, os que detinham maior poder em Esparta invejavam-no ( $\varphi$ Өóvoৎ), razão suficiente para convencerem os magistrados a matá-lo (24.4). 
costumes espartanos evidencia o carácter camaleónico de Alcibíades e a sua capacidade de aculturação dentro do espaço helénico: ${ }^{281}$

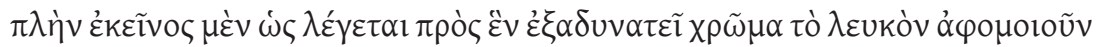

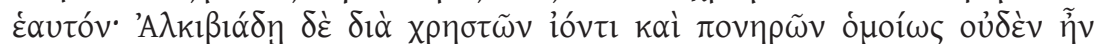

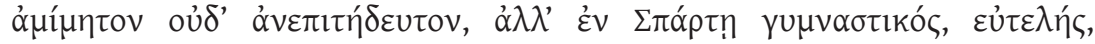

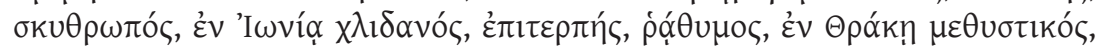

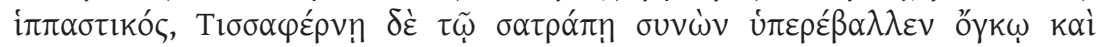

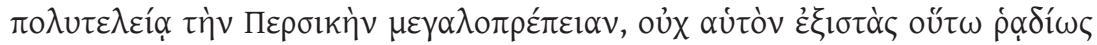

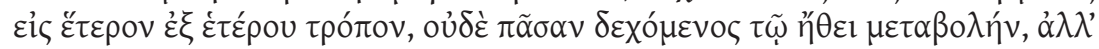

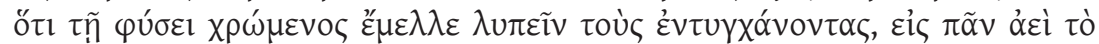

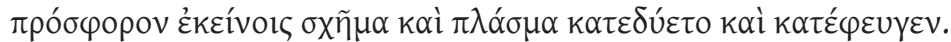

Em verdade, segundo conta, este animal é de todo incapaz de imitar a cor branca. Pelo contrário, Alcibíades passava do bem ao mal com facilidade e não havia nada que não pudesse imitar ou fazer. Em Esparta, dedicava-se ao exercício, era frugal e severo; na Jónia, era efeminado, libertino e indolente; na Trácia, bebia em excesso e montava a cavalo; junto do sátrapa Tisafernes, ultrapassava a magnificência dos Persas em grandiosidade e esplendor; em concreto, ele não passava facilmente de um estilo para outro, nem acolhia no seu carácter toda a mudança, mas sucedia que, pela sua natureza, teria necessidade de se confrontar com os que ia encontrando, e assim escondia-se e refugiava-se sempre em qualquer comportamento e artifício no relacionamento com eles.

É desta forma que Plutarco expõe a capacidade de Alcibíades em se adaptar às circunstâncias, muitas vezes adversas, recurso necessário para a manutenção das suas aspirações e da sua própria sobrevivência. Quando também os Espartanos, em especial os mais poderosos, pretenderam matá-lo, Alcibíades haveria de se refugiar junto de Tisafernes, conseguindo, mais uma vez, persuadir um antigo inimigo e adaptar-se a um novo estilo de vida.

Até regressar de novo à sua pátria muitos serão os confrontos em que participará, desejando ser objecto de admiração dos seus concidadãos por ter derrotado vários inimigos dos Atenienses ${ }^{282}$. Foi recebido de forma triunfal pela multidão, embora, mais uma vez, os poderosos receassem o seu regresso, pois, segundo Plutarco, a sua vida prova como foi vítima da própria $\delta o ́ \xi \alpha$, que, por meio da audácia $(\tau o ́ \lambda \mu \alpha)$ e da inteligência $(\sigma u ́ v \varepsilon \sigma ı \varsigma)^{283}$, adquiriu nas

${ }^{281}$ Cf. ibid. 23.4-5.

${ }^{282}$ Em Alc. 26, Plutarco descreve dois momentos em que Alcibíades salvou Atenas, especialmente quando se supõe ter conseguido evitar que os Espartanos recebessem as naus fenícias para combater contra os Atenienses.

${ }^{283}$ Ibid. 35.3 
muitas acções que empreendeu. Foi talvez por esta razão que passaram a não lhe desculpar qualquer erro: por acharem que as suas capacidades não eram dignas de um acção mal sucedida. Como facilmente se depreende, Alcibíades foi coleccionando inimigos por causa do seu carácter, do sucesso e da reputação que em determinadas alturas conseguiu, acabando por ser vítima dos seus próprios excessos e daqueles de que outros eram responsáveis.

Deixando em aberto várias respostas, como a da identificação do herói que se superioriza, a synkrisis deste par tem um tom negativo, até porque faz uma reinterpretação da narrativa ${ }^{284}$. Ambas as personagens deram provas de serem distintos politikoi, com acções políticas diferenciadas ${ }^{285}$. Alcibíades, no entanto, parece ser superior pelos êxitos que conseguiu. Tanto Coriolano como Alcibíades não conseguiram, nas suas praxeis, vencer a cólera, o que denota uma paideia muito insuficiente. De tal forma Plutarco valoriza a relação entre o herói e a sua pátria, como vimos nas biografias de Aristides e Catão Censor, que dedica parte substancial da synkrisis a avaliar a relação conflituosa que Coriolano e Alcibíades mantêm, respectivamente, com Roma e com Atenas.

Coriolano, muito por culpa da sua arrogância e orgulho, não conseguiu a eleição para a magistratura desejada, mas Alcibíades, apesar dos seus excessos e das derrotas que causou aos Atenienses, foi nomeado estratego. Contudo, a vida de ambas as personagens está longe de ser um modelo a adoptar, ainda que Plutarco pretenda passar a mensagem de que seguir cegamente um desejo, um sentimento vingativo ou uma paixão, sem dar lugar ao logismos e à paideia, em nada ajudará o indivíduo a encontrar a felicidade e a realização pessoal

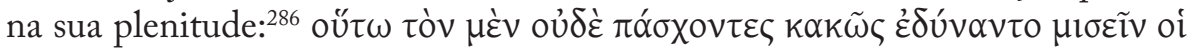

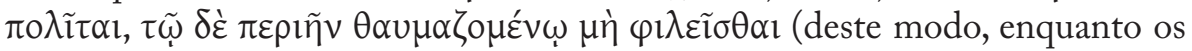
concidadãos não podiam odiá-lo, embora tivessem sofrido terrivelmente com ele [Alcibíades], em relação a Coriolano, pelo contrário, ainda que fosse alvo de admiração, não ganhou o amor deles).

Sem omitir o papel que a mãe e a esposa têm na vida de Coriolano ${ }^{287}$, criticando a forma como este abandona os Volscos, que usou para satisfazer a sua ira, Plutarco acaba por elogiar a forma decidida como Coriolano toma as decisões, sem olhar a benefícios pessoais ou à opinião da maioria, tal como Metelo, Aristides ou Epaminondas, embora estes tivessem sabido ser benevolentes com a sua pátria, não cedendo ao rancor $^{288}$. Além disso, a falta de escrúpulos de Alcibíades no uso de dinheiro não corresponde à conduta ética de Coriolano, sem qualquer mácula, com a particularidade de Plutarco

\footnotetext{
${ }^{284}$ Cf. T. Duff (1996: 333-349) e (2000: 158-160).

${ }^{285}$ Comp. Cor. - Alc. $1.3-4$.

${ }^{286}$ Ibid. 3.3

${ }^{287}$ Cf. De fort. Rom. 318F-319F.

${ }^{288}$ Comp. Cor. - Alc. 4.8-9.
} 
dizer que merece, por isso, ser equiparado aos melhores dos Gregos, o que não esconde a perspectiva helénica da sua análise.

Note-se, por fim, que Coriolano e Alcibíades, apesar de terem tido uma formação diferente, incorreram ao longo da sua vida em excessos semelhantes, como o desejo de vingança contra a sua própria pátria. Isto prova que a paideia e os seus efeitos reais dependem do empenho do indivíduo, mesmo após a educação escolar ou aquela que é ministrada pela família, e também da sua physis.

\subsubsection{Demosthenes-Cicero}

O leitor, atendendo às figuras que são protagonistas deste par biográfico, poderia ser levado a pensar que Plutarco fez esta escolha para comparar capacidades oratórias ${ }^{289}$, mas, na verdade, não é esse o seu objectivo, nem manifesta interesse em tecer considerações sobre a obra literária de ambos ${ }^{290}$, ainda que tivesse conhecimento dos textos escritos por Demóstenes e Cícero. Com efeito, concentra a narrativa na exposição do nível de participação que os dois tiveram na politeia. Estas biografias permitem-nos também tirar algumas conclusões pertinentes sobre a forma como Plutarco aborda a paideia, no contexto do paralelismo cultural.

No caso de Demóstenes, Plutarco compara-o, em alguns casos, a Fócion, elogiando a capacidade de concisão e a oratória deste último ${ }^{291}$. Avalia-se o orador pela capacidade de organização e pelo conteúdo do seu discurso, previamente elaborado e meditado. Em algumas ocasiões, ele terá de ser capaz de improvisar e de responder às questões colocadas. Demóstenes, no entanto, não possuía estas últimas facetas ${ }^{292}$. Dando como exemplo o facto de Péricles evitar o emprego de palavras que, devido ao tema do seu discurso, eram dispensáveis ${ }^{293}$, Plutarco manifesta-se a favor de uma oratória pensada

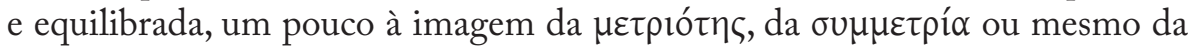

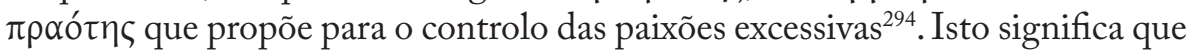
à qualidade do discurso deve equivaler uma alma racional e moderada.

${ }^{289}$ Cf. A. Billault (2001: 256-268), estudo que faz uma análise dos elementos retóricos neste par biográfico.

${ }^{290}$ Recorde-se que Tito Lívio aconselhava o filho a ler as obras de Demóstenes e Cícero (cf. Quint. 10.1.39).

${ }^{291}$ Cf. Phoc. 5.3-9, Dem. 10.4 (contraste entre a retórica de Demóstenes e a honestidade de Fócion), Praec. ger. reip. 803E. Note-se que Plutarco não compara a oratória de Demóstenes com a de Cícero, mas com a de outros oradores gregos (cf. e.g. Dem. 6).

${ }^{292}$ Cf. Dem. 8.3, 10.1-2 e Praec. ger. reip. 804A. Alcibíades, por sua vez, divagava ao tentar encontrar as palavras certas ou uma forma de organizar o discurso (Cf. Alc. 10.4);

${ }^{293}$ Cf. Per. 8.6.

${ }^{294}$ Cf. Plat. Quaest. 1009A-B, onde Plutarco considera que os princípios platónicos são

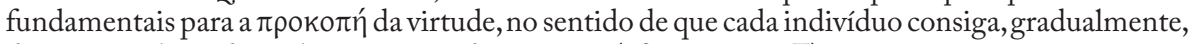
distinguir o bem do mal ou a justiça da injustiça (cf. De aud. 37F). 
Tanto Demóstenes como Cícero, um homo nouus como Catão Censor, são dois heróis sem uma clara ambição política ab initio, embora Cícero tenha tido uma intensa acção pública ${ }^{295}$. O próprio final de vida de ambos - Cícero é assassinado brutalmente, com 64 anos, a mando de António ${ }^{296}$, e Demóstenes suicida-se, longe das armas e dos seus companheiros ${ }^{297}$-, embora possa suscitar interpretações díspares, reforça o facto de serem dois homens mais ligados às letras e ao pensamento ${ }^{298}$.

A propósito da paideia, Plutarco justifica as dificuldades que Demóstenes sentiu com as seguintes palavras: ${ }^{299}$

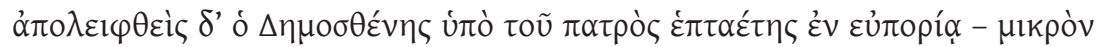

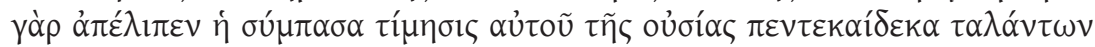

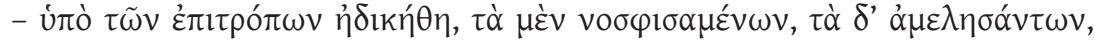

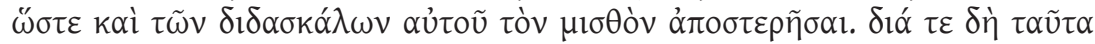

${ }^{295}$ Excluído da vida política, o orador romano afirmaria que a sua vida era semelhante à de Laertes, pai de Ulisses (cf. Cic. 40.3). Em An seni resp. 788A-B, Plutarco, ao defender que um idoso não deve abandonar a actividade política, salvo se tiver alguma doença ou outro impedimento grave, elogia Nestor, o mais velho dos Aqueus na guerra de Tróia, pela sua acção merecedora de honra e respeito, ao contrário de Peleu e Laertes que, afastados do combate heróico, ficaram em casa, onde levavam uma vida miserável (cf. Od. 1. 189 ss., 11.187 ss., 24. 205 ss.). Plutarco critica também esse tipo de vida em De tranq. an. 465D-E. Aliás, o tema da superioridade intelectual daqueles que atingem a velhice é recorrente na cultura grega, ainda que alguns autores defendam o contrário, como Aristóteles (cf. Pol. 1270b 35-1271a 1), Aristófanes (Nub. 1471) ou Menandro (fr. 639, 1: "os cabelos brancos não fazem com que se pense"). Contudo, o Estagirita, como outros autores clássicos, não reconhece aos jovens capacidade política suficiente (cf. EN 1142a10-15). Plutarco, no tratado An seni resp.789E, influenciado pela concepção platónica de que a cidade ideal deve ter à sua frente anciãos e de que um dos perigos da democracia consistia na igualdade entre jovens e velhos (cf. Resp. 563a-b), escreve:

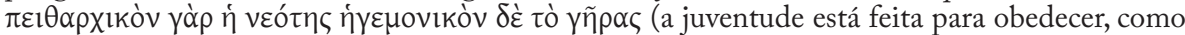
a velhice para mandar); o biógrafo de Queroneia vê em Augusto, Péricles e Agesilau, por esta ordem, exemplos de que a capacidade política cresce com a idade (cf. An seni resp. 784D-F). Outro exemplo claro encontramo-lo em Cam. 37.2, quando o povo pede a Camilo que exerça o cargo de tribuno pela sexta vez, apesar de ter oitenta anos.

${ }^{296}$ Cf. Cic. 47-49: Plutarco descreve como degolaram Cícero e ainda lhe cortaram as duas mãos, com que havia escrito as Filípicas. Porém, em Ant. 20.3, refere que cortaram apenas a tìv

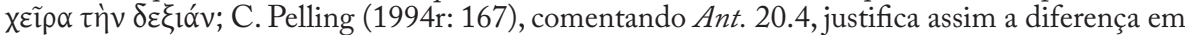
relação à versão de Cic.: "The discrepancy between $C i c$. and Ant. is perhaps carelessness, but i tis possible that, as at 19.3, P. here prefers a version found in his more recent reading".

${ }^{297}$ Comp. Dem.-Cic. 5.1-2; sobre a coragem na hora da morte, vide Comp. Nic.-Crass. 5.4; Comp. Sert.-Eum. 2.6-8; Comp.Ag./Cleom.-Gracch. 3.1; Comp. Demetr.-Ant. 6.3-4.

${ }^{298}$ Em Cic. 24.6, Plutarco dá-nos conta que Cícero preferia o discurso mais extenso de Demóstenes, ou seja, De cor., e o próprio Cícero numa carta escrita a um amigo terá dito que os discursos do orador grego lhe provocavam sono. Revelando ter conhecimento da obra de Cícero, o Queronense defende Cícero ao lembrar que este faz vários elogios a Demóstenes ao longo da sua (e.g. Brut. 141: Demosthenes...oratorum princeps), além de ter dado aos discursos contra António o mesmo título, as Filípicas, que Demóstenes dera aos que escrevera contra Filipe da Macedónia.

${ }^{299}$ Dem. 4.3-4. 


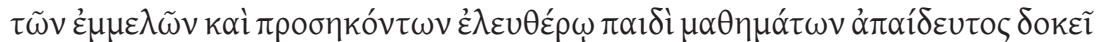

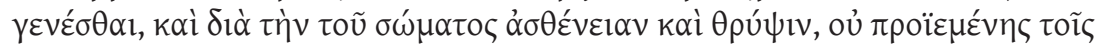

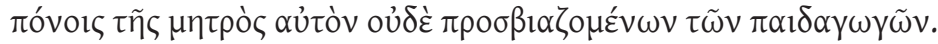

Demóstenes tinha sete anos quando o seu pai morreu e o deixou na abundância (um montante total da fortuna não inferior a quinze talentos), mas ele foi prejudicado pelos tutores, que roubaram uma parte e administraram negligentemente outra, de tal forma que até os professores dele ficaram privados do salário. Por estes motivos, parece que não teve a educação conveniente e adequada a uma criança de condição livre ${ }^{300}$; além disso, por ser fisicamente débil e delicado, a mãe não lhe permitia trabalhos pesados nem os mestres o sobrecarregavam.

Deste modo, a razão pela qual Demóstenes não recebeu a educação adequada é atribuída aos tutores, que não souberam administrar com competência os bens deixados pelo pai. Plutarco refere, uns capítulos mais à frente, que Demóstenes ao atingir a maioridade entrou em litígio com os seus tutores, com o objectivo de recuperar a sua herança ${ }^{301}$. Uma outra razão, acreditamos que menos importante, para Demóstenes não ter tido uma formação normal prender-se-ia com a sua débil condição física, que mereceria especial cuidado por parte da mãe e dos mestres.

$\mathrm{Na}$ sequência da leitura da biografia do orador ateniense, deparamos com mais alguns elementos relevantes sobre a sua paideia: ${ }^{302}$

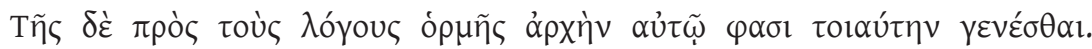

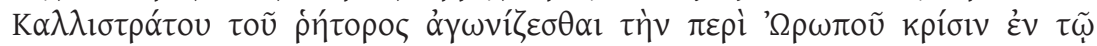

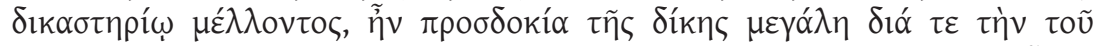

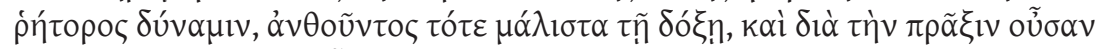

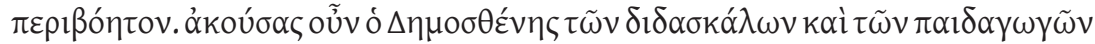

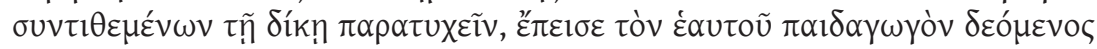

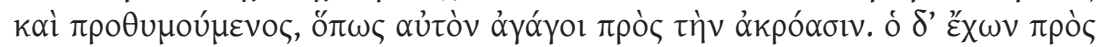

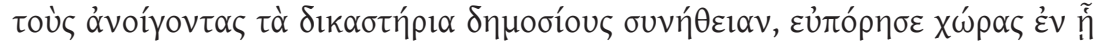

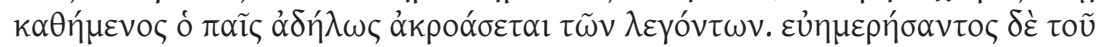

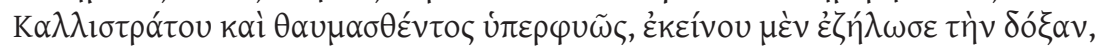

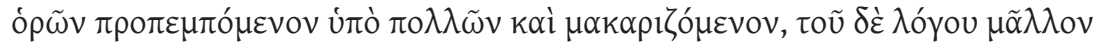

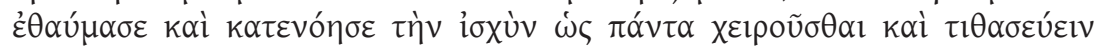

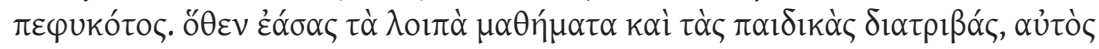

${ }^{300}$ Cf. Demóstenes, em De cor. 257, afirma, pelo contrário, que teve uma educação adequada.

${ }^{301} \mathrm{Em}$ Dem. 6.1, Plutarco diz-nos que, apesar de ter ganho a causa contra os tutores, de nada lhe valeu para recuperar a herença paterna. O próprio Demóstenes (De cor. 80) refere o insucesso do seu intento. Este processo, contudo, fez com que ganhasse a prática e o gosto pelo debate de ideias, entregando-se aos assuntos públicos.

${ }^{302}$ Dem. 5. 


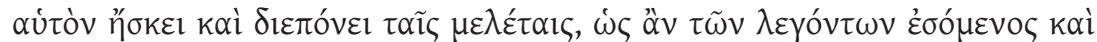

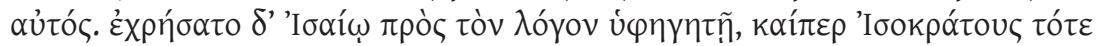

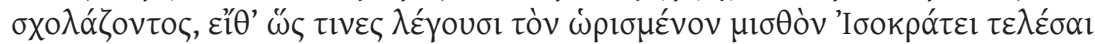

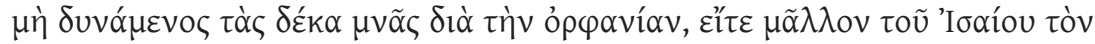

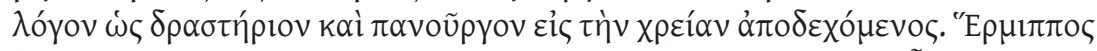

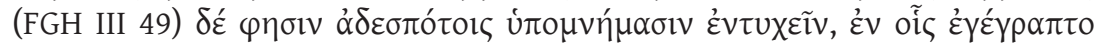

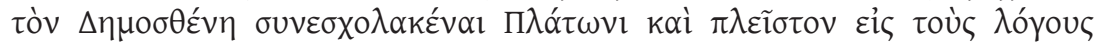

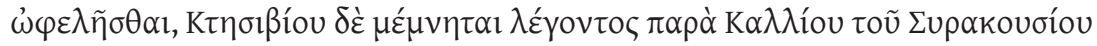

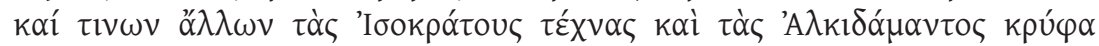

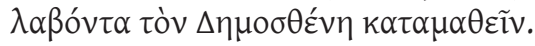

Dizem que o impluso para a oratória nasceu nele da seguinte forma: o orador Calístrato ia defender em tribunal um processo relativo a Oropo, o que suscitava um grande interesse por causa da virtude do orador, crescendo nesse momento muitíssimo a sua fama, e também por causa das suas acções, que são muito afamadas. Demóstenes, então, ao escutar os professores e mestres a marcar encontro para aquele processo, suplicou e esforçou-se por persuadir o seu próprio mestre a levá-lo para o meio da audiência. O mestre, conhecendo os funcionários que, por norma, abriam os tribunais, procurou um lugar onde a criança sentada, sem ser vista, ouvisse o que diziam. Pelo facto de Calístrato ter tido sucesso no processo e por ser admirado de forma prodigiosa, Demóstenes invejou a fama dele, observando como era rodeado por muitos e como o felicitavam, mas ele admirou, acima de tudo, o uso da palavra e observou como o seu poder, de forma natural, domava e acalmava todas as coisas. Pelo que, renunciando às restantes matérias e às ocupações infantis, o próprio Demóstenes se exercitou e se entregou às práticas oratórias, por pensar que também ele poderia ser um dos oradores. Embora, naquele tempo, Isócrates ainda tivesse uma escola, Demóstenes teve Iseu como guia para a arte da palavra, fosse, como alguns dizem, porque era órfão e não podia pagar o salário de dez minas definido por Isócrates, ou por ter preferido a oratória de Iseu, dado que acolheu favoravelmente o seu sentido prático e a sua astúcia. Hermipo disse ter encontrado umas memórias anónimas, nas quais estava escrito que Demóstenes tinha estudado junto de Platão e que isso o influenciou em muitos dos seus discursos; refere ainda Ctesíbio que Demóstenes, recebendo, secretamente, de Cálias de Siracusa e de outros as obras de retórica de Isócrates e de Alcídamas, as estudou com profundidade.

O texto descreve, desta forma, como nasceu desde tenra idade em

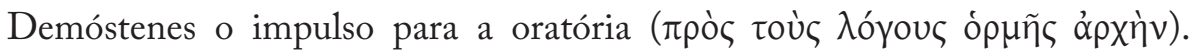
A oratória brilhante de Calístrato ${ }^{303}$ suscitou nele o desejo de emulação

${ }^{303}$ Foi um político do século IV a. C., strategos na Guerra Coríntia e esteve envolvido na Segunda Liga Ateniense, mas devido ao facto de a sua acção anti-tebana não ter tido os resultados esperados foi exilado em 361 a. C., o que acabou com a sua carreira política. 


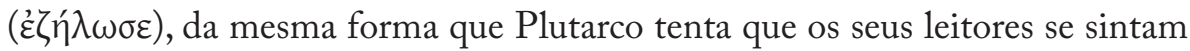
persuadidos a imitar as virtudes dos heróis do passado.

A partir desse momento, concentrou toda a sua diligência na instrução que o pudesse levar a fazer bom uso do poder da palavra, deixando de lado outras matérias e mesmo ocupações mais triviais, mais próprias da infância (ö $\theta \varepsilon v$ żó $\sigma \alpha \varsigma$

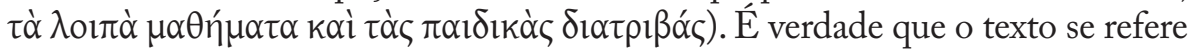

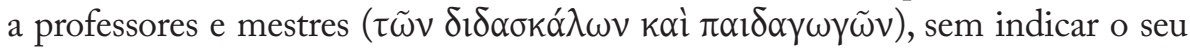
nome, mas não é clara a relação entre a inclinação de Demóstenes pela oratória e as lições desses pedagogos, parecendo mais verosímil acreditar que, neste caso, a paideia prática ou demonstrativa produziu maior efeito, pelo modo como a ida ao tribunal determinou a vocação do jovem aspirante a orador.

Relata também o texto que Iseu ${ }^{304}$ foi escolhido para ensinar a Demóstenes a arte da retórica ( Isócrates, provavelmente por falta de dinheiro. Para justificar esta preferência, Plutarco faz eco de duas fontes não identificadas que defendem as seguintes hipóteses: a primeira, que Demóstenes não tinha dinheiro para pagar os honorários de Isócrates, a segunda que terá preferido o sentido prático da retórica de Iseu. Tendo em conta as informações de Plutarco ${ }^{305}$, a primeira hipótese revela alguma coerência, muito embora Demóstenes, na sua obra, não faça alusão a tal situação. Quanto à outra razão apontada, não deixa de ser curioso o facto de Plutarco ser certamente mais sensível a uma retórica com uma evidente aplicação prática. Esta tendência é confirma pela sua concepção biográfica e pelo teor dos tratados morais, se tivermos em conta a estreita ligação entre ethos e praxis, que se estende a outros conceitos, como a politeia ou a própria paideia.

Também Platão, além de Iseu, terá exercido uma forte influência na escrita do orador ateniense, segundo uma fonte mencionada por Hermipo ${ }^{306}$, que, citando Ctesíbio, refere que Demóstenes recebeu para estudar as obras retóricas de Isócrates ${ }^{307}$ e de Alcídamas, um discípulo de Górgias que foi adversário do próprio Isócrates.

Em resumo, Calístrato, Iseu, Isócrates, Platão e Alcídamas, cada um à sua maneira, terão moldado e aperfeiçoado as capacidades oratórias de Demóstenes, tendo-se verificado da parte deste um grande esforço para conseguir superar os obstáculos, embora Plutarco não deixe de considerar que Fócion lhe era superior $^{308}$.

${ }^{304}$ Cf. $X$ or. uit. 844 B.

${ }^{305}$ Dem. 4.3-4.

${ }^{306}$ Fonte também referida nesta biografia em 11.4, 28.3 e 30.1; Gel. 3.13, porventura fazendo uso de Hermipo, refere também que Demóstenes recebeu lições de Platão.

${ }^{307} \mathrm{Em} X$ or. uit. $844 \mathrm{C}$ não se refere o nome de Isócrates, mas de Zetos de Anfípolis.

${ }^{308}$ Cf. Dem. 14.3. 
A biografia de Cícero terá exigido de Plutarco uma recolha apurada, se tivermos em conta não só o papel relevante que aquele desempenhou na história romana, ocupando cargos relevantes - logo, como se fosse uma fatalidade, terá incorrido em alguns erros, uma vez que não é possível ocultá-los quando se está no poder ${ }^{309}$ - como também a vasta e diversificada literatura de que foi autor. Desse modo, Cícero é um paradigma do homem intelectual e político, com convicções, ambição e curiosidade.

$\mathrm{Na}$ verdade, um dos traços mais marcantes do orador e político romano é precisamente a sua curiosidade e a vontade de aprender. Essa característica sobressai ainda mais pelo facto de Demóstenes não ter tido o mesmo impulso para aprofundar várias áreas do conhecimento, entregando-se com mais dedicação à poesia. ${ }^{310}$ Enfatiza-se, desta forma, o interesse de Cícero por diversas matérias, sem privilegiar a oratória, num claro sinal da sua curiosidade intelectual. Veja-se no texto o uso das palavras logos e paideia com o sentido abrangente de "saber", "conhecimento"e "cultura", ao contrário do que vimos na biografia de Coriolano ${ }^{311}$, onde esses vocábulos significam "razão" e "educação", respectivamente. O mais importante, contudo, é o Queronense salientar que, ao contrário de Cícero, Demóstenes canalizou a sua vocação para a aprendizagem da arte oratória ${ }^{312}$, temática que voltaremos a encontrar na synkrisis deste par biográfico: ${ }^{313}$

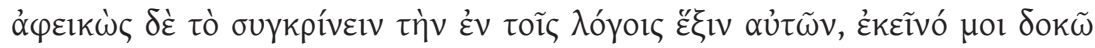

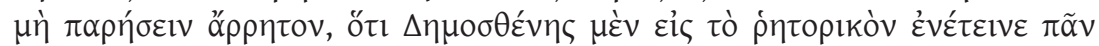

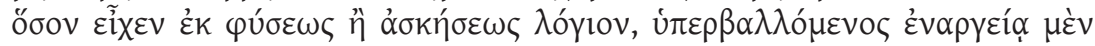

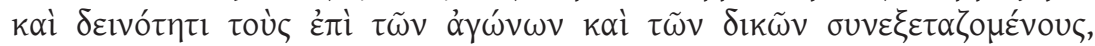

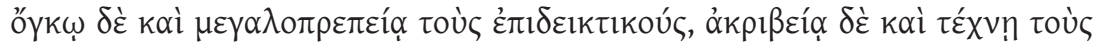

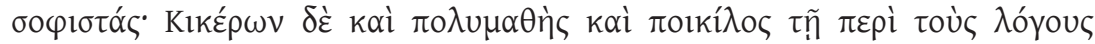

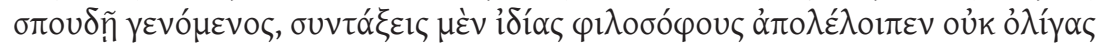

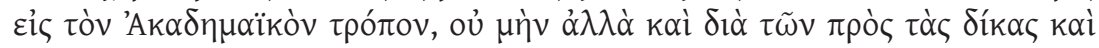

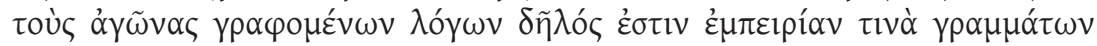

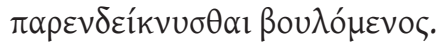

Eximo-me de comparar a capacidade oratória deles, mas parece-me que não posso deixar de dizer isto: Demóstenes aplicou à retórica toda a eloquência que possuía por natureza e por exercício prático, ultrapassando em expressividade

${ }^{309}$ Cf. Cic. 52.2 e An seni resp. 782E; a philotimia (Cic. 25.1) e uma desmesurada doxa são, na ideologia plutarquiana, características de uma paideia insuficiente ou deformada.

310 Cic. 2.3; em ibid. 46.6, Plutarco é bastante esclarecedor sobre este assunto: oủdèv

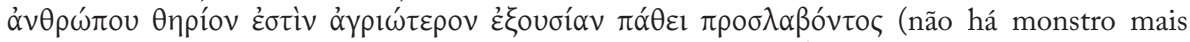
selvagem do que o homem quando à sua paixão se junta o poder).

311 15.4.

${ }^{312}$ Cf. Dem. 5.5

${ }^{313}$ Comp. Dem.-Cic. 1.2 . 
e talento os que se encontravam nas assembleias e nos processos judiciais, os pomposos em solenidade e magnificência, e os sofistas em precisão e arte; Cícero, no entanto, mostrando um grande saber e um interesse em variadas matérias, deixou variadíssimos tratados, particularmente filosóficos, segundo o estilo da Academia. Nos discursos que escreveu para os processos judiciais e para as assembleias mostra, todavia, que desejava expor um certo conhecimento de literatura.

Mesmo sem querer emitir uma opinião sobre qual dos dois se superiorizou na arte da eloquência, em coerência com aquilo que havia dito no início da biografia de Demóstenes ${ }^{314}$, e também por não saber suficientemente a língua latina ${ }^{315}$ para poder, com probidade, avaliar os discursos de Cícero, Plutarco, recorrendo a um vocabulário próprio da retórica (vejam-se as palavras recolhidas

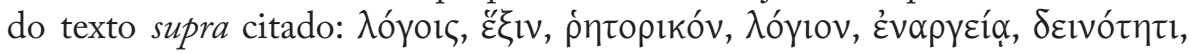

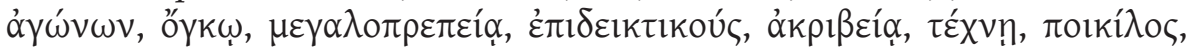

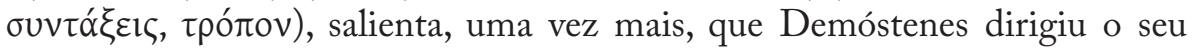
interesse para a oratória, ao contrário de Cícero que cultivou uma panóplia de matérias, algo que transparece nos discursos.

Aliás, só com muito esforço Demóstenes conseguiu atingir o nível de eloquência que lhe é reconhecido, o que não deixa de ser uma maneira de se valorizar o esforço ( $\pi$ óvoৎ) e a concentração que aplicava à aprendizagem da arte retórica, empenho que Plutarco elogia. ${ }^{316}$ Adquire, assim, especial relevo o papel do trabalho e do empenho (દ́k róvou) que Demóstenes, o orador

${ }^{314}$ Cf. Dem. 3.1-5.

${ }^{315}$ Cf. Dem. 2.

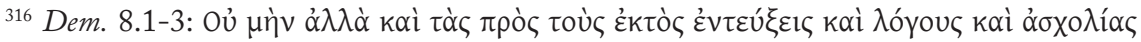

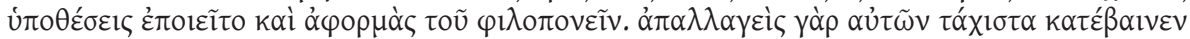

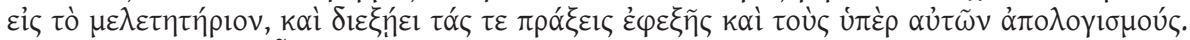

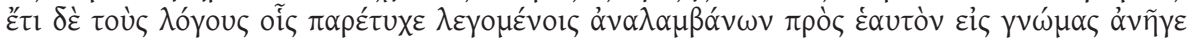

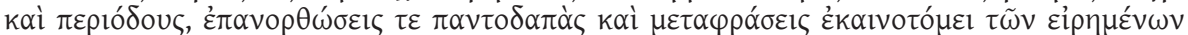

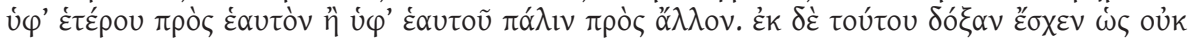

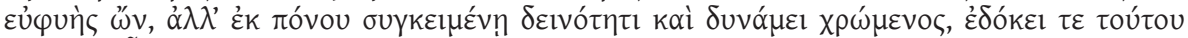

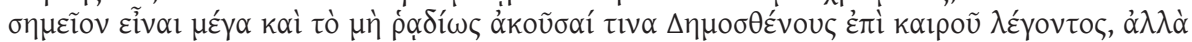

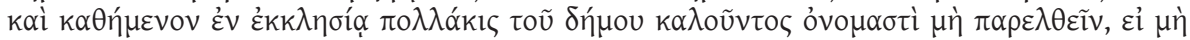

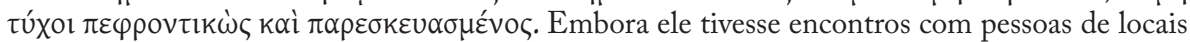
longínquos, conversas e ocupações que serviam de fundamento para o trabalho que amava, logo que se livrava deles descia a lugar de estudo e percorria, em pormenor, de uma ponta à outra, as acções e as argumentações por eles apresentadas. Nesse mesmo momento, recuperava, por ele mesmo, os discursos pronunciados e refazia-os em sentenças e períodos, e inovava com correcções e transformava de várias formas o que um outro lhe tinha dito e o que ele, em resposta, havia dito a outro. A partir disto adquiriu a fama de não ser dotado por natureza, mas de possuir a habilidade e a capacidade oratória com trabalho; parecia ser um importante sinal disso o facto de ninguém ouvir com facilidade Demóstenes falar de improviso, pois, quando se encontrava na assembleia, muitas vezes o povo chamava o seu nome, mas ele recusava ir para a tribuna, se não tivesse meditado e preparado o discurso. 
perfeito para o próprio Cícero ${ }^{317}$, colocava na actividade para a qual se sentia

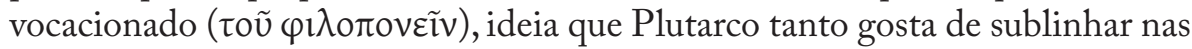
Vitae: a dimensão e o esforço pessoal na paideia. O texto revela um homem dedicado à meditação e ao trabalho oratório e que privilegia o refúgio do seu local de estudo ( que teve com outros. Por não ser especialmente dotado por natureza, e por, devido a isso, basear a sua arte no trabalho, Demóstenes recusa-se a improvisar

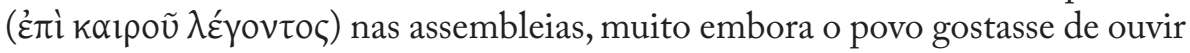
a sua argumentação. Só consentia falar depois de pensar bem nas matérias e de as preparar de forma conveniente.

Embora os elementos sobre a paideia no bios de Demóstenes não sejam de modo algum irrelevantes, é, no entanto, na biografia de Cícero que Plutarco nos oferece uma descrição mais longa e pormenorizada sobre o percurso, os condicionalismos, os lugares e os mestres que participaram na paideia do orador romano: ${ }^{318}$

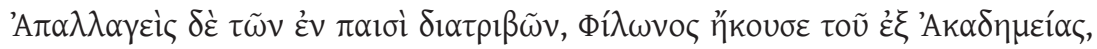

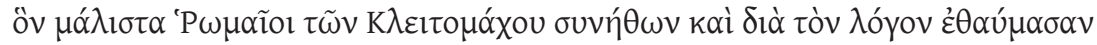

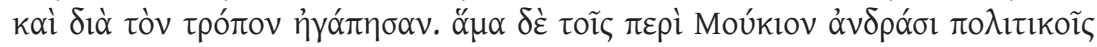

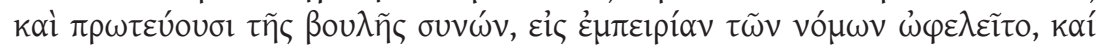

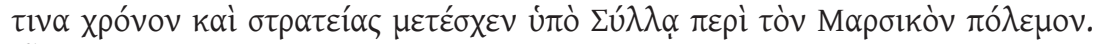

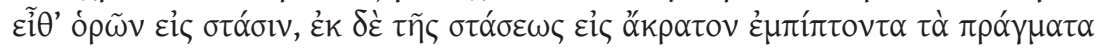

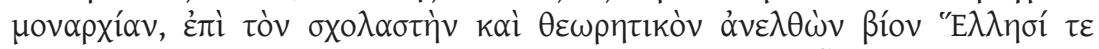

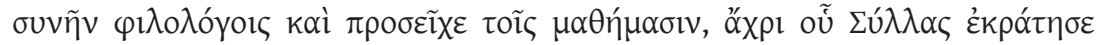

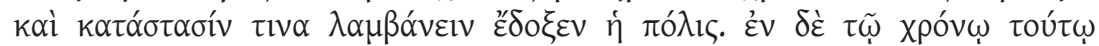

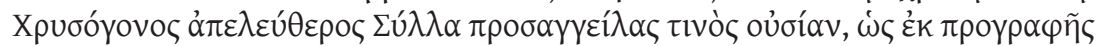

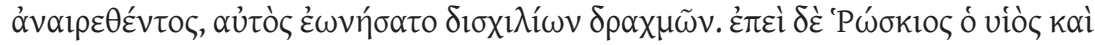

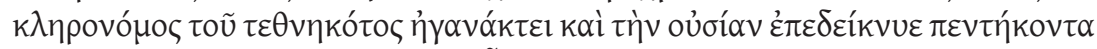

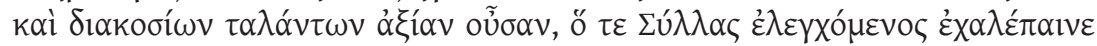

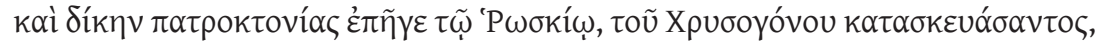

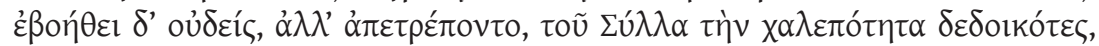

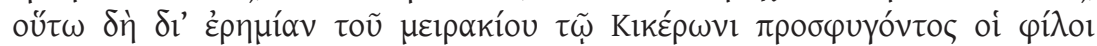

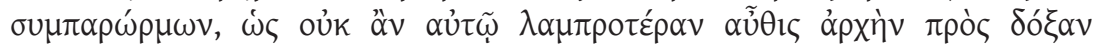

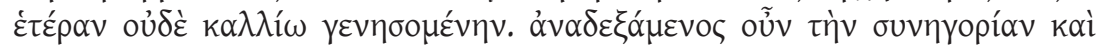

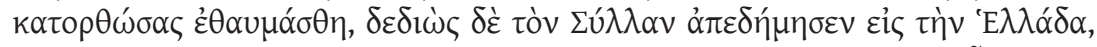

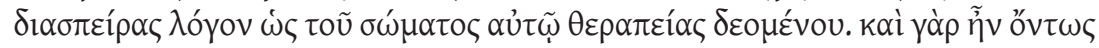

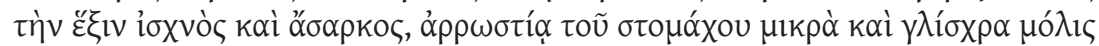

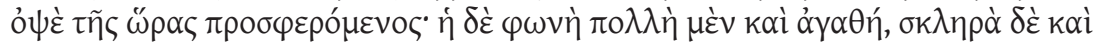

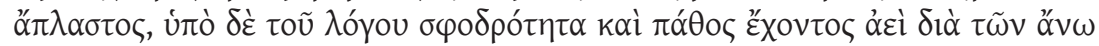

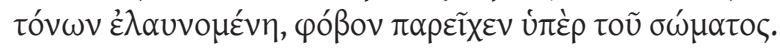

\footnotetext{
${ }^{317}$ Cf. Brut. 35.

${ }^{318}$ Cic. 3-4.
} 


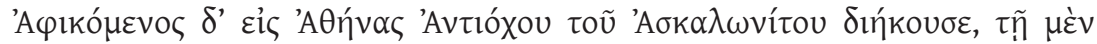

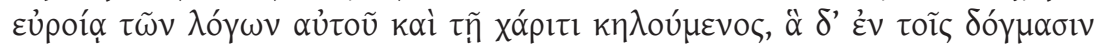

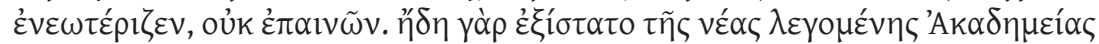

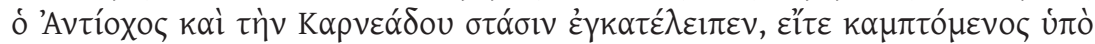

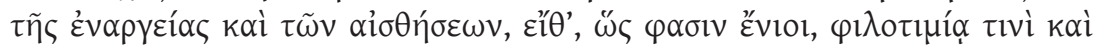

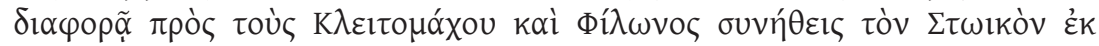

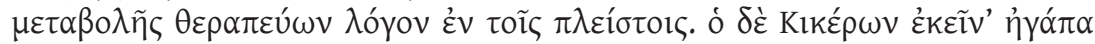

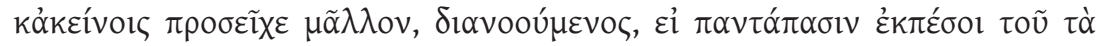

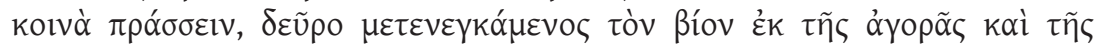

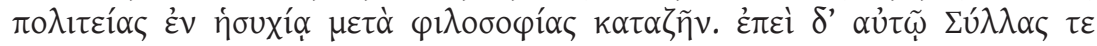

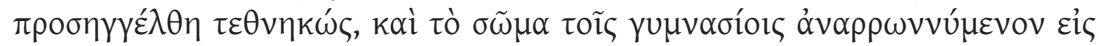

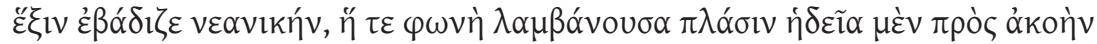

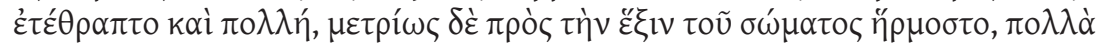

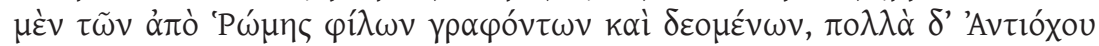

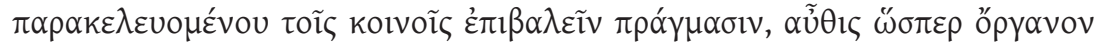

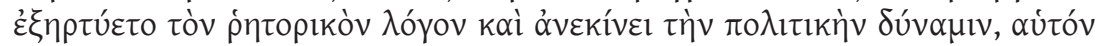

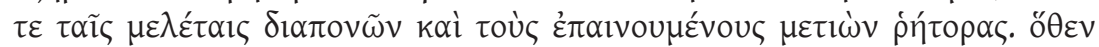

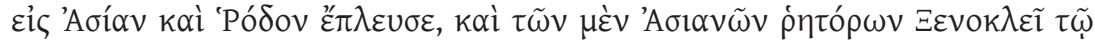

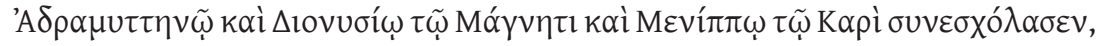

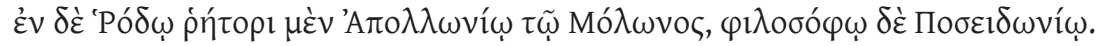

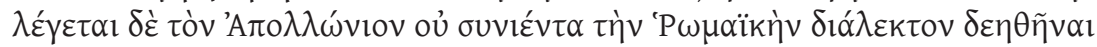

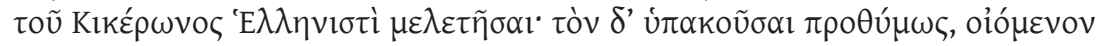

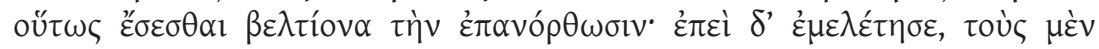

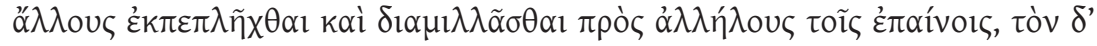

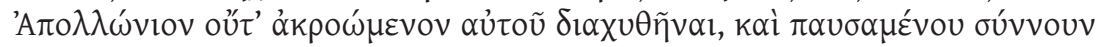

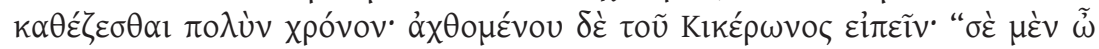

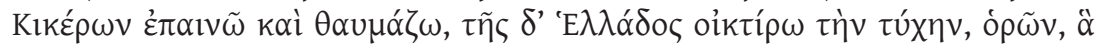

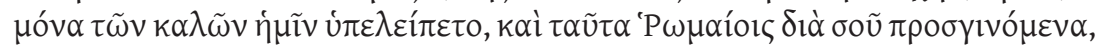

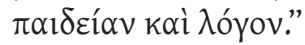

Ao deixar as ocupações de criança, ele ouviu as lições de Fílon, filósofo da Academia ${ }^{319}$, que, entre os discípulos de Clitómaco, os Romanos admiram pela sua eloquência e amam pela sua forma de ser. Ao mesmo tempo, Cícero relacionava-se com Múcio e homens políticos que tinham a primazia no Senado, pois achava que devia ter conhecimento das leis; e, durante algum tempo, participou sob o comando de Sula na Guerra Mársica. Depois, presenciando a dissensão política, e da dissensão as acções que resultaram numa monarquia absoluta, passou a uma vida dedicada ao estudo e à especulação na companhia de filólogos gregos e aplicou-se ao saber, até ao momento em que Sula governou e a urbe parece que, então, adquiriu alguma estabilidade. Naquele tempo, Crisógono, liberto de Sula, pôs em hasta pública a fortuna de um certo homem,

${ }^{319}$ Trata-se de Fílon de Larissa que chegou a presidir à Academia, embora não fosse um filósofo especialmente dotado. 
como se tivesse sido morto por causa da proscrição, e adquiriu-a, ele próprio, por duas mil dracmas ${ }^{320}$. Mas, quando Róscio, filho e herdeiro do morto, se indignou e demonstrou que a fortuna valia duzentos e cinquenta talentos, Sula, refutando as acusações, irritou-se e moveu, por maquinação de Crisógono, um processo a Róscio por parricídio; ninguém o defendeu, antes pelo contrário, afastaram-se dele por temerem a hostilidade de Sula; de tal forma que Róscio, ao ver-se só, recorreu a Cícero. Os amigos deste incitaram-no a fazer a defesa, pois não poderia ter um começo tão brilhante e belo para a sua fama. Depois de tomar a seu cargo a defesa de Róscio e de ter vencido o processo, foi objecto de admiração, porém, por receio de Sula, viajou para a Grécia, espalhando, por isso, a notícia de que precisava de tratar do seu corpo. Na verdade, ele tinha uma constituição frágil e magra, e por causa da debilidade do seu estômago comia, com dificuldade, alimentos pequenos e ligeiros, a uma hora tardia. A sua voz forte e bela, mas rígida e não modulada, pronunciada sempre em tons elevados por causa da veemência e da paixão que usava na eloquência, punha em perigo a sua saúde.

Foi, então, para Atenas, onde foi discípulo de Antíoco de Ascalão ${ }^{321}$, seduzido pela abundância e pela graciosidade da sua eloquência, apesar de não aprovar as suas doutrinas inovadoras. $\mathrm{Na}$ altura já Antíoco tinha saído da chamada Nova Academia e abandonado a doutrina de Carnéades, fosse por se ter deixado levar pela expressividade e pelos sentidos, fosse, como alguns referem, por uma certa ambição e divergência com os que acompanhavam Clitómaco e Fílon, abraçando, a partir da mudança, o estoicismo na maioria dos assuntos. Cícero, por sua vez, amava as velhas doutrinas e preferia-as a outras, planeando, se se afastasse de vez da acção pública, mudar-se para Atenas, longe do Foro e da actividade política, para passar a viver, em paz, junto da filosofia. Quando levaram a Cícero a notícia da morte de $\mathrm{Sula}^{322}$, o seu corpo, revigorado com os exercícios, caminhava para uma forma robusta e a voz, agradável e forte, depois de modulada, formou-se para o ouvido, além de se ter ajustado, com harmonia, à constituição do seu corpo. Por um lado, as muitas cartas, escritas pelos amigos, que vinham de Roma, a pedir-lhe que regressasse, por outro, Antíoco que o exortava a seguir de perto os assuntos da vida pública. Ele, então, começou novamente a cultivar a sua eloquência retórica, como se fosse um instrumento ${ }^{323}$, e estimulou a sua capacidade política, exercitando-se de forma aplicada e frequentando os retores de renome. Por isso, viajou para a Ásia e Rodes, e, dos retores asiáticos, teve lições com Xenócles de Adramiteu, Dionísio da Magnésia e Menipo de Cária, em Rodes, e também com Apolónio, filho de Mólon, e com o filósofo Posidónio. Conta-se que Apolónio, por não entender a língua latina, pediu a Cícero para declamar em Grego. Ele aceitou com

${ }^{320}$ Valor que não coincide com aquele que aparece em Cic. Pro Rosc. 21.

${ }^{321}$ Cf. Luc. 42.3.

${ }^{322}$ No ano 78 a. C. (cf. Sull. 37.4).

${ }^{323}$ Também em Cat. Mi. 4.3, Caes. 3 e Praec. ger. reip. 881C, a retórica surge como um instrumento necessário para o eficaz desempenho político. 
gosto, pensando que dessa forma seria mais facilmente corrigido. Depois de ele declamar, enquanto se admiravam e rivalizavam em elogios a Cícero, Apolónio, que, ao ouvi-lo, não se moveu, logo que ele chegou ao fim, permaneceu em reflexão durante muito tempo. Estando já Cícero irritado, Apolónio disse: "Cícero, louvo e admiro-te, mas lamento a sorte da Grécia, vendo que os únicos bens que nos estavam reservados, a cultura e a eloquência, estão, graças a ti, presentes nos Romanos" 324 .

O texto começa por lembrar três etapas da paideia de Cícero, logo após as actividades próprias da infância: as lições com Fílon de Larissa ${ }^{325}$, o primeiro contacto com as leis por meio de Múcio e a participação na guerra contra Mitridates. Quanto a Fílon - discípulo de Clitómaco, que foi, por sua vez, discípulo de Carnéades e a quem se ficou a dever o conhecimento do pensamento do mestre, obra que Plutarco terá mesmo consultado 326 - que durante a Guerra Mitridática deixou Atenas e se exilou em Roma ${ }^{327}$, sabemos que não foi ele, um representante da Antiga Academia, que proporcionou a Cícero o primeiro contacto com a filosofia ${ }^{328}$, mas Fedro quando aquele ainda era um puer ${ }^{22}$. Das relações com homens ligados à politeia romana e, em especial, com Quinto Múcio Cévola, cônsul em 95 e conhecido jurista, terá aprendido como funcionava o Senado. ${ }^{330}$ Além disso, participou como legatus na Guerra Mársica (ano 89), sob o comando de Sula, ganhando experiência

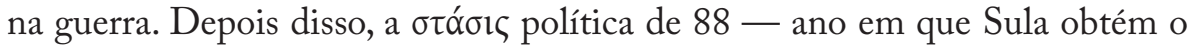
consulado e em que a $V r b s$ vive momentos de grande instabilidade, devido ao confronto entre Sula e Mário - marca o momento em que Cícero se retira para uma vida dedicada ao estudo e ao saber, cabendo à cultura grega um especial relevo nas matérias que pretende aprofundar. Plutarco não refere o

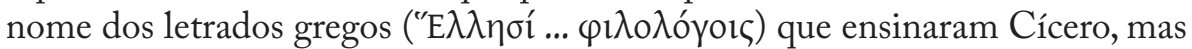
estará a referir-se ao estóico Diodoto ou a Apolónio, filho de Mólon ${ }^{331}$. Na sua obra $^{332}$, Cícero refere que foi com Diodoto que aprendeu diversas matérias, em particular a eloquência. A história que se segue, ocorrida no ano 80 a.

${ }^{324}$ Cf. C. Nepos, vir. ill. 81.2.

${ }^{325}$ Cf. D. Babut (t2003: 223 ss.).

${ }^{326}$ Cf. D. Babut (t2003: 33, n. 8; 48 ss.).

${ }^{327}$ Cf. Cic., Brut. 306. 198).

${ }^{328}$ Sobre a relação de Cícero com a filosofia grega, vide a síntese de G. Striker (2001: 189-

${ }^{329}$ Cf. Cic. Ad fam. 13.1.2.

${ }^{330}$ Cf. Cic. De or. 1.200.

${ }^{331}$ Cf. Cic. 4.5; tal como em Caes. 3.1, Plutarco atribui ao retor o nome de Apolónio, filho de Mólon, enquanto Cícero se refere a ele simplesmente como Mólon (cf. Brut. 245, 307, 312, 316); também Suet. Caes. 4. 1 e Quint. 3.1.16 mencionam Apolónio, e Strab. 14.2.13 distingue Apolónio de Mólon, daí a problemática subsistir.

${ }^{332}$ Cf. Brut. 308 ss. e Acad. 2.115. 
C. ${ }^{333}$, envolvendo Crisógono, um liberto de Sula, e Sexto Róscio, serve para demonstrar o início brilhante da carreira de Cícero, na defesa de uma causa que estaria à partida perdida, pelo facto de a contenda envolver Sula e o seu liberto. De modo a vencer o processo, baseou a sua argumentação no facto de Crisógono não ter respeitado a tramitação legal de um processo relativo a um proscrito, segundo a lex Cornelia de proscriptione, datada de 82 a. C..

Logo após este auspicioso começo, Cícero, receando Sula, foi para a Grécia, em 79 a. C., com o pretexto de necessitar de exercitar o seu corpo, uma vez que a sua constituição não era das mais fortes ${ }^{334}$. Aí foi discípulo de Antíoco de Ascalão, um nobilissimus et prudentissimus philosophus ${ }^{335}$ da Velha Academia ${ }^{336}$, cujas ideias se tinham diferenciado das de Clitómaco e Carnéades, da Nova Academia, e que tinha passado a seguir os preceitos estóicos ${ }^{337}$. Veja-se como, no texto, se confrontam dois modelos quando se refere o momento de meditação

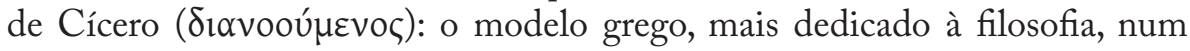
contexto de paz e tranquilidade, e a vida em Roma mais preenchida com os assuntos políticos e os debates. Estes dois estilos de vida não são mais do que o conhecido binómio otium-negotium, perante o qual Cícero revela alguma indecisão.

Após a morte de Sula, os amigos pedem a Cícero que regresse a Roma ${ }^{338}$, do mesmo modo que o próprio Antíoco o estimula para a politeia, numa altura em que o seu corpo e a sua voz exibiam uma saudável harmonia ${ }^{339}$. Nas viagens pela Ásia recebe, sobretudo, lições de retórica de Xénocles de Adramiteu, de quem se suspeitou ser um filo-Mitridates ${ }^{340}$, de Dionísio da Magnésia, muito ouvido por Cícero ${ }^{341}$, e de Menipo de Cária, tido pelo melhor retor da Ásia Menor e conhecido pelo seu aticismo ${ }^{342}$; em Rodes, foi seu mestre o retor

${ }^{333}$ Cf. Quint. 12.6.4.

${ }^{334} \mathrm{Tal}$ como a constituição física de Demóstenes, de tal forma que a mãe e os mestres não o deixavam cansar-se (cf. Dem.4.4).

${ }^{335}$ Cf. Cic. Brut. 315.

${ }^{336}$ No entanto, em Luc. 42.3 e Brut. 2.3, Antíoco aparece como um continuador de Platão; perante estas duas tradições diferentes e a partir da análise do tratado Adversus Colotem, D. Babut (t2003: 223-5) considera que a versão expressa na biografia de Cícero reproduz a opinião de Plutarco, enquanto nos outros casos se trata da opinião de Luculo e Bruto.

${ }^{337}$ Cícero (Brut. 315) nomeia Demétrio Sírio como seu mestre de retórica em Atenas, embora seja nas viagens à Ásia e a Rodes que irá encontrar os melhores retores.

${ }^{338}$ Em Caes. 3.1, Plutarco refere que, quando os amigos pedem a César para regressar a Roma após a morte de Sula, ele dirigiu-se para Rodes com o intuito de aprender junto de Apolónio, filho de Mólon, o mesmo de quem Cícero havia sido discípulo.

${ }^{339}$ Cf. Cic. 3.6-7; Cícero (Brut. 316) afirma que essa harmonia havia sido conseguida com a sua passagem pela Ásia e por Rodes, algo que em Plutarco acontece ainda em Atenas.

${ }^{340}$ Cf. Strab. 13.1.66.

${ }^{341}$ Cf. Cic. Brut. 316.

${ }^{342}$ Em Cícero (Brut. 315), é o primeiro retor a ser mencionado (Menippus Statonicensis); registe-se que nesta mesma obra Cícero incluía Ésquilo de Cnido na lista dos retores da Ásia 
Apolónio, a quem Cícero chama apenas $\mathrm{Mólon}^{343}$, e pelo filósofo estóico Posidónio de Apameia ${ }^{344}$, devendo-se a Plutarco muitos dos fragmentos que nos chegaram deste filósofo.

O texto termina com o discurso, em língua grega, proferido por Cícero a pedido de Apolónio, que o louva pela sua cultura ( $\pi \alpha 1 \delta \varepsilon i ́ \alpha v)$ e eloquência ( $\lambda$ óyov), duas qualidades helénicas que os Romanos se sentiam estimulados a cultivar. O conhecimento que Cícero tinha da língua grega ${ }^{345}$ será novamente salientado por Plutarco: ${ }^{346}$

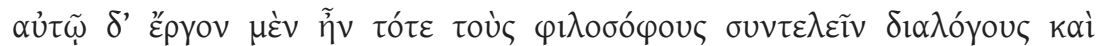

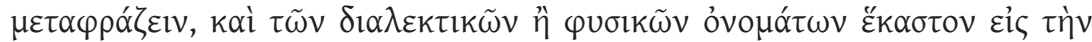

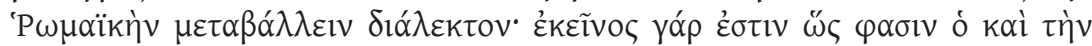

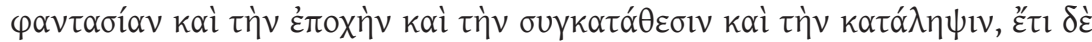

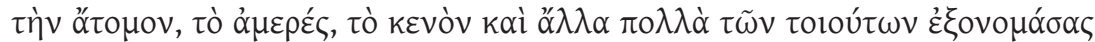

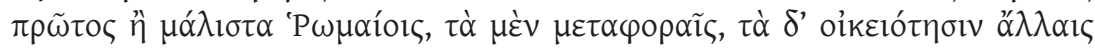

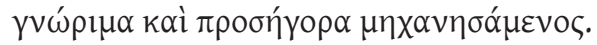

Neste momento, tinha o trabalho de compor tratados filosóficos e traduzi-los, e também de transpor cada um dos termos da dialéctica e da física para a língua latina. Dizem que foi ele que primeiro designou em latim phantasia, epoche, synkatathesis e katalepsis, ainda atomon, ameres, kenon e muitos outros desta classe, ou criou, quer com metáforas, quer com outras habilidades, vocábulos mais familiares e conhecidos para os Romanos.

Fica, desta forma, comprovada a cultura de Cícero, tanto como autor de tratados filosóficos, como na tarefa de tradutor dos tratados platónicos ${ }^{347}$. Traduziu ainda para Latim termos técnicos relacionados com a dialéctica e a física, processo que Lucrécio havia iniciado, mas não de forma tão sistemática ${ }^{348}$. Tal só seria possível com o conhecimento que Cícero tinha da língua grega, aliado ao seu manifesto interesse pela filosofia grega. $\mathrm{O}$ acto de tradução significa, ainda, a necessidade de introduzir em Roma noções que eram pouco divulgadas, sendo a Grécia uma fonte privilegiada para os autores latinos.

Menor, nome ignorado por Plutarco.

${ }^{343}$ Cf. Brut. 316.

${ }^{344}$ Outras referências a Posidónio em Thes. 25.5, Fab. 19.4, Aem. 20.6 e 21.7, Marc. 1.1, 9.7, 20.11 e 30.7, Pomp. 42.5 (reproduz o último discurso pronunciado por Posidónio, perante Pompeu), Cic. 4.5 e Brut. 1.6; nunca aparece a sua origem, sendo designado por philosophos ou apenas pelo nome; vide ainda Plac. philos. 885B, 888A e 893A.

${ }^{345}$ Cícero reconhece na sua obra que o conhecimento da língua grega lhe foi muito útil para a sua actividade (cf. e.g. Brut. 310).

${ }^{346}$ Cic. 40.2.

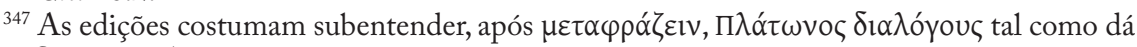
conta Quint. 10.5.2.

${ }^{348}$ Cf. S. Swain (1990a: 195, n. 10). 
Depois da sua formação retórica junto dos oradores gregos e, em especial, dos da Ásia Menor e dos que viviam em Rodes, Cícero, para Plutarco o mais eloquente dos oradores ${ }^{349}$, regressa a Roma, em 77 a. C., para participar de forma activa nos assuntos políticos. ${ }^{350}$ Refere Plutarco que o oráculo de Delfos, muito popular entre os Romanos ${ }^{351}$, aconselha Cícero a ter como guia na politeia e na vida, em geral, a physis e não a $\pi 0 \lambda \lambda \tilde{\omega} \nu \delta o ́ \xi \alpha$. Esta mensagem enquadra-se no valor que as Vitae atribuem às características inatas de cada

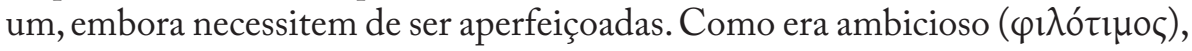
depressa começou a evidenciar o seu talento nas discussões do Foro, apesar de o seu percurso até ao momento em que regressou a Roma lhe valer sobrenomes

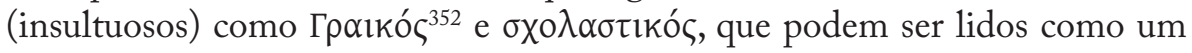
sinal de que haveria na época uma certa hostilidade para com aqueles que aprendiam a cultura grega e a difundiam. Se "Grego" (Граıкóৎ) se pode entender como aquele que estudou e passou a promover a cultura da Hélade, logo com sentido pejorativo e de algum sentimento anti-helénico, "estudioso" ( $\sigma \times 0 \lambda \alpha \sigma \tau 1 \kappa o ́ \varsigma)$, relacionado com o conceito latino de otium, que traduz a dedicação ao estudo e à reflexão filosófica, não tem uma carga negativa, a não ser

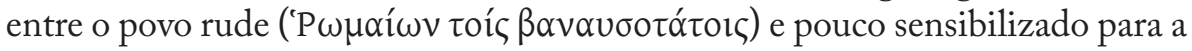
cultura ${ }^{353}$. Não se pense, contudo, que Cícero é sempre vítima de insultos, pois ele próprio usa esse tom na sua argumentação ${ }^{354}$, para desagrado de Plutarco ${ }^{355}$,

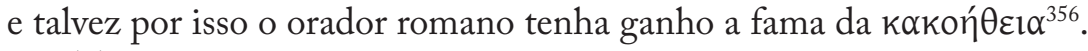

Tal como em vários capítulos deste par, Plutarco sublinha aqui o paralelismo entre Cícero e Demóstenes, neste caso as lacunas de ambos na declamação ${ }^{357}$. Por isso, apresenta-os a assistirem com atenção à representação dramática, promovendo uma aproximação entre o papel do orador e o do

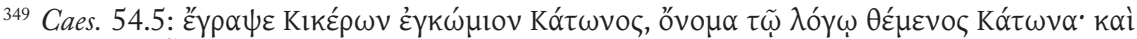
$\pi 0 \lambda \lambda$ oĩ

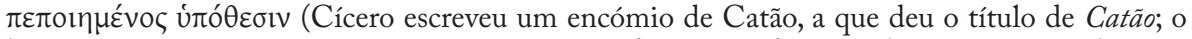
livro teve êxito entre muitas pessoas, como seria de esperar de uma obra composta pelo mais hábil dos oradores sobre um tema belíssimo).

${ }^{350}$ Cic. 5.

${ }^{351}$ Embora no tempo em que Cícero vive se note uma diminuição na devoção ao Oráculo, como o próprio reconhece em De diu. 1.38 .

${ }^{352}$ Cf. S. Swain (1990a: 194, n. 5).

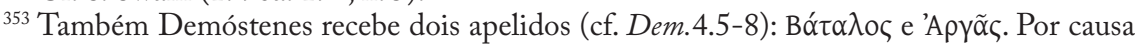
da sua débil fisionomia chamavam-lhe "Bátalo", nome de um flautista efeminado ou, segundo outros, de um poeta que terá composto versos licenciosos e mais próprios de pessoas ébrias. Quanto a "Argas", tinha como causa a forma de ser algo selvagem e dura, pois esse era também o nome dado por alguns poetas à serpente, além de ser o nome de um poeta medíocre. Para Ésquines (2.99), terá ganho o apelido de "Argas", após ter tentado processar os seus tutores.

${ }^{354}$ Cf. Cic. 38.4 .

${ }^{355}$ Cf. ibid. 25.1 e 27.1, Comp. Dem.-Cic. 1.4.

${ }^{356}$ Cf. Cic. 5.6.

${ }^{357}$ Sobre os defeitos de Demóstenes, vide Dem. 6.3-5. 
actor. Nesse sentido, Róscio e Esopo em Cícero, e Sátiro, actor trágico, em Demóstenes ${ }^{358}$, exercem uma função importante na performance oratória. Se, para Cícero ${ }^{359}$, o orador perfeito é aquele que ensina, diverte e comove o ânimo dos ouvintes (a diversão pela comédia, em Róscio, e a comoção pela tragédia em Esopo $)^{360}$, sem omitir as semelhanças com o desempenho do actor ${ }^{361} \mathrm{e} \mathrm{o}$ proveito que se pode tirar dele para a arte retórica, Plutarco parece não ser também alheio a esses objectivos, preferindo, no entanto, realçar a ligação entre a politeia e a retórica. Para Plutarco, o político deve como o actor adaptarse às circunstâncias da acçãa ${ }^{362}$, tal como Platão ${ }^{363}$ e Aristóteles ${ }^{364}$ já haviam preconizado: 365

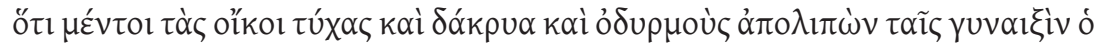

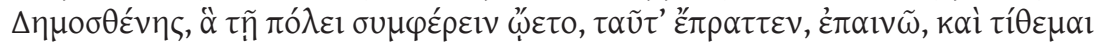

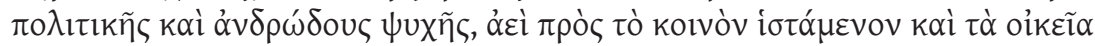

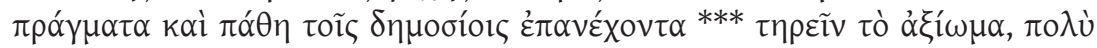

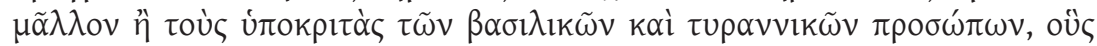

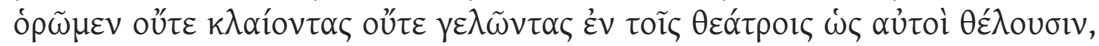

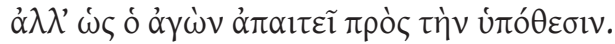

Contudo, Demóstenes deixou às mulheres as desventuras domésticas, as lágrimas e as lamentações. Fez isso por pensar que era proveitoso para a cidade, o que eu elogio, pois considero que é próprio da política e de uma alma viril estar junto do bem comum e submeter as obrigações e os sofrimentos domésticos aos assuntos públicos *** conservar a dignidade, muito mais do que os actores no papel de rei e de tiranos, por vermos nos teatros que eles nem choram nem riem como eles próprios desejam, mas como o tema da peça

${ }^{358}$ Cf. Dem. 7; em $X$ or. uit. 845A-B, não surge o nome de Sátiro, mas o de Andronico; em An seni resp. 795C, num episódio também narrado em Dem. 6.5, conta-se que Demostenes foi consolado por um velho de nome Eunomo, após um fracasso na assembleia, que lhe pediu para não se julgar mal a si próprio; este episódio também aparece em Foc. Bibl. 493a41.

${ }^{359}$ Cf. De opt. gen. or. 3.

${ }^{360}$ Róscio e Esopo eram amigos de Cícero (cf. respectivamente, De leg. 1.11 e De div.1.80). Róscio mantinha relações com importantes personalidades de Roma (cf. Sull. 36.2) e Cícero defendeu-o no Pro Roscio Comodeo; Clódio Esopo - que representou o Atreu de Ácio (cf. Tusc. 4.55), tragédia da qual só nos chegaram alguns fragmentos, mas que certamente versaria sobre o tema mítico das relações pouco pacíficas entre dois irmãos, Tiestes e Atreu - foi um dos que votou a favor do regresso de Cícero do exílio; Róscio e Esopo surgem várias vezes associados na literatura latina: Fro. AurCaes. 1.7.2.6, Hor. Ep. 2.1.81, Porph. Ep. 2.1.81, Quint. 11.3.111, V.Max. Mem. 8.10.2.6.

${ }^{361}$ Cf. De or. 1.128 ss.

${ }^{362}$ Embora tenha consciência das diferenças, em Praec. ger. reip., e.g. 813E-F, aponta diversas semelhanças entre o político e o actor.

${ }^{363}$ Phd. 272a e Epist. 326a-327e.

${ }^{364}$ Pol. 1312b, 1314b.

${ }^{365}$ Dem. 22.5. 
de teatro impõe.

É desta forma que o biógrafo manifesta a sua preferência por aqueles que fazem da politeia uma prioridade nas suas vidas ${ }^{366} \mathrm{e}$, apesar de haver semelhanças entre a acção de um político e a de um actor, reconhece as diferenças. O tempo da acção em ambas as actividades é, sem dúvida, muito importante, mas a realidade, neste caso, parece conferir, paradoxalmente, maior dramatismo ao que tem de tomar decisões. Se não se pode pôr em causa o papel basilar que o tempo desempenha na acção política, convém, no entanto, ter em conta que ele

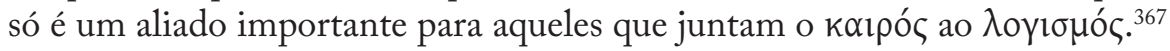

Apesar de tudo, Plutarco não deixa de reconhecer que a arte de representar pode ser um auxílio importante para a oratória, por causa da qualidade que pode

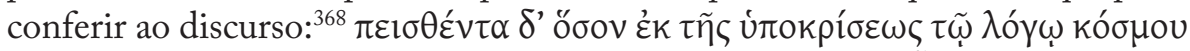

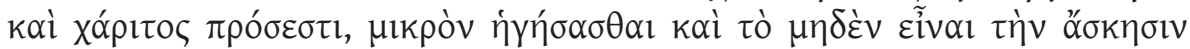

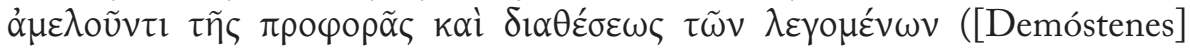
convence-se como a arte do actor está ligada ao ornamento e à beleza do discurso, e que o exercício pouco ou nada conta se se descuidar a declamação e a disposição do que se diz).

Quanto às qualidades de Demóstenes, Plutarco discorda de uma das suas

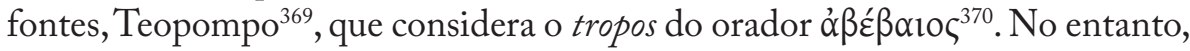
para o Queronense, uma das virtudes de Demóstenes é a sua coerência política

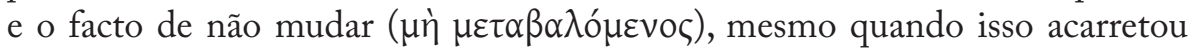
sacrifícios para a sua pessoa ${ }^{371}$. O próprio Demóstenes, nas suas obras, valoriza a honra e a dignidade, e a sua vida provou como foi um defensor desses princípios, a par da andreia e da honestidade de que investiu a sua praxis, sendo por isso equiparado, por Plutarco, não a oradores mas a homens como Címon, Tucídides e Péricles ${ }^{372}$.

Será ele a tentar convencer os Tebanos a juntarem-se às restantes poleis contra os Macedónios, mas os Gregos haveriam de perder a sua liberdade, por acção da $\tau u ́ x \eta ~ e ~ d a ~ \pi \varepsilon \rho ı \varphi o \rho \alpha ̀ ~ \pi \rho \alpha ү \mu \alpha ́ ́ \tau \omega v^{373}$, na famosa Batalha de Queroneia, em 338 a. C., que significou um momento de viragem no período helenístico.

366 Plutarco não é totalmente coerente, pois na biografia de Catão Censor, que atrás analisámos, elogia-o por dar primazia à família, em detrimento da politeia.

${ }^{367}$ Sert. 16.10: no seu contexto, este texto surge quando Sertório procura ensinar aos barbaroi o valor do kairos.

${ }^{368}$ Dem. 7.5; cf. Comp. Dem.-Cic. 1.4 e Praec. ger. reip. 802E.

${ }^{369}$ Plutarco também discorda de Teopompo quando este refere que é com injustiça e falta de

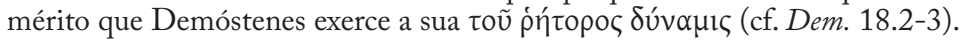

${ }^{370}$ Cf. Dem. 13.1.

${ }^{371}$ Cf. ibid. 13.2-4.

${ }^{372}$ Cf. ibid. 13.5.

${ }^{373}$ Cf. ibid. 19.1. 
Nesse confronto, Demóstenes, apesar de ser um ảvì $\alpha$ ả $\alpha \theta$ ó $\varsigma^{374}$, nada realizou de muito relevante, e por isso foi insultado e acusado pelos outros oradores pela derrota, mas acabou por ser absolvido pelo povo.

Após a morte de Filipe, Alexandre passaria a ser o protagonista, provocando com a vitória sobre os Tebanos enorme agitação em Atenas ${ }^{375}$. Demóstenes recusará integrar uma embaixada para estabelecer conversações com Alexandre e esse momento dita o início da perda do seu crédito, paralelo ao aumento da influência de Fócion e Démades ${ }^{376}$. Depois disso, o orador sai da cidade e passa o resto da sua vida em Rodes e na Jónia, onde exerce as funções de sofista. Por se ter deixado corromper por Hárpalo, o tesoureiro de Alexandre que, em 324, chega a Atenas, num claro sinal da sua então fraqueza de espírito, é preso e reage, como Cícero, muito mal ao exílio e a toda a adversidade da parte final da sua vida. ${ }^{377}$ É, assim, de uma forma pouco heróica que Demóstenes manifesta a sua desilusão pela vida. Como para Plutarco era importante manter a dignidade, a coragem, a moderação e a dynamis até ao fim, em especial numa situação de exílio ou ostracismo,

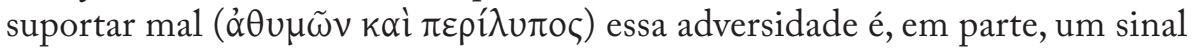
de que a paideia não foi suficientemente aprofundada e os seus valores não foram interiorizados.

Apesar de as poleis gregas disputarem entre si qual lhe prestaria maiores homenagens, até Cícero, que tinha tido uma formação diversificada, não evitou que os acontecimentos influenciassem negativamente o seu ethos, algo que não seria expectável num homem com a sua paideia ${ }^{378}$. Nesse contexto, Plutarco escreve: ${ }^{379}$

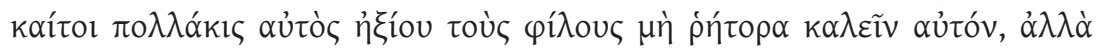

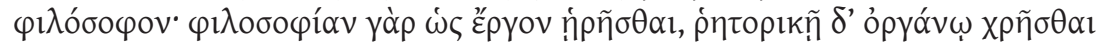

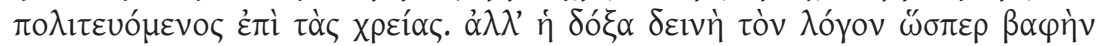

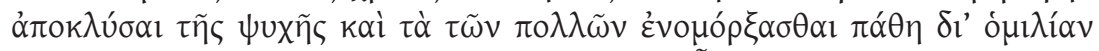

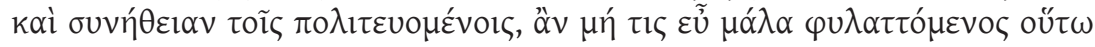

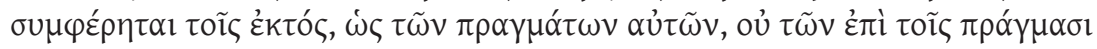
$\pi \alpha \theta \tilde{\omega} \nu \sigma \nu \mu \mu \varepsilon \theta \varepsilon \dot{\xi} \xi \omega \nu$.

$\mathrm{Na}$ verdade, era ele próprio que pedia aos amigos que não o chamassem retor,

${ }^{374}$ Cf. ibid. 20.2.

375 Cf. ibid. 23; vide também Alex. 11.7-12, onde Plutarco aproveita para realçar, apesar da derrota, a valentia e a ousadia dos Tebanos ao combaterem, em defesa da sua liberdade, um inimigo que possuia uma força mais numerosa.

${ }^{376}$ Cf. ibid. 24.1.

${ }^{377}$ Dem. 26.7.

${ }^{378}$ Cic. 32.5; cf. 41.8.

${ }^{379}$ Ibid. 32.6-7. 
mas filósofo, pois havia tomado a filosofia como trabalho, enquanto usava a arte retórica como instrumento para as necessidades da vida política. Mas a opinião tem o poder de apagar, como uma tintura ${ }^{380}$, a razão da alma, e imprimir as paixões da maioria nos que governam por meio do diálogo e do relacionamento. Tal não aconteceria no caso de uma pessoa se precaver muito bem e se relacionar com os que estão de fora, com o intuito de participar somente dos assuntos e não das paixões que dizem respeito a esses assuntos.

Entende Plutarco que um indivíduo não se deve deixar influenciar pela opinião $(\delta o ́ \xi \alpha)$ da maioria, nem pelas paixões $(\pi \alpha \theta \tilde{\omega} v)$ próprias dos assuntos que envolvem a politeia. Embora o exílio seja uma situação muito confrangedora, por implicar o afastamento da pátria, é nesses momentos que o espírito deve permanecer resoluto.

Apesar de Cícero ter revelado pouca perseverança no exílio, Plutarco desenvolve ao longo da biografia diversas qualidades evidenciadas por Cícero

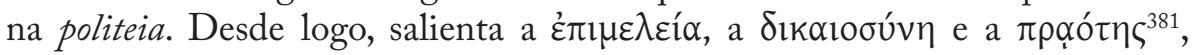
virtudes que lhe valeram, em 75 a. C., a nomeação para questor, ainda que o seu carácter não fosse isento de alguns excessos que desviam o homem de uma vida modelar, tais como o desejo de receber elogios e a paixão pela glória, que

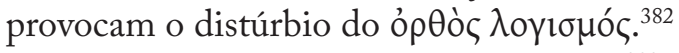

Não sendo um homem ganancioso ${ }^{383}$, algo que a sua posição social lhe poderia facilmente facultar, Cícero vivia com dignidade no meio de $\tau \tilde{\omega} v$

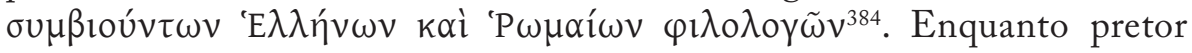
(66 a. C.), mostrou ser equitativo e íntegro nas suas decisões, e até ele

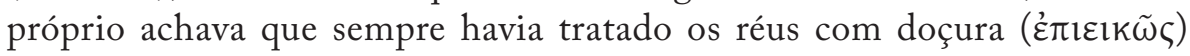
e humanidade $(\varphi 1 \lambda \alpha v \theta \rho \omega ́ \pi \omega \varsigma)^{385}$. No entanto, a virtude que mais deslumbrava os que directamente privavam com ele era a sua eloquência. ${ }^{386}$ Cícero defendia uma eloquência ligada à politeia, que visava o belo, o justo e a utilidade, sem se sacrificar a eficácia. O próprio Plutarco entende que o discurso não deve ser excessivamente teatral, mas ter por objectivo central aquilo que é útil ${ }^{387}$, sendo o logos um meio para se adquirir a benevolência junto dos ouvintes ${ }^{388}$.

\footnotetext{
${ }^{380}$ Cf. Per.8.1, Otho 73.4; Max. cum. princ. phil. 779C.

${ }^{381}$ Cf. Cic. 6.1.

${ }^{382}$ Cf. ibid. 6.5 .

${ }^{383}$ Cf. ibid. 8.2; em 36. 3-5, elogia-se a administração que Cícero fez dos bens.

${ }^{384}$ Cf. ibid. 8.4.

${ }^{385}$ Cf. ibid. 9.6 .

386 Ibid. 13.1.

${ }^{387}$ Cf. Praec. ger. reip. 803B.

${ }^{388}$ Cf. ibid. $801 \mathrm{C}$ ss.
} 
Os acontecimentos relacionados com a conjura de Catilina ${ }^{389}$, que ocupam uma parte significativa da narrativa, estimulam a inteligência, a sagacidade e a eloquência de Cícero. No momento de se decidir o castigo a dar aos conjurados,

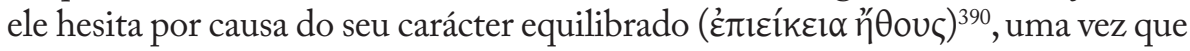
não desejava ser excessivo. $\mathrm{O}$ comportamento do orador nesse célebre processo

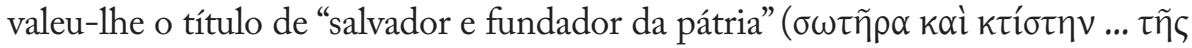

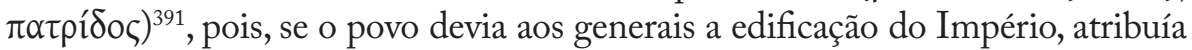
a Cícero a segurança e o facto de ter controlado e banido a conspiração. Aliás, o próprio Cícero haveria de jurar que salvaria a pátria e conservaria o Império ${ }^{392}$, tendo sido mesmo o primeiro a receber o título de $\pi \alpha \tau \varepsilon \dot{\varepsilon} \rho \alpha \pi \alpha \tau \rho i ́ \delta \circ \varsigma^{393}$, que lhe foi conferido por Catão de Útica na assembleia do povo.

A eloquência de Cícero, muito inclinada para o auto-elogio ${ }^{394}$, bem como uma ambição ( $\varphi$ ı ó $\imath \mu \alpha)$ desmedida pela glória, valeram-lhe muitos inimigos $^{395}$ o que acabaria por ditar o seu exílio. Tal como Demóstenes, Alcibíades e Coriolano, também ele haveria de regressar à sua cidade, no seu caso após dezasseis meses ${ }^{396}$, revelando, para descontentamento de Catão, algum excesso ${ }^{397}$.

Se, no prólogo deste par, havia feito referência às dificuldades que enfrentou para reunir fontes, no início da synkrisis, Plutarco volta a manifestar a consciência, própria de um historiador, de que nem todas as fontes e factos chegaram ao seu conhecimento ${ }^{398}$.

A synkrisis, na realidade, ajuda a reforçar a ideia de que, tanto Demóstenes, como Cícero atingiram um tão grande nível oratório porque souberam desenvolver, mediante a paideia e o exercício que lhe está fatalmente inerente, as suas capacidades naturais: os discursos do Grego distinguem-se pela exactidão

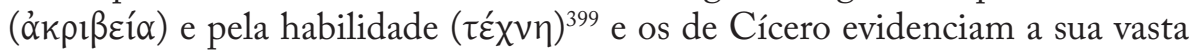
cultura, bem patente nos tratados que escreveu ${ }^{400}$.

\footnotetext{
${ }^{389}$ Cf. ibid. $14-22$.

${ }^{390}$ Cf. ibid. 19.6.

${ }^{391}$ Ibid. 22.5.

${ }^{392}$ Cf. ibid. 23.3.

${ }^{393}$ Ibid. 23.6.
}

${ }^{394}$ Além de ter elogiado oradores e filósofos do seu tempo, como, por exemplo, Cratipo, o peripatético, para quem chegou a pedir o direito à cidadania romana; também Catão Censor lhe merece críticas pela sua tendência para o auto-elogio.

${ }^{395} \mathrm{Cf}$. ibid. 24.1-5; este capítulo tem a curiosidade de Plutarco fazer referência a três autores gregos que serão alicerces importantes para a sua obra: Aristóteles, Platão e Teofrasto, por esta ordem; sobre inimizades que Cícero fez despontar, vide Cic. 27.

${ }^{396} \mathrm{Cf}$. ibid. 33: regresso do exílio.

${ }^{397}$ Cf. ibid. 34.2.

${ }^{398}$ Cf. Comp. Dem.-Cic. 1.1.

${ }^{399}$ Cf. ibid. 1.2 .

${ }^{400}$ Cf. ibid. 1.3 . 
Percebe-se, por conseguinte, que Plutarco atribui um papel fundamental à eloquência, especialmente aquela que não se distancia da acção e advém da experiência, como a de Demóstenes. Esta retórica opõe-se aos discursos que têm por fim a exposição do valor pessoal ou que são usados como formas de elogio, como os de Cícero ${ }^{401}$. Mas, como já afirmámos, quando o biógrafo procura definir o carácter das suas personagens recorre à acção e não simplesmente a discursos:402

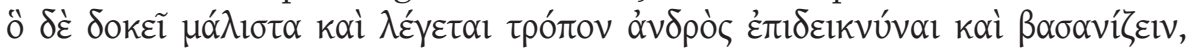

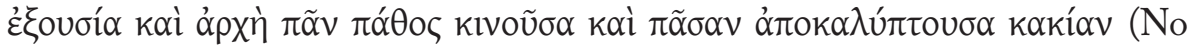
entanto, a autoridade e o poder, que agitam todas as paixões e descobrem todos os defeitos, parecem, acima de tudo, e diz-se que mostram e provam a maneira de ser de um homem). Deste modo, como aliás as Vitae bem o provam, Plutarco acredita que é por intermédio da politeia que se pode avaliar melhor o ethos, detectando-se os excessos, as virtudes e os defeitos. Note-se, ainda, que para Plutarco é quase uma fatalidade o poder estar associado às kakiai, daí ser premente o politikos ter uma adequada paideia, que o ajude a tomar as melhores decisões, a evitar uma excessiva ambição e a superar os obstáculos da governação, tudo para proveito dos cidadãos e da sua própria felicidade. Isso explica que a avaliação que Plutarco faz dos seus heróis não esqueça a dimensão de cidadania.

Sendo assim, se tivermos em atenção o exercício da politeia, Cícero desempenhou, sem dúvida, funções mais relevantes do que Demóstenes, e,

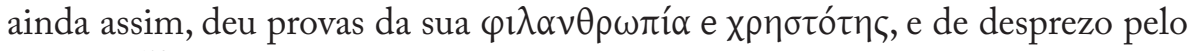
dinheiro ${ }^{403}$, motivo que já havíamos encontrado no par Aristides-Cato Maior. Mas, enquanto nesse par, Aristides não nutria qualquer interesse pelo dinheiro e Catão dava muito valor aos bens e à economia, no par que agora analisamos, por quiasmo, é o Romano que recusa as riquezas e o Grego, ao invés, aceita dinheiro e por isso foi acusado ${ }^{404}$.

Também a synkrisis reforçará a forma como os dois oradores, por terem caracteres distintos, enfrentaram o exílio ( $\varphi$ vүý). Se Demóstenes desenvolve nessa altura uma parte importante da sua carreira política, a ponto de Plutarco o considerar melhor cidadão do que Temístocles e Alcibíades, que viveram situações semelhantes, já Cícero entrega-se à inacção na Macedónia, o que vai contra os princípios que Plutarco postula para quem enfrenta dificuldades ou para o politikos, que não deve renunciar à actividade pública, mesmo quando tem uma idade avançada.

Segundo Plutarco, Demóstenes e Cícero, embora tivessem conseguido notoriedade no campo da oratória, manifestam, como procuramos registar,

\footnotetext{
${ }^{401}$ Cf. ibid. 2.

${ }^{402}$ Cf. ibid. 3.2.

${ }^{403}$ Cf. ibid. 3.3.

${ }^{404}$ Cf. ibid. 3.4-5.
} 
muitas diferenças. Uma delas, no entanto, tem especial significado para o tema central do nosso trabalho: a curiosidade intelectual de Cícero ${ }^{405}$ que o leva a aprofundar a sua paideia, alargando e consolidando os conhecimentos junto de mestres gregos, em filosofia e oratória, daí que Plutarco o qualifique como

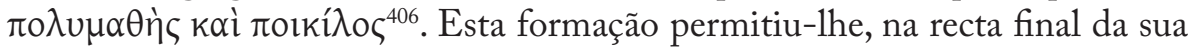
vida, sentir-se capaz de traduzir para Latim a filosofia grega ${ }^{407}$ e escrever uma história da sua pátria, coligindo e aproveitando muitas fontes helénicas ${ }^{408}$.

Além disso, é curioso que Cícero - que é, porventura, dos heróis romanos que o Queronense retrata, o que se aproxima mais do modelo ideal do nãogrego que sente apelo pela paideia helénica e a aprofunda - não mereça o título de philosophos, mas apenas o de rhetor ${ }^{409}$, ao contrário de Catão de Útica (Kó $\tau \omega v$ ó $\varphi \imath \lambda o ́ \sigma o \varphi \circ \varsigma)^{410}$, ainda que para Plutarco este seja sobretudo um homem de Estado, íntegro e mais propenso à acção do que à teoria ${ }^{411}$.

Em síntese, Cícero revela maior interesse pelo aprofundamento da paideia do que Demóstenes, ficando claro que Plutarco não pretende de modo algum usar a paideia para explorar a inferioridade cultural dos Romanos, mas para aproximar os dois povos, cabendo aos próprios Romanos tomarem a iniciativa de aprofundar as formas de pensamento e de expressão dos Helenos, podendo, nesse particular, vir a revelar maior argúcia e engenho do que os Gregos. Este par serve, ainda, para exemplificar que Plutarco considerava a paideia helénica, a mesma que levou Cícero a viajar com o desejo de aprender, a base do saber e da formação, tanto para Gregos como para Romanos.

\subsubsection{Sertorius-Eumenes}

Este é, como já referimos, um dos pares das Vitae em que a relação entre os dois biografados não se vislumbra numa análise superficial. Sertório e Êmenes têm personalidades muito diferentes, e desenvolvem a sua actividade política longe da pátria. Esse facto permitiu que alguns ${ }^{412}$, por exemplo, considerem Sertório um homem avarento, cruel, licencioso ou mesmo um traidor. Plutarco,

${ }^{405}$ Em Tusc. escreve sobre o interesse que tinha pela matemática (1.5) e pela filosofia (1.7).

${ }^{406}$ Cf. Comp. Dem.-Cic. 1.3

${ }^{407}$ Cf. Cic. 40.1-3.

${ }^{408}$ Cf. ibid. 41.1.

${ }^{409}$ Cf. Cic. 27.1 e 39.7.

${ }^{410}$ Cf. Cat. Ma. 27.7 (a referência a Catão de Útica surge no final da biografia de Catão Censor, quando Plutarco descreve, sumariamanente, os descendentes deste), Brut. 2.1 e Pomp. 40.2.

${ }^{411}$ Cf. Praec. ger. reip. 811A-B; Plutarco analisa sobretudo a acção política de Catão de Útica por não estar muito interessado em tecer considerações sobre a ligação que este tinha com o Estoicismo, até porque não concordava com muitas das ideias dessa corrente filosófica; cf. D. Babut (t2003: passim).

${ }^{412} \mathrm{O}$ retrato de Tito Lívio, atendendo às Periochae (79-80, 90-94 e 96), não é totalmente favorável, embora não negue a romanitas de Sertório; vide L. García Moreno (1992: 141). 
todavia, não perfilha essa opinião ${ }^{413}$, embora a biografia de Pompeio, mais próxima do retrato feito pelo historiador Posidónio, não seja tão favorável a Sertório ${ }^{414}$.

A verdade é que ambos, Êumenes e Sertório, surgem como uma espécie de desterrados ou estrangeiros ${ }^{415}$, com as qualidades necessárias para assumirem o poder e para comandarem tropas estrangeiras ${ }^{416}$. Êumenes, porém, mostra ser um amante da guerra, enquanto Sertório prefere a paz e a tranquilidade, mas a vida não o deixou fruir esses momentos ${ }^{417}$. Gera-se, por isso, nas duas biografias uma oposição entre voluntariedade e involuntariedade: Êmenes combate porque assume a sua oposição aos dirigentes macedónios, ao passo que Sertório se vê na necessidade de lutar contra aqueles que atentavam contra a sua integridade física. De uma forma geral, ficamos com a ideia de que Plutarco assume a sua preferência por Sertório, uma vez que este completava melhor o seu ideal de herói e tinha uma dimensão histórica maior do que Êmenes, figura que se perde um pouco no vazio deixado pela morte de Alexandre.

A biografia de Sertório, a principal do par $^{418}$, é muito escassa quanto a elementos sobre a sua educação, mas Plutarco afirma que a sua proairesis e a sua physis eram nobres. Tal como Coriolano ${ }^{419}$ ou Tibério Graco ${ }^{420}$, Sertório ficou órfão de pai e foi a sua mãe que assumiu o papel de educadora: ${ }^{421}$

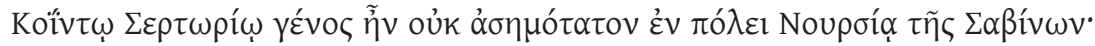

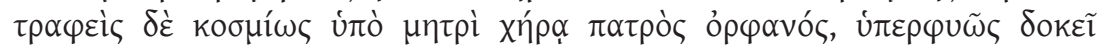

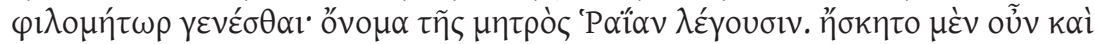

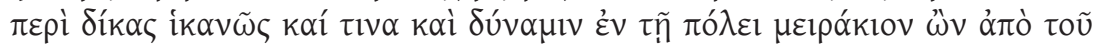

${ }^{413}$ As fontes historiográficas diferem na imagem que transmitem de Sertório, pois ele tanto é descrito com as características enunciadas como é generoso, moderado, virtuoso e austero; vide M. Neira (1986: 189-211); Plutarco terá usado como fonte a obra histórica de Posidónio, que não nos chegou, mas sobre a qual podemos ter alguma informação por intermédio de Diodoro Sículo, historiador que se terá baseado, para a figura de Sertório, na obra de Posidónio; Diodoro Sículo (37.22), a propósito do ethos de Sertório, refere que ele não era moderado nem tinha como qualidade a philanthropia; para C. Konrad (1994: liii-lvi), Salústio terá sido a principal fonte de Plutarco; vide, ainda, L. García Moreno (1992: 135 ss.) e B. Scardigli (1971: 33-64).

${ }^{414}$ Salústio, por sua vez, nas Historiae, sendo hostil com Pompeio, apresenta um retrato mais positivo de Sertório, o que leva a pensar que terá sido uma das fontes de Plutarco (cf. C. Jones (1971: 86) e D. Russel (2001²: 54)); Plutarco cita Salústio, por exemplo, em Luc. 11.5 e 33.3.

${ }^{415}$ No caso de Êmenes, Plutarco refere na synkrisis que ele é um desterrado, algo que ao longo da sua biografia não se deixa entender.

${ }^{416}$ Cf. Sert.1.11-12 e Comp. Sert. -Eum. 1.2.

${ }^{417}$ Cf. Comp. Sert.-Eum.

${ }^{418}$ Cf. Sert. 1.6.

${ }^{419}$ Cf. Cor. 1.2.

${ }^{420}$ Cf. Gracch. 1.5-7.

${ }^{421}$ Sert. 2.1-2. 


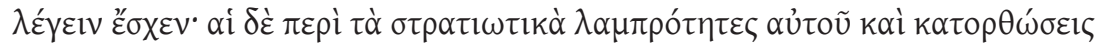

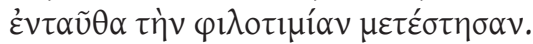

Quinto Sertório pertencia a uma família distinta da cidade de Núrsia, dos Sabinos. Por ser órfão de pai, ele foi criado de forma adequada pela mãe viúva, pela qual parece ter criado um extraordinário amor. Dizem que a mãe se chamava Reia. Com efeito, Sertório exercitou-se convenientemente em assuntos forenses e possuía também, na cidade ${ }^{422}$, uma certa influência por causa daquilo que dizia, ainda que fosse jovem. Porém, o brilhantismo e os êxitos em exercícios militares alteraram a sua ambição.

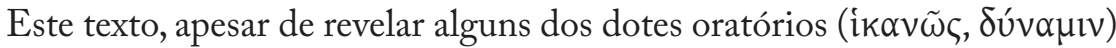

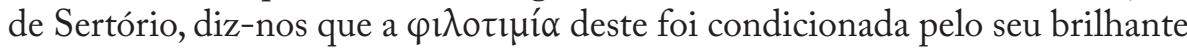

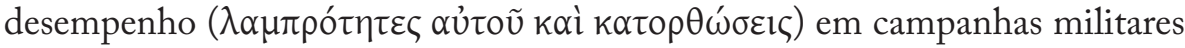
que Plutarco especifica no capítulo seguinte, tanto sob o comando de Cepião, quando os Cimbros e Teutões invadiram a Gália Transalpina, em 106 a. C., como às ordens de Mário, numa segunda investida dos inimigos, ocorrida no ano 102 a. C.. Sertório é, deste modo, um exemplo da alteração da ambição motivada pelo êxito. Na biografia de Coriolano ${ }^{423}$, Plutarco nota que o sucesso em tenra idade não deve satisfazer de imediato a natureza do indivíduo, mas, pelo contrário deve estimulá-lo a conseguir atingir algo superior, nunca temendo perder a reputação adquirida com a primeira vitória. No caso do bios de Sertório, é uma das biografias plutarquianas em que se nota de forma mais evidente como os acontecimentos podem alterar o ethos e a physis ${ }^{424}$.

Pela forma como se empenha nas referidas acções, onde enfrenta múltiplas

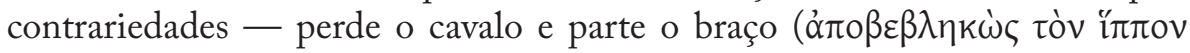

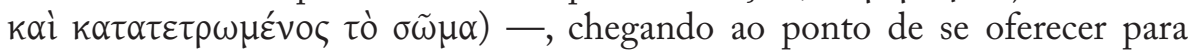

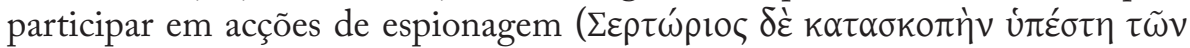
$\left.\pi \circ \lambda \varepsilon \mu u^{\prime} \omega v\right)$, Sertório merece o reconhecimento do seu valor: ${ }^{425} \tau o ́ \tau \varepsilon \mu \dot{\varepsilon} v$ oũv

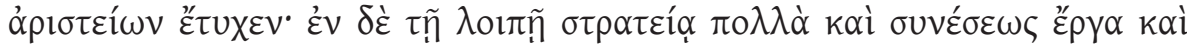

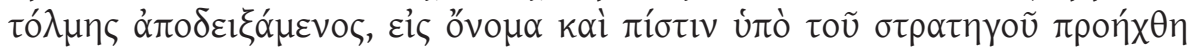
(Recebeu, então, o prémio da valentia. No resto da campanha, revelou, em muitas acções, inteligência e audácia, o que lhe valeu a fama e a confiança do general). Sertório possui, desta forma, as duas características fundamentais para um herói, a inteligência e a audácia em combate, valores que estão presentes na cultura grega desde os Poemas Homéricos. $\mathrm{Na}$ sequência do texto, a valentia

${ }^{422}$ Para uns Roma, para outros a própria cidade de Núrsia; pela proximidade entre $\varepsilon$ ย่ $\tau \tilde{n}$

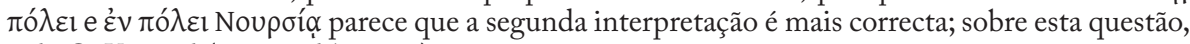
vide C. Konrad (1994: ad loc. 2.2)

${ }^{423} 4$.

${ }^{424}$ Cf. Sert. 10-5-7; vide outro exemplo da alteração do ethos em Sull.30.6.

425 Sert.3.4. 
de Sertório, reconhecida por aqueles que de mais perto privavam com ele e também pelo povo ${ }^{426}$, surge exemplificada com uma acção concreta e, diríamos, "épica": 427

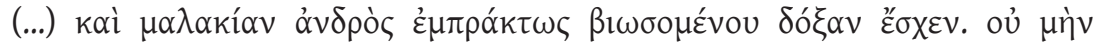

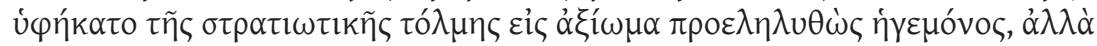

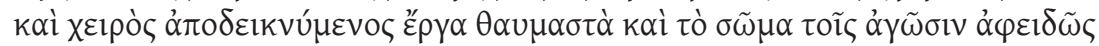

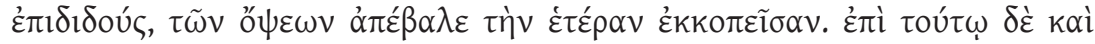

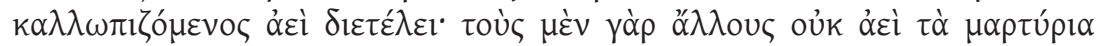

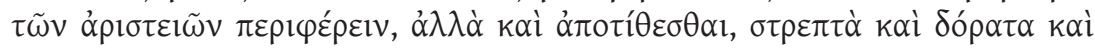

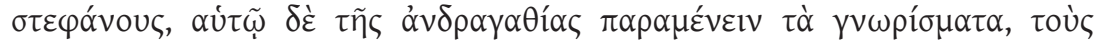

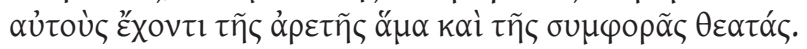

(...) ganhou a fama de um homem que passa a vida em excessiva actividade. Tendo assumindo o comando por causa do seu valor, Sertório não diminuiu certamente a sua audácia de soldado, mas do seu braço nasceram acções admiráveis e, além disso, empenhou-se nas batalhas, sem qualquer reserva, pelo que perdeu um dos olhos. Em virtude disso, passou a vida a vangloriar-se com as seguintes palavras: "os outros não trazem sempre consigo o testemunho dos prémios da sua valentia, mas tiram os colares, as lanças e as coroas, eu, porém, mantenho as marcas da coragem, e os que contemplam a minha desgraça são, ao mesmo tempo, os que observam a minha virtude".

A perda de um olho é, assim, um sinal ou um testemunho ( $\mu \alpha \rho \tau u ́ p ı$,

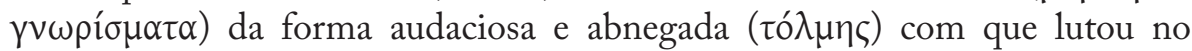
campo de batalha, tendo, ao contrário de outros, ficado com uma marca

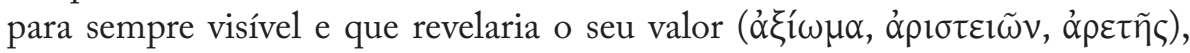
independentemente de quais fossem as suas funções militares. Pois, por causa da forma destemida como enfrentava o inimigo, os Lusitanos convidaram Sertório para ser o líder, pois precisavam de alguém com valor e experiência. ${ }^{428}$

${ }^{426} \mathrm{Em}$ Sert. 4.3, diz-se que, quando entrava no teatro, era entusiasticamente recebido, algo que a maior parte dos homens com funções relevantes não tinha direito (cf. Sal. Hist. 1.89).

${ }^{427}$ Sert. 4.3-5.

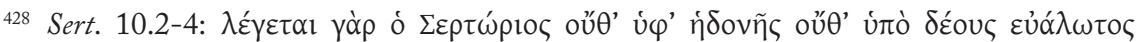

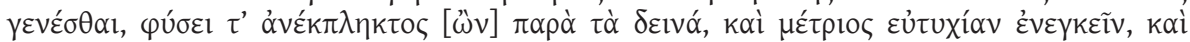

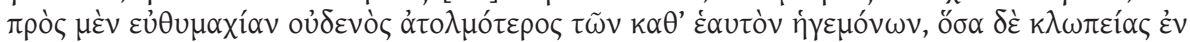

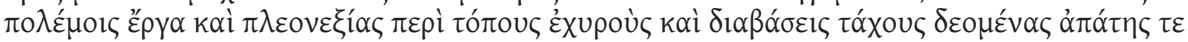

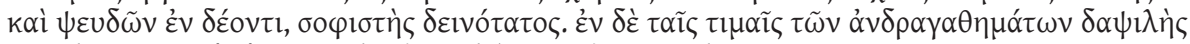

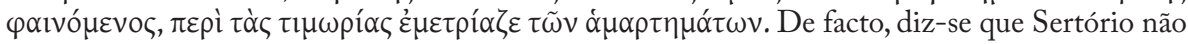
se deixava tomar facilmente pelo prazer e pelo medo, pois era, por natureza, intrépido com coisas funestas e moderado no sucesso; e, de modo nenhum, era mais cobarde no confronto directo do que cada um dos comandantes, pois ele era um homem terrivelmente sábio em acções guerreiras de captura e em conseguir a superioridade em sítios seguros e em travessias, onde era preciso ser rápido e astuto, ou mesmo na necessidade de mentir. Revelando-se generoso nas honrarias dos actos de valor, era moderado a castigar os erros. 
$\mathrm{Na}$ descrição do carácter de Sertório, Plutarco valoriza, assim, a forma intrépida como enfrenta os perigos e o facto de encarar o sucesso sem grandes triunfalismos. Estas são duas características que o Queronense gosta de enfatizar nos seus heróis e que estão relacionadas com a arete, neste caso guerreira, e com a sophrosyne. Pela sua capacidade de liderança e pela forma exemplar como combatia, Sertório revelava ser um homem que colocava nas suas acções guerreiras tanto a capacidade física como a sua eloquência e astúcia, qualidades vitais para um comandante que tem a seu cargo um conjunto de homens. A sua natureza moderada e a maneira como avaliava e decidia os assuntos de forma equitativa, com tanta ênfase no texto acima citado, torna-se vital para ganhar o respeito dos companheiros de combate. No seguimento deste texto sobre o carácter de Sertório, Plutarco relata uma alteração profunda das qualidades do Romano, pois passou a ser violento e cruel. Sugere o biógrafo a hipótese de essa transformação do $\tilde{\eta} \theta$ o se ficar a dever a uma intervenção da $\tau u ́ x \eta:{ }^{429}$

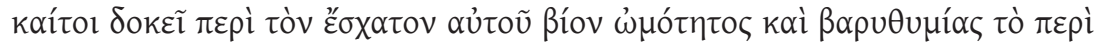

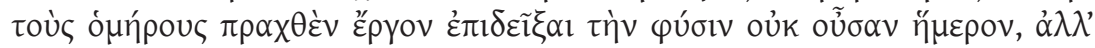

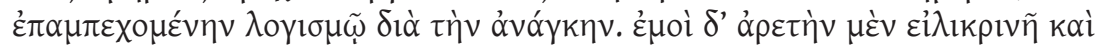

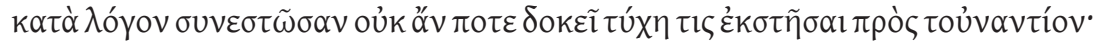

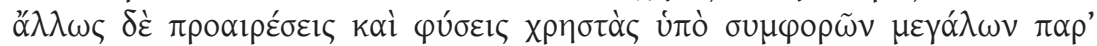

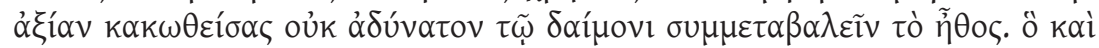

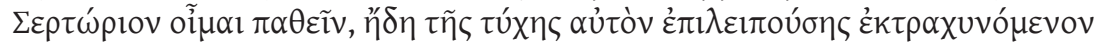

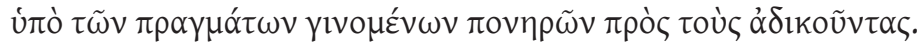

Não obstante, parece que, no fim da sua vida, ao agir para com os reféns de forma cruel e exaltada mostrou uma natureza que não estava civilizada, mas que se revestia, de argumentos, segundo a necessidade. Eu, no entanto, julgo que, se a virtude é pura e se forma conforme a razão, nenhum acto fortuito pode dar origem ao seu contrário. De resto, se os princípios e as naturezas virtuosas forem, contra o que tem valor, maltratados por grandes desgraças, não é impossível que, por destino, o carácter se altere. Penso que foi o que sucedeu a Sertório, que, mal foi abandonado pela sorte, se tornou rude, por via de acontecimentos penosos com aqueles que procediam injustamente.

No contexto do papel da tyche nos sucessos e errâncias do homem, este texto permite-nos avaliar até que ponto, para Plutarco, a intervenção das acções ou das contingências próprias da vida de um homem podem influenciar a formação do carácter. Se, no texto imediatamente anterior a este, Sertório parecia agir de acordo com a sua natureza, verifica-se, agora, que na parte final da sua vida, no massacre de $\mathrm{Osca}^{430}$, não conseguiu manter a moderação, cedendo

\footnotetext{
${ }^{429}$ Sert. 10.5-7.

${ }^{430}$ Cf. Sert. 25.4 .
} 
ao lado mais cruel e terrível do seu carácter. Parece-nos que essa atitude, que

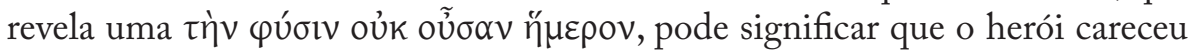
de uma boa paideia, a qual ajudaria a superar os obstáculos impostos pela sua intensa actividade de guerreiro. Isso é evidente quando Plutarco afirma que a virtude formada segundo a razão ( $\kappa \alpha \tau \grave{\alpha} \lambda o ́ \gamma o v)$ não está sujeita ao fortuito

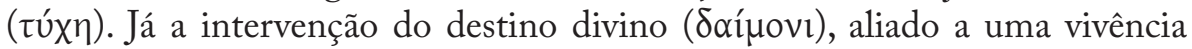
problemática, pode alterar o carácter. Assim sendo, da conciliação da falta de paideia e de uma vida passada em permanentes conflitos surge a transformação do ethos de Sertório.

O percurso político e o ethos de Sertório, o qual, como referimos, provinha de uma família com estatuto social relevante e cedo ficou órfão de pai, terão sido influenciados pela educação que recebeu da sua mãe. Plutarco mostra, assim, como entre os Romanos as mães viúvas tinham capacidade para educar os seus filhos, pois no caso de Alcibíades, também ele órfão de pai, não se

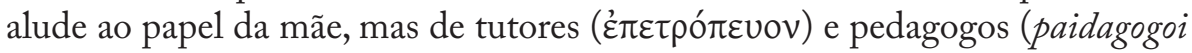
e didaskaloi) ${ }^{431}$. A relação intensa que estabelece com a mãe ( $\left.\varphi \imath \lambda o \mu \eta ́ \tau \omega \rho\right)$ será o único motivo pelo qual desejará regressar à sua pátria, sendo para ele muito doloroso receber a notícia da morte da mãe: ${ }^{432}$

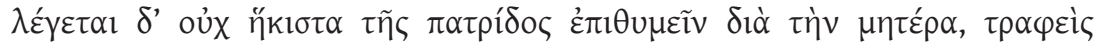

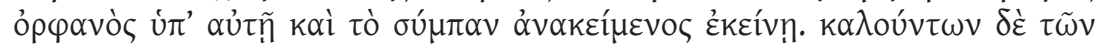

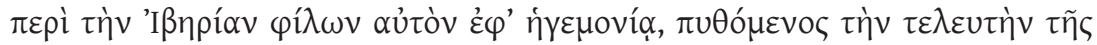

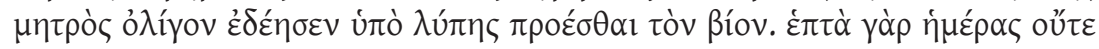

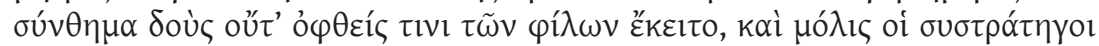

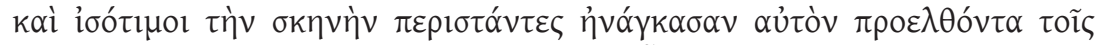

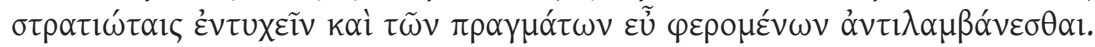

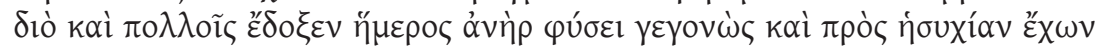

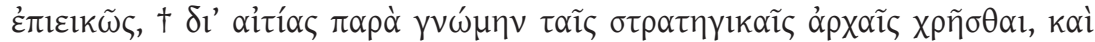

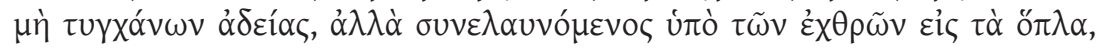

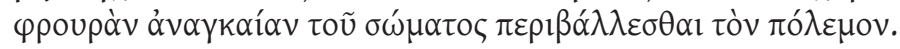

Diz-se que o desejo de regressar à pátria, por causa da mãe, não era pouco, pois como era órfão foi criado por ela e estava-lhe ligado por completo. Quando os amigos da Ibéria o chamaram para ser ele a tomar o comando, recebeu a notícia da morte da mãe e pouco faltou para, por causa da dor, acabar com a vida. Permaneceu inactivo durante sete dias, não dando qualquer sinal de vida nem sendo visto por nenhum dos amigos, e os generais e outros, de igual condição, que rodeavam a tenda, convenceram-no com dificuldade a sair, para ir ao encontro dos soldados e encarregar-se dos assuntos que, felizmente, corriam bem. Por isso, muitos consideravam-no um homem sensível por natureza e

\footnotetext{
${ }^{431}$ Cf. Alc. 1.1-3.
}

432 Sert. 22.9-12. 
que possuía com moderação uma vida tranquila, mas por algumas razões teve necessidade de, contra o seu desígnio, seguir os princípios do comando militar, e, não alcançando a segurança, foi impelido pelos inimigos para as armas, de modo a arranjar com a guerra uma protecção necessária para a sua vida.

Como se vê, o texto relaciona a philopatria com o amor que Sertório sente pela mãe $\mathrm{e}^{433}$, sentimento próprio da romanitas ${ }^{434}$ - nos casos em que Plutarco retrata órfãos, a ligação entre a mãe e os filhos, ou vice-versa, é muito mais intensa nos Romanos (Coriolano e Sertório) do que nos Gregos (Alcibíades) -, causando-lhe grande dor a perda da mãe, em 80 a. C., a ponto de tentar o suicídio, num momento de claro descontrolo emocional. É de realçar que Plutarco não faz qualquer alusão à esposa de Sertório ${ }^{435}$, de modo a concentrarse no herói e no amor que este nutria pela mãe $e^{436}$. Além disso, mais uma vez se desenvolve o tema das qualidades naturais e daquelas que se adquirem com os acontecimentos que a vida e o destino colocam no caminho de cada um. Sertório era dócil, por natureza, moderado e desejava ter uma vida tranquila,

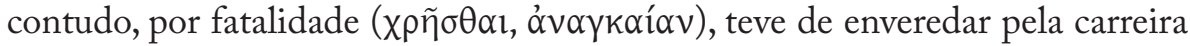
militar de modo a defender-se dos inimigos. Para Plutarco, Sertório é, acima de tudo, um homem violentado na sua natureza e que intervém no combate por uma questão de defesa, assumindo, desse modo, que, mesmo quando uma natureza é distinta e tem valores nobres, pode ser susceptível de alteração pelo efeito de episódios infelizes. Esta constatação só valoriza a paideia, por constituir a melhor forma de superar a adversidade.

Para salientar a $\mu \varepsilon \gamma \alpha \lambda \circ \varphi \rho \circ \sigma u ́ v \eta$ de Sertório, Plutarco mostra como ele é diferente de Metelo ${ }^{437}$, seu inimigo, o qual chegou, inclusive, a anunciar publicamente que daria cem talentos de prata e vinte mil plectros de terra ao Romano que matasse Sertório e, a um exilado que o fizesse, prometia o regresso a Roma ${ }^{438}$. Quer pelo modo como se vangloriava das suas vitórias,

${ }^{433}$ Vide o contraste com Comp. Cor.-Alc. 4.4-5.

${ }^{434}$ Outro sinal da romanitas de Sertório surge quando Plutarco aborda a forma como ele defendeu os interesses de Roma na Ásia (cf. Sert. 23); note-se que nos capítulos 22 a 24 da biografia encontramos descrição do Sertório "romano", por excelência.

${ }_{435}$ Segundo Valério Máximo 9.15.3, Sertório era casado; vide R. Cromey (1982: 203-212).

${ }^{436}$ L. García Moreno (1992: 151) interpreta da seguinte forma o amor que Sertório sente pela mãe: "The insistence that his mother had been his only love would certainly also serve the objective of presenting Sertorius as an austere sage, one far removed from luxuries or vices, in particular, a taste for gold and silver, women, wine and abundant food"; por isso, apresenta-se Sertório como um homem moderado, que substituía os diversos prazeres pelo exercício do corpo (Sert. 3.1), e que nos momentos de ócio bebia ou comia em excesso (ibid.13.2).

${ }^{437}$ Sobre as diferenças entre Sertório e os seus rivais, Metelo e também Perpena, vide Sert. 13.1, 15.1, 25.3, 26.4; a propósito de alguns dos philoi de Sertório, remetemos para C. Konrad (1987: 519-527).

${ }^{438}$ Cf. Sert. 22.1. 
em especial de uma que havia conseguido sobre Sertório, quer pelas formas de celebração das mesmas, Metelo era pouco amado pelo povo, ele que não deixava cair no esquecimento que Sertório era um escravo e um fugitivo ${ }^{439}$. Quanto à $\mu \varepsilon \gamma \alpha \lambda \circ \varphi \rho \circ \sigma u ́ v \eta$ de Sertório, ela tem as seguintes manifestações: ${ }^{440}$

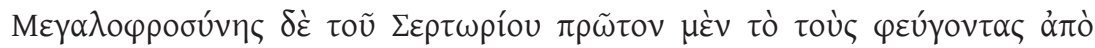

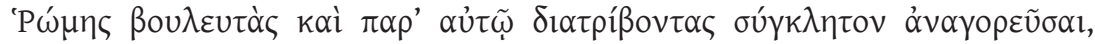

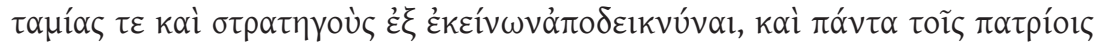

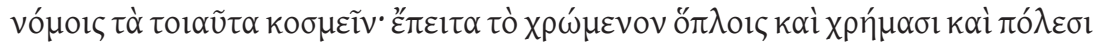

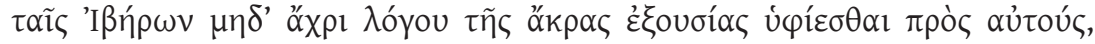

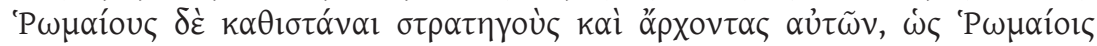

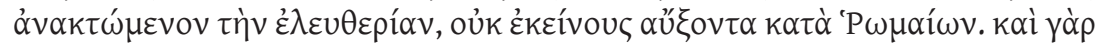

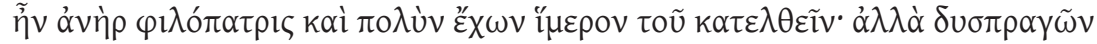

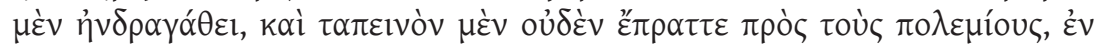

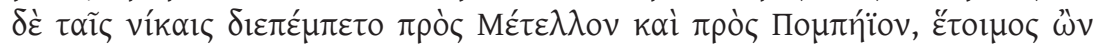

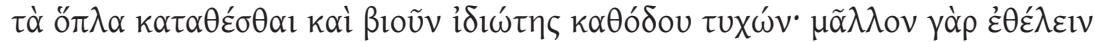

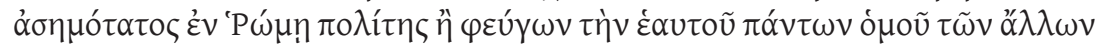

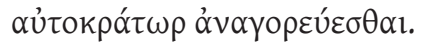

Um primeiro sinal da grandeza de espírito de Sertório foi ter instituído publicamente o senado para os senadores que fugiram de Roma e se juntaram a ele, e, de entre estes, nomeou os questores e os generais ${ }^{441}$, tomando todas estas medidas segundo as leis da sua pátria. De seguida, fazendo uso das armas, do dinheiro e das cidades dos Iberos, não thes concedeu, nem verbalmente, o poder mais elevado, mas colocou à frente deles generais e magistrados Romanos para recuperar a liberdade para os Romanos e não engrandecer os bárbaros em detrimento dos Romanos. Sertório, no fundo, era um homem que amava a pátria e que tinha um grande desejo de a ela regressar. Porém, mesmo sofrendo desventuras, procedia como um homem corajoso, e não se deixava humilhar à frente dos inimigos; nas vitórias, transmitia a Metelo e a Pompeio que estava disposto a depor as armas e a viver como um simples cidadão, logo que obtivesse autorização para regressar. De facto, desejava mais ser em Roma o mais obscuro dos cidadãos do que, sendo fugitivo, ser proclamado um general absoluto de todos os outros juntos.

A $\mu \varepsilon \gamma \propto \lambda \circ \varphi \rho \circ \sigma u ́ v \eta$ do herói manifesta-se, assim, pela forma digna com que trata os senadores, respeitando o mos maiorum, e constituindo o "senado

${ }^{439}$ Cf. ibid. 22.4.

${ }^{440}$ Ibid. 22.5-8.

${ }^{441}$ Muitas traduções optam por traduzir "questores e pretores”. No entanto, preferimos seguir a argumentação e a proposta de tradução de C. Konrad (1994: ad loc 22.5), autor que também explica a questão do "senado sertoriano". 
sertoriano", ao qual apenas Apiano ${ }^{422}$ fará referência. A ideia, contudo, não era fundar um segundo império na Hispânia, mas, envolvendo-se numa guerra civil, Sertório tenta salvaguardar os interesses dos Romanos, não permitindo que os bárbaros se tornassem excessivamente poderosos e colocassem, por

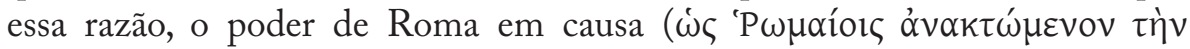

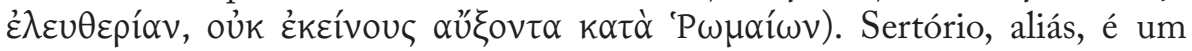
$\varphi \imath \lambda o ́ \pi \alpha \tau \rho ı \varsigma$ que ambiciona regressar a Roma, apesar de ter consciência de que o Senado dificilmente deixaria passar impunes as suas acções. Afirmava preferir ser um cidadão anónimo em Roma, do que assumir a hegemonia junto dos outros povos ${ }^{443}$.

A recusa em ajudar a tirar províncias asiáticas aos Romanos, mesmo com a promessa de dinheiro e de barcos por parte dos embaixadores de Mitridates, mostra como Sertório se mantinha fiel à sua pátria: ${ }^{444} \delta \varepsilon \tilde{v} v$ үò $\rho$

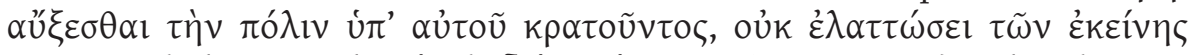

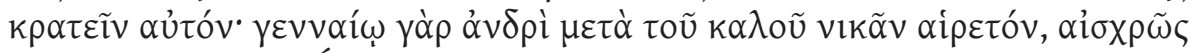
$\delta$ ' oủ $\delta \dot{\varepsilon} \sigma \omega \hat{\zeta} \zeta \varepsilon \sigma \theta \alpha$ l (É necessário que ele [Mitridates] engrandeça a cidade pela sua própria vitória, e não que a vitória a torne inferior. $\mathrm{Na}$ verdade, é preferível para um homem nobre conquistar a vitória com honra e não salvar-se com ignomínia).

À semelhança de Alexandre, também Sertório exerce um papel pedagógico junto dos barbaroi, de modo a transmitir-lhes alguns valores, que Plutarco não deixa de salientar: ${ }^{445}$

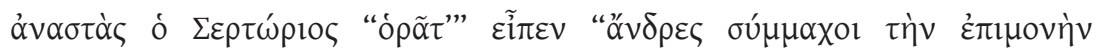

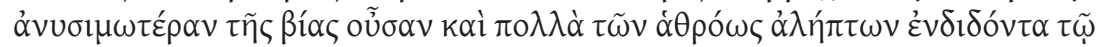

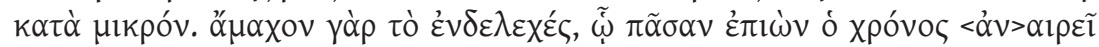

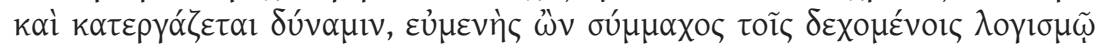

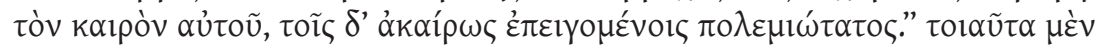

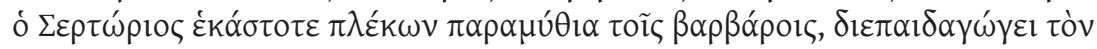
kaıpóv.

Sertório levantou-se e disse: "Companheiros de armas, vede como a perseverança é mais eficaz do que a violência e como muitas coisas que não se conseguem fazer de uma só vez podem realizar-se pouco a pouco. Em verdade,

${ }^{442} 108.507$.

${ }^{443}$ Quando César, depois de atravessar os Alpes, passa um pequena povoação bárbara, os companheiros perguntam-lhe se ali também havia lutas e invejas entre os homens para ocuparem os cargos de poder, e ele, em sentido inverso das palavras de Sertório, respondeu:

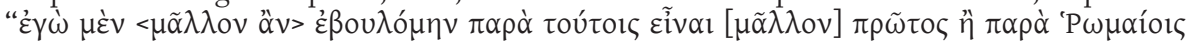

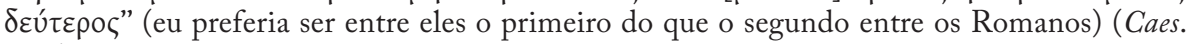
11.4).

${ }^{444}$ Sert. 23.7.

445 Sert. 16.9-11. 
a perseverança é invencível, pois, por ela, o tempo no seu percurso aniquila e atinge o poder. Ainda que seja um aliado benévolo para os que agem com razão na ocasião certa, é um grande inimigo para os que se apressam de forma despropositada”. Urdindo continuamente tais exortações aos bárbaros, Sertório ensinava-lhes o valor da oportunidade.

Como se vê, um dos valores que Sertório ensina aos barbaroi é a

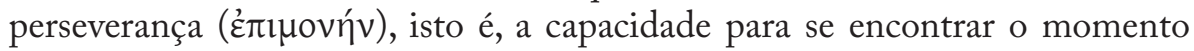
certo para empreender uma acção, pois isso denota auto-domínio, no sentido de não se tomar uma decisão por impulso, mas fundada na razão. Já antes deste texto, a acção civilizadora de Sertório havia sido realçada por Plutarco, em especial a capacidade que revelou ter para captar o afecto dos barbaroi. O autor valoriza também o facto de lhes ter conferido organização militar, gosto pelo belo, além da preocupação, ainda que não desinteressada, pela educação dos filhos deles. ${ }^{446}$

Plutarco descreve algumas das técnicas de persuasão usadas por Sertório para demonstrar a capacidade militar para liderar homens que este tinha. Um grupo desordenado de guerrilheiros é, com a adopção dos hábitos militares romanos, transformado num exército confiante. Além disso, e ainda mais relevante para a matéria central do nosso trabalho, Sertório romaniza os filhos dos homens que pertencem à elite, criando uma escola em Osca (actual Huesca, na região espanhola de Aragão), onde se transmitiam conhecimentos sobre as culturas grega e romana. Tudo isso, porém, fazia parte, segundo Plutarco, da política de domínio que Sertório planeava para a Hispânia, ou seja, a aculturação associada à consolidação

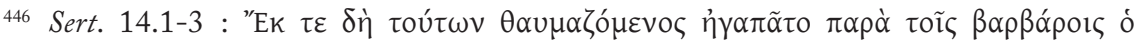

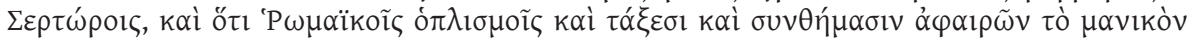

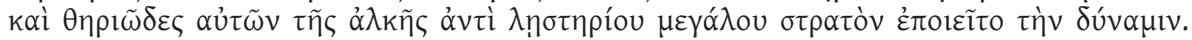

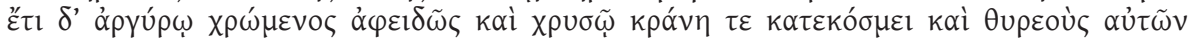

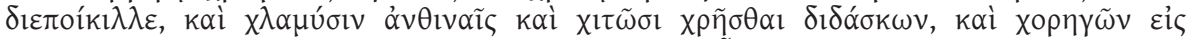

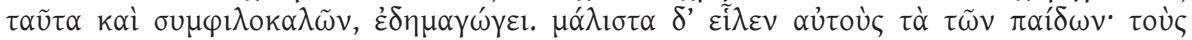
үà

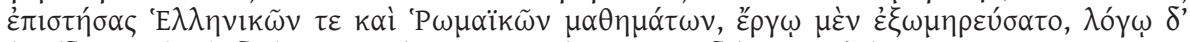

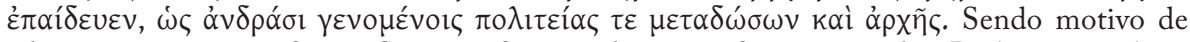
admiração por estes feitos, Sertório foi tratado com afecto junto dos Bárbaros, também porque, com o armamento, as disposições e as consígnias dos Romanos, retirou o desvario e a selvajaria da forma como lutavam e transformou um grande grupo de piratas num exército com poder. Além disso, usava, sem reservas, prata e ouro para embelezar os elmos e para adornar das mais diversas formas os escudos, e também os ensinou a usar clâmides e túnicas bordadas com flores. Por suportar os custos dessas coisas e pelo amor que nutria pela beleza, Sertório ia ganhando a confiança do povo. Mas conquistou-os sobretudo pelas suas acções em relação aos filhos deles. Reunindo em Osca, cidade importante, os que nasceram da mais nobre linhagem, colocou à sua disposição professores de matérias gregas e romanas. $\mathrm{Na}$ prática, tomava-os como reféns, mas educava-os com o argumento de que, ao chegarem à idade adulta, repartiriam a administração do Estado e também o poder. 
do poder romano.

Quanto a Êmenes de Cardia ${ }^{447}$ — a única personagem da época helenística que figura na produção biográfica de Cornélio $\operatorname{Nepos}^{448}$ a

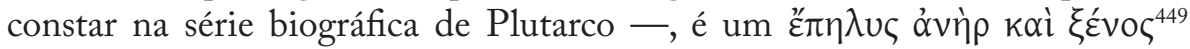
que desempenhou a exigente, mas pouco prestigiada ${ }^{450}$, função de primeiro

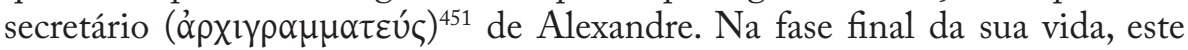
acabaria por nomeá-lo bipparchos ${ }^{452}$, tendo, após a morte do Macedónio, Eumenes vivido, como o único grego entre os sucessores ${ }^{453}$, momentos de grande tensão, muito por causa da disputa do poder. Fiel aos seus valores, distinguiu-se pelos seus dotes militares, pelo exercício da politeia e também pela sua capacidade diplomática.

Sobre a paideia de Êmenes, Plutarco é muito escasso nas informações que dá ao longo da biografia. É precisamente nas primeiras linhas que se encontram os elementos mais precisos: ${ }^{454}$

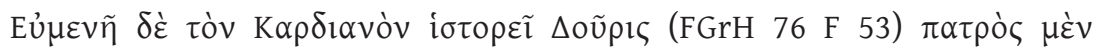

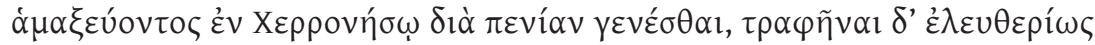

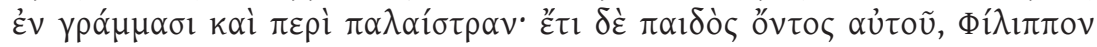

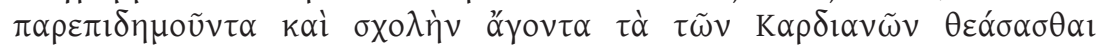

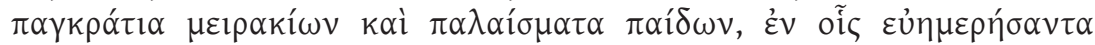

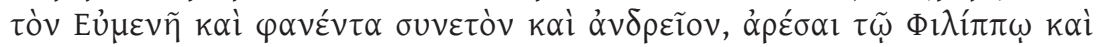
$\dot{\alpha} v \alpha \lambda \eta \varphi \theta \tilde{\eta} v \alpha 1$.

Dúris conta que Êmenes de Cardia tinha um pai que se tinha tornado cocheiro, no Queroneso, por causa da sua pobreza. Teve, porém, uma educação livre em letras e na palestra. Era ainda criança, quando Filipe, ao passar por ali e estando desocupado, foi ver o pancrácio dos jovens de Cardia e as lutas das crianças. Nestes, Êumenes teve tanto sucesso e manifestou tal inteligência e coragem que agradou a Filipe e este tomou-o a seu cargo.

${ }^{447} \mathrm{O}$ artigo de J. Geiger (1995: 173-185) discute vários elementos relevantes sobre a biografia de Êmenes, nomeadamente as fontes que Plutarco terá usado.

${ }_{448}$ Sobre a proximidade entre o retrato que Plutarco elabora de Êmenes e a biografia escrita pelo biógrafo romano, vide A. Bosworth (1992: 57).

${ }^{449}$ Eum. 8.1.

${ }^{450}$ Comp. Eum.-Sert. 1.2.

${ }^{451}$ Cf. Eum. 1.4.

${ }^{452}$ Cf. ibid. 1.5

${ }^{453}$ Cf. ibid. 3.

${ }^{454}$ Ibid. 1.1. 
Tendo como fonte Dúris ${ }^{455}$, um historiador nascido em Samos cerca do ano 340 a. C., Plutarco regista que, apesar de o pai de Êmenes ser pobre, este teve acesso a uma educação digna de um jovem livre: por um lado, ensinamentos de escrita, leitura e contacto com os primeiros textos literários

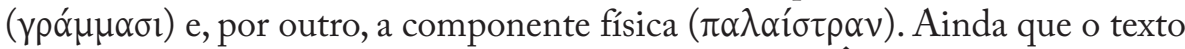
seja muito vago, sem especificar o nome dos mestres, Êmenes terá recebido alguns ensinamentos de Filipe, filho de Amintas, que se encarregou da sua educação, persuadido pelas suas capacidades.

Apesar da sua origem humilde, Êmenes conseguiu chegar a cargos importantes, graças às qualidades que evidenciava: inteligência, astúcia, determinação, fidelidade, capacidade de previsão, entre outras. De secretário de Alexandre, passou, após a morte de Filipe, no ano 336 a. C., a assumir funções de general. Êmenes, natural de Cardia, uma cidade na costa ocidental no Queroneso (Trácia), tem um percurso repleto de confrontos, polémicas, negociações, percurso em que vai fazendo inimigos que lhe prepararão um fim trágico.

Este homem de acção procura, tal como Sertório, manter-se fiel aos seus princípios, mesmo quando lhe fazem propostas aliciantes. É o caso de Cratero e Antípatro que lhe sugerem que abandone Perdicas e passe para o lado deles, a troco da manutenção das satrapias que detinha, a que se juntariam outros territórios. A posição de Êmenes perante esta proposta é clara: jamais pensa trair Perdicas para passar a tratar Antípatro, o mais prestigiado dos Macedónios, como amigo, ele que era um antigo inimigo seu ${ }^{456}$. Assim, a lealdade que devota à dinastia alexandrina e a luta que promove para manter a sua unidade são qualidades que Plutarco não deixa de explorar, mais valorizadas ainda pelo facto de Êmenes ser um homem de convicções fortes, que não teme discordar de Alexandre ou opor-se a Heféstion, o melhor amigo daquele ${ }^{457}$.

A sua acção ganhou maior importância após a morte de Alexandre, em Junho de 323 a. C., pois Êmenes, entre os Macedónios, teve uma atitude neutral e, assistindo à debandada dos companheiros de Alexandre, permaneceu na Babilónia com o intuito de apaziguar os soldados. Nas suas relações com Leonato, Antígono, Perdicas, Cratero, Neoptólemo e Antípatro, bem como nas acções que desenvolve nas satrapias que lhe foram destinadas (Capadócia,

${ }^{455}$ É a única fonte nomeada em toda a biografia (cf. Eum.1.1 = FGrH 76 F 53); juntamente com Jerónimo de Cardia, amigo de Êmenes, são as duas fontes privilegiadas para se conhecer a vida de Êumenes, ainda que Jerónimo apareça apenas como alguém que foi enviado por Antígona para estabelecer um tratado com Êmenes (vide Eum.12.1 (cf. Diod. 18.50.4)); curiosamente, Políbio nunca refere o nome de Êumenes na sua obra historiográfica.

${ }^{456}$ Cf. Eum. 5.5.

${ }^{457}$ Cf. ibid. 2. 
Paflagónia e a costa meridional do Ponto Euxino até Trapezunte) ${ }^{458}$, Êmenes, deixando-se, por vezes, conduzir por antigos ódios ( $\mu 1 \sigma o v \tilde{v \tau \varepsilon \varsigma ~ . . . ~ \pi ⿱ \alpha ́ \lambda ~} \alpha \mathrm{l})$ e pela ira (ỏpyń), em particular no confronto com Neoptólemo ${ }^{459}$, vê crescer a sua

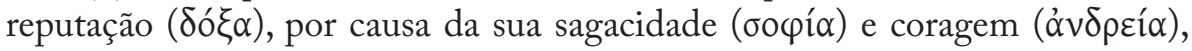

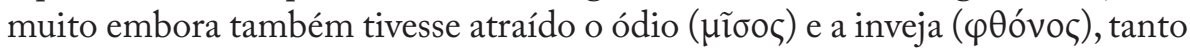
dos seus companheiros como dos inimigos ${ }^{460}$.

Obtendo a bonomia dos seus soldados, por meio da divisão dos despojos de guerra por todos, trava o ímpeto de Antígono e Antípatro, que tinham a missão de lutar contra ele, logo após a morte de Cratero. Consegue mesmo aumentar a popularidade entre as suas tropas, condição importante para o êxito, que se deve ao seu valor pessoal: ${ }^{461}$

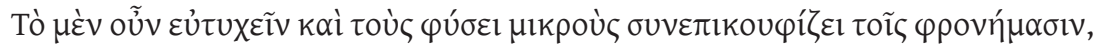

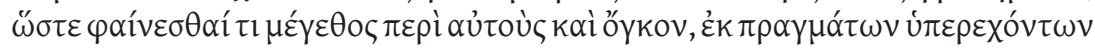

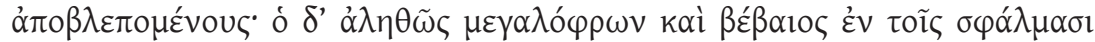

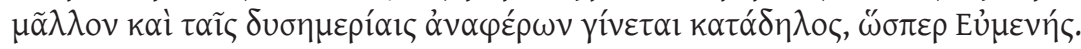

Em verdade, o sucesso engrandece o espírito, até dos que têm uma natureza débil, de tal forma que, elevando-se acima das acções, brilha sobre eles uma certa grandeza e esplendor. Mas o homem verdadeiramente generoso e firme mostra que o é nas desgraças e nos fracassos, como Êmenes.

Fazendo uso da sua inteligência e vocação para delinear estratégias, Êmenes possui, segundo Plutarco, uma mente tão polivalente quanto a sua

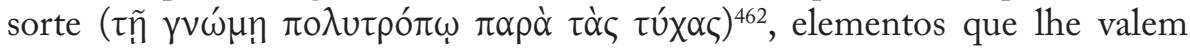
uma vida cheia de peripécias, um pouco à semelhança da sua morte. Perante a multidão, num discurso muito emotivo, argumenta que não merece receber tal castigo $^{463}$, o de ser um troféu para os Macedónios, se estes quiserem ser dignos vencedores. Neste momento de grande intensidade, relembra uma qualidade que ele próprio procurou cultivar durante a sua vida, a boa-fé, agora que se vê traído pelos seus supostos amigos. Acaba por pedir a morte ou, em opção, que o libertem para ele próprio acabar com a sua vida, de modo a manterem as mãos limpas ${ }^{464}$. Nem uma nem outra prece foram atendidas por Antígono, que só mais tarde permitiria a sua morte, tendo Êmenes mantido o seu orgulho

\footnotetext{
${ }^{458}$ Cf. ibid. 3.2.

${ }^{459}$ Cf. ibid. 7.7-8

${ }^{460}$ Cf. ibid. 8.1.

${ }^{461}$ Ibid. 9.1-2.

${ }^{462}$ Ibid. 16.6.

${ }^{463}$ Cf. ibid. 17.6-9.

${ }^{464}$ Cf. ibid. 17.6-11.
} 


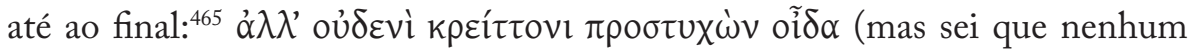
dos que encontrei é mais forte que eu).

$\mathrm{Na}$ synkrisis, Plutarco procura justificar como a guerra se cruzou, de forma distinta, na vida de Sertório e Êumenes. Sertório, um Romano prestigiado, liderou homens (Iberos e Lusitanos) com costumes bárbaros, incutindo-lhes hábitos de vida civilizados e uma organização baseada na justiça, enquanto Êmenes, um Grego, chefiou Macedónios, acima de tudo porque estes eram incapazes de se autocomandar e por lhe reconhecerem mérito. Êumenes teve um início de vida modesto e com muitos obstáculos, contrariamente a Sertório, que foi senador e general ${ }^{466}$.

Apesar de terem uma capacidade militar semelhante, a guerra tem um significado distinto para cada um deles: ${ }^{467}$

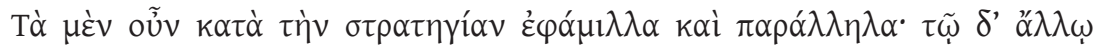

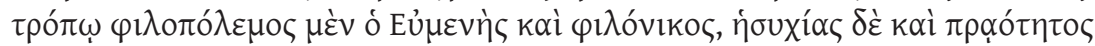

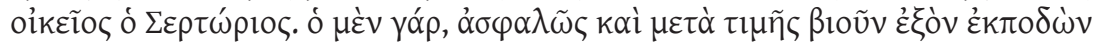

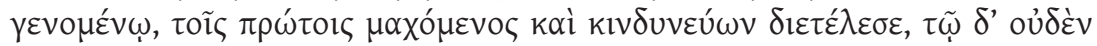

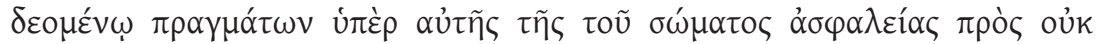

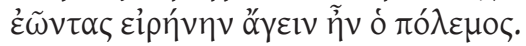

Em relação à capacidade militar rivalizam e têm semelhanças. Porém, no que diz respeito ao carácter, Êumenes amava a guerra e a disputa, enquanto Sertório apreciava a tranquilidade e a afabilidade. Aquele, podendo viver tranquilamente com honra, longe dos acontecimentos, passou a vida a lutar e a correr riscos na linha da frente; Sertório, por seu lado, sem desejar confrontos, empreendeu a guerra contra os que não permitiam a paz, em favor da segurança da sua própria vida.

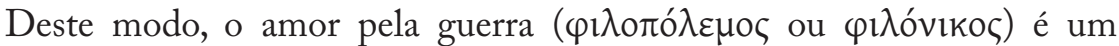
traço do carácter de Êmenes, enquanto Sertório preferia uma vida tranquila

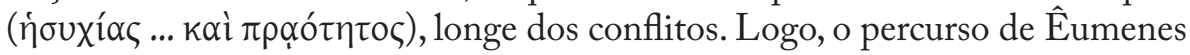
inicia-se com a sua ambição, que o leva a combater, para garantir a sua defesa (em resumo, ambição-guerra-segurança). Sertório, por sua vez, privilegia a segurança, acabando por passar a vida em lutas constantes, pelas quais adquire

\footnotetext{
${ }^{465}$ Ibid.18.8; em 10.4, num registo semelhante, Êumenes afirma que não considera ninguém superior a ele, enquanto se mantém na posse da sua espada.

${ }^{466}$ Pelas qualidades que patenteou na sua vida política e pelo respeito que os soldados tinham na sua autoridade, L. Garcia Moreno (1992: 134) coloca em oposição Sula e Sertório, afirmando: "Sertorius being the last representative of the old Roman generals and Sulla the father of the corrupt new soldier-general relationship".

${ }^{467}$ Comp. Sert.-Eum. 2.1.
} 
grande renome. Em resumo, a sua vida testemunha que o desejo de segurança o leva à guerra e esta fá-lo atingir a fama (segurança-guerra-fama). Têm, assim, objectivos distintos, mas os acontecimentos e a tyche levaram-nos a uma semelhante empresa: a guerra ${ }^{468}$.

Plutarco termina a synkrisis com a comparação da morte dos dois heróis, tendo Sertório sido surpreendido, enquanto Êmenes já esperava o seu fim. Além disso, considera Plutarco que a morte de Sertório não foi, de modo algum, digna do valor que ele evidenciou durante a vida, ao passo que Êmenes não soube enfrentar a morte com humildade ${ }^{469}$. Aliás, este acaba por ser mais um argumento para se defender a preferência de Plutarco por Sertório, pois constrói um retrato idealizado deste, sublimando as suas acções com a noção de que até as naturezas mais excelentes podem ser alteradas por efeito de infortúnios e sofrimentos involuntários. Nessa perspectiva, Sertório não é um traidor, pois a ele se deve a introdução de costumes romanos entre Iberos e Lusitanos ${ }^{470}$, sinal que se manteve fiel à sua romanidade.

Pode dizer-se que, neste par, a falta de elementos sobre a paideia é proporcional ao enorme espaço que os confrontos e as acções militares ocupam na narrativa biográfica, não sendo por isso fácil estabelecer uma relação inequívoca entre a paideia e os valores que enformam ambas as naturezas. O percurso de vida destes dois "estrangeiros" e "desterrados" foi o reflexo de uma insuficiente etapa formativa? As palavras de Plutarco não permitem uma resposta taxativa. Parece-nos, no entanto, ser possível afirmar que Êumenes e Sertório foram vencidos pelas acções que promoveram ou pelas opções que foram obrigados a tomar, não tendo sido a paideia deles suficiente para proteger a sua natureza contra acções exteriores, pois tanto Êumenes como Sertório são, usando uma metáfora agrícola, "campos férteis sem cultivo" ${ }^{471}$. Este par é ainda um exemplo de que Plutarco não tem por objectivo mostrar a superioridade dos Gregos, pois Êumenes em nada mostra ser mais culto do que Sertório, teo este inclusive procurado didaskaloi gregos e romanos para os barbaroi.

\subsubsection{Philopoemen-Flamininus}

Este par tem, desde logo, como curiosidade o facto de Filopémen e Flaminino serem contemporâneos e as suas vidas se terem cruzado, além de as suas biografias reflectirem a intervenção de Roma na Grécia ${ }^{472}$. A Grécia

\footnotetext{
${ }^{468}$ Vide análise da synkrisis em J. Boulogne (1994: 67-8).

${ }^{469}$ Coragem na hora da morte em Comp. Sert.-Eum. 2.6-8; parece haver alguma contradição com aquilo que Plutarco escreveu em Eum. 17-19.

${ }^{470}$ Cf. Sert. 22. Recordamos as palavras que Corneille coloca na boca do protagonista: "Rome n' est plus dans Rome, elle est toute où je suis." (Sertorius, Acto III, Cena $1^{\text {a }}$ ).

${ }^{471}$ Cf. Cor.1.2; vide ainda o prólogo do par Demetr.-Ant., analisado na Parte I.

${ }^{472}$ Recorde-se que, em Novembro de 67, Nero proclamou, em Corinto, por altura dos Jogos
} 
e aquilo que cada um dos dois fez por ela tornam-se o elemento central da narrativa, bem representado pela philonikia de Filopémen e pela philotimia de Flaminino ${ }^{473}$. Quanto a Flaminino, procônsul na Grécia, entre 197 e 194 a. C. ${ }^{474}$, desenvolveu várias acções na Hélade, como a guerra contra Nábis ${ }^{475}$, tirano de Esparta (195 a. C., primeira fase; 193-192 a. C., segunda fase), chegando mesmo a lutar, em conjunto com Diófanes, contra Filopémen, quando este defendia Esparta (191 a. C.). Filopémen, por sua vez, participou em diversos confrontos, como bem atestam as oito vezes em que exerceu as funções de estratego, embora o seu mérito se tenha construído nas guerras contra os seus compatriotas. Desta forma, ambas as vidas são marcadas por

Nemeus, a liberdade da Grécia (cf. Flam.12.13; D. Hal. 63.11.1 e Paus. 7.17.2), apesar de,

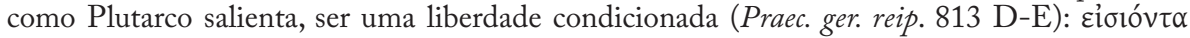

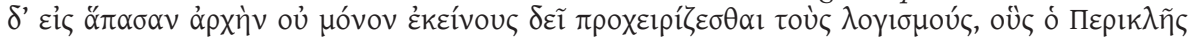

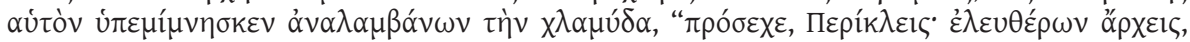

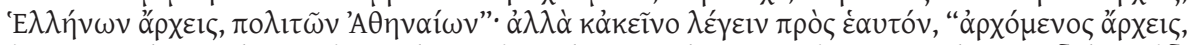

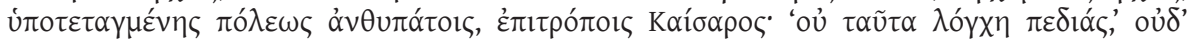

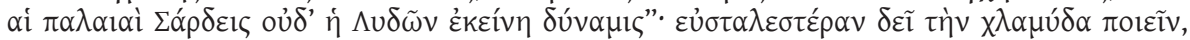

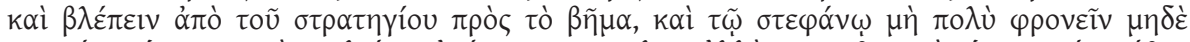

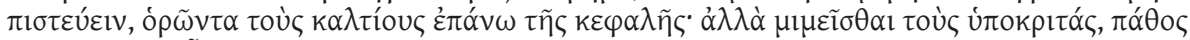
$\mu \varepsilon \dot{v}$ ’

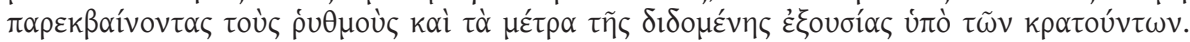
Quando se chega a um cargo, é necessário não apenas ter presente as reflexões que Péricles, ao vestir a clâmide, lembrava a si próprio: "Tem cuidado, Péricles, governas homens livres, governas Gregos, cidadãos Atenienses". Mas é também necessário dizer a si próprio: "Governas e ao mesmo tempo és governado, pois a tua cidade está submetida aos procônsules e aos procuradores de César". "Estas não são planícies de combate" [cf. Soph. Tr. 1058], nem a antiga Sardes, nem o poder dos Lídios. É preciso fazer uma clâmide mais modesta e olhar do acampamento de estratego para a tribuna; não se orgulhar muito com a coroa nem confiar muito nela, vendo o calçado dos Romanos por cima da cabeça. Convém antes imitar os actores que colocam na acção dramática a sua própria emoção, o carácter e a dignidade, ouvindo o ponto e não transgredindo o ritmo e os metros da liberdade concedida por aqueles que dirigem. Este texto descreve como a liberdade governativa dos Gregos era limitada, tão limitada quanto a arte de representar, pois cabia aos Romanos, aqueles que verdadeiramente detinham o poder, marcar o ritmo da actividade política. O acto de libertar a Grécia é também um sinal de piedade pela situação de declínio que se vivia na pátria, que outrora tinha vivido e participado em momentos prodigiosos; vide, ainda, as relações entre a Grécia e Roma, em Phil.17, onde mais uma vez Plutarco atribui à intervenção divina (daimon) e à tyche o poder dos Romanos. A propósito desta comparação, vide R. Aguilar (1984: 424), F. Becchi (1995: 57-60) e S. Swain (1998: 177-8). Sobre a decisão de Nero na literatura latina, vide Suet. Nero 24.2 e Plin. Nat. 4.22.

${ }^{473} \mathrm{O}$ facto de associar a philonikia e a philotimia num mesmo par biográfico suscita diversas interpretações, que abordaremos ao longo da nossa exposição, mas convém, desde já, referir que esses vocábulos reflectem o espírito agonístico da cultura grega. $\mathrm{Na}$ época de Plutarco, com toda a instabilidade social que se vivia e para a qual terá contribuído o domínio romano, luta-se muitas vezes pela promoção nas hierarquias governamentais; vide, a este propósito, T. Whitmarsh (2005: 37-40), que, sem dar o exemplo do par Phil.-Flam., recorre a textos de Filóstrato e Élio Aristides para provar essa competição.

${ }^{474}$ Em Flam. 20.1, Plutarco diz-nos que Flaminino foi, por sua vontade, tribuno militar após ter sido cônsul; cf. Cat. Ma.12.1.

${ }^{475}$ Cf. J.-L. Ferrary (1988: 88-95). 
numerosas descrições de combates, com o aliciante de Filopémen viver numa época de declínio helénico e Flaminino, pelo contrário, participar na expansão e consolidação do Império Romano.

Como acontece em diversas biografias, é logo no prólogo que Plutarco nos dá algumas informações sobre a paideia e sobre a philonikia de Filopémen: ${ }^{476}$

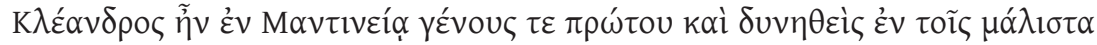

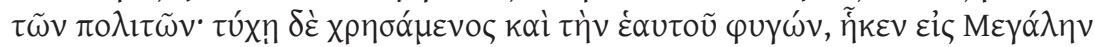
$\pi \operatorname{có}_{\imath} v$ oủx

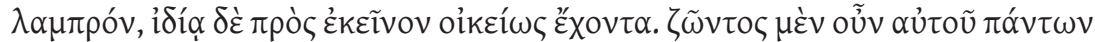

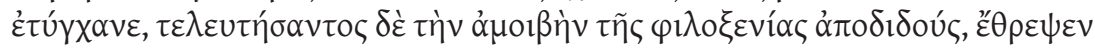

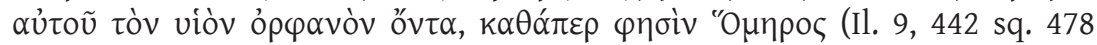

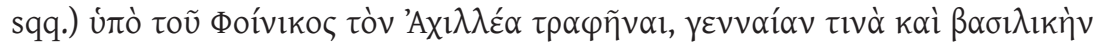

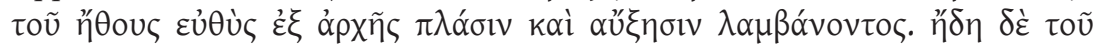

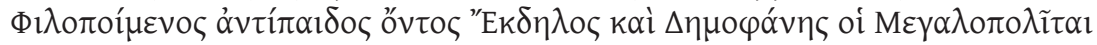

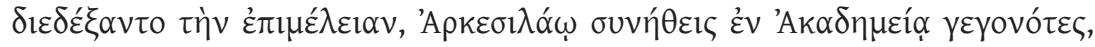

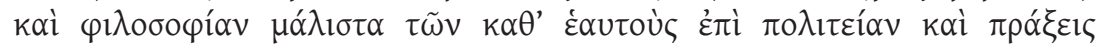

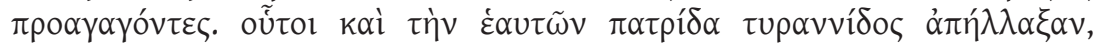

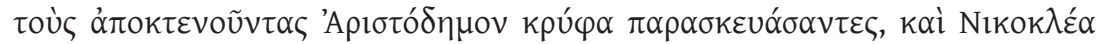

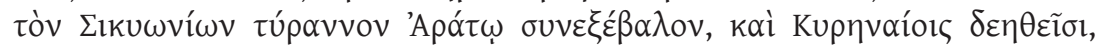

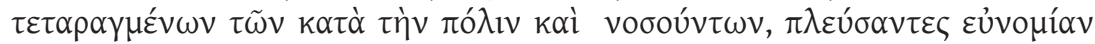

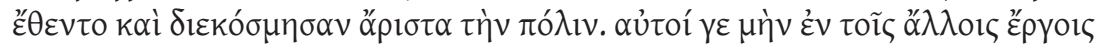

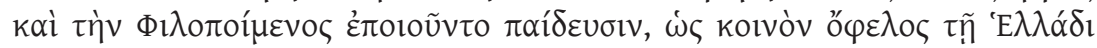

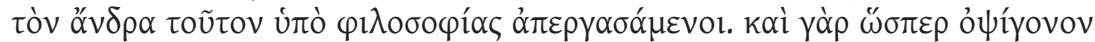

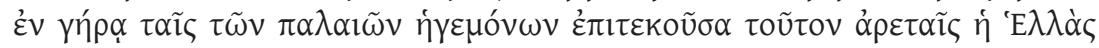

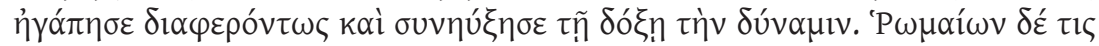

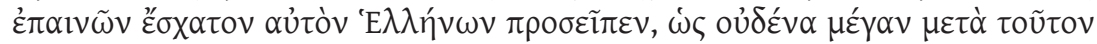

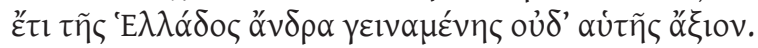

Cleandro pertencia a uma família ilustre de Mantineia e era um dos mais poderosos de entre os cidadãos, mas, tendo caído em desgraça, teve necessidade de fugir, dirigindo-se para Megalópolis, sobretudo por causa do pai de Filopémen, Cráugis, em tudo um homem brilhante, com quem teve uma relação particularmente próxima. Enquanto este viveu, Cleandro manteve tudo, mas, logo após a morte de Cráugis, como forma de compensar a sua hospitalidade, criou o filho dele, agora órfão, como Homero disse que Aquiles foi criado por Fénix, modelando e desenvolvendo de imediato, desde o princípio, a nobreza e a realeza do seu carácter. Quando Filopémen já estava a sair da infância, os Megalopolitas, Ecdelo e Demófanes, passaram a cuidar dele; eram discípulos de Arcesilau na Academia e estimularam, mais que os seus contemporâneos, a filosofia para a política e a acção. Os dois também libertaram a sua pátria da tirania, ao prepararem secretamente a morte de Aristodemo, além de terem

${ }^{476}$ Phil.1.1-7. 
ajudado Arato a capturar Nicocles, tirano de Sícion; atendendo à agitação e à má situação que dominava a cidade, e em resposta ao pedido dos Cirineus, eles, fazendo uma travessia por mar, estabeleceram a ordem e organizaram melhor a cidade. Entre outras tarefas, eles próprios se encarregariam também da educação de Filopémen, para edificarem pela filosofia um homem que fosse um bem para a Grécia. De facto, a Grécia, tendo gerado Filopémen na velhice como um rebento tardio, com as virtudes dos antigos comandantes, amou-o de forma especial e fez aumentar, simultaneamente, o poder e a glória. Um Romano, em sinal de louvor, chamou-o "o último dos Gregos", uma vez que, depois dele, a Grécia não haveria de gerar nenhum homem grande nem digno de Filopémen.

Filopémen, "o último dos Gregos" - epíteto que pode ser entendido como um elogio ou como uma forma de desprestígio dos seus sucessores e da politeia grega - recebe de Cleandro, após a morte do seu pai ${ }^{477}$, uma educação vocacionada para o ethos e de dois Megalopolitas, Ecdelo e Demófanes ${ }^{478}$, formação filosófica, base essencial para a politeia e para se atingir a doxa.

Faz-se alusão a outros didaskaloi e paidagogoi, embora sem se mencionarem os respectivos nomes, numa altura em que Filopémen começava a aprender a arte guerreira, manifestando $\dot{\varepsilon} \xi \hat{\alpha} \rho x \tilde{\eta} \varsigma$ uma enorme coragem e entrega ao fervor

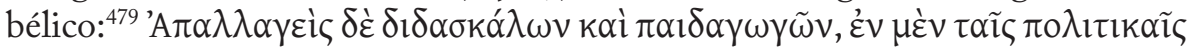

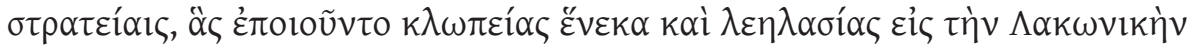

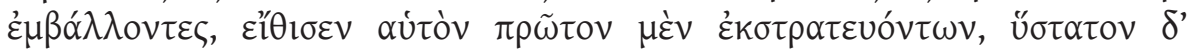

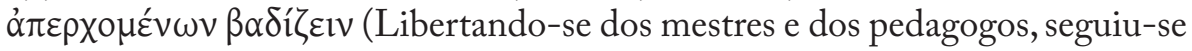
a formação militar. No ataque feito contra a Lacónia com o objectivo de roubar e pilhar, acostumou-se a ser o primeiro a empreender a marcha e o último a marchar para o regresso). Como se vê, Plutarco é muito vago quanto à fase inicial de formação de Filopémen, uma vez que não se refere às matérias que os didaskaloi e paidagogoi (mantemos a ordem do texto, facto que não costuma ser normal) privilegiaram. Parece, no entanto, que essa fase foi imediatamente sucedida por uma outra, mais vocacionada para a arte guerreira, facto que terá marcado de forma decisiva o ethos do Grego.

Mais à frente, Plutarco faz referência a outros momentos da paideia de Filopémen: ${ }^{480}$

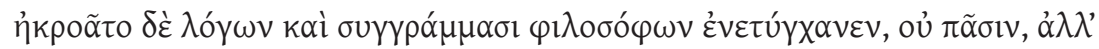

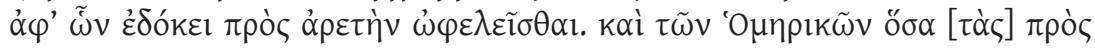

${ }^{477}$ Cf. Pol. 10.22.1; Políbio, uma das fontes de Plutarco para esta biografia, dá conta da origem aristocrática do pai de Filopémen.

${ }^{478}$ Cf. Pol. 10.22.10; Plutarco, em Arat. 5, refere apenas Ecdelo.

${ }^{479}$ Phil.4.1.

${ }^{480}$ Phil. 4.6-10. 


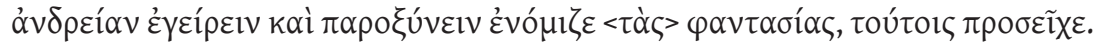

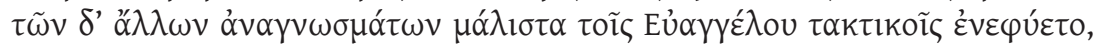

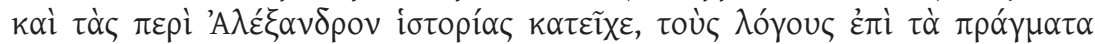

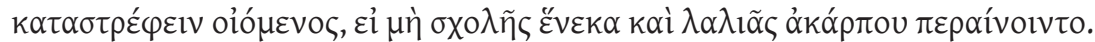

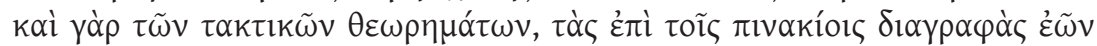

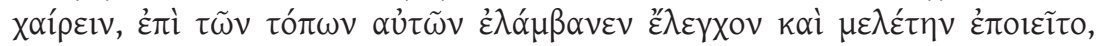

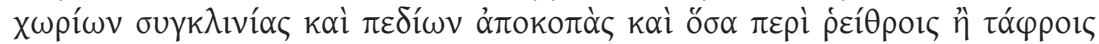

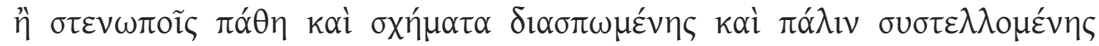

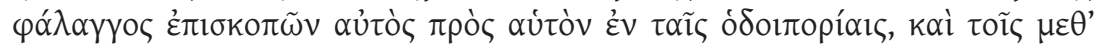

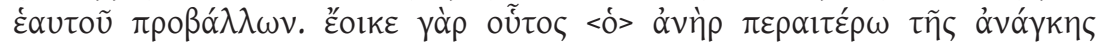

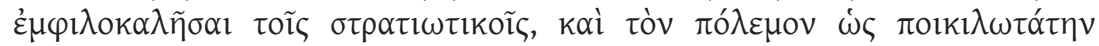

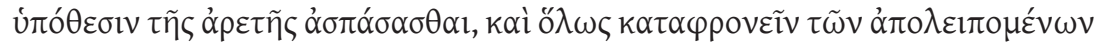
$\dot{\omega} \varsigma \alpha \grave{\alpha} \pi \rho \alpha ́ k \tau \omega v$.

Ouvia atentamente as lições dos filósofos e lia as obras deles, não todas, mas as que lhe pareciam ter utilidade para a virtude. Quanto aos Poemas Homéricos, ele voltava a sua atenção para os episódios que fortaleciam a coragem e estimulavam a imaginação. Em relação a outras leituras, ele inspirava-se sobretudo nas Tácticas de Evângelo e dedicava-se às histórias sobre Alexandre, por pensar que as palavras conduzem às acções, se elas não se deixarem invadir pela ociosidade e tagarelice estéreis. De facto, a partir dos estudos de táctica, ele tomava a liberdade de desenhar as estratégias nas tabuinhas, e nestas apontava informações e delineava o exercício (...). De facto, este homem parecia perseguir a honra na vida militar mais do que o necessário, tendo-se entregado à guerra como a ocupação mais diversificada para mostrar o seu valor, e desprezava os que desanimavam como se fossem inúteis.

Pode-se afirmar que, da mesma forma que Filopémen desejava mediante a leitura dos Poemas Homéricos e das Tácticas de Evângelo, uma obra provavelmente da época helenística, enriquecer a sua cultura guerreira (a arete e a andreia), também Plutarco, acreditando no valor da palavra, desejava que os leitores das Vitae sentissem o impulso de emular as diversas aretai ${ }^{481}$. No caso de Filopémen, ressalta o seu sentido prático e a sua capacidade de organização, entregando-se de forma algo excessiva ao confronto, sinal da sua philonikia ${ }^{482}$. Embora Filopémen manifestasse pouco interesse por matérias mais filosóficas,

${ }^{481} \mathrm{Em}$ De prof. in uirt. 79D, aludindo à leitura de Tucídides e Xenofonte, defende que só progridem ( $\pi \rho \circ$ ó́ $\pi \eta)$ os que tiram proveito prático das leituras e não aqueles que se limitam a admirar a linguagem ou o estilo, pois Plutarco dá muito valor à conexão entre palavra e acção, bem como à necessidade e à verdade nas realizações humanas.

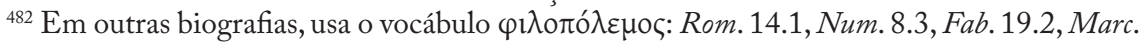
1.2, Comp. Sert.-Eum. 2.1 e 2.5. 
a pouca preocupação que tinha com a aparência ${ }^{483}$, o carácter incorruptível ${ }^{184} \mathrm{e}$, em especial, a luta persistente pela liberdade, podem ser interpretados como o resultado da sua formação. Terá sido, contudo, insuficiente para aplacar os seus acessos de cólera ${ }^{485}$.

Numa época de domínio romano, Filopémen cria nos seus compatriotas a esperança de que a dignidade e a grandeza de tempos passados poderão voltar. A forma brilhante e triunfal como se apresenta com a sua falange nas Nemeias é bastante sintomática a esse respeito. Plutarco conta o seguinte episódio sobre a sua entrada no teatro: ${ }^{486}$

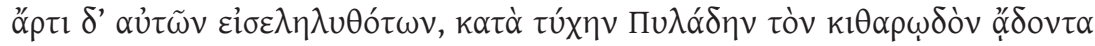

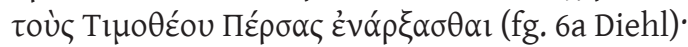

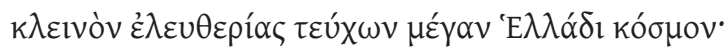

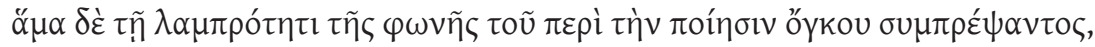

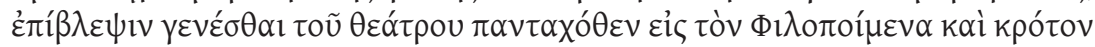

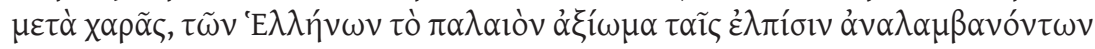

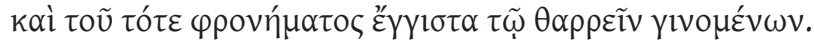

No preciso momento em que eles entraram, o citaredo Pílades começou por acaso a cantar os Persas de Timóteo ${ }^{487}$ :

"Ele criou para a Grécia a gloriosa e grande ordem da liberdade."

Estando a solenidade do poema em sintonia com o brilho da sua voz, todos os que estavam no teatro dirigiram o olhar para Filopémen e aplaudiram-no com regozijo, pois os Gregos tinham a esperança de retomar a antiga dignidade e a confiança de se aproximarem mais da grandeza de outrora.

Isto revela como um homem que inicialmente não inspirava confiança, por ter ainda uma reputação insignificante ${ }^{488}$, conseguiu por mérito das suas acções $^{489}$ granjear notoriedade e tornar-se uma esperança para os Gregos. Reconhecendo as suas capacidades, Antígono oferece-lhe um lugar de comando e dinheiro, mas ele, convicto de que não tinha um carácter favorável

${ }^{483}$ Cf. Phil. 2.2-4.

${ }^{484}$ Cf. ibid. $15.7-12$.

${ }^{485}$ Cf. ibid. 13.8 e 17.5 .

${ }^{486}$ Ibid. 11.3-4.

${ }^{487}$ Poeta do século $\mathrm{V}$ a. C. que escreveu, pelos fragmentos que nos chegaram, um poema a celebrar a vitória de Salamina.

${ }^{488}$ Cf. ibid. 6.7.

${ }^{489}$ Cf. ibid. 6. 
para um posto subalterno, recusa. No entanto, pelos seus feitos em Creta ${ }^{490}$, é nomeado hiparco (210-209 a. C.) no regresso a Atenass ${ }^{491}$.

Se Arato, que exerceu importante papel na Confederação Aqueia, praticou uma política essencialmente helénica e procurou tomar decisões com alguma humanidade ${ }^{492}$, numa época em que os Aqueus colocaram de lado as divisões para formarem um único bloco, Filopémen assumiu-se sobretudo como um guerreiro, com sede de vitória e muito menos amistoso ${ }^{493}$, uma vez que não se satisfazia em parecer o melhor, mas em sê-lo na realidade ${ }^{494}$.

A philotimia 495 de Flaminino e a philonikia de Filopémen são, sem dúvida, elementos estruturantes das biografias, conferindo-lhes unidade e coerência. ${ }^{496}$ Filopémen, mesmo sendo um homem admirável, trouxe à Grécia um conflito com terríveis consequências, além de, por via da sua philonikia, ter provocado a morte a mais Gregos do que Flaminino ${ }^{497}$. Este par demonstra como a tradicional oposição entre Gregos e Romanos não faz muito sentido no pensamento de Plutarco, ou seja, de um lado a cultura, os valores, a arte, a ciência, a filosofia e do lado dos descendentes de Rómulo a ambição guerreira

${ }^{490}$ Haveria de partir de novo para Creta, acção que foi entendida como deserção porque a sua pátria estava em guerra com Nábis. Só a intervenção de Aristainos evitaria que fosse condenado (cf. Phil. 13).

${ }^{491}$ Cf. ibid. 7.5.

${ }^{492}$ Cf. Marc. 3.6.

${ }^{493}$ Cf. Phil. 8.

${ }^{494}$ Cf. ibid. 15.7; vide também Arist. 3.5.

495 Traço do carácter, ligado à andreia e à tolma, com uma componente psicológica e social e que distingue o que participa no combate (cf. F. Frazier (1996: 199-200)), não sendo de estranhar que o substantivo ocorra mais de duzentas vezes nas obras de Plutarco; é, realce-se, na biografia de César que mais vezes ocorre (5.9, 6.1, 6.3, 7.2, 11.3, 17.1, 17.2, 54.4); Plutarco associa a philotimia à idade avançada, como avisa no tratado An seni resp. (785C-D, 793D, 794A) e se nota nas biografias de Luculo (38.3-4), Mário (2.4) e na do próprio Flaminino (20.1-2); cf. n. 472 .

496 Sobre a semelhança entre philonikia e philotimia, vide S. Swain (1988:344). A semelhança é clara quando Plutarco atribui a philotimia a Flaminino (cf. Flam. 7.2, 13.2); refira-se que Plutarco critica a philotimia dos Gracos (cf. Ag./Cleom. 2), mas não repete a crítica em relação à desmesurada philotimia de César; aliás, chega a elogiar a philotimia que em algumas situações Filopémen evidenciou (cf. Phil. 6.10); C. Pelling (1995: 359), numa leitura mais abrangente, prefere opor a philonikia à liberdade: "La liberta è tuttora preziosa e stimolante, la litigiosità sempre un pericolo"; vide, ainda, F. Frazier (1988a: 120 ss.), sobre a relação entre estas duas motivações psicológicas e princípios morais, que surgem na obra de Plutarco não como kakiai, mas como a expressão dos pathe, que é também um termo ambivalente. Já Platão havia associado a philonikia e a philotimia (Resp. 548C), relacionando-as com o thymos, não deixando de expressar que tanto podem ter um sentido pejorativo como positivo; as biografias de Lys. e Ages. são outro exemplo de como Plutarco deplora as formas excessivas com que se manifesta a philotimia e a philonikia (cf. Ages. 8.1-3 e Lys.23.11-13). No caso de Lisandro, é dito que a sua philotimia advém da educação espartana. Sobre a philotimia como uma motivação incorrecta da politeia, vide Max.cum princ. 777E-778A, An seni resp. 788C e 790C, Praec. ger. reip. 815C, 819F-821F.

${ }^{497}$ Cf. Comp. Phil.-Flam.1.3. 
e a conquista. J. Walsh (1992: 217) escreveu, sobre este assunto, o seguinte: "What Greece needs now, Plutarch seems to be saying, are politicians who are the opposite of Philopoemen and like Flamininus". Julgamos, no entanto, que a proposta de Plutarco não iria tão longe, ao ponto de recusar a Filopémen um lugar na política grega. Este não deixa, afinal, de ser um cidadão com espírito patriótico, valor tão importante para o autor, que se entregou aos seus ideais de forma abnegada ${ }^{498}$, até porque era um inimigo da $\sigma \chi 0 \lambda \eta^{499}$.

Quando tenta demover Diófanes de atacar Esparta por causa da ameaça

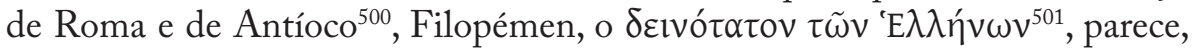
à primeira vista, seguir o conselho de Plutarco no tratado Praecepta gerendae reipublicae $e^{502}$, onde pede aos seus compatriotas para serem sensatos, de modo a não suscitarem nos Romanos o desejo de uma intervenção mais implacável. Diófanes não segue o conselho e, com a ajuda de Flaminino, ataca Esparta, onde depara com a oposição do próprio Filopémen ${ }^{503}$. Posteriormente, Plutarco encontrará o momento para realçar a luta de Filopémen pela liberdade contra

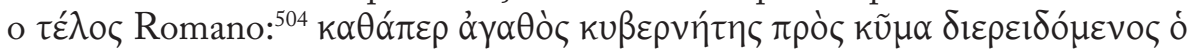

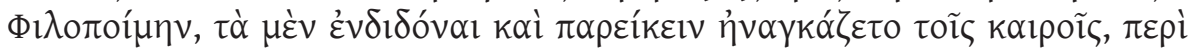

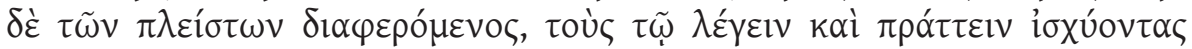

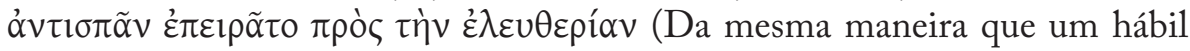
piloto resiste às ondas, assim Filopémen estava forçado a ceder e a sucumbir às circunstâncias. Mas, como de costume, ele resistia e esforçava-se por incitar à liberdade os que tinham poder para falar e agir). Plutarco, um phileleutheros, não disfarça a aprovação da atitude do herói, pois Filopémen não desiste de lutar, como aquele que tenta vencer a força das ondas, que metaforicamente representam os Romanos ${ }^{505}$, tentando convencer outros a preservar a liberdade.

Temos, assim, duas atitudes diferentes: enquanto Diófanes aceita a ajuda dos Romanos para sustentar a hegemonia aqueia, Filopémen, pelo contrário, mantém o seu espírito patriótico, em defesa do espaço e dos valores helénicos ${ }^{506}$.

${ }^{498}$ C. Pelling (1997: 139-47 e 309-18) discorda de J. Walsh, enquanto S. Swain (1988: 3457) faz uma leitura mais equilibrada.

${ }^{499}$ Cf. Phil. 13.5.

${ }^{500}$ Cf. Phil. 16.

${ }^{501}$ Flam. 13.3.

${ }^{502}$ Cf. 814E-815B.

${ }^{503}$ É com este tom laudatório que Plutarco descreve a atitude de Filopémen: $\alpha$ $\gamma \alpha v \alpha \kappa \tau \eta ́ \sigma \alpha \varsigma$

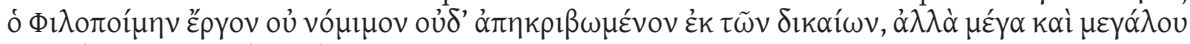

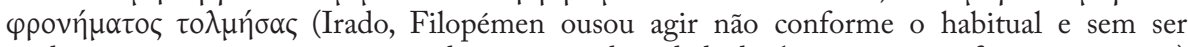
evidentemente justo, mas com grandeza e com a dignidade de alguém com um forte sentimento) (Phil.16.3).

${ }^{504}$ Phil. 17.3.

${ }^{505}$ Cf. Marc. 11.1, Caes. 28.3, 34.3 e Cat. Ma.19.7.

${ }^{506}$ E. Gruen (1986r: 462-480) faz uma leitura mais abrangente deste episódio, considerando que se trata de uma luta pelo poder no Peloponeso. 
Será, contudo, pelo facto de ser intransigente no seu orgulho e por não querer ceder aos Romanos que o próprio Filopémen se transforma no principal motivo da intervenção daqueles ${ }^{507}$. Plutarco pretende, com isto, chamar a atenção dos Gregos para, sem prescindir por completo da sua natureza, dos seus ideais e dos seus costumes, terem uma atitude sábia em relação aos Romanos. Essa sabedoria passava, sobretudo, pela manutenção de alguns lugares na hierarquia governativa, o que impediria os Romanos de anular a posição das elites gregas, habituadas a deter o poder.

A juntar a isso, Filopémen revelou em Esparta, já na qualidade de strategos, e depois de ter serenado a agitação interna, um enorme desrespeito pelos cidadãos, pela cidade e pelos seus usos e costumes: trouxe os exilados para a cidade; mandou matar oitenta ou trezentos Espartanos, conforme as versões de Políbio e de Aristócrates, respectivamente; e derrubou as muralhas da cidade; concedeu aos Megalopolitas uma parte muito significativa do território espartano; os que haviam sido declarados cidadãos de Esparta pelos tiranos foram enviados para a $\mathrm{Acaia}^{508}$, com excepção de três mil; aos que não obedeceram a esta medida, vendeu-os e com o dinheiro angariado mandou erigir um pórtico a Megalópolis, que havia sido destruído pelos próprios Espartanos. Como se ainda não bastasse, Filopémen toma outras duas medidas que são sintomáticas da sua philonikia: ${ }^{509}$

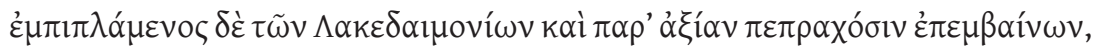

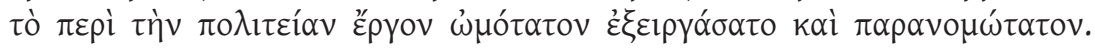

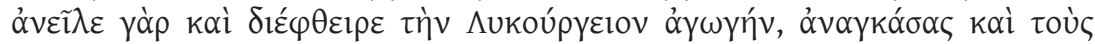

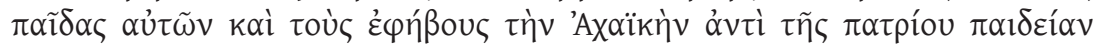

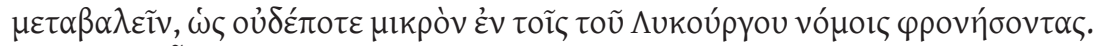

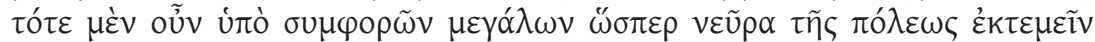

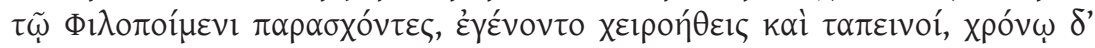

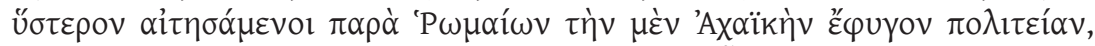

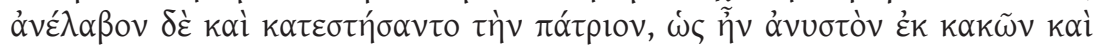
$\varphi \theta$

Saciando a sua ira contra os Lacedemónios e abusando de quem realizou acções meritórias, agiu da forma mais cruel e ilegal para com a constituição. Filopémen anulou e destruiu o sistema educativo de Licurgo, obrigando as crianças e os efebos a receber a educação aqueia em vez da tradicional, para que eles jamais reflectissem o quer que fosse sobre as leis de Licurgo. Nesse momento de grande infortúnio, eles, permitindo a Filopémen que, por assim dizer, cortasse os nervos da cidade, tornaram-se dóceis e humildes; algum tempo depois, os

\footnotetext{
${ }^{507}$ Cf. Phil. 17.

${ }^{508}$ Sobre a Acaia, a Grécia romana, vide S. Alcock (1996r: 14-17).

${ }^{509}$ Phil.16.7-9.
} 
Lacedemónios haveriam de pedir autorização aos Romanos para abandonarem o regime aqueu, tanto quanto era possível, depois de desgraças e de uma tão grande ruína.

Este texto aborda duas questões muito importantes: a substituição do sistema educativo de Licurgo e, associado a isso, a caracterização da paideia como forma de poder. Filopémen, sem ter consciência do que representava para os Lacedemónios esse sistema educativo e a própria legislação de Licurgo, pretende impor costumes aqueus, julgando que isso o ajudaria a consolidar o poder ${ }^{510}$. Assim, a abolição da constituição de Licurgo e a decisão de substituir a educação espartana pela aqueia são duas medidas que bem ilustram a philonikia de Filopémen ${ }^{511}$, defeito que surge associado à sua ópүท́. ${ }^{512}$ Embora

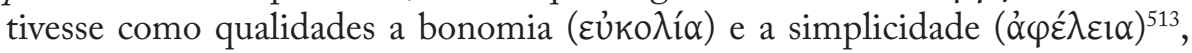

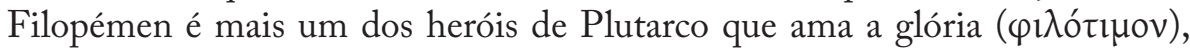
neste caso muito influenciada pela $\varphi \imath \lambda o v ı k i ́ \alpha$ e pela ó $\rho \eta^{514}$. Por causa dessa motivação, terá, provavelmente, direccionado a sua formação para a aquisição de conhecimentos que lhe pudessem ser úteis $(\chi \rho \eta \sigma i ́ \mu o r \zeta)^{515}$, para o combate e,

${ }^{510}$ Realce-se que esta atitude de Filopémen demonstra como a substituição ou anulação de hábitos, instituições ou leis nas poleis não era um processo pacífico. Muito mais fácil foi para Sertório apoiar-se na educação com o objectivo de conseguir a benevolência dos povos bárbaros.

${ }^{511}$ C. Pelling (1995: 356-8) considera que a destruição da constituição espartana é o clímax da philonikia de Filopémen.

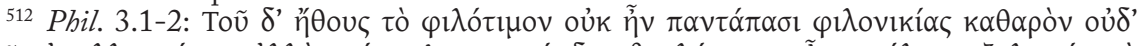

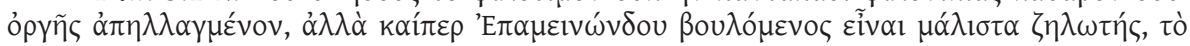

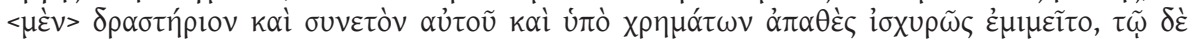

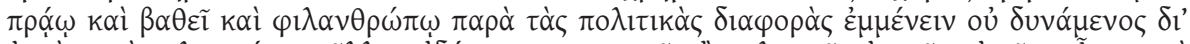

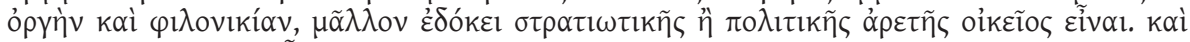

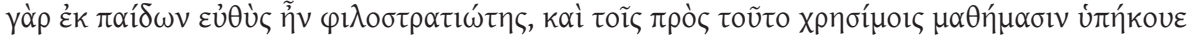

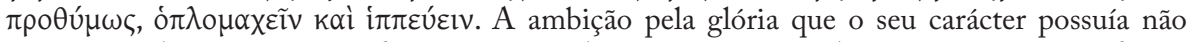
estava completamente isenta de uma certa inclinação para a querela e a ira, mas, com o desejo de, acima de tudo, imitar Epaminondas, Filopémen, por meio das suas façanhas, emulava com rigor a energia, a inteligência e a incorruptibilidade daquele, mas não conseguia ser fiel à sua doçura, gravidade e humanidade nas disputas políticas, por causa da sua cólera e carácter belicoso. Parecia, porém, que lhe era mais familiar a arte guerreira do que a política. De facto, logo demonstrou, desde a infância, amor pela vida militar e respondia de forma resoluta às matérias úteis para essa vida, como o combate com armas e a equitação.

${ }^{513}$ Cf. Phil. 2.1; a simplicidade está amiúde ligada à recusa da extravagância, como na biografia de Aristides, e o próprio Filopémen critica os hábitos sumptuosos dos soldados por considerá-los dispensáveis e pelo facto de o luxo provocar a $\mu \alpha \lambda \alpha$ kía (cf. 9.6-11); a mesma simplicidade, juntamente com a gravidade e carácter incorruptível, é realçada quando Filopémen recebe Timolau, um Espartano, enviado para lhe oferecer o dinheiro que conseguiram juntar com a venda dos bens de Nábis (cf. Phil. 15.5-11).

${ }^{514}$ Outras associações de $\varphi \imath \lambda$ ovıkía e ópyń em Them. 4.2, Cor. 21.6, Comp. Phil. -Flam. 1.4-1.6, Pyrrh. 21.15, Marc. 32.4, Pomp. 35.1, Phoc. 10.6, Cat. Mi. 51.3., Gracch. 9.3. Em Arist.

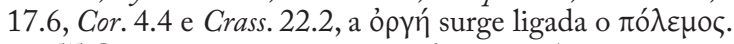

${ }^{515}$ Como úteis serão as amizades que cultivava para proveito da cidade (cf. Phil. 21.10-11). 
assim, satisfazer a sua $\varphi \imath \lambda o v i k i ́ \alpha$. Do mesmo modo que Timoleonte ${ }^{516}$ viu em Epaminondas o seu modelo, também Filopémen emula o estratego, homem de Estado e intelectual beócio ${ }^{517}$. Nesta synkrisis interna e paralela à que se faz entre Filopémen e Flaminino, Plutarco evidencia o facto de Epaminondas ter qualidades para se entregar à politeia e à guerra, enquanto Filopémen, por não

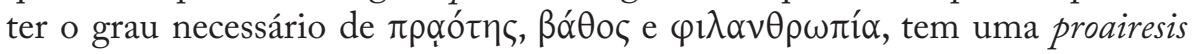
quase exclusivamente guerreira.

No final da sua vida ${ }^{518}$, muito embora ainda mantivesse alguma agilidade, Filopémen ambicionava mais a paz do que a guerra ${ }^{519}$, o que parece demonstrar que a philonikia se extinguia à medida que as forças físicas também diminuíam. Este homem, que ficaria conhecido pela luta audaz e brilhante ${ }^{520}$ que travou por amor à Grécia e à liberdade, entregar-se-ia de forma voluntária à morte, a qual provocou grande tristeza entre o povo.

Quanto a Flaminino, cuja vida se cruza com a de Filopémen, aparece

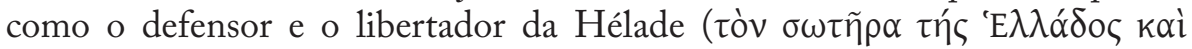
$\pi \rho o ́ \mu \alpha \chi o v)^{521}$, enquanto Filopémen, como vimos, luta pela liberdade helénica ${ }^{522}$

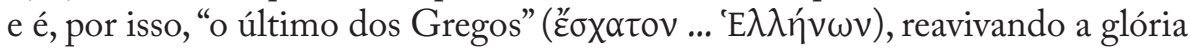
destes por muito tempo ${ }^{523}$. Não deixa de ser paradoxal que são precisamente aqueles contra quem Filopémen luta que restituem a liberdade aos Gregos ${ }^{524}$. De facto, é o próprio Flaminino quem o faz, na inesquecível cena dos Jogos Ístmicos, no ano 196 a .C. ${ }^{525}$. Serão os espectadores destes Jogos a explicar-nos

${ }^{516}$ Cf. Tim. 36.1.

${ }^{517}$ Em Phil. 14., Plutarco compara também Filopémen e Epaminondas, dizendo que ambos tinham menor capacidade no confronto naval, embora Filopémen, ao contrário de Epaminondas, estivesse erradamente convencido de que a arte de lutar por terra era suficiente para se lutar no mar.

518 C. Pelling (1989: 212-213) estabelece um paralelo entre a morte de Filopémen (Phil. 21.1-2) e a de Aníbal (Flam. 21.1-6), pois ambos são vítimas da falta de magnanimidade dos adversários.

${ }^{519}$ Cf. Phil.18.1.

${ }^{520}$ Cf. Phil.12.4-6; Praec. ger. reip. 817E.

${ }^{521}$ Flam. 10.7.

${ }^{522}$ Cf. Phil. 8.3, 10, 12.2, 12.4-5, 16.5 .

${ }^{523}$ Cf. Phil. 1.5-7, 17, 18.2, 21.10-12; Comp. Phil.-Flam. 2.1-2, 3.4.

${ }^{524}$ Cf. Phil. 17.

${ }^{525}$ Cf. Flam. 10-11. Atente-se na correlação entre estes Jogos e os Jogos Nemeus (ano 205), onde Filopémen festeja a vitória sobre o espartano Macânida; cf. Pol. 18.44-6 e T. Liv. 33.33.5-7. Refira-se que, enquanto Políbio e Tito Lívio focam, na descrição dos Jogos, mais o espírito, a clemência e o altruísmo dos Romanos, Plutarco, pelo contrário, concentra-se mais nos Gregos. A proclamação da devolução da liberdade ao povo grego é, sem dúvida, um momento que marca as relações entre Roma e o mundo helenístico, embora o Senado, cinquenta anos depois, tivesse ordenado a destruição de Corinto, a mesma cidade onde Nero, em 67, haveria de voltar a proclamar a liberdade da Grécia. A propósito da escolha de Corinto por Flaminino para fazer a célebre proclamação, J.-L. Ferrary (1988: 86) afirma:" C'est à Corinthe que s'était reuni en 481-0 le congrés panhellénique qui décida de reunir les forces 
o paradoxo: ${ }^{526}$

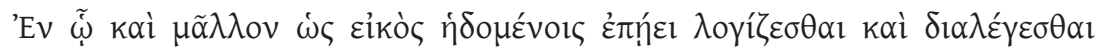

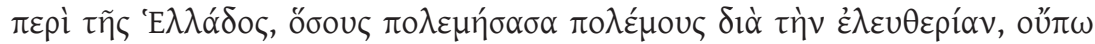

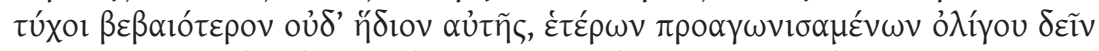

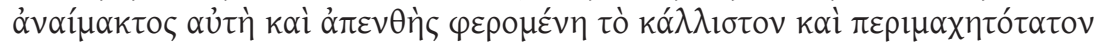

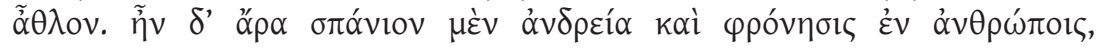

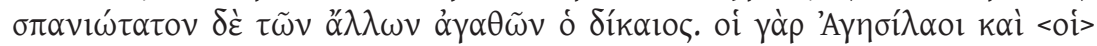

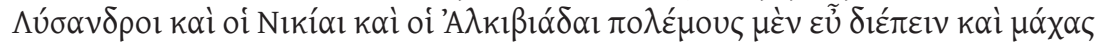

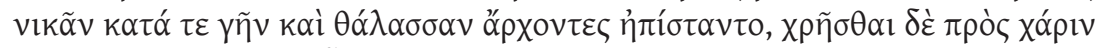

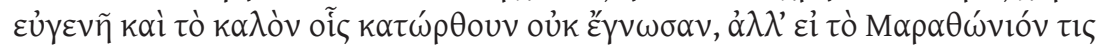

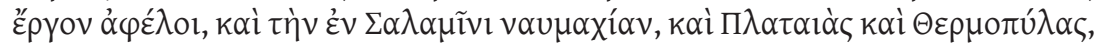

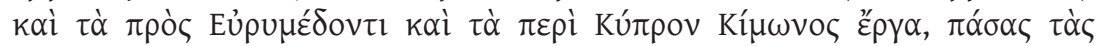

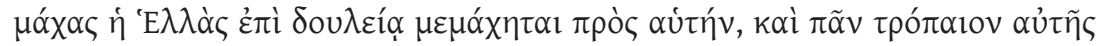

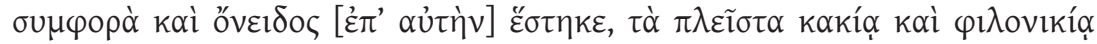

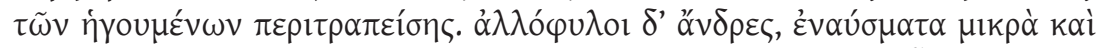

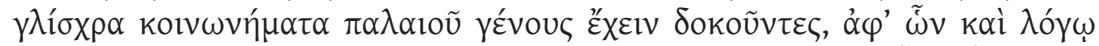

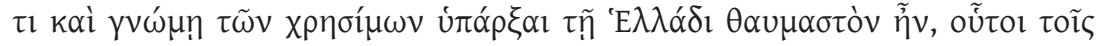

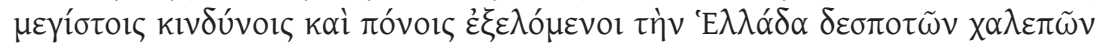

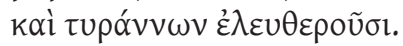

Naquele momento, ao que parece, Flaminino avançou com mais alegria para discursar e conversar sobre a Grécia: de quantas guerras empreendeu pela liberdade, em nenhuma alcançou mais segurança e mais prazer do que naquela, pois a Grécia, por intermédio do combate de outros em sua defesa, alcançou quase sem sangue nem luto o mais belo e o mais invejável dos prémios. A coragem e a inteligência eram raras entre os homens, mas o bem mais raro de todos era um homem justo. Homens como os Agesilaus, os Lisandros, os Nícias e os Alcibíades conduziam bem as guerras e, como comandantes, conseguiam vencer por terra e por mar, mas não souberam usar o sucesso para alcançarem um benefício nobre e belo. Se excluirmos as batalhas de Maratona, Salamina, Plateias ${ }^{527}$ e das Termópilas, e as acções de Címon em Eurimedonte e Chipre, a Grécia travou todos os combates contra ela própria para a sua escravidão e todos os troféus que levantou foram a desgraça e a vergonha, pois na maior parte das vezes caiu na maldade e na tendência litigiosa dos que a comandam. Pelo contrário, quanto aos homens estrangeiros, que parecem ter somente pequenas faíscas e ténues traços comuns à antiga estirpe [dos Gregos],

grecques sous l'hégémonie de Sparte, et de défendre contre Xerxès la liberté des Grecs (Diod., 11. 3)". Uma vez que as Guerras Medo-Persas faziam parte da propaganda política da época, Flaminino age por oposição a Xerxes e os Romanos não são confundidos com os Persas, nem com os costumes bárbaros destes.

${ }^{526}$ Flam.11.3-7.

${ }^{527}$ Em Comp. Arist.-Cat. Ma.5.1, considera Maratona, Salamina e Plateias as mais brilhantes e importantes acções dos Gregos. 
era admirável vir deles uma palavra e uma opinião útil para a Grécia, e eles próprios, correndo grandes perigos e suportando grandes sofrimentos, salvaram a Grécia e libertaram-na de déspotas terríveis e tirânicos.

Repare-se na importância que o texto dá ao facto de a philonikia ter conduzido os Gregos à auto-destruição ${ }^{528}$, enfatizando-se a discrepância entre o passado e o tempo presente dos Gregos. Tanto nos séculos III-II a. C. como na época de Plutarco, se mantém actual o problema da philonikia, o seu controlo e as consequências dos excessos por ela provocados no equilíbrio de forças dentro da Grécia e nas relações desta com Roma ${ }^{529}$. É precisamente por acção

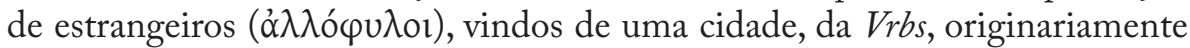
grega $^{530}$, que os Gregos são libertados. Na synkrisis deste par, Plutarco recordará que, ao mesmo tempo que Flaminino vence Filipe em plena Grécia, Filopémen luta em $\mathrm{Creta}^{531}$, acentuando dessa forma a diferença de atitude entre o Grego e o Romano ${ }^{532}$. Outro aspecto merecedor de referência é o facto de o relato da libertação da Grécia por Flaminino se concentrar mais na própria Grécia do que num louvor mais declarado a Roma e aos seus valores ${ }^{533}$. Isso não retira mérito à acção dos Romanos, antes serve para o Queronense lançar um aviso aos Gregos, no sentido de que estes se concentrem mais em manter a paz e a estabilidade do que em fomentar dissensões.

A intervenção de Flaminino é, sem dúvida, decisiva para a consolidação da eleutheria: mandou Lêntulo à Trácia para libertar as cidades e as ilhas do poder de Filipe, enquanto Públio Vílio foi ao encontro de Antíoco para libertar os Gregos que estavam sob a sua dependência; o próprio Flaminino vai a Cálcis estabelecer a autonomia dos povos; nos Jogos Nemeus (195 a. C.), o arauto anuncia de novo a liberdade dos Gregos ${ }^{534}$; Flaminino estabelece a عủvouía, a

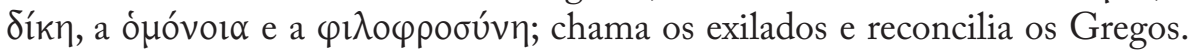
Refere Plutarco que tal era o valor das suas acções que a própria liberdade

${ }^{528} \mathrm{Na}$ synkrisis, Plutarco voltará a repetir a ideia de que os Gregos movera guerra aos próprios Gregos, enquanto Flaminino, um romano, fez a guerra pelos Gregos (cf. Comp. Phil.Flam.1.1-2).

${ }^{529}$ Em vários passos do tratado Praec. ger. reip. reflecte-se sobre a philonikia e as relações, por vezes tensas, entre a Grécia e Roma.

${ }^{530}$ Cf. n. 340 (Parte III)

${ }^{531}$ Cf. Comp. Phil.-Flam. 1.2.

${ }^{532}$ No entanto, note-se como Plutarco não aproveita a oportunidade em que elogia as atitudes dos "estrangeiros" para fazer referência à introdução na Grécia da pantomima e dos jogos de gladiadores, silêncio deliberado e revelador do seu helenismo.

${ }^{533}$ Políbio (18.44-46) e T. Lívio (33.33.5-7), ao contrário de Plutarco, concentram mais a narração nos Romanos do que nos Gregos.

${ }^{534}$ Esta informação, em Flam. 12.5, não é totalmente precisa, pois teria sido proclamada a liberdade de Argos, após a primeira fase da guerra contra Nábis. 
parecia o menor dos seus feitos ${ }^{535}$. Por tudo isto, merece o reconhecimento dos Gregos: ${ }^{536}$

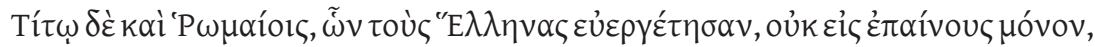

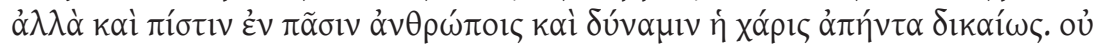

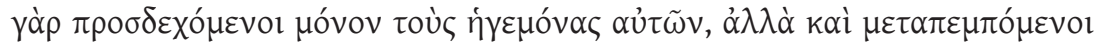

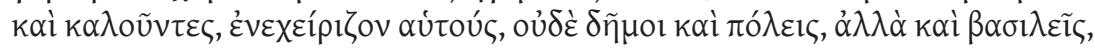

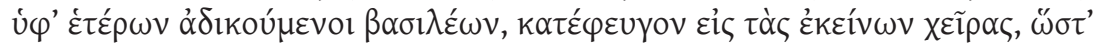

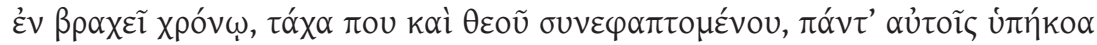

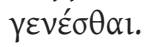

A recompensa chegou com justiça a Tito e aos Romanos, pelos benefícios que trouxeram aos Gregos, e revelou-se não só com louvores, mas também com confiança e autoridade em todos os homens. Não apenas admitindo-os como comandantes dos Gregos, mas mandando-os chamar e convidandoos, colocaram-se nas mãos deles. Quer os povos e as cidades, quer os reis que foram prejudicados por outros reis, refugiaram-se nas mãos dos Romanos, que, em pouco tempo, talvez também com a ajuda divina, submeteram tudo ao seu poder.

Reunir, com a ajuda dos Gregos, os Romanos feitos prisioneiros na guerra contra Aníbal, foi, no entanto, a melhor recompensa pelas acções de Flaminino,

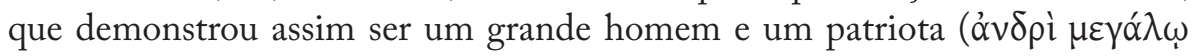

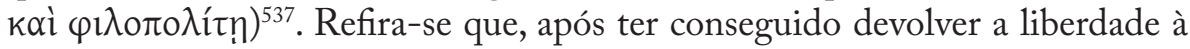
Grécia, Flaminino consagrou a Delfos um escudo de prata com uma inscrição, em que se intitulava "descendente de Eneias", e devotou aos filhos de Zeus, os Dióscoros, o melhor dos dons, a liberdade ${ }^{538}$. Consagra, ainda, uma coroa de ouro a Apolo, reafirmando ser descendente de Eneias ${ }^{539}$.

Por entender que os Romanos não são bárbaros ${ }^{540}$, pois nem a sua disciplina é semelhante à daqueles, Plutarco faz questão de realçar a educação

\footnotetext{
${ }^{535}$ Cf. Flam. 12.6.

${ }^{536}$ Ibid. 12.8-10.

${ }^{537}$ Ibid. 13.8.

${ }^{538}$ Cf. ibid.12.11.

${ }^{539}$ Cf. ibid. 12.12 .
}

${ }^{540}$ Cf. S. Swain (1989: 296); em Quaest. Rom. 22 sugere-se que os Romanos, antes de sofrerem a influência da cultura helénica, eram bárbaros; vide, ainda, Quaest. Rom. 32 e 59, que reforçam a ideia de que a civilização veio de Oriente para Ocidente, ou seja, da Grécia para Itália. Em Pyrrh. 14.6, 16.7 e 19.6, Pirro valoriza os Romanos, pois não os considera bárbaros, louva a sua disciplina e a sua forma de governo. De forma diferente pensa Díon de Prusa (cf. T. Duff (304, n.54)). D. Russel (20012: 132), no entanto, ao analisar a rejeição de Mário aos benefícios do helenismo, afirma: "Most Romans, for Plutarch had a potentiality for barbarism"; recorde-se que Plutarco relaciona a infeliz ambição de Mário em idade avançada com a rejeição dos valores helénicos (cf. Mar. 45.10-46.5). 
helénica de Flaminino, que se pode considerar a justificação do herói para com os Helenos: ${ }^{541}$

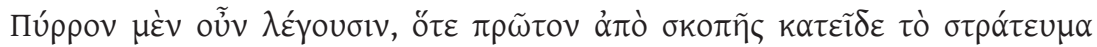

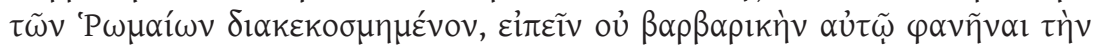

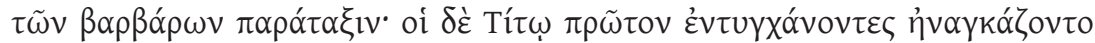

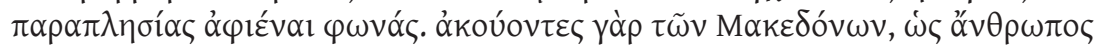

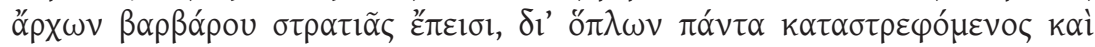

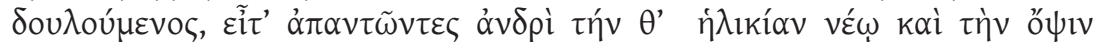

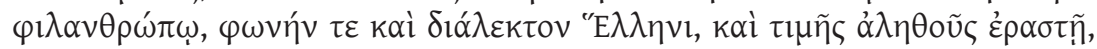

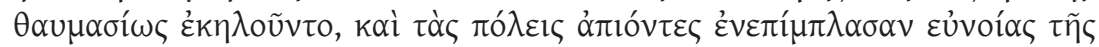

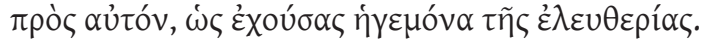

Contam que Pirro, quando, pela primeira vez, observou do alto o exército dos Romanos em formação, disse que o alinhamento daqueles bárbaros não lhes parecia de todo bárbaro. Os que encontraram Tito pela primeira vez tiveram necessidade de falar a mesma língua. Ouviram os Macedónios dizer que um homem marchava ao comando de um exército bárbaro, submetendo e escravizando tudo pelas armas; depois, encontraram um homem jovem e de aparência amável, que falava a língua grega, apaixonado pela verdadeira honra, e, assim, partiram completamente fascinados e espalharam pelas cidades a benevolência para proveito dele, pois ele tinha sido o autor da liberdade dos Gregos.

Flaminino age, deste modo, sob a influência da paideia, tirando proveito disso, uma vez que consegue a ajuda de outros para os seus objectivos. Tal como outros heróis retrados por Plutarco, também Flaminino ${ }^{542}$ se entrega, desde cedo, ao combate, interrompendo dessa forma a sua formação cultural, pois as exigências da $V r b s$ assim o ditavam. O facto de invejar a glória e as honrarias recebidas por Filopémen no teatro ${ }^{543}$ pode ser interpretado como um sinal de que a sua paideia estava incompleta: ${ }^{544} \Pi \alpha 1 \delta \varepsilon v \theta \varepsilon i \zeta \zeta \delta \dot{\varepsilon} \pi \alpha 1 \delta \varepsilon i ́ \alpha v$

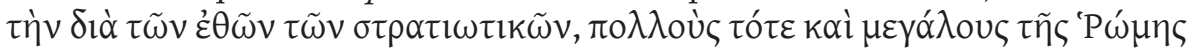

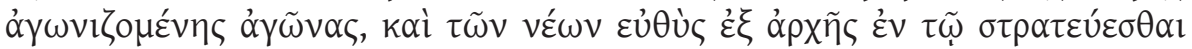

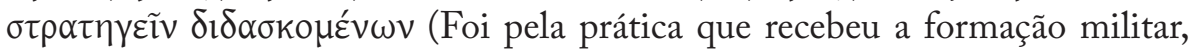
numa altura em que Roma travava muitos e importantes combates e quando os jovens, logo desde o início, aprendiam a comandar ao serviço de uma expedição militar).

${ }^{541}$ Cf. Flam. 5.6-7.

${ }^{542}$ Fúlvio e Mânio opuseram-se à sua rápida ascensão no cursus honorum, pois ele atingiu o consulado sem ter trinta anos (cf. Flam. 2.1-2).

${ }^{543}$ Cf. Phil. 15.1; por ter libertado a Grécia da escravidão de Filipe e dos Macedónios, Flaminino, como cônsul, considerava ser mais merecedor dessas honras.

${ }^{544}$ Flam. 1.4. 


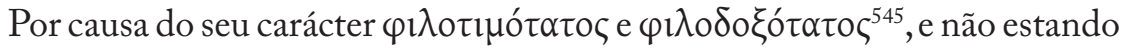
isento da ỏ $\rho \eta^{546}$, Flaminino recusa, ao contrário dos generais anteriores, passar o ano do seu consulado em Roma, onde perderia o seu tempo em disputas políticas, uma vez que desejava empreender uma guerra ${ }^{547}$. Aliás, Flaminino,

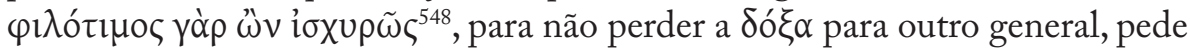
ao Senado que prorrogue o seu comando até ao final da guerra das Cinoscéfalas $(197 \text { a. C. })^{549}$ ou até concluir a paz ${ }^{550}$.

Flaminino, que haveria de atingir, em 189 a. C., a censura por causa das suas campanhas na Grécia e pelo desempenho na guerra contra Antíoco ${ }^{551}$, tinha um carácter complexo que merece o seguinte comentário de Plutarco::52

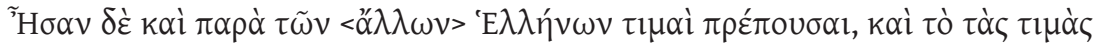

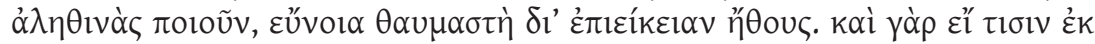

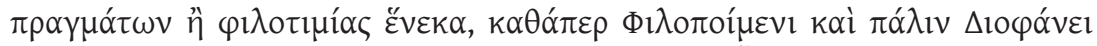

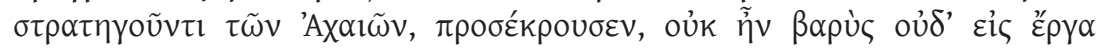

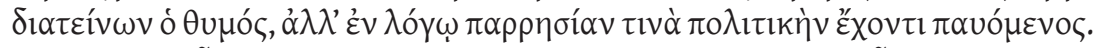

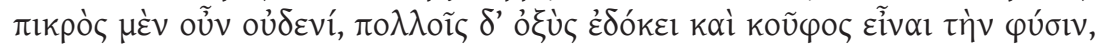

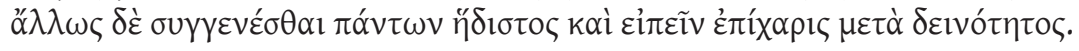

Também outros Gregos ofereceram a Tito honras dignas, e o que tornava estas honras genuínas era a admirável benevolência motivada pela bondade do seu carácter. De facto, se Flaminino, por causa de alguma das suas acções ou por ambição, se irritou, como por exemplo com Filopémen e de novo com Diófanes, um estratego dos Aqueus, a cólera não era grave nem se estendia veementemente às acções, mas ele libertava na sua eloquência uma certa franqueza política. Não era, na realidade, cruel com ninguém, pois para muitos parecia ser veemente e suave por natureza, de resto tratava todos muito agradavelmente e era eloquente na sua forma graciosa de falar.

Salientando a capacidade oratória de Flaminino, bem como a عüvora, a

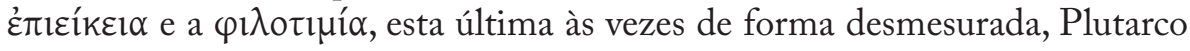

${ }^{545}$ Cf. Flam. 1.3.

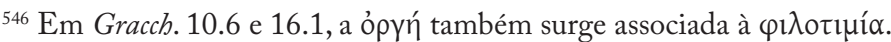

${ }^{547}$ Cf. Flam. 3.

${ }^{548}$ Ibid. 6.2.

${ }^{549}$ Sobre esta guerra, vide Flam. 7-8

${ }^{550}$ Igual sentimento em Flam. 13, quando parece ter poupado Nábis por não querer que viesse outro general de Roma arrebatar a sua glória ou, numa outra leitura, por inveja das honrarias que Filopémen recebeu pela sua acção na guerra contra Nábis, uma vez que, para

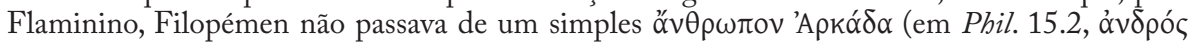

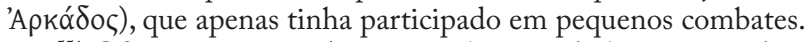

${ }^{551}$ Cf. Flam. 18.1; a Antíoco se haveria de ligar o grande inimigo de Roma, Aníbal, uma união que S. Swain (1989: 513) classifica de "opportune peace".

552 Flam. 17.1-3. 
não esconde que o herói romano se deixou dominar, com frequência, pela irracionalidade do $\theta u \mu o ́ \varsigma$, embora tenha conseguido atenuar o seu efeito nas praxeis. Porém, a parte final da biografia parece indicar o contrário ${ }^{553}$. Com os seus cerca de cinquenta e cinco anos, Flaminino continua a alimentar a sua grande paixão, a doxa, e, por isso, indigna-se com o facto de Aníbal continuar vivo, ao contrário da maioria dos Romanos que, tendo em conta a idade deste, o desprezavam, além de atribuírem a sua queda à tyche. Provando a sua natural ambição, Flaminino contribuiu para apressar o fim de Aníbal, o qual revelou ser um homem hábil e experiente ${ }^{554}$. Essa motivação foi entendida como um sinal da crueldade de Flaminino, por querer juntar o seu nome à morte de Aníbal, de forma a alcançar a glória ${ }^{555}$.

Assim, o epílogo desta biografia, ao contrário daquilo que se poderia esperar, não acentua as diferenças da philotimia e da philonikia de Flaminino e Filopémen, respectivamente, mas a forma como os últimos dias destes heróis são semelhantes ${ }^{556}$.

$\mathrm{Na}$ synkrisis, por sua vez, Plutarco deixa completamente à consideração do leitor/ouvinte a análise sobre qual dos dois se superiorizou pelas suas acções, talvez pelo facto de estarmos perante dois heróis que viveram no mesmo tempo e de forma próxima. Outro elemento que marca esta synkrisis é o facto de ela simplificar ${ }^{57}$ aquilo que na biografia é mais complexo: por exemplo, atribui à raiva ${ }^{558}$ de Filopémen a destruição do sistema educacional espartano, algo que não havia ficado esclarecido ${ }^{559}$; o mesmo acontece com o relato da campanha contra os Messénios, entendida na synkrisis como um acto de raiva ${ }^{560}$, o que não é claro na narrativa ${ }^{561}$. Isto faz com que a synkrisis não seja entendida apenas como um resumo, mas como uma estrutura de esclarecimento e de simplificação. Ou, então, temos de entender estas diferenças entre a narrativa e a synkrisis, como um acto de improvisação de Plutarco.

Apercebemo-nos, durante a narrativa, da elaboração de dois conceitos nucleares: a philonikia e a philotimia, que dão origem aos erros dos protagonistas. ${ }^{562}$ Numa avaliação simples daquilo que ambos significam, diríamos que a philotimia de Flaminino é menos negativa e coaduna-se com a

${ }^{553}$ Cf. ibid. 20.

${ }^{554}$ Cf. ibid. 21.8.

${ }^{555}$ Em ibid.21.6, Plutarco refere que a maioria considera Cipião superior a Flaminino pela forma como lidou com Aníbal.

${ }^{556}$ Para uma análise desta synkrisis, vide T. Duff (2002r:267 ss.).

${ }_{557}$ Cf. Comp. Phil.-Flam. 1.7.

${ }^{558}$ Cf. ibid. 1.6.

${ }^{559}$ Cf. Phil. 16.

${ }^{560}$ Cf. Comp. Phil.-Flam.1.7.

${ }^{561}$ Cf. Phil. 18.

${ }^{562}$ Cf. Comp. Phil.-Flam. 1.4. 
panóplia de valores idealizada por Plutarco. Contudo, não existe, ao longo da synkrisis, uma preferência por Flaminino, nem uma pronunciada superioridade deste $^{563}$, apesar de, no início, começar por lhe ser favorável. Mas tal apreciação não nos leva a dizer que o epílogo comparativo serve para dar a primazia a Filopémen, pois também não se vislumbram elementos para sustentar tal tese. Por isso, inclinamo-nos mais para uma interpretação que coloque a Grécia e a sua liberdade no epicentro da narrativa, e não Filopémen ${ }^{564}$. Se Flaminino foi

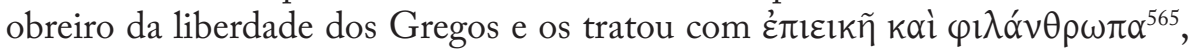
Filopémen, por sua vez, procurou de forma heróica lutar contra os Romanos em prol da liberdade. Percebe-se, por isso, a dificuldade de Plutarco em se

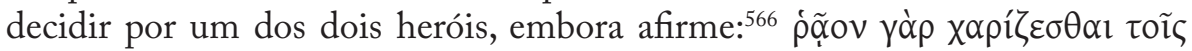

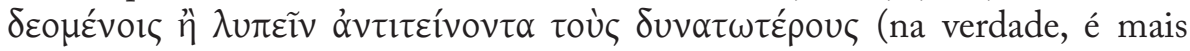
fácil agradar aos que precisam do que enfrentar e opor-se aos mais poderosos). Desta forma, valoriza, acima de tudo, a luta pela liberdade, valor que é muito caro para Plutarco, tendo Filopémen revelado ó $\rho \eta \underline{~ e ~} \varphi \imath \lambda o v \imath k i ́ \alpha$ nas suas

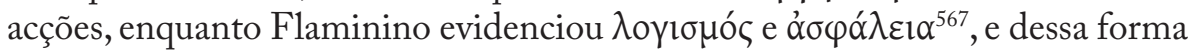
sacrificou a vida por valores diferentes ${ }^{568}$. Numa leitura adicional, poderemos pensar que a $\delta u ́ v \alpha \mu l \varsigma$ da pátria pode atenuar o mérito de um strategos vitorioso face a um outro dotado de meios mais modestos ${ }^{569}$, ou seja, o desempenho ou a imagem que um leitor guarda de um herói está em parte dependente das especificidades históricas e sociais da pátria ${ }^{570}$. Acrescente-se, ainda, que, no contexto histórico em que se desenvolve a narrativa, a philonikia pode traduzir uma atitude defensiva e heróica da Grécia perante a philotimia romana, podendo ambas contribuir para a realização de grandes empresas e para acções conducentes ao pathos.

Veja-se como nas duas biografias a paideia é tão omissa quanto as disputas se tornam o elemento mais actuante, não sendo possível estabelecer uma relação efectiva e coerente entra a formação e as qualidades. Filopémen e Flaminino são, sobretudo, homens concentrados nos seus objectivos. Para Filopémen, a paideia serve para melhorar a arte guerreira e, no caso de Flaminino, certamente que saber falar grego seria útil para o exercício das suas funções de procônsul da Grécia.

${ }^{563}$ Este aspecto pode ajudar a rebater a afirmação de J. Walsh (1992: 217), que atrás citámos.

${ }^{564}$ Cf. Comp. Phil.-Flam.1.1-3; cf. 3.4.

565 Ibid. 3.4.

${ }^{566}$ Ibid. 3.4

${ }^{567}$ Cf. ibid. 1.7.

${ }^{568}$ Cf. Comp. Lys.-Sull. 4.3-5; Comp. Pel.-Marc. 3. 1-8.

${ }^{569}$ Cf. Comp. Phil.-Flam. 2.2.

${ }^{570}$ Cf. F. Frazier (1987: 70); há casos em que, por exemplo, se alude ao facto de as qualidades morais da pátria terem sido corrompidas pelo excesso de poder: Comp.Arist.-Cat. Ma.1.2, Comp. Per.-Fab. 1, Comp. Lys.-Sull.1.2-3., Phoc. 1.3. 


\subsubsection{Pelopidas-Marcellus}

Se Pelópidas, que venceu os Lacedemónios e procurou imitar Epaminondas ${ }^{571}$, não passava de uma figura de segunda plano, Marcelo, que venceu três vezes Aníbal, foi, pelo contrário, um político de primeira linha, e ficou na história por ter vencido os Cartagineses, os Gauleses e de se ter apoderado de Siracusa. Em comum, estes heróis têm o facto de se terem deixado tomar pela temeridade e, por isso, conhecem a morte, ao exporem as suas vidas

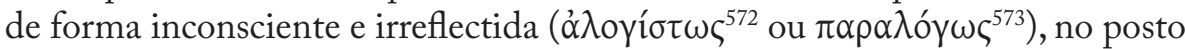
de comando contra os inimigos espartanos e cartagineses, respectivamente. Plutarco justifica, da seguinte forma, as escolhas de Pelópidas e Marcelo como par biográfico ${ }^{574}$ :

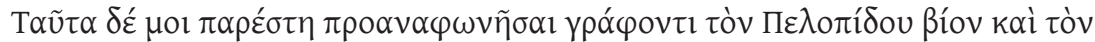

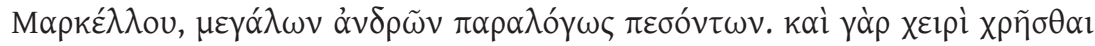

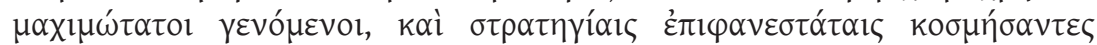

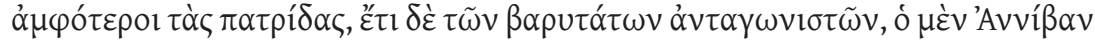

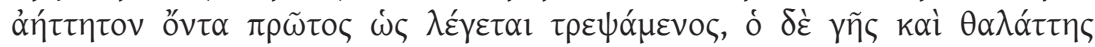

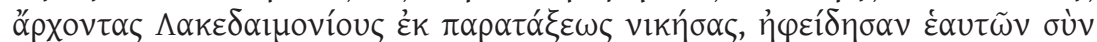

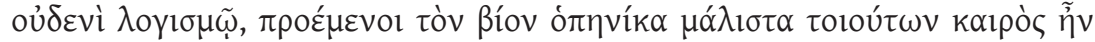

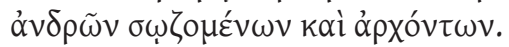

Estas são as considerações que me ocorrem para introduzir a biografia de Pelópidas e a de Marcelo, homens ilustres que tombaram na guerra de forma irreflectida. De facto, os dois eram muito agressivos na forma como se entregavam à acção e honravam a sua pátria com campanhas militares. Um foi o primeiro, segundo se diz, a pôr em fuga Aníbal, que era, até ao momento, invencível, o outro venceu em campo aberto os Lacedemónios, que dominavam por terra e por mar. Os dois expuseram-se ao perigo sem reflexão, descuidando as suas vidas num momento em que se pedia a tais homens que, acima de tudo, se conservassem vivos e ao comando.

Estas palavras finais do prólogo confirmam as considerações que Plutarco vinha fazendo desde o início sobre a morte e o papel do strategos, defendendo que o chefe de Estado deve proteger-se dos inimigos e, como cabeça de um

${ }^{571}$ Tanto Epaminondas como Pelópidas são célebres generais tebanos que se evidenciaram pela sua valentia e por serem extraordinários estrategos (cf. Reg. et imp. apopht. 192C-194E e De Alex. fort. aut uirt. 344D); entre a riqueza de Pelópidas e a pobreza de Epaminondas, institui-se a emulação da virtude (cf. Pel.3.4-8), resultado que Plutarco visa sempre nas suas synkriseis.

572 Pel. 1.1.

${ }^{573}$ Ibid. 2.9.

${ }^{574}$ Ibid. 2.9-11. 
conjunto de homens ${ }^{575}$, não deve expor-se em excesso para não colocar a vida dos que dependem dele em perigo ${ }^{576}$. A propósito de colocar a vida em risco, o autor defende que não se deve repreender quem foge da morte por desejar viver em defesa de nobres valores, tal como não é digno de louvor aquele que enfrenta a morte com falta de prazer pela vida ${ }^{577}$.

A escolha de Pelópidas pode ter sido ditada pela simples razão de ser natural da Beócia, tornando-se inevitável estabelecer um paralelo entre ele e Epaminondas. Plutarco não consegue, ou não quer, esconder o seu patriotismo beócio ${ }^{578}$, por meio de frequentes comparações com Atenas e Esparta, em que Tebas leva vantagem, ou quando refere que, ao contrário de Pelópidas e Epaminondas, os Atenienses pelejam mais entre si do que contra os inimigos ${ }^{579}$. Além disso, ao colocar em paralelo a libertação de Tebas por Pelópidas e pelos companheiros com a libertação de Atenas por Trasibulo, refere que a glória do Tebano é superior ${ }^{580}$; também aos olhos de Artaxerxes Pelópidas é superior aos Atenienses e aos Lacedemónios ${ }^{581}$; por fim, o próprio Pelópidas pretende provar que os Tebanos, contrariamente aos Atenienses e Lacedemónios, combatem apenas pelas vítimas da tirania e para pôr fim aos actos de domínio ilegal e violento na Grécia. ${ }^{582}$

Para o estudo da paideia, interessa-nos, sobretudo, o momento em que Plutarco faz referência às ocupações distintas a que se entregaram Pelópidas e

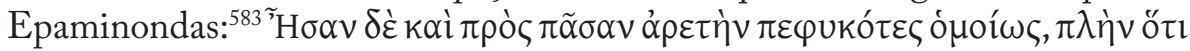

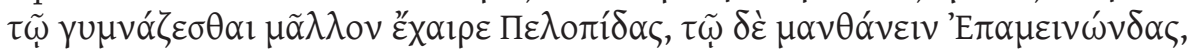

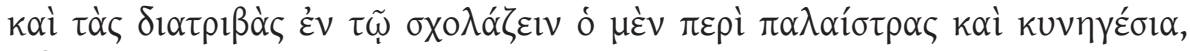

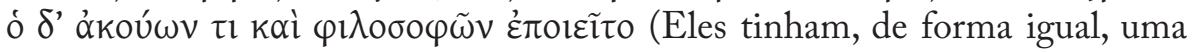
natureza dotada para todo o tipo de virtude, mas Pelópidas tinha mais prazer em praticar exercícios e Epaminondas, pelo contrário, em entregar-se ao estudo; um passava o tempo livre a frequentar as palestras e a caçar, o outro a ouvir e estudar filosofia). Esta diferença entre os dois tem consequências na

${ }^{575}$ Plutarco recorre à distinção e distribuição de funções feitas por Ifícrates (Cf. Pel. 2.1).

${ }^{576} \mathrm{Em}$ Pel. 35.1, Plutarco parece querer reabilitar o final de Pelópidas.

577 Ibid. 1.8.

578 Sobre os condicionalismos que as fontes usadas por Plutarco possam ter exercido na imagem que construiu de Pelópidas, vide J. Buckler (1978: 36-42), que discute as opiniões desenvolvidas por H. Westlake (1939: 11-22) e J. Wiseman (1969: 177-199); para R. Flacelière (1979: 265), Plutarco não esconde patriotismo beócio, mas considera-o sobretudo um "patriote panhellénique", que pretendeu demonstrar que a um Romano ilustre, a Grécia, agora dominada, pode opor um outro herói de igual mérito e superior, e também com os mesmo vícios.

${ }^{579}$ Cf. Pel. 4.3. Plutarco refere a mesma ideia ideia no par Phil.-Flam., atribuindo dessa forma aos Romanos a responsabilidade pelo apaziguamento interno.

${ }^{580}$ Cf. ibid. 13.4-7.

${ }^{581}$ Cf. ibid. 30.4-5.

${ }^{582}$ Cf. ibid. 31.6.

${ }^{583}$ Pel.4.1. 
forma como depois se entregam à politeia e nos valores que a vida de ambos demonstra. Isso é especialmente evidente quando, no regresso a Tebas, apesar das vitórias alcançadas na Messénia, na Arcádia e na Lacónia, Epaminondas e Pelópidas são processados por terem usurpado o cargo de beotarcas, acusação motivada sem dúvida por causa do $\varphi \theta$ óvoc e da $\delta$ ó $\alpha$. A grande diferença está na forma como reagem à ida a tribunal ${ }^{584}$, que resultou na libertação de

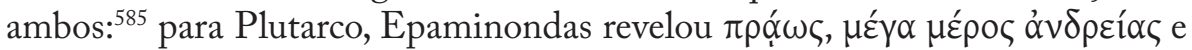

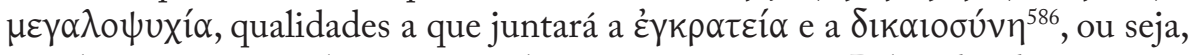
aquelas que mais enobrecem o ser humano; por sua vez, Pelópidas demonstrou

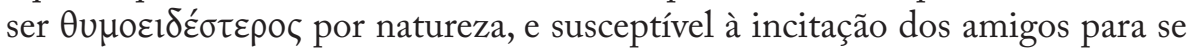
vingar. Esta discrepância de atitudes ajuda-nos a perceber o valor da filosofia e da paideia em geral na formação do espírito humano, de modo a enfrentar os obstáculos ou adversidades, no exercício da politeia. Este exemplo não deixa qualquer dúvida de que a paideia, quando instruída e aprofundada, dota o ser humano de serenidade e equilíbrio, ao passo que a sua ausência aumenta o risco do excesso e das paixões irracionais.

Por causa da sua entrega à filosofia ${ }^{587}$ e por ser um homem pobre, sem poder de influência, os Espartanos, após a tomada de Cadmeia (382 a. C.), fortaleza de Tebas, pelas forças de Fébidas, não consideraram Epaminondas uma ameaça $a^{58}$, ao contrário de Pelópidas e outros companheiros seus,

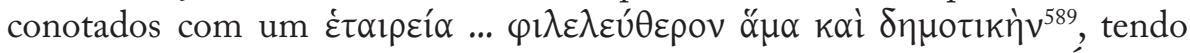
sido banidos ${ }^{590}$, uma vez que se opunham às ideias oligárquicas de Árquias, Leôntidas e Filipe. Neste episódio transparece também o sentimento antiespartano que se encontra em vários momentos da biografia ${ }^{591}$, e que se justifica pela forma cruel como Esparta trata os Tebanos. ${ }^{592}$ Além disso, para acentuar

${ }^{584}$ Cornélio Nepos realça o facto de Epaminondas ter assumido total responsabilidade, de forma a ilibar Pelópidas (Epam.7.3-8.5).

${ }^{585}$ Cf. Pel. 25.4.

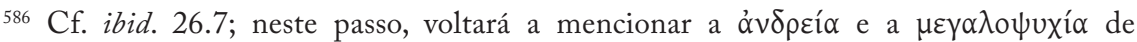
Epaminondas.

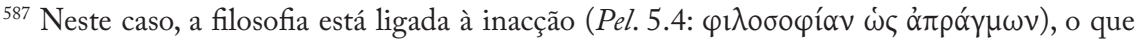
constituiu um estranho erro de análise dos Espartanos, até porque na guerra contra Mantineia (385 a. C.), tanto Epaminondas como Pelópidas, demonstraram suficientemente o seu valor em favor de Esparta.

${ }^{588}$ Cf. ibid. 5.4

${ }^{589}$ Ibid. 5.1.

${ }^{590}$ Ibid. 5.3.

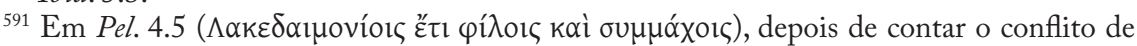
Mantineia, Plutarco introduz a mudança de atitude entre Lacedemónios e Tebanos; cf. Marc. 23.5.

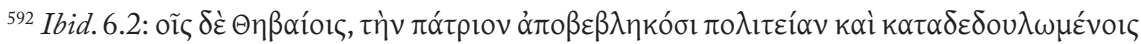

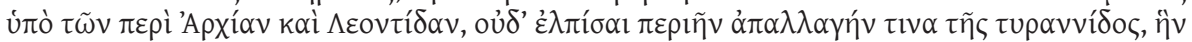

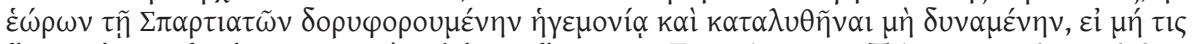

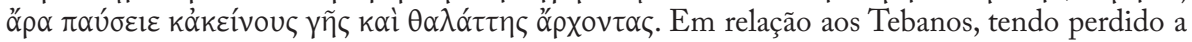


a conduta tirânica dos Espartanos, a quem reconhece técnica e sabedoria na arte militar ${ }^{593}$, Plutarco refere que eles desejavam que os exilados, entre eles Pelópidas, não fossem bem recebidos em Atenas. Os Atenienses, contudo, demonstraram a sua philanthropia ancestral ${ }^{194}$ e não causaram qualquer dano aos Tebanos.

Bem elucidativo dos valores de Pelópidas é o discurso que dirige aos seus companheiros, incentivando-os a combater pela liberdade de Tebas ${ }^{595}$ :

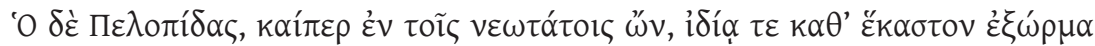

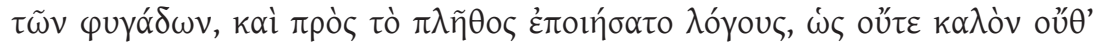

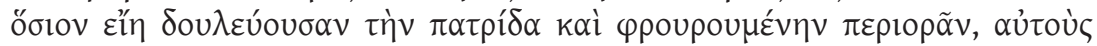

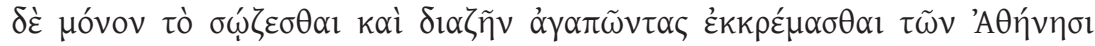

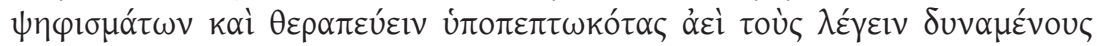

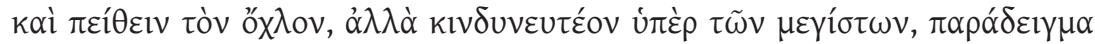

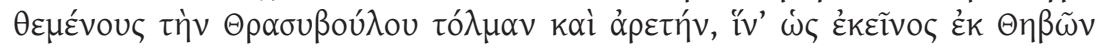

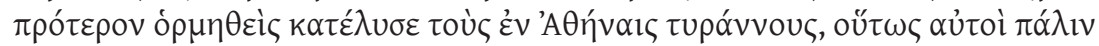

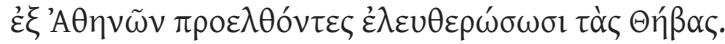

Embora fosse um dos mais jovens, Pelópidas incitava, em particular, cada um dos desterrados e discursava para a multidão, dizendo que não era belo nem justo olhar com indiferença para a pátria escravizada e ocupada, e que eles próprios, satisfeitos por estarem salvos, ao passarem a vida agarrados aos decretos de Atenas e ao tratarem de forma humilde os que podiam falar e persuadir o povo, deviam, ao invés, enfrentar o perigo por uma grande causa, seguindo como exemplo a audácia e a virtude de Trasibulo, uma vez que ele saiu rapidamente de Tebas para aniquilar os tiranos em Atenas, de modo que eles mesmos, em sentido contrário, partiram de Atenas para libertar Tebas.

Usando como exemplo Trasibulo, Pelópidas apela à honra, à piedade, à virtude, à coragem e à liberdade, princípios morais que são muito importantes na acção política dos heróis de Plutarco, uma vez que não se pode passar irresponsavelmente o tempo em ocupações e discussões que não visem a acção destemida em defesa da pátria.

Ao descrever a tentativa - que viria a ser bem sucedida - de libertar Tebas do poder espartano, Plutarco ${ }^{596}$ refere várias peripécias guerreiras em

sua forma de governo ancestral e submetidos ao poder de Árquias e Leôntidas, permaneciam sem esperança de se libertarem da tirania, que viam ser apoiada pela hegemonia dos Espartanos e impossível de ser destruída, salvo se alguém puder travar o poder deles por terra e por mar.

${ }_{593}^{593}$ Ibid. 23.4.

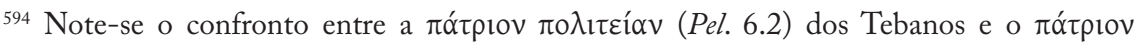

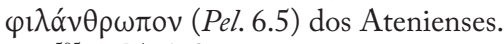

${ }^{595}$ Pel. 7.1-2.

${ }^{596}$ Cf. Pel. $7-12$. 
que Pelópidas, Epaminondas ou Górgidas, inter alios, participaram, usando o disfarce como estratégia para surpreender e derrotar os tiranos ${ }^{597}$. Pela forma audaciosa como defenderam a pátria nessa acção, Pelópidas acabou por merecer

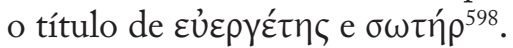

Seria, no entanto, na batalha de Leuctras (371 a. C.), precedida pela de Tégiras (371 a. C.), que os Espartanos seriam derrotados, assumindo os Tebanos, a partir desse momento, uma posição hegemónica ${ }^{599}$ e até agressiva. Depois de exaltar a íntima amizade entre soldados (atente-se no vocabulário:

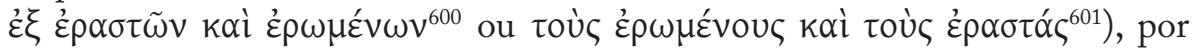

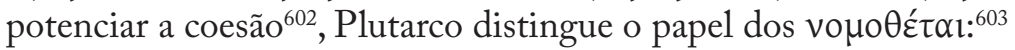

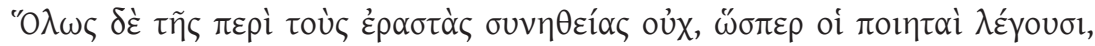

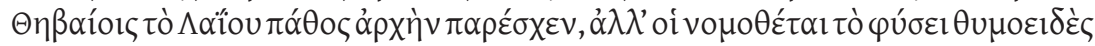

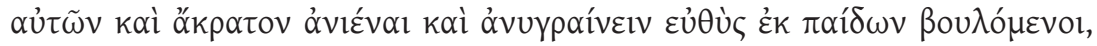

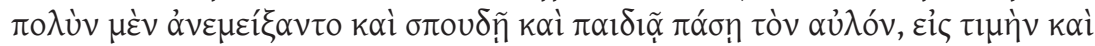

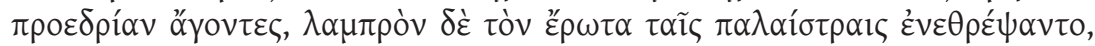

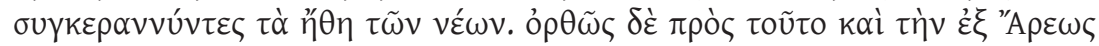

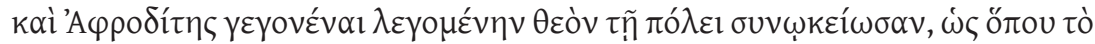

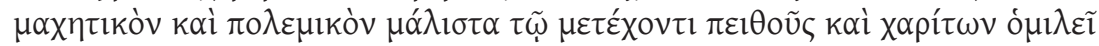

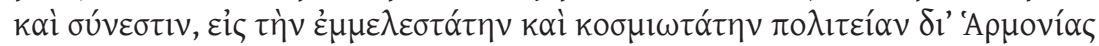

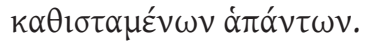

De facto, a paixão de Laio não deu origem, como dizem os poetas, às relações amorosas entre Tebanos, mas foram os legisladores, por quererem, logo desde a infância, deter e amolecer a natureza irascível ${ }^{604} \mathrm{e}$ violenta destes, que misturaram, com frequência, nas ocasiões sérias e nas festas o uso da flauta, acção que lhes traz honra e privilégio. Nas palestras suscitaram brilhantemente este género de amor, de modo a temperar o carácter dos jovens. Por causa disso, acomodaram na cidade, com justiça, a deusa que se diz ter nascido de Ares e Afrodite, convencidos de que onde o carácter combativo e guerreiro se encontrasse e tivesse uma relação próxima com a Persuasão e as Graças, tudo se disporia, por causa da Harmonia, para um Estado mais equilibrado e organizado.

${ }^{597}$ Cf. ibid. 11.

${ }^{598}$ Cf. ibid. 12.7.

${ }^{599}$ Depois da vitória de Leuctras, Epaminondas fundou a cidade de Megalópolis, na Arcádia, onde Filopémen e Políbio nasceram. A finalidade da sua fundação era fazer dela a capital da Liga Arcádia, o que também contribuiu para diminuir o poder de Esparta.

${ }^{600}$ Pel.18.2.

${ }^{601}$ Ibid. 18.5 .

${ }^{602}$ Cf. ibid. 18.2-19.2.

${ }^{603}$ Ibid. 19.1-2.

${ }^{604} \mathrm{O}$ carácter de Pelópidas tem essa característica (cf. Pel.25.4), tal como o de Alexandre de

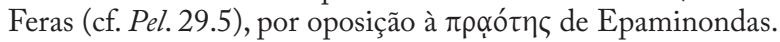


Além da abordagem do amor pederástico ${ }^{605}$, de que Laio, ao raptar Crisipo, filho de Pélops, é um dos primeiros exemplos na tradição helénica ${ }^{606}$, este texto prova o papel civilizador da $l \mathrm{ei}^{607}$, pela forma como pode moldar o carácter dos indivíduos: o uso da flauta é um meio para se evitar o excesso ${ }^{608}$. Por conseguinte, a lei, além do seu carácter normativo, desempenha uma função pedagógica importante na sociedade. A este respeito, Licurgo é, porventura, a personagem plutarquiana que melhor encarna o papel de legislador e, ao mesmo tempo, a de regulador e promotor da paideia entre os Espartanos.

Independentemente do seu cargo, quer fosse beotarca quer não, Pelópidas havia ganho o respeito e a confiança pelas provas que dera em prol da liberdade da pátria ${ }^{609}, e$, mesmo após ter conseguido os seus intentos, mostra ser contra as

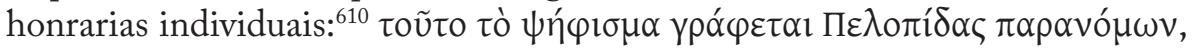

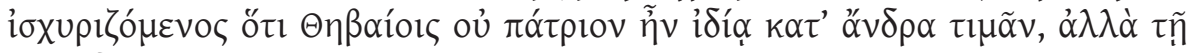

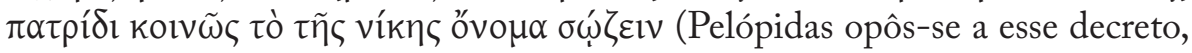
uma vez que o considerava ilegal, argumentando que não era um costume antigo entre os Tebanos honrar um homem em particular, mas guardar a fama da vitória para toda a pátria).

Por causa da sua glória, Pelópidas seria enviado como embaixador a Susa, onde falou melhor que os Atenienses e os Lacedemónios ${ }^{611}$, conseguindo atingir uma importante reputação na Ásia e, em particular, junto de Artaxerxes. Plutarco aproveita esta ocasião para salientar, de novo, a diferença entre um Tebano e um Ateniense: Pelópidas, como prova de que agiu de

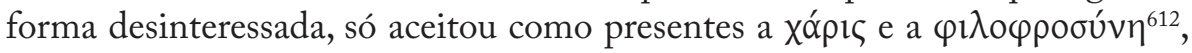
enquanto Timágoras não recusou o luxo dos presentes (ouro, prata, um séquito de servidores, oitenta vacas e boieiros) ${ }^{613}$.

$\mathrm{Na}$ parte final da biografia, antes da morte anunciada pelos sinais

${ }^{605}$ Cf. Amat. $750 \mathrm{~B}$; vide, ainda, P1. Lg. 836B e Ath. 602F.

${ }^{606}$ Cf. e.g. P1. Lg. 836b; vide ainda Amat. 750B.

${ }^{607}$ A ideia de que o legislador é um educador constitui uma marca platónica, como as Leges bem o demonstram; em Lyc. 14.1, apresenta a paideia como a tarefa mais importante do legislador, assumindo, assim, o seu valor na regulação social.

${ }^{608}$ Cf. Alc. 2.6 e Cor. 1.5; vide também sobre o efeito da música P1. Resp. 400a-c.

${ }^{609}$ Cf. Pel. 20.3 .

${ }^{610}$ Ibid. 25.13.

${ }^{611}$ Cf. ibid. 30.1; parece contradizer Praec. ger. reip. 819C, onde afirma que Pelópidas, por não ter facilidade no uso da palavra, escolheu Epaminondas.

${ }^{612}$ Cf. Pel. 30.8; comparar com 3.1-4.

${ }^{613}$ Cf. ibid. 30.10; Plutarco opina que, se foi por causa disso que Timágoras foi condenado à morte, esta foi justa e merecida; a mesma simplicidade e ausência de luxo são salientadas nos rituais fúnebres de Pelópidas (cf. 34.1); em Aem.39.6-7, é esclarecedor quando diz que os maiores tributos fúnebres não são as riquezas, mas o afecto, a honra e a gratidão. 
celestes $^{614}$, Plutarco volta a sublinhar que o percurso de Pelópidas, marcado, como o de Marcelo ${ }^{615}$, pela $\varphi \imath \lambda o \tau \imath \mu \alpha^{616}$, prova que os Tebanos só combatem pelas vítimas da tirania e para acabar com os poderes violentos e usurpadores na Grécia. Pelópidas lutaria, por fim, contra o tirano Alexandre de Feras, de modo a devolver aos Tessálios a liberdade, não conseguindo evitar a ira que

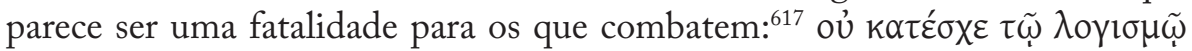

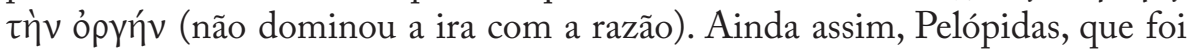
por treze vezes beotarca, merece o reconhecimento de Plutarco pela sua vida cheia de sucessos, na luta contra tiranos, acabando por morrer longe da pátria e dos seus, em prol da liberdade dos Tessálios.

Se se compreendem as questões patrióticas que terão envolvido a escolha de Pelópidas para este par, outras razões terão levado o autor a seleccionar Marcelo, político romano do século III a. C.. O comando em conjunto com Fábio Máximo, outro dos biografados, do exército contra Aníbal na 2a Guerra Púnica (218-201 a. C.) e, em especial, as lutas que travou contra os Cartagineses, são um elemento relevante da sua vida, mas interessa sobretudo a Plutarco a acção de Marcelo em Siracusa, local de encontro entre Roma e a cultura grega, tema transversal nas Vitae. Nesse espaço de confluência cultural, Plutarco tipificará os seguintes aspectos, que são, sem dúvida, preponderantes na narrativa e para a nossa interpretação da paideia: o carácter eminentemente guerreiro dos soldados romanos, o filo-helenismo de Marcelo e a dedicação de Arquimedes ao conhecimento científico.

$\mathrm{Na}$ apresentação sumária que faz de Marcelo no prólogo, percebemos qual é o seu carácter e o papel da paideia: ${ }^{618}$

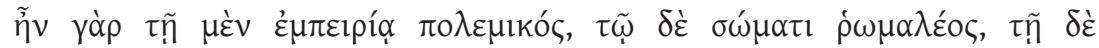

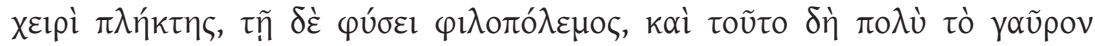

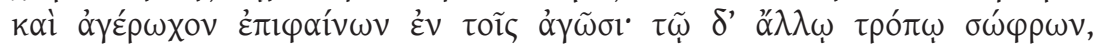

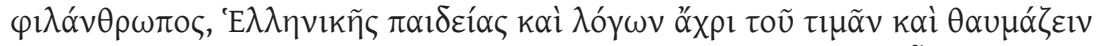

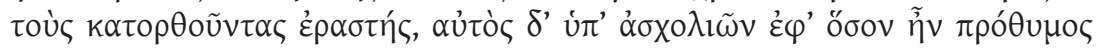

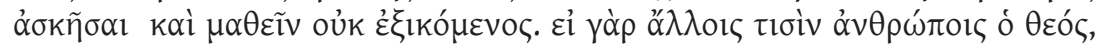

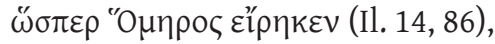

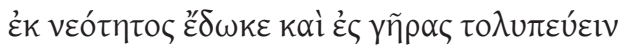

${ }^{614}$ Igual prenúncio na biografia de Marcelo (cf. Marc. 29.9-11).

${ }^{615}$ Cf. Marc. 28.6.

${ }^{616}$ Cf. Pel. 31.6.

${ }^{617}$ Pel. 32.9; em De coh. ira 458E, Plutarco dá a cólera de Pelópidas, como um exemplo de que a cólera mata muitíssimas pessoas antes da sua vingança.

${ }^{618}$ Marc. 1.2-5. 


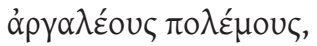

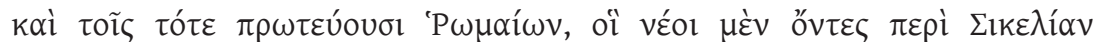

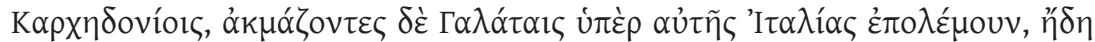

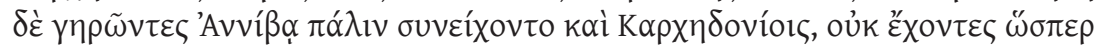

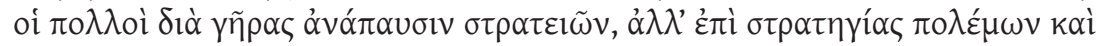

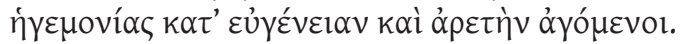

Ele tinha, na verdade, experiência na arte guerreira, um corpo vigoroso, mãos batalhadoras, uma natureza amante da guerra e demonstrava, nos combates, ser muito autoritário e dominador. Porém, quanto ao resto, era moderado, humano, amante da cultura e da literatura grega, a ponto de honrar e admirar os que se dedicam a elas com êxito, ainda que ele, por causa das suas ocupações, não conseguisse exercitá-las e estudá-las tanto quanto desejaria. Se, na verdade, a divindade, como disse Homero, aos outros homens:

"desde a juventude até à velhice deu por destino urdir terríveis guerras",

aconteceu primeiro isso aos Romanos daquele tempo. Enquanto na juventude combateram contra os Cartagineses na Sicília, na idade adulta, contra os Gauleses, para defender a própria Itália e, na velhice, enfrentaram de novo Aníbal e os Cartagineses. Não puderam, como a maioria, repousar das campanhas militares, mas eram levados a comandar e a dirigir os combates por causa da sua nobre linhagem e valor.

Esta introdução demonstra, desde logo, duas características importantes do carácter de Marcelo: tanto é amante da guerra, como admira a paideia grega. Era compreensível o facto de ser philopolemos, porque, como aconteceu a muitos outros Romanos, a guerra preencheu, desde cedo, a sua vida, retirandolhe tempo para se dedicar à cultura e ao estudo. Foi por esta razão que Marcelo não teve uma formação completa e perfeita, capaz de amenizar o seu espírito eminentemente guerreiro, mas, como Plutarco parece pensar que a guerra surge na vida dos Romanos como um fatalismo, o herói vê, em parte, a sua tendência guerreira justificada, pois o homem dificilmente consegue superar esse desejo superior, ainda que, noutras circunstâncias, o desafio da paideia sirva para dar autonomia ao próprio homem e para o responsabilizar pelos seus actos ${ }^{619}$.

Ao contrário de Mário, que se mantém voluntariamente distante da cultura helénica ${ }^{620}$,Marcelo tira benefício dessa cultura. Logo na parte inicial da

${ }^{619}$ Sobre o filho de Marcelo, que tinha o seu nome, Plutarco diz-nos que merecia a admiração dos cidadãos por causa da sua educação (cf. Marc. 2.5).

${ }^{620}$ Cf. Marc. 2. 
biografia, quando descreve os momentos que se seguiram ao final da Primeira Guerra Púnica (263-241 a. C.) e o receio que os Romanos sentiam pela proximidade dos Gauleses, Plutarco, recusando classificar os Romanos como um povo bárbaro, alude à influência helénica nos sacrifícios realizados pelos

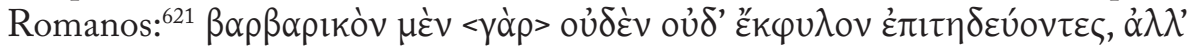

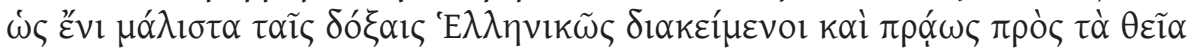
(De facto, os Romanos não praticavam nenhum rito bárbaro nem estrangeiro, mas seguiam o mais possível as crenças dos Gregos e eram brandos em relação às coisas divinas). Como bárbaros são, no entanto, classificados os Gauleses ${ }^{622}$.

No caso concreto de Marcelo, Plutarco não perde a oportunidade para fazer sobressair a sua ligação à cultura helénica. Isso é evidente, por exemplo, quando omite os crimes cometidos pelos Romanos na Sicília, por preferir realçar o comportamento justo de Marcelo, capaz de se equiparar aos valores helénicos, fazendo dele o primeiro Romano a mostrar aos Gregos que os Romanos também podiam ser justos. Esta idealização da figura de Marcelo é algo exagerada e talvez o próprio Plutarco tivesse consciência disso, uma vez que omite este elemento na synkrisis do par. $\mathrm{Na}$ verdade, parece-nos que o Queronense tenta provar que os Romanos não eram um povo exclusivamente vocacionado para a guerra. Esta mensagem é valorizada pelo facto de surgir na biografia de um Romano do séc. III a. C., o que também pode ser entendido como um aviso aos amigos romanos de Plutarco, lembrando-lhes que, já no passado, tinha havido compatriotas seus a agirem com justiça, respeito e até admiração pela paideia grega, e é isso que eles devem imitar:623

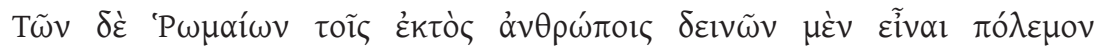

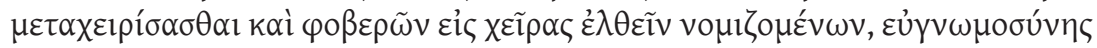

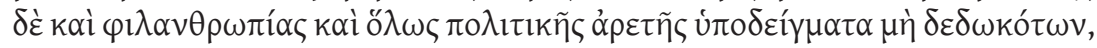

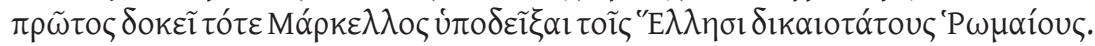

Para os estrangeiros, os Romanos eram considerados hábeis na condução da guerra e terríveis na luta, não tendo dado provas de benevolência, de humanidade e, em geral, de virtude política. Marcelo parece ter sido o primeiro a mostrar aos Gregos que os Romanos eram particularmente justos.

Até ao capítulo 13, quando Marcelo, designado pela terceira vez cônsul (214 a. C.), vai defender os interesses romanos na Sicília, Plutarco evidencia o carácter guerreiro do protagonista e o crescimento da sua reputação, quer

${ }^{621}$ Marc. 3.6; em Pel.21.6, expressa com maior clareza o que pensa sobre os sacrifícios; sobre a influência helénica na religiosidade romana vide Num.1.

${ }^{622}$ Cf. Marc. 8.1: o escudo de um bárbaro que Marcelo oferece ao deus; a propósito deste episódio, vide Val. Max. 3.2.5, Flor. 1.20.5 e Eutr. 3.6.

${ }^{623}$ Cf. Marc. 20.1; Políbio condena os actos de Marcelo (9.10). 
quando o Senado lhe concede em exclusivo o triunfo ${ }^{624}$, quer pela sua acção na Segunda Guerra Púnica ${ }^{625}$. Depois desses momentos, Plutarco centra a acção em Siracusa, de tal forma que dedica às acções aí desenvolvidas um terço da biografia. São objecto de particular realce Arquimedes e a sua actividade científica ${ }^{626}$. Tal é o espaço que ocupa na narrativa e o seu significado que parece formar uma estrutura paralela à própria biografia, o que só contribui para fazer sobressair a paideia helénica.

Em oposição à grandeza e ao poderio da armada romana ${ }^{627}$, Plutarco descreve assim Arquimedes e as suas máquinas: ${ }^{628}$

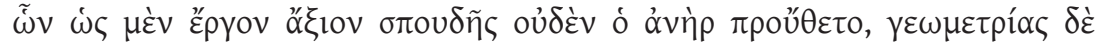

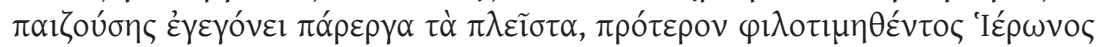

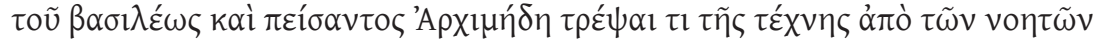

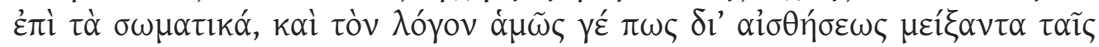

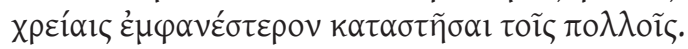

Arquimedes não considerava nenhuma das suas invenções como um trabalho digno de atenção, pois a maioria haviam sido acessórios do divertimento da geometria; antes, por esforço e persuasão do rei Hierão, Arquimedes direccionou alguma da sua técnica do abstracto para o concreto e tornou para todos o seu pensamento mais evidente, ao juntá-lo, de alguma maneira, a coisas proveitosas.

Percebe-se, por este texto, que Arquimedes, ao contrário de Marcelo ${ }^{629}$, não tem uma natureza vocacionada para a guerra e que só a pedido de Hierão de Siracusa procurou adaptar a sua capacidade intelectual, superior à do Romano, à arte guerreira. ${ }^{630}$ Esta ideia será reforçada pelo próprio Plutarco,

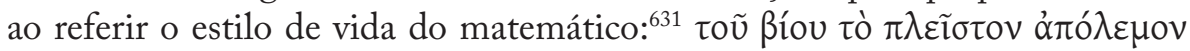

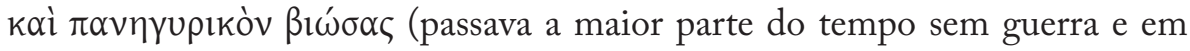
festas), ou quando enfatiza as qualidades de Arquimedes enquanto homem

${ }^{624}$ Cf. ibid. 8.1.

${ }^{625}$ Cf. ibid.9 (Marcelo e Fábio Máximo completam-se no combate) e 11 (Aníbal e Marcelo).

${ }^{626}$ Para A. Wardman (1971: 257-258), isso pode dever-se à falta de material histórico relativo à carreira de Marcelo ou à intenção de fazer uma digressão "ad Marcellum”. Parece-nos, contudo, que Plutarco pretende sobretudo colocar em confronto, numa mini-synkrisis bem ao seu estilo, Marcelo e Arquimedes, como procuraremos provar na interpretação de alguns textos; para uma interpretação da relação entre Marcelo e Arquimedes, vide A. Georgiadou (1992: 4249-4250).

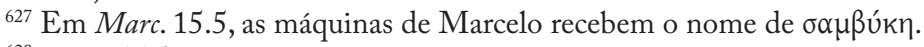

${ }^{628}$ Marc. 14.8.

${ }^{629}$ Cf. ibid. 1.2, 24.1-2.

${ }^{630}$ Em Marc. 14.11, sobre a questão da aplicação prática da geometria, Plutarco revela que Platão era contra essa prática por colocar em causa a excelência da geometria; cf. Quaest. conu. $718 \mathrm{E}-\mathrm{F}$.

${ }^{631}$ Cf. ibid. 14.15. 
que se aplica ao conhecimento científico. ${ }^{632}$ Se a philotimia de Arquimedes era perseguir a beleza, o conhecimento e a excelência mediante a geometria ${ }^{633}$, a de Marcelo era entregar-se de forma audaciosa às batalhas, com o fim de atingir a doxa. A dicotomia latente entre teoria/contemplação e prática/realização é não só visível quando analisamos o carácter de Marcelo e Arquimedes, mas também em relação a Fábio Máximo. Pois, apesar de este inspirar confiança e de a sua inteligência ser reconhecida ${ }^{634}$, faltava-lhe a capacidade de iniciativa e a coragem de Marcelo, e é por esta razão que Plutarco propõe como ideal uma mistura das qualidades dos dois. ${ }^{635}$

$\mathrm{Na}$ verdade, o episódio do encontro entre Arquimedes e Marcelo, que decorre numa ilha que é um símbolo do encontro de culturas ${ }^{636}$, personifica um pouco a concepção de "guerra científica", com anotações filosóficas sobre o pensamento, o conhecimento e a demonstração. Marcelo vivia uma situação pouco cómoda, por sentir, por um lado, a vontade de vencer e, por outro, pelo respeito que Arquimedes e o saber grego lhe mereciam. Uma das suas maiores preocupações era tratar os vencidos de forma respeitosa e é, por isso, que, quando recebe a notícia da morte de Arquimedes, fica desolado. ${ }^{637} \mathrm{Os}$

\footnotetext{
${ }^{632}$ Ibid. 17.5

${ }^{633}$ Prova do seu amor pela geometria é o facto de ter pedido aos seus amigos e familiares para colocarem sobre o seu túmulo um cilindro com uma esfera dentro, com a indicação do volume que havia entre esses dois sólidos (cf. Marc. 17.12); igual descrição em Cic. Tus. 5.23.64-66.

${ }^{634}$ Cf. Marc. 9.4; vide elogio da sua inteligência em Fab. 17.5-6.

${ }^{635}$ Cf. Marc. 9.5-6; Posidónio (FGrHist 87 F 42) terá dito que Fábio Máximo era o Өupeós

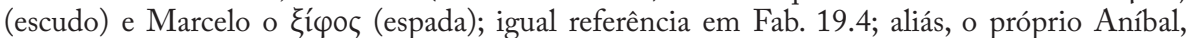
conhecendo o carácter de cada um deles, dizia temer Fábio como preceptor e Marcelo como adversário, pelo facto de, respectivamente, um impedia-o de fazer mal e o outro fazia-o sofrer (cf. Marc. 9.7 e Fab.19.1-4); nova comparação entre Marcelo e Fábio Máximo em Marc. 21.4-5.

${ }^{636}$ Cf. Marc. 20.

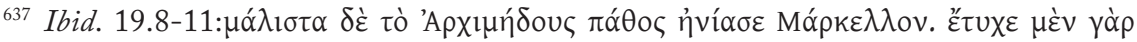

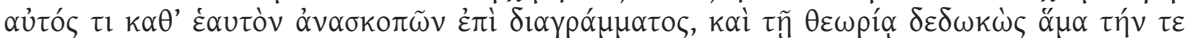

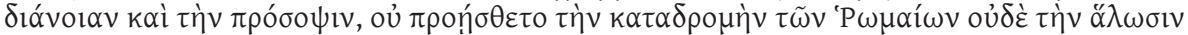

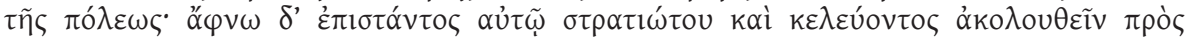

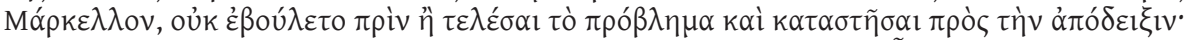

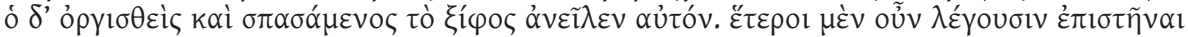

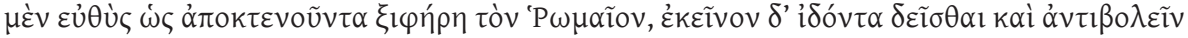

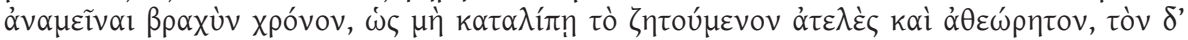

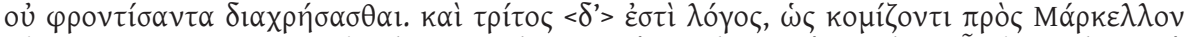

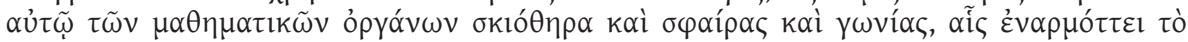

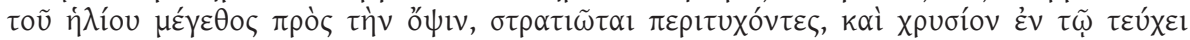

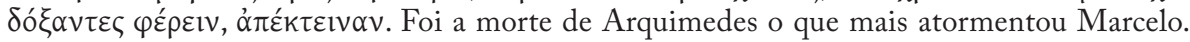
Arquimedes, sozinho, encontrava-se a examinar uma figura geométrica e, concentrando a reflexão e o olhar na contemplação desta, não se apercebeu da incursão dos Romanos nem da tomada da cidade. Subitamente, aproximou-se dele um soldado que lhe deu ordem para o acompanhar até Marcelo, mas Arquimedes não quis ir, antes de resolver o problema e de ter feito a demonstração. Irritando-se, o soldado tirou a espada e matou-o. Outros dizem que um Romano armado com uma espada se aproximou dele com a intenção de o matar,
} 
acontecimentos que envolvem a morte de Arquimedes indiciam que a justiça e o respeito pelo inimigo eram qualidades que os soldados de Marcelo não tinham interiorizado, podendo colocar-se a hipótese de que eles, por não conhecerem Arquimedes e muito menos o seu mérito científico, o mataram como matariam qualquer outro inimigo. Além disso, a descrição de Plutarco vem demonstrar, mais uma vez, a seriedade e o empenho com que Arquimedes se dedicava aos seus estudos. Se as versões, quanto à morte do matemático,

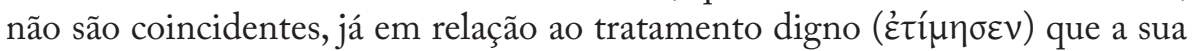
família mereceu da parte de Marcelo todas parecem concordar ${ }^{638}$, argumento que se insere no tom elogioso que Plutarco dispensa ao Romano.

Acentuando a dicotomia entre Gregos e Romanos, ou seja, entre a cultura ou a arte e o espírito belicoso, respectivamente, Plutarco interpreta de forma positiva $^{639}$ a decisão de Marcelo de levar as mais belas obras de arte de Siracusa para Roma, pois essa seria uma forma de educar o povo romano e sensibilizá-lo para a arte: ${ }^{640}$

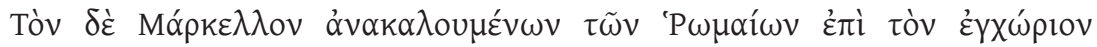

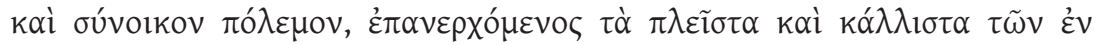

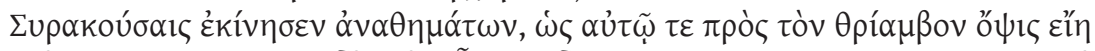

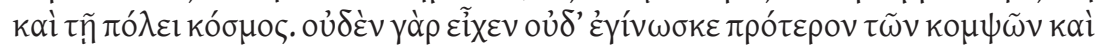

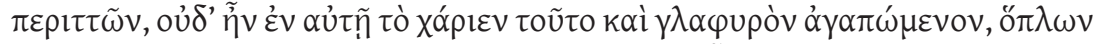

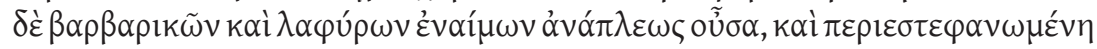

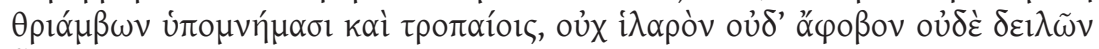

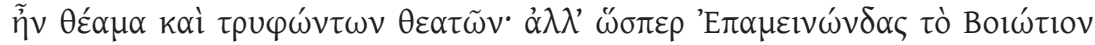

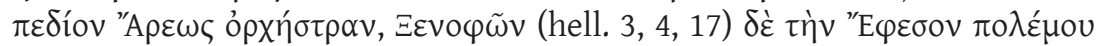

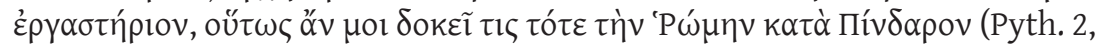

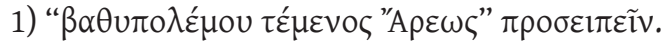

mas Arquimedes, ao vê-lo, pediu-lhe e suplicou-lhe para esperar um pouco, de modo a não deixar a sua pesquisa incompleta e sem ter sido demonstrada, mas o soldado, sem pensar, matou-o. Segundo uma terceira versão, Arquimedes, quando levava a Marcelo instrumentos matemáticos, como quadrantes solares, esferas e esquadros, que permitiam ver a grandeza do sol, foi encontrado, por mero acaso, por dois soldados, e estes, julgando que levava ouro na bolsa, mataram-no.

${ }^{638}$ Ibid. 20.12.

639 Ao invés, esta atitude de Marcelo merece a crítica de Políbio (9.10. 1-3) e de Tito Lívio (25.31.8-11; 25.40.1-3; 26.30.9; 26.31.9; 34.4.4); para Tito Lívio, o acto de Marcelo é legítimo, mas a verdade é que ele teve consequências nefastas para Roma. Plutarco provavelmente seguiu a lição de Posidónio, mais favorável à helenização de Roma; cf. R. Flacelière \& É. Chambry (1966: 218, n.1), J.-L. Ferrary (1988: 275, 573-578). Estes estudos notam, ao contrário do texto de Plutarco, que os Romanos já tinham tido contacto com a arte grega, quando, em 272 a. C., tomaram Tarento; vide, ainda, E. Gruen (1995: 94-103, 123-9); a propósito das fontes que Plutarco usou para compor a biografia de Marcelo, vide C. Pelling (1989: 203, n. 7).

${ }^{640}$ Marc. 21.1-3; para uma análise sobre a relação entre a cultura grega e Marcelo neste episódio vide C. Pelling (1989: 199-208). 
Quando os Romanos chamaram Marcelo para a guerra que se fazia no próprio país e perto da cidade, ele tirou no regresso a maior parte e as mais belas obras de arte existentes em Siracusa, com a intenção de mostrar o seu triunfo e para ornamentar a cidade. De facto, Roma não tinha nem conhecia antes nenhuma dessas elegâncias e magnificências, nem tinha amor por este tipo de beleza e pela delicadeza da arte, mas estava repleta de armas bárbaras e despojos ensanguentados, e coroada com monumentos e troféus dos triunfos. Não era um espectáculo alegre nem tranquilo, nem para espectadores tímidos e delicados. Porém, tal como Epaminondas chamava a planície da Beócia de orquestra de Ares e Xenofonte a Éfeso a oficina de guerra, assim também me parece que se pode dizer, segundo Píndaro, que a Roma desse tempo era o "santuário do belicoso Ares".

Dentro do tom laudatório que usa na biografia de Marcelo, devido à relação deste com o helenismo, Plutarco valoriza o saque das obras de arte gregas de Siracusa ${ }^{641}$, uma vez que, segundo o Queronense, Marcelo pretendeu helenizar os Romanos, ou seja, fazer suscitar neles o gosto pela arte e pela beleza, revelando esta informação que os Romanos necessitavam de ser civilizados. Políbio e Tito Lívio preferem, no entanto, realçar o facto de a atitude de Marcelo manifestar pouca clemência para com os Siracusanos, além de - e este é o aspecto mais importante - ter dado a conhecer o luxo aos Romanos, contribuindo para degenerar e corromper os seus valores tradicionais ${ }^{642}$. Ao lembrar os exemplos de Epaminondas e Xenofonte, Plutarco não esquece que também a história grega está repleta de guerras internas, que terão, porventura, relegado para segundo plano a contemplação da beleza. Fica-se com a ideia de que os Gregos e os Romanos promovem diferentes formas de arte, e que ambos os povos se vêem enredados, quase fatalmente, em guerras sucessivas, que os afastam da contemplação serena da beleza.

A intenção de introduzir a beleza helénica em Roma poderia, no entanto, suscitar reacções diferentes, especialmente por alguns pensarem que isso iria

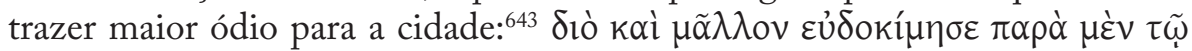

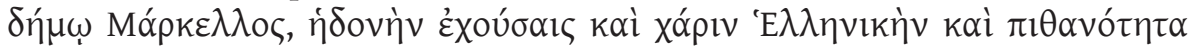

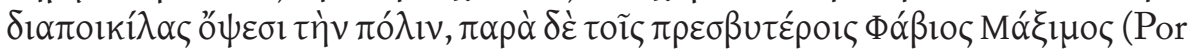
isso, Marcelo conseguiu ter maior reputação junto do povo, por ter adornado

${ }^{641}$ Segundo Cic., In Verr. IV 54. 120-121, Marcelo depositou uma parte considerável dessas obras de arte num templo que ele próprio fundou em honra da Virtude.

${ }^{642} \mathrm{~A}$ atitude de Marcelo tornou-se um topos da historiografia romana, sendo confrontada com o que Fábio Máximo fez com as estátuas tarentinas; cf. J.-L. Ferrary (1988: 510, 575 ss.).

${ }^{643}$ Marc. 21.4; atitude semelhante acontece em Pel. 25, após o regresso de Pelópidas da batalha de Leuctras. 
a cidade com a beleza, enquanto os mais ilustres apreciavam sobretudo Fábio Máximo $\left.{ }^{644}\right)$.

Plutarco regozija-se com o efeito pedagógico de Marcelo junto dos Romanos, por estes passarem a contemplar as maravilhas da Grécia. A cultura helénica de Marcelo não seria algo normal, nesta altura, em Roma: ${ }^{65}$ oủ $\mu \eta \dot{v}$

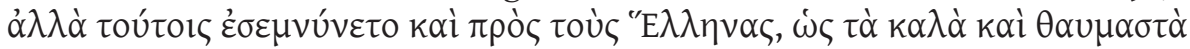

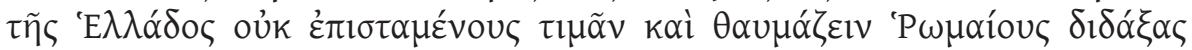
(Todavia, Marcelo vangloriava-se destes feitos, mesmo junto dos Gregos, por ter ensinado aos Romanos, que eram desconhecedores, a apreciar e a admirar as belezas e as maravilhas da Grécia). Plutarco aproveita o triunfo de Marcelo em Siracusa (termina a sua acção em 210 a. C.) - que ele afirma ser o terceiro, parecendo tratar-se de um erro ${ }^{646}$, se considerarmos que apenas havia vencido os Gauleses ${ }^{647}$, em 222 a. C.- e a descrição das várias formas de triunfo em Roma ${ }^{648}$ para apontar diferenças entre os Romanos e os Espartanos. Isto serve para elogiar estes, pois, segundo o pensamento do biógrafo, eram dois povos especialmente belicosos, mas, para os Espartanos, uma acção é tanto mais

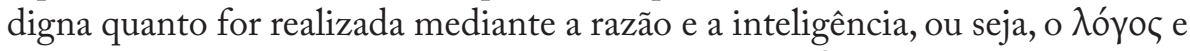

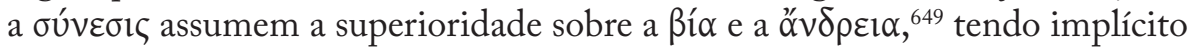
esta distinção um claro valor cultural. De acordo com este princípio, na biografia de Timoleonte ${ }^{650}$, Plutarco justifica a sua admiração pelo protagonista com o facto de, ao contrário de Epaminondas, Pelópidas ou Agesilau, a sua acção ter sido secundada pela tyche, a quem ele respeita e presta culto, não tendo por causa disso recorrido à violência, salvo no caso do seu irmão.

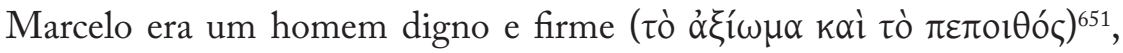
embora o fervor da guerra e da glória o tenham levado a cometer erros que trouxeram o infortúnio a Roma ${ }^{652}$, em particular a sua falta de moderação e paciência ${ }^{653}$. Ao contrário de outros cônsules e generais que temiam o Cartaginês ${ }^{654}$, Marcelo enfrenta-o com sucesso, exortando os seus concidadãos

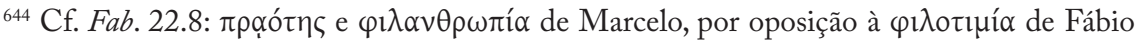
Máximo, apesar de, ao longo da biografia do Cunctator,Plutarco realçar sobretudo a sua $\pi \rho \alpha o^{\prime} \tau \eta \varsigma$

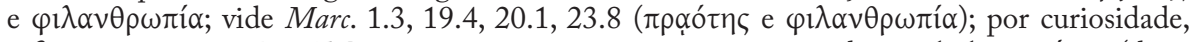

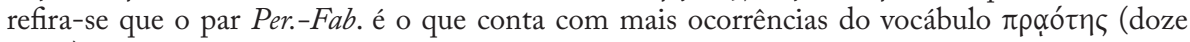
vezes).

\footnotetext{
${ }^{645}$ Ibid. 21.7.

${ }^{646}$ Repete o erro em comp. Pel.-Marc. 3.6.

${ }^{647}$ Cf. Marc. 8.1.

${ }^{648}$ Cf. ibid. 22.2-8.

${ }^{649}$ Cf. ibid. 22. 10.

${ }^{650}$ Cf. Tim. 36.

${ }^{651}$ Cf. ibid. 23.4.

${ }^{652}$ Cf. ibid. 25.

${ }^{653}$ Cf. ibid. 29.3.

${ }^{654}$ Cf. ibid. 24.1.
} 
a não perder a confiança. Será precisamente pela boca de Aníbal que Plutarco enfatizará as capacidades de Marcelo, reconhecendo a sua tenacidade , tanto no sucesso como na adversidade. ${ }^{655}$ Aliás, Aníbal revela, após a morte de Marcelo, um enorme respeito pelo seu cadáver ${ }^{656}$.

Toda a parte final do bios de Marcelo serve para Plutarco reafirmar a necessidade de se conservarem os mais nobres valores até ao fim da vida, pois o Romano, tal como Flaminino, haveria de se deixar vencer pela philotimia: 657

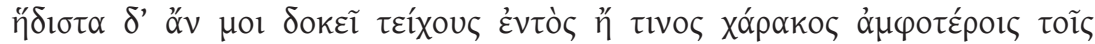

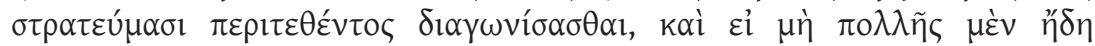

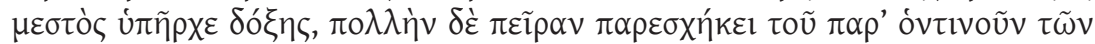

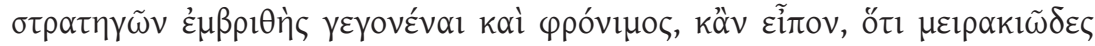

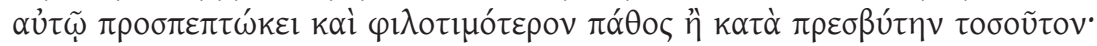

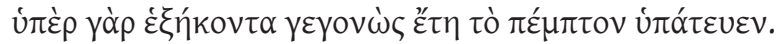

Parece-me que para ele era muito agradável combater dentro das muralhas ou de uma trincheira cercada por ambas as tropas e, se não estivesse já coberto de grande glória e não tivesse já dado uma grande prova de ser um general forte e sábio como qualquer outro, poderia dizer que ele havia caído num desejo juvenil e excessivamente ambicioso para alguém próximo da velhice como ele. De facto, foi cônsul pela quinta vez quando já tinha mais de sessenta anos.

A narrativa do par Pelopidas-Marcellus não esconde que estes dois homens tiveram vidas muito marcadas pelo combate e que participaram em episódios com alguma intensidade dramática. Além disso, nenhum dos dois heróis merece por parte de Plutarco um especial tratamento, pois é evidente o equilíbrio entre Pelópidas e Marcelo. Talvez possamos acrescentar que, de entre os heróis romanos biografados, a narrativa dos feitos de Marcelo é das mais favoráveis. Tal deve-se ao facto de Marcelo apreciar a paideia helénica e de a ter promovido entre os Romanos ${ }^{658}$, embora ele próprio não seja um modelo de entrega ao estudo.

Nas primeiras linhas da synkrisis menciona-se o facto de Pelópidas

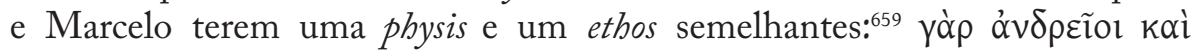

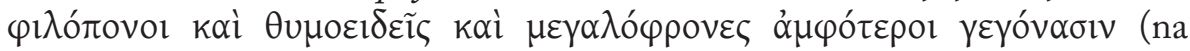
verdade, ambos foram corajosos, laboriosos, resolutos e magnânimos). Nas

${ }^{655}$ Ibid. 26.2; discurso semelhente em Tito Lívio 27.14.1.

${ }^{656}$ Cf. ibid. 30.1-2.

${ }^{657}$ Ibid. 28.6.

${ }^{658}$ Como escreve C. Pelling (1989: 203): "For Plutarch, Marcellus at least deserves credit for caring about Greek literature; and what he does for Rome is civilizing rather than debilitating”.

${ }^{659}$ Comp. Pel.-Marc. 1.2. 
suas realizações, Marcelo não evitou os massacres ${ }^{660}$, enquanto Pelópidas e Epaminondas não os fizeram. Considera, do mesmo modo, que os feitos de Pelópidas foram superiores, uma vez que tem muito mais valor dominar Esparta do que conquistar a Sicília. Além disso, o percurso de Marcelo sugere que a sua glória foi atingida por mérito pessoal, ao passo que Pelópidas tem de partilhar o seu êxito com Epaminondas, o que valoriza claramente o Romano. Isso leva-nos a afirmar que a figura de Pelópidas se define, acima de tudo, pela sua relação com Epaminondas e pelas diferenças existentes entre ambos, que a seu tempo evidenciámos. No caso de Marcelo, Plutarco aproveita a figura de Aníbal e a de Fábio Máximo para estruturar parte da narrativa, criando uma espécie de micro-synkrisis.

No entanto, há uma característica partilhada por ambos, que figura no prólogo deste par e que acaba por ser um dos elementos centrais da synkrisis: a morte ou, por outras palavras, a maneira como os dois heróis se entregaram aos seus objectivos, sem pensar no valor da vida ${ }^{661}$. Segundo a concepção plutarquiana, Pelópidas e Marcelo, embora mereçam rasgados elogios pela sua audácia e pela capacidade de liderança, têm um fim absurdo, uma vez que morrem por ambicionarem a vingança e a glória, descurando a razão ${ }^{662}$. Por conseguinte, defende-se a noção de que é melhor vencer e sobreviver, pois uma morte nestas circunstâncias é mais digna de um soldado do que de um general.

Se bem que se evite na synkrisis atribuir a superioridade a um dos dois, no momento em que se refere à trágica morte de ambos, fica-se a perceber que o Romano é mais distinto ${ }^{663}$, até porque a morte de Pelópidas era a mais evitável, mas ele não soube controlar o seu pathos ${ }^{664}$. Com este facto, Plutarco assume mais uma vez o valor da paideia no controlo dos excessos ${ }^{665}$, neste caso com a particularidade de Marcelo, um Romano, representar melhor os princípios helénicos.

Provoca alguma estranheza o facto de não haver qualquer referência a Arquimedes, a Siracusa e à admiração que Marcelo nutre pela cultura grega

${ }^{660}$ Assim classifica os actos em Siracusa, ao passo que em Marc. 20.1-2 não considera os actos de Marcelo como um massacre.

${ }^{661}$ Cf. Comp. Pel.-Marc. 3.

${ }^{662}$ No caso particular da morte de Marcelo, a forma trágica e mesmo patética como morre e o tratamento que o corpo merece por parte de Aníbal evidenciam semelhanças com a morte de Arquimedes (Marc. 19), associando, dessa forma, a tomada de Siracusa com a morte de Marcelo.

${ }_{663}$ L. García Moreno (1996: 362), apoiando-se em M. Mühl (1925), considera que o retrato idealizado de Marcelo se deve ao facto de Plutarco ter usado como fonte preferencial Posidónio; esse uso explicará também que Marcelo seja a única biografia de um romano do final da República com um correspondente grego do período clássico e não da época helenística, sendo esta normalmente menos valorizada pelos intelectuais do tempo de Plutarco (cf. E. Bowie (1970: 15 ss.); sobre a escolha dos heróis, vide J. Geiger (1995: 174 ss).

${ }^{664}$ Cf. Comp. Pel.-Marc. 3.3.

${ }^{665}$ Cf. Cor. 1.3-5 e Marc. 2.2-4. 
nos três capítulos da synkrisis. Pode, no entanto, ser uma consequência do considerável espaço que ocupam na narrativa da biografia ou Plutarco por não encontrar na biografia de Pelópidas um equivalente comparável. Uma terceira justificação pode estar relacionada com o objectivo que o autor tem de juntar duas personagens que se distingam sobretudo pelo combate, esbatendo-se as diferenças entre Gregos e Romanos.

\subsubsection{Alexander-Caesar}

A biografia de Alexandre Magno, tal como acontece com a de Pompeio, é mais do que uma biografia ${ }^{666}$. O gosto pela aventura e pela análise psicológica ultrapassa qualquer outra motivação. Em virtude dessas características, a biografia do Macedónio mais parece um romance, com elementos épicos e trágicos. A propósito da aproximação entre biografia e romance na obra de Plutarco, escreveu J. Sirinelli (2000: 315): “On pourrait sans grande crainte de se tromper imaginer que Plutarque, à force de labourer le champ de la biographie, a découvert non seulement la distance qui la séparait de l'Histoire, mais les relations étroites qu'elle ne pouvait manquer d'entretenir avec le roman". Além disso, embora Plutarco se tente distanciar do labor historiográfico no

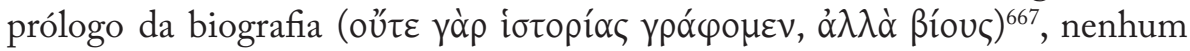
leitor fica indiferente à variedade de fontes usadas pelo biógrafo, o que denota um trabalho de pesquisa e selecção de informação apreciável: as cartas ${ }^{668}$ e os diários escritos ou mandados escrever por Alexandre, Aristobulo ${ }^{669}$, Cares ${ }^{670}$, Onesícrito ${ }^{671}$, Calístenes ${ }^{672}$ e Eratóstenes ${ }^{673}$, para referirmos apenas os mais citados $^{674}$.

Paralelamente à narração de um conjunto de acções que testemunham a acção civilizadora de Alexandre ${ }^{675}$, Plutarco apresenta-o como um governante respeitador da idiossincrasia dos povos conquistados - a corroborar essa ideia estará o facto de não haver qualquer ocorrência do verbo $\dot{\varepsilon} \lambda \lambda \eta v i ́ \zeta \varepsilon v^{676}$ e do vocábulo $\dot{\varepsilon} \lambda \lambda \eta v \imath \sigma \mu o ́ s$ na biografia —, pois nem a sua curta vida impediu que

${ }^{666}$ A admiração que o Queronense sente por Alexandre fica expressa nos dois tratados De Alex. fort. aut uirt. e pelas variadas histórias anedóticas que sobre ele conta em Reg. et imp. apopht.

${ }^{667}$ Cf. Alex. 1.2.

${ }^{668}$ J. Hamilton (1961: 9-20) cataloga trinta e uma cartas; vide, ainda, J. Powell (1939: 230).

${ }^{669} \mathrm{Cf}$. Alex. 15.2, 16.15, 18.4, 21.9, 46.2, 75.6.

${ }^{670}$ Cf. ibid. 20.9, 24.14, 46.2, 54.4, 55.9.

${ }^{671}$ Cf. ibid. 8.2, 15.2, 46.1, 60.6, 61.1, 65.2.

${ }^{672}$ Cf. ibid. 27.4, 33.1, 33.10.

${ }^{673}$ Cf. ibid. 3.3, 31.5.

${ }^{674}$ Para mais informações sobre as fontes usadas por Plutarco, vide J. Hamilton (2002r: lvlxviii), estudo fundamental para a análise da biografia de Alexandre.

${ }^{675}$ Cf. De Alex. fort. aut. virt. 328C-E; Alex. 5.7-8; 7.1-8; 26.1-7; 47.6.

${ }^{676}$ No tratado De Alex. fort. aut. virt. apenas ocorre uma vez (328D). 
fosse cumulado de glória. Aliás, podemos mesmo dizer que a acção civilizadora e a relação de Alexandre com a cultura helénica são dois dos motivos mais interessantes da biografia. O biógrafo realça no carácter de Alexandre dois traços essenciais: ${ }^{677}$

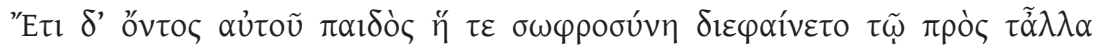

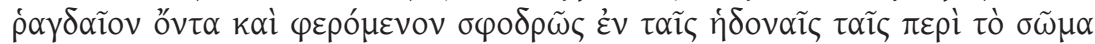

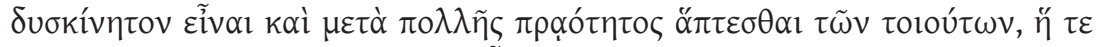

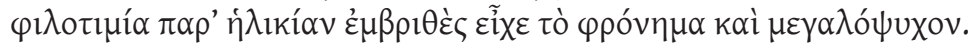

Quando ainda era criança, a sabedoria dele manifestava-se de forma intempestiva e veemente em algumas ocasiões, enquanto nos prazeres corporais era controlado e se entregava a estes com muita amabilidade. A ambição pela glória estava no seu espírito sério e magnânimo, que não era próprio da sua idade.

Assim, a $\sigma \omega \varphi \rho \circ \sigma u ́ v \eta$ e a $\varphi \imath \lambda o \tau \imath \mu i^{6}{ }^{678}$ são duas das características que Alexandre apresenta desde tenra idade, ele que sempre perseguiu a $\delta$ ó $\xi \alpha$ nas suas acções ${ }^{679}$. Além disso, as histórias que o Queronense conta da sua infância, quer o espanto que a sua personalidade causou nos embaixadores persas ${ }^{680}$, quer o conhecido episódio em que consegue, sem ninguém esperar, domar o cavalo Bucéfalo ${ }^{681}$, prefiguram a sua grandeza e o seu destino de conquistador, como o próprio pai compreende quando the dirige as seguintes palavras: ${ }^{682}$ "†ñ reino à tua medida! A Macedónia não é suficiente para ti”).

O episódio de Bucéfalo parece prefigurar a acção civilizadora de Alexandre, quando domou os Bárbaros, incentivando-os a sair do estado de selvajaria em que se encontravam. Note-se que nesta acção a paideia surge como meio

${ }^{677}$ Alex. 4.8.

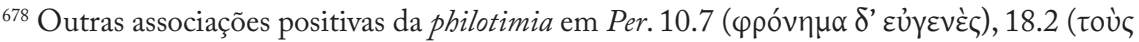

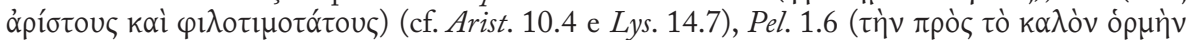

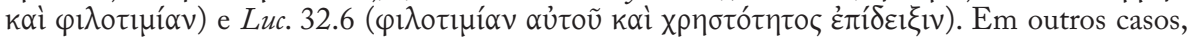
aparece associada a acções que revelam alguma nobreza: Ant. 3.8 (António revela ser clemente ao impedir o massacre) e Lys. 4.6 (Lisandro, por opção, não retira benefícios monetários).

${ }^{679}$ Sobre a conexão entre philotimia e doxa na caracterização dos heróis, vide F. Frazier (1988a: 119). Parecendo-nos que a relação entre philotimia e doxa ajuda a perceber que não é intenção de Plutarco apresentar a philotimia como um princípio naturalmente negativo, mas que surge devido a duas causas: a motivação individual e os condicionalismos próprios do momento histórico, em especial dos diversos conflitos internos na Grécia.

${ }^{680}$ Alex. 5.1-3.

${ }^{681}$ Cf. ibid. 6.; o famoso cavalo de Alexandre haveria de morrer, por causa das feridas (versão da maioria dos historiadores) ou pela sua idade (segundo Onesícrito), após a batalha contra Poro. Alexandre fundou em sua honra uma cidade com o nome de Bucefalia (cf. Alex. 61).

${ }^{682}$ Ibid. 6.8. 
estratégico para a consolidação do poder e para Alexandre conseguir atrair a benevolência dos conquistados, sem a qual seria difícil a manutenção da hegemonia.

Logo a seguir, Plutarco esclarece o sentido de philotimia, ao relacioná-lo com a arete e a doxa, percebendo-se que se trata, em primeiro lugar, de uma motivação individual para depois se tornar um princípio de acção mais generalizado, como acontece também em relação à philotimia que caracteriza Flaminino: 683

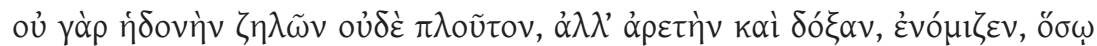

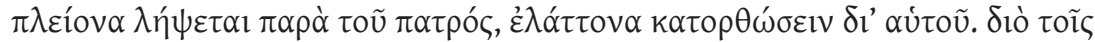

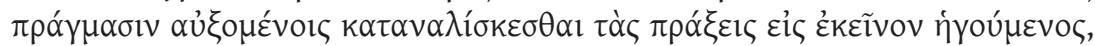

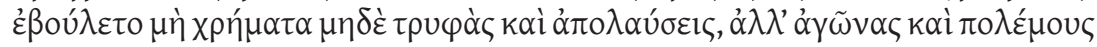

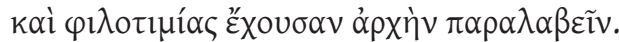

Por não perseguir nem o prazer nem a riqueza, mas a virtude e a glória, Alexandre considerava que quanto mais recebesse de seu pai menos êxitos conseguiria por sua própria acção. Por isso, Alexandre, acreditando que Filipe ao chefiar acções gloriosas esgotaria os feitos futuros dele, queria receber um reino que não tivesse bens nem luxos, mas confrontos, guerras e ambições.

Como se constata, Alexandre não perseguia bens materiais com os seus feitos ${ }^{684}$, mas tinha como especial intenção merecer o reconhecimento e a fama, por causa dos seus dotes, exercendo a sua philotimia. Enquanto o pai foi vivo, o jovem macedónio estava preocupado com o facto de os feitos do pai serem tantos que não poderia ser capaz de o superar e de deixar a sua marca na história, o que, afinal, se viria a verificar. As suas conquistas tiveram uma vertente obviamente guerreira e uma outra mais sócio-cultural, uma vez que Alexandre promoveu profundas alterações nas sociedades que conquistou, não se limitando a dominar. Este princípio estratégico de conquista viria, em parte, a ser imitado, como Plutarco salienta, pelos Romanos na construção do Império, de forma mais organizada e sistemática, e sobretudo com um propósito político bem planeado e executado. Apesar disso, ambos os impérios haveriam, por razões diferentes, de sucumbir, facto que em nada diminui o seu valor civilizacional e cultural, pois os ciclos temporais da própria história dizem-nos que os impérios conhecem, fatalmente, o seu fim. Ainda em relação à philotimia de Alexandre, ela prova como o seu carácter era resoluto, uma vez

${ }^{683}$ Ibid. 5.5-6.

${ }^{684}$ Esta pormenorização da intencionalidade da philotimia de Alexandre faz todo o sentido porque em muitos casos ela surge ligado a honrarias; a este propósito, vide F. Frazier (1988a: 116). 
que não reconhecia com facilidade que as suas ideias ou objectivos poderiam estar errados. ${ }^{685} \mathrm{~A}$ grande confiança que depositava nas suas capacidades, mesmo perante o perigo, é uma das virtudes que Plutarco louva no jovem rei ${ }^{686}$, que terá chegado mesmo a combater para aliviar a dor $(\pi \varepsilon ́ v \theta 0 \varsigma)^{687}$.

Quanto à paideia de Alexandre, sendo conhecida a sua admiração pela filosofia ${ }^{688}$ e pela cultura, Plutarco descreve diversos elementos, começando por mencionar os seus primeiros mestres: ${ }^{69}$

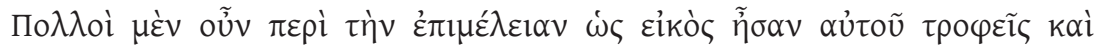

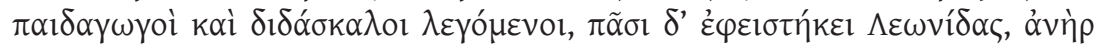

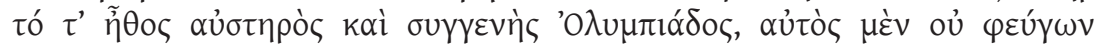

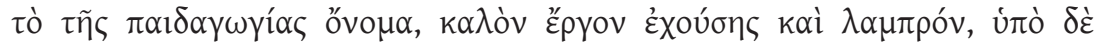

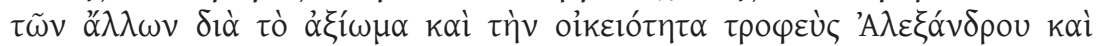

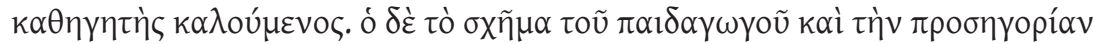

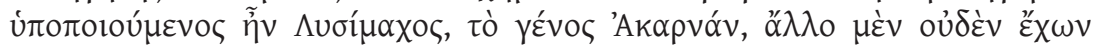

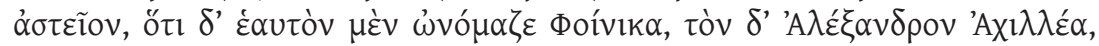

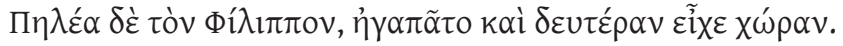

Como é natural, tinha a cuidar dele muitos educadores, pedagogos e mestres, mas à frente de todos estava Leónidas, um homem de carácter austero e da mesma família de Olímpia. Este, sem recusar o nome de pedagogo, por ter uma tarefa nobre e brilhante, era, no entanto, chamado pelos outros educador e guia de Alexandre, por causa da sua dignidade e parentesco. Foi Lisímaco, nascido em Acarnânia, que ocupou a posição e o nome de pedagogo, embora não tivesse qualquer encanto, mas, como se chamava a si próprio Fénix, a Alexandre Aquiles e a Filipe Peleu, era tratado de forma especial e ocupava a segunda posição.

Embora o texto não nomeie, infelizmente, os diversos educadores que Alexandre teria à sua disposição, somos informados de que Leónidas terá ocupado um lugar especial na sua formação e que tentou, de certeza, transmitir

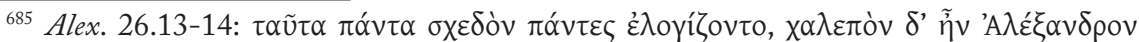

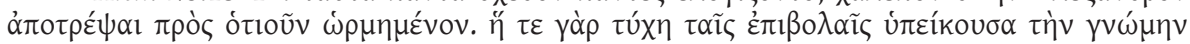

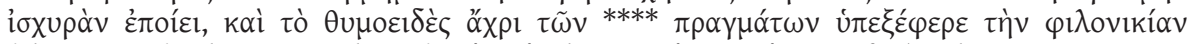

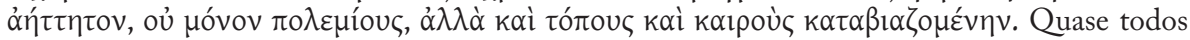
tinham em linha de conta este conjunto de condicionantes, mas era difícil dissuadir Alexandre depois de este se lançar numa acção. Na verdade, a fortuna, ao ceder aos seus intentos, fortalecia as suas opções e o carácter resoluto com que se empenhava até ao momento da execução tornava-o invencível nas disputas, dominando não apenas os inimigos, mas também os lugares e as circunstâncias.

${ }^{686}$ Cf. ibid. 32.4.

${ }^{687}$ Cf. ibid. 72.4.

${ }^{688}$ Apesar do seu amor pela filosofia, na Índia, Alexandre mandaria matar alguns filósofos que tentavam convencer os reis locais a não se unirem a ele (cf. Alex. 59.8).

${ }^{689}$ Alex. 5.7-8. 


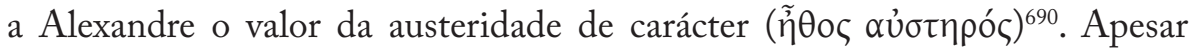
disso, Quintiliano ${ }^{691}$, usando como fonte o filósofo estóico Diógenes da Babilónia (século II a. C.), refere-se à influência negativa de Leónidas sobre o Macedónio, uma vez que lhe impregnou (inbuit) no carácter vícios que o acompanhariam até à idade adulta. Quanto a Lisímaco, era o pedagogo oficial, embora não fosse tão dotado como o primeiro $^{692}$. Note-se, ainda, que, em comparação com as restantes biografias que analisámos, apenas neste texto os educadores surgem hierarquizados. Essa classificação não parece, porém, ter em conta apenas as qualidades pedagógicas, mas também as virtudes morais e até o estatuto social da sua família.

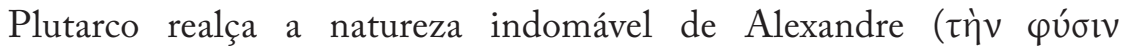

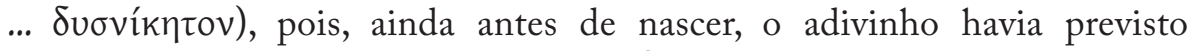
que Alexandre seria impulsivo $(\theta u \mu o \varepsilon ı \delta \tilde{\eta})$ e teria uma natureza de leão

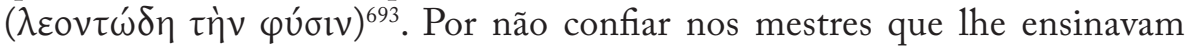
a mousike (leitura, música e aritmética simples) e o enkyklion paideuma (triuium: gramática, retórica e dialéctica; quadriuium: geometria, aritmética, astronomia e teoria musical), Filipe decide chamar Aristóteles, o mais ilustre e

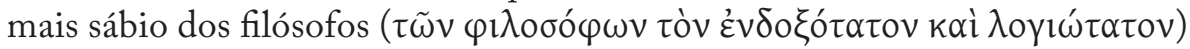
${ }^{694}$. Apesar da apresentação que se faz de Aristóteles, caracterização que está de acordo com a tradição, neste momento, ele não seria ainda um filósofo de renome e a sua escolha para mestre de Alexandre teria sido ditada por razões políticas, embora certamente já nessa altura Filipe apreciasse as qualidades do Estagirita ${ }^{695}$. Plutarco descreve, desta forma, a paideia de Alexandre, entregue às lições de Aristóteles: ${ }^{696}$

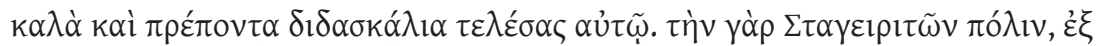

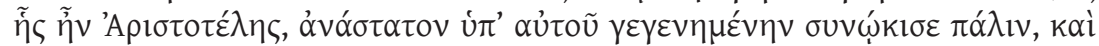

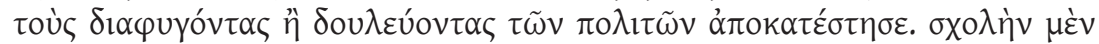

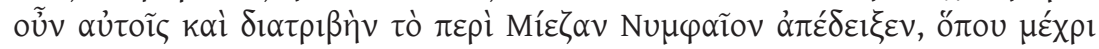

${ }^{690}$ Em Alex. 22.9-10, Plutarco refere que a tarefa de Leónidas ia ao ponto de ter designado a Alexandre os cozinheiros e que também examinava as roupas enviadas pela mãe para evitar os luxos; depois de conquistar Gaza, numa batalha da qual resultaria ferido, Alexandre enviou a Leónidas quinhentos talentos de incenso e cem de mirra, para que ele pudesse prestar sacrifícios aos deuses sem olhar a economias, como o próprio Leónidas aconselhara, na infância, a Alexandre (cf. Alex. 25.6-8; vide, ainda, Reg. et imp. apopht. 179E-F).

${ }^{691}$ Cf. 1.1.9.

${ }^{692}$ Alexandre arriscaria a vida para salvar Lisímaco, num confronto com os Árabes perto de Antilíbano (cf. Alex. 24.10). Sobre as dúvidas quanto à identificação do nome Lisímaco que se menciona em 55.2, vide J. Hamilton (2002r: ad loc.).

${ }^{693}$ Cf. ibid. 2.5.

${ }^{694}$ Cf. Alex. 7.2.

${ }^{695}$ Cf. J. Hamilton (2002r: ad loc. 7.2).

${ }^{696}$ Ibid. 7.2-8 


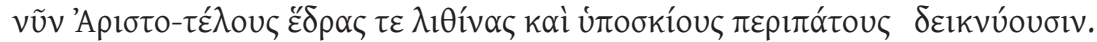

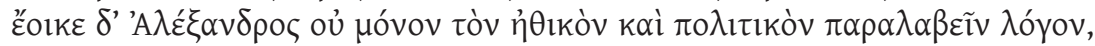

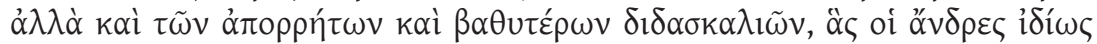

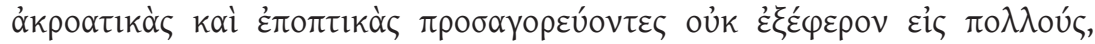

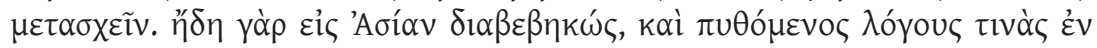

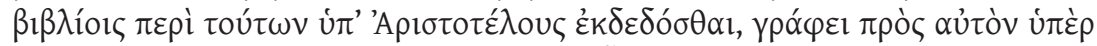

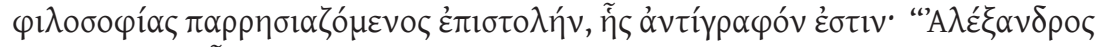

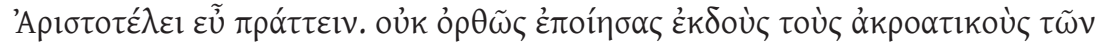

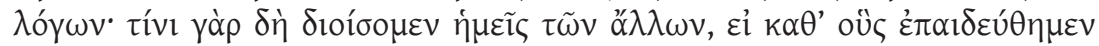

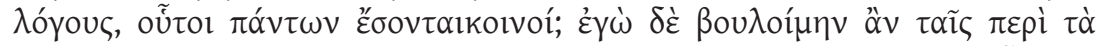

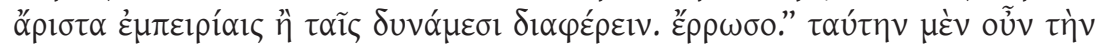

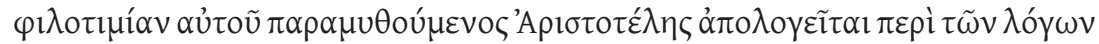

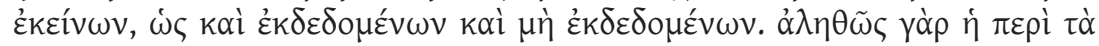

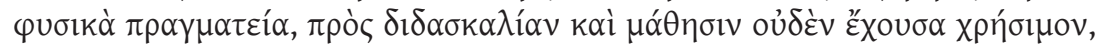

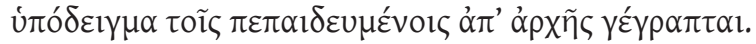

Filipe pagou a Aristóteles um salário digno e apreciável pelos ensinamentos. Reedificou a cidade de Estagira, onde tinha nascido Aristóteles e que ele próprio tinha destruído, e permitiu o regresso a ela dos cidadãos exilados ou escravizados. Deu a Aristóteles como escola e local de estudo o santuário das Ninfas de Mieza, onde ainda se podem ver os bancos de mármore de Aristóteles e os umbrosos locais por onde ele passeava. Parece que Alexandre não recebeu apenas lições de ética e política, mas também instruções secretas e mais íntimas: em particular, chamando-lhes de "acroáticas" e "epópticas", os homens evitam divulgá-las a todos. Quando Alexandre já tinha atravessado a Ásia, e sabendo que Aristóteles tinha publicado em livros alguns argumentos sobre esses assuntos, escreveu-lhe uma carta, por livre vontade, em defesa da filosofia. Esta é uma cópia dessa carta: "Alexandre felicita Aristóteles. Não agiste correctamente ao publicar as lições "acroáticas". Na verdade, em que nos diferenciamos dos outros, se as lições que foram ensinadas vão ser comuns a todos? Eu desejaria distinguir-me pelo conhecimento das coisas mais nobres e não pela força. Adeus". Com a intenção de consolar a ambição de Alexandre, Aristóteles justificou-se dizendo ter publicado e não ter publicado aqueles discursos. De facto, o estudo sobre física não tem verdadeiramente nenhuma utilidade para o ensino nem para a aprendizagem, uma vez que está escrito em forma de memorando para os que se têm instruído desde o início.

Percebe-se que Aristóteles, enquanto mestre de Alexandre, foi cumulado das mais nobres honrarias, tendo educado o jovem macedónio em questões éticas e políticas, bem como em matérias mais profundas e secretas, como as "acroáticas" (do verbo grego ơkpoóo $\alpha \propto \alpha$, que significa "ouvir" ou "ser discípulo") e as "epópticas" (indica um nível de inciação, no mais elevado grau) ${ }^{697}$, que

${ }^{697}$ Cf. Demetr. 26 (iniciação aos Mistérios de Elêusis). 
parecem ser as lições que se transmitiam oralmente, mas que não se publicavam. Isto explica a desilusão de Alexandre quando é informado da publicação destas lições e mostra de imediato o seu descontentamento numa carta enviada ao seu mestre ${ }^{698}$, que em resposta dirá que só aqueles que se iniciaram nessa instrução poderão compreender a profundidade dessas matérias. Além disso, a carta de Alexandre contém como motivo de interesse o facto de afirmar o seu entusiasmo e interesse pelo conhecimento, em detrimento do poder. Acrescente-se que o conteúdo da carta não esconde, em nossa opinião, um certo tom elitista da paideia, uma vez que Alexandre reclama a exclusividade dos ensinamentos de Aristóteles, um mestre que não estaria disponível para ensinar qualquer indivíduo.

Veja-se como a philotimia, mesmo ligada a uma motivação pessoal, está neste caso relacionada com a cultura e não com o desejo de combater ou com o exercício da politei $a^{699}$. Não é caso único nas Vitae, pois é também com essa conotação cultural que se descreve a philotimia de Arquimedes ${ }^{700}$ ou no prólogo do par Demosthenes-Cicero ${ }^{701}$. Em relação ao texto acima citado, realçamos mais um pormenor: Plutarco, talvez por se tratar de Aristóteles e para demonstrar a reputação deste junto de Filipe, especifica, ao contrário do que faz nas restantes biografias, o local em que Aristóteles transmitia os seus conhecimentos.

Os ensinamentos de Aristóteles, aproveitando a natural disposição de Alexandre para as letras e a filosofia, ajudaram a consolidar a sua formação e a absorver saberes diversificados que lhe foram úteis e que ele próprio reconhecia, como prova a homenagem que presta a Teodectes, orador e tragediógrafo que conseguiu oito vitórias em concursos dramáticos ${ }^{702}$.

O processo formativo de Alexandre é uma prova de como no carácter do indivíduo se conjugam as características que são próprias da natureza e aquelas que se desenvolvem por acção de um educador. Aristóteles, na verdade, teve um papel decisivo na inclinação do Macedónio para matérias literárias e

${ }^{698}$ Cf. Gel. 20.5.11-12. Este autor, afirmando ter usado como fonte Andronico de Rodes, filósofo do séc. I a. C., é mencionado em Sull. 26.1, reproduz o teor da carta e a resposta de Aristóteles, que Plutarco apenas parafraseia.

${ }^{699} \mathrm{Em}$ Alex. 29.2, o vocábulo philotimia serve para descrever a forma como os concorrentes competiram nos agones (coros ditirâmbicos e trágicos) organizados por Alexandre na Fenícia, depois de regressar do Egipto.

${ }^{700}$ Cf. Marc. 17.6.

${ }^{701}$ Dem. 2.4.

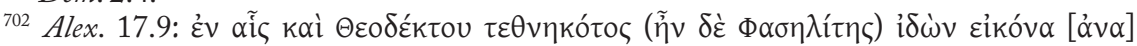

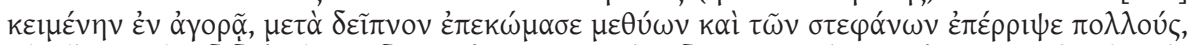

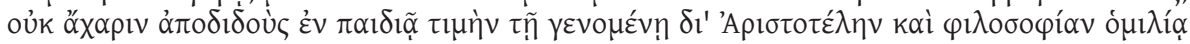

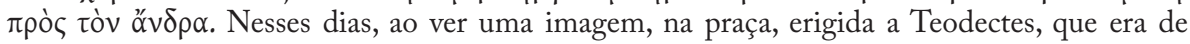
Fasélide e já tinha morrido, formou, depois do jantar e quando já estava embriagado, um cortejo e lançou-lhe muitas flores, prestando com uma brincadeira um tributo gracioso a um homem que tinha conhecido por meio de Aristóteles e da filosofia. 
também para a medicina e a filosofia: $:^{703}$

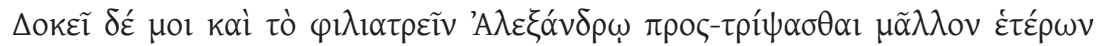

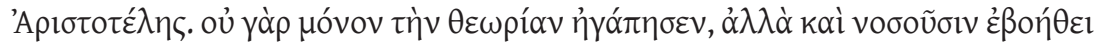

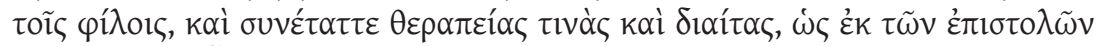

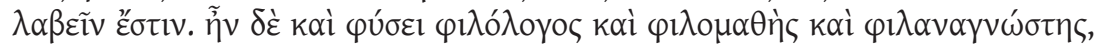

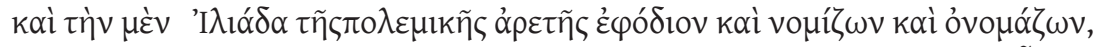

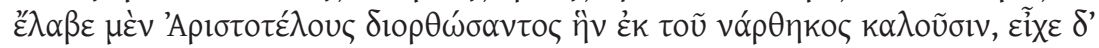

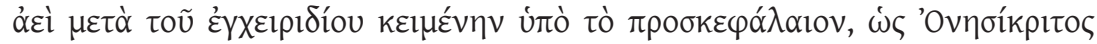

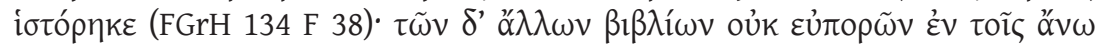

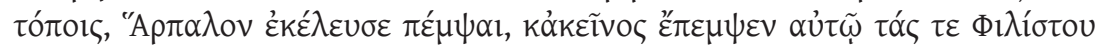

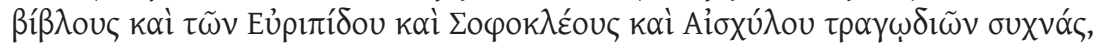

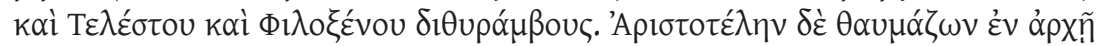

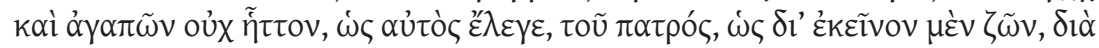

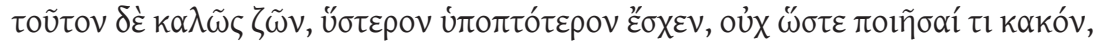

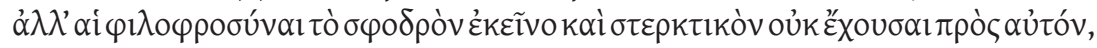

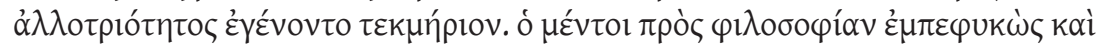

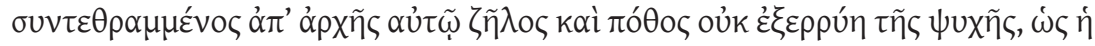

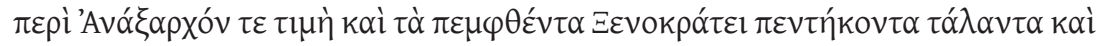

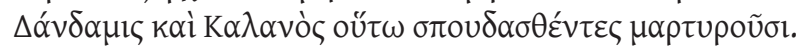

Parece-me que Aristóteles foi quem, mais do que outros, incutiu em Alexandre o amor pela medicina. Este, não só se apaixonou pela teoria, mas também socorreu os amigos doentes e prescreveu-lhes alguns cuidados e dietas, como se pode perceber pelas suas cartas. Ele era também, por natureza, um amante das letras, do estudo e da leitura. Por considerar a Ilíada um suporte para o valor guerreiro $^{704}$, e assim a denominava, tomou a versão corrigida por Aristóteles, que chamam "caixa", e tinha-a sempre debaixo da almofada, juntamente com um punhal, como contou Onesícrito. Como não conseguia adquirir outros livros nas zonas interiores da Ásia, ordenou a Hárpalo que lhos mandasse. Este enviou-lhe os livros de Filisto, um grande número de tragédias de Eurípides, Sófocles e Ésquilo, e os ditirambos de Telesto e Filóxeno. No início, admirando Aristóteles e amando-o não menos do que o seu próprio pai, pois, como ele dizia, era por causa deste que vivia, mas tinha sido o outro a ensiná-lo a viver bem. Mais tarde, Alexandre começou a desconfiar dele, não a ponto de lhe fazer algum mal, mas as suas manifestações de bondade para com ele já não tinham aquela veemência e ternura, e testemunhavam o distanciamento nas relações. Contudo, o zelo e o desejo que nele estavam enraizados e que nele cresciam, desde a infância, não desapareceram da sua alma, como o testemunham a honra

${ }^{703}$ Alex. 8.

${ }^{704}$ Sobre o proveito que tiraria de Homero, vide Alex. 26.3-7. Admirando Homero também pela sua habilidade arquitectónica, mandou traçar Alexandria conforme o lugar descrito em $\mathrm{Od}$. 4,354 s.. 
para com Anaxarco, os cinquenta talentos enviados a Xenócrates, assim como a solicitude revelada para com Dândamis e Calano.

Este texto não deixa dúvidas do interesse de Alexandre pela medicina e pela literatura ${ }^{705}$. Ele fazia-se acompanhar, nas suas campanhas, por obras literárias, em especial a Ilíada, pois revia-se, certamente, na atitude dos heróis homéricos ${ }^{706}$. Chegou mesmo ao ponto de pedir que lhe mandassem mais obras literárias. Além disso, percebemos que Alexandre e Aristóteles se viriam a distanciar, não querendo isso significar que Alexandre não reconhecesse o trabalho do filósofo-educador. Do mesmo modo, não se esqueceu de recompensar outros, como Anaxarco, um sofista seguidor de Demócrito ${ }^{707}$, Xenócrates, que liderou a Academia (339 a. C.) e dedicou a Alexandre quatro

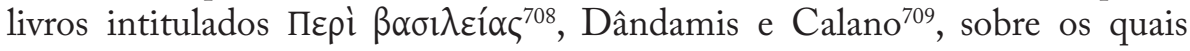
sabemos apenas que eram gymnosophistai. $\mathrm{O}$ momento em que se dividiram os despojos de Dario demonstra a preferência de Alexandre pela literatura em detrimento de bens materiais: ${ }^{710}$

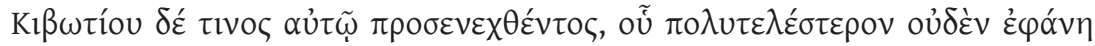

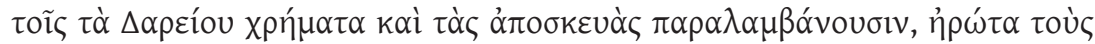

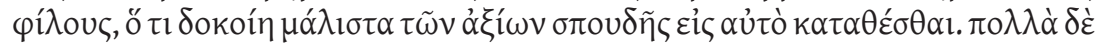

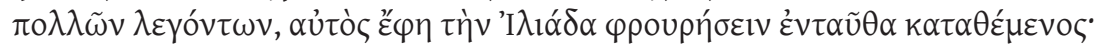

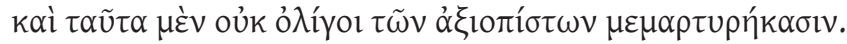

Quando lhe levaram um cofre, que parecia ser o mais precioso para os que tinham como função receber os bens e as bagagens de Dario, questionou os seus amigos sobre qual lhes parecia ser a coisa mais digna de mérito para guardar nele. Muitos emitiram opiniões diversas, mas ele disse que guardaria ali dentro a Ilíada. Não são poucos os autores dignos de crédito a dar testemunho deste acontecimento.

Ainda a propósito da formação de Alexandre, Plutarco conta-nos que ele terá recebido lições durante a sua estada no Egipto: ${ }^{711}$

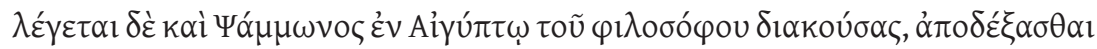

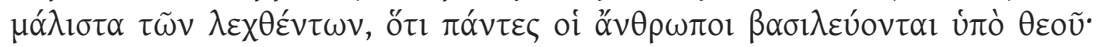

\footnotetext{
${ }^{705} \mathrm{Em}$ Alex. 72.1, Alexandre dedica-se à organização de representações teatrais, o que prova o seu gosto pela arte.

${ }^{706}$ Cf. De Alex. fort. aut uirt. 327F-328A; J. Mossman (1995: 211) presume que Plutarco usa como fonte Onesícrito para fundamentar o gosto de Alexandre por Homero.

${ }^{707}$ Cf. Alex. 28.4.

${ }^{708}$ Cf. De Stoic. rep. 1043D.

${ }^{709}$ Sobre os dois, vide Alex. 65 e 69.

${ }^{710}$ Alex. 26.1-2.

711 Alex. 27.10-11.
} 


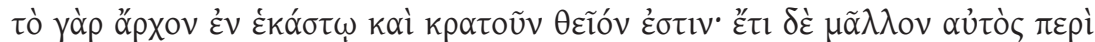

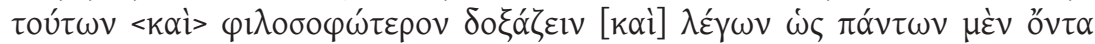

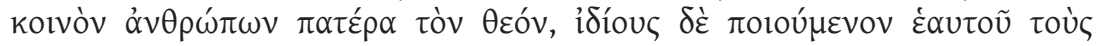

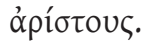

Diz-se que ouviu, no Egipto, as lições do filósofo Psâmon, aceitando sobretudo das suas palavras que "todos os homens são governados pela divindade; de facto, é um princípio divino que manda em cada um”. Então, o próprio Alexandre manifestou uma opinião ainda mais filosófica ao dizer que a divindade é o pai comum aos homens e que adoptava, em especial, como seus os melhores.

Depois da morte do pai ${ }^{712}$, Alexandre, com vinte anos, herda um reino que vivia permanentemente sob a ameaça dos Bárbaros. Outro problema era a instabilidade grega, pois, apesar de conquistados pelas armas, os Gregos não se deixavam subjugar pelos Macedónios. Se alguns acalentavam a esperança de que o jovem rei tivesse uma atitude branda ( $\left.\pi \rho \alpha \alpha_{\omega} \omega \varsigma\right)$ para com os Bárbaros e os Gregos, abdicando mesmo da Grécia, Alexandre, pelo contrário, procurou dar uma prova da sua força, de modo a evitar que o

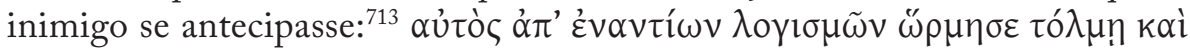

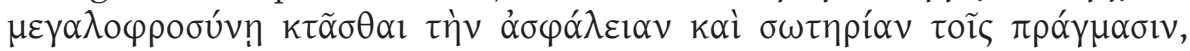

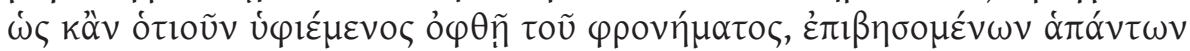
(Partindo de um pensamento oposto, Alexandre decidiu adquirir com audácia e grandeza a segurança e o bem-estar do reino com acções, pois se algum visse que vacilava nas suas decisões, logo todos o atacariam). Não se pense, no entanto, que o Macedónio se relacionava com Bárbaros e Gregos de forma indiferenciada, uma vez que era arrogante ( $\sigma \circ \beta \alpha \rho o ́ \varsigma)$ com os Bárbaros, mas tratava com moderação ( $\mu \varepsilon \tau \rho i ́ \omega \varsigma)$ os Gregos ${ }^{714}$.

Quanto aos confrontos que Alexandre promove contra Bárbaros e Gregos, Plutarco não esconde o seu patriotismo, ao enfatizar a forma como os Tebanos lutaram contra um opositor mais numeroso e forte: ${ }^{715} \eta \hat{\eta} \gamma \omega v i ́ \sigma \theta \eta \mu \dot{\varepsilon} v$

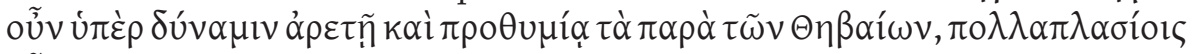

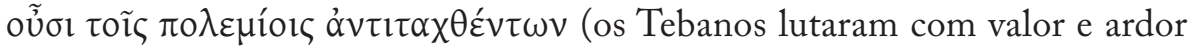
acima da sua força, opondo-se a um inimigo muito mais numeroso). Apesar

${ }^{712}$ Cf. Alex. 10.5 .

${ }^{713} \mathrm{Ibid}$. 11.4. O pensamento aqui expresso é melhor explicado na biografia de César, quando Plutarco afirma que os inimigos do Romano negligenciaram a influência e o poder que ele haveria de usufruir, pois aquilo que começa por não ter grande valor cresce e progride (cf. Caes. 4.6-7). Assim, César beneficiou dessa indiferença e Alexandre, no início do seu percurso, é um exemplo de quem não negligencia possíveis focos de instabilidade.

${ }^{714}$ Cf. ibid. 28.1.

715 Ibid. 11.9 . 
de ter vencido, Alexandre viveria para sempre atormentado com o infortúnio dos Tebanos ${ }^{716}$, mostrando ser um homem consciente da crueldade dessa luta. Como sinal do seu arrependimento pelos acontecimentos de Tebas, Alexandre é clemente com os Atenienses, aliados dos Tebanos. Plutarco justifica a clemência de Alexandre para com os Ateniense pelas características psicológicas daquele e não a considera resultado de questões estratégicas. ${ }^{717}$ Os acontecimentos anteriores à Batalha de Granico revelam Alexandre como um homem impetuoso, sensível ${ }^{718}$ e culto: o encontro, em Corinto, com Diógenes ${ }^{719}$; a ida a Delfos ${ }^{720}$; por fim, as libações em honra dos heróis, em Tróia, dedicando especial atenção ao túmulo de Aquiles ${ }^{721}$. Em relação à Batalha de Granico, a acção de Alexandre demonstra que a paideia não estava devidamente consolidada para aplacar a sua ira: ${ }^{722}$ ó $\delta \dot{\varepsilon} \theta u \mu \tilde{\omega} \mu \tilde{\alpha} \lambda \lambda o v$

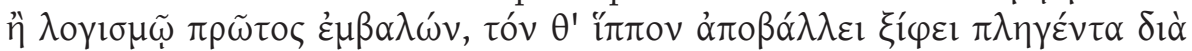

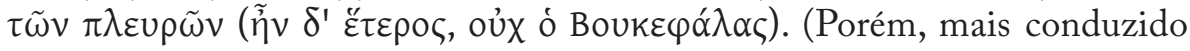
pela cólera do que pela razão, atacou primeiro e perdeu o cavalo, ferido nos flancos - não era Bucéfalo, mas um outro). Contudo, Plutarco, seguindo a

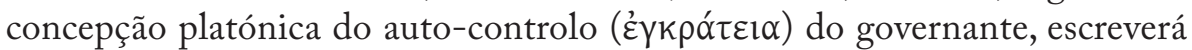
que Alexandre pensava que um rei devia mais dominar-se a si próprio do que vencer os inimigos ${ }^{723}$, o que nem sempre aconteceu ao longo da sua vida, mostrando que os preceitos da paideia não se consubstanciaram por completo na praxis política e guerreira.

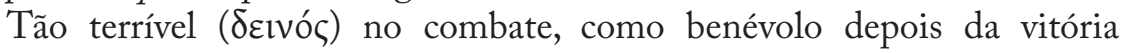

${ }^{716}$ Cf. ibid. 13.3.

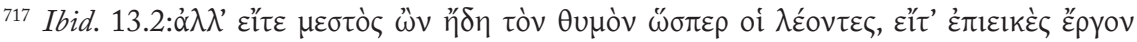

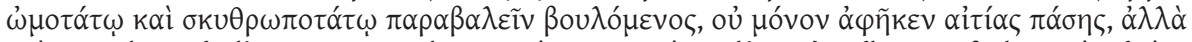

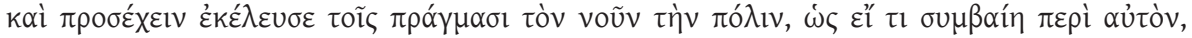

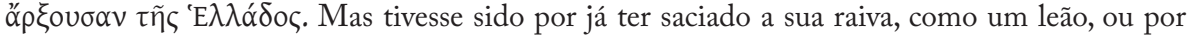
querer associar a um acto cruel e nefasto um feito moderado, não só os absolveu de toda a culpa, mas também ordenou que a cidade prestasse atenção aos acontecimentos, porque, se algo lhe sucedesse, ela dominaria a Hélade.

${ }^{718}$ Um episódio que manifesta claramente a sua sensibilidade e philanthropia é o tratamento que dá à mãe e à mulher de Dario, pois, como conta Plutarco, está mais comovido com o infortúnio dessas mulheres do que com a sua própria tyche (cf. Alex. 21.1-2). Também no momento da morte da mulher de Dario se revela magnânimo por não aproveitar a dor dos inimigos, dando mais provas da sua sophrosyne com as mulheres persas do que de andreia com os Persas (cf. ibid.30.10). Tratará da mesma forma as restantes cativas persas, ainda que a sua beleza

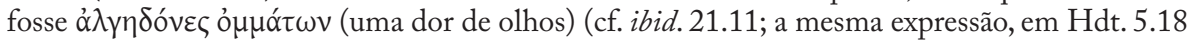
e Pseud.-Long. 1.4.7).

${ }^{719}$ Cf. ibid. 14.2-5.

${ }^{720}$ Cf. ibid. 14.6.

${ }^{721}$ Cf. ibid. 15.7; cf. De Alex. fort. aut uirt. 331D.

${ }^{722}$ Cf. ibid. 16.14 .

${ }^{723}$ Cf. ibid. 21.7. 


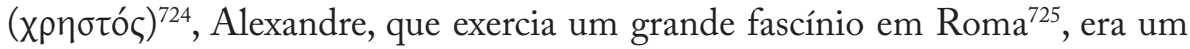
conquistador filósofo ${ }^{726}$, facto que bem personifica a complementaridade da acção e da palavra ${ }^{727}$. Ele agia pelo desejo de glória, pela ambição do poder e pela superação das expedições de Dioniso e Héracles ${ }^{728}$. Ainda que gostasse de conviver e beber ${ }^{729}$, era um homem especialmente vocacionado para a

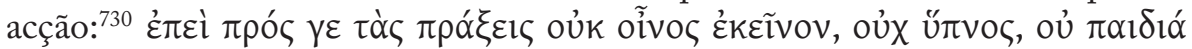

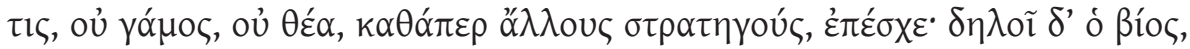

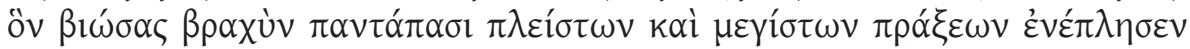
(Porque nem o vinho, nem o sono, nem o divertimento, nem o casamento, nem o espectáculo, o impediram de agir, como acontecia com outros generais. A vida dele demonstra que, embora tivesse vivido pouco tempo, esteve completamente preenchida por muitas e grandiosas acções).

Noutros casos, o seu carácter é enfatizado pela forma como formula o seu pensamento, ao estilo de um filósofo: ${ }^{731}$

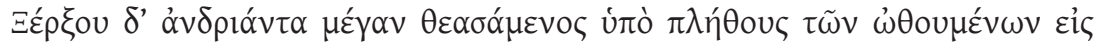

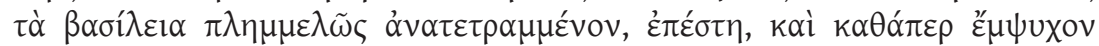

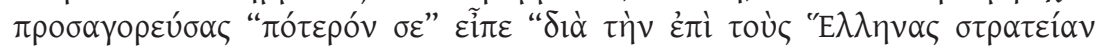

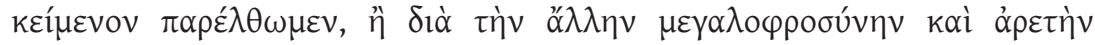

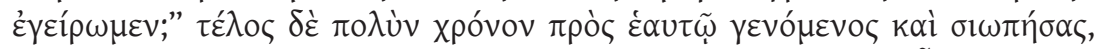

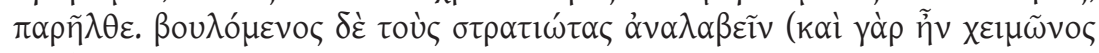

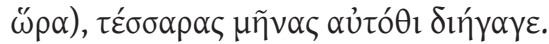

Vendo uma grande estátua de Xerxes, que, por falta de cuidado, foi derrubada pela multidão que se precipitava para o palácio, parou e, como se falasse para um ser vivo, disse: "Passaremos ao lado, deixando-te ao abandono por causa da expedição contra os Helenos, ou erguer-te-emos pela tua magnanimidade e virtude que mostraste nos outros aspectos da tua vida?". No fim, permaneceu

${ }^{724}$ Cf. ibid. 30.6.

${ }^{725}$ Cf. Pomp. 2.2-4, 34.7-8, 38.4-5, 46.1-4.

${ }^{726}$ É, por exemplo, com modos de filósofo que recrimina o luxo daqueles que o rodeavam (cf. ibid. 40-2). Na tradição gnomológica, Alexandre costuma aparecer como um filósofo da tradição socrático-cínica (cf. F. Adrados (2005: 35); cf. De Alex fort. aut uirt. 330A-D, 332E-F e 327E-329D, onde também aborda o seu papel civilizador entre os Bárbaros.

${ }^{727}$ Em Alex. 21.3-5, diz-se que as palavras que dirigiu à mãe e à mulher de Dario foram superadas pelas acções respeitadoras que tomou a seguir, como sinal da sua humanidade. Por exemplo, Filopémen lia por acreditar que as palavras estimulam não só a coragem e a imaginação, mas sobretudo a acção (cf. Phil. 4.6-8).

${ }^{728}$ Cf. De Alex. fort .aut. virt. 326B; Luc., Hist. ver. I.7; Vergílio (A. 6.801 ss.) compara as façanhas de Augusto a Alcides e a Baco, referindo que os terá superado.

${ }^{729}$ Para Plutarco, este vício não era tão grande como se costumava dizer (cf. Alex. 23.1), embora não esconda que ele pudesse estar, por vezes, embriagado (cf. e.g. ibid. 67.8) e que a bebida poderia ter repercussões no seu temperamento (cf. ibid. 4.7-8).

${ }^{730}$ Alex. 23.2.

${ }^{731}$ Ibid. 37.5-6. 
muito tempo junto da estátua, em silêncio, e passou ao lado. Como era Inverno, manteve-se ali quatro meses, por querer que os soldados recuperassem as forças.

A reflexão de Alexandre perante a estátua de Xerxes deixa a descoberto a memória helénica e a consciência do passado. Ao não erguer a imagem do filho de Dario, Alexandre vinga, em parte, a ousadia que o Persa tivera em lutar contra os Helenos.

A sua vitória sobre Dario $^{732}$, no célebre confronto de Gaugamela, que o torna rei da Ásia, permite a Plutarco estabelecer uma relação com a grandeza das Guerras Medo-Persas e realçar o carácter pan-helénico da empresa de Alexandre ${ }^{733}$. Ao mesmo tempo que o seu poder aumentava, para Plutarco é importante referir que as suas virtudes se mantinham e estavam ao nível da sua

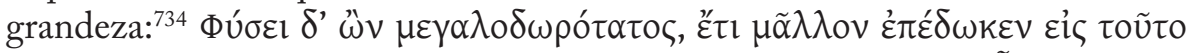

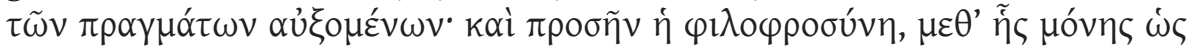
$\alpha \dot{\alpha} \eta \theta \tilde{\omega} \zeta$ oi $\delta 1 \delta o ́ v \tau \varepsilon \zeta ~ \chi \alpha \rho i ́ \zeta o v \tau \alpha l$ (Era, por natureza, muito benévolo, e esta qualidade ainda cresceu mais com o aumento da sua riqueza. A esta virtude juntava a generosidade, pois só com ela os que dão ganham, em verdade, o reconhecimento). Estas virtudes são ilustradas por várias histórias anedóticas ${ }^{735}$ que evidenciam a benevolência de Alexandre e mostram como, por exemplo, se irritava mais com aqueles que recusavam os seus presentes do que com aqueles que lhos pediam ${ }^{736}$. Para Alexandre, é preciso não imitar, após a vitória, os derrotados, condenando, por esse motivo, o luxo desmesurado daqueles que o acompanhavam: ${ }^{737}$

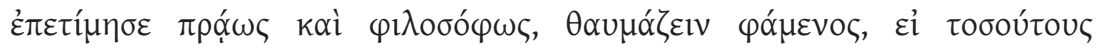

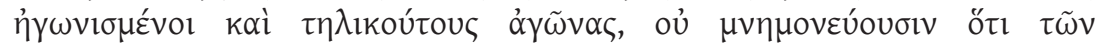

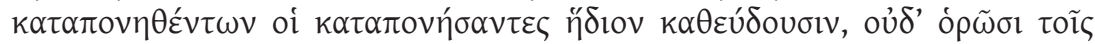

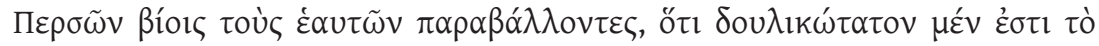

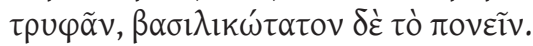

Repreendeu-os com brandura e seguindo o estilo de um filósofo ao afirmar que se admirava que, depois de terem combatido em tantos e tão importantes combates, não se lembrassem de que aqueles que submeteram dormem de forma mais agradável do que os que foram submetidos, e que, comparando a sua vida à dos Persas, não vissem que o mais servil era entregar-se à ociosidade e o mais régio à fadiga.

\footnotetext{
${ }^{732}$ Cf. ibid. 31.6-33.

${ }^{733}$ Cf. ibid. 34.

${ }^{734}$ Ibid. 39.1

${ }^{735}$ Cf. ibid. 39-42.

${ }^{736}$ Cf. ibid. 39.7-13.

${ }^{737}$ Ibid. 40.2.
} 
Aliás, o próprio Alexandre desempenha o papel de pedagogo, ao incitar os outros a praticar a virtude, prática que nem sempre era bem aceite pelos companheiros, já cansados da guerra. Seguia, quando não se deixava dominar pelo excesso, o princípio de que um rei devia, acima de tudo, fazer o bem e suportar que os outros falassem mal de $\mathrm{si}^{738}$. Se é verdade que os feitos guerreiros de Alexandre são de grande dimensão e a entrega à luta feita de forma audaciosa, mesmo quando está ferido ${ }^{739}$, interessa-nos sublinhar a estratégia que usou para assegurar a cooperação dos Persas ${ }^{740}$ e que se baseou nos costumes e na cultura. Ao vestir-se à maneira dos Bárbaros ${ }^{741} \mathrm{e}$ ao mandar ensinar a língua grega e técnicas militares às crianças ${ }^{742}$, Alexandre dava um claro sinal da necessidade de se aprofundarem os laços entre Macedónios e Persas, sem negligenciar a intencionalidade política do acto. ${ }^{743}$ Como prova de que tinha assimilado os hábitos bárbaros, ele próprio praticava a poligamia. ${ }^{744}$ Todas estas acções, promotoras da interculturalidade, têm como fundamento uma concepção cosmopolita ${ }^{745}$, cujo princípio seria a formação de uma só sociedade, com as mesmas leis, em que todos os cidadãos pudessem viver em igualdade. Esta mesma ideia também é desenvolvida nos tratados De Alexandri fortuna aut uirtute $i-i i^{746}$.

Paralelamente a estas acções, a sua ambição não parava de crescer. A sua natureza ia-se tornando cada vez menos condescendente com os que eram culpados ou representavam um obstáculo para os seus intentos ${ }^{747}$, convencido

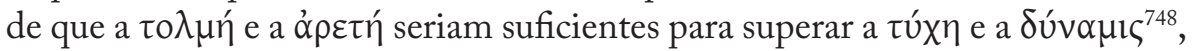
sem prestar atenção às consequências que a falta de comida ou os rigores do clima poderiam ter na expedição. Para Alexandre e para a sua aspiração por

\footnotetext{
${ }^{738}$ Cf. ibid. 41.2.

${ }^{739}$ Cf. e.g. ibid. 45.5

${ }^{740}$ Sobre o papel de Alexandre como promotor de uma fusão dos povos com alcance geo-
} político, vide De Alex. fort. aut uirt. 329B-F e 332A.

${ }^{741}$ Cf. ibid. 45: nem todos os Macedónios seguiram o seu hábito, Heféstion, por exemplo, foi um dos que aderiu, mas Cratero, que substitui Parménion, permaneceu fiel aos seus costumes helénicos (cf. ibid. 47.9).

${ }^{742}$ Viriam a ser homens bem preparados e com muita capacidade para a guerra, ganhando a admiração de Alexandre para descontentamento e receio dos Macedónios (cf. ibid. 71.1-2).

${ }^{743}$ Ibid. 47.5-6.

${ }^{744}$ Cf. ibid. 70.3 .

745 A propósito do ideal de cosmopolitismo de Alexandre Magno, vide M. Flower (2000: 96-135) e D. Leão (2005: 23-37).

${ }^{746}$ Sobre a ideia cosmopolita que está subjacente aos tratados, vide D. Babut (t2003: 100 s.).

${ }^{747}$ Cf. ibid. 57.3; já na Índia, embora fosse bem recebido por Táxiles, ao sentir a pressão dos que recusavam ter relações amistosas com ele, Alexandre monta uma cilada, após um pacto, matando-os todos, acto que Plutarco classifica como uma mancha nas acções bélicas de Alexandre (cf. ibid. 59.7).

${ }^{748}$ Cf. ibid. 58.2 . 
atingir a maior glória possível, era sobretudo importante que nenhum homem depois dele ultrapassasse os limites das suas conquistas ${ }^{749}$. Nem o seu estado de saúde ${ }^{750}$, nem os ferimentos ${ }^{751}$ abrandavam a sua philotimia, que, muitas vezes, o induzia a tomar decisões excessivas ${ }^{752}$, mesmo quando começava a emergir um sentimento de revolta entre os povos, por causa de injustiças cometidas, juntamente com os sinais de instabilidade que iam aumentando na Grécia e na Macedónia ${ }^{753}$. Em alguns momentos, como aquele em que Plutarco descreve Alexandre junto do túmulo de Ciro a ler o epitáfio ${ }^{754}$, o conquistador reflecte sobre as incertezas inerentes à existência humana, pois mesmo aqueles que conseguiram um dia grandes feitos conheceram a morte.

Também ele acabaria por morrer vítima de febre, ainda muito jovem ${ }^{755}$, após uma noite de folia ${ }^{756}$. Sobre as causas da sua morte, Plutarco segue a versão do diário de Alexandre ${ }^{757}$, pelo facto de constatar que a maioria dos historiadores considera a hipótese de envenenamento ${ }^{758}$, em que a sua mãe ou o próprio Aristóteles estariam envolvidos, uma pura invenção.

Os actos descritos por Plutarco revelam uma figura ambígua, pois tanto é benevolente como cruel. Do mesmo modo, a sua philotimia personifica essa dualidade com consequências na dinâmica épico-trágica: é movido pela ambição que constrói um império admirável, mas é também por causa dessa ambição que se vê possuído por uma espécie de cegueira, que trará um fim trágico para si e para os seus companheiros. Sendo Alexandre muito dado a interpretar os acontecimentos como se fossem um presságio ${ }^{759}$, não soube com a sua paideia acautelar o futuro da sua expedição. Por isso, o tom épico e trágico está muito presente na narrativa biográfica de Alexandre, procedendo Plutarco à síntese de dois géneros que são praticamente indissociáveis na literatura, como o testemunha a tragicidade da vida humana na Ilíada ou a heroicidade da tragédia clássica.

\footnotetext{
${ }^{749}$ Cf. ibid. 66.2.

${ }^{750}$ Cf. ibid. 68.3.

${ }^{751}$ Cf. e.g. ibid. 63.6.

${ }^{752}$ Cf. e.g. ibid. 71.4 (cólera de Alexandre).

${ }^{753}$ Cf. ibid. 68.3-7.

${ }^{754}$ Cf. ibid. 69.5.
}

755 Também Dario morreria cedo mas cheio de glória (cf. Alex. 19.8). Às portas da morte (cf.

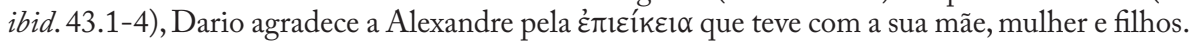
Alexandre, por sua vez, não revela qualquer entusiasmo com a morte do rival e, inclusive, castiga severamente o seu assassino, Beso (cf. ibid. 43.5-6).

${ }^{756}$ Cf. ibid. 75-76; apesar da tragicidade que perpassa a biografia, a descrição da morte, tal como ocorre na biografia de Demétrio, é simples e despida dos esteriotipos da historiografia.

757 À semelhança de Arriano 7.25.1; em De fort. Rom. 326A, Plutarco atribui a morte de Alexandre a um acto de benevolência da tyche para com a $\mathrm{Vrbs}$.

${ }^{758}$ Cf. Alex. 77.

${ }^{759}$ Cf. ibid. 75.1. 
Não é de forma involuntária que Plutarco evoca repetidamente, como vimos nos textos analisados, a épica homérica na biografia do Macedónio ${ }^{760}$, colocando, como ocorre em Diodoro Sículo e Arriano, Alexandre e Aquiles ${ }^{761}$ ao mesmo nível: Lisímaco, seu mestre, autodenominava-se Fénix, enquanto Alexandre e Filipe são associados, respectivamente, a Aquiles e Peleu; em Ílion, Alexandre faz libações aos heróis homéricos; logo que atravessa o Helesponto, deposita uma coroa de flores no túmulo de Aquiles; considera ser a Ilíada o bem mais digno de ser guardado no cofre que anteriormente pertencera a Dario; a dor que sente com a morte de Heféstion ${ }^{762}$ lembra o sofrimento de Aquiles com a morte de Pátroclo. Todos estes elementos remetem para um passado grandioso e heróico, que expõe as fragilidades da condição humana, mas que não está de todo isento de dramatismo. No tratado De Alexandri fortuna aut uirtute, por sua vez, ao descrever a physis de Alexandre, Plutarco compara as suas qualidades às de outras figuras históricas e às de heróis homéricos. ${ }^{763}$

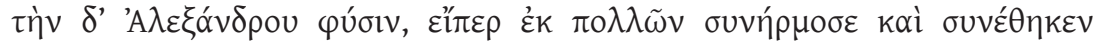

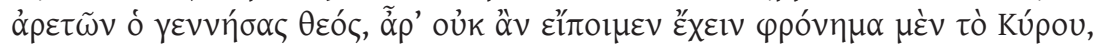

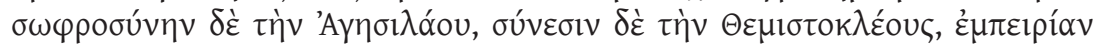

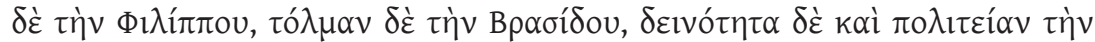

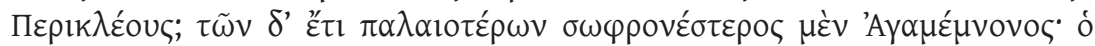

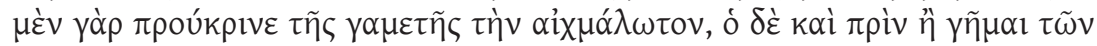

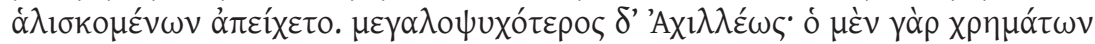

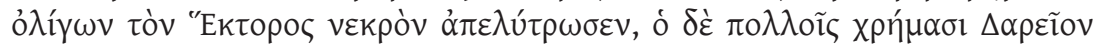

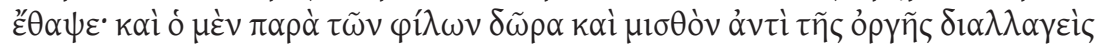

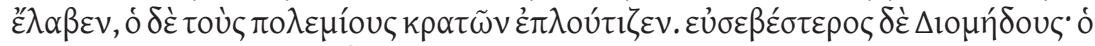

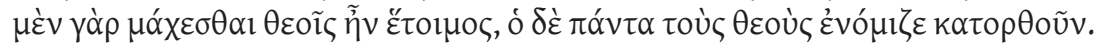

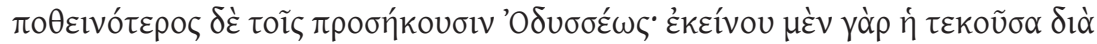

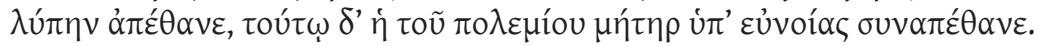

Quanto à natureza de Alexandre, se é verdade que, ao criá-lo, a divindade harmonizou e reuniu muitas virtudes, será que não podemos dizer que tinha o espírito de Ciro, a prudência de Agesilau, a inteligência de Temístocles, a experiência de Filipe, a audácia de Brásidas, a habilidade e a capacidade política de Péricles? E também em relação aos mais antigos, Alexandre foi mais moderado do que Agamémnon, pois este preferiu uma escrava à esposa, enquanto aquele, pelo contrário, se manteve, mesmo antes do casamento,

${ }^{760}$ Refira-se que, segundo Heródoto (1.4-5), a Guerra de Tróia justifica a discórdia entre Gregos e Persas, o que justifica a invasão de Dario e Xerxes. Plutarco, em De Herod. mal. 856F

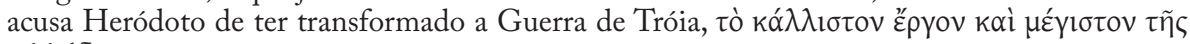
'E $\lambda \lambda \alpha ́ \delta$ os, num acto insensato.

${ }^{761}$ Aquiles surge também como modelo heróico em Pyrrh. 13, Cam. 12.4 e Arist. 7.8.

${ }^{762}$ Cf. Alex. 72.

763 343A-B. 
afastado das cativas; foi mais magnânimo do que Aquiles, uma vez que este pediu pelo resgate do corpo de Heitor pouco dinheiro, ao passo que Alexandre sepultou Dario com muitas riquezas; se Aquiles recebeu dos seus amigos presentes e recompensas para alterar a sua cólera, Alexandre, depois de conquistar os seus inimigos, enriqueceu-os; Alexandre foi mais piedoso do que Diomedes, uma vez que este estava decidido a enfrentar os deuses, enquanto aquele considerava que os deuses comandavam tudo; foi mais desejado pelos familiares do que Ulisses, pois a mãe deste morreu de tristeza, mas a mãe de um inimigo morreu juntamente com Alexandre por afeição.

Para descrever a physis de Alexandre, Plutarco recorre, assim, a uma série de comparações com Ciro, Agesilau, Temístocles, Filipe, Brásidas e Péricles, e também com os heróis Agamémnon, Aquiles, Heitor, Diomedes e Ulisses, que lhe permitem realçar as virtudes em que o Macedónio se distinguiu. No texto, os vocábulos $\varphi \rho o ́ v \eta \mu \alpha, \sigma \omega \varphi \rho o \sigma u ́ v \eta, ~ \sigma u ́ v \varepsilon \sigma v v, \tau o ́ \lambda \mu \alpha v, \delta \varepsilon ı$ ó $\eta \tau \alpha$,

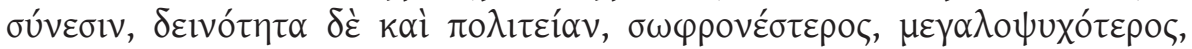

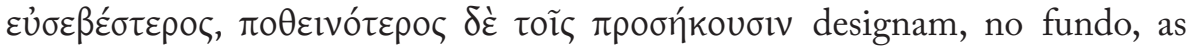
qualidades que um cidadão deve possuir para exercer a politeia.

Quanto ao carácter trágico da vida de Alexandre, há dois episódios que, pela sua crueldade, transgressão e desconhecimento das consequências são significativos: a destruição de Tebas $^{764}$ e a morte de Clito $^{765}$. Logo após o primeiro destes actos, de forma premonitória, Plutarco escreve que a expedição ficará incompleta $(\dot{\alpha} \tau \varepsilon \lambda \tilde{\eta})$ por causa da cólera $(\mu \tilde{\eta} v i \varsigma)$ - o uso de $\mu \tilde{\eta} v i \varsigma$, palavra que remete para a história do filho de Peleu, e não de ópүń, é mais um

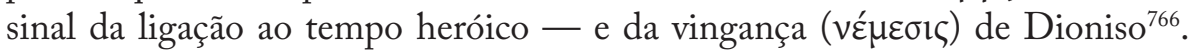
Deste modo, o destino de Alexandre parece estar já traçado, sem que isso retire mérito aos feitos alcançados ${ }^{767}$.

Nesta biografia, essas duas dimensões, a épica e a trágica, alternam-se na narrativa, numa escala diferente, expressando a inquebrantável vontade de superar as fragilidades inerentes à condição humana e à sua finitude. Atendendo a essa atmosfera que junta a grandeza e a fatalidade, poderia a declaração no prólogo de que pretendia escrever uma biografia e não uma obra histórica ser entendida como o resultado da consciência de que a narrativa individualizada estaria preenchida com cenas épicas e trágicas? Não nos parece, uma vez que

${ }^{764}$ Cf. ibid. 11-13.

${ }^{765}$ Cf. ibid. 50-52.

${ }^{766}$ Cf. ibid. 13.4.

${ }^{767}$ Note-se que os traços trágicos não são um exclusivo da biografia de Alexandre, pois também se encontram nos bioi de Pompeio, Lisandro, Filopémen, Demétrio e António; sobre outros elementos trágicos nas personagens de Alexandre, vide J. Mossman (1995: 212-213, n. 6 e 8$)$. 
também a historiografia contém episódios próprios desses dois géneros ${ }^{768}$.

Quando o texto afirma que a expedição e a glória de Alexandre ficarão incompletas, pois os companheiros de luta recusarão atravessar o Ganges, parece traçado o fim trágico, sem que isso retire mérito aos sucessos até aí atingidos. No meio destes acontecimentos que denotam heroicidade e tragicidade, a paideia representa um processo inicial de descoberta e posterior aprofundamento, tendente a valorizar o espírito de Alexandre, mas que se vê imersa pela sucessão dos acontecimentos. Mesmo que o apelo pela cultura e pelas artes se mantenha firme na natureza de Alexandre, é também verdade que as suas decisões obedecem muitas vezes a estímulos irracionais ditados pelo fervor da luta ou pela necessidade voraz de demonstrar o seu poder.

Ao contrário da caracterização positiva que Plutarco faz de Alexandre nos tratados De Alexandri fortuna aut virtute $i$ e $i$, a sua biografia não esconde as atitudes tirânicas tomadas ao longo da expedição ${ }^{769}$, ao mesmo tempo que o apresenta como o expoente máximo da paideia grega ${ }^{770}$, revelando-se a narração biográfica mais dinâmica, com mais apontamentos históricos e com menor enredo retórico. Nesses tratados, Plutarco sintetiza as qualidades de Alexandre, as quais considerava indispensáveis para a empresa no Oriente. Curiosamente, no entanto, a narrativa biográfica não confirma por completo essas virtudes: ${ }^{771}$

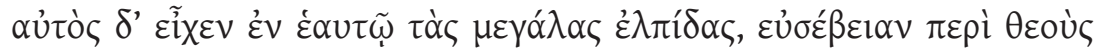

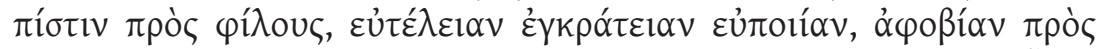

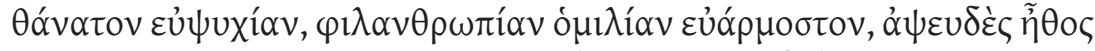

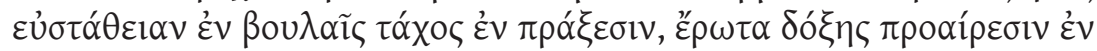
$\tau \tilde{\omega} \kappa \alpha \lambda \tilde{\omega} \tau \varepsilon \lambda \varepsilon \sigma$ loupyóv.

Alexandre tinha dentro dele grandes esperanças: a piedade pelos deuses, a fidelidade aos amigos, a simplicidade, a moderação, a beneficência, a intrepidez em relação à morte, a coragem, a humanidade, a afabilidade harmoniosa, a integridade de carácter, a consistência nas decisões, a

${ }^{768}$ J. Mossman (1995: 227) relaciona, com pertinência, a presença de elementos trágicos nesta biografia com Heródoto e a descrição que este faz da guerra Medo-Persas, até porque Alexandre se move numa área geográfica semelhante.

${ }^{769}$ Cf. ibid. 48-55.

${ }^{770}$ Sobre estes dois aspectos do carácter de Alexandre vide A. Wardman (1955: 100-7), J. Mossman (1995) e J. Pedro Serra (2002: 93-102); atendendo ao facto de os tratados referidos e a biografia apresentarem uma intencionalidade e temas distintos, é-nos difícil concordar com S. Humbert (1991: 170), quando defende a coerência entre estas obras; parece-nos mais correcto apontar diferenças de tratamento, por vezes complementares, de um Alexandre que acaba por ser uma síntese do Helenismo; a biografia, por causa da sua estrutura base, do genos à morte, oferece condições para circunscrever internamente os temas (cf. T. Rosenmeyer (1992: 212)), além de poder reproduzir uma fase de maior maturidade cultural por parte do autor.

${ }^{771}$ De Alex. fort. aut uirt. 342E-F. 
rapidez nas acções, o desejo de glória e a vontade de realizar coisas belas.

De facto, este conjunto de valores, que correspondem, de uma maneira geral, às características que definem o indivíduo ideal, pode ser detectado na biografia, mas aí Plutarco faz uma leitura crítica e, em alguns casos, percebemos que nem sempre o Macedónio conseguiu ser fiel a esses princípios, distanciando-se gradualmente deles, à medida que o final da sua vida se aproximava. A. Pérez Jiménez (2004c: 54-57) relaciona o texto acima citado

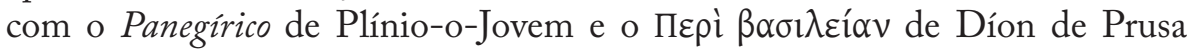
para concluir que as virtudes atribuídas a Alexandre são semelhantes às que se encontram nas obras dedicadas a Trajano, tal como as atitudes tirânicas e despóticas de Alexandre de Feras, em Pelopidas, ou do Lacedemónio Nábis, em Philopoemen, fazem lembrar as aç̧ões de Domiciano.

No entanto, tanto o referido tratado como a biografia partilham a ideia de que o sucesso de Alexandre se deveu mais à sua estratégia do que à intervenção

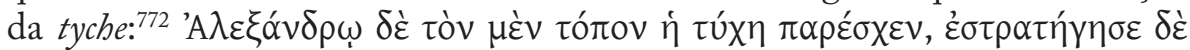

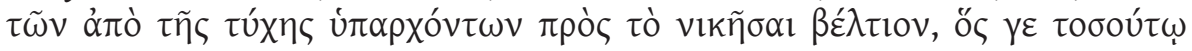

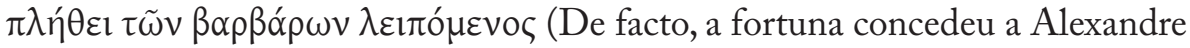
a vantagem do local, mas ele usou uma estratégia melhor para vencer do que a vinda da fortuna, embora tivesse um número de soldados inferior ao dos bárbaros). Se considerarmos que Plutarco terá usado as mesmas fontes para escrever os dois tratados incluídos nos Moralia e a biografia, com o importante recurso à tradição gnomológica, que valoriza traços épicos, morais e os que são próprios de um rei, inclinamo-nos a pensar que as diferenças de caracterização se devem sobretudo ao registo do género literário. ${ }^{773}$

Note-se, por fim, e para valorizar a presença do helenismo na figura de Alexandre, que apesar de lhe chamarmos Macedónio, Plutarco assume que a sua raça é grega, pois ele descende de Héracles ${ }^{774}$. É Grego tembém pela língua e, sobretudo, pelas qualidades que são apanágio dos Gregos: a $\sigma \omega \varphi \rho \circ \sigma u ́ v \eta^{775}$

772 Alex. 20.7.

${ }^{773}$ Julgamos que considerar os tratados De Alex. fort. aut. uirt. $i$ e ii, bem como o bios, obras pertencentes ao género encomiástico, como propõe F. Adrados (2005: 49) a partir da análise das gnomologias, não traduz a dimensão épica e trágica da biografia. Além disso, a interpretação dos dois tratados dos Moralia deve ser confrontada com a do De fort. Rom.

${ }^{774}$ Cf. Alex. 2.1; sobre as posições distintas de Demóstenes e Isócrates a propósito de as elites macedónias pertencerem ao mundo grego, vide M. Trédé (1991: 71-80).

775 Cf. e.g. Alex. 21.5 (episódio de Alexandre com a esposa e a filha de Dario) ou ibid. 20.13 (sobriedade de Alexandre perante o tesouro de Dario, realçada quando comparada com a ostentação desse espólio, longamente descrito); também em Sol. 27.3-4 se descreve a reacção de Sólon perante as sumptuosas riquezas bárbaras; vide ainda Hdt. 9.82. 


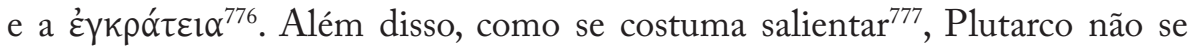
alonga muito na descrição dos hábitos bárbaros que Alexandre adoptou, como a proskynesis, justificando isso como um instrumento para dominar os Bárbaros $^{778}$, pois isso não colocava em causa o seu helenismo. Por conseguinte, não há dúvida de que existe ao longo da biografia a preocupação de demonstrar a adesão de Alexandre aos valores gregos, juntando-se a essa perspectiva o facto de, no tratado De Alexandri fortuna aut uirtute, o protagonista surgir como o difusor da grecidade no Oriente.

Embora em termos de dimensão textual possamos dizer que as duas biografias estão equiparadas, a verdade é que existe uma enorme diferença ao nível da grandeza e da análise ética entre a descrição de Alexandre e a de César, ocupando o primeiro evidente lugar de realce. Se a biografia de Alexandre está repleta de vicissitudes épicas e trágicas, a de César, ao contrário, detém-se mais na análise política e histórica. Refira-se, ainda, que a escolha de César para formar par com Alexandre pode, inicialmente, parecer óbvia, mas é preciso ter em conta que César é excluído da série de Vidas dos Césares elaborada pelo Queronense e que a preferência pelo dictator, em detrimento, por exemplo, de Pompeio, está relacionada com a alteração de atitude que se opera no principado de Trajano e da imitatio Alexandri de César. ${ }^{779}$

A biografia de César denota que a narração de factos políticos e militares, bem como a descrição do processo que leva à implementação da monarquia em Roma têm, sem dúvida, maior relevo do que a análise do ethos de César, ${ }^{780}$ pois nesta biografia está muito presente o binómio histórico demos-tyrannis: as atitudes da oposição levam-no à tirania ${ }^{781}$; o povo, por um lado, encoraja as suas ambições e dá-lhe apoio ${ }^{782}$, e, por outro, recusa-lhe esse mesmo apoio por causa das constantes campanhas militares e das suas aspirações ${ }^{783}$.

Não temos sobre a paideia de César tantos elementos como aqueles que encontramos na biografia de Alexandre. $\mathrm{O}$ texto que a seguir citamos alude

${ }^{776}$ Cf. e.g. Alex. 30.2-14 (episódio com o eunuco Tireu).

${ }^{777}$ Cf. e.g. S. Humbert (1991: 173).

${ }^{778}$ Cf. Alex. 28.6; vide, em De Alex. fort. aut. uirt. 330B, outra estratégia para ganhar a benevolência dos Persas.

${ }^{779}$ Cf. J. Geiger (2002: 96-97); no mesmo estudo, realça-se que a figura de Pompeio só é recuperada por Adriano, que restaurou o seu túmulo (cf. Pomp. 80).

${ }^{780}$ E.g., Plutarco é mais exaustivo do que Suetónio na narração das Guerras Gálicas (cf. Caes. 15-27); sobre este assunto vide C. Pelling (1984: 90-1); sobre a estrutura da biografia de César vide C. Pelling (1996: 323-331).

${ }^{781}$ Cf. Caes. 4.8, 6.3 e 6.6.

${ }^{782}$ Cf. ibid. 4.4-5, 4.8, 5.3, 5.8-9 e 6.9; vide ainda 20.2, 21.2, 21.8-9, 23.7.

${ }^{783}$ Cf. Caes. 29.5. 
às lições de retórica recebidas em Rodes, o que ilustra a proximidade entre a paideia e o logos: ${ }^{784}$

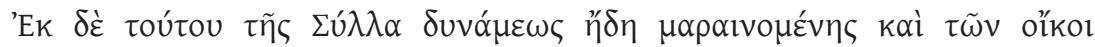

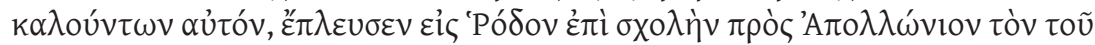

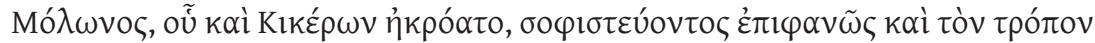

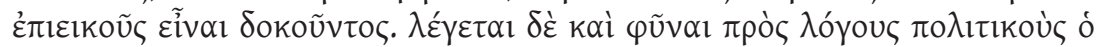

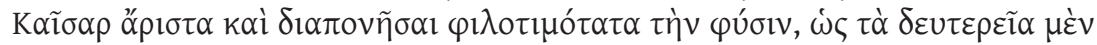

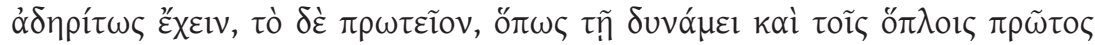

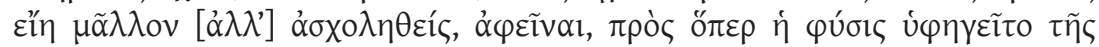

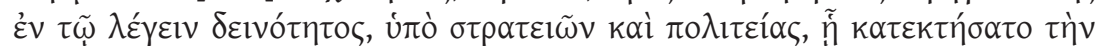

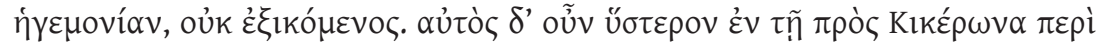

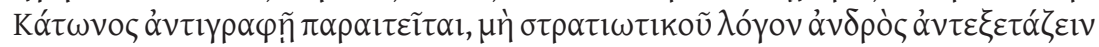

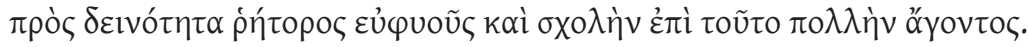

Em seguida, quando o poder de Sula se extinguia e o chamavam para casa, César navegou para Rodes com o propósito de estudar junto de Apolónio, filho de Mólon, de quem Cícero também foi discípulo e que era um retor ilustre e parecia ter um carácter equilibrado. Diz-se que César tinha excelentes qualidades naturais para discursos políticos e que exercitava a sua natureza com muita ambição, pois ocupava o segundo lugar sem dificuldade, deixando o primeiro, de forma a ser o primeiro sobretudo no poder e nos combates. E, por causa das acções militares e políticas em que se envolveu, a fim de conquistar o Império, não alcançou aquele nível de arte oratória que a natureza deixava prever. Ele próprio, mais tarde, numa carta de réplica contra Cícero, acerca de Catão ${ }^{785}$, pede que não se compare o discurso de um militar com a habilidade de um orador dotado por natureza e que teve muito tempo livre para se dedicar à sua arte.

Assim, apesar de ter recebido formação retórica junto de Apolónio, na viagem que realizou em $75-74$ a. C. ${ }^{786}$, e das suas qualidades naturais para a oratória escrita - por exemplo, durante o resgate junto dos cruéis Cilícios ${ }^{787}$ escreveu poemas e discursos- e oral, que lhe vale a admiração dos Romanos pela forma como elabora a defesa nos casos judiciais ${ }^{788}$ ou pelos discursos

${ }^{784}$ Caes. 3.1; cf. C. Pelling (2002d: 92-3) dá este texto como um dos exemplos do "chronological displacement", acrescentando a razão: "Caesar's rhetorical successes at Rome are now placed after the study in Rhodes, and it is natural to infer that they are the result of that teaching: a theme which alike suits Plutarch's Hellenism and his interest in education."; cf. Cic. 4.

${ }^{785}$ Cf. Caes. 54.3-6.

786 Em Brut. 261, Cícero elogia mais as capacidades oratórias de César do que os seus costumes.

${ }^{787}$ Cf. Caes. 2.4; sobre a crueldade deste povo vide Sert. 7.5, Pomp. 28.1 e Cras. 7.5.

${ }^{788}$ Cf. ibid. 4.4. 
fúnebres $^{789}$, César acaba por ser mais um daqueles heróis romanos que se vê privado de tempo para modelar os dotes da physis e aprofundar a paideia, por causa das batalhas que travou em prol dos seus ideais políticos. Além disso, a intenção de Plutarco é mostrar que César é muito mais conhecido pelos seus feitos na Gália ${ }^{790}$, por exemplo, do que pela sua capacidade oratória. É no campo de batalha que evidencia toda a sua audácia e coragem, embora a sua constituição física de modo algum o fizesse prever, uma vez que era magro, tinha muitas dores de cabeça e crises de epilepsia ${ }^{791}$. Segundo Plutarco, a guerra acabava por ser um exercício terapêutico para a sua aparente debilidade física ${ }^{792}$. César é, por conseguinte, um homem de acção e é isso mesmo que, em

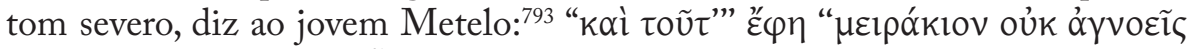

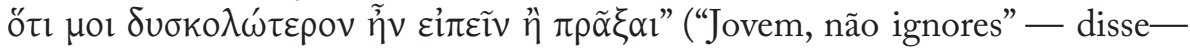
"que é mais difícil para mim falar do que agir").

Mesmo assim, Plutarco conta-nos que, durante as suas acções na Hispânia, aproveitando um breve momento de tempo livre ( $\sigma \chi 0 \lambda \eta ́)$, se pôs a ler uma obra sobre Alexandre, momento de reflexão que lhe provocou lágrimas: ${ }^{794} \tau \tilde{\omega} v \delta \dot{\varepsilon}$

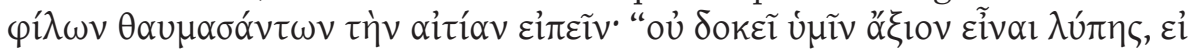

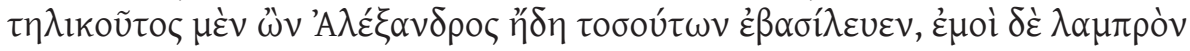

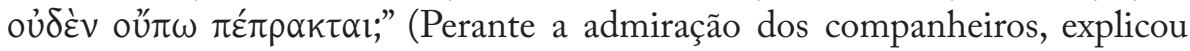
assim o motivo: "Não vos parece digno de tristeza, enquanto Alexandre reinava já, tão jovem, sobre tantas regiões, eu ainda nada fiz de brilhante?”). Enfatizando nos primeiros capítulos da biografia as divisões políticas em Roma, as tentativas, bem sucedidas, de César para persuadir a massa popular, bem como as relações pouco amistosas que este manteve com Sula, Catão e Pompeio, Plutarco não dispensará uma referência à ónóvol $\propto$ que César estabeleceu entre as cidades na Hispânia e a ter tido tanto sucesso na guerra como na paz. ${ }^{795}$

Ao contrário do que seria expectável, Plutarco não compara os feitos guerreiros de César aos do Macedónio ${ }^{796}$, mas aos de outros Romanos

${ }^{789}$ Cf. ibid. 5.2 (por ocasião da morte da sua tia Júlia, mulher de Mário); ibid. 5.4 (no funeral da sua esposa).

${ }^{790}$ Cf. ibid. 15.5 .

${ }^{791}$ Cf. ibid. 17.2; em 53.5-6, Plutarco descreve um ataque epiléptico de César e a consequente reacção deste.

${ }^{392}$ Cf. ibid. 17.3; cf. Alex. 72.4, onde o combate serve para aliviar a dor.

${ }^{793}$ Caes. 35.10.

${ }^{794}$ Caes.11.6; quando M.Léon (2005: 442), apoiando-se em G. Zecchini (1984:196), escreve que "La posición de equilibrio observada por Plutarco al abordar la cuestión de Alejandro le impide realizar un parangón entre éste y los romanos", julgamos que este passo da biografia de César indica o contrário, embora nos pareça que Plutarco prefira apresentar Alexandre como modelo do helenismo e da paideia.

${ }^{795}$ Cf. ibid. 12.2.

${ }^{796} \mathrm{O}$ único momento em que menciona Alexandre é no episódio em que César lê uma obra sobre Alexandre, passo já anteriormente analisado, onde se esboça uma comparação entre 
conhecidos: ${ }^{797}$

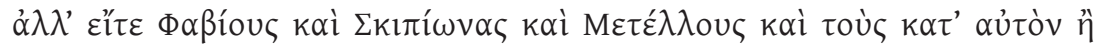

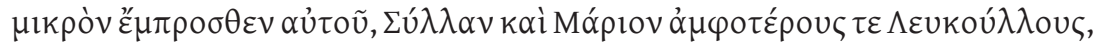

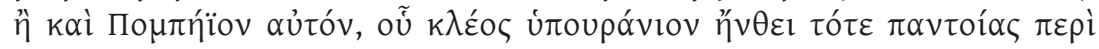

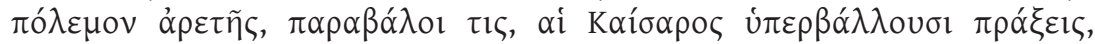

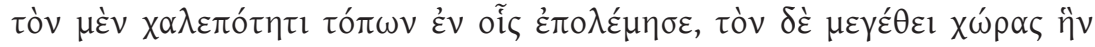

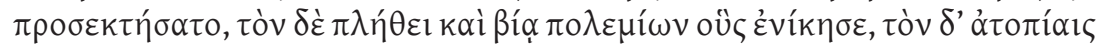

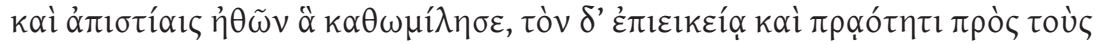

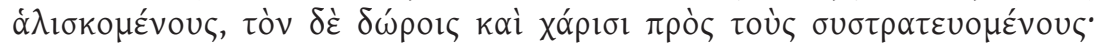

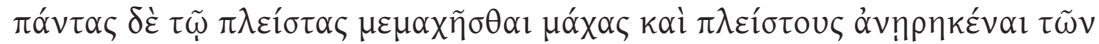

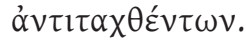

Mas, se o compararmos aos Fábios, aos Cipiões, aos Metelos e aos seus contemporâneos ou aos que viveram um pouco antes dele, como Sula, Mário e os dois Luculos, ou ao próprio Pompeio, cuja glória, elevando-se até ao céu, florescia, nessa altura, devido à sua capacidade multifacetada para a guerra, as acções de César ultrapassam um pela inacessibilidade dos lugares em que combateu, outro pelos grandes territórios que conquistou, outro pelo número e pela força dos inimigos que venceu, outro pela extravagância e perfídia dos costumes que conciliou, outro pela equidade e gentileza com os prisioneiros, outro pelos presentes e recompensas dados aos companheiros de combate, e a todos por ter combatido num maior número de batalhas e por ter aniquilado o maior número de rivais.

Chamamos a atenção para o facto de os termos comparativos acabarem por ser uma resenha dos principais elementos que caracterizam a acção de César ao longo do bios: a determinação que colocou nos combates, mesmo perante situações muito adversas; a grandeza das suas conquistas; o grande número de vitórias; a capacidade em conciliar costumes; a generosidade para com os seus amigos e companheiros de campanha. Qualquer uma delas, aliás, poderia ser atribuída também a Alexandre, pois ambos foram homens de acção e civilizadores. Faltava, porém, a César, parece-nos, a dimensão cultural e filosófica de Alexandre ${ }^{798}$.

ambos; aliás, César também só duas vezes é referido na biografia de Alexandre (1.1 e 69.8), sem que isso sugnifique qualquer análise comparativa, parecendo que Plutarco quer evitar estabelecer paralelos directos e explícitos entre os dois, talvez para deixar esse trabalho ao seu leitor ou por preferir estabelecer paralelos entre César e Pompeio, ou seja, uma comparação interna.

${ }^{797}$ Ibid. 15.3-5.

798 A propósito da caracterização de Alexandre como filósofo com sentido pragmático (cf. e.g. De Alex. fort. aut uirt. 328A-E), a que já aludimos algumas vezes durante o nosso trabalho, vide os comentários de T. Whitmarsh (2002: 179-80). 
Conhecido pelos seus feitos na Gália ${ }^{799}$ e pelo carácter intrépido, César ganhava o respeito dos seus companheiros e soldados, que ele incitava à philotimia $a^{800}$, partilhando com eles tanto os sofrimentos como as riquezas ganhas com as vitórias: ${ }^{801}$

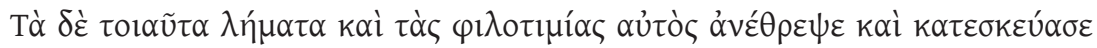

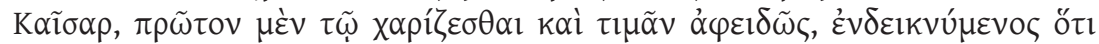

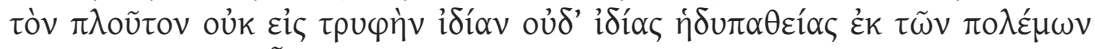

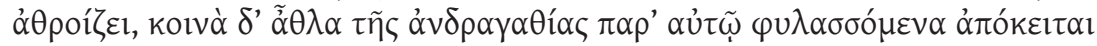

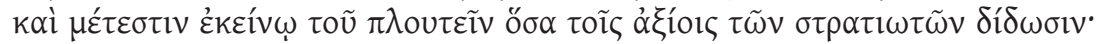

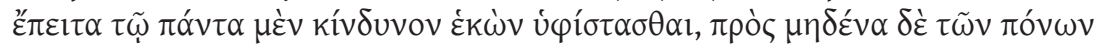

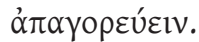

O próprio César estimulava e imaginava tais acções resolutas e ambiciosas. Primeiro dava recompensas e honrava sem reservas, demonstrando com clareza que recolhia a riqueza dos combates não para comodidade própria nem para deleites pessoais, mas estava reservada, sob a sua guarda, como um prémio comum para a coragem e que lhe correspondia tanta riqueza quanta aquela que recebiam os soldados merecedores. Em segundo lugar, enfrentava de forma espontânea todo o tipo de perigo, sem renunciar a nenhum sofrimento.

Ao longo da narrativa, muito preenchida com descrições de conflitos e pormenores do ambiente tenso que se vivia em Roma, enfatiza-se no protagonista a sua capacidade empreendedora, que se manifesta pela $\tau o ́ \lambda \mu \alpha$ e $\delta u ́ v \alpha \mu \iota \varsigma .{ }^{802}$ Como seria de prever, Plutarco haverá de relacionar estas qualidades com atitudes que têm origem num impulso pouco reflectido ou irracional, logo excessivo e contrário aos preceitos da verdadeira paideia $a^{803}$.

Sendo um homem de espírito persistente e combativo na adversidade, César tem ainda outra qualidade, que Plutarco bem aproveita na sua análise psicológica, que é indispensável para um líder de tropas que vivia num tempo em que a instabilidade se apoderava das várias classes sociais ${ }^{804}$ : sabe tirar todo o benefício do sucesso e tem uma grande perícia para aproveitar as

${ }^{799}$ Cf. ibid. 15.5 .

${ }^{800}$ A philotimia, como salientámos na análise da biografia de Flaminino, pode ser uma virtude, mas, quando se torna excessiva, pode levar o indivíduo a incorrer no erro. Na biografia de César, em 11.3, enquanto fonte dos males da cidade, a philotimia aparece associada à amilla (cf. Per. 11.3, Luc. 42.4, Cras. 5.6).

${ }^{801}$ Ibid. 17.1.

${ }^{802}$ Cf. ibid. 19.7 e 20.9.

${ }^{803}$ Cf. ibid. 32.8 .

${ }^{804}$ Cf. ibid. 34.3: menciona-se Roma com uma cidade à deriva, tal como um barco no meio da tempestade. 
oportunidades $^{805}$. Mesmo perante o desânimo das tropas, cansadas de lutar ${ }^{806}$, César trilha o caminho que havia inicialmente traçado, um pouco à semelhança do que fizera Alexandre.

Não deixava de perseguir a glória e o poder por meio dos seus feitos, mas mostrava-se magnânimo para com os companheiros de Pompeio, após a sua

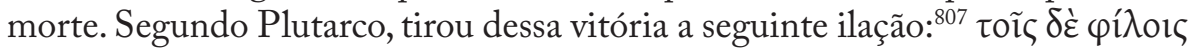

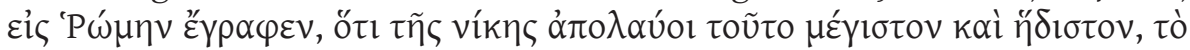

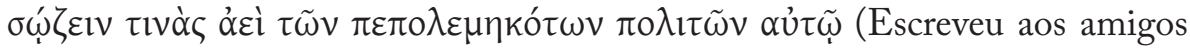
Romanos para dizer que a maior e mais agradável recompensa que tinha tirado da vitória tinha sido salvar alguns dos cidadãos que tinham sempre combatido contra ele).

A biografia de César, primeiro homem a colocar uma frota no Atlântico para empreender uma guerra ${ }^{808}$, é muito factual, mais próxima da narrativa histórica, ainda que recorra a processos de simplificação ou compressão cronológica ${ }^{809}$. Plutarco detém-se pouco na análise moral e do carácter, constatação que leva C. Pelling (2002d: 105) a não considerar esta uma biografia moralista, até porque se preocupa em realçar o espírito resoluto de César. As palavras, até

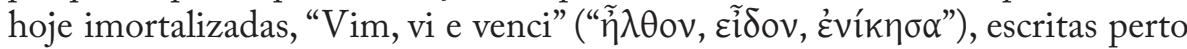
da cidade de Zela, situada junto do Mar Negro ${ }^{810}$, para anunciar ao seu amigo Mácio a vitória, traduzem bem o orgulho que sentia por causa do sucesso e da celeridade da batalha.

Como Alexandre, César soube aproveitar o apoio da tyche 811 e juntar-lhe a sua capacidade pessoal, além de manter uma ambição sem limites, apesar dos sucessivos êxitos alcançados. Sobre este aspecto do carácter de César, parecenos que Plutarco conseguiu sintetizar melhor a sua interpretação aqui do que

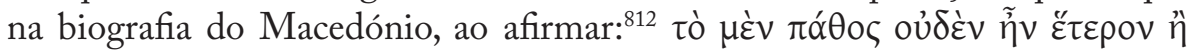

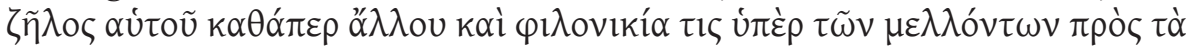
$\pi \varepsilon \pi \rho \alpha \gamma \mu \varepsilon ́ v \alpha$ (Esta paixão não era outra coisa senão a emulação de si próprio, como se fosse com outro, e uma espécie de rivalidade entre as coisas que estão por suceder e o que já tinha sido feito). Se até aqui já tínhamos apontado casos de emulação de outro indivíduo ou o apelo imitativo lançado pelas Vitae ao leitor, no passo citado trata-se de auto-emulação, ou seja, uma das motivações de César é conseguir superar-se a si próprio, o que se aplica também a Alexandre.

\footnotetext{
${ }^{805}$ Cf. ibid. 26.3 e 32.2 .

${ }^{806}$ Cf. ibid. 37.4-9.

${ }^{807}$ Cf. ibid. 48.4.

${ }^{808}$ Cf. ibid. 23.

${ }^{809}$ Cf. ibid. 7.7. e 21.8, respectivamente; sobre estes processos, vide C. Pelling (2002d).

${ }^{810}$ Cf. ibid. 50.3 .

${ }^{811}$ Cf. ibid. 53.3.

${ }^{812}$ Ibid. 58.5 .
} 
A ideia que passa para o leitor é a de um tempo marcado pela vertigem do conflito, das traições e da instabilidade política e social. Se, no par PhilopoemenFlamininus, Plutarco pretendeu transmitir a mensagem de que os Gregos lutavam mais entre si do que contra inimigos externos, nesta biografia essa imagem é associada aos próprios Romanos ${ }^{813}$, como os dois exemplos seguintes deixam perceber: faz-se referência a um censo cujos resultados evidenciariam as baixas causadas pela guerra civil ${ }^{814}$; a celebração da vitória sobre as tropas dos filhos de Pompeio, na Hispânia, desagradou aos Romanos pelo facto de se festejar a desgraça dos filhos da pátria e não dos bárbaros ${ }^{815}$. Mas o que causou, na perspectiva de Plutarco, maior ódio contra César foi terem percebido que ele desejava ser rei ${ }^{816}$.

Foi a este homem com uma vida repleta de façanhas notáveis e a quem se ficou a dever, por exemplo, a reforma do calendário ${ }^{817}$, tendo para isso recorrido a filósofos e a matemáticos, que os inimigos prepararam o seu fim. Não deixa de ser irónico que tenha sido assassinado junto da estátua de Pompeio, que assim parece presidir à vingança ${ }^{818}$. Morre aos cinquenta e seis anos, vítima da conspiração dos que lhe eram próximos, deixando como resultado dos combates que travou a glória e o seu nome para sempre inscritos na história da Vrbs.

Em síntese, e sem querer antecipar reflexões que deixaremos para outro momento, é na biografia de Alexandre que a paideia tem uma dimensão mais abrangente, sem paralelo nas restantes biografias plutarquianas: a paideia na sua vertente educacional e, mais importante, a paideia como processo de sociabilização e como factor civilizacional, pela forma como opera códigos de conduta e de civilidade. Alexandre teve uma formação privilegiada, junto de alguns mestres, entre os quais se realça, obviamente, Aristóteles, e isso influenciará a sua vida, quer na forma como se continua a instruir, quer na sua forma de pensar. Apesar disso, o carácter guerreiro, a ambição por vencer e o desejo de glória não se apagam da sua physis.

${ }^{813}$ Embora afirme, de forma exagerada, que César se tornou dono de toda a Itália em sessenta dias sem fazer derramar uma gota de sangue (cf. ibid. 35.3).

${ }^{814}$ Cf. ibid. $55.5-6$.

${ }^{815}$ Cf. ibid. 56.

${ }^{816}$ Cf. ibid. 60.1.

${ }^{817}$ Cf. ibid. 59.1.

${ }^{818}$ Para a descrição do assassinato vide ibid. 66.7 e ss. 


\subsection{A PAIDEIA E A POLITEIA}

Tendo em conta a apresentação feita no capítulo introdutório e a análise das Vitae no ponto anterior, parece não haver dúvidas sobre a estreita relação entre paideia e politeia, dois elementos determinantes na caracterização do herói de Plutarco. A politeia, especialmente quando é exercida segundo os padrões morais que Plutarco define nos tratados políticos, é a melhor vocação que um homem pode possuir ${ }^{819}$, pois a política é um modo de agir e de viver ${ }^{820}$, que a

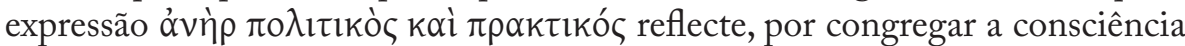
de cidadania, bem como as responsabilidades daí inerentes, nomeadamente a dinâmica das actividades levadas a cabo em favor dos concidadãos.

O sentido de politeia pode ser diverso. Desde o sentido genérico de 'constituição' ou 'regime' até poder ser usado para designar um regime político específico. Além disso, pode significar 'política', referindo-se à polis ou ao polites, ou 'organização política', 'poder político', 'actividade política', 'governo', 'comunidade ${ }^{821}$. Note-se que o uso deste vocábulo pode estar associado, por exemplo, a discursos que visam ter um determinado efeito político, como também, no âmbito da politeia filosófica, procurar descrever a melhor politeia, ou ainda, ter um objectivo mais científico, que passa pela identificação e análise de factos históricos, sem se emitir juízos de valor ${ }^{822}$. Por conseguinte, relacionar e explorar o sentido de politeia e paideia contribuirá para o melhor entendimento quer do pensamento de Plutarco, quer das próprias palavras.

O binómio paideia-politeia é significativo na obra de Plutarco, não só porque os heróis retratados exercem funções públicas com maior ou menor relevo, susceptíveis de serem imitadas e admiradas pelos contemporâneos, mas também pelo facto de a paideia, no seu sentido formativo, constituir uma fase preparatória importante para o exercício do poder ${ }^{823}$. Como não se deve enveredar pela vida política por um impulso emocional ${ }^{824}$, a paideia assume-se como o bem mais importante para qualquer indivíduo que aspire a desempenhar funções na polis ou na $\operatorname{Vrbs}{ }^{825}$. Aliás, conhecemos o perfil ético

${ }^{819}$ Cf. Comp. Arist.-Cat. Ma. 3.1; em Num. 5-6, Numa recusa assumir o reino por se considerar um filósofo, mas o pai tenta demovê-lo, argumentando que, para um sábio como ele, a governação é uma oportunidade de origem divina, que permitirá fazer uso da justiça e dos mais nobres valores.

${ }^{820} \mathrm{cf}$. An seni resp. 786B, Cum princ. philos.778C e F, Praec. ger. reip. 823C.

${ }^{821}$ Para estes e outros elementos, vide o estudo de J. Bordes (1982).

${ }^{822}$ Cf. F. Jacoby (1949)

${ }^{823}$ Cf. N. Livingstone \& Y. Too (Eds., 1998: passim).

${ }^{824}$ Cf. Gracch. 22; Praec. ger. reip.798C.

${ }^{825}$ Nesse sentido, D. Russel (1966: 141) considera que: "one of the leading themes of the Parallel Lives was to demonstrate to the Romans that the greatness of Greece had been political

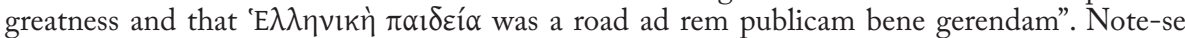
que, para Plutarco, a paideia política não deve ser usada apenas como forma de uma elite social 
dos biografados a partir da sua conduta política e das suas acções: ${ }^{826} \dot{\alpha} \lambda \lambda \dot{\alpha} \pi \varepsilon \rho \grave{i}$

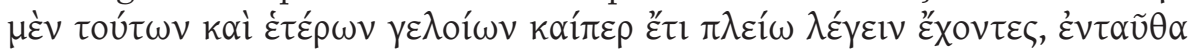

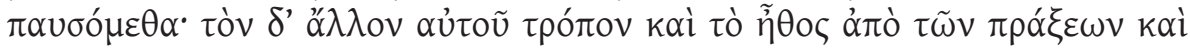

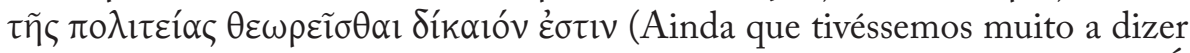
sobre estas matérias e outros assuntos ridículos, evitamos agora expô-los. É justo observar os outros traços da sua maneira de agir e do seu carácter a partir das acções e da actividade política).

Não é por acaso que, na arquitectura das Vitae, Plutarco se dedica primeiro à paideia e só depois à proairesis e à iniciação na vida pública, embora em alguns casos, como Alcibíades ou Sertório, as personagens se iniciem muito cedo na arte da guerra, sem terem dedicado o tempo conveniente a aprofundar as matérias educativas. Além disso, nem sempre aquele que recebeu a formação inicial adequada consegue evitar os vícios na actividade política, o que parece indiciar que a paideia, aqui mais no sentido abrangente de cultura, obriga o indivíduo a um regular empenho. De facto, a paideia exige uma askesis constante, para em cada momento se conseguirem tomar as que são as melhores decisões para o indivíduo e para a sociedade. A noção de uma askesis contínua, desde o nascimento até ao fim da vida, resulta de uma explicação racional e lógica para o fenómeno da paideia, ao qual os Sofistas e os Socráticos deram a primazia. Depois de os Sofistas terem considerado Homero o educador da Grécia, era necessário dar o passo para uma paideia mais sistemática, racional e com regras, em que os objectivos se baseassem numa educação política e ética, a qual pudesse controlar a desmesura e a violência que existe no íntimo de cada indivíduo.

O ingresso na vida pública ${ }^{827}$, podendo ser condicionado por questões naturais e externas, é, no fundo, uma das formas de materialização da paideia, e deve ser apoiado pela reflexão e ter por base os grandes modelos

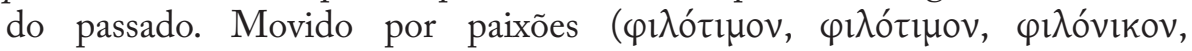
$\varphi \imath \lambda o ́ \tau \rho \omega \pi$ ov ou $\varphi \imath \lambda o \pi o ́ \lambda \varepsilon \mu o \varsigma$, entre outras) e com qualidades próprias da physis ou desenvolvidas pela paideia (que se pode manifestar por valores

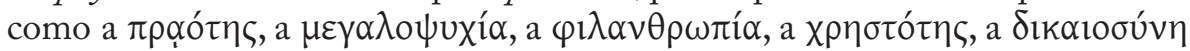
ou a $\mu \varepsilon \gamma \alpha \lambda \circ \varphi \rho \circ \sigma u ́ v \eta)^{828}$, o impulso para a politeia pode ser enfrentado de forma equilibrada, ainda que os bioi tendam a provar que existe uma espécie

se distinguir ou para ser exibida em confrontos e iniciativas convencionais, mas é um meio para persuadir os governados; vide C. Panagopoulos (1977: 229 e ss.).

${ }^{826}$ Dem. 11.7; cf. E. Valgiglio (1992: 4010-4014), para uma interpretação do valor das praxeis para a análise do ethos.

${ }^{827}$ Cf. A. Pérez Jiménez (1995: 363-381).

${ }^{828}$ A catalogação de virtudes e vícios do governante parece ser uma preocupação dos autores da época imperial, pois também Díon de Prusa lembra as virtudes que um rei deve possuir: não ser libertino, excessivo, insolente, nem ter a psyche perturbada com pela ira ou pelas paixões, mas saber ser guia e pastor do povo (cf. Or. 1.13 ss.). 
de inclinação trágica para o erro e o vício naqueles que ocupam funções de governo.

De nada valerá ter óptimos paidagogoi e didaskaloi se depois o homem não souber desenvolver os seus conhecimentos e tornar-se um verdadeiro pepaideumenos $^{829}$, com uma genuína e profunda cultura de cidadania. De facto, surge no século I a figura do homem culto que recorre à filosofia e à retórica, duas disciplinas que se aproximaram decisivamente por acção de Cícero ${ }^{830}$, que quis combinar eloquência e saber, síntese que Plutarco também defende. Propõem-se novamente os princípios platónicos, aristotélicos e isocráticos para o exercício da politeia ${ }^{831}$, uma vez que a natureza humana só se realiza em pleno na vida pública, perante o olhar atento dos demais cidadãos: ${ }^{832}$

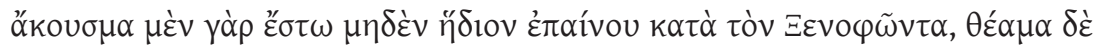

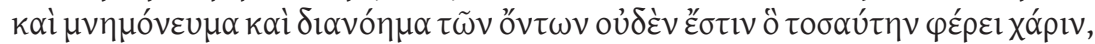

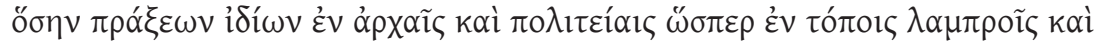

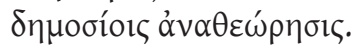

Segundo Xenofonte ${ }^{833}$, nada é mais agradável de ouvir do que um elogio. Não existe, porém, espectáculo, recordação ou pensamento que traga uma alegria tão grande como a observação das acções realizadas nas magistraturas e na governação, bem como em lugares com visibilidade e públicos.

No caso particular da retórica, a quem a tradição concede um valioso papel educativo, acessório indispensável da filosofia e da política ${ }^{834}$, ela assumese não só como estilo ou forma de discurso, mas também como meio para a educação das massas e para a obtenção da ordem civil, no período em que vive Plutarco ${ }^{835}$. Como tem sido referido por alguns autores, o Queronense distancia-se um pouco da oratória do seu tempo, pois não segue o optimismo de Dionísio de Halicarnasso ou de Díon de Prusa, nem o pessimismo de outros. Conhece as potencialidades da eloquência para o político ${ }^{836}$, mas não advoga

${ }^{829}$ Plutarco não usa na sua obra este vocábulo. Pelo contrário, encontramo-lo diversas vezes em Díon de Prusa (e.g. Or. 1.61, 4.30, 4.31, 12.43, 32.10, 32.24, 36.19, 38.29), em Luciano (e.g. Nigr. 13.19, 14.14, Dom. 2.6, 21.11, 28.2, Somn. 12.9, D. Mort. 12.4) e em Ateneu (Deipn.1.6, 3.51, 3.72, 5.2, 14.25). Refira-se, ainda, que em Filóstrato ou Élio Aristides, também eles autores da Segunda Sofística, não registamos, curiosamente, qualquer ocorrência.

${ }^{830}$ E.g., Orat. 14-16; cf. de Orat. 1.5, 1.20, 2.24.

${ }^{831} \mathrm{Cf}$. An seni resp. $790 \mathrm{~F}$.

${ }^{832}$ Ibid. 786E; sobre este assunto, vide a análise de J. Boulogne (2004: 212 ss.).

${ }^{833}$ Cf. Mem. 2.1.31.

${ }^{834}$ A respeito da oratória como organon para a vida política vide, por exemplo, Cic. 4.4, Fab. 1.7, Cat. Mi.4.3.

${ }^{835}$ Em Per. 15.2-3, Plutarco diz que a retórica serve para iluminar a alma.

${ }^{836}$ Cf. e.g. Comp. Dem.-Cic. 2-3; An seni resp. 789D e Praec. ger. reip. 801C-802E, 803A-804C. 
um princípio estratégico baseado na eloquência formal, pois o conteúdo deve prevalecer sobre os aspectos formais do texto ${ }^{837}$. Também não defende uma filosofia abstracta, mas o exercício da virtude prática ${ }^{838}$, pedindo-se ao político que seja, acima de tudo, virtuoso ${ }^{839}$, uma vez que a sua qualidade moral é mais importante do que o sistema político ${ }^{840}$. Deste modo, Plutarco, como Platão ou Aristóteles, valoriza a relação entre ética e política, defendendo, como veremos no tratado Praecepta gerendae reipublicae, que, no exercício de funções públicas, em prol da comunidade, os “fins justificam os meios". É por isso que na biografia de Rómulo, ao descrever o rapto das Sabinas, Plutarco não reprova o carácter agressivo e violento da iniciativa dos Romanos, pelo facto de dela depender a realização de grandes feitos ${ }^{841}$.

Para o político, além do desejo de perseguir constantemente a vitória e de encontrar as melhores decisões, o fim mais belo é ser um modelo de virtude para os cidadãos: ${ }^{842}$

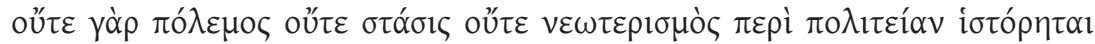

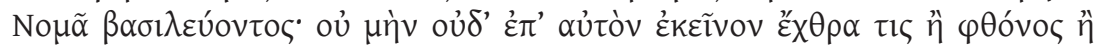

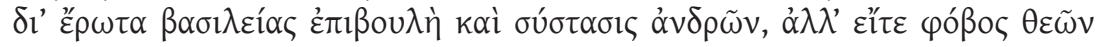

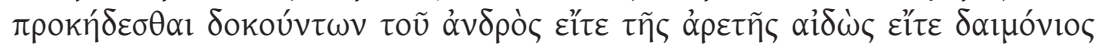

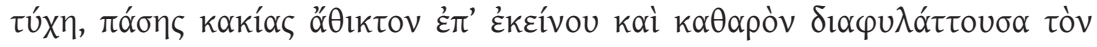

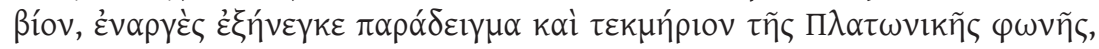

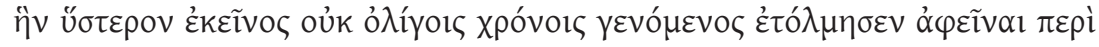

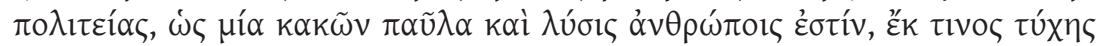

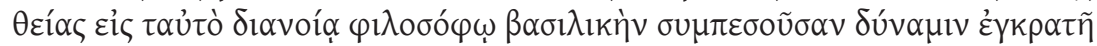

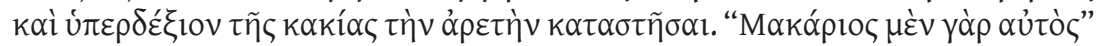

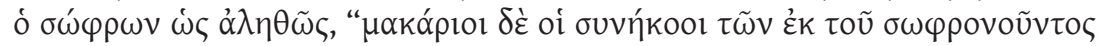

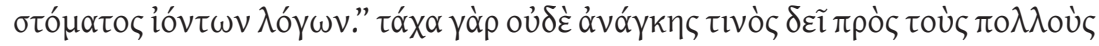

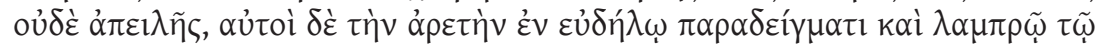

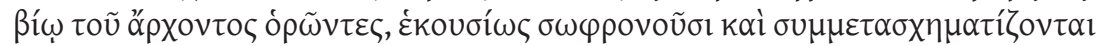

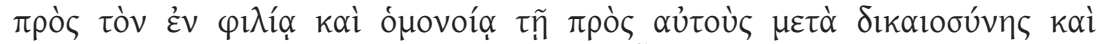

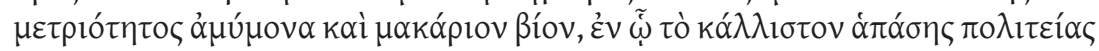

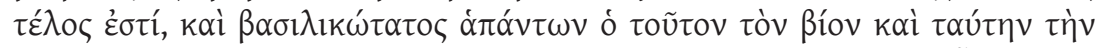

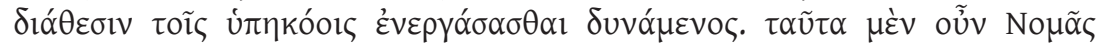

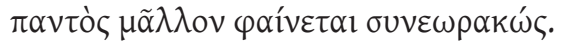

Conta-se que, durante o reinado de Numa, não houve guerra, dissensão ou revolução na política. Na verdade, nem existiu contra ele ódio algum ou inveja

\footnotetext{
${ }^{837}$ Cf. Praec. ger. reip. $802 \mathrm{E}-\mathrm{F}$.

${ }^{838}$ Cf. e.g. ibid. 799A, 800B-801A; Cor. 15.4.

${ }^{839}$ Cf. e.g. Ad princ. ind. $780 \mathrm{~B}$.

${ }^{840}$ Cf. G. Aalders (1982: 22 ss. e 33).

${ }^{841}$ No caso do rapto das Sabinas, Plutarco segue a tradição: Dion. Hal. 2.30-1; Liv. 1.9.

${ }^{842}$ Num. 20.5-8.
} 
nem conspirações ou sedições de homens motivadas pela ambição da coroa. Mas, tivesse sido por temor dos deuses, que pareciam preocupar-se com este homem, quer por respeito da sua virtude ou por uma sorte divina que the mantinha a vida ilesa e à margem de todos os males, deu um exemplo claro e um testemunho do preceito que Platão, que viveu muito tempo depois dele, teve a audácia de proferir sobre o Estado: depois de se conjugarem, com base na fortuna divina, o poder do rei com a reflexão filosófica, os homens têm apenas uma libertação e uma solução para os males que é a virtude se superiorizar e estar acima do mal. "De facto, bem-aventurado o que é verdadeiramente sensato", e "bem-aventurados os que ouvem as palavras que saem da boca de quem é sensato". Assim sendo, não é necessário usar qualquer tipo de violência contra a população, nem ameaças, mas ela própria, ao ver a virtude no exemplo visível e na vida brilhante do governante, torna-se sensata e adequa-se a uma vida irrepreensível e feliz, na amizade e na concórdia, mediante a justiça e a mesura. De facto, este é o objectivo mais belo de qualquer Estado e o melhor rei de todos é aquele que consegue inspirar esta forma de vida e este princípio aos seus súbditos. Numa, sem dúvida, parece ter cumprido isso mais do que qualquer um.

Para demonstrar que Numa foi um governante com capacidade para ganhar o respeito dos seus súbditos e tornar-se modelo destes, Plutarco baseia-se na concepção política e ética de Platão ${ }^{843}$, que se concentra em preceitos fundados na justiça, na moderação, na paz, na amizade e na virtude, fundamentais para consolidar a relação entre quem governa e quem é governado.

Aliás, uma das dificuldades daquele que exerce funções de Estado é a relação com os cidadãos, os quais, muitas vezes, sem entender as opções que os governantes tomam, se deixam persuadir por eloquentes propagandas que não conduzem a nada de positivo para a polis e que apenas ajudam a criar uma maior distância entre a elite que governa e os restantes cidadãos. Como a relação que existe entre o sol e o céu, segundo os matemáticos (astrónomos) ${ }^{844}$, o sol, por descrever uma espiral, não tem um movimento semelhante nem oposto ao do céu), também entre governante e cidadão deve existir uma relação salutar e de entendimento recíproco. No caso concreto da Grécia do século I, parece-nos que a reacção da elite aristocrática ao domínio romano, receosa de perder poder e protagonismo, não encontraria eco numa parte substancial da população, mais preocupada em sobreviver e em ver findar as intermináveis guerras.

No prólogo do par Phocion-Cato Minor ${ }^{845}$, Plutarco, a propósito do sentido de rigor de Catão de Útica, explica que, em política,é perigoso seguir,cegamente,

\footnotetext{
${ }^{843}$ Cf. Resp. 487e, 499b, 501e, Lg. 711e e 712a.

${ }^{844} \mathrm{Cf}$. De soll. anim. $974 \mathrm{~F}$ onde se percebe melhor a relação entre matemáticos e astrónomos. ${ }^{845}$ Phoc. 2.6-9.
} 
um caminho, por vezes duro e exigente, sem ouvir os cidadãos e indo, por vezes, contra a vontade popular. Para se criar um clima de responsabilização entre aquele que governa e o cidadão, a melhor opção, para o governante, é delinear um interesse comum, fazer algumas concessões, executando as actividades com $\pi \rho \alpha \omega_{\omega} \omega \varsigma$ e $\chi \rho \eta \sigma i ́ \mu \omega \zeta$. No fundo, o exercício da actividade política tem de ser sensato e harmonioso, conciliando-se a firmeza nas decisões com a bondade e a capacidade de dialogar. Logo que se identifiquem as necessidades, é preciso ser persuasivo e racional. Deste modo, o politikos deve socorrer-se da retórica e do logos, qualidades que decorrem da formação: a retórica como matéria que pertence a um nível superior da aprendizagem e o logos que se consolida com o processo formativo, por meio do controlo das emoções e dos impulsos excessivos.

Os tratados políticos, um pouco à semelhança do que acontece na synkrisis cultural das Vitae, constituem documentos valiosos para avaliar a noção que Plutarco tinha das relações entre a Grécia e Roma, uma vez que a filosofia política, por assim dizer, parece corroborar a ideia de que as duas culturas se devem conhecer melhor. Tal como Plutarco cultivou várias amizades com Romanos, também estes deviam deixar de ver os Gregos como Graeculi ${ }^{846}$, adjectivo com que os Romanos qualificavam aqueles que, como Cícero, se tinham instruído na língua, na literatura, na filosofia e na retórica dos Gregos. Apesar de Plutarco reconhecer o poderio dos Romanos, faz questão de lhes lembrar que, no passado, os Gregos tiveram homens tão valentes na acção como os actuais Romanos. Quanto aos Gregos, por sua vez, não podem olhar para os Romanos como se eles fossem bárbaros semelhantes aos Persas, mas procurar persuadi-los, com respeito pela sua idiossincrasia cultural, para os valores helénicos, forma que poderia atenuar a ascensão política e o poderio militar dos próprios Romanos.

Os tratados políticos, em especial os Praecepta gerendae reipublicae, apresentam exemplos com uma evidente finalidade prática, de modo a influenciarem a conduta e a formação dos politikoi, fundados numa série de teorias sobre o pensamento político do Queronense, que são mescladas, por um lado, com valores morais e, por outro, com uma clara vocação formativa. Para Plutarco, aquele que governa deve saber conduzir os cidadãos com a arete e o phronema, usando para isso o dom do logos, de forma a suscitar a admiração dos concidadãos. Assim se resumem as qualidades do politikos ideal: ${ }^{847}$

846 Sobre o uso deste diminutivo de sentido depreciativo, vide M. Dubuisson (1991: 322-329). Recordamos que o próprio imperador Adriano, por causa do seu interesse intelectual pela cultura grega, era chamado por alguns de Graeculus (Historia augusta 1.5).

${ }^{847}$ Praec. ger. reip. $823 \mathrm{~A}-\mathrm{C}$. 


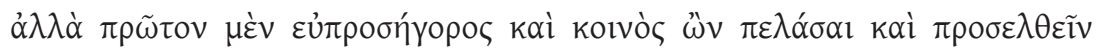

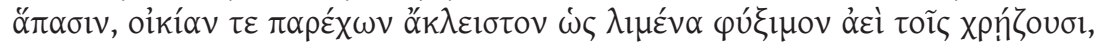

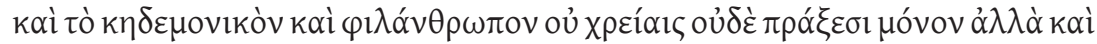

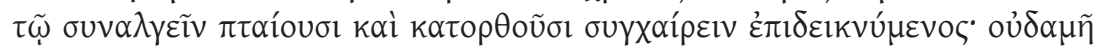

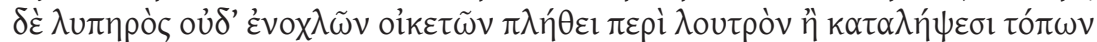

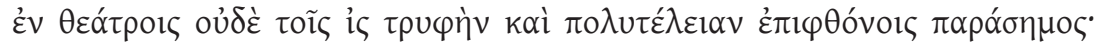

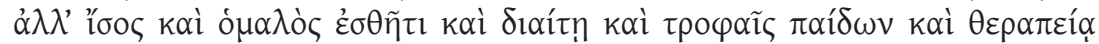

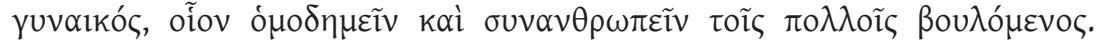

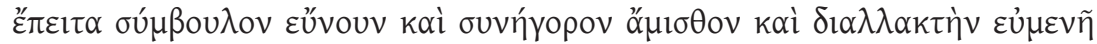

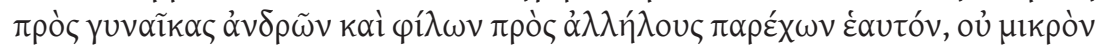

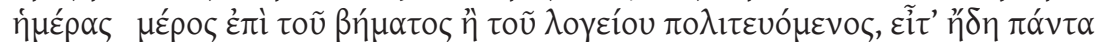

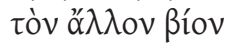

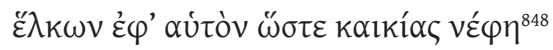

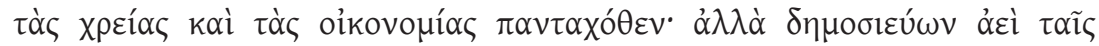

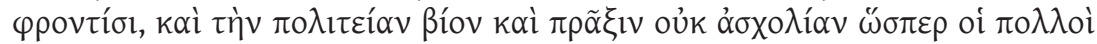

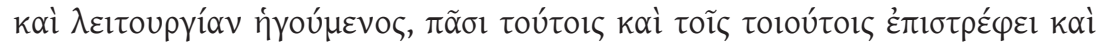

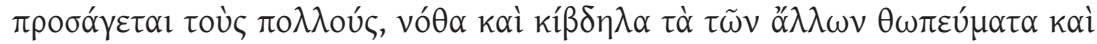

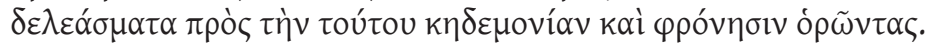

Mas, em primeiro lugar, [o homem de Estado] é afável e sociável com todos os que dele se aproximam e o consultam. Tem a casa aberta como um porto sempre pronto a acolher os necessitados e demonstra a sua solicitude e humanidade não apenas nos afazeres e acções mas também ao partilhar a dor com os que fracassam e a congratular-se com os que alcançam êxito. De modo algum é molesto ou causa perturbação na multidão de escravos que o acompanha no banho ou na obtenção de lugares nos teatros, nem se distingue por incorrer em odiosas manifestações de arrogância e sumptuosidade. Mas mostra-se igual aos outros no vestir, no tipo de vida, na educação dos filhos, na forma cuidadosa como trata a esposa, por desejar ter uma vida igual à do povo e estar entre as pessoas. De seguida, disponibiliza-se como conselheiro indulgente, advogado gracioso, benévolo conciliador dos maridos com as esposas e dos amigos uns com os outros. Não passa, na sua acção política, uma pequena parte do dia sobre a tribuna ou sobre o estrado do teatro, e depois passa o resto do seu tempo

puxando para si próprio, como o vento sudeste as nuvens,

ocupações e serviços domésticos de todas as partes. Ocupa-se, ao invés, diligentemente dos assuntos públicos, por julgar a política a razão da sua vida

${ }^{848}$ Trag. adesp. frg. 75 Nauck. 
e das suas acções e um serviço, não uma perda de tempo, como muitos pensam. Com todas estas formas de conduta e outras iguais, atrai a atenção para si e ganha a benevolência do povo, quando este vê que as lisonjas e as formas de sedução de outros são enganosas e falsas em comparação com a solicitude e a inteligência dele.

Este texto descreve, assim, dois aspectos da politeia. Pelo facto de o politikos ser, antes de tudo, um cidadão como os demais, quando exerce funções governativas não se deve esquecer disso e manter-se "̂́oఢ. Por outro lado, a politeia, obrigando a uma grande entrega, promove também a captatio beneuolentiae dos cidadãos, de forma a que estes se identifiquem com quem exerce o poder.

As qualidades que um homem de Estado deve possuir podem resultar da sua paideia e do efeito pedagógico que deve procurar incutir no povo que governa, para ganhar o seu respeito e para que se sinta persuadido a imitá-lo. Além disso, atendendo ao facto de os Romanos ocuparem o poder, exigia-se que os Gregos exercessem a politeia de forma moderada. Os políticos gregos tinham, assim, uma liberdade limitada, à semelhança dos actores dramáticos que estavam obrigados a respeitar as regras daqueles que os dirigiam, pois se os

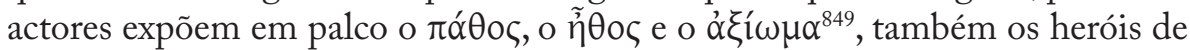
Plutarco manifestam essas motivações na praxis política. Registe-se que, apesar de muitos gregos terem ocupado importantes funções nas hierarquia política romana, Plutarco refere-se só uma vez, talvez para não provocar reacções negativas nos Romanos, ao lamento de alguns dos seus contemporâneos por causa da carreira política: ${ }^{850}$

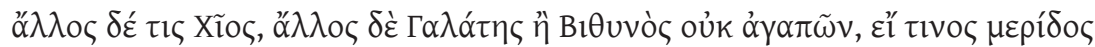

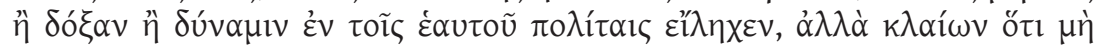

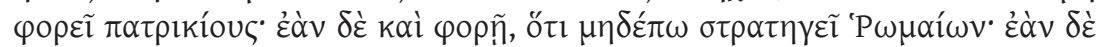

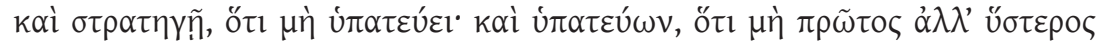

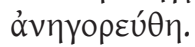

Um de Quios, outro Gálata ou Bitino, que não estando satisfeito com a parte de glória ou de poder que lhe coube entre os seus próprios concidadãos, mas chora por não usar calçado de patrício; mas, se o usa, chora por não ser ainda pretor dos Romanos; se já é pretor, porque não é cônsul; sendo cônsul, porque não foi o primeiro, mas o último a ser nomeado ${ }^{851}$.

${ }^{849}$ Cf. Praec. ger. reip. 813E; vide também 800B, 805D, 806A e 816F; cf. Quaest. conu. 711E, Arist. Pol.1461b 30; vide F. Becchi (1995: 51-64).

${ }^{850}$ De tranq. an. 470C; para uma análise deste passo vide S. Swain (1998r: 169-170).

${ }^{851}$ Cf. Cic. Mur 8.18, sobre o valor de ser nomeado em primeiro lugar. 
Como temos vindo a evidenciar, Plutarco analisa a paideia (a formação, a cultura, os valores) dos seus heróis em diversas circunstâncias. Não se fica pela apresentação abstracta de conceitos, mas prefere exemplificar as atitudes, as opções, os erros, as virtudes ou as dúvidas dos biografados a partir de casos concretos, em geral relacionados com a politeia. Além disso, só aqueles que têm proairesis política e sentem que desempenham um serviço em prol do bem comum deveriam dedicar-se à politeia. $\mathrm{Na}$ verdade, aquele que dirige e assume o comando da politeia tem de fomentar a justiça e a concórdia, evitar os excessos e, acima de tudo, ser modelo de princípios, que só se podem ter pela paideia, na qual a filosofia assume especial relevo. Nesta perspectiva, Plutarco apresenta uma solução intermédia entre o Estado educador de Platão e a autonomia moral defendida por Galeno, uma vez que não exclui a paideia

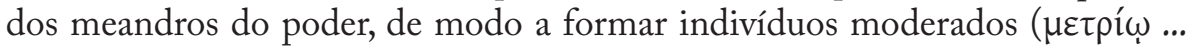
$\left.\eta{ }^{\theta} \varepsilon \imath\right)^{852}$. Plutarco tenta sempre conciliar as duas realidades: a individualidade, a personalidade e a physis do eu com a sociabilização a que esse eu está sujeito, tanto pela paideia como pelo contacto com a realidade exterior.

Vemos, assim, que Plutarco não negligencia na sua obra a politeia, que é uma das temáticas de maior interesse, mesmo sabendo que para imperadores como Domiciano ou Vespasiano, a colaboração, por exemplo, entre imperador e filósofos não era considerada importante ${ }^{853}$, facto que mudou substancialmente com a chegada de Trajano ao poder. À época de Trajano, juntamente com a do seu antecessor, Nerva, chama Tácito ${ }^{854}$ a felicitas temporum ou beatissimum saeculum, por causa da conciliação entre principatus e libertas. Assiste-se, nesta altura, a uma maior abertura e, com isso, os círculos intelectuais ganharam um novo impulso e uma maior liberdade para exporem os seus pensamentos ${ }^{855}$. Plínio, por exemplo, realça que a bumanitas é uma das virtudes de Trajano ${ }^{856}$. O que se pede a este imperador é um pouco daquilo que o sábio Numa, figura tanto lendária como mítica, conhecido pelo valor que atribuía à justiça ${ }^{857}$, tentou fazer: gerar a concórdia e a paz, eliminar os atritos entre Sabinos e

${ }^{852}$ Cf. Max. cum princ. $778 \mathrm{~A}$.

${ }^{853}$ Cf. e.g. J. Toynbee (1944: 43-58): alguns filósofos, especialmente estóicos e cínicos, no século I, decidiram retirar-se para um vida mais privada, como forma de mostrar o seu desagrado pela acção dos imperadores. Sobre a crueldade de Vespasiano, vide Amat. 771C.; em Num.19.7 e Quaest. Rom.276E , Plutarco revela alguns dos traços tirânicos de Domiciano. A respeito da damnatio memoriae de Domiciano, vide S. Levin (1985: 283-290) e L. de Blois (1997: 214-216).

${ }^{854}$ Hist. $1.1 ;$ Agr. 3.

855 Sobre o papel social que o filósofo desempenhava no século II, vide J. Dillon (2002: 29-40), servindo-se dos exemplos do próprio Plutarco, que foi sacerdote em Delfos, ou de Amónio, que foi por três vezes strategos em Atenas, além de se dedicar à educação de efebos; junta a estes exemplos o de L. Víbio Êumenes da Fócea, que era honrado pelos seus concidadãos como philosophos, strategos, boularchos, eirenarchos, ephebarchos, gymnasiarchos e agoranomos.

${ }^{856}$ Pan. 2.7, 3.4, 4.6, 24.2, 47.3, 49.5 e 71.5.

857 cf. Phoc. 3.8. 
Romanos, substituir o impulso para a guerra por uma maior vivência religiosa. Ora, esses príncípios são válidos no século II e constituem a base do ideal greco-romano, que Trajano deverá traduzir na sua política ${ }^{858}$.

Também Plutarco saiu favorecido por este novo clima, tendo defendido convictamente que o filósofo é uma peça essencial na politeia, cujo exercício tem

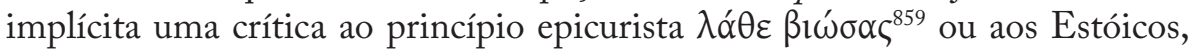
como Zenão, Cleantes e Crisipo, que não participaram na vida pública, apesar de terem escrito sobre a politeia ${ }^{860}$. Contudo, não encontrámos nos tratados que a seguir analisaremos, sempre com a paideia como pano de fundo, uma orgânica estruturada do Estado, mas um conjunto de preceitos políticos e éticos, que têm como preocupação central a integração do poder local da polis no ecumenismo do estado imperial, de modo a conservar, tanto quanto possível, um certo nível de autonomia. Não eram apenas os governadores enviados pelo Imperador que punham em causa o poder dos Gregos, mas também os centuriões, beneficiarii e pessoal militar que reforçavam a presença romana no terreno, até ao nível do controlo económico ${ }^{861}$.

Por conseguinte, o pensamento político de Plutarco indaga a validade do poder "municipal" ${ }^{62}$, das poleis, abordando questões relativas à administração das cidades gregas a Oriente, e, num plano mais teórico, discute a natureza, o carácter e a finalidade da ợxท́. Não são considerações abstractas por que tenta contribuir, com alguns conselhos, para a serenidade dessas poleis, por meio da acção pedagógica, ao tentar transmitir valores éticos e da própria paideia, para evitar impulsos despóticos e limitar a influência romana. Nesse sentido, diríamos que os tratados Maxime cum principibus philosopho esse disserendum e Ad principem indoctum (ineruditum) fazem, sobretudo, uma reflexão teórica sobre a ỏpxý, enquanto em An seni respublica gerenda sit e em Praecepta gerendae reipublicae se encontra a praxis política da administração local. Além disso, sublinhamos o apelo que se faz ao cumprimento da lei, mas sobretudo da lei

${ }^{858}$ Além desta relação de Numa com Trajano, a propaganda imperial estabelece também uma conexão entre Numa e Adriano (cf. A. Pérez Jiménez (2004c: 53, n. 13). No entanto, o mesmo estudo refere que a personagem de Plutarco que melhor reflecte a imagem de Trajano é Emílio Paulo, por ter sempre como objectivo o bem da comunidade, pela sua eusebeia e pela sua religiosidade e fidelidade ao culto dos deuses, como o provam os sacrifícios que faz à lua, antes da Batalha de Pidna, embora conheça a teoria que explica os eclipses; F. Brenk (1992: 4363-7), por sua vez, estabelece a relação entre Nero-Marco António e Demétrio.

${ }^{859}$ Cf. De lat. uiu.1128A-1130E e Praec. ger. reip. 824B. Plutarco critica os epicuristas por tentarem dissuadir todos da politeia, além de não valorizarem as figuras ilustres da politeia, tanto do passado como do presente (cf. Adu. Col.1127A-1127E).

${ }^{860}$ Cf. De Stoic. rep. 1033B-C; por causa dessa atitude, Plutarco afirma que, contrariamente às suas obras, esses estóicos viveram mais em consonância com os preceitos de Epicuro ou de Hierónimo (cf. ibid. 1033C).

${ }^{861}$ Cf. L. de Blois (2004: 60 ss.).

${ }^{862}$ Cf. P. Desideri (1985: 391-405). 


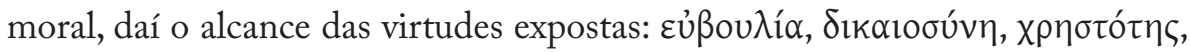
$\mu \varepsilon \gamma \alpha \lambda$ as suas ideias, o Queronense recorre a modelos do passado: Péricles, entre os Gregos, e Cipião Emiliano e Catão de Útica, entre os Romanos, em Maxime cum principibus; já no tratado Ad principem indoctum, surgem Epaminondas e Catão de Útica, repetindo-se e juntando-se a estes dois a figura de Alexandre, talvez por este permitir a distinção do filósofo-rei ${ }^{864}$.

Assim, mais do que teorizador político, papel que lhe poderia acarretar problemas com a classe dirigente, numa altura em que se sentia alguma tensão, Plutarco prefere ser conselheiro, não ao estilo de Platão em Siracusa ${ }^{865}$, mas, com um discurso ético-moral e sem apoiar reestruturações radicais, tenta construir a imagem ideal daquele que exerce funções políticas, ou seja, adopta sobretudo uma função de guia ${ }^{866}$. De acordo com os elementos que temos vindo a desenvolver, gera-se, em especial nos tratados políticos, uma tensão entre o papel relevante que o politikos deve desempenhar e as limitações que os Gregos sentiam perante o domínio romano. Por isso, a mensagem de Plutarco é essencialmente pragmática e reforça o sentido ético da politeia, de forma a que se crie entre Gregos e Romanos ou entre a classe dirigente e os cidadãos uma boa relação.

Em verdade, a vocação didáctica de Plutarco não tinha apenas uma intenção moralizante, mas também política, certamente influenciada pela propaganda que rodeava Nerva e Trajano, da qual fazem parte alguns discursos de Díon de Prusa e o Panegyricus de Plínio-o-Jovem ${ }^{867}$. Só dessa forma se percebem os seguintes paradoxos: Plutarco recusava todas as formas de tirania, mas mostra-se condescendente com o Império; não aprovava a intervenção do povo, designado por óx入oఢ, mas admirava e louvava os valores da Democracia Ateniense e da República Romana.

Atendendo a este conjunto de vectores, procederemos de seguida a uma análise dos elementos mais relevantes de cada um dos tratados políticos que integram os Moralia. Acreditando que isso ajude a enriquecer o significado da paideia na obra de Plutarco, até porque ele considerava que o politikos podia, por um lado, exercer uma influência positiva no ethos daqueles que dependem

\footnotetext{
${ }^{863}$ As quatro primeiras em Max. cum princ. e as outras em Ad princ. ind.

${ }^{864}$ Sobre as possíveis razões do uso de Alexandre como modelo, vide G. Zecchini (2002: 195).

${ }^{865}$ Tentou que Dionísio aí pusesse em prática o projecto que não conseguira implementar em Atenas (cf. P1. Epist. VII).

${ }^{866}$ Cf. C. Jones (1971: 111).

${ }^{867}$ Ao contrário de A Wardman (1974: 100-4), há quem veja nas qualidades desenvolvidas por Plutarco nas Vitae uma alusão às virtudes de Trajano.
} 
dele $^{868}$ e, por outro, interessar-se pela paideia da comunidade ${ }^{869}$, mediante, por exemplo, a recordação de feitos do passado, como o decreto de amnistia após a queda dos Trinta ou o castigo aplicado a Frínico por ter representado numa tragédia a tomada de Mileto $^{870}$.

\subsubsection{Maxime cum principibus philosopho esse disserendum 776B-779C}

Este tratado, que não consta no Catálogo de Lâmprias, desenvolve uma ideia fulcral no pensamento plutarquiano sobre a simbiose entre paideia e politeia: o filósofo deve estabelecer relações, de forma moderada, com aqueles que governam, para thes transmitir os verdadeiros valores, de modo a que a acção política tenha por fim o bem de todos os cidadãos. Logo, a philosophia, como interveniente activa na realidade e como matéria basilar da formação do pepaideumenos, torna-se parceira da politeia e tem nesta um papel relevante: ${ }^{871}$

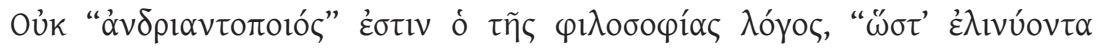

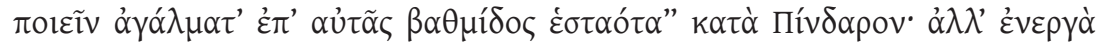

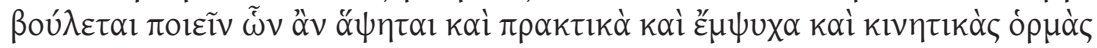

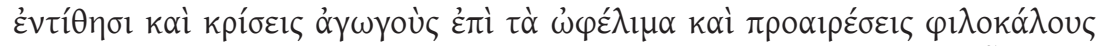

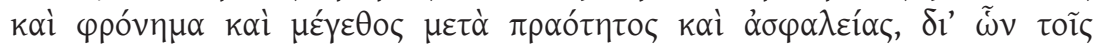

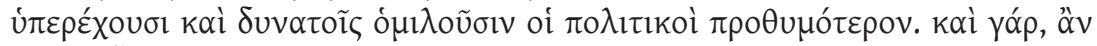

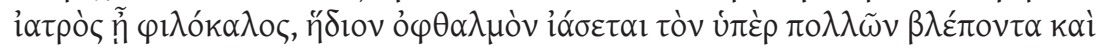

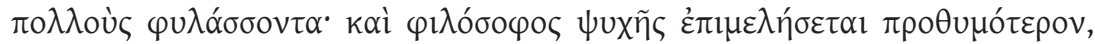

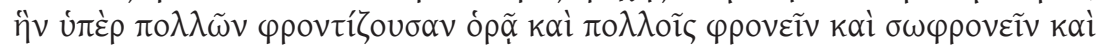

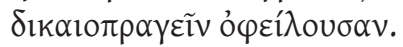

O discurso da filosofia não é "fazedor de estátuas", "a ponto de fazer estátuas que permanecem, em pé, inactivas sobre a sua própria base”, como afirmou Píndaro ${ }^{872}$. A filosofia, porém, deseja tornar activas, ágeis e vivas as coisas que possa atingir, e estimula a acção, decisões que conduzem ao que é útl, princípios de beleza, inteligência, grandeza de espírito juntamente com a doçura e a simplicidade. Por isso, os filósofos ${ }^{873}$ relacionam-se de forma mais benévola com os que dominam e com os poderosos. De facto, se um médico é virtuoso, tratará melhor um olho que olha por muitos e que a muitos protege, como o filósofo cuidará com maior benevolência da alma que vê preocupar-se com

${ }^{868}$ Cf. Lyc.30.4 e Ad princ. ind. 780B; sobre esta questão vide G. Aalders (1982: 45) e J. Hershbell (1995: 215-6).

${ }^{869}$ Neste particular, Licurgo supera Numa por promover a mesma educação para todos desde o início (cf. Comp. Lyc.-Num. 4.4-5), uma vez que considera a paideia o assunto mais importante que o legislador tem em mãos (cf. Lyc. 14.1).

${ }^{870}$ Estes e outros exemplos em Praec. ger. reip. 814B.

${ }^{871}$ Cf. ibid. 776C-D.

${ }^{872}$ Em Nem. 5.1.

${ }^{873}$ Aqui o vocábulo politikoi parece referir-se aos filósofos que se interessam pela politeia. 
muitos e que tem o dever de pensar, de agir com prudência e de praticar a justiça para benefício de muitos.

É deste modo que se defende a influência pedagógica da filosofia nos governantes, não devendo ela ser hermética, abstracta e alheia ao pulsar do seu tempo e dos problemas da sociedade ${ }^{874}$. Na verdade, o próprio autor apresenta o homem culto que participa activamente na politeia, tanto no exercício de cargos, como no papel de pensador que aconselha os seus amigos romanos e concidadãos gregos a enfrentarem as actuais circunstâncias.

Não só não é inusitado ou descabido que o filósofo mantenha relações cordiais com aqueles que detêm o poder ${ }^{875}$, como isso é um meio para que os princípios filosóficos cheguem a um maior número de pessoas ${ }^{876}$, como fez Anaxágoras com Péricles, Platão com Díon e Pitágoras com os mandatários itálicos ${ }^{877}$. Além destes exemplos, podemos mencionar o papel de Aristóteles junto de Alexandre e o de Sócrates com Alcibíades, ainda que, neste caso em particular, não se possa dizer que tenha tido consequências dignas de relevo ${ }^{878}$. Aliás, Platão, a quem Plutarco deve muitas das suas ideias, também não foi bem sucedido ao tentar influenciar o mais importante monarca do seu tempo, Dionísio II de Siracusa, ele que idealizara a fusão da função de filósofo e rei ${ }^{879}$.

Apesar da brevidade deste tratado, é visível a presença da dupla dimensão da filosofia: a privada e a pública. Por um lado, o mundo interior que fomenta a harmonia da alma e, por outro, um nível exterior, que procura a concórdia entre

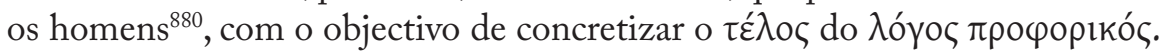

Atendendo a esta "magistratura da filosofia" pode afirmar-se que, pela influência que exerce junto dos políticos, o filósofo passa a ter também o papel de legislador. Contudo, não é esse o desempenho que mais nos interessa, mas a do filósofo educador, por Plutarco acreditar que a educação e a moralidade têm um sentido especial num momento em que a Grécia vive integrada no Imperium. Por isso, é fundamental que haja um bom imperador, até porque o próprio autor pôde testemunhar a acção política de Nero e Domiciano, tal como presenciou o conturbado ano de 69, com quatro imperadores. Além

${ }^{874}$ A filosofia, enquanto matéria de um nível superior de educação, está relacionada com o homem que exerce o poder, embora existam naturais diferenças entre a vida filosófica e a política (cf. Per. 16.7), tal como também se podem notar algumas semelhanças (cf. Praec. ger. reip. 798B); em Plutarco, por influência de Platão e de Aristóteles, a filosofia é uma componente fundamental da paideia (cf. F. Becchi (1999: 25-44)).

${ }^{875}$ Cf. ibid. 776B-C.

${ }^{876}$ Cf. Arist. EN 1094b 1-10 (procurar o bem para muitos na acção política).

${ }^{877}$ Cf. Max. cum princ.776E-777B.

${ }^{878}$ Cf. Alc. $4-7$.

${ }^{879}$ Cf. Resp. 519c-521b.

${ }^{880}$ Cf. ibid. 777B-D 
disso, também as elites romanas que presidiam aos destinos das cidades gregas deveriam ter consciência das suas responsabilidades. A filosofia pode, por

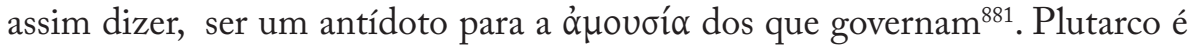

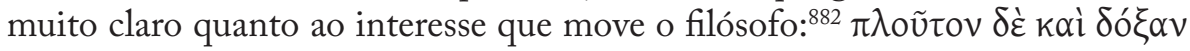

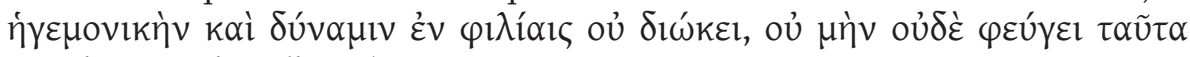
$\mu \varepsilon \tau \rho i ́ \omega$ que dá a liderança, nem o poder, mas não os recusa quando estão unidos a um carácter equilibrado). Assim, o filósofo não tem como prioridade a riqueza, a glória ou o poder, mas também não os deve recusar se isso estiver ligado a um ethos prudente e equilibrado ${ }^{883}$. À filosofia pede-se que consiga incutir nos governantes hábitos de justiça e a vocação para agir segundo aquilo que é correcto e benéfico para os cidadãos, pois só dessa forma eles conseguirão sentir-

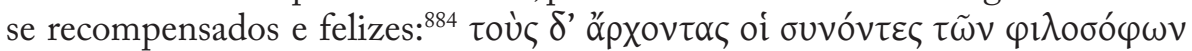

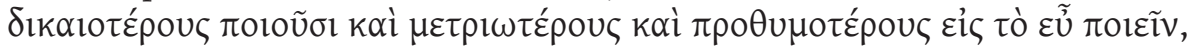

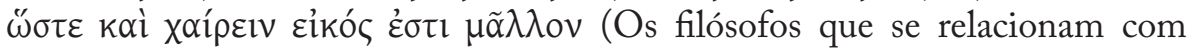
governantes tornam-nos mais justos, moderados e predispostos para fazer o bem, de tal forma que é natural que eles sintam maior alegria).

A intenção de Plutarco é, assim, incutir valores, como a magnanimidade, a doçura, a simplicidade, a equidade, a prudência ou a moderação, naqueles que são agentes activos da politeia, que Plutarco por vezes define como uma

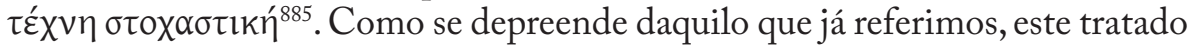
recupera um tema platónico ${ }^{886}$, talvez por Plutarco acreditar que essa concepção poderia ser útil no seu tempo, em que se tinha instalado uma crise de valores morais entre a classe dirigente. Da mesma forma, Díon de Prusa, num discurso a propósito da realeza, pronunciado, segundo se crê, na presença de Trajano ${ }^{887}$, considera que a palavra do sábio é uma orientação para aquele que governa: ${ }^{88}$

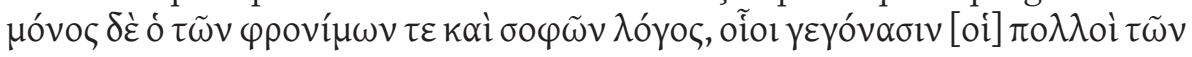

${ }^{881}$ Cf. ibid. 777D.

${ }^{882}$ Ibid. 778A.

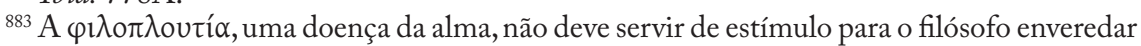
pela acção política (cf. 777D); vide, ainda, Praec. ger. reip. 798E-F e $819 \mathrm{E}$.

${ }^{884} \mathrm{Cf}$. ibid. $778 \mathrm{~F}$.

${ }^{885}$ Cf. An seni resp. 792D; vide Arist. EN 1109a e 1141 b.

${ }^{886} \mathrm{Na}$ Resp. e nas Lg., Platão apresenta-nos a cidade ideal regida por filósofos. Os poetas líricos e os primeiros filósofos também não deixaram de aconselhar os que governavam sobre o exercíco da politeia; sobre a concepção do filósofo-rei em Plutarco e as suas relações com o ideal platónico, vide G. Aalders (1982: 41), G. Aalders \& L. de Blois (1992: 3391), J. Hershbell (1995: 213) e B. Boulet (2005: 245-256). Plutarco, em Num. 20.8-9, parece querer dizer que esse ideal já havia sido realizado pelo rei Numa, e também depois Cícero cumpriria esse doutrina política (cf. Comp. Dem.-Cic. 3.4); vide, ainda, De lib. educ. 7F-8A.

${ }^{887}$ P. Desideri (1978: 350).

${ }^{888}$ Or. 1.8 . 


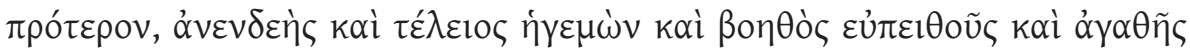

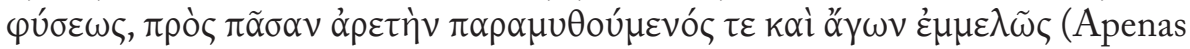
a palavra dos que são prudentes e sábios, como muitos dos antigos eram, é guia perfeita e eficaz, auxiliadora da natureza obediente e nobre, capaz de encorajar e de guiar de forma conveniente para a virtude plena).

No tratado de Plutarco, o vocábulo politikos significa não só aquele que exerce a politeia, o que detém o poder, mas sobretudo aquele que se interessa pelo bem-estar dos cidadãos. Isto aplica-se tanto ao político como ao filósofo. Aliás, a palavra philosophos, seguindo o modelo platónico, também pode significar o homem de Estado educado em filosofia. Resulta, deste modo, evidente que a comunidade só terá a ganhar com a cooperação entre o philosophos e o politikos, até porque o philosophos ajudará a evidenciar a $\varphi \imath \lambda o \kappa \alpha \lambda \lambda^{\prime} \alpha$ e a $\varphi \imath \lambda \alpha v \theta \rho \omega \pi i ́ \alpha$ do governante.

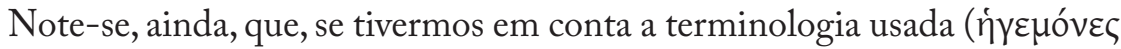
ou óp $\chi(\mathrm{v} \tau \varepsilon \varsigma)$, este tratado pode ter como destinatários os políticos locais como senadores, procônsules ou cônsules, sem que exista uma referência clara à figura

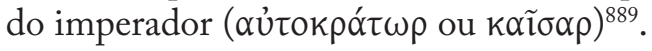

\subsubsection{Ad principem indoctum 779D-782F}

Se, no tratado anterior, Plutarco desenvolveu a ideia de que considerava fundamental a proximidade entre o politikos e o philosophos, neste assume que a formação dos soberanos é tão difícil quanto necessária, uma vez que o apaideutos ${ }^{890}$, o oposto de pepaideumenos, nunca poderá ser um bom governante ${ }^{891}$. Para a consumação desse objectivo, só a filosofia pode proporcionar uma boa educação, no sentido de o libertar de paixões e de lhe ensinar a virtude e a justiça ${ }^{892}$, ou seja, a paideia filosófica. Assim, o tratado Ad principem indoctum ou ineruditum ${ }^{893}$ recupera os princípios de Platão, de

${ }^{889}$ Para G. Roskam (2002: 179), isso revela as precauções que Plutarco tem em relação à figura do Imperador, ainda que esteja no seu espírito a possibilidade de este beneficiar com a presença do filósofo.

${ }^{890}$ G. Anderson (1989: 105) refere a este propósito: “The social prestige of paideia is often undisguised: a society polarising into honestiores and humiliores was able to polarise into

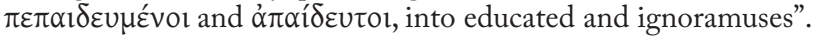

${ }^{891}$ A complementaridade entre os dois tratados levou A. Barigazzi (1982: 62-79) a defender que os dois formariam um único tratado. $\mathrm{O}$ uso de oľo $\theta \varepsilon$, em $781 \mathrm{E}$, e oľcl, em Cum princ. philos. $779 \mathrm{~A}$, pode dificultar a aceitação dessa tese. Dentro desta linha de pensamento,

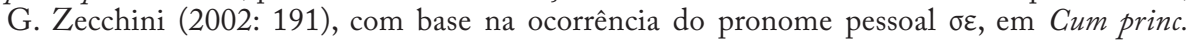
philos.778C, escreve: “(...) in the Maxime cum principibus there is one character, who is addressed in the second person singular and to whom the work is directed, that does not appear in the Ad principem ineruditum". Sobre o bom governante em Plutarco, vide A. Squilloni (1989: 225-243).

${ }^{892}$ Cf. 782 A.

${ }^{893}$ C. Jones (1971: 30) não afasta liminarmente a possibilidade de este tratado ter como 
Isócrates ou dos Estóicos, defensores da educação filosófica dos hegemonikoi, e dirige-se, possivelmente, ao princeps ${ }^{894}$.

Tanto nos Moralia como nas Vitae, Plutarco demonstra, recorrentemente, que aqueles que governam se encontram muito próximos dos defeitos ou das virtudes, do insucesso ou da glória, e temem que a paideia lhes faça perder a autoridade ${ }^{895}$. Os que assim agem só revelam que não interiorizaram o verdadeiro sentido do poder e os deveres que têm de respeitar para com os cidadãos, tornando-se muitas vezes tirânicos: ${ }^{896}$

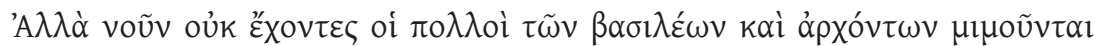

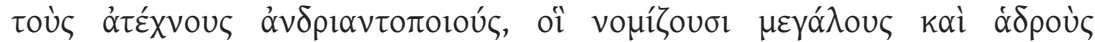

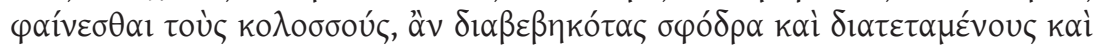

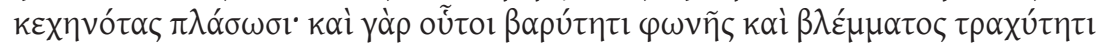

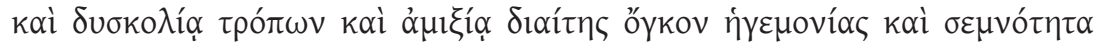

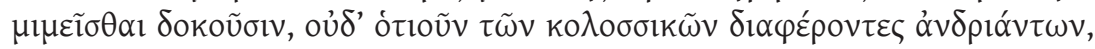

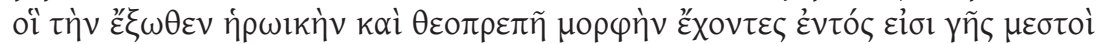

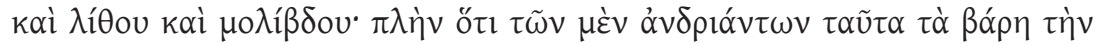

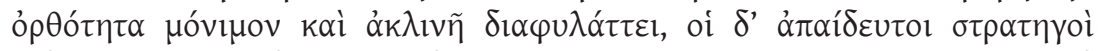

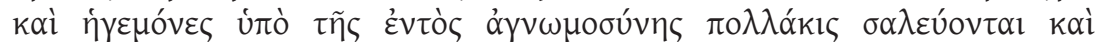

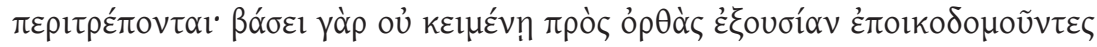

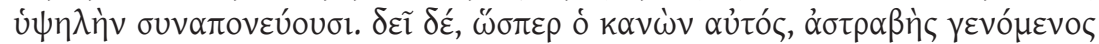

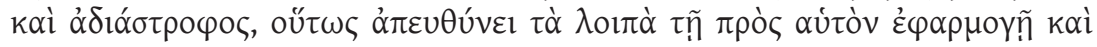

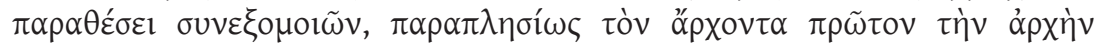

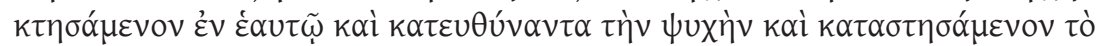

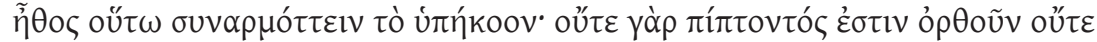

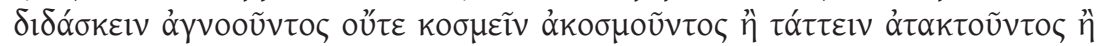

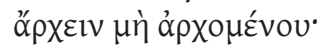

Porém, muitos dos reis e dos governantes, não tendo discernimento, imitam os escultores sem arte, os que consideram que os colossos parecem mais imponentes e grandiosos se os modelarem com as pernas em posição de andar e com os braços esticados e a boca aberta. Na verdade, os reis e os governantes julgam que imitam a majestade e a solenidade da hegemonia por usarem uma voz grave, terem um olhar lancinante e formas de agir irascíveis ou uma vida isolada, mas em nada diferem das estátuas dos colossos, que têm por fora um aspecto heróico e digno de uma divindade, mas por dentro estão cheias de

destinatário Trajano, mas, por não haver nenhuma referência explícita no texto, considera que ele "delivered before several hearers". O plural o’̌ $\sigma \theta \varepsilon$ (781E), acima mencionado, parece sugerir que se dirigia a várias pessoas, numa espécie de conferência ou lição pública.

${ }^{894}$ Sobre o destinatário e a antiga tradição do speculum principis, vide A. Tirelli (2005: 20-1), que sustenta a ideia de que as palavras de Plutarco, neste tratado, giram em torno do optimus princeps.

${ }^{895}$ Cf. 779D-F.

$896779 \mathrm{~F}-780 \mathrm{~B}$. 
terra, de pedra e de chumbo. Com a excepção de o peso das estátuas manter estas numa posição estável, sem tombar, enquanto os estrategos e os chefes sem instrução muitas vezes baloiçam e baqueiam por causa da ignorância que têm dentro. É que eles vacilam ao construírem a sua elevada autoridade em função do que é justo sobre uma base que não está consolidada. Tal como a régua é ela própria direita e indeformável, e dessa forma endireita as restantes coisas, assemelhando-as por conveniência e justaposição à sua forma, também o governante, após adquirir, primeiramente, o governo de si próprio, endireitando a alma e estabelecendo o seu carácter, deve, da mesma forma, ajustar os seus súbditos a ele. De facto, não se consegue endireitar o que cai, nem ensinar o ignorante, nem pôr em ordem aquilo que vive em desordem, corrigir o indisciplinado ou governar o que não se deixa governar.

Este texto critica os politikoi que, por causa de serem apaideutoi, se preocupam em transmitir a sua autoridade mais por meio do aspecto do que por uma convicção interior, repetindo-se os dois níveis tratados anteriormente: o interior e o exterior. Para se ganhar o respeito e a admiração dos concidadãos deve o político preocupar-se em instruir-se e adoptar os valores da paideia, auxílio primordial das suas decisões.

De facto, para se saber governar bem os outros é preciso que o soberano seja capaz de se governar a si próprio ${ }^{897}$, baseando-se a boa governação na razão ${ }^{898}$. Ora, será a filosofia a formar e modelar a razão ${ }^{899}$, pois não possuir a razão pode tornar-se perigoso, uma vez que isso permite ao indivíduo fazer o que quiser e ter atitudes mais de acordo com as kakiai do que com as areta $i^{900}$. Aqui reside o papel principal da filosofia: fazer com que a razão domine os preceitos de quem governa e da sociedade, levando a que se consolide a ordem, a justiça e a paz entre os cidadãos. Ao exercer as suas funções com justiça e inteligência, o politikos estará a ser um modelo para os cidadãos e ó $\mu$ oló $\eta \tau \tau \alpha \varepsilon \varepsilon \tilde{\omega}^{901}$.

Como se constata, interessa mais a Plutarco o exercício do poder do que a forma como se ascende a ele. Ele sabe que o poder tem tendência a desvirtuar as qualidades do homem e que, quando se exerce esse poder, se torna

${ }^{897} \mathrm{Cf}$. 780B-C; se aquele que governa julga que o seu primeiro privilégio consiste em não ser governado, engana-se por completo (cf. 789C).

${ }_{898}$ Cf. 780C-E; por oposição, existe a kakopoliteia, que Plutarco associa à fase final da República (cf. Pomp. 75.5 e Caes.28.4), declínio que a providência divina trava com a monarquia. Nas biografias de Sula (25.4-5), Sertório (24.5) e António (24.7-8; 68.6-8), Plutarco tece alguns comentários sobre a má administração, ao contrário do que faz na descrição de Flaminino ou Emílio Paulo, figuras romanas da fase intermédia da República.

${ }^{899}$ Cf. 781A-E; são exemplo disso Alexandre e Diógenes (cf. 781E-782B); em Alex. 52.3, recorre-se, sem grande sucesso, ao filósofo Calístenes para apaziguar a dor de Alexandre.

${ }^{900}$ Cf. $782 \mathrm{C}-\mathrm{F}$.

${ }^{901}$ Cf. ibid. 780E; recorde-se que este é um ideal platónico (cf. Theaetetus 176b); vide F. Becchi (1996: 321-35). 
impossível ocultar os vícios ${ }^{902}$. A paideia torna-se, deste modo, indispensável para o correcto desempenho do governante, com o objectivo de dotar este do equilíbrio necessário para saber enfrentar os momentos de maior entusiasmo com prudência ou para, perante os obstáculos, ser um modelo de perseverança junto dos seus concidadãos. Ao que carece da paideia, o apaideutos, mesmo que, por sorte, lhe toque a riqueza e a fama, mal atinge a akme política, é

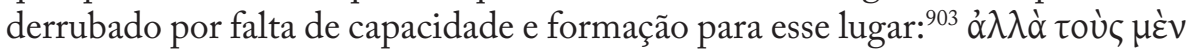

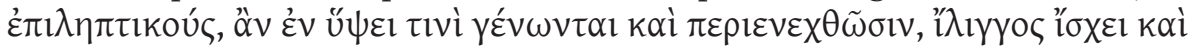

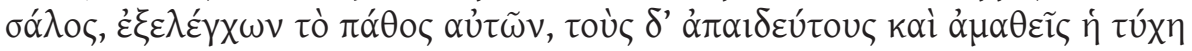

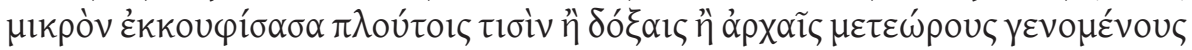

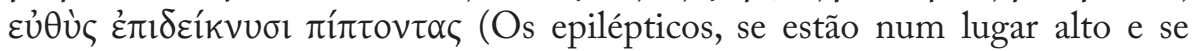
mexem, são possuídos por uma vertigem e uma agitação, que prova a doença deles. A sorte, por seu lado, elevando um pouco os que carecem de instrução e os ignorantes com algumas riquezas, fama ou poder, logo que chegam às alturas, ela de imediato os mostra a cair). Deste modo, o homem, para não estar dependente das incertezas da sorte, deverá dedicar-se à paideia, pois será ela o melhor baluarte para enfrentar as fragilidades próprias da condição humana. Veja-se que os tratados que discutem a razão do sucesso de Roma e de Alexandre (De fortuna Romanorum e De Alexandri fortuna aut uirtute, respectivamente) parecem indicar que Alexandre teve mais mérito individual, certamente alicerçado na sua paideia, na concretização dos seus feitos, do que os Romanos, mais dependentes da acção da tyche.

A paideia transmitida pelo filósofo tem uma componente teórica, na qual se inclui a compreensão do divino ${ }^{904}$, pois o soberano deve ser uma espécie de intermediário entre a divindade e o homem ${ }^{905}$, procurando igualar as virtudes desse divino sem querer substitui-lo ou superiorizar-se a ele. Além disso, a paideia possui uma parte mais prática, ligada à askesis, que visa um processo gradual de melhoria das capacidades intelectuais e morais do indivíduo, bem como o controlo dos excessos pela razão. Se, num cidadão comum, a falta de paideia potencia situações que revertem, essencialmente, para o próprio índivíduo, já num governante essa lacuna aumenta substancialmente as possibilidades de se cometerem erros, em particular quando está aliada ao aumento de poder ${ }^{906}$, sendo, por isso, necessário evitar o contacto com aduladores que apenas visam aproveitar-se dessas circunstâncias ${ }^{907}$.

${ }_{902}$ Cf. De fort. 100A, De Alex. fort. aut uirt. 336A-B e 337C, De tranq. an. 467B; vide, ainda, Cic. 52.2 e Luc. 25.2.

${ }^{903}$ Cf. $782 \mathrm{E}$.

${ }^{904}$ Cf. ibid. $781 \mathrm{~F}$.

${ }^{905}$ Cf. Praec. ger. reip. $823 \mathrm{~F}$ e Num. 6.2.

${ }^{906}$ Cf. Max cum princ. 782B-C.

${ }^{907}$ Cf. De ad. et am. 49C-D. 
Uma vez apreendida a paideia, conciliando a teoria e a prática, o novo politikos pode assumir plenamente as suas funções e tomar conta das matérias que dizem respeito aos cidadãos ${ }^{908}$, aos quais se deve adaptar. É esta a ideia que Plutarco desenvolve no tratado que se segue.

\subsubsection{An seni respublica gerenda sit 783B-797F}

An seni respublica gerenda sit é, na sua essência, um tratado de moral política, que coloca no centro da reflexão o papel que os anciãos podem e devem desempenhar na acção política ${ }^{909}$. O tema, se atendermos ao valor que Séneca e Plínio-o-Jovem, por exemplo, atribuíram ao otium na velhice, seria actual no tempo de Plutarco, que parece rejeitar os princípios estóicos sobre a velhice, identificando-se mais com as ideias peripatéticas ${ }^{910}$. Além disso, as obras de Teofrasto e de Demétrio Falero sobre a velhice, infelizmente ambas perdidas, e o De senectute de Cícero ${ }^{911}$, embora com muitas diferenças, terão servido de fonte para Plutarco compor este tratado.

Por considerar valiosa e muito útil a experiência, a inteligência e a sabedoria dos anciãos ${ }^{912}$, Plutarco defende que estes devem exercer os cargos públicos até ao limite das suas capacidades físicas e mentais, uma vez que a faculdade de pensar é afectada pela inactividade ${ }^{913}$. No caso de decidirem abandonar as funções, sem que estejam em condições que justifique o afastamento, isso deve ser entendido como uma traição à cidade.

Sem dúvida que enriquece a politeia a capacidade de previsão, a eloquência, a prudência ou a maturidade, qualidades da velhice, enquanto aos jovens compete a participação nas actividades bélicas ${ }^{914}$, advogando o autor que a juventude foi feita para obedecer, cabendo à velhice, por sua vez, mandar ${ }^{915}$. Mais importante do que essa função é a paideia que devem exercer sobre os

${ }^{908}$ Cf. Thes. 33.2 e Rom. 13.5 ; Ad princ. ind. 781C-D.

$909 \mathrm{Em} 791 \mathrm{C}$, Plutarco refere que a actividade política é um tipo de vida de um animal domesticado, tanto social como político, que nasceu para se entregar à causa pública.

${ }^{910}$ A. Barigazzi (1984a: 162 s.) refere que as ideias deste tratado podem ser entendidas como uma réplica aos epicuristas, pelos facto de os prazeres do espírito se superiorizarem aos prazeres epicuristas; em An seni resp. 786B, Plutarco afirma que se devem procurar para a alma os prazeres que tenham nobreza e que sejam uma manifestação de liberdade.

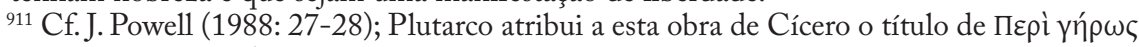
(Cat. Ma. 17 e Flam. 18).

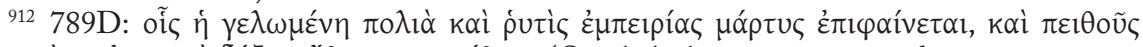

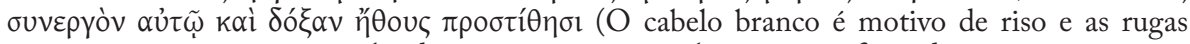
aparecem como um testemunho da experiência, e contribuem para a fama do seu carácter e para a sua persuasão).

${ }_{913}$ Cf. 788B; vide, em 793B-C, as palavras contra a ociosidade.

${ }^{914}$ Cf. 789D.

915 Ibid. 
mais jovens ${ }^{916}$, de modo a prepará-los convenientemente para virem a assumir funções mais importantes. Nesse sentido, Plutarco define quando se pode assumir funções de Estado, estando isso dependente de dois ciclos, um em

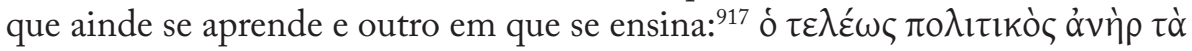

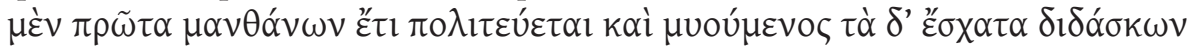

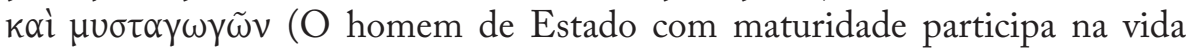
pública, em primeiro lugar, quando está a aprender e se está a iniciar, e, no final, ensinando e iniciando outros nos mistérios).

Usando como exemplo Péricles, que atingiu o seu maior poder na velhice ${ }^{918}$, Plutarco faz a defesa da actividade política em idade avançada, pois condena os homens que mal chegam a essa idade se refugiam, por cobardia, nos afazeres domésticos, mais próprios das mulheres ${ }^{919}$, até porque a dignidade e a grandeza da arete politike ${ }^{920}$ se perdem quando se dirigem para os assuntos domésticos ou

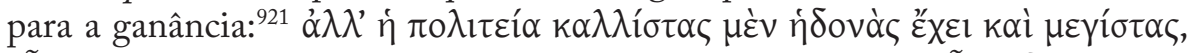

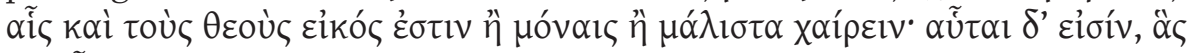

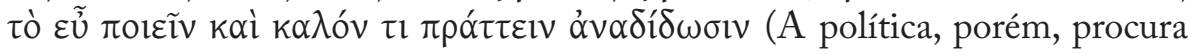
alcançar os maiores prazeres, os únicos que provavelmente agradam aos deuses, ou os que mais agradam. Pois estes são os que fazem brotar o bem-fazer e as belas acções).

Tal como no tratado Ad principem indoctum, também neste Plutarco discorre sobre as implicações do poder. Assume que alcançar a glória e o poder não é uma tarefa fácil, mas, logo que a glória seja grande, tudo se deve fazer para a aumentar e conservar ${ }^{922}$, sabendo-se que a inveja, o maior mal da vida pública $^{923}$, será sempre um obstáculo a ultrapassar por quem governa.

É óbvio que Plutarco sabe que a velhice traz ao político algumas condicionantes. Por isso, é necessário que a velhice se adapte às funções

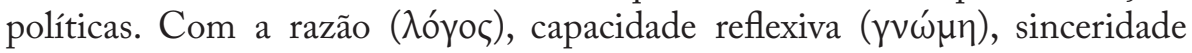

${ }^{916}$ Cf. 790E-F; em 795B-D, nota que os mais velhos, com o seu dom da palavra, devem aconselhar os jovens.

${ }^{917}$ Cf. 795E.

${ }^{918}$ Cf. 784E; Plutarco também dá exemplos de tragediógrafos já na velhice, para demonstrar que os anciãos devem imitá-los (cf. 785A-C).

${ }^{919}$ Cf. 784A.

${ }^{920}$ E.g. o par Phoc.-Cat.Mi. inicia-se com uma reflexão sobre a arete politike e a sua influência nos momentos de grande agitação política, revelando, dessa forma, a conexão que Plutarco procurou realçar entre o desempenho político e as intenções morais. Aliás, o mesmo tom moral está presente no par Ant.-Demetr.; vide também Sol. 3.8, Fab.1.1, Cor. 15.4, Marc. 20.1, Phil. 3.1, Pomp. 13.6, Comp.Ages.-Pomp. 2.3, An seni resp. 785D, Praec. ger. reip. 801D e De un. in rep. dom. 826B.

${ }^{921}$ Cf. 786B.

${ }^{922}$ Cf. 787A.

${ }^{923}$ Cf. 787E. 


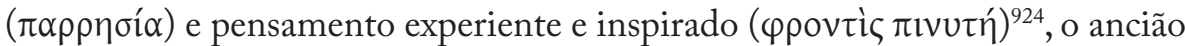
pode ajudar a melhorar a qualidade da vida pública, uma vez que $\pi \circ \lambda \lambda \grave{\alpha} \mu \varepsilon \dot{\varepsilon} p \eta$

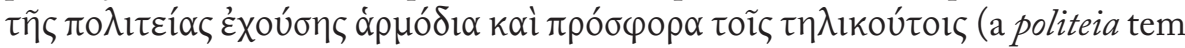
muitas funções convenientes e adaptadas aos que têm uma idade avançada) ${ }^{925}$.

Se no tratado anterior abordámos o tema da imagem do filósofo educador, neste parece-nos que sobressai o papel do ancião educador, capaz de transmitir aos jovens um legado político que respeite os valores da prudência, da sensatez, da justiça, da experiência e da persuasão ${ }^{926}$, no fundo, o amor pela humanidade individual e colectiva.

\subsubsection{Praecepta gerendae reipublicae 798A-825F}

Praecepta gerendae reipublicae foi o tratado político de Plutarco que maior influência exerceu no mundo ocidental, porventura por ser aquele que faz uma abordagem mais concreta da politeia e dos seus valores ${ }^{927}$. Atendendo ao momento sócio-político que se vive, Plutarco dirige os conselhos políticos ao aristocrata Menémaco de Sardes, que lhe pede para ser seu mentor ${ }^{928}$. Logo, podemos entender que os conselhos se dirigem a todos os aristocratas que desejam dedicar-se à politeia, em particular aos que vivem em poleis gregas ${ }^{929}$. Assim, no contexto deste tratado, Roma é uma potência exterior e um poder potencialmente ameaçador, não existindo um paralelo entre duas culturas iguais. Avançam-se, porém, preceitos para que possa existir um equilíbrio e, sobretudo, cooperação nas relações entre o poderio romano e a débil situação helénica, considerando-se a manutenção da harmonia como o objectivo principal do político grego ${ }^{930}$.

Com um fim didáctico e moral, Plutarco revela uma atitude conservadora, própria dos aristocratas que tentam manter a todo o custo a sua proeminência social e económica, ao não pretender suscitar a revolta dos cidadãos sob o

${ }^{924}$ Cf. 797E.

${ }^{925}$ Cf. 793A.

${ }^{926} \mathrm{Cf}$. as qualidades políticas em $792 \mathrm{D}$.

${ }^{927}$ Nas palavras introdutórias do tratado De cap. ex inim. ut. 86B-D, que dedica ao seu amigo C. Cornélio Pulquer, que desempenhou as funções de procurador na Acaia, Plutarco afirma que aquele tinha sempre nas suas mãos os Praec. ger. reip.

${ }_{928}$ Cf. 798B-C; outras referências em 800B, 804C, 809A, 810C, 813F, 819B-C-E, 821D, 822C, 824B-C e 825C; sobre a possibilidade, pouco provável, de Menémaco de Sardes ser o destinatário de outros tratados de Plutarco, vide A. Caiazza (1993: 11-13).

${ }_{929}$ Como bem nota S. Swain (1998r: 171), é estranho que Plutarco não mencione o facto de Sardes, no seu tempo, ter conhecido dois senadores gregos, merecendo-lhe isso o seguinte comentário: "This omission, together with Plutarch's condemnation of 'lucrative' posts in the equestrian service, suggests that he wanted to keep Greek politicians in Greek cities."

${ }^{930}$ Cf. 824B-E; M. Lopez Salvà (1990-1: 25-36) mostra como Plutarco e Díon de Prusa, com realismo, aconselham as populações a ter uma atitude cooperante com Roma, sem renunciar à legítima aspiração pela autonomia. 
domínio romano, por ser preferível aproveitar ao máximo a margem de liberdade existente. Por isso, partindo de uma perspectiva positiva, aconselha a harmonia cívica, em detrimento das acções bélicas levadas a cabo no passado, e recomenda que se façam amizades com aqueles que representam o poder romano ${ }^{931}$, para que daí se tirem benefícios para a própria cidade.

Tendo em conta que a acção política é distinta da representação teatral ${ }^{932}$, não deve enveredar pela politeia aquele que só procura o lucro e a riqueza (philoploutia $)^{933}$, mas aquele que, com base na reflexão e na razão, se sinta com proairesis, a base da politeia: ${ }^{934}$

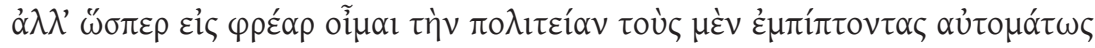

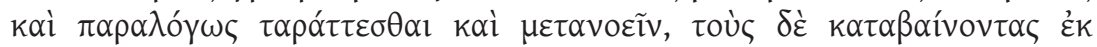

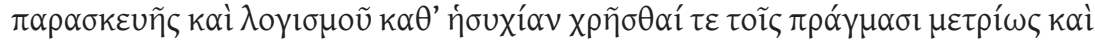

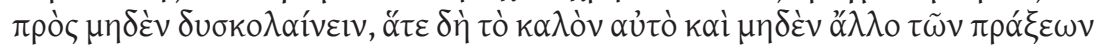

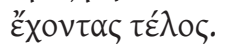

Mas, como quando se lançam para um poço, penso que aqueles que entram na vida pública de forma espontânea e sem raciocinar ficam perturbados e arrependem-se. Ao invés, os que chegam, paulatinamente, à política, com preparação e de forma pensada, dedicam-se aos assuntos com moderação e não se irritam com nada, pois não têm nenhum outro fim para as suas acções a não ser o bem.

Na verdade, a philoploutia e também a philotimia ${ }^{935}$ são, na maioria dos casos, más motivações para o homem que deseja exercer funções políticas, por desviarem o interesse público para o proveito pessoal.

Exige-se que o político, além de não descuidar nenhum dos assuntos públicos ${ }^{936}$, esteja bem preparado (દ่k $\left.\pi \alpha \rho \alpha \sigma \kappa \varepsilon \cup \tilde{\eta} \varsigma\right)$ e saiba observar o ethos dos seus concidadãos, de modo a conhecer as suas virtudes e defeitos, pois só

${ }^{931}$ Cf. 814C-D, com a ressalva de isso não significar uma atitude humilhante daquele que domina para com os súbditos (cf. 814E-F); refira-se, ainda, que Plutarco, embora aconselhe cautelas (na biografia deixa implícito um louvor a Aristides por ter chegado ao poder sem "falsas" amizades), não considera que a política e a amizade sejam incompatíveis (vide Sol. 15 e Ages. 13, sobre o cuidado a ter com as relações amistosas). Pode-se até ajudar um amigo, desde que isso não ponha em causa o interesse público (cf. $806 \mathrm{~F} \mathrm{s.);} \mathrm{paralelamente,} \mathrm{as} \mathrm{inimizades} \mathrm{privadas}$ não devem interferir no campo político, embora seja inevitável que condicionem as decisões (cf. 809B s.); no fundo, nenhum concidadão, por partilhar um mesmo colectivo, se pode considerar inimigo (cf. 809E).

${ }_{932}$ Cf. 799 A.

${ }_{933}$ Cf. $798 \mathrm{E}-\mathrm{F}$ e $819 \mathrm{E}$.

934 799A ; Cf. 798C ss.; sobre este assunto, vide A. Pérez Jiménez (1995: 363-381).

935 Plutarco, como acontece no par Phil.-Flam. ou na biografia de Alexandre, considera que existe uma boa e uma má philotimia (cf. 821A-F).

${ }^{936}$ Cf. 812 B. 
dessa forma saberá corrigir os erros deles ${ }^{937}$. A relação entre o soberano e os cidadãos é fundamental para a harmonia, cabendo a quem dirige saber incutir confiança $^{938}$ e modelos virtuosos, pois emular os grandes homens desperta a proairesis ${ }^{939}$. Plutarco considera, deste modo, que tanto a palavra como o carácter têm força persuasiva, uma vez que na relação com os cidadãos o valor e a eficácia do uso da palavra desempenham um papel especial ${ }^{940}$, embora o recurso à eloquência deva ser moderado ${ }^{941}$.

Pelo facto de a Grécia, privada de uma eleutheria completa, viver sob o domínio de Roma, Plutarco enfatiza nos seus conselhos a harmonia que deve existir entre soberanos e cidadãos. Os políticos gregos não deviam esquecer que o poder pertencia às autoridades romanas, cabendo-lhes, numa posição mais secundária, ser geradores de concórdia e nunca de conflito ${ }^{942}$. Tenta, assim, mostrar a debilidade da situação da Grécia e que é mais sensato tirar o maior e melhor proveito dela e viver em paz e concórdia ${ }^{943}$. O ideal será os próprios Gregos conseguirem ter a capacidade de solucionar os problemas da polis sem recorrerem às autoridades romanas ${ }^{944}$.

Atendendo às funções e ao desempenho que se exige ao homem de Estado, ele exerce, segundo Plutarco, uma espécie de medicina politica ${ }^{945}$, por ser o garante da "saúde" dos cidadãos, das instituições e dos valores, ou seja, por se preocupar com o bem comum ${ }^{946}$. O político modelar é aquele que se interessa continuamente pelos assuntos do foro público e que considera a politeia uma forma de vida ou uma actividade e não um passatempo ou a prestação de um serviç ${ }^{947}$.

Para que se estabeleça uma relação de confiança e respeito entre cidadãos e magistrados é necessário que a paideia politike forme cada cidadão para o exercício e a consciência da politeia e, acima de tudo, para que tenha a

${ }^{937}$ Cf 799B, 800A-B, 818A e $825 \mathrm{D}$ s.

${ }^{938}$ Cf. 801.

${ }^{939}$ Cf. Them. 3.4

${ }^{940}$ Cf. $801 \mathrm{C}$; em $802 \mathrm{D}$ afirma que um povo e uma cidade devem ser conduzidos pelas orelhas.

${ }^{941}$ Cf. 803.

${ }^{942}$ Cf. $814 \mathrm{~A}$ ss. e $824 \mathrm{D}$; Em 815C, Plutarco considera que o homem de Estado deve procurar a segurança e evitar a perturbação social. Em $816 \mathrm{C}-\mathrm{D}$, por sua vez, defende-se que a concórdia e a amizade devem presidir às relações entre magistrados. Curiosamente, é no tratado Praec. ger. reip. que mais vezes ocorre o vócabulo homonoia (805D, 808C, 824C, 824D e 824E), a par do tratado De frat. am., mas aí num contexto menos politizado.

${ }^{943}$ Cf. 824E; vide G. Bowersock (1973: 177-206).

${ }^{944}$ Cf. 814F.

${ }_{945}$ Cf. 815A-B.

${ }^{946}$ Cf. 817C-D.

${ }^{947}$ Cf. 823C. 
capacidade de ser governado ${ }^{948}$. Essa formação também será importante para se preservarem e cultivarem os bens mais importantes de uma cidade: a paz, a liberdade, a prosperidade, a abundância de homens e a concórdia, embora seja esta última a que compete especificamente ao político: ${ }^{949}$

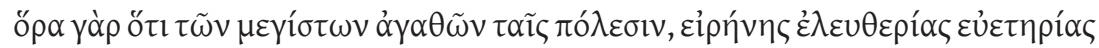

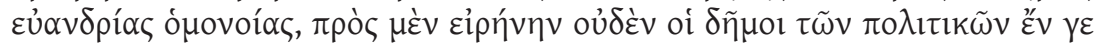

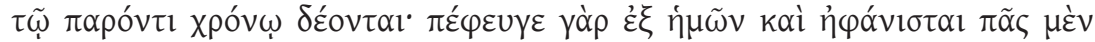

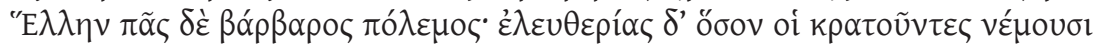

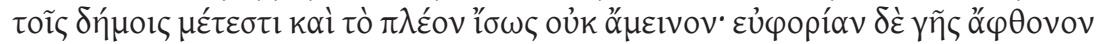

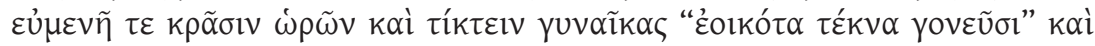

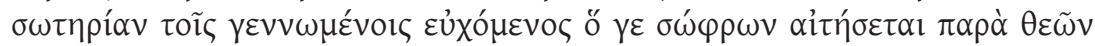

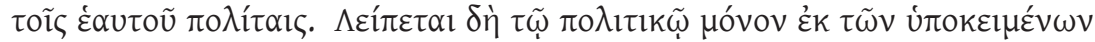

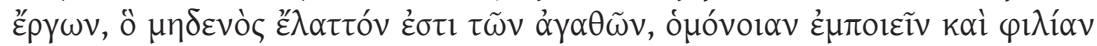

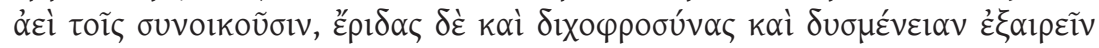
๙ँ $\pi \alpha \sigma \alpha \nu(.$.$) .$

De facto, vê que dos melhores bens que podem existir nas cidades - paz, liberdade, prosperidade, abundância de homens bons e concórdia -, em relação à paz, os povos não têm, actualmente, necessidade de políticos, pois toda a guerra, quer dos Gregos quer dos Bárbaros, desapareceu das nossas vidas e foi suprimida; quanto à liberdade, os povos têm tanta quanta a que os dominadores lhe permitem ter e mais não seria provavelmente melhor; no que diz respeito à fertilidade abundante da terra e à boa temperatura das estações, o homem prudente, com preces aos deuses em benefício dos seus concidadãos, suplica que as mulheres gerem filhos semelhantes aos pais ${ }^{950}$ e pede saúde para os que nascem. Assim, dos assuntos que estão submetidos ao político resta somente um que não é nada inferior aos outros bens: gerar a concórdia e sempre a amizade entre os cidadãos, eliminar as discórdias, as hostilidades e todo o tipo de animosidade (...).

Veja-se como de entre as virtudes que devem existir numa cidade apenas a concórdia é da competência do politikos e, curiosamente, a eleutheria, que tanto preocupa Plutarco, é relegada para segundo plano, pois a que existe é supostamente em quantidade necessária. Este facto merece-nos dois comentários: em primeiro lugar, como A. CAiAzza (1993: ad 824C, n. 417) também notou, isto revela que o Império, na impossibilidade de se restaurar a República, é um bem necessário, pelo clima de paz que conseguiu instaurar; numa segunda análise,julgamos que ao dizer que "os povos têm tanta [liberdade]

\footnotetext{
${ }_{948}$ Cf. 816E-F.

${ }^{949}$ Cf. 824C-D.

${ }^{950}$ Cf. Hes. Erg. 235.
} 
quanta os dominadores lhe permitem ter e mais não seria provavelmente melhor", Plutarco, embora seja notório que não está particularmente efusivo com a situação, parece resignado e tenta, com esta afirmação, suavizar a inclusão da eleutheria na lista dos bens da cidade, de forma a não provocar qualquer reacção negativa nos seus leitores/ouvintes romanos. É com cautela que Plutarco analisa o seu tempo, tentando que os Gregos conheçam os limites e as restrições impostas pelo domínio romano, sujeitas ao desejo do Imperador e circunscritas à política municipal, daí que condene revoltas contra os Romanos, como a de Pardalas, na segunda metade do século I d. C., em Sardes ${ }^{951}$.

Este tratado, sem desenvolver ideias muito originais sobre a concepção política de um Estado, denota um grande pragmatismo por parte de Plutarco. O próprio autor adopta uma atitude moderada e muito racional, sem abdicar do seu helenismo. Os conselhos dirigem-se sobretudo aos que gravitam junto do poder, os quais, fazendo uso dos valores da paideia, devem saber enfrentar as dificuldades.

\subsubsection{De unius in republica dominatione 826A-827C}

Atendendo à experiência política de Plutarco, seria de esperar que este tratado fragmentário de autoria discutida ${ }^{952}$ expusesse a sua reflexão pessoal sobre a teoria política, nomeadamente os sistemas de organização da sociedade, mas a sua brevidade não permite mais do que a exposição da teoria

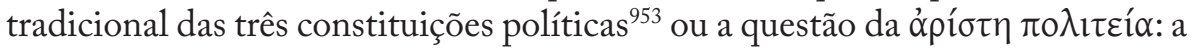
monarquia, a oligarquia e a democracia, representadas pelos Persas (monarquia absoluta), Espartanos (oligarquia aristocrática) e Atenienses (democracia livre e pura $)^{954}$, limitando-se a sintetizar ideias que outrora Platão ou Aristóteles haviam desenvolvido.

A perversão desses regimes recebe o nome de tirania, dinastia e oclocracia, regimes que são conotados, respectivamente, com a violência, a arrogância e a anarquia, e que surgem quando a insensatez mais não faz do que dar origem à desmedida e a formas excessivas ${ }^{955}$, logo muito distantes dos preceitos da paideia.

Além de ficarmos a saber que Plutarco considera a monarquia a melhor forma de governo ${ }^{956}$ — ideia de influência platónica ou uma adesão à

${ }^{951}$ Cf. Praec. ger. reip. 813F; em 824C, refere que essa iniciativa de Pardalas esteve quase a causar a destruição de Sardes.

952 J. Alonso-Nuñez (1985: 32-36) ou S. Swain (1998r: 162) fazem parte do grupo que duvida da sua atribuição a Plutarco, mas M. Cuvigny (1984) e A. Caiazza (1993) manifestam-se a favor da sua autenticidade.

${ }^{953}$ Cf. Hdt. 3.80-82.

954 Cf. $826 \mathrm{E}$.

${ }_{955}$ Cf. $826 \mathrm{~F}-827 \mathrm{~A}$.

956 Também a democracia pode ser boa, desde que tenha como participantes homens da 
política imperial - interessa-nos, sobretudo, verificar neste tratado os vários sentidos da palavra politeia: regime político ${ }^{957}$, participação nos direitos de cidadania $^{958}$, vida de um homem de Estado na sua actividade pública ${ }^{959}$, acção para o bem comum ${ }^{960}$ ou ordem e constituição que rege as actividades do Estado $^{961}$. Considerando estes diferentes significados, pode afirmar-se que a paideia intervém no desempenho da politeia e, como temos vindo a referir, é a etapa preparatória que pode contribuir para o sucesso, ainda que necessite de constante aprofundamento. De facto, a imperfeição é uma característica humana que a paideia não consegue eliminar, mas quando a paideia não existe ou é recusada tanto maior será o fracasso.

Ainda que acredite que a monarquia é a melhor forma de governo, Plutarco enfatiza ao longo dos seus trabalhos que o bom ou mau exercício governativo depende, essencialmente, da conduta moral e política de quem dirige os destinos da polis.

Como síntese do retrato que Plutarco idealiza do indivíduo que desempenha funções de Estado, registaríamos os seguintes traços: a entrega ao serviço do bem público, não por mero acaso, mas por proairesis; no seu percurso, deve subir degrau a degrau as escadas da carreira política, sem ter pressa; nas suas decisões é essencial que seja justo, de modo a inspirar confiança nos seus súbditos; só ganhará a confiança deles se os souber respeitar; convém que seja incorruptível; nos momentos de sucesso, deverá manter a moderação, sem cair em honrarias extravagantes; o seu lema, como o autor frisa, deve ser estabelecer

qualidade e da sabedoria de Milcíades, Címon, Aristides ou Péricles (Cf. An seni resp. 790A). Note-se que é sintomático que Plutarco não inclua nenhum homem do seu tempo... Há, no entanto, alguns elementos que ajudam a problematizar a preferência pela monarquia: os governos monárquicos dos Pisístratos, em Atenas, e dos Tarquínios, em Roma, fracassaram. Atendendo aos casos de Numa, Licurgo e Sólon, nem o governo monáquico é sinónimo de fracasso, nem o poder popular é de êxito. Depois de Augusto, o poder imperial, com os Cláudios e os Flávios, derivou para monarquias tirânicas. Temos de juntar a esta reflexão o facto de Plutarco ser um admirador da Grécia Clássica e democrática e também da República Romana. Ora, tudo isto demonstra as contradições da teoria plutarquiana, ou então o Queronense acreditava acima de tudo que os que detêm o poder devem ser sábios e tinha consciência de que não era possível substituir, durante o Império, as monarquias pela democracia, uma vez que o Império tinha trazido uma considerável estabilidade às poleis. A desconfiança na capacidade política do povo ou na democracia, partilhada também por Díon de Prusa (3.49), resulta da descrença nos demagogos, que não têm outro ideal além da satisfação do seu próprio interesse. Ainda assim, Plutarco sabe que a monarquia precisa de órgãos que controlem o poder do rei, desempenhando

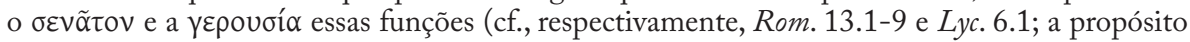
do valor propagandístico do passo da biografia de Rómulo, vide A. Pérez Jiménez (2004c: 60)).
${ }^{957}$ Cf. 826C.
958 Ibid..
${ }^{959}$ Cf. 826D.
${ }^{960} \mathrm{Ibid}$.
${ }^{961}$ Ibid. . 
a concórdia, acrescentamos, entre Gregos e Romanos. Esta panóplia de virtudes, completa-se com a adequada paideia do politikos, assente em conhecimentos filosóficos que ajudem a converter a governação num exercício superior, de modo a que aquele seja um espelho para os que dependem dele. Ou então, deve rodear-se de pessoas, preferencialmente philosophoi, que sejam um suporte sábio e racional para as suas decisões. Juntamos, ainda, a este conjunto de requisitos do politikos a techne rhetorike, recurso que o género biográfico não dispensa, pois já Cornélio Nepos incluía na caracterização das suas personagens a habilidade retórica ${ }^{962}$. Plutarco, por sua vez, relaciona a retórica, como arte de comunicar o pensamento e o conhecimento, com a ética e a política ${ }^{963}$, por entender que é um instrumento fundamental para quem governa ${ }^{964}$, não apenas como mero meio de persuasão, mas como apoio para uma conduta virtuosa. Fazendo a retórica parte da paideia, em Atenas, a partir do século V a. C., e, em Roma, desde o início da República (as épocas a que pertencem os heróis plutarquianos), é natural que se valorize nas Vitae o uso da palavra, com excepção das biografias de Licurgo, Ágis, Cleómenes e Címon, mais conhecidos pela bracbylogia, ou as de Filopémen e Coriolano. No caso do Grego por se ter dedicado quase exclusivamente à vida militar e o Romano por ter uma deficiente formação. Plutarco, na biografia de Catão Censor, por exemplo, descreve como o logos era

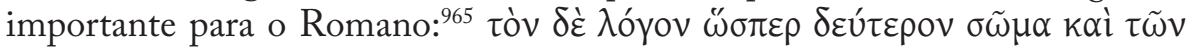

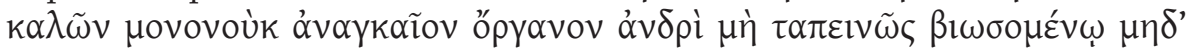

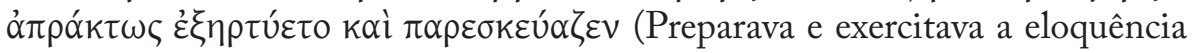
como um segundo corpo e como um instrumento necessário para o bem, por ser indispensável para o homem que não tem intenção de viver na obscuridade e na ociosidade).

A paideia é uma base fundamental para o bom desempenho do politikos, pois quanto mais instruído for o demos, tanto mais exigente e menos permissivo ele será com os governantes sem escrúpulos. Pelo contrário, a ignorância, muito tolerante com atitutes tirânicas, só abre caminho para que os demagogos usufruam do poder para seu proveito próprio, manipulando hipocritamente

${ }^{962}$ Cf. Alc. 1.2 e Epam. 5.1; Plutarco, na biografia que dedica a Alcibíades, diz que o Grego era hábil a adequar a forma ao conteúdo (Alc. 10.4).

${ }_{963}$ C. Pelling (2002n: 339-347) analisa o efeito da retórica na paideia e no percurso político dos heróis das Vitae. Vide, ainda, A. Pérez Jiménez (2002b: 258 ss.), que nos oferece um elemento interessante: em cinquenta por cento das biografias as capacidades retóricas fazem parte da apresentação inicial do biografado.

${ }^{964}$ Recorde-se que, em Praec. ger. reip. 801C-802E, Plutarco afirma que não basta ao governante parecer bom, mas tem de convencer os cidadãos disso.

${ }_{965}$ Cat. Ma.1.5; em De lib. educ. 7B também se relaciona logos e soma: $\kappa \alpha \theta \alpha ́ \pi \varepsilon \rho ~ \delta \dot{\varepsilon े ~ \tau o ̀ ~} \sigma \tilde{\omega} \mu \alpha$

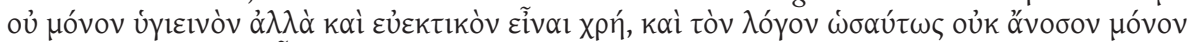

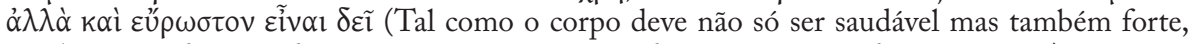
igualmente o discurso deve não apenas estar isento de erros como ainda ser vigoroso). 
o oclos ${ }^{966}$. As diversas reflexões que explana sobre os efeitos nocivos da tirania têm, provavelmente, o objectivo pedagógico de alertar os ả $\lambda \lambda o ́ \varphi v \lambda$ or, ou seja, os Romanos, para não repetirem as atitudes dos Cláudios e dos Flávios. Note-se que Plutarco vê a paideia como uma preparação para o $\operatorname{poder}^{967}$, defendendo um bios politikos, em vez de um bios theoretikos ${ }^{968}$.

Em traços gerais, os tratados políticos procuram definir as melhores técnicas de governação, especialmente as que dizem respeito à ética da ỏ $\rho x \eta^{969}$ e à sua legitimação junto dos cidadãos. Nesse sentido, parece-nos oportuno reproduzir as palavras de A. Tirelli (1995: 444) sobre a estrutura política proposta por Plutarco: "un sistema integrato di filosofia politica, mirante a consolidare e a legittimare su basi etico-religiose lo statu quo dell'assetto centrale e periferico dell'impero romano, com particolare riguardo alle province

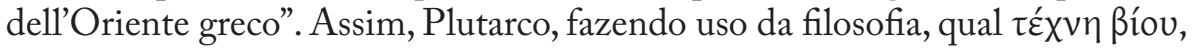
com uma vincada tendência pedagógica, exalta o fundamento ético da politeia, a qual deve reger-se pela razão e por preceitos justos, de modo a atingir o bem, como bem sintetizam as palavras de L. de Blois (1992: 4614): "The focus of attention is the moral and ethical quality of the leaders, which should be founded on an inner law, implanted in them by philosophical paideia and ancestral virtuousness, a nomos empsychos". Estas palavras são, sem dúvida, um bom mote para analisarmos com mais atenção o sentido da paideia em Plutarco.

966 Plutarco condena não só os que, como Coriolano (cf. Comp. Cor.-Alc. 1.3-4), suscitam o ódio do povo pela sua intransigência, como também os que, para conseguirem atingir o poder, bajulam o povo, à semelhança daquilo que fez Alcibíades.

${ }_{967}$ Cf. T. Morgan (2000r: 262-5).

${ }_{668}$ Pl. Resp. 471c-541b e Arist. EN 1095a já haviam desenvolvido a oposição entre uma atitude mais actuante e uma outra mais contemplativa.

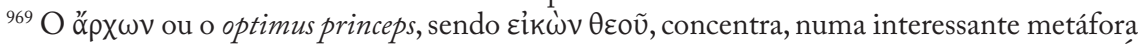
cosmológica, a instituição humana e a divina, mantendo estas duas partes um certa tensão. É o que Plutarco desenvolve no tratado Ad princ. ind.. A. Tirelli (2005: 29-33) considera que esse confronto reproduz a tensão entre a teoria helenística de realeza, de matriz pitagórica, e a doutrina de $\beta \alpha \sigma \imath \lambda \varepsilon i ́ \alpha$ cínico-estóica, sendo Plutarco mais devedor das ideias neo-pitagóricas, embora no pensamento plutarquiano a monarquia mantenha um carácter essencialmente laico. 

Parte III 



\section{O conceito de paidela em Plutarco}

A paideia desempenha, sem dúvida, uma função importante na formação humana ${ }^{1}$, por desencadear processos de autoconhecimento e de apreensão do meio envolvente. É ela que ajuda a conhecer a natureza e a sociedade que rodeia o homem e é também ela que disciplina as expressões humanas, tornando-as mais dignas. Se a divindade baseia o seu poder na sapiência ${ }^{2}$, também o indivíduo deve procurar aprofundar a paideia, para se exercitar nas acções virtuosas e, assim, poder exercer a politeia com justiça.

Assiste-se, precisamente nos séculos I e II d. C., a um processo de florescimento cultural $^{3}$, ligado a um período de alguma prosperidade económica, nas cidades gregas situadas a Oriente. Nestas, as elites culturais, que integram a conhecida Segunda Sofística, mostrando-se orgulhosas das formas de arte e de pensamento dos seus antepassados, revisitam essa paideia e revitalizam-na, até para que os próprios Gregos se consciencializassem melhor do que significava "ser Grego". Essa atitude é consentânea com a Segunda Sofistica, uma vez que

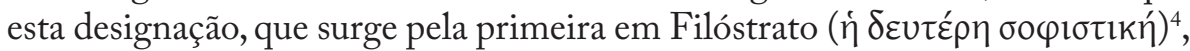
é uma expressão do helenismo e uma reacção cultural à ocupação romana ${ }^{5}$,

${ }^{1}$ Antifonte, frg. 60 Diels, usa as seguintes palavras para descrever o valor da paideusis:

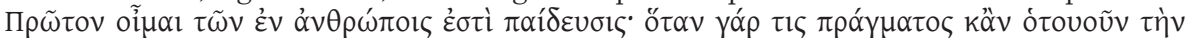

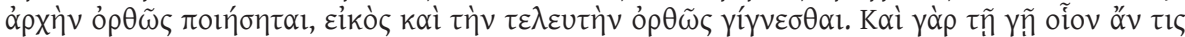

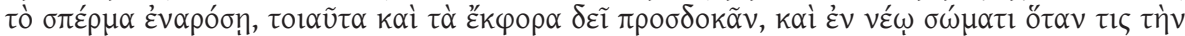

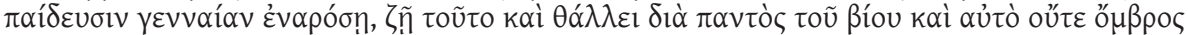

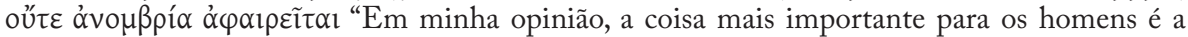
educação. De facto, quando o princípio de qualquer acção se executa rectamente, é natural também que o seu fim o seja de igual modo. E qual a semente que se lança à terra, tal o produto que se deve esperar. Do mesmo modo, quando alguém semeia num ser jovem uma educação nobre, esta vive e floresce durante toda a vida, e nem a chuva nem a secura a fará perecer." (trad. de J. Ribeiro Ferreira (1977-78: 39)).

${ }^{2}$ Cf. Is. et Os. 351D.

${ }^{3}$ R. Barrow (1967: 10), porventura com algum exagero, fala num vazio literário, na Grécia antes de Plutarco; a verdade é que antes do Queronense, encontramos autores como Diodoro Sículo, Dionísio de Halicarnasso e Estrabão, nenhum deles com origem na Grécia; não será demais dizer que Plutarco terá sido um dos responsáveis por esse florescimento cultural.

${ }^{4}$ Cf. VS 481 e 507; esta designação é aplicada a um estilo retórico fundado pelo ateniense Ésquines, no século IV a. C.. Por esta razão, não serve para designar o período romano ou imperial, mas o estilo literário cultivado por alguns.

${ }^{5}$ Esta perspectiva da Segunda Sofística, que o nosso trabalho aplica à análise da paideia de Plutarco, encontra-se mais próxima dos estudos de E. Bowie (1982), S. Swain (1998r), T. Schmitz (1997) e T. Whitmarsh (2001a) (2005) do que dos de G. Bowersock (1969) e C. Jones (1971), uma vez que, embora seja inegável o valor das perspectivas que apontam nos seus trabalhos, estes interpretam sobretudo a relação dos sofistas com Roma. Quanto a T. Whitmarsh (2005: 
aplicando-se à cultura literária dos três primeiros séculos da nossa era. Como B. Borg (2004) salienta, é mais do que um fenómeno literário, por traduzir um sistema de valores e de formas de pensar que se manifestam de modos distintos.

Presente de forma mais ou menos declarada na narrativa das Vitae, a paideia revela-se, como nos casos de Cícero ou Marcelo, sob a forma de um desejo pelas diversas formas do saber. Havia na Antiguidade a noção de que o conhecimento não é algo isolado e hermético, mas uma panóplia universal de fenómenos, em que cada parte só é inteligível com a compreensão do todo. Por conseguinte, podemos afirmar que uma determinada acção de um herói adquire um significado real quando é inserida numa sequência de elementos, em que a paideia ocupa um papel essencial.

Plutarco, um aristocrata, inscreve-se na tradição helénica daqueles que se acham dignos de assumir responsabilidades públicas e de aprofundar a sua formação ${ }^{6}$. Além disso, na linha do pensamento isocrático ${ }^{7}$, Plutarco entende que a paideia define a grecidade, por oposição aos bárbaros, uma vez que a diferença reside mais na cultura do que na natureza, demarcando-se, assim, o mundo Helénico do não-Helénico ${ }^{8}$. Contudo, especialmente as Vitae, passam a incorporar nessa paideia os próprios Romanos, facto que não é absolutamente inovador, na medida em que já Dionísio de Halicarnasso ${ }^{9}$ vê Roma como uma escola da paideia, desvanecendo-se a imagem dos Romanos como bárbaros, até porque os Romanos, além das suas qualidades políticas, são também eupaideutoi ${ }^{10}$. Aliás, se Dionísio de Halicarnasso tinha por intenção tornar os Romanos mais próximos da paideia helénica e avivar-lhes a sua herança cultural ${ }^{11}$, também Plutarco não foge a esses objectivos e, porventura, de uma forma mais incisiva. Esta concepção leva-nos, quase inevitavelmente, a Estrabão, que, na elaboração da geografia humana (ou geografia histórico-política) que desenvolve, advoga a necessidade de não se classificarem os povos como Gregos e Bárbaros, mas

9), na senda dos trabalhos de M. Gleason (1995) e S. Goldhill (Ed., 2001), aponta para uma definição nova da Segunda Sofística: "sophistic' has been aligned with literary sophistication, and 'secondariness' with intertextuality, allusiveness, and literary self-consciousness. (...) theatricality, performance, playfulness, and elusiveness have become indicators not of debased values but of a flourishing, energized culture reflecting actively, if giddily, on its own heritage".

${ }^{6} \mathrm{Em}$ Cim. 1.1 e De sera num. uind. 558A, Plutarco revela pertencer à aristocracia, até porque tem ascendência real.

${ }^{7}$ Paneg. 50.

${ }^{8}$ Cf. E. Gruen (2006: 295-314).

${ }^{9}$ A propósito da presença de Roma e da Grécia na obra de Dionísio de Halicarnasso, vide F. Hartog (1991: 149-167).

${ }^{10}$ Cf. Ant. Rom. 1.3.1.

${ }^{11}$ Recorde-se que as Ant. Rom., em língua grega, enfatizam as origens gregas dos Romanos. A este propósito, vide E. Gruen (1995: 6-51). 
antes pela sua arete $^{12}$, qualidade que está relacionada com o grau de civilidade ou, na sua ausência, com as manifestações de barbárie.

A concepção que Plutarco tem da paideia e do seu valor para a sociedade e para o indivíduo resulta, em grande parte, das raízes platónicas ${ }^{13}$ da sua filosofia, que ele aprendeu de Amónio. Não sendo um filósofo do nível de Platão ou Aristóteles, também não se pode dizer que tenha sido um filósofo amador, uma vez que está familiarizado com as formas e as técnicas que enformam a filosofia ${ }^{14}$, conseguindo, como o tratado De animae procreatione in Timaeo prova $^{15}$, atingir na sua análise um elevado grau conceptual e de abstracção, embora se possa dizer que recuperou muita da terminologia aristotélica e estóica, sem preservar totalmente o platonismo ${ }^{16}$, resultando daí uma ideologia ecléctica. $\mathrm{O}$ eclectismo plutarquiano ${ }^{17}$, marcado também pela sua oposição aos

${ }^{12}$ Cf. Geog. 1.4 .8 (entre os Gregos reina a organização, aquilo que é próprio da paideia, enquanto entre os Bárbaros é o inverso); na obra de Estrabão podemos encontrar, além da oposição entre Gregos e Bárbaros, as polaridades civilizados e não-civilizados e Romanos e não-Romanos.

${ }^{13} \mathrm{O}$ queronense via-se como um professor do platonismo (cf. De E Delph. 391A, De sera num. uind. 549E, Quaest. conu. 617F, 626F, 698E, 719F, 740A), com um bom conhecimento dos textos platónicos (cf. Quaest. conu. 718C), e celebrava, inclusivamente, o nascimento de Platão (cf. Quaest. conu. 717a ss).

${ }_{14}$ Cf. e.g. De adul. 63C, Coniug. praec. 139F-140A, De E Delph. 386F-387A, De tranq. an. 473D, De sera num. uind. 559B.

${ }^{15}$ Cf. D. Babut (1994: 516, n.65).

${ }^{16}$ Depois de o Liceu e a Academia terem deixado de funcionar como estruturas organizadas, e apesar de facilmente se admitir a existência de grupos de professores e estudantes que mantinham as diferentes correntes vivas, só em 179 d. C. se voltou a ter instituições para o ensino do Platonismo (cf. J. Dillon (1977: 184-233, 265); vide ainda do mesmo autor (1988: 357-64)

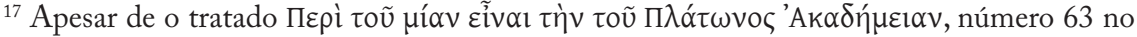
Catálogo de Lâmprias, se ter perdido, o tratado $A d u$. Col. permite perceber que Plutarco era sensível à problemática das mutações da tradição platónica ao longo dos séculos e ao debate existente entre os Cépticos e os Dogmáticos. Para o Queronense, o Cepticismo pode representar uma etapa prévia e válida para o conhecimento, mas o referido tratado serve para reforçar a ideia de que o inteligível e o divino são as bases para a análise da realidade, desvalorizando-se a percepção sensível, tão do gosto do Epicurismo, como critério dos factos tangíveis. Refira-se, por fim, que o estímulo e os problemas que o professor de filosofia transfere para os discípulos, por forma a conhecerem a verdade, método tão notório no tratado De aud., é interpretado como um dos sinais da influência da Academia céptica em Plutarco (cf. G. Roskam (2004: 103) e J. Opsomer (1998: esp. 189). Por causa da multiplicidade temática da sua obra, A. Tagliasacchi (1961: 71) considera Plutarco um eclético, definindo da seguinte forma o seu ecletismo: "è basato su di una profonda conoscenza e non há quindi niente di abborracciato o posticcio, in quanto assimilazione organica, consapevole e convinta, di principi che corrispondono pienamente alla sua natura. Ma vi è ancora un altro elemento che, come l' eclettismo, contradistingue le teorie estetiche, morali e filosofiche di Plutarco, e che, come l' eclettismo, è dovuto in gran parte alla situazione del tempo in cui egli visse: è questo l'accentuazione del valore pratico di ogni forma di sapere, accentuazione di carattere puramente romano, che fonda filosofia e morale in un' unica precettistica." 
Epicuristas ${ }^{18}$ e aos Estóicos ${ }^{19}$, tem enormes virtudes por causa da sua capacidade de síntese, da sua adaptação e reutilização de conceitos. Na verdade, a mesma síntese cultural caracteriza as Vitae e domina a paideia e a sua valorização, tanto no tempo dos heróis como no tempo do próprio autor, por ser um princípio estruturante e transversal da identidade grega, num momento que marca a transição da civilização antiga para os períodos bizantino e medieval.

A obra de Plutarco manifesta, assim, a confluência dos valores da grecidade e da hegemonia da Vrbs, caput mund $i^{20}$. Temos de referir, no entanto, que a tarefa de construir uma visão unitária e equilibrada entre o sistema tradicional das poleis e a realidade concreta do Imperium não era tarefa fácil, uma vez que o autor teve de abdicar de algum do seu patriotismo e orgulho perante a fatalidade do poderio romano, o que não se pode interpretar como uma desistência, mas como um sinal de inteligência por aconselhar a cooperação entre Gregos e Romanos, num plano ideológico e cultural que também tinha em vista a estabilidade social, económica e, em especial, a autonomia administrativa, mesmo que isso não significasse uma liberdade total. É sempre muito complexo falar de confluência de culturas, uma vez que esse processo implica, necessariamente, algum apagamento do protagonismo individual de uma cultura e, no caso da cultura grega, a sua força e riqueza criadora torna ainda mais difícil a amálgama cultural, pois as resistências a uma partilha ou adopção de hábitos, costumes, formas de pensar ou agir são muito maiores. Talvez por ter consciência dessa complexidade, Plutarco tenha optado por fazer parte das suas reflexões no contexto do género biográfico, com a análise individual dos agentes históricos, concentrando-se, sobretudo, nos seus caracteres.

Para Plutarco, herdeiro e intérprete da longa e riquíssima tradição clássica, a paideia e a vocação que tem para gerar a arete estão centralizadas essencialmente no indivíduo (cidadão, político, discípulo ou outro), para que ele saiba relacionar-se melhor com os outros e com a sociedade, logo estamos perante uma paideia menos intelectual e mais prática do que a de Platão, dirigida, em especial, aos que exercem funções superiores no Estado ${ }^{21}$.

${ }^{18}$ Cf. R. Flacelière (1959) e J. Hershbell (1992a). Para Plutarco, como afirma J. Boulogne (2003: 142), o Epicurismo conduz o homem a "un état de pure bestialité".

${ }^{19}$ Cf. D. Babut (t2003) e J. Hershbell (1992b).

${ }^{20}$ A. Barigazzi (1984b: 264-286) considera que esta síntese seria a base de uma sociedade para a história futura da humanidade. Recorde-se que, em Aem. 1.1, se reivindica a função pedagógica da história e se estreitam os laços entre o passado e o presente.

${ }^{21}$ Por isso, S-T. Teodorsson (2005a: 659) escreve: "Para Platón tal ética, relacionada con el individuo, no era suficiente. A su modo de ver, las obligaciones cívicas con el estado eran

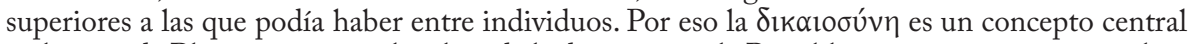
en la ética de Platón, como resulta claro de la discusión en la República, mientras que, en cambio, no es tan prominente en Plutarco"; sem estabelecer relação com Platão, J. Ribeiro Ferreira 
Usando apenas palavras da mesma raíz para apresentar o processo evolutivo, diríamos que, durante a fase de crescimento, o $\pi \alpha \tilde{\imath} \varsigma$ precisa de conjugar a parte

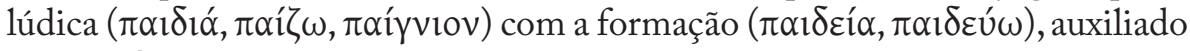
pelo $\pi \alpha 1 \delta \varepsilon v ́ \tau \eta \varsigma$, que se converte num modelo de virtude e sabedoria. A paideia dos heróis que se desenvolve ao longo das Vitae caracteriza-se por ser um conceito denso e que congrega vários valores que fomos referindo (dikaiosyne, praotes, philanthropia, andreia, phronesis, sophrosyne, synesis, tolma, eunoia, sophia, euteleia, eukolia, philotimia...), que acompanha o indivíduo na sua componente física e metafísica, e, por isso, ela tem uma dimensão moral, filosófica, estética e ética. Nesse sentido, a paideia é a base enformadora da totalidade do ser humano.

A reflexão sobre a paideia plutarquiana reveste-se de singular interesse por causa da presença de Roma e da construção do Império nas biografias e nos tratados morais. Para um Grego como Plutarco, com consciência do passado, não seria certamente fácil encarar o papel marginal da sua pátria, vendo como os Romanos e os Bárbaros dominavam a política mediterrânea. Por isso, a paideia, o antídoto da ỏ $\mu \alpha \theta i ́ \alpha$, ajuda-nos a perceber e a avaliar a atitude que Plutarco cultivou na sua época e a arquitectura retórica que idealizou para transmitir a sua mensagem, pela forma como ela surge associada à ética e à política.

Como vimos no primeiro capítulo, na estrutura das Vitae, a paideia precede, de um modo geral, o momento da entrada na vida pública. Junto da família ${ }^{22}$ ou com os paidagogoi e didaskaloi, cada indivíduo recebe os

(2005b: 570) considera, ao contrário de S.-T. Teodorsson, que a dikaiosyne é muito importante nas Vitae: "Nas Vidas Paralelas, o herói não é um homem só, mas surge como responsável por outros, um chefe que deve velar pela salvação do exército e do estado, cuja prudência protege e cuja resolução galvaniza os outros. Talvez por isso a virtude suprema nas Vidas seja a dikaiosyne, que se aproxima da philanthropia, mas também do que exprimem adjectivos como demotikós e hellenikós (e suas substantivações) - ou seja cultura, afabilidade, humanidade, benevolência, sociabilidade”. Refira-se que S.-T. Teodorsson, no estudo que supra indicamos, defende que $\varphi \imath \lambda \alpha v \theta \rho \omega \pi i ́ \alpha / \varphi \imath \lambda \alpha v \theta \rho \omega ́ \pi \omega \varsigma$ (bumanitas em Latim) é o conceito ético com maior alcance em Plutarco, até atendendo ao número de vezes em que aparece com outras palavras de sentido moral (55 vocábulos diferentes) e pelo número de ocorrências (82). Na mesma linha de pensamento de J. Ribeiro Ferreira, também A. Pérez Jiménez (2004a: 127) considera que a justiça é a mais importante das virtudes, dando como exemplo o seguinte texto de Flam. 11.4: $\tilde{\eta} v$

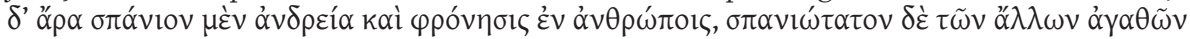
ó Síkalos (Em verdade, a coragem e a saberdoria eram raras entre os homens, mas o bem mais raro de todos era um homem justo). Na continuação deste texto, Plutarco refere os exemplos de Agesilau, Lisandro, Nícias e Alcibíades como excelentes e vitoriosos comandantes, que não souberam, no entanto, usar o seu sucesso para desenvolver acções generosas. F. Frazier (1996: 177 ss.) inclui a dikaiosyne na lista das virtudes mais importantes das Vitae, a par da phronesis, a andreia, a sophrosyne, relacionando-as com a tradição, pois Platão, em Lg. 631c, designa-as como bens superiores.

${ }^{22}$ F. Albini (1997: 59-71) defende, com razão, que a família pode condicionar o carácter dos heróis das Vitae, mas o empenho que cada um coloca na sua formação e a própria experiência 
primeiros ensinamentos que podem condicionar o seu comportamento. Só não afirmamos com mais certeza que a instrução regulará as acções futuras, porque a essa primeira etapa, que podemos designar por propaideia, é necessário que corresponda uma segunda: a adaptação do carácter e das acções do indivíduo à paideia. Por exemplo, na biografia de Filopémen, muito embora inclua na caracterização do protagonista vários elementos sobre a sua formação, Plutarco

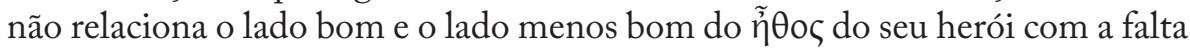
de paideia. O mesmo não acontece, contudo, na vida de Mário, em que existe uma conexão entre o $\tilde{\eta} \theta 0 \varsigma$ (que, neste caso, se caracteriza pela instabilidade emocional e a recusa da paideia.

Podemos juntar, ainda, dois exemplos que clarificam a relação entre a paideia e o $\tilde{\eta} \theta 0:^{: 3}$

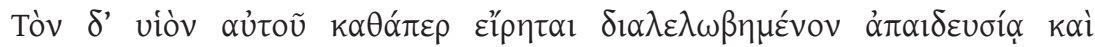

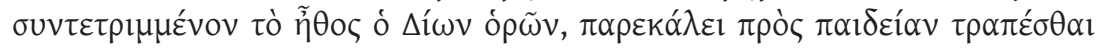

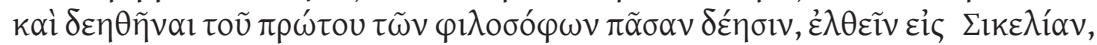

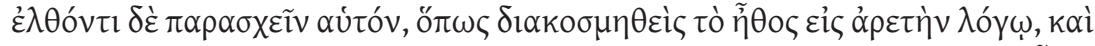

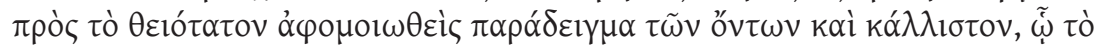

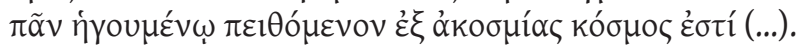

Observando o seu filho, como disse, corrompido pela falta de educação e com os costumes desgastados, Díon exorta-o a voltar-se para a educação e para a absoluta necessidade de o primeiro dos filósofos vir para a Sićlia; quando ele chegou, Dionísio submeteu-se a ele, de modo a ordenar o seu carácter segundo um princípio virtuoso e a imitar o paradigma mais divino e mais belo dos seres, aquele que guia, em tudo, alguém obediente a ter ordem, depois da desordem (...).

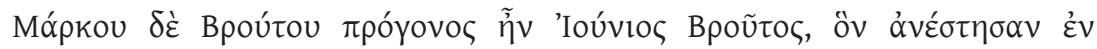

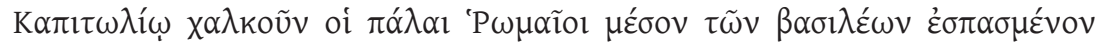

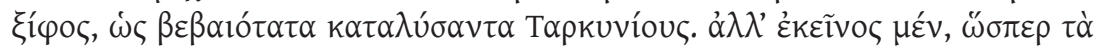

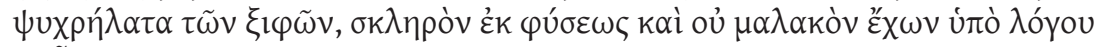

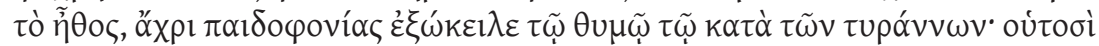

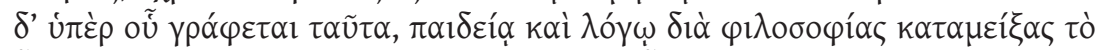

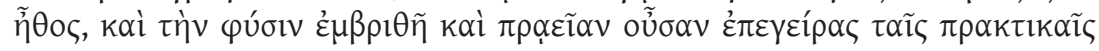

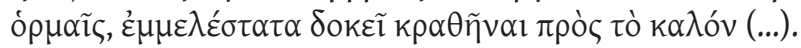

Quanto a Márcio Bruto, ele descendia de Júnio Bruto, a quem os antigos Romanos erigiram uma estátua de bronze no Capitólio, no meio dos reis, com a espada desembainhada, porque ele havia destruído, com muita firmeza, os Tarquínios. Mas ele, por natureza, tinha, como as espadas endurecidas, um carácter rude e não

de vida são decisivos para o ethos.

${ }^{23}$ Dion 10.1-2 e Brut. 1.1-3, respectivamente; cf. Cat. Ma. 20.9. 
brando para o estudo, e, até à morte dos seus filhos, perseguiu a cólera própria dos tiranos. Quanto a este outro Bruto, sobre o qual agora se escreve esta biografia, por misturar no seu carácter o estudo e a razão por meio da filosofia e por lançar no impulso prático a sua natureza grave e doce, conseguia, ao que parece, uma extraordinária harmonia no sentido do bem (...).

Ambos os textos são suficientemente esclarecedores sobre a intervenção decisiva da paideia na correcção do $\tilde{\eta} \theta$ os, capaz de transformar a akosmia em kosmos, ou seja, proporcionar a cada indivíduo o equilíbrio necessário para direccionar a ópuń para o bem, no caso dos heróis de Plutarco muito vocacionada para a politeia e para façanhas guerreiras. Pelo contrário, a $\alpha \dot{\alpha} \alpha \theta i ́ \alpha$ (noutros casos também designada por ớvol $\alpha$ ou $\pi \alpha \rho \alpha \varphi \rho \circ \sigma u ́ v \eta)^{24}$ e a $\alpha \pi \alpha \_\delta \varepsilon v \sigma i ́ \alpha$ apenas fragilizam a $\mathrm{alma}^{25}$, pois fazem com que ela se deixe seduzir pelo erro, pela desmesura, pela glória frívola ou por julgamentos erróneos ${ }^{26}$. Tal como a

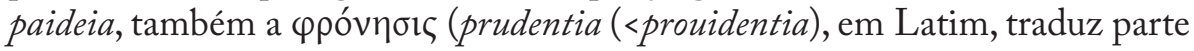
do sentido do vocábulo grego) é, para Plutarco, uma virtude do plano teórico ${ }^{27}$ $\mathrm{e}$, ao mesmo tempo, uma virtude da parte deliberativa da alma ${ }^{28}$, equiparada às

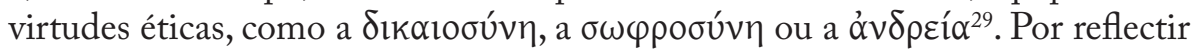
o carácter racional da sabedoria ${ }^{30}$, ela é uma qualidade que contribui para a justa medida ou moderação, ajudando a estabelecer uma proporção equilibrada entre as emoções e a racionalidade, pois, como já Aristóteles afirmava, a phronesis determina o equilíbrio nas paixões e nas acções ${ }^{31}$.

${ }^{24}$ Cf. De aud. 47D.

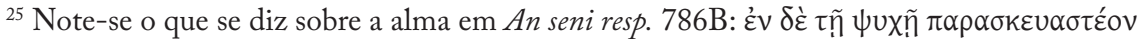

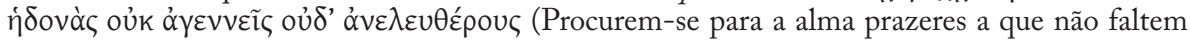
a nobreza e a liberdade); assim sendo, a paideia pode ajudar a encontrar os verdadeiros e bons prazeres, de modo a que se evitem os que são passageiros.

${ }^{26}$ Cf. Superst. $164 \mathrm{E}-\mathrm{F}$; Ad princ. ind. $782 \mathrm{E}-\mathrm{F}$.

${ }^{27}$ Cf. De uirt. mor. 440D. Para as virtudes da parte racional da alma, Aristóteles, em EE e $E N$, por exemplo, usa a designação de "dianoética". Pelo facto de o vocábulo phronesis ter sofrido algumas alterações semânticas, teve a tendência para assumir o significado de virtude ética, em sentido geral. Aristóteles tanto lhe atribui o sentido de conhecimento teórico da verdade como o de inteligência moral e sabedoria prática, ou seja, equivale a uma razão especulativa (cf. Metaph.

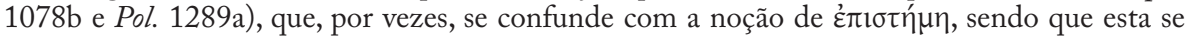
relaciona mais com a imutabilidade e o carácter científico (cf. EN 1143b, 1140b e 1144a). Em $M M$, obra pseudo-aristotélica, a phronesis aparece como virtude racional e virtude ética, com um sentido semelhante àquele que encontraremos em Plutarco. Vide, ainda, F. Becchi (1987: 37-46). Em geral, a sophia entende-se sobretudo como sabedoria teórica e a phronesis como sabedoria prática.

${ }^{28}$ Cf. De uirt. mor. $443 \mathrm{E}$.

${ }^{29}$ Cf. Aem. 2.3, Flam. 11.4, Demetr. 1.4, Dion 1.3 e 47.6, De fort. 97E, Mul. uirt. 243D, De Alex. fort. aut. uirt. 336C, Quaest. conu. 703C, An seni resp. 792D e 797E, De soll. anim. 967D, Brut. anim. F e De comm. not. 1073A.

${ }^{30}$ Cf. De Is. et Os. 351D.

${ }^{31}$ EN 1106b. 
Esta capacidade de dominar os impulsos, que o homem deve ter ou adquirir por meio da formação, constitui uma das ideias transversais do corpus plutarcheum. Aquele que exerce funções públicas ou comanda homens em combates deverá manter o discernimento necessário para, em cada momento, tomar a melhor decisão em prol do colectivo, sem ser obstinado ao ponto de recusar ouvir opiniões contrárias e, eventualmente, melhores. $\mathrm{Na}$ sua arquitectura ética, além dos valores que toma como referência primordial, Plutarco alicerça as suas ideias na evidência da mutabilidade e diversidade das acções humanas, que têm de ser, por um lado, objecto de autoconhecimento e de estudo e, por outro, de correcção. Tem muito presente, tal como Platão e Aristóteles, o binómio prática-teoria, verificando-se nas Vitae um predomínio da componente prática.

Por meio da paideia, o homem tornar-se-á mais equilibrado, mais consciente dos seus limites e menos susceptível ao excesso. Combinando a paideia com o exercício corporal (complementaridade que vem da época arcaica), o indivíduo estará em condições de atingir a tranquilidade (euthymia) e a felicidade

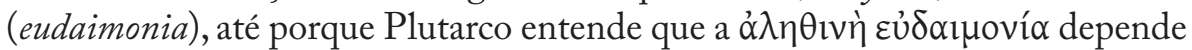
do carácter $(\tilde{\eta} \theta \circ \varsigma)^{32}$ e da disposição do espírito ( $\delta$ ı́́ $\left.\theta \varepsilon \sigma \iota \varsigma\right)$, cabendo a cada indivíduo a responsabilidade pessoal pelos seus actos, indiferentemente do local em que nasceu ${ }^{33}$, embora a biografia de Sertório enfatize as consequências dos condicionalismos externos nas qualidades e na physis e no estilo de vida, facto que desculpabiliza, de alguma forma, o percurso do herói romano e, eventualmente, os erros que possa ter cometido. Como animal social, seguindo a acepção aristotélica, o homem não é indiferente às contingências do seu tempo. Pode, certamente, influenciar com a sua atitude e com as suas acções o seu semelhante, mas a sua personalidade ou identidade também recebe dos outros e da sociedade contributos numerosos e diversos.

Além disso, a paideia representa um esforço ${ }^{34}$ intelectual e de formação do carácter que capacitará o homem a distinguir as kakiai das aretai, devendo preferir estas por conduzirem a uma vida feliz ${ }^{35}$. No tratado De uirtute et uitio ${ }^{36}$, Plutarco refere, claramente, que a eudaimonia não se consegue por meio da riqueza ou do poder, mas que o homem deve encontrar, no seu interior, a alegria,

${ }^{32}$ Cf. Aem. 2 e Cat. Mi. 1 (uma parte do carácter herda-se).

${ }^{33}$ Cf. Dem. 1.

${ }^{34}$ Este esforço é bem ilustrado pela imagem dos dois caminhos em Hes. Erga 289 ss., que

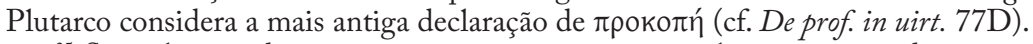

${ }^{35}$ Se a alma se deixa guiar por maus costumes, também necessita de ser recuperada pela paideia (cf. De uit. pud. 530E, De sera num. uind. 551D e De gen. Socr. 584E). O reconhecimento das consequências que a paideia pode ter numa vida feliz e boa é bem patente quando Plutarco nos diz que Alexandre nutria tanto tanto amor por Artistóteles como pelo pai (Alex. 8.4).

${ }^{36} 100 \mathrm{C}$; cf. De fort. 99E. 
cultivando a arete $^{37}$. Por conseguinte, a paideia tem um nível de interiorização e assimilação, e um outro em que pode e deve condicionar, de forma positiva, as decisões. Para Plutarco, a paideia não exige apenas uma predisposição moral ou

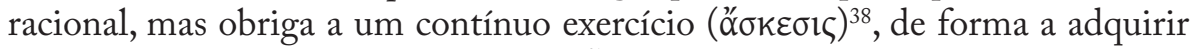
a virtude pelo $\varepsilon ̋ \circ$, até porque o $\tilde{\eta} \theta$ o s é substancialmente determinado

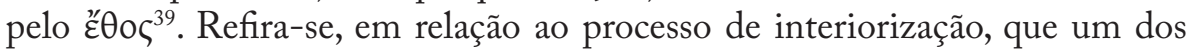
requisitos para a paideia prosperar, por meio do logos, é o indivíduo ouvir com atenção ${ }^{40}$. Foi por isso que a natureza nos dotou de duas orelhas e de uma só língua, como Plutarco refere no tratado De audiendis ${ }^{41}$. Ao aludir à

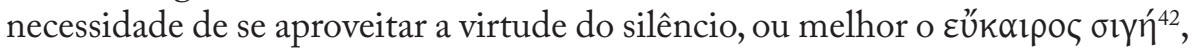
Plutarco recupera o princípio de Platão e também de Aristóteles ${ }^{43}$, que se opõe à $\alpha \delta \circ \lambda \varepsilon \sigma \chi i ́ \alpha$. Por conseguinte, o silêncio pode servir para manter a calma perante o inimigo ${ }^{44}$, para melhor interiorizar os progressos da virtude ${ }^{45}$ ou para ajudar a distinguir o adulador ${ }^{46}$. Juntamos, ainda, dois exemplos: na biografia de Licurgo, louvando a concisão dos Espartanos ao nível da sua expressão oral, atribui essa qualidade à prática do silêncio que se impunha às crianças desde a infância ${ }^{47}$; no tratado Quaestiones conuiuales, Plutarco conta ao seu amigo Sósio Senécio que Simónides, ao ver um estrangeiro em silêncio ( $\sigma \iota \omega \pi n ̣$ ), lhe

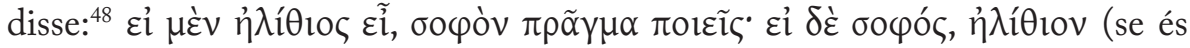
insensato, fazes uma coisa sábia, mas se és sábio, uma insensata). Em verdade,

${ }^{37}$ Ainda neste tratado, que não consta no Catálogo de Lâmprias, Plutarco tece, mais uma vez, um elogio ao estudo da filosofia, por considerar que ele ajudará o homem a enfrentar a riqueza ou a pobreza e a fama ou a falta dela (101D).

${ }^{38}$ Sobre os sentidos de askesis em Plutarco, vide F. Alesse (2005: 51-58), que, partindo da comparação do regime de vida do atleta e do soldado em Phil. 3.3, considera que o Queronense contribui para difundir na sua época a ideia de que a askesis é um valor necessário para a activa politeia e para que o indivíduo consiga enfrentar os obstáculos com tenacidade e coerência interior.

${ }^{39}$ Cf. S. Swain (1989a:62-68).

${ }^{40}$ Para se aprender, é necessário, em primeiro lugar, ouvir e só depois falar (cf. De garr. 506C).

${ }^{41}$ 37C; cf. De garr. 501C. Se, para Teofrasto, o acto de ouvir é o que está mais relacionado

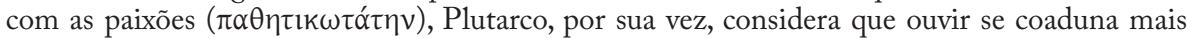

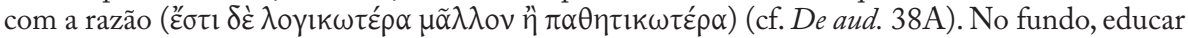
a audição é uma forma de evitar os vícios.

${ }^{42}$ De lib. educ. 10F.

${ }^{43}$ Para Platão, a sophrosyne da alma atinge-se, juntamente com outros recursos, com a prática do silêncio: Resp. 389E e Lg. 696C, 700C, 792A, 876B. Quanto ao Estagirita, inclui o silêncio entre as competência a desenvolver pelo jovem: $R h$. 1389B e EN1142A; vide C. Fuentes (2005: 191-198).

${ }^{44}$ Cf. De cap. ex inim. ut. 90D.

${ }^{45}$ Cf. De prof. in uirt. 81E; sobre a diferente noção que os Estóicos têm da progressão na virtude, vide K. Algra et al. (2005r: esp. 724-736).

${ }^{46}$ Cf. De adul. 58B-C.

${ }^{47}$ Cf. Lyc. 19.1-2; sobre a $\beta \rho \alpha \chi v \lambda o \gamma i ́ \alpha$, vide Ages. 7.2, Caes. 50.4, Phoc. 5.3, Brut. 2.5 e De Pyth. or. 408E, De garr. 510E e 511A-B.

${ }^{48} 644 \mathrm{~F}$. 
o acto de ouvir (ảkpó $\alpha \sigma \iota)^{49}$, que responsabiliza e exige esforço ao receptor ${ }^{50}$, uma vez que necessita de se autoconhecer e de interpretar as palavras do emissor para a comunicação ser absorvida, e a sabedoria do silêncio são duas metodologias que integram o processo educativo de Plutarco, por fazerem parte de um exercício em que se conjugam a atenção, o respeito, a moderação, o discernimento e a razão. Em suma, contribuem para um melhor conhecimento do próprio indivíduo e para a serenidade da $\mathrm{alma}^{51}$, num plano mais filosófico, sem que isso signifique que o político ou outro qualquer indivíduo fiquem privados da sua própria iniciativa, mas ouvir e guardar silêncio fundamentam melhor a aprendizagem e a própria criatividade: ${ }^{52} \mu$ óvol yò $\rho$ ă $\delta \varepsilon \tilde{\imath} \beta o u ́ \lambda \varepsilon \sigma \theta \alpha 1$

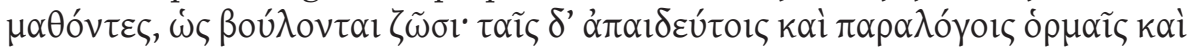

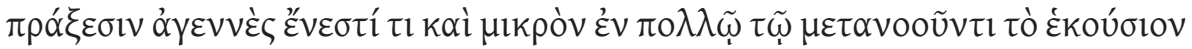
( $\mathrm{Na}$ verdade, apenas os que aprenderam a desejar o que é necessário podem viver como desejam. Nos impulsos e actos isentos de educação e irracionais existe algo ignóbil e, na maior parte das manifestações de arrependimento, o voluntarismo é exíguo).

Ainda em relação à arete, ela implica um processo contínuo de aprendizagem, a זроколи́, que, para Plutarco e ao contrário do que é preconizado pelos Estóicos ${ }^{53}$, traduz um fenómeno consciente e racional ${ }^{54}$,

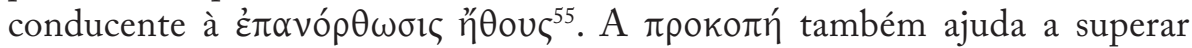

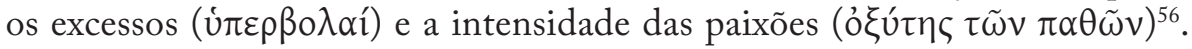
Aliado a isto, a paideia, na sua vertente filosófica, surge como um fármaco capaz de suster os pathe e o excesso ( $\tau$ ò ă $\gamma \alpha v$ ), preservando a razão e o

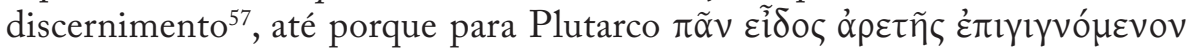

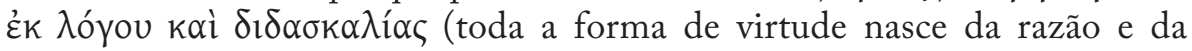
aprendizagem $)^{58}$. Isto significa que a conexão entre paideia, logos e arete

${ }^{49}$ Note-se que Plutarco usa por vezes o verbo ơkoúw para traduzir a relação entre mestre e discípulo (cf. e.g. Cic. 3.1); é, no tratado De aud., que se encontram os principais preceitos relacionados com o processo de audição.

${ }^{50}$ Cf. De aud. 40A-B.

${ }^{51}$ Cf. De tranq. an. $470 \mathrm{~B}$.

${ }^{52}$ De aud. 37E.

${ }^{53}$ No tratado De prof. in uirt., Plutarco critica a concepção estóica de $\pi \rho \circ$ копń, devido ao facto de os Estóicos acreditarem que só um homem sábio poderia ser virtuoso e por não considerarem os vários graus de um defeito ou de uma virtude. Plutarco, pelo contrário, acredita, por exemplo, que a injustiça pode variar de indivíduo para indivíduo. Além disso, recusa, como os Estóicos faziam, adaptar os actos às doutrinas, violentando-se a natureza; cf. D. Babut (t2003: 59-62).

\footnotetext{
${ }^{54}$ Cf. Demetr. 1.4.

${ }_{55}$ Aem. 1.3, Oth. 46.4, 73.5, 79.3; De aud. 46D.

${ }^{56}$ Cf. De prof. uirt. 84A.

${ }^{57}$ Cf. Cor. 15.4 (paideia e logos).

${ }^{58}$ Cf. De aud. poet. $32 \mathrm{E}$.
} 
surge como o alicerce fundamental para a vida de qualquer indivíduo. Ainda assim, o próprio Plutarco estabelecia a diferença entre as virtudes da physis de um indivíduo, geralmente apresentadas, de forma sumária, nos primeiros capítulos da narrativa biográfica, e aquelas que se desenvolvem por meio do contacto com os mestres, com a sociedade ou por influência de algum acontecimento particular ${ }^{59}$.

Não havendo homens perfeitos, é também possível que não exista uma paideia perfeita, nem tão-pouco uma arete pura, como explica o Queronense no tratado De animae procreatione in Timaeo ${ }^{60}$. Alcibíades e Coriolano ou Demétrio e António são exemplos de que nem sempre a paideia se consegue sobrepor às ambições, aos desejos ou a qualquer outro tipo de vontade. De igual forma, Teseu, Péricles, Filopémen, Flaminino, Alexandre, César, Bruto ou Catão de Útica também não são heróis isentos de vícios. Parece-nos que Plutarco, ao apresentar estas figuras com valores tão ambíguos, traça uma estratégia retórica que visa sobretudo valorizar a paideia e o efeito social de uma sólida e modelar conduta moral.

Ficamos com a certeza de que a ausência da paideia e dos valores que ela gera afastará certamente ainda mais o homem de uma conduta de vida exemplar, pois é mediante a paideia que este pode corrigir os excessos do

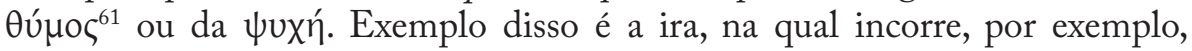

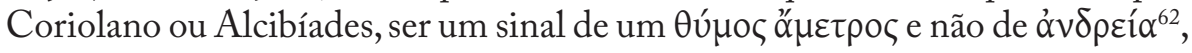
como Plutarco explica no tratado De cohibenda ira ${ }^{63}$. Por causa das exigências

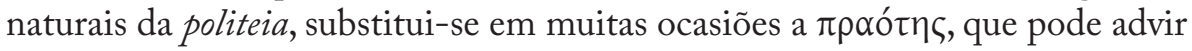
da educação filosófica ${ }^{64}$, pela ó $\rho \eta^{65}$, e Plutarco sublinha a necessidade de se

${ }^{59}$ Cf. Comp. Dion-Brut. 2.1 e 4.1, Comp. Pel.-Marc. 1.6; Comp. Lyc.-Num. 2.2, Comp. Lys.Sull. 1.4-6.

60 1025D. Na análise da arete, Plutarco propõe uma solução de compromisso entre a perspectiva estóica de que as paixões são uma manifestação da parte racional e a concepção peripatética que considera que as aretai são do domínio do pathos; sobre este tratado, vide C. Froidefond (1987: 184-233) e J. Hershbell (1987: 234-247).

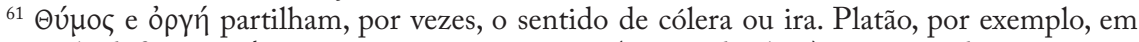

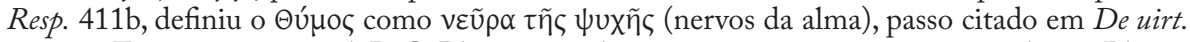
mor. 449F; em De coh. ira 457B-C, Plutarco também cita esse passo, mas sem o atribuir a Platão, preferindo realçar o papel da psyche na origem da cólera; vide C. Froidefond (1987: 184-233) e F. Becchi (2005b: 385).

${ }^{62}$ Cf. De coh. ira 463B.

63 Além deste tratado omitido pelo Catálogo de Lâmprias, chegou-nos em estado

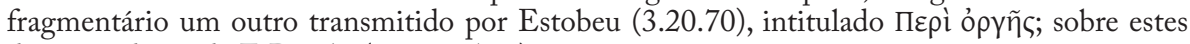
dois tratados, vide F. Becchi (2003: 95 ss.).

${ }^{64}$ Recorde-se que a diferença entre Epaminondas e Pelópidas é um sinal da influência no ethos.

${ }^{65}$ Cf. De coh. ira 457D, 458C, 459B-D, 460E-F. 
controlar a cólera ${ }^{66}$, que se acumula na alma ${ }^{67}$. É de salientar que, um pouco à semelhança dos Estóicos, Plutarco partilha da ideia de que alguns indivíduos seguem mais a natureza e outros o hábito, uns a parte racional e outros a parte irracional ${ }^{68}$, não advogando - indo assim contra os preceitos estóicos, que pretendiam banir todos os elementos da parte irracional, por constituírem um erro - que se deva eliminar a parte mais irracional, mas que ela merece ser

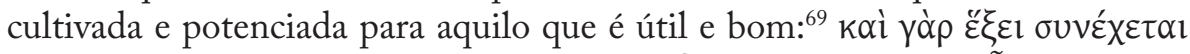

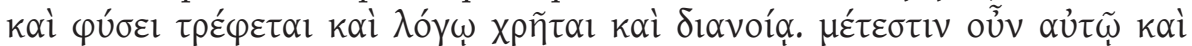

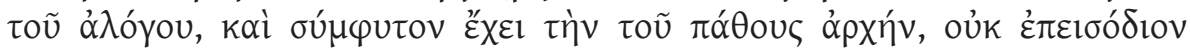

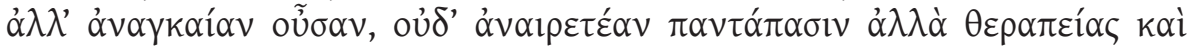

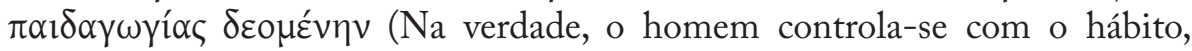
alimenta-se com a natureza e serve-se da razão e da inteligência. Também está presente nele o irracional e possui, de forma inata, o princípio da paixão, que não é acessório mas necessário, nem deve ser completamente suprimido, mas precisa de cuidado e educação). Para Plutarco, a parte irracional da alma está mais próxima da concepção aristotélica do que da platónica, pois defende a sua unidade, ao contrário do filósofo do Liceu que distingue nela o $\theta u ́ \mu о \varsigma$

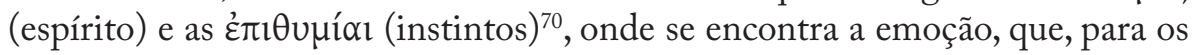
Estóicos, é um erro ${ }^{71}$. A irracionalidade tem de ser, segundo Plutarco, usada e modelada da melhor forma possível, sendo a paideia um apoio vital para esse controlo e para, lato sensu, a aquisição das virtudes éticas. Por aqui se entende que a philotimia de Flaminino, a philonikia de Filopémen ou o amor de Marcelo pela guerra (philopolemos) só são defeitos quando a parte irracional não está devidamente formada para manter esses traços do carácter dentro dos limites da moderação, querendo isso dizer que a acção e os efeitos da paideia incidem maioritariamente nos aspectos mais defeituosos que a parte irracional desenvolveu. Na concepção ética dos Moralia e das Vitae prevalece o princípio da metriopatheia, ou seja, o domínio e o equilíbrio das paixões mediante o logos e a paideia ${ }^{72}$.

${ }^{66}$ Cf. e.g. De aud. poet. $31 \mathrm{~A}$.

${ }^{67}$ Sobre a ideia da alma como o depósito da cólera, vide De coh. ira 461A.

${ }^{68} \mathrm{O}$ dualismo da alma tem paralelo na psicologia do indivíduo, na sua identidade e alteridade (cf. De uirt. mor. 441E-442A), distinguindo Plutarco a mente da alma (cf. De fac. lun. 943A).

${ }^{69}$ De uirt. mor. $451 \mathrm{C}$.

${ }^{70}$ Cf. ibid. 442B.

${ }^{71}$ Cf. ibid. 449D-E.

${ }^{72}$ Cf. De aud. 38D, De prof. uirt. 83B e 84A, De uirt. mor. 442C-445A, 451F-452B, De coh. ira 453A e 458C, De sera num. uind. 551A, De fac. lun. 943D. Se para H. Krämer (1959: 1534, 160-6, 279-302), este princípio tem uma origem platónica, já P. Donini (1974), F. Becchi (1975) (1978) (1981) ou J. Dillon (1977) e (1983) apontam para uma origem aristotélica que os Platónicos da época de Plutarco aceitaram. Num trabalho recente, F. Becchi (2005b: 395) define da seguinte forma a metriopatheia plutarquiana: "Anche per P. la metriopatheia non è

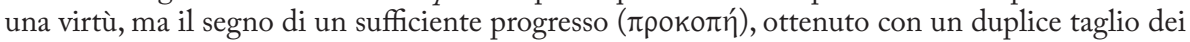


Plutarco revela, assim, que acredita no efeito positivo que a paideia pode exercer em cada ser humano e, quando nos apresenta os defeitos dos seus heróis, está certamente a veicular a ideia de que eles ou a própria sociedade em que se inserem não quiseram ou não puderam entregar-se de forma consciente e continuada à formação, tanto literária e retórica, como literária e moral, de forma a cultivar os valores que permitem alcançar o bem pessoal e, sobretudo, o colectivo, até porque é sempre muito difícil dissociar nas Vitae o herói da sua pátria ou da sua polis. Nesse sentido, a paideia tem benefícios pessoais que quase obrigatoriamente se estenderão ao colectivo, aplicando-se semelhante raciocínio às acções ou aos vícios. Aquele herói que, como fez Aristides ao esquecer o ostracismo e a continuar a lutar pelos Gregos contra os Persas, souber harmonizar as suas convicções pessoais com os objectivos do colectivo, merece de Plutarco os maiores elogios.

Tal como, na actividade pública, é difícil conjugar a utilidade com a justiça ${ }^{73}$, muitas vezes também é muito exigente para o homem harmonizar os valores que incorporam a paideia com as contingências da vida ou com os seus desejos ou pathe $e^{74}$. Quando assim acontece, a paideia teórica ou espiritual diverge da paideia prática, e é precisamente nesta conciliação que assinalamos a dificuldade de uma vivência global da paideia. Na verdade, a paideia exige esforço (spoude) e uma entrega total do ser humano, para que, com o uso da razão e da inteligência (synesis, nous), consiga, inicialmente, apreender a paideia dos paidagogoi e dos didaskaloi, para de seguida, num processo contínuo de auto-paideia, assimile e consubstancie os valores que lhe são inerentes. Para Plutarco, paideia, logos, spoude integram, conforme os princípios aristotélicos, o processo formativo que deve tornar o homem capaz de integrar a vida pública e de distinguir-se nas suas actividades. Em relação a este processo, no tratado De sollertia animalium considera-se que o logos não pode prescindir da

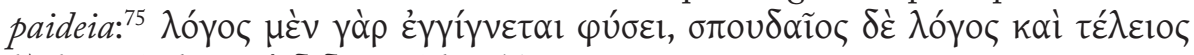

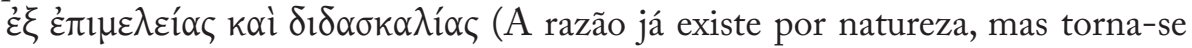
diligente e completa a partir da solicitude e da instrução).

$\mathrm{Na}$ verdade, Plutarco, ao assumir como objectivo moldar o carácter dos

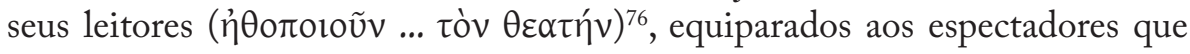
assistem ao teatro, atribui à paideia um papel singular na formação moral e na

$\pi \lambda \varepsilon \varepsilon_{\alpha} \sigma \mu o i ́$, né necessari né naturali, delle passioni, dovuti ad un giudizio falso e irragionevole che è dentro di noi"; vide, ainda, J. Opsomer (2001: 187-200).

${ }^{73}$ Arist. ou Phoc. 32.6-7.

${ }^{74} \mathrm{Em}$ Ad Demonicum 52, Isócrates considera ser necessário aspirar a uma paideia plena de conhecimento, para se conseguir o que é mais útil ( $\tau \dot{\alpha} \chi \rho \eta ́ \sigma l \mu \alpha)$, tal como a abelha procurar tirar o que há de melhor nas flores.

75 962C ; cf. C. Pelling (2002o: 339)

${ }^{76}$ Per. 2.4. 
prática das acções. Da mesma forma que caracteriza as technai no prólogo de Demetrius-Antonius ${ }^{77}$, também a paideia dota o homem da capacidade de agir e de decidir com razão, não deixando que o prazer ou a paixão se sobreponham ${ }^{78}$.

Mesmo aqueles que, por natureza, se inclinam mais para o vício e para as coisas perniciosas, podem, por meio da paideia e da katartysis ${ }^{79}$, corrigir os seus defeitos, pois acredita-se no papel que a educação pode desempenhar na aquisição de valores e no desempenho prático do indivíduo. Assim, a paideia pode exercer um papel importante na physis, uma vez que, para Plutarco, se devem distinguir as acções que seguem a physis das que são tomadas ao arrepio desta ${ }^{80}$. Um exemplo evidente desses dois tipos de decisão ou acção ocorre quando os tribunos pretendem obrigar Coriolano a justificar uma série de actos faltosos, como ter instigado o Senado a abolir o poder do povo ou

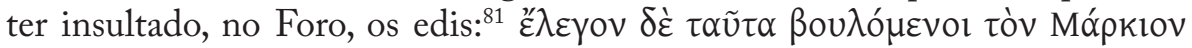

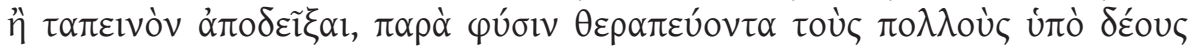

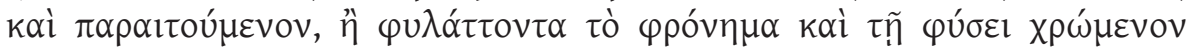

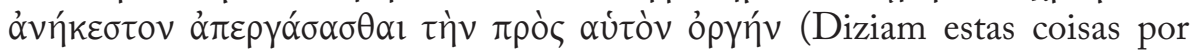
quererem humilhar em público Márcio, para que fosse, contra a sua natureza, solícito com o povo e, por medo, lhe suplicasse, ou mantendo o seu espírito e, seguindo a sua natureza, fizesse uso do seu lado funesto, de forma a desencadear, contra si, a ira do povo).

Plutarco outorga um valor especial à paideia, por acreditar que ela pode corrigir erros, evitar excessos, dignificar o indivíduo e dotar a natureza das qualidades indispensáveis para superar a adversidade. É o que sustenta no pequeno opúsculo $A n$ uirtus doceri possit ${ }^{82}$ : que a arete, sendo uma arte, pode ser

${ }^{77}$ Cf. 1.3-4.

${ }^{78}$ Recorde-se que hoje a palavra técnica está sobretudo associada a uma vontade de dominar os diversos fenómenos, mas, na Antiguidade, techne significava "habilidade" ou "perícia", denotando o seu sentido uma disposição para o saber ou para a cultura.

${ }^{79}$ Cf. Them. 2.7.

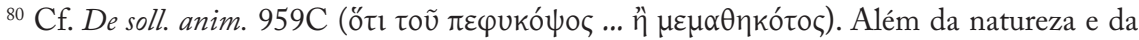
aprendizagem, o carácter humano pode ser condicionado pelos desafios que encontra. $\mathrm{O}$ homem não é, por natureza, mau, mas a crueldade da vida pode obrigá-lo a ser. Como também Sertório que se viu obrigado a tornar-se um guerreiro e um comandante de homens, mesmo indo contra

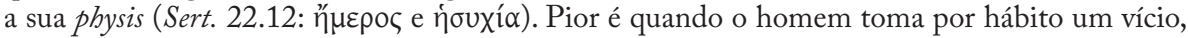
como a inimizade, e, depois, mesmo quando vive numa situação diferente, em que prevalece a paz, não se consegue libertar dele (cf. De cap. ex inim. ut. 91B ss.). Recorde que Demócrito, no frg. 33D, desenvolve a ideia da transformação operada pelo ensino ( $\delta 1 \delta \alpha \chi \eta ́)$ no homem e como isso se repercute na natureza (vide J. Ribeiro Ferreira (1977-78: 39)).

${ }^{81}$ Cor. 18.2 .

${ }^{82}$ A. Barigazzi (1987: 47-71) colocou a hipótese de os tratados fragmentários De fort., An uirtus doceri possit, Animine an corporis affectiones sint peiores, An uitiositas ad infelicitatem sufficiat e De uirtute et uitio fazerem parte de um só tratado com o título De uirtute an docenda sit, daí juntar estes tratados numa mesma edição (cf. A. Barigazzi (1993)). Esta tese não é seguida por E. Melandri (2003: 111 ss.). 
ensinada, sem negar, por completo, que cada indivíduo possui, por natureza, características que o levam a ter uma inclinação para determinadas qualidades ou acções.

Atendendo à forma como Plutarco aborda cada um dos heróis e como estabelece a relação entre as aretai ou as kakiai e as praxeis, a paideia tem um sentido compósito, ou seja, agrega valores e comportamentos concretizados nos combates, na politeia ou nos contactos interpessoais. Por exemplo, a sophrosyne $e^{83}$ ou a philanthropia, conceitos transversais na cultura grega, fazem parte da paideia e confundem-se com ela. Se a paideia se sobrepõe às fronteiras como traço distintivo do homem, também a philanthropia surge como uma qualidade que exerce grande influência nas atitudes sociais e no desempenho da actividade política. Como H. Martin Jr. (1961: 164-175) prova, apoiando-se na atitude filantrópica de Prometeu, este conceito desde a sua origem está conotado com a difusão civilizacional entre os Helenos. Por philanthropia, Plutarco traduz não só uma atitude que tem implícito um sentido de humanidade, mas também actividades tão simples como o banho ou o tratamento do $\operatorname{corpo}^{84}$, sinais civilizacionais, ou uma qualidade muito importante para o político ganhar a confiança dos seus súbditos ou para enfrentar tempos de crise, como aqueles que a Grécia vivia.

O próprio interesse de Plutarco pela leitura faz parte das características de um pepaideumenos, ou seja, aquele que é um intelectual ou político ${ }^{85}$, conhecedor de literatura e com formação ${ }^{86}$, por oposição ao idiotes ${ }^{87}$ ou aos agroikoi ("rústicos") $)^{88}$, e que, nos séculos I e II, pertence à elite cultural do

${ }^{83} \mathrm{Em}$ Demetr. 1.4, diz-se que a sophrosyne, a dikaiosyne e a phronesis são $\tau \varepsilon \lambda \varepsilon \omega ́ \tau \tau \alpha \tau \alpha$ de todas

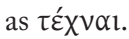

${ }^{84}$ Cf. Lyc. 16.12.

${ }^{85}$ Cf. Quaest. conu. 715B, 723A, 736D.

${ }^{86}$ Cf. De gar. 514C, Non posse suau. 1095A-B e 1096A-C, Adu. Col. 1107E; alguns desses pepaideumenoi fazem da literatura a sua actividade profissional (cf. Quaest. conu. 618F e 622A), como, por exemplo, Aufídio Modesto, que escreveu comentários sobre Vergílio (cf. Quaest. conu. 618F e 632A), ou Téon que terá escrito um sobre Álcman (cf. De fac. lun. 940A).

${ }^{87}$ Vide Luc. Dom. 2.6.

${ }^{88}$ Cf. S. Swain (1998r: 113-114). Sobre a construção da imagem (irónica) do rústico, num contexto sofisticado, dão-se os exemplos das obras de C. Eliano e de Longo, respectivamente, Epistulae rusticae e Daphnis et Chloe. O texto de Longo, escrito em Grego ático elegante, representa a rusticidade num ambiente com várias alusões a Teócrito e a Safo; T. Whitmarsh (2001: 101) sintetiza a construção do texto de Longo: "In reliving the erotic paideia of the rusticus, the readership also undertakes a paradigmatic cultural journey from the origins of civilization to the hyper-intellectual climate of contemporary Greece."; vide ainda Díon de Prusa, Or. Eub. e Philostr. VS 487; recorde-se que Plutarco conta que, no momento da votação do ostracismo de Aristides, um dos agrammatoi e agroikoi the pediu, sem o conhecer, para escrever o nome de Aristides no ostrakon, sinal de que havia cidadãos em Atenas que não sabiam escrever (Arist. 7.7-8). 
Império, que acabaria por ficar conhecida como Segunda Sofística ${ }^{89}$. O "rústico" está associado aos antigos valores, conservadores e mais ligados ao trabalho da terra, enquanto o pepaideumenos é exemplo do homem culto que optou pela paideia acessível ao cidadão imperial, pertencente, no entanto, a uma elite. A diferenciação social entre os educados e os não-educados é sublinhada nos textos pelo uso da linguagem, que, sem dúvida, define uma identidade social ${ }^{90}$.

Para Plutarco, a acção educativa ou a transmissão da essência da paideia não se deve ficar pela teoria ou pelos livros, mas consubstanciar-se nos actos. É isso mesmo que desenvolve no tratado An seni respublica gerenda sit ${ }^{91}$, quando defende que os jovens não têm maturidade e capacidade para governar, pois aquilo que aprenderam mediante a leitura de um livro ou na escola é insuficiente. Fazendo uso da sua experiência, caberá aos gerontes educar os jovens, tanto pelas palavras como pelos actos. Este é, assim, o binómio em que assenta a paideia: palavra e acção $\mathrm{o}^{92}$.

Muito embora seja evidente o peso da paideia na obra de Plutarco ${ }^{93}$, são poucas as informações concretas sobre a educação dos heróis e sobre os paidagogoi ou didaskaloi, pois, em vários pares, não aborda a questão da formação ou, então, faz referências muito genéricas ${ }^{94}$. Sintetizemos, de seguida,

${ }^{89}$ Sobre Plutarco e o seu círculo social, vide C. Jones (1971: 48-60) e B. Puech (1992).

${ }^{90} \mathrm{~T}$. Whitmarsh (2005: 41-41) lembra que, apesar do processo da koine desde o período helenístico, a questão da linguagem na época imperial não deixa de ser complexa: "The full picture of dialectal usage under the empire is, as one would expect, more complex than this implies. Some imperial texts (e.g. the Gospels, or Epictetus' philosophy (...) are composed in a dialect that can be squarely identified as koine; others show all the signs of a coherent and consistent attempt to Atticize (e.g. the works of Lucian and Philostratus); still others, e.g. by Dio Chrysostom, Plutarch, and Galen (...), however, represent something else again, more linguistically ambitious than regular koine but without the ostentatious archaism of 'full' Atticism. Language use in the second century was a capacious and complex field".

${ }^{91} \mathrm{Cf} .790 \mathrm{E}-\mathrm{F}$.

${ }^{92}$ Em An seni Resp. 792B, diz-se que Luculo "conservava a inteligência graças à acção", porém, quando se entregou à ociosidade, "tornou-se um cadáver enfraquecido como as esponjas no mar tranquilo."

${ }^{93}$ De aud. poet. e De aud. são claramente tratados pedagógicos. Também se podem considerar tratados educacionais De prof. in uirt., Max. cum princ. phil. esse dis. e Ad princ. ind. (cf. S. Swain (1990b: 128, n. 23)). Por fim, incluem-se neste grupo os tratados De lib. educ. e De mus., embora se considerem espúrios.

${ }^{94}$ Deixando de parte biografias do corpus por merecerem um tratamento mais pormenorizado, pode-se agrupar as vidas pelos seguintes grupos: sem qualquer referência (Lyc., Pub., Cam., Fab., Tim., Aem., Phirr., Sull., Nic., Pom., Demetr., Art., Galb., Oth.); vidas com elementos muito escassos (Numa (Num. 1.3-4), Sólon (Sol. 2. 1-2), Lisandro (Lys. 2) e os Gracos (Gracch. 1.67)); informações um pouco mais desenvolvidas nas vidas de Temístocles (Them. 3), Crasso (Cras. 3.3), Agesilau (Ages. 1), Fócion (Phoc. 4.2), Ágis (Ag. 4), Cleómenes (Ag./Cleom. 2), Bruto (Brut. 1-2) e António (Ant. 2); por sua vez, nas vidas de Mário (Mar. 1), Luculo (Luc. 1), Díon (Dion 4) e Arato (Arat. 3.1-3) faz-se referência, com algum pormenor, à educação dessas personagens; elementos mais pormenorizados podem ser encontrados nas vidas de Péricles (Per. 4-6) e Catão de Útica (Cat. Mi. 1). 
os elementos que podemos colher das biografias analisadas:

a) Thes.-Rom.: além de sabermos que Cónidas ${ }^{95}$ terá sido paidagogos do herói Teseu, mais nada é referido; quanto a Rómulo, é dito que foi enviado, juntamente com seu irmão, a Gábios ${ }^{96}$ para aprender letras e tudo o que era digno de uma boa linhagem;

b) Arist.-Cat. Ma.: se, sobre Aristides, nada é referido, já em relação a Catão Censor temos algumas informações; o Romano terá recebido lições do pitagórico $\mathrm{Nearco}^{97}$ e, em idade avançada, aprendeu com os livros de Tucídides e Demóstenes princípios de retórica, ao mesmo tempo que se interessou pela paideia bellenike ${ }^{98}$

c) Cor.-Alc: em virtude da morte do pai, a mãe de Coriolano assumiu a sua educação99; além disso, Coriolano, segundo Plutarco, é o exemplo de que, se a physis, ainda que seja de boa estirpe, não se submete à paideia, dá origem a maus e bons frutos ${ }^{100}$; quanto a Alcibíades, sabemos que Zópiro foi seu paidagogos ${ }^{101}$ e que manteve com Sócrates uma relação muito próxima ${ }^{102}$;

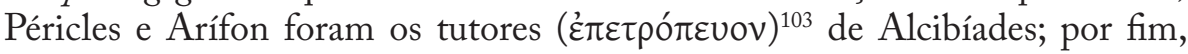
faz-se uma vaga referência a didaskalo $i^{104}$ e a um $\gamma \rho \alpha \mu \mu \alpha \tau o \delta 1 \delta \alpha \sigma \kappa \alpha \lambda \varepsilon \tilde{I}_{0} v^{105}$, cujo nome não é referido;

d) Dem.-Cic.: o orador grego teve como v́ $\varphi \eta \gamma \eta \tau \tilde{n} \varsigma$ Iseu ${ }^{106}$ e Cálias de Siracusa ${ }^{107}$; a biografia refere ainda que a formação de Demóstenes foi prejudicada pela falta de dinheiro para pagar aos didaskaloi, por causa da má gestão dos epitrofoi $i^{108}$; conta-se que frequentou a Academia e que teve "alguns outros [paidagogoi]" no estudo da retórica de Isócrates e Alcídamas ${ }^{109}$; o bios de Cícero oferece-nos pormenorizadas informações sobre a educação: era de tal maneira talentoso, que os pais dos seus colegas iam à escola testemunhar a sua

\footnotetext{
${ }^{95}$ Cf. Thes. 4.1.
}

${ }^{96} \mathrm{Cf}$. Rom. 6.2: cidade próxima do Palatino e um ponto de difusão da cultura helénica; Dion.

Hal. 1.84.5 fornece mais elementos sobre a educação de Rómulo e Remo em Gábios.

${ }^{97}$ Cf. Cat. Ma. 2.3.

${ }^{98} \mathrm{Cf}$. ibid. 2.5.

${ }^{99}$ Cf. Cor. 1.2; tal como Sert. 2.1; Gracch. 1.5-7.

100 ibidem; esta ideia já aparece em Platão, quando trata dos efeitos da má educação (cf. Rep. VI.491); também na vida de Címon o autor faz questão de expressar a falta de educação (Cim. 4.5); no prefácio de Demetr. surge a ideia de que a boa physis origina o vício e a virtude.

${ }^{101}$ Cf. Alc. 1.2 .

${ }^{102}$ Cf. esp. Alc. $1.2 ; 4-7$.

${ }^{103}$ Cf. Alc. 1.1

${ }^{104}$ Cf. ibid. 2.4 .

${ }^{105}$ Mestre das primeiras letras (Cf. Alc. 7.1; outras referências a este vocábulo em Quaest. Rom. 278E e Quaest. conu. 712A).

${ }^{106}$ Cf. Dem. 5.6.; Vit. X or. uit. 844B.

${ }^{107}$ Cf. ibid. 5.7.

${ }^{108}$ Cf. Dem. 4.3.

${ }^{109}$ Cf. Dem. 5.7. 


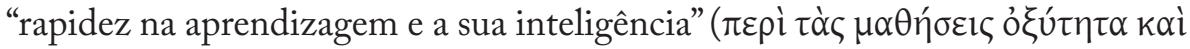

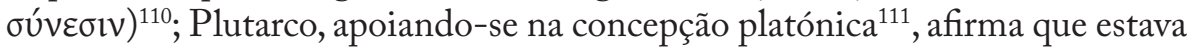
na sua physis o desejo por aprender ( $\varphi \imath \lambda \circ \mu \alpha \theta n ́ \varsigma)$ e a aptidão para a philosophia, não desdenhando nenhuma área da paideia ${ }^{112}$; teve como mestre Fílon, filósofo da Academia, após a formação inicial ${ }^{113}$, ao mesmo tempo que frequentava a casa do senador Q. Múcio Cévola, o áugure, ${ }^{114}$ onde aprofundou os seus conhecimentos sobre nomoi ${ }^{115}$; enquanto na República se travava a stasis ${ }^{116}$, Cícero entregou-se à meditação e ao estudo junto de philologoi hellenikoi; em Atenas, foi discípulo do académico Antíoco de Ascalão ${ }^{117}$, amigo de Luculo ${ }^{118}$; recebeu lições de retórica, na Ásia, de Xénocles de Adramiteu, Dionísio da Magnésia e Menipo de Cária e, em Rodes, do retor Apolónio ${ }^{119}$ e de Posidónio, um filósofo estóico de Apameia ${ }^{120}$; no regresso a Roma, o comediante Róscio e o actor trágico Esopo ajudaram-no a corrigir os defeitos gestuais e de pronúncia ${ }^{121}$;

e) Sert.-Eum.: sobre a educação de Q. Sertório, que era órfão de pai, apenas se diz que foi a mãe que assumiu o papel de educadora' ${ }^{122}$; de Eumenes de Cardia, o único Grego entre os sucessores de Alexandre, só se diz que

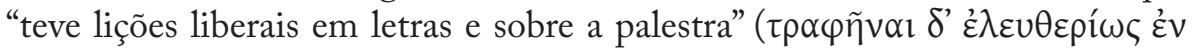

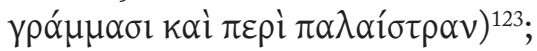

f) Phil.-Flam.: após a morte de Cráugis, pai de Filopémen, Cleandro de Mantineia, como forma de agradecer a hospitalidade dele, encarregou-se de formar o carácter $(\tilde{\eta} \theta 0 \varsigma)$ de Filopémen de forma nobre ( $ү \varepsilon v \vee \alpha \tilde{\imath} \alpha)$ e real $\left(\beta \alpha \sigma \imath \lambda_{\imath k n ́ v}\right)^{124}$; depois, Ecdelo e Demófanes ${ }^{125}$, discípulos de Arcesilau na

${ }^{110}$ Cic. 2.2.

${ }^{111}$ Cf. Resp. $475 \mathrm{~B}$.

${ }^{112}$ Ao contrário de Demóstenes que privilegiou a oratória (Cf. Dem. 4.4, 5.5; Comp. Dem.Cic. 1.1).

${ }^{113}$ Cf. Cic. 3.1.

${ }^{114}$ Apesar de não o referir, após a morte de Cévola, Cícero recebeu também ensinamentos de jurisprudência de Q. Múcio Cévola, pontifex maximus (De leg. 2.47 e 49; Lael. 1).

115 Cf. Cic. 3.2.

116 Sobre os dois tipos de staseis (conflito entre classes sociais e outra que diz respeito às diferenças que existem dentro de uma mesma classe social), vide A. Bravo Garcia (1973: 175 ss.).

${ }_{117}$ Cf. Cic. 4. 1-2.; Cícero refere-o várias vezes na sua obra: De fin. 5.1; Acad. 1.13, 2.98, 2.113; De nat. deor. 1.6; Tusc. 5.22-3; Ad Att. 13.19.

${ }^{118}$ Cf. Luc. 42.3.

119 Por não saber Latim, pediu a Cícero para falar em Grego.

${ }^{120}$ Cf. Cic. 4.5 .

${ }^{121}$ Cf. Cic. 5.4-5.

122 Sert. 2.1.

${ }^{123}$ Eum. 1.1.

${ }^{124}$ Phil. 1.1-2.

${ }^{125}$ Cf. Pol. 10.22.2; Paus. 8.49.2. 
Academia, tiveram a missão de lhe ensinar filosofia, orientando-o para a politeia e a praxis, uma vez que queriam, por meio da filosofia, tornar Filopémen "um

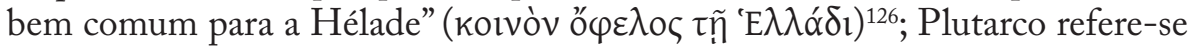
a outros didaskaloi e paidagogoi, mas sem mencionar os respectivos nomes ${ }^{127}$; na biografia de Flaminino, além de sabermos que recebeu educação na arte militar

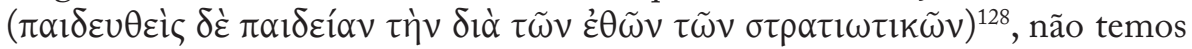
nenhuma informação;

g) Pel.-Marc.: sobre a educação do tebano Pelópidas, Plutarco fornece poucos elementos, pois apenas sabemos que ocupava as horas livres na palestra

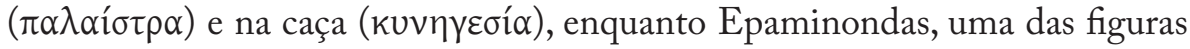
mais mencionadas e elogiadas pelo autor, ouvia as lições dos mestres e estudava filosofia; ${ }^{129}$ também nada se diz de concreto sobre a educação de Marcelo, a não ser que cultivava um gosto especial pela cultura e pelas letras helénicas

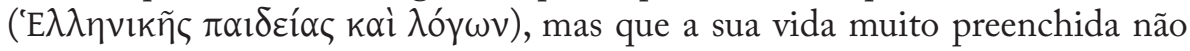
deixou que se dedicasse, como desejava, ao estudo ${ }^{130}$;

h) Alex.-Caes.: a biografia do Macedónio dá, como seria de esperar, maior ênfase ao seu mais conhecido mestre, Aristóteles ${ }^{131}$, que foi chamado por Filipe, pois desconfiava da educação que até então o seu filho estava a seguir ${ }^{132}$; antes, porém, realçam-se, de entre os muitos educadores, pedagogos

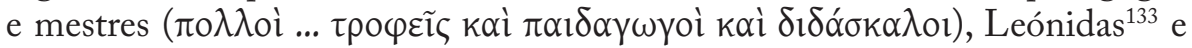
Lisímaco ${ }^{134}$; conhecemos ainda o seu gosto pela medicina, interesse incutido, segundo Plutarco, por Aristóteles; além disso, a leitura da Ilíada, dos livros de Filisto, das tragédias de Eurípides, Sófocles e Ésquilo (referidos por esta ordem) e dos ditirambos de Telestes e Filoxeno muito deve ter contribuído para a sua formação ${ }^{135}$; por fim, saliente-se a forma como protegeu e prezou Anaxarco, Xenócrates, Dândamis e Calano, numa fase em que a sua relação com Aristóteles já não era tão próxima, mas em que o seu amor pela filosofia permanecia intacto ${ }^{136}$; na biografia de César, faz-se referência às lições de retórica que recebeu de Apolónio, de quem também Cícero fora discípulo ${ }^{137}$.

\footnotetext{
${ }^{126}$ Phil. 1.5 .

${ }^{127}$ Cf. ibid. 4.1.

${ }^{128}$ Cf. Flam. 1.4.

${ }^{129}$ Cf. Pel. 4.1

${ }^{130}$ Cf. Marc. 1.3.

${ }^{131}$ Cf. Alex. 7-8

${ }^{132}$ Cf. ibid. 7.1-2.

${ }^{133}$ Cf. ibid. 5.7, 22.9, 25.3.

${ }^{134}$ Cf. ibid. 5.8, 24.10.

135 Cf. ibid. 8.1-3.

${ }^{136}$ Cf. ibid. 8.4-5.

${ }^{137}$ Cf. Caes. 3.
} 
Esta síntese permite-nos discutir diversos aspectos curiosos sobre a paideia nas Vitae. Desde logo, a comunicação, fundamental no processo educativo, entre educador e educando produz-se em diferentes níveis ${ }^{138}$ e, em geral, desde tenra idade, pois é nesse período que a mente está mais predisposta para a instrução: ${ }^{139}$

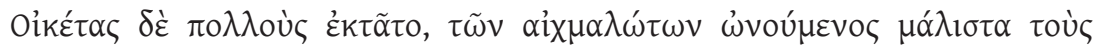

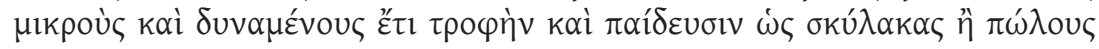

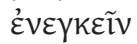

([Catão Censor] Comprou muitos escravos, adquirindo a maioria dos prisioneiros de guerra quando ainda eram pequenos e podiam ainda ser criados e educados, como os cachorros ou os potros).

$\mathrm{e}$

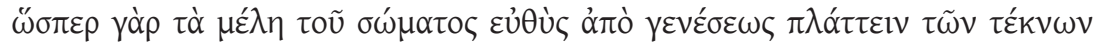

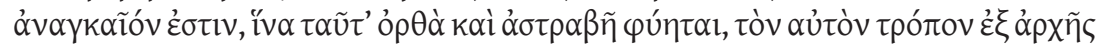

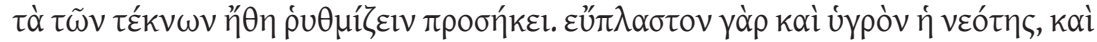

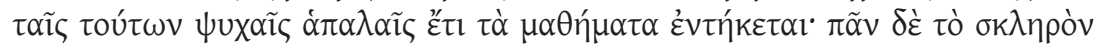

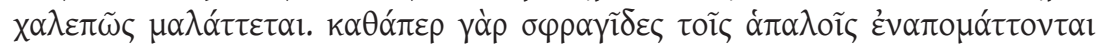

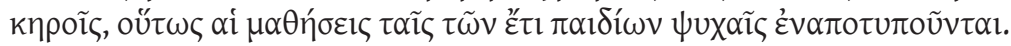

Tal como é necessário que os membros do corpo sejam modelados, correctamente, desde o nascimento, para que cresçam direitos e sem defeito, da mesma forma convém, desde o início, orientar os costumes das crianças. $\mathrm{Na}$ verdade, a juventude é fácil de formar e é flexível, pois ainda se incutem nas suas almas delicadas os ensinamentos. O que é duro dificilmente se suaviza. Tal como os selos se imprimem na cera delicada, também os ensinamentos nas almas dos que ainda são crianças.

Por conseguinte, as crianças aprendem, desde cedo, a ler, a escrever, a fazer contas, mas, ao mesmo tempo, introduzem-se na sua formação alguns princípios morais. Nesta fase, são os paidagogoi e os didaskaloi ${ }^{140}$ que assumem um papel preponderante, não sendo fácil definir com exactidão as funções

${ }^{138}$ Foi-nos útil a leitura do artigo de G. Roskam (2004: 93-114), que propõe uma análise do processo educativo em dois grandes níveis: um propedêutico, onde se inclui a acção do

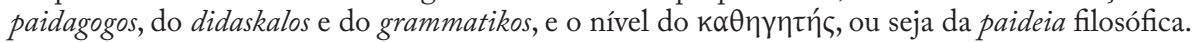

${ }^{139}$ Cat. Ma. 21.1 e De lib. educ. 3E-F, respectivamente; refira-se que, na sequência deste

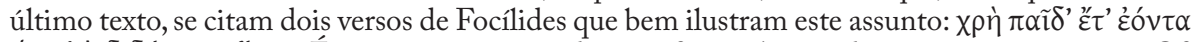
/ $\kappa \alpha \lambda \grave{\alpha} \delta 1 \delta \alpha ́ \sigma K \varepsilon ı v ~ \varepsilon ̌ p \gamma \alpha$. É necessário que ainda na infância / aprendam as acções virtuosas. Cf. C. Pelling (2002m: 301-338).

${ }^{140}$ Surgem muitas vezes interligados em Plutarco: Dem. 5.2, Phil. 4.1, Alex. 5.7, Cat. Mi. 16.3, Aem. 33.6, Lyc. 30.5, Galb. 17.2, De aud. 37D e De gen. Socr. 589F; vide, ainda, De lib. educ. 9D, $12 \mathrm{~A}$ e $12 \mathrm{~B}$. 
de cada um, porque as diferenças nem sempre são mantidas ${ }^{141}$. No entanto, parece que ao didaskalos cabe a formação dita mais intelectual ${ }^{142}$, enquanto o paidagogos assume a educação moral ${ }^{143}$ e a askesis para a virtude ${ }^{144}$. Apesar do valor atribuído à paideia, a profissão de paidagogos não tinha uma importância correspondente, podendo mesmo ter uma conotação negativa, como acontece com Leónidas, um dos educadores de Alexandre, quando Plutarco afirma

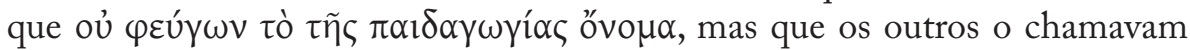

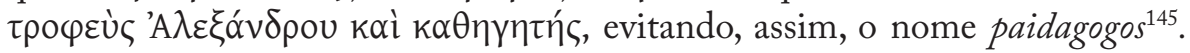
Além disso, o exercício da paidagogia não significava que esses mestres não exercessem outras actividades, sendo relevante verificarmos que sobre dois paidagogoi referidos na biografia de Temístocles, o persa Sicino ${ }^{146}$ e Ólbio ${ }^{147}$, respectivamente educadores dos filhos de Temístocles e Nicógenes, Plutarco se ocupou mais das suas acções militares ou políticas do que do seu papel educativo.

Nem sempre os vocábulos paidagogos e didaskalos designam aqueles que ensinam a leitura ou a escrita, pois, em alguns passos, adquirem um sentido metafórico ${ }^{148}$ : didaskalos de leis ${ }^{149}$, de economia e agricultura ${ }^{150}$, de virtudes ${ }^{151}$, da arte de governar ${ }^{152}$, de administração financeira ${ }^{153}$, da arte de caçar ${ }^{154}$, de matérias teológicas ${ }^{155}$ ou da vida sã ${ }^{156}$; paidagogos de matérias teológicas ${ }^{157} \mathrm{e}$ políticas ${ }^{158}$. Com isto percebe-se que a paideia, no seu sentido mais prático, ganha uma grande amplitude e os seus agentes assumem diversas facetas. Leónidas, por exemplo, não se limita a transmitir a Alexandre os seus

${ }^{141}$ Cf. T. Morgan (2000r: 17 e 28); o paidagogos é sobretudo aquele que acompanha a criança numa fase inicial, enquanto o didaskalos tem funções educativas mais alargadas, como o ensino da literatura e a correcção dos comportamentos; cf. P1. Prt. 325c.

${ }^{142}$ Cf. Alc. 7.

${ }^{143}$ Cf. Marc. 9.7.

${ }^{144}$ Cf. An uirt. doc. 439F.

145 Cf. Alex. 5.7; vide outros exemplos em Fab. 5.5 e Ant. 10.6; em Quaest. conu. 620C,

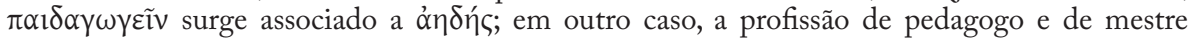
aparece ao mesmo nível da de porteiro ou de um homem ligado à vida marítima (cf. De uit. aer. al. 830B) .

${ }^{146}$ Cf. Them. 12.4.5.

${ }^{147}$ Cf. ibid. 26.2.

${ }^{148}$ G. Roskam (2004: 94-95) também refere esses sentidos de paidagogos e didaskalos.

${ }^{149}$ Cf. Thes. 25.2.

${ }^{150}$ Cf. Comp. Arist.-Cat. Ma. 3.2.

${ }^{151}$ Cf. Pel. 33.1.

${ }^{152}$ Cf. Sept. Sap. conu. 151D-E.

${ }^{153}$ Cf. Cat. Mi. 16.3.

${ }^{154}$ Cf. Aem. 6.9.

${ }^{155}$ Cf. Amat. 763C.

${ }^{156}$ Cf. Lyc. 30.5 .

${ }^{157}$ Cf. Num. 15.1.

${ }^{158}$ Cf. Arat. 48.4. 
conhecimentos, pois também selecciona para ele os cozinheiros e ensina-lhe o valor da frugalidade ${ }^{159}$.

Embora, como vimos, o nome de paidagogos possa ter tido conotações menos positivas, a verdade é que Cónidas, paidagogos e epistate de Teseu, merece ser lembrado e honrado, segundo Plutarco, por parte dos Atenienses, até ao presente, com o sacrifício de um carneiro, num claro sinal de reconhecimento, que certamente se deve muito à dimensão da figura de Teseu ${ }^{160}$. A própria influência dos educadores na actividade futura dos seus educandos é reconhecida por Plutarco: Demóstenes, como já referimos, depois de convencer o seu paidagogos a deixá-lo assistir ao processo em que o orador Calístrato iria defender Oropo, fica espantado com o uso que este fazia da palavra e daí nasce o seu impulso e a sua total entrega à arte oratória ${ }^{161}$.

Deste modo, o momento e os critérios de escolha dos paidagogoi e didaskaloi assumem muita importância, como o seguinte texto do tratado $D e$ liberis educandis comprova: ${ }^{162}$

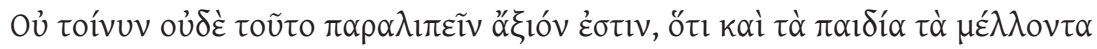

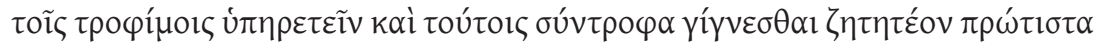

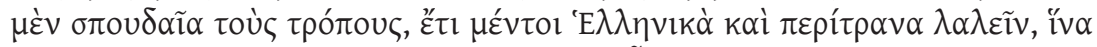

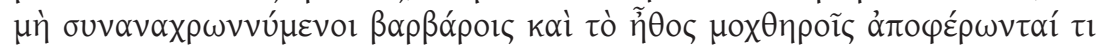

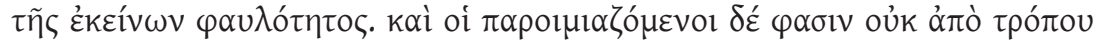

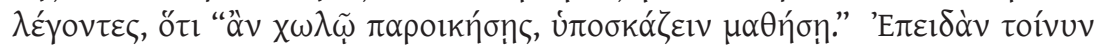

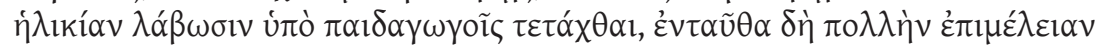

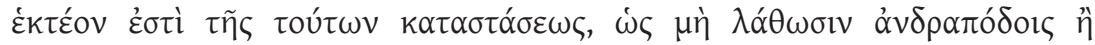

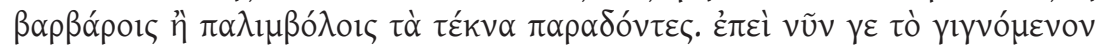

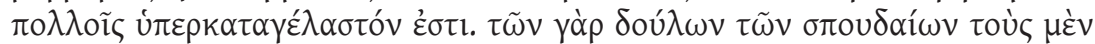

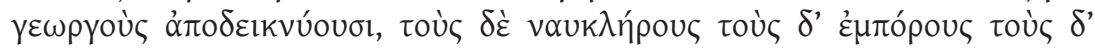

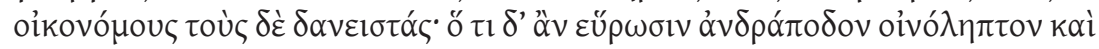

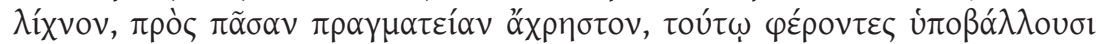

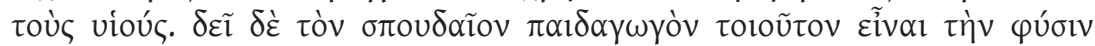

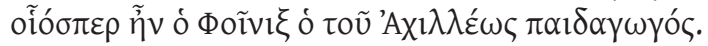

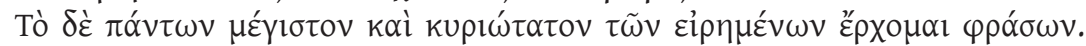

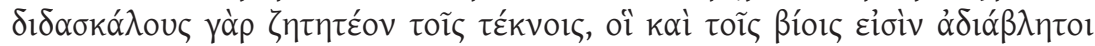

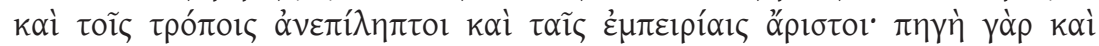

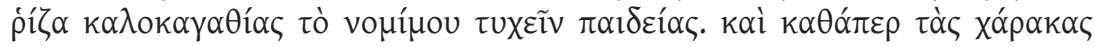

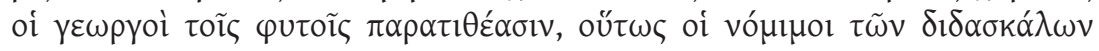

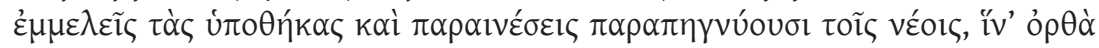

${ }^{159}$ Cf. Alex. 22.9-10.

${ }^{160}$ Cf. Thes. 4.1.

${ }^{161}$ Cf. Dem. 5.

162 3F-5A (o itálico na tradução é nosso, pois optamos por transcrever os vocábulos relacionados com os educadores). 


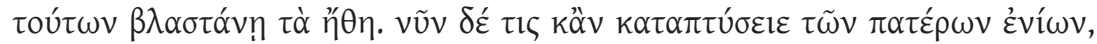

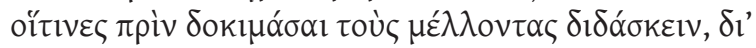

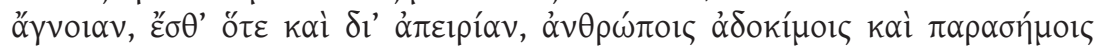

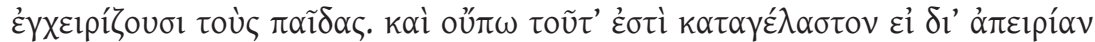

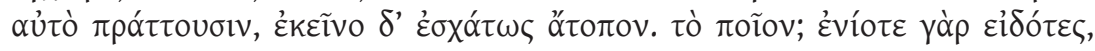

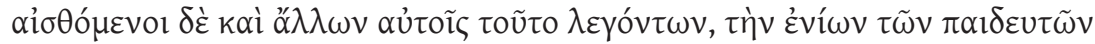

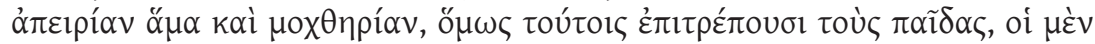

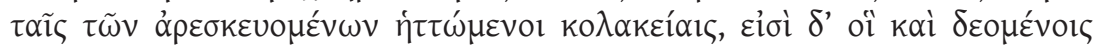

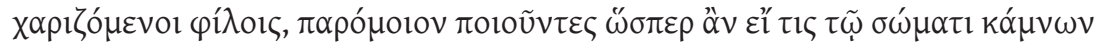

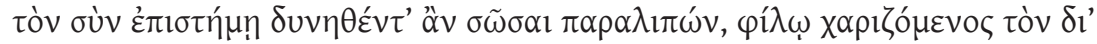

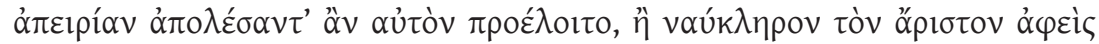

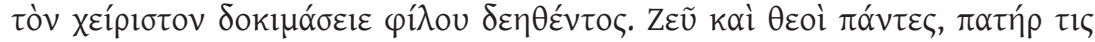

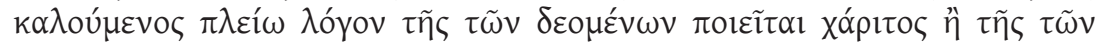

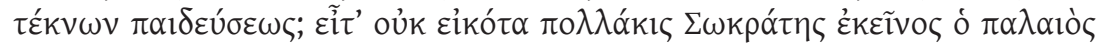

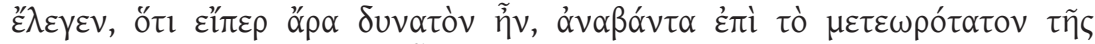

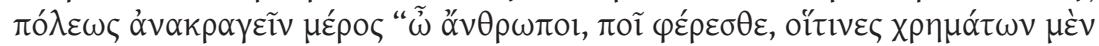

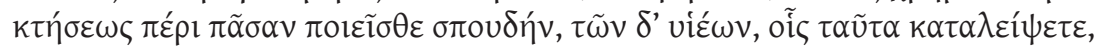

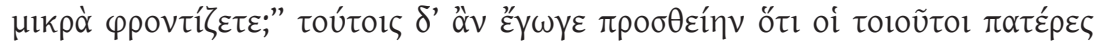

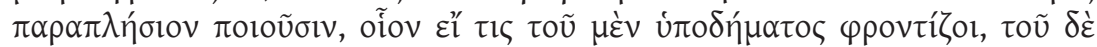

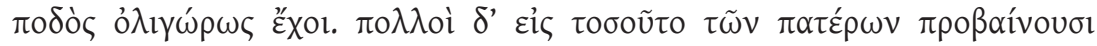

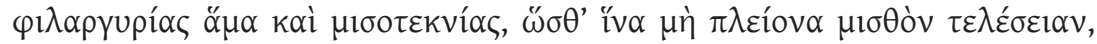

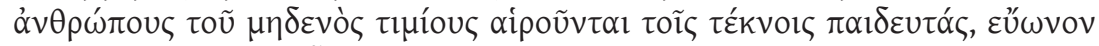

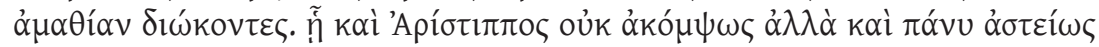

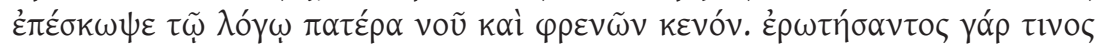

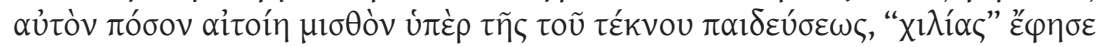

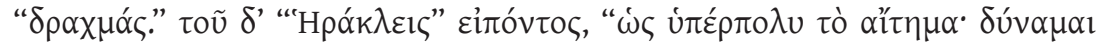

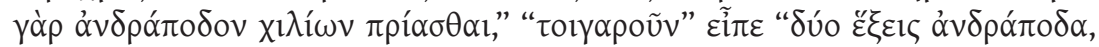

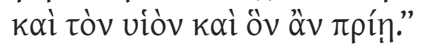

É por isso que não merece ser descuidado o seguinte: os jovens escravos que estão destinados a servir os filhos desses pais e a conviver com eles devem ser escolhidos, acima de tudo, pelo seu carácter virtuoso e, com certeza, devem falar a língua grega com fluência, para que, com o convívio com bárbaros de costumes perversos, as crianças não se deixem contagiar pelos seus vícios. Os que falam por meio de provérbios dizem, com verdade, que "quem vive perto de um coxo, aprende a coxear". Quando as crianças atingirem a idade de serem entregues aos paidagogoi ${ }^{163}$, nesse momento deve ter-se muito cuidado na escolha destes, a fim de não se permitir que os filhos sejam entregues a escravos bárbaros ou instáveis. É que o que hoje muitas pessoas fazem é extremamente ridículo. De entre os escravos diligentes, nomeiam os agricultores, os armadores de barcos, os comerciantes, os administradores e os usurários. Mas, se descobrem um escravo ébrio e glutão, inútil para qualquer actividade, é a esse que levam os

${ }^{163}$ Aos 7 anos. 
filhos e os entregam. É necessário, contudo, que o paidagogos sério tenha uma natureza como a de Fénix, o paidagogos de Aquiles ${ }^{164}$. Vou expor a questão mais importante de todas as que até agora referi. Procurem-se para os filhos didaskaloi que tenham uma conduta de vida irrepreensível, uma moral acima de qualquer censura e que sejam os melhores pela sua experiência. A fonte e a raíz da honestidade perfeita encontram-se na educação que é conforme aos bons costumes. Tal como os agricultores põem estacas nas plantas, assim também os didaskaloi, por meio de bons hábitos, enxertam nos jovens os princípios e os conselhos convenientes, para que brote neles um carácter recto. É possível, porém, condenar alguns dos pais de hoje que, antes de avaliar os que devem ensinar, por ignorância ou também por inexperiência, entregam os filhos a homens de má índole e falsos. Se os pais agem por inexperiência, de nenhuma maneira isso é ridículo, mas o cúmulo do absurdo! O quê?! Algumas vezes têm conhecimento - ou então percebem por aquilo que outros dizem — da inexperiência aliada à perversidade de alguns paideutai, e, mesmo assim, confiam-lhes os filhos, seja porque os pais não são capazes de resistir a tratá-los com adulações, seja para agradarem aos amigos que lhes pedem, agindo como quem, tendo o corpo doente, o despreza, ainda que possa curá-lo com a ciência; ou como o homem que, só para agradar a um amigo, prefere escolher aquele que o fará perder por causa da inexperiência; ou como aquele que, a pedido do amigo, despede o melhor armador de barcos, como se julgasse ser o pior. Por Zeus e todos os deuses! Para aquele que merece ser chamado pai tem mais valor agradar aos pedidos ou à educação dos seus filhos? Sobre isto, o velho Sócrates dizia, muitas vezes, que não é conveniente, ainda que fosse possível, subir à parte mais alta da cidade ${ }^{165}$ e gritar: "Homens, onde ides? Fazeis todo o esforço para adquirir a riqueza, porém pouco vos preocupais com os filhos. Que coisas abandonastes por eles?” Pela minha parte, posso aduzir a estes factos que esses pais agem de forma semelhante à daquele que, por um lado, se preocupa com o calçado e, por outro, tem pouco cuidado com o pé ${ }^{166}$. Muitos pais valorizam tanto o amor ao dinheiro ${ }^{167}$, juntamente com o ódio aos filhos, que, para não gastarem um salário elevado, escolhem homens de modo algum válidos para paideutai dos filhos, procurando uma ignorância de baixo preço. Também Aristipo zombou num discurso, não sem elegância, mas, sem dúvida, com fineza, de um pai privado de inteligência e de senso. Depois de ele perguntar a Aristipo que salário pediria para a educação do filho, respondeu "mil dracmas". "Por Héracles", disse, "como é excessivo o teu pedido. Na verdade, com mil dracmas posso comprar um escravo"; "Dessa forma", replicou Aristipo, "terás dois escravos, o teu filho e o que puderes comprar".

\footnotetext{
${ }^{164}$ Il. 9,443 e ss.

${ }^{165}$ Atenas. Cf. Pl. Clit. 407 a.

${ }^{166} \mathrm{Cf}$. De tranq. an. $466 \mathrm{E}$; o ethos dá forma à vida e acaba por se identificar com ela.

${ }^{167}$ Sobre o dinheiro na educação, vide P1. Ap. 19 d-e e 20 b.
} 
Este texto, apesar de muito provavelmente não ter sido escrito por Plutarco ${ }^{168}$, reúne algumas ideias e críticas que ele perfilha. A boa educação dos filhos deve tornar-se uma das prioridades dos pais. Assim aconteceu com Filipe, pai de Alexandre, que chamou Aristóteles por não confiar nos mestres que ele tinha ${ }^{169}$. Recordamos, a este respeito, o discurso de Ésquines, In Timarchum, onde se aborda a preocupação na selecção dos educadores para

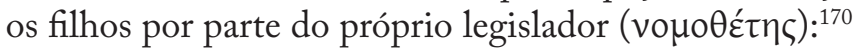

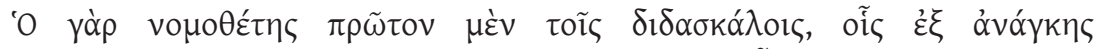

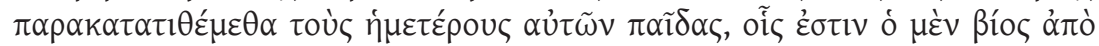

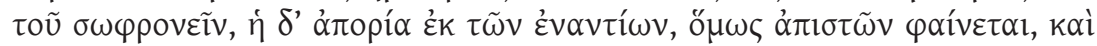

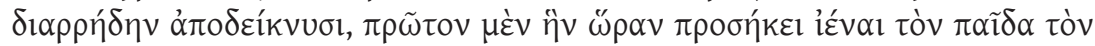

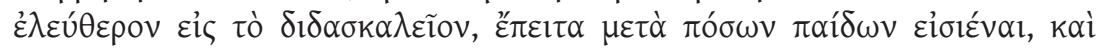

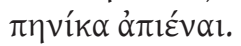

De facto, o legislador, em primeiro lugar, mostra desconfiar dos mestres a quem, por necessidade, confiamos os nossos filhos e cujo sustento thes vem da prudência e a penúria, pelo contrário, advém de uma conduta contrária e determina, primeiro, de forma precisa, em que momento deve ir para a escola uma criança de condição livre, depois, com quantas crianças deve entrar e a que horas deve sair.

Porém, o papel dos pais não se resume a escolher bem os educadores para os filhos, uma vez que eles próprios devem ser modelos e empenhar-se directamente na sua educação, como fez Catão Censor e Filipe com Alexandre. Plutarco conta-nos também como Emílio Paulo, um filo-heleno, nascido na gens Aemilia - também conhecido pelo cognomen de Macedónio, cuja vitória em Pidna ${ }^{171}$ abriu as portas aos Romanos para a conquista da Grécia -, que afirmava descender de Numa e de Pitágoras ${ }^{172}$, se preocupou em dar aos filhos uma educação tradicional e, em paralelo, thes deu a conhecer a paideia

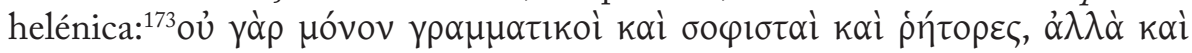

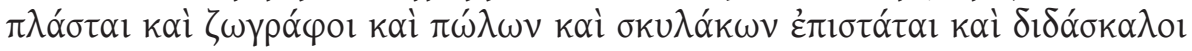

${ }^{168}$ Cf. Sobre esta questão, vide E. Berry (1958: 387-99), F. Albini (1997: 59-71) e J. Pinheiro (2003: 473-484) e (2007: 349-362).

${ }^{169}$ Cf. Alex. 7.1-2.

1709.

${ }^{171}$ Recorde-se que, do tão valioso espólio macedónio, Emílio Paulo apenas se interessou pela Biblioteca de Perseu que ofereceu aos seus dois filhos (cf. Aem. 28.11; Pol. 31.23.4); outra das consequências da batalha de Pidna foi o encontro entre Políbio e Cipião Emiliano, que principia a aproximação entre a cultura grega e os Romanos, sendo um bom exemplo das palavras de Horácio que servem de epígrafe ao próximo capítulo.

${ }_{172}^{172 m}$. 2.1-2 e Num. 8.18-19.

173 Aem. 6.8-10. 


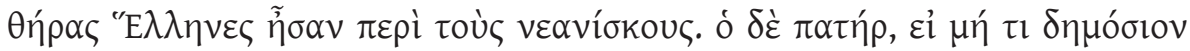

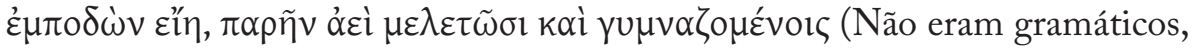
sofistas e retores, mas também escultores, pintores, domadores de potros e de cachorros, mestres de caça - todos Gregos - os que acompanhavam os jovens. $\mathrm{O}$ pai, se não tivesse nenhum impedimento, presenciava sempre os seus estudos e exercícios).

$\mathrm{Na}$ sua acção junto dos filhos, de modo a conseguirem modelar os seus caracteres e conduzi-los para a virtude, os paidagogoi e os didaskaloi definem regras e assumem a sua autoridade, dando os paidagogoi especial atenção às

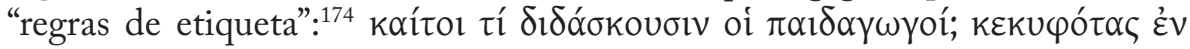

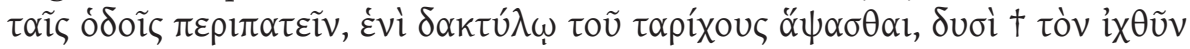

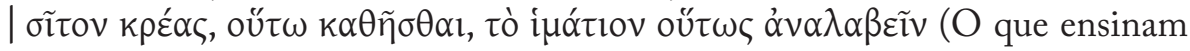
os paidagogoi? A caminhar pela rua com a cabeça baixa, a tocar as conservas com um só dedo, com dois o peixe, o pão e a carne, a sentar-se de uma certa forma e a colocar o manto de uma maneira correcta). Ambos, paidagogoi e didaskaloi, lideram o processo educativo, de forma por vezes ríspida ${ }^{175}$, como se assume na biografia de César quando se comparam os golpes que as mulheres recebiam nas mãos por esta acção supostamente as ajudar a ter um bom parto ou para ficarem grávidas com as palmadas que em criança recebiam na escola $^{176}$, mas são eles que se responsabilizam por tudo o que envolve a paideia e, por isso, Plutarco considera correcta a atitude de Diógenes quando deu uma bofetada num paidagogos, uma vez que a culpa se deve atribuir ao que não soube ensinar ${ }^{177}$. Pode afirmar-se que existe, na maioria dos casos, uma relação de lealdade e de admiração ${ }^{178}$, tendo o pupilo, em geral, uma atitude passiva, ainda que se encontrem alguns casos de maior independência e crítica face ao educador, como acontece com Alcibíades. Este prestava atenção a todos os didaskaloi, com excepção daquele que ensinava a tocar flauta, por considerar que era uma arte indigna de um homem livre, atitude que, no entanto, não pode ser interpretada como uma falta de respeito, mas apenas como um juízo crítico por parte do Grego ${ }^{179}$. Da mesma forma, Catão de Útica obedecia ao paidagogos, mas isso não invalidava que o questionasse sobre o motivo (aitia) e a razão (logos) das suas ordens (prostagma $)^{180}$. Apesar dos exemplos de Alcibíades

${ }^{174}$ An uirt. doc. 439F; cf. De fort. 99D; também Arist., Nub. 973 ss. se refere à forma de andar na rua e de se sentar e em $A v .1568$ a forma de pôr o manto.

${ }^{175} \mathrm{Em}$ De aud. 37D são qualificados de $\chi \alpha \lambda \varepsilon \pi$ où $\delta \varepsilon \sigma \pi$ ó $\alpha \varsigma$.

${ }^{176}$ Cf. Caes. 61.3.

${ }^{177}$ Cf. An uirt. doc. 439E; em Cam. 10.1-5 e Ant. 81.1-2 encontram-se casos de professores que não corresponderam às expectativas.

${ }^{178}$ Em De uirt. mor. 448E, Plutarco dá o exemplo dos jovens que, numa fase inicial, sentem

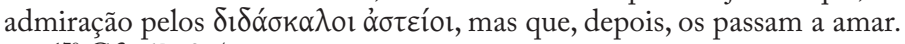

${ }^{179}$ Cf. Alc. 2.5.

${ }^{180}$ Cf. De aud. poet. 28B e Cat. Mi.1.10. 
e de Catão de Útica, a comunicação educacional processa-se, na maioria dos casos, do professor para o aluno, não se verificando o processo maiêutico, pelo menos nesta primeira fase da educação.

De seguida, a nossa análise não pode deixar de salientar que, nas Vitae, Plutarco dá poucos exemplos concretos da actividade do grammatikos $^{181}$, precisamente aquele que desenvolve a paideia iniciada pelo paidagogos e pelo didaskalos. A função do grammatikos é sobretudo o ensino da poesia, a fase propedêutica, pois a leitura dos poetas é uma preparação para a filosofia ${ }^{182}$ e um meio para se transmitirem conhecimentos gerais. Aliás, o papel do grammatikos surge suficientemente desenvolvido no tratado De audiendis poetis, onde, além de se descrever a metodologia de análise que ele procura incutir nos discípulos ${ }^{183}$, se enfatiza que a leitura da poesia deve ter como objectivo a formação moral, incrementando-se a capacidade de se distinguir a realidade da ficção, o bem do mal, o verosímil da verdade. Logo, mais do que prestar atenção ao efeito estético das palavras deve o leitor/discípulo deter-se no conteúdo e na utilidade do logos para a sua vida quotidiana ${ }^{184}$. Só dessa forma, a paideia conseguirá estimular os seus agentes a imitar os melhores modelos e a rejeitar aquilo que os afastará da infelicidade e do mal.

Num nível superior, encontra-se a paideia filosófica, que tem por objectivo iniciar o aluno na filosofia e nas suas diferentes doutrinas, e, em paralelo, consolidar a sua formação moral. Este nível só é profícuo quando o aluno se interessa pelo conhecimento e pela componente moral ${ }^{185}$, sabe reconhecer os seus defeitos e deseja eliminá- $\operatorname{los}^{186}$. Estamos a falar de um $\varphi \imath \lambda o \mu \alpha \theta \eta ́$, qualidade que o homem possui por natureza ${ }^{187}$, mas que precisa de ser incentivada e trabalhada. Cícero ${ }^{188}$ e Alexandre ${ }^{189}$ são dois $\varphi 1 \lambda$ o $\mu \alpha \theta \varepsilon \tilde{c} \varsigma$, pela forma como se entregaram à paideia e pelo apelo que sentiam por uma diversidade de conhecimentos. Neste nível da paideia, o discípulo tem um papel menos passivo do que aquele que tinha junto do paidagogos, do didaskalos e do grammatikos, pois ele é chamado a demonstrar uma atitude crítica perante

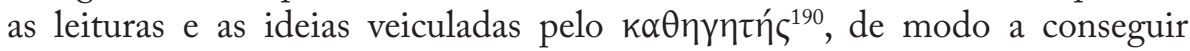

${ }^{181}$ É em Xenofonte (Mem. 4.2.20) que surge pela primeira vez este vocábulo, tal como o oposto, o agrammatos.

${ }^{182}$ Cf. De aud. poet. 37B.

${ }^{183} \mathrm{Cf}$. ibid. $19 \mathrm{~A}$ e ss.

${ }^{184}$ Cf. ibid. 14F, 28E, 30E e 32E-F.

${ }_{185} \mathrm{Cf}$. De aud. 39D, De prof. in uirt. 80B-C.

${ }^{186}$ Cf. De aud. 43D-E, De prof. in uirt. $81 \mathrm{~F}-82 \mathrm{~F}$.

${ }^{187}$ Cf. Per. 1.2.

${ }^{188}$ Cf. Cic. 2.3.

${ }^{189}$ Cf. Alex. 8.1.

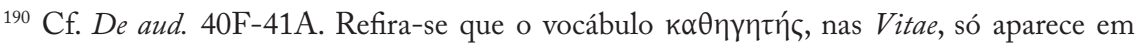

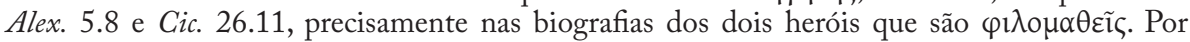

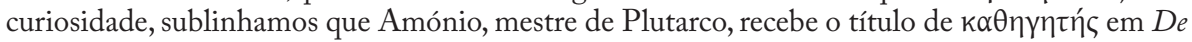


separar o supérfluo do essencial e, sobretudo, a formular um pensamento

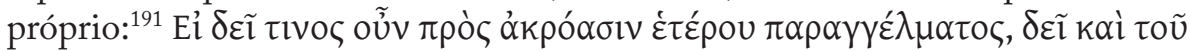

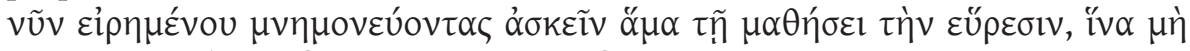

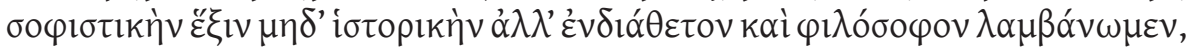

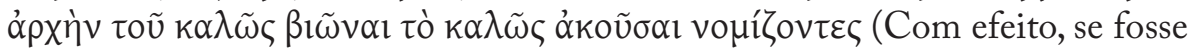
necessária uma outra advertência sobre a acção de escutar, juntaríamos que também se deve, recordando o que até agora dissemos, exercitar a capacidade de descoberta em paralelo com a instrução, para que tomemos um hábito nem sofístico nem histórico, mas muito íntimo e filosófico, considerando que saber ouvir bem é o princípio de viver bem). Note-se no texto a preocupação que Plutarco tem sempre presente: $\kappa \alpha \lambda \tilde{\omega} \varsigma \beta 1 \tilde{\omega} v \alpha l$ (viver bem), que significa viver virtusosamente, ao contrário de $\dot{\eta} \delta \varepsilon \omega \varsigma \zeta \tilde{\eta} v$ (viver segundo o prazer) ${ }^{192}$. Após absorver o conteúdo dos textos e das palavras do professor, o discípulo deverá necessariamente estar apto a formular questões pertinentes ${ }^{193}$, cabendo ao professor responder ou problematizar a questão, por meio de $\pi \rho o ́ \beta \lambda \eta \mu \alpha$ ou $\alpha i \tau i ́ \alpha$, para o próprio aluno encontrar a melhor resposta. Deste modo, estimula-se a imaginação e a capacidade individual de pesquisa $(\zeta \eta ́ \tau \eta \sigma ı)^{194}$, num processo bastante próximo da técnica maiêutica ${ }^{195}$, uma vez que existe, não só maior comunicação entre professor e discípulo, mas também reciprocidade na transmissão filosófica ( $\sigma u \mu \varphi$ i $о \sigma \circ \varphi \varepsilon \tilde{v} v)^{196}$. Como facilmente se depreende, também neste nível de transmissão do conhecimento filosófico se procura consolidar a formação moral, e, para isso, a kpí

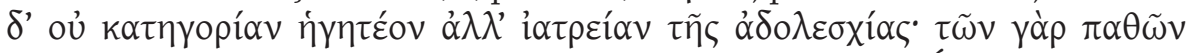

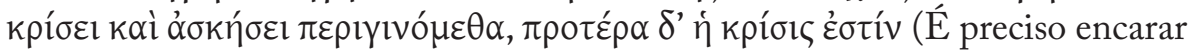
isto não como uma acusação, mas como tratamento para a charlatanice; na verdade, tornámo-nos superiores às paixões com o discernimento e com o

adul. 70E e que, em Coniug. praec. 145C, Plutarco afirma que é honroso uma mulher considerar

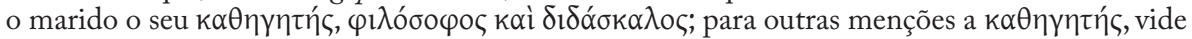
De adul. 71C, De prof. in uirt. 85D, De Alex. fort. aut. uirt. 327B, Quaest. conu. 617D, 634A, 717B, 719D, X or. uit. 832D, De comm. not. 1069A e Non posse suau. 1100A.

${ }^{191}$ Ibid. 48D.

${ }^{192}$ Cf. Alex. 8 e An uirt. doc. 439A.

${ }^{193}$ Cf. ibid. 42F-43B; as questões devem ser colocadas no momento oportuno (39C e 42F) e de acordo com a competência do professor (43B-D).

${ }^{194}$ G. Roskam (2004: 103) considera que o incentivo à resolução de questões ou problemas, conducentes à procura da verdade, é uma atitude que "fits in very well with Plutarch's episthemological position, which is influenced by the sceptical Academy. For Plutarch, indeed, philosophy itself is in the end a continuing search for the truth".

${ }^{195}$ Cf. Quaest. Plat. 1000D-E. Sobre a maiêutica socrática como processo educacional que se baseia no diálogo, uma techne para se atingir o conhecimento, vide Pl. Tht. 148 ss.

${ }^{196}$ Cf. Cic. 24.8 ; vide, ainda, Dion 20.2, Brut. 12.3 e 24.1, De prof. in uirt. 77B-C, De tuenda san. $122 \mathrm{~B}$ e De gen. Socr. $578 \mathrm{~F}$.

${ }^{197}$ Cf. De gar. 510C. 
exercício, mas o discernimento está em primeiro lugar). Com isto, Plutarco não quer dizer que a krisis visa eliminar os pathe, mas apenas dar-lhes outra configuração e moderá-los ${ }^{198}$.

Quando um indivíduo entra na idade adulta não deixa de ter um

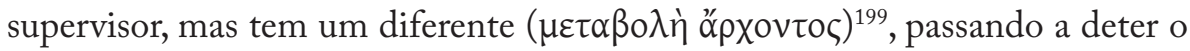
próprio indivíduo maior iniciativa própria e a examinar constantemente a sua conduta moral ${ }^{200}$. Da mesma forma que Plutarco estimula os leitores a imitar os valores dos heróis das Vitae, também o indivíduo deve sentir o apelo por esses paradigmas do passado e, por meio do exercício, progredir na virtude ${ }^{201}$. Aquele que consegue fazer progressos no carácter e na prática da virtude sente tristeza pelo facto de o professor e o seu pai, ambos já falecidos, não poderem assistir à sua evolução: ${ }^{202}$

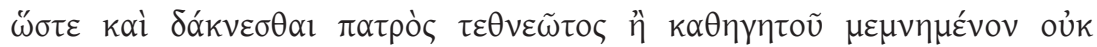

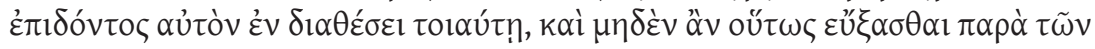

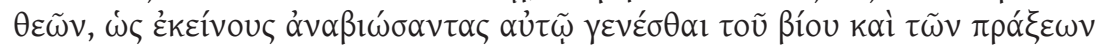

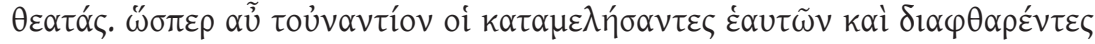

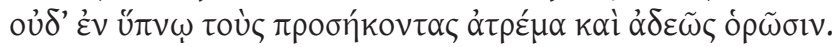

De tal maneira se lastima ao recordar-se do seu pai ou do seu mestre já falecidos por não o poderem ver na presente condição, que nenhum outro motivo o faria rogar aos deuses a não ser o desejo de fazer reviver aqueles para assistirem à sua vida e às suas acções. Ao invés, os que, de forma contrária, foram, por completo, descuidados consigo próprios e se deixaram corromper, nem em sonhos vêem com tranquilidade e sem medo os seus familiares.

Sobre o respeito pelos mestres ${ }^{203}$, pode dar-se Alexandre como exemplo de um educando que se sente agradecido ao mestre pelos ensinamentos que recebeu: num momento, arrisca a sua vida por Lisímaco ${ }^{204}$ e, noutro, envia a Leónidas uma parte dos despojos (quinhentos talentos de incenso e cem de mirra), não só como sinal de agradecimento, mas para este não ser parcimonioso nos sacrifícios aos deuses ${ }^{205}$. Da mesma forma, na biografia de Cícero, Plutarco

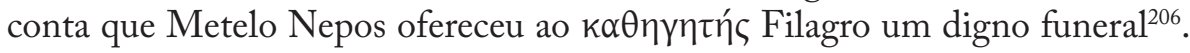

${ }^{198}$ Cf. De uirt. mor. 449B; vide, ainda, ibid. 443A e 447E, De cohib. ira 459C.

${ }^{199}$ Cf. De aud. 37D-E.

${ }^{200}$ Cf. De prof. in uirt. 82A e 83A-B.

${ }^{201}$ Cf. ibid. 84B-85B.

${ }^{202}$ Ibid. 85D.

${ }^{203}$ Exemplo contrário ao que damos é Epicuro, uma vez que se distingue pela rejeição dos seus mestres (cf. Non posse suau. 1100A).

${ }^{204}$ Cf. Alex. 24.10-11.

${ }^{205}$ Cf. ibid. 25.6-8.

${ }^{206}$ Cf. Cic. 26.11. Em Reg. et imp. Apopht. 205A, Plutarco, provavelmente por confusão, em 
Podemos também incluir o próprio biógrafo nesta lista de discípulos que se sentem agradecidos aos mestres, uma vez que dedicou a Amónio um dos seus

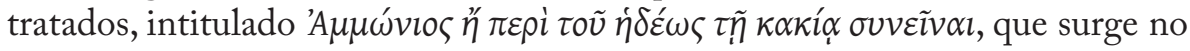
Catálogo de Lâmprias ( $n^{\circ}$ 84), além das diversas vezes que se refere a ele ${ }^{207}$. Aliás, sobre a sua experiência como discípulo de Amónio conta-nos uma história que não deixa de ser curiosa: ${ }^{208}$

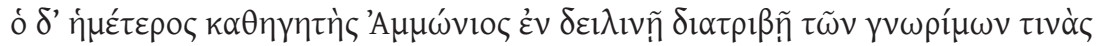

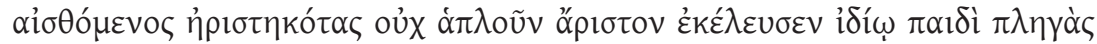

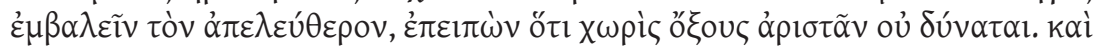

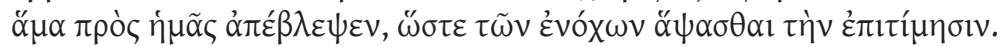

O nosso mestre Amónio, numa reunião vespertina, percebendo que alguns dos discípulos haviam preparado um almoço pouco frugal, ordenou a um liberto que batesse no seu próprio escravo, dizendo que ele não podia almoçar sem vinagre; ao mesmo tempo, olhou para nós, por forma que o castigo recaísse sobre os culpados.

Diga-se, ainda, que Amónio não terá sido apenas mestre de filosofia ou retórica, mas Plutarco também deve ter aprendido com ele preceitos políticos, por exemplo quando o acompanhou aos Jogos Píticos, realizados em Delfos no ano 67, com a presença de Nero, como relata no tratado De E apud Delphos ${ }^{209}$.

Pela análise que temos vindo a fazer da relação entre professor e discípulo, fundada num código de lealdade e até de amizade ${ }^{210}$, verifica-se que Plutarco detecta um primeiro nível, a fase propedêutica, em que existe fundamentalmente uma transmissão de conhecimentos e de valores do professor para o discípulo (emissor-professor-activo> receptor-discípulo-passivo). Num segundo nível, o da paideia filosófica, o professor segue mais a metodologia maiêutica ou dialógica do que a ex cathedra, conduzindo o discípulo até às respostas e às hipóteses que ele próprio desenvolve, numa espécie de ơvó́ comunicação pedagógica tenha sucesso, é necessário que o aluno, conhecendo as ideias dos principais filósofos, consiga desenvolver um pensamento autónomo e uma atitude crítica. Além disso, só aquele que é consciente das suas lacunas e dos erros que comete pode fazer progressos na virtude, um dos objectivos nucleares da paideia. Ao que educa, por sua vez, a par da sua necessária sabedoria e elevada moral, pede-se que saiba colocar questões e que estimule os alunos a apontar soluções e hipóteses, num são e produtivo

vez de Filagro, refere o nome de Diodoto.

${ }^{207}$ Cf. e.g. Them. 32.6; outras referências em De E Delph., De def. orac. e Quaest. conu.

${ }^{208}$ De adul. 70E.

209 385B.

${ }^{210}$ cf. De uirt. mor. 448E e Max. cum princ. 779D. 
ambiente educativo. Estas duas fases acabam, em parte, por reproduzir a concepção platónica: nos livros II e III da Respublica, educam-se os jovens com menos de vinte anos para a coragem, a temperança, o autocontrolo ou a piedade, de modo a libertá-los das convulsões da parte irracional da alma; por sua vez, nos livros VI-VII, que correspondem ao segundo nível, a paideia tem por objectivo desenvolver e treinar $\tau \tilde{\eta} \varsigma \psi \cup x \tilde{\eta} \varsigma$ ö $\psi v v$ ou $\tau \tilde{\eta} \varsigma \psi \cup x \tilde{\eta} \varsigma$ ő $\mu \mu \alpha^{211}$. Isto significa que, numa primeira fase, o indivíduo absorve conhecimentos e práticas, desenvolvendo, desde logo, hábitos (corporais e mentais) e condutas morais dignas de um cidadão, para depois passar a observar e a analisar aquilo que o rodeia, mantendo uma atitude dialética e crítica com a realidade.

Além dos elementos referidos, confirma-se que as informações sobre a paideia dos heróis não são tão numerosas e tão pormenorizadas como se poderia inicialmente supor ${ }^{212}$, pois temos poucos elementos concretos sobre os curricula, as instituições que promoviam a educação, o conteúdo dos manuais de apoio à leitura. Em alguns casos, o nome dos mestres aparece omitido e nem sabemos como se processava a avaliação.

Plutarco aborda, em parte, este problema, quando afirma, em relação a diversas figuras contemporâneas de Alcibíades, que não se sabe o nome da mãe, mas que, quanto a ele, sabemos não só o nome da mãe, mas também o da ama e o do paidagogos ${ }^{213}$. Isto poderá querer dizer que Plutarco estaria interessado em referir os nomes daqueles que participam na paideia, mas que, na maioria dos casos, essa informação lhe faltaria, o que pode explicar a ausência de elementos nas Vitae. Ou então, nos casos em que omite elementos concretos sobre a paideia, Plutarco consideraria que eles não eram relevantes para o telos da sua narrativa. Pode ainda pensar-se que partiria do princípio de que os leitores/ ouvintes das biografias conheceriam já suficientemente a paideia dos heróis e que, por essa razão, seria desnecessário repeti-la na narrativa. Parece-nos, no entanto, que esta última hipótese não tem sustentação: como se explica, então, que na biografia de Alexandre, figura sobejamente conhecida, enumere diversos elementos sobre a formação do Macedónio? Teriam os Gregos, mesmo os da aristocracia, um conhecimento tão profundo da história romana para ele dispensar a narração, com algum pormenor, da paideia de Pompeio, César, Sertório, Flaminino ou Publícola? Como se percebe, as razões dever-se-ão

${ }^{211}$ Resp. 519b e 533d.

${ }^{212}$ A igual conclusão chegou A. Velázquez Fernández (2001: 441-450), pois, em diversas biografias, não se faz qualquer referência à educação do herói, a saber: Licurgo (4, 2-3 vaga alusão sobre a educação do herói já em idade adulta), Publícola, Camilo, Fábio Máximo, Timoleonte, Emílio Paulo, Pelópidas, Marcelo, Flaminino, Pirro, Sula, Nícias, Pompeio, César, Demétrio, Artaxerxes, Galba e Otão. Nestas biografias não só dispomos de informações muito vagas quanto à educação dos heróis, como os dados em relação aos educadores são ainda mais reduzidos.

${ }^{213}$ Cf. Alc. 1.2 . 
certamente aos elementos que ele conseguiu coligir para o seu trabalho de redacção e ao propósito temático que preside a cada biografia. Ainda sobre os dados que nos são disponibilizados pelas Vitae relativamente à paideia, é fácil perceber que o processo educativo é dominado pelos homens, uma vez que são eles, ao contrário das mulheres, que aspiram a desempenhar o poder, assunto a que voltaremos ao longo deste capítulo ${ }^{214}$. Além disso, nas biografias de Demóstenes, Cícero, Filopémen e Alexandre encontramos referências explícitas aos mestres de retórica e filosofia, talvez por Plutarco querer salientar o valor destas disciplinas na formação do indivíduo.

Nas biografias de Aristides, Sertório, Êumenes, Pelópidas e César — só para referir os casos mais evidentes - omite-se o nome dos mestres ou existe uma total ausência de elementos sobre a matéria educativa. Outra conclusão a extrair é que temos mais elementos sobre a paideia dos Romanos do que sobre a dos Gregos nos pares Aristides-Cato Maior, Demosthenes-Cicero e PelopidasMarcelus, enquanto nos pares Alexander-Caesar e Philopoemen-Flamininus ${ }^{215}$ acontece o inverso. No caso do par Coriolanus-Alcibiades, é na biografia de Alcibíades que Plutarco especifica melhor a educação recebida. É, contudo, na figura romana desse par que a análise sobre as consequências da paideia na praxis e no ethos se torna mais consequente. Para S. Swain (1990: 129) a justificação para tal só pode ser uma: "The only plausible explanation of this situation is that Plutarch feels that good education cannot be assumed for Romans as it can for Greeks, since $\pi \alpha 1 \delta \varepsilon i ́ \alpha$ had not been available from the start at Rome but had been introduced later on (as a result of contact with Greece)."

Julgamos, porém, que a causa para Plutarco dedicar maior atenção à paideia nas biografias dos Romanos se pode encontrar com a ajuda das Quaestiones Romanae e das Quaestiones Graecae ${ }^{216}$, obras etiológicas que não escondem uma

${ }^{214}$ T. Morgan (2000r: 48-9), conhecedora da paideia na Antiguidade e dos papiros do Egipto helenístico relacionados com a aprendizagem, assegura que havia mulheres que aprendiam a ler e a escrever com base nos mesmos materiais que os homens, e que algumas delas chegaram mesmo a ser mestres (grammatike ou deskale), ainda que não haja consenso sobre a quantidade de mulheres que enveredavam pela literacia, o que estaria dependente do seu estatuto social e económico. Em relação aos períodos clássico e helenístico, os elementos são escassos e não permitem avaliar, com total certeza, o nível de literacia entre as mulheres, embora se acredite que, no século V a.C., seria uma excepção uma mulher saber ler e escrever. Note-se, por exemplo, que, de entre as personagens femininas das tragédias que nos chegaram, apenas Fedra (E. Hipp. 856-81) sabe escrever; a este propósito, vide S. Cole (1992r: 219-245).

${ }^{215}$ Para mais elementos sobre outras biografias que o nosso estudo não abarca, vide S. Swain (1990b: esp.131-136), estudo que fornece linhas de leitura pertinentes.

${ }^{216}$ Segundo J. Boulogne (1992: 4707), o objectivo dos problemata é "augmenter les chances d'appréhender les réalités humaines dans leurs diverses dimensions”. Por sua vez, G. Harrison (2000: 193-4), listando, de acordo com o Catálogo de Lâmprias, as obras plutarquianas com formato semelhante ao dos problemata, olha para essa obras sob a perspectiva dos géneros e 
certa tendência helenocêntrica. Nelas se constata que os valores e os costumes helénicos servem de justificação a grande parte das aitiai romanas e as questões gregas incidem sobre matérias que não requerem grandes explanações por serem do conhecimento geral ${ }^{217}$. Ora, mutatis mutandis, a paideia dos Gregos não exigiria também uma explicação especial, preferindo Plutarco dedicar-se a um outro tema, que é o contacto dos Romanos com essa paideia. Esta é uma fórmula eficaz para a valorizar e para demonstrar a possibilidade de os Romanos cultivarem esses valores, em consonância com o ambiente intelectual da Segunda Sofística: a elite grega e a questão da construção da identidade no Império Romano. Note-se que essa reflexão tem por base uma ideia de complementaridade cultural, em que o passado ajuda a reflectir sobre o presente. Nos autores que pertencem à Segunda Sofística - não se trata apenas de um movimento literário ou académico, mas de uma expressão cultural, relacionada com a actividade política e social - são recorrentes temas da história grega até à morte de Alexandre, o declínio da democracia ateniense, mitos homéricos, temáticas sobre ética, psicologia, filosofia e crítica literária ${ }^{218}$, logo assuntos que exigem um nível de conhecimento elevado, próprio dos pepaideumenoi ou daqueles que exercem funções pedagógicas nas poleis. Além disso, do ponto de vista retórico, o efeito do helenismo e a capacidade da paideia para criar uma nova mentalidade e potencialidades distintas surtem maior efeito quando são aplicados aos não-Gregos, neste caso, aos Romanos.

Isto remete-nos para uma outra questão: poderá, assim, a quantidade de informação sobre a paideia estar relacionada com o valor da própria paideia nas Vitae? Julgamos que não, se tivermos em conta, por exemplo, as biografias de Cícero, Luculo e Mário. A biografia do orador latino é a que oferece maior número de dados sobre a educação, mas não se pode duvidar de que a paideia tem enorme valor em qualquer uma dessas vidas, independentemente do números de referências.

das inovações ou transformações introduzidas por Plutarco: "his role in the transformation and revitalization of several genres most suited to the elegant evolution of philosophical disquisition". Sobre estes tratados etiológicos, vide os trabalhos reunidos em P. Payen (Ed., 1998).

${ }^{217}$ Cf. J. Boulogne (1992: 4682-4702). Segundo R. Preston (2001: 109), "the difference between the strategies deployed to provide ali $\tau$ a in the Roman Questions, and those used in the Greek Questions, reinforces the opposition between Roman culture as Other and Greek culture as Self". Embora esta afirmação seja válida, parece-nos que a intenção de Plutarco, socorrendose da tradição etiológica, é reforçar a partilha cultural entre Romanos e Gregos, sendo estes a base, pois foram eles que ajudaram a banir a barbárie primitiva dos Romanos.

${ }^{218}$ Cf. E. Bowie (1970: 3-41) e (1974: 208-9), G. Anderson (1989) e (1993), S. Swain (1998r), T. Whitmarsh (2001) e (2005); para P. Vasunia (2003: 382): "the engagement with the past that occurs in Plutarch and the Second Sophistic is part of na attempt to forge a Greek cultural identity under the conditions of Roman colonisation"; a propósito da geografia da Segunda Sofística e das variantes culturais, vide E. Bowie (2004: 65-75). 
A diferença de tratamento da paideia entre Gregos e Romanos nas Vitae pode ser detectada em vários aspectos. Quando Plutarco enfatiza a educação de um Romano, como é o caso de Marcelo, quase nada sabemos sobre o elemento grego do par (Pelópidas) ${ }^{219}$. Nos casos em que se verifica exactamente o contrário, ou seja, em que temos várias informações sobre a educação dos Gregos, como acontece nas biografias de Alcibíades ou Alexandre, Plutarco raramente estabelece um nexo entre os defeitos ou as virtudes desses homens e a paideia. Daqui se pode desde já concluir que Plutarco, embora trabalhasse nas várias vidas de forma simultânea, pretendeu analisar a paideia dos Gregos e dos Romanos de forma distinta. Talvez o par Coriolanus-Alcibiades seja aquele em que encontramos um maior equilíbrio no tratamento do tema da paideia, embora no caso do Grego a educação esteja ligada a uma figura com o peso cultural de Sócrates, daí que Plutarco estabeleça um contraste entre a formação filosófica de Alcibíades e o treino físico e militar de Coriolano ${ }^{220}$.

Em relação a esta diferença de tratamento, há casos que são absolutamente paradigmáticos. No bios de Demóstenes, o Queronense não estabelece qualquer relação de causa-efeito entre uma deficiente educação e as kakiai do orador, mas na do seu par romano, Cícero, realça o desejo de philotimia e de doxa e, em especial, o momento do exílio em que a educação mostrou as suas falhas ${ }^{221}$. Um outro caso ocorre no par Coriolanus-Alcibiades, onde os erros do Romano são claramente atribuídos à falta da paideia ${ }^{222}$, por ser um homem

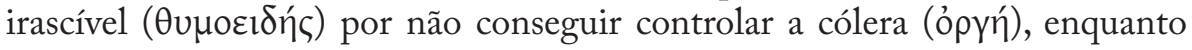
na biografia de Alcibíades refere os defeitos realçados por Sócrates no seu carácter ${ }^{223}$, mas, ao longo da narrativa, não volta a abordar este assunto. Um caso mais caricato, por isso aqui registado, encontramo-lo no par PyrrhusMarius, em que se desenvolvem vários elementos sobre a paideia de Pirro ${ }^{224}$. É na biografia do Romano, no entanto, que Plutarco expõe os defeitos que são comuns a ambos. Preferia Plutarco estabelecer esse nexo nas biografias romanas por ser ele próprio um heleno? Pensamos que não, até porque os destinatários da sua obra não eram exclusivamente os seus compatriotas. Deste facto resultam dois aspectos: primeiro, apontar num Grego uma educação filosófica e retórica seria certamente menos extraordinário do que fazê-lo na biografia de um Romano e, com isso, Plutarco insinua que a cultura grecoromana é dominada pelos valores e pelas formas de pensamento helénicos, pois os próprios Romanos se sentem seduzidos por essa paideia; além disso, a

\footnotetext{
${ }^{219} \mathrm{O}$ mesmo acontece nos pares Aem.-Tim. e Cim. - Luc. .

${ }^{220}$ Cf. Alc. 3.1-6.5 e Cor. 2.1.

${ }^{221}$ Cf. Cic. 32.5-7.

${ }^{222}$ Cf. Cor. 1.3-6, 15.4-5.

${ }^{223}$ Cf. Alc. 6.5

${ }^{224}$ Cf. Pyrrh. 1.4, 8.3.
} 
análise feita na segunda biografia do par, geralmente ocupada por uma figura romana, serve para clarificar o que havia sido dito na primeira biografia, tanto ao nível dos erros como das virtudes. Veja-se que a philonikia de Filopémen se compreende melhor quando a comparamos à philotimia de Flaminino, como também entendemos melhor a relação de Aristides com a politeia e o seu patriotismo depois da leitura da biografia de Catão Censor, e, de igual modo, a interpretação da ambição de Alexandre sai enriquecida quando se compara com o percurso de César. Por conseguinte, diríamos que se pode falar de um paralelismo estruturado e contínuo, de uma biografia para outra, e não de simples justaposição de biografias. Por isso mesmo, os princípios da paideia desenvolvidos por Plutarco devem, em nosso entender, ser lidos à luz de uma tentativa de criar preceitos comuns para Gregos e Romanos, sem eliminar diferenças próprias da contextualização histórica ${ }^{225}$.

Não se pense, contudo, que, nas biografias dos Romanos, os defeitos são sempre uma consequência da falta ou da deficiência da sua instrução. César é o expoente máximo da ambição romana ${ }^{226}$, mas esse seu excesso não é justificado com a ausência da paideia $a^{227}$. Do mesmo modo, Crasso e Pompeio são homens muito ambiciosos, mas, também nessas biografias, isso não é atribuído à falta de

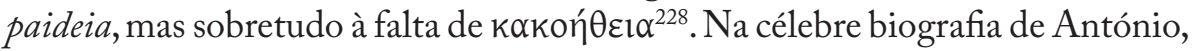
por sua vez, também não se considera que o ethos deste seja o resultado de uma educação diferente ${ }^{229}$, até porque, e talvez aí esteja o motivo, não interessa a Plutarco fazer nesse bios um contraste entre Helenos e Romanos. A biografia de Emílio Paulo ajuda também a perceber que Plutarco não aponta nos Romanos uma incapacidade nata para controlar os excessos. Apresenta-nos Emílio Paulo como um homem culto, que recebeu uma educação tipicamente romana e que, além de se mostrar favorável à $\mathrm{Grécia}^{230}$, privilegiando uma educação grega para os seus filhos ${ }^{231}$, encara o triunfo sobre Perseu com moderação e racionalidade notáveis, contrariamente ao rei macedónio.

A paideia, ou a sua ausência, nem sempre constitui a única forma de se explicarem os defeitos, como se constata na biografia de Catão de Útica, em

${ }^{225}$ R. Preston (2001: 105-6) escreveu a este respeito: "Plutarch's view of the world is not an arbitrary, cultural construction, but the only way of viewing the world. Indeed, Greek culture is not, therefore, cultural at all, since that would imply human agency, it is simply the natural order of things", assumindo, acrescentamos, a paideia helénica um lugar ímpar na naturalidade do devir histórico, no caso presente, do Império.

${ }^{226}$ Cf. Caes. 58.4-5.

${ }^{227}$ S. Swain (1990b: 133) considera que isso se deve ao facto de a ambição não ser destrutiva para ele.

${ }^{228}$ Cf. Pomp. 49.14 e Cras. 7.5; mas em Marc. 25.8 e Cic. 5.6 a análise é diferente.

${ }^{229}$ Cf. Ant.10.6 e 29.1.

${ }^{230}$ Cf. Aem. 27-8.

${ }^{231}$ Cf. ibid. 6.8-10. 
que os defeitos são relacionados com o interesse deste pela filosofia estóica. $\mathrm{Na}$ biografia de Bruto, pelo contrário, não se vislumbram críticas à sua conduta

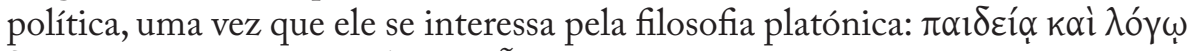

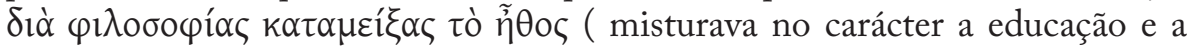
razão por meio da filosofia) ${ }^{232}$.

É também de salientar que Coriolano, Alcibíades e Sertório, além dos Gracos, têm não só em comum o facto de terminarem as suas vidas em conflito com as próprias cidades, mas também terem ficado cedo órfãos de pai. Há, no entanto, uma diferença significativa neste conjunto de heróis que sublinhamos aquando da análise dessas biografias: se, nas vidas dos Romanos, se evidencia o papel educativo da mãe após a morte do pai, na de Alcibíades, porém, referem-se vários pedagogos, sem se aludir à educação recebida da mãe. Isto poderá resultar de uma diferença cultural entre Romanos e Gregos, facto que se comprova quando Plutarco, nas biografias romanas, dá maior relevo ao papel educativo que as mães desempenham nos filhos órfãos e as consequências dessa proximidade.

Este conjunto de elementos prova, segundo nos parece, que as circunstâncias e não apenas a paideia explicam, em alguns casos, os defeitos dos biografados. Mais do que a quantidade de pormenores educativos, interessa enfatizar a ideia de que Plutarco aponta erros e virtudes tanto a Gregos como a Romanos, mas é especialmente nas vidas destes últimos que identifica a deficiente paideia como a causa principal dos erros, tornando este aspecto central na análise do ethos dos Romanos e no momento de apontar diferenças. Veja-se que é sempre a paideia grega que está em causa, aquela que os Romanos imitam e tentam cultivar. Se nem sempre ela foi suficiente, talvez isso prove que a paideia não era congénita e eles não a assumiam plenamente. Quanto aos Gregos, ainda que a paideia lhes fosse algo natural e mesmo inconsciente, o que terá levado Plutarco a não sentir a necessidade de se alongar muito nas considerações que tece nas biografias, também não são perfeitos e cometem erros. Isto indicia que a paideia é um processo contínuo de elevada exigência, pois cada indivíduo é colocado perante situações em que terá de responder segundo a sua formação e a sua própria razão, uma vez que $\mu \alpha v \theta \alpha ́ v \varepsilon l v$ é $\pi \alpha ́ \sigma \chi \varepsilon \varepsilon v^{233}$.

Parece não haver dúvidas de que a concepção plutarquiana de paideia privilegia os valores e os ideais helénicos, sem que isso signifique total desprezo pelas realizações romanas, pois, como temos vindo a referir, a paideia não é um exclusivo dos heróis Gregos das Vitae. De facto, Plutarco não disfarça a sua

${ }^{232}$ Brut. 1.3 ; cf. ibid. 2.2-3 (Bruto e o contacto com a filosofia platónica por meio de Antíoco de Ascalão, com quem também Cícero recebeu lições; Bruto estava receptivo a aprender com outros

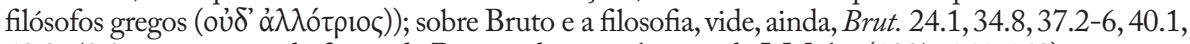
48.2, 52.2 ; a propósito da figura de Bruto e da sua cultura, vide J. Moles (1997: 141-168).

${ }^{233}$ Cf. Cat. Mi. 1.8. 
admiração pela capacidade empreendora e organizativa dos Romanos, mesmo que isso nem sempre se possa atribuir à sua arete, mas à tyche ou ao daimon, até porque ele sabia que também na história grega nem tudo se justificava exclusivamente pelo mérito pessoal.

Além disso, a paideia, só por si, não garante a vitória, a glória, a perfeição ou a felicidade, seja para os Gregos, seja para os Romanos, uma vez que cada indivíduo está sujeito a acontecimentos inesperados que podem alterar o rumo da sua vontade, como acontece a Sertório, um homem sempre associado a conflitos, apesar de não serem ditados pela sua natureza. Cícero, Flaminino, Marcelo ou Luculo ${ }^{234}$ foram confessos admiradores da $\pi \alpha i \delta \varepsilon i ́ \alpha$ 'E $\lambda \lambda \eta v i k \eta ́$, mas isso não foi suficiente para que se tornassem paradigmas para os outros. Do mesmo modo, Pelópidas, Filopémen e Alcibíades, nascidos na pátria do conhecimento, das artes e da cultura, não careciam de defeitos. Daqui se pode concluir que a paideia pode variar de época para época e consoante o espaço, noção que já estava presente, por exemplo, em Xenofonte ${ }^{235}$.

O entendimento que temos da paideia é que ela é, sobretudo, um exercício ou uma atitude que visa o conhecimento e que intervém na natureza humana, a qual tanto se deixa seduzir pelo bem como pelo mal, cabendo à paideia o papel de dotar cada ser das competências necessárias para encontrar as soluções mais justas e equilibradas. Como apontámos na análise das biografias, Plutarco atribui muito valor à forma como os heróis são capazes de se autocontrolar e, nesse contexto, a forma como se relacionam com as riquezas (despojos de guerra, geralmente) assume um significado digno de ser assinalado ${ }^{236}$. Ora, o desejo pela riqueza ou pela luxúria não é algo que está, por inerência, na alma, mas é uma doença que aí se infiltra devido a razões externas ${ }^{237}$, e, além disso, o dinheiro, só por si, não explica a degeneração moral ${ }^{238}$. Nesse sentido, a paideia deve contribuir para a moralidade e a ética da sociedade e do indivíduo.

${ }^{234}$ S. Swain (1990a: 192-203) analisa a relação de Cícero, Catão de Útica e Bruto com a paideia: Cícero e Bruto com o platonismo; Catão de Útica com o Estoicismo, que Plutarco reprova; Este autor verifica que "the role of Platonism is not overdone in 'Brutus', and really Brutus himself has similarities with an idealized statesman like Numa; unlike Cicero and Cato with their human flaws, Brutus like Numa emerges as something of a moral abstraction whose one major failing Plutarch excuses by a method, unique to him, of pointing to the failings of others" (193-4).

${ }^{235}$ Cf. Anab. 4.6.14-16: diferenças da paideia em Atenas e Esparta.

${ }^{236}$ Aristides (cf. Arist. 5.5), Pelópidas (cf. Pel. 3.1-4) e Filopémen (cf. Phil. 3.1, 15.4-6) são bons exemplos, pela forma como se relacionaram com a riqueza; sobre a justa atitude que o sábio deve ter com o dinheiro, vide D. Babut (t2003: 342 ss.).

${ }^{237}$ Cf. Cat. Ma. 18.4-5.

${ }^{238}$ Cf. Ant. 24.9 e Cam. 2.6. Quando questiona as razões da corrupção na sociedade romana, na biografia de Catão Censor, Plutarco não aponta a luxúria e a cultura helénica como causas,

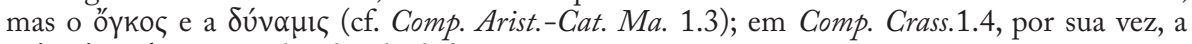

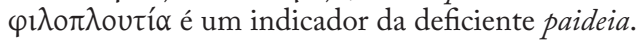


$\mathrm{Na}$ análise da paideia, Plutarco tem a seu favor o xpóvos, na medida em que a adopção de uma atitude de estudioso e observador da História the possibilita ver os efeitos que uma determinada atitude teve no devir histórico. Isso é evidente quando analisa a posição conservadora de Catão Censor contra os efeitos da introdução da cultura helénica na $V r b s^{239}$. Se, para Catão Censor, isso pode pôr em causa as acções (pragmata) futuras, para Plutarco, com uma visão temporal e espacial naturalmente distinta, a $\pi \alpha 1 \delta \varepsilon i ́ \alpha$ 'E $\mathrm{\lambda} \lambda \eta v i k \eta ́$ ajudou Roma a atingir a akme. Um bom contraponto a Catão e à sua atitude defensiva e conservadora para com a cultura grega é Emílio Paulo, seu contemporâneo, pela forma ${ }^{240}$ como admirava os valores da $\pi \alpha 1 \delta \varepsilon i ́ \alpha$ 'E $\lambda \lambda \eta \nu \imath k \eta ́:{ }^{241}$

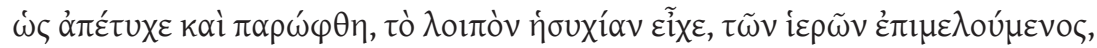

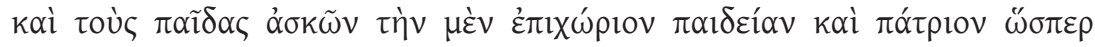

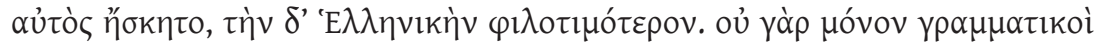

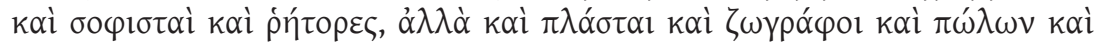

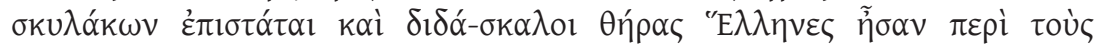

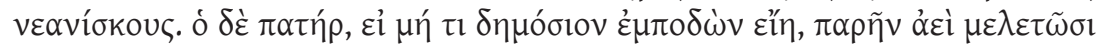

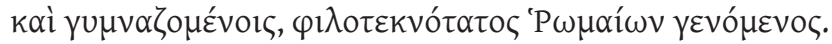

Como não alcançou o consulado e foi desdenhado, Emílio mantinha-se quanto ao resto tranquilo, ocupando-se dos sacrifícios divinos e proporcionando aos filhos quer a educação da sua pátria quer a ancestral, como ele próprio havia recebido, mas dedicando maior zelo à cultura grega. De facto, eram gramáticos, sofistas e retores, mas também escultores, pintores, domadores de potros e de cachorros, mestres de caça - todos Gregos — os que acompanhavam os jovens. $\mathrm{O}$ pai, se não tivesse nenhum impedimento relacionado com assuntos públicos, assistia sempre aos estudos e aos exercícios, dando mostras de ser entre os Romanos o que mais amava os seus filhos.

O texto explana a preocupação de Emílio Paulo com a educação dos filhos. Complementava a educação tradicionalmente recebida por um jovem aristocrata romano com realce especial para matérias helénicas. O elogio no final do texto tem certamente um efeito preventivo nos leitores, se tivermos em conta que Emílio Paulo repudiou, sem motivo aparente, a sua primeira esposa, tendo dado, como a lei previa, em adopção os dois filhos (Quinto Fábio Máximo Emiliano adoptado pela família dos Fábios Máximos e Públio Cipião Emiliano por Públio Cipião, filho de Cipião Maior). Além disso, Plutarco alerta para o facto de a carreira política de Emílio Paulo, na qual se inclui, por

${ }^{239}$ Cf. Cat. Ma. 23.3 (ver análise na Parte 2,1.2.2.).

${ }^{240}$ A filha de Emílio Paulo, Emília Tércia, casou com o filho de Catão Censor; Cf. Aem. 21.1 e Cat.Ma. 20.12.

${ }^{241}$ Aem. 6.8-10 (na p. 325, este texto é parcialmente citado). 
exemplo, a campanha que promoveu na Grécia, entre outras em que participou, o terá privado de estar próximo dos seus descendentes.

Ainda em relação a Catão Censor e à sua atitute defensiva para com a cultura grega, ela está associada a uma ideia que tem ressonâncias diversas na cultura latina: a de que o helenismo poderia ser nocivo, por promover a luxúria e a degradação dos valores ancestrais dos Romanos ${ }^{242}$. Plutarco, porém, esclarece que não concorda com esses receios, demonstrando, por meio de Aristides, o par de Catão Censor, que os Gregos cultivam a simplicidade e a philantropia, princípios que não se opõem à austeridade.

Se tivermos em conta que os diversos valores que Plutarco desenvolve nas Vitae têm, em primeiro lugar, uma motivação pessoal e que, de seguida, se tornam princípios gerais da sociedade, também a paideia tem esses dois níveis, apelando o autor à racionalidade humana e à própria paideia, de modo a conseguir ultrapassar os excessos e os desafios impostos pela vida ou pelo destino. Por isso, entende-se a valorização da paideia no seio da politeia, uma vez que se tem por objectivo a preparação de indivíduos que saibam, com competência e autoridade moral, governar e conduzir os seus concidadãos para uma vida tranquila e feliz. Como a filosofia ocupa um lugar muito importante no processo formativo, podendo ser ela a base da eudaimonia, Plutarco considera-a essencial na vida dos seus heróis.

É elucidativa a este respeito a concepção que Plutarco tem de um filósofo. No tratado De Alexandri fortuna aut uirtute i, considera que Alexandre, numa época marcada por crises e convulsões na Grécia e na Macedónia, pode ser considerado um filósofo, por ter civilizado ${ }^{243}$ reis bárbaros, por ter fundado cidades e por ter ensinado os princípios da lei e da paz a tribos que

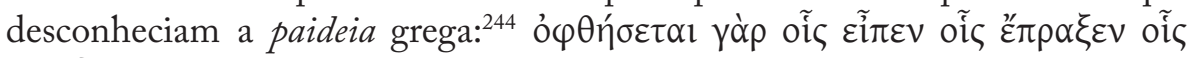

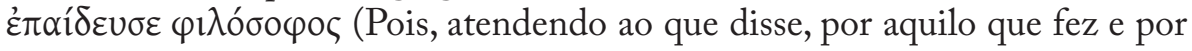
aquilo que ensinou, vê-se que foi um filósofo). Desta forma, reforça-se, por um lado, a ideia de que Alexandre é um homem de acção e de pensamento ${ }^{245}$, e, por outro, de que a filosofia não é um conjunto abstracto de ideias, mas que pode participar directamente na acção ${ }^{246}$ ou manifestar-se por meio da palavra ${ }^{247}$,

${ }^{242}$ Cf. E. Gruen (1995: 223-71).

${ }^{243}$ Cf. De Alex. fort. aut uirt. 329A.

${ }^{244}$ Ibid. 328B.

${ }^{245}$ Cf. e.g. ibid. 329B.

${ }^{246}$ A relação entre filosofia e acção não era aceite por todos os Gregos, além de ser uma concepção com oscilações consoante as épocas. Lembramos, a este propósito, o episódio contado em Pel. 5.3-4: enquanto Pelópidas e outros foram banidos, Epaminondas permaneceu na pátria pelo facto de os inimigos o considerarem uma pessoa inofensiva, uma vez que se dedicava à filosofia e, além disso, vivia na pobreza, o que fazia dele uma pessoa pouco influente.

${ }^{247}$ Para aqueles que apenas subscrevem a filosofia ao domínio da escrita ou da palavra, Plutarco, imediatamente antes do passo citado lembra que tanto Pitágoras como Sócrates, 
pois ele, como difusor do helenismo, metamorfoseou os povos orientais: ${ }^{248}$

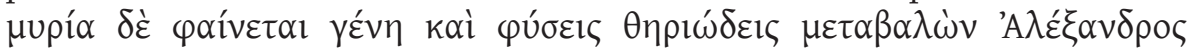
(manifestamente, Alexandre transformou muitas raças e naturezas selvagens). Aliás, isso demonstra que esses povos bárbaros estavam propensos a serem civilizados e que a helenização passa sobretudo pela paideia ${ }^{249}$ e não pela força: Alexandre promoveu, como um gesto da homonoia, os casamentos mistos ( $\gamma \alpha \mu \varepsilon \tilde{v} v$, verbo que significa uma instituição social distinta do simples relacionamento sexual) ${ }^{250}$ e fez com que os Bárbaros adoptassem as práticas religiosas dos Gregos ${ }^{251}$. Diga-se que a difusão do helenismo passa também pela aquisição da cultura literária, nomeadamente pela leitura de Homero, Sófocles ou de Eurípides ${ }^{252}$, tal como nas cidades fundadas por Alexandre se adopta a organização política das cidades gregas ${ }^{253}$. Por estes motivos, pode dizer-se que existe uma confluência entre os conceitos de civilização e helenismo, uma vez que os povos orientais parecem passar da barbárie à civilização, que é a civilização grega. Salvaguarde-se, no entanto, que, nas Vitae, não são apenas os Gregos que civilizam mediante os seus valores, pois Plutarco também realça o papel civilizador de Sertório na Península Ibérica.

Tanto a paideia como a moralidade daquele que exerce um cargo público têm, na obra de Plutarco, um sentido especial porque se vive numa época em que a Grécia é dominada pelo Imperium ${ }^{254}$. Assim sendo, era não só importante e vantajoso haver um bom imperador, louvando Plutarco a figura do princeps optimus, como Nerva, Trajano e Adriano, por oposição ao tirano, pois ele próprio testemunhou as políticas de Nero e Domiciano, como também era indispensável que o procurador romano nas poleis gregas fosse moderado, de modo a evitar os excessos e os pathe $e^{255}$.

Arcesilau ou Carnéades são considerados filósofos e nada escreveram.

${ }^{248}$ De Alex. fort. aut uirt. 329A.

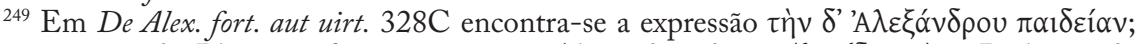
no mesmo tratado, Plutarco afirma mesmo que Alexandre educou ( $\dot{\pi} \alpha i ́ \delta \varepsilon v \sigma \varepsilon)$ os Bárbaros, da mesma forma que os filósofos ensinaram os seus discípulos, mas com maior eficácia, apreciação que revela algum sentido irónico.

${ }^{250}$ De Alex. fort. aut uirt. 328C.

${ }^{251}$ Ibid. (os Índios veneram deuses gregos e os Cítios, em vez de comerem os mortos, enterram-nos).

${ }^{252}$ Ibid.

${ }^{253} \mathrm{Ibid}$.

${ }^{254}$ Como referimos anteriormente, Plutarco, em Praec. ger. reip., defende a concórdia entre os aristocratas gregos e o poder romano, uma vez que não se deve suscitar a revolta dos cidadãos sob o domínio estrangeiro. Numa atitude conservadora, própria da aristocracia, procura indicar formas de se aproveitar a liberdade existente e o clima de pacificação social. Plutarco impõe, especialmente, limites a manifestações nacionalistas ou patrióticas, mas não abdica da intervenção da paideia na política e na sociedade, pois é por essa via que pode manter a sua eleutheria, da qual ele é muito zeloso, mesmo que seja mais interior do que exterior.

${ }^{255}$ Cf. Praec. ger. reip. 813E; o logos e a paideia, num processo de formação dos costumes, são 
Por isso, entende-se que o homem deve ter uma formação capaz, para participar na construção de um Estado sólido, organizado e equilibrado ${ }^{256}$, pois aquele que não tem educação (apaideutos), e é, por isso, mais susceptível de se deixar guiar pelas emoções do lado irracional da alma ${ }^{257}$, viverá condicionado pela boa ou má tyche. Recuperando, por um lado, a imagem platónica ${ }^{258}$ do homem como um animal domesticado e, por outro, a ideia aristotélica ${ }^{259}$ de que o homem é um animal com claro instinto social e político, Plutarco entende a actividade política e a vocação colectiva do homem ${ }^{260}$ como algo

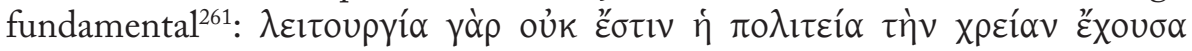

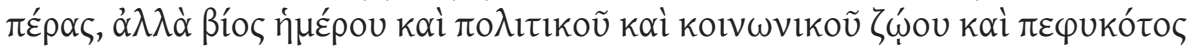

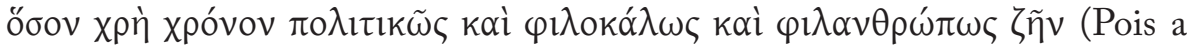
actividade política não é nenhum serviço público que tem o que se pede como fim, mas é o tipo de vida de um animal domesticado, social e político, e que nasceu para viver o tempo que lhe está destinado em prol da cidade, do bem e dos homens).

As virtudes de um homem com responsabilidades políticas devem ser: valor, honestidade, justiça, sabedoria e capacidade para ganhar o afecto dos soldados $^{262}$. Sobre esta última, Plutarco considerava-a mais um defeito do

essenciais para se evitarem as paixões (cf. De coh. ira 452D); vide C. Jones (1971: $110 \mathrm{ss).}$

${ }^{256}$ Para representar a organização do Estado, o Queronense usa a imagem da colmeia (Cf. Praec. ger. reip. 813C, 818 C, 821A e 823F); não é uma imagem original porque já a encontrámos em P1., Resp. 520b, Pol. 301d-e e em Xen. Cyr. 5.1.24.

${ }^{257}$ Cf. De aud. poet. $31 \mathrm{C}$.

${ }^{258}$ Cf. $L g .766$ a.

${ }^{259}$ Cf. EE 1242a, 22-26 e Top. 128b, 15; Em De am. prol. 495C, Plutarco afirma que, por natureza, o homem é um ser sociável.

${ }^{260}$ Aristóteles já tinha sido suficientemente claro quanto aos objectivos da acção política

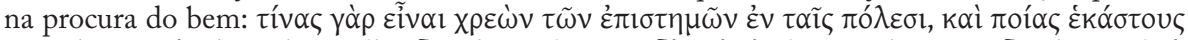

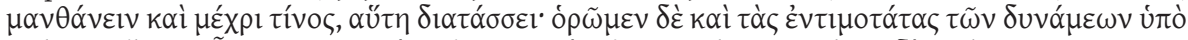

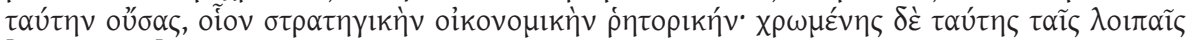

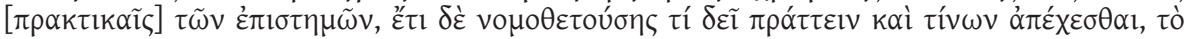

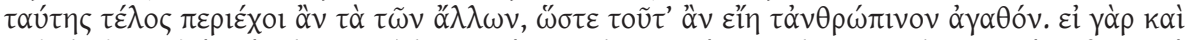

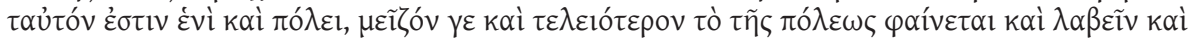

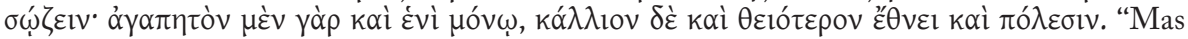
a perícia política não faz apenas uso das restantes outras perícias que dizem respeito à razão, ela ainda legisla a respeito do que se deve fazer e de que coisas se têm de evitar. $\mathrm{O}$ fim que ela persegue envolve de tal modo os fins das restantes, ao ponto de tratar-se do bem humano. Porque, mesmo que haja um único bem para cada indivíduo em particular e para todos, em geral, num Estado, parece que obter e conservar o bem pertencente a um Estado é obter e conservar um bem maior e mais completo. O bem que cada um obtém e conserva para si é suficiente para se dar a si próprio por satisfeito; mas o bem que um povo e os Estados obtêm e conservam é mais belo e mais próximo do que é divino." (EN1094a 28-1095a 10, trad. de A. Caeiro (2004)).

${ }^{261}$ An seni resp. 791C; vide descrição semelhante da vida política em De un. in rep. Dom.. 823C; em Cat. Ma. 24.11, contudo, Plutarco louva Catão pela sua dedicação ao serviço público (leitourgia), por ser algo vitalício.

${ }^{262}$ Luculo tem todas estas qualidades com excepção da última, como se pode ver em Luc. 
que uma virtude, em especial nos governantes ou nos generais do fim da República, que, por todos os meios, se empenhavam em conseguir o apoio dos soldados, muitas vezes sem moralidade, o mesmo se aplicando aos súbditos do Império ${ }^{263}$. Defende-se, acima de tudo, o ideal ético de que o homem deve dedicar o melhor que tem à causa pública. Esse mesmo homem deve respeitar a lei e saber ser útil à polis quando manda e quando é mandado ${ }^{264}$.

$\mathrm{Na}$ verdade, indicar as virtudes dos biografados nem sempre é uma tarefa fácil, uma vez que elas manifestam-se, na prática, de forma compósita e diversificada: ${ }^{265}$

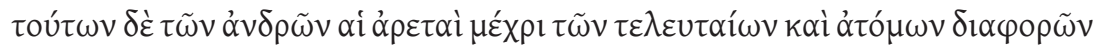

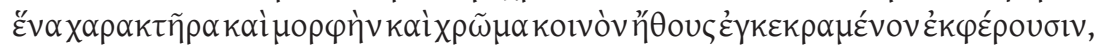

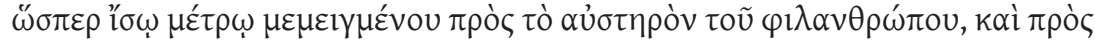

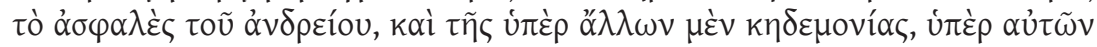

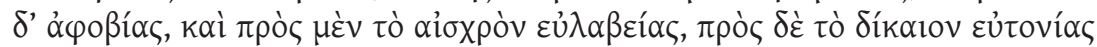

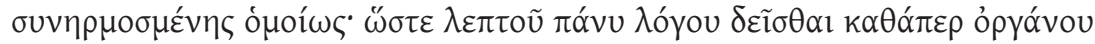

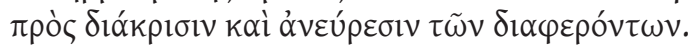

Mas as virtudes destes homens [Fócion e Catão de Útica] mostram, até às últimas e inseparáveis diferenças, um só carácter, aspecto e moral, formada de uma matiz comum, como se tivessem misturado em igual medida a austeridade e a humanidade, a coragem e a prudência, a solicitude pelos outros e a intrepidez por eles próprios, a precaução contra actos vis e o ardor, igualmente harmonioso, pela justiça. Por conseguinte, é necessário usar, como instrumento, um discurso extremamente subtil para separar e descobrir as diferenças.

Fócion, nascido em 402 a. C., era um ỏvì $\alpha$ $\gamma \alpha \theta o ́ \varsigma^{266}$ a quem chamavam

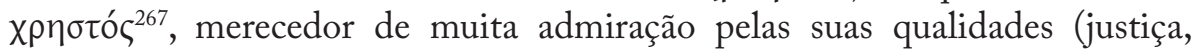
simplicidade, austeridade, entre outras, que a $\mu \varepsilon \gamma \alpha \lambda o \psi v x x^{\prime} \alpha^{268}$ sintetiza) em

36.5; Plutarco enumera as capacidades que um político deve ter em An seni resp. 792D.

${ }^{263}$ Cf. Sull. 12.11-12; sobre este assunto, vide C. Jones (1971: 100). A tradição historiográfica favorável a Luculo justifica os fracassos do general romano com a animosidade que mantinha com os soldados, que não teve origem na crueldade ou insensibilidade do general, mas no facto de Luculo, fazendo uso da moderação e da praotes (cf. Luc. 2.1), se opor às infracções cometidas na Ásia pelos soldados. Além disso Luculo não colocou de lado a sua firmeza, no momento de condenar os traidores e os soldados corruptos de Fímbria, habituados à desordem e à extorsão (cf. Luc. 7.1-2), que acabariam por se vingar do seu general; sobre Luculo, vide L. Ballesteros Pastor (1999: 333 ss.)

${ }^{264}$ Cf. Pl., Lg. 643e; Arist., Pol. 1261b, 47 e 1317a, 14; cf. A. Masaracchia (1995: 231 s.).

${ }^{265}$ Phoc. 3.8; cf. Mul. uirt. 243C e Quaest. conu. 732B.

${ }^{266}$ Cf. Phoc. 5.10.

${ }^{267}$ Cf. ibid. 10.4; Cornélio Nepos, em Phocion 1.1, diz que o cognome de bonus se devia à integritas uitae de Fócion.

${ }^{268}$ Cf. ibid. 36.1. 
todo o mundo helénico ${ }^{269}$, facto que lhe mereceu a eleição para estratego em quarenta e cinco ocasiões ${ }^{270}$ e até uma estátua ${ }^{271}$, embora também tenha cometido alguns erros, como a excessiva confiança que depositou em Nicanor. Ora este homem apresenta diversas semelhanças com Catão de Útica, figura importante da história romana do século I a. C., digno do nome de philosophos ${ }^{272}$ e também ele, como Plutarco, havia sido sacerdote de Apolo ${ }^{273}$. Além disso, no texto acima traduzido, é notória a intenção de Plutarco em aprofundar a análise psicológica dos seus heróis, em detrimento do rigor filosófico com que Platão tinha definido os actos virtuosos.

Deste retrato da paideia que temos vindo a desenvolver resulta ainda a ideia de que é, em grande medida, o género masculino que domina o processo formativo. Os educadores são homens e os educandos também, não se desenvolvendo muito o papel da mãe ou das amas, estas mais ligadas ao crescimento das crianças ${ }^{274}$. Na verdade, são os homens que precisam de ser formados para exercer o poder e a autoridade, enquanto para as mulheres, por lhes estar vedado o acesso às hierarquias da politeia, a paideia não tem o mesmo objectivo. No final do tratado De liberis educandis, sugere-se que a formação das mulheres serve essencialmente para educar os filhos ${ }^{275}$. Plutarco, no entanto, teria escrito um tratado sobre a necessidade de as mulheres serem educadas ${ }^{276}$, pensamento que não era propriamente uma novidade, uma vez que Platão, por exemplo, também já havia aflorado esse assunto ${ }^{277}$. Nos tratados Mulierum uirtutes e Coniugalia praecepta, ao contrário do que acontece nas Vitae, deixa passar algumas ideias sobre a paideia da mulher, nomeadamente o facto de a arete ser a mesma quando se trata de homens ou mulheres ${ }^{278}$ ou que é pelo

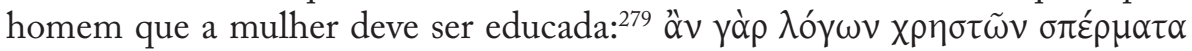

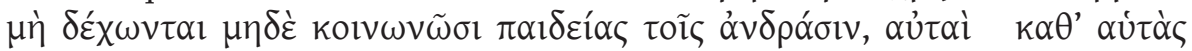

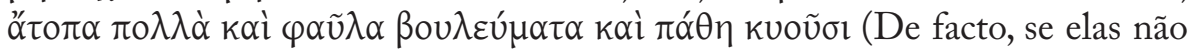
recebem as sementes de discursos úteis, nem participam, em comum com os maridos, da educação, elas próprias, sozinhas, originarão muitos e perniciosos

${ }^{269}$ Cf. ibid. 14.7.

${ }^{270}$ Cf. ibid. 8.2 .

${ }^{271}$ Cf. ibid. 38.1.

${ }^{272}$ Cf. Cat. Ma. 27.7.

${ }^{273}$ Cf. Cat. Mi. 4.1.

${ }^{274}$ T. Morgan (2000r: 48, n. 149) aborda as várias teorias que há sobre a literacia feminina na Antiguidade, recorrendo a vários estudos, uns mais optimistas outros mais moderados.

$27514 \mathrm{~B}$.

${ }^{276}$ Cf. frags. 128-32 Sandbach.

${ }^{277}$ Cf. Resp. 451d-457b, Lg. 804d-805b; em Lg. 658d, Platão refere-se às $\alpha i ̈ \tau \varepsilon \pi \varepsilon \pi \alpha 1 \delta \varepsilon u \mu \varepsilon ́ v \alpha l$

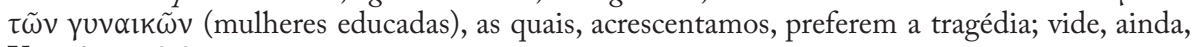
Xen. Symp. 2.9.

${ }^{278}$ Cf. Mul. uirt. $242 \mathrm{~F}$.

${ }^{279}$ Cf. Coniug. praec. $145 \mathrm{D}-\mathrm{E}$. 
projectos e sofrimentos). Assim, diríamos que Plutarco vê a paideia da mulher como uma forma de o oikos poder ter melhor qualidade de vida e um maior equilíbrio. Um pouco à semelhança do filósofo estóico Musónio Rufo ${ }^{280}$, considerado o Sócrates romano, o Queronense perspectiva a educação da mulher segundo a physis, com objectivos necessariamente diferentes da do homem. Note-se que, num contexto de androcracia, o vocábulo pepaideumenos aplica-se quase exclusivamente ao homem e raramente aparece no feminino. Mesmo quando se aborda a questão da formação feminina é segundo uma perspectiva masculina, com os mesmos modelos, sem que exista a intenção de tornar os dois géneros iguais, pois cada um tem na sociedade um papel distinto e também complementar.

Regressando ao tema de fundo do nosso trabalho, diríamos que, sem omitir as conotações filosóficas da paideia, a verdade é que Plutarco tenta conciliar o mais possível este e outros conceitos com o concreto. Por termos heróis muito vinculados à politeia, a construção dos modelos não é abstracta, mas racionaliza-se, humaniza-se e, diríamos mesmo, historiciza-se. A paideia conceptualiza-se no evolver histórico do qual é activa participante, uma vez que a indagação histórica tem muitas vezes por objectivo evidenciar o ethos dos seus agentes. Para Plutarco, o mais digno de ser recordado são precisamente as figuras históricas do passado, com as suas virtudes e defeitos, porque é nelas que está a génese do sentimento e da identidade própria. De uma amálgama composta pelo indivíduo, pela paideia, pela história (grega e romana) e pela retórica resultam biografias que são uma espécie de filosofia civil, domínio que haveria de ser explorado, por exemplo, por Kant ou por Eric Voegelin. Aliás, ao valorizar o ethos, Plutarco remete-nos para os preceitos aristotélicos, como observa V. Cilento: "the Lives are the daughters not of history, but of philosophy - above all the Nicomachean Ethics"281.

Por conseguinte, e atendendo aos heróis analisados, parece-nos que não existem quaisquer dúvidas da nítida correlação entre paideia e politeia, devendo o jovem ser preparado, para assumir o seu papel activo de cidadão. A paideia prepara para a politeia, podendo esta, caso os conhecimentos e os valores não estejam consolidados, corromper e anular a progressão gradativa da virtude. Ao longo das Vitae - que P. Stadter (2000: 504), considerando a audiência que tiveram, apelida de adult education program - Plutarco, baseando-se nos preceitos platónicos, peripatéticos e estóicos, não impõe uma paideia, mas usa um método diferente: cada um dos destinatários, ao ler as biografias, deve questionar-se sobre as suas qualidades. Nesse processo introspectivo, a sua consciência ditar-lhe-á se está mais próximo dos defeitos

\footnotetext{
${ }^{280}$ Cf. J. Dillon (2004).

${ }^{281}$ Citado por D. Russel (1966: 144).
} 
de António ou das virtudes de Aristides, da philotimia de Flaminino ou da philonikia de Filopémen, por exemplo. É fundamental que cada indivíduo saiba inspeccionar (ephoran) ${ }^{282}$ o seu carácter, com critérios rigorosos, de forma a corrigir os erros e a procurar a melhor forma de ganhar, cada vez mais, controlo sobre os seus excessos. A continuidade do processo educativo e a permanente (auto)-avaliação que a paideia impõe provam que cada um, depois de receber os ensinamentos dos mestres, terá de desenvolver capacidades e de ter um espírito crítico, para saber adaptar-se às contingências que a vida lhe traz a cada instante. Assim aconteceu com Alexandre que, tendo tido por mestre o sábio Aristóteles, manteve e intensificou, por sua própria vontade, a curiosidade intelectual e o gosto pela cultura, elementos basilares da sua acção no Oriente, ainda que essa formação não tenha sido suficiente para evitar que cometesse alguns erros decisivos, que condicionaram a prossecução dos seus planos.

Por isso, Plutarco prefere não apontar um modelo de paideia perfeita, até porque os seus heróis são de tempos e espaços diversificados, mas antes persuadir o seu ouvinte a observar com atenção as motivações, as decisões e as etapas que cada herói percorreu, de modo a tirar daí um proveito concreto para a sua vida. Aliás, o evolver do tempo é acompanhado pela progressão da arete, idealmente no sentido positivo, um processo do qual a paideia não se deve alhear. Como Plutarco entende que é problemático que a paideia recebida na infância seja só por si suficiente para o resto da vida, espera que as virtudes morais consigam prevalecer nos mais variados cenários (guerra, vida política ou família), pois acredita na capacidade humana. Mesmo aqueles que evidenciam muitos defeitos, como António, Demétrio, Alcibíades, Coriolano, Címon ou Luculo, também possuem grandes virtudes. Esta crença do Queronense, que pode ser considerada ingénua, preenche uma parte substancial da construção dos perfis psicológicos dos seus heróis e justifica a escolha de personagens menos positivas e a sua opção por não esconder o lado mais negativo. Nessa perspectiva, os ouvintes, especialmente os menos dotados de qualidades morais, devem sentir o apelo da paideia para enriquecer as suas vidas e imitar a grandeza e a nobreza dos homens do passado.

Não existe uma paideia perfeita, nem um modelo único que se adapte a todas as circunstâncias. Na synkrisis do par Lycurgus-Numa, Plutarco apresenta dois modelos de educação dos filhos: o sistema permissivo de Numa e o modelo mais directo de Licurgo, que Plutarco prefere, pois admira a grandeza moral e a capacidade pedagógica que o Espartano imprime à sua liderança:283

\footnotetext{
${ }^{282}$ Cf. De coh. ira $452 \mathrm{~F}-453 \mathrm{~A}$.

283 Comp. Lyc. - Num. 4.2-3
} 


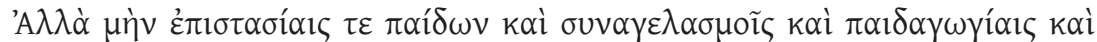

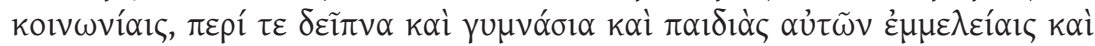

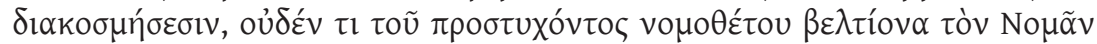

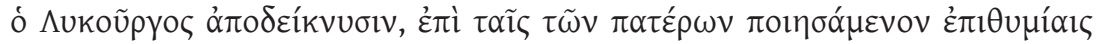

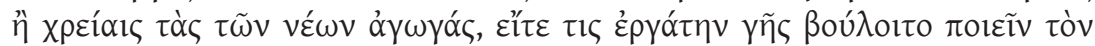

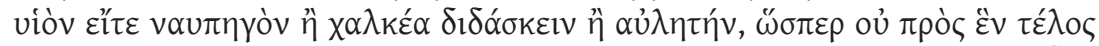

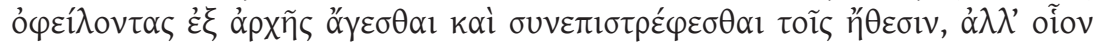

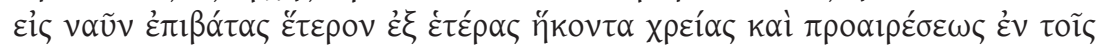

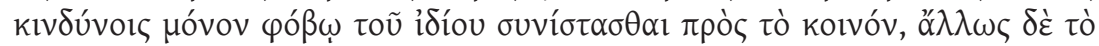

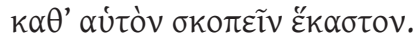

$\mathrm{Na}$ verdade, com a vigilância das crianças, a reunião em grupos, os métodos educativos, a convivência, a harmonia e a organização relativa a refeições, a exercícios e a jogos, Licurgo prova, sem dúvida, que Numa não era de modo nenhum melhor do que um qualquer legislador, uma vez que elaborou a educação dos jovens contra os desejos e o interesse dos pais, quer daquele que desejava tornar o filho um trabalhador da terra, quer do que queria ensinar o filho a ser construtor de barcos, ferreiro ou tocador de flauta, com a intenção de que, se não tivessem um propósito, deveriam desde o início ser guiados e dirigidos os seus hábitos, pois, como os que sobem a uma nau, vindo cada um por motivações e interesses diferentes, uniam-se, nos perigos, para o bem comum apenas por medo daquilo que era privado e, noutros casos, cada um zelava por aquilo que era seu.

As leis de Licurgo são mais duradouras, por oposição à efemeridade das de Numa, devido à sua permissividade. Ainda assim, a Esparta de Licurgo e

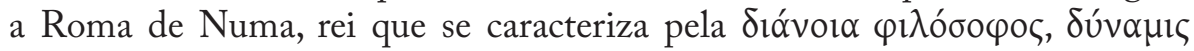

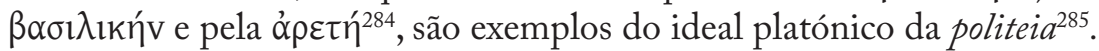

Atendendo aos perfis dos heróis que fomos traçando e ao papel da paideia no seu desempenho, notamos que, na concepção de Plutarco, os princípios que enformam o carácter de um herói podem levá-lo a praxeis brilhantes e épicas, mas também o podem empurrar para a catástrofe. Marcelo, por exemplo, por ser um philopolemos ${ }^{286}$, consegue tomar Siracusa e aí evidenciar o seu apelo pela cultura helénica, mas isso não é suficiente para ultrapassar as suas limitações, como a sua morte evidencia. $\mathrm{O}$ mesmo acontece com Alexandre, figura que concentra manifestações épicas e trágicas, complementadas com uma significativa presença de elementos civilizacionais. Refira-se, ainda, o efeito da philonikia de Filopémen e da philotimia de Flaminino, dois conceitos

${ }^{284}$ Cf. Num. 20.8-12.

${ }^{285}$ Cf. J. Hershbell (1995: 214). Em Num. 20.8, Plutarco escreve as seguintes palavras sobre

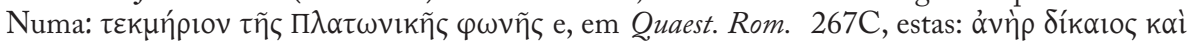

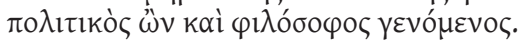

${ }^{286}$ Cf. Marc. 1.2-3. 
paradoxais por impulsionarem os heróis para feitos dignos de louvor, mas que também podem levar à desmesura.

A paideia integra, sem dúvida, o processo ético que Plutarco considera

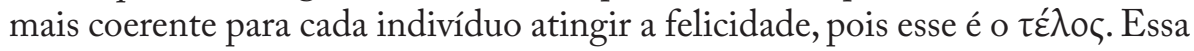
felicidade emana, em parte, da paideia ou da sabedoria, enquanto a infelicidade

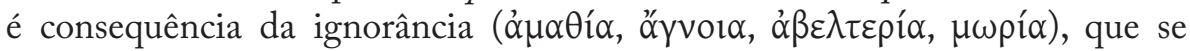
manifesta pelo domínio das paixões na alma ${ }^{287}$. Sendo o homem um ser que reúne o voũ $\varsigma$, a $\psi v x \eta ́$ e o $\sigma \tilde{\omega} \mu \alpha^{288}$, pode dizer-se que a paideia tem a virtude de equilibrar estes elementos, com a sua intervenção psico-somática. Não é apenas considerar, como faziam os Espartanos, que o mais belo dos ensinamentos é saber mandar e obedecer ${ }^{289}$, de modo a preparar os jovens para a actividade militar, mas incluir na paideia preceitos de ordem moral e filosófica, úteis para o exercício da politeia e para as relações do indivíduo com a família, os companheiros e a sociedade.

Querendo resistir ao perigoso impulso de generalizar, pois a diversidade de caracteres e de situações é deveras extensa nas Vitae, e o nosso trabalho não abarca a totalidade do corpus biográfico, importa ter presente no entendimento da paideia plutarquiana a sua natureza compósita. Não são apenas os mestres e as suas matérias formativas que podem ser diferentes, nem somente o interesse individual que pode ser diversificado (por exemplo, Cícero é mais curioso do que Demóstenes) ou a própria paideia que pode manifestar-se pela humanidade, pela simplicidade, pela doçura, pela justiça ou pela aversão ao excesso. É a consciência de que o ecletismo e o sincretismo filosófico, caracterizadores dos primeiros séculos da época imperial, influíram certamente nos contornos da paideia. A cada homem é colocado o desafio do exercício da sapiência ( $\varphi \rho o ́ v \eta \sigma ı)$ ), do logismos e da prática da virtude, no plano privado e público. A paideia, de facto, não é uma atitude meramente do plano racional ${ }^{290}$, segundo os preceitos dos Estóicos, mas deve ser implementada nas praxeis.

Por que motivo Plutarco pretendia reforçar na sua época os valores da paideia? O seu filo-helenismo, como atitude defensiva em face do poderio Romano, não parece justificar a intensidade dos seus conselhos e também a forma como aplica essa paideia aos heróis Romanos retira alguma força a uma leitura deste género, ainda que possa ser uma das razões. Julgamos que uma

${ }^{287}$ Esta concepção ética não é inovadora, pois Platão e Aristóteles desenvolveram a interdependência entre conhecimento e felicidade, preferindo o Estagirita valorizar o hábito da prática da virtude. Os estóicos haveriam de se concentrar no aspecto racional desta matéria, enquanto os Epicuristas no passional; cf. F. Becchi (2005a: 199-208).

${ }^{288}$ Cf. De fac. lun. $943 \mathrm{~A}$.

${ }^{289}$ Cf. Ages. 20.2.

${ }^{290}$ Plutarco exprime-se contra a ética teórica e abstracta em An corp. affect. 500E e An uit. ad inf. suff. 499E-F. 
outra justificação, mais coerente, se relaciona com o facto de Plutarco ter do seu tempo e dos homens que nele viviam uma visão pouco optimista, pois,

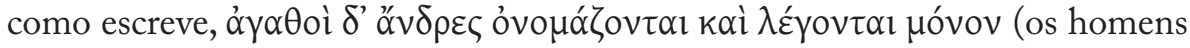
apenas são bons de nome e de reputação) ${ }^{291}$ e porque necessitam de se formar, de se exercitar e de provar as suas virtudes. Na época de Plutarco, vivia-se uma grande inquietação, em que a ira e a intemperança se propagavam, tal como a avidez de poder, de glória ou de riqueza, qualidades que se transformam em doenças da alma quando se tornam excessivas. O biógrafo, todavia, sabia que pouco podia fazer para combater esses males, a não ser propor os valores da paideia, assumidos individualmente e, depois, concretizados para o bem da sociedade.

Só um homem verdadeiramente formado poderia ajudar a banir os vícios e a conseguir ele próprio atingir a eudaimonia, de modo a contagiar os outros. Sobre esta questão, as palavras de F. Becchi (2005a: 207) são esclarecedoras: "per il Cheronese la saggezza, che rende la vita ad un tempo molto bella e piacevole, rappresenta l'arte più importante e perfetta e la pratica della filosofia, che è arte di vita, costituisce la condizione stessa della felicita e della pienezza dell'esistere". Deste modo, a paideia, ao estabelecer a ponte entre os valores helénicos e os ancestrais preceitos romanos, bem como a vocação destes para assuntos relacionados com a administração ou a politeia, serviria de base a uma sociedade que se queria mais equilibrada, não querendo Plutarco desperdiçar a oportunidade de dotar o imperium do espírito helénico, solução que amenizaria a pressão romana e salvaguardaria a memória cultural dos Gregos. Por conseguinte, ao contrário da paideia de Díon de Prusa, muito mais de âmbito filosófico do que educacional ${ }^{292}$, em Plutarco existe um maior equilíbrio entre a representação da necessidade da formação puramente educacional e o alcance filosófico da paideia, sem esquecer a ligação destes elementos ao exercício da politeia. O bom ethos pode nascer da paideia, por meio da influência desta na physis, cabendo ao núcleo do genos (ou eugeneia ${ }^{293}$, "bom nascimento", denotando uma origem distinta) também um papel relevante.

A forma como a bipolaridade, ou seja, os elementos identitários dos Gregos e dos Romanos, se confronta e dialoga entre si nas Vitae é o tema do capítulo que se segue, onde temos a intenção de avaliar até que ponto Plutarco veicula a ideia de uma sociedade una, utópica ou não, e se ela surge mais como

${ }^{291}$ Cf. An uirt. doc. 439A-B.

${ }^{292}$ Cf. E. Bowie (1991: 183-204). Em traços gerais, existe, para Díon de Prusa, uma paideia ligada à sophia, mais de âmbito livresco e escolar, e uma outra que se define melhor por meio da óv $\delta \rho \varepsilon i ́ \alpha$ e da $\mu \varepsilon \gamma \alpha \lambda$ $\varphi \rho \circ \sigma u ́ v \eta$.

${ }^{293}$ Cf. e.g., Thes. 7.2, Rom. 6.2, Cor. 15.6, Marc. 1.5 e 10.3, Arist. 12.2, Cat.Ma. 16.4, Sert. 15.2 e 25.2; De lib. educ. 1B e 5C, De aud. poet. 34D, De fort. Rom. 320D, De E Delph. 391A, De uit. pud. 535B, Praec. ger. reip. $798 \mathrm{~B}$ e $X$ or. uit. 842D. 
um desejo ou uma necessidade por parte dos Gregos, acabando a paideia não só por ter um papel civilizador, bem ilustrado por Alexandre, mas também por constituir uma possibilidade de manter a eleutheria, mesmo que seja, em determinados períodos históricos, mais espiritual do que factual.

Se chegou a vingar na Grécia a ideia de que a paideia tinha limitações biológicas ou étnicas, as conquistas de Alexandre vêm demonstrar que outros homens, inclusive Bárbaros, podem partilhar desse ideal. Na verdade, as Vitae provam que a paideia é uma possibilidade para Gregos e não-Gregos (Romanos e Bárbaros), tendo o Império Romano também ajudado a abolir as fronteiras e a difundir a bumanitas $^{294}$, como meios de formar o homem (Bildung). Assim, deixa de ser o espaço a definir o homem, mas os valores que ele cultiva e manifesta na sua praxis. Isto contribuíu para um melhor conhecimento do outro e para aprofundar o saber intelectual, com a intensificação da comunicação intercultural.

A paideia é crucial para o entendimento da construção, um pouco elitista, da identidade do espaço greco-romano ${ }^{295}$, das actividades que se geram nas poleis e do impacte que a governação romana tem na Grécia e nas suas colónias, uma vez que ela tem implicações no perfil de cada indivíduo e também a nível social e político. $\mathrm{Na}$ sua manifestação literária, a paideia, como testemunham as Vitae, não pode ser descontextualizada do mundo onde emerge ${ }^{296}$, pois molda-se em função dele e ajuda a comprendêlo melhor, havendo uma dinâmica recíproca e complexa entre texto e realidade exterior. Note-se que, no decorrer da Época Helenística, de forma a responder às novas necessidades de um mundo mais abrangente, surge a preocupação de criar um projecto para a educação intermédia, entre a acção desenvolvida, por um lado, pelo paidagogos e pelo grammatistes (ensinava a leitura, a escrita, a aritmética e a literatura; além disso, o aluno dedicavase à música e à educação física; a medicina e retórica eram ensinadas em escolas especializadas) e, por outro lado, pelas escolas superiores (escola de filosofia e retórica de Isócrates; a Academia de Platão, com matemática e filosofia; o Liceu de Aristóteles). Para cumprir esse objectivo, ampliou-se o plano de estudos ${ }^{297}$, ganhando forma o conceito da $\varepsilon$ $\gamma \kappa u ́ k \lambda$ เo $\pi \alpha \imath \delta \varepsilon i ́ \alpha$, que é

${ }^{294}$ Humanitas engloba o sentido de philanthropia e de paideia, pelo menos no tempo de Varrão e Cícero (A. Gel. 13.27). Na época imperial, conserva quase exclusivamente o sentido de philanthropia, passando as palavras doctrina e disciplina, por exemplo, a traduzir o sentido de paideia. Remetemos para as explicações de M. H. Rocha Pereira (19892: 417-423) sobre a humanitas.

${ }^{295}$ Cf. e.g. G. Anderson (1989) e (1993), E. Bowie (1991), S. Swain (1998r).

${ }^{296}$ A propósitio de Plutarco e desse mundo, vide C. Pelling (1989), S. Swain (1990a) e (1990b), e T. Duff (2002r).

${ }^{297}$ Relativamente às disciplinas que faziam parte da enkyklios paideia, escreveu H. Marrou (t1990: 277) que a "enkyklios paideia procurou absorver a filosofia e também outras disciplinas 
como a Medicina, arquitectura, direito, desenho e arte militar. Porém, a sua base programática continua a ser constituída pelo trivium (gramática, retórica e dialéctica) e pelo quadrivium (geometria, aritmética, astronomia e teoria musical), segundo a divisão tradicional".

${ }^{298}$ De lib. educ. 7.3; H. Marrou (t1990: 276) refere a propósito da enkyklios paideia: "Com efeito, nos escritores da época helenística e romana encontram-se numerosas menções deste termo, que não caberia transcrever literalmente por "enciclopédia", noção esta bem moderna (a palavra data apenas do século XVI) e que não corresponde, absolutamente, à expressão antiga. "Enciclopédia" evoca, para nós, um saber universal: por mais elásticos que possam ter sido

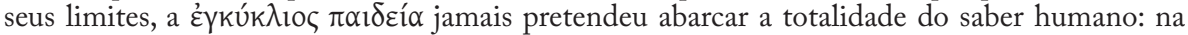

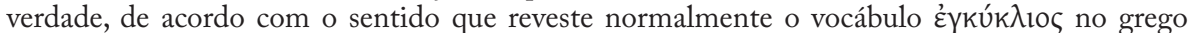

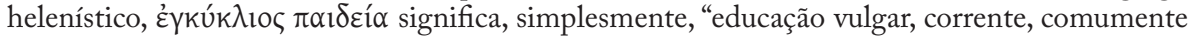
transmitida" - donde a tradução que propus: "cultura geral". Tal noção sempre apresentou contornos bastante vagos: o uso que dela se faz hesita entre duas concepções: ora é a cultura geral que convém ao perfeito cavalheiro, sem referência explícita ao ensino, e que reúne o teor de toda a educação, secundária e superior, escolar e pessoal; ora é a cultura de base, a propedêutica, as $\pi \rho \circ \pi \alpha 1 \delta \varepsilon u ́ \mu \alpha \tau \alpha$, que devem preparar o espírito para receber as formas superiores do ensino e da cultura, ou, numa palavra, o programa ideal do ensino secundário. Esta concepção é, em

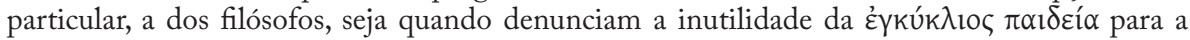
cultura filosófica, como o fazem Epicuro e, com ele, os cínicos e o céticos de todas as escolas, seja quando insistem em sua necessidade, como convém fazê-lo a maioria das seitas e, notadamente, desde Crisipo, os estóicos"; vide também G. Lachenaud (1997 : 65-102). Não podemos deixar de referir o estudo de T. Morgan (2000r), por definir a evolução do sentido e da estrutura da enkyklios paideia. Na conclusão, afirma T. Morgan (op. cit.: 272): "Nor did enkyklios paideia hold quite the unchallenged eminence in society that some of its apologists liked to claim. It competed everywhere with other forms of educations - numerate, physical, military, professional and social education, to name only a few - which had a value and values of their own. The development of the young took place in a dense web of influences, which was not less real because writers on literate education chose by and large to ignore it. Those who learned to read and write may have learned many other things that they valued more highly than Homer or grammar. Moreover, illiteracy, which remained the condition of the vast majority throughout antiquity, was not the disastrous handicap in most areas of society that writers on literate education would like us to believe. The force with which some authors promote enkyklios paideia may be a sign not so much of success as of competition - of the need to stake their claim to importance in a society which did not necessarily take the status of literate education for granted"; cf. Arist., Pol. 1269b, Cael. I 279a (enkyklia philosophemata), Dem., 20.21,25.74, Estrabão, Geog. 1.1.22 (a enkyklios agoge dá qualificação cultural, por oposição a apaideutos. Entre os autores latinos, Plínio-o-Velho (cf. Nat. $1,14)$, por exemplo, recomenda o enkyklion paideuma grega como prefácio a outras actividades; por sua vez, Vitrúvio (De arch. 6.4) aconselha-a como introdução ao estudo da arquitectura; é, no entanto, Quintiliano (1.10.1) que define as áreas educativas da orbis doctrinae: leitura e escrita; gramática; literatura; geometria; astronomia; princípios de música e lógica; como se constata, Quintiliano exclui a filosofia da orbis doctrinae, tal como a retórica; os autores latinos tardios não usaram a expressão orbis doctrinae, mas institutio, educatio, studia, liberalia studia, artes, principia, praecipienda ou litterae. Ainda relativamente à relação entre a enkyklios e a filosofia, N. Abbot (1980: 162) tece as seguintes considerações: "The old Academy and Peripatetics considered them an indispensable preparation for the study of philosophy (...), while Cynics, Cyrenaics and Epicureans because of their preoccupation with ethics, and Sceptics because of their reservations about the possibility of knowledge, attached no importance to them at all. The Stoics were sometimes closer to the second view (e.g. Zeno, at least in his Politeia: SVF I 129), sometimes to the first (e.g. Chrysippus SVF III 378, Posidonius). P's attitude to the encyclia, to judge from this passage, is mildly positive: he evidently sees some value in them and wishes 
educação mais diversificada, o jovem estaria mais bem preparado para dar o seu contributo à sociedade. Nas Vitae, apenas uma menção se faz da enkyklios paideia, na biografia de Alexandre ${ }^{299}$, o que pode significar que no século IV a. C. esse tipo de educação seria normal, mas a tradição não o parece confirmar, uma vez que não se refere a ela. Significa isso que a referência de Plutarco na biografia do Macedónio pode ser anacrónica, porventura por a enkyklios paideia estar devidamente consolidada na Época Imperial.

Para Plutarco, o projecto da paideia $a^{300}$ é, sem dúvida, simultaneamente uma necessidade e uma possibilidade que o indivíduo deve aprofundar. Essa paideia, com conotações pedagógicas, filosóficas e éticas, confunde-se com grecidade e civilização, por oposição à barbárie. $\mathrm{Na}$ concepção do mundo, parece haver um momento antes da paideia e um momento depois dela, em que a cultura helénica ocupa um plano de natural superioridade, como as Quaestiones Romanae comprovam, pois é nesse sentido que Plutarco aconselha os Romanos a não terem práticas religiosas ao estilo dos Bárbaros, mas a comportarem-se à imagem dos Gregos ${ }^{301}$.

Resulta, assim, que a paideia é um traço identitário, independente do genos, da língua ou do local onde se vive. Mais importante do que "ser Grego" ou "ser Romano" é adquirir os valores da paideia, o que faz lembrar as palavras de Isócrates: ${ }^{302}$

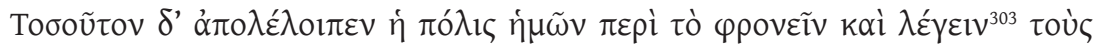

them at least to be glanced at, but there is no evidence that he considers them necessary or even helpful as a preparation for the study of philosophy which is his main concern". Sobre a enkyklios paideia, vide, ainda, H. Koller (1955: 174-189) e H. Mette (1960: 300-307); H. Koller defende que a noção de enkyklios paideia deriva do exercício "musical", que é o resultado do kyklios choros dos cidadãos livres da Ática. Na mesma linha de pensamento, L. Rijk (1965: 2493) relaciona a enkyklios paideia com a mousike e a choreia paideusis, remetendo a sua origem para o Pitagorismo, por este incorporar a antiga tradição grega do canto e da dança. Refira-se que H. Marrou (t1990) não concorda com estas leituras, preferindo remeter a origem para Isócrates e Platão e realçar a complementaridade da enkyklios paideia: por um lado, o estudo das letras e da literatura e, por outro, o exercício da matemática. Por fim, A. Bos (1989: 179-198) identifica a influência platónica e aristotélica no sentido da enkyklios paideia: "I shall have to conclude that the term enkyklios paideia cannot be adequately explained without the influence of Plato's Phaedrus, although Plato himself did not use it. That might give us a reason to suspect that the notion of enkyklios paideia is a product of Aristotle's reflections on the theory of science. (...) I should like to advance the hypothesis, therefore, that the notion of the enkyklios paideia is a product of philosophical reflection, as laid down in the lost writings of Aristotle, on kinds of knowledge in relation to kinds of objects of knowledge".

2997.2 .

${ }^{300}$ Cf. De uirt. mor. 452D: a paideia intervém no carácter e forma as qualidades que "fazem" o indivíduo e o movem na acção.

${ }^{301}$ Cf. Marc. 3.4.

${ }^{302}$ Paneg. 50 (trad. M. H. Rocha Pereira $\left(2003^{8}\right)$ ).

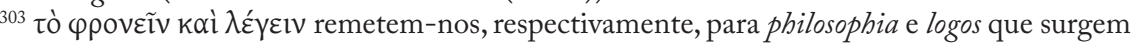




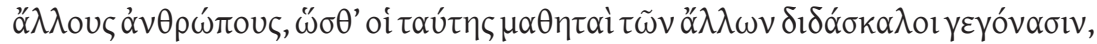

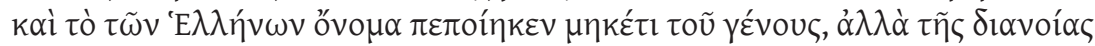

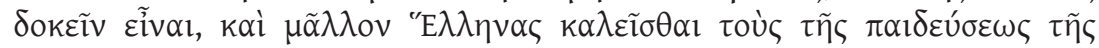

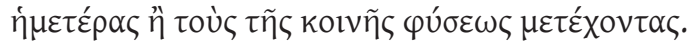

De tal modo se distanciou a nossa cidade dos outros homens, no que toca ao pensamento e à palavra, que os seus alunos se tornaram mestres dos outros e o nome dos Gregos já não parece ser usado para designar uma raça, mas uma mentalidade, e chamam-se Helenos mais os que participam da nossa cultura do que os que ascendem a uma origem comum.

Note-se que Isócrates, consciente das dificuldades do seu tempo, da ausência de uma unidade forte e sólida entre as poleis e do facto de o poder ter caído nas mãos de demagogos, concebe a paideia como cultura e educação, de forma a recuperar o esplendor helénico e a difundi-lo, negando o seu carácter exclusivamente "helénico", mas conferindo-lhe uma dimensão universal ${ }^{304}$. Se é verdade, por um lado, que a palavra "Helenos" vê a sua aplicação ser alargada por poder passar a definir os que não são Gregos por natureza, Isócrates, por outro lado, enfatiza a ideia de que só aqueles que tiverem uma educação segundo o modelo ateniense farão parte da grecidade. Esta declaração, que tem no horizonte a homonoia, mais do que sugerir um ideal pan-helénico, pretende afirmar a hegemonia de Atenas,

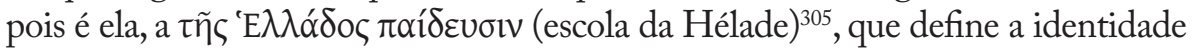

nos períodos anteriores, percebendo-se melhor o objecto de didaskaloi.

${ }^{304}$ A ideia da paideia universal será aprofundada por Plutarco na descrição dos feitos de Alexandre. Para P. Desideri (2005: 15), "nessuno, a quanto pare, aveva pensato di interpretar la conquista di Alessandro come strumento per la diffusione della $\pi \alpha 1 \delta \varepsilon i ́ \alpha$, per non dire come programma di 'ellenizzazione' generalizzata, necessaria premessa per la realizzazione di un progetto cosmopolitico. Sobre a concepção de paideia de Isócrates, T. Morgan (1999: 58) considera que: "He is claiming, for himself and for Athens, the first ascendancy based on a system of literate cultural education. For the first time literacy and politics are not just coexistent or correlated but intimately, necessarily linked".

${ }^{305} \mathrm{Cf}$. Th. 2.41.1. Refira-se que o famoso texto em que Tucídides relata a oração fúnebre serve para apresentar Atenas como um modelo democrático para as outras cidades, elogiando-se o seu papel nas relações comerciais, a sua abertura a outros vindos de fora e o seu gosto pela beleza com simplicidade e pela sabedoria (

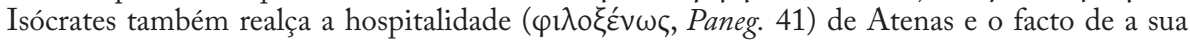

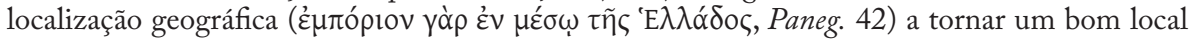
para se obterem todos os bens; além disso, foi Atenas que ensinou aos outros a philosophia (cf. Paneg. 47). Vários séculos depois, Élio Aristides (cf. Panathenaikos 99) reafirma Atenas como

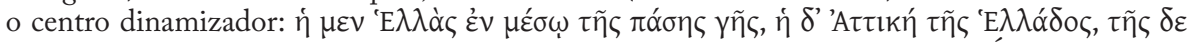

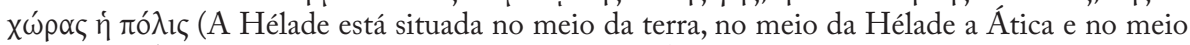
desta a polis); em Panathenaikos 330, afirma que os Ateniense são hegemones de toda a paideia e sophia; sobre esta obra de Élio Aristides, vide S. Saï (2006: 47-60), que demonstra como o autor, por um lado, imita a representação clássica de Atenas, na linha de Isócrates, e, por outro opera algumas transformações, de modo a conseguir adaptar-se à realidade do Império Romano; também Plutarco procede, como demonstra R. Lamberton (1997: 151-160), a uma romanização 
grega $^{306}$. Num processo de reciprocidade, a paideia não visa apenas reformar o Estado a partir da formação do indivíduo, mas é também a realidade sóciopolítica que influi no carácter do indivíduo. A paideia, para Isócrates, tinha essa capacidade regeneradora. Da mesma forma Plutarco, perante a complexa situação administrativa e política da Grécia, recorre à paideia para encontrar equilíbrios entre Gregos e Romanos. Estrabão, por sua vez, é mais incisivo no momento de relacionar paideia e hegemonia. Segundo Éforo, conta-nos o geógrafo ${ }^{307}$, os Beócios tinham todos os recursos naturais para exercerem a hegemonia na Grécia, no entanto, não a conseguiam conservar por carecerem da paideia, uma vez que valorizavam as qualidades guerreiras em detrimento da cultura. Isto indica que não se pode exercer a hegemonia sem a paideia ou sem a arete. Este problema coloca-

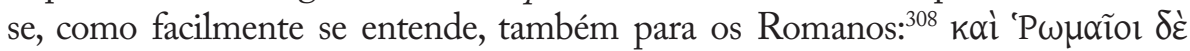

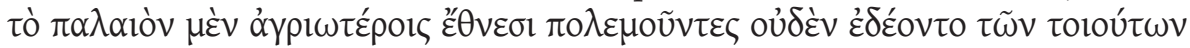

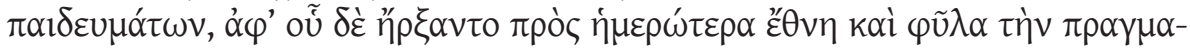

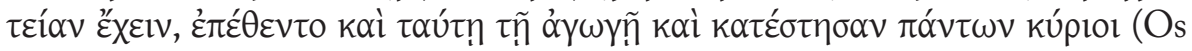
Romanos, antigamente, como combatiam contra povos com costumes mais selvagens, não tinham necessidade de tal cultura, mas, logo que começaram a relacionar-se com povos mais civilizados, também eles se deixaram seduzir por essa educação e tornaram-se os senhores de todos).

Parece, assim, que é apenas quando entram em contacto com os Gregos que os Romanos sentem necessidade da paideia e esta é uma condição sine qua non para a dynamis do império universal. Uma das vertentes dessa construção é a necessidade de assimilar a educação e a cultura dos conquistados, da mesma forma que Plutarco, na biografia de Marcelo ${ }^{309}$, lembra que os Romanos desconheciam a prática das aretai e que foi Marcelo o primeiro a revelar aos

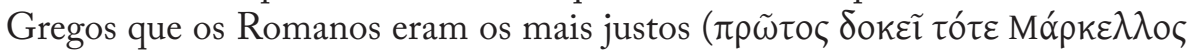

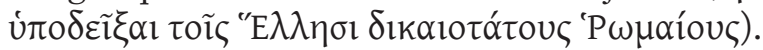

Correspondendo a um outro momento histórico, a oposição clássica entre Gregos e Bárbaros ${ }^{310}$ é substituída por uma outra mais premente para Plutarco. Referimo-nos à sempre problemática relação entre Gregos e Romanos, que em muito se deve à excelência de ambas as culturas, com vocação imperialista. Plutarco, cidadão do Império, quer passar a mensagem de que a paideia não define apenas aqueles que nasceram de um estirpe aristocrática, nem tão pouco os que são Helenos, mas todos os que desejam participar dessa cultura: para

de Atenas.

${ }^{306}$ Cf. Y. Too (1995: 129).

307 9.2.2.

${ }^{308}$ Ibid.

${ }^{309}$ Cf. Marc. 20.1.

${ }^{310}$ Vide, de uma forma geral, os textos contidos em Th. Harrison (Ed., 2002) e o estudo de P. Cartledge (2002r: 51-77). 
os Gregos ela será um suporte fundamental para enfrentarem o domínio romano e uma forma de manterem viva a memória de um passado heróico e de superarem a privação de uma autonomia plena, enquanto para os Romanos a paideia helénica constituirá a chave do sucesso do Império. Mesmo aquele que tem uma physis nobre, como Coriolano, não pode prosperar sem a paideia ${ }^{311}$, atribuindo-lhe Plutarco um papel central na formação humana e intelectual do indivíduo, bem como na configuração civilizacional. Assim, a paideia intervém de forma decisiva na cadeia physis-ethos-logos, a doutrina dos três elementos, tão divulgada pelo movimento sofístico e que teve presença muito significativa nos pensamentos platónico e aristotélico ${ }^{312}$, assim descrita no tratado De liberis educandis: ${ }^{313}$

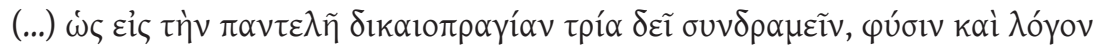

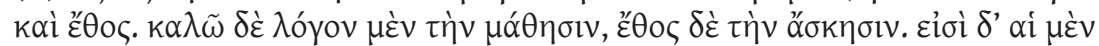

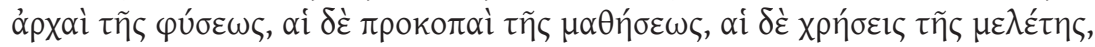

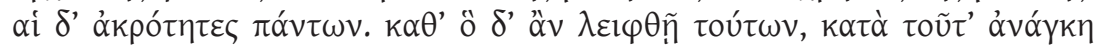

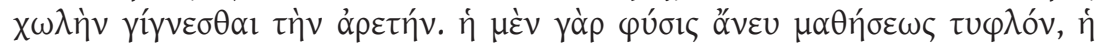

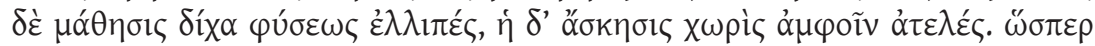

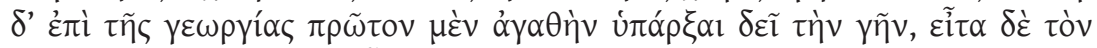

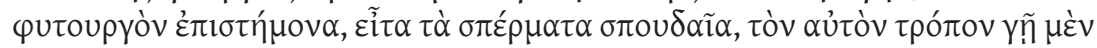

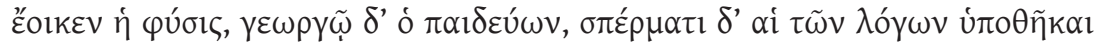

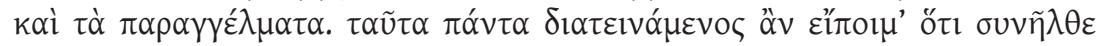

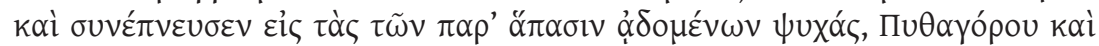

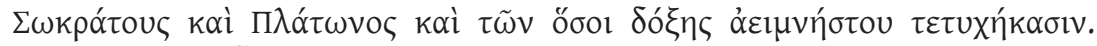

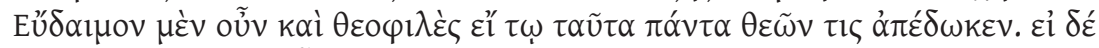

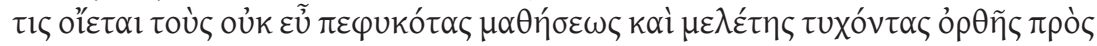

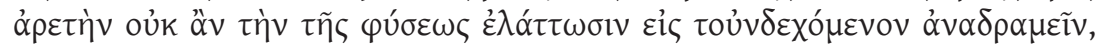

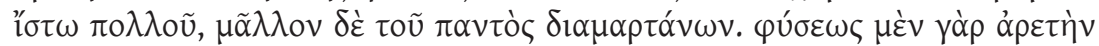

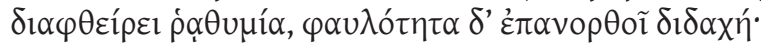

(...) para uma conduta justa é necessário congregar, completamente, três elementos: a natureza, a razão e o costume. Chamo razão à aprendizagem e costume à prática. Os princípios advêm da natureza e os progressos da educação; a prática advém dos exercícios e a perfeição resulta de todos estes elementos. Porém, se, por fatalidade, faltasse alguma destas coisas, a virtude ficaria imperfeita. É que, de facto, a natureza sem instrução é cega, do mesmo

311 Cf. Cor. 1.2-4.

312 e.g., Pl., Men. 70 A, Phaedr. 269 D, Prt. 323 D; Arist., Pol. 1333a22, 1334b5-28, , EN 1103a 16 ss., 1179b; vide, ainda, Xen., Mem. 3.9.2, 2.6.39, 3.3.11; Isoc., Paid. 3, Lucr. 3.319 ss.;

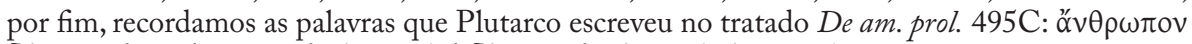

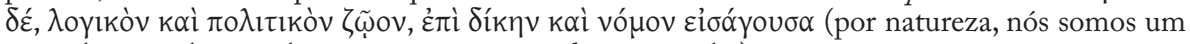
animal racional e social com uma concepção de justiça e lei).

${ }^{313} 2 \mathrm{~A}-\mathrm{D}$. 
modo que a instrução separada da natureza é insuficiente e o exercício separado das duas não produz resultados. Tal como para a agricultura é necessário, em primeiro lugar, haver uma terra fértil e depois um agricultor sabedor e sementes adequadas, da mesma forma a natureza é semelhante à terra, o educador ao agricultor e os ensinamentos e os preceitos à semente. Eu poderia dizer, insistindo, que todas estas coisas se reúnem e contribuem para as almas dos que são venerados por todos, como Pitágoras, Sócrates, Platão e todos aqueles que, igualmente, alcançaram uma glória eterna. Se um dos deuses dá tudo isto a alguém, esta pessoa será, sem dúvida, feliz e afortunada. Se há alguém que pense que os que não tiveram um bom nascimento não poderiam corrigir, tanto quanto possível, um defeito congénito, mediante a aprendizagem e o exercício vocacionados para a virtude, saiba que incorre num grande erro. $\mathrm{Na}$ verdade, a indolência corrompe a natureza predisposta para a virtude, enquanto a instrução corrige a ignorância.

Este texto não deixa dúvidas sobre a possibilidade de a arete ser aperfeiçoada pela askesis e pelo ethos, que a acção da paideia promove, embora isso não garanta que se consigam eliminar por completo os defeitos, nem aquilo que vem do genos ${ }^{314}$. Mas as alterações que a paideia pode operar na physis têm, a nosso ver, consequências mais vastas: quando Plutarco questiona, por exemplo, se Alexandre ou os Romanos devem os seus sucessos mais à thyche ou à arete ${ }^{315}$, e sabendo-se que a paideia valoriza e aprofunda as aretai, vemos como a paideia pode ajudar a ganhar no confronto com o determinismo ${ }^{316}$. Por conseguinte, o autor concilia a imagem clássica da tyche, ligada a acontecimentos pouco esperados e que pode pender tanto para o bem como para o mal, com uma outra, mais de acordo com o seu tempo, que tem em conta a realização humana

${ }^{314}$ Por isso, T. Whitmarsh (2001: 98) considera que a paideia é apresentada como um "meritiocratic principle: it cannot completely efface the institutionalized imbalances of social hierarchies, but it can provide a certain counterbalance". O estudo T. Whitmarsh ajudou-nos a entender e a contextualizar a problemática da paideia e da identidade, embora o autor raríssimas vezes argumente as suas ideias com as Vitae, mas antes com os Moralia, e, especialmente, com autores posteriores a Plutarco, como Díon de Prusa, Luciano ou Filóstrato.

${ }^{315}$ Cf. De Alex. fort. aut uirt. e De fort. Rom..

${ }^{316}$ Sobre a capacidade para interferir na tyche, vide Arist., $R h .1368$ a ss.. Como S. Swain (1989b: 272-302) notou, Plutarco usa a palavra tyche de forma diferenciada, uma vez que nos Moralia distingue theos, daimon ou pronoia (factos guiados pela providência) da tyche (acção fortuita, acaso, azar ou sorte), ao passo que nas Vitae essa distinção nem sempre se repete. F. Mestre \& P. Gómez (2005: 298), por sua vez, apontam duas perspectivas para a análise da tyche nas Vitae: como factor exterior e como elemento inato, encontrando exemplos para ambos os casos. Este mesmo estudo refere que, em alguns casos, o herói não tem consciência de que ele próprio administra a tyche. Podemos dar dois exemplos sintomáticos do uso de tyche nas biografias: em Dem. 19.1, Plutarco afirma que não sabe se foi por acção de uma tyche daimonios ou pela ordem cíclica dos acontecimentos que a Grécia perdeu a liberdade; por sua vez, em Sert.

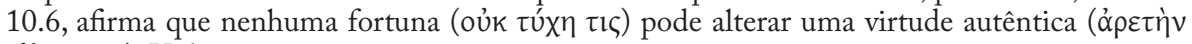

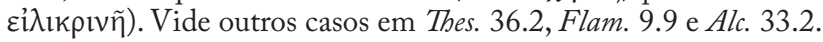


e o esforço, onde se pode e deve enquadrar a paideia, para, numa atitude activa,

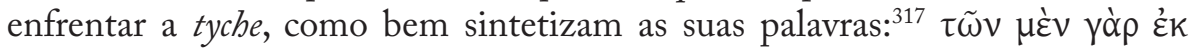

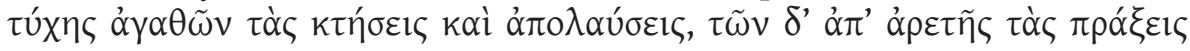
$\alpha \gamma \alpha \pi \tilde{\omega} \mu \varepsilon v$ (Desejamos adquirir e possuir os bens vindos da fortuna, mas os que têm origem na virtude desejamos realizá-los). Também a paideia é, acima de tudo, uma valorização interior, que se realiza e revigora com o esforço

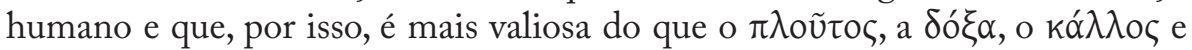
a ý$^{\prime} \varepsilon \alpha^{318}$. Segundo Plutarco, se o indivíduo deve a vida aos progenitores, que tiveram a ajuda divina ( $\mu \varepsilon \tau \hat{\alpha} \tau \tilde{\omega} v \theta \varepsilon \tilde{\omega} v)$, já aos filósofos ou mestres, por causa

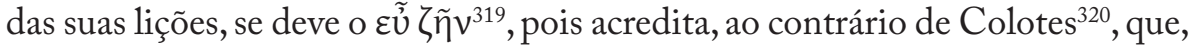
em tempo de dificuldades, a educação supera a ausência das leis, da justiça, dos magistrados e dos reis.

Embora Plutarco não deixe de estabelecer diferenças entre os Gregos e os Bárbaros e também entre os Gregos e os Romanos, usa sem dúvida um tom conciliador, o que levou J. Boulogne (1994: 150-1) a apelida-lo de "médiateur transculturel", expressão que, a nosso ver, traduz o contacto e as influências interculturais, mas que, e bem, não apaga a identidade própria de cada povo, a sua memória histórica e colectiva. Com a reflexão sobre a paideia, Plutarco responde à autoridade política dos Romanos e à forma como estes se sentiram persuadidos - alguns ameaçados - pela supremacia cultural dos Gregos.

A análise da paideia nas Vitae de Plutarco, complementada com os elementos que podemos recolher dos três tratados educacionais (De liberis educandis, Quomodo adulescens poetas audire debeat e De recta ratione audiendi) ajuda-nos a perceber que a produção literária e a realidade do domínio imperial que lhe está subjacente formam uma dinâmica dialógica e, ao mesmo tempo, inspiradora. O Queronense, tal como Arriano e Filóstrato, era um cidadão

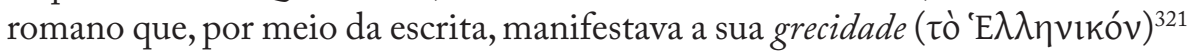
ou identidade, na qual a paideia ocupava um lugar especial, pois ela também era uma forma de marcar a superioridade: os pepaideumenoi opunham-se aos idiotai e aos barbaroi, defendendo-se que a paideia define, distingue e valoriza o indivíduo ou a sociedade que a promove e que tenta transmitir aos outros (não-Gregos e Bárbaros) essa cultura ${ }^{322}$. Essa paideia podia ter manifestações

${ }^{317}$ Per. 2.3.

${ }^{318}$ Cf. De lib. educ. 5D.

${ }^{319}$ Cf. Adu. Col. 1108 C.

${ }^{320}$ Cf. ibid. $1124 \mathrm{D}$.

${ }^{321}$ Cf. Hdt. 8.114.2.

${ }^{322}$ A este propósito, T. Morgan (2000r: 23) afirma: "Literacy and literate education provided a means by which Greek culture could be identified and distributed and the Greek ruling class could be defined. Moreover, literate and numerate education had a further function, giving nonGreek a channel of assimilation into (cultural, not legal) Greekness”. 
distintas, da história à filosofia, incluindo a biografia ou a retórica, com perspectivas diferentes, tal como diferentes eram as estruturas do pensamento filosófico (Pitagóricos, Académicos, Peripatéticos, Epicuristas, Estóicos, Cínicos ou Cépticos).

A construção do pensamento de Plutarco permite-nos afirmar que as atitudes dos imperadores (Domiciano exila filósofos, enquanto Trajano e Adriano promovem a actividade intelectual dos $\mathrm{Gregos}^{323}$ ) têm muita influência na definição da paideia, podendo, dessa forma, o poder condicionar, alterar ou promover diferentes vias culturais, sinal da interacção entre a ideologia romana e a paideia grega. A criação literária contribui para a consolidação de um modelo de identidade, que explora a simbiose e a possibilidade de existir uma complementaridade entre a paideia grega e o poder romano ${ }^{324}$. Daí que a paideia tenha uma dimensão política, já desde a época clássica (a tragédia grega era uma expressão da polis), e, ao mesmo tempo, é um processo de sociabilização do indivíduo, pois acreditava-se que a formação intelectual e moral seria uma garantia para a manutenção do equilíbrio do Estado. Isso tem naturais implicações nas estruturas do poder, uma vez que a paideia e o seu exercício englobavam os que passariam a governar e aqueles que eram dominados, uns para encontrar as melhores soluções económicas, políticas e sociais, outros para respeitarem as ordens e tudo fazerem para serem uma parte activa e positiva da politeia.

Deste modo, as Vitae baseiam-se numa concepção de que para ser completo o homem necessita de ser educado. Isso consegue-se por diversos meios, que se podem complementar: a educação que se recebe dos diversos elementos da família; as lições junto dos mestres, no âmbito de uma paideia mais estruturada e convencional; o conjunto de conhecimentos que a própria sociedade proporciona ao indivíduo; as opções que cada um toma (aceitação, recusa, reacção crítica, selecção de valores, etc.) em cada etapa do seu percurso. Os heróis de Plutarco espelham esses diferentes níveis de paideia, não sendo fácil, como hoje também não é, avaliar, por exemplo, qual o grau de influência da sociedade no desenvolvimento das capacidades de Aristides, Flaminino e Sertório ou no carácter excessivo de Alcibíades e Coriolano. No caso destes dois heróis, é necessário repartir as razões pela physis, pela paideia pouco consequente e pelas condições sociais que tiveram de enfrentar. $\mathrm{O}$ tempo e o espaço são, por isso, dois factores que não se podem negligenciar na construção das aptidões e na formulação da condição humana. A memória, a

${ }^{323}$ Ateneu refere que Ptolomeu VIII expulsou da cidade grammatikoi, philosophoi, geometroi, mousikoi, zographoi, iatroi e muitos outros technitoi (cf. 4.184,), facto que revela, juntamente com os outros exemplos referidos, que o Estado tinha uma intervenção decisiva na educação.

${ }^{324}$ Sobre a dicotomia entre, por um lado, a cultura e o conhecimento dos Gregos e, por outro, o poder político dos Romanos, vide A. Wallace-Hadrill (1988: 224-33). 
Parte III

disposição mimética e os vínculos com outras consciências contribuem para a aprendizagem do indivíduo, uma vez que em cada indivíduo existe a revelação de outros. 


\section{GRAECLA CAPTA OU ROMA CAPTA: DUALIDADE E UNIDADE}

Graecia capta ferum uictorem cepit et artes

Intulit agresti Latio

(Hor. Epist. 2.1.156-157)

Numa época muito marcada pelo contacto e pela transferência cultural, a produção literária é a melhor metáfora para as interacções sociais, daí a exploração que a antropologia social tem feito dos textos. De facto, as narrativas, pela forma como espelham a sociedade e como descrevem as relações entre os indivíduos, contêm múltiplos elementos culturais. A literatura da época de Plutarco, ou, se quisermos generalizar, da Segunda Sofística, conhecida por valorizar o discurso retórico e pela meta-linguagem, não tende apenas a representar Roma e o seu poderio, mas a desenvolver, de forma dinâmica, imagens herdadas do passado e identidades, de forma a construir e a representar, na sua função mimética, um olhar novo sobre o tempo vigente ${ }^{325}$. Essa recuperação do passado, a cargo das elites culturais que escrevem e que estão preocupadas com a questão da herança cultural, é também uma tentativa de reformular ou salvaguardar uma identidade que possa sobreviver ao poderio romano. Esse olhar sobre o passado não é apenas de nostalgia, de admiração ou com o objectivo de imitar os modelos clássicos, mas operam-se transformações e reescritas, de modo a que a mensagem dê uma resposta à realidade presente ${ }^{326}$. As Vitae de Plutarco são um bom exemplo desse esforço de afirmação da Grecidade face à nova hegemonia, realçando-se sobretudo os valores paradigmáticos, em detrimento de feitos gloriosos.

$\mathrm{Na}$ condição de leitor do corpus literário de Plutarco, verificamos a tendência, por vezes inconsciente, de este fazer uma análise centrada na política e na identidade, por causa dos elementos que remetem para o que implica "ser Grego" e cidadão do Império. As Vitae são, sem dúvida, um bom paradigma da complementaridade do "literário" com o "cultural", por estrategicamente colocarem em paralelo Gregos e Romanos, numa estrutura carregada de simbolismo e também de alguma ironia, mas esta em menor grau do que se encontra em Díon de Prusa e Luciano. Mais do que uma questão que diga respeito à forma, este paralelismo, susceptível de nem sempre ser interpretado de forma coincidente, denota uma intenção deliberada do autor, consentânea com a sua época, de abordar a temática da identidade cultural.

325 Para T. Whitmarsh (2001: 32), a literatura tem sobretudo uma relação ontológica com a cultura greco-romana: "it is not a reflex of a pre-existing Greek identity, but precisely the space in which identity is constructed and disseminated".

${ }^{326}$ Cf. G. Anderson (1989: 144) e S. Swain (1998r: 87 ss.); esta nova concepção é assim descrita por S. Goldhill (2001: 8): "veined with a complex dynamic of attraction and rupture, affiliation and dismissal". 
Cada herói carrega um conjunto de marcas próprias da sua identidade, da sua physis, do seu genos, purgados ou não pela paideia, que se confrontam, transformam ou anulam perante uma identidade superior, mais alargada e que caracteriza um sistema comum. A tarefa de interpretar a identidade cultural por meio da criação literária tem, no entanto, algumas limitações, uma vez que o conteúdo pode ser condicionado por estratégias literárias, que, porém, não the retiram interesse, especialmente numa época em que a literatura, representando as relações entre Gregos e Romanos, é uma mimesis da estrutura social, com tendência para construir valores identitários.

A identidade cultural ${ }^{327}$ não é algo imediatamente inato ao ser humano e ao colectivo a que pertence, mas obedece a um processo de construção, que se repete várias vezes, com recuos, desvios e avanços, causados por acontecimentos históricos e culturais que moldam essa identidade ${ }^{328}$. Por isso mesmo, os autores gregos não definem to hellenikon, o "ser Grego" ou a "grecidade", sempre da mesma forma. Heródoto, por exemplo, usa as seguintes

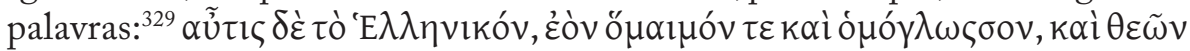

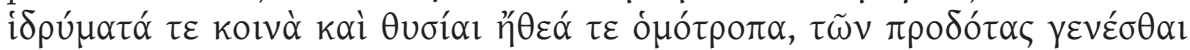

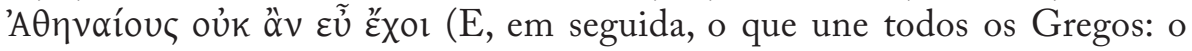
mesmo sangue e a mesma língua, santuários e sacrifícios comuns dos deuses, costumes e gostos idênticos. Atraiçoar tudo isso, para os Atenienses não seria admissível). Dionísio de Halicarnasso, por sua vez, no final do primeiro livro das Antiquitates Romanae descreve aquilo que caracteriza to bellenikon, na sequência da descrição de Roma como uma cidade que recebeu vários povos bárbaros, mas que, ao contrário de outros, não se deixou barbarizar,

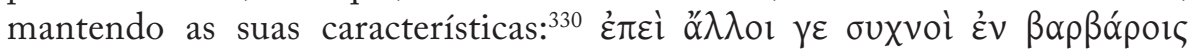

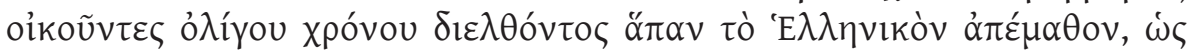

${ }^{327}$ Sobre a identidade cultural no âmbito do Império Romano, vide F. Millar (1993), M. Gleason (1995), S. Swain (1998r), S. Alcock (1996r), R. Laurence \& J. Berry (Ed., 2001), (1998), R. Preston (2001), T. Whitmarsh (2001); o citado trabalho de R. Preston, na página 88, apoiando-se em S. Hall (1992) e E. Said (1994) e (1995), considera que é mais correcto falar-se em identidades: "identity is viewed not as a static position, a set of unchanging attitudes, but as a complex process of construction, negotiation and contestation. Indeed, to use the singular term 'identity' is in itself misleading, since identity is necessarily complicated and multiple. It is not a single, static, easily defined and apolitical entity, but a complex process of negotiating a place in the world and of engaging in the contest over political power". Aliás, a própria vida de Plutarco dá-lhe um sentido pan-helénico e proporciona-lhe um contacto privilegiado com o poder e com povos de identidades diferentes. Recorde-se que Plutarco gozou da cidadania romana, foi sacerdote de Delfos e membro da Anfictionia Délfica; remetemos, por fim, para D. Konstan (2001: 29-50), que aborda os elementos que enformam a identidade grega.

328 A este propósito, refere R. Miles (1999: 8): "identities are produced, consumed and regulated within culture".

329 8.144.14-17 (trad. de J. Ribeiro Ferreira (2002b)).

${ }^{330}$ Ant. Rom. 1.89.4. 


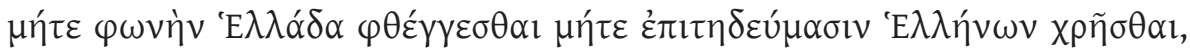

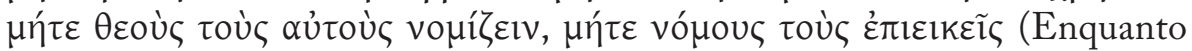
outros ao habitarem entre Bárbaros esqueceram em pouco tempo tudo o que era próprio dos Gregos: de modo que não falam a língua grega, nem conservam os costumes dos Gregos, nem reconhecem os mesmos deuses, nem têm leis adequadas).

À semelhança de Heródoto, Dionísio de Halicarnasso refere a língua grega, os costumes e a religião, mas, em contrapartida, junta a estes elementos as leis (nomoi) e, acima de tudo, não alude à questão do ö $\mu \alpha \iota \mu o v$, para definir a grecidade. Logo, o segundo texto, revelador da evolução do sentido de to hellenikon, está mais próximo daquilo que Plutarco pensa sobre a possibilidade de partilhar uma cultura e adequa-se melhor à nova estrutura social que preconiza.

Além disso, a identidade cultural ganha maior complexidade quando se estudam as influências da tradição ou o contributo de outras culturas, não sendo fácil, em alguns casos, definir com exactidão as formas originais ou os modelos. Se, hoje, reflectir sobre sociedades multiculturais ou multiétnicas é quase obrigatório, esse fenómeno não era de todo alheio à época de Plutarco, marcada pela diversidade cultural, pelo cosmopolitismo, pela herança alexandrina, quase se exigindo o conhecimento e a tolerância do outro $^{331}$. Aliás, não é fácil encontrar no corpus literário da Antiguidade uma obra tão heterogénea ${ }^{332} \mathrm{e}$, sobretudo, com dados tão valiosos para uma análise antropológica. A philanthropia, também ela manifestação da paideia, é um sinal de abertura social e de diálogo entre mentalidades e condutas diferentes, ainda que Plutarco nos apresente um mundo dividido em duas partes: aqueles que usufruem da paideia e os que persistem na barbárie ${ }^{333}$.

Falar de identidade cultural não significa apenas definir um conjunto de valores, preceitos, instituições ou produções (literárias ou arquitectónicas, entre

${ }^{331}$ São geralmente dois os textos que se usam para sustentar a visão poliétnica de Plutarco: De Alex. fort. aut uirt. e o De exil.; vide, a este respeito, a análise de G. D' Ippolito (2005: 179-196), estudo que conclui de forma sugestiva: "si tratta di una filantropia [a de Plutarco], ellenocentrica sí, ma che non solo accetta teoricamente il polietnismo ma praticamente lo segue negli atti della vita, dove, l'elemento discriminante non è la razza ma la virtù. In Alessandro, campione di Ellenismo, in quanto, ben che macedone, nutrito di cultura greca, Plutarco vede una prefigurazione dell'impero di Roma, la sola istituzione che potrà assicurare l'unione dei popoli sotto l'egida della non mai sopita civiltà ellenica"; para uma análise mais geral do Outro e da construção da sua imagem na Antiguidade, remetemos, por exemplo, para R. Browning (2002: 257-277) e W. Nippel (2002: 278-310); F. Walbank (1992r: 60-78) ao questionar a homogeneidade no período helenístico, não hesita em apontar as diferenças religiosas, linguísticas e sociais que marcam esse tempo.

332 Como refere A. Nikolaidis (1991: 153-186), a vastidão da obra provocou inevitáveis contradições e incoerências.

${ }^{333}$ Vide A. Nikolaidis (1986), J. Pelegrín Campo (1997) e T. Schmidt (1999). 
outras), mais ou menos padronizadas, mas implica associar-lhe o indivíduo, bem como o seu tempo e espaço. Por isso, ao falarmos de identidade cultural não nos reportamos tanto a uma nação ou raça, mas à construção ou à representação que nas Vitae se opera do indivíduo no contexto da sociedade imperial. Convém, contudo, referir que a discussão sobre a paideia e a natureza identitária da Grécia na Época Imperial tem de ter sempre presente o facto de se viver sob o domínio romano e também haver uma focalização, quase exclusiva, numa elite, à qual se pretende transmitir uma paideia assente nos valores gregos do passado. A própria elite grega, que, devido à presença de governadores e de outros oficiais romanos, viu o seu poder ser diminuído nas poleis, precisava de se adaptar às novas circunstâncias e, por meio da prudência e da sabedoria, aproveitar os benefícios que podiam advir da nova potência.

A avaliação da identidade cultural na época de Plutarco tem de ter em conta, forçosamente, esse dado: a hegemonia romana. A oposição GregoBárbaro, própria da época clássica, foi substituída por uma visão mais pluralista, cosmopolita e multicultural, em que os Romanos tendem a ofuscar a posição helénica ${ }^{334}$. Esta alteração tem, como se imagina, consequências entre os Gregos: uns sentem-se persuadidos a aderir aos novos valores, enquanto outros preferem preservar o passado e as tradições. Plutarco também terá sentido essa ambiguidade e nem sempre é fácil, a partir da sua obra, saber em que lado posicioná-lo, embora nos pareça que, fazendo jus ao seu sentido pragmático, não se manifeste frontalmente contra a nova ordem social e política imposta pelos Romanos, preferindo ressalvar aquilo que distingue os Gregos: a sua paideia. Aliás, a conquista romana terá certamente contribuído para que houvesse um florescimento do espírito de união entre os Gregos ${ }^{335}$, unidade que sempre experimentou grandes resistências, mesmo com o panhelenismo, até por causa do estatuto político das poleis. Lembramos, contudo, que, se não é fácil, na discussão sobre a identidade na obra plutarquiana, fugir à dicotomia gerada entre Romanos e Gregos, da qual resulta muitas vezes um louvor do patriotismo helénico, também nos parece essencial sublinhar que o pepaideumenos, homem culto que emerge do ambiente da Segunda Sofística, está muitas vezes mais comprometido com a tradição do que com aquilo que é o Helenismo, até porque vive, com algum constrangimento, a ambiguidade de se ver confrontado com diversas identidades ${ }^{336}$.

${ }^{334}$ Se, para Plutarco, os Romanos e os Gregos se opõem aos Bárbaros, Élio Aristides, em $A d$ Rom. 63, defende que o mundo se encontra dividido entre Romanos e não-Romanos; Estrabão (1.4.9) prefere a polaridade "bom" e "mau".

${ }^{335}$ Cf. T. Whitmarsh (2001: esp. 22-23); o mesmo estudioso, a partir de alguns exemplos da literatura latina, afirma que é claro que "in the Roman imaginary, Greece's status as 'educator' was intrinsically linked with Rome's as conqueror."

${ }^{336}$ C. Jones (2004: 13-21) demonstra como o valor da tradição ocupa um lugar central nas 
No caso particular das Vitae, a própria estrutura das biografias, colocando em paralelo um Grego e um Romano, com uma synkrisis final, não deixa dúvidas sobre o interesse de Plutarco em discutir a identidade cultural, revelando diferenças e semelhanças entre Gregos e Romanos, das quais resulta uma base para a criação de uma identidade greco-romana. Identidade não significa forçosamente unidade, antes se refere a dois povos que partilham variadíssimos traços culturais. As cautelas que temos em defender uma concepção unitária da identidade resultam, em grande medida, do facto de o sentimento de partilha de valores ter significado apenas para um grupo social privilegiado, pertencente a uma elite económica e política, que produz e consome cultura. Esta elite é composta por aqueles a quem se dirigem os pensamentos de Plutarco, ficando à margem deste processo os que - e são muitos - não têm acesso a essa cultura. Além disso, convém não esquecer que uma parte significativa do ideário desenvolvido nos textos terá sido condicionado ou inspirado pelo poder do Império.

Como Plutarco tantas vezes refere nos seus textos, os acontecimentos, fruto do destino ou graças a um empenho voluntário, podem determinar o carácter do indivíduo, intervindo na physis, pois cada povo ou cada indivíduo carrega uma marca cultural distintiva, multifacetada e que pode moldar-se ao longo do tempo. A paideia, tal como a identidade, não pode ser confundida com entidades contínuas, estáveis e que simplesmente se transmitem, como o património cultural ${ }^{337}$, pois ela tem a capacidade de se transformar e de provocar o mesmo efeito nos outros. Além disso, adapta-se, sem muitas vezes termos consciência disso, ao meio envolvente e, em alguns casos, é ela própria a força motriz de uma nova atitude. Por exemplo, a philonikia de Filopémen ganha contornos de necessidade por causa do momento histórico que se vive na Grécia, do mesmo modo que a atitude filo-helénica ${ }^{338}$ de Marcelo preconiza uma acção cultural que pode gerar diversas transformações sociais. Por isso, as diversas leituras que temos vindo a fazer apontam, em larga medida, para aquilo a que se pode chamar a antropologia da paideia, expressão que traduz

narrativas de Pausânias e Élio Aristides.

${ }^{337}$ Ideia discutida por G. Vinsonneau (2002).

${ }^{338}$ Queremos esclarecer que a expressão filo-helenismo, por nós diversas vezes usada ao longo do trabalho, serve para designar os Romanos que têm algum tipo de fascínio por aquilo que é Grego, mas convém dizer que, nas épocas clássica e helenística, o filo-heleno é o rei bárbaro que, de algum maneira, favoreceu os Gregos, vindo mais tarde a designação a aplicar-se a alguns imperadores romanos, como Nero, Adriano e Marco Aurélio. Além disso, registe-se, em relação aos termos "filo-heleno" ou "filo-helenismo", que nas Vitae apenas uma vez ocorre o

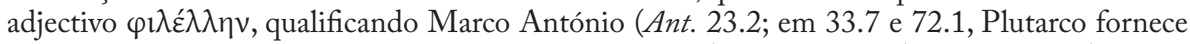
mais elementos sobre a ligação do romano à cultura grega); J.-L. Ferrary (1988: 497-504) chama a atenção para o facto de o referido adjectivo não constar em muitos textos e de ser raro na documentação epigráfica. 
as implicações da educação e da cultura na estrutura social. Plutarco, aliás, ao aprofundar mais esses efeitos nas biografias romanas dá um sinal claro de que não pretende com as Vitae ilustrar simplesmente a paideia dos heróis gregos, mas sobretudo reflectir sobre as implicações que ela pode ter na vida dos Romanos, tanto nos casos em que se nota uma aproximação (por exemplo, Marcelo), como naqueles em que existe uma atitude mais defensiva em relação a esses valores, como acontece com Catão Censor. Essas duas formas de reacção à paideia grega acabam por reflectir aquilo que se encontra na Literatura Latina (por exemplo, a comédia, a sátira, as Epistulae de Cícero ou as Noctes Atticae de Aulo Gélio): o reconhecimento e a exemplaridade do contributo que a paideia grega deu às artes, à literatura, à retórica e ao pensamento intelectual romano, em geral; uma outra reaç̧̃̃o mais conservadora que vê nessa paideia grega uma ameaça séria aos ancestrais valores romanos, por pensar que estes poderiam ser desvirtuados.

$\mathrm{Na}$ verdade, quando duas culturas entram em contacto, tendo uma, neste caso a grega, uma notória superioridade, este tipo de reacção é habitual, com a particularidade de a parte com maior pujança militar, e por isso dominadora, se sentir atraída pela outra cultura ou recear o impacte que ela pode ter nos alicerces da sua identidade, uma vez que, na Antiguidade, tal como acontece hoje, se tinha a percepção da capacidade transformativa da paideia, tanto no indivíduo como na sociedade. Esse debate cultural constitui uma das linhas de pensamento de autores como Apuleio, Frontão, Aulo Gélio, Arriano ou Díon Cássio, que nos legaram importantes documentos sobre a sobrevivência das duas identidades culturais, a romana e a grega, levando-nos a dizer que a cultura romana exerceu menor fascínio do que a grega e que mesmo a ideia de que a elite romana era bilíngue não é totalmente correcta, uma vez que, se muitos dos contemporâneos de Cícero sabiam Grego, o mesmo já não se aplica ao século II d. C.

Por isso, coloca-se a questão: fusão de culturas ou cada uma trilha caminhos próprios? Vimos no capítulo anterior que, no caso do contacto dos Gregos com os Bárbaros, exemplificado com a acção de Alexandre, não se trata de uma fusão, mas de uma tentativa de estender a esses povos o helenismo ${ }^{339}$. Com os Romanos, no entanto, esse contacto tem outras condicionantes, como sejam: o alcance da romanização e a dimensão da humanitas, a possibilidade de existir um equilíbrio cultural entre Roma, que Plutarco apresenta como uma cidade grega ${ }^{340}$, e a Grécia e a conjugação da missão imperial dos

${ }^{339}$ Esta ideia é marcante no tratado De Alex. fort. aut uirt.

${ }^{340}$ Em Cam. 22.3, Plutarco refere-se à capital do Império da seguinte forma: $\pi$ ó $\lambda ı v ~ ' E \lambda \lambda \eta v i ́ \delta \alpha$ 'Póun, tal como Heraclides Pôntico já o havia feito (cf. FGrHist 840 F 23). A mesma ideia é

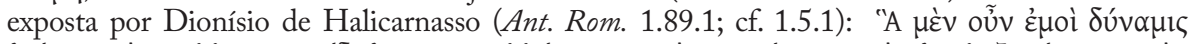

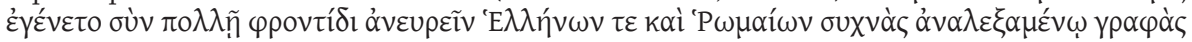


Romanos com a identidade cultural dos Gregos. Além disso, torna-se sempre vital ter presente que Plutarco escreve num momento de domínio romano e, talvez por isso, encontre em Alexandre uma forma de transmitir aos seus contemporâneos que a nova ordem política também pode ajudar a difundir o helenismo. Com efeito, a própria inserção de heróis romanos nas Vitae indicia que Plutarco não foge ao desafio de colocar em paralelo os universos grego e romano, usando a estratégia de se servir do passado grego em contraponto ao domínio presente dos Romanos, uma marca característica da oratória da Segunda Sofística, nomeadamente em autores como Díon de Prusa ou Élio Aristides. Considerando-se que C. Jones (1971: 24 ss.) tem razão quando afirma que a produção literária de Plutarco é reduzida durante a dinastia dos Flávios por causa do risco de ser censurado pelo Imperador ${ }^{341}$, nas Vitae ele terá sentido maior liberdade, mas sempre com um paradoxo por resolver: ser Grego e súbdito de Roma ao mesmo tempo. No entanto, uma leitura dos textos de Plutarco deixa perceber que se sente orgulhoso dos valores helénicos, os quais se devem adaptar a uma nova estrutura social e política, sem que isso signifique uma especial animosidade em relação aos Romanos, até porque, para ele, o outro não é forçosamente um inimigo. Dos três grandes pólos que dominam a sua vida e a sua escrita, diríamos que Atenas se identifica com a cultura $^{342}$, Delfos com o lado religioso e Roma com a componente política e

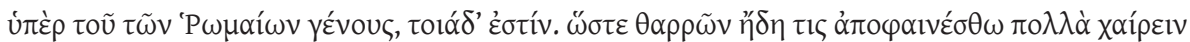

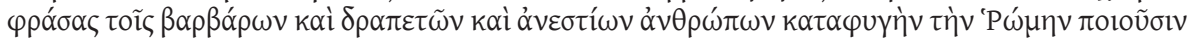

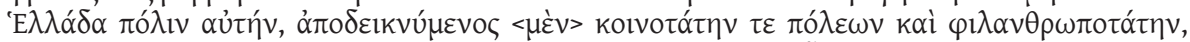

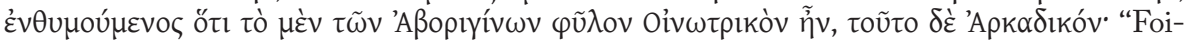
me possível descobrir estas coisas com muita reflexão, após ter lido numerosos textos dos Gregos e dos Romanos sobre a origem de Roma. De tal forma que já se pode, com confiança, fazer ver claramente que ela é uma cidade grega e mandar calar os que fazem de Roma um refúgio para os bárbaros, fugitivos e vagabundos, demonstrando que é a mais sociável e humanitária das cidades, e reflectindo que a raça dos Aborígenes era a dos Enótridas e a destes a Arcádia."

Por sua vez, na biografia de Rómulo, numa das habituais explicações etimológicas de Plutarco, diz-se que o nome de Roma tem origem grega (cf. Rom. 1.1(rhome)), pois foram os Pelasgos, de origem helénica, que lhe puseram esse nome. Por fim, um elemento que serve para demonstrar melhor a origem helénica da Vrbs é o facto de Evandro ter chegado à cidade antes de Eneias (Cf. Rom. 15.4; Marc. 8.7; Num. 7.10). Apesar de Plutarco apontar estas raízes helénicas, não atribui especial significado à influência da língua grega na língua latina: Marc. 22.7, Num. 7.10-11 (cf. Marc. 5.5 e Quaest. conu. 274C) e 13.9-10. Segundo C. Ando (1999: 7), "It is easy enough to suggest that Greeks of the second century B.C. viewed Rome and her empire as two distinct entities, a polis that conquered many territories and an empire that possessed no more affective cohesion than a Hellenistic kingdom”.

${ }^{341}$ Recorde-se que se coloca a hipótese de Plutarco ter sido um dos condenados à morte ou ao exílio durante o principado de Domiciano, numa época em que muitos filósofos, inclusivamente alguns seus amigos, sido expulsos de Roma.

${ }^{342}$ Vide Quaest. conu. 720C e De E Delph. 384D-E, onde Atenas surge como a cidade de maior nível cultural, mas, por aquilo que escreve em Praec. ger. reip. 799C, a polis não está isenta de defeitos, embora o texto não deixe de marcar a filantropia dos Atenienses (cf.

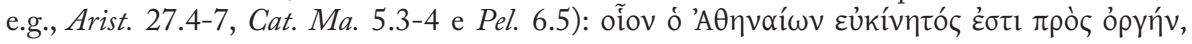


administrativa, o que mostra como Plutarco sente a necessidade de elaborar um sincretismo equilibrado dessas partes, do qual resulta o esboço de uma sociedade greco-romana, ainda idealizada, mas possível de erigir.

Em geral, quando se fala de helenização e romanização, parte-se sempre do princípio de que os Gregos mantiveram a sua cultura e língua, passando aos Romanos esses elementos da sua identidade ${ }^{343}$, enquanto os Romanos, ao contrário daquilo que sucedeu a Ocidente, não conseguiram impor a sua língua e outros vectores da sua cultura a Oriente. Esta ideia é rebatida por G. Woolf (1994: 115-143) que, apoiado em vários estudos, considera que existe algum exagero na avaliação das repercussões da romanização a Oriente, quando se reduz a sua acção à influência do direito romano ou à popularidade dos jogos de gladiadores. Além deste aspecto, não se costuma ter em linha de conta que, por exemplo, a arquitectura de edifícios públicos e privados no Oriente Grego que integrava o Império adoptou os modelos romanos, com uma escala de construção nova, que transformou a aparência das cidades greco-romanas.

Note-se que o conceito de romanização não se define apenas pela vertente cultural, stricto sensu, mas abarca aspectos da área social, política e mesmo económica, não se limitando a transposições de formas literárias e de pensamento. A reacção de alguns Romanos quando Marcelo traz da Sicília objectos de arte gregos é a prova de que a aculturação não se faz só por meio da literatura mas também por outras vias, porventura até mais eficazes. Junte-se a estas considerações o facto de a influência do helenismo na ética da bumanitas não se circunscrever a um período curto, mas compreender um processo complexo, feito de adaptações, imitações, rejeições ou proibições, entre meados da República e o século III d. C. ${ }^{344}$. Em relação à romanização em solo grego, ela adaptou-se às circunstâncias locais, não se baseando apenas na soberania política, mas também em valores que certamente provocaram alterações, pois os Romanos cultivavam a grauitas e tinham um capital assinalável de experiência acumulado. Nesse sentido, G. Woolf (1994: 125), ao reflectir sobre o impacte da romanização, conclui: "Iura and leges, in the east as in the west, were a means

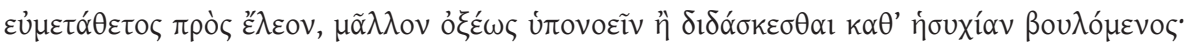

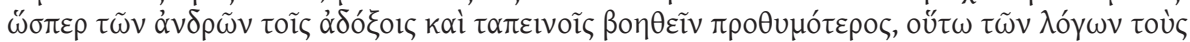

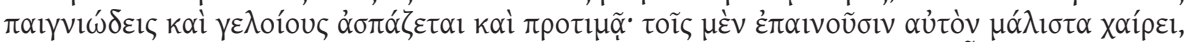

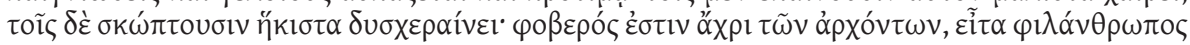

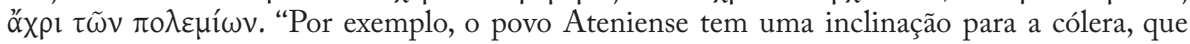
facilmente transforma em piedade, pois quer mais conjecturar de imediato do que aprender com tranquilidade. Tal como considera muito benévolo auxiliar os homens desprezados e humildes, também acolhe e prefere as palavras com humor e engraçadas; regozija-se principalmente com aqueles que o louvam, mas pouco se irrita com os que zombam dele; é terrível com os seus governantes, mas revela-se humano até com os inimigos."

${ }^{343}$ Cf. D. Roman \& Y. Roman (1994: esp. 97-187, 219-309).

${ }^{344}$ Cf. A. Wallace-Hadrill (1988: 224-33) e (1989: 157-64). 
of cultivating civilization, and of imposing mores throughout the world". Não há dúvida de que, relativamente aos povos ocidentais, os Romanos tiveram maior facilidade em estimular as elites e a restante população a aderir aos princípios da bumanitas para ultrapassarem o estado de barbárie, ao passo que, a Oriente, a situação era diferente, uma vez que os próprios conquistadores sentiam que o passado dos povos dominados era mais digno de ser emulado do que simplesmente abolido.

Os versos horacianos ${ }^{345}$ que servem de epígrafe a este capítulo ilustram a percepção que existia em Roma da aculturação aos valores gregos ${ }^{346}$, embora a helenização da Roma republicana seja um processo mais complexo e menos linear do que inicialmente se possa pensar, dado que a adaptação do drama grego, o gradual desaparecimento do verso saturnino e a influência grega, em geral, na literatura latina não significam que a introdução da paideia grega tenha sido pacífica, nem apaga as diferenças inerentes às duas culturas, como Vergílio, no contexto profético da catábase, realçou: ${ }^{347}$

excudent alii spirantia mollius aera
(credo equidem), uiuos ducent de marmore uultus,
orabunt causas melius, caelique meatus
describent radio et surgentia sidera dicent:
tu regere imperio populos, Romane, memento
(hae tibi erunt artes), pacique imponere morem,
parcere subiectis et debellare superbos.'

«Outros modelarão, bem o creio, bronzes com vida e sem dureza; extrairão do mármore seres animados; defenderão melhor as causas; medirão com o compasso o curso dos céus e anunciarão o nascer dos astros.

Tu, Romano, sê atento a governar os povos com o teu poder

- estas serão as tuas artes - a impor hábitos de paz,

a poupar os vencidos e derrubar os orgulhosos.»

A ênfase na dicotomia é ainda mais conseguida por termos, por um lado, o vocativo Romane, aplicado a Eneias, enquanto os Gregos, por outro, surgem de forma anónima, como os alii. Por isso, ao contrário de R. Austin (1986: ad 847-853), que considera estes versos "the conjunction of two complementary cultures”, parece-nos que Vergílio marca a diferença entre as duas culturas.

${ }^{345}$ Cf. Cic. Brut. 254.

${ }^{346}$ Segundo N. Rudd (1989: 101-102), as palavras de Horácio referem-se a uma fase próxima do final da Segunda Guerra Púnica (201 a. C.) e reproduzem o que se passava nas cidades gregas da Magna Grécia, logo uma fase ainda inicial da aculturação.

${ }^{347}$ Aen. 6.847-853 (trad. de M. H. Rocha Pereira (20004)). 
Note-se, ainda, que, de forma ambivalente, o texto vergiliano, um pouco à semelhança dos conhecidos versos horacianos já citados, define as artes dos Gregos mais ligadas ao conhecimento, à escultura, à ciência, à cultura em geral, enquanto os Romanos dominam sobretudo as artes da guerra, da paz e da adiministração, juntando-se dessa forma uma linguagem de cultura e uma outra de poder, que estão, na época de Plutarco, interligadas ${ }^{348}$.

Também Plínio-o-Velho realça o papel civilizador dos Romanos, marca que faz parte do seu destino: ${ }^{349}$

numine deum electa quae caelum ipsum clarius faceret, sparsa congregaret imperia ritusque molliret et tot populorum discordes ferasque linguas sermonis commercio contraheret ad conloquia et humanitatem homini daret breuiterque una cunctarum gentium in toto orbe patria fieret.

[Roma] foi eleita por vontade dos deuses para tornar o próprio céu mais claro, para unir impérios dispersos e para tornar mais civilizados os costumes e reduzir, de modo a permitir a conversação, as línguas diferentes e selvagens de tantos povos mediante relações, humanizar o homem e tornar-se, em pouco tempo, a única pátria de todas as raças no mundo inteiro.

Para Cícero, por sua vez, as artes e os studia podem ser helénicos, mas os mores e as uirtutes são romanas ${ }^{350}$, da mesma forma que a constituição romana é superior à dos Gregos ${ }^{351}$. Cícero substitui também a dicotomia GregosBárbaros pela distinção entre civilização e barbárie ${ }^{352}$.

Nesse processo de transformação, mais ou menos acentuado, a paideia dará certamente o seu contributo, como demonstram as biografias de Plutarco, que surgem numa época em que o contacto cultural e a necessidade de ultrapassar diferenças se tornam quase obrigatórios, cabendo à Grécia saber adaptar-se ao domínio do Império. A este propósito, escreveu Dionísio de Halicarnasso ${ }^{353}$ :

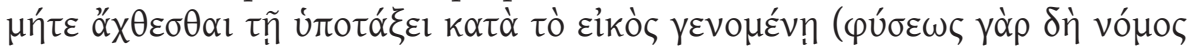

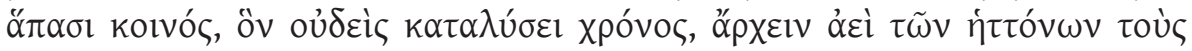

${ }^{348}$ Para T. Whitmarsh (2001: 15), os textos de Horácio e Vergílio merecem o seguinte comentário: "In such cases of surprising terminological interchange, the exceptions as it were proving the rule, it becomes clear that in the Roman imaginary, Greece's status as 'educator' was intrinsically linked with Rome's as conqueror."

${ }^{349}$ Nat. 3.39.

${ }^{350}$ Cf. Tusc. 1.1.2-3.

${ }^{351}$ Cf. Rep.1-2.

${ }^{352}$ Cf. Rep. 1.37.58, Tusc.5.36.104.

${ }^{353}$ Ant. Rom. 1.5.2.10; sobre Dionísio de Halicarnasso, G. Bowersock (1995: 7) escreveu o seguinte: "We will not forget that Dionysius himself was the historian who attempted to justify the domination of Rome to the Greek world by arguing that the Romans were, in fact, Greeks themselves", ideia que Plutarco também desenvolve. 


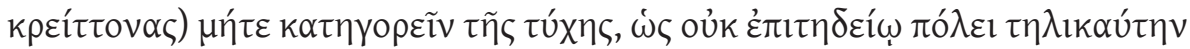

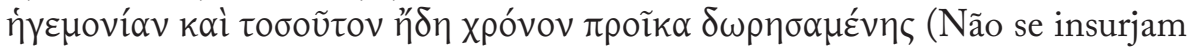
contra a submissão por ser natural (de facto, há uma lei da natureza, comum para todos, que nenhum período destruirá), nem acusem a fortuna, que assenta no princípio de que os mais fortes governam sempre sobre os que são inferiores). Deste modo, não devem os Gregos amaldiçoar a tyche por ter dado uma tão importante e duradoura hegemonia a uma cidade que baseava a sua força em valores ilustres. Para o Queronense, a relação entre Gregos e Romanos não se circunscreve à condição de conquistados e conquistadores ${ }^{354}$, pois pretende demonstrar que ambas as culturas partilham uma base comum, fundada, em última análise, nos alicerces da filosofia helénica. Aliás, se tivermos em conta que Plutarco apresenta as conquistas de Alexandre como a prefiguração do Império Romano ${ }^{355}$, percebe-se que o ideal de conquista se complementa com a paideia e a sua transmissão, tão bem ilustrados no bios de Alexandre ${ }^{356}$. Também Emílio Paulo, que temos identificado como um dos biografados romanos que melhor mostra a admiração pela cultura grega, é um bom exemplo dessa dinâmica cultural comum quando faz descender a gens Aemilia de Pitágoras ${ }^{357}$ ou no relato da sua acção em Delfos: ${ }^{358} \dot{\varepsilon} v \delta \dot{\varepsilon} \Delta \varepsilon \lambda \varphi$ oĩ

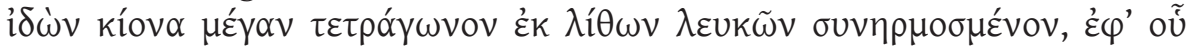

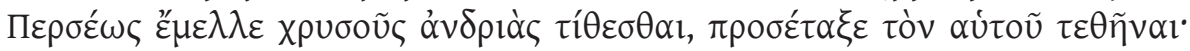

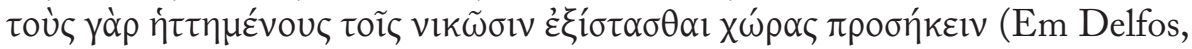
observando um grande pilar quadrangular, construído em pedra de mármore, sobre o qual deveria assentar uma estátua em ouro de Perseu, Emílio mandou colocar no pilar a dele próprio, argumentando que, na verdade, convinha que os vencidos cedessem o lugar aos vencedores). Note-se que, apesar desta atitude do Romano, Plutarco não o critica nem é irónico, uma vez que está mais interessado em salientar o seu carácter e a sua relação com a cultura helénica. Tendo, sem dúvida, orgulho na sua herança helénica ${ }^{359}$, Plutarco tem a perfeita noção das implicações do domínio romano sobre a Queroneia e a Grécia. Sabe

${ }^{354}$ M. Hadas (1950: 135), constatando que os efeitos do imperialismo romana na Grécia são diferentes daquilo que aconteceu a Ocidente, considera que "for Plutarch's whole career was devoted to raising Hellenism to a cult which could survive under the rule of Rome".

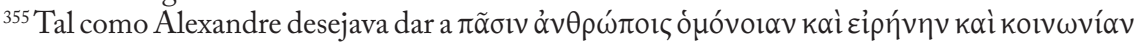
(cf. De Alex. fort. aut uirt. 330E), também os Romanos, por meio da tyche e da arete, tinham em

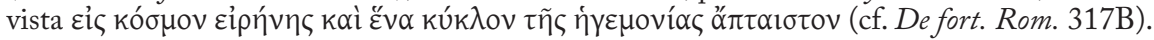

${ }^{356}$ S. Humbert (1991: 170) considera que Plutarco usa a figura de Alexandre para fazer a síntese das diferentes concepções de helenismo que surgiram depois da época clássica, uma vez que ele incarna as qualidades gregas do período pós-guerras Medo-Persas e a nova forma de helenismo mais centrada na paideia.

${ }^{357}$ Cf. Aem.2.2.

${ }^{358}$ Ibid. 28.4; nessa coluna encontra-se a seguinte inscrição: L. Aemilius L. f. imperator de rege Perse Macedonibusque.

${ }^{359}$ Cf. De sera num. uind. 558A-B 
também que, em paralelo, ocorre um processo de helenização dos Romanos e de romanização da Grécia, ainda que esta, ao contrário dos territórios ocidentais do Império, resista à assimilação, defendendo a sua língua, a sua literatura e os seus hábitos, especialmente por se considerar culturalmente superior. Por quererem evitar a introdução de costumes romanos, mesmo figuras ilustres como Cícero $^{360}$ e Plínio-o-Jovem ${ }^{361}$ entendiam essa cultura como um modelo da sua humanitas. Perante o poderio natural dos Romanos, os Gregos alicerçam a sua posição de resistência na memória de um passado histórico glorioso- o próprio Plutarco é um dos que recupera essa memória ao escrever a vida de grandes vultos da Antiguidade que muito significam para os Helenos - e nos valores que as suas artes transmitem, assistindo-se, no final do século I d. C., a um renascimento da literatura, durante a Segunda Sofística, corrente estética que tem como um dos elementos caracterizadores a afirmação do valor da cultura grega perante os Romanos e os próprios Gregos. Díon de Prusa ${ }^{362}$, por exemplo, analisa os valores da cidadania e advoga a cooperação entre as cidades gregas e o Império Romano. Assim, dentro desse clima de mútua colaboração, os aristocratas Gregos terão aprendido a língua do poder, o Latim. Veja-se o caso de Arriano, que escreveu a Adriano os relatórios na língua do Lácio. Não se põe, no entanto, em causa que o Grego seja a língua da cultura e, por isso mesmo, Marco Aurélio redigiu os seus pensamentos nessa língua.

O próprio método comparativo das Vitae indicia essa dinâmica (transformações e competição), estando Plutarco atento ao facto de ter uma audiência de Romanos filo-helénicos e de Gregos filo-romanos. Por conseguinte, aquilo que se poderia qualificar como um acto de observação, análise e exemplaridade do passado, é, sobretudo, uma manifestação de respeito pela memória dos antepassados ou um sinal do espírito patriótico face ao domínio romano, contrapondo figuras do passado heróico dos Gregos a grandes figuras da história romana. No entanto, no tratado Praecepta gerendae reipublicae, o Queronense lança um aviso sobre os perigos da exaltação do passado: 363

$\pi 0 \lambda \lambda \grave{\alpha}$ yò

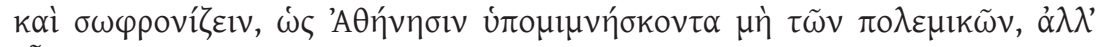

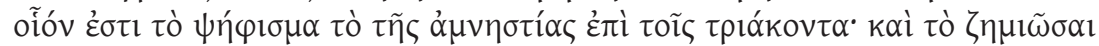

${ }^{360}$ Cf. Pro Flacco 61-62.

${ }^{361}$ Cf. 8.24.2.

${ }^{362}$ Cf. C. Jones (1978), P. Desideri (1978), G. Salmeri (1982), S. Swain (1998r: 187-241) e (2000: 13-50); na comparação com Plutarco, Ph. Stadter (2002: 3) escreve: “Where Dio’s style is confrontational and dramatic, impressing his audience with his own contacts and experience so as to be more persuasive, Plutarch seems more tolerant, more quiet, yet more sure of his audience. He does not lecture his reader so much as counsel him."

363 814A-C. 


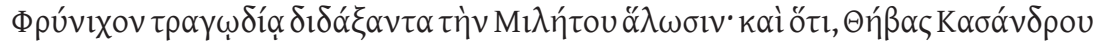

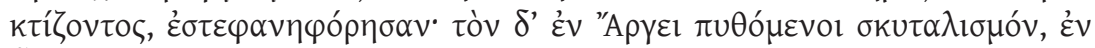

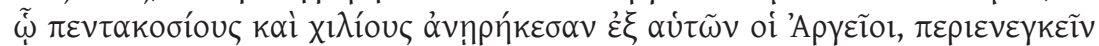

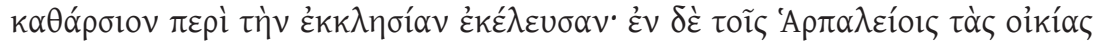

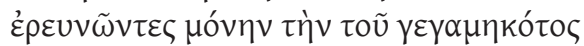

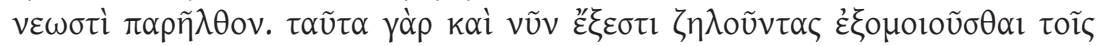

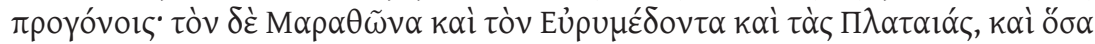

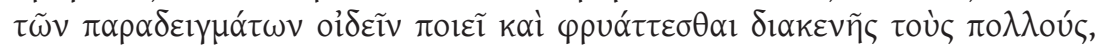

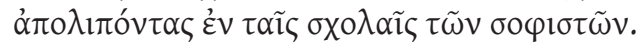

De facto, é possível alterar e corrigir o carácter dos nossos contemporâneos, referindo-lhes múltiplas acções de Gregos que viveram num outro tempo; em Atenas, por exemplo, recordando não os feitos bélicos, mas o decreto de amnistia, após a queda dos Trinta ${ }^{364}$; ou a multa imposta a Frínico por ter representado numa tragédia a tomada de Mileto ${ }^{365}$; ou que, enquanto Cassandro reconstruiu Tebas, colocaram coroas na sua cabeça ${ }^{366}$; ou que, sabendo da "bastonada" de Argos, onde os Argivos mataram mil e quinhentos dos seus e mandaram transportar à volta da assembleia uma vítima oferecida para um sacrifício expiatório; ou os Atenienses que, em relação ao assunto de Hárpalo, revistaram as casas, e apenas deixaram de parte a de um recém-casado. $\mathrm{Na}$ verdade, é possível, ao emular estas acções, ser semelhante aos antepassados, deixando Maratona, Eurimedonte e Plateias nas escolas dos Sofistas, e quantos exemplos que levam muitos a engrandecer-se e a bramir em vão.

Esta advertência acontece por causa do domínio romano e por Plutarco saber que, nos seus discursos e progymnasmata retóricos (suasoriae controuersiae), os sofistas recorriam com frequência a paradigmas do passado, nomeadamente à vitória sobre os Persas, correndo o risco de essas representações retóricas não serem adequadas ao momento presente ${ }^{367}$. Para o autor das Vitae não interessava enfatizar os erga, mas sobretudo a essência, ou seja, apresentar os Gregos como um paradeigma, processo que será também explorado por Élio Aristides, no Panathenaicus.

Essas leituras, contudo, podem levar-nos a julgar que Plutarco estaria satisfeito com a situação de liberdade parcial da Grécia, limitando-se a veicular preceitos morais e políticos que promovessem a manutenção da situação

${ }^{364}$ Decreto da responsabilidade de Trasibulo, em 403 a. C..

365 Também Heródoto (6.21) conta que Frínico, tragediógrafo anterior a Ésquilo, Sófocles e Eurípides, compôs um drama, em 493 a. C., sobre a tomada de Mileto, que ocorrera um ano antes, mas que por causa dos lamentos que suscitou no público se ordenou que mais ninguém voltasse a usar esse tema em dramas.

${ }^{366}$ A cidade de Tebas foi reconstruída em 316-5 a. C., após a destruição de Alexandre Magno em 335 a. C.; cf. De sera num. uind. 552E e Paus. 4.27.10 e 9.3.6.

${ }^{367}$ Cf. R. Webb (2006: 44). 
vigente. Parece-nos, porém, que, como homem pragmático, aproveita a ocasião para lançar as bases de uma nova sociedade, com padrões greco-romanos, que pudessem ser determinantes no futuro da Humanidade, servindo-se do passado para a configuração renovada da sociedade. Acrescentaríamos que da educação tradicional, assente no mos maiorum, se passa para uma mais concentrada no indivíduo. Deixando de estar manietado por imposições familiares ou pelos costumes tradicionais, a valorização ética torna-se uma prioridade, conduzindo o indivíduo, com a ajuda de mestres, à sua descoberta interior e ao conhecimento do espaço e do tempo em que vive, de modo a ser capaz de, com responsabilidade e liberdade, tomar as melhores decisões, quando for chamado a participar na politeia.

$\mathrm{O}$ efeito criado pelo paralelismo das Vitae coloca em evidência naturais diferenças entre Gregos e Romanos, mas tem também a virtude de aproximar a história dessas culturas. Basta verificar que as tensões sociais e políticas são comuns ao século $\mathrm{V}$ a. C. e ao fim da República ${ }^{368}$, com a emergência, segundo Plutarco, de elementos democráticos nem sempre de grande utilidade para a resolução dos problemas, adensando-se a oposição entre o povo e o poder estabelecido $^{369}$. Desenvolve-se a ideia de que, tanto na Grécia, como em Roma, as lutas políticas se foram tornando gradualmente mais acesas, ou seja, assistiuse a uma degeneração do poder ${ }^{370}$.

Para um povo, como os Gregos, com uma cultura com tendências assumidamente hegemónicas e com uma história tão influente em todo o Mediterrâneo, não seria seguramente fácil ver as suas poleis dominadas por aristocratas romanos. Com a sua perspectiva pragmática da filosofia ${ }^{371}$, Plutarco, ao promover uma revitalização moral do exercício da politeia, considera mais importante discutir a melhor forma de os Gregos se adaptarem à irreversibilidade do Império. Esta atitude é mais benéfica do que entrar numa lógica de confronto, que só agudizaria a precária situação helénica. De facto, a aristocracia grega viu o seu papel político ser reduzido pelo triunfo romano, com a agravante de o vencedor sentir a necessidade de recorrer à tradição helénica para consolidar os fundamentos do seu imperium ideal ${ }^{372}$. O Império Romano, depois da tentativa falhada de união alargada que o domínio macedónio havia sido - muito por culpa da morte prematura de

${ }^{368}$ Cf. e.g. Arist. 2.1, Caes. 14.2, Aem. 38.2-6, Cim. 15.1-2, Per. 7.8.

${ }^{369}$ Cf. e.g. Thes. 24-25, 32.1-2, Rom. 13.7, 27.8-9, Num. 2.3.

370 Sobre a degeneração do poder, vide Cat. Ma. 4.2 (cf. Per. 15.1-2); vide, em Cim. 17.9 e Gracch. 20.1, referências a conflitos políticos moderados e, em Per. 11.2-3, Alc. 13.5, Nic. 6.1, Phoc. 34.6 e Mar. 35.1, as lutas mais intensas.

${ }^{371}$ F. Titchener (2002: 136) começa assim o seu texto: "Plutarch, a pragmatist...", qualificação que se ajusta bem ao Queronense pela forma como adapta a narrativa aos seus objectivos, capacidades pessoais e recursos (fontes); vide também H. Ingenkamp (1984: 79-81).

372 Cf. D. Plácido (1995: 136). 
Alexandre ${ }^{373}$-, substitui essa ideia de governo universal ${ }^{374}$. Esse governo deveria distinguir-se, preferencialmente, pela sua acção civilizadora, tal como Alexandre, digno de se chamar filósofo ${ }^{375}$, havia feito: ${ }^{376}$

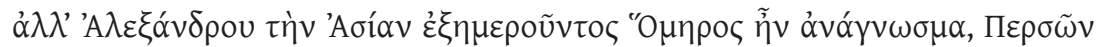

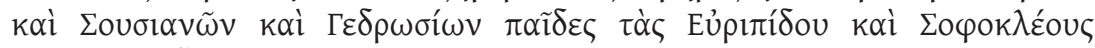

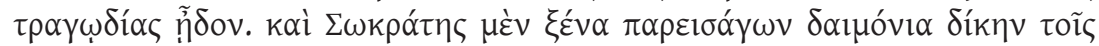

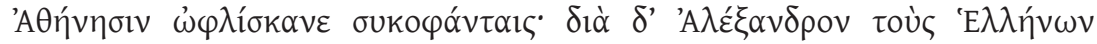

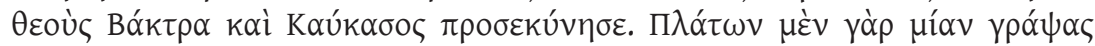

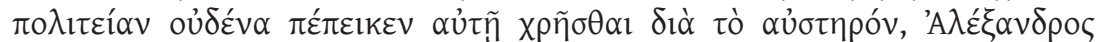

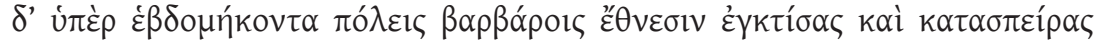

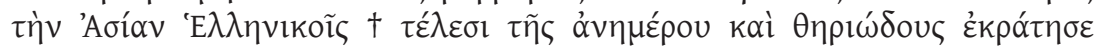

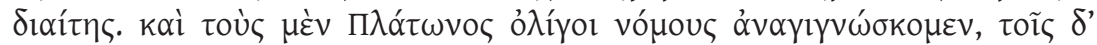

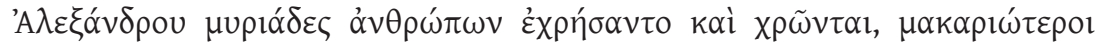

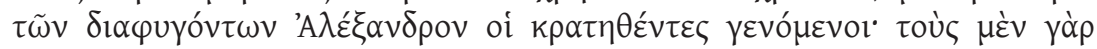

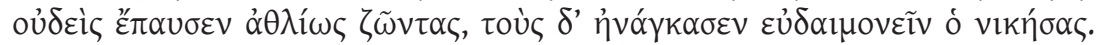

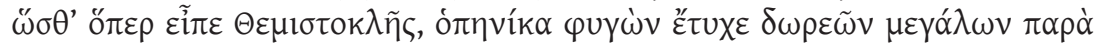

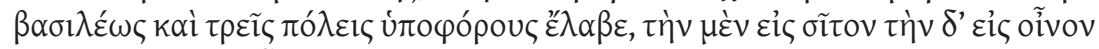

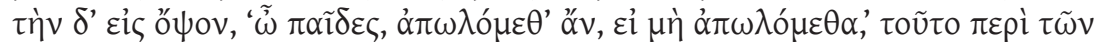

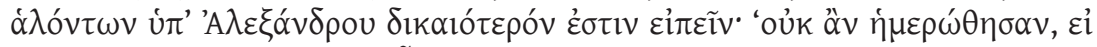

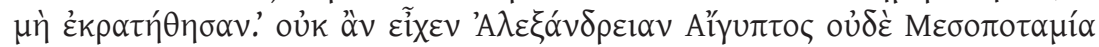

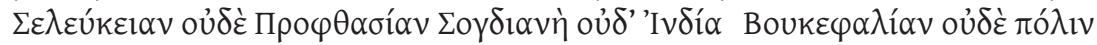

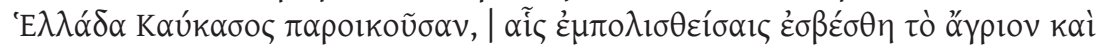

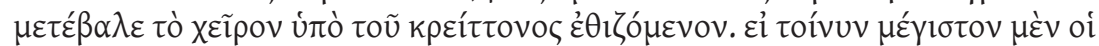

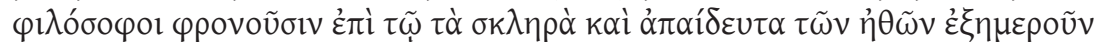

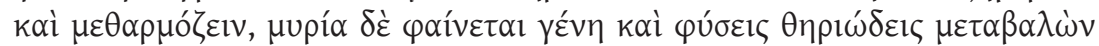

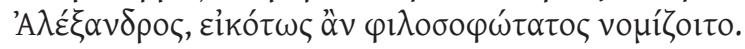

Mas, quando Alexandre civilizava a Ásia, recitavam Homero e as crianças da Pérsia, de Susa e da Gerdósia cantavam as tragédias de Eurípides e de Sófocles. Junto dos Atenienses, Sócrates foi condenado pelos sicofantas por introduzir divindades estrangeiras. Pelo contrário, a Báctria e o Cáucaso adoraram os deuses gregos por intermédio de Alexandre. Se Platão, tendo escrito um tratado

${ }^{373}$ Arriano reproduz palavras de Alexandre em que este fala de um mundo comum a Gregos e Persas, em que prevaleceria a concórdia (cf. Anab. 8.11.9).

${ }^{374} \mathrm{Na}$ verdade, se Alexandre tivesse regressado da sua empresa no Oriente, teria havido uma hegemonia grega, que difundiria a sua paideia, mas, por acção da tyche, Roma seria favorecida pela morte daquele e a história sofreria uma alteração (cf. De fort. Rom. 326A s.).

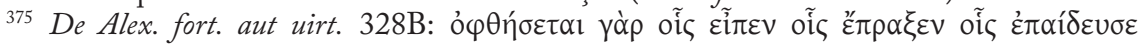

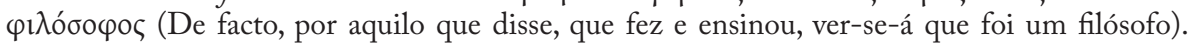
$\mathrm{O}$ facto de ter civilizado ou educado povos de natureza selvagem torna-o, segundo Plutarco, merecedor de ser considerado um distinto filósofo (cf. ibid. 329A), muito embora não tenha escrito tratados filosóficos, da mesma forma que Pitágoras, Sócrates, Arcesilau e Carnéades também não escreveram (cf. ibid. 328A).

${ }^{376}$ Ibid. 328D-329A. 
sobre política [República], não convenceu ninguém a pô-lo em prática por causa da sua austeridade, Alexandre, por sua vez, tendo fundado mais de setenta cidades entre os bárbaros e semeado na Ásia as jurisdições helénicas, reprimiu o modo de viver selvagem e animalesco deles. Poucos lemos as Leis de Platão, mas muitos homens usaram e ainda usam as leis de Alexandre; os conquistados são mais felizes do que aqueles que escaparam a Alexandre. De facto, ninguém pôs fim à vida penosa que estes levavam, mas o vencedor levou-lhes a felicidade. De tal maneira que aquilo que Temístocles - quando esteve no exílio conseguiu grandes presentes do rei: recebeu três cidades que pagavam o tributo, uma para o pão, outra para a vinho e outra para a carne - disse: "Filhos, nós poderíamos morrer, se ainda não morremos", seria muito justo dizer-se sobre as cidades conquistadas por Alexandre: "Não poderiam ter sido civilizadas, se não tivessem sido dominadas". O Egipto não teria Alexandria, nem a Mesopotâmia Selêucia, nem a Sogdiana Proftásia, nem a Índia Bucefalia, nem o Cáucaso estaria perto de uma cidade grega;... com estas fundações extinguiu-se o que havia de selvagem e o pior, ao acostumar-se ao melhor, transformou-se. Pois bem, se os filósofos tanto se orgulham por civilizar e mudar os caracteres rudes e sem formação, Alexandre parece que transformou muitas raças e naturezas selvagens, por isso poder-se-ia considerar, com razão, um grande filósofo.

Esta acção civilizadora de Alexandre junto dos Bárbaros, já mencionada na análise da sua biografia, estaria certamente relacionada com a educação filosófica que recebeu de Aristóteles, que o preparou melhor do que aquela que recebeu de Filipe, seu pai ${ }^{377}$.

Apesar de se poder encontrar um sentimento anti-romano na historiografia grega entre os séculos I a. C. e II d. C. ${ }^{378}$, verifica-se, nesta altura, uma tendência para aproximar ou fundir o helenismo e a romanidade, numa visão unitária da sociedade, sendo Plutarco um dos autores que prefere lançar os fundamentos de uma sociedade comum e cooperante, em vez de se concentrar excessivamente nas diferenças entre Gregos e Romanos ${ }^{379}$. Note-se que, em $D e$ Alexandri fortuna aut uirtute ${ }^{380}$, o autor não esconde que Alexandre foi, ao aliar a sua paideia à capacidade militar, o primeiro a aproximar-se da consolidação dessa sociedade comum, realizando o que já Zenão havia escrito na sua obra intitulada Respublica ${ }^{381}$, onde advoga o princípio de uma comunidade que

377 ibid. $327 \mathrm{~F}$.

${ }^{378}$ Cf. A. Barigazzi (1984b: 266-7); o mesmo estudioso dá o exemplo de Demétrio de Calátis (primeira metade do século II a. C.), como um autor que já tinha uma noção ecuménica do mundo.

${ }^{379}$ Dionísio de Halicarnasso, da época de Augusto, foca o legado grego na cultura romana, nomeadamente a língua, nem bárbara nem grega por completo, mas eólia (Ant. Rom. 1.90.1; cf. Quintiliano 1.4.8).

380 329A-B.

${ }^{381}$ Outras referências em Quaest. conu. 653E e Lyc. 31.2. 
reunisse todos os cidadãos, sob a mesma lei. Por conseguinte, o objectivo de os povos da terra terem uma só razão e um só governo foi herdado pelos Romanos, que, com a ajuda divina e por acção do destino, assumiram a supremacia da terra habitada, impondo a sua ordem e suprimindo a instabilidade crónica dos povos conquistados ${ }^{382}$.

Ora, nesse novo período histórico, por assim dizer, a Grécia contribuiria com o esplendor e a humanidade da sua paideia ${ }^{383}$ e Roma com a sua capacidade e sabedoria governativa, e o engenho militar. Mais do que colocar em dúvida a hegemonia romana, Plutarco entende ser mais importante criticar a falta de profundidade espiritual desse imperialismo, tal como Políbio havia denunciado a riqueza, o luxo e a consequente corrupção que alastrava em Roma $^{384}$. Nas palavras finais da synkrisis do par Lycurgus-Numa, o Queronense expõe, claramente, o que pensa sobre esta matéria: ${ }^{385}$

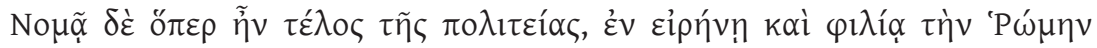

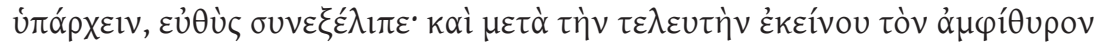

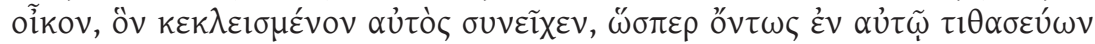

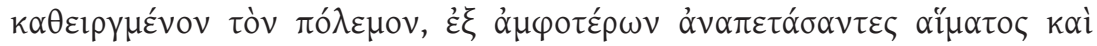

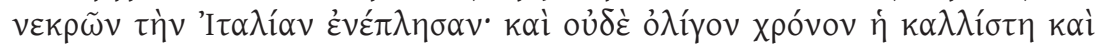

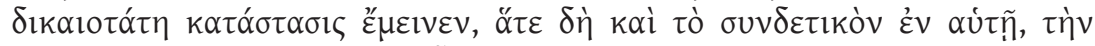

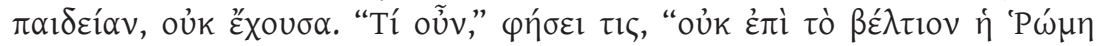

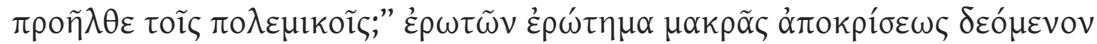

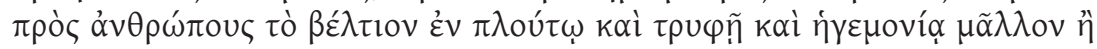

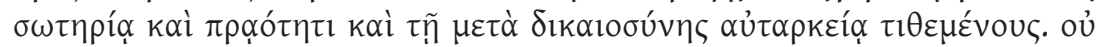

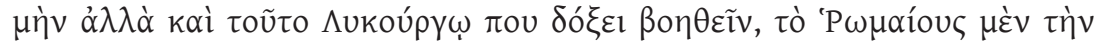

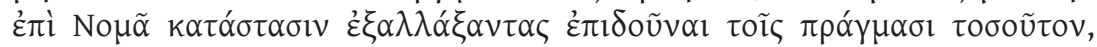

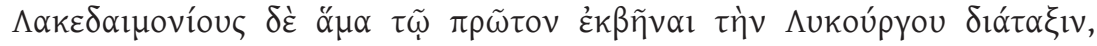

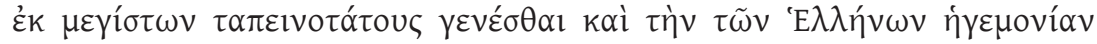

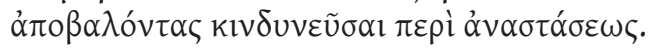

Porém, para Numa o objectivo da constituição, que era Roma viver em paz e amizade, desapareceu de imediato; depois da morte dele, a casa de dupla porta, que ele manteve encerrada, como se nela guardasse encerrada a guerra, logo se abriu enchendo de sangue e mortes a Itália; e esta tão bela e justa constituição desapareceu depressa, pois não havia nela a união e a educação. Alguém dirá: "Roma, então, não se desenvolveu melhor com as acções bélicas?", colocando uma questão que necessita de uma alargada resposta perante homens que dão

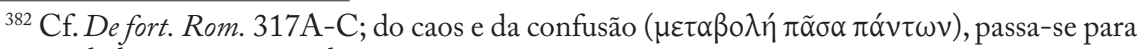
uma sociedade mais organizada.

${ }^{383}$ Já havia conquistado, por meio de Alexandre, o Oriente e tinha conseguido ser o âmago da nova ordem imposta pelo Império Romano (cf. De Alex. fort. aut uirt. 389A).

3849.10 .

385 4.6-8. 
mais valor ao dinheiro, ao luxo e à hegemonia do que à salvação, à doçura e à autarcia na companhia da justiça. Não obstante, também isto parece, de alguma maneira, vir em auxílio de Licurgo: tendo os Romanos deixado a constituição de Numa, os seus feitos cresceram muito, enquanto os Lacedemónios, logo que saíram da ordem de Licurgo, de muito importantes tornaram-se modestos e, tendo perdido a hegemonia dos Gregos, correram o perigo de serem destruídos.

Além de essa idealização reflectir, sobretudo, o pensamento de um homem preocupado com a criação de alicerces duradouros para uma configuração social, política e cultural abrangente, em vez da reflexão de um cidadão muito vinculado a um Estado, ela demonstra claramente que Plutarco entendia que uma associação ou comunidade de povos necessitava de leis comuns, ou seja, de uma organização administrativa e, em especial, de uma paideia moral, que tornasse os cidadãos justos, bem como os seus governantes, os quais deviam ser escolhidos em conformidade com critérios assentes na ética e não na quantidade de bens, pois só desse modo se obteria a igualdade ${ }^{386}$.

Essa alteração no curso da história, ditada por razões humanas e também divinas (pronoia), tal como Plutarco a vê, é, segundo A. Barigazzi (1984: 269), uma forma de historiografia: "alle forze naturali immanenti nell'uomo e nel suo ambiente è sostituita una forza personale, quella suprema che è fondamento e spiegazione di ogni evento", daí a presença da dicotomia tyche e arete na análise do percurso dos Romanos e do próprio Alexandre, podendo as duas cooperar $^{387}$.

Nos tratados políticos, como vimos, Plutarco aconselha os seus compatriotas a manter a sensatez, a criar amizades com os administradores romanos e a, tanto quanto possível, participar no governo das poleis. No fundo, respeitar os Romanos, mas nunca renunciar à liberdade. É nesse contexto que citamos as palavras que melhor retratam aquilo que Plutarco sente em relação ao momento que a Grécia vive: ${ }^{388}$

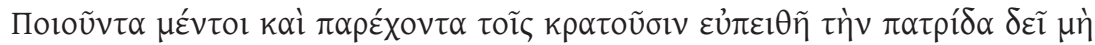

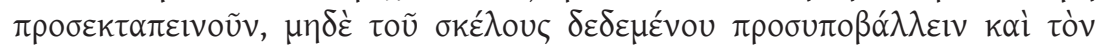

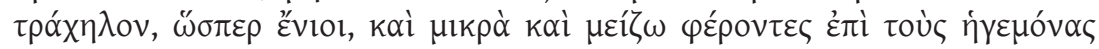

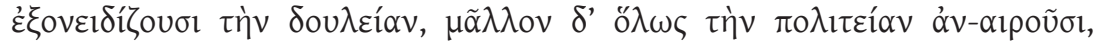

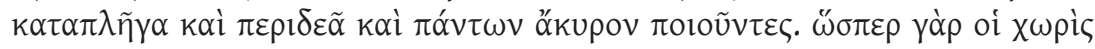

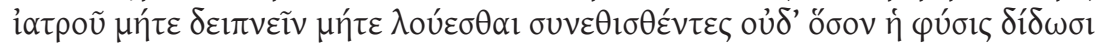

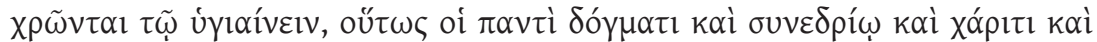

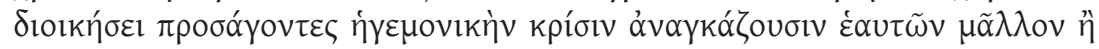

${ }^{386}$ Refira-se que já Aristóteles (Pol. 1280a 25-1281a 10) havia feito depender o sucesso de uma comunidade de povos da sua formação moral e cívica.

${ }^{387}$ Dessa união, resultou a mais bela acção humana (cf. De fort. Rom. 316E); vide Rom. 8.9.

${ }^{388}$ Praec. ger. reip. $814 \mathrm{E}-\mathrm{F}$. 


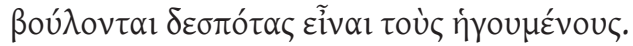

Ainda que a pátria se torne e se mostre dócil com os que a dominam, é necessário que não se rebaixe ainda mais, nem, tendo já a perna atada, deixe que lhe apertem também o pescoço, como fazem alguns que agravam ainda mais a sua escravidão ao consultar os dominadores tanto sobre as coisas importantes como sobre aquelas que são irrelevantes, e assim anulam por completo a sua actividade política, fazendo com que seja tímida, submissa e sem qualquer autoridade. Assim como aqueles que se habituam a não comer e a não lavar-se sem o consentimento do médico não possuem a saúde que a própria natureza lhes concede, assim também os que procuram o juízo dos dominadores em relação a todo o tipo de decreto, assembleia deliberativa, concessão ou acto administrativo forçam os dominadores a serem mais senhores absolutos do que aquilo que desejam.

Além de ser necessário realçar a crítica que faz aos que se humilham perante a força dominadora, interessa a semântica do texto: os Gregos estão atados ( $\delta \varepsilon \delta \varepsilon \mu \varepsilon ́ v o u)$ e vivem uma situação de escravidão ( $\delta o u \lambda \varepsilon i ́ \alpha v)$, que ainda se torna mais difícil de suportar ao ver os que perderam auto-estima, subjugandose por qualquer razão à vontade dos Romanos.

Por sua vez, na biografia de Flaminino, um Romano que tem uma vivência especial nas relações entre Roma e a Grécia, Plutarco aponta algumas razões para a aceitação do domínio estrangeiro: ${ }^{389}$

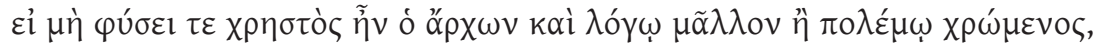

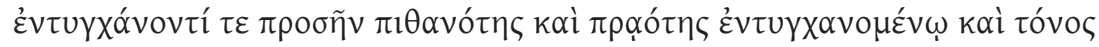

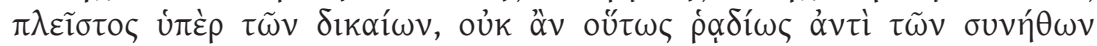

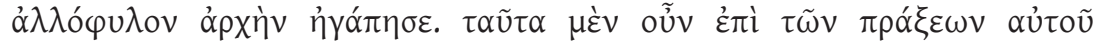
$\delta \eta \lambda o \tilde{\tau} \tau \alpha$.

Se o comandante não fosse nobre por natureza e não desejasse mais a palavra do que a guerra; se não tivesse capacidade persuasiva com os que interpela, doçura com os que o interpelam e uma imensa fadiga em prol da justiça, com certeza que a Grécia não teria preferido um domínio estrangeiro em vez daquele a que estava habituada. Isto é o que, sem dúvida, demonstram as acções de Flaminino.

Assim, segundo Plutarco, a Grécia cede ao domínio dos $\alpha \lambda \lambda \operatorname{có}_{\varphi} \cup \lambda \lambda \mathrm{\lambda}$ — vocábulo que denota uma categoria étnica, tal como ó $\mu$ ó $\varphi \nu_{\lambda o 1^{390}}$-, não dos barbaroi, pelo facto de os dominadores terem demonstrado que não desprezavam os valores, a paz, a eloquência, a doçura e a justiça e, porventura,

\footnotetext{
${ }^{389}$ Flam. 2.5.

${ }^{390}$ Cf. J. Hall (1997: 40-51).
} 
por acreditar que, com a ajuda dos Romanos, a Grécia poderia reabilitar as suas instituições e as qualidades do passado. Mas é sobretudo por causa da existência de um clima de paz que Plutarco se sente satisfeito: ${ }^{391}$ Tà $\delta \dot{\varepsilon} v \tilde{v} v$

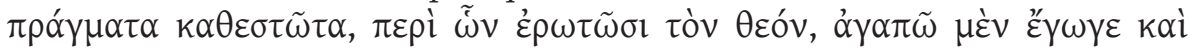

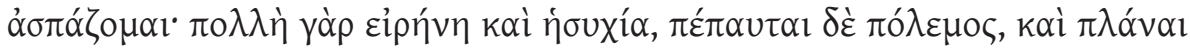

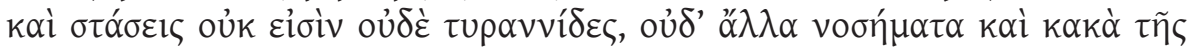

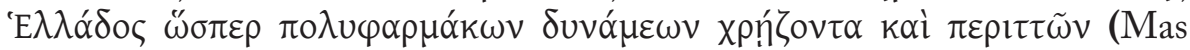
agora os acontecimentos, sobre os quais se interroga a divindade, demonstram que eu estou satisfeito e me congratulo; de facto, existe uma paz sólida e tranquilidade; terminou a guerra, não há errâncias e dissensões, nem tiranias, nem outras doenças e males da Grécia, como os que desejam um poder corrosivo e desmesurado). Poderíamos, ainda, acrescentar que Plutarco pretende aproveitar a realidade inegável da hegemonia romana para difundir os princípios da paideia helénica, até porque um Estado em paz tem mais tempo para se dedicar à formação. Recordando mais uma vez Aristóteles ${ }^{392}$, o político deve ter como um dos seus objectivos principais a criação de condições para a paz, para se fruir da paideia, tal como os legisladores devem evitar as leis que apenas promovem a subjugação ou o desejo de riqueza, sem educar os cidadãos para épocas em que passem da situação de dominador a dominado, em vez de assegurar que se tornem bons e se dediquem às melhores actividades.

$\mathrm{Na}$ verdade, Grécia e Roma, com histórias distintas, partilham variadíssimas características e parecem, quase por vontade divina, condenadas a encontrarem-se no grande campo da história. Plutarco, um erudito muito consciente da memória histórica, sabe isso, de tal forma que a concepção metodológica das Vitae favorece a confrontação de padrões culturais. É certo que, por natureza, a sua análise tem um ponto de vista helénico, mas, ao contrário de Luciano, não declara abertamente a superioridade dos Gregos, muito menos dos Romanos, preferindo optar por uma solução compósita ou de krasis cultural: uma civilização ou oikoumene greco-romana, resultado de uma nova consciência, que não era grega, nem latina, mas universal e que já o célebre Círculo de Cipião parecia configurar. Plutarco, ao repartir os defeitos e virtudes pelos Gregos e Romanos, pretende dar um sinal dessa nova definição cultural: a sociedade greco-romana. É curioso verificar que as críticas que faz a algumas manifestações ou instituições culturais romanas, como os combates de gladiadores, a escravatura e a divinização do Imperador ainda em vida, são um sentimento comum entre autores gregos e mesmo entre intelectuais romanos.

Nesse espaço civilizacional, passariam a conviver os tradicionais valores helénicos e romanos, o engenho criativo dos Gregos, bem como a capacidade

\footnotetext{
${ }^{391}$ De Pyth. or. 408B.

${ }^{392}$ Cf. Pol. 1333a 35 ss.
} 
pragmática e de realização dos Romanos, que Tito Lívio assim sintetizou: ${ }^{393}$ gens lingua magis strenua quam factis (uma raça [a dos Gregos] mais diligente em palavras do que em acções). Então, para Plutarco é necessário passar-se de uma cultura de subordinação a uma de cooperação, em que se promova o intercâmbio cultural, num ambiente pacífico e profícuo para ambos os povos. Numa outra perspectiva, complementar à opção de esboçar uma civilização greco-romana que tende a abolir a alteridade que para um Grego representa o Romano, Plutarco esforça-se por inscrever a sua escrita num plano histórico e temporal mais abrangente, se quisermos, mais universal: ${ }^{394}$

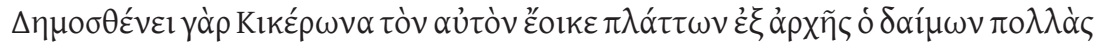

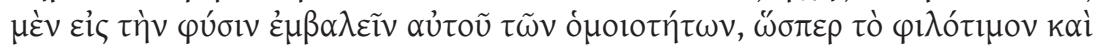

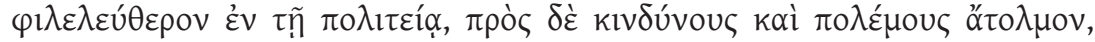

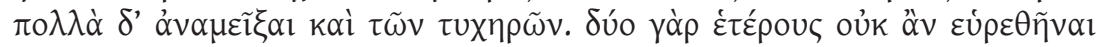

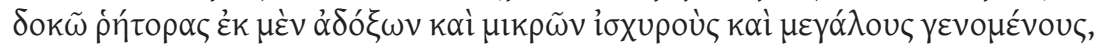

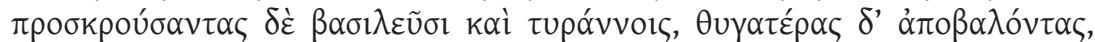

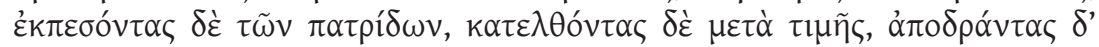

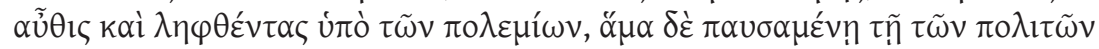

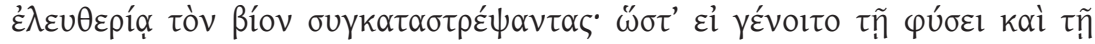

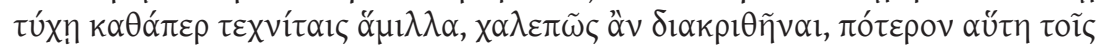

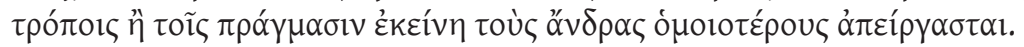

A divindade tornou Cícero semelhante a Demóstenes, modelando muitas das suas características de forma semelhante para as introduzir na natureza dele, como a ambição, o amor pela liberdade na vida política, a falta de coragem perante os perigos e os conflitos; a divindade parece ter estabelecido entre eles, por diversas vezes, semelhanças nos acontecimentos fortuitos da vida. $\mathrm{Na}$ verdade, julgo que não poderíamos encontrar outros dois oradores que, inicialmente sem fama e insignificantes, se tornaram poderosos e grandes, que entraram em conflito com reis e tiranos, perderam as filhas, foram desterrados das suas pátrias, voltaram com honra, depois fugiram novamente e foram capturados pelos inimigos, e acabaram a vida ao mesmo tempo que a liberdade dos concidadãos chegou ao fim. Por conseguinte, se houvesse confronto entre a natureza e a fortuna, como entre artífices, seria difícil decidir se foi a natureza que tornou os homens muito semelhantes por meio dos caracteres ou a fortuna pelas circunstâncias.

Dois homens que viveram em tempos e espaços diferentes, além de terem tido uma formação diferenciada por cedo terem demonstrado vocações distintas, não só possuem várias características semelhantes,

\footnotetext{
3938.22 .8 .

${ }^{394}$ Dem. 3.3-5.
} 
como tiveram experiências de vida repetidas, como a perda de uma filha ou o desterro. A universalidade que esta constatação denota é atribuída, por

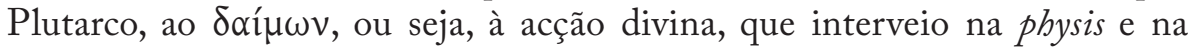
tyche de Demóstenes e Cícero. Com efeito, essa justificação fica-se a dever, essencialmente, ao facto de não ser fácil atribuir à natureza ou à fortuna a causa para os seus caracteres e as suas vidas apresentarem tantas semelhanças. Aliás, essa dificuldade acompanha Plutarco, tal como os seus leitores, no momento de analisar o percurso dos heróis das Vitae, atendendo à intervenção do daimon, às características inerentes à physis, aos elementos fortuitos (tyche), ao papel da paideia e, claro, ao esforço pessoal de cada indivíduo. Cada um, à sua maneira, modela o carácter e condiciona a acção, sem que muitas vezes seja possível determinar a causa profunda de uma atitude. Este texto regista, em definitivo, que Gregos e Romanos ( $\left.\alpha^{\prime} \mu \alpha\right)$ pertencem ao mesmo processo histórico e que comungam valores, tristezas, amarguras e qualidades. Esta constatação leva Plutarco a propor, de forma subtil, uma civilização grecoromana, sem abolir ou ignorar as diferenças que, por natureza (physei), esses povos corporizam.

Desta forma, Gregos e Romanos, lado a lado, são os principais actores de uma prosa histórico-biográfica que visa aprofundar valores demonstrados na acção. Atendendo aos acontecimentos dos I e II séculos é quase obrigatório entender a identidade cultural como algo que não é fixo ou unitário. No caso particular das Vitae, concebidas por um Grego, mais tarde também cidadão romano, adquire especial significado a verificação dos valores culturais dos heróis e, em particular, se existe uma supremacia da cultura helénica sobre os ideais romanos.

Ao agrupar sucessivamente um Grego e um Romano, marca metodológica e o grande leitmotiv das Vitae, Plutarco "conscient de sa dualité et de son unité", como escreveu J. Sirinelli (2000: 288), reflecte uma característica própria da sua época: dois povos, gregos e romanos, com um elo cultural estreito e intenso. Aliás, a biografia servirá de instrumento para aproximar as duas culturas, num plano ético-político, pejado de valores, tendo a synkrisis um papel central na construção da identidade de Gregos e Romanos. Acreditamos, ainda, que a estrutura comparativa aproxima os destinatários gregos e romanos, que sentem o apelo para valores similares, sem alienar nenhuma das partes. Assim, as Vitae, consolidando a noção do paralelismo histórico, promovem uma espécie de jogo de espelhos, a partir do qual se constroem os conceitos de grecidade e romanidade 395 , a que se deve juntar o fim pedagógico que esses espelhos

395 Tradução de greekness e romanness, conceitos desenvolvidos, por exemplo, em S. Swain, T. Duff, T. Morgan ou T. Whitmarsh; as atitudes tipicamente conotadas com a grecidade ou helenicidade, como a philanthropia (cf. Comp. Lyc.-Num. 1.9-10, Pyrrh. 1.3, Phil. 8.1), opõem-se 
significam para o leitor ou ouvinte.

A presença de Roma e dos seus ideais na obra de Plutarco prova a consciência que ele tem da supremacia da cidade do Lácio no Mediterrâneo e o fascínio que os Romanos sentem pela cultura helénica, com algumas excepções, como o caso de Mário: ${ }^{396}$

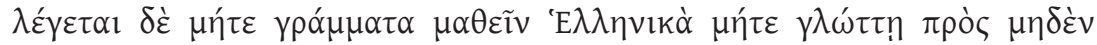

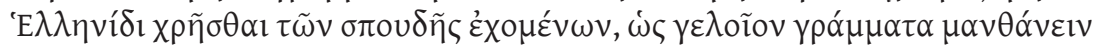

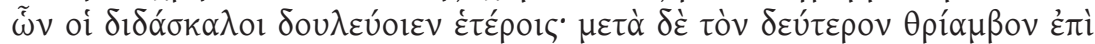

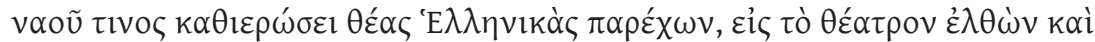

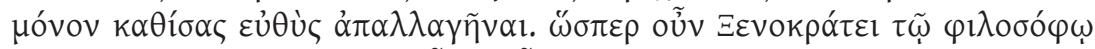

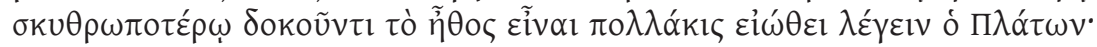

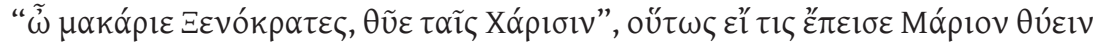

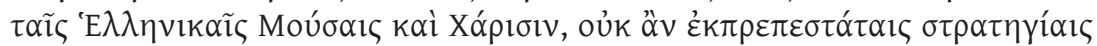

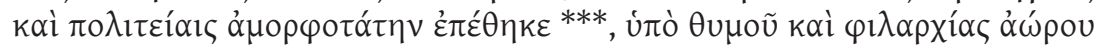

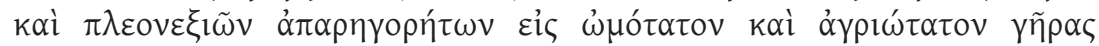

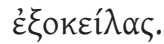

Conta-se que nem aprendeu as letras gregas nem fazia uso da língua grega em nenhum assunto sério, pois achava ridículo aprender as letras que eram ensinadas por escravos de outros. Porém, após o seu segundo triunfo, no momento de fazer a dedicatória a um templo, ofereceu um espectáculo helénico e dirigiu-se ao teatro, mas sentou-se aí apenas por breves instantes e logo se retirou. Assim como Platão tinha por costume dizer ao filósofo Xenócrates, cujo carácter parecia ser muito soturno: "Querido Xenócrates, faz sacrifícios às Graças!", se alguém persuadisse Mário a fazer sacrifícios às Musas e às Graças Helénicas, ele não teria terminado as suas belas acções militares e políticas de forma tão infeliz e, seguindo a sua cólera, um desejo intempestivo pelo poder e as suas ambições insaciáveis, não se teria perdido numa velhice muito cruel e violenta.

É, assim, por meio de um exemplo a contrario que demonstra que a paideia é vital para a obtenção dos valores gregos, atribuindo os defeitos de Mário e as suas más opções à apaideusia, ou seja, à ausência da cultura grega, com palavras que não escondem aquilo que um Romano poderia sentir face às letras

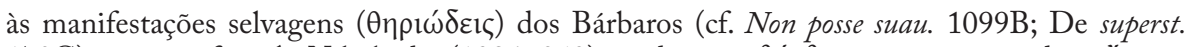
170C); como refere A. Nikolaidis (1986: 242) o adjectivo $\beta \alpha ́ \rho \beta \alpha \rho \circ \varsigma$ está associado a ớ $p 10 \varsigma$ (cf. De comm. not. 1075A e Cat. Mi. 63.6); no mesmo estudo, A. Nikolaidis esquematiza a oposição semântica, com enorme alcance cultural, entre Gregos e Bárbaros, também merecendo os Gregos ser criticados por Plutarco quando as suas acções se distanciam da natureza própria de um hellenikos.

${ }^{396}$ Mar. 2.2-4. 
gregas $^{397}$. No caso de Sula, a perspectiva é ligeiramente diferente, uma vez que, segundo Plutarco, ele tinha um desejo terrível e desmesurado por conquistar a Grécia, destruindo as suas terras e estimulando os soldados a fazer pilhagens ${ }^{398}$. Isto revela como a cultura grega é vítima do descontrolo e da violência de Sula.

Os Romanos tentaram, ao controlar a Grécia, manter as estruturas das poleis, assegurando o controlo dessas mediante o apoio das elites locais. Plutarco, que integra essa aristocracia, não se revolta contra o domínio romano, pois insinua que a pax romana $a^{399}$ pôs termo às guerras internas ${ }^{400}$, algo que ele aceita, tal como Díon de Prusa, por ter posto fim à vulgaridade e à obsessão pelo poder dos monarcas helenísticos ${ }^{401}$, embora não esconda o seu desejo de

${ }^{397}$ Cf. Sall. Jug. 85.32 e Cic. Pro Font. 15.33.

${ }^{398}$ Cf. Sull. 13.1-2.

${ }^{399} \mathrm{O}$ tema da pax romana como uma realidade que veio alterar a situação vigente surge com maior ênfase em An seni resp. 784F e Praec. ger. reip. 805A e 824C; em De fort. Rom. 317B-C,

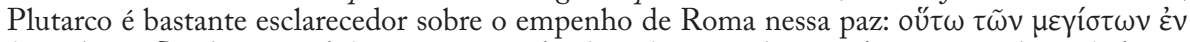

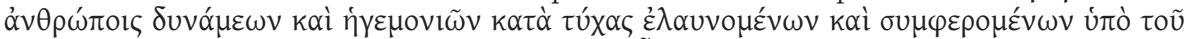

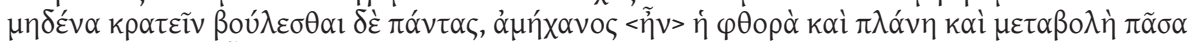

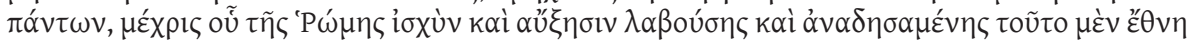

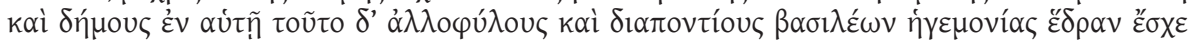

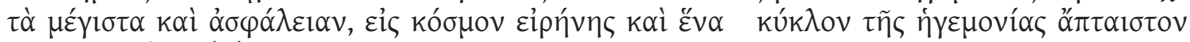
$\pi \varepsilon \rho і \varphi \varepsilon \rho о \mu \varepsilon ́ v \eta \varsigma$ (...). "Da mesma forma, as maiores forças e poderes humanos movimentavamse, ao acaso, e chocavam porque ninguém dominava, embora todos o desejassem; nenhum movimento, extravio e alteração das coisas tinha solução, até que Roma cresceu, fortaleceu-se e juntou a ela não só os seus povos e as gentes, mas também estrangeiros e reinos que ficam além-mar. As coisas mais importantes tiveram estabilidade e segurança, e o seu domínio sem faltas guindou-a à ordem e a um único ciclo de paz (...)." Para Plutarco, é importante, como refere em De tranq. an. 469E, que o polemos ou a stasis (vide a associação destes dois vocábulos em Cor. 11.6, Alc. 21.8, Arist. 12.3 e Cic. 3.2 ) não se repitam, de forma a poder o homem fruir

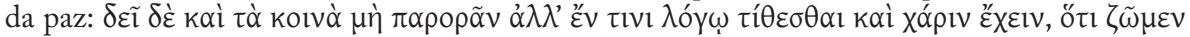

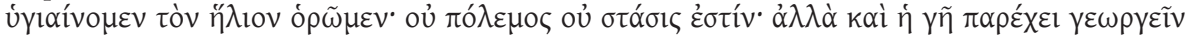

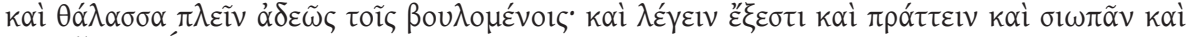

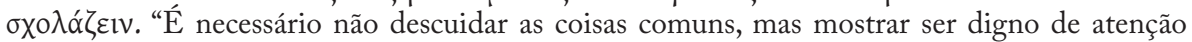
e ter prazer por estar vivo e com saúde e ver o sol. Não há guerra, nem dissensão, mas a terra permite o cultivo e o mar a navegação, com facilidade, a quem o deseja. É permitido falar e agir, bem como estar em silêncio e descansar." Veja-se como a eirene é um bem que cria condições para o homem poder sentir outros bens, como a agricultura e a navegação. No entanto, Plutarco e outros compatriotas sabem que a paz lhes pode custar a perda do poder. Daí que, na synkrisis do par Cim.-Luc. 2.4, elogie o facto de o Grego ter conseguido manter a eirene e a homonoia, sem ter perdido a hegemonia.

${ }^{400}$ Refira-se que a crítica que Plutarco faz aos Gregos por terem empreendido muitas guerras internas, descurando os inimigos exteriores, também se aplica em parte aos Romanos, pois as guerras civis são um testemunho claro da decadência na República (cf. Cat. Ma. 4.2-3, Phoc. 3.3, Sull. 1.5, Pomp. 70), que só a monarquia pode travar (cf. Caes. 28.6 e 51.1, Pomp. 5.4-5), nomeadamente Augusto, fundador da pax romana.

${ }^{401}$ Cf. Pyrrh. 12.3 e De adul. 56F; em Ad princ. ind. 779F-780A, Plutarco critica esses monarcas, comparando-os a estátuas de aspecto colossal, mas que por dentro são apenas chumbo e pedra. 
liberdade. Perante isso, torna-se um fervoroso patriota ${ }^{402}$ ou tenta harmonizar a sua identidade e formação com a alteridade romana? Sublinhe-se que este novo tempo de paz é, no fundo, o reconhecimento do declínio da Grécia, da Grécia esplendorosa da Época Clássica: um bom exemplo é o facto de esse declínio vir associado à alteração verificada no Óraculo de Delfos, uma vez que antes eram necessários três sacerdotes, enquanto no presente um apenas seria suficiente ${ }^{403}$. Por exemplo, a felicidade de Téon, personagem que surge no tratado De Pythiae oraculis, por viver em paz $^{404}$ é muitas vezes interpretada como uma forma de louvar a acção dos Romanos, até porque a unidade que estes trouxeram aproximava-se bastante da que Alexandre um dia havia idealizado. Contudo, T. Duff (2002r: 292), com razão, argumenta que os Romanos não são mencionados como os autores dessa paz, nem a sua aç̧ão surge claramente referida em De Pythiae oraculis ou em De defectu oraculorum. ${ }^{405} \mathrm{O}$ que parece evidente é que Plutarco não é indiferente a um tema: o das fronteiras entre grecidade e romanidade ${ }^{406}$.

${ }^{402}$ Há quem veja na sua decisão de continuar na Queroneia (cf. Dem. 2.1-2) uma atitude patriótica e uma ligação íntima à terra dos seus ancestrais. Em Praec. ger. reip. 814D, critica aqueles que, a troco de lugares lucrativos na administração romana, abandonam as suas cidades; cf. An seni resp. 792E-F (o dever de regressar à pátria). F. Titchener (2002: 138-141), fazendo uma leitura mais pragmática da opção de Plutarco por permancer na Queroneia, discute algumas das razões, entre as quais realçamos: por razões monetárias, pois viver em Atenas era muito mais dispendioso; a Queroneia permitia-lhe bons acessos à Itália, à Macedónia ou ao Egipto; estando relativamente longe de Atenas, conseguia passar despercebido aos imperadores, pois alguns amigos de Plutarco, como Aruleno Rústico e C. Avídio Nigrino, haviam sido executados. Outra leitura, que o estudioso, com razão, recusa, relaciona-se com o possível receio de Plutarco competir com outros numa grande cidade, mas que a sua carreira política, preenchida com diversas funções, parece não corroborar. Queroneia seria, talvez, o melhor local para Plutarco conseguir conciliar duas coisas muito importantes para ele: a ligação à sua terra de origem e a manutenção de uma posição neutral face ao poderio romano, eximindo-se de criticar os aspectos negativos da vida urbana. Sobre a sua forte ligação à Beócia, vide, ainda, Cim. 1.3, facto que se pode testemunhar pela sua nomeação para o cargo de beotarca. Lembre-se que foi para restaurar a imagem dos seus antepassados, acusados de philobarbaroi por Heródoto, que escreveu o tratado De mal. Her.. Acrescente-se que o prólogo de Dem. concilia uma preocupação filosófica e moralizadora com uma mais histórica, quando aborda a problemática do acesso às fontes; em De E Delph. 384E, um diálogo filosófico que não tem o cariz da narrativa histórica, também

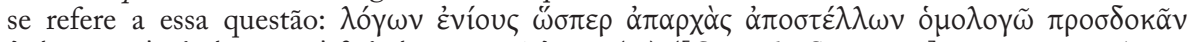

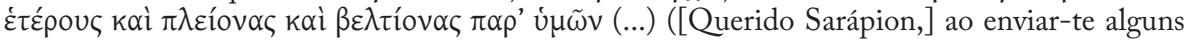
discursos, como se fossem primeiros frutos, espero de vós outros, mais extensos e de melhor qualidade (...)), isto porque o amigo de Plutarco, Sarápion, vivia na polis, onde mais facilmente se conseguia aceder à cultura.

${ }^{403} \mathrm{Em}$ De Pyth. or. 408B-C, Téon diz que os tempos mudaram e por isso também o Oráculo de Delfos mudou, a ponto de o seu sacerdote já não responder em hexâmetros.

${ }^{404}$ Cf. ibid.

405 Pausânias também não sugere uma aceitação pacífica da pax romana, reflectindo uma atitude um pouco indiferente (cf. E. Bowie (1994: 207-230)).

${ }^{406}$ Cf. De soll. anim. 959C e De seu carn. 997B-C; D. Chr. Or. 21.121-2; Phil. Apoll. 4.22; Cic. Ad fam. 7.1.3, Sen. Ep. 7.2-5 (cf. S. Swain (1998r: 174 n. 118)). 
Ainda em relação à questão atrás formulada, a sua resposta deve basearse, em especial, no retrato que Plutarco compõe dos Romanos, mas não apenas nisso. Como referimos no capítulo introdutório, dedica ou introduz nos diálogos das suas obras várias personagens da elite romana ${ }^{407}$, sendo as mais conhecidas Sósio Senécio e Méstrio Floro, num claro sinal de que mantinha relações estreitas com Roma, mas também que desejava que a sua obra reflectisse isso. Concentrando-nos, brevemente, no tratado Quaestiones conuiuales, notamos que, apesar de participarem no symposium vários Romanos, as questões que são discutidas relacionam-se, na sua grande maioria, com a cultura grega, muito embora os Romanos nem sempre estejam preparados para promover conversas com essa temática. Talvez Plutarco queira demonstrar que precisam de melhor formação e que devem ser estimulados a aprofundar os seus conhecimentos sobre assuntos relativos à $\mathrm{Grécia}^{408}$, ou porque o próprio autor não se sentisse suficientemente preparado para aprofundar a cultura latina. Em Quaestiones Romanae, por exemplo, fazendo um estudo sobre as raízes e diversos costumes que caracterizam os Romanos, numa perspectiva antropológica, remete variadíssimas vezes para a cultura grega, a qual surge, invariavelmente, como o ponto de partida e o modelo.

Tal como Políbio, Plutarco também não esconde a sua admiração pelo poder de Roma, em especial pela beleza e grandeza ${ }^{409}$, além de considerar Roma um local sagrado, centro do mundo habitado e civilizado ${ }^{410}$. É dentro dessa perspectiva que, na biografia de Rómulo, enfatiza a capacidade para conciliar e agrupar os povos conquistados ${ }^{411}$, pois reconhece, pela sua experiência, a paz trazida pelos Romanos ${ }^{412}$ aos Gregos que bem conheciam as consequências nefastas da guerra ${ }^{413}$. Esta atitude de Plutarco, de aparente submissão ao poder romano, de modo algum significa que age como um simples colaborador de Roma, mas que a sua romanofilia é mais uma reacção defensiva, prudente e pensada, pois o valor patriótico, tão evocado nas Vitae, mantém-se vivo e apenas se adaptou a novos condicionalismos, como defende J. Boulogne (1994: 42): "Son patriotisme, bien évidemment, n'est pas totalement désintéressé; il exprime largement l'idéologie d'une aristocratie soucieuse de préserver

${ }^{407}$ E. Rawson (1985: 57) refere que os autores gregos dos séculos II e I a. C. não dedicavam obras aos patronos romanos; para S. Swain (1990b: 129-130), Plutarco parece seguir este princípio, com a excepção dos tratados $D e$ fac. lun. e $A d$ Col., que são mais complexos por causa do seu conteúdo filosófico.

${ }^{408}$ Cf. Aem.1.2.

${ }^{409}$ Cf. De fort. Rom. 316C, 316E-F, 325D-E

${ }^{410}$ Cf. ibid. 317A.

${ }^{411}$ Cf. Rom. 16.3.

${ }^{412}$ Cf. De fort. Rom. 317B-C; vide, ainda, Praec. ger. reip. 784F, 805A e 824C sobre o papel dos Romanos no desaparecimento da guerra entre Gregos e Bárbaros.

${ }^{413}$ Cf. De def. orac. $413 \mathrm{~F}-414 \mathrm{~A}$. 
ses avantages et ses privilèges". Se tivermos em conta os três povos que predominam na narrativa, os Gregos, os Persas e os Romanos, o antagonismo que prevalece entre os Gregos e os Persas não se aplica às relações entre Gregos e Romanos, pois, neste caso, não existe uma incompatibilidade cultural, uma vez que as duas culturas partilham palavras, costumes e deuses ${ }^{414}$, além de os Romanos serem parcialmente Gregos pelo sangue ${ }^{415}$ e de o casamento dos Romanos com as Sabinas também os ligar aos Gregos, pelo facto de elas descenderem dos Espartanos ${ }^{416}$. Seguindo em parte a tradição calimaquiana das aitiai e dos problemata pseudo-aristotélicos ${ }^{417}$, os tratados Quaestiones Graecae, Quaestiones Romanae e as Quaestiones Barbarae (este último consta no Catálogo de Lâmprias ( $n^{\circ} 139$ ) mas perdeu-se) reflectem esses pólos culturais e testemunham o maior paralelo entre Gregos e Romanos, que parecem fazer parte de uma só cultura, que partilha diversos aspectos civilizacionais ${ }^{418}$.

Um pouco à semelhança das Vitae, as Quaestiones estabelecem a relação entre passado e presente, com alusão a locais, costumes e a histórias míticas do passado que servem para definir melhor a identidade de cada povo, pois, como refere R. Preston (2001: 94): "Works of aetiology, far from being dull antiquarianism, were deeply implicated in the construction of identity". No entanto, o conteúdo das questões e das respostas revela que, além de existirem ligações entre ambas as culturas, há também diferenças significativas. Desde logo, ninguém é indiferente ao facto de, nas Quaestiones Romanae, Plutarco oferecer ao leitor um conjunto de hipóteses de resposta à questão formulada, enquanto nas Quaestiones Graecae avança apenas com um resposta, denunciando uma maior certeza na obtenção da melhor resposta, não se repetindo as possíveis hesitações e incertezas que sentia quando se tratava da cultura romana. Esta diferença indica ainda que o leitor de ambas as obras etiológicas era grego, daí que as palavras latinas surjam transliteradas ou traduzidas e outros elementos da vida política, social e cultural de Roma sejam identificados e explicados,

${ }^{414}$ Sobre a helenização da identidade romana ao nível da religião, vide Quaest. Rom. 269A e $274 \mathrm{E}-\mathrm{F}$.

${ }^{415}$ Cf. Quaest. Rom. 272C-D.

${ }^{416}$ Cf. Rom. 16.1 e Num. 1.5 .

${ }^{417}$ Cf. R. Barrow (1967: 70), J. Boulogne (1992: 4683 ss.) e P. Hardie (1992: 4751), estudos que seguimos para a melhor compreensão das Quaestiones. Se compararmos os Problemata com as Quaest. Graec., verificamos que estas têm um nível retórico distinto e respostas mais simplificadas às questões; a respeito da presença de Calímaco em Plutarco, vide os trabalhos recentes de J. Ribeiro Ferreira (2005a: 207-214) e E. Magnelli (2005: 215-242), o qual, numa abordagem mais geral, demonstra que Calímaco e Arato são os poetas helenísticos mais vezes citados.

${ }^{418}$ A propósito da tradição etiológica, vide J. Boulogne (1992: 4683-7); para S. Goldhill (2001: 271), "you can see in Greek and Roman Questions Plutarch doing the cultural work of trying to maintain and authorize a Greek cultural perspective in the face of Roman power. This is the negotiation of cultural difference in process". 
ao passo que se detém muito menos nas temáticas helénicas. Atendendo a este desnível estético e de conteúdo, com alcance ideológico, os Romanos desempenham o papel dos "outros", que Plutarco quer dar a compreender aos seus leitores. Tendo em conta que a cultura Grega, em ambas as obras, se confunde com civilização, poderíamos dizer que Plutarco, especialmente por aquilo que se lê nas Quaestiones Romanae, exibe uma visão helenocêntrica.

Nas Quaestiones Graecae e Quaestiones Romanae, servindo a cultura grega como padrão - até as perguntas romanas têm respostas gregas-, não se escamoteiam as diferenças, mas, por um lado, enfatizam-se os costumes romanos que derivam dos Gregos e, por outro, o uso da etiologia serve para explanar a concepção helénica do mundo.

Sublinhe-se que Plutarco não foi o primeiro a desenvolver a ideia das raízes helénicas dos Romanos, uma vez que já Dionísio de Halicarnasso, nas Antiquitates Romanae, por exemplo, faz uma abordagem da história romana sob uma perspectiva profundamente helenocêntrica ${ }^{419}$. Entre outras coisas, apresenta Roma como uma polis grega, fundada por Gregos, com uma língua que não passava de um dialecto do Grego e cujo sucesso se justifica por causa de ter aderido à arete helénica, ideia que Plutarco, em parte, corrobora na biografia de Catão Censor ${ }^{420}$. Plutarco, no entanto, distingue os Romanos dos Bárbaros e, nas Vitae, coloca Gregos e Romanos lado a lado, sem que os Romanos sejam descritos como inferiores ${ }^{421}$.

Aliás, para Plutarco, e para o próprio Dionísio de Halicarnasso, os povos não-gregos com quem os Romanos entram em contacto são barbaroi, em pé de igualdade com os barbaroi persas ${ }^{422}$. Em termos gerais, diríamos que a virtude está para os Helenos como os vícios estão para os Bárbaros, que são, em geral, menos capazes de dominar os seus sentimentos, porventura um sinal do seu desconhecimento da paideia ${ }^{423}$. Os Romanos como Cícero,

${ }^{419}$ Por causa dessa perspectiva de Dionísio de Halicarnasso, R. Preston (2001: 100) afirma que "for Dionysius, there is no Roman culture".

${ }^{420}$ Cf. F. Hartog (1991) e E. Gabba (1991: 109-110).

${ }^{421}$ Cf. A. Nikolaidis (1986: 229-244); para Díon de Prusa, ao contrário de Plutarco, os Romanos são bárbaros (cf. Or. 32.40, 45.1), sendo a cultura grega superior; vide E. Bowie (1991: 194-201).

${ }^{422}$ Cf. Antiq. Rom. 1.16.1, 1.20.1; Sert. 14.1 e Marc. 14.1.

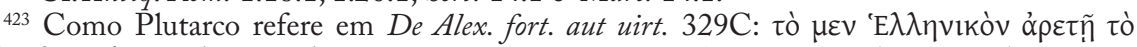

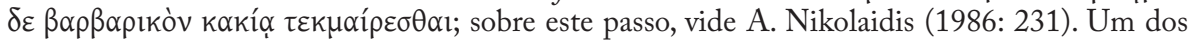
aspectos em que os Bárbaros se mostram mais desmesurados (em parte pelo gosto da luxúria e pela sua arrogância) do que os Gregos é na forma como vivem o luto (cf. Cons. ad Apoll. 113A, Dem. 22.5, Sol. 12.8 e 27.8, Pel. 34), tema que A. Nikolaidis desenvolve no trabalho acima referido. Sobre o caso particular da luxúria, vide Luc. 39-41, onde a luxúria é tomada como algo típico dos Bárbaros e onde se sublinha a desaprovação dos Gregos, mais adeptos da simplicidade (cf. De sera num. uind. 558A). Sobre a falta de aptidão cultural dos Bárbaros, vide Reg. et imp. apophth. 205F. Recordamos, brevemente, que também os Gregos que se instalaram no sul de 
Marcelo ou Emílio Paulo, pelo contrário, jamais poderiam ser confundidos com os Bárbaros pela forma como se entregam à paideia, pois a civilização greco-romana perspectivada por Plutarco tornar-se-ia no novo modelo cultural e social, com influências recíprocas, banindo-se as formas bárbaras. Refira-se que, além disso, os Bárbaros não ocupam um papel central na obra de Plutarco, pois apenas se conhece o tratado Quaestiones barbaricae, que se perdeu, e a biografia de Artaxerxes, embora haja elementos suficientes para podermos classificar de negativa a avaliação que Plutarco fazia dos Bárbaros ${ }^{424}$,

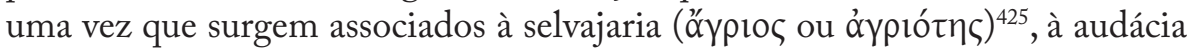

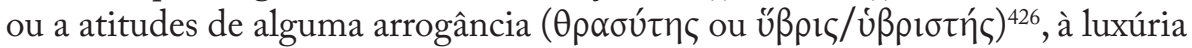

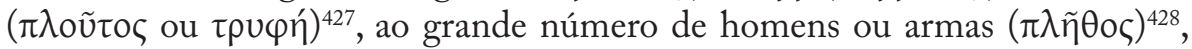

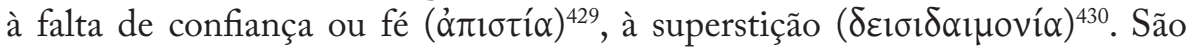

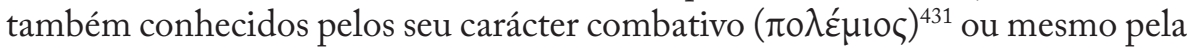

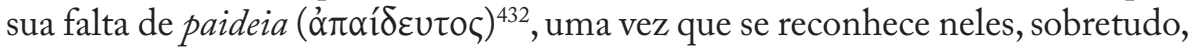

Itália (Tarento, Régio e Nápoles) foram contaminados pela barbárie, quando a sua cultura entrou em declínio, fenómeno que, por exemplo, G. Bowersock (1995: 3-14) estudou, partindo da

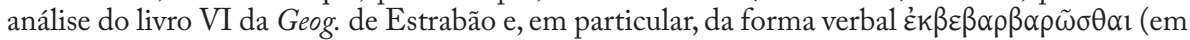

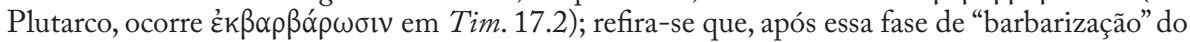
helenismo se seguiria uma de "desbarbarização", como a época de Augusto testemunha, com o reconhecimento do legado grego, suficientemente testemunhado pela epigrafia, organização social ou representações teatrais. Assim, aprofunda-se a adopção do helenismo (e.g. realização de jogos gregos em Nápoles) entre os Romanos, transformação que, segundo G. Bowersock (1995: 14), "anticipated the creation of the Greek Panhellenion of the second century and Hadrian's aspirations for a coherent Hellenic culture in his empire". O Panhellenion, fundado por Adriano em 131-2, é uma Liga que reúne várias poleis gregas, com sede em Atenas. Para J. Hall (2002: 225) é fruto do ambiente que se vive e que a literatura da Segunda Sofística reflecte: "the 'archaism' exhibited by writers of the Second Sophistic derives from the fact that they are entering into dialogue with the fifth-century debate on the nature and definitional criteria of Hellenic identity”. Também I. Romeo (2002: 21-40) defende que a constituição desta Liga sugere uma "archaizing conception of Greek ethnic identity". Sobre o Panhellenion, S. Swain (1998r: 75) refere que "prospective members had to demonstrate good long-term relations with Rome and Greekness in respect of race and culture". Vide, ainda, A. Spawforth \& S. Walker (1985: 78-104) e (1986: 88-105).

${ }^{424}$ Devemos realçar que uma boa parte desses traços negativos já surgiam, por exemplo, nos Persae de Ésquilo.

${ }^{425}$ Cf. De fort. Rom. 320C, De gen. Socr. 578C; De uit. aer. al. 828F; Estrabão em alternativa ao vocábulo barbaroi usa, por vezes, agrioi (11.11.8 e 12.3.18).

${ }^{426}$ Cf. Sert. 16.1, Dion 30.6, Luc. 41.7; De uit. aer. al. 828F.

${ }^{427}$ Cf. Lys. 6.6, Luc. 41.7, Alex. 20.11; Apopht. Lac. 222D.

${ }^{428}$ Cf. Them. 13.5, 15.4, Arist. 14.3, Alex. 20.7 e 20.11; Par. min. 305B, 306D e 307E.

${ }^{429}$ Cf. Cam. 20.2 e Sert. 9.6.

${ }^{430}$ Cf. Sert. 11.6, Cons. ad Apoll. 166A e Amat. 756C; Plutarco, como moralista pragmático que não se distancia da vida real, condena, em vários passos da sua obra, a superstição: por exemplo, De aud. poet. 21A, 26B, 34A, De adul. 53E, 54C, 66C, De Is. et Os. 355D, 378D, 379E, De sera num. uind. 552A, 556B e De gen. Socr. 579F.

${ }^{431}$ Cf. Them. 23.5, Arist. 16.3, Cat. Ma. 23.4, Eum. 15.7 e Alex. 50.9.

${ }^{432}$ Cf. Caes. 2.4. 
a rudeza ( $\varphi \alpha u \lambda o ́ \tau \eta \varsigma)^{433}$. No entanto, como T. Schmidt (1999: 239-70) analisou no seu estudo, Plutarco também realça algumas qualidades positivas dos Bárbaros, como a coragem, a inteligência e a sabedoria, características que não conseguem apagar a imagem negativa, claramente dominante nos textos, com a finalidade de, por um lado, fazer sobressair os valores dos Gregos e dos Romanos ${ }^{434}$ e, por outro, de glorificar o tempo das vitórias sobre os Persas, em que participaram Temístocles, Aristides, Lisandro, Timoleonte e Alexandre. Plutarco defende um mundo helénico diferenciado do bárbaro ${ }^{435}$, verificandose entre os autores da Segunda Sofística, como sustenta S. Swain (1998r: 68), uma oposição entre Gregos e Bárbaros "alive and kicking".

A visão helenocêntrica presente na narrativa de Plutarco resulta, em nosso entender, do facto de o Queronense usar na avaliação dos Romanos ${ }^{436}$ concepções e critérios ético-políticos próprios da cultura helénica, sugerindo a universalidade dessa paideia, sem se deter nos conceitos romanos associados ao mos maiorum, preferindo notar diferenças de teor político relacionadas com o Senado ou o papel do $\delta \tilde{\eta} \mu о \varsigma$. A forma como descreve a ascensão política de César patenteia a sua perspectiva: um líder que se torna popular e que, ao ganhar o poder por via da demagogia, se transforma num tirano, sendo assassinado numa altura em que o povo se revoltava contra a sua forma de governo. Ora, demagogia e tirania são dois aspectos nucleares da politeia grega aplicados - neste caso, com conotações negativas - a um Romano. ${ }^{437} \mathrm{E}$ óbvio que Plutarco, quando contrapõe Gregos e Bárbaros, não esconde o seu

${ }^{433}$ Cf. De aud. poet. 29F e De adul. 59C.

${ }^{434}$ Cf. A. Nikolaidis (1986: 229-44, esp. 244). Da mesma forma, Plínio-o-Jovem, no Pan. 12.3-4, 14.1-5, 16-3-5, por exemplo, serve-se da caracterização negativa dos Bárbaros para realçar as qualidades de Trajano; T. Schmidt (2002: 64-67) realça o facto de a oposição entre Trajano e os Bárbaros ser um dos motivos da propaganda imperial, da laudatio Caesaris, pois as próprios moedas desse tempo ilustravam as vitórias de Trajano na Dácia, por exemplo, e o seu papel na instauração da pax e da felicitas entre as gentes, fazendo do imperador o uictor omnium gentium.

${ }^{435}$ T. Schmidt (2002: 58-9) considera que essa ideia de Plutarco pode ser considerada anacrónica, uma vez que a realidade dos séculos I-II d.C. é muito diferente: "in a time when Trajan was fighting his Dacian and Parthian Wars, the "timelessness" of Plutarch's barbarians may seem utterly anachronistic"; no entanto, quando compara a descrição que Plutarco faz dos barbaroi com as de Díon de Prusa e Cáriton nota-se que, com algumas diferenças, seguem o mesmo estereótipo, de acordo com aquilo que se verifica no tempo de Trajano e dentro da propaganda imperial; sobre a oposição entre Gregos e Bárbaros, vide também E. Bowie (1991: 183-204).

${ }^{436}$ Lembremos que tem muitas vezes mais cuidado em descrever as instituições romanas ou em usar palavras latinas do que relativamente às matérias helénicas: Comp. Thes.-Rom., Crass. 7.1, Caes. 37.3, Cat. Ma. 16.1-3, Cor. 19.1.

${ }^{437}$ Cf. A. Wardman (1974: 49-57). Refira-se que, ao contrário de César, Fábio Máximo é apresentado como um líder que resiste ao populismo e que faz face aos demagogos com a

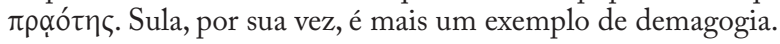




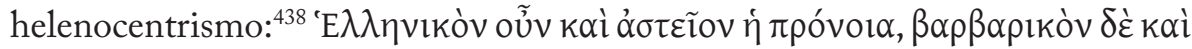

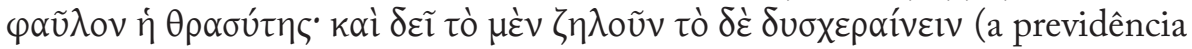
é própria de um homem heleno e culto, enquanto a temeridade o é de um homem bárbaro e vulgar; uma imita-se, a outra não se suporta).

Um outro aspecto a ter em conta é a apresentação de Alexandre como modelo de conduta imperial ${ }^{439}$, não só pela sua intenção de unificar os povos, mas também pela alteração do conceito de barbaros, que passa a incorporar elementos de natureza ética e civilizacional, pois os valores morais ultrapassam os vínculos geográficos ${ }^{440}$. Apesar desta confluência, Plutarco não abdica de enraizar nessa cultura comum os valores helénicos, pois os Romanos, na sua análise, estariam desde a origem predispostos para a helenização. Nas synkriseis, por exemplo, da combinação das qualidades do par resulta um homem novo: com capacidade de comando e clarividente, patriótico e que luta pelo bem comum, sem perseguir riquezas pessoais, íntegro, moderado e justo; resoluto e adverso à demagogia; propenso à praotes, à epieikeia e à philanthropia ${ }^{441}$; habilitado a conciliar o logos e a paideia. Os valores desse homem novo são, na sua maioria, helénicos, mas os Romanos também os conhecem e praticam tão bem ou melhor que os próprios Gregos ${ }^{442}$. Apesar disso, continua a haver um homem grego e outro romano, com diferenças, que Plutarco não omite na sua obra, mas tenta demonstrar que elas não constituem um obstáculo para as duas culturas se aproximarem e partilharem os seus valores.

Assim o indica a própria estrutura paralela das Vitae, forma que Plutarco usa para esboçar uma unidade cultural, sem apagar as diferenças entre Gregos e Romanos ${ }^{443}$, uma vez que existem elementos que aproximam os povos. Desta opinião partilha S. Goldhill (2002: 270): "It's rather that the boundaries of

${ }^{438}$ De aud. 29F; em ibid. 30C, Plutarco volta a referir-se à dicotomia Grego/Bárbaro, dizendo que estes suplicam e lançam-se aos pés dos adversários, enquanto os Gregos combatem pela vitória, mesmo que isso signifique a morte.

${ }^{439}$ No século II, autores como Díon de Prusa, Arriano e Élio Aristides, transmitem uma imagem positiva de Alexandre, considerando-se que o imperador se tornou superior ao modelo. Plutarco, todavia, nunca tal reconheceu, mantendo uma posição equilibrada, uma vez que também não podia, de forma deliberada, pronunciar-se a favor da superioridade do Macedónio; sobre esta matéria, vide G. Zecchini (1984: 197 ss.). Sublinhe-se que, na dinastia dos Antoninos, se assiste a uma revitalização da figura do Macedónio, ao contrário do que sucedera nas dinastias dos Júlio-Cláudios e dos Flávios.

${ }^{440}$ Em De exil. 601C-F, Plutarco defende que qualquer cidade pode ser a pátria de um indivíduo e que o mundo deve ser visto como propriedade pessoal deste.

${ }^{441}$ F. Frazier (1996: 231 ss.), na esteira de J. de Romily (1979), classifica esta tríade de virtudes como "les trois vertus 'douces' traditionelles"; vide ainda H. Martin Jr. (1960: 55-70).

${ }^{442}$ Cf. Marc. 3.6: por se inspirarem nos Gregos conseguem ser igualmente virtuosos.

${ }^{443}$ Para P. Desideri (1992a: 4471) "l'unità della cultura antica nelle sue essenziali e parallele componenti greca e romana è un punto di arriva, e non di partenza, della riflessione plutarchea"; para S.-T. Teodorsson (2005b: 438), por usa vez, "the coalescence of Greek and Roman culture in the late Imperial period produced a sentiment of cultural unity in the Empire". 
Greekness and Romanness - as with all myths of cultural origin at the site of cultural conflict - prove all too permeable, all too intertwined. Establishing and preserving the value of Greekness becomes not just the assertion of an identity but a set of questions about cultural self-positioning". Por sua vez, os epílogos comparativos tendem a ocupar-se dos feitos militares e do exercício da politeia ${ }^{444}$ para classificar o carácter dos biografados. De uma forma geral, constata-se que, quando se avalia o valor guerreiro, os Romanos se superiorizam aos Gregos por participarem em campanhas de maior dimensão e contra oponentes mais belicosos ${ }^{445}$.

Quando analisamos, no entanto, a presença dos Gregos na administração romana do século II, torna-se difícil compreender se ela reflecte uma união identitária ou se é apenas fruto das circunstâncias sócio-políticas ${ }^{446}$. Mesmo que não signifique por si só uma união total, pois estamos a falar apenas de elites, esta participação pode ter contribuído para uma maior aproximação e para uma troca de valores. Porém, alguns membros da aristocracia grega Plutarco é um exemplo disso - tornaram-se cidadãos romanos, o que não anulou a sua identidade grega, aquela que permanecia na physis, nem deixaram de defender os seus princípios ${ }^{447}$.

Por terem em comum diversas características, a associação tradicional dos Romanos à arte da guerra, por oposição aos Gregos que cultivavam valores sublimes e pacificadores, nem sempre encontra eco nas Vitae. Mesmo pensando o Queronense que os Romanos não se distinguiam pelas suas capacidades oratórias ou pelo amor à filosofia, não podia, por se encontrar numa posição fragilizada, criticar simplesmente a arte guerreira dos Romanos, da qual dependeu, por vezes, a eleutheria dos Gregos.

É verdade, no entanto, que a humanidade grega tem como equivalente, em alguns casos, a potencial barbárie dos Romanos, mais predispostos para o combate: Mário, pela sua $\varphi v ́ \sigma \varepsilon l ~ \alpha ̊ v \delta \rho \omega ́ \delta \eta \varsigma^{448}$, sente maior impulso para as actividades militares do que para a vida pública, tendo muita dificuldade em controlar a sua cólera. Na biografia de Marcelo, quando descreve a acção deste em Siracusa, realça o facto de os Romanos não serem conhecidos pela sua

${ }^{444} \mathrm{Um}$ dos aspectos em análise prende-se com a forma como os cidadãos são tratados. Em Comp. Lyc.-Num. 4.15; Comp. Demetr.-Ant. 5.3-4; Comp. Ag./Cleom.-Gracc. 4.1-5; Comp. Lys.Sull. 2.1-7; Comp. Nic.-Crass. 2.1-3.

${ }^{445}$ Cf. e. g. Comp. Arist.-Cat. Ma.

${ }^{446}$ H. Halfmann (1979: 112-15), K. Hopkins (1983: 184-93) e T. Duff (2002r: 289) consideram que isso não significa uma união progressiva, pois as identidades mantêm-se separadas. Por sua vez, C. Jones (1971: 39-64, 107-9, 122-30) e D. Babut (1975: 210), por exemplo, interpretam isso como uma união das elites.

${ }^{447}$ Cf. F. Millar (1964) e S. Swain (1998r: 171-2).

${ }^{448}$ Cf. Mar. 2; vide, ainda, Galb. 1, Cam. 12, Cor. 15, Num. 3. 


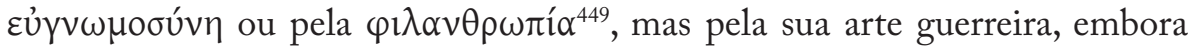
tenha sido Marcelo o primeiro a demonstrar que também os Romanos davam valor à justiça, tratando com benevolência as cidades conquistadas ${ }^{450}$. Deste modo, Plutarco pretende elogiar a figura central da biografia, neste caso Marcelo, e assim atenuar as diferenças entre Romanos e Gregos, embora careça a argumentação histórica de algum rigor ${ }^{451}$. Eis, assim, mais um caso em que a valorização moral assume maior protagonismo do que a acribia histórica. $\mathrm{Na}$ mesma biografia, quando relata a morte de Arquimedes e a decisão de Marcelo de levar as obras de arte de Siracusa para Roma, Plutarco aproveita para acentuar as diferenças entre Gregos e Romanos, elogiando, obviamente, a tentativa pedagógica que Marcelo protagoniza.

Plutarco, contudo, nem sempre é muito explícito na apresentação das relações entre a potência conquistadora e o povo vencido. No par PhilopoemenFlamininus, por exemplo, o autor não esconde, por um lado, a sua admiração pelo empenho de Filopémen na defesa da liberdade helénica e, por outro, sugere que é a vontade dos deuses que determina a conquista romana ${ }^{452}$. $\mathrm{Na}$ biografia de Flaminino ${ }^{453}$, em particular, explora de forma elucidativa a relação entre Gregos e Romanos. Aí desenvolve a ideia de que os Romanos dão aos Gregos a eleutheria, restabelecendo a eunomia, a dike, a homonoia e a philophrosyne entre os cidadãos e as cidades, criando nos Helenos a pistis, de modo que os reis pedem o auxílio romano e acolhem-nos, submetendo-se, de forma pacífica e graças à acção divina ${ }^{454}$, ao seu império.

Transparece nas Vitae uma crítica às acções que apenas contribuem para o enfraquecimento interno da Grécia, algo que muito ajudou os Romanos a sedimentar e a fortalecer a sua influência no espaço helénico. $\mathrm{Na}$ biografia de Pelópidas ${ }^{45}$, para valorizar a boa relação entre o próprio Pelópidas e Epaminondas, e não escondendo o seu patriotismo beócio e a vantagem

${ }^{449}$ Marc. 20.1.

${ }^{450}$ Cf. ibid. 20.2-11.

${ }^{451}$ E. Gabba (1993: 82) afirma que Marcelo é sujeito a uma "trasfigurazione idealizzata”; além disso, se confrontarmos este passo com a descrição que Tito Lívio faz do massacre de Enna (cf. 24.39.9), constataremos diferenças evidentes e percebemos como Plutarco omite a carnificina; por fim, não deixa de ser curioso que, na synkrisis, Plutarco não faça alusão ao conteúdo de 20.1-2, mas admita que Marcelo tenha ordenado massacres (cf. Comp. Pel.-Marc. 1.3).

${ }^{452}$ Cf. Phil. 17.2-3, Flam. 12.3 e Comp. Phil.-Flam. 3.4.

45312 .

${ }^{454}$ Cf. De fort. Rom.

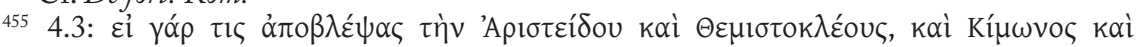

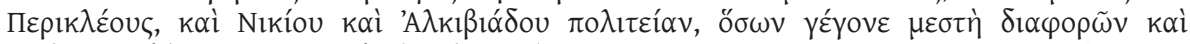

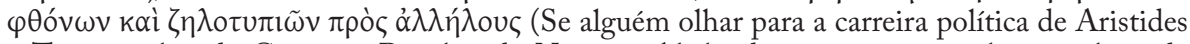
e Tesmístocles, de Címon e Péricles, de Nícias e Alcibíades, vemos como ela está cheia de diferenças, ciúmes e rivalidades contra uns e outros). 
que dá a Tebas nas comparações com Atenas e Esparta, Plutarco salienta que Atenienses como Aristides e Temístocles, Címon e Péricles, Nícias e Alcibíades, passaram mais tempo com as suas rivalidades do que a combaterem os inimigos.

Também na biografia de Flaminino ${ }^{456}$, critica, porventura de forma mais sarcástica, os conflitos em que os Gregos se empenharam, com excepção das Guerras Medo-Persas e das que Címon travou em Eurimedonte e Chipre, pois a maioria das guerras apenas trouxeram sofrimento e escravidão. Esse texto resume o leitmotiv da biografia de Flaminino: os Romanos são agentes e garantia de eleutheria, por terem libertado a Grécia do jugo macedónio ${ }^{457}$. Por conseguinte, os Gregos são salvos por acção de um povo com um parentesco com a Grécia.

Se, como temos vindo a referir, uma descende da outra, o elogio da romanidade pode ser interpretado de diversas formas. Desde logo, Plutarco pode mediante esse elogio querer exaltar a grecidade 458 ou assumir que os valores da paideia grega foram decisivos para a construção do imperium. Além disso, também é legítimo pensar-se, na sequência das ideias e dos exemplos expostos, que os Gregos são convidados a emular os valores romanos pela grandeza que conferiram a esse povo. Desta simbiose, resulta um homem novo, greco-romano, reflexo da koine cultural, que traduz uma osmose entre a helenização intelectual dos Romanos e a romanização política dos Gregos. A propósito do contacto e das influências culturais que se geraram no Império Romano, D. Braund (2001: 22) escreveu:

Further, the Roman self-image as a beneficent imperial power (self-criticism notwithstanding) came to be broadly accepted among provincials themselves, even among provincials who asserted the value of their own cultural heritage. That acceptance is both a cause and a symptom of the success of the Roman Empire in incorporating a range of other, non-Roman, cultural identities, which in turn helps to account for the paucity of revolts against Roman power in the provinces. For all its concern with legal status and for all the capacity of Romans to differentiate culturally, the Roman Empire did not require individuals or even communities to adopt a distinctly Roman identity to the exclusion of all other identities. Local identities survived and flourished under the Roman Empire, whether individual, communal, regional or supra-regional: the most striking example of the latter is perhaps the trenchant Hellenism of the empire, particularly that of the second and third centuries $\mathrm{AD}$.

\footnotetext{
456 11.6-7.

${ }^{457}$ Cf. e.g. Flam. 5.7-8.

${ }^{458}$ Cf. J. Boulogne (1994: 115).
} 
É muito interessante verificar que, para Plutarco, é possível um Romano ser melhor exemplo das virtudes gregas do que um Grego. Saliente-se, a este propósito, Numa, que é um exemplo de duas qualidades muito apreciadas por Plutarco, a philanthropia e a praotes ${ }^{459}$. Em comparação com o espartano

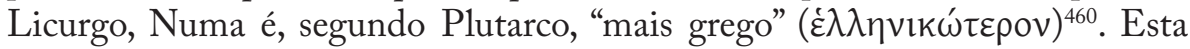
é, porventura, uma forma subtil de afirmar a universalidade da cultura grega.

Na verdade, as motivações subjacentes à conquista da Grécia pelos Romanos podem ter mais do que uma interpretação, como testemunha o que Plutarco escreve no par Philopoemen-Flamininus, em que, tendo em conta os valores que tradicionalmente caracterizam as duas culturas, as qualidades dos dois heróis

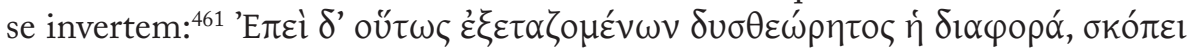

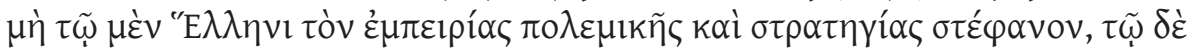

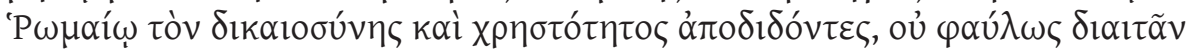
$\delta o ́ \xi o \mu \varepsilon v$ (Com efeito, ao examinarmos desta forma os acontecimentos, é difícil avaliar as diferenças entre os dois; vê se não parecemos ajuizar de forma correcta com a atribuição da coroa ao Grego pela sua experiência guerreira e capacidade de liderança e ao Romano pelo seu sentido de justiça e bondade). Assim, como

${ }^{459}$ Cf. H. Martin Jr. (1960) e (1961); para D. Russel (1968: 135), estes são os dois valores mais importantes na concepção moralista de Plutarco. Segundo S. Saïd (2006: 52): "Under the influence of the Roman universal empire and the emphasis on the Roman virtue of humanitas, the theme of Athenian philanthropia and praos is renewed and enlarged, for her beneficiaries

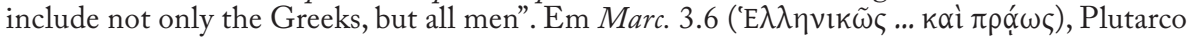
parece definir praos como uma qualidade helénica, podendo os Romanos partilhar dessa

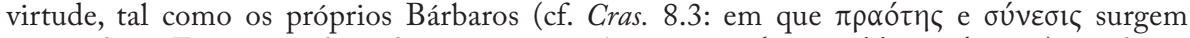

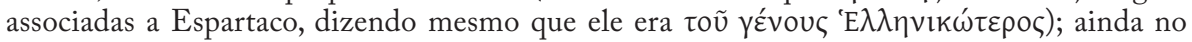
que diz respeito a Numa, Plutarco, em Quaest. Rom. 267C, qualifica a figura do rei romano com os adjectivos dikaios e politikos, além de acrescentar que ele se tornou um philosophos, pois o seu carácter não estava dominado pela belicosidade típica dos Romanos, mas interessou-se por difundir a amizade e a paz, segundo os seus preceitos filosóficos (cf. Quaest. Rom. passim), servindo, dessa forma, a figura de Numa para realçar o contraste entre a virtuosidade da filosofia helénica e a tendência natural dos Romanos para o conflito. Fica implícito, portanto, que os Romanos também podem usufruir dessa filosofia/paideia para apaziguar a sua physis. No entanto, para se rejeitar a influência grega na cultura romana alguns recusam estalebecer uma relação entre Numa e Pitágoras (cf. Cic. Rep. 2.15.28-9), enquanto outros, como Ovídio (Met.15.1-481, Fasti 3.153), não deixam de fazer essa associação. Na biografia de Numa, Plutarco, sem dar uma resposta inequívoca sobre esta relação, estabelece diversos paralelos entre a política de Numa e a doutrina pitagórica, levando o leitor a pensar que essa influência se operou (cf. Num.8,11.1,14.2-3, 22.3-4) e que Numa e Rómulo, este mais belicoso e sempre com a intenção de alargar a influência romana a outros espaços geográficos, ilustram diferentes facetas da cultura romana. Ou então, talvez a falta de uma resposta conclusiva sirva para deixar em aberto a possibilidade de a cultura romana ser independente e mais interessada nas letras e na filosofia do que se poderia pensar. Vide J. Boulogne (1994: 70), C. Pelling (1989) e S. Swain (1990b).

${ }^{460}$ Cf. Comp. Lyc.-Num. 1.10; cf. Crass. 8.3, Comp.Nic.-Cras. 2.7.

${ }^{461}$ Cf. Comp. Phil.-Flam. 3.5. 
sugere a forma imperativa ( $\sigma$ Kó $\varepsilon \imath$ ), caberá ao narratário ${ }^{462}$ avaliar cada uma das vidas e decidir qual the parece mais digna de louvor. Note-se que o uso

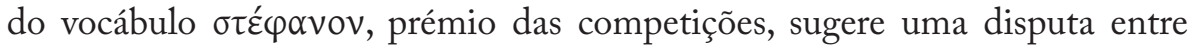
Filopémen e Flaminino ou entre Gregos e Romanos, central no par biográfico. Neste caso, trata-se, sobretudo, de uma luta pela glória ${ }^{463}$.

Tendo em conta as diferenças culturais entre os dois povos, conjuntamente com o padrão helénico que serve de base a Plutarco para fazer a avaliação dos heróis romanos, e a forma subtil com que advoga a cultura de resistência dos Gregos frente aos Romanos, não nos parece existir nas Vitae uma unidade cultural plena entre uns e outros. Acima de tudo, temos a percepção de que ambos os povos repartem algumas características, até porque a história se repete em diferentes tempos e espaços, mas que são intrinsecamente distintos. O pensador de Queroneia aborda várias vezes a questão da repetição, casual ou não, de eventos, com causas e consequências que podem ser iguais ou diversas. Assim acontece no prólogo da biografia de Sertório ${ }^{464}$ :

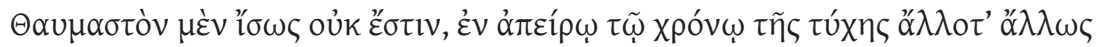

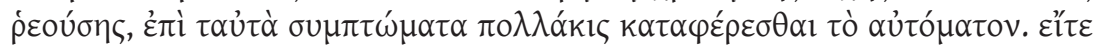

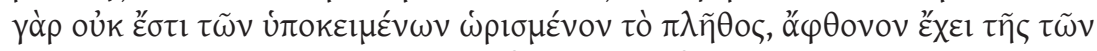

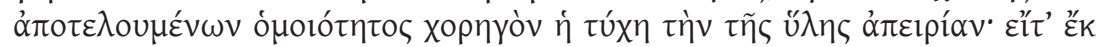

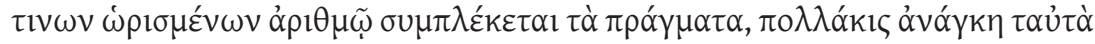

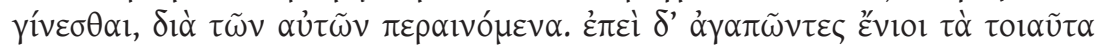

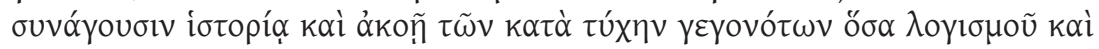

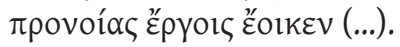

Não é, certamente, com surpresa que, atendendo à forma como a fortuna flui na imensidão do tempo, tanto para um lado como para outro, vemos como os mesmos acontecimentos se repetem de forma natural. Quer por o número de acontecimentos ser ilimitado, pois, à semelhança do corego, a fortuna oferece um número infinito de acontecimentos que podem coincidir, quer por as acções se encadearem em número ilimitado. Por isso, é inevitável que, muitas vezes, as mesmas causas conduzam aos mesmo fins. Por conseguinte, alguns indivíduos que se interessam por estas coisas reúnem a investigação e o que ouviram dizer que aconteceu devido à fortuna, esperando que pareçam acções da razão e da previdência (...).

É, em particular, sobre o que é tipicamente helénico ou latino que discorre

${ }^{462}$ A mesma responsabilidade é pedida ao leitor em Dem. 31.7 e Lys. 30.8, num recurso retórico apropriado a quem deseja criar uma maior proximidade entre a narrativa e o narratário.

${ }^{463}$ A propósito de outras expressões que sugerem competição ou metáforas teatrais, vide Phil. 11.1-4, 14.2, 15.1 e Flam. 7.6, 10.7, 11.3, 12.5, 13.3.

${ }^{464} 1.1-2$. 
o polígrafo de Queroneia, encontrando semelhanças e diferenças, vícios e virtudes que se repetem. Muito embora essas diferenças existam, nada impede que se possam cultivar relações profícuas e vantajosas, sendo certo que, no tempo de Plutarco, Roma revela uma força magnificente, como outrora Alexandre e o seu exército, cabendo então à Grécia, a antiga potência, o papel de subjugada, que é mais territoral e institucional do que intelectual. Nesta perspectiva, a paideia surge como um valor que não se confina a fronteiras definidas, mas que se apodera, por vezes de forma inconsciente, do pensamento e das acções do homem, quer no plano meramente filosófico quer ao nível da própria organização das etapas formativas do indivíduo. A paideia consegue gerar empatias com aqueles que a olham como algo estranho e pouco natural ou suscitar forças adversas por parte daqueles que a temem e, por defesa dos valores ancestrais, a rejeitam.

Como estudioso da natureza humana e do papel que a paideia exerce no comportamento humano, Plutarco promove, superando as diferenças do genos, a aproximação da dualidade grega e romana num só ideal, greco-romano, em que o contributo dominante pertence à paideia grega, mas sem eliminar aquilo que ele entende ser próprio da physis dos Romanos, como a estabilidade, a disciplina, o rigor ou a austeridade. Transmite essa sua ideia na análise mais pormenorizada da paideia nos heróis romanos, ora lamentando o facto de não terem sido sensíveis a esse apelo cultural, muito por culpa da obrigação de defender a sua pátria, ora louvando o interesse pela cultura helénica e fazendo depender disso algumas qualidades ou considerando que a formação deve ser um acto de contínua exigência, até ao fim da vida. Estas mensagens são válidas para ambos os povos e são também perenes, uma vez que a cultura, que é tantas vezes um factor de separação, deve promover o conhecimento, a alteridade e a tolerância da diferença.

Por estarmos na presença de um autor grego, com sentido patriótico e que não renuncia à liberdade, é de acreditar que, na reflexão sobre a identidade, manipularia o ideal de cultura grega, de forma a servir os seus fins. Além disso, como é por meio da literatura que explana essa identidade, seria lógico que Plutarco a conciliasse com uma estratégia retórica ${ }^{465}$, sem ficar, no entanto, reduzida a uma mera criação estética, pois é enquadrada no contexto social e político da escrita que se compreende melhor esta questão.

Pragmático e realista, Plutarco prefere explorar as ideias que ligam a génese de Roma aos Gregos e insinuar, por meio da caracterização das personagens, que as características partilhadas por ambos os povos são em maior número

${ }^{465}$ T. Whitmarsh (2001b: 305) escreve: "literary self-presentation, in Roman Greece, was a crucial aspect of the competitive structure of elite society"; vide, a este propósito, M. Gleason (1995: 159-168) e S. Swain (1998r: 63-4). 
do que as diferenças, de modo a tornar a paideia o grande pilar da sociedade greco-romana. O desafio lançado pelo polígrafo de Queroneia não vai no sentido de se transformar cada Romano num Grego, mas de salientar que a paideia é superior às relações entre conquistador e conquistado, possivelmente circunstanciais. Os valores que integram a paideia são duradouros e devem ser vividos por todos, independentemente do seu genos. Além disso, cabe a ambos os povos descobrir a paideia, vivendo-a interiormente e difundindo os seus princípios, da mesma forma que Alexandre, Luculo, Emílio Paulo ou Timoleonte ${ }^{466}$, que contribuiram para a paideia prevalecer em vez da barbárie ${ }^{467}$.

Tanto os Gregos como os Romanos, após tanto tempo de convivência, mantiveram-se, na generalidade, fiéis à sua identidade. Os Gregos, interiorizando a sua superioridade cultural, especialmente com o recurso aos feitos do passado, contaram com a ajuda dos próprios Romanos, que reconheciam o brilho desse tempo e permitiram que a língua grega fosse o meio de comunicação oficial. Além disso, os Gregos eram suficientemente flexíveis para aceitar novas ideias e concepções, tanto a nível cultural como na sua vivência social e política, sem sentirem que isso seria uma ofensa à sua identidade. Quanto às tensões que irromperam na Grécia com a finalidade da autonomia total, segundo G. Woolf (1994: 131): "served only to reinforce a sense of collective cultural alienation and hence integrity".

É extraordinária a lucidez de Plutarco quando propõe que a identidade de um povo de origens diversas e de contornos geográficos dispersos deve ter respeito pelas raízes culturais. Nesta sociedade, o conhecimento não deve ser da cultura pela cultura, mas processar-se pelo aprofundamento do sentido da paideia, desde o seu âmbito mais escolar até à sua vertente mais filosófica, ainda que o logos philosophos de Plutarco não seja de todo alheio à acção. Por conseguinte, após a aquisição da paideia, compete ao indivíduo saber adequar os preceitos desta à sua vida, contribuindo para a sua difusão e constante regeneração.

Ainda assim, atendendo ao facto de que a mensagem plutarquiana sobre a paideia e o seu valor para o indivíduo ocorre sobretudo nas biografias romanas e que o mesmo acontece nos Moralia, quando trata de personagens ou de questões relativas a Roma, não é fácil compreender até que ponto a cultura romana se identifica mais com o militarismo de Rómulo e de César ou com o filo-helenismo de Marcelo e Emílio Paulo, se está mais próxima do espírito pacífico e filosófico de Numa ou da philotimia de Flaminino. Este paradoxo

${ }^{466}$ Timoleonte ficou conhecido, entre outras coisas, pela sua acção de re-helenização da Sicília; vide R. Talbert (1974: passim).

${ }^{467}$ Sobre Luculo e o par Emílio Paulo e Timoleonte, vide, respectivamente, S. Swain (1992a: 307-16) e (1989c: 314-34). 
do ethos romano em Plutarco pode significar que não pretende representar os Romanos nem como gregos nem como bárbaros ${ }^{468}$, mas apenas distinguilos destes e aproximá-los mais da paideia helénica, dando dessa forma um contributo importante para o debate sobre a identidade e a cultura na Segunda Sofística e deixando aos seus leitores - como faz em algumas synkriseis - o caminho aberto para uma reflexão sobre esta matéria. Foi esse caminho que trilhámos, certos de que a discussão sobre a paideia e a identidade durante o período imperial se reveste de grande complexidade, especialmente quando se concentram na produção literária de um autor personagens de épocas diferentes e de culturas com muitas afinidades. Há, porém, elementos que não se podem negligenciar: a paideia, sendo um conceito de elite, para mais numa época em que o fosso entre ricos e pobres era grande ${ }^{469}$, constitui uma forma de preservação do helenismo, de uma identidade e de uma memória que dignificam o homem como cidadão ou como agente preponderante da aç̧ão política. Porque, no tempo de Plutarco, as fronteiras entre povos e culturas são cada vez mais difusas, processo que se estende ao nosso tempo, por vezes travado por nacionalismos fundamentalistas, o helenismo adquire uma amplitude universalista, confundindo-se com o sentido de civilização.

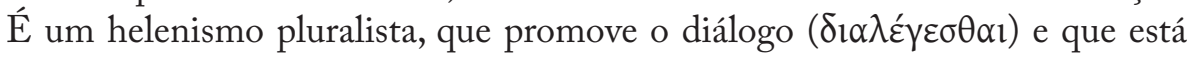
acessível a toda a elite do Império. Desse modo, a paideia tende a atravessar barreiras sócio-culturais e o helenismo, na esteira de Isócrates, é mais ético do que étnico.

Por conseguinte, existe uma corrente mais tradicionalista, onde o peso do passado se fazia sentir de forma inequívoca, e uma visão mais inovadora. Não será, em nosso entender, Plutarco a representar melhor estas duas concepções, mas Luciano, em Somnium (ou Vita Luciani), um texto autobiográfico. Com sentido metafórico e metalinguístico, o autor de Samósata descreve duas mulheres entre as quais tem de escolher uma: a Hermoglyphike e a Paideia. De que forma pode isto representar as duas concepções que têm consequências na identidade cultural? A Hermoglyphike, que o pai de Luciano prefere, representa a tradição, a linearidade e, de certa forma, as raízes de Luciano, que se situam num universo bárbaro (Samósata localiza-se na Síria), enquanto a Paideia suscita a curiosidade e cria uma dinâmica de conhecimento e de transcendência do homen. A dificuldade que Luciano sente em optar por uma das duas representa o dilema que muitos sentem na época imperial: continuar aprisionado a algo que é conferido pelo genos (estático como a pedra de uma escultura) ou aderir ao desafio de aprofundar o conhecimento. A paideia, na verdade, enquanto impulsionadora da construção identitária, gera a possibilidade de transfigurar

${ }^{468}$ Cf. e.g. C. Jones (1971), C. Pelling (1989) e S. Swain (1998r).

${ }^{469}$ Cf. K. Hopkins (1965: 12-26). 
os traços que distinguem um indivíduo ou uma sociedade, pois aquele que é educado sofre um reajustamento cultural, tornando-se outro. Por conseguinte, a paideia não serve apenas para consolidar uma identidade, mas para abrir espaço a uma nova ${ }^{470}$. Se pensarmos na acção contínua da paideia e de todas as circunstâncias que lhe são exteriores, compreendemos por que motivo alguns colocam em causa a existência das identidades culturais.

Sem querer generalizar esta questão, será oportuno, ao chegarmos ao final do capítulo, notarmos que a própria noção de "Grecidade", que no fundo traduz uma identidade que se consolidou na época clássica, ajudada pela vocação panhelénica, não pode ser considerada como prova da existência de uma unidade da Grécia, mas apenas como um desejo de unidade. A comédia aristofânica é um bom exemplo da variedade dialectal, de costumes culturais e práticas religiosas diferentes na Grécia, o que é um indício de que a unidade que suporta a referida noção é condicionada por múltiplas diferenças existentes entre as poleis. Plutarco tinha certamente consciência da existência dessas diferenças presentes no passado, que, na verdade, ainda não tinham desaparecido, mas isso não o impediu de lançar as bases de uma estrutura nova, a que poderíamos chamar greco-romana e que, por meio da paideia, fomentaria a paz e a partilha de traços identitários diversos.

Assim, julgamos poder concluir que a identidade cultural não é uma estrutura homogénea e hermética que se transmite de um povo para outro. Pelo contrário, está sujeita a múltiplas influências (sociais, políticas e económicas) e pode ser aceite, recusada, manipulada ou transformada. Se é possível encontrar, entre os Romanos, uma atitude defensiva perante o apelo da grecidade, também os Gregos usam a sua identidade cultural como forma de preservar os valores que os distinguem, num tempo em que se vêem dominados pelos Romanos. Assim, haveria uma unidade que incorparava diferentes formas de pensamento e de compreensão da realidade, em alguns casos, complementares. A síntese cultural que Plutarco propõe nas Vitae, mesmo que não tenha tido uma concretização real e efectiva, cumpre o objectivo de reflectir sobre uma matéria muito presente na época imperial: a paideia como veículo de identidade e, ao mesmo tempo, como sinal e instrumento de poder social. É a paideia que, por meio da sabedoria e das virtudes (sentido de justiça, moderação, humanidade e candura), assegura a valorização pessoal e civiliza as formas de exercício do poder e aqueles que estão sujeitos a esse poder.

${ }^{470}$ A este propósito, citamos T. Whitmarsh (2001: 129): "becoming educated is a process of rebirth, the creation of a new self; but in certain cases, it allows for a more radical reorientation, a quite liberal (but also symbolically freighted) change of culture". 


\section{Conclusão}

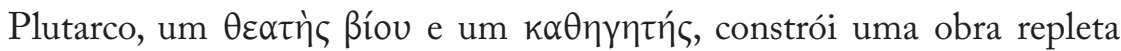
de sentidos que só se conseguem interpretar quando fazemos uma leitura devidamente contextualizada do corpus e relacionamos as suas ideias com o tempo da sua escrita. Erudito como poucos, Plutarco não se limita a descrever o perfil dos heróis, mas, por via de um conjunto variado de preceitos que explora, eleva-os a uma dimensão social e cultural que é crucial para entendermos o seu tempo. Transferindo do passado os modelos, escolhe uma forma literária, a biografia, nem sempre tão distinta quanto se possa pensar da historiografia, na qual valores morais, provérbios, relatos anedóticos, feitos grandiosos e pormenores se fundem para transmitir uma ética válida para o quotidiano de cada indivíduo.

Esses heróis ou modelos do passado servem de base à formulação de questões sobre a proairesis, a doxa, a tyche, a arete, a eudaimonia, entre outras, o que é uma consequência do processo de observação e análise do outro. É o que sugere a imagem do espelho, no prólogo da biografia de Emílio Paulo. A pedagogia e a exemplaridade do passado servem, deste modo, para Plutarco elaborar logismoi sobre si próprio e, simultaneamente, para os leitores aprenderem e adquirirem consciência ética e histórica, que é estimulada pelo efeito mimético, uma das marcas da escrita biográfica de Plutarco.

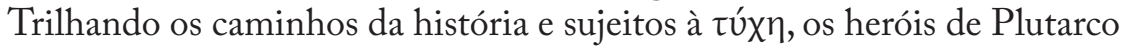
vêem-se obrigados a decidir entre a justiça e a utilidade, gerando-se muitas vezes na aç̧ão um conflito entre o entendimento pessoal e o compromisso para com a comunidade. Aliás, a paideia, enquanto processo formativo e transformador, como vimos, tem também essa dupla dimensão: a formação pessoal e a responsabilidade de fazer com que os outros se sintam persuadidos pelos valores que caracterizam a boa formação. É o que evidenciam, por exemplo, as acções de Alexandre ou Sertório, que se empenham em civilizar, respectivamente, os Bárbaros e os Iberos e Lusitanos. Além disso, a paideia, enquanto sistema social dinâmico e flexível, muitas vezes em articulação com o poder, acompanha e ajuda a construir os limites identitários dos povos, originando novas estruturas, aparentemente pacíficas, ou servindo de bandeira aos que persistem em resistir à imposição política. Pela sua latitute temática e pelas áreas onde intervém, a paideia engloba não apenas o simples percurso pedagógico, mas também a arte, a arquitectura, a literatura, a politeia ou os valores éticos, ou seja, tudo aquilo que pertence ao domínio da identidade. Neste contexto, as Vitae são um exemplo da representação literária de uma 
identidade cultural greco-romana ainda e sempre em construção.

De uma forma ou outra, todos fazemos uso da memória e a paideia cria um vínculo com o passado, estabelecendo uma relação exigente com a herança cultural. Plutarco, contudo, torna-se um caso singular, pela forma como legou o passado, por meio da palavra, muitas vezes carregada de dramatismo e simbolismo por causa da grandeza dos heróis e dos seus feitos, e, ao mesmo tempo, pela maneira como tornou esse passado tão actuante, quer no seu tempo, quer num tempo mais alargado, que vai da Antiguidade aos nossos dias. Por isso, ler o corpus plutarcheum é empreender uma viagem pela Antiguidade, atendendo à quantidade e diversidade de temáticas, nomes, épocas e lugares. Muitas vezes, a memória transforma-se, como dissemos, num espelho, no qual a vida e as experiências passam como diapositivos... Olhamo-nos a esse espelho e ora nos identificamos com a ambição de Flaminino, Alexandre e César, ora com a cólera de Coriolano ou, então, com os defeitos de Alcibíades, António, Demétrio ou Mário. Noutros casos, desejamos imitar o sentido de justiça de Aristides, a austeridade de Catão Censor ou a audácia de Filopémen.

A actualidade da obra de Plutarco resulta, acima de tudo, da necessidade de se educar o espírito humano e de se modelar a physis, para que o erro seja evitado e a virtude se torne o objectivo sublime da acção. Sem a paideia, muitas vezes associada à razão e à filosofia, por mais nobre que seja a origem do indivíduo, até as melhores qualidades se transformam em motivo de desgraça,

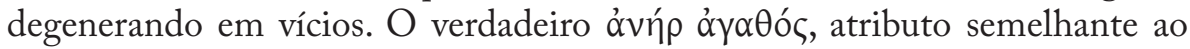

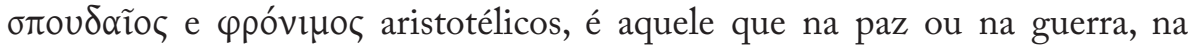
família ou na assembleia, no poder ou obediente a ele, consegue assimilar e concretizar os valores que definem, em sentido amplo, a paideia. Em termos abstractos, aceita-se e defende-se a ideia de que a paideia tem consequências profundas na vida de um indivíduo, mas a análise e a realidade concreta da narrativa das Vitae demonstra que Plutarco, por norma, não estabelece uma relação de causalidade consciente e inequívoca entre as alterações de carácter, nas quais acredita como Teofrasto e Políbio, e as tomadas de decisão e a paideia, embora, no plano teórico e em especial nos Moralia, faça depender da paideia a consolidação do carácter. Além disso, por ser um reflexo do ecumenismo político e cultural da época, a paideia proposta por Plutarco funda-se numa ideia pacificadora e, acima de tudo, complementar: Roma lidera o processo político e administrativo, enquanto a Grécia se encarrega, pela força da tradição, de proceder à construção ideológica, ou seja, à formulação dos valores e da cultura que consolidariam o imperium, uma vez que sem a conciliação da tyche, da capacidade natural e da emulação das qualidades helénicas jamais os Romanos teriam conseguido atingir um poder tão vasto.

Os heróis de Plutarco, não sendo perfeitos, tornam-se paradigmas que suscitam a admiração, o entusiasmo, a repulsa ou a curiosidade dos 
leitores de todos os tempos. Aliás, hoje temos tendência a repetir o processo plutarquiano... Se Plutarco foi ao passado buscar os heróis para iluminar as realizações do presente, também nós empreendemos essa viagem, e podemos olhar para Alexandre, Cícero, Alcibíades, Catão ou Marcelo como homens muito próximos de nós, tais são as semelhanças das atitudes e das formas sociais e morais com que se descreve o Homem, tanto na sua individualidade como nos seus deveres como membro de uma comunidade. Essa é, aliás, uma das concepções que Plutarco repete na sua obra: os acontecimentos e os caracteres repetem-se em diferentes momentos históricos, em diferentes situações e também em diferentes culturas. Por conseguinte, as Vitae distinguem-se pela sua multiplicidade temática e conceptual, tal como a dinânima multicultural e cosmopolita do tempo de Plutarco, nelas sobressaindo as qualidades do seu autor: pensador, erudito, biógrafo, educador, director de consciências, homem político, filósofo ou sacerdote. Como salientou S. Saïd (1990: 43), Plutarco concilia contrários: a tradição e a razão, o Império Romano e o desejo grego de autonomia.

Poucas dúvidas subsistem quanto ao facto de o rigor histórico ser preterido em relação à análise do carácter, da alma e dos sentimentos humanos. Parece que as palavras de Plutarco se geram em torno da concepção moral dos biografados, do ethos ou do sentido ético que os move nas praxeis. Ao dirigir, nas Vitae, o seu olhar para o homem e as suas valências, Plutarco deixa em plano secundário o tempo em que viveram ou o espaço que percorreram. Parece-nos que essa intenção contribui em muito para se pensar que temos à nossa frente uma protoconcepção do homem greco-romano, resultado da crase cultural de dois povos a quem a história marcou, por destino, um encontro, nem sempre pacífico, mas que determinou, em parte, aquilo que hoje somos e os nossos códigos cognitivos.

Por aquilo que temos vindo a anotar e que decorre de dois níveis presentes nas Vitae, um nível interior (a alma, os sentimentos, o carácter, o pensamento, o conhecimento, etc.) e um nível exterior (a acção, a história), percebe-se que o conjunto das biografias se situa nos domínios da psicologia, da ética, da antropologia cultural, além do plano literário. O próprio paralelismo cultural não tem apenas um valor erudito e retórico, mas também epistemológico e hermenêutico, por se enquadrar na realidade política e social da época. Plutarco não foi, nem poderia ser, indiferente à política imperial romana e às consequências disso na liberdade das pessoas e dos povos da Hélade. Por isso, a paideia, elemento criador de identidade, que primeiro passa do mestre para o aluno e que, depois, a este desenvolve individualmente na fase adulta, adquire contornos antropológicos e filosóficos, bem alicerçados na praxis da politeia, uma vez que o projecto da paideia é a formação ética daqueles que governam os destinos dos homens, num duplo sentido: os filósofos e mestres têm a função 
de educar e de acompanhar de perto o político ou aquele que ambiciona sêlo; o político deve também promover a paideia e a arete dos cidadãos, sendo essa cadeia educativa capaz de gerar a mimesis, quer a um nível pessoal, quer a um mais comunitário. Mais do que um sistema institucionalizado, a paideia, associada ao logos, é, para Plutarco, a interiorização educacional e cultural, segundo o modelo helénico, que proporciona a estabilidade do indivíduo.

Em Plutarco, a estrutura paralela, acompanhada do epílogo comparativo, obriga-nos a fazer uma leitura mais integrada, com constantes interrogações sobre o que é "ser Grego" e "ser Romano" ou, numa análise mais ambiciosa, o que é "ser cidadão da civilização greco-romana". Uma perspectiva mais antropológica do que puramente literária ou estética permite-nos concluir que as Vitae promovem um diálogo cultural que, por um lado, nos remete para as raízes identitárias, como é o caso das biografias de Teseu e Rómulo, mas que, por outro, ilumina o tempo presente, perspectivando e projectando acontecimentos futuros, como o debate, tão actual, sobre a relação entre Império e Cultura. É por isso que entendemos a produção literária de Plutarco, reconhecendo obviamente os artifícios narrativos e retóricos do autor, num contexto social, como um acto individual de representação crítica do mundo real.

Por a sua mensagem evidenciar a Grécia e Roma, as diferenças ( $\delta \iota \alpha \varphi \circ \rho \alpha i ́)$

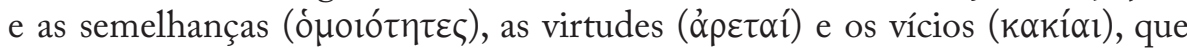
transparecem numa pesquisa arqueológica do ethos, deixam muitas vezes ao leitor caminho aberto para a ponderação dos factos. Foi como mais um desses leitores que nos aproximámos do corpus plutarcheum, em especial das Vitae, tentando percorrer as marcas da identidade cultural, ou seja, aquilo que caracteriza os povos. Nesse percurso não deixámos de nos surpreender com a actualidade da obra de Plutarco. Hoje, como antes, a história repete-se com sinais e protagonistas distintos, num mundo de forças dominantes e de culturas que subsistem com dificuldade. Por isso, o diálogo intercultural, a alteridade e o (re)conhecimento do Outro são temas perenes da condição humana, cabendo a cada indivíduo usar a razão, moderar a ambição, ter consciência cívica, ser philanthropos, aprofundar a paideia e ter presente, sem que isso o oprima, as

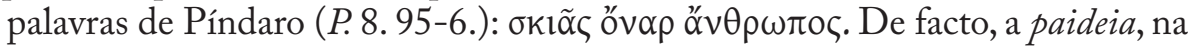
sua acção introspectiva, renova a memória, transforma, (re)identifica e desafia constantemente o homem na procura do conhecimento.

Além disso, a análise das Vitae permitiu-nos abordar outros aspectos sobre a paideia. Desde logo, a problemática relativamente à intervenção da paideia na physis, ou seja, como é possível a paideia (cultura/educação), um macroconceito, desempenhar um papel importante na physis ou mesmo na personalidade, quando estas dizem respeito à dinâmica individual. Como vimos, Plutarco acredita na capacidade da paideia para modelar o ethos, o eu e a identidade e na possibilidade de a arete ser ensinada. $\mathrm{O}$ indivíduo, porém, parece manter 
um conjunto de tendências e impulsos que apenas podem ser apaziguados. Muitas vezes, a tyche acaba por determinar o percurso de cada um e mesmo a sua personalidade. Um outro elemento que resulta do comportamento de alguns heróis plutarquianos (Alexandre e Sertório, por exemplo) é o efeito de sociabilização da paideia, como estratégia do conquistador. A política de aculturação dos povos bárbaros significa, em primeiro lugar, que se parte do pressuposto de que a cultura daquele que domina é superior e que a consolidação do poder se pode atingir com a ajuda da paideia. Para Plutarco, a paideia, num contexto social e político adverso, serve para redefinir a Hélade como educadora e paradigma de valores, não só em benefício dos Gregos, mas do ser humano em geral. Deste modo, transforma-se a submissão em liderança intelectual. Além disso, se tivermos em conta que dedica ao seu amigo romano Sósio Senécio o tratado em que defende, ao contrário dos estóicos, a possibilidade de se progredir na virtude (De prof. in uirt. 75A-86A), Plutarco usa a sua concepção de paideia, especialmente nas biografias romanas, como forma de travar a influência do Estoicismo entre a elite romana.

Por fim, embora uma parte da configuração do indivíduo surja de forma espontânea e da sua experiência pessoal, conclui-se que a paideia ajuda a completar o "humano": a estrutura familiar, as lições dos mestres ou a sociedade participam, com pesos distintos e de difícil avaliação, nesse processo. Assim, a physis, o genos, a paideia e a politeia, que representam a interacção do eu com aquilo que o rodeia, contribuem para formar a personalidade, cultivar os valores e determinar as ambições de cada ser humano, tendo este a característica de nunca deixar de tentar tornar-se mais completo. 



\section{Bibliografia ${ }^{\mathrm{I}}$}

\section{Edições, traduções e comentários do corpus ${ }^{2}$}

VITAE

\section{Theseus-Romulus}

R. Flacelière , É. Chambry \& M. Juneaux (1964), Plutarque. Vies. Tome I: Thésée-Romulus. Lycurge-Numa, Paris, "Les Belles Lettres".

C. Ampolo \& M. Manfredini (19993), Plutarco. Le Vite di Teseo e di Romolo, Fondazione Lorenzo Valla, Milano, Arnoldo Mondadori Editore.

K. Ziegler \& H. Gärtner (20005), Plutarchi Vitae Parallelae Vol. I. Fasc. 1, Stutgardiae et Lipsiae, Teubner.

D. Leão (2006), Plutarco. Vida de Rómulo, Coimbra.

\section{Aristides-Cato Maior}

R. Flacelière \& É. Chambry (1969), Plutarque. Vies. Tome V:Aristide-Caton l'Ancien. Philopoemen-Flamininus, Paris, "Les Belles Lettres".

D. Sansone (1989), Plutarch: The Lives of Aristides and Cato, Warminster, Aris \& Philips.

K. Ziegler \& H. Gärtner $\left(2000^{5}\right)$, Plutarchi Vitae Parallelae Vol. I. Fasc. 1, Stutgardiae et Lipsiae, Teubner.

\section{Coriolanus-Alcibiades}

R. Flacelière \& É. Chambry (1964), Plutarque. Vies. Tome III: PériclèsFabius Maximus. Alcibiade-Coriolan, Paris, "Les Belles Lettres".

K. Ziegler \& H. Gärtner (19944), Plutarchi Vitae Parallelae Vol. I. Fasc. 2, Stutgardiae et Lipsiae, Teubner.

L. Raffaelli (20013), Plutarco.Coriolano-Alcibiade, introduzione e note (respectivamente) di M. Cesa e L. Prandi, con contributi di B. Scardigli e M. Manfredini, Milano, Rizzoli.

\footnotetext{
${ }^{1}$ Para a lista bibliográfica não se tornar muito extensa, incluímos, salvo algumas excepções, apenas os autores que são citados ao longo da dissertação, deixando de parte outras obras que serviram de apoio, como Dicionários, Enciclopédias e Histórias da Literatura e da Cultura (Grega e Latina).

${ }_{2}^{2}$ Para as restantes Vitae e Moralia, bem como para os autores clássicos, usámos, em geral, as edições e traduções da Teubner, da "Les Belles Lettres", do Corpus Plutarchi Moralium, da Rizzoli, da Mondadori, da Oxford, de Cambridge, da Gredos, entre outras; relativamente aos fragmentos plutarquianos, socorremo-nos da edição de F. Sandbach (1969), Plutarch's Moralia, vol. XV. Fragments, Cambridge-Mass.-London, Loeb Classical Library.
} 


\section{Demosthenes-Cicero}

R. Flacelière \& É. Chambry (i 976), Plutarque. Vies. Tome XII: DémosthèneCicéron, Paris, "Les Belles Lettres".

K. Ziegler \& H. Gärtner (19944), Plutarchi Vitae Parallelae Vol. I. Fasc. 2, Stutgardiae et Lipsiae, Teubner.

C. Longo \& B. Mugelli (20004), Plutarco. Demostene-Cicerone, (respectivamente) introduzione e note di C. Longo, e introduzione di J. Geiger e note di L. Ghilli, con contributi di B. Scardigli e M. Manfredini, Milano, Rizzoli.

J. Moles (1988), Plutarch. The life of Cicero, Warminster.

\section{Sertorius-Eumenes}

R. Flacelière \& É. Chambry (I973), Plutarque. Vies. Tome VIII: SertoriusEumenes. Agésilas-Pompée, Paris, "Les Belles Lettres".

K. Ziegler \& H. Gärtner (19933), Plutarchi Vitae Parallelae Vol. II. Fasc. 1, Stutgardiae et Lipsiae, Teubner.

C. Konrad (1994), Plutarch's Sertorius: a historical commentary, Chapel HillLondon, The University of North Carolina Press.

\section{Philopoemen-Flamininus}

R. Flacelière \& É. Chambry (i 969), Plutarque. Vies. Tome V:Aristide-Caton l'Ancien. Philopoemen-Flamininus, Paris, "Les Belles Lettres".

K. Ziegler \& H. Gärtner (1994³), Plutarchi Vitae Parallelae, Vol. II. Fasc. 2, Stutgardiae et Lipsiae, Teubner.

E. Melandri (1997), Plutarco.Filopemene-Tito Flaminino, introduzione e note di C. Pelling, Milano, Rizzoli.

\section{Pelopidas-Marcellus}

R. Flacelière \& É. Chambry (1966), Plutarque. Vies. Tome IV: TimoléonPaul Émile. Pélopidas-Marcellus, Paris, "Les Belles Lettres".

K. Ziegler \& H. Gärtner (1994³), Plutarchi Vitae Parallelae, Vol. II. Fasc. 2, Stutgardiae et Lipsiae, Teubner.

P. Fabrini (1998), Plutarco. Pelopida-Marcelo, introduzione (respectivamente) di A. Georgiadou e S. Bocci, note di L. Ghilli, con contributi di B. Scardigli e M. Manfredini, Milano, Rizzoli.

\section{Alexander-Caesar}

K. Ziegler \& H. Gärtner (1994³), Plutarchi Vitae Parallelae, Vol. II. Fasc. 2, Stutgardiae et Lipsiae, Teubner.

J. Hamilton $\left(2002^{2}\right.$ ), Plutarch: Alexander, foreword and bibliography by $\mathrm{Ph}$. 
Stadter, Bristol Classical Press.

\section{MORALIA}

\section{Maxime cum principibus philosopho esse disserendum}

M. Cuvigny (1984), Plutarque. Oeuvres morales. Tome XI-Première partie, Paris, "Les Belles Lettres".

\section{Ad principem ineruditum}

M. Cuvigny (1984), Plutarque. Oeuvres morales.Tome XI-Première partie, Paris, "Les Belles Lettres".

A. Tirelli (2005), Plutarco. Ad un governante incolto, Corpus Plutarchi Moralium, Napoli, M. D’Auria Editore.

\section{An seni respublica gerenda sit}

M. Cuvigny (1984), Plutarque. Oeuvres morales.Tome XI-Première partie, Paris, "Les Belles Lettres".

\section{Praecepta gerendae reipublicae}

J.-Cl. Carrière \& M. Cuvigny (1984), Plutarque. Oeuvres morales. Tome XI2e partie, Paris, "Les Belles Lettres".

A. Cainzza (1993), Plutarco. Precetti Politici, Corpus Plutarchi Moralium, Napoli, M. D'Auria Editore.

\section{De unius in republica dominatione}

J.-Cl. Carrière \& M. Cuvigny (1984), Plutarque. Oeuvres morales. Tome XI2e partie, Paris, "Les Belles Lettres".

A. Cainzza (1993), Plutarco. Monarchia, Democrazia, Oligarchia, Corpus Plutarchi Moralium, Napoli, M. D’Auria Editore.

\section{Estudos}

Aalders, G. (1982), Plutarch's Political Thought, Amsterdam, Oxford \& New York.

Aalders, G. \& De Blois, L. (1992: 3384-4302), «Plutarch und die politische Philosophie der Griechen», ANRW II.36.5.

Аввот, N. (1980), The Treatise De liberis educandis attibuted to Plutarch, Oxford.

Adrados, F. (2005: 33-50), "Alejandro, Plutarco y las gnomologías griegas", in M. Jufresa et al. (Eds.). 
Aguilar, R. (1984), 421-427, "Plutarco, el teatro y la politica", Estudios Clásicos 26.

Albini, F. (1997: 59-71), "Family and the formation of character in Plutarch", in J. Mossman (Ed.).

Alcocк, S. (1996r), Graecia capta: the landscapes of Roman Greece, Cambridge.

Alesse, F. (2005: 51-58), "Alcuni significati del termine askesis nell'opera di Plutarco", in M. Jufresa et al. (Eds.).

Alexiou, E. (1999: 61-74), "Paralletät und Die Moralischen Ziele Plutarchs: 'Coriolanus' und 'Alkibiades', Hermes 127.

Algra, K. et al. (2005r), The Cambridge History of Hellenistic Philosophy, Cambridge.

Alonso-Nuñez,J. (1985: 32-36), "Il supposto trattato di Plutarco sulle forme di governo", $A \mathcal{E}^{2} R 30$.

Anderson, G. (1989: 79-208), "The pepaideumenos in action: Sophists and their outlook in the Early Roman Empire", $A N R W$ II.31.1.

(1993), The Second Sophistic: a cultural phenomenon in the Roman Empire, London \& New York.

Ando, C. (1999: 5-34), "Was Rome a polis?", $C A 18.1$.

Artacho, M. (1994: 247-252), "El elemento religioso en la Vida de Arístides de Plutarco”, in M. García Valdés (Ed.).

- (2001: 337-344), "La Vida de Arístides. Aproximaciones a la idea de justicia", in A. Pérez Jiménez \& F. Casadesús Bordoy (Eds.).

Asirvatham, S. (2000), Macedonia and Memory: the Legacy of Alexander in Second Sophistic rhetoric and historiography, Ph. D. Thesis, Columbia.

(2005: 107-125), "Classicism and Romanitas in Plutarch's 'De Alexandri Fortuna aut Virtute", $A J P h 126$.

Astin, A.(1978), Cato the Censor, Oxford.

Austin, R. (1986), P. Vergili Maronis Aeneidos Liber Sextus, Oxford

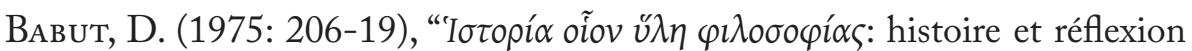
morale dans l'œuvre de Plutarque”, REG 88.

(1994: 505-529), «Plutarque, Aristote et l'Aristotélisme», in Parerga. Choix d'articles de Daniel Babut (1974-94), Lyon (= in L. Van Der Stockt (ed. 1996: 1-28)).

(1999: 175-189), «Sur Soclaros de Chéronée et sur le Nombre des Enfants de Plutarque: Méthodologie d'une Mise au Point», $R P h 73$.

___ (t2003), Plutarco e lo stoicismo, Milano. 
Baldassarri, M. (1992: 16-21), "Etica e psicologia platonica, peripatetica e stoica nel De virtute morali di Plutarco", $A \mathcal{E} R 37$.

Ballesteros Pastor, L. (1999: 331-343), "Aspectos contrastantes en la tradición sobre L. Licinio Lúculo”, Gérion 17.

Barbu, N. (1976), Les Procédés de la peinture des caractères et la Verité historique dans le biographies de Plutarque, Paris.

BARIgAzZI, A. (1981: 193-214), "Note critiche ed esegetiche agli scritti politici di Plutarco (I)", Prometheus 7.

(1982: 61-79), Note critiche ed esegetiche agli scritti politici di Plutarco (II), Prometheus 8.

(1984a: 37-64), "Note critiche ed esegetiche agli scritti politici di Plutarco (III)", Prometheus 10.

(1984b: 264-286), "Plutarco e il corso futuro della storia", Prometheus 10.

- (1987: 47-71), "Per il recupero di una declamazione di Plutarco sulla virtù", Prometheus 13.

(Ed., 1993), Se la virtù si debba insegnare, Corpus Plutarchi Moralium, Napoli.

Barrigón, Ma . (1996: 447-458), "Plutarco y Simónides de Ceos", in J. Fernández Delgado-F. Pordomingo Pardo (Eds.).

Barrow, R. (1967), Plutarch and his Times, London.

Batstone, W. (1988: 1-29), "The Antitesis of virtue: Sallust's synkrisis and the crisis of Late Republic", CA 7.1.

Bearzot, C. (1985), Focione tra storia e trafigurazione ideale, Milano.

Becchi, F. (1975: 160-180), "Aristotelismo ed Antistoicismo nel De Virtute Morali di Plutarco", Prometheus 1.

- (1978: 261-275), "Aristotelismo funzionale nel 'De virtute morali' di Plutarco", Prometheus 4.

- (1981: 125-145; 263-284), "Platonismo medio ed etica plutarchea", Prometheus 7.

(1987: 37-46), "La nozione di phronesis negli scritti postaristotelicoperipatetici di etica”, Prometheus 13.

(1990: 1-16), "A proposito degli studi sugli scritti etici di Plutarco", AEंR 35.

(1995: 51-64),"La saggezza del politico e la saggezza dell'attore: una questione di Quellenforschung", in I. Gallo \& B. Scardigli (Eds.). 
(1996: 321-35), "Plutarco e la dottrina dell' omoiosis theo[grego] tra platonismo ed aristotelismo", in I. Gallo (Ed.).

(1999: 25-44), "Plutarco tra platonismo e aristotelismo: la filosofia come paideia dell'anima”, in A. Pérez Jiménez, J. García López \& Rosa M. Aguilar (Eds.).

(2001: 119-135), "Biopsicologia e giustizia verso gli animali in Teofrasto e Plutarco", Prometheus 27.

- (2003: 89-109), «La pensée morale de Plutarque et le : une nouvelle interprétation», Humanitas 55.

—_ (2005a: 199-208), "La dottrina del TE $\Lambda$ O $\Sigma$ nel pensiero e nell'opera di Plutarco", in M. Jufresa et al. (Eds.).

(2005b: 385-400), “Apatheia e Metriopatheia in Plutarco”, A. Casanova (Ed.).

Bеск, Н. (2002: 467-489), "Interne Synkrisis Bei Plutarch”, Hermes 130.

BECK, M. (2000: 15-32), "Anecdote and the representation of Plutarch's ethos", in L. Van der Stockt (Ed.).

(2002: 163-173), "Plutarch to Trajan: the Dedicatory Letter and the Apophthegmata Collection", in Ph. Stadter \& L. Van der Stockt (Eds.).

Berry, E. G. (1958: 388-99), “The De liberis educandis of Ps.-Plutarch”, $H S C P h 63$.

Billault, A. (2001: 256-268), «L'Histoire de la Rhétorique dans les Vies Parallèles de Plutarque: L'exemple des Vies de Démosthène et de Cicéron», REG 114.

Bollansée, J. (1999), Hermippos of Smyrna and his Biographical Writings. A Reappraisal, Studia Hellenistica 35, Louvain.

Bordes, J. (1982), Politeia dans la pensée grecque jusqu'à Aristote, Paris.

Borg, B. (Ed., 2004), Paideia: the world of the second sophistic, MilleniiumStudien 2, De Gruyter.

Bos, A. (1989: 179-198), "Exoterikoi Logoi and Enkyklioi Logoi in the Corpus Aristotelicum and the origin of the idea of the Enkyklios Paideia", Journal of the History of Ideas 50.2.

Borthwick, E. (1991: 560-2), "Bee imagery in Plutarch”, CQ 41.

Bosworth, A. (1992: 56-89), "History and practice in Plutarch's Eumenes", in $\mathrm{Ph}$. Stadter (Ed.).

Boulet, B. (2004: 245-256), "Is Numa the genuine philosopher king", in Lukas de Blois et al. (Eds.). 
Boulogne, J. (1992: 4682-4708), «Les 'Questions Romaines' de Plutarque, $A N R W$ II.33.6.

- (1994), Plutarque. Un Aristocrate Grec sous l'Occupation Romaine, Presses Universitaires de Lille.

-_ (2000: 33-44), «Les SYNKRISEIS de Plutarque. Une Rhétorique de la SYNKRASIS», in L. Van der Stockt (ed.).

-_ (2003), Plutarque dans le miroir d'Épicure, Lille.

(2004: 211-225), «L'Imaginaire Politique de Plutarque», in Lukas de Blois et al. (Eds.)

- _ (2005 : 287-300), «Plutarque lecteur de Théophraste», in A. Casanova (Ed.).

Bowersock, G. (1969), Greek Sophists in the Roman Empire, Oxford. (1973: 177-206), «Greek Intellectuals and the Imperial Cult in the Second Century A.D.», in Le Culte des souverains dans l'Empire Romain, Entretiens sur l'Antiquité Classique XIX, VandoeuvresGinebra.

(1995: 3-14), “The Barbarism of the Greeks”, HSCPh 97.

(1998: 193-210), "Vita Caesarum: remembering and fogetting the past", in W. Whlers (Ed.), La biographie antique, Entretiens Hardt 44, Genève.

Bowie, E. (1970: 3-41), “The Greeks and their Past in the Second Sophistic”, $P \mathcal{S} P 46$.

(1982: 29-59, “The Importance of Sophists”, YCS 27.

(1989: 209-258), "Greek Sophists and Greek Poetry in the Second Sophistic”, ANRW II.31.1.

(1990: 53-90), "Greek poetry in the Antonine Age", in D. Russel (Ed.), Antonine Literature, Oxford.

(1991: 183-204), "Hellenes and Hellenism in writers of the Early 2nd Sophistic”, in S. Said (ed.), Hellenismos. Quelques jalons pour une histoire de l'identité grecque, Leiden, New York. Kobenhavn. Koln.

(1994: 207-30), "Past and Present in Pausanias", in Pausanias bistorien, Entretiens Hardt 41, Genève.

(1997: 1-15), “Adrian, Favorinus, and Plutarch", in J. Mossman (ed.).

(2004: 65-75), “The geography of the Second Sophistic: Cultural variations", in B. Borg (Ed.).

Braund, D. (2001: 10-24), "Cohors: the governor and his entourage in the 
self-image of the Roman Republic”, in R. Laurence \& J. Berry, Cultural Identity in the Roman Empire, London \& New York.

Bravo García, A. (1973: 141-192), "El pensamiento de Plutarco acerca de la paz y de la guerra”, Cuadernos de Filología Clásica 5.

Brenk, F. (1998), Relighting the Souls: Studies in Plutarch, in Greek Literature, Religion, and Philosophy, and the Nerw Testament Background, Stuttgart.

(1992: 4347-4469), "Plutarch's Life 'Markos Antonios': A Literary and Cultural Study, $A N R W$ II.33.6.

Browning, R. (2002: 257-277), "Greeks and Others: from Antiquity to the Renaissance", in Th. Harrison (Ed.).

Brozek, M. (1963: 68-80), "Nock über die Selbstzitate als chronologischen wegweiser in Plutarchs Parallelbiographien”, Eos 53.

Bucher-Isler, B. (1972), Norm und Individualität in den Biographien Plutarchs, Bern.

Buckler, J. (1978: 36-42), "Plutarch on the Trials of Pelopidas and Epameinondas (369 B.C.)”, CPh 73.1. (1992: 4788-4830), "Plutarch and Autopsy", $A N R W$ II.33.6.

Burlando, A. (2000: 61-68), "Breve note a Plutarco, Demostene 1-2", in L. Van der Stockt (Ed.).

Burridge, R. (1997: 371-391), "Biography", in S. Porter (Ed.), Handbook of Classical Rhetoric in the Hellenistic Period 330 B.C.-A.D. 400, LeidenNew York-Köln.

Busine, A. (2002), Les Sept Sages de la Grèce antique. Transmission et utilisation d'un patrimoine légendaire, d'Hérodote à Plutarque, Paris.

Caeiro, A. (2004), Aristóteles. Ética a Nicómaco, Lisboa.

Cairns, F. (1982: 203-4), “Cleon and Péricles: a suggestion”, JHS 102.

Cammarota, M. (1992: 105-124), "Il De Alexandri Magni fortuna aut virtute come espressione retorica: il panegirico", in I. Gallo (ed.), Ricerche plutarchee, Università degli Studi di Salerno, Quaderni del Dipartimento di Scienze dell' Antichità 12, Naples.

Candau, J. (1999: 139-144), "La Vida de Demetrio como biografia negativa”, in R. Gallé Cejudo, J. Montes Cala \& M. Ortiz de Landaluce \& (Eds.).

Carney, T. (1961: 98-121), “The flight and Exile of Marius”, GE 8.

Carrière, J. (1977 : 236-251), «À propos de la politique de Plutarco», DHA.

Cartledge, P. (2002r), The Greeks: a portrait of self and others, Oxford.

Casanova, A. (Ed., 2005), Plutarco e l'Età Ellenistica. Atti del Convegno 
Internazionale di Studi, Firenze, 23-24 Settembre 2004, Firenze.

Cerezo Magán, M. (1992), Perfil ético-psicológico de los héroes plutarqueos, Tesis Doctoral, Universitat de Barcelona.

(1996a), Plutarco: virtudes y Vicios de sus heroes biográficos, Estudi General.

(1996b: 267-280), "Algunas observaciones en torno a la originalidad de la técnica biográfica plutarquea”, in J. Fernández Delgado-F. Pordomingo Pardo (Eds.).

Cerri, G. (2001: 413-26), “Biografia, storiografia, dialogo: I generi letterari in Plutarco", MediterrAnt 4.

Churchill, J. (2001: 98-107), "The Lucky Cato, and his wife", Phoenix 55.1/2.

Cizer, E. (1989: 3-35), «La littérature et les cercles culturels et politiques à l'époque de Trajan» $A N R W$ II.33.1.

Cole, S. (1992r: 219-245), "Could Greek Women Read and Write?", in H. Foley (Ed.), Reflections of Women in Antiquity, Philadelphia.

Costanza, S. (1955: 127-156), "La synkrisis nello schema biografico di Plutarco",Messana (Studi diretti da Michele Catalano), vol.IV, Messina.

de Blois, L. (1992: 4568-4615), “The Perception of Politics in Plutarch's Roman 'Lives”, $A N R W$ II.33.6.

(1997: 209-224), "Political concepts in Plutarch's Dion and Timoleon”, AncSoc 28.

(2004: 57-63), "Classical and Contemporary Statesman in Plutarch's Praecepta”, in L. de Blois et al. (Eds.).

(Ed., 2004), The Statesman in Plutarch's Works: Plutarch's Statesman and his aftermath. Political, Philosophical, and Literary aspects, vol. 1, Brill.

De Blois, L. ET AL. (ed., 2004), The Statesman in Plutarch's Greek and Roman Lives, Leiden \& Boston.

De Lacy, P. (1952: 159-171), "Biography and Tragedy in Plutarch”, AJPh 73.

Delvaux, G. (1988: 27-48), "Retour aux sources de Plutarque”, LEC 56. (1989: 127-46), "L'annaliste Fenestella et Plutarque”, LEC 57.

(1995: 97-113), «Plutarque: Chronologie Relative des Vies Parallèles», LEC 63.

(1996: 107-17), "Panétius, le pseudo-Théopompe, une source dês Viés parallèles des Grecs de Plutarque", LAC 65.

Den Boer, W. (1969), “Theseus: the Growth of a myth in history”, G\&R 16, 1-13. 
Desideri, P. (1978), Dione di Prusa: un intellettuale greco nell'impero romano, Florence.

- (1985: 391-405), "Ricchezza e vita politica nel pensiero di Plutarco", Index 13.

(1989: 199-215), "Teoria e Prassi storiografica in Plutarco: una proposta di lettura della coppia Emilio Paolo-Timoleonte”, Maia 41.

- (1992a: 4470-4486),'La Formazione delle Coppie nelle 'Vite' plutarchee", $A N R W$ II.33.6.

(1992b: 4536-4567), "I documenti di Plutarco", ANRWII.33.6.

(1998: 60-87), "Forme dell'impegno politico di intelletuali greci dell'impero [Plutarco]", RSI 110 .

(2005: 3-21), "Impero di Alessandro e impero di Roma", in A. Casanova (Ed.).

Dinle, A. (1956), Studien zur Entstehung der griechischen Biographie, Göttingen. (1987), Die Entstehung der historischen Biographie, Heidelberg.

Dillon, J. (1977), The Middle Platonists: a Study of Platonism 80 B.C. to A.D. 220, London.

—_ (1988: 357-64), "Plutarch and Platonist Orthodoxy", ICS 13.

(1997: 235-240), "Plutarch and the end of history", in J. Mossman (Ed.).

(2002: 29-40), "The social role of the philosopher in the second century C.E.: some remarks", in Ph. Stadter \& L. Van der Stockt (Eds.).

- (2004), Morality and Custom in ancient Greece, Indiana.

Dillon, J. \& Long, A. (Eds., 1988) The question of "Eclectism". Studies in Later Greek Philosophy, Berkely, Los Angeles \& London.

D’Ippolito, G. (1991: 9-18), "Il corpus plutarcheo come macrotesto di un progetto antropologico: modi e funzioni della autotestualità", in G. D'Ipollito \& I. Gallo (Eds.), Strutture formali dei "Moralia" di Plutarco (Atti del III Convegno plutarcheo, Palermo, 3-5 maggio 1989, Napoli.

(1996: 17-29), "Stilemi Ilomorfici nel Macrotesto Plutarcheo", in J. Fernández Delgado-F. Pordomingo Pardo (Eds.).

(2005: 179-196), "Filantropia, ellenocentrismo e polietnismo in Plutarco", in A. Pérez Jiménez \& F. Titchener (Eds.).

Dittenberger, W. (Eds., 1915-24³), Sylloge Inscriptionum Graecarum.

Donini, P. (1974), “Il Platonismo medio e l'interpretazione dell' etica aristotelica", in Tre studi sull' aristotelismo nel II secolo D. C., Torino. 
(1986a: 97-110), "Plutarco, Ammonio e l'Academia”, in F. Brenk \& I. Gallo, Miscellanea Plutarchea, Ferrara.

- (1986b: 203-226), "Lo scetticismo academico, Aristotele e l'unità della tradizione platonica secondo Plutarco", in G. Cambiano (Ed.), Storiografia e Dossografia nella Filosofia Antica, Torino.

(1988a: 15-33), "The History of the Concept of Eclecticism", in J. Dillon \& A.A.Long (eds.).

(1988b: 126-144), "Science and Metaphysics. Platonism, Aristotelianism, and Stoicism in Plutarch's On the face of the Moon", in J. Dillon \& A.Long (eds.).

(1994: 35-60), "Plutarco e la rinascita del platonismo", in Lo spazio letterario della Grecia antica, vol. I, tomo III, Roma.

Dubuisson,M.(1991:315-335), «GRAECVS, GRAECVLVS, GRAECARI:

L'emploi péjoratif du nom des Grecs en Latin», in S. Saïd (Ed.).

Ducat, J. (2006), Spartan Education, Classical Press of Wales.

Duchemin, J. (1969: 533-535), «La thème du héros au Labyrinthe dans la Vie de Thésée», Actes du VIII congres, Paris.

Duff, T. (1996: 333-349), "The Structure of Coriolanus-Alcibiades", in J. Fernández Delgado-F. Pordomingo Pardo (Eds.).

__ (2000: 141-162), "Plutarchean Synkrisis: comparisons and contradictions", in L. Van der Stockt (Ed.).

__ (2001: 351-364), "The prologue to the Lives of Perikles and Fabius (Per.1-2), in A. Pérez Jiménez \& F. Casadesús (Eds.).

- (2002r), Plutarch's Lives. Exploring Virtue and Vice, Oxford.

(2004: 157-166), "The first five anecdotes of Plutarch's Life of Alkibiades", in L. de Blois et al. (Eds.).

Durán López, Ma . (1996: 405-414), “Citas y Anécdotas en Plutarco”, in J. Fernández Delgado-F. Pordomingo Pardo (Eds.).

___ (2004: 33-41), "Plutarco, Ciudadano Griego y Súbdito Romano”, L. de Blois et al. (ed.).

Edwards, M. \& Swain, S. (Eds., 1997), Portraits. Biographical Representation in the Greek and Latin Literature of the Roman Empire, Oxford.

Ehlers, W. (Ed., 1998), La Biographie Antique, Entretiens sur l'Antiquité Classique 44, Vandoeuvres-Genevè, Fondation Hardt.

Erbse, H. (1956: 398-424), «Die Bedeutung der Synkrisis in den Parallelbiographien Plutarchs», Hermes 84. 
Eyben, E. (1996: 79-112), «Children in Plutarch», in L. Van der Stock (ed.), Plutarchea Lovaniensia. A Miscellany of Essays on Plutarch.

Fears, J. (1974: 113-130), "The Stoic View of the Career and Character of Alexander the Great”, Philologus 118.

Fernández Delgado, J. \& Pordomingo Pardo, F. (Eds., 1996), Estudios sobre Plutarco: Aspectos Formales, Actas del IV Simposio Español sobre Plutarco (Salamanca, 26 a 28 de Mayo de 1994), Madrid.

Ferrary, J.-L. (1988), Philhellénisme et impérialisme. Aspects idéologiques de la conquête romaine du Monde hellénistique, Roma.

FiAlho, Ma Do CÉu (2002: 66-79), “Teseu em Plutarco à luz da tradição”, in J. Ribeiro Ferreira (Coord.).

Fialho, Ma do CÉu ET Al. (2001), Plutarco. A coragem das mulheres, Coimbra.

Flacelière, R. (1948: 67-103), «Sur quelques passages des Vies de Plutarque.

I. Thésée-Romulus II. Lycurge-Numa», REG 61.

(1949: 120-32), «Sur quelques passages des Vies de Plutarque”, $R P h$ 23.

- (1959 : 197-215), «Plutarque et l'Epicurisme”, Epicurea 10.

(1963: 28-47), «Rome et ses Empereurs vues par Plutarque», AC 32.

(1964), Sagesse de Plutarque, Paris.

(1979: 264-275), «La Pensée de Plutarque dans les Vies», Bull. Ass. Guill. Budé.

Flacelière, R. \& Irigoin, J. (1987: ccxxvii-cccx), «Histoire du texte des «Oeuvres Morales» de Plutarque», in Plutarque, Oeuvres Morales, tome 1, 1er partie, Introduction générale.

Flower, M. (2000: 96-135), "Alexander the Great and Panhellenism", in

A. Bosworth \& E. Baynham, Alexander the Great in Fact and Fiction, Oxford.

Focke, F. (1923: 317-68), «Synkrisis», Hermes 58.

Frazier, F. (1987: 65-75), «À propos de la composition des couples dans les Vies parallèles de Plutarque», $R P h 61$.

(1988a: 109-127), «À propos de la philotimia dans les Vies de Plutarque», $R P h 62$.

(1988b: 297-309), «Remarques à propos de l'usage des citations en matière de chronologie dans le Vies», ICS 13.2.

(1992: 4487-4535), «Contribution à l'étude de la composition des 'Vies' de Plutarque: l'élaboration des grandes scènes», $A N R W$ II.33.6. 
(1995: 147-171) «Principes et décisions dans le domaine politique d'après les Vies parallèles», I. Gallo \& B. Scardigli (Eds.).

- (1996), Histoire et Morale dans les Vies parallèles de Plutarque, Paris.

Froidefond, C. (1987: 184-233), «Plutarque et le Platonisme», ANRW36.1.

Frost, F. (1961: 182-193), “Some documents in Plutarch's Lives”, CËM 22.

(1984: 65-73), "Plutarch and Theseus", CB 60 (1984).

Fuentes, C. (2005: 191-198), "El oportuno silencio: una norma educativa para Plutarco", in M. Jufresa et al. (Eds.).

Fuhrmann, F. (1964), Les Images de Plutarque, Paris.

Fuscagni, S. (2000: 19-28), "Le Vite come genere letterario ovvero Plutarco: uno storico e il suo genere", in I. Gallo \& C. Moreschini (Eds.).

Gabba, E. (1991), Dionysius and the history of Archaic Rome, Berkeley, Los Angeles, Oxford.

(1993), Aspetti Culturali dell' imperialismo romano, Firenze.

(2004: 311-316), "Plutarco e Polibio", in I. Gallo (Ed.).

Gallé Cejudo, R., Montes Cala, J. \& Ortiz de Landaluce, M. (eds. 1999), Plutarco, Dioniso y el Vino (Actas del VI Simposio Español sobre Plutarco, Cádiz, 14-16 de mayo de 1998), Madrid.

Gallo, I. (1974: 173-186), "L'origine e lo sviluppo della biografia greca", QUCC 18 .

(1988), Aspetti dello Stoicismo e dell'Epicurismo in Plutarco, Ferrara.

(1990: 9-27), "Problemi vecchi e nuovi della biografia greca", Quad. Del Liceo Class. 13.

(1992: 4729), "Forma letteraria nei 'Moralia' di Plutarco", $A N R W$ II.33.6.

- (Ed., 1996), Plutarco e la religione: Atti del VI Convegno plutarcheo (Ravello, 29-31 maggio 1995), Napoli.

- (1996: 3-16), "Strutture Letterarie dei «Moralia» di Plutarco: Aspetti e Problemi”, in J. Fernández Delgado-F. Pordomingo Pardo (Eds.), (1997r: 167-184),"Nascita e Sviluppo della Biografia Greca: Aspetti e Problemi”, in Studi Sulla Biografia Greca, Napoli (= I. Gallo \& L. Nicastri (a cura di, 1995: 7-22), Biografia e autobiografia, Napoli).

- (1997r), Studi sulla biografia greca, Napoli.

(2000: 9-17), "I generi Letterari nel Corpus Plutarcheo: Aspetti e Problemi”, in I. Gallo \& C. Moreschini (Eds.). 
(2001: 297-304), "L'idea di Roma in Plutarco", in F. Giordano (a cura di), L'idea di Roma nella cultura antica, Napoli, 2001.

(Ed., 2004), La Biblioteca di Plutarco. Atti del IX Convegno plutarcheo (Pavia, 13-15 giugno 2002), Napoli.

Gallo, I. \& Scardigli, B. (Eds., 1995), Teoria e Prassi Politica nelle Opere di Plutarco, Atti del V Convegno plutarcheo (Certosa di Pontignano, 7-9 giugno 1993), Napoli.

Gallo, I. \& Moreschini, C. (Eds., 2000), I generi Letterari in Plutarco (Atti del VIII Convegno Plutarcheo, Pisa, 2-4 giugno 1999), Napoli.

Gamberale, L. (1995: 433-40), "Un probabile errore di latino in Plutarco, Tib. Gracch. 13.6”, RFIC 123.

García Blanco, J. (1984: 567-98), "Literatura Griega Imperial", en A. Martínez Díez (ed.), Actualización Cientifica en Filologia Griega, Madrid.

García López, J. (1983: 83-90), “Educación y critica literaria en la helenidad tardia: el De Liberis educandis, atribuido a Plutarco", in Unidad y pluralidad en el mundo antiguo. Actas del VI Congreso Español de Estudios Clásicos II, Madrid.

(1984: 411-419), "Sobre el De audiendis poetis de Plutarco", Apophoreta Philologica M. Fernández Galiano II.

García Moreno, L. (1992: 132-158), "Paradoxography and Political Ideals in Plutarch's Life of Sertorius", in Ph. Stadter (Ed.), London.

(1996: 357-367), "Plutarco y la Rapacidad de los Romanos", in J. Fernández Delgado-F. Pordomingo Pardo (Eds.).

García Bravo, A. (1973: 141-191), "El pensamiento de Plutarco acerca de la paz y de la guerra", Cuad. De Filol. Clás. 5.

Garzya, A. (1988), Percorsi e tramiti di cultura. Saggi nella civiltá letteraria tardoantica e bizantina com una giunta sulla tardizione defli studi classici, Napoli.

Geiger, J. (1985), Cornelius Nepos and the Ancient Political Biography, Stuttgart. (1988: 245-256), "Nepos and Plutarch: from Latin to Greek Political Biography”, ICS 13.

(1995: 165-90), "Plutarch's Parallel Lives: The choice of heroes", in B. Scardigli (Ed.) (= Hermes 99 (1981: 85-104)).

(2000: 39-45), "Political Biography and the art of Portraiture: some Parallels", in I. Gallo \& C. Moreschini (Eds.).

(2002: 93-102), "Felicitas temporum and Plutarch's choice of heroes", in $\mathrm{Ph}$. Stadter \& Van Der Stockt (Ed.). 
(2005: 231-242), "Plutarch's choice of Roman Heroes: further considerations", in A. Pérez Jiménez \& F. Titchener (Eds.).

Gentili, B. \& Cerri, G. (1978: 7-27), “L'idea di biografia nel pensiero greco”, QUCC 27.

(1983), Storia e biografia nel pensiero antico, Bari.

Georgiadou, A. (1992: 4222-4257), "Bias and Character-portrayal in Plutarch's Lives of Pelopidas and Marcellus", $A N R W$ II.33.6.

(1992: 4616-4623), "Idealistic and Realistic Portraiture in the Lives of Plutarch", $A N R W$ II.33.6.

Giannattasio, R. (2000: 81-91), "Galba e Otone tra biografia e storia”, in I. Gallo \& C. Moreschini (Eds.).

Gleason, M. (1995), Making men: Sophists and Sel-Representation in Ancient Rome, Princeton.

Goldhill, S. (1988: 128-93), "Battle narrative and politics in Aeschylus' Persae", JHS 108.

(Ed., 2001), Being Greek under Rome. Cultural Identity, the second Sophistic and the Development of Empire, Cambridge.

- (2002), Who Needs Greek? Contests in the Cultural History of Hellenism, Cambridge.

Gómez, P. \& Mestre, F. (1997: 209-228), "Historia en Plutarco: los Griegos y los Romanos", in C. Schrader et al. (Eds.).

- (2001: 365-378), "Lo religioso y lo politico: personajes del mito y hombres de la historia", in A. Pérez Jiménez \& F. Casadesús (Eds.).

Gomme, A. (1945), A Historical Commentary on Thucydides, I, Introduction and Commentary on Book I, Oxford.

Gruen, E. (1986r), The Hellenistic World and the Coming of Rome, Berkeley, Los Angeles \& London.

- (1995), Culture and National Identity in Republican Rome, Cornell University Press. (2006: 295-314), "Greeks and non-Greeks", in G. Bugh (Ed.), The Cambridge Companion to the Hellenistic World, Cambridge.

Hadas, M. (1950: 131-139), “Aspects of nationalist survival under Hellenistic and Roman Imperialism”, Journal of the History of Ideas 11.2.

Halfmann, H. (1979), Die Senatoren aus den östlichen Teil des Imperium Romanum bis zum Ende des 2. jabrhunderts n. Chr., Hypomnemata 58, Göttingen. 
Hall, J. (1997), Ethnic Identity in Greek Antiquity, Cambridge. (2002), Hellenicity: betweem ethnicity and culture, Chicago.

Hall, S. (1992: 273-326), "The questions of cultural identity", in S. Hall, D. Held \& T. McGrew (Eds.), Modernity and its futures, Cambridge.

Hamilton, Ch. (1992: 4201-4221), "Plutarch's 'Life of Agesilaus”, ANRW II.33.6.

Hamilton, J. (1961: 9-20), “The letters in Plutarch's Alexander”, PACA 4.

Hardie, Ph. (1992: 4743-4787), "Plutarch and the Interpretation of Myth", $A N R W$ II.33.6.

HARris, W. (2001), Restraining rage: the ideology of anger control in Classical Antiquity, Cambridge, Mass., London.

Harrison, G. (1992: 4646-4681), "The Critical Trends in Scholarship on the Non-Philosophical Works in Plutarch's 'Moralia”, ANRW II.33.6.

(2000: 193-9), "Problems with the Genre of Problems: Plutarch's literary innovations", $C P$ 9 95.2.

Harrison, Th. (Ed., 2002), Greeks and Barbarians, Edimburgh.

Hartog, F. (1991: 149-167), «Rome et la Grèce: les choix de Denys d'Halicarnasse», in S. Said (Ed.).

- (1998: 161), “Du paralléle à la comparaison”, in P. Payen (Ed.).

Helmbold, W. \& O’Neil, E. (1959), Plutarch's quotations, Baltimore.

Henrichs, A. (1995: 243-261), "Graecia capta: Roman Views of Greek Culture”, HSCPh 97.

Herbert, K. (1957: 83-8), “The identity of Plutarch's Lost Scipio”, AJPh 78.1

Hershbell, J. (1987: 234-247), "Plutarch's De animae procreatione in Timaeo: an analysis of structure and content", $A N R W 36.1$.

—_ (1988: 365-81), “Socrates in Plutarch”, ICS 13.2.

- (1992a: 3353-83), "Plutarch and epicurism”, ANRW II.36.

(1992b: 3336-52), "Plutarch and Stoicism”, ANRW II.36.

(1995: 209-225), "Paideia and politeia in Plutarch: the influence of Plato's Republic and Laws”, in I. Gallo \& B. Scardigli (Eds.).

(1997: 225-243), "Plutarch's Concept of History: Philosophy from Examples", AncSoc 28.

(2004: 151-162), "Plutarch's Political Philosophy: Peripatetic and Platonic", in L. de Blois et al. (Eds.). 
Hirzel, R. (1912), Plutarch, Leipzig.

Hoff, M. \& Rotroff, S. (Eds., 1997), The Romanization of Athens, Proceedings of an International Conference held at Lincoln, Nebraska (April 1996), Oxford.

Homeyer, H. (1962: 75-85), “Zu den Anfängen der griechischen Biographie”, Phil. 106.

Hopkins, K. (1965: 12-26), "Elite Mobility in the Roman Empire”, PEPP 32. (1983), Death and renewal: Sociological Studies in Roman History, ii, Cambridge.

Humbert, S. (1991: 169-182), «Plutarque, Alexandre et l'hellénisme», in S. Saïd (Ed.).

Ingenkamp, H. (1984: 79-81), Plutarch as pragmatist”, $C B$ 60.4. (2004: 67-86), "How to Present a Statesman?", in L. de Blois et al. (Eds.).

IRIGOIN, J. (1986: 318-331), «Le catalogue de Lamprias: tradition manuscrite et éditions imprimées», REG 99.

Jасову, F (1949), Atthis. The local chronicles of ancient Athens, New York.

Jaeger, W. (t2001), Paidéia. A Formação do Homem Grego, São Paulo.

Jenkinson, E. (1973: 703-719), “Genus scripturae leve: Cornelius Nepos and the Early History of Biography at Rome", $A N R W 1.3$.

Jolowicz, H. (1974: 82-90), “The wicked guardian”, JRS 37.

Jones, C. (1966: 61-74), “Towards a Chronology of Plutarch's works”, JRS 56. (=B. Scardigli (1995: 75-123)).

(1967: 205-213), “The Teacher of Plutarch”, HSCPh 71.

(1971), Plutarch and Rome, Oxford.

(1978), The Greek world of Dio Chrysostom, Cambridge MA and London.

- (2004: 13-21), "Multiple identities in the age of the Second Sophistic", in B. Borg (Ed.).

Jufresa, M. et al. (Eds., 2005), Plutarc a la seva època: Paideia i societat (Actas dels VIII Simposio Internacional de la Sociedad Española de Plutarquistas, Barcelona, 6-8 nov. 2003), Barcelona.

Kennel, N. (1995), The Gymnasium of virtue: education and culture in Ancient Sparta, Chapel Hill \& London.

Koller, H. (1955: 174-189), “ENKYK IO

Konrad, C. (1987: 519-527), "Some friends of Sertorius”, AJPh 108.3. 
Konstan, D. (2001: 29-50), "To Hellenikon ethnos: ethnicity and the construction of ancient Greek identity", in I. Malkin (Ed.), Ancient perceptions of Greek ethnicity, Washington.

Konstan, D. \& Saïd, S. (Eds., 2006), Greeks on Greekness: viewing the Greek Past under the Roman Empire, Cambridge Classical Journal, Proceedings of the Cambridge Philological Society 29, Cambridge.

Krämer, H. (1959), Arete bei Platon und Aristoteles. Zum Wesen und zur Geschichte der platonischen Ontologie, Heidelberg.

Kraus, C. (Ed., 1999), The limits of historiography: genre and narrative in ancient bistorical texts, Leiden-Boston-Köln.

LACHENAUd, G. (1997:65-102), «L'enkyklios paideia etl'espritencyclopedique dans l'Antiquité», $R P h$ 71.1.

Lamberton, R. (1997: 151-160), "Plutarch and the Romanizations of Athens”, in M. Hoff \& S. Rotroff (Eds.).

- (2002), Plutarch, New Haven and London.

Larmour, D. (1988: 361-371), "Plutarch's compositional methods in the Theseus and Romulus, TAPhA 118.

(1992: 4154-4200), "Making Parallels: Synkrisis and Plutarch's 'Themistocles and Camillus", $A N R W$ II.33.6.

(2004: 42-51), "Statesman and self in The Parallel Lives", in L. de Blois et al. (Eds.).

Larsen, T. (1942), Papyri Graecae Hunienses, Copenhague.

Laurence, R. \& Berry, J. (Ed., 2001), Cultural Identity in the Roman Empire, London and New York.

LEÃo, D. (2003: 23-41), “Os Sete Sábios como agentes de formação”, Biblos. Culturas em Diálogo n.s. 1.

(2005: 23-37), "Alexandre Magno: da estratégia pan-helénica ao cosmopolitismo", in A. Casanova (Ed.).

(2006: 35-78), "A tradição dos Sete Sábios: o sapiens enquanto paradigma de uma identidade", in D. Leão, J. Ribeiro Ferreira \& $\mathrm{M}^{\mathrm{a}}$ do Céu Fialho, Paideia e Cidadania, Coimbra.

Leo, F. (1901), Die griechisch-römische Biographie nach ibrer litterarischen Form, Leipzig.

LÉon, M. (2005: 439-444), "Política y sociedad en la obra de Plutarco”, in M. Jufresa et al. (Eds.).

Levi, M. (1955), Plutarco e il V secolo, Milan. 
Levin, S. (1985: 283-290), "Plutarch's part in the Damnatio memoriae of the Emperor Domitian", in La Béotie Antique, Lyon-Saint-Étienne, 16-20 mai 1983, Colloques Internationaux du CNRS, Paris.

LÉvy, E. (1990 : 125-57), "L' art de la déformation historique dans les Helléniques de Xénophon”, in H. Verdin, D. Schepens \& E. De Keyser (Eds.), Purposes of History: Studies in Greeek Historiography from 4th to the $2^{\text {nd }}$ Centuries BC, Studia Hellenistica 30, Leuven.

Livingstone, N. \& Y. Too (Eds., 1998), Pedagogy and Porver, Cambridge.

Lopez Salvà, M. (1990-1: 25-36), "Reflexiones de Plutarco e Díon de Prusa sobre las ciudades griegas del este y su relación com Roma”, Faventia 12-13.

Magnelli, E. (2005: 215-242), "Poeti ellenistici in Plutarco: tipologie e preferenze", in A. Casanova (Ed.).

Marincola, J.(1999: 281-324), "Genre, convention, and innovation in Grecoroman historiography", in C. Kraus (Ed.), The Limits of Historiography: genre and narrative in ancient historical texts, Leiden-Boston-Köln.

Marrou, H.-I. (t1990), História da Educação na Antiguidade, São Paulo.

Martín del Pozo,J.(1996:185-192),"El Médico como Referente Pedagógico en Plutarco", in J. Fernández Delgado-F. Pordomingo Pardo (Eds.).

Martin JR., H. (1960: 65-73), “The concept of «praotes» in Plutarch's Lives”, GRBS 3.

(1961: 164-175), “The concept of Philanthropia in Plutarch's Lives", AJPh 82.2.

(1995: 13-18), "Moral Failure without vice in the Athenian Lives", Ploutarchos 12.1.

(1997: 716-736), "Plutarch”, in S. E. Porter (Ed.).

Martínez-Lacy, J. (1988: 476-481), “Agis's and Cleomenes's Reforms and their relationship to expression and appearance of resistence by the ruled", in Forms of Control and Subordination in Antiquity, Leiden-New York-Copenhage-Colonia.

Martos Montiel, J. (1996: 205-210), "Sophrosyne o Akrasia: los Animales como Modelo de Comportamiento en los Moralia de Plutarco", in J. Fernández Delgado-F. Pordomingo Pardo (Eds.).

Masaracchia, A. (1995: 227-234), "Tracce aristoteliche nell' An seni res publica gerenda sit e nei Praecepta gerendae rei publicae", in I. Gallo \& B. Scardigli (Eds.).

Mattern, S. (1999), Rome and the Enemy: Imperial Strategy in the Principate, Berkeley \& Los Angeles. 
Mazza, M. (1995: 245-268), "Plutarco e la política romana. Alcune riconsiderazioni”, in I. Gallo \& B. Scardigli (Eds.).

Melandri, E. (2003: 111-127), "I Cosiddetti Frammenti dell'Opera An Virtus Docenda Sit di Plutarco", Humanitas 55.

Mestre, F. \& P. Gómez (2005: 295-305), “Tyche e individuo: ambigüedad de usos en las Vidas Paralelas de Plutarco", in. A. Pérez Jiménez \& F. Titchener (Eds.).

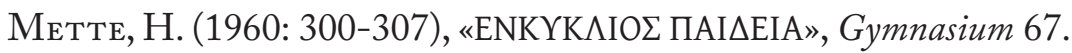

Mewaldt, J. (1907: 564-78), “Selbstcitate in den Biographieen Plutarchs”, Hermes 42. (1930:431-4), Gnomon 6. (recensão de Stolz (1929)).

Meyer, E. (1899: 1-87), “Die Biographie Kimons”, Forschungen zur alten Geschichte, II, Halle.

Miles, R. (1999: 1-15), "Introduction: constructing identities”, in R. Miles (Ed.), Constructing identities in Late Antiquity, London.

Millar, F. (1964), A Study of Cassius Dio, Oxford. (1993: 232-60), “The Greek City in The Roman Period”, in M. Hansen (Ed.), The Ancient Greek City State, Copenhagen.

Moles, J. (1989: 229-33), Review of J. Geiger (1985), CR 39. (1997: 141-168), "Plutarch, Brutus and Brutus' Greek and Latin Letters”, in J. Mossman (Ed.).

Momigliano, A. (t1991), La naissance de la biographie en Grèce ancienne, Strasbourg. Morales Otal, C. (1994: 625-630), «E1 mito en la Vida de Teseo», in M. García Valdés (Ed.).

Morgan, T. (1999: 46-61), "Literate Education in Classical Athens", CQ 49. - (2000r), Literate Education in the Hellenistic and Roman Worlds, Cambridge.

Mossman, J. (1995: 209-228), “Tragedy and Epic in Plutarch's Alexander”, in B. Scardigli (ed.), Essays on Plutarch's Lives, Oxford.

(1999), "Is the Pen Mightier Than the Sword? The Failure of Rhetoric in Plutarch's Demosthenes"[http://www.dur.ac.uk/Classics/ histos/1999/mossman.html (03.11.2006)].

(Ed., 1997), Plutarch and his Intellectual World. Essays on Plutarch, The Classical Press of Wales.

Moxon, I. ET AL. (1986), Past perspectives: Studies in Greek and Roman Historical Writing, Cambridge. 
Mühl, M. (1925), Poseidonios und der Plutarchische Marcellus, KlassischPhilologische Studien 4, Berlin.

Neira, M. (1986: 189-211), "Aportaciones al estudio de las fuentes literarias antiguas de Sertorio", Gerión 4.

Nikolaidis, A. (1986: 229-244), "Ellenikos-Barbarikos. Plutarch on Greek and Barbarian Characteristics", WS 20.

(1988: 319-33), "Is Plutarch fair to Nikias?”, ICS 13.2

(1991: 153-186), "Plutarch's Contradiction”, C\&M 42.

(1995: 301-312),"Plutarch's heroes in action: does the end justify the means?”, in I. Gallo \& B. Scardigli (Eds.).

(1997: 329-341), "Plutarch's criteria for judging his historical sources",in C. Schrader et al. (Eds.).

(2005: 283-324), "Plutarch's methods: his cross-references and the sequences of Parallel Lives", in A. Pérez Jiménez \& F. Titchener (Eds.).

Nippel, W. (2002: 278-310), "The construction of the 'Other", in Th. Harrison (Ed.).

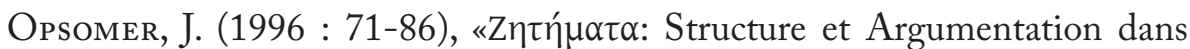
les Quaestiones Platonicae", in J. Fernández Delgado-F. Pordomingo Pardo (Eds.).

(1997: 17-39), "Favorinus versus Epictetus on the philosophical heritage of Plutarch. A debate on epistemology", in J. Mossman (Ed.).

- (1998), In search of the truth. Academic tendencies in Middle Platonism, Brussels.

(2001: 187-200), “Neoplatonism cristicism of Plutarch”, in. A. Pérez Jiménez \& F. Casadesús (Eds.).

Ostenfeld, E. (Ed., 2002), Greek Romans and Roman Greeks, Aarhus University Press.

Payen, P. (Ed., 1998), Plutarque: Grecs et romains en Questions, Entretiens d'archéologie et d'histoire, Saint-Bertrand-de-Comminges.

Panagopoulos, C. (1977: 197-235), «Vocabulaire et mentalité dans les Moralia de Plutarque», DHA 3.

Pancera, C. (2006), La paideia grega. Dalla cultura arcaica ai dialoghi socratici, Milano.

Paton, W. (1913: 131-2), "Plutarch and Satyrus", CR 27.4.

Pausch, D. (2004), Biographie und Bildungskultur, Millenium-Studien, De Gruyter. 
Payen, P. (Ed., 1998), Plutarque: Grecs et Romains. Entretiens d'archéologie et d'histoire, Saint-Bertrand-de-Comminges.

Pedro Serra, J. (2002: 93-102), "Alexandre Educador ou o Império da Finitude", in J. Ribeiro Ferreira (coord.).

Pelegrín Campo, J. (1997: 367-378), "La noción de barbárie en las Vidas Paralelas de Plutarco de Queronea”, in C. Schrader et al. (Eds.).

Pelling, C. (1984: 88-103), "Plutarch on the Gallic Wars”, CB 60. (1989: 199-232), "Plutarch: Roman heroes and Greek culture", in M. Griffin \& J. Barnes (Eds.), Philosophia Togata. Essays on Philosophy and Roman Society, Oxford.

- (1994r), Plutarch: Life of Antony, Cambridge

(1995: 343-362), "Il moralismo delle Vite di Plutarco, in I. Gallo \& B. Scardigli (Eds.).

- (1996: 323-331), "The structure of Plutarch's Caesar” in J. Fernández Delgado-F. Pordomingo Pardo (Eds.).

(1997), "Introduzione", in Plutarco. Filopemene-Tito Flaminino, Milano [são da sua autoria também as notas às duas traduções].

- _ (2002), Plutarch and History, The Classical Press of Wales and Duckworth.

(2002a: 1-44), "Plutarch's method of work in the Roman Lives", in Plutarch and History.

- (2002b: 45-63), "Plutarch and Catiline", in Plutarch and History.

(2002c: 65-90),’The Apophthegmata Regum et Imperatorum and Plutarch's Roman Lives", in Plutarch and History.

___ (2002d:91-115), "Plutarch's adaptation of source-material”, in Plutarch and History.

___ (2002e: 117-141), "Plutarch and Thucydides", in Plutarch and History. (2002f: 143-170), “Truth and fiction in Plutarch's Lives”, in Plutarch and History.

- (2002g: 171-195),'Making myth look like history': Plutarch's Theseus-Romulus", in Plutarch and History.

- (2002h: 207-236), "Plutarch and Roman Politics", in Plutarch and History. (2002i: 237-251), “The moralism of Plutarch's Lives", in Plutarch and History.

(2002j: 253-265), "Plutarch's Caesar: a Caesar for the Caesars?" in Plutarch and History. 
(2002k: 267-282), “'You for me ad me for you...': narrator and narrative in Plutarch's Lives", in Plutarch and History.

___ (20021: 283-300), "Aspects of Plutarch's caractherization”, in Plutarch and History.

___ (2002m: 301-338), "Childhood and Personality in Greek Biography”, in Plutarch and History.

(2002n: 339-347), "Rhetoric, Paideia, and Psychology in Plutarch's Lives" in Plutarch and History.

(2002o: 349-363), "Synkrisis in Plutarch's Lives", in Plutarch and History.

(2002p: 365-386), "Is death the end? Closure in Plutarch's Lives",in Plutarch and History.

(2004: 87-103), “Do Plutarch's Politicians never learn?”, L. de Blois et al. (Eds.)

—_ (2005: 325-340), "Synkrisis revisited", in A. Pérez Jiménez \& F. Titchener (Eds.).

Pérez Jiménez, A., (1978) La Biografia griega como género literário. Plutarco e la biografia antigua, Barcelona.

(1980: 145-153), "Pobreza, justicia y patriotismo en la Vida de Arístides de Plutarco", Sodalitas 1.

(1995: 363-381), "Proairesis: las formas de acesso a la vida pública y el pensamiento politico de Plutarco”, in I. Gallo \& B. Scardigli (Eds.).

- (1996: 257-265), "La Asociación de Ideas como Criterio Formal en las vidas Paralelas", in J. Fernández Delgado-F. Pordomingo Pardo (eds.).

(2000a: 29-37), "Retrato Literario y Biografía Menor en el Corpus Plutarcheum”, in I. Gallo \& C. Moreschini (Eds.).

- (2000r), "Introducción General", in Plutarco.Vidas Paralelas I (TeseoRómulo, Licurgo-Numa), Madrid.

- (2000b: 341-353), "La retórica del silencio: el discurso de Volumnia en la Vida de Coriolano", in L. Van der Stockt (ed.)

- (2002a: 105-114),"Exemplum: the paradigmatic education of the ruler in the Lives of Plutarch", in Ph. Stadter \& Van Der Stockt (Ed.).

(2002b: 253-270), "La elocuencia como instrumento político en las Vidas paralelas de Plutarco", Cuadernos de Filología Clásica: Estudios griegos e indoeuropeos 12. 
(2004a: 127-136), "Los Héroes de Plutarco y su Elección entre la Justicia y la Utilidad”, L. de Blois et al. (Eds.).

- (2004b: 165-178), "Dos héroes fundadores: Las Vidas de Teseo y Rómulo de Plutarco", in J. Candau Morón, F. González Ponce \& G. Cruz Andreotti (Eds.), Historia y mito. El passado legendario como fuente de autoridad, Málaga.

(2004c: 49-64), “'las Biografías de Plutarco como medio de propaganda imperial?", in A. Pérez Jiménez \& J. Ribeiro Ferreira \& $\mathrm{M}^{\mathrm{a}}$. do Céu Fialho (eds.), O Retrato Literário e a Biografia como estratégia de teorização politica, Universidad de Málaga.

- (2005: 341-354), "La estructura literaria de la Vida de Teseo de Plutarco", in A. Pérez Jiménez \& F. Titchener (Eds.).

Pérez Jiménez, A. \& Casadesús Bordoy, F. (Eds., 2001), Estudios sobre Plutarco. Misticismo y religiones Mistéricas en la Obra de Plutarco (Actas del VII Simposio Español sobre Plutarco, Palma de Mallorca, 2-4 nov. 2000), Madrid-Málaga.

Pérez Jiménez, A., Garcia López, J. \& Aguilar, R. (Eds., 1999), Plutarco, Platón y Aristóteles: Actas del $V$ Congreso Internacional de la I.P.S. (MadridCuenca, 4-7 de mayo de 1999), Madrid.

Pérez Jiménez, A. \& Titchener, F. (Eds., 2005), Valori Letterari delle Opere di Plutarco. Studi Offerti al Professore Italo Gallo dall' International Plutarch Society, Málaga - Logan.

Pernot, L. (1983: 121-9), «Chance et destin dans la rhétorique épidictique grecque à l'époque impériale», in F. Jouan (Ed.), Visages du destin dans les mythologies : Mélanges Jacqueline Duchemin (Actes du colloque de Chantilly $1^{\text {er }}-2$ mai 1980), Paris.

Peter, M. (1965r), Die Quellen Plutarchs in den Biographien der Römer, Amsterdam.

Piccirilli, L. (1977: 1007-1016), "Cronologia relativa e fonti della Vita Solonis di Plutarco, ANSP 7, 3.

- (1989: 5-21), "La tradizione 'nera' nelle biographie degli Ateniesi del sesto e del quinto secolo", in A. Ceresa-Gataldo (ed.), Gerolamo e la Biografia Letteraria (Pubblicazioni del Dip. Di Archeologia, Filologia Classica e loro tradizioni, ns 125, Genoa).

(1990: ix-xl), "Introduzione", in C. Carena, M. Manfredini \& L. Piccirilli (Eds.), Plutarco. Le Vite di Cimone e di Lucullo, Milano.

- (1998: 39-60), "Biografia e storia: il metodo di Plutarco", SIFC XVI.

Pimentel, C. (1997), Catão Censor, Colecção Vultos da Antiguidade, no 5, Mem Martins. 
Pinheiro, J. (2003: 473-484), "Significado de Paideia no tratado pedagógico De liberis educandis", in M. Gonçalves Abreu \& M. Castro (Coord.), Estudos de Tradução - Actas de Congresso Internacional, Cascais.

(2006: 23-34), "O exercício da virtude na vida pública: o exemplo de Aristides”, Classica 25.

(2007: 349-362), "Análise do conteúdo pedagógico do tratado De liberis educandis", J.A. Fernández Delgado, F. Pordomingo \& A. Stramaglia (Eds.), Escuela y literatura en Grecia Antigua (Actas Simposio Internacional Universidad de Salamanca, noviembre 2004), Università degli Studi di Cassino.

Plácido, D. (1995: 131-138), «L'image d'Alexandre dans la conception plutarchéene de l'Empire Romaine», DHA 21.2.

Podlecki, A. \& Duane, S. (1992: 4053-4127), “A Survey of Work on Plutarch's Greek Lives, 1951-1988”, ANRW II.33.6.

Podlecki, A. (1988: 231-243), "Plutarch and Athens", ICS 13.2.

Polman, G. (1974: 169-77), "Chronological Biography and Akme in Plutarch”, CPh. 69.

Pordomingo Pardo, F. (2005: 117-132), "Los Papiros escolares y Plutarco”,in M. Jufresa et alii (Eds.).

Porter, S. (Ed., 1997), Handbook of Classical Rhetoric in the Hellenistic Period. 330 B.C. - A.D. 400, Leiden.

Poucet, J. (1972:48-135), «Les sabines aux origines de Rome», ANRW 1.1.

Powell, J. (1939), “The sources of Plutarch's Alexander”, JHS 59.

Poweel, J. (1988), Cicero: Cato Maior de senectute, Cambridge.

Prandi, L. (2000: 375-386), "L'Alessandro di Plutarco (Riflessioni su De Al. Magn. Fort. e su Alex.)", in L. Van der Stockt (Ed.).

Press, G. (1982), The Development of the Idea of History in Antiquity, KingstonMontreal.

Preston, R. (2001: 86-119), "Roman Questions, Greek Answers: Plutarch and the construction of identity", in S. Goldhill (ed.).

Puech, B. (1992: 4831-4893), «Prosopographie des amis de Plutarque», $A N R W$ II.33.6.

Race, W. (1987 : 131-155), «Pindaric encomium and Isokrates' Evagoras», TAPhA 117.

Ramón Palerm (1992), V., Plutarco y Nepote: Fuentes e Interpretacion del Modelo Biográfico Plutarqueo, Departamento de Ciencias de la Antigüedad de la Universidad de Zaragoza. 
(1996: 281-289), «Morfología del apotegma en la Obra Biográfica de Plutarco: propuestas y Perspectivas de estudio», in J. Fernández Delgado-F. Pordomingo Pardo (eds).

Rawson, E. (1985), Intelectual Life in the Late Roman Republic, London.

Redfield, J. (2002: 24-49), "Herodotus the tourist”, in Th. Harrison (Ed.).

Ribeiro Ferreira, J. (1977-78: 21-50), "O Problema Educativo no «Filoctetes»", Humanitas 29-30.

(1992), Hélade e Helenos. I. Génese e evolução de um conceito, Coimbra.

(coord., 2002), Actas do Congresso "Plutarco Educador da Europa", Porto.

—— \& C. Soares (2002b), Heródoto. Histórias - livro 8, Lisboa.

—_ (2004: 47-54), “Simonide in Plutarco", in I. Gallo (Ed.).

—__ (2005a: 207-214), "Calímaco em Plutarco: as citações como demonstração", in A. Casanova (Ed.).

(2005b: 569-576), "Demotikos e demokratikos na paideia de Plutarco", in M. Jufresa et al. (Eds.).

(2006: 13-34) "Educação em Esparta e em Atenas: dois métodos e dois paradigmas", in D. Leão, J. Ribeiro Ferreira \& Ma do Céu Fialho, Paideia e Cidadania, Coimbra.

Rıjк, L. (1965: 24-93), "Enkyklios paideia. A study of its original meaning”, Vivarium 3.

Rовв, K. (1994), Literacy and Paideia in Ancient Greece, New York \& Oxford.

Rocha Pereira, M. H. da (1989²), Estudos de História da Cultura Clássica. II Volume-Cultura Romana, Lisboa.

(1999: 7-26), "Introdução", in Plutarco. Vida de Sólon, Lisboa.

- (20004), Romana. Antologia da Cultura Latina, Coimbra.

-_ (20038), Hélade. Antologia da Cultura Grega. Porto.

Roman, D. \& Roman, Y. (1994), Rome, L'Identité romaine et la culture hellénistique, Paris.

Romeo, I. (2002 : 21-40), “The Panhellenion and Ethnic Identity in Hadrianic Greece”, $C P$ \% 97.1.

Romilly, J. de (1979), La douceur dans la pensée grecque, Paris.

Rosalia, A. DE (1991: 445-459), “Il latino di Plutarco”, in I. Gallo \& D’Ippolito (Eds.), Strutture formali dei Moralia di Plutarco, Napoli.

Rosenmeyer, T. (1992: 205-230), “Beginnings in Plutarch’s Lives”, YCS 29. 
Rosкam, G. (2002: 175-189), "A paideia for the ruler: Plutarch's Dream of a Collaboration between Philosopher and Emperor", in Ph. Stadter \& L. Van der Stockt (Eds.).

(2004: 93-114), "From Stick to reasoning. Plutarch on the communication between teacher and pupil", WS 117.

(2005: 133-138), "Political education in the service of the public interest. Plutarch on the motivations of the statesman", in M. Jufresa et al. (Eds.).

Rossi, A. (2004: 359-381), "Parallel Lives: Hannibal and Scipio in Livy's Third Decade", TAPhA 134.2 (2004: 359-381).

Rossi, L. (1971: 69-94), "I generi letterari e le loro leggi e non scritte nelle letteratura classiche", BICS 18.

Rudd, N. (1989), Horace: Epistles Book II and Epistle to The Pisones (Ars Poetica), Cambridge.

Russel, D. (1963: 21-28), "Plutarch's Life of Coriolanus", JRS 52. (1966: 139-154), “On Reading Plutarch's 'Lives”, GERR 13.2. (1968: 130-146), “On Reading Plutarch's 'Moralia”, GER 15.2 (20012), Plutarch, foreword and bibliography by Judith Mossman, London.

SAID, E. (1994), Culture and Imperialism, London. (1995), Orientalism: Western conceptions of the Orient, London.

SAÏ̀, S. (1984: 27-53), «Grecs et Barbares dans les tragédies d'Euripides: le fin des différences», Ktema 9.

- (Ed., 1991), Hellenismos. Quelques jalons pour une histoire de l'identité grecque, Leiden, New York. Kobenhavn. Koln.

(2004: 7-25), "Plutarch and the People in the Parallel Lives", L. de Blois et al. (Eds.).

(2006: 47-60), "The rewriting of the athenian past: from Isocrates to Aelius Aristides", in D. Konstan \& S. Saïd (Eds.).

SAÏD, S. ET AL. (Eds., 2004), Histoire de la Littèrature Grecque, PUF.

Salmeri, G. (1982), La politica e il potere: saggio su Dione di Prusa, Catania.

SÁnchez Marín, J. (1982: 211-220), “Conceptos de biografia en Nepote, Plutarco y Suetonio", Estudos de Filologia Latina 3.

Scardigli, B. (1971: 33-64), "Considerazioni Sulle Fonti Della Biografia Plutarchea di Sertorio”, SFII 43. 
- (1979), Die Römerbiographien Plutarchs, Munich.

(Ed., 1995), Essays on Plutarch's Lives, Oxford.

(1995: 1-46), “Introduction”, in B. Scardigli (Ed.).

Schamp, J. (1995: 155-184), «Le Plutarque de Photios», AC LXIV

Schettino, M. (2004: 351-361), "I Soggetti Politici e i conflitti civili del 68/69 D.C. in Plutarco", L. de Blois et al. (Eds.).

Schmidt, T. (1999), Plutarque et les barbares. La rhétorique d'une image, Leuven and Namur.

(2000: 455-464), "La rhétorique des doublets chez Plutarque: les cas

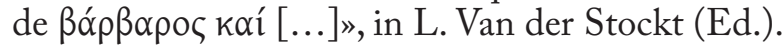

(2002: 57-71), "Plutarch's timeless barbarians and the age of Trajan", in Ph. Stadter \& L. Van der Stockt (Eds.).

Schmitz, T. (1997), Bildung und Macht: zur sozialen unde politischen funktion der Zweiten Sophistik in der Griechischen welt der Kaiserzeit, Munich.

Schrader, C. (1997: 29-63), "Plutarco y la oratoria panegírica del siglo IV", in C. Schrader et al. (Eds.).

Schrader, C. et AL. (Eds., 1997), Plutarco y la Historia.Actas del V Simposio Español sobre Plutarco (Zaragoza, 20-22 de junio de 1996), Zaragoza.

SchröDER, St. (1991: 151-7), “Zu Plutarchs Alexanderreden”, MH 48.

SÉchan, L. (1942: 83-106), «Plutarque au miroir du Thésée», REG 56.

Shar Ples, R. (1996), Stoics, Epicureans and Sceptics.An Introduction to Hellenistic Philosophy, London \& New York.

Shipley, D. (1997), A Commentary on Plutarch's Life of Agesilaos, Oxford.

Shrimpton, G. (1971: 55-59), "Plutarch's Life of Epaminondas”, Pacific Coast Philology 6.

Sirago, V. (1989 : 36-79), "La seconda sofistica come espressione culturale della classe dirigente del II sec.", $A N R W$ II.31.1.

Sirinelli, J. (2000), Plutarque de Chéronée. Un philosophe dans le Siècle, Paris.

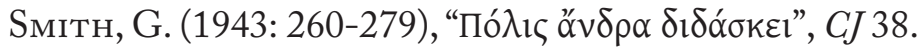

Spawforth, A. \& Walker, S. (1985: 78-104), "The World of the Panhellenion: I. Athens and Eleusis", JRS 75.

(1986: 88-105), “The World of the Panhellenion: II. Three Dorian Cities", JRS 76.

Seuilloni, A. (1989: 225-243), "L'ideale del buon governante nel pensiero politico di Plutarco", Civ. Class. e Crist. 10. 
Stadter, Ph. (1965), Plutarch's Historical Methods: an analysis of the Mulierum Virtutes, Cambridge.

(1987: 251-269), “The Rhetoric of Plutarch's Pericles”, Ancient Society 18.

(1988: 275-295),”The Proem's of Plutarch's Lives”, ICS 13.2.

(Ed., 1992), Plutarch and the Historical Tradition, Londres et New York.

(1996: 291-303), "Anecdotes and the thematic Structure of Plutarchean Biography", in J. Fernández Delgado-F. Pordomingo Pardo (Eds.).

(1997: 65-81), "Plutarch's Lives: the statesman as moral actor", in C. Schrader et al. (Eds.).

(2000: 493-510), “The Rhetoric of Virtue in Plutarch's Lives”, in L. Van der Stockt (Ed.).

(2002: 1-26), "Introduction: Setting Plutarch in his context", in Ph. Stadter \& L. Van der Stockt (Eds.).

(2005a: 419-435), "Revisiting Plutarch's Lives of The Caesars", in A. Pérez Jiménez \& F. Titchener (Eds.).

—_ (2005b: 653-658), "Plutarco fra Presente e Passato", in M. Jufresa et al (Eds.).

Stadter, Ph. \& L. VAn Der Stockt (Eds., 2002), Sage and Emperor: Plutarch, Greel Intellectuals, and Roman Power in the Time of Trajan (98-117 A.D.), Leuven.

Stiefenhofer, A. (1914: 462-503), "Zur Echtheitsfrage der biographischen Synkriseis Plutarchs", Philologus 73.

Sтовасн, A. (1997), Plutarch und die Sprachen.Eisn beitrag zur Fremdsparchenproblematik in der Antike, Stuttgart.

Stolz, C. (1929), Zur relativen Chronologie der Parallelbiographien, Leipzig.

Striker, G. (2001: 189-198), "Cicero and Greek Philosophy", in G. Nagy (Ed.), Greek Literature in the Roman Period and in Late Antiquity (Greek Literature, vol. 8), New York.

Stuart, D. (1928), Epochs of Greek and Roman Biography, Berkeley.

Swain, S. (1988: 335-47), "Plutarch's Philopoemen and Flamininus", ICS 13.2. (1989: 504-516), "Plutarch's De fortuna romanorum”, CQ 39. (1989a: 62-8), "Character change in Plutarch", Phoenix 43. (1989b: 272-302), "Plutarch: Chance, Providence, and History", AJP 110. 
(1989c: 314-34),"Plutarch's Aemilius and Timoleon", Historia 38.

(1990a: 192-203), "Plutarch's Lives of Cicero, Cato, and Brutus", Hermes 118.

(1990b: 126-145), "Hellenic Culture and the Roman Heroes of Plutarch", JHS 110 (= B. Scardigli (1995: 229-64).

(1991: 148-63), “The Reability of Philostratus' Lives of the Sophists”, ClAnt 10.

(1991: 318-30) , "Plutarch, Adrian, and Delphi”, Historia 40.

(1992: 101-11), "Plutarchan Synkrisis”, Eranos 90.

(1992: 307-16), "Plutarch's Characterization of Lucullus", $R b M 135$.

(1997:1-37), "Biography and biographic in the literature of the Roman Empire”, in M. Edwards \& S. Swain (Ed.), Portraits: Biographical representation in the Greek and Latin Literature of the Roman Empire, Oxford.

(1998r), Hellenism and Empire. Language, Classicism, and Power in the Greek World, ad 50-250, Oxford.

- (2000), Dio Chrysostom: Politics, Letters, and Philosophy, Oxford.

Syme, R. (1958), Tacitus, 2 vols., Oxford.

(1963: 3-20), "The Greeks under Roman Rule", Proceedings of the Massachusetts Historical Society 72, 1957-60 [= E. Badian (ed. 1979: 566-81, Ronald Syme: Roman papers ii, Oxford; versão revista em Greeks Invading the Roman Government, Brookline, 1982, que foi reimpressa em R. A. Birley (ed.,1988).].

(1980: 104-28), "Biographers of The Caesars", Roman Papers III, Oxford.

Tagliasacchi, A. (1961: 71-117),"Le Teorie estetiche e la critica letteraria in Plutarcho", Acme 14.

Talbert, R. (1974), Timoleon and the revival of Greek Sicily 344-317 B.C., Cambridge.

Teodorsson, S.-T. (1996: 39-47), "Principles of Composition in the Quaestiones Convivales", in J. Fernández Delgado-F. Pordomingo Pardo (eds.),

(1997: 439-47), "Ethical historiography. Plutarch's attitude to historical criticism", in C. Schrader et al. (Ed.).

(2005a: 659-664), "El programa de Plutarco para la conducta social", in M. Jufresa et al. (Eds.). 
(2005b: 433-440), "Plutarch, amalgamator of Greece and Rome", in

A. Pérez Jiménez \& F. Titchener (Eds.).

Theander, C. (1951), Plutarch und die Geschichte, Lund.

(1958: 12-20), «Zur Zeitfolge der Biographien Plutarchs», Eranos 56.

Thomas, R. (1989), Oral Tradition and Written Record in Classical Athens, Cambridge.

Titchener, F. (1991: 153-8), "Why did Plutarch write about Nicias?", $A H B$ 5.5 .

(1992: 4128-4153), “Critical Trends in Plutarch's Roman Lives, 19751990”, $A N R W$ II.33.6.

(1996: 351-355), “The Structure of Plutarch's Nicias”, in J. Fernández Delgado-F. Pordomingo Pardo (Eds.).

(2002: 136-141), "Plutarch and Roman(ized) Athens", in E. N. Ostenfeld (Ed.).

Too, Y. (1995), The Rhetoric of identity in Isocrates. Text, power, pedagogy, Cambridge.

(Ed., 2001), Education in Greek and Roman Antiquity, Leiden-BostonKöln.

- (2003r), The Pedagogical Contract. The Economies of Teaching and Learning in Ancient World, Ann Arbor.

Torraca, L. (1992: 4724), “Lingua e stile nei 'Moralia' di Plutarco”, $A N R W$ II.33.6.

Toynbee, J. (1944: 43-58), "Dictators and philosophers in the first century A.D.", GERR 13.

Tracy, H. (1941-2: 213-6), "Notes on Plutarch's Biographical Method”, CJ 37.

TrÉDÉ, M. (1991: 71-80), «Quelques définitions de l'hellénisme au Ive siècle av. J.-C. et leurs implications politiques», in S. Saï (Ed.).

Tronson, A. (2000: 359-394), “The History and Mythology of 'Pericles' Panhellenic Congress in Plutarch's Life of Pericles, 17”, EMC 19.3.

Uxkull-Gyllenband, W. (1927), Plutarch und die griechische Biographie. Studien zu Plutarchischen Lebensbeschreibungen des V. Jahrhunderts, Stuttgart.

Valgiglio, E. (1987: 50-70), "Historia e bios in Plutarco", Orpheus VIII (1987).

(1992: 3963-4051), "Dagli 'Ethicà' ai 'Bioi' in Plutarco, ANRW II.33.6. 
Van Der stockt, L. (1990: 23-31), «L'expérience esthétique de la mimèsis selon Plutarque», QUCC 36.

(1992), Twinkling and twilight. Plutarch's reflections on literature, Bruxelles.

(Ed., 1996). Plutarchea lovaniensia. A Miscellany of essays on Plutarch, Lovanii.

(Ed., 2000), Rhetorical Theory and Praxis in Plutarch, Acta of IVth International Congress of The International Plutarch Society, Leuven, July 3-6, 1996, Louvain.

VAN DER VALK, M. (1982: 301-337), "Notes on the composition and arrangement of the Biographies of Plutarch", Studi i Onore di A. Colonna, Ist. di Filologia class.

Van Raalte, M. (2004: 75-112), ), "More Philosophico: Political virtue and Philosophy in Plutarch's Lives”, L. de Blois et al. (ed.), The Statesman in Plutarch's Works. Vol. II: The Statesman in Plutarch's Greek and Roman Lives (Proceedings of the Sixth International Conference of the International Plutarch Society, Nijmegen/Castle Hernen, May 1-5, 2002), Leiden \& Boston.

Vasunia, P. (2003: 369-389), "Plutarch and the return of the Archaic", in A. Boyle \& W. J. Dominik (eds.), Flavian Rome: Culture, Image, Text, Brill.

Velásquez Fernández, A. (2001: 441-450), "Presencia y Ausencia del Educador en las Vidas de Plutarco", in A. Pérez Jiménez \& F. Casadesús (Eds.).

Verdegem, S. (2004: 167-178), "De Gloria Alcibiadis. Alcibiades'Military value and its relation to his Doxa in Plutarch's Alcibiades", in L. de Blois et al. (Eds.).

Vernière, Y. (1977), Symboles et Mythes dans la pensée de Plutarque. Essai d'interprétation philosophique et religieuse des Moralia, Paris.

Vinsonneau, G. (2002), L'Identité Culturelle, Paris.

Wallace-Hadrill, A. (1988: 224-33), "Greek knowledge, roman power", CPh 83.

(1989: 157-64), "Rome's cultural revolution", JRS 79.

Walsh, J. (1992),"Syzygy, Theme and History. A Study in Plutarch's Philopoemen and Flamininus", Philologus 136.

Wilamowitz-Moellendorf, U. von (1995r: 47-74), "Plutarch as biographer", in B. Scardigli (Ed.).

Walbank, F. (1992r), The Hellenistic World, Cambridge. 
Wardman, A. (1955: 96-107), "Plutarch and Alexander", CQ 5, 1/2. (1971: 254-61), "Plutarch's Methods in the Lives", CQ 21. (1974), Plutarchs Lives, London.

Warren, E. (2005), Spartan Education, Boston.

Wевв, R. (2006: 27-46), "Fiction, mimesis and the performance of the Greek past in the Second Sophistic", in D. Konstan \& S. Saï (Eds.).

Westaway, K. (1922), The Educational Theory of Plutarch, London.

Westlake, H. (1939: 11-22), "The sources of Plutarch's Pelopidas”, CQ 33.

Whitmarsh, T. (2001a), Greek Literature and the Roman Empire: the Politics of Imitation, Oxford.

(2001b: 269-305), "Greece is the world': exile and identity in the Second Sophistic", in S. Goldhill (Ed.).

(2002: 174-92), "Alexander's Hellenism and Plutarch's textualism", CQ 52 .

(2005), The Second Sophistic, Greece \& Rome, New Surveys in the Classics no 35, Oxford.

Wiseman, J. (1969: 177-199), “Epaminondas and the Teban Invasions”, Klio 51.

Wolman, H. (1972: 645-678), “The philosophical intentions of Plutarch's Roman Lives", in Studi Classici in onore di Q. Cataudella II, Catania.

Woolf, G. (1994: 115-143), "Becoming Roman, staying Greek: Culture, identity and the civilizing process in the Roman East", $P C P h S 40$.

Yaginuma, S. (1992: 4726-4742), "Plutarch's Language and Style”, ANRW II.33.6.

Zadorojnyi, A. (1999), Plutarch's Literary Paideia, University of Exeter.

__ (2005: 493-512), "Plutarch and the Forbidden City: Demosthenes 1-2", in A. Pérez Jiménez \& F. Titchener (Eds.).

Zecchini, G. (1984: 195-212), "Alessandro Magno nella cultura dell'età Antonina", in M. Sordi (Ed.), Alessandro Magno tra storia e mito, Milano.

(2002: 191-200), "Plutarch as political theorist and Trajan: some reflections", in Ph. Stadter \& Van Der Stockt (Eds.).

Zeigler, K. (1951: 636-962), "Plutarchos von Chaironeia”, RE 21.1. 



\section{ÍNDICE REMISSIVO DAS VITAE E DOS MORALIA}

\section{VITAE}

Aem., 20, 32 n. 37, 41 ns. 82, 84-85, 45 n. 107,47 n. 118,57 ns. 173 e 175 , 59 n. 189,79 n. 295,82 n. 308,107 n. 390,136 n. $92,157,188$ n. 344 , 233 n. 613,304 n. 20,307 n. 29 , 308 n. 32,310 n. 55,316 n. 94,320 n. 140,321 n. 154,325 ns. $171-$ 173,334 n. 219,335 n. 230,338 ns. $240-1,369$ n. 357,372 n. 368 , 384 n. 408

Ag./Cleom., 36 n. 55, 41 n. 85, 47 ns. 119 e 123,55 n. 162,57 ns. 175 e 178,110 n. 401,167 n. 248,177 n. 297,216 n. 496,316 n. 94,390 n. 444

Ages., 43 n. 92, 44 n. 94, 47 n. 120, 66 n. 218, 71 n. 255, 139 ns. 109 e 113, 216 n. 496,289 n. 920,291 n. 931 , 309 n. 47, 316 n. 94, 347 n. 289

Alc., 20, 21, 40 n. 79, 47 n. 120, 48 n. 124, 52 n. 139, 59, 90, 96 n. 345 , 98 n. 351, 108 n. 395, 151 n. 159 , 157-176 passim, 201 n. 431, 202 n. 433, 233 n. 608, 282 n. 878, 296 n. 962,297 n. 966,317 ns. 101-5, 321 n. 142, 326 n. 179, 331 n. 213, 334 ns. $220-3,355$ n. 316,372 n. 370,382 n. 399

Alex., 20, 21, 28 n. 13, 31 n. 33, 34 n. 45, 45 n. 103,46 n. 114,48 ns. 124 e 129,51 n. 133,54 n. 157, 66 n.
214, 67 n. 224,78 n. 294, 98 n. 351, 108 n. 394, 109 n. 399, 124 n. 36,130 n. 59,154 n. 177,192 n. 375,286 n. 899,308 n. 35,319 n. 131,320 n. 140,321 n. 145,322 n. 159,325 n. 169,327 ns. 189 e 190, 328 n. 192, 329 n. 204, 387 ns. 427,428 e 431

Ant., 21, 35, 36 n. 59, 38 n. 67, 47 ns. 119 e 123, 48 ns. 125-6, 57 ns. 175-6, 79 n. 295, 82 n. 309, 95, 96 n. 345,158 n. 200,177 ns. 296-7, 210 n. 471,245 n. 678,289 n. 920 , 316 n. 94,321 n. 145,326 n. 177 , 335 n. 229,337 n. 238,363 n. 338 , 390 n. 444

Arat., 41 n. 85, 47 n. 123, 102 n. 372, 213 n. 478, 316 n. 94,321 n. 158

Arist., 20, 29 n. 16, 34 n. 45, 36 n. 54, 47 ns. $119-120,55$ n. 160, 57 ns. $176-7,71$ n. 254,72 n. 261,74 ns. 271 e 273,80 n. 302,86 n. 321,95 n. 343,131 n. 64,216 n. 494, 219 ns. 513-4, 221 n. 527, 227 n. 570, 245 n. 678,259 n. 761,270 n. 819 , 313 n. 73,315 n. 88, 317, 321 n. 150,337 ns. 236 e 238,348 n. 293, 365 n. 342,372 n. 368,382 n. 399 , 387 ns. 428 e 431,390 n. 445

Art., 316 n. 94

Brut., 47 n. 119,48 ns. 124 e 126, 51 ns, 134, 52 n. 143, 57 n. 177, 58 n. 184, 
99 n. 357,136 n. 92,160 n. 206, 177 n. 298,183 n. 317,186 ns. 327 , 331-2, 187 ns. 336-7, 188 ns. 3445,196 n. 410, 264 n. 786, 306 n. 23, 309 n. 47,311 n. 59,316 n. 94,328 n. 196,336 n. 232, 367 n. 345 .

Caes., 44 n. 98, 45 n. 103, 46 n. 114, 47 n. 123,48 ns. 127 e 129,51 n. 133,75 n. 278,81 n. 305,139 n. 109,185 n. 323,186 n. 331,187 n. 338, 189 n. 349, 204 n. 443, 217 n. 505, 244-269 passim, 286 n. 898, 309 n. 47, 319, 326 n. 176, 335 n. 226, 372 n. 368,382 n. 400, 387 n. 432, 388 n. 436

Cam., 18 n. 2, 47 n. 120, 51 n. 133, 95 n. 343,177 n. 295,259 n. 761,316 n. 94,326 n. 177,337 n. 238,364 n. 340,387 n. 429,390 n. 448

Cat. Ma., 27 n. 9, 34 n. 45, 35 n. 49, 43 n. 92,47 ns. $119-120,48$ n. 124 , 52 n. 139,55 n. 160,57 ns. $176-7$, 68 n. 232,72 n. 261,79 n. 295,80 n. 297,82 n. 308,131 n. $64,136-$ 157 passim, 196 n. 410,211 n. 474, 217 n. 505,221 n. 527,227 n. 570 , 270 n. 819,288 n. 911,296 n. 965 , 306 n. $23,317,320$ n. 139,321 n. 150, 337 ns. 237-8, 338 n. 239, 341 n. 261,343 n. 272,348 n. 293, 365 n. 342,372 n. 370,382 n. 400 , 387 n. 431,388 n. 436,390 n. 445

Cat. Mi., 41 n. 82, 46 n. 114, 47 n. 123, 48 n. 124,51 n. 133,57 n. 180,79 n. 295,80 n. 302,103 n. 377,139 n. 109,185 n. 323,219 n. 514,272 n. 834,289 n. 920,308 n. 32, 316 n. 94 , 320 n. 140, 321 n. 153, 326 n. 180, 336 n. 233,343 n. 273,381 n. 395

Cic., 45 n. 103, 47 ns. 121 e 123, 51 n. 134,55 n. 163,56 n. 166, 63 n. 203,75 n. 278,80 n. 297,87 n. 325,95 n. 343,98 n. 351,99 n. 357, 176-196 passim, 264 n. 784, 272 ns. 834 e 836,283 n. 886,287 n. 902,310 n. $49,317,318$ ns. 110 e 112-121, 327 n. 188,327 n. 190, 328 n. 196, 329 n. 206, 334 n. 221,
335 n. 228,382 n. 399.

Cim., 48 n. 124, 57 ns. 175 e 178, 58 n. 182,72 ns. 260 e 261,79 n. 295 , 80 n. 304,87 n. 322,108 n. 396, 109 n. 400, 138 n. 104,139 n. 109 , 302 n. 6,317 n. 100,334 n. 219 , 372 ns. 368 e 370,382 n. 399,383 n. 402

Cor., 34 n. 45,41 n. 85,47 n. 120,48 n. 124,69 n. 239,74 n. 272,95 n. 343, 96 n. 345,100 n. 359,152 n. 162, 157-176 passim, 197 n. 419, 202 n. 433,210 n. 471,219 n. 514 , 233 n. 608,243 n. 665,273 n. 838 , 289 n. 920,297 n. 966,310 n. 57 , 314 n. 81,317 n. 99,334 ns. 220 e 222, 348 n. 293, 354 n. 311,382 n. 399, 388 n. 436, 390 n. 448

Crass., 57 ns. $176-8,177$ n. 297,219 n. 514,337 n. 238, 388 n. 436, 390 n. 444, 393 n. 460

Dem., 32 n. 34, 34 n. 45, 36 n. 56, 43 n. 92,45 n. 103,47 ns. 121 e 123,48 ns. $125-6,51$ n. 134,52 n. 139,55 n. 163,56 n. 166,66 n. 214,72 n. 262,75 n. 278,76 ns. $280-1$ e 283 , 77 n. 290,79 n. 295,80 n. 297 , 96 n. 345,101 n. 367,102 n. 371 , 154 n. 177, 176-196 passim, 250 n. 701,271 n. 826, 272 n. 836, 283 n. 886, 308 n. 33, 317 ns. 106-109, 318 n. 112,320 n. 140,322 n. 161 , 350 n. 298,355 n. 316,379 n. 394 , 383 n. 402, 386 n. 423, 394 n. 462

Demetr., 36 n. 59, 38 n. 67,39 n. 70, 41 n. 85,47 ns. 119 e 123,48 n. 125 , 57 ns. $175-6,80$ n. 300,96 n. 345 , 97 n. 350,108 n. 394,111 n. 402 , 158 n. 200,177 n. 297,210 n. 471 , 249 n. 697,289 n. 920,307 n. 29 , 310 n. 54,315 n. 83,316 n. 94,317 n. 100,390 n. 444

Dion, 25 n. 1, 32 n. 34,47 n. 119, 48 n. 124,51 n. 134,56 n. 171,57 n. 177 , 131 n. 64,136 n. 92,167 n. 248 , 306 n. 23,307 n. 29,311 n. 56, 316 n. 94,328 n. 196,387 n. 426 
Eum., 45 n. 101, 48 n. 128, 51 n. 134, 57 ns. 175 e 177,177 n. 297,214 n. 482,318 n. 123,387 n. 431

Fab., 45 n. 106, 47 n. 119, 55 n. 163, 57 ns. 176 e 178,74 n. 272,78 n. 294, 79 n. 295,97 n. 347,188 n. 344,214 n. 482,227 n. 570,238 ns. $634-5,241$ n. 644,272 n. 834 , 289 n. 920,316 n. 94,321 n. 145

Flam., 30 n. 26, 47 n. 120, 56 n. 166, 57 n. 175,59 n. 190,70 n. 246 , 96 n. 345,131 n. 64,139 n. 114 , 160 n. 210, 210-227 passim, 229 n. 579, 288 n. 911,291 n. 935,305 n. 21, 307 n. $29,318,319$ n. 128,355 n. 316,377 n. 389,391 n. 452,392 n. 457,393 n. 461,394 n. 463

Galb., 78 n. 294, 316 n. 94,320 n. 140, 390 n. 448

Gracch., 36 n. 60, 41 n. 85,47 ns. 119 e 123,53 n. 149,55 n. 162,84 n. 313,177 n. 297, 197 n. 420, 219 n. 514,225 n. 546,270 n. 824,316 n. 94, 317 n. 99,372 n. 370

Luc., 41 n. 85,53 n. 149,57 ns. 175 e 178,58 n. 182,84 ns. $313-4,95$ n. 343, 187 n. 107,139 n. 109, 146 n. 143, 185 n. 321, 187 n. 336, 197 n. 414,245 n. 678,267 n. 800, 287 n. 902, 316 n. 94,318 n. 118,334 n. 219,341 n. 262,342 n. 263,382 n. 399,386 n. 423,387 ns. $426-7$

Lyc., 41 n. 85, 47 n. 120, 48 n. 126, 56 n. 164,66 n. 214,87 n. 324,96 n. 344, 98 n. 351, 120 n. 21, 136 n. 92, 138 n. 109, 151 n. 159, 169 n. 260, 233 n. 607, 281 ns. 868-9, 295 n. 956,309 n. 47,311 n. 59 , 315 n. 84,316 n. 94,320 n. 140 , 321 n. 156,345 n. 283,374 n. 381 , 380 n. 395,390 n. 444,393 n. 460

Lys., 47 n. 120, 57 ns. 175 e 177, 96 n. 345, 216 . 496, 227 ns. 568 e 570, 245 n. 678,311 n. 59, 316 n. 94, 387 n. 427,390 n. 444, 394 n. 462

Mar., 41 n. 85, 47 n. 123, 48 n. 124, 51 n. 133,69 n. 239,95 n. 343,96 n.
345, 98 n. 351, 138 n. 107, 140 n. 117,157 n. 198,158 n. 199, 160 n. 207, 223 n. 540, 316 n. 94,372 n. 370, 381 n. 396,390 n. 448

Marc., 45 ns. 105-6, 46 n. 108, 47 n. 120,51 n. 134,53 n. 149,56 n. 166,57 n. 176,58 n. 185,70 n. 248, 74 n. 276,84 n. 313,160 n. 209, 188 n. 344,214 n. 214,216 n. 492, 217 n. 505, 219 n. 514, 227 n. 568, 228-244 passim, $250 \mathrm{n}$. 700, 289 n. 920,311 n. 59, 319, 312 n. 143,335 n. 228,346 n. 286,348 n. 293, 351 n. 301,353 n. 309,365 n. 340, 386 n. 442, 391 ns. 449 e 451, 393 ก. 459

Nic., 41 n. 85, 46 n. 114,55 n. 161, 57 ns. $176-6,67$ n. 225,79 n. 295,80 ns. 297 e 300,83 n. 310, 96 n. 345 , 101 n. 370,102 n. 372,103 n. 375 , 108 n. 395,138 ns. 104 e 107,177 n. 297,316 n. 94,372 n. 370,390 n. 444,393 n. 460

Num., 37 n. 65,39 n. 72,41 n. 85,47 n. 120,56 n. 164,74 n. 276,87 n. 345, 98 n. 351, 136 n. 92,139 n. 111,214 n. 482,236 n. 621,270 n. 819,273 n. 842,278 n. 853,281 n. 869,283 n. 886,287 n 905,311 n. 59,312 n. 72,316 n. 94,321 n. 157,325 n. 172,345 n. 283, 346 n. 284,365 n. 340,369 n. 359,372 n. 369,380 n. 395,385 n. 416,390 ns. 444 e 448,393 n. 459

Oth., 310 n. 55, 316 n. 94

Pel., 30 n. 26, 36 n. 57, 41 n. 86, 43 n. 92, 45 n. 105, 46 n. 108, 48 n. 125 , 51 n. 134,53 n. 149,54 n. 154,56 n. 166,57 n. 176,58 ns. 181 e 185 , 74 ns. 271 e 274,84 n. 313,95 n. 343, 142 n. 125,227 n. 568, 228243 passim, 245 n. 678,311 n. 59, 319,321 n. 151,337 n. 236,339 n. 246, 365 n. 342, 386 n. 423, 391 n. 451

Per., 29 n. 22, 33 n. 43, 40 n. 79, 41 ns. 853 86, 45 n. 106, 47 ns. 119 
e 123,55 n. 163,57 ns. 176 e 178 , 66 n. 214,70 n. 251,71 ns. $256-7$, 76 n. 282,79 n. 295,94 ns. $337-8$, 95 n. 343,97 n. 347,99 n. 357,102 n. 372,138 n. 104,169 n. 257,176 n. 293,193 n. 380,227 n. 570,241 n. 644,245 n. 678,267 n. 800,272 n. 835,282 n. 874,313 n. 76,316 n. 94,327 n. 187,356 n. 317,372 ns. 368 e 370

Phil., 30 n. 26, 34 n. 45, 39 n. 76, 47 n. 120,56 n. 166,57 n. 175,59 n. 190, 82 n. 308, 98 n. 351, 106 n. 385, 139 n. 109, 210-227 passim, 229 n. 579,255 n. 727,289 n. 920 , 291 n. 935, 309 n. 38, 318, 319 n. 126, 320 n. 140, 337 n, 236, 380 n. 395, 391 n. 452, 393 n. 461, 394 n. 463

Phoc., 31 n. 29, 43 n. 92, 46 n. 114, 47 n. 123,51 n. 135,56 ns. 168 e 171 , 57 n. 180,80 n. 297,98 n. 351,109 n. 400,139 n. 109,140 ns. 116 e 117,144 n. 137,176 n. 291, 219 n. 514, 227 n. 570, 274 n. 845, 278 n. 857,289 n. 920,309 n. 47, 313 n. 73,316 n. 94,342 ns. $265-6,372$ n. 370,382 n. 400

Pomp., 41 n. 85, 47 n. 120, 48 n. 127, 79 n. 295,80 n. 300,188 n. 344 , 196 n. 410,219 n. 514,255 n. 725 , 263 n. 779,264 n. 787,286 n. 898 , 289 n. 920,335 n. 228,382 n. 400

Publ., 55 n. 163, 131 n. 64, 138 n. 107

Pyrrh., 47 ns. 120 e 123, 51 n. 133, 95, 343, 96 n. 345,219 n. 514, 223 n. 540,259 n. 761,334 n. 224, 380 n. 395, 382 n. 401

Rom., 18 n. 2, 41 n. 85,74 n. 276,76 n. 280,79 n. 295,105 n. $382,124-$ 136 passim, 214 n. 482,288 n. 908 , 295 n. $956,317,348$ n. 293, 365 n. 340,372 n. 369,376 n. 387,384 n. 411, 385 n. 416,388 n. 436

Sert., 45 n. 101, 51 n. 134, 54 n. 157 , 57 ns. 175 e 177,74 n. 271,109 n. 398,112 n. 405, 177 n. 297, 191 n.
367,214 n. 482,264 n. 787,314 n. 80,317 n. $99,318,340$ n. 293,355 n. 316,386 n. 422,387 ns. 426 e 429-430

Sol., 47 n. 120,55 n. 163,56 n. 171,57 ns. 176 e 178,66 n. 214,67 n. 226 , 74 n. 272,76 n. 280,79 n. 295,104 n. 380,131 n. 64,136 n. 92,262 n. 775,289 n. 920,291 n. 931,316 n. 94,386 n. 423

Sull., 40 n. 81,41 n. 85,47 ns. 120 e 123, 57 ns. 175 e 177,76 n. 286 , 96 n. 345,98 n. 351,109 n. 398 , 139 n. 109,185 n. 322,190 n. 360 , 198 n. 424,227 ns. 568 e 570,250 n. 698,311 n. 59,316 n. 94,342 n. 263, 382 ns. 398 e 400, 390 n. 444

Them., 36 n. 61, 47 n. 120, 48 n. 124, 51 n. 133,74 n. 273,79 n. 295,98 ns. 351-2, 219 n. 514, 292 n. 939, 314 n. 79, 316 n. 94, 321 n. 146, 330 n. 207,387 ns. 428 e 431

Thes., 34 n. 45, 36 n. 52, 39 n. 74, 47 n. 123,69 n. 237,79 n. 295,87 n. 322, 124-136 passim, 188 n. 344, 288 n. $908,317,321$ n. 149,322 n. 160,348 n. 293,355 n. 316,372 n. 369,388 n. 436

Tim., 36 n. 58, 41 n. 85, 43 n. 92, 45 n. 106,47 n. 118,57 n. 175,59 n. 189,70 n. 243,108 n. 393,130 n. 59, 136 n. 92,220 n. 516, 241 n. 650, 316 n. 94,334 n. 219, 387 n. 423 


\section{Moralia}

Ad princ. ind., 30 n. 26,104 n. 379, 273 n. 839, 284-288 passim, 297 n. 969 , 307 n. 454, 316 n. 93, 382 n. 401

Adu. Col., 41 n. 86, 279 n. 859, 303 n. 17,315 n. 86,356 n. 319

Amat., 41 n. 85, 54 n. 157,165 n. 237, 233 ns. $605-6,278$ n. 853,321 n. 155,387 n. 430

An corp. affect., 38 n. 66, 347 n. 290

An seni. resp., 22, 31, 33 n. 42, 63 n. 203, 70 n. 243, 99 n. 357,118 n. 4, 120 n. 21,136 n. 93,137 n. 98 , 161 n. 214,177 n. 295,181 n. 309 , 190 n. 358, 216 ns. 495-6, 270 n. 820,272 ns. 831 e 836, 279, 283 n. 885, 288-290 passim, 295 n. 956, 307 ns. 25 e $29,316,341$ n. 261, 342 n. 262, 382 n. 399,383 n. 402

An uirt. doc., 321 n. 144, 326 n. 174 e 177, 328 n. 192, 348 n. 291

An uit. ad inf. suff., 347 n. 290

Apopht. Lac., 387 n. 427

Coniug. praec., 64 n. 205, 303 n. 14, 328 n. 190, 343 n. 279

Cons. ad Apoll., 41 n. 85, 386 n. 423, 387 n. 430

De adul., 41 n. 85,64 n. 205, 76 n. 284, 160 n. 205, 167 n. 251, 303 n. 14, 309 n. 46,328 n. 190,330 n. 208, 382 n. 401, 387 n. 430, 388 n. 433

De Alex. fort. aut uirt., 39 n. 76, 70 n. 245, 80 n. 297, 228 n. 571, 244 ns. 666 e 675-6, 252 n. 706, 254 n. 721,257 n. 740, 261 n. 771, 266 n. 798,287 n. 902,307 n. 29, 339 n. 243,340 ns. 248 ss., 355 n. 315 , 361 n. 331,364 n. 339,369 n. 355 , 373 n. 375,375 n. 383,386 n. 423

De am. mult., 36 n. 5

De am. prol., 341 n. 259, 354 n. 312

De aud., 33 n. 42, 34 n. 47, 35 n. 51, 97 n. 348,99 n. 356,176 n. 294,303 n. 17,307 n. 24,309 n. 41,310 ns. 49, 50, 52 e 55, 312 n. 72, 316 n.
93, 320 n. 140, 326 n. 175, 327 n. 185 e 190, 329 n. 199,389 n. 433

De aud. poet., 34 n. 47, 53 n. 152, 93 n. 336,310 n. 58,312 n. 66,316 n. 93 , 326 n. 180,327 n. 182,341 n. 257 , 348 n. 293, 387 n. 430, 388 n. 433

De cap. ex inim. ut., 41 n. 86, 70 n. 243, 290 n. 927,309 n. 44,314 n. 80

De coh. ira, 38 n. 66, 41 n. 85, 53 n. 152, 96 n. 344, 108 n. 391, 136 n. 93,139 n. 112,234 n. 617,311 ns. 61-2 e 65, 312 ns. 67 e 72, 341 n. 255,345 n. 282

De comm. not., 307 n. 29, 328 n. 190, 381 n. 395

De cup. diu., 139 n. 111

De def. orac., 41 n. 85, 69 n. 236, 330 n. 207, 384 n. 413

De E Delph., 303 ns. 13 e 14, 330 n. 207, 348 n. 293, 365 n. 342, 383 n. 402

De exil., 76 n. 284, 361 n. 331, 389 n. 440

De fac. lun., 32 n. 34, 66 n. 215, 312 ns. 68 e 72,315 n. 86,347 n. 288 , 384 n. 407

De fort., 308 n. 36, 314 n. 82, 326 n. 174

De fort. Rom., 30 n. 24, 41 n. 85, 54 ns. 154 e $155,, 82$ n. 308,175 n. 287,258 n. 757,262 n. 773,348 n. 293, 355 n. 315,369 n. 355,373 n. 374,375 n. 382,376 n. 387,382 n. 399, 384 ns. 409 e 412,387 n. 425 , 391 n. 454

De frat. am., 32 n. 34, 292 n. 942

De garr., 44 n. 96, 309 ns. 40-1 e 47

De gen. Socr., 43 n. 92,53 n. 152, 66 n. 214, 308 n. 35, 320 n. 140, 328 n. 196, 387 ns. 425 e

De gloria Ath., 40 n. 78, 52 n. 139, 54, 100

De Herod. mal., 72 n. 260, 99 n. 355, 101 n. 369,102 n. 372,259 n. 760

De Is. et Os., 307 n. 30, 387 n. 430 
De laude ips., 108 n. 391

De lib. educ., 105 n. 383, 283 n. 886, 296 n. 965,309 n. 42, 316 n. 93, 320 ns. 139 e 140,348 n. 293, 350 n. 298,356 n. 318

De mus. 316 n. 93

De prof. in uirt., 32 n. 34, 33 n. 42, 35 n. 49,36 n. 62,53 n. 152,107 n. 390,172 n. 273,214 n. 481,308 n. 34, 309 n. 45,310 n. 53, 316 n. 93, 327 ns. $185-6,328$ ns. 190 e 196, 329 n. 200, 403

De Pyth. or., 309 n. 47, 378 n. 391, 383 n. 403

De sera num. uind., 32 n. 34, 41 n. 85, 97 n. 349, 108 n. 391, 302 n. 6, 303 ns. 13 e 14,308 n. 35, 312 n. 72, 396 n. 359, 371 n. 366,386 n. 423,387 n. 430

De soll. anim., 59 n. 181, 108 n. 392, 150 n. 155,274 n. 844,307 n. 29, 314 n. 80, 383 n. 406

De Stoic. rep., 37 n. 63, 252 n. 708, 279 n. 860

De superst., 54 n. 157, 381 n. 395

De tranq. an., 32 n. 34,39 n. 75 , n. 84 n. 315,177 n. 295,277 n. 850,287 n. 902,303 n. 14,310 n. 51,324 n. 166, 382 n. 399

De tuenda san., 41 n. 85, 80 n. 297, 122, 328 n. 195

De uirt. et uit., 40 n. 77, 106 n. 386, 108 n. 391

De uirt. mor., 38 n. 66, 41 n. 85, 99 n. 357,104 n. 378,307 ns. $27-8,311$ n. 61,312 ns. $68-9$ e 72,326 n. 178 , 329 n. 198,330 n. 210,351 n. 300

De uit. aer. al., 321 n. 145 , 387 ns. 425-6

De uit. pud., 308 n. 35, 348 n. 293

De un. in rep. dom., 289 n. 920, 294297 passim, 341 n. 261

Max. cum princ., 27 n. 9, 104 n. 379, 193 n. 380,216 n. 496,278 n. $852,281-$ 284 passim, 316 n. 93,330 n. 210

Mul. uirt., 59 n. 188, 307 n. 29, 342 n.
265,343 ก. 278

Non posse suau., 161 n. 214, 315 n. 86, 328 n. 190, 329 n. 203, 381 n. 395

Plac. philos., 188 n. 344

Plat. Quaest., 41 n. 86, 176 n. 294

Praec. ger. reip., 25 n. 4, 31 n. 30, 32 n. 39, 37 n. 64,41 n. 85,70 ns. $243-4,99$ ns. $358-9,105$ n. 381,136 ns. 93-4, 138 n. 109,139 n. 112,154 n. 175 , 157 n. 196,176 ns. $291-2,185$ n. 323, 190 n. 362,191 n. 368,193 n. 387 , 196 n. 411,211 n. 472,216 n. 496, 220 n. 520,222 n. 529,233 n. 611 , 270 ns. 820 e 824,272 n. 836,273 n. 837,275 n. 847,277 n. 849,279 n. 859,281 n. 870,282 n. 874,283 n. 883,287 n. 905,289 n. $920,290-297$ passim, 340 ns. 254-5, 341 n. 256, 348 n. 293, 365 n. 342,376 n. 388 , 382 n. 399, 383 n. 402,384 n. 412

Quaest. conu., 27 n. 8, 32 n. 34, 33 n. 42, 35 n. 51, 39 n. 73, 41 ns. 85-6, 52 n. 139,74 n. 276,75 n. 277,76 n. 284,106 n. 389,237 n. 630,277 n. 849,303 n. 13, 307 n. 29, 309, 315 ns. 85-6, 317 n. 105, 321 n. 145,328 n. 190,330 n. 207, 342 n. 265,365 ns. 340 e 342,374 n. 381,384

Quaest. Graec., 53 n. 151, 85, 133, 332, $351,384,385-6$

Quaest. Rom., 44 n. 96, 51 n. 132, 53 n. 151,69 n. 241,70 n. 241,74 n. $276,85,133,135$ n. 84,223 n. 540 , 278 n. 853,317 n. 105,346 n. 285 , 385 ns. 414-4, 393 n. 459

Reg. et imp. apopht., 29 n. 18,70 n. 245, 80 n. 297,108 n. 392,228 n. 571 , 244 n. 666,248 n. 690,329 n. 206 , 386 n. 423

Sept. sap. conu., 321 n. 152

Stoic. absurd. poet., 41 n. 87

$X$ or. uit., 52 n. 139,66 n. 214,100 n. 365,180 ns. 304 e 307,190 n. 358 , 317 n. 106, 328 n. 190,348 n. 293 


\section{ÍNDICE REMISSIVO GERAL}

Aalders, G., 25 n. 3,273 n. 840,281 n. 868,283 n. 886

Abbot, N., 350 n. 298

Adrados, F., 255 n. 726, 262 n. 773

Adriano, 20, 26, 52 n. 137, 90 n. 333, 263 n. 779,275 n. 846,279 n. 858 , 340, 357, 363 n. 338, 370, 387 n. 423

Agesilau, 43 n. 92, 44, 45, 54, 65, 66 n. $218,71,88$ n. 326,139 n. 113,144 n. 137,177 n. $295,221,241,259$, $259,260,305$ n. 21

Ágis, 19, 36, 39, 44, 53, 89, 296

Aguilar, R., 41 n. 86, 211 n. 472

Albini, F., 159 n. 201, 305, n. 22, 325 n. 168

Alcibíades, 43, 109, 142 n. 125, 143 n. $129,157,159$ n. 201, 194, 195, 201, 202, 221, 271, 282, 296 n. 962, 297 n. 966,305 n. $21,311,317,326,331$, $332,332,336,337,345,357,391 \mathrm{n}$. $455,392,400,401$

Alcock, S., 218 n. 508, 360 n. 327

Alesse, F., 309 n. 38

Alexandre, 27 n. 9, 28, 30, 42-4, 48-9, 52-54, 66, 72-3, 78-9, 97, 100, 108 n. $394,109-10,120$ n. 20, 123, 134 n. $82,192,197,204,206,207,214$, 244-269 passim, 280, 282, 286 n. 899, 287, 291 n. 935,308 n. 35, 311, $318,321,325,327,329,331-5,339$ -
$340,345-6,349,351,352$ n. 304 , 355, 364-5, 369, 371 n. 366, 373-6, 383, 388-9, 395-6, 399-401, 403

Alonso-Nuñez, J., 294 n. 952

Amónio, 30 n. 27, 278 m. 855, 303, 327 n. 190,330

Anderson, G., 56 n. 170, 86 n. 320, 284 n. 890,333 n. 218,349 n. 295,359 n. 326

Ando, C., 365 n. 340

andreia, 56, 139 n. 114, 161, 191, 214, 216 n. 495,254 n. 718,305 n. 21

Aníbal, 74 n. 271, 106 n. 388, 145 n. 140, 220 n. 518, 223, 225 n. 551, $226,228,234,235,237$ n. 625,238 n. $635,242,243$

Antípatro, 207, 208

António, 36, 44, 89 n. 329, 95, 97, 109, $157,177,245$ n. 678,260 n. 767, 279 n. 858, 286 n. 898, 311, 335, 345,363 n. 338,400

Apiano, 39 n. 72, 76, 204

Arato, 39, 44, 110, 213, 216, 316 n. 94

arete, 38,40 n. $77,54-6,59$ n. 188,72 , 73, 94, 97, 106 n. 384, 109, 121, $122,126,131,152,156,170,200$, 214, 246, 275, 286, 289, 303, 304, 308-311, 314, 315, 337, 343, 345, $353,355,369$ n. $355,376,389,399$, 402 
Aristides, 31 n. 28, 42-3, 45, 47, 55, 59, 71, 74, 110, 112, 136-157 passim, 175, 195, 291 n. 931, 295 n. 956, $313,317,332,335,339,345,357$, 388, 391 n. 455, 392, 400

Aristófanes, 52, 118, 177 n. 295

Aristóteles, 32 n. 35, 35 n. 51, 41, 61, 63, 64 n. 208, 65, 66, 71 n. 257, 93 n. $336,110,118,119,120,121$ n. 26 , 122,143 n. 129,167 n. 251,177 n. 295, 190, 194 n. 395, 248-252, 258, 269, 273, 282, 294, 303, 307, 308, $309,319,325,341$ n. 260, 345, 347 n. $287,349,374,376$ n. 386,378

Arquíloco, 63

Arquimedes, 234, 237-9, 243 n. 662, 250,391

Arriano, 76, 258 n. 757, 259, 356, 364, 370,373 n. 373,389 n. 439

Artaxerxes, 19, 39, 45 n. 101, 229, 2 33, 331 n. 212,387

Astin, A., 146 n. 143,148 n. 150

Atenas, 29, 30, 33 n. 43, 40 n. 78, 46 n. 115, 54, 61 n. $194,75,76,89,91$, $100,118,120,121,124$ n. 41, 125-6, 128,137 n. 98,138 n. $103,139,144$ n. 130,174 n. $282,175,185,186$, 187 ns. 337 e 339, 192, 216, 229, 231, 278 n. 855, 280 n. 865, 295 n. 956, 295, 315 n. 88, 318, 324 n. 165, 337 n. 235, 352, 353 n. 305, 365, 371, 383 n. 402, 387 n. 423, 392

Augusto, 39, 43, 44 n. 98, 61, 70 n. 248, 132, 177 n. 295, 255 n. 728, 295 n. 956, 374 n. 379,382 n. 400, 387 n. 423

Aulo Gélio, 112 n. 404, 364

Austin, R., 367

Babut, D., 109 n. 400, 186 ns. 325-6, 187 n. 336, 196 n. 411, 257 n. 746, 303 n. 15,304 n. 19,310 n. 53, 337 n. 236,390 n. 446

Ballesteros Pastor, L., 342 n. 263

Bárbaro, 51, 54 n. 157, 70, 89, 100, 120, 149, 150, 153 n. 174, 191 n. 367,
203-5, 209-10, 219 n. 510, 221 n. 525, 223-4, 236, 245, 253, 255 n. 726, 257, 262-3, 269, 275, 293, 302, 303 n. 12, 305, 323, 339, 340, 349, 351, 353, 356, 360-8, 374, 377, 381 n. $395,383,384$ n. $412,386-9,393$ n. $459,397,399,403$

Barbu, N., 63 n. 201, 73 n. 268, 80 ns. 298 e 301

Barigazzi, A., 25 n. 3, 69 n. 241, 284 n. 891, 288 n. 910,304 n. 20, 314 n. 82,374 n. 378,376

Barrow, R., 18 n. 1, 26 n. 6, 27 n. 7, 150 n. 155,301 n. 3,385 n. 417

Batstone, W., 52 n. 141

Becchi, F., 74 n. 269, 211 m. 472, 277 n. 849, 282 n. 874, 286 n. 901, 307 n. 27,311 ns. 61 e 63,312 n. 72,347 n. 287,348

Beck, M., 29 n. 18, 47 n. 111

Berry, E., 325 n. 168

Bollansée, J., 65

Borg, B., 302

Bos, A., 351 n. 298

Bosworth, A., 206 n. 448

Boulogne, J., 40 n. 79, 55 ns. 159 e 1634, 56 n. 167,210 n. 468, 272 n. 832, 304 n. 18, 332 n. 216,333 n. 217, 256, 384, 385 ns. 417-8, 392 n. 458, 393 n. 459

Bowersock, G., 39 n. 73, 86 n. 320, 292 n. 843,301 n. 5,368 n. 353,387 n. 423

Bowie, E., 54 n. 153, 85 n. 317, 86 n. 320, 243 n. 663, 301 n. 5, 333 n. 218, 348 n. 292, 349 n. 295, 383 n. 405, 386 n. 421,388 n. 435

Braund, D., 392

Bravo García, A., 318 n. 116

Brenk, F., 59 n. 192,279 n. 858

Browning, R., 361 n. 331

Brozek, M., 20, 45 ns. 99 e 100

Bruto, 44, 88, 306-7, 311, 336, 337 n. 234 
Bucher-Isler, B., 38 n. 69, 51 n. 130, 101

Buckler, J., 77 n. 292, 229 n. 578

Burlando, A., 75 n. 278

Burridge, R., 51

Busine, A., 63 n. 200

Caiazza, A., 290 n. 298, 293, 294 n. 952

Calímaco, 66, 385 n. 417

Calístenes,

Cambises, 64-5

Camilo, 46, 48, 139 n. 112, 331 n. 212

Cammarota, M., 66 n. 221

Candau, J., 108 n. 394

Cartledge, P., 353 n. 310

Catálogo de Lâmprias, 39 n. 74, 40 n. 79,71 n. 257,72 n. 259,85 n. 318 , 106, 281, 303 n. 17, 309 n. 37, 311 n. $63,330,332$ n. 216,385

Catão Censor, 35, 45, 53, 55, 59, 110, 112, 136-157 passim, 162 n. 218, 175, 177, 189 n. 349, 191 n. 366, 194 n. 394, 195, 296, 317, 320, 325, 335, 337 n. 238, 338, 339, 364, 386, 400, 401

Catão de Útica, 52, 103, 104, 144 n. 131, 194, 196 n. 410, 274, 280, 311, 316, 326, 327, 335, 337 n. 234, 342, 343

Cerezo Magán, M., 38 n. 69, 68 n. 229

César, 39 ns. 72-3, 48, 52, 55, 78, 81, 109, 187 n. 338, 204 n. 443, 211 n. 472, 216 ns. 495-6, 244-269 passim, $311,319,326,331,332,335,388$, 396, 400

Churchill, J., 153 n. 164

Cícero, 52, 53, 63 n. 203, 70 n. 249, 75, $87,123,131$ n. 70,145 n. 141,147 n. $146,153,167,176-196$ passim, 264, 272, 275, 283 n. 886, 288, 302, 317-9, 327, 329, 333-337 passim, 347,349 n. 294, 364, 368, 370, 379, 380, 386, 401

Címon, 43, 45, 63 n. 202, 81, 109, 140 n. 115,142 n. $125,191,221,295$ n. 956, 296, 317 n. 100, 345, 391 n. 455,392
Ciro, 52, 54, 61 n. 194, 64, 65, 258-260

Cleómenes, 39, 44, 53, 89, 296

Cole, S., 332 n. 214

Coriolano, 52, 70 n. 249, 74 n. 272, 95, 109, 152 n. 162, 157-176 passim, 181, 194, 197, 198, 202, 296, 297 n. 966, 311, 314, 317, 334, 336, 345, 354, 357, 400

Cornélio Nepos, 43, 44, 53, 61, 64, 66 n. 219,70 n. $248,83,84,112,137,167$ n. 251,186 n. $324,206,230$ n. 584 , 296, 342 n. 267

Costanza, S., 51 n. 133,55 n. 159

Crasso, 45, 55, 146, 316 n. 94, 335

Crisipo, 40 n. 77, 233, 279, 350

Cromey, R., 202 n. 435

Cuvigny, M., 294 n. 952

D' Ippolito, G., 42 n. 88

Dario, 252, 254 n. 718, 255 n. 727, 256, 258 n. 755, 259 n. 760, 260, 262 n. 775

de Blois, L., 56 n. 169, 278 n. 853, 279 n. 861,283 n. 886, 297

de Romily, J., 384 n. 441

Delfos, 18, 26, 29, 189, 223, 254, 278 n. $855,330,360$ n. $327,365,369,383$

Delvaux, G., 45 n. 99, 69 n. 234

Demétrio, 36, 44 n. 96, 89 n. 329, 95, 97, 109, 157, 258 n. 756, 260 n. 767, 279 n. $858,311,331$ n. 212, 345, 400

Demóstenes, 36, 43, 44, 52 n. 139, 66 n. 214, 75-7, 101, 120 n. 20, 145, 146, 169, 1726-196 passim, 262 n. 774, 317, 318 n. 112, 322, 332, 334, 347, 379, 380

Desideri, P., 79 n. 295,83 n. 311,87 n. 323, 107 n. 390, 279 n. 862, 283 n. 887, 352 n. 304, 370 n. 362, 389 n. 443

Dihle, A., 64

dikaiosyne, 139, 305, 315 n. 83, 393 n. 459 
Dillon, J., 46 n. 111, 278 n. 855, 303 n. 16,312 n. 72,344 n. 280

Diodoro Sículo, 126, 197 n. 413, 259, 301 n. 3

Diógenes Laércio, 61, 63 n. 200

Díon Cássio, 76, 364

Díon de Prusa, 29, 86, 223 n. 540, 262, 271 n. 828, 272, 280, 283, 290 n. 930, 295 n. 956,315 n. $88,348,355$ n. $314,359,365,370,382,386$ n. 421, 388 n. 435,389 n. 439

Díon, 44, 282, 306, 316 n. 94

Dionísio de Halicarnasso, 44 n. 96, 72, 73, 81-3, 87, 131 n. 70, 133, 161 n. 212, 162 n. 221, 272, 301 n. 3, 302 n. $9,360,361,364$ n. 340,368 n. 354,374 n. 379,386

Domiciano, 29, 32 n. 34, 33, 39, 262, 278 n. $853,282,340,357,365$ n. 341

Donini, P., 41 n. 86, 66 n. 215, 312 n. 72

doxa, 181 n. 309, 213, 226, 238, 245, 246, 334, 399

Dubuisson, M., 275 n. 846

Ducat, J., 118 n. 5

Duchemin, J., 126 n. 49

Duff, T., 11, 32 n. 34,34 n. 45, 47 ns. 118 e 120,51 ns. 130 e 132, 52 n. 138,53 n. 150,56 ns. 167 e 170,57 ns. 179 e 181, 59 n. 191, 63 n. 204, 68 n. 227,78 n. 294,79 n. 295,94 ns. $338-9,95$ n. 341,96 n. 345,110 , 135 n. 89, 140 n. 120,157 n. 195 , 167 n. 251, 175 n. 284, 223 n. 540, 226 n. 556,349 n. 296,380 n. 395 , 383,390 n. 446

Éforo, 70 n. 247, 353

eleutheria, 128, 222, 292, 293, 294, 340 n. $254,349,390,391,392$

Élio Aristides, 86 n. 321, 211 n. 473, 272 n. 829, 352 n. 305, 362 n. 334, 363 n. 336, 365, 371, 389 n. 439

Emílio Paulo, 30, 279 n. 858, 286 n. $898,325,331,335,338,369,387$, 396, 399
Empédocles, 17, 65

enkyklios paideia, 349 n. 297, 350 n. 298, 351

Epaminondas, 20, 26, 34 n. 45, 36 n. 53, 43 n. 92,54 n. 154, 74, 88, 106 n. 388,142 n. $125,146,155,161,175$, 219 n. 512,220 n. $517,228-233$ passim, 240-1, 243, 280, 311 n. 64, 319,399 n. 246, 391

Epicteto, 29, 40 n. 77, 53 n. 153, 316 n. 90

epicurismo, 35 n. 51, 39 n. 75, 41 n. 87, 138 n. $105,279,288$ n. 910,303 n. $17,304,329$ n. 203,347 n. 287,350 n. 298,357

Erbse, H., 51 ns. 130 e 133, 55 n. 158, 57 n. 181,77 n. 292

Ésquilo, 52, 89, 90, 91, 251, 319, $371 \mathrm{n}$. 365,387 n. 424

Estesímbroto de Tasso, 65

estoicismo, 38 n. 66, 41 n. 87, 52 n. 140, 53 n. 153, 63 n. 203, 66 m. 215, 80 n. 303,95 n. 343,138 n. 106,147 , 185-188, 196 n. 411, 248, 278 n. 853, 279 n. 860, 285, 288, 297 n. $969,303,304,309$ n. 45,310 n. 53, 311 n. $60,312,318,336,337$ n. 234, $344,347,350,357,403$

Estrabão, 52, 301 n. 3, 302, 303 n. 12, 350 n. 298, 353, 362 n. 334, 387 ns. 423 e 425

ethos, 34 n. 45, 46, 48, 49, 56 n. 164, 58, 65 n. 213, 66-68, 73-4, 80, 89, 106, 113, 118, 122, 135, 137, 150 n. 155, 152,159 n. $201,167,173$ n. 278 , 180, 192, 195, 197 n. 413, 198, 201, 213, 242, 263, 271 n. 826, 280, 283, 291, 306 n. 22, 311 n. 64, 324 n. 166, 332, 335-6, 344, 348, 354, 355, $397,401-2$

ética, 32 n. 35, 38, 42 n. 88, 62, 77, 79 n. $295,91,101,104,107,110-2$, 118 n. 8, 126, 137, 141, 144, 156, $162,167,175,249,263,271,273-$ 4, 296, 297, 304 n. 21, 305, 307 n. $27,308,312,333,337,347$ ns. 287 
e $290,351,366,372,376,389-9$, 401

eudaimonia, 19, 40 n. 77, 95, 308, 339, 348,399

Êumenes de Cardia, 44 ns. 95-6, 59, 90, $196,197,318,332$

Eurípides, 52, 89 n. 331, 126, 128 n. 52, $251,319,340,371$ n. 365, 373

Fábio Máximo, 47, 48, 74 n. 272, 145, 153, 234, 237 n. 625,238 n. 635, 240 n. 642,241 n. $644,243,331$ n. 212,388 n. 437

Fábio Pictor, 130 ns. 62-3, 131 n. 70, 149

Ferrary, J.-L., 211 n. 475, 220 n. 525, 239 n. 639,240 n. 642,363 n. 338

Fialho, Ma., 10, 88 n. 326, 124 n. 37

filo-helenismo, 20, 21, 90 n. 333, 149 n. $151,153,234,325,347,363$ n. 338 , 370,396

Fílon de Alexandria, 61

Fílon de Larissa, 184, 185, 186, 318

Filopémen, 30 n. 26, 34 n. 45, 36, 42, 44, 47, 81, 82, 96 n. 345, 106 n. 385, 210-227 passim, 232 n. 599, 255 n. 727, 260 n. 767, 296, 306, 311, 318, $319,332,335,337,345,346,363$, 391, 394, 400

Filóstrato, 61,86 n. 321, 211 n. 473, 272 n. $829,301,355$ n. 314,356

Flacelière, R., 18 n. 1, 33 ns. 41 e 43, 39 n. 74,44 n. 99,45 n. 100,229 n. 578 , 239 n. 639,304 n. 18

Flaminino, 21, 30 n. 26, 42, 44 n. 96, 47, 70 ns. 246 e 249,96 n. 345,110 , 160, 210-227 passim, 242, 246, 267 n. 800,286 n. $898,311,312,319$, 331 n. 212, 335, 337, 345, 346, 357, $377,391,392,394,396,400$

Floro, 27

Flower, M., 257 n. 745

Fócio, 61 n. 193

Fócion, 31, 44, 66 n. 214, 89, 137 n. 98, 144 n. $137,176,180,192,316$ n. 94 , 342
Focke, F., 45 n. 103,51 n. 135,52 n. 138 , 55 ns. 158 e 159

Frazier, F., 18 n. 1, 25 n. 2, 30 n. 26, 38 ns. 67 e 69, 45 ns. 99, 103 e 107 , 46, 56 n. 172, 62, 71 n. 253, 80 ns. 299 e 304

Froidefond, C., 311 ns. 60 e 61

Frost, F., 66, 124 n. 39

Fuentes, C., 309 n. 43

Fuscagni, S., 32 n. 34, 73 n. 298, 87

Gabba. E., 40 n. 80, 386 n. 420, 391 n. 451

Galba, 39, 331 n. 212

Gallo, I., 64 n. 205, 65, 73 ns. 266-7

García Moreno, L., 196 n. 412, 197 n. 413, 202 n. 436, 209 n. 466, 243 n. 663

Geiger, J., 18 n. 1, 29 n. 17, 39 n. 73, 43 n. 93,44 ns. $95-6$ e 98,45 n. 99,47 n. 118,53 n. 149,57 n. 180,64 ns. 207-8, 65 n. 210,73 n. 268,77 n. 292, 83 n. 312, 206 n. 447, 243 n. 663,263 n. 779

Gentili, B. \& Cerri, G., 64 n. 209, 79 n. 295

Georgiadou, A., 237 n. 626

Gleason, M., 302 n. 5, 360 n. 327, 395 n. 465

Goldhill, S., 18, 89 n. 331, 112, 302 n. 5, 359 n. 326, 385 n. 418, 389

Gómez, P. \& Mestre, F., 79 n. 295, 355 n. 316

Gomme, A., 45 n. 100, 68, 69 n. 234

Gracos,

G. Graco, 39, 44, 53, 55, 216 n. 496, 316 n. 94,336

Tibério Graco, 36, 39, 44, 53, 55, 197 , 216 n. 496, 316 n. 94,336

Grécia, 17, 22, 30, 32 n. 34, 70, 86, 90 n. 333,106 n. $388,110,118,120$ n. $20,139,146$ n. $143,149,185-8$, 210, 211 n. 472, 213, 215-6, 218 n. 508, 220 n. 525, 221-225, 227, 229, 234, 241, 245 n. $679,253,258,271$, 
274-5, 282, 292, 295 n. 956, 301 n. 3,302 n. $9,315,325,335,339,340$, $349,353,355$ n. $316,362-4,367$ n. 346, 368-370, 372, 375-8, 382-4, 391-3, 395-6, 398, 400, 402

greco-romana, 17, 76 n. 285, 86, 97 n. $348,111,279,334,349,359$ n. 325 , $363,366,372,378-380,387,392$, 395-6, 398, 400-2

Gruen, E., 146 ns. 143 e 145, 148 n. 150, 149 ns. 151 e 153,217 n. 506, 239 n. 639,302 ns. 8 e 11, 339 n. 242

Hadas, M., 369 n. 354

Halfmann, H., 390 n. 446

Hall, J., 70 n. 250, 377 n. 390, 387 n. 423

Hall, S., 360 n. 327

Hamilton, J., 42 n. 90, 66 n. 221, 68 n. 230, 75 n. 278,244 ns. 668 e 674 , 248 ns. 692 e 695

Hardie, Ph., 103 n. 374, 385, 417

Harris, W., 80 n. 303

Hartog, F., 85, 302 n. 9, 386 n. 420

helenocêntrica, 333, 386, 388, 389

Helmbold, W. C. \& O’Neil, E. N., 29 n. 19,68 n. 231,82 n. 308

Henrichs, A., 153 n. 174

Héracles, 36, 39 n. 74, 126, 128, 255, 262,324

Heraclides, 65

Heraclito, 163 n. 227, 165 n. 237

Herbert, K., 106 n. 388

Hermipo, 61, 65-6, 179, 180 n. 306

Hermógenes, 52 n. 138

Heródoto, 63-5, 72, 76 n. 285, 79 n. 295, 89, 99, 102 n. 372, 109, 142 n. 124, 259 n. 760, 261 n. 768, 360-1, 371 n. 365,383 n. 402

Hershbell, J., 40 n. 78, 41 n. 86, 72 n. 259, 79 n. 295,152 n. 161,281 n. 868, 283 n. 886, 304 ns. 18 e 19, 311 n. 60,346 n. 285

Hesíodo, 17, 39 n. 74, 52, 62, 63, 117 n.

\section{3, 121,145 n. 141,155}

Hipócrates, 149, 150

Hirzel, R., 51 n. 130,

Homero, 39 n. 71, 52, 62, 65, 93, 145 n. $141,146,147,171,198,212,214$, 235, 251 n. 704, 252, 271, 333, 340, 350,373

Homeyer, H., 64

Hopkins, K., 390 n. 446, 397 n. 469

Horácio, 325 n. 171, 367 n. 346, 368 n. 348

humanitas, 278, 305 n. 21, 349, 364, 366-8, 370, 393 n. 459

Humbert, S., 66 n. 221, 261 n. 770, 263 n. 777,369 n. 356

identidade, 9, 22, 27 n. 7, 39, 54, 63 n. 204, 86, 88 n. 326, 112, 136, 165, 304, 308, 312 n. 68, 316, 333-366 passim, 369, 380, 383, 385, 387, 390, 392, 395-402 passim

Idomeneu, 71 n. 257, 138

Ingenkamp, H., 372 n. 371

Íon de Quios, 65

Isócrates, 52, 61, 65, 66, 100, 117 n. 3, 118-120, 126, 148, 179, 180, 262, 272, 285, 302, 313 n. 74, 317, 349, 351-3, 397

Jacoby, F., 65, 270 n. 822

Jaeger, W., 117

Jolowicz, H., 169 n. 259

Jones, C., 18 n. 1, 20, 26 n. 6, 27 ns. 7 e 10, 30 n. 27,32 n. 34 e 39, 33 ns. 41 e 43,38 n. 68,39 n. 73,45 n. 99 , 75 n. 278,77 n. 292,86 n. 320,95 n. 341,96 n. 345,107 n. 390,197 n. 414, 280 n. 866, 284 n. 893, 301 n. 5, 316 n. 89,341 n. 255,342 n. 263 , 362 n. 336, 365, 370 n. 362, 390 n. 446, 397 n. 468

kakia, 38, 40 n. 77, 55, 59 n. 188, 97, 195, 216 n. 496, 286, 308, 315, 334

Kennel, N., 118 n. 5

Koller, H., 351 n. 289 
Konrad, C., 197 n. 413, 198 n. 422, 202 n. 437,203 n. 441

Konstan, D., 360 n. 327

Krämer, H., 312 n. 72

Lachenaud, G., 350 n. 298

Lacy, Ph. de, 73 n. 266

Larmour, D., 55 n. 159, 58 n. 181, 69 n. 240, 70 n. 249,125 n. 43

Latim, 52 n. 138, 53, 61, 74-75, 134, 144 n. 138, 147, 149 n. 154, 182, $185,188,189,190$ n. $360,196,305$, 307,318 n. $119,339,350$ n. 298, 362 n. $335,364,365$ n. 340,367 , 370, 378, 384, 385, 388 n. 436, 394

Leão, D., 63 n. 200, 105 n. 382, 129 n. 58,257 n. 745

Leo, F., 63, 64

Léon, M., 265 n. 794

Levi, M., 64

Levin, S., 278 n. 853

Licurgo, 36, 52, 69, 87 n. 327, 91, 122, 151 n. 159, 218, 219, 233, 281 n. 869, 295 n. 956, 296, 309, 331 n. 212, 345, 346, 376, 393

Lisandro, 43, 216 n. 496, 221, 245 n. 678, 260 n. 767,305 n. 21, 316 n. 94,388

Lisímaco (pai de Aristides), 137, 143 n. 129,144

Lisímaco (paidagogos de Alexandre), $247,248,259,319,329$

logos, 56 n. 164, 97 n. 347, 98, 105, 109, 117 n. $3,118,119$ n. $18,122,157$ n. 198, 159, 164, 167, 172, 181, 193, 264, 275, 296 n. $965,309,310$ n. 57 , $312,313,326,327,340$ n. 255,351 n. $303,354,389,396,402$

Luciano, 61, 72, 86 n. 321, 272 n. 829, 355 n. 314, 359, 378, 397

Lucrécio, 75 n. 278, 188

Luculo, 28, 30, 46, 109, 123, 187 n. 336, 216 n. 495, 266, 316 ns. 92 e 94, $318,333,337,341$ n. 262,342 n. $263,345,396$
Magnelli, E., 385 n. 417

Maratona, 36, 74 n. 271, 140, 154, 221, 371

Marcelo, , 21, 30, 42, 58, 160, 228-244 passim, 302, 312, 319, 331 n. 212, 334, 337, 346, 353, 363, 364, 366, 387, 390, 391, 396, 401

Marcial, 29, 75 n. 278

Marco Aurélio, 90 n. 333, 363 n. 338, 370

Marincola, J., 62 n. 196

Mário, 44 n. 96, 95, 146, 147 n. 146, 157, 160, 186, 198, 216 n. 495, 223 n. 540, 235, 265 n. 789, 266, 306, 316 n. $94,333,381,390,400$

Marrou, H., 349 n. 297, 350-1, n. 298

Martín del Pozo, J., 97 n. 346

Martin Jr., H., 86 n. 321, 166 n. 243, 315 n. 196, 389 n. 441,393 n. 459

Martos Montiel, J., 35 n. 48

Masaracchia, A., 342 n. 264

Melandri, E., 314 n. 82

Menandro, 177 n. 295

Mette, H., 351 n. 298

Mewaldt, J., 20, 44 n. 99, 45 n. 100

Milcíades, 35 n. 49, 36, 37, 141, 142, 154,295 n. 956

Miles, R., 360 n. 328

Millar, F., 360 n. 327, 390 n. 447

mimesis, 20, 22, 35, 80 n. 299, 93-113 passim, 126, 358, 360, 399, 402

mito, 20, 42 n. $88,43,51,63,89$ n. 327 , 99, 103 n. 374, 124, 125, 135, 136, 190 n. $360,278,333,385$

Moles, J., 70 n. 249, 79 n. 295, 83 n. 312, 336 n. 232

Momigliano, A., 64, 79 n. 295

Montaigne, 22, 52

Morales Otal, C., 124 n. 37

Morgan, T., 118, 119 n. 13, 121 n. 26, 297 n. 967,321 n. 141,332 n. 214 , 343 n. 274,350 n. 298,352 n. 304 , 
Índice remissivo geral

356 n. 322,380 n. 395

Mossman, J., 75 n. 278, 252 n. 706, 260 n. 767,261 ns. 768 e 770

Mühl, M., 243 n. 663

Nearco, 145, 317

Nero, 43, 90 n. 333, 210-1 n. 472, 220 n. 525,279 n. $858,282,330,340$, 363 ก. 338

Nícias, 43, 44, 45, 48, 55, 101, 102 n. 372,142 n. 125,168 n. 253, 169 , 172 n. 268, 174 n. 282, 221, 305, 331 n. 212, 391 n. 455, 392

Nikolaidis, A., 45 ns. 99 e 101, 67 n. 222, 71 n. 257,72 n. 263,78 n. 293, 96 n. 345,139 n. 112,361 ns. 332 e 333, 381 n. 395, 386 ns. 421 e 423, 388 n. 434

Nippel, W., 361 n. 331

Numa, 69, 87, 91, 93, 135, 144 n. 137, 270 n. 819, 273, 274, 278, 279 n. 858, 281 n. 869, 283 n. 886, 295 n. 956, 316 n. $94,325,337$ n. 234, 345, $346,375,376,393,396$

Opsomer, J., 54 n. 153, 303 n. 17, 313 n. 72

Otão, 39, 331 n. 212

Ovídio, 75 n. 278, 393 n. 459

Pancera, C., 122 n. 30

Panécio, 52 n. 140, 138

pathos, 167, 227, 243, 311 n. 60

Pausch, D., 111 n. 404

Payen, P., 333 n. 216

Pelling, C. 28 n. 15,32 n. 38,38 n. 67 , 39 n. 73,45 n. 102, 46 n. 116, 47 ns. 118-120, 51 n. 130,56 ns. 167,168 e 170, 57 n. 181,68 ns. 227 e 233 , 70 ns. 242 e 249,72 n. 260,73 ns. 264 e 266,74 n. 275,75 n. 278,78 n. 293, 80 n. 300,81 n. 305,89 n. 328 , 96 n. 345,101 ns. 366 e 368,112 , 124 n. $37,139,150$ n. 155,177 n. 296, 216 n. 496, 217 n. 498, 219 n.
511, 220 n. 518,239 ns. 639 e 640 , 242 n. 658,263 n. 780,264 n. 784 , 268, 296 n. 963, 313 n. 75, 320 n. 139, 349 n. 296, 393 n. 459, 397 n. 468

Pelópidas, 26, 30 n. 26, 36, 43, 54 n. 154, 58, 74, 88, 142 n. 125, 311 n. 64, 319, 331 n. 212, 332, 334, 337, 339 n. 246,391

pepaideumenos, 19, 29, 67, 123, 272, 281, 284, 315 n. 86, 316, 333, 344, 356, 362

Pérez Jiménez, A., 20, 34 n. 45, 37 n. 64, 39 n. 71, 41 n. 86, 47 n. 122, 65 n. 210, 73 n, 268, 74 ns. 270 e 272,94 n. 339,124 n. 37,125 n. 43,137 ns. 98 e 99,139 ns, 112 e 113, 140, 162 n. $221,262,271$ n. 827,279 n. 858 , 291 n. 934,295 n. 956,296 n. 963 , 305 n. 21

Péricles, 29 n. 16, 33, 43, 44, 47, 70, 71, 81, 94, 100, 102, 103, 119, $120 \mathrm{n}$. 21, 126, 142 n. $125,146,151$ n. 159 , $167,169,172,176,177$ n. 295,191 , 211 n. 472, 259, 260, 280, 282, 289, 295 n. 956, 311, 316 n. 94, 317 n. 455, 392

peripatos, 41 n. 86, 63-66, 74, 80 n. 303, 111, 138, 194 n. $394,288,311$ n. 60, $344,350,357$

Pernot, L., 56 n. 170

philantbropia, 128, 153, 173, 197 n. 413, 231, 254 n. 718, 305 n. 21, 315, 349 n. $294,361,380$ n. $395,389,393$ n. 459, 402

philonikia, 36 n. 53, 56, 96 n. 345, 211 n. 473, 212, 214, 216 n. 496, 218-227 passim, 312, 335, 345, 346, 363

philosophia, 18 n. 2, 22, 27, 33 n. 39, 54 n. 153,90 n. $333,122,187,188$ n. 344, 196, 278 n. 855, 279, 281-284, 296, 297, 316 n. $90,318,328$ n. 194, 333 n. $216,343,344,350-1$ ns. 298 e 303,352 n. 305,357 n. 323,393 n. 459,396

philotimia, 47, 56, 109, 110, 125 n. 43, 
181 n. 309,211 n. 473,216 n. 4956, 226, 227, 238, 242, 245 ns. 678-9, 246 n. 684,250 n. $699,258,267$ n. 800, 291 n. 935, 305, 312, 334, 335, 345, 346, 396

physis, 41 n. 86, 73, 98 n. 351, 105, 119 n. $18,121,122,136,167,176,189$, 197, 198, 242, 259, 260, 265, 269, 271, 278, 308, 311, 314 n. 8, 317 n. 100, 318, 344, 348, 354, 355, 357, $360,363,380,390,393$ n. 459, 395, 400, 402, 403

Piccirilli, L., 66 n. 214, 67 n. 225, 71 n. 256,77 n. 292,96 n. 345,102 n. 371,138 n. 104

Pimentel, C., 137 n. 95

Pinheiro, J., 137 n. 98, 325 n. 168

Pirro, 44, 153, 223 n. 540, 224, 331 n. 212,334

Plácido, D., 372 n. 372

Platão, 41 n. 86, 54, 63 ns. 200 e 203, 65, 73, 93 n. 336, 96 n. 344,117 n. 1, 118, 119 n. 18, 120, 121, 122 n. 30,137 n. 101, 145 n. 141, 160, 169, 179,180 n. 306, 187 n. 336, 190, 194 n. 395, 216 n. 496, 237 n. 630, 273, 274, 278, 280, 282 n. 874, 283 n. $886,284,294,303$ n. $13,304-305$ n. $21,308,309$ n. 43,311 n. 61,317 n. 100,343 n. 277,347 n. 287, 349, 351 n. $298,355,373,374,381$

Plauto, 75, 278

Plínio-o-Jovem, 29, 112 n. 404, 262, $278,280,288,370,388$ n. 434

Plínio-o-Velho, 39 n. 72, 53, 350 n. 298, 368

Podlecki, A., 29 n. 16, 40, 79

Políbio, 40 n. 80, 44 n. 96, 52, 53, 70 n. $247,79,80$ n. $301,81,82$ n. 308,83 , $87,90,102$ n. $372,112,138$ n. 107 , 146, 147, 207, 213 n. 477, 218, 220 n. 525,222 n. 533,232 n. 599,236 n. 623,239 n. $639,240,325$ n. 171 , $375,384,400$

politeia, 21, 22, 27, 31, 35 n. 49, 37, 56, 73 n. 268, 74, 84, 89, 104, 120, 137,
$143,144,154$ n. $179,156,172,180-$ 195 passim, 206, 213, 216 n. 496, 220, 230, 250, 260, 301, 307, 309 n. $38,311,315,319,335,339,343$, 344, 346, 347, 350 n. 298, 357, 372, 388, 390, 399, 401, 403

Polman, G., 46 n. 110, 47 n. 122

Pompeio, 45, 52 n. 140, 53, 55, 78, 81, 109, 144 n. 131, 197, 203, 244, 260

n. $767,263,265,266,268,269,331$ n. 212,335

Posidónio, 52 n. 140, 185, 188 n. 344, 197 n. 413, 238 n. 635,239 n. 639, 243 n. $663,318,350$ n. 298

Prandi, L., 67 n. 221

praxis, 19, 21, 25, 48 n. 126, 95, 99, 106, $117,118,167,180,191,254,277$, $279,319,332,349,401$

praotes, 123, 154 n. 177, 166, 305, 342 n. $263,389,393$ n. 459

Press, G., 79 n. 295

Preston, R., 333 n. 217, 335 n. 225, 360 n. $327,385,386$ n. 419

proairesis, 34, 37 n. 64, 94 n. 339, 197, 220, 271, 278, 291, 292, 295, 399

pronoia, 54 n. 155, 355 n. 316, 376

Publícola, 48, 83, 161, 331 n. 212

Puech, B., 32 n. 34,32 n. 39, 316 n. 89

Quellenforchung, 68 n. 231

Queroneia, 18, 21, 25, 27, 42, 47, 59, 71, 75, 85 n. 318, 103, 106, 108, 137, 154, 177 n. 295, 191, 369, 383 n. 402, 394, 395, 396

Quintiliano, 294, 350 n.298, 374 n.379

Race, W., 66 n. 217

Ramón Palerm, V., 83 n. 312, 137 n. 99, 53 n. 149

Rawson, E., 384 n. 407

Redfield, J., 89 n. 330

Remo, 129, 130, 131 n. 65, 317 n. 96

Retórica, 29, 30, 32 n.38, 33, 35, 39, 46, 48, 51 n.132, 52, 56, 58, 63 
n.204, 67, 110, 119 n.18, 121, 145, 146,148 n.150, 157 n. 198, 162 n. 221, 164 n. 234,176 ns. 289 e 291 , 179,180--195 passim, 203 n.441, 248, 261, 264, 272, 275, 296, 301, $305,311,313,317,318,319,326$, $330,332,333,334,338,344,349$, 350, 357, 359, 364, 371, 385 n.417, 394 n. $462,395,401,402$

Ribeiro Ferreira, J., 19, 70 ns. 243 e 250, 118 n. 51, 121, 122 n. 29,301 n. 1 , 304 n. 21, 305 n. 21, 314 n. 80, 360 n. 329,385 n. 417

Rijk, L., 351 n. 298

Robb, K., 118 n. 6

Rocha Pereira, M. H., 29 n. 22, 107 n. 390, 349 n. 294, 351 n. 302, 367 n. 347

Roman, D. \& Roman, Y., 366, n. 343

romanitas, 196 n. 412, 202

romanização, 205, 352 n. 305, 364, 366, 370,392

romanocêntrica, 94, 148

Rómulo, 69, 70 n. 249, 91, 105 n. 382, 216, 273, 295 n. 956, 317, 365 n. 340, 384, 393 n. 459, 396, 402

Rosalia, A. de, 75 n. 278

Rosenmeyer, T., 261 n. 770, 47 n. 120

Roskam, G., 284 n. 889, 303 n. 17, 320 n. 138,321 n. 148,328 n. 194

Rossi, A., 53 n. 146

Russel, D., 18 n. 2, 26 n. 6, 29 ns. 15 e 19,51 n. 130,56 n. 165,69 ns. 234 e 236, 70 n. 249,72 n. 260,74 n. 276 , 78 n. 293,79 n. $295,86,89$ n. 328 , 97, 101 n. 368,159 n. 203, 197 n. 414, 223 n. 540, 270 n. 825, 344 n. 281, 393 n. 459

Ruud, N., 96 n. 345

Saïd, S., 21, 30 n. 25, 89 n. 331, 352 n. 305, 393 n. 459, 401

Salmeri, G., 370 n. 362

Salústio, 52 n. 141, 53, 197 ns. 413 e 414

Sanchéz Marín, J., 112 n. 404
Scardigli, B., 69 n. 235, 71 n. 253, 74, 197 n. 413

Schmidt, T., 51 n. 136, 361 n. 333, 388

Schmitz, T., 86 n. 320, 301 n. 5

Schrader, C., 71 n. 252

Schröder, St., 54 n. 154

Séchan, L., 124 n. 37

Segunda Sofística, 21, 30, 46, 86, 272 n. $829,301,302$ n. 5, 316, 333, 359, $362,365,370,387,388,397$

Semónides, 145 n. 141

Séneca, 52 n. 138,75 n. 278, 288

Senécio, 32, 33 n. 39, 106 n. 388, 124, 309, 284, 403

Sertório, 41 n. 83, 44 n. 96, 59, 74 n. $271,90,112,191$ n. 367,219 n. 510 , 271, 286 n. 898, 308, 314 n. 80, 318, $331,332,336,337,340,357,394$, 399, 403

Shipley, D., 71 n. 255, 139 n. 113

Sicília, 172, 235, 236, 243, 306, 366, 396 n. 466

Simónides, 70 n. 243, 118, 309

sinecismo, 127-8, 134

Sirinelli, J., 26 n. 6, 27, 33 n. 43, 42 n. 89,76 n. 279,106 n. $388,244,380$

Sócrates, 54, 56 n. 168, 64, 98 n. 354, 138 n. 108,139 n. 112,143 n. 129 , $148,151,152,155,167,169,170$, $282,317,324,334,339$ n. 247,344 , 355,373

Sófocles, 122, 145 n. 141, 251, 319, 340, 371 n. 365,373

Sólon, 43, 44, 63, 67 n. 226, 74 n. 272, 93, 145 n. 141, 262 n. 775, 295 n. 956, 316 n. 94

sophia, 54 n. 155, 100, 104, 112, 305, 307 n. 27,348 n. 292,352 n. 305

sophrosyne, 56, 139 n. 109, 200, 254 n. 718,305 n. 21,309 n. 43,315 n. 83

Spawforth, A. \& Walker, S., 387 n. 423

Squilloni, A., 284 n. 891

Stadter, Ph., 26 n. 6, 28 n. 14, 32 ns. 38- 
9, 39 n. 73,46 n. 114,47 ns. 117 e 120, 58 n. 181, 67 n. 223,69 n. 235, 74,75 n. 278,77 n. 292,90 n. 332 , 139 n. $110,344,370$ n. 362

Stiefenhofer, A., 51 n. 130, 57 n. 181

Stolz, C., 44 n. 99, 45 n. 100

Striker, G., 186 n. 328

Strobach, A., 74 n. 276,75 n. 278

Suetónio, 29, 39 ns. 72-3, 62, 63 n. 204, 111,112 n. 404, 263 n. 780

Sula, 32 n. 34, 41 n. 83, 132, 146, 164 n. 233, 184-187, 209 n. 466, 264-6, 286 n. 898,331 n. $212,382,388$ n. 437

Swain, S., 29 n. 22,41 n. 83, 51 ns. 130 e 132-4, 55 n. 159,56 n. 170,57 n. 174,58 n. 181,59 n. 191,62 ns. 1967, 86 ns. $320-1,106$ n. 388,131 n. 64 , 188 n. 348,189 n. 352,211 n. 472 , 216 n. 495,217 n. 498,223 n. 540, 225 n. 551, 277 n. 850,290 n. 929 , 294 n. 952,301 n. 5, 309 n. 39,315 n. 88,316 n. 93,332 n. 215,333 n. 218,335 n. 227,337 n. 234, 349 ns. 295-6, 355 n. 316,359 n. 326,360 n. 327,370 n. 362,380 n. 395,383 n. 406, 384 n. 406, 384 n. 407, 387 n. 423, 388, 390 n. 447, 393 n. 459, 395 n. 465,396 n. 467,397 n. 468

Syme, R., 32 n. 34, 33 n. 41, 39 n. 73

synkrisis, 19, 21, 25, 30 n. 26, 41, 51-59 passim, 84, 87, 91, 111, 124, 128, 132 n. 76, 133, 135, 154, 156, 175, 181, 194, 195, 197 n. 415, 209, 210, 220, 222, 226, 227, 228 n. 571,236 , 237 n. 626, 242, 243, 244, 275, 345, $363,375,380,382$ n. 399, 389, 391 n. 451,397

Tácito, 29, 62, 98 n. 354, 278

Tagliasacchi, A., 93 n. 335, 303 n. 17

Talbert, R., 396 n. 466

Tebas, 106 n. 388, 161 n. 214, 229, 230, $231,254,260,371,392$

Temístocles, 35 n. 49, 36, 37, 43, 45, 52, 54,70 n. $241,74,98,100,112,139-$ 146 passim, 154, 156, 195, 259-260,
316 n. $94,321,374,388,392$

Teodorsson, S.-T., 78 n. 293, 99 n. 356, 304-5 n. 21, 389 n. 443

Teofrasto, 40 n. 79, 63 n. 203, 65, 72 n. 259, 144, 172, 194, 288, 309 n. 41, 400

Terêncio, 75 n. 278

Teseu, 26,36, 158 n. 181,69, 70 n. 249, 90, 124-136 passim, 311, 317, 322, 402

Theander, C., 44 n. 99, 68 n. 228, 69 n. 245

Thomas, R., 118 n. 6

Timoleonte, 36, 44, 220, 241, 331 n. $212,388,396$

Tirelli, A., 285 n. 894, 297 n. 969

Tirteu, 63

Titchener, F., 11, 96 n. 345, 372 n. 371, 383 n. 402

Too, Y., 120 n. 19, 270 n. 823, 353 n. 306

Toynbee, J., 278 n. 853

Trajano, 29 n. 18,32 n. 34, 33, 39 ns. 72 e 73,42 n. 89,90 n. 333,262 , 263, 278, 279 n. 858, 280, 283, 285 n. $893,340,357,388$ ns, 434 e 435

Trasibulo, 36, 169, 229, 231, 371

Trédé, M., 262 n. 774

Tronson, A., 71 n. 252

Tucídides, 44 n. 96, 52, 63, 68, 72, 76 n. 285, 77 n. 288,79 n. 295,80 n. 297 , 89,95 n. 342,96 n. $345,102,112$, 120 n. $21,121,145,146,172,191$, 214 n. 481, 317, 352 n. 305

tyche, 38, 41, 43, 54 ns. 154 e 155, 56 n. $172,57,72,73,94,95,98$ n. 351,99 n. 355,130 n. $60,136,157$ n. 198 , 200, 210, 211 n. 472, 226, 241, 254, $258,262,268,287,337,341,355 \mathrm{n}$. 316, 356, 369 n. 355, 373, 376, 380, 399, 400, 403

Uxkull-Gyllenband, W., 64

Valgiglio, E., 32 n. 39, 47 n. 118, 52 n. 138,53 n. 150,79 n. 295, 106 n. 387,271 n. 826 
Índice remissivo geral

Van der Stockt, L., 35 n. 51

Varrão, 53, 61, 349 n. 294

Vasunia, P., 333 n. 218

Velázquez Fernández, A.,

Vergílio, 75, 255 n. 728, 315 n. 86, 367, 368 n. 348

Vernière, Y., 103 n. 374

Vinsonneau, G., 363 n. 337

Vitélio, 39, 43

Walbank, F., 361 n. 331

Wallace-Hadrill, A., 357 n. 324, 366 n. 344

Walsh, J., 77 n. 292, 96 n. 345, 217, 227 n. 563

Wardman, A., 34 ns. 44 e 45, 38 n. 69, 107 n. 390,126 n. 48,237 n. 626, 261 n. 770,280 n. 867,388 n. 437

Warren, E., 118 n. 5

Westaway, K., 121 n. 25

Whitmarsh, T., 86 n. 320, 211 n. 473, 266 n. 798,301 n. 5, 315 n. 88, 316 n. 90,333 n. 218,355 n. 314,359 n. 325,360 n. 327,362 n. 335,368 n. 348,380 n. 395,295 n. 465,398 n. 470

Wilamowitz-Moellendorf, U.von, 51 n. 130, 160 n. 388

Wiseman, J., 229 n. 578

Woolf, G., 90 n. 333, 366, 396

Xenofonte, 44 n. 96, 52, 61, 65, 66 ns. 218 e $219,71,72,76$ n. 285, 112, 121 n. 26, 214 n. 481, 240, 272, 327 n. 181,337

Zadorojnyi, A., 33 n. 39, 42 n. 88, 75 n. 278

Zecchini, G., 265 n. 794, 280 n. 864, 284 n. 891,389 n. 439

Ziegler, K., 32 n. 34, 44 n. 99, 51 n. 130, 89 n. 316,106 n. 388 


\section{Volumes publicados na Colecção Humanitas SUPPLEMENTUM}

1. Francisco de Oliveira, Cláudia Teixeira e Paula Barata Dias: Espaços e Paisagens. Antiguidade Clássica e Heranças Contemporâneas. Vol. 1 - Linguas e Literaturas. Grécia e Roma (Coimbra, Classica Digitalia/CECH, 2009). 288 p.

2. Francisco de Oliveira, Cláudia Teixeira e Paula Barata Dias: Espaços e Paisagens. Antiguidade Clássica e Heranças Contemporâneas. Vol. 2 - Linguas e Literaturas. Idade Média. Renascimento. Recepção (Coimbra, Classica Digitalia/CECH, 2009). 199 p.

3. Francisco de Oliveira, Jorge de Oliveira e Manuel Patrocínio: Espaços e Paisagens. Antiguidade Clássica e Heranças Contemporâneas. Vol. 3 - História, Arqueologia e Arte (Coimbra, Classica Digitalia/CECH, 2010). 331 p.

4. Maria Helena da Rocha Pereira, José Ribeiro Ferreira \& Francisco de Oliveira (Coords.): Horácio e a sua perenidade (Coimbra, Classica Digitalia/CECH, 2009). $180 \mathrm{p}$.

5. José Luís Lopes Brandão: Máscaras dos Césares. Teatro e moralidade nas Vidas suetonianas (Coimbra, Classica Digitalia/CECH, 2009). 461 p.

6. José Ribeiro Ferreira, Delfim Leão, Manuel Tröster \& Paula Barata Dias (eds): Symposion and Philanthropia in Plutarch (Coimbra, Classica Digitalia/CECH, 2009). $573 \mathrm{p}$.

7. Gabriele Cornelli (Org.): Representações da Cidade Antiga. Categorias históricas e discursos filosóficos (Coimbra, Classica Digitalia/CECH/Grupo Archai, 2010). 173 p.

8. Maria Cristina de Sousa Pimentel e Nuno Simões Rodrigues (Coords.): Sociedade, Poder e Cultura no Tempo de Ovídio (Coimbra, Classica Digitalia/CECH/ $\mathrm{CEC} / \mathrm{CH}, 2010) .288 \mathrm{p}$.

9. Françoise Frazier et Delfim F. Leão (eds.): Tychè et pronoia. La marche du monde selon Plutarque (Coimbra, Classica Digitalia/CECH, École Doctorale 395, ArScAn-THEMAM, 2010). 298 p.

10. Juan Carlos Iglesias-Zoido: El legado de Tucídides en la cultura occidental. Discursos e historia (Coimbra, Classica Digitalia/CECH, ARENGA, 2011). 301 p.

11. Gabriele Cornelli, O pitagorismo como categoria historiográfica (Coimbra, Classica Digitalia/CECH, 2011). 265 p.

12. Frederico Lourenço, The Lyric Metres of Euripidean Drama (Coimbra, Classica Digitalia/CECH, 2011). 451 p.

13. José Augusto Ramos, Maria Cristina de Sousa Pimentel, Maria do Céu Fialho, Nuno Simões Rodrigues (coords.), Paulo de Tarso: Grego e Romano, Judeu e Cristão (Coimbra, Classica Digitalia/CECH,/CHUL, CEC, 2012). 306 p. 
14. Carmen Soares e Paula Barata Dias (coords.), Contributos para a história da alimentação na antiguidade (Coimbra, Classica Digitalia/CECH, 2012). $116 \mathrm{p}$.

15. Carlos A. Martins de Jesus, Claudio Castro Filho, José Ribeiro Ferreira (coords.), Hipólito e Fedra - nos caminhos de um mito (Coimbra, Classica Digitalia/CECH, 2012). 228 p.

16. José Ribeiro Ferreira, Delfim F. Leão, \& Carlos A. Martins de Jesus (eds.): Nomos, Kosmos E Dike in Plutarch (Coimbra, Classica Digitalia/CECH, 2012). 277 p.

17. José Augusto Ramos \& Nuno Simões Rodrigues (coords.), Mnemosyne kai Sophia (Coimbra, Classica Digitalia/CECH/CHUL, 2012). 200 p.

18. Ana Maria Guedes Ferreira, O homem de Estado ateniense em Plutarco: o caso dos Alcmeónidas (Coimbra, Classica Digitalia/CECH, 2012). 396 p.

19. Aurora López, Andrés Pociña \& Maria de Fátima Silva (coords.), De ayer a hoy: influencias clásicas en la literatura (Coimbra, Classica Digitalia/CECH, 2012). $594 \mathrm{p}$.

20. Cristina Pimentel, José Luís Brandão \& Paolo Fedeli (coords.), O poeta e a cidade no mundo romano (Coimbra, Classica Digitalia/CECH/CEC,2012). 240 p.

21. Francisco de Oliveira, José Luís Brandão, Vasco Gil Mantas \& Rosa Sanz Serrano (coords.), A queda de Roma e o alvorecer da Europa (Coimbra, Imprensa da Universidade de Coimbra, Classica Digitalia, 2012). 252 p.

22. Luísa de Nazaré Ferreira, Mobilidade poética na Grécia antiga: uma leitura da obra de Simónides (Coimbra, Imprensa da Universidade de Coimbra, Classica Digitalia, 2013). 472 p.

23. Fábio Cerqueira, Ana Teresa Gonçalves, Edalaura Medeiros \& José Luís Brandão, Saberes e poderes no mundo antigo. Vol. I - Dos saberes (Coimbra, Imprensa da Universidade de Coimbra, Classica Digitalia, 2013). 282 p.

24. Fábio Cerqueira, Ana Teresa Gonçalves, Edalaura Medeiros \& Delfim Leão, Saberes e poderes no mundo antigo. Vol. II - Dos poderes (Coimbra, Imprensa da Universidade de Coimbra, Classica Digitalia, 2013). 336 p.

25. Joaquim J. S. Pinheiro, Tempo e espaço da paideia nas Vidas de Plutarco (Coimbra, Imprensa da Universidade de Coimbra, Classica Digitalia, 2013). 458 p. 



$$
\text { (G+ }
$$

$\frac{1}{T}$ 